\title{
La dinámica del cambio constitucional en México
}

José María SERNA DE LA GARZA Isidro DE LOS SANTOS OLIVO Coordinadores

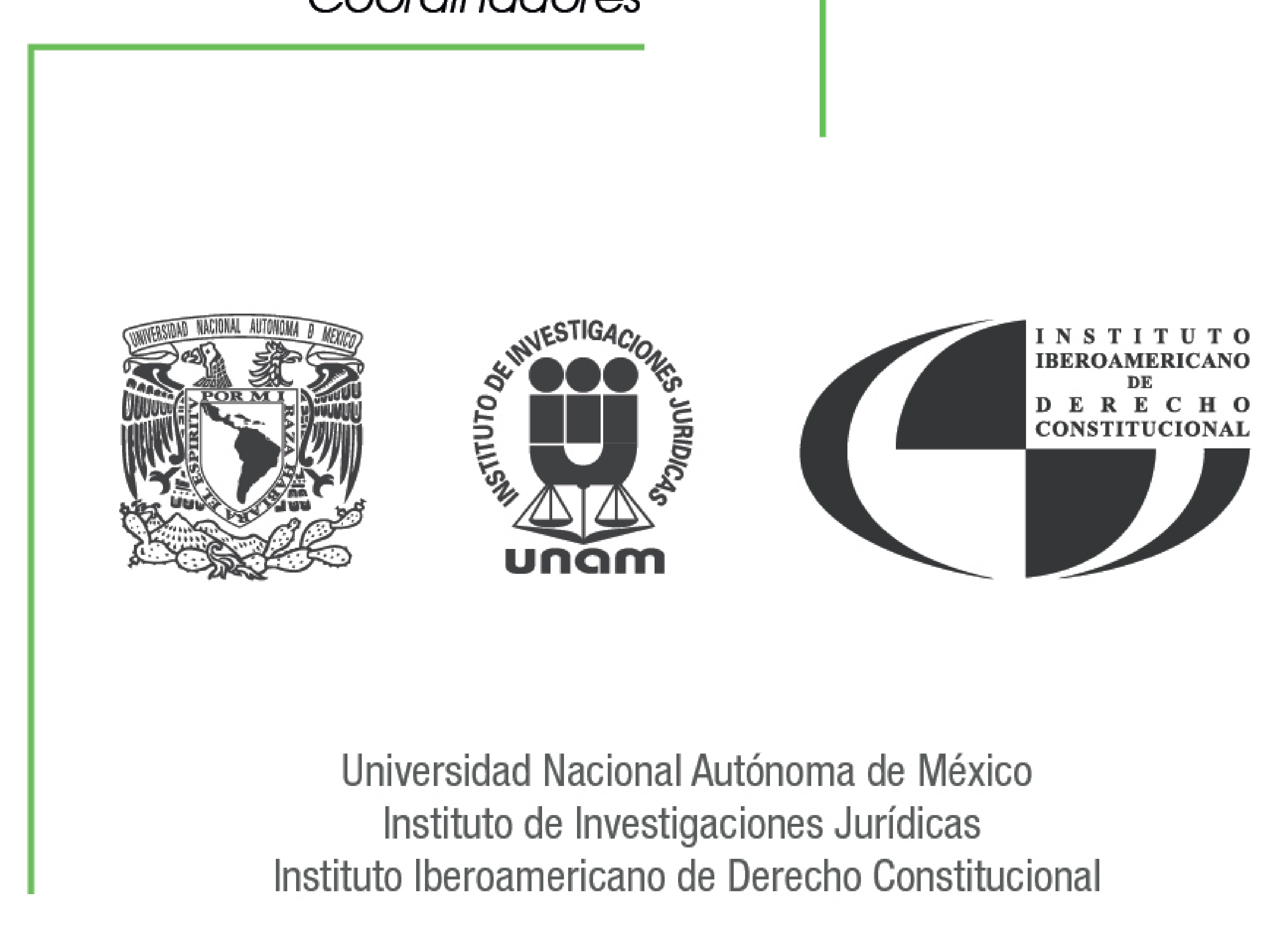


LA DINÁMICA DEL CAMBIO

CONSTITUGIONAL EN MÉXICO 


\section{INSTITUTO DE INVESTIGACIONES JURÍDICAS}

Serie VERSIÓN DE AUTOR, núm. 13

\section{COORDINACIÓN EDITORIAL}

Lic. Raúl Márquez Romero

Secretario Técnico

Lic. Wendy Vanesa Rocha Cacho

Jefa del Departamento de Publicaciones

María Teresa de Jesús Baena Sánchez

Apoyo editorial

Ana Julieta García Vega

Formación en computadora

Mauricio Ortega Garduño

Elaboración de portada 

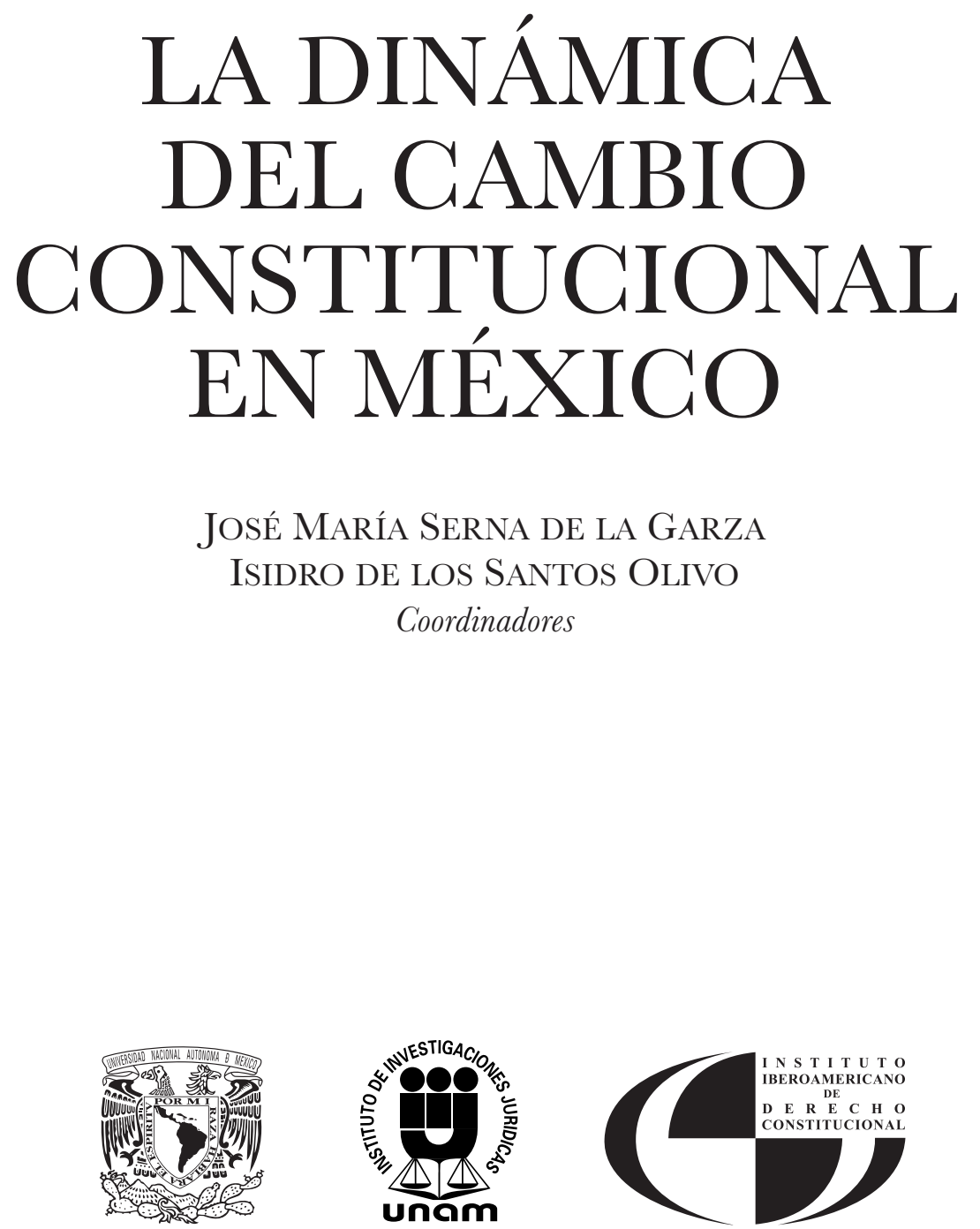

UNIVERSIDAD NACIONAL AUTÓNOMA DE MÉXICO INSTITUTO DE INVESTIGACIONES JURÍDICAS INSTITUTO IBEROAMERICANO DE DERECHO GONSTITUCIONAL MÉXICO, 2018 
Primera edición: 15 de febrero de 2018

DR (C) 2018. Universidad Nacional Autónoma de México

\section{INSTITUTO DE INVESTIGACIONES JURÍDICAS}

Circuito Maestro Mario de la Cueva s/n

Ciudad de la Investigación en Humanidades

Ciudad Universitaria, 04510 Ciudad de México

Impreso y hecho en México

ISBN (libro electrónico): 978-607-30-0265-3 


\section{GONTENIDO}

Teoría y cambio constitucional en México: Tensiones y contradicciones en la refundación contemporánea del Estado de Derecho . . . . Raúl ÁviLA ORTIZ

Mitos y paradigmas sobre la Constitución mexicana y su reforma. Breve reflexión en torno al próximo Centenario y ante la necesidad de una nueva constitucionalidad . . . . . . . . . . . . . . José Luis Caballero OchOA

La Constitución a detalle desde la perspectiva de la teoría constitucional en México . . . . . . . . . . . . . . . . . . . . . . . . .

José Miguel Cabrales Lucio

Constructivismo Jurídico, Entropía y Neguentropía en el Constitucionalismo contemporáneo . . . . . . . . . . . . . . Enrique CÁceres Nieto

El neoliberalismo y las grietas del neoconstitucionalismo . . . . . . . Jaime CÁRDENAS GARCía

Algunas reflexiones en torno a la teoría y práctica del cambio constitucional en México. . . . . . . . . . . . . . . . . . . . . . . . . 113 Manlio Fabio CaSARín LEÓN

Reordenación y consolidación del texto constitucional respecto del control ex officio de convencionalidad en materia electoral (trayectoria y problemas). . . . . . . . . . . . . . . . . .

Eduardo de Jesús Castellanos Hernández

La reforma constitucional en México: disfuncionalidad del modelo demo-

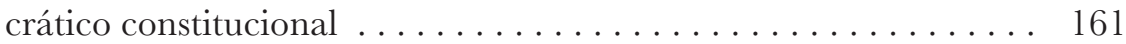
Hugo Alejandro Concha Cantú

La desnaturalización de los artículos transitorios en la reforma constitucional político-electoral de $2014 \ldots \ldots \ldots \ldots \ldots \ldots \ldots$

Oswaldo GHACÓn Rojas 
El caso español. La crisis del régimen de 1978 y las posibilidades de una reforma constitucional (un análisis sociopolítico desde la perspectiva de la inteligencia emocional) . . . . . . . . . . . Javier Esteban GuINEA

La dialéctica cambio-permanencia constitucional: a propósito del anteproyecto de texto reordenado y consolidado de la Constitución Política de los Estados Unidos Mexicanos. . . . . . . . . . . . . . Imer B. FLORES

El cambio constitucional en América Latina. (Nota sobre un fenómeno

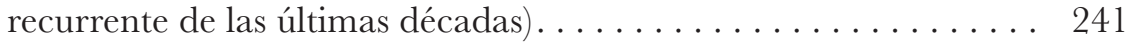
Domingo García BeLAUNDE

Teoría y práctica del cambio constitucional en México .......... María del PILAR HERNÁNDEZ

La forma de la norma. Reflexión sobre el carácter reglamentario de algunas disposiciones constitucionales. . . . . . . . . . . Carla Huerta

Desafíos en la instrumentación de una reforma constitucional de claroscuros en materia electoral . . . . . . . . . . . . . . . 299 Saúl Mandujano Rubio

La necesidad de esquematizar el contenido de los derechos humanos de la Constitución mexicana de $1917 \ldots \ldots \ldots \ldots \ldots \ldots \ldots$ Sergio Arnoldo Morán NAVARRO

El diseño de la reforma constitucional en México. . . . . . . . . . . . Mariana del Pilar Olmeda GaRcía

¿Reforma, mutación o enmienda constitucional? . . . . . . . . .

José F. Palomino Manchego

¿Nueva Constitución para México?. . . . . . . . . . . . .

Francisco José PAOLI BOLIO

Las ineficacias legales y políticas del Hiper-Reformismo Constitucional

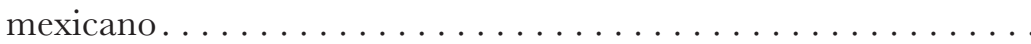

Francisca POU GIMÉnEz

El procedimiento de la Reforma Constitucional: un examen crítico. . 409 Andrea Pozas LOYO

La constitución en piezas: asistematicidades y reforma constitucional. . 415 Mauro Arturo RIVERA LEÓN 
La Constitución de 1917, reforma de las constituciones estatales y las nuevas constituciones de Guerrero y de la Ciudad México. . . . . . . Marcial RODRÍGUEZ SALDAÑA

Revisión del diseño y la técnica constitucionales en México . . . . . . . Miguel Ángel RodRíGuez VÁzQUEZ

La dinámica de la Constitución en México. Circunspecciones entre la novedad y la revisión constitucional $\ldots \ldots \ldots \ldots \ldots \ldots \ldots$ Isidro de los SANTOS Olivo

La dinámica del cambio constitucional en México: hacia una agenda de investigación . . . . . . . . . . . . . . . . . José Ma. SERna de la GARZA

Los problemas de técnica constitucional en México . . . . . . . . . José María Soberanes DíEz

La reforma constitucional en México: algunas notas para orientar la

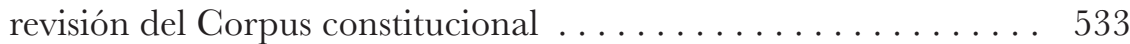

Enrique URIBE ARZATE

Martha Guadalupe Bustamante Medrano

La dinámica del cambio constitucional en Sinaloa y la protección de los derechos humanos de la población indígena . . . . . . . . . . . 549 Gonzalo ARMienta HeRnández Karla Elizabeth MARISGAL URETA

Los retos del constitucionalismo del siglo XXI, bajo la óptica de la Constitución $1917 \ldots \ldots \ldots \ldots \ldots \ldots \ldots \ldots \ldots \ldots \ldots \ldots \ldots$ Daniel Montero Zendejas

Balance y perspectivas de la reforma constitucional penal del 18 de junio del 2008 a febrero del $2016 \ldots \ldots \ldots \ldots$. . . . . . . . . . 593 Rafael SÁNCHEZ VÁZQUEZ

El modelo mexicano de gobiernos de coalición. . . . . . . . . . . Francisco TORTOLERO CERVANTES 
Esta obra forma parte del acervo de la Biblioteca Jurídica Virtual del Instituto de Investigaciones Jurídicas de la UNAM

\title{
TEORÍA Y GAMBIO CONSTITUGIONAL EN MÉXICO: TENSIONES Y GONTRADIGGIONES EN LA REFUNDAGIÓN CONTEMPORÁNEA DEL ESTADO DE DERECHO
}

\author{
Raúl Ávila OrTiz *
}

\begin{abstract}
SUMARIO: I. Introducción. II. Teoría y práctica del cambio constitucional. III. Las transiciones: Científico-epistémica, Económica, Social, Política y Furídica. IV. Avances y contradicciones en la refundación del Estado de Derecho: Legitimidad y eficacia en juego. V. Desafios persistentes y retos urgentes. VI. Conclusiones.
\end{abstract}

\section{INTRODUCGIÓN}

Este trabajo tiene por objeto mostrar el resultado de un análisis practicado en torno a la coherencia entre teoría y práctica del cambio constitucional en el México de los últimos veinticinco años, enfatizar la correlación entre las transiciones científico-epistémica, socioeconómica y política con el cambio jurídico, no sólo pero sí sobre todo en ese lapso--, hacer notar las inconsistencias entre los cambios jurídicos y la pretendida refundación contemporánea del Estado de Derecho, y apuntar algunos de los principales desafios urgentes que encara tal proceso.

Por una parte, es claro que la teoría del cambio constitucional en México se ha enfrentado en la práctica a diversas distorsiones generadas por el peculiar contexto histórico en que ha transcurrido y del cual este ensayo da cuenta. Los es también que tal dinámica reformista ha contribuido a forjar un patrón institucional cargado de fortalezas y debilidades que es conveniente identificar y que, un cuarto de siglo después, se ha tornado rígido y abigarrado, a imagen y semejanza del texto constitucional. Por la otra, esta

* Doctor en Derecho por la UNAM. Profesor de Posgrado de la misma universidad, de la Universidad Autónoma Metropolitana, la Universidad Autónoma de Tlaxcala y la Universidad de Xalapa. 
Esta obra forma parte del acervo de la Biblioteca Jurídica Virtual del Instituto de Investigaciones Jurídicas de la UNAM

realidad constitucional - formal y material - plantea nuevos retos que vencer, de los cuales se ocupa hoy con denuedo la ciencia jurídica preocupada por los alarmantes índices a la baja de cultura constitucional, déficit legal e ineficacia normativa que se experimentan en el país. En este sentido, simple y sencillamente, constitucionalizar "desde arriba" el orden jurídico es inútil sin constitucionalizar "desde abajo" la mente y el espíritu del pueblo. A la vez, institucionalizar la reconstrucción jurídica de la democracia constitucional en un entorno globalizado no será un proceso viable y exitoso sin el prioritario cambio en las mentalidades de los principales actores académicos e intelectuales pero, por supuesto, con el concurso de la participación social y ciudadana a través de los instrumentos que hemos venido forjando mediante la propia democracia pluralista.

En ese orden de ideas, el texto revisita de manera breve la teoría del cambio constitucional, aborda el contexto histórico relevante en que se ha venido practicando - transiciones en los sistemas sociales, incluido el sistema jurídico-, identifica fortalezas y debilidades de ese proceso, apunta los desafíos más notorios y asienta las conclusiones respectivas.

\section{TEORÍA Y PRÁCTICA DEL CAMBIO CONSTITUCIONAL}

En términos epistémicos convencionales, positivistas o la determinación de la verdad en tanto correspondencia entre pensamiento, discurso y realidad externa al sujeto (no en términos de coherencia entre construcciones hermenéuticas intersubjetivas y resultados sociales) ${ }^{1}$ se observa en la experiencia mexicana del más reciente cuarto de siglo suficiente coherencia entre la teoría sobre el cambio constitucional y sus productos normativos. Esto es notorio sobre todo a través de la reforma al texto, es decir, de “... los procesos de acomodación de las normas constitucionales a la realidad..." que incluyen las complejas mutaciones constitucionales o actos de complementación constitucional, de interpretación y construcción constitucionales, y

1 Véase, al efecto de esta distinción y otros problemas epistémicos relacionados: Cáceres Nieto, Enrique, "Institucionalismo jurídico y constructivismo social", en Boletín Mexicano de Derecho Comparado, Número 100, Enero-Abril 2001, Nueva Serie, Año XXXIV, Consultado en Biblioteca Jurídica Virtual, UNAM-Instituto de Investigaciones Jurídicas; y "La Constitución emergente (Un ensayo de meta-teoría constitucional desde el constructivismo jurídico", en Serna de la Garza, José María (coord.), "Contribuciones al Derecho Constitucional", UNAM-Instituto de Investigaciones Jurídicas, Instituto Iberoamericano de Derecho Constitucional, Serie Versiones de Autor, núm. 1, México, 2015, pp. 139 -158. 
Esta obra forma parte del acervo de la Biblioteca Jurídica Virtual del Instituto de Investigaciones Jurídicas de la UNAM

prácticas político sociales convertidas en convenciones constitucionales. ${ }^{2}$ En efecto, si a partir de literatura constitucional relevante ${ }^{3}$ consideramos cinco indicadores: a) fuentes del cambio, b) frecuencia, c) procedimientos, d) límites y d) contenidos reformistas, es posible establecer lo siguiente:

a) En dicho periodo el cambio no sólo se ha expresado en abundantes reformas legislativas sino en mutaciones vía cada vez más intensa y extensa actividad reglamentaria, pero sobre todo de fuente jurisprudencial $-\mathrm{y}$ de manera sustancial para completar o incluso recrear disposiciones legislativas - cuando en el periodo previo, es decir, entre 1970 y 1990 la dinámica del cambio constitucional se concentraba en el texto legislado.

En efecto, y tan sólo a manera de ejemplo, productos de investigación empírica recientes confirman el crecimiento exponencial de la producción legislativa constitucional y la pertinencia de proceder a reordenar y consolidar el texto. ${ }^{4}$

En este tenor, siguiendo tan significativo reporte, se extrae que la dinámica de la reforma constitucional entre 1921 y julio de 2015 concretó 642 cambios mediante 235 decretos de reforma constitucional a múltiples artículos, y que fue a partir de 1982 (el sexenio del presidente Miguel de la Madrid) cuando dicha dinámica se aceleró registrando el $66.9 \%$ y $56.4 \%$ de esas modificaciones.

2 Cfr. Da silva, José Alfonso, "Mutaciones constitucionales", en Cuestiones Constitucionales. Revista Mexicana de Derecho Constitucional, Número 1, Julio-diciembre 1999, en Biblioteca Jurídica Virtual, UNAM-Instituto de Investigaciones Jurídicas. En el mismo sentido, ya otro autor emblemático, apoyado en Loewenstein, había anticipado una década antes que la mutación “....denota la transformación del poder político, de la estructura social o del equilibrio de intereses sin que el texto constitucional se actualice en el sentido que se hayan producido esos cambios. Es decir, la mutación constitucional no contempla los cambios habidos en el texto sino los producidos en la realidad" y "...no necesariamente implica un falseamiento o quebrantamiento de la Constitución", Cfr. Valadés, Diego, "la Constitución reformada", UNAM-Instituto de Investigaciones Jurídicas, Serie G, Estudios Doctrinales, núm. 108, México, 1987, p. 15.

3 Véase, por ejemplo, los rubros o indicadores referidos y utilizados en el texto de Salvador Valencia Carmona, "Constitución y reforma constitucional en México", en Varios, "Liber ad Honorem Sergio García Ramírez", UNAM-Instituto de Investigaciones Jurídicas, México, 1999, Tomo I, pp. 681-705. En la misma obra, en particular sobre los límites a la reforma y la doctrina mexicana: Huerta, Karla, "Sobre la reforma a la Constitución", pp. 303-319.

4 Véase, desde luego, en lo que sigue y salvo cita en diversa: Fix-Fierro, Héctor y Diego Valadés (coords), "Constitución Política de los Estados Unidos Mexicanos. Texto reordenado y consolidado. Anteproyecto. Ley de Desarrollo Constitucional. Anteproyecto", UNAMInstituto de Investigaciones Jurídicas, Cámara de Diputados, Instituto Iberoamericano de Derecho Constitucional, México, 2016. 
Esta obra forma parte del acervo de la Biblioteca Jurídica Virtual del Instituto de Investigaciones Jurídicas de la UNAM

Pero, más todavía, junto a ese fenómeno habría que apuntar que el desarrollo de textos jurídicos procedentes de fuente administrativa y de fuente judicial han llegado a provocar silenciosas subversiones a contenidos y sentidos del propio texto constitucional escrito. ${ }^{5}$ Esta aseveración se fortalece si se considera la mutación provocada por la apertura del sistema jurídico mexicano a fuentes supranacionales ${ }^{6}$ y el formidable impacto que está cobrando sobre éste último la gobernanza global. ${ }^{7}$

b) Consecuentemente, la frecuencia del cambio se ha incrementado, según lo revela aquel estudio, lo que ha provocado la sobre-extensión del propio documento escrito. Al respecto, el citado reporte muestra que, medido en el número de palabras, si la versión original de la Constitución de 1917 contenía 21 mil, en 1982 había alcanzado casi 30 mil, es decir había aumentado un $42.6 \%$. Desde entonces, la frecuencia del cambio se intensificó. En breve, del extremo menor de dos decretos y 8 reformas realizadas en el cuatrienio 1920-1924 o el caso de 1 decreto y 2 reformas entre 1952 y 1958, o bien el intermedio de 8 decretos y 11 reformas del periodo 1964-1970, entre 1970 y 2015 ningún periodo sexenal ha registrado menos de 14 decretos y 30 reformas. Más aún, de las 864 palabras que las reformas de 1970 a 1976

5 Lamento, claro está, no haber podido consignar aquí los datos sobre la producción jurisprudencial mexicana en clave diacrónica, por ejemplo, entre las tres últimas épocas jurisprudenciales, y menos sus principales líneas e impactos sobre la Constitución legislada. Nótese, sin embargo, la importancia que el neo-constitucionalismo le asigna a la interpretación judicial pues, como asienta al respecto Pedro Salazar, “...En esa medida el contenido de la Constitución no solo se encuentra en el texto del documento normativo que lleva ese nombre sino también en las interpretaciones que están contenidas en las sentencias judiciales", Salazar, Pedro, "Sobre el concepto de Constitución", en Favra Zamora, Jorge Luis y Ezequiel Spector (eds), "Enciclopedia de Filosofía y Teoría del Derecho”, Volumen Tres, UNAM-Instituto de Investigaciones Jurídicas, México, 2015, p. 1944.

$6 \mathrm{Al}$ respecto, Astudillo, César, "El bloque y el parámetro de constitucionalidad en México", Tirant Lo Blanch, México, 2014.

7 Véase, si no, los siete mensajes de Serna de la Garza al introducir su más reciente obra, cuando advierte sobre la expansión inédita del papel formal e informal de las instituciones multilaterales; el incrementado alcance, densidad y grado de influencia de normas de fuente internacional en las sociedades nacionales; cambios de fondo en la comprensión político-jurídica y ética de la soberanía estatal y la relación entre Estado, ciudadano y comunidad internacional; apertura de Estados nacionales a influyentes regímenes internacionales diversos; creciente interpenetración entre derechos internacional y nacional, instituciones internacionales y aparatos administrativos domésticos; y la emergencia de esquemas de redes de interacciones - interdependientes en ausencia de una autoridad política global - en lugar de una subordinación jerárquica entre actores. Cfr. Serna de la Garza, José María, "Estudio introductorio", en Serna de la Garza, José María (Coord), "Gobernanza global y cambio estructural del sistema jurídico mexicano", UNAM-Instituto de investigaciones Jurídicas, México, 2016, pp. 3-4 (Consultado en www.jurídicas.unam.mx el 28.03.16). 
Esta obra forma parte del acervo de la Biblioteca Jurídica Virtual del Instituto de Investigaciones Jurídicas de la UNAM

le agregaron al texto, hay que considerar que en solo dos periodos sexenales presidenciales, el de 2006-2012 y el de 2012 hasta julio de 2015 - este último aún en curso pues concluirá hasta 2018 - se aprobaron 58 decretos y 200 reformas, es decir el 31.2\% de todas las reformas, y sumaron 20,708 palabras al texto o casi el equivalente a las 21 mil palabras originales que contenía el año de su entrada en vigor (1917), lo que entraña que el texto se ha triplicado en extensión en poco menos de cien años.

c) El procedimiento reformista ha sido, ciertamente, el mecanismo previsto en la propia Constitución escrita, es decir en el artículo 135, que involucra mayorías calificadas en las dos cámaras del Congreso de la Unión más la mayoría de las legislaturas de los Estados de la República. Sin embargo, el escenario luce ampliado si se considera que la apertura y parametrización internacional introducida en junio de 2011, en materia de derechos humanos, multiplica las disposiciones de orden legislativo, las normas aplicables y las interpretaciones construidas sobre ellas, no menos que su obligatoriedad en términos de la jurisprudencia de la propia Suprema Corte de Justicia de la Nación. ${ }^{8}$

Cabe destacar, en clave crítica, que la dinámica reformista mexicana sigue dejando de lado el refrendo popular en todo tipo de reformas, ya no se diga en aquellas que tocan principios constitucionales. En este punto es válida la pregunta sobre el grado de flexibilización de la Constitución, central en la teoría y la práctica de la democracia constitucional pro derechos fundamentales y la organización gubernativa para efectos de la estabilidad de la primera, y la gestión y tutela eficaces de los segundos. Tal acertijo halla respuesta, en mi criterio, no en la Constitución formal sino en la Constitución material, en particular en la composición y dinámica real del sistema de partidos, hegemónico hasta antes de 1997 y pluralista moderado con tendencia a la fragmentación a partir de entonces, así como en los intereses de la elite dirigente en el país. ${ }^{9}$

d) La cuestión de los límites se mantiene sin definición formal en el texto constitucional, pero es claro que no hay principios ni instituciones fundamentales explícitos o implícitos que pudieran funcionar como diques a la reforma, según lo prueban, precisamente, las llamadas "reformas estructurales" que fueran incorporadas al texto entre 2013 y 2014. No obstante, el

$8 \mathrm{Al}$ respecto: Astudillo, César, "El bloque...", Ob. Cit., Supra, Nota 5.

9 Me refiero, desde luego, a las reformas de fondo o estructurales que tocan el nervio económico del país y que sólo han sido posibles mediante el llamado Pacto por México al que concurrieron a finales de 2012 los tres partidos políticos nacionales más grandes, PAN, PRI y PRD. 
Esta obra forma parte del acervo de la Biblioteca Jurídica Virtual del Instituto de Investigaciones Jurídicas de la UNAM

principio de progresividad de los derechos obliga a interpretar y justificar su mejor "garantización" institucional, lo que a su vez abre espacio al ajuste no menos que a la posible manipulación de la parte orgánica - y, por qué no, de la propia parte dogmática- de la Constitución. Esto, en su turno, está generando interesantes controversias jurídicas de carácter doctrinal y práctico pues caben ponderaciones entre tales principios e instituciones, ya entre federalismo y democracia, ya entre derechos y seguridad, o bien entre derechos y soberanía económica, por ejemplo. ${ }^{10}$

e) En el rubro de contenidos, se registra un claro aumento en catálogos de derechos mezclados con métodos y técnicas de garantía en varios artículos. ${ }^{11}$ Es notoria la atención prioritaria a normas sobre acceso al poder (la materia electoral) y menos atención a las condiciones de su distribución, división y equilibrio, ejercicio y control, aunque hay esfuerzos en marcha en estos ámbitos, especialmente en materia de transparencia y rendición de cuentas. ${ }^{12}$ Si se adoptara como parámetro la literatura profesional predominante en términos del constitucionalismo garantista, podría suavizarse la crítica si es que la sobre-extensión de los artículos transitorios abonara a la efectiva "garantización" procedimental de los compromisos constitucionales incorporando instructivos vía artículos transitorios, solo que en los hechos, además de problemas de coherencia y sistematizción (duplicidades, terminología, proporción y profundidad, reglamentación y expresión de programas de go-

10 Tales debates has estado y continúan presentes con intensidad variable entre actores académicos y políticos. Véase, en el caso de la tensión entre democracia y federalismo: Molina Piñeiro, Luis, et. al (coords), "Sobre el nuevo federalismo electoral en México", UNAM, COPUEX, INE, México, 2015.

11 Según el reporte coordinado por Fix-Fierro y Valadés, las materias más importantes, objeto de las reformas han incluido "el control de la constitucionalidad de leyes; autonomía de gobierno y administración de los municipios; sistema electoral y representativo (federal y local); derechos fundamentales, tanto individuales como sociales y sus medios de protección; derechos y autonomía de los pueblos indígenas; propiedad y justicia agrarias; transparencia y acceso a la información pública gubernamental; sistemas de justicia penal y seguridad pública; presupuesto control del gasto público y rendición de cuentas; relaciones del Estado con las Iglesias y las comunidades religiosas; independencia, gobierno y carrera judiciales; rectoría del Estado sobre el desarrollo nacional y sistema de planeación democrática; y explotación de recursos energéticos y empresas productivas del Estado", ello además de la renovación y creación de diversas instituciones.

$12 \mathrm{Al}$ respecto, Peschard, Jacqueline (coord.), "Hacia el sistema nacional de transparencia", UNAM-Instituto de Investigaciones Jurídicas, Seminario Universitario de Transparencia, México, 2016; y, en particular, Gutiérrez Salazar, Miguel Ángel, "La importancia de construir un Sistema Nacional de Rendición de Cuentas en México", en Hechos y Derechos. Revista electrónica de opinión académica, UNAM-Instituto de Investigaciones Jurídicas, Número 19, Enero-Febrero 2014, consultado en wrer.juridicas.unam.mx. 
Esta obra forma parte del acervo de la Biblioteca Jurídica Virtual del Instituto de Investigaciones Jurídicas de la UNAM

bierno y políticas públicas, según el reporte aludido) se aprecia el incumplimiento legislativo en los plazos para la reglamentación respectiva. Esta mala práctica hace que cobre aún más pertinencia la propuesta de introducir en el sistema jurídico nacional las leyes de desarrollo constitucional, propuestas en el reporte arriba mencionado de Fix-Fierro y Valadés.

\section{LAS TRANSICIONES: CIENTÍFICO-EPISTÉMICA, ECONÓMICA, SOCIAL, POLÍTICA Y JURÍDICA}

Ahora bien, es importante poner de relieve que el cambio constitucional referido es parte de una transición jurídica mayor que está ocurriendo dentro del contexto más amplio signado por múltiples transiciones. Veamos cuatro de ellas, antes que la propiamente jurídica y antes de volver al cambio constitucional mexicano acelerado a lo largo de los recientes decenios.

a) La transición científica de cuño europeo supone tres ciclos de cambio cognitivo y epistémico que van de la transición de la filosofía especulativa medieval al objetivismo racionalista, empirista, trascendental, pragmatista y analítico - positivista - de los siglos XIX y XX y, de allí, a diversas formas de pos-positivismo hermenéutico, contextual, humanista y constructivista post-segunda Guerra Mundial que en los entre-siglos XX y XXI se intensifican con la irrupción del neo-pragmatismo - una suma práctica de aquellas posturas-, el cual está en la base de las más recientes aceleraciones del capitalismo global. ${ }^{13}$ En México, en donde tales movimientos filosóficos se han recibido y practicado desfasada y con frecuencia incompleta y distor-

13 Para apreciar ese decurso histórico panorámico, véase, por ejemplo: Oldroyd, David, "El arco del conocimiento. Introducción a la Filosofía y Metodología de la Ciencia", Crítica, Madrid, 1993; Hottois, Gilbert, "Historia de la Filosofía del Renacimiento a la Posmodernidad"; D Agostini, Franca, "Analíticos y Continentales: Guía filosófica de los últimos treinta años", Cátedra, Madrid, 2009; o bien, Rorty, Richard, "La filosofía y el espejo de la naturaleza", Cátedra, Madrid, 1983 y, del mismo autor, "Consecuencias del pragmatismo", Tecnos, Madrid, 1995. Véase, igualmente, García, Rolando, "La epistemología genética y la ciencia contemporánea. Homenaje a Jean Piaget en su centenario, Gedisa, Madrid, 1977, y Cáceres Nieto, Enrique, "La Constitución emergente...", ob, cit., Supra, nota 1, en particular cuando advierte: "Junto con Rolando García, sostengo que en la historia ha habido dos grandes derrumbes epistémicos: el de la epistemología especulativa y el segundo el del empirismo" positivista que presupone "...la existencia de una realidad dada, objetiva y ontológicamente independiente de cualquier mente que la piense y que en el caso del derecho corresponde al derecho positum, o dado en el mismo sentido que las manzanas que caen de los árboles. Dos conmociones han removido al empirismo desde sus cimientos: la demostración de que la realidad es un constructo cognitivo y el fin del determinismo", pp. 141-142. 
Esta obra forma parte del acervo de la Biblioteca Jurídica Virtual del Instituto de Investigaciones Jurídicas de la UNAM

sionadamente en el propio contexto, el referido tercer ciclo - neo-pragmatista - apenas comienza y ya enfrenta serios opositores. ${ }^{14}$

b) La transición económica, más estudiada y sobre la que reina más amplio consenso, significa que durante los últimos años se asiste en escala planetaria a la Cuarta Revolución Industrial. ${ }^{15}$ Las tres primeras revoluciones científicas y tecnológicas propulsadas en el mundo occidental impactaron desfasadamente en México. La primera, manifiesta entre 1750 y 1850 con base en la mecanización de la agricultura y la industria textil, la máquina de vapor y el ferrocarril, el carbón, el acero y la hulla, así como el motor de combustión interna, aceleraron el desarrollo liberal capitalista urbanoburgués y vio, mediante revoluciones democráticas en los dos lados del Atlántico, la implantación de constituciones y el Estado de derecho de la legalidad proyectado en el movimiento codificador, lo que en México se reflejó tardía y frágilmente en la Constitución de 1857 y el Porfiriato. ${ }^{16}$ La segunda, básicamente fundada en nuevas fuentes de energía, comunicaciones y transportes: petrolera y eléctrica, cable submarino, telégrafo y teléfono, radio, aviación y televisión se extendió de mediados del siglo XIX hasta mediados del siglo XX y generó la economía industrial masificada junto con la ampliación del sufragio, la dialéctica capitalismo-socialismo y la consolidación del Estado-nación de legalidad, que entró en crisis en Europa Occidental luego de la Segunda Guerra Mundial, cuando aquélla - la segunda revo-

14 Así, por ejemplo, para algunos historiadores de las ideas europeo-latinoamericanas, los momentos epistémicos cartesiano (hasta finales del siglo XIX), el momento freudeano (primera mitad del siglo XX) y el momento lacaniano (segunda mitad del siglo XX) de origen europeo no se corresponden en tiempos e impactos con los ritmos y contenidos intelectuales americanos en los que también se advierten posturas híbridas y propias antipositivistas, críticas, liberadoras y poscoloniales. Más aún, posturas revisionistas y emancipadoras del colonialismo y la dependencia filosófica y epistémica, que pasan por la obra de Leopoldo Zea y sus discípulos, por ejemplo, Dussel, o bien de autores como Boaventura de Souza, aún no encuentran motivación suficiente en la intelectualidad y academia mexicanas. Véase: Cancino Troncoso, Hugo, Sussane Klengel y Nanci Leonzo (Eds), "Nuevas perspectivas teóricas y metodológicas de la Historia intelectual de América Latina", Vervuert Iberoamericana, Madrid, 1999; Dussel, Enrique, "Historia de la Filosofía y Filosofía de la Liberación. Textos completos”, Editorial Nueva América, Bogotá, 1994, y Dussel, Enrique, Eduardo Mendieta y Carmen Bohórquez (Eds), "El pensamiento filosófico latinoamericano, del Caribe y 'latino'(1300-2000): historia, corrientes, temas y filósofos", Siglo XXI, México, 2009.

15 Sobre las revoluciones económicas o industriales, como las llama la literatura internacional, y en particular la revolución en curso, véase: Schwab, Klaus, "The Fourth Industrial Revolution", World Economic Forum, 2016.

16 Sobre este punto, véase: Ávila Ortiz, Raúl, Eduardo de Jesús Castellanos Hernández y María del Pilar Hernández (coords), "Porfirio Díaz y el Derecho. Balance Crítico", Cámara de Diputados, UNAM-Instituto de Investigaciones Jurídicas, México, 2015. 
Esta obra forma parte del acervo de la Biblioteca Jurídica Virtual del Instituto de Investigaciones Jurídicas de la UNAM

lución industrial - en parte motivó la Revolución Mexicana de 1910 y la Constitución de 1917, sobrepasó estos acontecimientos y se prolongó, sobre todo a partir de la Gran Depresión y el cardenismo, con economía y sistema político protegido hasta finales de los años ochenta. ${ }^{17}$ La tercera revolución: informática, microelectrónica y telemática, genómica, de la inteligencia artificial y robótica, comunicación satelital y celular, red electrónica y economías cada vez más abiertas y globalizadas, entre otras, propulsada desde mediados hasta finales del siglo XX ha marcado la transición del capitalismo industrial al capitalismo financiero y bancario en Europa y Norteamérica, sustituido legalidad por constitucionalidad e iniciado el largo camino hacia la democracia constitucional supranacional y cosmopolita -en tanto en México, desde finales de los ochenta en adelante, ha yuxtapuesto aquellos dos procesos, es decir la constitucionalización democrática nacional y su supra-estatalidad. ${ }^{18}$ La cuarta revolución industrial, apenas advertida en los años que corren, además de la sustitución del petróleo por nuevas fuentes de energía, tiene que ver, en síntesis, con la digitalización intensiva, expansión e interconectividad de las tecnologías de información y comunicación en red o el llamado "internet de las cosas y servicios". Esto aumentaría la flexibilización, calidad, eficiencia y asertividad en todo el ciclo económico y de e-gobierno y políticas públicas de fuente constitucional multidimensional y se mezcla riesgosamente con la economía informal y la del crimen. En México este proceso avanzará sobrepuesto a los procesos de las dos etapas previas y se apreciará refractado en una estructura socioeconómica, política y jurídica cada vez más compleja. Ella se definirá por su capacidad de acceso a economías en red, de manera desigual en diferentes regiones del país y con mayor vinculación y aceleración en los centros industriales y de servicios (de Puebla, Estado de México y Querétaro a El Bajío y el eje SaltilloMonterrey, o bien el eje Cancún y Riviera Maya, a manera de ilustración), desde luego en claves transnacional y globalizada en relación, especial pero no sólo exclusivamente, con los Estados Unidos de América.

17 Sobre este largo ciclo político mexicano, pre y post revolucionario, véase: Cárdenas García, Nicolás, "La formación de un régimen autoritario, 1880-1929", en Hernández Chávez, Alicia (coord), "México Contemporáneo 1808-2014. La Política", Fundación MAPFRE, FCE, El Colegio de México, México, 2015, pp.155-201, Tomo II.

18 Según lo he tratado de fundamentar en: Ávila Ortiz, Raúl, "Historia y Derecho en México: Reflexiones para su reinterpretación desde el constitucionalismo garantista", en Carbonell, Miguel, y Oscar Cruz Barney (Coords), "Historia y Constitución. Homenaje a José Luis Soberanes Fernández", UNAM-Instituto de Investigaciones Jurídicas, México, 2015, pp. 31-60. 
Esta obra forma parte del acervo de la Biblioteca Jurídica Virtual del Instituto de Investigaciones Jurídicas de la UNAM

c) En otro ámbito inter-conectado, en esos mismos veinticinco años el cambio en la estructura y las tendencias sociales es más que visible. ${ }^{19} \mathrm{En}$ breve, si las dos primeras revoluciones económicas provocaron la aparición y consolidación de las clases típicas de la industrialización: burguesía y proletariado o propietarios y no propietarios de los medios de producción, en las dos subsecuentes la globalización con énfasis neoliberal ha venido afectando la composición y concepciones mismas de aquellas. Así, por ejemplo, se ha formado una suerte de meta-burguesía global bancaria y financiera des-nacional, asociada con un complejo mediático y tecnológico-militar que desplaza y controla a la tradicional burguesía industrial y debilita al máximo todo actor y organización procedentes de las etapas previas, inadaptadas a las nuevas condiciones y contrarias a sus designios, incluidos Estados-Nación y sus clases sociales y políticas tradicionales, cuyos márgenes de maniobra soberanos o autónomos resultan reducidos al mínimo. ${ }^{20}$ Se trata de un nuevo imperialismo: tecnológico, financiero, bancario, electrónico y mediático que somete pueblos, naciones y estados enteros y que compite, esto hay que observarlo con cuidado, con las economías informal y del crimen transnacional en la conquista de territorios y personas, que es decir mercados, en franco detrimento de formas clásicas de autoridad y poder.

d) En particular, tales cambios han venido acompañados e impulsados por el cambio político, de regímenes cerrados a regímenes liberalizados o más abiertos y con tendencia a su constitucionalización y democratización. ${ }^{21}$ En este punto, si utilizamos la concepción de las tres o cuatro "olas y contra-olas democratizadoras" que van, la primera del siglo XIX (1828) a inicios del siglo XX (1926) en el Norte de Europa, Norteamérica y Australia; la segunda, de la mitad del siglo XX en adelante (1943 a 1962) en el centro de Europa y otras regiones; la tercera ola, que cubre de mediados de los setenta en adelante varios países del sur de Europa y América Latina, y la cuarta ola en partes del Mundo Árabe y el Norte de África en el más reciente decenio, podrá apreciarse su sincronía con las revoluciones científica, económica y social. Si en las dos primeras olas o revoluciones democráticas

19 Véase, por ejemplo, el ya clásico de Touraine, Alan, “¿Podremos vivir juntos? Iguales y diferentes", PPG Editorial, Madrid, 2003, o bien, Ramonet, Ignacio, "El quinto poder", en Le Monde Diplomatique, edición española, Octubre 2003, (Consultado en la Web el 21.03.16).

20 Véase: Piketty, Thomas, "El capital en el siglo XXI”, FCE, México, 2014.

21 En lo que sigue, véase: Huntington, Samuel, "La tercera ola. La democratización a finales del siglo XX", Madrid, Paidós Ibérica, 1994, y Carpizo, Jorge, "Concepto de democracia y sistema de gobierno en América Latina", UNAM-Instituto de Investigaciones Jurídicas, México, 2007. 
Esta obra forma parte del acervo de la Biblioteca Jurídica Virtual del Instituto de Investigaciones Jurídicas de la UNAM

la transición se orientó de viejos imperios y fuente del poder supra-terrenal a los estados-nación y fuente de poder popular canalizada vía democracia representativa, en las dos subsecuentes la transición se ha conjugado con el movimiento hacia la construcción de estados-región y repúblicas geográficas compartidas o multidimensionales, imbricados con regímenes jurídicos públicos y privados supra-nacionales flexibles y una reconstrucción conceptual consustancial a tales procesos. En México, cuyo estado-nación con base en la legalidad formal entró en consolidación después de la Segunda Guerra Mundial, la "tercera ola democratizadora" le ha conducido a implantar, luego de más de siete décadas de Estado de legalidad, una democracia constitucional en doble vertiente, nacional y supranacional regional que continúa penosa y contradictoriamente en proceso de reconfiguración en el contexto de la globalización neoliberal.

e) En lo que toca a la transición jurídica el cambio corresponde, según se ha atisbado líneas arriba, al tránsito del estado de legalidad al estado de constitucionalidad en tres momentos. ${ }^{22}$ Esto significa que la trayectoria poco más que bicentenaria del derecho europeo continental ha experimentado dos "revoluciones" o refundaciones y se enfrenta a una más a lo largo del más reciente cuarto de siglo. Por una parte, el paso del Derecho premoderno propio del estado autocrático feudal previo al siglo XIX al derecho moderno estatal y nacional propio del siglo XIX y primera mitad del siglo $\mathrm{XX}$. Y de aquí al derecho posmoderno posterior a la segunda mitad del siglo XX, al cual se suma el giro del jus-constitucionalismo supranacional, cosmopolita o multinivel de finales del siglo XX e inicios del siglo XXI. Por la otra, en el caso mexicano la historia del derecho permite afirmar que tal evolución ha venido teniendo lugar en su propio contexto al transitar del Derecho indiano jusnaturalista divino y racional que caracterizó la época pre-moderna virreinal (1521-1821) a su primera refundación como derecho del Estado legislativo (1821-1994) y de aquí a su segunda refundación en curso (1994 en adelante) en términos del Estado de Derecho constitucional, sólo que en su doble faceta: nacional y supranacional o multinivel y tendencialmente cosmopolita. En uno y otro casos, tales revoluciones y refundaciones científico jurídicas han alterado y continúan provocando impactos en la estructura y operación del Derecho pues el sistema jurídico ha pasado o se está transformando de nomoestático a nomodinámico y de allí a nomoes-

22 Para las líneas siguientes, véase, en particular: Ferrajoli, Luigi, "la democracia a través de los derechos. El constitucionalismo garantista como modelo teórico y como proyecto político", trad. de Perfecto Andrés Ibáñez, Trotta, Madrid, 2014; y Ávila Ortiz, Raúl, "Historia y Derecho en México...", Ob. Cit, Supra, Nota 17. 
Esta obra forma parte del acervo de la Biblioteca Jurídica Virtual del Instituto de Investigaciones Jurídicas de la UNAM

tático y nomodinámico; la norma de reconocimiento ha transitado de la verdad cristiana a los principios laicos de legalidad y constitucionalidad; las fuentes han cambiado de plurales, particularistas y dispersas a unificadas, generales y codificadas, y de aquí a una nueva pluralidad de fuentes en clave constitucional abierta; la relación entre derecho y moral se ha deslizado de una ecuación de identidad a otra de no identidad y de allí a su interacción vía principios combinando validez y democracia de derechos en las dimensiones formal y sustancial; el actor jurídico principal se ha desplazado del monarca al Congreso y el legislador, y de aquí al legislador, el administrador y el juez constitucional -así como a espacios extra-estatales y supranacionales; la filosofía jurídica ha mutado del jusnaturalismo de corte doctrinal y jurisprudencial al juspositivismo formalista y de aquí al neoconstitucionalismo, juspositivismo crítico o simplemente pos-positivismo; y el papel del jurista y la ciencia jurídica ha navegado del oficio de glosador y comentarista a descriptor y crítico del derecho legítimo e ilegítimo, y de aquí a una función crítica y proyectiva sustancial para prever y resolver contradicciones y llenar lagunas normativas. Más aún, se plantea el reto de aumentar su legitimidad y eficacia para atajar y superar problemas sociales y proteger la dignidad humana de los más débiles frente a los más fuertes en todas las esferas de la vida en común.

Bajo las premisas anteriores, en las siguientes dos partes de este trabajo se identificarán fortalezas, debilidades y retos del proceso de refundación contemporánea del Estado de Derecho en México, lo que está vinculado de manera íntima al cambio constitucional.

\section{AVANGES Y GONTRADICGIONES EN LA REFUNDACIÓN DEL ESTADO DE DERECHO: LEGITIMIDAD Y EFICACIA EN JUEGO}

Ya hace algunos años que la doctrina constitucional mexicana viene promoviendo y siguiendo el curso de la reconfiguración del Estado de Derecho en clave constitucional en México.

Entre los autores y textos más asiduos en el tema, procede aquí considerar, sólo como botones de muestra, a Miguel Carbonell, Pedro Salazar y Diego Valadés.

Ya Carbonell, ${ }^{23}$ a través de su abundante obra analítica y de divulgación apuntaba y sugería hace más de una década las reformas mínimas necesa-

23 Véase, tanto sólo como recurso ilustrativo: Carbonell, Miguel, "La Constitución de 1917 hoy: Cinco retos inmediatos", en Varios, "Hacia una nueva constitucionalidad", UNAM-Instituto de Investigaciones Jurídicas, México, 2000, pp. 33-52. 
Esta obra forma parte del acervo de la Biblioteca Jurídica Virtual del Instituto de Investigaciones Jurídicas de la UNAM

rias y la orientación que asumiría el proceso - digamos - reconstituyente mexicano, a la vez que llamaba a una renovación jurídica con énfasis en los derechos, la regulación de los poderes emergentes, diseños para la gobernabilidad democrática, una nueva interpretación constitucional y otra cultura constitucional que, entre otras cosas, refrescara y relevara los textos doctrinales mexicanos entonces predominantes.

Una década después, para Carbonell y Salazar ${ }^{24}$ la reforma en derechos humanos de junio de 2011, la cual modificó once artículos de la Constitución y emitió mandatos precisos en varios artículos transitorios, daba un paso crucial en la consolidación del constitucionalismo mexicano en favor de los derechos, a la vez tan rezagados y vulnerados en la realidad social. Más aún, en texto ulterior, Salazar sostuvo con entusiasmo que dicha reforma aceleraba la marcha mexicana hacia la democracia constitucional y comprometía a múltiples actores, operadores y sectores de la vida jurídica nacional para adaptarse al cambio.

Para Valadés, ${ }^{25}$ además del gran ausente en la Constitución mexicana: un eficaz sistema de control del poder, que lo ha llevado a proponer incluso la disciplina del Derecho procesal político en el marco “...de la República por venir: la República de las garantías", ${ }^{26}$ aquélla se enfrenta por momentos a procesos de des-constitucionalización e incluso al riesgo de regresiones graves al no fortalecer la institucionalidad democrática del Estado constitucional.

Sumado a lo anterior, cabe mencionar que el Instituto de Investigaciones Jurídicas ha promovido encuestas para medir y entender la cultura constitucional y la cultura jurídica de los mexicanos, que arrojan resultados a la vez decepcionantes pero alentadores por cuanto el interés mostrado, a contrapunto, de los ciudadanos por los temas públicos. ${ }^{27}$ De los bajos índices de conocimiento de la Constitución se infiere que el discurso y la práctica

24 Carbonell, Miguel y Pedro Salazar (coords), "La reforma constitucional de derechos humanos: Un nuevo paradigma", UNAM-Instituto de Investigaciones Jurídicas, México, 2011 .

25 Véase: Valadés, Diego, "El control del poder", UNAM-Instituto de Investigaciones Jurídicas, México, 1998; o bien "La parlamentarización de los sistemas presidenciales", UNAM-Instituto de Investigaciones Jurídicas, México, 2008.

26 Valadés, Diego, "La República en México", en Carbonell, Miguel y Oscar Cruz Barney (coords), "Historia y Constitución. Homenaje a José Luis Soberanes Fernández", UNAM-Instituto de Investigaciones Jurídicas, México, 2015, Tomo I, p. 508.

27 Recomendable leer, al menos, las respectivas conclusiones de los reportes "Segunda Encuesta Nacional de Cultura Constitucional. Legalidad, legitimidad de las instituciones y rediseño del Estado", UNAM, INE, México, 2011 y la colección "Los mexicanos vistos por sí mismos. Los grandes temas nacionales", en particular los volúmenes "Percepción del desem- 
Esta obra forma parte del acervo de la Biblioteca Jurídica Virtual del Instituto de Investigaciones Jurídicas de la UNAM

del constitucionalismo en México circunscribe su impacto a los operadores jurídicos principales y a los agentes interesados en la normatividad pero penetra muy débilmente en las capas medias y bajas de la sociedad. Esta limitante se erige en uno de los principales retos para el cambio constitucional y la transición jurídica mexicana en curso.

Desde mi perspectiva, el tema de fondo es el equilibrio indispensable entre legitimidad y eficacia de las instituciones renovadas o de nueva creación pues el Estado constitucional no tendría sentido alguno como construcción conceptual e institucional si no arraiga en las prácticas y las creencias políticas y sociales, y esto tiene menos probabilidad de ocurrir si las instituciones no ofrecen resultados eficaces y comprobables en favor de las personas.

En esa dinámica se observan nuevos avances y contradicciones añejas que registrar como son los siguientes:

En términos de avances, hay que hacer notar algunas de las reformas estructurales de 2013-2014 que fortalecen derechos y mecanismos de control y garantía, si bien otras tensan principios y afectan valores tradicionales. ${ }^{28}$ Me referiré de manera breve a las reformas en materia educativa, electoral, en transparencia, sociedad de la información y el conocimiento, combate a la corrupción (2015), y el Distrito Federal (2016).

Para empezar, la reforma educativa, cuyo eje es el artículo $3^{\circ}$, ha colocado en el centro del discurso y la reforma institucional los principios de calidad, inclusión y equidad, y ha construido las bases de un andamiaje normativo que re-centraliza diversas funciones en la materia, en particular en el tema de la profesionalización de la función docente. Si en el papel la reforma refleja una lógica impecable, en el contexto en que pretende ser aplicada se enfrenta a poderes fácticos, en particular la disidencia sindical en varios estados del sureste, sobre todo pero no sólo en Oaxaca, que defienden y atacan con una lógica diferente, menos técnica y más integral pero igualmente ideológica, detrás de la cual su mayoría, cada vez más debilitada, ya ni siquiera esconde intereses ilícitos que se niegan a declinar. Pero una cosa es reprobar los métodos de movilización, boicot y daños a terceros con que suelen operar los grupos de maestros disidentes y otra no atender los planteamientos críticos justificables que suelen enarbolar puesto que las limitaciones del sistema educativo mexicano, como tampoco sus fortalezas,

peño de las instituciones de seguridad y justicia" y "El déficit de la democracia en México", UNAM, México, 2015, (consultables ambos documentos en wrer.juridicas.unam.mx).

28 Véase, en este último sentido, Cárdenas Gracias, Jaime, "La Constitución de 1917 y las reformas estructurales", en Guerrero Galván, René y Carlos María Pelayo Moller (coords), "100 años de la Constitución Mexicana: De las garantías individuales a los derechos humanos”, UNAM-Instituto de Investigaciones Jurídicas, México, 2016, pp. 119-139. 
Esta obra forma parte del acervo de la Biblioteca Jurídica Virtual del Instituto de Investigaciones Jurídicas de la UNAM

se reducen a la idoneidad de los docentes o a los vicios de sus líderes, más que de sus bases sindicales. Si bien el sentido garantista de la reforma es nítido, su contradicción reside en presentar un parámetro nacional en un muestrario espacial y demográfico demasiado heterogéneo y desnivelado.

En otro sector del ordenamiento, la reforma electoral, centrada en el artículo 41 - el más extenso del texto constitucional - ha intentado fortalecer y homologar en todo el territorio nacional, en todo ámbito electivo, sea federal o local, la garantía ciudadana a elecciones libres y auténticas, consustancial a la democracia representativa, mediante la disminución del principio federalista y la redistribución de competencias en favor del Instituto Nacional Electoral, el cual sustituyó al Instituto Federal Electoral. Asimismo, se rediseñaron las formas de nombramiento de los integrantes de los organismos electorales locales con el objeto de reducir o evitar la presunta causa de la heterogeneidad local en índices de integridad y calidad democrática: los gobernadores. No obstante que la reforma establece como propósito la búsqueda explícita de elecciones más equitativas e imparciales, de la primera experiencia de implementación durante las elecciones locales y federales que tuvieron lugar en junio de 2014 se advierten fuertes tensiones relativas al nuevo modelo y la llamada a introducirle diversos ajustes pues no queda claro si se lograron dichos objetivos. Esto es particularmente notorio en ciertas contradicciones: una corresponde a las formas de nombramiento de fuente federal (INE para los consejeros electorales locales y Senado para los magistrados electorales locales) de los integrantes de organismos electorales pero presupuesto público de fuente local (vía Congreso local, que es decir vía Gobernador y, peor aún, Secretaría de Finanzas local), lo que tensa las relaciones interinstitucionales; otra tiene que ver con el modelo de financiamiento y fiscalización de recursos otorgados a los competidores, partidos políticos y candidatos independientes, que no ha producido sino un aumento en el costo de la democracia mexicana, es decir lo contrario a lo que la reforma se propuso; otro más se relaciona con el modelo de comunicación política que mantuvo rigideces notorias sobre las campañas electorales, la libertad de expresión y el debate público, además de su contribución invisible a prácticas informales y el costo de las elecciones; y una más, en fin, a la cuestionable proposición de que la equidad y la imparcialidad puede ser garantizada, al menos predominantemente, desde la normatividad y la intervención del Estado.

Otro tanto ha ocurrido con el derecho de acceso a la información pública y, en parte, el derecho a la protección de datos personales cuando se ha reorientado y rediseñado la arquitectura institucional fundada en el ciclo 
Esta obra forma parte del acervo de la Biblioteca Jurídica Virtual del Instituto de Investigaciones Jurídicas de la UNAM

2002-2007. Esta reforma, inspirada en el nuevo modelo electoral arriba referido, modificó el artículo $6^{\circ}$ constitucional para crear el Instituto Nacional de Transparencia, Acceso a la Información y Protección de Datos Personales, en sustitución del Instituto Federal de Acceso a la Información Pública (IFAI), y lo erigió como órgano garante rector de la transparencia y los mencionados derechos en el marco de un esquema de cooperación con los órganos garantes de las entidades federativas y otras instancias federales. Al mismo tiempo, la ampliación de los sujetos obligados, sobre todo a partidos políticos, sindicatos y universidades, y a toda persona que ejerza recursos públicos y ejerza actos de autoridad; la ampliación de sus respectivas obligaciones mínimas de transparencia, y, en general, el refuerzo de facultades, mecanismos, procedimientos, instrumentos y sanciones para evitar fraudes a la Constitución -según suele realizarse- vía legislación, administración o malas prácticas, debería redundar en la anhelada eficacia que la reforma pretende. No obstante ello, precisamente malas prácticas como la imprevisión presupuestal desde las constituciones o leyes generales o especiales respectivas, las incoherencias normativas cuya probabilidad es mayor en la medida de la extensión y detalle de los textos jurídicos, su correlación con otras piezas normativas (desde la legislación sobre archivos hasta la relativa a responsabilidades de los servidores públicos y las sanciones conducentes) o bien y quizás peor aún, la omisión o demora legislativa y/o administrativa más las operaciones interpretativas y la decisión judicial ya revelan debilidades de tan ambiciosa renovación de instituciones que podrían deslegitimarlas al no satisfacer las expectativas ciudadanas.

Importante, aunque ha pasado relativamente desapercibida en la doctrina, la reforma al propio artículo $6^{\circ}$ en términos del derecho de acceso a internet y la sociedad de la información y el conocimiento, así como los derechos de los usuarios de telecomunicaciones y de las audiencias, lo que refleja las condiciones tecnológicas progresivas e irreversibles en que transcurre la vida contemporánea. Nuevamente, en el papel la consagración de ese tipo de derechos de cuarta generación es más que justificable no menos que el esfuerzo institucional que se ha empeñado para concretarlo. Sin embargo, de nueva cuenta, la distancia entre los anhelos constitucionales formales y las condiciones reales para su ejercicio es enorme, lo que no debe, por supuesto, desmotivar su curso.

La reforma en combate a la corrupción, publicada en Diario Oficial de la Federación recién el 27 de mayo de 2015, avanza no sin titubeos en la complementación del sistema de transparencia y, sobre todo, en la consolidación de controles al desempeño de la función pública y la garantía del 
Esta obra forma parte del acervo de la Biblioteca Jurídica Virtual del Instituto de Investigaciones Jurídicas de la UNAM

buen gobierno mediante la creación de un Sistema Nacional Anticorrupción operado por un Comité Coordinador interinstitucional y con participación de la sociedad civil (artículo 113 constitucional), el fortalecimiento de la Auditoría Superior de la Federación, una Fiscalía Especializada en Combate a la Corrupción, un Tribunal de Justicia Administrativa y un nuevo régimen de responsabilidades de los servidores públicos. En este caso, la idoneidad de un diseño constitucional aun no probado en la práctica se enfrenta de entrada a la dilación en la construcción y ensamblado de las piezas legislativas secundarias para ponerlo en acto. Huelga decir que de la eficacia del modelo que debería ser integral de rendición de cuentas depende si bien no el entero sí que una parte esencial de la operación, legitimidad y eficacia del Estado constitucional en reconstrucción.

En el caso de la reforma al Distrito Federal, que se ha convertido desde el 29 de enero de 2016, fecha de publicación del decreto reformista en el Diario Oficial de la Federación, en el Estado de la Ciudad de México, es claro que los derechos de sus habitantes se fortalecen al sustituir las Delegaciones por demarcaciones territoriales gobernadas por alcaldías integradas por un alcalde y concejos con representación plural, dotada de una Constitución propia diseñada y aprobada por una Asamblea Constituyente prevista en el propio artículo 122 reformado, es decir, mediante un mecanismo sui generis, que ha recibido críticas agudas, ${ }^{29}$ pero no deja, desde mi perspectiva, de significar un ensayo valioso e ilustrativo para el futuro.

Ahora bien, por encima de tales avances reformistas, me permito apuntar una serie de debilidades globales del proceso constitucional mexicano. Tres en particular: la persistencia de lógicas históricas constitucionales yuxtapuestas, las tensiones entre constitución formal y constitución material intra-nacional, y las tensiones entre la constitución formal y material nacional frente a la arquitectura constitucional supranacional o lo que se denomina, según se vio líneas arriba: gobernanza multidimensional, o bien un nuevo modelo de constitucionalidad en la globalidad.

En primer término, en el texto constitucional conviven en realidad cuatro lógicas constitucionales: la de 1857, 1917, el largo ciclo reformista de corte estatista a partir de 1933 y, finalmente, el giro liberal contradictorio que va de Miguel de la Madrid en los años ochenta a las reformas impulsadas por Felipe Calderón y Enrique Peña Nieto. Al respecto, baste recordar que el propio Valadés ha hecho notar en varias ocasiones, lo que ha detalla-

29 Véase, Salazar, Pedro, "La Asamblea Constituyente: un poder constituido", en El Universal, Opinión, 26.02.2016. 
Esta obra forma parte del acervo de la Biblioteca Jurídica Virtual del Instituto de Investigaciones Jurídicas de la UNAM

do otro constitucionalista en una obra reciente, ${ }^{30}$ los desfases en el lenguaje y la sistemática constitucional, detrás de lo cual pervive el grave problema de la falta de sincronía en la acción comunicativa, la comprensión, interpretación y eficacia de los textos con graves daños y perjuicios a la cultura jurídica.

En segunda instancia, pese al intenso ritmo de reformas constitucionales y legales, y no obstante que la hegemonía partidaria del Presidente de la República desapareció desde 1997 en adelante, con lo cual se suprimieron prácticas políticas que favorecían un modelo hiper-presidencial de gobierno, a partir de la alternancia ha quedado desnuda, por un lado, la debilidad orgánica formal del Presidente mexicano frente al poder formal y real de los gobernadores, partidos y Congreso federal, y, por el otro, ante antiguos y nuevos poderes fácticos lícitos e ilícitos. En todos estos casos, pero sobre todo en relación con gobernadores y poderes locales, partidos y Congreso, el formato federal mexicano aguarda importantes reajustes, más allá de la coyuntural reconcentración de poder vía práctica política. ${ }^{31}$ La creación de la Conferencia Nacional de Gobernadores (CONAGO) en 2002 debe ser entendida como un ejemplo típico de mutación constitucional que alteró los equilibrios políticos y que, salvo que desaparezca en el futuro cercano tras la reconcentración de poder y autoridad en curso a partir del regreso del PRI al Poder Ejecutivo Federal en 2012, debería ser formalizada en la Constitución en tanto parte de una nueva correlación de fuerzas dentro del federalismo. Otro rediseño está pendiente hacia adentro de las entidades federativas en donde prevalecen las dinámicas extrajurídicas que la mutación constitucional post-alternancia alentó en beneficio de gobernadores sin controles institucionales y sociales efectivos, pues hasta el voto ciudadano y los nuevos mecanismos de transparencia y rendición de cuentas lucen insuficientes en contextos específicos. ${ }^{32}$

En tercer lugar, y según ya se ha mencionado en el presente trabajo, la debilidad consistente en que tanto estructuras constitucionales como conceptos para entenderlas, comprenderlas y re-expresarlas se encuentran en

30 Soberanes Díez, José María, "Análisis formal de las reformas constitucionales", UNAM-Instituto de Investigaciones Jurídicas, CONACYT, México, 2015.

31 Véase, de reciente aparición: Barceló Rojas, Daniel A., "Teoría del federalismo y del Derecho Constitucional Estatal Mexicano", UNAM-Instituto de Investigaciones Jurídicas, México, 2016.

32 Véase, para una ilustración práctica de este problema: Flores Cruz, Cipriano, "Gobernar Oaxaca: Bonapartismo, parroquialismo, mitos y realidad política en un Estado del sur de México”, Edición de Raúl Ávila Ortiz y Prólogo de Carlos Ramírez, Plaza y Valdés, México, 2015. 
Esta obra forma parte del acervo de la Biblioteca Jurídica Virtual del Instituto de Investigaciones Jurídicas de la UNAM

transformación en medio del cambio de época, que es decir en el contexto de las transiciones científica, económica, social, política y jurídica referidas en la segunda parte de este documento, no hace sino aumentar la complejidad y la incertidumbre de los procesos constitucionales contemporáneos. El esfuerzo teórico, doctrinal e institucional avanza, aunque por momentos no con la celeridad debida.

\section{DESAFÍOS PERSISTENTES Y RETOS URGENTES}

$\mathrm{Y}$ es que, hasta cierto punto, me parece que asiste la razón a Cáceres Nieto en el sentido de que estructura y funciones de sistemas jurídicos contemporáneos en plena transformación tornan inútil pretender describir el fenómeno en términos convencionales pues, habría que conceder lógicamente, la propia teoría del cambio constitucional estaría mutando en el contexto de la gobernanza global. No obstante, estimo prudente intentar ubicar un haz de desafíos nada nuevos y otros que se han tornado urgentes y que asedian la dinámica reformista y al propio modelo de constitucionalidad mexicano en el umbral, por cierto, de la conmemoración del centenario de la Constitución de 1917. Los hay en el ámbito de la ciencia, el estado y la sociedad nacionales, y los hay entre varios agentes en el espacio supranacional. Por ahora sólo los dejaré enunciados en pocas palabras.

En el ámbito nacional, todos los operadores jurídicos y políticos, de todos los sectores - público, privado y social — están vinculados y, a la vez, limitados y comprometidas normativamente con los valores y principios que emanan del artículo $1^{\circ}$ constitucional. En particular, dado que el Estado constitucional, tanto su representación epistémica cuanto su encarnación institucional y normativa, y, mejor aún, su concreción efectiva, dependen en buena medida de su arraigo en la conciencia y la participación social y ciudadana, entonces sigue siendo urgente, como lo ha sido desde los orígenes del constitucionalismo mexicano, definir y poner en práctica una pedagogía jurídica inteligente y proactiva en términos de política de Estado. La extraestatalidad de las nuevas dinámicas jurídicas exigen, por ende, una actitud y conducta mucho más incisiva en la materia, lo mismo por parte de empresas y consorcios académico, científicos y comunitarios, de sindicatos y organizaciones civiles, ya sin mencionar a los medios de comunicación tradicionales y las redes sociales.

En el ámbito supra-nacional, el desplazamiento de poder extra-territorial que entraña la gobernanza global supone, simultáneamente, la suscripción y puesta en acto de compromisos específicos en favor de los derechos 
Esta obra forma parte del acervo de la Biblioteca Jurídica Virtual del Instituto de Investigaciones Jurídicas de la UNAM

por parte de los diversos agentes internacionales que están concurriendo a la compleja interacción en curso. Sin embargo, ello debería tener lugar sin que tales agentes, con frecuencia no ajenos a intereses extra-institucionales, incurrieran en la tentación de lesionar injustificadamente, con motivo de la defensa y protección de derechos fundamentales, núcleos de competencias reservadas desde el propio bloque de constitucionalidad a los Estados nacionales, y, a la vez, sin que éstos justifiquen sus malas prácticas en tales núcleos competenciales.

\section{CONCLUSIONES}

En este trabajo he tratado de plasmar una serie de apreciaciones y consideraciones en torno a la teoría del cambio constitucional y su práctica en México con relación a la transición jurídica contemporánea que se experimenta en el país y que se conoce como transición del Estado de legalidad al Estado de Constitucionalidad.

Para hacerlo, he iniciado con una referencia a la teoría conforme a ciertos indicadores procedentes de la literatura profesional disponible y destacado que si bien se ha privilegiado la reforma al texto escrito no debe desconsiderarse la función interpretativa judicial constitucional que ha reescrito dicho texto en varios sentidos de manera abundante y sustancial en ese mismo periodo.

He colocado el cambio constitucional y la transición jurídica mexicana contemporánea en el contexto amplificado de las transiciones científicoepistémica, económica, social y jurídica que se registran cíclicamente en el mundo occidental moderno con el propósito de hacer notar que el cambio de paradigma científico-epistémico impulsa cambios sistémicos tanto como éstos inciden en los cambios paradigmáticos.

Me he referido a una serie de reformas, conocidas en México como "reformas estructurales", que desde por lo menos 2011 y, en particular en los años 2013 a 2016, incluso, han incentivado la transición jurídica hacia el Estado de Constitucionalidad, desde luego de manera compleja, discutida y hasta contradictoria.

He apuntado, finalmente, algunos de los retos que enfrenta la refundación en curso del Estado de Derecho en México, en particular en torno a la transformación de la cultura jurídica constitucional de los mexicanos, en el umbral de la celebración del centenario de la Constitución de 1917. Este acontecimiento, que ahora es sincrónico con el ensayo re-constituyente en curso de la Ciudad de México, también merecería un ejercicio institucional, 
Esta obra forma parte del acervo de la Biblioteca Jurídica Virtual del Instituto de Investigaciones Jurídicas de la UNAM

al menos como el que propone el Instituto de Investigaciones Jurídicas de la UNAM en términos de reordenamiento y consolidación del texto escrito de la Constitución, a efecto de encarar fortalecidos aquellos retos apelando a una sociedad afligida por antiguas y nuevas plagas. Una sociedad urgida de dinámicas de reconstitución de su propia confianza, identidad y acceso a un mejor futuro, aun cuando éste no se asemeje más al futuro por el que lucharon quienes fundaron, reformaron y revolucionaron el México moderno que, virtud a la globalización, ya no podrá ni deberá ser como entonces fue. 
Esta obra forma parte del acervo de la Biblioteca Jurídica Virtual del Instituto de Investigaciones Jurídicas de la UNAM

\title{
MITOS Y PARADIGMAS SOBRE LA GONSTITUCIÓN MEXICANA Y SU REFORMA. BREVE REFLEXIÓN EN TORNO AL PRÓXIMO GENTENARIO Y ANTE LA NEGESIDAD DE UNA NUEVA GONSTITUGIONALIDAD.
}

\author{
José Luis Gaballero OCHOA*
}

\begin{abstract}
SuMARIO: I. Nota introductoria. II. Mitos sobre la reforma a la Constitución Política de los Estados Unidos Mexicanos. III. Consideración sobre la propuesta sustentada por el Instituto de Investigaciones furídicas de la UNAM. IV. Conclusión. Nuevos paradigmas que tendrían que plantearnos una nueva constitucionalidad.
\end{abstract}

\section{NOTA INTRODUCTORIA ${ }^{1}$}

Ante el Centenario de la Constitución Política de los Estados Unidos Mexicanos (en adelante CPEUM o la Constitución), y en el contexto de lo que se está perfilando en México, mi propuesta puntual tiene como cometido analizar algunos de los mitos que giran en torno a la reforma constitucional y sus implicaciones. De igual forma, hago un breve comentario sobre la propuesta coordinada por los Doctores Héctor Fix-Fierro y Diego Valadés, "Constitución Política de los Estados Unidos Mexicanos. Texto reordenado y consolidado. Anteproyecto" y que ha sido asumida por el Instituto de Investigaciones Jurídicas de la Universidad Nacional Autónoma de México (o indistintamente, IIJ-UNAM) como un proyecto de resignificación del texto constitucional

* Académico - investigador en la Universidad Iberoamericana, Ciudad de México. Agradezco a Cuba Flores Aranda y a Daniel Álvarez Toledo sus puntos de vista sobre este trabajo.

1 En este texto desarrollo la ponencia presentada el día 5 de febrero de 2016, en el marco del VII Congreso Nacional de Derecho Constitucional en la ciudad de San Luis Potosí, coordinado por los Doctores José Ma. Serna de la Garza e Isidro de los Santos Olivo. 
Esta obra forma parte del acervo de la Biblioteca Jurídica Virtual del Instituto de Investigaciones Jurídicas de la UNAM

en razón de su "extensión, desorden, asistematicidad y descuido de técnica jurídica." 2

Básicamente su idea es, sin cambiar los contenidos, llevar algunas partes más propias de otro tipo de normas que de una Constitución a una Ley de Desarrollo Constitucional - dando así carta de naturalización a las también llamadas "leyes orgánicas" - y reordenar algunos contenidos en otras secciones del texto.

Finalmente, hago un breve recuento de los paradigmas que, a mi juicio, deben replantearse en un ejercicio más amplio de una nueva constitucionalidad y que deberían cruzar el eje de discusión en torno al Centenario; más allá de la pertinencia o no de adoptar un nuevo texto, tema que desde al menos un par de décadas se discute entre nosotros, ya en la academia o en diversos foros públicos.

\section{Mitos SOBRE LA REFORMA A LA CONSTITUGiÓN Política de los Estados Unidos Mexicanos}

Las constituciones nacen con una marcada aspiración de estabilidad, pero con el tiempo las reglas, principios y valores que encarnan pueden tornarse obsoletos; es una gran paradoja que se debe solventar, mayormente por vía de interpretación, como garantía ordinaria de viabilidad constitucional; y, al mismo tiempo, deben transitar a la postre, las reformas que se requieran cuando no sea posible el ajuste interpretativo - la garantía extraordinaria. ${ }^{3}$ Por ello es necesario prever mecanismos que permitan su adecuación a la realidad social del momento, y con eso garanticen su pretensión de ser un texto perenne, como en el caso mexicano establece el artículo 136 de la CPEUM. ${ }^{4}$ Sin embargo, nuestro país alberga una serie de construcciones epistemológicas que pretenden condicionar la realidad a un supuesto ima-

2 Fix-Fierro, Hector y Valadés, Diego (Coords.), Constitución Politica de los Estados Unidos Mexicanos. Texto reordenado y consolidado. Anteproyecto, IIJ-UNAM, México, 2016, p. 1.

3 Tomo las expresiones "garantía ordinaria" y "garantía extraordinaria" de Javier Pérez Royo, en su magnífico trabajo "Del derecho político al derecho constitucional: las garantías constitucionales", Revista del Centro de Estudios Constitucionales, número 12, Madrid, Centro de Estudios Constitucionales, mayo - agosto de 1992.

4 "Esta Constitución no perderá su fuerza y vigor, aún y cuando por alguna rebelión se interrumpa su observancia. En caso de que por cualquier trastorno público, se establezca un gobierno contrario a los principios que ella sanciona, tan luego como el pueblo recobre su libertad, se restablecerá su observancia, y con arreglo a ella y a las leyes que en su virtud se hubieren expedido, serán juzgados, así los que hubieren figurado en el gobierno emanado de la rebelión, como los que hubieren cooperado a ésta" 
Esta obra forma parte del acervo de la Biblioteca Jurídica Virtual del Instituto de Investigaciones Jurídicas de la UNAM

ginario pacífico en torno a la reforma constitucional ${ }^{5}$ y que se han fortalecido como "mitos", porque le atribuyen a este procedimiento cualidades o excelencias ${ }^{6}$ de las que carece.

Un mito es el que sostiene que al "elevar" (así, empleando ese verbo) a rango constitucional las diferentes previsiones normativas, mágicamente éstas adquieren un estatuto de pureza ontológica, vacunado de cualquier afectación de ambigüedad, incoherencia, desde luego, inconstitucionalidad con respecto a otras previsiones presentes en el texto. Además, soporta la idea de que es necesario reformar la Constitución continuamente, incluso con cuestiones que bien podrían encontrarse en otro tipo de normas, pero ante la "debilidad" que ofrece el resto de ámbitos normativos en relación con el estrato constitucional.

Es una especie de Constitución fetiche, que manda el mensaje de que dicha elevación a rango constitucional genera un círculo absolutamente aséptico en torno al contenido normativo. Un ejemplo interesante y, al mismo tiempo, desastroso es haber "elevado" a rango constitucional la institución del arraigo en 2008, cuando desde 2005 la Suprema Corte de Justicia de la Nación (en adelante SCJN o Suprema Corte) había determinado su inconstitucionalidad.

Emerge también el mito relativo al mismo proceso de reforma constitucional, como solvente en sí mismo, cuando en el artículo 135 de la CPEUM se encuentran algunas lagunas; por ejemplo, si efectivamente o no, sería posible modificar cualquier precepto constitucional e introducir cuestiones regresivas, especialmente en materia de derechos humanos; o bien, la cabal dimensión de la participación de las entidades federativas, y la forma de efectuar el computo de sus votos. Otro tema pasa por la conformación o no de un órgano ad hoc para llevar a cabo la tarea de la reforma; ${ }^{7} \mathrm{y}$ así, incluso, la imposibilidad real de controvertir la aplicación de esta disposición, que es muy amplia y afectada de alguna vaguedad, según mi punto de vista.

5 Como seguramente sucede en la mayoría de los estados constitucionales; véase por ejemplo la dificultad de la reforma constitucional en España, por cuestiones del propio diseños de la Constitución de 1978, y también por las cuestiones políticas que debe transitar, especialmente cuando se trata de una reforma por medio del procedimiento agravado.

6 Según la definición de "mito" de la RAE, http://dle.rae.es/?id=PQM1Wus $\mid$ PQMf1C3

7 El texto establece: "La presente Constitución puede ser adicionada o reformada. Para que las adiciones o reformas lleguen a ser parte de la misma, se requiere que el Congreso de la Unión, por el voto de las dos terceras partes de los individuos presentes, acuerden las reformas o adiciones, y que éstas sean aprobadas por la mayoría de las legislaturas de los Estados y de la Ciudad de México". 
Esta obra forma parte del acervo de la Biblioteca Jurídica Virtual del Instituto de Investigaciones Jurídicas de la UNAM

Otro mito, es el de la imposibilidad de cuestionar la constitucionalidad de las reformas constitucionales por cualquier vía. ${ }^{8}$ Las razones que la Suprema Corte ha dado para no entrar a conocer de fondo - incluso cuestiones implicadas en el mismo procedimiento de reforma constitucional- se dirigen a la idea de que el Órgano Reformador de la Constitución no tuvo la intención de que las modificaciones a la Constitución o su proceso de creación, puedan ser sometidas a un control de constitucionalidad, pues para ello se estableció el procedimiento especial que se regula en el artículo 135.

Sobre estos tres mitos, indefectiblemente conectados, reflexiono brevemente.

\section{El mito sobre la necesidad de la reforma constitucional: la Constitución fetiche}

En nuestro país subsisten una serie de lugares comunes sobre el sentido de la construcción del texto constitucional y sobre la proclividad de acudir indiscriminadamente al procedimiento de reforma constitucional, que si no se replantean, no nos permitirán situarnos en un estado de cosas distinto ante la reflexión que debe impulsar el Centenario.

Me parece que un mito se afinca en la rigidez de la Constitución que, paradójicamente, conforma un imaginario bajo el cual se protege la hiperactividad de la reforma constitucional, e intenta exorcizar cualquier sospecha de un déficit del texto profusamente modificado, en una numeralia que nos asombra cada día. ${ }^{9}$ Es decir, como tenemos un procedimiento rígido, entonces no importa las veces que se pueda emplear. En realidad, es una cuestión que patentiza la fragilidad de la actualización del texto por vía de interpretación y la adecuación constitucional cotidiana en legislación, política pública, decisiones judiciales.

Esta especie de garantía en el procedimiento agravado, solventa la idea de que todo lo que se incorpora a la CPEUM la actualiza, la vigoriza, adquiere posibilidades de producir cambios, y ha permitido transitar la enorme cantidad de reformas sin cuestionar una problemática más de fondo que

8 A lo largo de los años, la SCJN se ha pronunciado al respecto, al señalar que ni el amparo, ni la controversia constitucional, ni la acción de inconstitucionalidad son vías idóneas para controvertir una reforma.

9 En sus 99 años de existencia, se han emitido 642 reformas o adiciones. Las últimas dos reformas son: el Decreto de desindexación del salario mínimo, publicado en el Diario Oficial de la Federación (D.O.F.) el 27 de enero de 2016; y el Decreto de Reforma Política de la Ciudad de México, publicado en el D.O.F., el día 29 de enero de 2016. 
Esta obra forma parte del acervo de la Biblioteca Jurídica Virtual del Instituto de Investigaciones Jurídicas de la UNAM

se encuentra detrás: la debilidad misma del texto, que se integra por disposiciones de distinta naturaleza e índole no propias de una Constitución; las suspicacias políticas y la desconfianza de poder lograr acuerdos, elevando el costo a nivel constitucional de lo que es posible manipular en la legislación que no se vota por mayoría reforzada; ${ }^{10}$ la debilidad del Poder Judicial, que no ha sido del todo eficaz en la adecuación del texto, a través de la interpretación; de las mismas entidades federativas, que han aprobado sin mayor cuestionamiento todo lo que ha sido reformado o adicionado previamente por el Congreso de la Unión.

\section{El mito sobre la construcción de la reforma constitucional:}

¿Quién lo hace? ¿Cómo lo hace?

De la mano de la idea de la garantía del procedimiento reforzado, como garantía del contenido, va también la idea de las capacidades del Órgano Reformador de la Constitución (el llamado "constituyente permanente"), que se conformaría como un órgano ad hoc, no susceptible de revisión.

La ruta interpretativa de la Suprema Corte en relación con la imposibilidad absoluta para ejercer un control mínimo al Órgano Reformador de la Constitución, tuvo su máxima expresión con la resolución de la Controversia Constitucional 82/2001, presentada por el Ayuntamiento de San Pedro Quiatoní, Oaxaca, ante la reforma constitucional en materia indígena, de 14 de agosto de 2001. En una de las tesis de jurisprudencia emitidas, la SCJN señaló que la función realizada por el Congreso de la Unión y las legislatura de las entidades federativas, no se hace en "su carácter aislado de órganos ordinarios constituidos, sino en el extraordinario de Órgano Reformador de la Constitución, realizando una función de carácter exclusivamente constitucional, no equiparable a ninguno de los ordenes jurídicos parciales"11 Más adelante, al referir a la imposibilidad de ejercer algún control a la tarea de este órgano, la SCJN señaló que tal impedimento se debe a que "en la conformación compleja del órgano y en la atribución constitucional de su función, se encuentra su propia garantía." 12

10 Como lo ha señalado Pedro Salazar, "Sobre la democracia constitucional en México (pistas para arqueólogos)", Política y derecho. Derechos y garantías. Cinco ensayos latinoamericanos, México, Fontamara, 2013, p. 99

11 Se trata de la Tesis P./J. 39/2002, publicada en el Semanario fudicial de la Federación y su Gaceta, t. XVI, septiembre de 2002, p. 1136, de rubro: "PROCEDIMIENTO DE REFORMAS Y ADICIONES A LA CONSTITUGIÓN FEDERAL. NO ES SUSCEPTIBLE DE CONTROL JURISDICGIONAL".

12 Idem. 
Esta obra forma parte del acervo de la Biblioteca Jurídica Virtual del Instituto de Investigaciones Jurídicas de la UNAM

Estas razones, que permiten la abdicación de la SCJN para revisar el procedimiento y el producto de la reforma, están pues en la conformación y en la atribución del órgano. Lo enormemente preocupante, es que más allá de la "conformación compleja", nos encontramos necesariamente frente a un órgano constituido que se sustrae automáticamente de uno de los engranajes del principio de la división del poder: el control.

La "conformación compleja" también ha permitido transitar cualquier cuestionamiento que se haga al Órgano Reformador de la Constitución incluso, como ya señalaba, las ambigüedades que se desprenden del artículo 135 de la CPEUM y de su práctica cotidiana, como es el concluir el computo de las votaciones de las entidades federativas cuando se obtiene la mayoría de votos en el sentido aprobatorio, sin esperar el pronunciamiento del resto de las legislaturas. En la misma Controversia Constitucional 82/2001, el Ayuntamiento de San Pedro Quiantoní argumentó que el proceso a través del cual había derivado esa reforma constitucional era irregular, y que ello obedecía a que la Comisión Permanente, al momento de realizar el cómputo de las votaciones emitidas por las Legislaturas de los estados, no había tenido a la vista su totalidad, pues le había bastado con la aprobación de las 17 entidades suficientes para obtener la mayoría. Para abonar a los silencios de la disposición, ahora se suma cómo proceder en caso de empate de las entidades federativas en la aprobación de la reforma constitucional, porque nos encontramos ya frente a las 32 integrantes, habiéndose incluido a la Ciudad de México, mediante la reforma constitucional de 29 de enero de 2016.

\section{El mito sobre el control de la reforma constitucional}

Otro mito, férreo, ha sido la imposibilidad de cuestionar el trabajo del Órgano Reformador de la Constitución, que además se ha acompañado de criterios inconsistentes de la Suprema Corte.

Con independencia del antecedente más remoto e importante en las últimas décadas, el decreto de reformas constitucionales de 17 de noviembre de 1982, que reformó el artículo 28, quinto párrafo de la CPEUM, sobre el monopolio del Estado en materia de banca y crédito, y que fue impugnado por vía de amparo, ${ }^{13}$ la SCJN conoció del amparo en revisión 1334/98 (el

13 Una importante reflexión sobre el tema y en particular sobre este caso en González Schmal, Raúl, “¿Una reforma a la Constitución puede ser inconstitucional?”, Memoria del Simposio Internacional, El significado actual de la Constitución, México, IIJ-UNAM, 1998, p. 320 
Esta obra forma parte del acervo de la Biblioteca Jurídica Virtual del Instituto de Investigaciones Jurídicas de la UNAM

llamado "Caso Camacho Solís") ${ }^{14}$ A partir de este asunto, la Suprema Corte entendió que el ejercicio de la reforma constitucional debía respetar el contenido del artículo 135 de la CPEUM, reconociendo al Órgano Reformador de la Constitución como poder constituido subordinado en todo caso al mandato que, por lo que respecta a los requisitos de su funcionamiento, contiene el texto constitucional.

En este sentido, la idea de concebir al poder que realiza la reforma - más allá de su necesaria sofisticación- como un poder constituido, es central para el tema del control. A contrario sensu, evidentemente el concepto de "constituyente permanente" refuerza el imaginario de la subsistencia de un órgano primario no sujeto a ningún tipo de supervisión lo que, como ya señalaba, pugna con las dimensiones del ejercicio del poder en un Estado constitucional. ${ }^{15}$ Esta decisión de la Suprema Corte supuso, en su momento, una transformación de máxima relevancia, pues a partir de los criterios surgidos en la resolución de este asunto, era posible interponer el juicio de amparo en contra de la reforma constitucional que se considerase que no había cumplido con los requisitos de carácter procedimental. ${ }^{16}$

No obstante lo anterior, el momento más alto de la abdicación de la Suprema Corte en su tarea de control de los órganos del poder público, vino con la Controversia Constitucional 82/2001 ya citada. El 6 de septiembre de 2002, la SGJN determinó que la institución procesal de la controversia constitucional no era un medio idóneo para controvertir el proceso que da origen a una reforma constitucional, así como la imposibilidad absoluta de

14 Sobre el particular también reflexiona Raúl González Schmal, Ibidem, pp. 321 - 322. De igual forma, Miguel Carbonell, "Reforma constitucional: límites y controles", en Astudillo, César y Córdova Vianello, Lorenzo (Coords), Reforma y control de la Constitución, México, IIJ - UNAM, 2011, pp. 33 - 36.

15 En este mismo sentido, Miguel Carbonell califica esta posición como "peligrosa idea"; no habría tal reiteración de un "poder constituyente" con calidad de permanente. Ibidem, p. 34.

16 Ver Tesis P. LXII/99, publicada en el Semanario Fudicial de la Federación y su Gaceta, Novena Época, Pleno, t. X, septiembre de 1999, p. 11, de rubro: "REFORMA CONSTITUCIONAL, AMPARO CONTRA SU PROGESO DE CREACIÓN. EL INTERÉS JURÍDICO DERIVA DE LA AFECTACIÓN QUE PRODUCE, EN LA ESFERA DE DERECHOS DEL QUEJOSO, EL CONTENIDO DE LOS PRECEPTOS MODIFICADOS". Tesis P. LXVI/99, Ibidem, p. 12, de rubro: "REFORMA CONSTITUCIONAL, AMPARO CONTRA SU PROGESO DE GREACIÓN. PARA SU PROGEDENCIA NO SE REQUIERE DE LA EXPRESIÓN, EN EXCLUSIVA, DE VIOLACIONES RELACIONADAS CON EL ARTículo 135 DE LA CONSTITUCiÓN". Tesis P. LXIII/99, Ibídem, p. 13, de rubro: "REFORMA CONSTITUCIONAL, AMPARO CONTRA SU PROCESO DE CREACIÓN. PROCEDE POR VIOLACIÓN A DERECHOS POLÍTICOS ASOCIADOS CON GARANTÍAS INDIVIDUALES". 
Esta obra forma parte del acervo de la Biblioteca Jurídica Virtual del Instituto de Investigaciones Jurídicas de la UNAM

revisar el producto de las reformas o adiciones, ante la garantía que ofrece la conformación y atribución del Órgano Reformador de la Constitución. ${ }^{17}$

Este criterio sobre la improcedencia absoluta para revisar reformas constitucionales, tuvo un punto de inflexión, debido seguramente a la resolución del Caso Castañeda Gutman contra México por la Corte Interamericana de Derechos Humanos, el 6 de agosto de 2008. ${ }^{18}$ La condena a nuestro país devino por una violación al artículo 25 de la Convención Americana sobre Derechos Humanos, ${ }^{19}$ porque la víctima no contó con un recurso judicial efectivo para impugnar la supuesta inconstitucionalidad de la prohibición de registrar candidaturas independientes a los cargos de elección popular. De esta manera, la Corte Interamericana estimó que era necesario que cualquier violación a derechos humanos contara con un recurso judicial efectivo para hacerla valer ante los tribunales. ${ }^{20}$ De tal suerte que, la Suprema Corte se hizo cargo de esta tarea y consideró que la improcedencia absoluta para revisar el procedimiento de la reforma constitucional, era un resquicio de falta de acceso a la justicia, que contravenía el estándar marcado por la Corte Interamericana. ${ }^{21}$

Así, en el Amparo en Revisión 186/2008, resuelto el 29 de septiembre de 2008, la Suprema Corte modificó su postura para establecer de nueva cuenta que a través del juicio de amparo sí es posible impugnar el procedi-

17 Fueron dos tesis las que se emitieron a partir de este expediente. Tesis P./J. 40/2002, publicada en elSemanario Fudicial de la Federación y su Gaceta,Novena Época, Pleno,t. XVI, septiembre de 2002, p. 997, de rubro: "CONTROVERSIA CONSTITUCIONAL. ES IMPROCEDENTE PARA IMPUGNAR EL PROCEDIMIENTO DE REFORMAS Y ADICIONES A LA CONSTITUCIÓN FEDERAL". Tesis: P./J. 39/2002, Ibidem, p. 1136: "PrOCEDIMIENTO DE REFORMAS Y ADICIONES A LA CONSTITUCIÓN FEDERAL. NO ES SUSCEPTIBLE DE CONTROL JURISDICGIONAL".

18 Excepciones Preliminares, Fondo, Reparaciones y Costas. Sentencia de 6 de agosto de 2008. Serie C, número 184.

19 "Protección Judicial.

1. Toda persona tiene derecho a un recurso sencillo y rápido o a cualquier otro recurso efectivo ante los jueces o tribunales competentes, que la ampare contra actos que violen sus derechos fundamentales reconocidos por la Constitución, la ley o la presente convención, aún cuando tal violación sea cometida por personas que actúen en ejercicio de sus funciones oficiales.

2. Los Estados partes se comprometen:

a) a garantizar que la autoridad competente prevista por el sistema legal del Estado decidirá sobre los derechos de toda persona que interponga tal recurso;

b) a desarrollar las posibilidades de recurso judicial, y

c) a garantizar el cumplimiento por las autoridades competentes de toda decisión en que se haya estimado procedente el recurso."

20 párr. 92.

21 Véase la sesión pública del Pleno del lunes 29 de septiembre de 2008. Consultable en: http://wrww.scjn.gob.mx 
Esta obra forma parte del acervo de la Biblioteca Jurídica Virtual del Instituto de Investigaciones Jurídicas de la UNAM

miento de reforma constitucional. ${ }^{22}$ En esa ocasión la Corte dijo que cuando el Congreso de la Unión y las Legislaturas Locales actúan en su carácter de Órgano Reformador de la Constitución deben respetar las normas del procedimiento de reforma contenidas en el artículo 135 constitucional, lo cual implica que es jurídicamente posible que dicho poder emita alguna reforma con desapego a tal procedimiento. Cuando esto sucede y algún particular promueve un juicio de amparo contra dicho acto, los jueces de distrito no pueden, sin más, considerar que en esos casos se actualiza de manera manifiesta e indudable la improcedencia de este juicio. De cualquier forma, la Suprema Corte consideró que no había materia para conocer el fondo del asunto. ${ }^{23}$

Después de este adelanto en los criterios, el debate volvió a la SCJN el 28 de abril y el 2 de mayo de 2016, cuando el Tribunal Pleno resolvió dos casos en los que se enfrentó a una temática similar. Al resolver los recursos de reclamación 8/2016 y 9/2016, la Suprema Corte abordó el problema jurídico consistente en determinar si era procedente la Acción de Inconstitucionalidad contra reformas o adiciones a la Constitución, o si tenía la facultad para invalidar el resultado de una reforma constitucional. En esta ocasión,

22 Véase la Tesis: P. LXXVI/2009, publicada en el Semanario Fudicial de la Federación y su Gaceta, Novena Época, Pleno,t. XXX, diciembre de 2009, p. 15, de rubro: "PROCEDIMIENTO DE REFORMAS A LA CONSTITUCIÓN POLÍTICA DE LOS ESTADOS UNIDOS MEXICANOS. NO ES MANIFIESTA NI INDUDABLE LA IMPROCEDENCIA DEL JUICIO DE AMPARO PROMOVIDO EN SU CONTRA".

23 En otro precedente similar, el llamado Caso de los Intelectuales, la Suprema Corte volvió a tocar el tema de las impugnaciones de las reformas constitucionales. Al resolver el amparo en revisión 2021/2009, en sesión de 28 de marzo de 2011, la Suprema Corte confirmó el sobreseimiento dictado por un Juez de Distrito. Esta vez la SGJN optó por una vía más técnica; esto es, apeló a la imposibilidad de que la hipotética concesión del amparo pudiera irradiar a sujetos diversos a los que accionaron el juicio constitucional, aunque no señaló la imposibilidad de cuestionar el procedimiento de reformas.

Concretamente, los quejosos impugnaron el artículo 41, fracción III, párrafo tercero, de la CPEUM, que contiene dos categorías de prohibiciones: a) Contratar propaganda en radio y televisión dirigida a influir en las preferencias electorales de los ciudadanos, a favor o en contra de partidos políticos o de candidatos a cargos de elección popular; y b) Transmitir en territorio nacional este tipo de mensajes contratados en el extranjero. En este sentido, la Suprema Corte señaló que la protección constitucional que hipotéticamente llegara a otorgarse a los quejosos les permitiría llevar a cabo, dentro o fuera del país, la adquisición de tiempo en radio y televisión para transmitir propaganda dirigida a influir en el electorado, a favor o en contra de determinado partido o de candidatos de elección popular. Lo anterior implicaba que en el caso concreto el efecto natural de una hipotética concesión del amparo estaría caracterizado por proporcionar un beneficio no solamente a quienes hubieran obtenido la protección constitucional, sino también a otras personas, lo que implicaría atentar contra uno de los principio que sostiene al juicio de amparo, como lo es la relatividad de las sentencias. 
Esta obra forma parte del acervo de la Biblioteca Jurídica Virtual del Instituto de Investigaciones Jurídicas de la UNAM

al analizar la impugnación presentada por dos partidos políticos a través de la cual, vía acción de inconstitucionalidad, reclamaron la invalidez de la llamada reforma de la Ciudad de México, misma que fue desechada por el Ministro Instructor por ser notoriamente improcedente, la Suprema Corte tuvo la oportunidad - por tratarse de una nueva integración del Tribunal Pleno ${ }^{24-}$ de abordar el tema bajo un contexto y perspectiva jurídica diferentes, pues el análisis debía realizarse a partir de la reforma constitucional de derechos humanos de junio de 2011. La respuesta fue de nueva cuenta negativa, esta vez por vía de idoneidad del medio, pues el Tribunal Pleno por mayoría de votos resolvió:

“... la Constitución no otorga facultad a esta Suprema Corte para revisar reformas constitucionales por la vía de acción de inconstitucionalidad. Esta circunstancia tan determinante es patente desde el momento en que es presentada la demanda, pues basta advertir de su lectura que se impugnan normas de este rango (constitucionales), sean cuales sean los motivos de inconstitucionalidad que se aduzcan, para entender que se trata de aspectos que no pueden ser analizados a través de un medio de control constitucional... "'25

Cerrar así, la vía del control, es una imposibilidad disruptiva de nuestro sistema jurídico. La Contradicción de Tesis 293/2011 en la que la SCJN determinó la conformación de un solo bloque de derechos humanos entre la Constitución y los tratados internacionales, salvo que se tratara de las restricciones a los mismos previstas en la CPEUM, ${ }^{26}$ tiene de trasfondo este

24 En diciembre de 2015, se integraron al Tribunal Pleno la Ministra Norma Lucía Piña Hernández y el Ministro Javier Laynez Potisek.

25 Cfr. Recurso de Reclamación 8/2016, derivado de la acción de inconstitucionalidad 15/2016, resuelto por mayoría de siete votos por el Tribunal Pleno de la Suprema Corte de Justicia de la Nación en sesión de 28 de abril de 2016.

26 Uno de los criterios derivados de dicha resolución se plasmó en la Tesis: P./J. 20/2014 (10a), publicada en la Gaceta del Semanario Fudicial de la Federación,Décima Época, Pleno,Libro 5, abril de 2014, t. I, p. 202: "DERECHOS HUMANOS CONTENIDOS EN LA CONSTITUCIÓN Y EN LOS TRATADOS INTERNAGIONALES. CONSTITUYEN EL PARÁMETRO DE CONTROL DE REGULARIDAD CONSTITUCIONAL, PERO GUANDO EN LA CONSTITUCIÓN HAYA UNA RESTRICGIÓN EXPRESA AL EJERCICIO DE AQUÉLLOS, SE DEBE ESTAR A LO QUE ESTABLEGE EL TEXTO CONSTITUCIONAL", que señala:

"[...] De la interpretación literal, sistemática y originalista del contenido de las reformas constitucionales de seis y diez de junio de dos mil once, se desprende que las normas de derechos humanos, independientemente de su fuente, no se relacionan en términos jerárquicos, entendiendo que, derivado de la parte final del primer párrafo del citado artículo lo., cuando en la Constitución haya una restricción expresa al ejercicio de los derechos humanos, se deberá estar a lo que indica la norma constitucional, ya que el principio que le brinda supremacía comporta el encumbramiento de la Constitución como norma fundamental del orden jurídico mexicano, lo que a su vez implica que el resto de las normas jurídicas deben 
Esta obra forma parte del acervo de la Biblioteca Jurídica Virtual del Instituto de Investigaciones Jurídicas de la UNAM

aspecto. ¿Por qué lo afirmo? Porque habiendo señalado reiteradamente en mis trabajos, que se trató de mantener la supremacía de la Constitución por encima de los tratados internacionales - lo que nos conduce al tema anacrónico de la "guerra de las fuentes" y no en la centralidad que debe tener el contenido de las normas sobre derechos humanos - no se puso la mirada en la necesidad de verificar un test de compatibilidad de las restricciones con otros derechos presentes en la Constitución.

Así, en relación con el punto concreto que se aborda en este texto, me parece que el aspecto nodal no está en la discusión de la prevalencia de la CPEUM sobre los tratados internacionales, sino en que las restricciones a los derechos humanos no se acreditan en sí mismas; deben convalidarse en la protección de otro derecho, y manteniendo un mínimo de ejercicio del derecho que ha sido sometido a la restricción..$^{27}$ De manera que se trata de un test que necesariamente deben pasar las restricciones a los derechos humanos, y que no ha sido considerado por la SCJN, si estas restricciones se encuentran en la CPEUM.

En este sentido, sostengo que detrás de esta reticencia se encuentra en realidad la intención de evitar a toda costa un examen de las normas constitucionales (en este caso, las restricciones). La resistencia subsistente en nuestro sistema de interpretación, para conceder que las disposiciones de la Constitución puedan someterse a una revisión y control. Sin embargo, en la Contradicción de Tesis referida, la SGJN pasó por alto una cuestión muy importante, y es que no puede ser posible escapar a este cuestionamiento ante nuestro modelo específico de interpretación/control en las normas de derechos humanos, que no va de la Constitución hacia los tratados internacionales, como es el caso del derecho comparado, sino hacia la Constitución y los tratados. Es decir, el párrafo segundo del artículo $1^{\circ}$ de la CPEUM señala que todas las normas deben ser interpretadas de conformidad con la Constitución y los tratados internacionales, incluso otras normas constitucionales; incluyendo, desde luego, las restricciones..$^{28}$ De manera que se nos ha dejado con un gran faltante de la ecuación: el contraste de las res-

ser acordes con la misma, tanto en un sentido formal como material, circunstancia que no ha cambiado [...]." El subrayado es propio.

27 He planteado una crítica puntual al tema de las restricciones en La interpretación conforme. El modelo constitucional ante los tratados internacionales sobre derechos humanos y el control de convencionalidad, segunda edición, México, Porrúa/Instituto Mexicano de Derecho Procesal Constitucional, 2014, pp. 256 - 260.

28 La disposición señala: "Las normas relativas a los derechos humanos se interpretarán de conformidad con esta Constitución y con los tratados internacionales de la materia favoreciendo en todo tiempo a las personas la protección más amplia. 
Esta obra forma parte del acervo de la Biblioteca Jurídica Virtual del Instituto de Investigaciones Jurídicas de la UNAM

tricciones constitucionales en relación con derechos previstos en la propia Constitución. ${ }^{29}$

El tema no debería ser tan complejo, si en la ruta interpretativa pudieran ser solventadas las restricciones mediante el ajuste en su interpretación de conformidad con la Constitución y los tratados internacionales. Ya en la propia Contradicción de Tesis 293/2011, la SCJN entendió que la interpretación conforme es una herramienta que "obliga a los operadores jurídicos que se enfrenten a la necesidad de interpretar una norma de derechos humanos -incluyendo las previstas en la propia Constitución (subrayado añadido) - a considerar en dicha interpretación al catálogo de derechos humanos que ahora reconoce el texto constitucional." 30 La remisión interpretativa de la Constitución, ha sido una cuestión sobre la que la SCJN era reticente y en la que ha ido avanzando, como se demuestra en la esta cita.

El tema que sí puede ser muy complejo es lo que pueda suceder si como resultado del ejercicio interpretativo, las restricciones constitucionales no solventan una compatibilidad constitucional/convencional con respecto al bloque. Esto es, estamos frente una ruta que la SCJN quiere evitar a toda costa, pero que evidencia la problemática de no ejercer un control interpretativo de las previsiones constitucionales. Una posible solución, en algunos casos, es que el resultado del control podría ser inaplicación o declaración de inconstitucionalidad de normas secundarias que pudiesen desarrollar los preceptos constitucionales. Así lo he planteado para el caso del arraigo. ${ }^{31}$

\section{CONSIDERAGIÓN SOBRE LA PROPUESTA SUSTENTADA POR EL INSTITUTO DE INVESTIGAGIONES JURÍDICAS DE LA UNAM}

El libro "Constitución Politica de los Estados Unidos Mexicanos. Texto reordenado y consolidado. Anteproyecto" de los doctores Héctor Fix-Fierro y Diego Valadés se ha convertido en una aportación fundamental para el tema de qué hacer con la Constitución y su reforma. Esta ha sido una discusión que nos ha ocupado los últimos 20 años, ya desde 1997, año crucial en la transición democrática porque el Partido Revolucionario Institucional perdió la mayoría

29 Esta reflexión en: Caballero Ochoa, José Luis, "La interpretación conforme en el escenario jurídico mexicano. Algunas pautas para su aplicación a cinco años de la reforma constitucional de 2011 ", Revista del Centro de Estudios Constitucionales de la Suprema Corte de Fusticia de la Nación, En prensa.

30 Considerando Quinto. Estudio de Fondo, p. 34.

31 La interpretación conforme. El modelo constitucional ante los tratados internacionales sobre derechos humanos y el control de convencionalidad, Op. Cit., pp. $211-219$. 
Esta obra forma parte del acervo de la Biblioteca Jurídica Virtual del Instituto de Investigaciones Jurídicas de la UNAM

en la Cámara de Diputados; también poco tiempo después, en el ejercicio que se realizó en 2000 sobre la reforma del Estado, en el contexto de la alternancia en la Presidencia de la República.

Un estudio fundamental, derivado de un importante congreso sobre el tema en 1999, es el que publicó el Instituto de Investigaciones Jurídicas bajo el título "Hacia una nueva constitucionalidad"32, y en donde las posturas teóricas se dividieron primordialmente entre quienes pensaban en la necesidad de un nuevo texto constitucional producto de una especia de "pacto fundante" nuevamente de la República, ante una amplia negociación política que permitiera arribar a ciertos consensos básicos y plasmarlos en otra Constitución. Por otro lado, se encontraban quienes sostenían que no era necesario un nuevo texto, sino más bien pensar en la transición de forma gradual y con los cambios que hicieran falta.

A partir de entonces, la idea de una nueva Constitución, que remonte los mitos aquí descritos y la gran problemática a que hace frente el texto, vuelven al debate público con cierta frecuencia, y ante el Centenario la cuestión regresa a la agenda, aunque me parece que con menor intensidad - mucho menor - que en los albores del presente siglo. Coincido en mi apreciación con Héctor Fix - Fierro en el sentido de que la idea de una nueva Constitución que lo podrá todo, nos conduce de nueva cuenta al "fetichismo de la ley", y también en que algunas modificaciones graduales que ya se han realizado, y que se requerían desde entonces en las propuestas de "nueva Constitución" han quedado ya plasmadas, pero se descalifican por la razón de que no son elementos integradores de un nuevo texto reformado integralmente. ${ }^{33}$ Es así, una iniciativa con una buena carga de pretensiones simbólicas.

De ahí que la apuesta del Instituto de Investigaciones Jurídicas de la UNAM sobre la reordenación y consolidación de la CPEUM me parece de gran relevancia. Sin embargo, el debate debe ir al fondo de los paradigmas constitucionales que se juegan con las continuas reformas, y con los mensajes que está enviando la Constitución mexicana a la sociedad en el rostro que tiene al cumplir cien años. Me parece que es necesario movilizar algunos ejes paradigmáticos, sobre los que haré alguna enunciación un poco más adelante.

32 V.V.A.A., Hacia una nueva constitucionalidad, México, IIJ - UNAM, 1999.

$33 \mathrm{Su}$ análisis en "Hacia el Centenario de la Constitución mexicana de 1917. Una reflexión a propósito de reformas, textos, modelos y culturas constitucionales", Carbonell, Miguel; Fix-Fierro, Héctor; González Pérez, Luis Raúl; Valadés, Diego (Coords) Estado constitucional, derechos humanos, justicia y vida universitaria. Estudios en homenaje a forge Carpizo. Estado constitucional, Tomo IV, Volumen 1, México, IIJ - UNAM, 2015, pp. 704 - 705 
Esta obra forma parte del acervo de la Biblioteca Jurídica Virtual del Instituto de Investigaciones Jurídicas de la UNAM

De forma muy puntual, hago comentarios sobre algunos elementos novedosos que introduce la propuesta, además del proyecto de reordenación y consolidación en sí mismo considerado.

1.- Me parece un acierto sacar del armario de nuestro sistema normativo a las leyes de desarrollo constitucional, mediante la remisión de aquellas disposiciones que no se han considerado propias de la Constitución. Considero que es una cuestión que ha estado pendiente entre nosotros en términos de las fuentes, es decir, establecer legislación que amplíe a la Constitución mediante mayorías reforzadas en el Congreso y que las distingan del resto de la legislación ordinaria. Se trata pues, del sentido auténtico de las "leyes del Congreso de la Unión que emanen de ella (la Constitución)", que establece el artículo 133 de la CPEUM, además de las leyes generales, que fue abordado por la Suprema Corte hace algunos años.

2.- En efecto, el tema se discutió en 2007, cuando la SCJN dio carta de naturalización a las llamadas "leyes generales", distintas a la legislación federal, a las que la Suprema Corte había equiparado de alguna forma. La vía argumentativa para sostener esta especie de equiparación fue, en general, que tanto las leyes federales como las generales tenían el mismo ámbito de validez en el territorio mexicano y que, en definitiva, eran aprobadas por el Congreso de la Unión sin distinciones en la aplicación del artículo 72 de la CPEUM, específicamente en el tema de las mayorías, a diferencia de lo que ocurre en otros países. Finalmente, en el Juicio de Amparo en Revisión 120/2002, Caso "Mac Cain México, S. A. de C.V.", resuelto por el Pleno de la SCJN el 13 de febrero de 2007, se reconoció la existencia de las leyes generales, que inciden en todos los órdenes del Estado. ${ }^{34}$

No obstante, algunas voces hicieron valer un punto de vista crítico, precisamente ante la ausencia de mayorías reforzadas para la votación de las leyes generales. Así, en la sesión de discusión del caso referido el Ministro José Ramón Cossío señaló exactamente que no había condiciones jurídicas

34 De esta manera, en el Caso Mac Cain, la SCJN determinó:

["Que] las leyes del Congreso de la Unión a las que se refiere el artículo 133 constitucional, no corresponden a las leyes federales, (...), sino que se trata de las leyes generales, esto es, aquellas que válidamente pueden incidir en todos los órdenes jurídicos parciales que integran al Estado Mexicano."

Amparo en revisión 120/2002. Mc. Cain México, S.A. de C.V. 13 de febrero de 2007. Mayoría de seis votos. Disidentes: José Ramón Cossío Díaz, Margarita Beatriz Luna Ramos, José Fernando Franco González Salas, José de Jesús Gudiño Pelayo y Juan N. Silva Meza. Ponente: Sergio Salvador Aguirre Anguiano. Secretarios: Andrea Zambrana Castañeda, Rafael Coello Cetina, Malkah Nobigrot Kleinman y Maura A. Sanabria Martínez. 
Esta obra forma parte del acervo de la Biblioteca Jurídica Virtual del Instituto de Investigaciones Jurídicas de la UNAM

para generar otra división entre las leyes, como sí ocurría, por ejemplo, en España con respecto a las leyes orgánicas. ${ }^{35}$

3. Me parece importante, pues, el reconocimiento de estas leyes en el nuevo artículo 69 (que sería prácticamente el 71 del texto actual), ${ }^{36}$ además de las de carácter general, lo que contemplaría dos tipos de legislación en las leyes de carácter nacional "emanadas de la Constitución" en un sentido material de las que habla el artículo 133 de la CPEUM y, con esto, habría que asumir una nueva interpretación de esta disposición que, por cierto, no merece ninguna modificación a juicio de los autores de la propuesta del IIJ-UNAM.

Los autores proponen, y yo coincido, que se presente una revisión previa de constitucionalidad por parte de la Suprema Corte. Sería además muy interesante ver cómo disposiciones otrora en la Constitución sin ningún vicio de constitucionalidad por todo lo expresado en este trabajo, pudiesen devenir en inconstitucionales, ahora presentes en legislación secundaria. A mi juicio, además de todos los preceptos señalados por los autores como propios de ley y no de la Constitución, deberíamos incluir la figura del arraigo, a ver si así la Suprema Corte se decide de una vez a determinar su inconstitucionalidad/inconvencionalidad de forma radical.

\section{Gonclusión. Nuevos PARAdigmas QUE TENDRÍAN QUE PLANTEARNOS UNA NUEVA GONSTITUGIONALIDAD}

A continuación, de forma conclusiva, me refiero muy brevemente a los paradigmas que, a mi juicio, deben guiar la reflexión sobre el Centenario y

35 "Yo el día de ayer expliqué por qué me parece que éste es un criterio primero, que no tiene una sólida teorización. Cuáles son estas ideas de las leyes constitucionales, cómo las diferenciamos, no hay un proceso agravado de creación como las leyes orgánicas en el caso del ordenamiento español, no tienen una materialidad específica, en fin, es una idea que no tiene o que no, a mi juicio, un enorme sustento teórico, como primera condición" Versión taquigráfica de la discusión pública del Pleno de la Suprema Corte de Justicia de la Nación, del día 13 de febrero de 2007, p. 13

36 La descripción de estas leyes en la Constitución reordenada sería a propuesta de los autores: "El Congreso podrá expedir las leyes para desarrollar el contenido de las normas constitucionales. Estas leyes podrán ser iniciadas en cualquiera de las Cámaras y para su aprobación se requerirá el voto favorable de dos tercios de los miembros presentes en cada Cámara. El Presidente de la República no podrá formular observaciones en relación con a estas leyes de desarrollo constitucional. Antes de su publicación, el Presidente del Congreso consultará a la Suprema Corte de Justicia de la Nación acerca de la constitucionalidad de la ley correspondiente. La Suprema Corte deberá pronunciarse en un plazo de treinta días naturales" Constitución política de los Estados Unidos Mexicanos. Texto reordenado y consolidado. Anteproyecto, Op. Cit., p. 93 
Esta obra forma parte del acervo de la Biblioteca Jurídica Virtual del Instituto de Investigaciones Jurídicas de la UNAM

que conducen a un replanteamiento del modelo constitucional presente en nuestro país.

\section{El conflicto existente entre la verticalidad de las fuentes y el trabajo en redes.}

Se trata de dejar atrás una ordenación piramidal de las fuentes; lo que llamo la "desjerarquización de las fuentes" y establecer a la Constitución como base de articulación de diversos órdenes normativos. Transitar hacia el "pluralismo constitucional" o "transconstitucionalismo", como se ha llamado en otros contextos al entramado legal que confluye en la resolución de la problemática que implica a sedes normativas distintas. ${ }^{37}$

En este contexto, me parece que es necesario revisitar el sistema federal y dar mayor protagonismo a las entidades federativas, a sus propios textos constitucionales y a sus propios medios de defensa de los derechos humanos. Las últimas reformas centralizadoras, con el propósito de desincentivar incidencias indebidas de los gobernadores o para generar legislación de carácter nacional, no pueden implicar un debilitamiento del sistema federalestadual.

\section{La reconformación del Poder y el papel de los órganos constitucionales autónomos.}

Desde hace años, se discute la pertinencia de una reforma profunda del Estado que reconforme las relaciones Ejecutivo - Legislativo, modulando el presidencialismo y, quizás, transitando a un modelo semi parlamentario. Atender este paradigma me parece fundamental, así como discutir el im-

37 Sobre pluralismo constitucional, o transconstitucionalismo, entre otros: Serna, José María, Impacto e implicaciones constitucionales de la globalización en el sistema jurídico mexicano, México, IIJ-UNAM, 2012; Krisch, Nico, "International law in times of hegemony: unequal power and the shaping of the international legal order, The European fournal of International Law, volumen 16, número 3, Florencia, 2005; Kabbers, Jan, Peters, Anne y Ulfstein, Geir, The constitutionalization of international law, New York, Oxford University Press, 2009; Walker, Neil, "Taking constitutionalism beyond the State" Political Studies, vol 56, Nottingham, 2008;; García Roca, Javier y Fernández Sánchez, Pablo (Coords), Integración europea a través de derechos fundamentales: de un sistema binario a otro integrado, Madrid, Centro de Estudios Políticos y Constitucionales, 2009, pp. XXI - XXII; Neves, Marcelo, "Transconstitucionalismo, con especial referencia a la experiencia latinoamericana", Bogandy, Armin Von, Ferrer Mac - Gregor, Eduardo, y Morales Antoniazzi, Mariela (Coords.), La justicia constitucional y su internacionalización. ¿Hacia un ius constitucionale commune en América Latina?, México, IIJ-UNAM/ Instituto Iberoamericano de Derecho Constitucional/Instituto Max Planck, 2010. 
Esta obra forma parte del acervo de la Biblioteca Jurídica Virtual del Instituto de Investigaciones Jurídicas de la UNAM

pacto de la profusión de órganos constitucionales autónomos en las últimas reformas constitucionales y su sentido en los equilibrios del Estado.

\section{La emancipación de los sectores marginados y excluidos.}

Con independencia de la gran reforma en materia de derechos humanos, de 10 de junio de 2011, que mandó un contundente mensaje de centralidad en la persona del sistema constitucional mexicano, es importante recuperar el sentido emancipatorio de la Constitución que permita reconocerla como una verdadera carta de empoderamiento social, especialmente de los sectores más pobres y excluidos. Este fue uno de los mensajes más importantes de la Constitución de 1917 al momento de su promulgación.

\section{El sentido de la reforma constitucional.}

Otro paradigma que necesariamente debe ser revisitado es el de la reforma constitucional: los contenidos pétreos que no podrían modificarse sino mediante un procedimiento agravado; los actores que intervienen; quizás la participación directa de la sociedad en el procedimiento agravado, vía referéndum; el control de las reformas, etcétera. Los temas que han estado puestos en la reflexión jurídica en los últimos 30 años y sobre los que se han generado tabús convertidos en mitos. 
Esta obra forma parte del acervo de la Biblioteca Jurídica Virtual del Instituto de Investigaciones Jurídicas de la UNAM

\title{
LA CONSTITUGIÓN A DETALLE DESDE LA PERSPEGTIVA DE LA TEORÍA GONSTITUCIONAL EN MÉXICO ${ }^{1}$
}

\author{
José Miguel Cabrales LuCiO*
}

\begin{abstract}
SUMARIO: I. Introducción: argumentos conceptuales, teóricos y filosóficos sobre las constituciones abstractas y aquellas de detalle. II. Indeterminación de las normas constitucionales por su carácter concreto o abstracto y la necesidad de su interpretación. III. ¿Es la Constitución mexicana de 1917 una Ley excesivamente detallada?. IV. Consecuencias de una sobre-regulación constitucional o de la elección de una Constitución a detalle. V. Reflexiones conclusivas, propositivas y prospectivas. VI. Bibliografia.
\end{abstract}

\section{INTRODUCGIÓN: ARGUMENTOS CONCEPTUALES, TEÓRICOS Y FILOSÓFICOS SOBRE LAS CONSTITUCIONES ABSTRACTAS Y AQUELLAS DE DETALLE}

Para abordar el tema de la reglamentación estipulada en nuestra Constitución de 1917 es necesario hacer referencia de manera básica y panorámica, aunque no por ello menos reflexiva, de algunos conceptos fundamentales de la teoría del Derecho Constitucional. Empezaríamos con el concepto de Constitución democrática.

* Profesor de grado y posgrado (Maestría) de las asignaturas de Derecho constitucional, Derechos Humanos, Derecho procesal constitucional e Investigación jurídica en la Unidad Académica de Ciencias Jurídicas y Sociales de la Universidad Autónoma de Tamaulipas (UACJS/UAT). Coordinador de investigación de la División de Estudios de Posgrado e Investigación de la UAGJS/UAT.

1 Texto completo de la ponencia presentada en la mesa II titulada "el problema del carácter reglamentario de muchas disposiciones constitucionales". Congreso Nacional de Derecho Constitucional, San Luis Potosí 3, 4 y 5 de febrero de 2016. Agradezco a los coordinadores del Evento la consideración y el apoyo de la Unidad Académica de Ciencias Jurídicas y Sociales (Tampico) de la Universidad Autónoma de Tamaulipas para la participación en este Congreso. 
Esta obra forma parte del acervo de la Biblioteca Jurídica Virtual del Instituto de Investigaciones Jurídicas de la UNAM

Por otro lado también debemos hacer referencia a la conveniencia de tener una Constitución normativa. Antes de entrar a definir lo que entendemos por Constitución normativa, hay que hacer la distinción básica y pertinente para nuestros objetivos en este trabajo, de Constituciones normativas y Constituciones Políticas, desde un punto de vista teórico.

Muy rápidamente, Una Constitución Política sería aquella que consagra los valores fundamentales del Estado en un momento originario y por acuerdo social para lograr una gobernabilidad ordenada, en definitiva los factores reales de poder político, por ello, es una Constitución Política, lo que lleva implícito de suyo que los métodos de interpretación y su efecto sea eminentemente político y no jurídico².

Desde este momento asumimos el ideal de que una Constitución debe ser normativa, es decir, debe concebirse y expresarse como una norma jurídica, en nuestro caso, la norma fundamental del Estado.

El presente trabajo de investigación se centrará en abordar temas relacionados con el valor de la Constitución, desde el punto de vista de su redacción, abstracción, detalle y alcance temporal, así como de su carácter vinculante y normativo, entre otros. Asimismo este análisis nos permitirá tener una base teórica para abordar el tema del carácter reglamentario o no de nuestra Constitución Federal y su pertinencia, viabilidad y efectos desde una óptica teórica pero con implicaciones y consecuencias prácticas muy importantes.

\section{Concepto, naturaleza y contenido de la Constitución desde un punto de vista instrumental}

Respecto a lo que debe contener una Constitución, diríamos que la doctrina a lo largo de mucho tiempo ha ido perfilando un contenido mínimo, con referencia a la experiencia histórica y a las aportaciones teóricas que mejor han dado respuesta a la realidad. Con base en ello sostenemos que, aunque no de manera limitativa si de manera básica, una Constitución democrática y normativa debe contener expresamente el principio de soberanía popular e incluso la forma de garantizarlo, el catalogo mínimo de derechos de las personas y los mecanismos para su ejercicio y protección; por último aunque no menos importante, el establecimiento de la división de funciones y competencias para ejercer el poder y los mecanismos de ga-

2 Véase por ejemplo y fundamentalmente a LASALLE, Ferdinand. ¿Que es una Constitución?, Barcelona: Ariel, 2001, p. 119. Traducción de W. Roces. 
Esta obra forma parte del acervo de la Biblioteca Jurídica Virtual del Instituto de Investigaciones Jurídicas de la UNAM

rantía de esta división ${ }^{3}$. Dentro de este esquema configurador de la Constitución, las constituciones democráticas aparecen, según Stern como «...la expresión libre de la autodeterminación de la nación» ${ }^{4}$.

La Constitución normativa y Democrática debe ser abierta ${ }^{5}$, donde aparece como principal característica la posibilidad de ser cambiada o reformada con procedimientos asequibles para las generaciones presentes. Así, la conducta de la sociedad que vive la Constitución no estará sometida a la voluntad del poder constituyente creador de la misma, regulando las conductas de las generaciones vivas las cuales están sometidas al régimen jurídico que proporciona la Constitución, en otras palabras la Constitución Democrática no debe tener límites jurídicos. Incluso desde el Siglo XVIII se hablaba de la imposibilidad de someter a generaciones futuras a las voluntades de generaciones pasadas en el art. 33 de la Declaración de derechos de 1793:

Como resultado del carácter normativo que reconocemos a la Constitución, ésta tiene que ser vigente, es decir, de aplicación actual, ésta aplicación debe hacerse en el marco de fuerzas políticas, que en conjunto forman la realidad estatal, es decir, la organización del Estado. Mientras más adecuación y cobertura hay entre las prescripciones constitucionales y la realidad, más se alcanza la pretensión de vigencia y con ello la Constitución jurídica alcanzará la fuerza normativa buscada ${ }^{6}$.

Las constituciones actuales generalmente traen consigo la característica de normatividad y el carácter democrático, estas características están íntimamente ligadas y es difícil comprender una Constitución que sea democrática pero que no sea normativa. A este respecto se ha manifestado ARAGON, cuando dice que «Solo es Constitución "normativa" la Constitución democrática y solo a partir de ella puede configurarse el Estado constitucional como forma política». ${ }^{7}$ Con esta expresión se resume la naturaleza de la Constitución a la que haremos referencia en adelante. Así como la organización política que, en forma de Estado constitucional, se desprende

3 En buena medida estos elementos se pueden encontrar también en Linde PANIAGUA, Enrique. Constitucionalismo democrático. Madrid: Colex, 2002, p. 96.

4 Stern, Klaus. Derecho del Estado de la República Federal alemana. Madrid: Centro de estudios constitucionales, 1987, p. 58.

5 Abierta, entendiendo este vocablo, en este contexto en particular, como la característica de la Constitución que la hace susceptible de poder ser modificada en función a las necesidades de cada generación, y no este radicalmente cerrada, limitando a la generación actual tener su propia Constitución.

6 Hesse en Escritos de Derecho constitucional... ob cit. p. 68.

7 Aragón Reyes, Manuel. Constitución...ob cit. pp. 13 -14. 
Esta obra forma parte del acervo de la Biblioteca Jurídica Virtual del Instituto de Investigaciones Jurídicas de la UNAM

de éste tipo de Constitución, y en donde se desenvuelve todo el entramado constitucional de la interpretación, de sus criterios y de sus principios en el marco de una sociedad moderna.

Habiendo expuesto algunas consideraciones sobre los dos aspectos inherentes a la Constitución (democrático y normativo) que nos servirán para identificar y contextualizar la Constitución, también creemos necesario considerar el tema de la rigidez ${ }^{8}$ o flexibilidad de la Constitución, ya que éste juega un papel importante en la garantía de su permanencia, así como en la limitación de las voluntades que intenten la modificación arbitraria de ella.

En buena medida la clasificación entre constituciones a detalle y constituciones abstractas está en la naturaleza de los términos que se incluyen y la forma en la que se inscriben. En otras palabras, en aquellas constituciones a detalle los términos generalmente son concretos, objetivos o con esa pretensión, y detallados (igualmente con esa pretensión). También Ferreres destaca la mayor y natural indeterminación y abstracción de las cláusulas que contienen derechos en las constituciones, lo que las hace especialmente interpretables.

\section{El precompromiso como pilar estructural de la supremacía} constitucional y de la importancia del establecimiento original del contenido jurídico

Es necesario destacar que la supremacía de la Constitución tiene una íntima relación con el tema del precompromiso ${ }^{9}$ que entabla la sociedad para sujetarse a decisiones que fueron tomadas en el pasado por personas que formaron el poder constituyente, y que encarnaban la voluntad de esa generación, más no la actual, regulando jurídicamente el presente. El precompromiso se basa fundamentalmente en la idea de una obligación previa que

8 Una defensa del carácter rígido de las Constituciones puede verse en Ferreres Comella, Víctor. "Una defensa de la rigidez constitucional". En Doxa, núm. 23, 2000, pp. 29 - 47.

9 DE LORA, Pablo. La interpretación originalista de la Constitución. Una aproximación desde la Filosofía del Derecho. Madrid: Centro de Estudios Constitucionales, 1998. algunos autores clásicos Jefferson, T. Thomas Fefferson: political writings. Cambridge: Cambridge University Press, 1999, 623 p. ELSTER hace hincapié, para ejemplificar éste aspecto, al caso de Ulises y las sirenas, cuando decide por voluntad propia y previo al evento del cual se considera vulnerable, es decir, del canto de las sirenas, que los acompañantes en el viaje le aten las manos para que no se deje influenciar por dichos cantos (ELSTER, Jon. Ulysses unbound: studies in rationality, precommitment, and constraints. Cambridge University Press, 2000, 308 p.). También recogido por Moreso, Juan José. La indeterminación del Derecho y la interpretación de la Constitución. Madrid: CEPC, 1997, pp. 165 - 167. 
Esta obra forma parte del acervo de la Biblioteca Jurídica Virtual del Instituto de Investigaciones Jurídicas de la UNAM

busca conservar valores fundamentales que no puedan ser modificados al libre albedrío de la voluntad de la generación actual o de cada generación futura, pudiendo con ello adecuar el establecimiento de los valores fundamentales de la sociedad de acuerdo con intereses que a final de cuentas son los de la mayoría.

Según $\mathrm{Moreso}^{10}$, si se concibe a la Constitución como un sistema originario de un orden jurídico, que determina un conjunto de consecuencias de sistemas jurídicos, entonces, contextualmente hablando la primacía del orden originario, es decir, el orden establecido por el Constituyente, que en muchos de los casos ya no es parte de la generación viva, hacia la generación que si lo está, se entiende en el seno de las Democracias constitucionales y en el mecanismo de racionabilidad colectiva del precompromiso adoptado para con los elaboradores de la carta fundamental. Esta idea del precompromiso, refleja una postura de superioridad de aquellos que diseñaron el modelo de Estado ya que se pre-diseña la conducta que deberán tener las generaciones futuras. La cuestión sería aquí saber de que forma y con qué grado de detalle se hace o se debe hacer este diseño. Esta cuestión es precisamente el punto medular en este trabajo.

En definitiva, la asimilación y comprensión del precompromiso como vector de la supremacía constitucional, la jerarquía de normas, donde la Constitución ocupa el lugar de fundamento de todo el ordenamiento jurídico, así como el papel del poder constituyente en la conformación de esa supremacía desde el punto de vista de su legitimación, colaboran para expresar la inequívoca posición suprema de la Constitución en el engranaje jurídico del Estado, así como su redacción precisa y concreta.

\section{INDETERMINACIÓN DE LAS NORMAS CONSTITUCIONALES POR SU GARÁCTER CONGRETO O ABSTRACTO Y LA NECESIDAD DE SU INTERPRETACIÓN}

Habiendo analizado la función y la naturaleza del poder constituyente como fundamento de la supremacía de la Constitución, es necesario destacar la evidente indeterminación de las cláusulas constitucionales debido a la propia naturaleza de norma suprema y marco jurídico para el desarrollo de las demás leyes ordinarias que la desarrollaran ${ }^{11}$. En este orden de ideas,

10 Moreso, Juan Jose. La indeterminación del Derecho ... ob. cit.

11 Debemos reconocer que la evidente indeterminación de las cláusulas jurídicas, no es exclusiva de las Constituciones, ya que en las leyes ordinarias también existen (por ejemplo, en materia civil, la buena fe) y eso causa un gran problema de indeterminación y por ende de necesidad de interpretación y de determinación, tarea que realizan constantemente los 
Esta obra forma parte del acervo de la Biblioteca Jurídica Virtual del Instituto de Investigaciones Jurídicas de la UNAM

el control de constitucionalidad aparece como garante de esa supremacía, y es la práctica de ese control el que plantea la cuestión de la necesidad de la interpretación constitucional. Así mismo, como dice MORESO solo atendiendo al significado del texto constitucional puede entenderse la idea de supremacía de la Constitución ${ }^{12}$.

Si sostenemos con Perez Luño que «la norma jurídica no es el presupuesto sino el resultado del proceso interpretativo» ${ }^{13}$, y recordamos a su vez la condición de norma jurídica superior que posee la Constitución, entonces la interpretación se hace necesaria en virtud de que la norma se presenta como su resultado más que como su presupuesto. Esta afirmación tiene puntos que es necesario destacar, por un lado, que la norma no adquiere verdadera existencia hasta que se complete la interpretación o más exactamente hasta que se aplique. Por otro lado, que la norma en realidad es el presupuesto de la tarea de comprensión, como puede serlo la tradición o la cultura jurídica en la que opera el intérprete. Siendo así las cosas, podemos decir que desde la perspectiva de la teoría del Derecho la asimilación de que la normatividad jurídica (esto es la Constitución, las leyes y demás ordenamientos) goza de eficacia propia y la comprensión de estas y su interpretación mantiene una vinculación con la realidad, entonces la interpretación de las normas, en particular de la Constitución es no solo necesaria algunas veces, sino que es siempre necesaria. Como afirmaría el profesor español de filosofía Prieto Sanchís «Con ello solo se pretende señalar que el producto de la interpretación es un significado al que podemos denominar normaproducto concretamente el significado atribuido a la norma-dato lo que equivale a sostener que la interpretación incorpora una dimensión volitiva, esto es propiamente normativa, en modo alguno que las leyes o normas- dato sean creadas por el intérprete» ${ }^{14}$.

Es aquí donde creemos oportuno confirmar; primero, el reconocimiento de la abstracción de los preceptos constitucionales y segundo, la necesi-

jueces ordinarios —allá donde existe una separación entre jurisdicción constitucional y jurisdicción ordinaria - sólo que nosotros destacamos los problemas interpretativos relativos a las cláusulas constituciones, por considerarlos relevantes para entender la problemática del control constitucional de las leyes.

12 Moreso afirma que la primacía es de carácter semántico, y no sintáctico, ya que no se comprende, dentro del engranaje lógico - Constitucional, que se le pueda atribuir primacía a un conjunto de símbolos no interpretados (MORESO, Juan José. La indeterminación del Derecho... ob. cit. p. 184.)

13 Perez Luño, A., Derechos Humanos, Estado de Derecho y Constitución. Madrid: Tecnos, 1984, p. 254.

14 Prieto Sanchis, Luis. Ideología e interpretación jurídica. Madrid: Tecnos, 1987, p. 84. 
Esta obra forma parte del acervo de la Biblioteca Jurídica Virtual del Instituto de Investigaciones Jurídicas de la UNAM

dad de interpretar estos preceptos para poder hacerlos efectivos y de aplicación directa, tal como exigen las características de normativa y vigente que hemos atribuido antes, a las constituciones.

Por otro lado, existe la tendencia en clasificar las constituciones, según las previsiones que contengan. Así, se podrían mencionar dos grandes tipos; aquellas que son abstractas o abiertas ${ }^{15}$ en su formulación, y aquellas que son elaboradas lo más precisas posibles, o cerradas, ${ }^{16}$ también llamadas a detalle. ${ }^{17}$ Esta clasificación es pertinente recordarla debido a que la indeterminación de las normas se presenta en un tipo de Constitución, aquella considerada como abierta, donde sus cláusulas poseen la característica de abstracción en mayor medida.

La indeterminación de los conceptos utilizados en una Constitución abierta se hace necesaria desde una óptica lógico - funcional, y esto es debido a que la contraposición, es decir, la existencia de un texto fundamental meticulosamente detallado, o concreto «debe gozar de un consenso muy amplio y arraigado, que permita aventurar que podrán resistir los esfuerzos críticos de las generaciones futuras que habrán de organizar su vida colectiva bajo esa Constitución» ${ }^{18}$. Por lo tanto, no negando que pueda existir tal consenso en una Constitución a detalle, parece más difícil alcanzar éste, mientras que por otro lado parece más factible la aparición de las constituciones con cláusulas abiertas bajo las cuales sea posible adecuar a la realidad presente. Esta es una postura muy coherente con el sistema prevaleciente, al menos en las constituciones de la segunda mitad del Siglo XX.

$15 \mathrm{Al}$ respecto puede verse LuCAS Verdú, Pablo. La Constitución abierta y sus "enemigos". Madrid: Servicio de Publicaciones de la Facultad de Derecho, Universidad Complutense, 1993, 93 p.

16 Sería una exageración decir que existen cláusulas constitucionales totalmente cerradas, ni mucho menos totalmente abiertas, y todo será cuestión de grados, habrá aquellas que tengan un grado mayor de abstracción, con posibilidad de concreción judicial a la hora de interpretarla, y habrá aquellas que tengan un mayor grado de concreción, donde la amplitud o campo de maniobra del juez constitucional será menor.

17 Una de las principales críticas, sin ser la única, es la que hace Victor Ferreres al decir: que «...La Constitución a detalle conlleva la vinculación injustificable de la generación actual y de la futura de las decisiones de una generación ya muerta» Recordando así mimo que una Constitución con estas características «...no permite acoger nuevas exigencias éticas derivadas de aspectos de la libertad y la dignidad humana...» donde por supuesto con un margen de interpretación atribuido a los jueces podrían éstos incluir en las prerrogativas actuales de la Constitución sectores y valores de la sociedad en un escenario más plural para beneficio de la Democracia misma. (FERRERES COMELLA. Víctor. Fusticia constitucional...ob cit. p. 138).

18 Ídem. 
Esta obra forma parte del acervo de la Biblioteca Jurídica Virtual del Instituto de Investigaciones Jurídicas de la UNAM

El grado de abstracción que poseen las Constituciones se hace presente, tanto en aquellas cláusulas que se refieren a los Derechos Humanos, como también cláusulas relativas al régimen de gobierno y relaciones entre órganos del Estado. Un buen ejemplo, es el caso de España y su Constitución de 1978, donde como dice Pedro de Vega, «...la introducción en el ordenamiento de fórmulas como dignidad del hombre, libertad, principios del régimen político o Estado de Derecho exigen del juez una definición previa de lo que debe entenderse por tales preceptos. Y es obvio que esta definición más que jurídica, es una definición política». ${ }^{19}$ Debido a la anterior advertencia del autor español, obtenemos dos consideraciones; la primera es que, cada que se hable de necesidad de interpretar la Constitución, así como de concretar las cláusulas constitucionales, se hará referencia tanto a las que contienen Derechos Fundamentales como a las que establecen las relaciones entre los órganos de gobierno o la misma forma de Estado que adopta determinado país. La segunda es que la esfera donde debemos buscar la definición de estas cláusulas abstractas es, fundamentalmente política, debido a que la definición es política, más que jurídica. Lo anterior trae consigo una serie de problemas interpretativos, ya que, en primer lugar quien se encarga de la interpretación, al menos en última instancia, es un Tribunal constitucional o una Corte Suprema, órgano de naturaleza eminentemente jurídica.

La atribución de significado a los textos constitucionales, no es una tarea fácil, ya que es un tema eminentemente práctico, con matices teóricos y una fundamentación filosófica importante que es necesario saber. Con relación al sujeto de la interpretación constitucional, es decir, las cortes y tribunales constitucionales quienes realizan ésta interpretación, se hace referencia constantemente a que estos no son propiamente los más legítimos (desde el punto de vista democrático) para atribuir significado a las cláusulas constitucionales.

En resumen, visto con detenimiento el carácter normativo de la Constitución, resulta imprescindible y por demás fundamental la interpretación de la constitución, si queremos preservar y consolidar su naturaleza normativa. ${ }^{20}$

19 De Vega, Pedro. "Jurisdicción constitucional y crisis de la Constitución”. En Revista de estudios olíticos, $\mathrm{N}^{\mathrm{o}} 7,1979$, p. 115.

20 En este sentido se pronuncia HESSE, cuando resalta el valor de la interpretación constitucional, y de su íntima relación con el carácter normativo de la Ley fundamental, donde manifiesta que la propia interpretación podría en su momento cambiar el sentido de las cláusulas constitucionales, pero que ello no debe afectar su aspecto normativo. (Hesse. Escritos de Derecho ...ob cit. p. 74). Así mismo, en el contexto americano encontramos el punto de la postura de HESSE que consiste en la expuesta por el jurista $\mathrm{O}$. W. Holmes quien afirma que 
Esta obra forma parte del acervo de la Biblioteca Jurídica Virtual del Instituto de Investigaciones Jurídicas de la UNAM

Ahora bien, la clasificación de las constituciones en abiertas y cerradas en función del grado de abstracción que poseen sus cláusulas, nos coloca en el punto de considerar que las constituciones abiertas parecen más adecuadas para cumplir la tarea de adaptación de contenidos a la realidad actual, haciéndolas por tanto, vigentes. Ya que solo atendiendo al significado del texto constitucional, lo que hace aún más necesario su interpretación, tal como lo dice Moreso ${ }^{21}$, puede entenderse la idea de la primacía de la Constitución, que venimos argumentando en párrafos anteriores. El autor español afirma que, siendo la primacía de carácter semántico, y no sintáctico, no se comprende, dentro del imaginario lógico-constitucional, ni menos jurídico, que se le pueda atribuir primacía a un conjunto de símbolos no interpretados ${ }^{22}$.

\section{III. ¿ES LA GONSTITUGiÓN MEXICANA DE 1917 UNA LEY EXCESIVAMENTE DETALLADA?}

Algunos estudios comparados y autores ya se han pronunciado sobre la excesiva regulación de la Constitución Federal de nuestro País ${ }^{23}$. En este sentido acordamos y continuamos estos estudios con confirmaciones en este sentido. Un diagnóstico que nos coloca a diferencia de otros países como poseedores de una Constitución a detalle. Muchas disposiciones reglamentarias contenidas en la Constitución regulan en exceso los derechos, los órganos, las instituciones, las funciones, entre otras cuestiones. Esta situación provoca que nuestra Constitución sea de las más extensas del mundo.

En el marco de un análisis de si la Constitución mexicana es de detalle en su conjunto, en su mayoría o en qué porcentaje o número de artículos y clausulas lo es, en definitiva clasificar a la Constitución, de cualquier país y sobre todo la nuestra, es una tarea difícil. En esta tarea debemos esclarecer y definir que existen dos tipos por lo menos de "regulación a detalle" constitucional para nuestros efectos. Por un lado la cantidad de palabras o la ex-

la nación es una living Constitution, al crecer y transformarse constantemente, en este sentido «las provisiones de la Constitución no son fórmulas matemáticas que tengan su esencia en su forma, son orgánicas, instituciones vivientes transplantadas de la tierra inglesa. Su significado es vital, no formal; tiene que ser determinado no simplemente cogiendo las palabras y un diccionario, sino considerando su origen y la línea de su desarrollo» en Gompers Vs. United States, 233 U.S. 604, 1914.

21 Moreso, Juan José. La indeterminación del Derecho... ob cit. p. 184.

22 Ídem.

23 Pou Giménez, Francisca. "La Constitución de Cádiz y nosotros: reflexiones en torno a los modelos de constitución”. En Estudios 104, vol. xi, primavera 2013, p. 110. 
Esta obra forma parte del acervo de la Biblioteca Jurídica Virtual del Instituto de Investigaciones Jurídicas de la UNAM

tensión física de los artículos, partes o textos que componen la Constitución y por otro, el nivel interno de detalle regulatorio - reglamentario que cada artículo tenga, independientemente de su redacción larga o corta.

\section{a. La Constitución de Cádiz: un directo antecedente y quizá, —una causa muy fuerte- de la configuración a detalle de la Constitución mexicana de 1917.}

Sin hacer un repaso ni estudio pormenorizado de la historia de la Constitución mexicana vigente ni de todo el constitucionalismo mexicano, bien valdrá la pena recordar nuestros antecedentes en la medida en la que encontremos algunas respuestas a nuestra hiper-regulación textual. En primer lugar una arraigada y natural relación causal entre el imperio romano, el derecho escrito y el carácter latino de nuestra tradición jurídica.

En otro orden de ideas, y en momentos posteriores, la España colonizadora y nuestra historia al respecto. Ene se punto histórico, por mencionar un ejemplo concreto del constitucionalismo español, la Constitución de Cádiz de 1812, por ejemplo contenía 384 artículos y una reproducción importante de conductas y disposiciones regulatorias de detalle llamativas. Ente estas cláusulas o expresiones que se contenían ahí estaban por ejemplo: las palabras textuales de funcionarios públicos que asumían algún cargo de elección popular. En efecto, el art. 117 del texto original establecía: "En todos los años el día 25 de febrero se celebrará la última junta preparatoria, en la que se hará por todos los diputados, poniendo la mano sobre los Santos Evangelios, el juramento siguiente: ¿Juráis defender y conservar la religión católica, apostólica, romana, sin admitir otra alguna en el reino? -R. Sí juro. ¿Juráis guardar y hacer guardar religiosamente la Constitución política de la Monarquía española, sancionada por las Cortes generales y extraordinarias de la Nación en el año de mil ochocientos y doce? -R. Sí juro. ¿Juráis haberos bien y fielmente en el encargo que la Nación os ha encomendado, mirando en todo por el bien y prosperidad de la misma Nación? -R. Sí juro. Si así lo hiciereis, Dios os lo premie; y si no, os lo demande"24. Entre otras disposiciones muy propias de la época monárquica. Lo que se quiere destacar aquí es como desde la propia influencia que pudiera tener la Constitución gaditana se puede ver una relación entre nuestra historia colonial y la excesiva regulación. Solo por recordar otro punto que nos conectaría. La

24 El señalamiento lo hace muy atinadamente Pou Giménez, Francisca. "La Constitución de Cádiz y nosotros: reflexiones en torno a los modelos de constitución". En Estudios 104, vol. xi, primavera 2013, p. 110 y ss. 
Esta obra forma parte del acervo de la Biblioteca Jurídica Virtual del Instituto de Investigaciones Jurídicas de la UNAM

Constitución de Cádiz dedicaba a la regulación del poder legislativo y todo lo referente al proceso normativo de creación de estas, 68 artículos ${ }^{25}$. Esta situación podría en buena medida ofrecer algunas ideas lógicas respecto a las razones del porqué nuestra historia constitucional conlleva textos de unas extensa regulación, llegando a crecer de forma inimaginable para el propio poder constituyente como el caso de nuestra vigente Constitución.

\section{b. Análisis cuantitativo de la Constitución Federal y la constatación de su carácter de detalle}

En los anteriores apartados hemos recordado argumentos teóricos, filosóficos y constitucionales respecto a la naturaleza de las constituciones y de la situación particular de la Constitución de México. El motivo principal de este trabajo - recordamos también, es el de mostrar y analiza la situación de la Constitución Federal y de su excesiva regulación, concluyendo su potencial consecuencia dañina. En este apartado revisaremos con precisión cuantitativa la realidad de las cláusulas constitucionales. Entre los 136 artículos existen innumerables características obvias que nos llevan a pensar que la Constitución es de detalle y que es excesivamente regulatoria, por ejemplo existe algunos artículos (3, 27, 123, por mencionar algunos) evidentemente algunos que no son posibles leer ni siquiera de una sola vez.

En concreto por mencionar los artículos de la Constitución que contienen una excesiva regulación serían, aquí dedicaremos espacio a aquellos que consideramos más relevantes desde el punto de vista cuantitativo para los efectos del objetivo de este trabajo de investigación;

Por ejemplo el arts. 2, relativo a los pueblos indígenas con 1332 palabras, una extensión excesiva, en su fracción II del apartado B establece:

"Garantizar e incrementar los niveles de escolaridad, favoreciendo la educación bilingüe e intercultural, la alfabetización, la conclusión de la educación básica, la capacitación productiva y la educación media superior y superior. Establecer un sistema de becas para los estudiantes indígenas en todos los niveles. Definir y desarrollar programas educativos de contenido regional que reconozcan la herencia cultural de sus pueblos, de acuerdo con las leyes de la materia y en consulta con las comunidades indígenas. Impulsar el respeto y conocimiento de las diversas culturas existentes en la nación".

25 Ídem. La autora señala por ejemplo como todo el poder legislativo estaba contemplado desde los artículos 35 al 167. 
Esta obra forma parte del acervo de la Biblioteca Jurídica Virtual del Instituto de Investigaciones Jurídicas de la UNAM

Fracción V: "Propiciar la incorporación de las mujeres indígenas al desarrollo, mediante el apoyo a los proyectos productivos, la protección de su salud, el otorgamiento de estímulos para favorecer su educación y su participación en la toma de decisiones relacionadas con la vida comunitaria”. De estos dos breves ejemplos de redacción del artículo podemos observar como el mandato es tan directo y tan detallado que bien podría estar contenido en disposiciones secundarias que sean más concretas.

El artículo 3 relativo a la educación con 1509 palabras, contiene por ejemplo:

Fracción II "El criterio que orientará a esa educación se basará en los resultados del progreso científico, luchará contra la ignorancia y sus efectos, las servidumbres, los fanatismos y los prejuicios.

Además:

a) Será democrático, considerando a la democracia no solamente como una estructura jurídica y un régimen político, sino como un sistema de vida fundado en el constante mejoramiento económico, social y cultural del pueblo;

b) Será nacional, en cuanto - sin hostilidades ni exclusivismos- atenderá a la comprensión de nuestros problemas, al aprovechamiento de nuestros recursos, a la defensa de nuestra independencia política, al aseguramiento de nuestra independencia económica y a la continuidad y acrecentamiento de nuestra cultura;

c) Contribuirá a la mejor convivencia humana, a fin de fortalecer el aprecio y respeto por la diversidad cultural, la dignidad de la persona, la integridad de la familia, la convicción del interés general de la sociedad, los ideales de fraternidad e igualdad de derechos de todos, evitando los privilegios de razas, de religión, de grupos, de sexos o de individuos, y

d) Será de calidad, con base en el mejoramiento constante y el máximo logro académico de los educandos";

Más adelante se dice, por ejemplo:

"Para dar pleno cumplimiento a lo dispuesto en el segundo párrafo y en la fracción II, el Ejecutivo Federal determinará los planes y programas de estudio de la educación preescolar, primaria, secundaria y normal para toda la República. Para tales efectos, el Ejecutivo Federal considerará la opinión de los gobiernos de los Estados y del Distrito Federal, así como de los diversos sectores sociales involucrados en la educación, los maestros y los padres de familia en los términos que la ley señale. Adicionalmente, el in- 
Esta obra forma parte del acervo de la Biblioteca Jurídica Virtual del Instituto de Investigaciones Jurídicas de la UNAM

greso al servicio docente y la promoción a cargos con funciones de dirección o de supervisión en la educación básica y media superior que imparta el Estado, se llevarán a cabo mediante concursos de oposición que garanticen la idoneidad de los conocimientos y capacidades que correspondan. La ley reglamentaria fijará los criterios, los términos y condiciones de la evaluación obligatoria para el ingreso, la promoción, el reconocimiento y la permanencia en el servicio profesional con pleno respeto a los derechos constitucionales de los trabajadores de la educación. Serán nulos todos los ingresos y promociones que no sean otorgados conforme a la ley. Lo dispuesto en este párrafo no será aplicable a las Instituciones a las que se refiere la fracción VII de este artículo";

"Los particulares podrán impartir educación en todos sus tipos y modalidades. En los términos que establezca la ley, el Estado otorgará y retirará el reconocimiento de validez oficial a los estudios que se realicen en planteles particulares. En el caso de la educación preescolar, primaria, secundaria y normal, los particulares deberán:

a) Impartir la educación con apego a los mismos fines y criterios que establecen el segundo párrafo y la fracción II, así como cumplir los planes y programas a que se refiere la fracción III, y

b) Obtener previamente, en cada caso, la autorización expresa del poder público, en los términos que establezca la ley;

Dentro del mismo art- 3 la reciente creación del Sistema Nacional de Evaluación Educativa y por consiguiente el Instituto Nacional Para la Evaluación Educativa, que por ejemplo afirma más adelante: “...La Junta de Gobierno será el órgano de dirección del Instituto y estará compuesta por cinco integrantes" (4 párrafos de la Constitución). Hay remisión a las leyes reglamentarias, sin embargo de la excesiva regulación se desprende una desconfianza en el legislador ordinario al no dejar mucha libertad para regular o en su defecto podría hablarse de una desconfianza al intérprete.

Encontramos en esta larga redacción, aspectos tan detalladas sobre la educación, la forma, las modalidades, y muchos otros detalles que solo reflejan una intención desmedida en la regulación de aspectos que si bien es cierto son importantes, deberían estar quizá a disposición del legislador ordinario, quien representaría la voluntad temporal de la generación presente.

En otro caso, el artículo 4to multifacético y multitemático, el problema de la sobre - regulación viene a partir del párrafo 6 relativo que dice:

"Toda persona tiene derecho al acceso, disposición y saneamiento de agua para consumo personal y doméstico en forma suficiente, salubre, acep- 
Esta obra forma parte del acervo de la Biblioteca Jurídica Virtual del Instituto de Investigaciones Jurídicas de la UNAM

table y asequible. El Estado garantizará este derecho y la ley definirá las bases, apoyos y modalidades para el acceso y uso equitativo y sustentable de los recursos hídricos, estableciendo la participación de la Federación, las entidades federativas y los municipios, así como la participación de la ciudadanía para la consecución de dichos fines". Es una disposición como muchas otras donde hay también un mandato al legislador ordinario al exigir que la ley secundaria contenga ciertos aspectos relativos al mandato, sin embargo esa libertad del legislador ordinario esta condicionada al precepto constitucional.

En el mismo artículo, en el párrafo 7mo por ejemplo se estipuló no hace mucho tiempo que: "La autoridad competente expedirá gratuitamente la primera copia certificada del acta de registro de nacimiento". Esta situación refleja un riesgoso paso hacia la adminsitrativización de la Constitución, ya que con el fin de proteger ampliamente el derecho humano a la identidad, se hacen consideraciones del orden civil administrativo, la expedición de un documento acreditativo de la identidad.

En el art- 5to relativo al derecho a la profesión por ejemplo puede leerse: "El contrato de trabajo sólo obligará a prestar el servicio convenido por el tiempo que fije la ley, sin poder exceder de un año en perjuicio del trabajador, y no podrá extenderse, en ningún caso, a la renuncia, pérdida o menoscabo de cualquiera de los derechos políticos o civiles. La falta de cumplimiento de dicho contrato, por lo que respecta al trabajador, sólo obligará a éste a la correspondiente responsabilidad civil, sin que en ningún caso pueda hacerse coacción sobre su persona". Esta redacción podría estar perfectamente tanto en la Ley Federal del Trabajo como en un Código Civil, no en la Constitución, aunque claro, como en muchos otros casos, esto puede deberse a la razón histórica revolucionaria, sin embargo en el Siglo XXI.

$\mathrm{El}$ art. 6 con 1919 palabras, contiene expresiones como: "El Estado garantizará el derecho de acceso a las tecnologías de la información y comunicación, así como a los servicios de radiodifusión y telecomunicaciones, incluido el de banda ancha e internet. Para tales efectos, el Estado establecerá condiciones de competencia efectiva en la prestación de dichos servicios".

Este tipo de redacción tiene la peculiaridad de al ser de detalle introduce palabras contemporáneas como "banda ancha" o "internet". Quizá algunas palabras como avances de la tecnología podría dar cobertura a aspectos tan concretos como los señaladas anteriormente, sin embargo, la propia legislación secundaria tendría que tener la posibilidad de regular aspectos tecnológicos que por su propia naturaleza cambiante deben poder ser reformados de manera sencilla y no tan difícil como lo sería reforma la Consti- 
Esta obra forma parte del acervo de la Biblioteca Jurídica Virtual del Instituto de Investigaciones Jurídicas de la UNAM

tución. Sin contar con que este tipo de términos, haría repensar seriamente sobre los valores, principios y bienes más importantes de una sociedad como la mexicana si consideramos que estas deben estar en una Constitución como la nuestra, quizá habría que pensar si estos son realmente los más importantes como para tener este lugar en el ordenamiento jurídico.

Otra gran sección de nuestra Constitución de la cual se puede hablar de una excesiva regulación es lo relativo al derecho de acceso a la información (apartado A). Incluso cuando ella misma afirma que son los principios y bases bajo los cuales se regirá tal derecho, es evidente que estamos en presencia de una reglamentación detallada. En esta regulación destaca por ejemplo también la fracción VIII con la creación del órgano responsable de garantizar este derecho (con 16 párrafos destinados a su regulación). El apartado $\mathrm{B}$ relativo a la radiodifusión y las telecomunicaciones del art- 6to no es menos detallado, y es como en el caso del internet, un aspecto tan concreto, propio naturalemten de una generación, de la nuestra en este caso que puede ser considerada como la sociedad del conocimiento de las nuevas tecnologías, pero que resulta bastante complicado creer que deba estar en la Constitución y no en una ley que contenga los aspectos técnicos propias del área.

Otro artículo que presenta importantes características de regulación detallada es el 16, uno de los más importantes de nuestro sistema de justicia penal, con más de 1000 palabras con evidente materia penal. En este caso es entendible la importancia de la regulación de detalle, debido a la incidencia que tiene en la libertad del ser humano este artículo, algo que se puede pregonar en buena medida con el art. 18 y el art- 19 que también se pronuncian sobre aspectos penales y de la libertad de las personas, quizá sea conveniente dejar buena parte de esta regulación a las leyes secundarias específicas del ámbito penal, en materia sustantiva y adjetiva. En estos momentos, la regulación es prácticamente un sistema procesal penal.

Dentro de la parte orgánica, la función de uno de los poderes también es excesivamente detallada, como no podía ser de otro modo, ya que la función del Estado Legislador siempre es tan amplia. En concreto el art. 73 relativo a las funciones y facultades legislativas con sus 3176 palabras, naturalmente iba a ser extenso y detallista debido a la búsqueda natural de un Estado de Derecho. Desarrollo y fortalecimiento del principio de legalidad en la que se dé cobertura a la siempre intervención del Estado en la vida de los ciudadanos a través de las leyes.

El art. 79 con 1671 palabras regula la Auditoria Superior de la Federación establece su naturaleza, composición, funcionamiento, que por sus pre- 
Esta obra forma parte del acervo de la Biblioteca Jurídica Virtual del Instituto de Investigaciones Jurídicas de la UNAM

tensiones de concreción se amplía considerablemente, engrosando el contenido de la Constitución, confirmando nuestras primeras observaciones en este trabajo. En concreto, lo relativo a la excesiva institucionalización, algo que debería estar contemplado en leyes reglamentarias, sino más precisamente, en reglamentos administrativos de organización de instituciones.

En la misma línea el art. 99 con 1234 palabras regula el Tribunal Electoral del Poder Judicial de la Federación con una minuciosidad orgánica y administrativa que podría simplificarse desde una perspectiva constitucional. El art. 102 con 1322 palabras regula a detalle el Ministerio Público desde un punto de vista orgánico que bien podría ser regulado en leyes secundarias. El artículo 109 con 1004 palabras relativas al juicio político de los servidores públicos por responsabilidad que bien podría estar regulado en la Ley Federal o estatal de responsabilidades administrativas. Si revisamos nuestro ordenamiento jurídico, encontramos una amplia gama de leyes secundarias y ordinarias que puede perfectamente cubrir esta regulación.

El articulo 113 con 418 palabras que aunque en extensión no es amplio, el contenido relativo al sistema nacional anticorrupción evidentemente indica una forma de organización para erradicar un problema tradicional en México. Algo que podría y en buena medida estar contemplado no solo el leyes ordinarias sino en políticas públicas, normativa administrativa y reglas de menor jerarquía, algunas de las cuales pueda elaborarse de manera unilateral y estratégica para logar el objetivo.

$\mathrm{El}$ art. 115 con 1727 palabras relativas al municipio, solo estableciendo las bases, refleja una incapacidad para describir con palabras más concretas y en menor cantidad unas verdaderas bases constitucionales. Incluso el referirse a esta regulación como bases, denota un falta de precisión, ya que la regulación es tan detallada y excesiva que bien podría dejarse, ya sea a los propios municipios esta regulación o distribuirse en tanto en el legislador, o incluso los estados, solo sería cuestión de hacer una racionalización del poder y de la descentralización administrativa en México, una tarea que por cierto está pendiente. El art. 116 con 2683 palabras relativas al poder público de las entidades de la República y a la forma de organización interna de estas, también puede ser objeto de las mismas observaciones del artículo anterior.

El art. 122 con 3403 palabras hasta antes del reforma de 2016 relativa a la naturaleza jurídica y denominación del Distrito Federal, cambiando a la Ciudad de México, es otro de la grandes artículos que con su extensión intenta asegurar la supervisión por parte del Constituyente, desde su origen hasta su desarrollo. Sion embargo, es excesivamente detallada y con ello se 
Esta obra forma parte del acervo de la Biblioteca Jurídica Virtual del Instituto de Investigaciones Jurídicas de la UNAM

restringe hasta cierto punto la capacidad autónoma de legislar de la propia ciudad de México, lo que en mayor medida se produce en el caso de las entidades federativas.

El art. 123 por ejemplo con sus ya conocidas 3716 palabras y su extensión regulatoria respecto a las leyes sobre el trabajo, sentando (de nuevo) las bases de la legislación, vuelve a ser excesivamente regulatorio. En este caso es evidente la influencia aún marcada por nuestra historia revolucionaria que pregonaba entre otras cosas por los derechos sociales que se encuentran - en materia de trabajo precisamente en este artículo.

\section{CONSECUENCIAS DE UNA SOBRE-REGULACIÓN CONSTITUGIONAL O DE LA ELEGGión DE UNA CONSTITUGión A DETALLE}

La existencia de una Constitución excesivamente detallista provocaría una serie de consecuencias que deben considerarse a la hora del diseño o rediseño que se pretendan en cualquier país y en México no es la expresión. Enlistaremos una serie de esas consecuencias aquí, sin que ello signifique un elenco limitativo o exhaustivo.

A. Limitación de la jurisdicción constitucional. Con una Constitución a detalle se deja poco espacio para la interpretación en su versión más objetiva posible, es decir, no hay campo para la asignación o encuentro de significado en las clausulas constitucionales por parte de los jueces, en particular aquellos que tienen la obligación de resolver problemas constitucionales, ya sea a través del amparo o de cualquier otro proceso constitucional determinado en nuestro ordenamiento jurídico mexicano.

B. Incidencia en la legitimidad democrática de la dirección del país y de la sociedad. Con una Constitución a detalle que sobre pase los límites razonables, se incide en la legitimidad democrática, ya que las generaciones que producen los consenso sociales de manera directa o por medio de los representantes políticos, cambian constantemente como cualquier sociedad. Se muestran valores, principios, voluntades que van generando una necesidad de cambio y adaptación por vía interpretativa. El hecho es que al dejar en manos del poder constituyente originario e incluso del permanente, se limita la generación presente y esta limitación se hace más acuciante y critica en los casos en que la Constitución tenga tantos años como en el caso de México. 
Esta obra forma parte del acervo de la Biblioteca Jurídica Virtual del Instituto de Investigaciones Jurídicas de la UNAM

Sometiendo generaciones presentes y futuras a voluntades muertas y anacrónicas cultural, social, económica y políticamente hablando.

C. Se tecnocratiza la Constitución. Se tecnifica la interpretación y aplicación de la Constitución y se cierra paulatina y progresivamente el grupo de intérpretes adecuados o cualificados para desentrañar el sentido final de las clausulas constitucionales que a la postre son aplicadas en cada uno de los procesos con carácter vinculante. Este elemento, trae consigo la reviviscencia de las críticas aún no salvadas completamente en la teoría de la Constitución, de la legitimidad democrática de los jueces constitucionales controladores del ordenamiento jurídico interno en un país.

D. Sobre - intervención en los derechos humanos. Se presenta una intervención discutible en el espacio de libertad general de las personas en el caso de que la regulación excesiva este en las clausulas sobre derechos humanos. Las decisiones tomadas en el momento constituyente o en épocas futuras por los representantes respecto a los derechos humanos generan un mayor libertad para el Estado al regular con mayor detalle cada actividad de la persona lo que invariablemente reducirá en la misma proporción el espacio de libertad que se puede ver reflejado en todos o algunos derechos específicos, libertad de expresión, tránsito, entre muchos otros.

E. Sobre - intervención en la estructura y división de los poderes. Una Constitución a detalle incide de manera muy intensa en la parte orgánica, sobre todo en materia de organización y funcionamiento de los poderes constituidos. Esta cuestión paradójicamente y a diferencia del punto número 4 anterior. Limita la actuación del Estado, cuestión que quizá este justifica y deseada desde una perspectiva de derechos humanos no así desde una perspectiva del Estado de Derecho, la seguridad jurídica, las instituciones, lo que consecuentemente puede generar una debilidad del Estado sobre todo para abatir problemas de indudable relevancia y urgencia como lo sería el narcotráfico, pobreza, educación, entre otros problemas estructurales.

F. Potencial sobre - regulación de órganos constitucionales autónomos. Los órganos autónomos poseen una naturaleza funcional e institucional necesaria para lograr sus objetivos. Esta característica los posiciona como instituciones que necesitan estar regulados pormenorizadamente, pero en disposiciones secundarias o reglamentarias, ya sea emitida por el Poder Legislativo o por el Poder Ejecutivo. Regular a detalle estos órganos en la Constitución provocaría una sobre carga 
Esta obra forma parte del acervo de la Biblioteca Jurídica Virtual del Instituto de Investigaciones Jurídicas de la UNAM

del contenido del texto constitucional en cuanto a su texto en lo referente a la parte orgánica.

G. Una potencial invasión de facultades y competencias. La sobre-regulación lleva necesariamente el siempre riesgo de invadir esferas de competencias entre los diferentes poderes ejecutivo, legislativo y judicial. En la medida en que se pretenda establecer funciones, facultades, desarrollo interrogantico de instituciones del poder respectivo, en la misma medida se podrá, por descuido o falta de técnica constitucional fusionar o invadir competencias entre los diferentes poderes.

\section{REFLEXIONES CONCLUSIVAS, PROPOSITIVAS Y PROSPECTIVAS}

En principio, es dificil pronunciarse sobre la mejor manera de redactar una Constitución. Sin embargo creo que podemos proponer una combinación de cláusulas abstractas y concretas que logre un equilibro entre un documentos político y un documento normativo eficaz. Este aspecto era destacado por David Strauss como una virtud de la Constitución de los Estados Unidos de América. Entonces aquí surgiría el problema de saber ¿cuál es el equilibrio y medida concreta de cláusulas de detalle y abstractas que debe tener una Constitución, o si se quiere una buena Constitución. La propuesta vendría de asumir la necesidad de que la Constitución posea el número y cantidad de cláusulas de detalle necesarias para preservar los valores más importantes de una sociedad fincados en su origen (en su CONSTITUCIÓN) y por otro lado el número justo de cláusulas abiertas y generales que permitan ir interpretando y asignando el significado propio de cada generación que vive esa Constitución con el objetivo (entre otros) de lograr la plena -o por lo menos, mínima- convivencia en paz para una sociedad civilizada y regulada por el Estado Constitucional de Derecho.

Muchas de las categorías teóricas y clasificaciones de contenido de las Constituciones deben reconsiderarse para adaptarlas a la realidad. Desde momentos constituyentes históricos y ejemplares en la historia constitucional como el de los Estados Unidos de América, donde personajes ilustres afirmaban el contenido y forma de una Constitución, hasta momentos coyunturales, entre los que destaca la aportación de Hans Kelsen en la Europa continental, han ofrecido una buena dosis de certidumbre que ahora debe reafirmarse. El momento actual y seguramente el futuro no muy lejano requiere considerar una realidad evidente, y es el resultado de la convivencia con Constituciones sustanciales, eminentemente valorativas, axiológicas y materiales, iniciada en su mayoría a partir de la segunda mitad del Siglo XX. 
Esta obra forma parte del acervo de la Biblioteca Jurídica Virtual del Instituto de Investigaciones Jurídicas de la UNAM

Asumiendo el peligro detectado por juristas sobre el problema que resultaría las Constituciones materiales, con principios o directrices abstractas, debemos ahora replantearnos si éstas aún son la mejor opción para conducir eficazmente los caminos de la sociedad mundial en aspectos tan relevantes como los principios rectores del Estado y los Derechos Humanos. En el caso de México, las opciones por lograr la concreción, la sistematización y la claridad son posibles, en un momento de coyuntura política, histórica y constitucional en al que nos encontramos a un año del centenario de la Constitución Federal de 1917 y con la propuesta inédita y extraordinaria del Instituto de Investigaciones Jurídicas de la UNAM al respecto.

En esta labor titánica con total seguridad la teoría del Derecho y más concretamente la teoría constitucional tiene una función de primordial relevancia. Es una buena teoría la que daría respuestas lógicas y razonables y por tanto aceptables, al problema que aquí se plantea. En este sentido la exigencia se extiende a la necesidad de una construcción de una teoría moderna y amplia en materia constitucional que ofrezca respuestas a las interrogantes aquí planteadas. Esa sería tarea de investigaciones futuras.

\section{BIBLIOGRAFÍA}

ARAgÓn Reyes, Manuel. Constitución y control del poder. Argentina: Ediciones Ciudad Argentina, 1995, 205 p. LASALLE, Ferdinand. ¿Que es una Constitución?, Barcelona: Ariel, 2001, p. 119. Traducción de W. Roces.

DE LORA, Pablo. La interpretación originalista de la Constitución. Una aproximación desde la Filosofía del Derecho. Madrid: Centro de Estudios Constitucionales, 1998.

ELSTER, Jon. Ulysses unbound: studies in rationality, precommitment, and constraints. Cambridge University Press, 2000, 308 p.

Ferreres Comella, Víctor. "Una defensa de la rigidez constitucional". En Doxa, núm. 23, 2000, pp. $29-47$.

Hesse, Konrad. Escritos de derecho constitucional. Madrid: Centro de Estudios Constitucionales, 1983, 112 p. Introducción y traducción de Pedro Cruz Villalón.

Jefferson, T. Thomas fefferson: political writings. Cambridge: Cambridge University Press, 1999, 623 p.

Linde Paniagua, Enrique. Constitucionalismo democrático. Madrid: Colex, 2002, 116 p. 
Esta obra forma parte del acervo de la Biblioteca Jurídica Virtual del Instituto de Investigaciones Jurídicas de la UNAM

Moreso, Juan José. La indeterminación del Derecho y la interpretación de la Constitución. Madrid: CEPC, 1997, pp. 165 - 167.

Pou Giménez, Francisca. La Constitución de Cádiz y nosotros: reflexiones en torno a los modelos de constitución". En Estudios 104, vol. xi, primavera 2013, p. 110.

Stern, Klaus. Derecho del Estado de la República Federal alemana. Madrid: Centro de estudios Políticos y Constitucionales, 1987, 909 p. Traducción de Javier Pérez Royo y Pedro Cruz Villalón. 
Esta obra forma parte del acervo de la Biblioteca Jurídica Virtual del Instituto de Investigaciones Jurídicas de la UNAM

\title{
GONSTRUGTIVISMO JURÍDICO, ENTROPÍA Y NEGUENTROPÍA EN EL GONSTITUGIONALISMO CONTEMPORÁNEO
}

\begin{abstract}
Sumario: I. Introducción. II. Problema. III. Pregunta de Investigación central. IV. Objetivo de la Investigación. V. Hipótesis. VI. Fustificaciones epistémica, metodológica y teórica. VII. Justificación social. VIII. Presupuestos teóricos y epistemológicos. IX. Modelo formal de la nomodinámica del constitucionalismo pre-globalizado. X. Entropia y neguentropía en el constitucionalismo globalizado. XI. Procesos cognitivos (operadores) para "subsanar" los "defectos" del sistema Z. XII. A modo de conclusión.

XIII. Futuras investigaciones. XIV. Bibliografia.
\end{abstract}

\section{Enrique GÁCERES NIETO*}

\section{INTRODUCGIÓN}

Las teorías jurídicas son artefactos epistémicos, subproductos de reglas de procesamiento cognitivo de información "paradigmática" en los cortes sincrónicos en que son desarrolladas. Es así que la concepción dicotómica del derecho dividido entre el derecho de los hombres y el derecho de los dioses expuesta en Antígona recoge las creencias politeístas de la época; la concepción del derecho como algo emanado de la voluntad divina propuesta por San Agustín y Santo Tomás de Aquino es generada a partir de la escolástica; la arquitectura de la división de poderes de Montesquieu es un producto del estilo de pensamiento característico de la ilustración y el positivismo jurídico es una manifestación de la epistemología empirista. Desde luego y de forma especial en el terreno de las ciencias sociales, una concepción basada

* Investigador de tiempo completo del Instituto de Investigaciones Jurídicas de la Universidad Nacional Autónoma de México, Miembro del Sistema Nacional de Investigadores nivel 3. 
Esta obra forma parte del acervo de la Biblioteca Jurídica Virtual del Instituto de Investigaciones Jurídicas de la UNAM

en algún soporte teórico puede ser el resultado de la integración de dos o más de esos estilos. Es así que en la concepción dominante acerca del derecho integra elementos de la escuela de la exégesis, en tanto que el derecho se encuentra contenido en ciertos textos y las normas que los constituyen se consideran objetivas, "puestas" al igual que los objetos estudiados por la física o la biología.

\section{PROBlema}

Desde un punto de vista cognitivo, la tesis de la objetividad del derecho característica de las representaciones sociales dominantes cubre con un velo de la ignorancia (en un sentido diferente y más literal que el usado por Rawls) a la comprensión de las prácticas que tienen lugar en los procesos de construcción social de la realidad en los que intervienen operadores jurídicos.

Si dicha objetividad fuera correcta: ¿por qué necesitamos recurrir a la interpretación?; ¿por qué dos operadores jurídicos que identifican al mismo enunciado normativo como el aplicable a un caso, pueden entrar en desacuerdo?; ¿por qué pueden surgir contradicciones aún entre instancias del más alto nivel como ocurre en el caso de los Tribuales Colegiados en México?

En congruencia con los presupuestos referidos previamente, lo que en las prácticas jurídicas es denotado por 'derecho' sobre todo en la familia romano-germánica, tiene un dominio de denotación que privilegia a los textos legislativos y constitucionales.

La tesis del objetivismo ingenuo que identifica al derecho con los enunciados contenidos en los cuerpos normativos, incluyendo a las constituciones, no puede ser admitida debido a que la determinación de las normas aplicables al caso concreto requieren del procesamiento cognitivo de los operadores jurídicos y no de un mero acto de constatación o reconocimiento. Conforme a esto, lo que podemos denotar como 'norma jurídica' no se refiere a los enunciados normativos, sino a las proposiciones normativas, a los significados atribuidos a dichos enunciados por parte de los operadores jurídicos.

Con base en lo anterior, surge una pregunta fundamental con respecto a la identidad de lo que denotamos con "constitución": ¿la expresión "constitución' denota al conjunto de los enunciados contenidos en el texto constitucional, o al conjunto de todas las proposiciones normativas generables a 
Esta obra forma parte del acervo de la Biblioteca Jurídica Virtual del Instituto de Investigaciones Jurídicas de la UNAM

partir de dicho texto mediante la aplicación de las reglas de procesamiento cognitivo por parte de los operadores jurídicos?

Responder a esta cuestión no es nada fácil si consideramos como fuente sólo al texto o carta constitucional, pero se complica de manera exponencial si la identidad unitaria de dicho texto deja de ser el referente único para las decisiones de constitucionalidad.

El paso de una concepción del constitucionalismo centrado en la constitución como un sistema cerrado, a otra como sistema abierto en el que los enunciados del texto constitucional pierden el monopolio de ser fuentes de las decisiones constitucionales, caracteriza al constitucionalismo de la globalización. Una manifestación palpable de este fenómeno se encuentra en el surgimiento del concepto de bloque de constitucionalidad.

Con la globalización jurídica, las discrepancias entre distintas interpretaciones de los enunciados constitucionales (aquellos que se encuentran contenidos en el bloque de constitucionalidad) presenta un problema adicional. Los operadores jurídicos, especialmente los jueces, no únicamente pueden tener discrepancias respecto a la construcción semántica de las normas constitucionales, sino también respecto a la selección de los insumos sobre los que habrán de realizar su tarea interpretativa, entre enunciados que van más allá de los producidos por el constituyente.

Otra de las consecuencias derivadas de la globalización jurídica que se suma a las anteriores consiste en el surgimiento de una comunidad interpretativa difusa, organizada en forma de red trasnacional de operadores jurídicos. Una manifestación interesante de este fenómeno radica en la exportación de argumentos usados por jueces de jurisdicciones diferentes, pertenecientes a una red judicial internacional.

En forma sumaria podemos decir que el constitucionalismo contemporáneo se caracteriza por su carácter difuso en lo que se refiere a la identificación de las fuentes de la normatividad. Estas incluyen tanto una comunidad heterogénea de agentes generadores de dichos textos (los jueces de otras jurisdicciones cuyos argumentos son empleados para fundamentar decisiones adjudicativas, decisiones de la Corte Interamericana de Derechos Humanos, de la Comisión Interamericana de Derechos Humanos, del Tribunal Europeo, etc.), como de textos normativos (tratados internacionales, sentencias de instituciones internacionales, soft law, etc.). Este carácter difuso trae aparejado el riesgo de incoherencia del sistema constitucional contemporáneo, cada vez más trasnacional, pero también menos definido. Por otra parte, si tal como hemos señalado el término 'norma jurídica' no denota a los enunciados de un sistema, independientemente del criterio empleado para determinar su 
Esta obra forma parte del acervo de la Biblioteca Jurídica Virtual del Instituto de Investigaciones Jurídicas de la UNAM

membrecía, sino a los constructos normativos generados por los operadores jurídicos, entonces la coherencia de un sistema de constitucionalidad estará determinada por las relaciones entre las proposiciones normativas producidas en el contexto difuso previamente referido. El grado de incoherencia de dicho sistema, o dicho en términos cibernéticos, su grado de entropía, redunda en la certeza jurídica y comprensión del sistema mismo.

\section{PREgunTA DE INVESTIGACIÓN CENTRAL}

¿Es posible generar un modelo teórico que permita prevenir la entropía y en su caso "neguentropizar" al sistema de constitucionalidad que está emergiendo durante el proceso de la globalización jurídica?

\section{OBJETIVO DE LA INVESTIGACIÓN}

Lo que me propongo en este trabajo es analizar el fenómeno apuntado desde la perspectiva del constructivismo jurídico, con el objeto de esbozar un modelo que prevenga y facilite la "neguentropización" del sistema, es decir, que contribuya a reducir el grado de desorden que pudiera generarse en los sistemas constitucionales por su falta de coherencia.

\section{HIPÓTESIS}

Es posible generar dicho modelo, incluso mediante el desarrollo de un sistema computacional.

\section{JUSTIFICACIONES EPISTÉMICA, METODOLÓGICA Y TEÓRICA}

El trabajo constituye un desarrollo generado a partir de la teoría general que constituye mi investigación principal a la que he denominado: "Constructivismo Jurídico".

\section{JUSTIFICACIÓN SOCIAL}

Ejercer control intersubjetivo sobre las decisiones judiciales relativas a la constitucionalidad. 
Esta obra forma parte del acervo de la Biblioteca Jurídica Virtual del Instituto de Investigaciones Jurídicas de la UNAM

\section{PResupuestos TeÓRICOS Y EPISTEMOLÓGICOS ${ }^{1}$}

\section{A. Constructivismo jurídico (C.F.)}

Constituye la propuesta en que he estado trabajando desde hace ya varios años y que defino como: Un enfoque epistémico, teórico y metodológico, naturalizado mediante la integración de las ciencias cognitivas y la teoría de los sistemas complejos, cuyo objetivo es actualizar nuestra comprensión de la incidencia del derecho positivo y la teoría jurídica en la construcción social de la realidad a través de agentes e instituciones.

\section{B. Definición de 'Derecho' para el Constructivismo Furídico}

"Derecho" es una palabra polisémica entre cuyos significados se encuentran: derecho positivo, derecho natural, derecho objetivo, derecho subjetivo, "ciencia" del derecho y derecho en sentido coloquial.

Para el C.J. el sentido nuclear de la expresión es: Conjunto de subconjuntos no vacíos de textos constitutivos, creados por agentes constituidos por textos pertenecientes al mismo sistema. Dichos textos constituyen potenciales de significación y de acción a partir de su corporeización como reglas de interacción por parte de los agentes e instituciones por ellos constituidos.

\section{Conceptos cognitivos básicos:}

No es este el lugar para exponer todos los conceptos característicos del constructivismo jurídico, muchos de los cuales ya han sido expuestos en otros trabajos ${ }^{2}$ de derecho constitucional. Me limito a referir de manera sucinta solo algunos que funcionarán como columna vertebral de este trabajo.

1 Cáceres, Enrique, Constructivismo Furídico y Metateoría del Derecho, México, Instituto de Investigaciones Jurídicas, UNAM, 20

$2 \mathrm{Al}$ respecto véase: Cáceres, Enrique: La Constitución Emergente (Un ensayo de meta-teoría constitucional desde el constructivismo jurídico), México, Instituto de Investigaciones Jurídicas, UNAM, 2007 y Cáceres, Enrique, Repensando el concepto de "Derecho" en la era de la globalización (Consideraciones metateóricas con referencia especial al derecho constitucional), Gobernanza Global y cambio estructural del sistema jurídico mexicano, México, Instituto de Investigaciones Jurídicas, UNAM, 2016 
Esta obra forma parte del acervo de la Biblioteca Jurídica Virtual del Instituto de Investigaciones Jurídicas de la UNAM

a) Agente: Para el C.J., los hombres son considerados como procesadores de información, no únicamente de manera racional e inferencial, sino también corporeizada.

b) Operandos, operadores y clausura de operación (outcomes): El procesamiento racional de los agentes implica dos tipos de elementos: 1) los operandos, es decir, los elementos sobre los que se realiza el procesamiento y 2) los operadores o reglas con las que se realiza el procesamiento de los operandos. Por ejemplo, tanto la adición; " $2+3$ "; como en la multiplicación: " 2 x 3" tenemos los mismos operandos $(2,3)$, pero distintos operadores $(+, \mathrm{x})$ y diferentes outcomes o clausuras de operación $(5,6)$. En el terreno del derecho, un mismo enunciado normativo (operando) podría ser procesado a partir de diferentes operadores correspondientes a distintos métodos de interpretación: literal, analógica, extensiva, restrictiva, etc. (operadores) y dar lugar a distintas propuestas de constructos normativos (las interpretaciones resultantes).

c) Propiedad Multiplexora: Un mismo agente puede emplear distintas bases de conocimiento correspondientes a distintos tipos de operandos, con diferentes operadores para producir diferentes clausuras de operación. Dichas bases pueden pertenecer a dominios distintos. Por ejemplo, alguien puede procesar información proveniente de textos filosóficos en la mañana, en la tarde seguir una partitura musical mientras escucha una versión de su obra favorita e interpretar textos religiosos en la noche. Pero también es posible que la propiedad multiplexora tenga lugar dentro de un mismo dominio. Por ejemplo, un juez de lo familiar activa distintas bases de conocimientos con distintos operandos y operadores para distintos casos: un divorcio, la solicitud de una pensión alimenticia, etc. Desde luego, dos operadores jurídicos pueden procesar de manera diferente y razonable el mismo caso en función de los operandos y operadores que seleccionen, dando lugar a interpretaciones contradictorias, lo que redunda en un incremento en el grado de entropía del sistema.

\section{Conceptos básicos provenientes de las ciencias de la complejidad: ${ }^{3}$}

a) Sistema adaptativo complejo: Conjunto de elementos homogéneos o heterogéneos, cuya dinámica no es producto de una unidad de control central, sino de los procesos autoorganizativos que tienen lugar entre sus

3 Cáceres, Enrique, Constructivismo Furídico y Metateoría del Derecho, México, Instituto de Investigaciones Jurídicas, UNAM, 2007 
Esta obra forma parte del acervo de la Biblioteca Jurídica Virtual del Instituto de Investigaciones Jurídicas de la UNAM

elementos constitutivos y que se adapta a las modificaciones de su entorno. Por ejemplo, cada neurona individualmente considerada es un agente estúpido, pero de la interacción autoorganizativa de nuestras neuronas emerge el pensamiento que se adapta a diferentes contextos.

b) Red compleja: Forma de representación de los sistemas complejos, constituida por nodos y aristas o conectores. La dinámica de la constitucionalidad durante la globalización puede modelarse como un sistema adaptativo complejo representable mediante una red de fundamentaciones jurídicas y decisiones adjudicativas que se interconectan a nivel global. Por ejemplo, todas las decisiones locales que han adoptado los criterios de la Corte Interamericana de Derechos Humanos.

c) Entropía: En estricto sentido es un término perteneciente a la física relacionado con la segunda ley de la termodinámica. Permite medir el grado de desorden molecular de un sistema, debido al intercambio de energía que realiza con su entorno durante su evolución. Sin embargo, debido a su capacidad de extensión analógica para explicar fenómenos distintos a la termodinámica, se extendió a otras áreas del conocimiento. Por ejemplo, en teoría de la información denota a la medida de incertidumbre que se produce por un conjunto de mensajes.

Su aplicación analógica se ha extendido a terrenos tales como la administración o la economía.

En este trabajo se usa en un sentido próximo al empleado en la teoría de la información y se refiere a la medida del grado de incertidumbre derivado de una diversidad de enunciados y proposiciones normativas. Con base en ello, podemos decir que, por ejemplo, el número de contradicciones en un sistema normativo, o el número de criterios diversos para resolver un mismo tipo de casos, o la diversidad de criterios para seleccionar materiales diferentes como enunciados normativos, son indicativos del grado de incertidumbre de la comunidad jurídica para la cual ese sistema de normas es válido.

d) Neguentropía: También perteneciente a la termodinámica, este término se refiere a la exportación de energía inútil realizada por un sistema para mantener su estado de equilibrio.

La expresión ha corrido la misma suerte que 'entropía' y hoy se usa analógicamente para indicar el grado en que se puede revertir la medida de entropía de un sistema. Por ejemplo, en teoría de la información, la eliminación de mensajes contradictorios lleva a un decremento de la incertidumbre producida por el conjunto de dichos mensajes, es decir, disminuye su grado de entropía: "neguentropiza" al sistema. 
Esta obra forma parte del acervo de la Biblioteca Jurídica Virtual del Instituto de Investigaciones Jurídicas de la UNAM

En el caso del derecho, la eliminación de la contradicción entre normas mediante derogación de alguna de ellas, o la determinación de uno de los criterios contradictorios generados por Tribunales Colegiados permite "neguentropizar" al sistema.

Este concepto es básico en este trabajo dado que busca proporcionar un modelo apto para evitar la entropía en el constitucionalismo contemporáneo y, en su caso, "neguentropizarlo".

\section{E. Conceptos básicos de análisis semántico ${ }^{4}$}

Con base en la dicotomía elaborada por Saussure entre un elemento empíricamente perceptible (el significante) y el resultado de atribuir sentido a ese significante (el significado), junto con la teoría de los agentes como procesadores de información, puede decirse que los significantes son operandos, su procesamiento corresponde a las reglas cognitivas por las que se les atribuye significado y el significado es el outcome o clausura de operación.

Los operadores propios del análisis semántico de las palabras son los que hacen posible determinar si una expresión es polisémica, si tiene sinónimos, si está afectada de vaguedad o de ambigüedad, etc.

En una escala gramatical superior, los enunciados conformados por significantes organizados conforme a las reglas gramaticales de un idioma también son operandos, cuyo contenido proposicional o significado corresponde al outcome resultante de su procesamiento mediante operadores cognitivos.

La relación entre la semántica de las palabras y la proposicional es innegable, pues el significado de los enunciados, se determina a partir de los significados de las palabras que constituyen su significante. Por ejemplo: al procesar el enunciado; 'Juan fue detenido con un ladrillo (operando), se obtienen al menos tres proposiciones distintas (outcomes o clausuras de operación): P1 A Juan le dieron un ladrillazo; P2: A Juan se le impidió que continuara su camino cuando llevaba un ladrillo (material de construcción); P3: Juan fue aprehendido cuando llevaba un paquete de droga, mismos que corresponden a la actualización del potencial de significación del enunciado.

4 Para un tratamiento más extenso véase: Cáceres, Enrique, ¿Qué es el derecho? Iniciación a una concepción lingüística, 2000, México, UNAM, IIJ, y Cáceres, Enrique, Lenguaje y Derecho, las normas jurídicas como sistema de enunciados, 2000, México, UNAM, IIJ,. Si se tiene interés en realizar ejercicios de análisis proposicional, Véase ejercicios de Cáceres Enrique, Introducción Práctica al cálculo lógico aplicado al derecho, Capítulo "Cálculo Lógico"., Ed. Porrúa, México, 2014 
Esta obra forma parte del acervo de la Biblioteca Jurídica Virtual del Instituto de Investigaciones Jurídicas de la UNAM

Como es fácil observar, la semántica de la proposición es el resultado de la polisemia de las palabras que lo constituyen.

\section{F. Implicaciones de los conceptos anteriores en el esbozo de una teoría constructivista de la interpretación jurídica.}

'Interpretar' es un término afectado de ambigüedad proceso-producto. En el sentido "proceso" denota la acción consistente en aplicar las reglas de procesamiento de información propias de la profesión a enunciados o textos normativos.

En el sentido de "producto" denota a la clausura de operación resultante del procesamiento de información. Esto equivale a la norma o conjunto de normas jurídicas resultantes de la interpretación.

El modelo del procesamiento de información presentado previamente es compatible con la ambigüedad de 'interpretación' dado que su sentido de proceso corresponde con las reglas de procesamiento de información, mientras que su sentido de producto denota al outcome obtenido de procesar los operandos.

En el derecho constitucional dichos operandos son los enunciados contenidos en los textos constitucionales y los outcomes las proposiciones que actualizan su potencial de significación, obtenidas después de la aplicación de los operadores semánticos.

A pesar de ser correcta, una teoría de la interpretación jurídica queda incompleta si únicamente hace referencia a reglas de procesamiento semántico pues, además de éstas, que son las mismas empleadas por cualquier procesador de lenguaje, los operadores jurídicos cuentan con operadores propios de su profesión. Estos son de carácter hermenéutico y corresponden a lo que se conoce como métodos de interpretación: Entre ellos pueden citarse algunos considerados clásicos como son la interpretación literal, la extensiva, restrictiva, sistemática, a contrario, teleológica, analógica, etc., y otros provenientes fundamentalmente de la filosofía del derecho contemporánea como es el caso de la propuesta interpretativa de Dworkin o la teoría de la ponderación de Alexy.

Además de las reglas de procesamiento de enunciados, ya sea mediante procesamiento semántico o hermenútico, otras reglas de procesamiento son de carácter estructural y están vinculadas con la conectividad interna del sistema de enunciados. Por ejemplo, las reglas de conectividad explícita (remisiones normativas) o implícitas gracias a las cuales se conectan enunciados normativos que pueden estar dispersos a lo largo del sistema para, a 
Esta obra forma parte del acervo de la Biblioteca Jurídica Virtual del Instituto de Investigaciones Jurídicas de la UNAM

partir de la conexión y conjuntamente con el procesamiento semántico y/o hermenéutico, generar un constructo normativo.

A las reglas estructurales habría que agregar otras que cobran particular importancia en el contexto de este trabajo y que son las que buscan mantener la coherencia del sistema, es decir, prevenir y en su caso "neguentropizarlo". Son ejemplos de estas reglas: en caso de contradicción entre una norma general y otra particular prevalece la particular; en caso de contradicción entre una norma posterior y una anterior prevalece la posterior, etc. Dicho tipo de reglas no únicamente operan respecto de los enunciados normativos, sino también entre interpretaciones. Por ejemplo: de dos interpretaciones normativas, una de las cuales niega sentido al contenido de un enunciado normativo y otra le asigna sentido, prevalece la que le asigna sentido: de dos interpretaciones normativas, una de las cuales permite resolver un universo de casos superior a otra interpretación, prevalece la que permite resolver mayor número de problemas, etc.

\section{G. Alcances del esbozo de teoría constructivista de la interpretación en la filosofia del derecho constitucional.}

Una discusión añeja que ha recuperado nueva fuerza en la filosofía del derecho constitucional contemporánea es la protagonizada por posturas anti-textualistas, originalistas e interpretativistas. Desafortunadamente, por razones de espacio y de los objetivos de este trabajo no me detendré a exponer las diferentes posturas y sus representantes. En todo caso, doy por sentada la familiaridad con la misma por parte del auditorio de especialistas a quien va dirigido este trabajo.

De manera sumamente sintética: los originalistas se oponen a la interpretación evolutiva de la constitución por parte de los jueces argumentando su falta de legitimidad social al no ser electos democráticamente y por tanto arguyen que no pueden desviarse de lo establecido por los órganos constituyentes que sí cuentan con esa legitimidad. Por otra parte, señalan el riesgo de dejar al derecho en manos de una aristocracia hermética. Los antitextualistas se oponen a los textos constitucionales argumentando que constituyen un obstáculo para la flexibilidad requerida por el derecho para irse adaptando a nuevos contextos, problemas y circunstancias sociales. Finalmente, para los interpretativistas, los textos constitucionales no constituyen un obstáculo para la evolución del derecho y rechazan la crítica por la falta de legitimidad a jueces racionales. La versión más influyente dentro de esta postura es la que utiliza la analogía de los textos constitucionales como 
Esta obra forma parte del acervo de la Biblioteca Jurídica Virtual del Instituto de Investigaciones Jurídicas de la UNAM

un árbol viviente cuyas ramas van creciendo de manera natural dentro de las limitaciones que su estructura original les impone.

Naturalizando las tres posturas desde el constructivismo jurídico, encontramos que el modelo originalista asume un sistema con agentes que no comparten un estilo de procesamiento de información definido, sino que las decisiones son dejadas a la discrecionalidad de los mismos. Si tal como hemos visto, aun contando con textos constitucionales y un arsenal de reglas de procesamiento de la información compartidos por la comunidad judicial se corre un gran riesgo de generar un sistema entrópico, con más razón ocurriría esto si la generación de constructos normativos se deja al libre albedrío de los operadores jurídicos, sobre todo durante el actual proceso de globalización.

Por su parte, los antitextualistas proponen un sistema constitucional con agentes carentes de funciones adaptativas al momento de generar constructos normativos, lo cual, como se verá a continuación, va en contra de las propiedades biológicas de nuestra cognición.

En mi opinión y conforme a los estándares de aceptación epistémica impuestos por la naturalización cognitiva, la tesis más justificable corresponde a la sostenida por los interpretativistas que suscriben la metáfora del árbol viviente.

Nuestro sistema cognitivo, de manera autoorganizativa y corporeizada, es decir, sin que necesariamente intervenga el control consciente, es un sistema adaptativo complejo en constante adaptación a los cambios del entorno. Gracias a ello comprendemos el mundo, interactuamos con él y resolvemos los problemas que nos desafían.

Estas propiedades adaptativas constituyen la base cognitiva para la evolución del lenguaje, de la moral, de las prácticas políticas y desde luego la evolución del derecho en función de la dinámica social. Luego entonces, aun si contamos con textos constitucionales su aplicación y protección por parte de los agentes cognitivos que son los jueces, no puede ser fija e inmutable. Cada vez que un nuevo problema requiere de una solución práctica a efecto de proteger algún derecho constitucional las estructuras adaptativas de nuestro sistema cognitivo entran en acción.

Por otra parte, estudios muestran que las estructuras o modelos mentales disponibles de los sujetos cognoscentes, generadas con base en experiencias previas, son las que determinan la generación adaptativa de nuevas estructuras cuando nos enfrentamos a problemas novedosos. De hecho nuestra tendencia natural consiste en interpretar el mundo con base en los modelos mentales o estructuras cognitivas que han emergido a partir de experiencias previas. El juego conocido como "tetris" es una buena metáfora para explicar la forma en que la configuración de estructuras previas constituyen los andamios en los que las nuevas estructuras serán acopladas. 
Esta obra forma parte del acervo de la Biblioteca Jurídica Virtual del Instituto de Investigaciones Jurídicas de la UNAM

Una vez que la metáfora del árbol viviente ha sido naturalizada considerando las propiedades cognitivas descritas previamente, resulta plenamente justificada. Los términos abstractos y la textura semántica abierta empleados en los textos constitucionales son el equivalente a las estructuras iniciales del juego del tetris; constituyen el punto de partida para la futura actualización del potencial de significación de los textos constitucionales.

En la misma línea argumentativa que estamos desarrollando y en relación con la propiedad multiplexora referida anteriormente, Gregory Bateson ${ }^{5}$ sostiene que tenemos distintos "yoes situacionales" en relación a los contextos en que interactuamos: Esta identidad contextual es la que se manifiesta de manera distinta cuando estamos en una ceremonia solemne en la mañana y cuando asistimos a una fiesta en la noche.

Desde esta perspectiva, resulta claro que la mente de los jueces se conforma en función del universo simbólico que caracteriza a su comunidad de referencia. La influencia de ese universo simbólico en el cual ha sido socializado opera fuera de su control consciente. La comunidad judicial opera como un mecanismo de control intersubjetivo que restringe y controla los significados atribuidos a los enunciados constitucionales por parte de los jueces y por tanto, la generación de constructos normativos.

\section{H. La metáfora del árbol viviente como sistema adaptativo complejo $y$ sus limitaciones como explanans}

La metáfora del árbol viviente es consistente con los resultados tanto de las ciencias cognitivas, como de las ciencias de la complejidad y en ese sentido también es compatible con el constructivismo jurídico.

Para el C.J., los jueces son agentes procesadores de información (multiplexores) que comparten un arsenal de reglas de procesamiento de información y criterios para identificar los operandos sobre los que tienen que actuar. Estos operandos se contienen en los textos constitucionales, cuyo potencial de significación es actualizado cuando los jueces construyen los constructos normativos (outcomes) mediante la aplicación de las reglas de operación como las ejemplificadas en el esbozo de teoría de la interpretación constructivista previamente expuesta. El riesgo de la entropía del sistema se limita por el control intersubjetivo ejercido por la comunidad de operadores jurídicos en el que interactúan y son socializados los jueces. Es decir por

5 Bateson, Gregory., Pasos hacia una ecología de la mente, Buenos Aires, Ediciones Carlos Lohlé, 1972. 
Esta obra forma parte del acervo de la Biblioteca Jurídica Virtual del Instituto de Investigaciones Jurídicas de la UNAM

virtud de la interacción autoorganizativa que los jueces tienen en el entorno en el que se desempeñan.

Sin embargo, a pesar de sus virtudes epistémicas, el modelo anterior resulta limitado para dar cuenta del proceso que está teniendo lugar en el constitucionalismo contemporáneo. El explanandum para el cual resulta apto corresponde a lo que podríamos llamar "constitucionalismo pre-globalizado" en el cual los operadores jurídicos elegían los operandos dentro del universo cerrado de los enunciados contenidos en los textos constitucionales. Sin embargo, como se estableció previamente, la evolución misma del constitucionalismo derivada de la autoorganizatividad impuesta por la globalización presenta una dinámica muy distinta con propiedades que ya no son cubiertas por el explanans del modelo evolutivo.

Como se ha indicado anteriormente, el paso de sistema cerrado a sistema abierto global lleva aparejado el riesgo de entropía en el sistema de proposiciones normativas globalmente generadas, mismas que se van agregando a la manera de nodos de una red compleja a nivel global sin surgir de una fuente constituyente única y menos estática encerrada en un texto constitucional.

Lo que desarrollaré a continuación es un modelo de las condiciones ideales del sistema de constitucionalidad en la época de la globalización cuya finalidad es prevenir la entropía autoorganizativa y en su caso neguentropizarla a través del conjunto de operadores aplicables a los distintos textos que contengan enunciados constituicionales.

En primer término me centraré en levantar un modelo formal de los sistemas constitucionales pre-globalizados para, a partir de ahí, generar un modelo alternativo sobre las condiciones ideales de un sistema de constitucionalidad globalizado.

\author{
IX. MODELO FORMAL DE LA NOMODINÁMICA \\ DEL GONSTITUCIONALISMO PRE-GLOBALIZADO
}

\begin{abstract}
A. Definiciones simbólicas:
$\mathrm{S}=$ Sistema jurídico

$\mathrm{Z}=$ Sistema normativo jurídico globalizado.

$\mathrm{Q}=$ Soft law
\end{abstract}


Esta obra forma parte del acervo de la Biblioteca Jurídica Virtual del Instituto de Investigaciones Jurídicas de la UNAM

$\mathrm{V}=(\mathrm{n} \mid \mathrm{n}$ es una norma válida); Se lee: toda norma "n" talque "n" es una norma válida. Las fórmulas subsecuentes con la misma estructura formal se leen de manera equivalente.

$\mathrm{K}=(\mathrm{n} \mid \mathrm{n}$ es una norma creada por el poder constituyente)

$\mathrm{C}=$ (nIn es una norma constitucional)

$\mathrm{G}=(\mathrm{nIn}$ es una norma general)

$\mathrm{L}=$ (nIn es una norma legislada)

$\mathrm{J}=$ (nln es una norma jurisprudencial)

$\mathrm{I}=$ (nIn es una norma jurisprudencial internacional)

$\mathrm{D}=(\mathrm{nIn}$ es una norma individualizada)

$\mathrm{V}=$ (nIn es una norma válida)

$\mathrm{T}=$ (nIn es una norma contenida en instrumentos internacionales)

$\mathrm{W}=$ (nIn es creada conforme a una norma válida)

$\mathrm{F}=$ (nIn es creada conforme a un norma válida que regula el proceso de creación normativa)

$\mathrm{A}=$ (nIn es una norma individualizada creada mediante la aplicación de una norma general)

$\mathrm{U}=(\mathrm{n} \mid \mathrm{n}$ es una norma subconstitucional)

$\mathrm{H}=(\mathrm{n} \mid \mathrm{n}$ establece derechos humanos)

$\uparrow=$ Norma derrotante. Una norma es derrotante es aquella que elimina a otra con la que ha entrado en conflicto.

$\rightarrow £ \leftarrow=$ Contradicción lógica. Se presenta una contradicción lógica cuando dos normas contienen o proporcionan soluciones al mismo caso con operadores deónticos excluyentes.

$\rightarrow_{\bar{A}} \leftarrow=$ Contraposición axiológica. Se presenta contraposición axiológica cuando se asume que la eficacia de una norma puede obstaculizar la emergencia de un estado de cosas considerado valioso. Desde luego no excluye el caso en que las normas en contraposición tengan ambas contenido axiológico.

\section{B. Nomodinámica del constitucionalismo pre-globalizado.}

Es frecuente escuchar interpretaciones equivocadas acerca del constructo teórico desarrollado por Kelsen denotado por 'Grundnorm'. La distorsión más frecuente y relevante para este trabajo es la que sostiene que dicho término denota a las constituciones dadas. Sin embargo, los estatus epistémicos que este autor atribuyó a su propio constructo en obras correspondientes a etapas distintas de su evolución intelectual nada tienen que ver con esa afirmación. Ya fuere como supuesto hipotético trascendental (Teo- 
Esta obra forma parte del acervo de la Biblioteca Jurídica Virtual del Instituto de Investigaciones Jurídicas de la UNAM

ría Pura del Derecho) ${ }^{6}$ o como Als $O b$ (Teoría General de las Normas) ${ }^{7}$, al naturalizar dicho constructo se pone de relieve que se está refiriendo a una creencia implícita en las representaciones sociales de la comunidad jurídica: Actuar conforme a lo que establezca cualquier constitución dada.

La tergiversación de la propuesta kelseniana a través de blancos de paja es la que hace posibles algunos de los desatinados contra-argumentos que supuestamente impactan en su pensamiento; entre ellos, que el concepto de Grundnorm no soporta la objeción de los cambios de constitución por vía revolucionaria, o que el estatus epistémico de la Grundnorm en realidad es el de una norma moral con lo que rompe el compromiso de la pureza metódica. Sea como fuere, no insistiré aquí en este debate por no ser el sitio para hacerlo, sin embargo sí deseo resaltar el encuadre naturalizado del concepto como creencia central en las representaciones sociales de los juristas, porque es el que opera como regla de reconocimiento necesario para la identificación de las reglas que forman parte de un sistema dado. Es relevante referir dicha creencia en este trabajo porque es precisamente lo que está evolucionando durante el proceso de globalización.

Con base en lo anterior, el papel de la constitución como regla de reconocimiento (o sistema de reglas de reconocimiento) y su función generadora de cualquier sistema jurídico " $\mathrm{S}$ " es modelada formalmente en los siguientes términos:

a)Definiciones para el modelo nomodinámico de S:

1. $(\forall \mathrm{n})(\mathrm{n} \in \mathrm{K}) \leftrightarrow(\mathrm{n} \in \mathrm{G})$

2. $(\forall \mathrm{n})(\mathrm{n} \in \mathrm{C}) \rightarrow(\mathrm{n} \in \mathrm{V})$

3. $(\forall \mathrm{n})(\mathrm{n} \in \mathrm{W}) \rightarrow(\mathrm{n} \in \mathrm{V})$

Guya interpretación es:

1. $(\forall \mathrm{n})(\mathrm{n} \in \mathrm{K}) \leftrightarrow(\mathrm{n} \in \mathrm{C})$ : Para toda norma "n", si y sólo si pertenece al conjunto de las normas creadas por el poder constituyente $(\mathbf{K})$, entonces pertenece al conjunto de las normas constitucionales $(\mathrm{C})$ para el sistema $\mathrm{S}$.

2. $(\forall \mathrm{n})(\mathrm{n} \in \mathrm{C}) \rightarrow(\mathrm{n} \in \mathrm{V})$ : Para toda norma "n", si pertenece al conjunto de las normas constitucionales $(\mathrm{C})$, entonces pertenece al conjunto de las normas válidas $(\mathrm{V})$ para el sistema $\mathrm{S}$.

6 Kelsen, Hans, Teoría Pura del Derecho, Trad. Vernengo, Roberto J., $2^{\circ}$ Edición, , México, Instituto de Investigaciones Jurídicas, UNAM ,1982

7 Kelsen, Hans, Teoría General de las Normas, México, Ed. Trillas, 2007, 
Esta obra forma parte del acervo de la Biblioteca Jurídica Virtual del Instituto de Investigaciones Jurídicas de la UNAM

3. $(\forall \mathrm{n})(\mathrm{n} \in \mathrm{W}) \rightarrow(\mathrm{n} \in \mathrm{V})$ : Para toda norma "n" si pertenece al conjunto de las normas creadas conforme a una norma válida $(\mathrm{W})$, entonces es una norma válida $(\mathrm{V})$ para el sistema $\mathrm{S}$.

Por razones de economía, en lo sucesivo dejaré de hacer explícita la referencia a $\mathrm{S}$.

4. $(\forall \mathrm{n})(\mathrm{n} \in \mathrm{G}) \leftrightarrow(\mathrm{n} \in \mathrm{F})$ : Para toda norma "n", pertenece al conjunto de las normas generales $(\mathrm{G})$ si y solo si pertenece al conjunto de las normas creadas conforme a normas válidas que regulan el proceso de creación normativa $(\mathrm{F})$.

5. $(\forall \mathrm{n})(\mathrm{n} \in \mathrm{L}) \rightarrow(\mathrm{n} \in \mathrm{G})$ : Para toda norma " $\mathrm{n}$ ", si pertenece al conjunto de las normas las (L), entonces pertenece al conjunto de las normas generales $(G)$.

6. $(\forall \mathrm{n})(\mathrm{n} \in \mathrm{J}) \rightarrow(\mathrm{n} \in \mathrm{G})$ : Para toda norma "n", si pertenece al conjunto de las normas jurisprudenciales (J), entonces sí pertenece al conjunto de las normas generales $(\mathrm{G}) . \leftrightarrow(n \in F)$ : Para toda norma "n", pertenece al conjunto de las normas legisladas (L) sí y solo sí pertenece al conjunto de las normas creadas conforme a normas válidas que regulan el proceso de creación normativa $(\mathrm{F})$.

7. $(\forall \mathrm{n})(\mathrm{n} \in \mathrm{D}) \leftrightarrow(\mathrm{n} \in \mathrm{A})$ : Para toda norma "n", pertenece al conjunto de las normas individualizadas (D) si y sólo si pertenece al conjunto de las normas válidas que aplican normas generales (A).

b)Leyes de la nomodinámica:

Aplicando la ley lógica de la bicondicionalidad (conforme a la cual de un bicondicional se infiere un condicional para cada sentido de la bicondicionalidad) a:"4", conjuntamente con " 2 ", "5" y "6" se construye el siguiente sistema de premisas:

$$
\begin{aligned}
& \text { 8. }(\forall n)(n \in G) \rightarrow(n \in F) \\
& \text { 9. }(\forall n)(n \in F) \rightarrow(n \in W) \\
& \text { 10. }(\forall n)(n \in W) \rightarrow(n \in V)
\end{aligned}
$$

De las cuales, mediante aplicación de la ley del silogismo hipotético se sigue:

$\therefore$

$(\forall \mathrm{n})(\mathrm{n} \in \mathrm{G}) \rightarrow(\mathrm{n} \in \mathrm{V})$ : cuya interpretación es: si una norma pertenece al conjunto de las normas generales, entonces pertenece al conjunto de las normas válidas.

Incorporando las normas que pertenecen al conjunto de normas legisladas al argumento anterior se obtiene; 
Esta obra forma parte del acervo de la Biblioteca Jurídica Virtual del Instituto de Investigaciones Jurídicas de la UNAM

$$
\begin{aligned}
& \text { 11. }(\forall \mathrm{n})(\mathrm{n} \in \mathrm{L}) \rightarrow(\mathrm{n} \in \mathrm{G}) \\
& \text { 12. }(\forall \mathrm{n})(\mathrm{n} \in \mathrm{G}) \rightarrow(\mathrm{n} \in \mathrm{F}) \\
& \text { 13. }(\forall \mathrm{n})(\mathrm{n} \in \mathrm{F}) \rightarrow(\mathrm{n} \in \mathrm{W}) \\
& \text { 14. }(\forall \mathrm{n})(\mathrm{n} \in \mathrm{W}) \rightarrow(\mathrm{n} \in \mathrm{V})
\end{aligned}
$$

De donde, de nuevo mediante la aplicación del silogismo hipotético, se obtiene:

$\therefore$

$(\forall \mathrm{n})(\mathrm{n} \in \mathrm{L}) \rightarrow(\mathrm{n} \in \mathrm{V})$ : Cuya interpretación es: Si una norma pertenece al conjunto de las normas legisladas, entonces pertenece al conjunto de las normas válidas.

Repitiendo la misma operación de incorporación, pero ahora con las normas jurisprudenciales, se obtienen las premisas:

$$
\begin{aligned}
& \text { 15. }(\forall \mathrm{n})(\mathrm{n} \in \mathrm{J}) \rightarrow(\mathrm{n} \in \mathrm{G}) \\
& \text { 16. }(\forall \mathrm{n})(\mathrm{n} \in \mathrm{G}) \rightarrow(\mathrm{n} \in \mathrm{F}) \\
& \text { 17. }(\forall \mathrm{n})(\mathrm{n} \in \mathrm{F}) \rightarrow(\mathrm{n} \in \mathrm{W}) \\
& \text { 18. }(\forall \mathrm{n})(\mathrm{n} \in \mathrm{W}) \rightarrow(\mathrm{n} \in \mathrm{V})
\end{aligned}
$$

De las cuales, mediante aplicación del silogismo hipotético se sigue:

$$
\therefore
$$

$(\forall \mathrm{n})(\mathrm{n} \in \mathrm{J}) \rightarrow(\mathrm{n} \in \mathrm{V})$ : cuya interpretación es: Si una norma pertenece al conjunto de las normas jurisprudenciales, entonces pertenece al conjunto de las normas válidas.

Finalmente, con respecto a las normas individualizadas (sentencias, contratos, convenios, etc) tenemos que, de la aplicación de la ley de la bicondicionalidad a "8", se sigue el condicional:

$$
\text { 19. }(\forall \mathrm{n})(\mathrm{n} \in \mathrm{D}) \rightarrow(\mathrm{n} \in \mathrm{A})
$$

A partir del cual se construye el sistema de premisas:

20. $(\forall \mathrm{n})(\mathrm{n} \in \mathrm{D}) \rightarrow(\mathrm{n} \in \mathrm{A})$

21. $(\forall \mathrm{n})(\mathrm{n} \in \mathrm{A}) \rightarrow(\mathrm{n} \in \mathrm{W})$

22. $(\forall \mathrm{n})(\mathrm{n} \in \mathrm{W}) \rightarrow(\mathrm{n} \in \mathrm{V})$

$\therefore$

$(\forall \mathrm{n})(\mathrm{n} \in \mathrm{D}) \rightarrow(\mathrm{n} \in \mathrm{V})$ por aplicación de la ley del silogismo hipotético tenemos: Si una norma pertenece al conjunto de las normas individualizadas, entonces pertenece al conjunto de las normas válidas y por tanto también son un subconjunto de las normas válidas. 
Esta obra forma parte del acervo de la Biblioteca Jurídica Virtual del Instituto de Investigaciones Jurídicas de la UNAM

Con base en lo anterior, la definición para normas subconstitucionales quedaría de la siguiente manera:

$(\forall \mathrm{n})(\mathrm{n} \in \mathrm{L}) \mathrm{o}(\mathrm{n} \in \mathrm{D}) \leftrightarrow(\mathrm{n} \in \mathrm{U})$ : Para toda norma "n" sí y sólo sí pertenece al conjunto de las normas legisladas o al conjunto de las normas individualizadas, entonces pertenece al conjunto de las normas subconstitiucionales.

$(\forall \mathrm{n})(\mathrm{n} \in \mathrm{H}) \rightarrow(\mathrm{n} \in \mathrm{G})$ : Para toda norma "n", si pertenece a las normas que establecen derechos fundamentales, entonces pertenecen al conjunto de las normas constitucionales.

Finalmente:

$(\forall \mathrm{n})(\mathrm{n} \in \mathrm{S}) \leftrightarrow(\mathrm{n} \in \mathrm{V})$ : Para toda norma " $\mathrm{n}$ ", 'pertenece al conjunto de las normas de un sistema jurídico "S", si y sólo si, pertenece al conjunto de las normas válidas (V) para $\mathrm{S}$.

\section{B. Propiedades ideales del sistema normativo en el constitucionalismo pre-globalizado}

En el constitucionalismo pre-globalizado, las leyes de la nomodinámica expuestas corresponden al sistema de creencias con base en el cual los operadores jurídicos generan los sistemas jurídicos.

Para autores como Carlos Alchourrón, Eugenio Bulligyn ${ }^{8}$ y Daniel Mendonca $^{9}$, un modelo ideal de estos sistemas normativos debería satisfacer las propiedades de: coherencia, completitud e Independencia. Se hace notar que para estos autores 'ideal' no denota ningún patrón de perfección existente más allá de la experiencia, sino un ideal regulativo.

Es importante señalar que el término 'sistema normativo' es polisémico. En uno de sus sentidos denota al conjunto de normas de un sistema $\mathrm{S}$, sin tomar en cuenta su relación con el mundo empírico. En un segundo sentido denota al conjunto de relaciones existentes entre un universo de normas y un universo de casos para los cuales ese sistema es relevante. El universo de casos se caracteriza por el universo de propiedades constitutivas de los casos, los casos considerados y las inferencias deónticas que tienen lugar en función de la estructura normativa del sistema en cuestión. A efecto de distinguir entre ambos sistemas, en este trabajo estipulo 'sistema jurídico

8 Alchourrón, Carlos y Bullygin, Eugenio., Introducción a la metodología de las ciencias jurídicas y sociales, Buenos Aires, Ed., Astrea, 1974

9 Ver Mendonca, Daniel., Cómo hacer cosas con la constitución: una introducción al análisis constitucional, Asunción, Ed. Litocolor,1999, 
Esta obra forma parte del acervo de la Biblioteca Jurídica Virtual del Instituto de Investigaciones Jurídicas de la UNAM

normativo 1' para el primer sentido y SJN2 para el segundo. En el modelo nomodinámico se emplea la expresión en sentido 1. En el modelo ideal que se expone a continuación se usa en su sentido 2, razón por la cual me referiré a el con SJN2. El sistema jurídico normativo en sentido 1 es presupuesto por un sistema jurídico normativo en sentido 2 (SJN2).

a. Definiciones:

Un SJN2 es coherente cuando no existen soluciones distintas e incompatibles para resolver un mismo caso.

Un SJN2 es completo si no tiene lagunas.

Un SJN2 presenta una laguna cuando en el mismo no existe una solución para alguno de los elementos constitutivos de su universo de casos.

Un SJN2 es independiente si no tiene redundancias o semiredundancias.

Un SJN2 es redundante si contiene al menos una duplicidad de normas para el mismo caso.

Un SJN2 es semiredundante si existen dos normas análogas que den solución no contradictoria al mismo caso.

A pesar del alto grado de estructuración de las leyes nomodinámicas del constitucionalismo pre-globalizado, en la práctica es muy poco probable que un SJN2 llegue a satisfacer las propiedades de un sistema ideal.

Junto con Alchourrón, Bullygin y Mendonca asumo que las inferencias deónticas, en función de distintas normas de un sistema, sus "defectos" y la comparación entre diversos SJN2 pueden ser representadas mediante una matriz.

b. Matriz de propiedades de los SJN2 en el constitucionalismo pre-globalizado

Supongamos la existencia de las siguientes propiedades constitutivas de antecedentes (en sentido lógico) de normas constitucionales relativas a la concesión de la nacionalidad:

$\mathrm{R}$ : Si un extranjero contrae matrimonio con un nacional que tenga su domicilio en el país...

N: Si un extranjero es hijo de padre o madre extranjero...

P: Si un extranjero ha permanecido como residente por más de 5 años en territorio nacional, mostrando un modo honesto de vivir ...

Cuyos consecuentes deónticos pueden ser: 
Esta obra forma parte del acervo de la Biblioteca Jurídica Virtual del Instituto de Investigaciones Jurídicas de la UNAM

1)...entonces, la Secretaría de Relaciones Exteriores (o su equivalente en otro país) deberá conceder la nacionalidad. Es decir, la conducta es obligatoria (representado por $\mathrm{Oa}$ ); ó

2) ...entonces, la Secretaría de Relaciones Exteriores ( o su equivalente en otro país) podrá conceder la nacionalidad. Es decir, la conducta es facultativa o discrecional (representado por $\mathrm{Fa}$ ).

Como toda matriz, la que presentamos a continuación está constituida por columnas (verticales) y filas (horizontales). En las primeras columnas y las filas se registran las variables y en el interior de la matriz, un sistema de coordenadas.

La matriz consta de una primera columna que contiene el universo de casos (UC); una segunda las propiedades cuya combinatoria da lugar a los distintos tipos de casos de la primer columna y 4 columnas subsecuentes correspondientes a 4 sistemas jurídicos normativos (S1, S2, S3, S4).

Debajo de la columna correspondiente al universo de casos se encuentran los tipos de casos (C1, C2, C3, C4, C5).

Debajo de la columna correspondiente al universo de propiedades, se encuentran las columnas $(\mathrm{R}, \mathrm{N}, \mathrm{P})$ que corresponden a cada una de las propiedades cuya presencia o ausencia, verdad o falsedad (+.-) configura cada uno de los casos.

Debajo de la columna correspondiente a cada uno de los sistemas comparados, se encuentran, para cada sistema, distintas normas cuyo antecedente corresponde a la combinatoria de propiedades para cada caso en cada una de las filas.

En el espacio de coordenadas se registra la inferencia deóntica $(\mathrm{Oa}$, ó Fa) que se sigue en función del antecedente y el consecuente de cada una de las normas y su satisfacción empírica.

En el espacio de coordenadas también se registran los errores sistémicos representados con cuadros con diferentes tonalidades.

En el espacio de coordenadas de la matriz se representan las inferencias deónticas.

Por ejemplo: La norma N4 del sistema S1, para el caso C1 sería la siguiente: "Si un extranjero renuncia a su nacionalidad, es hijo de padre o madre extranjero y ha permanecido como residente por más de 5 años en territorio nacional, mostrando un modo honesto de vivir, entonces la Secretaría de relaciones exteriores deberá concederle la nacionalidad".

Dado que en este caso C1 se satisfacen (son verdaderas) todas las propiedades exigidas por la norma N4, lo que se señala instanciando todas las propiedades R, N, P con un signo “+”, entonces, la inferencia deóntica es 
Esta obra forma parte del acervo de la Biblioteca Jurídica Virtual del Instituto de Investigaciones Jurídicas de la UNAM

que la Secretaría de Relaciones Exteriores debe conceder la nacionalidad. Ello queda registrado con "Fa" debajo de la columna N4 del sistema S1 en la fila correspondiente al caso C1.

La comparación entre las normas de distintos sistemas se puede constatar si se presta atención a las normas N4 del sistema S2 y N7 del sistema S3. En ellos cuáles el consecuente de las normas indica una facultad discrecional y, por tanto, ante la satisfacción de las mismas propiedades, le inferencia deóntica es que la Secretaría podrá decidir discrecionalmente si concede o no la nacionalidad, a diferencia de los que ocurre bajo las mismas circunstancias en el ejemplo del C1, en el sistema S1.

Otro ejemplo: Dentro del mismo sistema S1, otra norma establece que: Si un extranjero es hijo de padre o madre extranjero y ha permanecido como residente por más de 5 años en el territorio nacional, mostrando un modo honesto de vivir, entonces la Secretaría de Relaciones Exteriores podrá concederle la nacionalidad.

Igual que en los ejemplos anteriores se puede ver que en los hechos se satisfacen las dos propiedades "N" $\mathrm{y}$ "P" en el universo de propiedades respecto del caso $\mathrm{C} 2$, lo que permite hacer la inferencia deóntica "Fa" en la columna N1 del sistema S1 para el caso C2.

En lo que respecta a los "defectos" del sistema, quedan representados de la manera siguiente:

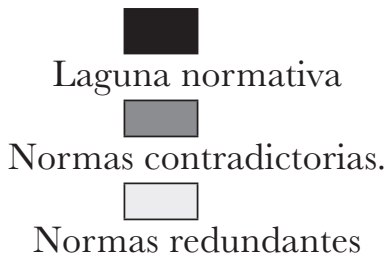

Por ejemplo, en las coordenadas del caso C4, sistema S1, normas N1 y N2, iluminados con color blanco, se representa el hecho de que dichas normas (que podrían corresponder a una ley su reglamento) contienen exactamente la misma norma, lo que produce una redundancia en el sistema. 
Esta obra forma parte del acervo de la Biblioteca Jurídica Virtual del Instituto de Investigaciones Jurídicas de la UNAM

MATRIZ PARA LOS SJN210

\begin{tabular}{|c|c|c|c|c|c|c|c|c|c|c|c|c|c|c|c|c|}
\hline & \multicolumn{3}{|c|}{ UP } & \multicolumn{4}{|c|}{$\mathrm{S} 1$} & \multicolumn{4}{|c|}{ S2 } & \multicolumn{3}{|c|}{ S3 } & \multicolumn{2}{|c|}{$\mathrm{S} 4$} \\
\hline $\mathrm{UC}$ & $\mathrm{R}$ & $\mathrm{N}$ & $\mathrm{P}$ & N1 & $\mathrm{N} 2$ & N3 & $\mathrm{N} 4$ & N3 & N4 & N5 & N6 & N2 & N3 & N7 & N3 & N5 \\
\hline $\mathrm{C} 1$ & + & + & + & & & & $\mathrm{Oa}$ & & $\mathrm{Fa}$ & & & & & $\mathrm{Fa}$ & & \\
\hline $\mathrm{C} 2$ & - & + & + & $\mathrm{Fa}$ & & & & & & $\mathrm{Oa}$ & & & & & & $\mathrm{Oa}$ \\
\hline C3 & + & - & + & & $\mathrm{Oa}$ & & & & & & $\mathrm{Oa}$ & $\mathrm{Oa}$ & & & & \\
\hline $\mathrm{C} 4$ & - & - & + & $\mathrm{Oa}$ & $\mathrm{Oa}$ & & & & & & $\mathrm{Oa}$ & $\mathrm{Oa}$ & & & & \\
\hline C5 & + & + & - & & $\mathrm{Oa}$ & & & $\mathrm{Oa}$ & & & & & $\mathrm{Oa}$ & $\mathrm{Fa}$ & $\mathrm{Oa}$ & \\
\hline C6 & - & + & - & $\mathrm{Oa}$ & & $\mathrm{Oa}$ & & $\mathrm{Oa}$ & & & & & $\mathrm{Oa}$ & & $\mathrm{Oa}$ & \\
\hline C7 & + & - & + & & $\mathrm{Oa}$ & $\mathrm{Oa}$ & & & & & & $\mathrm{Oa}$ & $\mathrm{Oa}$ & & & \\
\hline
\end{tabular}

\section{c. Operadores cognitivos y propiedades ideales del SJN2}

Previamente se ha enfatizado que el término "norma jurídica" no denota a los enunciados del sistema, sino a los outcomes o interpretaciones derivadas de aplicarles operadores semánticos, hermenéuticos o estructurales por parte de los operadores jurídicos.

Esto significa que las variables correspondientes a las normas de la matriz no son instanciadas con enunciados normativos, sino con las proposiciones resultantes de la interpretación de los enunciados.

Este cambio de encuadre pone de manifiesto la enorme dificultad que entraña la satisfacción de las propiedades ideales del sistema como consecuencia del número indeterminado de interpretaciones que pueden tener los enunciados de un sistema y el número indeterminado de casos que se deben resolver a partir de ellos. No obstante la utilidad de la matriz, el concepto de 'caso' empleado en la misma resulta sumamente simplificado para dar cuenta de lo que ocurre en la práctica. Un constructo teórico de "caso" más fructífero tendría que tomar en consideración que la determinación de la satisfacción o no del universo de propiedades en distintos casos implica toda una serie de procesos cognitivos previos a la determinación de su verdad o falsedad. Estos procesos tienen que ver con las dificultades epistémicas que conlleva la determinación de la verdad de las proposiciones fácticas con las

10 Una versión de esta tabla en materia civil puede verse en el trabajo de Mendonca, Op. Cit, p.60. 
Esta obra forma parte del acervo de la Biblioteca Jurídica Virtual del Instituto de Investigaciones Jurídicas de la UNAM

que se instancia el universo de propiedades. Estas dificultades se refieren a cuestiones tales como la ponderación probatoria, la determinación de la satisfacción o no del estándar probatorio de dichas proposiciones fácticas, etc., incrementan de manera exponencial el riesgo de entropía en un sistema construido por la comunidad epistémica de operadores jurídicos que actúan de manera aislada asumiendo un ingenuo presupuesto derivado del racionalismo conforme al cual todos los hombres están dotados de la misma capacidad racional y por tanto a partir de los enunciados del sistema deben inferir una única respuesta correcta. A este fenómeno se refieren frecuentemente los jueces afirmando que "cada caso es único y distinto a los demás".

Además del procesamiento de los enunciados normativos, se encuentran los problemas a nivel de sistema y no de enunciados aislados. Es decir, los resultantes de los "defectos" del sistema respecto de sus propiedades ideales. Ellos constituyen una fuente fundamental de la entropía en la práctica jurídica.

No obstante, no deja de ser paradójico constatar que no obstante que los operadores jurídicos son conscientes de que las normas del SJN2 no satisfacen las propiedades ideales referidas, emplean una serie de operadores cognitivos para realizar los "ajustes" necesarios para que hacer "como si" dichas propiedades se satisficieran.

Algunos de estos operadores, empleados para "subsanar" los "defectos" del sistema son:

1) En caso de lagunas (operando), los operadores más utilizados son: integración analógica, integración a contrario sensu, integración por mayoría de razón.

2) En caso de redundancias (operando): el operador consiste en la eliminación de una de las normas.

3) En caso de incoherencia por contradicción jerárquica, tenemos:

A. $\{[(n \in C \rightarrow \mathcal{E} \leftarrow n \in U)] \rightarrow[(n \in C \uparrow):$ Si una norma "n" perteneciente al conjunto de las normas constitucionales es contradictoria de una norma perteneciente al conjunto de las normas subconstitucionales, entonces la norma perteneciente al conjunto de las normas constitucionales es derrotante.

B. Un criterio semejante se sigue en caso de contraposición axiológica:

$\left\{\left[\left(\mathrm{n} \in \mathrm{C} \rightarrow_{\bar{\AA}} \leftarrow \mathrm{n} \in \mathrm{U}\right)\right] \rightarrow[(\mathrm{n} \in \mathrm{C} \uparrow)):\right.$ Si una norma "n" perteneciente al conjunto de las normas constitucionales entra en contraposición axiológica con una norma perteneciente al conjunto de 
Esta obra forma parte del acervo de la Biblioteca Jurídica Virtual del Instituto de Investigaciones Jurídicas de la UNAM

las normas subconstitucionales, entonces la norma perteneciente al conjunto de las normas constitucionales es derrotante.

\author{
X. ENTROPÍA Y NEGUENTROPÍA \\ EN EL CONSTITUCIONALISMO GLOBALIZADO
}

Como se ha visto previamente, el hecho de que el constitucionalismo preglobalizado cuente con leyes nomodinámicas rigurosas para la producción normativa, no ha impedido la entropía derivada de la diversidad de normas generadas a partir de los enunciados del sistema jurídico normativo y los defectos sistémicos del mismo. Es decir, a pesar de criterios bien definidos para la identificación de los enunciados (operandos) del sistema sobre los cuáles realizar procesamiento cognitivo con operadores bien conocidos por parte de la comunidad epistémica de los operadores jurídicos.

Con el proceso de globalización, la entropía se multiplica exponencialmente debido a la falta de criterios claros para la identificación de los enunciados (operadores) a procesar, reglas de reconocimiento que sustituyan a las reglas de validez característica de los sistemas pre-globalizados, pluralidad de agentes generadores de normas a nivel trasnacional cada uno actuando conforma a sus propias dinámicas, etcétera.

En el constitucionalismo globalizado, el sistema generador de cadenas de validez normativo cede el paso a otro susceptible de ser representado como:

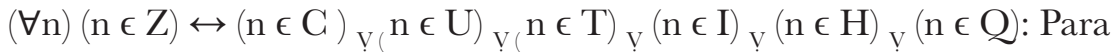
toda norma " $n$ ", pertenece al conjunto de sistema normativo jurídico $\mathrm{Z}$ globalizado sí y sólo sí pertenece al conjunto de las normas constitucionales o al de los instrumentos internacionales, o al de la jurisprudencia internacional, o al de los derechos humanos, o al del soft law.

Dada la diversidad de operandos y generadores de los mismos, la tesis del positivismo conforme a la cual se puede identificar las normas de un sistema a partir de un conjunto bien definido de enunciados a partir de reglas de validez y procesarlos conforme a operadores compartidos por parte de la comunidad de operadores jurídicos y en su caso subsanar sus "defectos" con operadores bien conocidos por la comunidad deja de tener sentido.

En el sistema globalizado, el control de la entropía se desplaza hacia la homogeneización en los operadores cognitivos, más que en el reconocimiento preciso de enunciados como parte de un sistema cerrado y las propiedades pasan a serlo del sistema globalizado $\mathrm{Z}$.

A continuación se muestra la matriz para Z: 
Esta obra forma parte del acervo de la Biblioteca Jurídica Virtual del Instituto de Investigaciones Jurídicas de la UNAM

MATRIZ PARA Z

GuAdro GOMPARATIVO DE SISTEMAS

DEL BLOQUE GONSTITUCIONAL

\begin{tabular}{|c|c|c|c|c|c|c|c|c|c|c|c|c|c|c|c|c|}
\hline $\mathrm{UC}$ & $\mathrm{R}$ & $\mathrm{N}$ & $\mathrm{P}$ & N1 & $\mathrm{N} 2$ & N3 & $\mathrm{N} 4$ & N3 & $\mathrm{N} 4$ & N5 & N6 & N2 & N3 & N7 & N3 & N5 \\
\hline $\mathrm{C} 1$ & + & + & + & & & & $\mathrm{Fa}$ & & $\mathrm{Fa}$ & & & & & $\mathrm{Fa}$ & & \\
\hline $\mathrm{C} 2$ & - & + & + & $\mathrm{Oa}$ & & & & & & $\mathrm{Oa}$ & & & & & & $\mathrm{Oa}$ \\
\hline C3 & + & - & + & & $\mathrm{Oa}$ & & & & & & $\mathrm{Oa}$ & $\mathrm{Oa}$ & & & & \\
\hline $\mathrm{C} 4$ & - & - & + & $\mathrm{Oa}$ & $\mathrm{Oa}$ & & & & & & $\mathrm{Oa}$ & $\mathrm{Oa}$ & & & & \\
\hline C5 & + & + & - & & $\mathrm{Oa}$ & & & $\mathrm{Oa}$ & & & & & & $\mathrm{Fa}$ & $\mathrm{Oa}$ & \\
\hline C6 & - & + & - & $\mathrm{Oa}$ & & $\mathrm{Oa}$ & & $\mathrm{Oa}$ & & & & & $\mathrm{Oa}$ & & $\mathrm{Oa}$ & \\
\hline $\mathrm{C} 7$ & + & - & + & & $\mathrm{Oa}$ & $\mathrm{Oa}$ & & & & & & $\mathrm{Oa}$ & $\mathrm{Oa}$ & & & \\
\hline
\end{tabular}

\section{PROGESOS GOGNITIVOS (OPERADORES) PARA "SUBSANAR" LOS “DEFEGTOS” DEL SISTEMA Z}

1) En caso de lagunas: Emisión de normas estipulativas, emisión de normas aditivas, Procesos hermenéuticos tradicionales (Integración analógica, integración a contrario sensu Integración por mayoría de razón).

2) La redundancia entre normas provenientes de distintas fuentes no puede ser resuelta mediante eliminación normativa como sucede en el caso del constitucionalismo pre-globalizado.

3) En caso de Semiredundancia: Aplicación del principio Pro-Persona.

4) En caso de Contradicción Lógica o contraposición axiológica: Ponderación (Nótese que en estos casos no procede la derrotabilidad normativa con base en el criterio de jerarquía).

\section{A MODO DE CONCLUSIÓN}

1) La naturalización de las teorías protagonistas del debate en la filosofía del derecho defendidas por originalistas, anti-textualistas e interpretativistas convalida las tesis de estos últimos, especialmente la de los 
Esta obra forma parte del acervo de la Biblioteca Jurídica Virtual del Instituto de Investigaciones Jurídicas de la UNAM

defensores de la metáfora del árbol viviente: Las operaciones interpretativas son procesos cognitivos naturales realizados por los operadores jurídicos (en nuestro caso los jueces) responsables del desarrollo de las "ramas y hojas del árbol constitucional".

2) La metáfora del árbol viviente es un explanans apto para modelar al constitucionalismo pre-globalizado, pero adolece de defecto de cobertura explicativa si el explanandum corresponde al proceso de globalización en el que se encuentra inmerso el derecho, incluyendo al derecho constitucional.

3) Actualmente las normas resultantes (outcomes) de los procesos cognitivos (operadores) realizados sobre enunciados normativos (operandos) no pueden identificarse conforme a una regla de clausura basada en cadenas de validez normativas.

4) Los cambios que caracterizan al constitucionalismo contemporáneo generan cambios en la forma de procesar los mismos textos sobre los que se operaba en el constitucionalismo clásico e implican el procesamiento de otros textos

5) La estructura del sistema $\mathrm{S}$ durante el constitucionalismo clásico era de carácter piramidal y cerrado en relación con normas no generadas a partir de los procesos constituyentes del mismo sistema.

6) El paso de un constitucionalismo basado en un modelo de sistema cerrado a un modelo de sistema abierto, requiere dejar de comprender al derecho constitucional como la cúspide de una pirámide y buscar nuevas estrategias de modelado conceptual.

7) Actualmente las constituciones son mejor comprendidas como nodos importantes de redes complejas evolutivas, pero no los únicos en la dinámica de los sistemas $Z$ que están emergiendo.

8) Son nodos pertenecientes a una red distribuida ya no jerárquica.

9) Idealmente, en esta situación, el conjunto de los órganos de interpretación de la constitucionalidad, al manejar las mismas reglas de procesamiento de información, deben estar promoviendo la emergencia de un nuevo sistema $\mathrm{Z}$ que satisfaga las condiciones de coherencia, completitud e independencia referidas previamente.

10) Dicho sistema posee propiedades dinámicas y adaptativas que hacen que pueda considerarse como un sistema emergente en actual proceso autoorganizativo sub-emergente.

11) Contar con una matriz sobre el sistema $Z$ puede servir como un artefacto compartido que sirva como medio para homogeneizar la forma en que los operadores jurídicos de distintos sistemas S están aplican- 
Esta obra forma parte del acervo de la Biblioteca Jurídica Virtual del Instituto de Investigaciones Jurídicas de la UNAM

do el derecho en proceso de globalización. Con ello se favorecería la prevención de la entropía en dicho sistema y en su caso se neguentropizaría la existente.

\section{FUTURAS INVESTIGACIONES}

1) La teoría de las redes complejas aplicadas exitosamente en diversos terrenos, como sucede en el desarrollo de modelos sobre la conectividad en internet o el modelado de la conectividad neuronal puede ser un buen punto de partida para la elaboración de modelos sobre los cambios en los estados de fase o cambios de espacios de estados de fase del sistema que están caracterizando a la dinámica del sistema Z .

2) Una investigación empírica de este tipo puede proporcionar importantes datos sobre el comportamiento de la red, sus nodos más importantes, la forma en que dicha red se está configurando, etc.

3) La justificación social de dicha investigación puede ir más allá del ámbito local y arrojar luces sobre lo que está ocurriendo durante el proceso de globalización jurídica. Por ejemplo constituir una herramienta para modelar la dinámica de lo que se ha dado en llamar ius comune latinoamericano.

4) Gracias al apoyo de GONACYT a través del programa Fronteras de la Ciencia quien ha aprobado el proyecto: "Constructivismo Jurídico: Cognición, Complejidad y Derecho" dicho proyecto está empezando a desarrollarse en el Instituto de Investigaciones Jurídicas de la Universidad Nacional Autónoma de México.

\section{BibliografíA}

Alchourrón, Carlos y Bullygin, Eugenio, Introducción a la metodología de las ciencias jurídicas y sociales, Buenos Aires, Ed. Astrea, 1974

Bateson, Gregory., Pasos hacia una ecología de la mente, Buenos Aires, Ediciones Carlos Lohlé, 1972.

CÁCERes, Enrique, Constructivismo Jurídico y Metateoría del Derecho, México, Instituto de Investigaciones Jurídicas, UNAM, 2007

-, Enrique, Repensando el concepto de "Derecho" en la era de la globalización (Consideraciones metateóricas con referencia especial al derecho constitucional), Gobernanza Global y cambio estructural del sistema jurídico mexicano, México, IIJ, UNAM, 2016 
Esta obra forma parte del acervo de la Biblioteca Jurídica Virtual del Instituto de Investigaciones Jurídicas de la UNAM

- Enrique, ¿Qué es el derecho? Iniciación a una concepción linguïstica, 2000, México, UNAM, IIJ, Cáceres Enrique, Lenguaje y Derecho, las normas jurídicas como sistema de enunciados, 2000, México, UNAM, IIJ

— Enrique, Introducción Práctica al cálculo lógico aplicado al derecho, Capítulo "Cálculo Lógico"., Ed. Porrúa, México, 2014

Kelsen, Hans, Teoría Pura del Derecho, Trad. Vernengo, Roberto J., $2^{\circ}$ Edición, Instituto de Investigaciones Jurídicas, México, UNAM, 1982 - Hans, Teoría General de las Normas, México, Ed. Trillas, 2007

Mendonca, Daniel., Cómo hacer cosas con la constitución: una introducción al análisis constitucional, Asunción, Ed. Litocolor, 1999, 
Esta obra forma parte del acervo de la Biblioteca Jurídica Virtual del Instituto de Investigaciones Jurídicas de la UNAM

\title{
EL NEOLIBERALISMO Y LAS GRIETAS DEL NEOGONSTITUCIONALISMO
}

\author{
Jaime CÁRdenAS GRACIA
}

\begin{abstract}
SUMARIO: I. Introducción. II. La respuesta neoconstitucionalista al neoliberalismo. III. La revisión de las teorías neoconstitucionales contemporáneas para responder al neoliberalismo globalizador. IV. Conclusiones.
\end{abstract}

\section{INTRODUCGIÓN}

El neoliberalismo tiene sus fundamentos en la teoría neoclásica de la economía que se desarrolló en Inglaterra, Estados Unidos y el resto de Europa a finales del siglo XIX y principios del siglo XX. La teórica neoclásica sostiene como principales tesis que: el estudio de la economía debe concentrarse en la utilización óptima de los recursos disponibles y que son escasos para satisfacer las necesidades y deseos de los agentes económicos; la utilidad de los bienes y de los servicios, no es otra que la que representa, en el margen, para los consumidores; el equilibrio general corresponde a la utilización óptima de los recursos escasos, y se le puede identificar como un conjunto de valores para todas las variables, precios y cantidades que prevalecen de manera simultánea; los precios tienen significado como indicadores de la escasez (en relación a las preferencias de los consumidores); y, la distribución del ingreso se determina por la contribución, que en el margen hacen los factores de la producción ${ }^{1}$.

Para los autores neoclásicos, el tema central de la economía está relacionado con la utilización óptima de los escasos recursos disponibles para satisfacer las necesidades y deseos que los agentes económicos experimentan en lo individual. El valor de las mercancías y de los servicios depende de la utilidad que les reporta a los consumidores. Estas visiones conceptuales

1 Tello, Carlos e Ibarra, Jorge, La Revolución de los Ricos, México, UNAM, 2012, p. 45. 
Esta obra forma parte del acervo de la Biblioteca Jurídica Virtual del Instituto de Investigaciones Jurídicas de la UNAM

fueron dominantes en el mundo económico hasta antes de la Gran Depresión y fueron sustituidas por el pensamiento keynesiano - hasta las crisis de los años setentas y ochentas del siglo XX-porque la teoría neoclásica no ofrecía una explicación adecuada de lo que estaba ocurriendo en esa etapa, principalmente porque no tomaba en cuenta los aspectos contextuales en su análisis, en particular el peso del Estado y sus regulaciones en la economía, así como el papel de las clases sociales.

El neoliberalismo económico que reformuló a la teoría neoclásica, constituye una visión extrema de esa teoría. Apuesta por la economía irrestricta del mercado y por un Estado que intervenga, no para enfrentar las desigualdades sociales y económicas que provoca el mercado como lo hacía el keynesianismo, sino para salvaguardar y extender la presencia del mercado, para garantizar su buen funcionamiento y, para enfrentar las barreras e impedimentos regulatorios a la libre competencia.

El neoliberalismo, sin embargo, no sólo es una estructura económica sino un esquema integral geopolítico que conjuga la violencia política, militar, ideológica, jurídica y estatal, para que las transformaciones estructurales de carácter económico que promueve, pongan a las anteriores variables de su lado, con el propósito de modificar en beneficio de las clases dominantes los elementos que conforman la convivencia social y la nueva forma de dominación política de carácter planetario pero con anclajes nacionales ${ }^{2}$.

Jurídicamente el neoliberalismo consiste en desmantelar o diluir la soberanía de los Estados-nación. Un elemento fundamental de éstos, el más importante sin duda desde Bodin, es la soberanía. Como lo señala Gustavo Zagrebelsky la soberanía en los nuevos Estados neoliberales se ha transformado. En el Estado nación del siglo XIX y buena parte del siglo XX, la soberanía interna indicaba la inconmensurabilidad del Estado frente a cualesquiera otros sujetos y, por tanto, la imposibilidad de entrar en relaciones jurídicas con ellos, pues frente al Estado soberano no podían existir más que relaciones de sujeción. Desde una perspectiva externa, los Estados se presentaban como fortalezas cerradas protegidas por el principio de la no injerencia ${ }^{3}$.

En el Estado contemporáneo del neoliberalismo, ambas dimensiones de la soberanía se han modificado. Internamente, el pluralismo jurídico, el

2 HaRvey, David, Breve historia del neoliberalismo, Madrid, Akal, 2007; HARVEY, David, El nuevo imperialismo, Madrid, Akal, 2004; HARVEY, David, El enigma del capital y la crisis del capitalismo, Madrid, Akal, 2012; y, HARVEY, David, Seventeen Contradictions and the End of Capitalism, Oxford-New York, Oxford University Press, 2014.

3 Zagrebelsky, Gustavo, El derecho dúctil. Ley, derechos, justicia, Madrid, Trotta, 1995, pp. $10-11$. 
Esta obra forma parte del acervo de la Biblioteca Jurídica Virtual del Instituto de Investigaciones Jurídicas de la UNAM

fortalecimiento de poderes fácticos nacionales que disputan con el Estado el poder y, la creciente integración de los Estados a entidades supranacionales propician que la soberanía desde su dimensión interna no le brinde al Estado la prevalencia que tuvo anteriormente. Externamente, la globalización y el desarrollo de poderes fácticos e institucionales internacionales, han acabado con el principio de no injerencia nacional. Hoy en día, las grandes corporaciones económicas y las instituciones internacionales condicionan la vida interna de los países y parecen aniquilar el principio de autodeterminación nacional.

En el nivel interno de los Estados, los cambios jurídicos de la globalización neoliberal se perciben claramente. Gerardo Pisarello, advierte la aparición de procesos deconstituyentes en las naciones que falsean el sentido garantista -maximizador de los derechos humanos y de la democracia- de los marcos constitucionales y destaca también el desarrollo de un constitucionalismo liberal oligárquico que responde a la vigencia de las redes jurídicas internacionales y a la importancia que en ellas tiene la nueva "lex mercatoria" vinculada a los intereses de las grandes empresas trasnacionales, a los organismos financieros y comerciales internacionales y, por supuesto a las grandes potencias que están detrás de todos esos procesos. $\mathrm{Al}$ interior de los Estados, los órganos de defensa de la Constitución -ejecutivos, parlamentos, tribunales constitucionales- han asistido impotentes, cuando no han alentado, el vaciamiento normativo nacional, el que es promovido desde instancias estatales y supraestatales. Las Constituciones y los marcos jurídicos nacionales se vuelven flexibles frente a las presiones antisociales de la globalización y rígida frente a las exigencias democratizadoras provenientes de las sociedades locales, principalmente de los sectores más desfavorecidos ${ }^{4}$.

Las características del derecho interno paulatinamente van modificándose. El Estado ya no concentra el monopolio de la producción jurídica sino que lo comparte con las instancias supranacionales, tanto públicas como privadas. La "Lex mercatoria" implica la existencia de un ordenamiento espontáneo de los negocios del comercio internacional al margen del Estado. Se comienza a transformar el esquema piramidal y jerárquico de las normas del derecho interno y se sustituye por la pluralidad de redes normativas internacionales. En el derecho internacional con consecuencias jurídicas internas se manifiesta un "soft law" que carece de sanciones explícitas, por ejemplo, la pluralidad creciente en el derecho interno de lineamientos, directrices, códigos de conducta y normas técnicas. Vinculado a lo expuesto

4 PISARello, Gerardo, Procesos constituyentes. Caminos para la ruptura democrática, Madrid, Trotta, 2014, pp. 16-17. 
Esta obra forma parte del acervo de la Biblioteca Jurídica Virtual del Instituto de Investigaciones Jurídicas de la UNAM

se presenta en los Estados-nación el vaciamiento normativo del derecho público y el avance de un derecho privado orientado por los criterios de la globalización. Con lo anterior, el ordenamiento jurídico interno pierde certeza jurídica porque compite con el de las redes jurídicas de la globalización y, principios como el de supremacía se diluyen; se trastocan las viejas virtudes de generalidad y abstracción, pues el derecho de la globalización neoliberal es casuístico y fugaz y, las características de unidad y coherencia del ordenamiento, por la fuerza de las redes jurídicas de la globalización, obligan a que el sistema jurídico se fragmente, aumenten las lagunas y las antinomias jurídicas.

\section{LA RESPUESTA NEOGONSTITUCIONALISTA AL NEOLIBERALISMO}

En las épocas de la globalización, y como dice Ferrajoli, se alude al pluralismo de los ordenamientos más que a monismo o dualismo. Lo anterior significa que los derechos estatales forman una pluralidad de ordenamientos y, el derecho internacional está formado por una pluralidad de instituciones y de ordenamientos. Esas pluralidades de ordenamientos y de instituciones de carácter internacional y estatal se relacionan mediante vínculos de distinta naturaleza - de coordinación, subsidiariedad, subordinación, integraciónque son determinadas por distintas normas de derecho positivo. En muchos casos, los ordenamientos e instituciones no son derivados sino originarios, aunque ello no significa la existencia de ordenamientos soberanos o ilimitados por provenir de un poder constituyente originario, sino de ordenamientos e instituciones restringidas en su soberanía según lo establezca cada concreta disciplina del derecho positivo ${ }^{5}$.

Ferrajoli advierte la progresiva pérdida de relieve de los Estados, que se han, como dice él, revelado demasiado grandes para las cosas pequeñas y demasiado pequeños para las cosas grandes. El Estado nacional pierde su autosuficiencia y exclusividad normativa en el plano jurídico, su soberanía en el plano político, su centralidad en el económico. La crisis tiene que ver con la globalización neoliberal y ha generado problemas de carácter supraestatal. Entre esos problemas se señalan el retorno de la guerra como instrumento de solución de controversias entre Estados, el desarrollo de la criminalidad internacional, del terrorismo internacional, del profundo crecimiento de las desigualdades, y con ellas del hambre y las enfermedades

5 Ferrajoli, Luigi, Principia iuris. Teoría del derecho y de la democracia, Madrid, Trotta, tomo 2, 2011, p. 473. 
Esta obra forma parte del acervo de la Biblioteca Jurídica Virtual del Instituto de Investigaciones Jurídicas de la UNAM

que afligen a millones de seres humanos, al igual que las perturbaciones ecológicas que amenazan el futuro de la humanidad. Según Ferrajoli, las realidades del modelo globalizador neoliberal sólo pueden enfrentarse con un nuevo paradigma jurídico, el que tendrá que basarse en tres elementos: la limitación jurídica de todos los poderes supranacionales y estatales, la garantía de la paz a nivel mundial y nacional y, por medio de un reforzamiento y ampliación de los derechos humanos en todas las instituciones y organizaciones relevantes de las sociedades nacionales e internacionales, incluyendo a las grandes corporaciones económicas ${ }^{6}$.

Las nuevas formas de organización jurídica mundial del neoliberalismo globalizador se debaten entre la construcción de un federalismo mundial integrado por los actuales Estados-nación, de esquemas de integración mixta en donde convivan modelos federales y confederales entre los Estados o, por la vía de una gran confederación mundial. La suerte y prevalencia de cada uno de estos posibles escenarios dependerá de la voluntad de los Estados y, desde luego, de los intereses de las grandes corporaciones trasnacionales que buscarán las formas de organización jurídica política que más les convengan. En estos procesos de integración supranacional, las sociedades nacionales pueden tener un papel relevante si se organizan y apuestan por estructuras de organización política orientadas por los derechos humanos, la paz y la limitación de los poderes supranacionales. El futuro, por tanto, está en manos de la lucha política y de la correlación de las fuerzas existentes.

Sin embargo, el planteamiento de Ferrajoli tiene, desde mi punto de vista, un flanco muy débil que es común a todas las teorías de su tipo, que podemos llamar neoconstitucionalistas. La concepción de la llamada democracia constitucional ferrajoliana desdeña el papel de las mayorías, del pueblo. Ferrajoli considera que el poder de las mayorías desemboca en construcciones fascistas y, por eso, los derechos humanos no deben pertenecer al ámbito de la democracia, forman parte de un ámbito no sujeto al regateo, a la negociación o a la discusión de las mayorías. El alcance de los derechos, su extensión y sus garantías de protección no son parte de la deliberación democrática. Los derechos humanos pertenecen al ámbito de lo indecidible para las mayorías. El pueblo soberano no puede en contra de los derechos humanos de las minorías o aún respecto a los derechos humanos de una sola persona ${ }^{7}$.

6 Ferrajoli, Luigi, Principia iuris. Teoría del derecho y de la democracia, Madrid, Trotta, tomo 2, 2011, p. 471.

7 Ferrajoli, Luigi, Principia iuris. Teoría del derecho y de la democracia, Madrid, Trotta, tomo 2, 2011, p. 478. 
Esta obra forma parte del acervo de la Biblioteca Jurídica Virtual del Instituto de Investigaciones Jurídicas de la UNAM

La cuestión es quién define el alcance, extensión y garantía de los derechos humanos. En las sociedades contemporáneas el espacio de los derechos humanos lo determina una élite de funcionarios internacionales o nacionales que son designados por las autoridades estatales o supranacionales y, que en ocasiones tienen vínculos, ya sea con las corporaciones económicas supranacionales o con movimientos de la sociedad civil supranacional. Ellos son los que dicen cuándo estamos en presencia de un derecho humano, qué extensión tiene el derecho humano y cómo se debe proteger y garantizar. Casi siempre estos funcionarios no son electos por el pueblo - por ejemplo los jueces constitucionales- y sus decisiones, muchas veces, no se adoptan mediante deliberación pública y transparente. Sin embargo, les conferimos el inmenso poder de definir lo qué es un derecho humano y lo qué no lo es.

La circunstancia expuesta obliga, desde mi punto de vista, a replantear las tesis de Ferrajoli y de buena parte de la teoría jurídica contemporánea. Las sociedades nacionales y supranacionales deben tomar parte no sólo en el debate de los derechos humanos sino en su definición. Los derechos humanos no tienen sólo fundamento en una moral objetiva ${ }^{8}$ sino en las luchas políticas y en las conquistas históricas de los pueblos. No es nada justo sustraer el alcance, extensión y garantías de los derechos humanos a los pueblos. Éstos deben tener amplia y permanente intervención en el debate de los derechos humanos. Es verdad que los pueblos se pueden equivocar y pueden reducir derechos o hasta negarlos, tal como la élite internacional y nacional que ahora los define. Sin embargo, los derechos humanos son en estos tiempos un instrumento de lucha para oponerse a los excesos de la globalización neoliberal y por ello resulta imprescindible que su defensa y definición esté en manos de las personas, las sociedades nacionales y las supranacionales. Los derechos humanos deben ser privados del elitismo que hoy en día los delimita para ponerlos al alcance del debate y deliberación de todos.

En nuestro tiempo y para tener la capacidad de lucha y oposición al neoliberalismo globalizador, debemos comenzar por reconocer, como lo hace Ferrajoli, lo siguiente: 1) que los derechos humanos siguen siendo una promesa no realizada en muchos lugares del mundo, principalmente los derechos económicos, sociales y culturales, y que esa ineficacia de los derechos tiene que ver fundamentalmente con las características del modelo económico neoliberal que no está interesado en el desarrollo de sociedades libres e igualitarias; 2) que las soberanías de los Estados son profundamente

8 Dworkin, Ronald, fusticia para erizos, traducción de Horacio Pons, México, Fondo de Cultura Económica, 2014, pp. 22-27. 
Esta obra forma parte del acervo de la Biblioteca Jurídica Virtual del Instituto de Investigaciones Jurídicas de la UNAM

desiguales, que existen soberanías casi absolutas como la de Estados Unidos frente a las soberanías de los demás Estados y que entre las soberanías de los Estados existen niveles y grados diversos de desigualdad; 3) que las ciudadanías también están desequilibradas, pues existen ciudadanos "optimo iure" con todos los derechos y semiciudadanos con permisos de residencia, refugiados, irregulares y clandestinos; situaciones jurídicas que en el mundo globalizado son fuente de exclusión y de discriminación entre las personas; 4) que las normas y las instituciones del derecho internacional son aún muy débiles e imperfectas, tanto desde sus ilegitimidades democráticas de origen y de ejercicio como de las vías para exigir su acatamiento, pues en el ámbito supranacional aún nos encontramos en muchos sentidos en un estado de naturaleza hobbesiano, en el que por un lado hay ausencia o imperfección de reglas y, por otro, existencia de la influencia de los más poderosos, sean las grandes potencias o los intereses económicos más relevantes, los que imponen la ley del más fuerte; y, 5) que no hemos ideado hasta el momento un derecho internacional que traslade los fines del constitucionalismo a la esfera mundial y que el propio constitucionalismo nacional recibe los embates de la globalización neoliberal ${ }^{9}$.

Ferrajoli sostiene que la "lex mercatoria" se afirma como la nueva "Grundnorm" del orden internacional y nacional con las consiguientes inversiones de las relaciones entre Estado y mercado, pues ya no son la política ni el Derecho los que gobiernan y controlan a la economía sino que ocurre exactamente al revés: el Derecho y la política están al servicio de la economía neoliberal globalizadora. Para argumentar su tesis identifica cinco dimensiones del nuevo Derecho de la economía neoliberal globalizadora: 1) Concentración y confusión de poderes, en donde los poderes privados nacionales y supranacionales se colocan por encima de la esfera pública e institucional para subordinarla y ponerla a su servicio a fin de beneficiar al mercado y, para que el orden jurídico deje de promover el interés general para concentrarse en la defensa de los intereses privados, principalmente en la defensa del derecho de propiedad de las grandes corporaciones; 2) La reducción del Derecho a mercancía en tanto que se da una competencia entre ordenamientos nacionales para que los ordenamientos con menor protección y garantía de los derechos laborales, medioambientales y que menos protegen los recursos naturales nacionales resulten más atractivos económicamente para las grandes corporaciones supranacionales, las que irán a invertir en los Estados menos garantistas; 3) La existencia de un mercado

9 Ferrajoli, Luigi, Principia iuris. Teoría del derecho y de la democracia, Madrid, Trotta, tomo 2, 2011, pp. 480-485. 
Esta obra forma parte del acervo de la Biblioteca Jurídica Virtual del Instituto de Investigaciones Jurídicas de la UNAM

trucado que favorece los intereses de las empresas de las grandes potencias por encima de los intereses económicos de las empresas de los países más débiles, es decir, en el concierto mundial no existe un auténtico mercado entre iguales; 4) La explotación ilimitada del trabajo, en donde éste deja de ser considerado un derecho humano y pasa a ser la mercancía por antonomasia, lo que permite una acumulación capitalista ilimitada que transfiere enormes riquezas de los trabajadores a las empresas, por lo que el Derecho de nuestro tiempo promueve la reducción de los salarios, la disminución de las garantías jurídicas laborales y el debilitamiento de la tutela sindical; y 5) La destrucción del medio ambiente porque la economía neoliberal globalizadora es fundamentalmente extractiva y uno de sus pilares consiste en el saqueo y expoliación de los recursos naturales al costo que sea necesario para acrecentar la acumulación capitalista ${ }^{10}$.

Para hacer frente a las características nocivas de la "lex mercatoria" del neoliberalismo globalizador, Ferrajoli desbroza sus propuestas. Así insiste en: 1) Un constitucionalismo mundial que prohije un federalismo global multinivel, en donde los ordenamientos nacionales e internacionales estén coordinados de suerte que se limite cualquier poder arbitrario, se garanticen los derechos humanos y se preserve la paz; 2) Los derechos civiles de autonomía que dan fundamento al mercado deben quedar subordinados a los derechos humanos, tanto de libertad como a los de carácter social; 3) La orientación de todo Derecho debe estar enmarcado en la garantía de la paz y de los derechos humanos; 4) Las funciones de garantía de los derechos humanos, tanto nacionales como internacionales, deben subordinar cualquier acción de gobierno nacional e internacional que se pretendan colocar por encima de ellas; y, 5) Se deben articular las competencias del nivel federal mundial con los estatales, de suerte que se produzca un nuevo federalismo cooperativo, capaz de subordinar la economía al Derecho, a través, entre otras medidas, de la democratización y perfeccionamiento jurídico de las actuales instituciones internacionales ${ }^{11}$.

Las propuestas de Ferrajoli pueden ser consideradas utópicas por muchos, por eso él en su descargo insiste que estimar el constitucionalismo global como no realista equivale a una falacia semejante a la naturalista, que confunde lo que acaece con lo que no puede acaecer y, por tanto, ese pensamiento constituye una abdicación de la razón y de la política. La conclusión de Ferrajoli, que recuerda a la izquierda hegeliana -todo lo racional es real-

10 Ferrajoli, Luigi, Principia iuris. Teoría del derecho y de la democracia, Madrid, Trotta, tomo 2, 2011 , pp. 516-521.

11 Ferrajoli, Luigi, Principia iuris. Teoría del derecho y de la democracia, Madrid, Trotta, tomo 2, 2011 , pp. 540-544. 
Esta obra forma parte del acervo de la Biblioteca Jurídica Virtual del Instituto de Investigaciones Jurídicas de la UNAM

no carece de fundamentos, aunque la creación de las condiciones de un nuevo constitucionalismo mundial que enfrente los excesos e injusticias del neoliberalismo globalizador, no sólo depende exclusivamente de la razón sino también de la voluntad y de la lucha política democrática de las sociedades para llevar a cabo ese proyecto jurídico-político, pues siempre estarán en duda las posibilidades de lo jurídico para transformar el "estatus quo".

Desde otras posturas críticas, diversas al actual Ferrajoli, y que provienen o reciben influencia del marxismo, tales como la escuela del uso alternativo del Derecho ${ }^{12}$ o los partidarios del Critical Legal Studies ${ }^{13}$, siempre se ha sostenido: 1) el uso ideológico del Derecho por sus operadores en respaldo de las clases o de los intereses dominantes y, 2) El histórico papel instrumental del Derecho en apoyo al status quo, y la necesidad, a partir de los planteamientos críticos, para que éste sea en adelante un medio a favor de la transformación social. Es verdad que esas posturas teóricas hasta recientemente no habían llevado sus categorías al estudio del derecho de la globalización neoliberal, sin embargo, hoy en día comienzan a realizarlo de manera persistente para advertir como la estructura económica de dominación mundial neoliberal exige un análisis no sólo desde esa estructura económica sino desde las superestructuras, entre ellas la del Derecho ${ }^{14}$.

Para las posturas críticas, la superestructura jurídica no es un simple reflejo o instrumento, sino que es una instancia que proporciona las condiciones generales y contextuales de la existencia de la estructura misma. En este sentido el Derecho expresa las contradicciones de la lucha mundial de las clases sociales y aunque generalmente juega a favor de los intereses de las clases dominantes también puede jugar a favor de las clases dominadas cuando éstas imponen condiciones en la estructura y en el funcionamiento de los aparatos del Estado. Es verdad que entre los sostenedores de las posturas críticas no existen unanimidades y existen visiones pesimistas que estiman que el Derecho nunca puede colocarse del lado de los débiles, pero también están, los que consideran que el Derecho, sobre todo la teoría pero también la práctica jurídica, pueden aportar contribuciones esenciales para la emancipación de

12 Poulantzas, Nicos, "Marx y el Derecho moderno", en Hegemonía y dominación en el Estado moderno, Buenos Aires, Cuadernos de Pasado y Presente, Siglo XXI Argentina, 1975; Cerroni, Umberto, Introducción al Pensamiento Político, México, Siglo XXI, 1994; LóPEZ CALERA, Nicolás y otros, Sobre el uso alternativo del Derecho, Valencia, Fernando Torres Editor, 1975.

13 Kennedy, Duncan, Libertad y restricción en la decisión judicial, Bogotá, Universidad de los Andes, Pontificia Universidad Javeriana, Ediciones Uniandes, Instituto Pensar, Siglo del Hombre Editores, 1999.

14 De Cabo Martín, Carlos, Pensamiento crítico, constitucionalismo crítico, Madrid, Trotta, 2014 
Esta obra forma parte del acervo de la Biblioteca Jurídica Virtual del Instituto de Investigaciones Jurídicas de la UNAM

clase. En este sentido las teorías críticas tienen mucho que aportar en la construcción de un derecho alternativo al derecho neoliberal de la globalización ${ }^{15}$.

Carlos de Cabo expone las siguientes características del Derecho, según la teoría crítica: 1) Ser el Derecho del conflicto, básicamente del conflicto socioeconómico pero también de otras aproximaciones como las del poder; 2) Asumir que el Derecho es uno de los mecanismos básicos de legitimación y de ocultamiento de la realidad; y 3) Desbloquear el positivismo jurídico: no acudir a la pureza metódica, romper con la neutralidad jurídica, y asumir el papel crítico que le corresponde realizar al Derecho. De Cabo insiste, que en el Derecho de la globalización es muy importante desenmascarar el rol ideológico y de manipulación que juega el ordenamiento jurídico a favor de los poderes fácticos nacionales y trasnacionales ${ }^{16}$. Uno de los asuntos cruciales para la teoría crítica consiste en reelaborar, no solo sociológica o políticamente el concepto de pueblo, ${ }^{17}$ sino de también realizar esa tarea jurídicamente ${ }^{18}$.

\section{LA REVISIÓN DE LAS TEORÍAS NEOCONSTITUGIONALES CONTEMPORÁNEAS PARA RESPONDER AL NEOLIBERALISMO GLOBALIZADOR}

Si una posible solución jurídica existe para enfrentar las incorrecciones del neoliberalismo globalizador es la mundialización del constitucionalismo.

15 Bernal, Angélica, M., "The Meaning and Perils of Presidential Refounding in Latin America", Constellations. An International Fournal of Critical and Democracy Theory, Volume 21, No. 4, New York, 2014; Finchelstein, Federico, "Returning Populism to History", Constellations. An International Fournal of Critical and Democracy Theory, Volume 21, No. 4, New York, 2014; y, STavrakakis, Yannis, "The Reurn of the People: Populism in the Shadows of the European Crisis", Constellations. An International fournal of Critical and Democracy Theory, Volume 21, No. 4, New York, 2014.

16 De Cabo Martín, Carlos, Pensamiento crítico, constitucionalismo crítico, Madrid, Trotta, 2014, pp. 52 y ss.

17 LaClaU, Ernesto, La razón populista, Buenos Aires, Fondo de Cultura Económica, 2005, pp. 91 y ss; y, HARDT, Michael-NEGRI, Antonio, Empire, Cambridge Massachussets, Harvard University Press, 2000.

18 El profesor portugués Gomes Canotilho afirma que una de las características que tiene el pueblo como titular del poder constituyente es la de entenderlo desde su grandeza pluralista formada por individuos, asociaciones, grupos, iglesias, comunidades, personalidades, instituciones, vehículos de intereses, ideas, creencias y valores plurales convergentes y conflictuales. Sólo ese pueblo concebido como comunidad abierta de sujetos constituyentes que pactan y consienten, tiene el poder de disponer y de conformar el orden político-social. Gomes Canotilho, J. J, Direito constitucional e teoria da Constituicao, Coimbra, Almedina, 1998, pp. 71 y 72 . 
Esta obra forma parte del acervo de la Biblioteca Jurídica Virtual del Instituto de Investigaciones Jurídicas de la UNAM

Cuando se habla de constitucionalismo, no podemos dejar de lado las versiones más influyentes de nuestro tiempo: el neoconstitucionalismo, el constitucionalismo popular y, el nuevo constitucionalismo latinoamericano. Por eso, conviene reflexionar sobre cada una de ellas para situar sus límites y, para entender si con alguna de las mencionadas podemos efectivamente hacer frente a las consecuencias negativas del neoliberalismo globalizador.

El noeconstitucionalismo o constitucionalismo contemporáneo ha sometido a crítica y revisión todas las tesis tradicionales del positivismo tradicional ${ }^{19}$. La Constitución ha rematerializado el ordenamiento, es decir, supone un orden de valores que condicionan la validez de las normas infraconstitucionales. La Constitución es el origen inmediato y directo de los derechos y obligaciones, y no sólo la fuente de fuentes. La tesis de la separación entre Derecho y moral no puede señalarse de manera absoluta porque la Constitución ha incorporado los valores de justicia en sus principios jurídicos constitucionales. El legislador ya no es la viva voz del soberano, pues debe acomodar su actuación a la Constitución. El principio de legalidad ha cedido a un principio de juridicidad y de constitucionalidad ${ }^{20}$. La interpretación y aplicación del Derecho se ha trastocado por la inclusión de los principios constitucionales, y el peso de la argumentación retórica sobre una argumentación lógico formal del Derecho ${ }^{21}$. Las normas constitucionales no tienen la estructura clásica de las reglas legales y, por tanto, no se prestan a la subsunción. Sin embargo, ello no debe desembocar en un puro decisionismo arbitrario del juez, sino en la necesidad que éste tiene de justificar adecuadamente sus fallos recurriendo a las técnicas más variadas de la argumentación, según teorías como las de Viehweg, Perelman, Toulmin, MacCormick, Alexy, Aarnio, Peczenick, etcétera ${ }^{22}$.

Según Guastini, el neoconstitucionalismo tiene como notas distintivas las siguientes: 1) La rigidez de la Constitución; 2) El control de constitucionalidad de las leyes; 3) La fuerza vinculante de la Constitución; 4) La sobreinterpretación de las disposiciones constitucionales; 5) La aplicación directa de tales disposiciones por parte de los jueces; 6) La interpretación conforme de la ley ordinaria; y, 7) La influencia directa de la Constitución en las rela-

19 Carbonell, Miguel (ed.), Teoría del neoconstitucionalismo. Ensayos escogidos, Madrid, Trotta, 2007.

20 Zagrebelsky, Gustavo, El derecho dúctil. Ley, derechos, justicia, Madrid, Trotta, 2008, pp. 144-153.

21 Atienza, Manuel, Las razones del derecho. Teorías de la argumentación jurídica, editorial Centro de Estudios Constitucionales, Madrid, 1991, pp. 32 y ss.

22 Atienza,Manuel, Las razones del derecho. Teorías de la argumentación jurídica, obra citada, 1991. 
Esta obra forma parte del acervo de la Biblioteca Jurídica Virtual del Instituto de Investigaciones Jurídicas de la UNAM

ciones políticas ${ }^{23}$. En el neoconstitucionalismo, la interpretación de y desde la Constitución ${ }^{24}$ y los tratados, es tan importante que se sitúa en el núcleo mismo de la teoría jurídica y constitucional. A consecuencia de lo anterior, los jueces constitucionales han adquirido un papel inusitado que logra desplazar en muchas ocasiones al legislador democrático.

Es sobre todo por el impacto de los principios constitucionales que se modifica la interpretación jurídica al estimular nuevas formas de razonamiento jurídico. El uso de la proporcionalidad y el configurar el caso de forma abierta y no cerrada como en las reglas. El juicio de proporcionalidad obliga al intérprete al desarrollo de una racionalidad material o sustantiva mucho más compleja que la subsunción, una racionalidad cercana a la manera de argumentación de la moral. Los principios exigen también el análisis de las reglas a la luz de los propios principios, la argumentación por principios obliga al intérprete a utilizar pautas de interpretación que colocan en su fin a la discrecionalidad del juez a la manera como lo habían entendido Kelsen o Hart.

Estas notas del noeconstitucionalismo significan una evolución y una alteración del positivismo tradicional. Como dice Prieto: “....el legislador ha dejado de ser el dueño absoluto del Derecho; el juez ha salido de la alternativa entre "boca muda" o "juez legislador"; y la moral ya no penetra en el Derecho exclusivamente a través de las decisiones legales, sino que aparece mucho más difusamente en una simbiosis entre Constitución y jurisdicción, es decir, entre los valores y principios constitucionales y la racionalidad práctica de su aplicación" 25 .

La reforma constitucional mexicana en materia de derechos humanos publicada en el día 10 de junio de 2011 en el Diario Oficial de la Federación, principalmente, cuando ésta modificación constitucional prevé la obligación para todas las autoridades de realizar interpretación conforme a la Constitución y pro homine (párrafo segundo del artículo primero de la Constitución) y, cuando el párrafo tercero del artículo 1 de la Constitución se refiere a los métodos y criterios de interpretación en materia de derechos fundamentales: interdependencia, universalidad, indivisibilidad y progresividad, confirma su impronta neoconstitucionalista. Lo mismo podemos decir de las resoluciones del pleno de la Suprema Corte de Justicia de la

23 Guastini, Ricardo, "La constitucionalización del ordenamiento jurídico: el caso italiano”, en Carbonell, Miguel (ed.), Neoconstitucionalismo(s), Madrid, Trotta, 2003, pp. 49-57.

24 Vigo, Rodolfo Luis, Interpretación constitucional, editorial Abeledo- Perrot, Buenos Aires, 1993, pp. 81-104.

25 Prieto Sanchís, Luis, Constitucionalismo y positivismo, México, Fontamara, 1997, p. 23. 
Esta obra forma parte del acervo de la Biblioteca Jurídica Virtual del Instituto de Investigaciones Jurídicas de la UNAM

Nación en el expediente varios 912/2010 (caso Rosendo Radilla) que previó el control difuso de constitucionalidad y convencionalidad para las diversas autoridades del país y la resolución que resolvió la contradicción de tesis 293/2011 que estableció con claridad bastante definitiva los conceptos de bloque de constitucionalidad y de parámetro de constitucionalidad.

El cambio en la cultura jurídica que significan las transformaciones constitucionales anteriores entraña que algunos métodos y argumentos jurídicos -como el sistemático o todos los derivados de la interpretación y argumentación de principios- podrían cobrar en cuanto a su eficacia, una importancia mayor a la que tradicionalmente han tenido en la vida cotidiana de autoridades y jueces, así como también el empleo de los métodos y argumentos surgidos del derecho de los tratados, incluyendo la vinculación de los tribunales internos a resoluciones de órganos supranacionales. En esta misma tesitura estaría la interpretación constitucional ex officio para que los tribunales y autoridades analicen, independientemente del planteamiento de las partes, si las normas secundarias que piensan aplicar tienen o no fundamentos constitucionales y convencionales y, en su caso, puedan desaplicarlas, expulsarlas del sistema o realizar una interpretación conforme, previo reconocimiento en todos los supuestos de su constitucionalidad y convencionalidad o de su inconstitucionalidad e inconvencionalidad.

Lo anterior que parece muy innovador e importante para el Derecho porque constitucionaliza y convencionaliza a todo el ordenamiento jurídico para proteger y garantizar derechos humanos, presenta, sin embargo, varios defectos. Enumero con apoyo en al trabajo de Alterio los siguientes: 1) Se da al juez, principalmente al juez constitucional un papel inusitado, por encima de los demás poderes establecidos, incluyendo al legislativo; 2) El juez constitucional carece de legitimidad democrática de origen, porque los integrantes de los máximos tribunales de cada país no son electos por los ciudadanos; 3) El juez constitucional suele ser designado por las fuerzas políticas mayoritarias de alguna de las Cámaras del Congreso y por tanto reproduce las concepciones del "status quo" que son afines a esas fuerzas políticas mayoritarias; 4) El juez constitucional representa las concepciones elitistas de la sociedad, pues sus miembros son integrantes de esos sectores; 5) El modelo neoconstitucionalista desconfía de la participación popular y estima como Ferrajoli o Dworkin que los derechos humanos no forman parte del debate democrático, en tanto que los derechos humanos son cartas de triunfo, integran el ámbito de lo no decidible, son un coto vedado; 6) La democracia electoral se modifica por una democracia llamada sustancial -la de los derechos humanos y principios- que subordina a la democracia polí- 
Esta obra forma parte del acervo de la Biblioteca Jurídica Virtual del Instituto de Investigaciones Jurídicas de la UNAM

tica; 7) El control de constitucionalidad y convencionalidad está por encima de la voluntad mayoritaria; 8) La política se subordina a la Constitución, los tratados y la interpretación; 9) Los derechos humanos forman parte de una moral objetiva que existe más allá de la voluntad de las personas y por tanto no pueden estar limitados por las decisiones mayoritarias; y, 10) El neoconstitucionalismo tiene un fundamento iusnaturalista indudable ${ }^{26}$.

Aunque el modelo neoconstitucionalista puede resultar muy atractivo y, en algunos casos, como en la teoría de Ferrajoli, se proponga mundializar el constitucionalismo para enfrentar los elementos nocivos del neoliberalismo globalizador, resulta para los efectos de este análisis, que las teorías neoconstitucionalistas en general son ajenas al derecho de la globalización neoliberal. Bien podemos decir, que se trata en su mayor parte de teorías jurídicas ancladas en el esquema del Estado nación, que no han percibido aún las complejidades del nuevo derecho del mundo globalizado. Además, y esto tal vez sea lo que resulta más grave para las nuevas condiciones del planeta, son teorías que apuestan por un modelo elitista del Derecho y de la democracia ${ }^{27}$, muchas veces opaco porque la mayoría de los ciudadanos desconocen las razones y el procesamiento de las decisiones de los tribunales o los motivos que los dirigentes políticos tuvieron para aceptar acuerdos y tratados internacionales que no pasan por el referéndum ciudadano. Es decir, las teorías neoconstitucionalistas que prohíjan una llamada democracia constitucional, carecen de elementos democráticos fundados en la participación y en la amplia deliberación de los ciudadanos ${ }^{28}$. Las teorías neoconstitucionalistas son esquemas conceptuales que dotan a ciertos funcionarios no elegidos ni supeditados al control de los ciudadanos del poder de definir qué es o no es un derecho humano y que alcance o extensión tiene éste.

Como hemos insistido en estas páginas, si hay una vía para moldear la globalización del Derecho a favor de las personas, ésta pasa por la participación activa de todas las personas y sectores sociales de las sociedades

26 Alterio, Ana Micaela, "Corrientes del Constitucionalismo contemporáneo a debate", en Revista Problema. Anuario de Filosofía y Teoría del Derecho, México, número 8, enerodiciembre de 2014, pp. 227-306.

27 De Cabo Martín, Carlos, Pensamiento crítico, constitucionalismo crítico, Madrid, Trotta, 2014 .

28 Como dice Ian Shapiro al referirse a la democracia estadounidense, el sistema competitivo shumpeteriano ha sido sustituido por el papel del dinero que desplaza la competencia de los votos por la competencia por las aportaciones y gastos de campaña, por las bajas tasas de renovación entre los cargos políticos, por el dominio bipartidista de las instituciones electorales y por un modelo que en el fondo es anticompetitivo y antipluralista. SHAPIRO, Ian, El estado de la teoría democrática, Barcelona, ediciones Bellaterra, 2005, p. 207. 
Esta obra forma parte del acervo de la Biblioteca Jurídica Virtual del Instituto de Investigaciones Jurídicas de la UNAM

contemporáneas. Quién puede ponerle un hasta aquí al neoliberalismo globalizador sólo son los ciudadanos a través de su amplia participación y de la deliberación de los asuntos públicos. Por eso, las notas más negativas del derecho de la globalización neoliberal, que son su ilegitimidad democrática y opacidad, sólo pueden ser superadas por la construcción de un nuevo constitucionalismo y de teoría democrática radical que devuelva a las personas la capacidad de determinar cuáles son sus derechos humanos y cuáles deben ser sus alcances y extensiones ${ }^{29}$. La teoría jurídica que requerimos debe desde luego apostar por la democratización radical de todas las instituciones nacionales y supranacionales, pero principalmente, debe apostar por el poder ciudadano. Se debe dejar atrás el miedo ferrajoliano a la soberanía popular.

El constitucionalismo popular está integrado por aportaciones, principalmente del ámbito norteamericano pero que han tenido impacto en América Latina, principalmente en Sudamérica ${ }^{30}$. Sus notas distintivas son: 1) Flexibilizar la Constitución y excederla; 2) Desafiar la supremacía judicial y en ciertos casos impugnar cualquier forma de control judicial de constitucionalidad; 3) Proponer la interpretación extrajudicial de la Constitución; 4) Sostener la democratización de todas las instituciones políticas y económicas; y, 5) Recuperar la relación entre derecho y política ${ }^{31}$. Entre las finalidades destacadas de esta corriente teórica están, el cuestionar el papel del juez constitucional como monopólico máximo intérprete de la Constitución y del ordenamiento ${ }^{32} \mathrm{y}$, promover al máximo la participación ciudadana en las decisiones colectivas, pues la legitimidad democrática de las mismas depende del grado de participación de las personas en ellas ${ }^{33}$.

El Derecho en el constitucionalismo popular es cambiante y dinámico. Los ciudadanos participan en su procesamiento y en su definición. El control judicial de las leyes debe ser eliminado a favor del control ciudadano de las mismas. Los autores que reivindican esta posición son conscientes de los

29 SAnín Restrepo, Ricardo, Teoría crítica constitucional. La democracia a la enésima potencia, Valencia, Tirant Lo Blanch, 2014.

30 Gargarella, Roberto, "Acerca de Barry Friedman y el "constitucionalismo popular mediado", Revista Furídica de la Universidad de Palermo, Buenos Aires Argentina, año 6, número $1,2005$.

31 Alterio, Ana Micaela, "Corrientes del Constitucionalismo contemporáneo a debate", en Revista Problema. Anuario de Filosofía y Teoría del Derecho, México, número 8, enerodiciembre de 2014, pp. 254-255.

32 KRAMER, Larry D., Constitucionalismo popular y control de constitucionalidad, Madrid, Marcial Pons, traducción de Paola Bergallo, 2011.

33 Tushnet, Mark, Taking the Constitution Away From the Courts, Princeton, Nueva Jersey, Princeton University Press, 1999. 
Esta obra forma parte del acervo de la Biblioteca Jurídica Virtual del Instituto de Investigaciones Jurídicas de la UNAM

"riesgos" de la participación popular: el fascismo, el anti intelectualismo, la persecución de minorías impopulares, la exaltación de la mediocridad y la romántica exageración de las virtudes de la masa ${ }^{34}$. Sin embargo, consideran que sólo el pueblo puede dotar de legitimidad a los gobiernos y que el miedo a la sociedad o a la mayoría de ella implica mantener los intereses del "status quo".

La finalidad del Derecho es la de promover la regla de la mayoría y otras formas de participación y deliberación ciudadana para que la totalidad del entramado institucional y la definición de los derechos humanos dependa de la sociedad y no de una élite de ilustrados -los jueces constitucionales- que representan los intereses del status quo. Los constitucionalistas populares se dividen entre los que sostienen que las decisiones trascendentes de la Corte Suprema de los Estados Unidos deben ser revisadas por el Congreso de ese país y, los que de plano estiman que la revisión de la constitucionalidad en los asuntos fundamentales -inconstitucionalidad de leyes y de normas generales- debe corresponder al pueblo mismo ${ }^{35}$.

Los constitucionalistas populares han propuesto diversos cambios en el derecho norteamericano para alentar la participación ciudadana en la definición de los derechos humanos. Estas modificaciones implicarían: 1) Alentar en los Estados Unidos los procedimientos de reforma constitucional; 2) Elegir popularmente, por voto ciudadano, a los jueces de la Corte Suprema de los Estados Unidos; 3) Facultar a los ciudadanos y a ciertos poderes públicos a revisar las decisiones de la Corte Suprema; 4) A revocar popularmente los nombramientos de los jueces de la Corte Suprema; y, 5) A desobedecer socialmente las decisiones judiciales ${ }^{36}$. Todas estas medidas están fundadas en el valor axiológico y no sólo técnico de la regla de la mayoría, en la importancia constitucional de la soberanía popular como origen y fin de las instituciones y normas, en la trascendencia de la deliberación de los asuntos públicos y, en la idea de que el proceso democrático debe definir el sentido y el alcance del Derecho, incluyendo a los derechos humanos.

Es evidente que el constitucionalismo popular no desarrolla nociones, conceptos o categorías para enfrentar los elementos nocivos del derecho de la globalización neoliberal. No obstante esta importante ausencia, encontramos en él, lo que no existe en el neoconstitucionalismo, que es la

34 Balkin, Jack M., "Populism and Progressivism as Constitutional Categories", Faculty Scholarship Series, Paper 268, 1995, pp. 1950-1951.

35 Post, Robert y Siegel, Reva, "Popular Constitucionalism, Departamentalism, and Judicial Supremacy", California Law Review 92, 2004.

36 Post, Robert y SiEgel, Reva, "Popular Constitucionalism, Departamentalism, and Judicial Supremacy”, California Law Review 92, 2004, p. 1039. 
Esta obra forma parte del acervo de la Biblioteca Jurídica Virtual del Instituto de Investigaciones Jurídicas de la UNAM

recuperación del papel de los ciudadanos como definidores del Derecho y determinadores últimos de los derechos humanos. La insistencia del constitucionalismo popular en democratizar las instituciones y el Derecho, aunque se promueva en sus parámetros, que son los del Estado-nación, puede perfectamente extenderse a escala planetaria. Si consideramos que existen posibilidades para mundializar el constitucionalismo, éstas necesariamente pasan por la participación y deliberación ciudadana de las sociedades nacionales y de la sociedad mundial. El Derecho del neoliberalismo globalizador sólo puede ser desenmascarado desde la legitimidad democrática que pueden brindar los ciudadanos a través de su participación en los asuntos públicos y, desde su poder para transparentar y poner coto a los intereses de las grandes corporaciones trasnacionales.

El nuevo constitucionalismo latinoamericano que teoriza en torno a las Constituciones de Venezuela de 1999, de Ecuador de 2008 y de Bolivia de 2009, contiene rasgos deplorables pero posee otros que son luminosos. Entre los deplorables está el hiperpresidencialismo que ha fomentado, pero tiene, entre sus facetas positivas las siguientes notas: 1) Busca construir realidades más igualitarias ${ }^{37}$; 2) amplía los mecanismos de democracia participativa; 3) establece fórmulas democráticas al control de constitucionalidad; 4) rescata el papel del Estado en la economía para superar las desigualdades económicas y sociales; y, 5) plantea una integración internacional más simétrica que la que se predica en otras latitudes ${ }^{38}$. Podemos decir, que es un constitucionalismo, en el que la voluntad constituyente de las clases populares se

37 GARGARELLA, Roberto, "El constitucionalismo latinoamericano de ayer a hoy: promesas e interrogantes", mimio. Ver también: GARGARELLA, Roberto, "El nacimiento del constitucionalismo popular", en GargarelLa, Roberto, Teoría y crítica del Derecho Constitucional, Buenos Aires, Abeledo Perrot, tomo I, 2008, pp. 249- 262.

38 Viciano Pastor, Roberto y Martínez DalmaU, Rubén, "Aspectos generales del nuevo constitcionalismo latinoamericano", en El nuevo constitucionalismo en América Latina, Quito, Ecuador, Corte Constitucional, 2010, 9-43. En este trabajo se distinguen entre características formales y materiales del nuevo constitucionalismo latinoamericano. Entre sus características formales señalan que los nuevos textos se distinguen por: 1) Incorporar nuevas categorías jurídicas que el viejo constitucionalismo latinoamericano no preveía; 2) Proponer una nueva institucionalidad basada en la aparición de nuevos órganos e instituciones; 3) Son constituciones extensas; 4) Son constituciones complejas; y, 5) Son constituciones más rígidas que las tradicionales. Entre las características materiales, los rasgos que mencionan para el nuevo constitucionalismo latinoamericano, son: 1) Formas amplias de participación ciudadana; 2) Son constituciones con extensos catálogos de derechos fundamentales; 3) Son constituciones que proponen vías para la integración de sectores históricamente marginados como los indígenas; 4) Son constituciones que dotan de legitimidad democrática directa a los tribunales constitucionales; y, 5) Son constituciones que rescatan el papel del Estado en la economía, es decir, son constituciones anti neoliberales. 
Esta obra forma parte del acervo de la Biblioteca Jurídica Virtual del Instituto de Investigaciones Jurídicas de la UNAM

manifiesta en una vasta movilización social y política que configura un constitucionalismo desde abajo, protagonizado por los excluidos y sus aliados, con el objetivo de expandir el campo de lo político más allá del horizonte liberal, mediante una institucionalidad nueva (plurinacionalidad), una territorialidad nueva (autonomías asimétricas), una legalidad nueva (pluralismo jurídico), un régimen político nuevo (democracia intercultural) y nuevas subjetividades individuales y colectivas (individuos, comunidades, naciones, pueblos, nacionalidades), en donde todos esos cambios constitucionales buscan garantizar la realización de políticas anticapitalistas y anticoloniales ${ }^{39}$.

Uno de los rasgos del nuevo constitucionalismo latinoamericano, que ha provocado un fuerte debate, tiene que ver con la legitimidad democrática directa de los titulares de algunos órganos constitucionales autónomos ${ }^{40}$, tales son los casos, de la elección mediante sufragio universal de los magistrados del Tribunal Constitucional Plurinacional que se prevé en la Constitución de Bolivia y la elección por sufragio universal de los titulares del Consejo de la Magistratura en Argentina. Los artículos 197 y 198 de la Constitución de Bolivia indican que el Tribunal Constitucional Plurinacional estará integrado por magistradas y magistrados elegidos con criterios de plurinacionalidad, con representación del sistema ordinario y del sistema indígena ordinario campesino y, que las magistradas y los magistrados del Tribunal Constitucional Plurinacional se elegirán mediante sufragio universal, según el procedimiento, mecanismo y formalidades de los miembros del Tribunal Supremo de Justicia que también se eligen mediante sufragio universal. En Argentina, la presidenta Cristina Fernández envió al Congreso de la Nación, el día 8 de abril de 2013, seis proyectos para reformar al poder judicial de ese país. Una de las propuestas implicaba la elección por sufragio universal de los titulares del Consejo de la Magistratura. Las leyes fueron aprobadas en el Congreso argentino pero el 18 de junio de 2013 la Corte Suprema de ese país declaró la inconstitucionalidad de la ley, argumentando que el artículo 114 de la Constitución Argentina, alude a los "estamentos" de jueces y "abogados de la matrícula", lo que implica una representación corporativa que debe ser observada.

El nuevo constitucionalismo latinoamericano promueve amplísimos medios de democracia participativa y deliberativa, incluyendo al recono-

39 Santos, Boaventura de Sousa, Refundación del Estado en América Latina. Perspectivas desde una epistemología del Sur, México, Guatemala y Buenos Aires, Universidad de los Andes, Sigo del Hombre Editores y Siglo Veintiuno Editores, 2010, p. 85.

40 Salazar, Pedro, "El nuevo constitucionalismo latinoamericano (Una perspectiva crítica)", en GONZÁLEZ PÉREZ, Luis Raúl y VALADÉS, Diego, El constitucionalismo contemporáneo. Homenaje a forge Carpizo, México, UNAM, 2013, pp. 345-387. 
Esta obra forma parte del acervo de la Biblioteca Jurídica Virtual del Instituto de Investigaciones Jurídicas de la UNAM

cimiento del derecho de resistencia y la democracia intercultural. Es un constitucionalismo que libera a los Constituyentes originarios de las ataduras que puedan imponer a su desarrollo los tratados y acuerdos internacionales firmados con anterioridad a las elaboraciones de las Constituciones respectivas. Es una teoría que desconfía del poder elitista de los tribunales constitucionales y por eso intenta mitigar el poder de éstos con fórmulas participativas como explicamos en el párrafo anterior. En la Constitución se determinan criterios expresos para la interpretación constitucional a fin de evitar la discrecionalidad judicial ${ }^{41}$ y, en algunos casos, se establecen las acciones populares de inconstitucionalidad para que los ciudadanos, sin acreditar legitimación procesal específica, puedan plantear cuestiones de inconstitucionalidad ante los tribunales constitucionales ${ }^{42}$.

Además, el nuevo constitucionalismo latinoamericano afirma la soberanía nacional por encima de los intereses del derecho de la globalización neoliberal. Así se recuperan para las respectivas naciones el control sobre sus recursos naturales, se insiste en la renacionalización de todos esos recursos que han sido privatizados y, se exige que sean los respectivos Estadosnación los que exploten esos recursos en beneficio de las sociedades nacionales. En este tenor, la teoría del nuevo constitucionalismo latinoamericano recupera a favor del Estado la rectoría de las economías nacionales para promover la igualdad material entre los ciudadanos. Es un constitucionalismo respetuoso y garante de las culturas originarias y, por ello algunas constituciones, como la de Bolivia, reconocen el carácter plurinacional del Estado Boliviano. Igualmente se añaden al catálogo de los derechos fundamentales derechos de origen indígena como el derecho de la madre tierra y el derecho al buen vivir. Son constituciones que promueven todas las formas de cooperación y solidaridad entre las personas, se alienta la autogestión, la cogestión, las cooperativas, las cajas de ahorro y, las empresas comunitarias.

La teoría democrática del nuevo constitucionalismo latinoamericano reconoce diferentes formas de deliberación democrática para respetar a las culturas de los pueblos originarios, asume por tanto diferentes criterios de representación democrática, reconoce los derechos fundamentales de carácter colectivo de los pueblos como condición del ejercicio de los dere-

41 Villabella, Carlos, Nuevo constitucionalismo latinoamericano. ¿Un nuevo paradigma?, México, Grupo Editorial Mariel, Instituto de Ciencias Jurídicas de Puebla, A.C., Universidad de Guanajuato, Juan Pablos Editor, 2014.

42 Alterio, Ana Micaela y Niembro OrTega, Roberto, “¿Qué es el constitucionalismo popular? Una breve referencia al uso de las fuerzas armadas en México como fuerzas de seguridad", en Alterio, Ana Micaela y Niembro OrTega, Roberto, Constitucionalismo popular en Latinoamérica, México, Porrúa, 2013, p. 178. 
Esta obra forma parte del acervo de la Biblioteca Jurídica Virtual del Instituto de Investigaciones Jurídicas de la UNAM

chos individuales, amplia el catálogo de derechos fundamentales de carácter social e identitario y, sostiene una educación compatible con las diversas culturas a fin de despojar a la cultura de elementos neocolonialistas. En el nuevo constitucionalismo latinoamericano la política, es decir, la soberanía popular determina el alcance de la Constitución y de los derechos humanos.

Seguramente, el nuevo constitucionalismo latinoamericano puede recibir críticas, porque como he señalado, ha alentado el hiperpresidencialismo en América Latina, pero debe ser tomado en serio, como una vía para enfrentar las consecuencias nocivas del modelo jurídico del neoliberalismo globalizador. Su carácter alternativo, su insistencia en la igualdad material, su énfasis en los derechos de los pueblos originarios, la recuperación de las distintas formas de participación democrática, la defensa de los recursos naturales a favor de la nación, la rectoría económica que promueve a favor del Estado-nacional, la ampliación de los derechos sociales y colectivos desconocidos en el derecho occidental y, la orientación de una política basada en la solidaridad y en la cooperación frente al individualismo posesivo del neoliberalismo globalizador son, a todas luces poderosos instrumentos para superar los profundos elementos negativos del neoliberalismo globalizador.

\section{Gonclusiones}

Para elaborar una teoría jurídica alternativa al neoliberalismo globalizador que esté a favor de los más débiles debe mundializarse el constitucionalismo como lo propone Ferrajoli. Pero además y, en contra de Ferrajoli, debe ampliarse la participación y la deliberación social, política y jurídica para que sean los ciudadanos los que definan el sentido, contenidos y alcance de los derechos humanos, tanto a nivel interno como externo. En las cuestiones fundamentales para una sociedad, la decisión última, no debe estar en manos de los tribunales constitucionales, sino que debe corresponder a las personas que componen la comunidad. Las características elitistas del neoconstitucionalismo deben ser eliminadas para que la soberanía regrese al pueblo. Para ello se deben pensar vías democráticas de elección de los jueces constitucionales, así como en instrumentos de auditoría social y de revocación de mandato que permitan que la función de control constitucional esté supervisada por el pueblo.

Es imprescindible para construir un derecho alternativo al del neoliberalismo globalizador consolidar en los Estados-nación los medios de democracia participativa y deliberativa. Sin ellos, las sociedades no cuentan con instrumentos procesales de carácter horizontal para garantizar adecua- 
Esta obra forma parte del acervo de la Biblioteca Jurídica Virtual del Instituto de Investigaciones Jurídicas de la UNAM

damente los derechos humanos ni los procedimientos democráticos. Toda cuestión importante - una reforma a la Constitución o la aprobación de un Tratado (sobre todo de los tratados que comprometen la soberanía nacional)- debe pasar por el referéndum popular. Los integrantes de la sociedad requieren contar con instrumentos como la acción ciudadana o popular de inconstitucionalidad y, la revocación del mandato respecto a todas las autoridades que hayan sido electas popularmente para que éstas tengan siempre presente en donde descansa la soberanía y el poder para definir el ordenamiento jurídico.

En sintonía con el nuevo constitucionalismo latinoamericano, la teoría jurídica debe propender a: fortalecer el carácter alternativo del Derecho frente al status quo, a fin de garantizar la igualdad material de las personas, realizar los derechos de los pueblos originarios, introducir las distintas formas de participación democrática y deliberativa, defender los recursos naturales a favor de la nación, y garantizar la rectoría económica a favor del Estado-nación, así como ampliar la garantía de los derechos sociales y colectivos y, basar la organización social y jurídica en la solidaridad y en la cooperación frente al individualismo posesivo del neoliberalismo globalizador.

El logro de los anteriores objetivos no es simple, las luchas jurídicas y sociales de las sociedades en el mundo entero pondrán a la luz las enormes contradicciones de la globalización neoliberal ${ }^{43}$. Desde la teoría jurídica nuestro papel es el desenmascarar la injusta faz del Derecho que ha producido el proceso político-económico del neoliberalismo y, proponer las formas alternativas de un nuevo Derecho para el siglo XXI. Como dice Boaventura de Sousa Santos, los fines de ese nuevo Derecho alternativo son: desmercantilizar las relaciones jurídicas y sociales; democratizar radicalmente las instituciones y los procesos de creación y aplicación normativa; y, descolonizar el Derecho para ponerlo al servicio de los más débiles, principalmente de los pueblos originarios ${ }^{44}$.

43 En contra del punto de vista que expongo sobre las posibilidades de cambio ver: BYUnG-Chul Han, “¿Por qué hoy no es posible la revolución?”, Madrid, periódico El País, 3 de octubre de 2014.

44 Santos, Boaventura de Sousa, Refundación del Estado en América Latina. Perspectivas desde una epistemología del Sur, México, Guatemala y Buenos Aires, Universidad de los Andes, Sigo del Hombre Editores y Siglo Veintiuno Editores, 2010, pp. 157-163. 
Esta obra forma parte del acervo de la Biblioteca Jurídica Virtual del Instituto de Investigaciones Jurídicas de la UNAM

\title{
ALGUNAS REFLEXIONES EN TORNO \\ A LA TEORÍA Y PRÁCTICA DEL CAMBIO CONSTITUGIONAL EN MÉXICO
}

\begin{abstract}
SUMARIO: I. Introducción. II. El estado actual de la teoría de la Constitución. III. La Constitución del Estado constitucional. IV. El necesario cambio constitucional en México: entre constitucionalismo y democracia. V. Conclusión.
\end{abstract}

Manlio Fabio CASARÍn LEÓN*

\section{INTRODUCGIÓN}

La Constitución Política de los Estados Unidos Mexicanos promulgada por el constituyente de Querétaro en 1917 está a punto de cumplir 100 años de vida. Muchos son los aportes de sus preceptos al constitucionalismo universal, como es el caso de la consagración de los derechos sociales y el perfeccionamiento de la técnica del amparo como instrumento de control constitucional. Igualmente, fue considerada como documento emanado de un proceso revolucionario que buscaba alcanzar en el país la justicia social y, en general, mejores condiciones de vida de sus habitantes.

Sin embargo, durante los años de su vigencia hemos podido constatar la escasa efectividad y vinculación de sus disposiciones, sobre todo a partir de la concepción política y no jurídica que le imprimió el régimen autoritario emanado de la revolución mexicana, que duró en el poder hasta el año 2000 cuando se da la alternancia en favor de distinta fuerza política, lo que en su momento fue interpretado como la transición a la democracia pero que la realidad nos demostró lo contrario, al recuperar en 2012 la presidencia de la república el partido revolucionario institucional, acentuándose no solo las viejas prácticas corporativas y de clientelismo electoral sino también el

* Doctor en Derecho Público. Investigador del Instituto de Investigaciones Jurídicas y Catedrático de la Facultad de Derecho de la Universidad Veracruzana. 
Esta obra forma parte del acervo de la Biblioteca Jurídica Virtual del Instituto de Investigaciones Jurídicas de la UNAM

desmantelamiento y desfiguración del proyecto de nación fraguado por el constituyente originario, en virtud de las más de 600 reformas realizadas hasta este momento al texto constitucional.

Aún cuando el discurso oficial siempre ha sostenido que la Constitución mexicana ha requerido adaptarse a los tiempos cambiantes de la realidad, resulta evidente que la gran mayoría de las reformas sufridas han sido el producto, o bien de decisiones unilaterales a cargo del titular del poder ejecutivo federal en turno, cuando con la sumisión del poder legislativo y gobiernos locales ha llevado al texto fundamental su programa de gobierno, o como hemos observado en los últimos años, el fruto de los pactos realizados por las principales fuerzas políticas del país a cambio de negociaciones y privilegios que solo impactan favorablemente en la clase política gobernante, pero que desde el punto de vista social acusan un severo déficit de legitimidad democrática.

La conclusión es evidente, tenemos un texto constitucional excesivamente reglamentado que ha perdido su coherencia, consistencia, sistemática y la claridad de un proyecto de nación, además de representar un elemento cada vez más ajeno a los intereses y deseos de los ciudadanos en virtud de estar cooptado por las fuerzas políticas representadas en los órganos gubernamentales de decisión, quienes incentivan a través de sus actividades una comprensión relativizada y secundaria de sus preceptos, no obstante que en forma reiterada pregonen - al menos en el discurso- la cultura de legalidad y el cumplimiento irrestricto del Estado de Derecho.

La prueba más contundente de lo anterior, la tenemos representada a partir de estudios, indicadores y datos duros no sólo de sectores importantes de la sociedad civil y organismos internacionales, sino incluso de las propias instancias gubernamentales, además de la percepción social negativa en varios ámbitos de la actividad estatal. Por ejemplo, cómo explicar los inaceptables niveles de pobreza, desigualdad, inseguridad, corrupción, impunidad, la baja calidad de los servicios educativos, de salud, el alarmante deterioro del medio ambiente, la crisis de derechos humanos, el costoso e ineficiente sistema electoral, y en general, la erosionada y opaca gobernabilidad democrática en los tres niveles de gobierno, cuando paradójicamente año con año se destinan millonarios presupuestos públicos para garantizar un mayor bienestar de la población y se alardean cambios legislativos o políticas públicas aparentemente encaminadas a transformar al país por el sendero de un real y auténtico desarrollo.

Con todo, creemos firmemente que una de las principales respuestas para resolver paulatinamente la gran cantidad de problemas nacionales, 
Esta obra forma parte del acervo de la Biblioteca Jurídica Virtual del Instituto de Investigaciones Jurídicas de la UNAM

la constituye el cambio constitucional a través de una reforma integral a la Constitución federal, pero inscrita en clave democrática, no solamente para plantear un profundo rediseño institucional del Estado mexicano -soportado desde luego en los principios del Estado de derecho y forma republicana y federal de gobierno- a efecto de que pueda cumplir adecuadamente los fines, principios y valores contenidos en sus preceptos, sino ante todo, para que la sociedad actual se atribuya la paternidad de este importante ejercicio de renovación constitucional, de tal suerte que por un lado se generen esquemas de corresponsabilidad con los órganos de gobierno en cumplir y hacer cumplir el texto fundamental, y que por el otro, se establezcan las bases para que dicho texto pueda gozar de estabilidad en el tiempo, pero también de una dinámica traducida en la posibilidad de su adaptación a circunstancias cambiantes mediante procedimientos de iniciativa y participación popular claros y efectivos, insertos dentro de su contenido.

Ciertamente, hablar del cambio constitucional no se limita exclusivamente a ver el problema desde un punto de vista aislado y con propuestas emanadas de la inercia en la teórica y praxis imperante hasta ahora en México, sino que va más allá, es decir, se impone la necesidad de enmarcar la discusión dentro de los postulados del paradigma de Estado constitucional y democrático de derecho, para determinar con claridad el rumbo de país que queremos aportando lo mejor del constitucionalismo y la democracia como elementos estructurales que darán soporte y legitimarán en los próximos tiempos las instituciones nacionales, así como la búsqueda y concreción paulatina de los valores, principios y fines estatales.

Así las cosas, me propongo en el presente trabajo exponer algunas reflexiones que a mi juicio resultan necesarias para poder encausar adecuadamente el debate en torno al necesario cambio constitucional en nuestro país, sosteniendo como hipótesis de trabajo que el referido cambio conlleva implicaciones de carácter teórico, ideológico, técnico y metodológico que nos llevan a pensar en términos estructurales y no sesgados el tema. Para tal efecto, abordaremos ideas en torno al estado actual de la teoría de la Constitución, haciendo énfasis en la propuesta del denominado "neoconstitucionalismo", para continuar con la explicación de lo que representa en el mundo la Constitución del Estado constitucional y, con base en ello, establecer algunas líneas de acción para una eventual reforma integral de la Constitución mexicana.

Como podemos observar, se trata de que en los futuros e inminentes debates en torno a la renovación constitucional, cada una de las propuestas y métodos para realizarla tenga como trasfondo la comprensión a cabalidad 
Esta obra forma parte del acervo de la Biblioteca Jurídica Virtual del Instituto de Investigaciones Jurídicas de la UNAM

de lo que representa o debe ser un auténtico Estado constitucional y democrático de derecho, haciendo congruentes los fines perseguidos con la evolución y desarrollo de las instituciones jurídicas fundamentales en favor de la dignidad de la persona humana y sus derechos, incluyendo a la democracia como su consecuencia organizativa.

\section{El ESTADO ACTUAL DE LA TEORÍA DE LA CONSTITUGiÓN}

Con independencia de las concepciones elaboradas desde el siglo XIX en torno al derecho político o constitucional, y de la evolución histórica de las doctrinas constitucionales hasta nuestros días, ${ }^{1}$ la teoría de la Constitución puede ser comprendida en dos grandes vertientes: como teoría política que estudia los fenómenos y procesos mediante los cuales se ordena e institucionaliza el poder, y como teoría jurídica que intenta explicar, describir y justificar las categorías, principios, estructura, métodos y funciones asignados al derecho constitucional, entendido como el derecho de la Constitución.

Ahora bien, el derecho constitucional de nuestro tiempo encuentra como marco histórico el constitucionalismo emanado de la segunda posguerra en Europa continental, especialmente en Alemania e Italia, ${ }^{2}$ caracterizándose por un proceso de reconstitucionalización de sus ordenamientos jurídicos, soportado de un lado por las ideas del constitucionalismo clásico como técnica de limitación del poder, y del otro por los postulados democráticos fuertemente conectados con la garantía efectiva de los derechos fundamentales. Lo anterior, dio vida a una nueva forma de organización política que bajo las denominaciones de Estado democrático, Estado constitucional o Estado constitucional y democrático de derecho impactaría de manera determinante en la teoría de la Constitución.

A partir de entonces, surge un nuevo paradigma no solo en el ámbito del derecho constitucional sino en la ciencia del derecho en general, mismo que se relaciona con la crítica y superación del positivismo jurídico y que ha sido denominado por la doctrina como "neoconstitucionalismo", es decir, el estudio científico y filosófico del Estado constitucional y democrático de derecho. Por tanto, el neoconstitucionalismo se asume como una teoría de la Constitución del Estado constitucional y democrático de derecho.

$1 C f r$. Vega, Pedro de, "Apuntes para una historia de las doctrinas constitucionales del siglo XX" en La ciencia del derecho durante el siglo XX, México, UNAM, Instituto de Investigaciones Jurídicas, 1998, pp. 3-44.

2 Cfr. Barroso Luís Roberto, El neoconstitucionalismo y la constitucionalización del derecho, México, UNAM, Instituto de Investigaciones Jurídicas, 2008, pp. 1-2. 
Esta obra forma parte del acervo de la Biblioteca Jurídica Virtual del Instituto de Investigaciones Jurídicas de la UNAM

Muchos han sido los autores contemporáneos identificados con esta corriente de pensamiento. ${ }^{3}$ Sin embargo, como afirma Luis Prieto Sanchís, se trata de un neologismo ambiguo y extremadamente vago que puede y de hecho es utilizado en varios sentidos, por lo que resulta conveniente referirse a neoconstitucionalismo(s) en plural. ${ }^{4}$ Con todo, se trata de una propuesta que atendiendo a sus distintas versiones, intenta construir respuestas globales a los grandes problemas y desafios emanados del funcionamiento de los sistemas constitucionales actuales, y más aún, a la teoría del derecho tradicional. ${ }^{5}$

De manera particular, las diversas posturas doctrinales coinciden en centrar su reflexión en el modelo de Estado constitucional surgido en Europa después de la segunda guerra mundial, mismo que fue replicado con posterioridad en algunos países iberoamericanos e incluso en la tradición jurídica norteamericana. Como afirma Rodolfo Luis Vigo, ${ }^{6}$ se trata de una nueva teoría que busca respaldar la constitucionalización del derecho vigente y sus consiguientes derivaciones, criticando las limitaciones, riesgos y errores que suponía el Estado de derecho legal o "débil", así como la rígida teoría iuspositivista que le servía de soporte y difusión teórica.

En ese orden de ideas, independientemente de las realidades concretas en donde se ha materializado el tipo Estado constitucional y democrático de derecho, tenemos como características comunes a los mismos, las siguientes: ${ }^{7}$

a) La instauración de Constituciones escritas que gozan de supremacía y fuerza normativa, esto es, textos emanados de un pacto originario

3 Por ejemplo, Rodolfo Luis Vigo en su obra Constitucionalización y judicialización del derecho, México, Porrúa, 2013, aporta una gran cantidad de autores identificados con el neoconstitucionalismo. 23-24.

4 Cffr. Vigo, Rodolfo Luis, El constitucionalismo de los derechos, Madrid, Trotta, 2013, pp.

5 Como veremos más adelante, el enfoque neoconstitucionalista nos lleva a plantear intensos debates de filosofía política y jurídica, relacionados por ejemplo, con el modo de organizar las instituciones democráticas, la crítica del positivismo jurídico y su deslinde del iusnaturalismo, el concepto de derecho y su relación con la moral, la naturaleza de las normas jurídicas y su interpretación, y en general, la función que debe asumir la ciencia jurídica en las sociedades actuales. A este respecto, Cfr. Carbonell, Miguel (Editor), Teoría del neoconstitucionalismo, Madrid, Trotta, 2007 y del mismo autor, Neoconstitucionalismo(s), Madrid, Trotta, 2009.

Op. cit., p. 35.

7 En este punto seguimos la propuesta de Luis Prieto Sanchís, quien en lugar de hablar de neoconstitucionalismo prefiere la expresión el constitucionalismo de los derechos. Op. cit., pp. 25-32. 
Esta obra forma parte del acervo de la Biblioteca Jurídica Virtual del Instituto de Investigaciones Jurídicas de la UNAM

(a través del poder constituyente como titular de la soberanía popular) que vincula a los poderes constituidos incluido el legislador democrático, así como a los gobernados;

b) La resustancialización de los contenidos constitucionales, a partir de la incorporación de valores y principios que no solo hacen del texto fundamental una norma de garantía que traza límites negativos a los poderes públicos, sino también una norma que los vincula positivamente hacia la consecución de los referidos elementos axiológicos;

c) La garantía jurisdiccional y aplicación directa de la Constitución, esto es, para guardar consistencia con el carácter normativo y principialista de aquélla es menester conferirle a los jueces la facultad para garantizar su cumplimiento -aún en ausencia de la previa intervención del legislador-, creándose al efecto una jurisdicción especial a cargo de tribunales o cortes constitucionales que controlan -junto con los jueces ordinarios- la conformidad de las normas y actos que integran el ordenamiento jurídico, con las disposiciones y contenidos de la ley suprema; y

d) La rigidez constitucional, entendida no solo como técnica de garantía frente a los poderes constituidos, sino ante todo como condición indispensable para preservar - generalmente a través de cláusulas de intangibilidad- el núcleo axiológico de la Constitución frente a sus posibilidades de cambio o reforma, como sería el caso de los derechos fundamentales y las formas mediante las cuales se organiza el Estado democrático.

El paradigma neoconstitucionalista puede ser comprendido con mayor amplitud a partir del análisis de sus marcos histórico, filosófico y teórico, ${ }^{8} \mathrm{de}$ donde no solamente se pueden evidenciar las virtudes y rasgos positivos del tipo Estado constitucional, sino también los aspectos que implican riesgos y desafíos para su correcto funcionamiento, incluso, como ha puesto de manifiesto la doctrina, la generación de conocimiento que propicia el desarrollo y superación de un modelo de ciencia del derecho por otro anterior.

Con relación al marco histórico, tal y como lo hemos expresado con anterioridad, a mediados del siglo XX se genera en Europa el tránsito del Estado de derecho legal al Estado constitucional básicamente a partir de la experiencia vivida al término de la segunda guerra mundial. Dentro de los cambios sufridos en la realidad europea destaca - entre otros- la superación de la sinonimia entre ley y derecho surgida en el siglo XVIII a partir de la

8 Barroso, Luis Roberto, op. cit., pp. 1-17. 
Esta obra forma parte del acervo de la Biblioteca Jurídica Virtual del Instituto de Investigaciones Jurídicas de la UNAM

Revolución francesa y plasmada por primera ocasión en Alemania en la Ley Fundamental de Bonn (1949).

La densidad axiológica traducida en los valores y principios que impregnaron los preceptos constitucionales (como sería el reconocimiento de la dignidad de la persona humana) estableció límites materiales a la acción del legislador, creándose ex profeso una jurisdicción constitucional que se encargaría de proteger la norma suprema frente a las leyes que la violentaran. Ejemplo de lo anterior serían el Tribunal Constitucional alemán (1951) y la Corte Constitucional italiana (1956), quienes impulsaron una fecunda producción teórica y jurisprudencial que marcó une nueva etapa en el conocimiento científico del derecho constitucional, sobre todo en los países de tradición romano-germánica.

Así, el dogma de la ley como expresión de la voluntad popular emanado del proceso revolucionario francés, considerada hasta ese momento como la fuente de fuentes del ordenamiento, cedería ante las exigencias formales y materiales de una norma jurídica superior cuya tutela quedaría encomendada a los jueces, quienes dejarían de considerarse la boca inanimada de la ley para convertirse en funcionarios con facultades para fiscalizar y controlar los actos del legislador, en aras de su conformidad a los valores y principios contenidos en el texto constitucional.

En otras palabras, como afirma Gustavo Zagrebelsky, ${ }^{9}$ se trata de un cambio genético que implica una profunda transformación que afecta incluso a la propia concepción del derecho, pues la idea del Estado de derecho, del principio de legalidad y del concepto de ley (positivismo jurídico) se expresaba en una situación histórico concreta que era la concentración de la producción jurídica en una sola instancia constitucional (poder legislativo), reduciendo todo lo que pertenece al mundo del derecho -incluyendo los derechos y la justicia- a lo dispuesto por la ley.

En cambio, la fórmula del Estado constitucional afecta a la posición de la ley la cual viene sometida a una relación de adecuación y por tanto de subordinación a un estrato más alto de derecho establecido por la Constitución, llevando hasta sus últimas consecuencias la completa sujeción al derecho de todas las funciones ordinarias del Estado incluida la legislativa, ${ }^{10}$ transformándose el papel de la jurisdicción y de la figura del juez como sim-

9 Cfr. Zagrebelsky, Gustavo, El derecho dúctil, Trad. Marina Gascón, Madrid, Trotta, 1997, p. 33.

10 Ibidem, p. 34. 
Esta obra forma parte del acervo de la Biblioteca Jurídica Virtual del Instituto de Investigaciones Jurídicas de la UNAM

ple intérprete de la ley a sujeto facultado para proteger los valores y principios consagrados en el texto fundamental. ${ }^{11}$

Por cuanto hace al marco filosófico, el neoconstitucionalismo se asocia con las posturas doctrinales denominadas post positivistas en virtud de que intenta convertirse en el puente o conciliación de dos grandes corrientes de pensamiento que plantean -en principio- una concepción opuesta del derecho, como son el iusnaturalismo y el positivismo, pero que pueden resultar complementarias en la medida en que se construya una doctrina del Estado justo, en donde la Constitución del Estado constitucional regule y organice de la mejor forma posible a la sociedad política y le proporcione garantías efectivas para hacer valer sus derechos y libertades fundamentales.

Como recuerda Luis Roberto Barroso, ${ }^{12} \mathrm{el}$ iusnaturalismo moderno desarrollado a partir del siglo XVI estableció la aproximación entre la ley y la razón, transformándose en la filosofía natural del derecho que postulaba entre otros aspectos los principios de justicia con validez universal, mismos que fueron utilizados como bandera de las revoluciones liberales y plasmados tanto en las Constituciones escritas como en los productos normativos emanados de la codificación.

Sin embargo, al ser considerado el derecho natural como un elemento metafísico y establecerse por parte de los juristas la necesidad de la objetividad científica en la disciplina, se inicia a finales del siglo XIX la era del positivismo jurídico el cual logró dominar el pensamiento de la primera mitad del siglo XX, destacando dentro de sus postulados la equiparación

11 De especial importancia resultan las palabras de Maurizio Fioravanti, al referirse a la evolución del Estado legislador al constitucional, cuando señala: "La constitución democrática del siglo XX, a partir de Weimar, pretende superar los confines fijados por la precedente forma constitucional estatal y parlamentaria. En pocas palabras, ya no pretende limitarse al ordenamiento de los poderes y al reenvío a la ley para garantizar los derechos; más bien pretende, sobre todo, significar la existencia de algunos principios fundamentales generalmente compartidos, que el ejercicio del poder soberano constituyente del pueblo ha colocado en la base de la convivencia civil. A partir de aquí comienza una nueva historia que, en buena medida, consiste en la búsqueda de los instrumentos institucionales necesarios para la tutela y para la realización de estos principios fundamentales. Baste decir que entre éstos existen al menos dos que, desde este punto de vista, presentan problemas de notable relevancia: el principio de la inviolabilidad de los derechos fundamentales, que de nuevo propone la gran cuestión del control de constitucionalidad de las leyes en relación con las constituciones que han enunciado esos derechos normativamente, y el principio de igualdad que -en las constituciones democráticas- tiende a afirmarse más allá de la mera prohibición de la discriminación, situándose en el plano del acceso a los bienes fundamentales de la convivencia civil... poniendo así de manifiesto la otra gran cuestión de la garantía y de la realización de los derechos sociales". Cffr. Constitución. De la antigüedad a nuestros días, Trad. Manuel Martínez Neira, Madrid, Trotta, 2001, p. 150.

12 Op. cit., pp. 4-5. 
Esta obra forma parte del acervo de la Biblioteca Jurídica Virtual del Instituto de Investigaciones Jurídicas de la UNAM

entre derecho y ley además de prescindir de temas insertos en el ámbito de la filosofía como la legitimidad y la justicia.

Como sabemos, la decadencia y punto de quiebre del positivismo jurídico se encuentra estrechamente relacionada con la caída de los gobiernos totalitarios fascista (Italia) y nazista (Alemania), quienes promovieron cualquier cantidad de actos de barbarie amparados en la legalidad. Es por ello que al finalizar la segunda guerra mundial la ética y los valores volvieron a la reflexión jurídica con la propuesta del post positivismo, que intenta ir más allá de la legalidad estricta a partir de una lectura moral del derecho, que de manera crítica trata de superar las limitaciones, riesgos y errores que supuso el Estado legal. ${ }^{13}$

$\mathrm{Al}$ referirnos al marco teórico del neoconstitucionalismo, tenemos que no solo impacta en la teoría clásica de la Constitución sino que va más allá al proponer un nuevo modelo de ciencia jurídica basado en la renovación de la teoría positivista, capaz de explicar las nuevas realidades a través de conceptos y categorías que Luis Prieto Sanchis resume de la siguiente manera: 1) constitucionalismo en lugar de legalismo, 2) conflictualismo en lugar de coherentismo, 3) principios en vez de reglas, 4) ponderación frente a subsunción y 5) argumentación frente a discrecionalidad. ${ }^{14}$

Con relación al primer punto, la teoría de las fuentes en el positivismo jurídico fue eminentemente legalista al considerarse la ley como norma suprema del ordenamiento jurídico. A partir del constitucionalismo de la segunda posguerra, el cambio se produce cuando se subordina la ley al derecho y se disocia la vigencia (existencia formal) de la validez de aquélla (adecuación a los principios constitucionales); la consecuencia es el desplazamiento de la norma legal a un segundo plano, misma que sin dejar de

13 Como bien apunta Rodolfo Luis Vigo, aquel escenario jurídico e institucional europeo en las décadas siguientes a Nuremberg termina transformado, por lo que aquella exitosa tesis iuspositivista normativista que se había forjado al hilo de la escuela exegética, la escuela histórica, el primer Ihering y culminado con Kelsen, entra en desorientación y comienza a padecer crecientes conversiones y críticas desde las más prestigiosas cátedras europeas, destacándose - continúa el autor- los testimonios de Radbruch en Alemania, denunciando la complicidad teórica del iuspositivismo frente al nazismo; el de Bobbio con su teoría funcional que dejaba atrás las visiones estructurales del derecho kelsenianas; el de Dworkin cuando combate al normativismo en nombre del principialismo; el de Perelman incorporando la razón en los problemas valorativos y decisionales; el de Nino criticando los modelos epistemológicos de Kelsen, Ross y Bulygin-Alchourron en tanto silencian la dimensión valorativa del derecho, y Atienza cuando afirma su confianza en un cierto objetivismo y cognitivismo ético de la ciencia jurídica. Op. cit., p. 34.

14 Cfr. El constitucionalismo de los derechos, op. cit., pp. 37-38. 
Esta obra forma parte del acervo de la Biblioteca Jurídica Virtual del Instituto de Investigaciones Jurídicas de la UNAM

considerarse fuente del derecho estaría supeditada desde ahora a la Constitución como texto fundamental. ${ }^{15}$

Con esto, resulta evidente la expansión y el fortalecimiento de la jurisdicción en la tarea de limitación y sujeción del poder al derecho; en particular, el cambio de ubicación del juez frente a la ley, no solamente por cuanto hace a los tribunales constitucionales encargados del control de constitucionalidad de los actos legislativos, sino también de los jueces ordinarios que tienen el poder y el deber de activar dicho control convirtiéndose en garantes de los valores y principios constitucionales, destacando por supuesto la protección de los derechos fundamentales.

Respecto del segundo punto, la teoría positivista -elaborada en torno a la preeminencia de la leyera considerada coherentista, en virtud de que concebía un ordenamiento jurídico capaz de regular de manera homogénea todas las conductas sociales, contando con reglas específicas para la resolución de antinomias; tal es el caso del criterio jerárquico (norma superior deroga a norma inferior), el criterio temporal (norma posterior deroga a norma anterior) y el criterio material (norma especial deroga norma general).

El neoconstitucionalismo por el contrario, se manifiesta abiertamente conflictivista en virtud de que parte de considerar a la Constitución no ya como una regla fundante o punto de partida de un proceso normativo creador, sino como la convergencia de una multiplicidad de intereses (pluralismo) que coexisten bajo la forma jurídica de principios y derechos, muchos de ellos tendencialmente contradictorios y que en su conjunto no expresan de manera concreta y unívoca una determinada moral social, sino que a partir de ese pluralismo los actores públicos y privados construyen, mediante fórmulas democrática, un derecho capaz de amalgamarse con mayor eficacia a las circunstancias de esa realidad.

El tercer punto, se refiere a la propuesta del neoconstitucionalismo para distinguir en un ordenamiento jurídico los principios plasmados en la Constitución de las reglas previstas en la Ley; ${ }^{16}$ con relación a estas últimas, se

15 El mismo Luis Prieto señala que la ley sigue siendo una fuente del derecho que dispone de una incuestionable esfera de libre configuración normativa, pero en el contexto de una Constitución concebida como norma suprema y dotada de un denso contenido sustantivo, razón por la cual puede ser siempre cuestionada y sometida a revisión. Idem.

16 Como nos recuerda Manuel Atienza y Juan Ruiz Manero, la discusión acerca de los principios jurídicos arranca con Ronald Dworkin, quien en 1967 publica un famoso artículo denominado "El modelo de las reglas", en donde dirige una fuerte crítica a la versión más poderosa del positivismo jurídico representada en ese entonces por H.L.A. Hart, sosteniendo básicamente la incapacidad de dicha teoría para dar cuenta de la presencia en el Derecho de pautas distintas a las reglas (principios), lo que le privaría también de la posibilidad de 
Esta obra forma parte del acervo de la Biblioteca Jurídica Virtual del Instituto de Investigaciones Jurídicas de la UNAM

trata de normas de textura cerrada que definen en abstracto las conductas prohibidas, obligadas o permitidas, además de traer aparejadas consecuencias jurídicas concretas; si una regla es considerada válida entonces resulta obligatorio hacer precisamente lo que ordena. En cambio, los principios son normas de textura abierta que poseen un contenido moral y forma jurídica, que cuentan además con un mayor grado de indeterminación que las reglas, por lo que los operadores jurídicos -atendiendo a las circunstancias fácticas y normativas- podrán concretarlos con diferente intensidad incluso frente a principios y reglas que juegan en sentido contrario. ${ }^{17}$

Como consecuencia de la distinción entre principios (neoconstitucionalismo) y reglas (positivismo jurídico), surge el cuarto punto que se refiere a la ponderación frente a la subsunción. En efecto, las reglas se aplican sin más a partir de un esquema silogístico basado en la subsunción; esto es, al actualizarse la hipótesis contenida en la norma se tendrán que producir indefectiblemente las consecuencias jurídicas que ella misma establece, sin que exista la posibilidad de arribar a un resultado o efecto distinto. Por el contrario, en virtud de la naturaleza abierta e indeterminada de los principios, el método de resolución de conflictos derivados de su aplicación tendrá que ser necesariamente la ponderación en cada caso concreto. ${ }^{18}$

En términos generales, la doctrina ha considerado que ponderar consiste en atribuir un peso específico a los principios que resultan aplicables en un caso concreto, de tal suerte que una vez verificadas las circunstancias fácticas y jurídicas (condiciones de aplicación) y realizados los juicios de valor correspondientes, se preferirá a uno en lugar del otro. Esto quiere decir que en el ordenamiento jurídico no existe una jerarquía a priori entre los princi-

comprender aspectos esenciales del razonamiento judicial, sobre todo en los denominados casos dificiles. Cffr. Atienza, Manuel, Las piezas del derecho, Ariel, Barcelona, 2004, p. 23.

17 Para Robert Alexy, las reglas son mandatos definitivos en tanto ordenan algo para el caso de que se satisfagan determinadas condiciones, por lo que pueden cumplirse e incumplirse. En cambio, los principios se refieren a normas que ordenan la realización de algo en la mayor medida posible, atendiendo a las posibilidades fácticas y jurídicas; se trata -dice el autor alemán- de mandatos de optimización en virtud de que pueden ser cumplidos en diferentes grados. Cfr. Su trabajo "La fórmula del peso" en Carbonell, Miguel (Coord.), Argumentación jurídica, México, Porrúa, 2011, p. 1-2.

18 Con relación al tema, Gustavo Zagrebelsky afirma que los dos principales esquemas lógicos para la aplicación de las reglas son el silogismo judicial y la subsunción del supuesto de hecho concreto en el supuesto abstracto de la norma; por el contrario, la aplicación de los principios es completamente distinta pues se requiere -continúa manifestando el jurista italiano- que cuando la realidad exija de nosotros una reacción, se tome posición ante ésta de conformidad con aquéllos. Op. cit., p. 111. 
Esta obra forma parte del acervo de la Biblioteca Jurídica Virtual del Instituto de Investigaciones Jurídicas de la UNAM

pios, sino aquello que Riccardo Guastini ${ }^{19}$ denomina "jerarquía axiológica móvil" en función de la naturaleza y características del caso específico. ${ }^{20}$

Finalmente, el quinto punto se refiere a una de las mayores conquistas en el campo de la teoría del derecho y en particular de la teoría de la Constitución, que es la argumentación jurídica del Estado constitucional frente a la discrecionalidad propia del Estado legal. Lo anterior, en virtud de que uno de los postulados del positivismo jurídico fue considerar al derecho como un sistema imperfecto cuyo lenguaje generaba amplias zonas de penumbra, y que a pesar de que contaba con el auxilio de la lógica desembocaba inevitablemente en la discrecionalidad judicial.

En cambio, en el neoconstitucionalismo los principios limitan la discrecionalidad porque suponen de una parte la concreción de los valores insertos en las disposiciones constitucionales, y de otra porque requieren y exigen un razonamiento más complejo que el tradicional de la subsunción, es decir, una justificación racional de la decisión capaz de evitar un ejercicio de arbitrariedad incontrolable. ${ }^{21}$ Como afirma Atienza, ${ }^{22}$ el Estado constitucional supone un incremento cuantitativo y cualitativo en cuanto a la tarea justificativa de los órganos públicos y, por tanto, una mayor demanda de argumentación jurídica que la requerida por el Estado legal; en última instancia, se trata del sometimiento completo del poder al derecho y a la razón.

Desde luego que la teoría de la Constitución presenta en la actualidad enormes retos y desafíos, no solamente asociados con su relación y pertenencia a una red de teorías que, con diversas denominaciones (teorías de la democracia, teorías de la justicia, teorías del discurso, teorías de sistemas, constitucionalismo multinivel, constitucionalismo del pluralismo y constitucionalismo global, entre otras ${ }^{23}$ tratan de explicar la realidad estatal, sino

19 Cfr. Guastini, Riccardo, Estudios de teoría constitucional, México, Fontamara, 2001, p. 145.

20 Señala Luis Prieto Sanchís que la propia ponderación se endereza a la construcción de una regla apta para la subsunción, pues ponderar consiste en atribuir un peso relativo a los principios relevantes a la luz de las circunstancias del caso, esto es, consiste en precisar la condición de aplicación (en los principios en sentido estricto) o la consecuencia jurídica (en las directrices) que en el enunciado constitucional aparecen indeterminadas. En pocas palabras -refiere el autor español-, la ponderación trata de dar respuesta a esta pregunta: a la luz de las propiedades que presenta un caso en el que resultan relevantes dos principios, cuál de ellos debe triunfar y cuál debe ceder; o en qué medida resulta exigible lo que establece uno de ellos. Op. cit., p. 46. $42-43$.

21 Cfr. Prieto Sanchís, Luis, Constitucionalismo y positivismo, México, Fontamara, 1997, pp.

22 Cfr. Su trabajo "El derecho como argumentación" en Atienza, Manuel y Ferrajoli, Luigi, Jurisdicción y argumentación en el estado constitucional de derecho, México, UNAM, 2005, p. 11.

23 Cfr. La obra Temas y tendencias del constitucionalismo contemporáneo, México, UNAM, Instituto de Investigaciones Jurídicas, 2016. 
Esta obra forma parte del acervo de la Biblioteca Jurídica Virtual del Instituto de Investigaciones Jurídicas de la UNAM

también a los problemas que en lo particular condicionan el funcionamiento del multicitado Estado constitucional y democrático de derecho.

A este respecto, como apunta José Joaquim Gomes Canotilho, la teoría de la Constitución puede y debe continuar estructurándose como reflexión, explicación y justificación de las leyes fundamentales y de sus principios materiales estructuradores, en especial del Estado constitucional democrático - ahora también europeo, internacional y ecológico - en la medida en que se encuentre anclado en un sistema jurídico normativo informado por una pretensión de justicia en sus reglas. ${ }^{24}$

\section{LA CONSTITUCiÓN DEL ESTADO GONSTITUCIONAL}

Mencionábamos en el apartado anterior, que actualmente una teoría de la Constitución es ante todo una teoría del Estado constitucional y democrático de derecho soportada esencialmente a partir de los postulados del paradigma neoconstitucionalista, mismo que representa además la superación del modelo de ciencia jurídica identificado con el positivismo el cual ha sido insuficiente para explicar, describir y justificar la organización y fines de las sociedades políticas presentes.

Por eso, para que las categorías del derecho constitucional puedan servir como criterio de acción o de juicio para la praxis, deben encontrar una combinación que ya no deriva del dato indiscutible de un punto de partida o centro de ordenación (Constitución) que establece un proyecto predeterminado de vida en común, sino que atendiendo al carácter plural de las sociedades actuales representadas por grupos con intereses, ideologías y proyectos diferentes, se requiere una política constitucional que a partir del texto fundamental genere las condiciones para hacer posible dicha convivencia. ${ }^{25}$

24 Cfr. Gomes Canotilho, José Joaquim, Teoría de la Constitución, Trad. Carlos Lema Añón, Madrid, Dykinson, 2004, p. 42.

25 Zagrebelsky, Gustavo, El derecho dúctil, op. cit., pp. 13-14. Nos dice el profesor italiano que la asunción del pluralismo en una Constitución democrática es simplemente una propuesta de soluciones y coexistencias posibles y no un proyecto rígidamente ordenador que pueda asumirse como un a priori de la política con fuerza propia, de arriba hacia abajo. Por eso -afirma-, solo así podremos tener Constituciones abiertas que permitan, dentro de los límites constitucionales, tanto la espontaneidad de la vida social como la competición para asumir la dirección política, condiciones ambas para la supervivencia de una sociedad pluralista y democrática. 
Esta obra forma parte del acervo de la Biblioteca Jurídica Virtual del Instituto de Investigaciones Jurídicas de la UNAM

Siguiendo a Joseph Aguiló, ${ }^{26}$ los Estados constitucionales cuentan con Constituciones que poseen las siguientes características:

a)Rígidas o formales. Se trata de textos diferenciados de la forma legal ordinaria, por lo que el régimen jurídico de las disposiciones constitucionales es cualitativamente distinto y de mayor grado jerárquico que las propias disposiciones legales. Así, una Constitución será rígida cuando el procedimiento para su reforma o derogación es agravado frente a aquel utilizado para la legislación secundaria, teniendo el texto fundamental una autoridad superior a la ley.

b) Constitutivas y regulativas. Las Constituciones responden a las pretensiones normativas del constitucionalismo relacionadas con la limitación del poder y la garantía de los derechos, pero también imponen deberes y guías de conducta a los poderes públicos para asegurar los principios y valores contenidos en sus disposiciones. Esto quiere decir que la parte constitutiva se refiere a la incorporación o establecimiento de los órganos y procedimientos básicos del Estado, incluyendo las fuentes del derecho y el principio dinámico del sistema jurídico-político, y la parte regulativa hará alusión al reconocimiento - no creación- de una dimensión valorativa que, como elemento estático, será necesario proteger, promocionar y garantizar (a través del control jurisdiccional de constitucionalidad) pues con ello se dotan de sentido a las formas de acción política creadas por las propias Constituciones. ${ }^{27}$

c) Positivas y practicadas. Esta característica implica la aceptación de la Constitución como norma fundamental en torno a la cual se ha consolidado una práctica jurídica y política de la comunidad. Sin duda, un elemento determinante para comprobar la eficacia de sus disposiciones y desde luego para el fortalecimiento de la cultura constitucional.

26 Cfr. Aguiló, Joseph, La Constitución del Estado constitucional, Lima-Bogotá, Ed. Palestra/ Temis, 2004, pp. 50-53.

27 El propio Aguiló señala que la dimensión constitutiva de toda Constitución es obvia: Los parlamentos (unicamerales o bicamerales), los tribunales constitucionales, las comunidades autónomas, las elecciones generales, las mayorías cualificadas, etc., son todas ellas realidades institucionales creadas por los propios textos fundamentales. Ahora bien, estos últimos no solamente crean órganos y procedimientos sino que además tienen una dimensión valorativa, reconocen estados de cosas como valiosos y, por tanto, resultan merecedores de ser protegidos o promocionados (dimensión regulativa), como es el caso de la soberanía popular, la independencia de la nación, la libertad, la igualdad, la dignidad y la seguridad de las personas, el pluralismo político, la diversidad cultural, la educación, la salud pública, etc. Ibidem, pp. 44-45. 
Esta obra forma parte del acervo de la Biblioteca Jurídica Virtual del Instituto de Investigaciones Jurídicas de la UNAM

Desde la perspectiva histórica, Maurizio Fioravanti ${ }^{28}$ señala que este tipo de Constituciones representan el intento de recomponer la gran fractura entre democracia y constitucionalismo, esto es, en la fórmula contemporánea de la democracia constitucional parece estar contenida la aspiración a un justo equilibrio entre el principio democrático y la idea inherente a la tradición constitucionalista de los límites de la política mediante la fuerza normativa de la Constitución, garantizada en última instancia a través del control de constitucionalidad.

Con ello -afirma el autor-, la legalidad constitucional se emancipa del dominio del poder constituyente soberano sin renunciar a dotar de significado y de grandes objetivos a la concreta vía de las democracias contemporáneas, oponiendo al mito democrático revolucionario (constituyente) los valores de la estabilidad, equilibrio y límite, con la finalidad de garantizar los derechos de los ciudadanos sin perder su carácter directivo fundamental para el futuro. De ahí que este tipo de Constituciones democráticas asumen -en distinta forma y medida- el principio de igualdad como eje central, no solamente por cuanto hace a la prohibición de la discriminación sino también como indicador normativo para la promoción y generación paulatina de condiciones semejantes entre los ciudadanos, relacionadas con el acceso a algunos bienes sociales esenciales. ${ }^{29}$

En esta misma dirección apunta el pensamiento de Luigi Ferrajoli, ${ }^{30}$ cuando a partir de su propuesta de constitucionalismo garantista pugna por la construcción de un modelo más denso y vigoroso de Constitución normativa, misma que debe contener la regulación no sólo del quién y del cómo se manda, sino también de qué puede o debe mandarse; no solo debe incorporar normas de competencia y procedimiento condicionantes de la vigencia de la ley, sino también normas sustantivas condicionantes de su validez. ${ }^{31}$

28 Cfr. Constitución. De la antigüedad a nuestros días, op. cit., pp. 163-164.

29 Idem

30 Cfr. Ferrajoli, Luigi, Principia iuris. Teoría del derecho y de la democracia, Vol. 1, Madrid, Trotta, 2011, p. 535. Aunque algún sector de la doctrina no considera a Ferrajoli como neoconstitucionalista, es evidente que sus planteamiento pugnan en todo momento por concebir un constitucionalismo rematerializado a partir de una fuerte carga axiológica (valores y principios) que traerá consecuencias estructurales no solo en la teoría de la Constitución, sino en la teoría del Derecho en general.

31 En este aspecto, si la regulación de las formas caracteriza al positivismo jurídico y el Estado de derecho en sentido "débil", la regulación de sus significados mediante normas sustantivas caracteriza en cambio el constitucionalismo y el Estado de derecho en sentido "fuerte", mismo que exige de todos los poderes -incluyendo el legislativo- el sometimiento a los límites y vínculos de sus contenidos. Idem. 
Esta obra forma parte del acervo de la Biblioteca Jurídica Virtual del Instituto de Investigaciones Jurídicas de la UNAM

Con relación a esto último, el jurista italiano sostiene que el respeto por las reglas de la democracia - entendidas como formas y procedimientos de producción legislativa- representa solamente una condición necesaria para asegurar la vigencia o validez formal de la ley pero no así la validez sustancial de las decisiones, es decir, para que una ley sea válida se requiere la conformidad de sus significados con las reglas y principios establecidos constitucionalmente.

De esta manera, serán los preceptos sustantivos -en particular los derechos fundamentales- aquellos que se encuentran en la base del constitucionalismo garantista, pues forman parte de lo que el propio Ferrajoli denomina "la esfera de lo indecidible"; esto quiere decir que los vínculos y limites que pesan sobre el legislador (mayoría contingente) al momento de incidir sobre los referidos derechos se consideran también democráticos, al tratarse esencialmente de prerrogativas que pertenecen a los ciudadanos y que pueden ser consideradas contrapoderes o fragmentos de soberanía popular en manos de todos y cada uno de ellos, incluso más directos y consistentes que la propia representación política. ${ }^{32}$

Una última cuestión relacionada con el papel de la Constitución del Estado constitucional se refiere al control del cambio social. Como señala Dieter Grimm, ${ }^{3}$ las Constituciones estabilizan la relación entre continuidad y cambio a través de la institucionalización de mayores controles, tanto en el plano de los principios como en el ámbito de su realización y concreción; y no lo hacen tanto impidiendo el cambio sino aumentando las exigencias de justificación y consenso, ya sea poniendo dificultades al procedimiento o retrasando la decisión.

Así, independientemente de los ciclos políticos, los textos fundamentales configuran la autoprotección de la sociedad frente a actuaciones precipitadas, creando el marco para el aprendizaje social; en última instancia, la Constitución misma no puede excluirse del cambio pero ha de prever adecuadamente su propia acomodación o modificación. ${ }^{34}$

Por estas razones, existe la necesidad de democratizar la teoría del poder constituyente y las normas sobre la reforma constitucional, de tal suerte que el constitucionalismo democrático materializado en la Constitución goce de mayores grados de legitimidad. Por ello, simultáneamente a la pre-

32 Cfr. Ferrajoli, Luigi, Garantismo. Una discusión sobre derecho y democracia, Trad. Andrea Greppi, Madrid, Trotta, 2009, pp. 99-100. Con esta propuesta, quedaría superada la tradicional tensión entre constitución y democracia, entre decisión mayoritaria y derechos.

33 Cfr. Grimm, Dieter, Constitucionalismo y derechos fundamentales, Trad. Raúl Sanz Burgos y José Luis Muñoz de Baena Simón, Madrid, Trotta, 2006, p. 201.

34 Idem. 
Esta obra forma parte del acervo de la Biblioteca Jurídica Virtual del Instituto de Investigaciones Jurídicas de la UNAM

visión de procesos de reforma constitucional sustanciales (que no afecten cláusulas de intangibilidad) validados en última instancia ad referéndum por los ciudadanos, o aquellos relacionados con revisión constitucional a cargo de los poderes constituidos (reformas no fundamentales), deberán incorporarse mecanismos efectivos de participación ciudadana, ya sea convocando a la reforma o validándola en última instancia. ${ }^{35}$

\section{EL NECESARIO GAMBIO GONSTITUCIONAL EN MÉXICO: ENTRE CONSTITUCIONALISMO Y DEMOGRACIA ${ }^{36}$}

Una vez que hemos abordado en términos muy generales la situación actual de la teoría de la Constitución y en particular los rasgos esenciales de las Constituciones de los Estados constitucionales, es pertinente ahora referirnos al necesario cambio constitucional en México desde una perspectiva estructural, esto es, trazando algunas directrices fundamentales en torno a su concreción tomando como base el marco histórico, filosófico y teórico del neoconstitucionalismo. Sin duda un ejercicio reflexivo necesario, previo a la discusión de los temas a reformar en lo particular.

Tomando en consideración diversas voces de la clase política, de la academia y de sectores importantes de la sociedad civil, en el sentido de que resulta insostenible seguir contando con una Constitución excesivamente modificada, que adolece de escasa vinculación normativa, que ha sido incapaz de contemplar soluciones efectivas a los grandes problemas del país, básicamente reconducidos a la grave desigualdad social, históricos niveles de corrupción e impunidad, crisis de inseguridad pública, déficits democráticos en la toma de decisiones gubernamentales y un Estado de derecho débil, entre otros aspectos, se impone reflexionar en torno a la necesidad de asistir

35 Cfr. A este respecto, la obra de Colón-Ríos Joel I., La constitución de la democracia, Trad. Graciela Rivera Muñoz, Bogotá, Universidad Externado de Colombia, 2013. Señala el autor que un orden constitucional que aspira a lograr la legitimidad democrática debería contar con mecanismos, en adición al procedimiento ordinario de reforma, diseñados para permitir a los ciudadanos proponer, deliberar y decidir acerca de cambios constitucionales fundamentales; con ello, se facilitaría el ejercicio del poder constituyente al traducirse en un proceso abierto y participativo. Como ejemplo de dichos mecanismos hace alusión a la iniciativa popular para proponer reformas a la Constitución o la convocatoria a Asamblea Constituyente promovida desde los órganos constituidos, en particular desde el poder legislativo.

36 Parte de estas reflexiones forman parte de la ponencia presentada en el XII Congreso Iberoamericano de Derecho Constitucional, celebrado en el mes de septiembre de 2015 en la Universidad Externado de Colombia. 
Esta obra forma parte del acervo de la Biblioteca Jurídica Virtual del Instituto de Investigaciones Jurídicas de la UNAM

a un nuevo arreglo político-institucional mediante una reforma integral, esto es, el cambio constitucional a través del propio ordenamiento supremo.

Resulta inadmisible seguir sosteniendo - al menos desde los últimos 15 años - que no existen las condiciones idóneas para llevar a cabo una reforma constitucional profunda, simple y sencillamente porque nunca llegará ese momento ideal, y que por el contrario, seguir retardando el cambio conllevará mayores perjuicios. Por tanto, es imprescindible provocar las circunstancias necesarias y suficientes para dar ese gran paso discutiendo la metodología para lograrlo, siempre bajo elementos de claridad, razonabilidad y certeza jurídica.

La reforma integral que aquí se propone, se considera la mejor opción por las siguientes razones:

a) El cambio constitucional tiene como fundamento el propio orden constitucional. Lo anterior, constituye el punto medular en cuanto a la certeza del procedimiento para conocer, deliberar y, en su caso, aprobar una Constitución renovada a cargo del órgano competente (poder revisor).

b) La reforma integral debe traducirse en un ejercicio legislativo por depurar, actualizar y enriquecer el texto fundamental, no solo por cuanto hace a la superación de las contradicciones derivadas por los numerosos cambios sufridos por décadas -incluyendo el tratamiento anacrónico u obsoleto de ciertos temas como consecuencia de su longevidad-, sino ante todo plasmando un proyecto de nación congruente con los valores y principios que inspiran el Estado social y democrático de derecho, en el corto, mediano y largo plazo. ${ }^{37}$

c) Lo anterior, no quiere decir que el poder revisor de la Constitución esté facultado para cambiar los elementos estructurales mediante los cuales se cimenta nuestro Estado de derecho (derechos fundamentales, separación de poderes, responsabilidades públicas, régimen federal, entre otros), sino únicamente cualificarlos y enriquecerlos a partir de un adecuado diseño normativo-institucional acorde a las nuevas realidades.

d) Por cuanto hace a la legitimidad del cambio constitucional, es muy probable que una reforma integral brinde mayores niveles de acepta-

37 Existe un importante estudio académico realizado por el Instituto de Investigaciones Jurídicas de la UNAM, en torno al texto reordenado y consolidado de la Constitución Política de los Estados Unidos Mexicanos, disponible en: http://www2.juridicas.unam.mx/ constitucion-reordenada-consolidada// 
Esta obra forma parte del acervo de la Biblioteca Jurídica Virtual del Instituto de Investigaciones Jurídicas de la UNAM

ción y consenso entre las fuerzas políticas y la sociedad; en el caso de los actores políticos, se parte de reglas y procedimientos conocidos, muchos de los cuales realizan cotidianamente en el seno de las instancias de deliberación como es el caso del Congreso de la Unión y las Legislaturas de los Estados; tratándose de los ciudadanos, el factor de validación más importante del cambio constitucional será la aprobación ad referéndum del texto renovado.

e) La reforma constitucional integral evitará una ruptura en el entendimiento del contenido de la norma suprema a cargo de los operadores jurídicos, sobre todo el máximo intérprete de la Constitución; por el contrario, dicho órgano contará con mejores elementos para fortalecer y hacer evolucionar la doctrina constitucional plasmada en su jurisprudencia, dotando de estabilidad y eficacia a la ley suprema, contribuyendo a la certeza jurídica de las autoridades y ciudadanos.

f) Existen ejercicios de ingeniería constitucional relativamente recientes a nivel subnacional, en donde se ha optado por la reforma integral de los textos constitucionales estaduales y no por la convocatoria a un constituyente para redactar una nueva Constitución, como es el caso del Estado de México en 1995 y el Estado de Veracruz en el año 2000. En estos casos, el poder reformador previsto en las normas supremas locales ha realizado la actualización de sus disposiciones, incluso incorporando instituciones y figuras más avanzadas que aquellas contenidas en el texto federal. ${ }^{38}$

Es importante mencionar, que tanto la doctrina nacional como extranjera que se inclina por la reforma integral de la Constitución mexicana de 1917, coincide en señalar que no existe ningún impedimento para llevarla a cabo a partir de modificar previamente su artículo $135 .{ }^{39}$ Por nuestra parte, creemos que en virtud de la naturaleza y función del órgano reformador de

38 No desconocemos el caso de la reciente reforma política al Distrito Federal, mediante la cual se hace la convocatoria a una Asamblea Constituyente que deberá redactar y aprobar, a más tardar en enero de 2017, la Constitución Política de la Ciudad de México como entidad federativa. Sin embargo, este ejercicio reviste un alto grado de atipicidad y desnaturaliza la figura del poder constituyente, al integrarse dicho órgano tanto por representantes que designan directamente los poderes constituidos $(40 \%)$ como por ciudadanos que serán electos en próximos comicios locales $(60 \%)$. Se trata de un ejercicio constituyente con déficit de legitimidad democrática.

39 Cfr. Por todos, Díaz Ricci, Sergio, Teoría de la reforma constitucional. Buenos Aires: UNAM-EDIAR-UGM, 2004. 
Esta obra forma parte del acervo de la Biblioteca Jurídica Virtual del Instituto de Investigaciones Jurídicas de la UNAM

la Constitución como poder constituido, deberá sujetarse a los límites que deriven explícitamente del texto fundamental. ${ }^{40}$

En particular, me parece que básicamente los artículos 1, 39, 40 y 135, referidos al Estado constitucional/convencional de derecho, al principio de la soberanía popular, a la forma de Estado y de gobierno, y a la propia reforma o adición de la ley suprema, representan el fundamento para permitir la actualización y adaptación de la Constitución a los tiempos que vive la sociedad mexicana, pero haciendo explícitos los límites a la acción reformadora de dicho órgano.

Ahora bien, por cuanto hace al procedimiento para llevar a cabo tan importante tarea, es indispensable reformar el artículo 135 para concebir un poder revisor de la Constitución acorde con las exigencias de un verdadero Estado constitucional y democrático de derecho, esto es, exigirse una votación calificada de los integrantes de las cámaras de diputados y senadores, así como la aprobación de las tres cuartas partes de los Estados de la República, incorporando textualmente la posibilidad de la reforma integral y la aprobación de los cambios constitucionales ad referéndum.

Una vez realizadas las anteriores reflexiones, intentaré exponer de manera breve aquellas propuestas que desde mi punto de vista -de manera enunciativa y no limitativa-, deberán ser tomadas en cuenta para una eventual reforma integral a la Constitución mexicana:

1) Previo al articulado, es indispensable contar con un preámbulo de la Constitución. En este apartado, se deben exponer con claridad las aspiraciones del pueblo mexicano soportadas por una serie de principios y valores que le den sentido y congruencia al Estado constitucional y democrático de derecho;

2) Incorporar plenamente el derecho internacional de los derechos humanos, a efecto de hacer exigibles en el Estado mexicano todas las generaciones de derechos frente a actos u omisiones de las autoridades o de particulares que los conculquen, superándose con ello el

40 Para el caso mexicano, podemos decir que todas sus Constituciones -desde Cádiz en 1812 hasta la vigente de 1917-, han sido elaboradas por una asamblea popular que claramente expresa su diferencia con respecto a la tradicional instancia revisora, esto es, se formula la reserva expresa de que todo aquello que tenga que ver con la forma de gobierno no podrá ser reformado sino mediante la participación del titular de la soberanía que es el pueblo. Por tanto, podemos decir que la naturaleza del llamado poder revisor en México es la de un poder constituido, en virtud de que le viene impuesta la obligación de acatar las normas previstas en el texto supremo, sean estas de tipo procedimental para la substanciación de las reformas, o bien aquellas que se refieren a contenidos materiales que solamente pueden ser tocados por obra de la soberanía (pueblo), a través del poder constituyente. 
Esta obra forma parte del acervo de la Biblioteca Jurídica Virtual del Instituto de Investigaciones Jurídicas de la UNAM

paradigma exclusivamente interamericano reconocido por la Constitución y la jurisprudencia nacional.

3) Reformular el sistema federal a efecto de clarificar desde la norma suprema las facultades de la federación, estados, distrito federal y municipios, buscando un adecuado equilibrio en función de nuestra realidad política, económica, social y cultural, definiendo asimismo las bases para la coordinación y ejercicio concurrente de atribuciones.

4) Reformar el sistema electoral a efecto de configurar un modelo estable que sea acorde con las exigencias del paradigma democrático en términos sustantivos, conciliando la democracia representativa con la semidirecta o participativa; ${ }^{41}$

5) Acotar el régimen presidencial mediante la instauración del "gobierno de gabinete"; ${ }^{42}$ a efecto de generar mayor interlocución en el entramado institucional, favoreciendo acuerdos entre las fuerzas políticas y un mejor ejercicio de los derechos ciudadanos;

6) Definir las bases esenciales para la creación de un estatuto de la función pública en los tres niveles de gobierno; ${ }^{43}$

7) Rediseñar e incorporar los tribunales administrativos al poder judicial de la federación y crear como contrapeso el tribunal constitucional como órgano constitucional autónomo; 44

8) Un sistema integral de medios de control constitucional, tanto a nivel federal como en el ámbito de las entidades federativas. Lo anterior, constituye un principio elemental de descentralización de la justicia

41 En este punto, se propone contemplar la segunda vuelta en las elecciones de presidente de la república; la reelección legislativa; la eliminación de la representación proporcional en el senado; la apertura de la representación proporcional en la cámara de diputados a personas representativas de sectores de la sociedad civil, grupos vulnerables, comunidades indígenas, entre otros; la reducción significativa del financiamiento público a partidos políticos; la reformulación de la consulta pública y la incorporación, con un adecuado diseño institucional, de la revocación de mandato, plebiscito y referéndum.

42 Cfr. Valadés, Diego, El gobierno de gabinete, México, UNAM, 2005.

43 Lo anterior, implica estandarizar las reglas y principios en torno al acceso, permanencia y remoción de los funcionarios, servidores y empleados públicos, incluyendo códigos deontológicos así como sus remuneraciones, incompatibilidades y un sistema estricto de responsabilidades penales y administrativas, eliminando la denominada responsabilidad política por ser visiblemente incompatible con un régimen democrático. Este aspecto será determinante para combatir eficazmente los altos niveles de corrupción e impunidad que observamos el día de hoy en la función pública.

44 Algunas reflexiones en torno a la creación del Tribunal Constitucional se contienen en mi trabajo "Balances y perspectivas del derecho procesal constitucional mexicano", publicado en la obra coordinada por Carbonell, Miguel, Derecho constitucional, Memoria del congreso internacional de culturas y sistemas jurídicos comparados, México, UNAM, 2004, pp. 309-340. 
Esta obra forma parte del acervo de la Biblioteca Jurídica Virtual del Instituto de Investigaciones Jurídicas de la UNAM

que contribuye a garantizar la fuerza normativa y eficacia directa de la Constitución. ${ }^{45}$

9) Reducción de los órganos constitucionales autónomos, configurando una adecuada articulación y coordinación con los demás poderes del Estado; 46

10) Resustancializar la Administración Pública mediante la incorporación de principios de actuación que garanticen los derechos fundamentales en su dimensión individual y colectiva, en aras de satisfacer el interés general. ${ }^{47}$

\section{Gonalusión}

A lo largo del presente trabajo, hemos intentado exponer algunas de las implicaciones teórico doctrinales derivadas de la comprensión actual de la teoría de la Constitución y de su vinculación a la forma de Estado constitucional y democrático de derecho, mediante las aportaciones del paradigma denominado "neoconstitucionalismo".

Dicha perspectiva resulta determinante para la discusión en México del necesario cambio constitucional, pues por un lado exige un proceso de renovación profundo, capaz de concebir una organización efectiva y mejores

45 Aunado a los mecanismos actuales de defensa constitucional, es menester pugnar por su perfeccionamiento e incorporar - por ejemplo a nivel federal- mecanismos como el control previo de tratados internacionales, la acción por omisión legislativa, la cuestión de inconstitucionalidad, la acción popular de inconstitucionalidad y la responsabilidad patrimonial del Estado extendida a todos sus órganos (Estado-juez, legislador y administrador). Para una visión general del tema, $c f r$. Casarín León, Manlio Fabio, "La justicia constitucional en México: algunas ideas en torno a su consolidación", en Ferrer Mac-Gregor, Eduardo y Zaldívar Lelo de Larrea, Arturo, La Ciencia del derecho procesal constitucional. Estudios en homenaje al profesor Héctor Fix-Zamudio, Tomo III, México, UNAM, 2008, pp. 99-121.

46 Existen en México actualmente 10 órganos de esta naturaleza, muchos de ellos de reciente creación; una primera evaluación nos ha demostrado aspectos negativos, tales como la subordinación al poder ejecutivo o a los partidos políticos así como conflictos derivados de la aparente invasión de competencia con otros sectores estatales, básicamente identificados con la administración pública. En mi opinión, solo se justifican como órganos con autonomía constitucional la Comisión Nacional de Derechos Humanos, el Banco de México, el Instituto Nacional Electoral y la Fiscalía General de la República, debiéndose adicionar la Contraloría General de la República y el Tribunal Constitucional.

47 Destacan en este aspecto, la prohibición de la indefensión, transparencia y rendición de cuentas, interdicción de la arbitrariedad, el derecho a una buena administración y la planeación del desarrollo nacional con visión de largo plazo, incluyendo asignaciones presupuestales multianuales en rubros específicos como educación, salud, medio ambiente, ciencia y tecnología, seguridad social, entre otros. 
Esta obra forma parte del acervo de la Biblioteca Jurídica Virtual del Instituto de Investigaciones Jurídicas de la UNAM

controles del poder político para garantizar adecuadamente los derechos fundamentales, y por el otro la realización de la Constitución como norma directiva fundamental a partir de la concreción de sus principios y valores.

Creemos que la mejor forma de transitar a este proceso de reconstitucionalización del ordenamiento jurídico mexicano, es a partir de una reforma integral a la Constitución federal en donde se conserven los principios históricos que le han dado vida a nuestro Estado de derecho, pero que se cualifiquen y enriquezcan a partir de las mejores aportaciones del Estado constitucional y democrático.

El procedimiento de reforma integral propuesto, deberá contener aspectos formales y sustantivos que permitan materializar el cambio constitucional con altos niveles de legitimidad democrática, de tal suerte que todos los actores involucrados asuman la paternidad de una norma suprema renovada y se hagan corresponsables de su cumplimiento, estabilidad en el tiempo, y revisión y actualización cuando las circunstancias y necesidades sociales así lo ameriten.

En suma, la inminente celebración del centenario de la Constitución de Querétaro debe ser un motivo más que justificado para honrarla y otorgarle un nuevo traje normativo, que haga posible transitar a un proyecto de nación sustentado en una forma de organización estatal democrática y constitucional, capaz de proporcionar soluciones efectivas a los grandes problemas que enfrenta nuestro país. 
Esta obra forma parte del acervo de la Biblioteca Jurídica Virtual del Instituto de Investigaciones Jurídicas de la UNAM

\title{
REORDENACIÓN Y CONSOLIDACIÓN \\ DEL TEXTO CONSTITUGIONAL RESPECTO \\ DEL CONTROL EX OFFICIO \\ DE CONVENCIONALIDAD EN MATERIA \\ ELEGTORAL (TRAYEGTORIA Y PROBLEMAS)
}

Eduardo de Jesús Castellanos HernándeZ*

\begin{abstract}
SuMARIO: I. Introducción. II. Antecedentes. III. Control de convencionalidad. IV. Control difuso de constitucionalidad. V. Características político institucionales de la reforma constitucional que llevó a la situación actual del control difuso ex officio de convencionalidad. VI. Control difuso de convencionalidad ex officio en materia electoral. VII. La regulación constitucional vigente. VIII. Regulación en el texto reordenado y consolidado. IX. Conclusiones y propuestas. X. Bibliografia.
\end{abstract}

\section{INTRODUCCIÓN}

Como es natural mi reflexión y análisis se formula a partir del estudio académico realizado en el seno del Instituto de Investigaciones Jurídicas de la UNAM $^{1}$, del cual surge un texto reordenado y consolidado de la Constitución Política de los Estados Unidos Mexicanos, a efecto de evaluar la actualidad, pertinencia y viabilidad de dicho texto reordenado y consolidado

* Investigador Visitante del Instituto de Investigaciones Jurídicas de la UNAM. Investigador Nacional, Nivel I. Miembro del Registro CONACYT de Evaluadores Acreditados. Área 5, Económicas y Sociales.

1 Constitución Política de los Estados Unidos Mexicanos. Texto reordenado y consolidado. Estudio académico, LXII Legislatura. Cámara de Diputados. UNAM. Instituto de Investigaciones Jurídicas, México, Julio de 2015, 543 páginas. Disponible para consulta virtual en la página del Instituto de Investigaciones Jurídicas de la UNAM. 
Esta obra forma parte del acervo de la Biblioteca Jurídica Virtual del Instituto de Investigaciones Jurídicas de la UNAM

para regular como Ley Fundamental de la República el control difuso de convencionalidad ex officio en materia electoral.

Esto implica trazar una estrategia, en primer lugar, de análisis del cambio constitucional respecto del control difuso de la convencionalidad en materia electoral en su trayectoria y problemas hasta llegar al momento actual. En segundo lugar, estudiar la evolución deseable y el escenario prospectivo de dicho control difuso de la convencionalidad en materia electoral para que éste cumpla plenamente su función de promoción, respeto, protección y garantía de los derechos humanos en su vertiente de derechos político electorales de los ciudadanos. Esto implica, en tercer lugar, analizar las características político institucionales de la reforma constitucional en el tema y materia que señalo a efecto de evaluar la viabilidad de las alternativas que se ofrecen al texto ordenado y consolidado que ahora estudiamos. Finalmente, es obligado analizar la regulación que para dichos tema y materia ofrece el texto reordenado y consolidado y proponer conclusiones.

\section{ANTEGEDENTES}

El Estudio Académico en comento, en lo sucesivo "El Estudio", en su parte introductoria afirma que "es el año de 1982 el que podemos considerar como un parteaguas, pues en esa fecha se inicia un proceso de reformas, que dura hasta nuestros días, en el que hay una renovación importante de las instituciones existentes y la creación de otras muchas que modernizan y actualizan nuestro ordenamiento constitucional....En lo particular, la Constitución se ha reformado de manera importante en las siguientes materias:"

- Control de constitucionalidad de las leyes

- Autonomía de gobierno y administración de los municipios

- Sistema electoral y representativo (federal y local)

- Derechos fundamentales, tanto individuales como sociales, y sus medios de protección

- Derechos y autonomía de los pueblos indígenas

- Propiedad y justicia agrarias

- Transparencia y acceso a la información pública gubernamental

- Sistemas de justicia penal y seguridad pública

- Presupuesto, control del gasto público y rendición de cuentas

- Relaciones del Estado con las iglesias y las comunidades religiosas

- Independencia, gobierno y carrera judiciales 
Esta obra forma parte del acervo de la Biblioteca Jurídica Virtual del Instituto de Investigaciones Jurídicas de la UNAM

- Rectoría del Estado sobre el desarrollo nacional y sistema de planeación democrática

- Explotación de recursos energéticos y empresas productivas del Estado

Dicha parte introductoria de El Estudio precisa lo siguiente respecto de la dinámica constitucional: "A diferencia de otros tiempos, en que la reforma constitucional era sustancialmente un producto de las decisiones más o menos unilaterales del Presidente de la República, en la actualidad los cambios constitucionales se derivan de los acuerdos de los partidos políticos nacionales, los que tienen fuertes incentivos para incluir en el texto constitucional los detalles puntuales de dichos acuerdos, a fin de protegerlos frente a las mayorías legislativas ordinarias y evitar también la posible impugnación de su constitucionalidad ante los tribunales".

En el estudio se describen sin afán de exhaustividad, entre otros, los siguientes defectos y errores que han provocado el "notable desorden y falta de técnica y sistemática en los temas regulados en los diversos artículos constitucionales"2:

1. Presencia de disposiciones duplicadas

2. Uso variable e inconsistente de la terminología

3. Disparidad en el alcance y profundidad de la regulación

4. Desorden y falta de sistema en la materia regulada en los artículos constitucionales

5. Deficiente ubicación de las disposiciones constitucionales

6. Errores en la actualización del texto

7. Artículos reglamentarios

Por cuanto a los criterios y pasos esenciales para reordenar y consolidar el texto constitucional, en El Estudio se afirma haber observado los siguientes lineamientos:

1. La misma Constitución de 1917, lo cual entraña no alterar las decisiones jurídicas y políticas que contiene además de respetar el número total de artículos del texto (136).

2. Reordenación, a efecto de "reubicar las disposiciones constitucionales en el artículo, apartado, fracción o párrafo que resulte más con-

2 Ibid., p. 15 y siguientes. 
Esta obra forma parte del acervo de la Biblioteca Jurídica Virtual del Instituto de Investigaciones Jurídicas de la UNAM

veniente desde un punto de vista sistemático y técnico, sin alterar su redacción, salvo para corregir errores evidentes".

3. Consolidación, "se mejora la puntuación y la redacción; en algunos casos se sintetiza el contenido, suprimiéndose redundancias e inconsistencias; se articula la redacción de los párrafos reordenados; se mejora la presentación sistemática, en apartados, fracciones e incisos; y, finalmente, se traslada el contenido de las partes que se han considerado "reglamentarias" a la Ley de Desarrollo Constitucional".

4. Explicación, se ilustra al lector mediante una "cuarta columna de los cuadros comparativos con una explicación detallada de los cambios de ubicación y redacción propuestos; se presenta el texto suprimido o que se propone reenviar a la Ley de Desarrollo Constitucional".

Como medida "concomitante y necesaria" se propone la aprobación de una Ley de Desarrollo Constitucional a la manera propuesta en diferentes momentos de la historia constitucional de México, y de su estudio, tanto por Mariano Otero en su célebre voto particular que desembocó en el Acta de Reformas de 1847, como por el Maestro Héctor Fix Zamudio y otros autores estudiosos del cambio constitucional.

En la presente contribución me limitaré, como ya lo he expresado, a evaluar la actualidad, pertinencia y viabilidad del texto consolidado que nos presentan los autores de El Estudio Académico, para efecto de regular en el momento presente y en los años por venir el control difuso de convencionalidad ex officio en materia electoral.

\section{CONTROL DE CONVENCIONALIDAD}

Eduardo Ferrer Mac-Gregor, al desarrollar la voz "Control de convencionalidad (sede interna)" en el Diccionario de Derecho Procesal Constitucional y Convencional ${ }^{3}$, le atribuye tres objetivos: 1) Prevenir la aplicación de normas nacionales manifiestamente incompatibles con la Convención Americana de Derechos Humanos; 2) Servir como una institución que permita a todas las autoridades del Estado cumplir adecuadamente con su obligación de respeto y garantía de los derechos humanos protegidos por la Convención Americana y otros tratados, y con el cumplimiento de sentencias dictadas en contra del Estado al que la autoridad pertenece, y 3) Servir como un medio para permitir y acrecentar el diálogo, especialmente un diálogo jurispru-

3 Tomo I, A-F, págs. 233 a 236 
Esta obra forma parte del acervo de la Biblioteca Jurídica Virtual del Instituto de Investigaciones Jurídicas de la UNAM

dencial en materia de derechos humanos, entre los tribunales nacionales y la Corte Interamericana.

Para López Olvera y Pahuamba Rosas ${ }^{4}$, el control difuso de convencionalidad "implica que cuando se encuentra una incompatibilidad entre una norma que se pretende aplicar con la CPEUM y los tratados internacionales, no se declara inconstitucional la norma, es decir, no se expulsa del ordenamiento, únicamente, el órgano jurisdiccional desaplica la norma incompatible al caso concreto, pero esa norma queda vigente".

El control difuso de convencionalidad ex officio es un proceso jurisdiccional reciente en nuestro país que si hubiera que darle fecha de nacimiento no cuesta trabajo ubicarla el 23 de noviembre de 2009, fecha en que la Corte Interamericana de Derechos Humanos (CorteIDH) resolvió el caso Rosendo Radilla Pacheco contra Estados Unidos Mexicanos; fecha a la que habría que agregar el 10 de junio de 2011 en que se publica la reforma constitucional en materia de derechos humanos. Tan reciente es que la Suprema Corte de Justicia de la Nación (SGJN) al conocer la sentencia de la CorteIDH en la que se condenó a nuestro país a ejercer control difuso de convencionalidad se interrogó a sí misma sobre lo que debería de hacer, pues no había ningún precedente legal, ni jurisprudencial, menos aún una sentencia internacional condenatoria contra México previa que involucrase en su cumplimiento a la Suprema Corte de Justicia de la Nación ${ }^{5}$. Es por ello que la SCJN tramitó los expedientes varios 489/2010 y 912/2010, para decidir que le correspondía como parte del Estado Mexicano acatar la parte de la sentencia de la CorteIDH, cuyo resolutivo en la materia que nos ocupa era la SCJN a la que, como autoridad competente del Estado Mexicano, tocaba cumplir su mandato. Insisto, el mandato o condena jurisdiccional era establecer y ejercer el control difuso de convencionalidad.

El párrafo 339 de la sentencia de la CorteIDH resolvió lo siguiente:

4 López Olvera, Miguel y Pahuamba Rosas,Baltazar, Nuevos paradigmas constitucionales, Editorial Express, 2014, México, p. 224.

5 Arturo Saldívar Lelo de Larrea afirma en su prólogo al libro El Nuevo fuicio de Amparo. Guía de la Reforma Constitucionaly la Nueva Ley de Amparo (p. XV), que "lo resuelto por el Pleno de la Suprema Corte de Justicia de la Nación en el expediente Varios 912/2010, relativo al cumplimiento de la sentencia de la Corte Interamericana de Derechos Humanos que condenó a México en el caso Radilla, en el que partiendo de una lectura conjunta del segundo párrafo del artículo $1^{\circ}$ constitucional en relación con el 133 de la propia Norma Fundamental, concluimos que, en el ejercicio de la función jurisdiccional, los jueces de toda la República están obligados a preferir los derechos humanos contenidos en la Constitución y en los tratados internacionales, a pesar de las disposiciones en contrario establecidas en cualquier norma inferior, lo que se traduce en un control difuso de convencionalidad ex officio en materia de derechos humanos." 
Esta obra forma parte del acervo de la Biblioteca Jurídica Virtual del Instituto de Investigaciones Jurídicas de la UNAM

“339. En relación con las prácticas judiciales, este Tribunal ha establecido en su jurisprudencia que es consciente de que los jueces y tribunales internos están sujetos al imperio de la ley y, por ello, están obligados a aplicar las disposiciones vigentes en el ordenamiento jurídico. Pero cuando un Estado ha ratificado un tratado internacional como la Convención Americana, sus jueces, como parte del aparato del Estado, también están sometidos a ella, lo que les obliga a velar porque los efectos de las disposiciones de la Convención no se vean mermados por la aplicación de leyes contrarias a su objeto y fin, que desde un inicio carecen de efectos jurídicos. En otras palabras, el Poder Judicial debe ejercer un 'control de convencionalidad' ex officio entre las normas internas y la Convención Americana, evidentemente en el marco de sus respectivas competencias y de las regulaciones procesales correspondientes. En esta tarea, el Poder Judicial debe tener en cuenta no solamente el tratado, sino también la interpretación que del mismo ha hecho la Corte Interamericana, intérprete última de la Convención Americana."

Es oportuno recordar al respecto que el 24 de febrero de 1999 se había publicado el Decreto que contiene la Declaración para el reconocimiento de la competencia contenciosa de la Corte Interamericana de los Derechos Humanos, en los siguientes términos:

"Ernesto Zedillo Ponce de León, Presidente de los Estados Unidos Mexicanos, a todos los que el presente vieren, sabed:

El veintidós de noviembre de mil novecientos sesenta y nueve, se adoptó en la ciudad de San José, Costa Rica, la Convención Americana sobre Derechos Humanos "Pacto de San José de Costa Rica", a la que el Gobierno de los Estados Unidos Mexicanos se adhirió el veinticuatro de marzo de mil novecientos ochenta y uno.

En ejercicio de la facultad que el artículo 62, numeral 1, de la Convención citada, otorga a todo Estado Parte, el Gobierno de los Estados Unidos Mexicanos sometió a la consideración de la Cámara de Senadores del Honorable Congreso de la Unión, la Declaración para el Reconocimiento de la Competencia Contenciosa de la Corte Interamericana de Derechos Humanos, misma que fue aprobada por dicha Cámara el primero de diciembre de mil novecientos noventa y ocho, según Decreto publicado en el Diario Oficial de la Federación del ocho del propio mes y año, en los términos siguientes:

DEGLARACIÓN PARA EL REGONOGIMIENTO DE LA COMPETENGIA CONTENCIOSA DE LA GORTE INTERAMERICANA DE DERECHOS HUMANOS

1.Los Estados Unidos Mexicanos reconocen como obligatoria de pleno derecho, la competencia contenciosa de la Corte Interamericana de Derechos Humanos, sobre los casos relativos a la interpretación o aplicación de 
Esta obra forma parte del acervo de la Biblioteca Jurídica Virtual del Instituto de Investigaciones Jurídicas de la UNAM

la Convención Americana sobre Derechos Humanos, de conformidad con el artículo 62.1 de la misma, a excepción de los casos derivados de la aplicación del artículo 33 de la Constitución Política de los Estados Unidos Mexicanos.

$2 \ldots \ldots . . . "$

Con estos antecedentes, el Pleno de la Suprema Corte se pronunció de la manera siguiente al resolver el expediente varios 912/2010:

En este sentido, esta Suprema Corte no es competente para analizar, revisar, calificar o decidir si una sentencia dictada por la Corte Interamericana de Derechos Humanos, esto es, en sede internacional, es correcta o incorrecta, o si la misma se excede en relación a las normas que rigen su materia y proceso. Esta sede de jurisdicción nacional no puede hacer ningún pronunciamiento que cuestione la validez de lo resuelto por la Corte Interamericana de Derechos Humanos, ya que para el Estado mexicano dichas sentencias constituyen, como ya dijimos, cosa juzgada y, por ende, lo único procedente es acatar y reconocer la totalidad de la sentencia en sus términos.

En la sesión del 12 de julio, cuando se realizó la votación sobre el Considerando Octavo de la resolución correspondiente al expediente varios 912/2010, que se refiere al control de convencionalidad, se decidió por mayoría de 7 votos, que de conformidad con el párrafo 339 de la sentencia dictada por la Corte IDH en el caso Radilla Pacheco, "el Poder Judicial de la Federación debe ejercer el control de convencionalidad ex officio entre las normas internas y la Convención Americana en el marco de sus respectivas competencias y de las regulaciones procesales correspondientes". Además, el Tribunal Pleno resolvió, por mayoría de 7 votos, que la obligación de realizar el control de convencionalidad es para todos los jueces del Estado Mexicano.

Es por ello que en el expediente varios 912/2010 la SCJN estableció el siguiente modelo de control de constitucionalidad y convencionalidad: 
Esta obra forma parte del acervo de la Biblioteca Jurídica Virtual del Instituto de Investigaciones Jurídicas de la UNAM

\begin{tabular}{|c|c|c|c|c|}
\hline Tipo de control & $\begin{array}{c}\text { Órgano y medios de } \\
\text { control }\end{array}$ & $\begin{array}{l}\text { Fundamento } \\
\text { constitucional }\end{array}$ & Posible Resultado & Forma \\
\hline Concentrado: & $\begin{array}{l}\text { Poder Judicial } \\
\text { de la Federación } \\
\text { (tribunales de } \\
\text { amparo): } \\
\text { a) Controversias } \\
\text { Constitucionales } \\
\text { y Acciones de } \\
\text { Inconstitucionalidad } \\
\text { b) Amparo Indirecto } \\
\text { c) Amparo Directo }\end{array}$ & $\begin{array}{c}105, \\
\text { fracciones } \\
\text { I y II } \\
103,107, \\
\text { fracción } \\
\text { VII } \\
\text { 103, 107, } \\
\text { fracción IX }\end{array}$ & \begin{tabular}{|} 
Declaración \\
de inconsti- \\
tucionalidad \\
con efectos \\
generales \\
o interpartes \\
No hay \\
declaratoria de \\
inconstitucionalidad
\end{tabular} & Directa \\
\hline 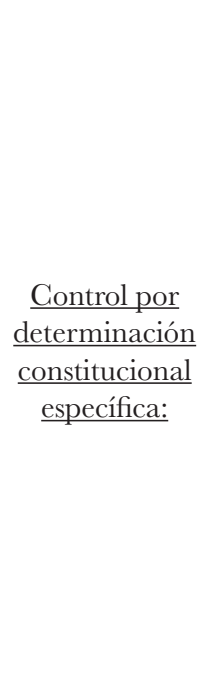 & $\begin{array}{l}\text { a) Tribunal } \\
\text { Electoral en } \\
\text { Juicio de revisión } \\
\text { constitucional } \\
\text { electoral de actos } \\
\text { o resoluciones } \\
\text { definitivos y firmes } \\
\text { de las autoridades } \\
\text { electorales locales } \\
\text { en organización } \\
\text { y calificación } \\
\text { de comicios o } \\
\text { controversias en } \\
\text { los mismos } \\
\text { b) Tribunal } \\
\text { Electoral del Poder } \\
\text { Judicial de la } \\
\text { Federación }\end{array}$ & $\begin{array}{c}\text { Art. 41, } \\
\text { fracción } \\
\text { VI, 99, } \\
\text { párrafo } 60 .\end{array}$ & $\begin{array}{c}\text { No hay } \\
\text { declaración } \\
\text { de inconstitu- } \\
\text { cionalidad } \\
\text { sólo inaplicación }\end{array}$ & $\begin{array}{l}\text { Directa e } \\
\text { incidental }\end{array}$ \\
\hline Difuso: & $\begin{array}{l}\text { A) Resto de los } \\
\text { tribunales } \\
\text { a) Federales: } \\
\text { Juzgados de Distrito } \\
\text { y Tribunales } \\
\text { Unitarios de proceso } \\
\text { federal y Tribunales } \\
\text { Administrativos } \\
\text { b) Locales: Judiciales, } \\
\text { administrativos y } \\
\text { electorales }\end{array}$ & $\begin{array}{c}\text { 1o., } 133, \\
104 \text { y } \\
\text { derechos } \\
\text { humanos en } \\
\text { tratados } \\
\\
\\
\text { 1o., 133, } \\
116 \text { y } \\
\text { derechos } \\
\text { humanos en } \\
\text { tratados }\end{array}$ & $\begin{array}{c}\text { No hay } \\
\text { declaración } \\
\text { de inconstitu- } \\
\text { cionalidad, } \\
\text { sólo inaplicación }\end{array}$ & Incidental* \\
\hline
\end{tabular}


Esta obra forma parte del acervo de la Biblioteca Jurídica Virtual del Instituto de Investigaciones Jurídicas de la UNAM

\begin{tabular}{|c|c|c|c|c|}
\hline$\frac{\text { Interpretación }}{\text { más favorable: }}$ & $\begin{array}{c}\text { Todas } \\
\text { los autoridades } \\
\text { del Estado } \\
\text { mexicano }\end{array}$ & $\begin{array}{c}\text { Artículo } \\
\text { lo. y } \\
\text { derechos } \\
\text { humanos } \\
\text { en tratados }\end{array}$ & $\begin{array}{c}\text { Solamente } \\
\text { interpretación } \\
\text { aplicando } \\
\text { la norma más } \\
\text { favorable a las } \\
\text { personas sin } \\
\text { inaplicación o } \\
\text { declaración de } \\
\text { inconstitucionalidad }\end{array}$ & $\begin{array}{c}\text { Fundamenta- } \\
\text { ción } \\
\text { y } \\
\text { motivación. }\end{array}$ \\
\hline
\end{tabular}

Fuente: Diario Oficial de la Federación de 04.10.2011, párrafo 36.

Posteriormente, a través de la contradicción de tesis 293/2011 la SCJN formuló las siguientes precisiones:

— "DEREGHOS humanos GONTENIDOS EN LA GONSTITUCiÓN Y EN LOS TRATADOS INTERNAGIONALES. CONSTITUYEN EL PARÁMETRO DE CONTROL DE REGULARIDAD CONSTITUCIONAL, PERO CUANDO EN LA CONSTITUCIÓN HAYA UNA RESTRICGIÓN EXPRESA AL EJERCICIO DE AQUÉLLOS, SE DEBE ESTAR A LO QUE ESTABLEGE EL TEXTO CONSTITUCIONAL.

— "JURISPRUDENGIA EMITIDA POR LA CORTE INTERAMERICANA DE DERECHOS HUMANOS. ES VINCULANTE PARA LOS JUECES MEXICANOS SIEMPRE QUE SEA MÁS FAVORABLE A LA PERSONA."

En la que la Suprema Corte de Justicia de la Nación sostuvo en el engrose de su resolución que las normas que componen el bloque de constitucionalidad "no pueden contravenir el principio de supremacía constitucional precisamente porque forman parte del conjunto normativo respecto del cual se predica la supremacía"6

\section{Control difuso DE GOnStituGionALIDAD}

En la cita de pie de página número 3, a fojas 30 y 31 del engrose de la resolución del expediente varios 912/2010, aparece la siguiente descripción del camino que ha seguido la Suprema Corte de Justicia respecto del control

6 Engrose de la Contradicción de tesis 293/2011, p. 51. 
Esta obra forma parte del acervo de la Biblioteca Jurídica Virtual del Instituto de Investigaciones Jurídicas de la UNAM

difuso de la constitucionalidad, originalmente aceptado y posteriormente rechazado para ser nuevamente aceptado y otra vez rechazado:

En abril de 1919, el criterio del Tribunal Pleno era que todas las leyes que se opusieran a lo dispuesto en la Constitución no debían ser obedecidas por ninguna autoridad, éste criterio se expresaba en la tesis de rubro: "CONSTITUCIÓN, IMPERIO DE LA" (registro IUS 289, 870). En mayo de 1934, la Segunda Sala, estableció una tesis aislada con el rubro: "CONSTITUCIONALIDAD DE LA LEY" (número de registro IUS 336,181), la cual reflejaba un criterio consistente en que conforme con el artículo 133 de la Constitución Federal, todos los jueces de la República tenían la obligación de sujetar sus fallos a los dictados de la misma, a pesar de las disposiciones que en contrario pudieran existir en otras leyes secundarias. $\mathrm{Al}$ año siguiente, en agosto de mil novecientos treinta y cinco, la misma Sala señaló que los únicos que pueden determinar la inconstitucionalidad de algún precepto son los tribunales de la Federación, al emitir la tesis aislada de rubro: "LEYES DE LOS ESTADOS, CONTRARIAS A LOS PRECEPTOS CONSTITUCIONALES" (número de registro IUS 335,247). Guatro años después, en febrero de 1939, la Tercera Sala de la Corte, determinó en un criterio aislado que la observancia del artículo 133 de la Constitución Federal es obligatoria para los jueces locales de toda categoría, el rubro de la tesis es: "LEYES, CONSTITUCIONALIDAD DE LAS" (número de registro IUS 356,069). Posteriormente, en abril de 1942, la Segunda Sala se pronuncia nuevamente en el sentido de que todas las autoridades del país deben observar la Constitución a pesar de las disposiciones en contrario que pueda haber en otras leyes, las tesis tienen como rubro: "CONSTITUCIONALIDAD DE LAS LEYES, COMPETENCIA DEL TRIBUNAL FISCAL PARA EXAMINARLA Y ESTATUIR SOBRE ELLAS" (REGISTRO IUS 326,678) Y "CONSTITUCIONALIDAD DE LA LEY DEL IMPUESTO AL SUPERPROVECHO COMPETENCIA DEL TRIBUNAL FISCAL PARA DECIDIR SOBRE ELLA" (Registro IUS 326, 642). En el año de 1949 la misma Segunda Sala emite un criterio contrario a los anteriores, en donde vuelve a sostener que solo las autoridades judiciales de la Federación puede conocer de los problemas de "anticonstitucionalidad", la tesis tiene como rubro: "LEYES, CONSTITUCIONALIDAD DE LAS" (registro IUS 320,007). En septiembre de1959, la Segunda Sala consideró que la vía adecuada para resolver los problemas sobre la oposición de una ley secundaria y la Constitución era el juicio de amparo, la tesis tiene como rubro: "CONSTITUCION Y LEYES SECUNDARIAS, OPOSICIÓN EN LAS" (registro IUS 268, 130). En 1960 la Tercera Sala resuelve que si bien las autoridades judiciales del fuero común no pueden hacer declaratorias de inconstitucionalidad de leyes, en observancia al artículo 133 están obligadas a aplicar en primer término la Constitución Federal cuando una ley ordinaria la contravenga directamente, la tesis es de rubro: "CONSTITUCIÓN. SU APLICACIÓN POR PARTE DE LAS AUTORIDADES DEL FUERO COMÚN GUANDO SE ENCUENTRA CONTRAVENIDA 
Esta obra forma parte del acervo de la Biblioteca Jurídica Virtual del Instituto de Investigaciones Jurídicas de la UNAM

POR UNA LEY ORDINARIA” (registro IUS 270, 759). En septiembre de 1968, la Tercera Sala emite un criterio en el que considera que sólo el Poder Judicial de la Federación puede calificar la constitucionalidad de las leyes a través del juicio de amparo, el rubro es: "CONSTITUGIONALIDAD DE LAS LEYES, EXÁMEN DE LA, IMPROGEDENTE, POR LA AUTORIDAD JUDICIAL COMÚN” (número de registro IUS 269,162). En agosto de 1971, la Tercera Sala se pronunció en el sentido de que todas las autoridades judiciales deben apegar sus resoluciones a la Constitución, la tesis tiene el rubro: "LEYES, CONSTITUCIONALIDAD DE LAS. SU VIOLAGIÓN ALEGADA ANTE EL TRIBUNAL DE APELACIÓN" (número de registro IUS 242, 149). En junio de 1972, la Tercera Sala consideraba que el examen de la constitucionalidad de las leyes solamente estaba a cargo del Poder Judicial Federal a través del juicio de amparo, el rubro de la tesis es: "CONSTITUCIONALIDAD DE LAS LEYES, EXAMEN DE LA, IMPROGEDENTE POR LA AUTORIDAD JUDICIAL COMÚN” (registro IUS 242, 028).

Ya en la novena época y mediante criterio plenario emitido en mayo de mil novecientos noventa y cinco, reiterado en junio de mil novecientos noventa y siete y en tres precedentes de mil novecientos noventa y ocho, se determinó que el artículo 133 de la Constitución no autoriza el control difuso de la constitucionalidad de normas generales, la tesis es la P./J. 74/99 y lleva por rubro: "CONTROL DIFUSO DE LA GONSTITUGIONALIDAD DE NORMAS GENERALES. NO LO AUTORIZA EL ARTÍCULO 133 DE LA CONSTITUGIÓN”. Este criterio se reitera mediante la tesis plenaria P./J. 73/99 de rubro: "CONTROL JUDICIAL DE LA CONSTITUGIÓN. ES ATRIBUCIÓN EXCLUSIVA DEL PODER JUDICIAL DE LA CONSTITUCiÓN". En agosto de dos mil cuatro, la Segunda Sala reitera el criterio en la tesis de jurisprudencia 2a./J. 109/2004 de rubro: "CONTENCIOSO ADMINISTRATIVO. EL TRIBUNAL FEDERAL DE JUSTICIA FISCAL Y ADMINISTRATIVA CARECE DE COMPETENCIA PARA PRONUNCIARSE SOBRE LOS VICIOS DE CONSTITUGIONALIDAD QUE EN LA DEMANDA RESPECTIVA SE ATRIBUYAN A UNA REGLA GENERAL ADMINISTRATIVA”.

En la misma novena época, esta Suprema Corte de Justicia al resolver la Contradicción de Tesis 2/2000, emitió la tesis P./J. 23/2002 de rubro: "TRIBUNAL ELEGTORAL DEL PODER JUDICIAL DE LA FEDERACIÓN. CAREGE DE COMPETENGIA PARA PRONUNCIARSE SOBRE INGONSTITUGIONALIDAD DE LEYES", la que quedó posteriormente sin efecto por la reforma constitucional al artículo 99 publicada el 13 de noviembre de 2007 en el Diario Oficial en la que se facultó a las Salas del Tribunal Electoral para inaplicar leyes electorales contrarias a la Constitución. 
Esta obra forma parte del acervo de la Biblioteca Jurídica Virtual del Instituto de Investigaciones Jurídicas de la UNAM

Respecto de este camino sinuoso en materia de control de constitucionalidad, Alberto Abad Suárez Ávila afirma lo siguiente en su libro La protección de los derechos fundamentales en la Novena Época de la Suprema Corte?:

El comportamiento de la SCJN en la protección de los derechos fundamentales en el periodo 1995-2006 fue deficiente. Como describen varios autores, la cuestión de la protección de los derechos fundamentales es un déficit histórico del poder judicial en México en general y de la SCJN como cabeza del mismo. Durante el presidencialismo priista, la SCJN se mantuvo disciplinada al régimen de partido hegemónico y por lo tanto la justicia constitucional subordinada a los componentes políticos. La Constitución mexicana fue más un manifiesto político que un documento normativo, lo que limitó el trabajo de interpretación que podría realizar la SGJN respecto de los derechos fundamentales. En particular, el predominio de un solo partido político en el control del poder, coartó las posibilidades de un poder judicial fuerte encargado de la revisión constitucional.

En su libro La política desde la justicia. Cortes supremas, gobierno y democracia en Argentina y México ${ }^{8}$, Karina Ansolabehere afirma respecto de las relaciones entre las cortes supremas y el poder político que:

La relación Corte Suprema- poder político, se reconstruye a partir de tres dimensiones de análisis: a) la historia institucional de relación con el poder político; b) la capacidad de veto de la Corte de las decisiones del poder político (capacidad de control de ésta sobre el poder político), y c) la capacidad de influencia del poder político en las reglas que regulan el funcionamiento del Poder Judicial (capacidad de control del poder político sobre la Corte y el Poder Judicial).

Por cuanto a la relación Corte Suprema- Poder Judicial, la autora en cita afirma ${ }^{9}$ :

En este caso son dos las dimensiones de análisis que se tomarán en cuenta: a) la capacidad de influencia de la Corte Suprema respecto de las decisiones de los jueces y magistrados (posibilidad de control de la Corte sobre las instancias inferiores del Poder Judicial) y b) la capacidad de las instancias inferiores del Poder Judicial de constreñir el accionar de la Corte.

7 UNAM. Porrúa. Instituto Mexicano de Derecho Procesal Constitucional, México, 2014 , p. 321.

8 FLACSO México. Fontamara, México 2007, p. 74.

9 Ibid., p. 79. 
Esta obra forma parte del acervo de la Biblioteca Jurídica Virtual del Instituto de Investigaciones Jurídicas de la UNAM

Tanto la descripción jurisprudencial transcrita al inicio de este acápite como las reflexiones invocadas de ambos autores, nos serán de utilidad para llegar al contexto inmediato del control de convencionalidad en materia electoral.

\section{CaraCterísticas POLÍTICO INSTITUCiOnALES \\ DE LA REFORMA CONSTITUCIONAL QUE LLEVÓ \\ A LA SITUACIÓN ACTUAL DEL CONTROL DIFUSO \\ EX OFFICIO DE CONVENGIONALIDAD}

En mi contribución a la serie de estudios publicados en homenaje a los 40 años de vida académica del Dr. Jorge Witker ${ }^{10}$, reseño el curso de la reforma constitucional de 2011 en materia de derechos humanos que, junto con la sentencia del Caso Radilla, se encuentra al origen y da fundamento constitucional expreso al control difuso de convencionalidad ex officio.

La ruta crítica expuesta en dicho trabajo permite advertir los siguientes elementos que influyen y finalmente determinan la adopción del control difuso de convencionalidad ex officio en nuestro país: 1) Reformas constitucionales; 2) Reformas legislativas; 3) Criterios jurisprudenciales nacionales; 4) Creación de organismos y unidades administrativas en la administración pública del Ejecutivo federal; 5) Sujeción a jurisdicciones internacionales, sentencias y criterios jurisprudenciales de éstas; 6) Presencia de organismos internacionales y recomendaciones de éstos respecto de conductas internas; 7) Acción política plural al interior del país, y 8) Sentencia condenatoria de la CorteIDH en el caso Rosendo Radilla.

\section{CONTROL DIFUSO DE CONVENCIONALIDAD EX OFFICIO EN MATERIA ELECTORAL}

Felipe de la Mata Pizaña en su libro Manual del Sistema de Protección de los Derechos Político- Electorales en México, afirma ${ }^{11}$ :

De acuerdo con lo establecido por la Suprema Corte en el asunto Varios 912/2010, todas las autoridades del país, dentro del ámbito de sus respectivas competencias, se encuentran obligadas a velar por los derechos contenidos en la Constitución federal y los tratados internacionales signados por México,

10 UNAM. IIJ. Posgrado Derecho. Tecnológico de Monterrey, 2015

11 Porrúa. Universidad Panamericana. México 2012, p. 9. 
Esta obra forma parte del acervo de la Biblioteca Jurídica Virtual del Instituto de Investigaciones Jurídicas de la UNAM

adoptando la interpretación más favorable, a pesar de las disposiciones en contrario que se encuentren en cualquier norma inferior, lo que se traduce en un nuevo modelo de control de constitucionalidad y convencionalidad.

Los periodos en que puede dividirse la aplicación del control de convencionalidad en materia electoral varían de un autor a otro de los citados en la bibliografía que abordan expresamente el tema ${ }^{12}$. En mi opinión, en la materia electoral hay que distinguir, primero, entre la época en que el juicio de amparo fue procedente para resolver cuestiones político electorales y, segundo, la siguiente etapa, vigente hasta la fecha, en que el juicio de amparo ya no fue procedente. Esa primera época termina cuando se abandona la tesis de la incompetencia de origen sostenida durante el periodo en que fue presidente de la Suprema Corte el Ministro José María Iglesias ${ }^{13}$; criterio jurisprudencial que se mantuvo no obstante que la legislación de amparo vigente en la época dispuso expresamente que el amparo era improcedente en materia político electoral. Desde luego que esta diversidad de criterios entre el poder Legislativo y el poder Judicial refleja, de una parte, la independencia entre los poderes federales derivada en buena medida de la vía electoral (indirecta) para la integración de la Suprema Corte de Justicia de la Nación, pero también del conflicto entre los poderes que finalmente fue resuelto por la vía armada, concretamente con el Plan de Tuxtepec ${ }^{14}$, el triunfo militar y electoral del general Porfirio Díaz y la presidencia de la Suprema Corte a cargo del Ministro Ignacio L. Vallarta.

En segundo lugar, el control de convencionalidad en materia electoral debe ser analizado a la luz de los criterios jurisprudenciales en materia de control difuso de constitucionalidad, particularmente en su etapa reciente, es decir, a partir de la contradicción de tesis 2/2000 ${ }^{15}$. Lo anterior, en virtud de que la jurisdicción electoral también es reciente pues, salvo el breve periodo de vigencia del criterio jurisprudencial de la incompetencia de origen, recordemos que la solución de los conflictos electorales estuvo en manos de los colegios electorales de las cámaras legislativas hasta 1996, fecha

12 Me refiero a los textos de Santiago Nieto Castillo, J. Jesús Orozco Henríquez y Roselia Bustillo Marín que parecen en la bibliografía.

13 Cfr.: Una tesis y una antítesis: Iglesias- Vallarta, acápite en el libro Derecho Electoral Procesal Mexicano de Flavio Galván Rivera, p. 211 y siguientes.

14 Cfr.: Derecho electoral y presidencialismo durante el gobierno de Porfirio Díaz, capítulo de mi autoría en el libro colectivo Porfirio Díaz y el derecho. Balance crítico, p. 85 y siguientes.

15 Consultar el capítulo La contradicción de tesis 2/2000 y el sistema mexicano de justicia electoral, en el libro fusticia electoral y garantismo jurídico de J. Jesús Orozco Henríquez, p. 99 y siguientes. 
Esta obra forma parte del acervo de la Biblioteca Jurídica Virtual del Instituto de Investigaciones Jurídicas de la UNAM

en la que desaparece el último colegio electoral para calificar la elección de presidente de la República; previamente, en 1993, habían desaparecido los colegios electorales para calificar las elecciones de diputados y senadores. Paralelamente habían surgido, primero, el Tribunal de lo Contencioso Electoral (1986), el Tribunal Federal Electoral (1990), la Sala de Segunda Instancia del Tribunal Federal Electoral (1993) y, finalmente, en 1996, el Tribunal Electoral del Poder Judicial de la Federación. Es decir, que hubo durante este periodo, 1986-1996, un sistema mixto jurisdiccional y político, compuesto por los tribunales electorales mencionados y los colegios electorales de las cámaras legislativas, para la solución de conflictos electorales ${ }^{16}$.

La tercera etapa de esta evolución del control de convencionalidad en materia electoral, tiene que tomar en cuenta la aparición formal, constitucional y legislativa, de medios de defensa constitucional de los derechos político electorales de los ciudadanos mexicanos. Estos medios de defensa constitucional, teóricamente, aparecen en 1996 con la creación del Tribunal Electoral del Poder Judicial de la Federación en el artículo 99 constitucional y la regulación inicial en el mismo precepto de los medios de impugnación, regulados puntualmente en la Ley General del Sistema de Medios de Impugnación en Materia Electoral.

Una vez que desaparecen totalmente los colegios electorales de las cámaras legislativas para resolver los conflictos electorales por vía política y aparecen como único medio de solución jurisdiccional de dichos conflictos los medios de impugnación regulados en el ordenamiento antes citado, encontramos un control concreto de constitucionalidad en materia electoral a cargo del Tribunal Electoral del Poder Judicial de la Federación y un control abstracto de constitucionalidad en la materia electoral a cargo de la Suprema Corte de Justicia de la Nación al resolver las acciones de inconstitucionalidad en materia electoral a partir de 1996 (en la reforma constitucional de 1994 fueron excluidas expresamente las leyes electorales de la procedencia de acciones de inconstitucionalidad aparecidas a partir de esta reforma). Sin embargo, muy pronto, mediante la contradicción de tesis 2/2000, la SCJN sostuvo que era el único órgano de control de constitucionalidad de leyes electorales y, por lo tanto, que el TEPJF no tenía competencia para pronunciarse sobre tal tema, ni siquiera al tratarse de un caso concreto. Las dos reformas constitucionales de $2007^{17}$ al artículo 99, devolvieron esta

16 Consultar: Castellanos, Eduardo, Nuevo Derecho Electoral Mexicano, Ed. Trillas, 2014, México.

17 Diario Oficial de la Federación de 27 de septiembre y DOF de 13 de noviembre de 2007. 
Esta obra forma parte del acervo de la Biblioteca Jurídica Virtual del Instituto de Investigaciones Jurídicas de la UNAM

competencia de control de constitucionalidad al TEPJF - la reforma publicada el 13 de noviembre de 2007 lo hizo incluso de manera expresa en un nuevo párrafo sexto del artículo 99, pero ya la del 27 de septiembre de ese año lo había hecho de manera implícita en el párrafo único de la fracción IV del mismo numeral donde se agregó la expresión "se viole algún precepto establecido en esta Constitución"; expresión que solo duró mes y medio en el texto vigente de la Constitución pues dicho párrafo único se modificó nuevamente en la siguiente reforma publicada el 13 de noviembre del mismo año para dar cabida a la mención expresa que ahora aparece en el nuevo párrafo sexto mencionado- ${ }^{18}$.

Antes de las reformas constitucionales de 2007 citadas, el TEPJF ejerció control de convencionalidad en los casos Hank Rhon ${ }^{19}$ y Tanetze de Zaragoza $^{20}$, no obstante la vigencia de la contradicción de tesis 2/2000. De tal suerte que el control difuso de convencionalidad en materia electoral ejercido por el TEPJF inmediatamente antes y a partir de las reformas de 2007, puede ser clasificado también antes y después de dichas reformas, es decir, sin facultad de control de constitucionalidad y con ésta. Podemos recordar aquí a Karina Ansolabehere cuando habla de instancias inferiores que constriñen el actuar de la Corte.

Por cuanto a la forma de motivar y fundamentar el control de convencionalidad en materia electoral y sus efectos, encontramos las siguientes modalidades: aplicación expresa y directa de preceptos de instrumentos internacionales en materia de derechos humanos así como su interpretación conforme, además de la aplicación de criterios jurisprudenciales de la CorteIDH. De otra parte, podemos encontrar que el control de convencionalidad implique inaplicar normas nacionales inconvencionales o bien que solo permita maximizar y potenciar derechos fundamentales, es decir, derechos humanos protegidos en el texto constitucional. Es importante destacar que si bien conforme a lo establecido en el artículo $1^{\circ}$ constitucional, todas las autoridades públicas pueden ejercer control difuso de convencionalidad ex officio, solo los tribunales nacionales pueden inaplicar normas inconvencionales o inconstitucionales, conforme a lo previsto en el expediente varios $912 / 2010$. Desde luego que en algunos casos en que pudiera haber existido una confrontación entre dos derechos fundamentales o convencionales, se

18 Consultar: Reformas constitucionales 2006-2012, Secretaría de Gobernación, Tercera edición octubre de 2012, páginas 61 y 67 respectivamente.

19 SUP-JDC-695/2007.

20 SUP-JDC-11/2007. 
Esta obra forma parte del acervo de la Biblioteca Jurídica Virtual del Instituto de Investigaciones Jurídicas de la UNAM

realizó un ejercicio de ponderación, característica adicional en este bosquejo de tipología del control de convencionalidad en materia electoral.

No obstante los avances anteriores, queda claro hasta el momento que los tribunales electorales nacionales y concretamente la Sala Superior del TEPJF, no se han atrevido a declarar la inconvencionalidad de una disposición constitucional, como sucedió en los casos SUP-JDG-1749/2012 y SUP-JDC-1774/2012, respecto al derecho de libertad de expresión. Lo anterior, no obstante que como ha quedado transcrito, el decreto que reconoce la jurisdicción contenciosa de la CorteIDH solo excluye las restricciones de derechos humanos previstas en el artículo 29 constitucional nuestro.

\section{LA REGULAGIÓN CONSTITUGIONAL VIGENTE}

El control de convencionalidad en materia electoral es resultado de la aplicación armónica de las disposiciones constitucionales que regulan, de una parte, la protección y defensa de los derechos humanos en el numeral uno de la Ley Fundamental, así como las que de otra parte regulan las acciones de inconstitucionalidad de leyes electorales y los medios de impugnación en materia electoral. Por razón natural, esas disposiciones sobre control constitucional electoral se complementan con lo establecido en el artículo 133 constitucional.

Reitero que el fundamento constitucional vigente de la regulación del control de convencionalidad en materia electoral se encuentra en los artículos 1, 99, 105 y 133 del texto vigente de la Constitución Política de los Estados Unidos Mexicanos. En consecuencia, transcribiré tales disposiciones en su parte conducente a efecto de compararlas con la propuesta de texto constitucional reordenado y consolidado contenida en El Estudio, para más adelante formular mis conclusiones.

Como ya lo he expuesto en acápites anteriores, estas disposiciones constitucionales han sido interpretadas por la SGJN, entre otros precedentes jurisdiccionales y criterios jurisprudenciales, en el expediente varios 912/2010 y en la contradicción de tesis 293/2011, que sin ser los únicos han sido los más conocidos e invocados. Desde luego que para efectos prácticos de la función jurisdiccional, el criterio sostenido por la SCJN en el sentido de que la jurisprudencia no puede ser sometida a control de constitucionalidad ni de convencionalidad por los jueces ordinarios (Contradicción de tesis 
Esta obra forma parte del acervo de la Biblioteca Jurídica Virtual del Instituto de Investigaciones Jurídicas de la UNAM

299/2013), impacta de manera determinante en la materia que ahora nos ocupa $^{21}$.

Por cuanto al TEPJF, doy cuenta de los dos siguientes criterios jurisprudenciales ${ }^{22}$ :

XXXIII/2012. Libertad de expresión en materia electoral. La restricción constitucional de adquirir tiempos en radio y televisión no puede sujetarse al control de convencionalidad.

IV/2014. Órganos jurisdiccionales electorales locales. Pueden inaplicar normas jurídicas estatales contrarias a la Constitución Política de los Estados Unidos Mexicanos y a tratados internacionales.

\section{REGULACIÓN EN EL TEXTO REORDENADO Y CONSOLIDADO}

El texto vigente de los artículos 1, 99, 105 y 133 corresponde a los numerales $1,100,105$ y 133 del texto reordenado y consolidado, como se aprecia en la transcripción siguiente que facilita la comparación:

\begin{tabular}{|c|c|}
\hline Texto constitucional vigente & Texto reordenado y consolidado \\
\hline $\begin{array}{l}\text { Artículo lo. En los Estados Unidos } \\
\text { Mexicanos todas las personas gozarán } \\
\text { de los derechos humanos reconocidos } \\
\text { en esta Constitución y en los tratados } \\
\text { internacionales de los que el Estado } \\
\text { Mexicano sea parte, así como de las } \\
\text { garantías para su protección, cuyo ejercicio } \\
\text { no podrá restringirse ni suspenderse, salvo } \\
\text { en los casos y bajo las condiciones que esta } \\
\text { Constitución establece. } \\
\text { Las normas relativas a los derechos } \\
\text { humanos se interpretarán de conformidad } \\
\text { con esta Constitución y con los tratados } \\
\text { internacionales de la materia favoreciendo } \\
\text { en todo tiempo a las personas la protección } \\
\text { más amplia. }\end{array}$ & $\begin{array}{l}\text { Artículo lo. } \\
\text { En los Estados Unidos Mexicanos todas las } \\
\text { personas gozarán de los derechos humanos } \\
\text { reconocidos en esta Constitución y en los } \\
\text { tratados internacionales de los que el Estado } \\
\text { Mexicano sea parte, así como de las garantías } \\
\text { para su protección. Su ejercicio no podrá } \\
\text { restringirse ni suspenderse, salvo en los casos } \\
\text { y bajo las condiciones que esta Constitución } \\
\text { establece. } \\
\text { Las normas relativas a los derechos humanos } \\
\text { se interpretarán conforme a esta Constitución } \\
\text { y a los tratados internacionales de la materia, } \\
\text { favoreciendo en todo tiempo a las personas la } \\
\text { protección más amplia. }\end{array}$ \\
\hline
\end{tabular}

21 Consultar: Cossío, José Ramón y Lara Chagoyán, Roberto, “¿Derechos humanos o jurisprudencia infalible?”, en Cuestiones Constitucionales, número 32, 2015, p. 81 y siguientes.

22 Compendio Tematizado de Furisprudencia y Tesis. Procesos Electorales Federales y Locales 20142015 , p. 49. 
Esta obra forma parte del acervo de la Biblioteca Jurídica Virtual del Instituto de Investigaciones Jurídicas de la UNAM

\begin{abstract}
Todas las autoridades, en el ámbito de sus competencias, tienen la obligación de promover, respetar, proteger y garantizar los derechos humanos de conformidad con los principios de universalidad, interdependencia, indivisibilidad y progresividad. En consecuencia, el Estado deberá prevenir, investigar, sancionar y reparar las violaciones a los derechos humanos, en los términos que establezca la ley.
\end{abstract}

Artículo $99 . \ldots \ldots \ldots$
$\ldots \ldots \ldots \ldots$
I. $\quad$ a X................

Sin perjuicio de lo dispuesto por el artículo 105 de esta Constitución, las salas del Tribunal Electoral podrán resolver la no aplicación de leyes sobre la materia electoral contrarias a la presente Constitución. Las resoluciones que se dicten en el ejercicio de esta facultad se limitarán al caso concreto sobre el que verse el juicio. En tales casos la Sala Superior informará a la Suprema Corte de Justicia de la Nación.

Cuando una sala del Tribunal Electoral sustente una tesis sobre la inconstitucionalidad de algún acto o resolución o sobre la interpretación de un precepto de esta Constitución, y dicha tesis pueda ser contradictoria con una sostenida por las salas o el Pleno de la Suprema Corte de Justicia, cualquiera de los Ministros, las salas o las partes, podrán denunciar la contradicción en los términos que señale la ley, para que el pleno de la Suprema Corte de Justicia de la Nación decida en definitiva cuál tesis debe prevalecer. Las resoluciones que se dicten en este supuesto no afectarán los asuntos ya resueltos.

Artículo 105. La Suprema Corte de Fusticia de la Nación conocerá, en los términos que señale la ley reglamentaria, de los asuntos siguientes:

............

II. De las acciones de inconstitucionalidad que tengan por objeto plantear la posible contradicción entre una norma de carácter general y esta Constitución.
Todas las autoridades, en el ámbito de sus competencias, tienen la obligación de promover, respetar, proteger y garantizar los derechos humanos de conformidad con los principios de universalidad, interdependencia, indivisibilidad y progresividad. El Estado deberá prevenir, investigar, sancionar y reparar las violaciones a los derechos humanos, en los términos que establezca la ley.

Artículo 100.

....

I. a IX.....

Sin perjuicio de lo dispuesto por el artículo 105 de esta Constitución, las salas del Tribunal Electoral podrán resolver la no aplicación de leyes sobre la materia electoral contrarias a la presente Constitución. Las resoluciones que se dicten en el ejercicio de esta facultad se limitarán al caso concreto sobre el que verse el juicio. En tales casos, la Sala Superior informará a la Suprema Corte de Justicia de la Nación.

Guando una sala del Tribunal Electoral sustente una tesis sobre la inconstitucionalidad de algún acto o resolución o sobre la interpretación de un precepto de esta Constitución, y dicha tesis pueda ser contradictoria con una sostenida por las salas o el Pleno de la Suprema Corte de Justicia, cualquiera de los Ministros, las salas o las partes, podrán denunciar la contradicción en los términos que señale la ley, para que el Pleno de la Corte decida en definitiva cuál tesis debe prevalecer. Las resoluciones que se dicten en este supuesto no afectarán los asuntos ya resueltos.

\section{Artículo 105.}

La Suprema Corte de Justicia de la Nación conocerá, de manera exclusiva y en los términos que señale la ley reglamentaria, de los asuntos siguientes:

II. De las acciones de inconstitucionalidad que tengan por objeto plantear la posible contradicción entre una norma de carácter general y esta Constitución. 
Esta obra forma parte del acervo de la Biblioteca Jurídica Virtual del Instituto de Investigaciones Jurídicas de la UNAM

\begin{abstract}
Artículo 133. Esta Constitución, las leyes del Congreso de la Unión que emanen de ella y todos los Tratados que estén de acuerdo con la misma, celebrados y que se celebren por el Presidente de la República, con aprobación del Senado, serán la Ley Suprema de toda la Unión. Los jueces de cada Estado se arreglarán a dicha Constitución, leyes y tratados, a pesar de las disposiciones en contrario que pueda haber en las Constituciones o leyes de los Estados.
\end{abstract}

\begin{abstract}
Artículo 133.
Esta Constitución, las leyes del Congreso de la Unión que emanen de ella y todos los tratados que estén de acuerdo con la misma, celebrados y que se celebren por el Presidente de la República, con aprobación del Senado, serán la Ley Suprema de toda la Unión. Los jueces de cada Estado se arreglarán a dicha Constitución, leyes y tratados, a pesar de las disposiciones en contrario que pueda haber en las Constituciones o leyes de los Estados.
\end{abstract}

\section{CONCLUSIONES Y PROPUESTAS}

En México el control de convencionalidad está necesariamente asociado al control de constitucionalidad. Toda vez que venimos de una tradición de control concentrado de constitucionalidad, las resistencias para hacer realidad el control difuso de convencionalidad ex officio pudieran parecer insuperables puesto que primero deben salvarse las barreras que impone la conversión del control concentrado de constitucionalidad en control difuso de constitucionalidad. Encontramos aquí en el juicio de amparo y la jurisprudencia respectiva necesariamente obligatoria por ley y no sujeta a control de convencionalidad según el criterio jurisprudencial citado, una barrera hasta el momento difícil de superar.

Por cuanto al control de convencionalidad en materia electoral el reto es igualmente mayor. Ahí todavía venimos de más lejos, de cuando los derechos político electorales no eran derechos humanos, a lo sumo eran derechos de legalidad, es decir, de teórica protección legal sin que hubiera instrumentos para garantizar jurisdiccionalmente su protección. Todos los conflictos electorales los resolvían en última instancia, hasta 1993 y 1996, respectivamente, los colegios electorales de las cámaras. Ni siquiera había tribunales para proteger los derechos nacidos de la ley, derechos legales, frente a los constitucionales y convencionales de hoy.

El momento crucial del control concentrado de constitucionalidad en materia electoral lo tenemos en la contradicción de tesis 2/2000, por virtud de la cual la Suprema Corte de Justicia de la Nación impidió al Tribunal Electoral del Poder Judicial de la Federación ejercer el control de constitucionalidad en materia electoral incluso en el caso concreto. Ya hemos visto la forma en la que el Tribunal Electoral superó el impedimento, es decir, mediante control de convencionalidad antes de las reformas constitucionales de 2007. Pero el hecho es que la tradición de control concentrado 
Esta obra forma parte del acervo de la Biblioteca Jurídica Virtual del Instituto de Investigaciones Jurídicas de la UNAM

de constitucionalidad se traslada al control (nacional) concentrado de convencionalidad. Teóricamente, el control concentrado de convencionalidad corre a cargo de la CorteIDH, pero en la práctica, en México, el control de convencionalidad es un control concentrado conforme a las competencias en materia de amparo y, en materia electoral, en función del modelo derivado del varios 912/2010 y sus modificaciones vía jurisprudencia. En cualquier hipótesis, en materia electoral, el control concentrado corre a favor del Tribunal Electoral del Poder Judicial de la Federación. Es decir, de la misma manera que el amparo concentra el control de convencionalidad en el control de constitucionalidad, en la materia electoral el control de convencionalidad igualmente es concentrado en los medios de impugnación que resuelve el Tribunal Electoral del Poder Judicial de la Federación.

¿Y qué tiene que ver todo esto con el texto reordenado y consolidado de la Constitución General de la República que da materia central a este VII Congreso Nacional de Derecho Constitucional? Pues, sencillamente, que he reseñado de manera sumarísima la dinámica del cambio constitucional en la materia jurisdiccional y jurisprudencial electoral, específicamente, respecto del control de convencionalidad ex officio de la misma, a efecto de dar cuenta, de una parte, de la falta de sistematicidad del texto constitucional para asegurar una interpretación progresiva en materia de control difuso de la constitucionalidad y de la convencionalidad en la materia electoral y sin duda también en otras. Cuando digo progresiva, me refiero a que amplíe de manera sistemática el momento y el número de sujetos de derecho protegidos, y de órganos del Estado nacional protectores de los derechos humanos en su vertiente político electoral. Pero también, para mostrar, de otra parte, las ventajas que en este momento ofrece El Estudio para conservar y proteger los avances logrados en la materia que nos ocupa.

El diálogo, la colaboración, el conflicto o la subordinación entre los poderes legislativo y ejecutivo se muestran, entre otros momentos y aspectos, en las reformas constitucionales. Ese tipo de relaciones aparece igualmente entre ambos poderes y el Poder Judicial de la Federación, manifestado no solo en las reformas constitucionales -las de 2007 ya comentadas, por ejemplo, arbitraron una diferencia entre la Suprema Corte y la Sala Superior del Tribunal Electoral-, sino también en los criterios jurisprudenciales.

El largo y sinuoso camino para llegar a las actuales instituciones y procedimientos judiciales electorales - ejemplo de la dinámica constitucional-, en la hipótesis de un nuevo texto constitucional, se enfrentaría a la disyuntiva entre la progresividad ya definida o la regresión. Ahora bien, un cambio de la envergadura de un nuevo texto constitucional en todos los valores, prin- 
Esta obra forma parte del acervo de la Biblioteca Jurídica Virtual del Instituto de Investigaciones Jurídicas de la UNAM

cipios, instituciones y procedimientos que regula una ley fundamental, en la historia nuestra, ha sido consecuencia de movimientos armados, aunque también de la evolución y cambios constitucionales sucesivos: en realidad, el texto constitucional de 2016 se parece muy poco al de 1917. Por fortuna estamos muy lejos de un movimiento armado para cambiar la Constitución vigente por otra, pero estamos también lejos de un congreso constituyente (integrado incluso a partir de una representación proporcional pura que, paradójicamente, excluiría a candidatos independientes), pues se interpone la elección presidencial de 2018, con la consecuente nueva distribución de las fuerzas políticas que protagonizan la decisión política que alimenta el cambio constitucional.

He evocado brevemente el cambio constitucional solo en materia de control difuso de convencionalidad ex officio para identificar a los protagonistas institucionales del cambio: Ejecutivo federal, Senado de la República, Suprema Corte de Justicia de la Nación, a través de la suscripción de instrumentos internacionales y de un reconocimiento nacional de la competencia contenciosa de un tribunal internacional, que a su vez permite el ingreso de un nuevo protagonista: la Corte Interamericana de Derechos Humanos a través de sus resoluciones. La CorteIDH condenó al Estado Mexicano a ejercer control difuso de convencionalidad, independientemente de que el mismo implicara de manera automática un control difuso de constitucionalidad hasta entonces no practicado, como pudimos apreciar en la transcripción de precedentes jurisprudenciales al respecto. La contradicción de la contradicción de tesis 293/201123 muestra a su vez las dificultades de adopción, y de cabal cumplimiento, de una sentencia internacional. Pero independientemente del sentido que tengan los siguientes criterios jurisprudenciales, la dinámica del cambio constitucional está siempre presente, entre otros, en los actores señalados que desde luego no son los únicos. La academia jurídica es uno más de esos actores. Pero a lo que voy es a la complejidad del cambio constitucional. Es una complejidad que no quedaría resuelta con un nuevo texto constitucional, por el contrario, un nuevo texto abriría nuevos debates, nuevas rutas de definición de la sistematicidad para el cambio.

Luego entonces, el texto reordenado y consolidado que aquí -en el VII Congreso y en mi ponencia- sometemos a análisis, nos ofrece a mi juicio una alternativa de mayor seguridad para mantener lo alcanzado - en la materia electoral, sin duda, pero también en las demás por cuanto al respeto, promoción, protección y garantía de los derechos humanos- y avanzar en una complejidad ya conocida-de inevitables reformas constitucionales futuras e

23 Pues la materialización de las dos hipótesis que sustenta podrían entrar en contradicción. 
Esta obra forma parte del acervo de la Biblioteca Jurídica Virtual del Instituto de Investigaciones Jurídicas de la UNAM

interpretación e integración jurisprudencial incluso de un texto constitucional no modificado-, antes de entrar a las complejidades políticas de negociar y redactar un texto totalmente nuevo al interior de un Constituyente convocado e integrado con una nueva distribución de fuerzas políticas.

Además, el texto reordenado y consolidado que nos ofrece El Estudio facilitaría en su momento, cuando las condiciones políticas del país lo permitan, la negociación y redacción de una nueva Constitución. Es por todo ello que reitero mi deseo y mi propuesta para que el Constituyente Permanente de la República adopte El Estudio y éste sea promulgado el 5 de febrero de 2017 como Ley Fundamental de la República.

\section{BibliografíA}

Ávila Ortiz, Raúl, Castellanos Hernández, Eduardo de Jesús y Hernández María del Pilar, Porfirio Díaz y el Derecho. Balance crítico, Cámara de Diputados. Instituto de Investigaciones Jurídicas de la UNAM, México, 2015.

ASTUDILLO, César, El bloque y el parámetro de constitucionalidad en México, UNAM.

Tirant lo Blanch, México, 2014.

Bustillo Marín, Roselia y Monika Gilas, Karolina, Lineas jurisprudenciales en materia electoral, Tribunal Electoral del Poder Judicial de la Federación. Tirant Lo Blanch, Monografías, México, 2014.

Castellanos Hernández, Eduardo de Jesús, Nuevo Derecho Electoral Mexicano, IIJ. UNAM. Trillas, México, 2014.

- El impacto de la reforma constitucional en materia de derechos humanos de 2011 en la enseñanza del Derecho, publicado en: Wendy A. Godínez Méndez y José Heriberto García Peña (Coordinadores) Metodologías: Enseñanza e Investigación Jurídicas. 40 años de Vida Académica. Homenaje al Dr. Jorge Witker, (UNAM. IIJ. Posgrado Derecho. Tecnológico de Monterrey, 2015).

(Coordinador), Reformas constitucionales 2006-2012, Secretaría de Gobernación, México, Tercera edición octubre de 2012.

Compendio Tematizado de Jurisprudencia y Tesis. Procesos Electorales Federales y Locales 2014-2015, Tribunal Electoral del Poder Judicial de la Federación, México, 2015.

Constitución Politica de los Estados Unidos Mexicanos. Texto reordenado y consolidado. Estudio académico, LXII Legislatura. Cámara de Diputados. UNAM. Instituto de Investigaciones Jurídicas, México, Julio de 2015.

Cossío Díaz, José Ramón y Lara Chagoyán, Roberto, “'Derechos humanos o jurisprudencia infalible?", publicado en Cuestiones Constitucionales, Revista Mexicana de Derecho Constitucional, número 32, enero-junio 2015. 
Esta obra forma parte del acervo de la Biblioteca Jurídica Virtual del Instituto de Investigaciones Jurídicas de la UNAM

De la Mata Pizaña Felipe, Manual del Sistema de Protección de los Derechos PolíticoElectorales en México, Editorial Porrúa. Universidad Panamericana, México 2012.

FERRER Mac-Gregor, Eduardo, Martínez Ramírez, Fabiola y Figueroa Mejía, Giovanni A. (Coordinadores), Diccionario de Derecho Procesal Constitucional y Convencional, Tomos I y II, Poder Judicial de la Federación. Consejo de la Judicatura Federal. Universidad Nacional Autónoma de México. Instituto de Investigaciones Jurídicas, México 2014.

FERRER Mac-Gregor, Eduardo y Sánchez Gil, Rubén, El nuevo juicio de amparo. Guía de la reforma constitucional y la nueva Ley de Amparo, UNAM. Porrúa. Instituto Mexicano de Derecho Procesal Constitucional, México 2013.

Galván Rivera, Flavio, Derecho procesal electoral mexicano, Editorial Porrúa, México 2002.

GARCía Morales, Gumersindo, Control de convencionalidad de los derechos humanos en los tribunales mexicanos, Serie Cuadernos de Divulgación de la Justicia Electoral, Número 31, Tribunal Electoral del Poder Judicial de la Federación, México 2015.

LóPEz Olvera Miguel Alejandro y Pahuamba Rosas Baltazar, Nuevos paradigmas constitucionales. Dignidad humana, principios fundamentales, derechos humanos, Estado de derecho, democracia y control de convencionalidad, Espress, México, 2014.

Nieto Castillo, Santiago, Control de convencionalidad y la reforma constitucional en materia de derechos humanos, Serie Cuadernos de Divulgación de la Justicia Electoral, Número 30, Tribunal Electoral del Poder Judicial de la Federación, México 2014.

Orozco Henríquez, J. Jesús, Control de la convencionalidad en materia electoral, Serie Guadernos de Divulgación de la Justicia Electoral, Número 29, Tribunal Electoral del Poder Judicial de la Federación, México 2014.

Fusticia electoral y garantismo jurídico, Editorial Porrúa, México 2006.

SÁnchez Gil, Rubén, Escritos procesales constitucionales, Porrúa. Instituto Mexicano de Derecho Procesal Constitucional, México 2012.

SERIE Comentarios a las Sentencias del Tribunal Electoral, Número 9, Interpretación conforme a la Constitución. Antinomias y lagunas: caso Hank Rhon, Alfonso J. García Figueroa. Nota introductoria Eduardo Hernández Sánchez y Sergio Arturo Guerrero Olvera, México 2008.

Número 23, Reflexiones Iusfilosóficas de una decisión judicial. Suplencia de la queja total en los juicios electorales, Rodolfo Luis Vigo. Nota introductoria José Eduardo Vargas Aguilar, TEPJF, México 2009. 
Esta obra forma parte del acervo de la Biblioteca Jurídica Virtual del Instituto de Investigaciones Jurídicas de la UNAM

\title{
LA REFORMA GONSTITUGIONAL EN MÉXICO: DISFUNGIONALIDAD DEL MODELO DEMOGRÁTICO CONSTITUGIONAL*
}

\author{
Hugo Alejandro CONCHA CANTú**
}

\begin{abstract}
SUMARIO: I. Introducción. II. Funciones del proceso de reforma constitucional. III. Las disfuncionalidades del proceso de reforma constitucional en México. IV. La realidad del Estado constitucional mexicano: una constitución al servicio de la política. V. Conclusiones.
\end{abstract}

\section{INTRODUCCIÓN}

Para la teoría constitucional contemporánea, la reforma constitucional es un delicado proceso que busca cumplir con dos objetivos principales de manera simultánea, los cuales en principio son antagónicos: dotar de flexibilidad a la norma superior del ordenamiento jurídico para poder adaptar su contenido a la cambiante realidad pero al mismo tiempo, otorgar protección a la norma para sustentar y potenciar su naturaleza diferente y suprema. Es decir, se busca cumplir con dos objetivos opuestos que se encuentran en una tensión permanente, pues mientras que uno busca encontrar la manera de cambiar la norma, tiene como objetivo el cambio, el otro, objetivo

* Este trabajo surgió de las reflexiones vertidas en el Seminario sobre Cambio y eficacia constitucional: el caso del hiper-reformismo mexicano organizado en el Instituto de Investigaciones Jurídicas de la UNAM por la Dra. Andrea Pozas Loyo el 20 de noviembre de 2015 y se presentó en el VII Congreso Nacional de Derecho Constitucional, que se celebró del 3 al 5 de febrero de 2016 en la Facultad de Derechos de la Universidad Autónoma de San Luis Potosí. Una versión más elaborada fue realizada para la obra Derechos del Pueblo Mexicano. México a través de sus Constituciones, Tomo sobre convencionalidad, 9na edición, en prensa.

** Investigador del Instituto de Investigaciones Jurídicas de la UNAM y profesor de Derecho Constitucional del Instituto Tecnológico Autónomo de México. 
Esta obra forma parte del acervo de la Biblioteca Jurídica Virtual del Instituto de Investigaciones Jurídicas de la UNAM

de la estabilidad, busca protegerla contra cambios constantes que le diluyan su carácter extraordinario ${ }^{1}$.

El procedimiento para poder cambiar, agregar, o sustituir disposiciones constitucionales acaba materializando la doble naturaleza, política y jurídica, del ordenamiento constitucional así como toda su problemática. En ese mismo sentido, el constitucionalista alemán Peter Häberle señala con precisión que las modificaciones constitucionales pueden servir para adaptar la norma a procesos que ya se han transformado en la realidad social, pero que también pueden pretender inducir tales cambios, "...Deben distinguirse pues la modificación de adaptación y la modificación de creación". ${ }^{2}$

Como quiera que sea el caso, una reforma constitucional debe de elaborarse en un contexto de oportunidad en donde los cambios realizados, sean para alcanzar la dinámica social, o bien para detonar un camino de transformaciones, logren alcanzar sus objetivos, pues es claro que una reforma constitucional que no lo logra acaba por convertirse en un proceso de desgaste y deslegitimación de la propia norma suprema. Ese problema, caracterizado por la existencia de una constitución sin eficacia, acaba por detonar toda una crisis del modelo normativo y de convivencia social.

El acelerado y amplio espectro del proceso de reforma constitucional mexicano de los últimos años, requiere de un serio y detallado análisis para poder entender el alcance de estos cambios en un doble sentido, por la importancia que tiene la temática material de los cambios en específico, como también el alcance que tienen en cuanto a principios mas generales del Estado constitucional en su conjunto, como son la eficacia o grado de observancia de la normativa constitucional, la estabilidad política o bien, la democratización del Estado, a partir de su grado de legitimidad y niveles de interacción democrática entre instituciones estatales y sociedad.

Es por estas razones que se requiere de un análisis que permite contestar preguntas de extraordinaria importancia relacionadas con la práctica constitucional, como por ejemplo si el carácter acelerado, la velocidad de un proceso de reforma constitucional tiene algún significado sobre la rigidez del proceso de reforma y por tanto si afectan su carácter supremo; si un amplio

1 Se trata de la tensión existente en el Estado constitucional señalada por el profesor español Pedro de Vega entre el principio democrático y el principio de supremacía en su paradigmático libro La reforma constitucional y la problemática del poder constituyente, Madrid, Madrid: Editorial Tecnos S.A., 1985.p. 60.

2 Ver Häberle, Peter, El Estado constitucional. Traducido por Héctor Fix Fierro. México, D.F.: UNAM, Instituto de Investigaciones Jurídicas, 2001, p. 140, donde alude que desde la perspectiva de la duración y la estabilidad de una comunidad se puede requerir o no la modificación constitucional, dependiendo de cada caso particular. 
Esta obra forma parte del acervo de la Biblioteca Jurídica Virtual del Instituto de Investigaciones Jurídicas de la UNAM

espectro (número) de reformas constitucionales trastorna la estabilidad jurídica y política de un Estado, consecuencias del hiper-reformismo; si el contenido específico de algunas reformas (de mayor o menor profundidad en el funcionamiento de las instituciones, creando o modificando) afecta de distinta manera el funcionamiento constitucional en su conjunto o; de que manera un uso reiterado de la reforma constitucional está relacionado con la función de interpretación constitucional por parte del tribunal constitucional, ya sea porque está interpretación es errática e insuficiente, o bien como una fórmula en manos de los actores políticos para evitar que sea este el camino que establece en última instancia la orientación de las políticas públicas del Estado y no el órgano jurisdiccional, y; finalmente un asunto muy estudiado por la doctrina, si el control jurisdiccional en manos del tribunal constitucional puede incluir la revisión de los procesos de reforma constitucional (tanto en su forma como en su contenido ${ }^{3}$. En resumidas cuentas, si las constantes y aceleradas reformas constitucionales contribuyen a fortalecer el funcionamiento de la Constitución en su doble dimensión de fuente originaria y principal de todo el ordenamiento jurídico y como el conjunto de acuerdos e instituciones políticas. Si las funciones de la Constitución, legales y políticas, se ven afectadas por un proceso de reformas acelerado e intenso ${ }^{4}$.

La constitución mexicana, a pesar de su extensión y tamaño, contiene tan solo una disposición relativa al procedimiento de reforma constitucional, sin que incluya ninguna mención a la naturaleza del órgano reformador (vis a vis el poder constituyente originario o la Suprema Corte de Justicia en su papel de tribunal constitucional) o algún tipo de límite, lo que ha generado que en un régimen presidencialista donde además ha predominado un partido político, por muchos años se ha abusado del procedimiento como una forma de imponer y proteger las políticas públicas que el Ejecutivo busca promover.

\section{FUNCIONES DEL PROCESO DE REFORMA CONSTITUCIONAL}

Pedro de Vega nos presenta un marco muy puntual para analizar un proceso de reforma constitucional, el cual utilizaremos para el caso mexicano contemporáneo.De acuerdo con el constitucionalista español la reforma

3 Ver diversos trabajos en concreto sobre este problema en México en Astudillo y Córdova, (coord). Reforma y control de la Constitución: Implicaciones y límites. México, D.F.: UNAMInstituto de Investigaciones Jurídicas, 2011

4 Ver la ponencia de Francisca Pou Giménez, Hyper-reformism and constitutionalinefficacies in Mexico, presentado en el VII Congreso Nacional de Derecho Constitucional citado en nota preliminar de este ensayo, que justamente aborda esta interesante perspectiva. 
Esta obra forma parte del acervo de la Biblioteca Jurídica Virtual del Instituto de Investigaciones Jurídicas de la UNAM

constitucional cumple con tres funciones en la organización democrática contemporánea ${ }^{5}$ :

A. Debe ser un instrumento de adecuación entre la realidad jurídica y la realidad política ( o social)

B. Debe ser un mecanismo de articulación de la continuidad jurídica del Estado.

C. Debe de constituirse como una institución de garantía frente al resto de los poderes constituidos.

Conforme se analicen estas funciones y sus particulares complejidades en el caso mexicano, estaremos revisando las cuestiones que la doctrina identifica como los ámbitos problemáticos en torno al proceso de reforma de una Constitución.

\section{A. Adecuación jurídica (con la realidad)}

La Constitución busca constituirse como la realidad política en un Estado. A través de su declaración de derechos fundamentales esbozará el alcance de las relaciones entre los habitantes de una comunidad y específicamente de la relación de estos con las instituciones estatales, en forma de prerrogativas (derechos y libertades) con límites(prohibiciones) y con garantías que aseguren su cumplimiento. A través de su parte orgánica, la Constitución establece un modelo de régimen político con la integración de tres poderes públicos. Hasta ahí un primer modelo de Constitución, considerado como clásico o liberal, que ha sido rebasado por la realidad desde hace muchos años.

Modelos posteriores con alto contenido social y de reconocimiento al juego democrático con fuerzas plurales y distintas entre sí, evolucionaron a efecto de que las constituciones contemporáneas (en su gran mayoría) además establezcan otro tipo de disposiciones tales como las relativas a protecciones específicas de grupos, sistemas electorales para llevar a cabo la interacción y competencia democrática, órganos técnicos que requieren de autonomía política para cumplir con una amplia gama de funciones al margen de intereses sociales o políticos, así como también sistemas para luchar contra la corrupción y la integridad de los servidores públicos. De esta manera, diversas constituciones como las latinoamericanas y en particular la

5 De Vega, op. cit., p. 67 y siguientes. 
Esta obra forma parte del acervo de la Biblioteca Jurídica Virtual del Instituto de Investigaciones Jurídicas de la UNAM

mexicana, son constituciones a detalle, que establecen amplias declaraciones de derechos y múltiples instituciones y órganos para llevar a cabo las políticas públicas del Estado y cumplir con muy diversos objetivos.

Ahora bien, la Constitución como un conjunto de principios y enunciados normativos apoyados por las fuerzas sociales, se erige como un modelo que pretende encuadrar y dirigir la realidad social. Se considerará eficaz aquél modelo que logré conformar la realidad que regula y por el contrario poco eficaz aquella constitución que se encuentre alejada de la realidad.

Sin embargo, aunque tal es la pretensión teórica de toda constitución y en general de toda norma jurídica (bajo presupuesto teórico del positivismo jurídico ${ }^{6}$ ), diversas teorías y enfoques han explicado que en realidad se trata de una relación bidireccional de influencias y adaptaciones mutuas entre el derecho y la realidad ${ }^{7}$, pues una norma jurídica no solo establece un modelo prescriptivo a la que la realidad social se adapta. Es la propia realidad la que obligará a la norma a adaptarse a la hora de su aplicación o bien posteriormente a que el propio legislador o intérprete reformule los elementos de la norma a efecto de que esta pueda efectivamente regular una conducta social ${ }^{8}$.

En otras palabras, la realidad en su acelerada dinámica, va generando nuevas necesidades, expectativas y demandas que obligarán a la norma a un proceso continuo de adaptación. Esta adaptación de todas las normas, incluyendo las constitucionales, se da por dos caminos, dependiendo de las características de cada régimen y de sus instituciones y formas de operar. En aquellos sistemas jurídicos donde la norma es general y la tarea de su aplicación corresponde fundamentalmente a los órganos encargados de interpretarla, mientras que en aquellos países de tradición codificada o derecho escrito, de naturaleza altamente casuística, la reforma legislativa a la norma jurídica será el método predominante para su adaptación. Los sistemas pueden convivir pero en cada tradición y sistema jurídico uno es el mecanismo predominante.

6 Ver el famoso ensayo de Bobbio, Norberto, El problema del positivismo jurídico.

7 En general este es uno de los planteamientos principales de la llamada escuela de sociología del derecho o sociología jurídica, con una historia ya larga y diferentes perspectivas, destacando la estadounidense a cargo de la Law and SocietyAssociation, http://wrere. lawandsociety.org, o la europea por el Research Committee on Sociology of Law perteneciente a la International Sociological Association, http://wwrw.isa-sociology.org/rc12.htm. Una buena introducción general de la disciplina y sus presupuestos teóricos la ofrece el profesor Vincenzo Ferrari, Primera lección de sociología del derecho. México, D.F.: UNAM-IIJ, 2015.

8 Es así como Ferrari afirma que "Entre las normas y las acciones inspiradas por aquellas existe una relación biunívoca, de condicionamiento recíproco, ya que las normas, al circular entre los actores sociales, influyen en su acción y esta, a su vez, retroalimenta continuamente al mundo normativo, modificándolo”, ibid., p. 41. 
Esta obra forma parte del acervo de la Biblioteca Jurídica Virtual del Instituto de Investigaciones Jurídicas de la UNAM

En el sistema mexicano, como en muchos más, la reforma es el mecanismo fundamental para que el propio ordenamiento se adapte y mantenga su vigencia. La Constitución, como norma fundamental corre la misma suerte, pues se reforma, a final de cuentas, para sobrevivir, aunque su reforma debiera ser excepcional, trascendente para que no altere su estabilidad y certidumbre respecto a los derechos que reconoce, las instituciones que crea, y en general los principios y valores que contiene.

Sin embargo en México las cosas no parecen desenvolverse de esa forma. Por muchos años, la constitución fue modificada conforme el Presidente en turno lo deseaba ${ }^{9}$. Al ser la figura que controlaba políticamente a todos los órganos políticos (por la naturaleza del sistema de partido hegemónico), el Ejecutivo Federal decidía que contenidos quería que tuvieran fuerza de norma constitucional para avalar su plan de gobierno o bien para apoyar alguna medida que consideraba importante darle toda la legitimidad, fuerza y publicidad. De esta forma, aún cuando la Constitución mexicana de 1917 establece un método extraordinario para llevar a cabo una reforma constitucional en su artículo $135^{10}$, en realidad esa excepcionalidad era tan solo de forma, pues para el Presidencialismo la reforma constitucional no era un método auténticamente rígido o difícil y la alternancia política en la Presidencia de la República no han cambiado este desafortunado abuso de la reforma constitucional. Tal y como lo señala un estudio sobre el desordenado texto constitucional mexicano, del total de las 642 reformas constitucionales que se han efectuado, 200 han sido hecha en los últimos 10 años (110 durante la administración del Presidente panista Felipe Calderón y ya más de 90 durante los cuatro años del Presidente del PRI, Enrique Peña Nieto, considerando hasta julio del 2015), lo que equivale al $31.2 \%$ del total, de 1921 a $2015^{11}$.

9 En el sugerente estudio elaborado por Diego Valadés y Héctor Fix Fierro, Constitución Politica de los Estados Unidos Mexicanos. Texto reordenado y consolidado, México, D.F.: UNAM-IIJ, CEDIR, Senado de la República, Cámara de Diputados, 2016, se ilustra que del año de la primera reforma, 1921, a julio de 2015, se habían realizado un total de 642 reformas constitucionales en 225 decretos.

10 "Artículo 135. La presente Constitución puede ser adicionada o reformada. Para que las adiciones o reformas lleguen a ser parte de la misma, se requiere que el Congreso de la Unión, por el voto de las dos terceras partes de los individuos presentes, acuerde las reformas o adiciones, y que éstas sean aprobadas por la mayoría de las legislaturas de los Estados. El Congreso de la Unión o la Comisión Permanente en su caso, harán el cómputo de los votos de las Legislaturas y la declaración de haber sido aprobadas las adiciones o reformas."

11 Ver Valadés y Fierro, op.cit. La suma de reformas durante la administración en curso del Presidente Peña ya se ha incrementado de la fecha del estudio a agosto de 2016. 
Esta obra forma parte del acervo de la Biblioteca Jurídica Virtual del Instituto de Investigaciones Jurídicas de la UNAM

Un somero análisis de las varias y aceleradas últimas reformas (más de 90 en cuatro años) cuestiona esta función constitucional, sobre que tanto se está adecuando la norma a la realidad, o es la norma, como instrumento político la que persiste en su lucha por querer transformar a la realidad y de ser así, el grado de éxito que ha tenido. Lo que es cierto, es que la naturaleza rígida de la Constitución en México ha quedado tan solo como forma, pues los acuerdos políticos entres los principales partidos políticos han permitido que lo extraordinario del proceso de reforma sea tan solo un trámite. Sin la rigidez, la norma constitucional pierde su valor único y diferenciado, y consecuentemente, eficacia.

\section{B. Continuidad jurídica.}

La reforma constitucional tiene también como función ser un mecanismo que articule la continuidad jurídica del Estado y de esta manera cumplir con uno de los objetivos mas importantes de todo Estado de Derecho, la seguridad o certidumbre jurídica. Esto significa que una comunidad jurídicamente organizada cambiará, se adaptará a las exigencias y necesidades sociales, pero de manera limitada, conservando su estructura y su funcionamiento básico, generando estabilidad en la propia vida comunitaria o social. Es de esta manera que la reforma constitucional es de naturaleza excepcional para lograr cambios que resultan importantes en el funcionamiento de los órganos de poder y estructura institucional, así como cambios en la manera en que se ejercen y protegen los derechos, pero sin alterar de manera fundamental ni quebrantar el orden jurídico en su integralidad.

El primer cuestionamiento que surge entonces de esta segunda función, es hasta donde la frecuencia y extensión de las reformas constitucionales perjudica la estabilidad y continuidad del orden jurídico o en realidad se está transformando de raíz éste, y de ser así, de qué manera el poder reformador o revisor de la constitución está cumpliendo con su papel o está apropiándose de un papel que no le corresponde al cambiar la constitucionalidad. Es justamente ese el punto que aborda Pedro Vega cuando explica que la reforma constitucional es una función contenida en la propia constitución y por tanto a cargo de un poder constituido, llamado revisor o reformador que obtiene su legitimidad en el propio ordenamiento ya que su función de reformar es una operación esencialmente jurídica. ${ }^{12}$

12 De Vega, op.cit., p. 68. 
Esta obra forma parte del acervo de la Biblioteca Jurídica Virtual del Instituto de Investigaciones Jurídicas de la UNAM

La discusión respecto a la naturaleza del órgano que reforma la constitución sigue siendo un debate abierto y de importancia pues dependiendo del enfoque se entiende el alcance de la función reformadora (total o parcial). Por una parte existe una perspectiva que establece al orden constitucional como un orden jerárquicamente superior o supra-ordenado con funciones muy específicas. De ahí que su nombre es poder constituyente permanente, pues no tiene límite material o temporal para llevar a cabo las modificaciones o adiciones que considere pertinentes. Su naturaleza es la misma que tiene el Tribunal Constitucional para proteger a las normas constitucionales a través de distintos recursos o medios jurisdiccionales, diferenciándose de los órganos constituidos de los órdenes subordinados y secundarios como son el orden federal o el orden local.

La estabilidad del orden jurídico, en un modelo idealmente funcional, debería de recaer en un ejercicio prudente e inteligente de reformas constitucionales ocasionales pero oportunas, que den paso a una serie de interpretaciones por parte del tribunal constitucional, afinando el alcance de las nuevas disposiciones pero creando entre ambas operaciones un ordenamiento jurídico estable y al mismo tiempo adaptable. El problema que la realidad mexicana nuevamente nos presenta es que tanta estabilidad se puede lograr por parte de una doctrina de interpretación constitucional cuando el referente cambia de manera abrupta, rápida y poco razonada. En estas circunstancias es prácticamente imposible poder contar con una doctrina constitucional, aunque esta no sea el único impedimento para que exista.

Un segunda perspectiva es aquella que distingue la función reformadora de la función creadora de la constitución. La función reformadora fue diseñada y prevista por el órgano constituyente, y encargado a un órgano especial sí, pero finalmente constituido al igual que los otros poderes. Para este razonamiento, "el poder de revisión, que tiene competencia para efectuar la reforma, para lo que, en ningún caso, poder tenerla es para hacer la revolución. Esto quiere decir, como demostraremos mas adelante, que la reforma está por necesidad sometida a límites; incluso cuando, disparatada y absurdamente, en la propia normativa legal, se reconoce, como sucede en nuestro ordenamiento, la posibilidad de reformas totales". ${ }^{13}$

Es ahí entonces, donde esta segunda perspectiva abre una pregunta fundamental, respecto a cuáles son o deberían ser los límites de la reforma constitucional en nuestro país y de haberlos, si estos límites han sido transgredidos por la gran cantidad y profundidad de reformas llevadas a cabo en los últimos años.

13 De Vega, Ibid. 
Esta obra forma parte del acervo de la Biblioteca Jurídica Virtual del Instituto de Investigaciones Jurídicas de la UNAM

\section{Garantía constitucional: Garantía jurídica y política.}

Además de ser el mecanismo previsto por la propia constitución para lograr cambiar y adecuarse a la realidad y dar continuidad jurídica, la reforma constitucional se erige también como el mecanismo a través del cual se logra materializar la supremacía de la norma. Gracias a que el procedimiento de reforma constitucional es extraordinario, por ser un procedimiento especial que se lleva a cabo por un órgano integrado de manera diferenciada, la Constitución se protege de ser modificada por simples modas o caprichos de los actores políticos, pues el consenso que se requiere para llevar a cabo este procedimiento reúne a mayorías calificadas tanto del orden federal como de las legislaturas locales. Este procedimiento agravado debería, en teoría, coadyuvar a la rigidez y por tanto a la estabilidad de la norma constitucional sin cerrar de manera absoluta su posibilidad de cambio. Es este procedimiento una garantía jurídica de la norma, pues una diferencia de procedimiento significa una diferencia de sustancia ya que así la norma constitucional adquiere una estabilidad mucho más clara y contundente que cualquier otra norma, dotándola así de esta característica de rigidez que la convierte en una norma superior en su forma de modificación. Serán los contenidos específicos de las normas constitucionales los que además la dotarán de una supremacía material.

La cualidad diferente y suprema de las normas constitucionales son así cuidadas en una doble vertiente jurídica. La primera, ya señalada, a través de su particular y agravado proceso de modificación. La segunda está relacionada con la existencia del sistema de control constitucional a través del Tribunal Constitucional, pues será esté el órgano que tendrá a su cargo la revisión de los contenidos de todas las normas del ordenamiento en el sentido de que no contravengan a los establecido por las normas constitucionales, pues de lo contrario las podrá declarar invalidas.

Pero un problema interesante y delicado se presenta al preguntarnos si el Tribunal Constitucional está facultado para revisar una reforma constitucional. La respuesta es solucionada fácilmente cuando el constituyente previó incluir normas que regularán justamente esta situación. Sin embargo en un buen número de constituciones esto no se presenta, tal y como acontece en el caso mexicano. La discusión sobre la naturaleza del órgano revisor vuelve a presentarse, pues si se considera que se trata de un órgano constituido, el Tribunal Constitucional debiera estar en capacidad de examinar la eventual constitucionalidad de las normas introducidas o modificadas. Pero si por el contrario, se estima que el revisor es en realidad un poder ex- 
Esta obra forma parte del acervo de la Biblioteca Jurídica Virtual del Instituto de Investigaciones Jurídicas de la UNAM

traordinario como poder constituyente permanente, no queda claro que el Tribunal Constitucional pueda controlar su labor.

La interpretación de la Suprema Corte de Justicia no ha sido clara tampoco a este respecto. Se ha tratado de un criterio "incierto y oscilante". ${ }^{14} \mathrm{El}$ resumen de esta situación es resumida claramente por Astudillo y Córdova.

\section{LAS DISFUNCIONALIDADES DEL PROCESO \\ DE REFORMA GONSTITUGIONAL EN MÉXICO}

Una revisión de la forma en que ha funcionado el proceso de reforma constitucional en México, nos presenta el siguiente panorama:

Se ha utilizado la reforma constitucional de manera intensa, lo que en gran medida pone en duda su carácter extraordinario (diferenciado y supremo) ya que el elemento "agravado" que implica este procedimiento, es decir las mayorías calificadas de voluntades de representantes políticos tanto del Congreso federal como de las legislaturas locales, ha sido superado por otros medios extra legales basados en negociaciones, acuerdos e intercambios políticos. Esto trastoca directamente las tres funciones del procedimiento constitucional:

La primera función de adecuación del texto normativo a la realidad se cumple sin duda alguna, pero para adecuar el texto a razones y justificaciones basadas en negociaciones e intercambios políticos y no necesariamente a necesidades sociales imperantes. La amplia gama de temas involucrados en las reformas llevadas a cabo en los últimos años carecieron de diagnósticos, debates nacionales que puntualizaran la importancia y las prioridades de las mismas. Por el contrario, fueron temas y prioridades impuestas por el Ejecutivo federal y secundado por los partidos políticos. Esto equivaldría a aseverar que la Constitución mexicana, a pesar de sus múltiples cambios y adiciones, no es una constitución que establezca una estructura ni un conjunto de derechos y garantías adecuados para las necesidades sociales del país.

Por lo que toca a la continuidad del ordenamiento jurídico, esta función se ha conseguido cumplir desde una perspectiva formal, ya que la validez y legalidad del procedimiento ha sido cuidada, pues las reformas han sido efectuadas siguiendo lo establecido en el procedimiento del artículo 135 constitucional con la aprobación de los poderes constituidos. Sin embargo, desde una perspectiva material de lo que significa el papel de la constitución como sistema de fuentes del todo el ordenamiento, si lo que la Constitución

14 Ver Astudillo, y Córdova, op.cit., p. IX. 
Esta obra forma parte del acervo de la Biblioteca Jurídica Virtual del Instituto de Investigaciones Jurídicas de la UNAM

busca es generar un conjunto de reglas que sirvan como mandatos para la acción, es decir que auténticamente establezcan las pautas de reconocimiento del resto de las normas jurídicas y particularmente pautas para la actuación (adjudicación) de los poderes judiciales, esta situación esta lejos de lograrse pues como asevera Francisca Pou, en México los diferentes actores gastan una cantidad irracional de tiempo y esfuerzo a la operación primaria de descubrir lo que la Constitución establece. De esa manera, para ella las líneas de continuidad que deben existir entre un programa constitucional y la substancia del resto del sistema legal simplemente no existe o lo que existe es confuso e ineficaz ${ }^{15}$.

Finalmente, por lo que se refiere a analizar el procedimiento de reforma como una garantía, tanto jurídica como política, de todo el sistema constitucional, esta función ha sido seriamente alterada pues al abusarse en su uso y condicionar la posibilidad de reformas al intercambio o negociación entre fuerzas políticas, la reforma constitucional deja de ser un mecanismo de protección de la norma y por el contrario convierte a la norma constitucional en moneda de cambio, en instrumento al servicio de los intereses partidistas los que claramente no representan los intereses de toda una comunidad, sino tan solo de algunos de tipo coyuntural y de los que les conviene de manera específica en su búsqueda por el poder político. La garantía para que sistema jurídico cumpla con sus diferentes funciones se pierde pues como muy bien afirma la Doctora Pou, el sistema jurídico pierde certeza, con lo que deja de dar pautas para la acción o cumplimiento espontáneo de los ciudadanos así como también deja de dar pautas o directrices para una construcción sistemática de interpretaciones judiciales que puedan generar una doctrina constitucional ${ }^{16}$. Si esto no fuera suficientemente delicado, el uso desmedido de la reforma constitucional también afecta su naturaleza de garantía del sistema político, por tres razones. En primer lugar, la discusión de temas claramente acotados, con consenso nacional se pierde y es substituido por una ilimitada gama de temas (todos los contenidos de las 11 reformas "estructurales" del la administración el Presidente Peña Nieto, sumadas a una gran cantidad de reformas de la administración anterior) en donde prácticamente todo tema de política pública se discute, sin prioridades, sistema, método o rigor. En segundo lugar, la Constitución difícilmen-

15 Pou Francisca, op.cit., nota 8 en sus conclusiones.

16 Me refiero al trabajo de Pou, Francisca, Ibid. así como a su intervención en el propio VII Congreso Nacional de Derecho Constitucional, nota preliminar. De la misma manera la falta de elementos para construir una doctrina constitucional es abordada por Cossío, José Ramón. La teoría constitucional de la Suprema Corte de Fusticia, Fontamara, México, 2002. 
Esta obra forma parte del acervo de la Biblioteca Jurídica Virtual del Instituto de Investigaciones Jurídicas de la UNAM

te es conocida y apropiada por la ciudadanía pues es un documento largo complejo y muy cambiante. Si la ciudadanía no cuenta con este instrumento de manera cotidiana y natural, no la puede utilizar para hacer demandas claras y exigir una rendición de cuentas del desempeño del gobierno y representantes razonada y apegada a la legalidad Y. finalmente, en tercer sitio, los jueces constitucionales, los ministros de la Suprema Corte en el caso mexicano, se sobre-empoderan, pues se espera de ellos la claridad que el texto constitucional no es capaz de brindar por sí mismo ${ }^{17}$.

\section{LA REALIDAD DEL ESTADO CONSTITUGIONAL MEXICANO: UNA CONSTITUCIÓN AL SERVICIO DE LA POLÍTICA}

Ahora bien, quedando establecido como la reforma constitucional genera disfuncionalidades que afectan al sistema jurídico y al sistema político, es también importante analizar lo que le sucede a la norma constitucional en su interior, como si se tratase de un ente independiente. En la medida que la teoría de la Constitución es una teoría que busca el modelo de "buena" Constitución, es importante, en palabras de Häberle, y necesario en mi opinión personal, analizar un conjunto de problemáticas a las que se enfrenta la reforma o modificación constitucional ${ }^{18}$ mexicana desde esta perspectiva.

El uso extensivo (frecuencia) e intenso (profundidad) de la reforma constitucional en México genera distorsiones a la estructura y problemas al funcionamiento propiamente de la Constitución, de diversas maneras. Para explicar esta afirmación, planteo dos ámbitos de distorsión o disfuncionalidad constitucional: El funcionamiento y eficacia del procedimiento agravado de modificación constitucional, las violaciones o distorsiones a la estructura del federalismo.

En primer lugar, la mayoría calificada que en teoría se busca a través de las representaciones políticas del poder revisor de la Constitución queda subordinado a una figura "meta constitucional"19.

Claramente las instituciones establecidas en la Constitución como son el poder revisor, la representación política y, consecuentemente, la rigidez constitucional, están siendo avasalladas por el enorme poder del Presiden-

17 Pou, Ibid.

18 Häberle, op.cit., p.141 y siguientes.

19 Utilizando el concepto generado por Jorge Carpizo en su célebre El presidencialismo mexicano, ya que se refería a mecanismos políticos extra legales, la jefatura informal del partido hegemónico y su voluntad única para nombrar a su sucesor, que acababan por ser decisivos para entender el poder del Presidente mexicano. 
Esta obra forma parte del acervo de la Biblioteca Jurídica Virtual del Instituto de Investigaciones Jurídicas de la UNAM

te de la República. Para ilustrar esto, tomemos como ejemplo varias de las reformas constitucionales aprobadas en el año de 2013, como fueron la llamada reforma educativa, la reforma energética o la reforma en telecomunicaciones, las cuales no formaban parte de la agenda de los partidos de izquierda, como claramente lo explicitaron en la prensa nacional ${ }^{20}$, pero el partido de izquierda, en ese entonces mayoritario en el Congreso, decidió apoyar (o en algún caso por lo menos no obstaculizar) así como también en las legislaturas locales, la aprobación de las mismas a cambio de poder obtener apoyos en otros temas.

De esta manera, la rigidez constitucional se convirtió simplemente en un trámite más largo que el habitual proceso de reforma legislativa, pero donde las bancadas de los partidos mayoritarios, PRI, PAN y PRD aprobaron en todo el país, pues eran temas ya negociados en el Pacto por México ${ }^{21}$.

En segundo lugar, muchas de las reformas que se aprobaron en 2013 y algunas medidas más, han afectado seriamente la organización del Estado federal. En pos de un pragmatismo político que provea dividendos inmediatos, el Ejecutivo federal acordó y negocio reformas que van en contra del modelo federal como la base organizativa establecida en el Estado mexicano desde su primera Constitución en 1824 y reafirmada en los procesos constitucionales de 1857 y de 1917 y fortalecido, si bien con múltiples distorsiones, a lo largo de nuestra vida constitucional contemporánea. La primera tendencia en contra del Estado federal, conformada por más de una decena de reformas al artículo 73, es el relativo a la creación de competencias específicas del Congreso de la Unión para que pueda crear las llamadas leyes generales. Estas leyes son en realidad leyes de alcance nacional que van mucho mas allá de lo que se supone que es la facultad originaria del Congreso de la Unión para crear leyes en el ámbito federal. Las leyes generales permiten que el Congreso federal establezca en el instrumento normativo las competencias de los tres niveles u órdenes de gobierno, lo que le corresponde a los órganos federales, lo que les corresponde a los estatales y lo

20 Algunos ejemplos: contra la reforma educativa http://wrere.animalpolitico.com/2013/09/ la-reforma-educativa-parte-en-dos-al-prd/, contra la reforma energética http://wrewanimalpolitico.com/2013/12/prd-anuncia-plan-contra-reforma-energetica/, https://wrerw.google.com. $m x /$ webhp? sourceid $=$ chrome-instant Eंion $=1$ Eespv $=2$ Eie $=U T F-8 \# q=P R D+y+$ reforma + energeti $c a+2013$; contra la reforma en telecomunicaciones http://aristeguinoticias.com/2203/lomasdestacado/prd-explica-su-voto-a-favor-de-la-reforma-en-telecomunicaciones/, por citar tan sólo algunas notas que revelan lo controversial del tema.

21 En ese sentido es necesario ver los compromisos gubernamentales derivados del Pacto por México que en muchos casos involucraban reformas constitucionales o legales, http:// wrere.redpolitica.mx/contenido/los-compromisos-del-pacto-por-mexico. 
Esta obra forma parte del acervo de la Biblioteca Jurídica Virtual del Instituto de Investigaciones Jurídicas de la UNAM

relativo a los municipales. A partir de estas leyes puede además crearse legislación federal, local y municipal, o bien quedarse como único instrumento para uno o varios órdenes de gobierno. Lo que estas leyes están haciendo es suplantar la facultad que solo tiene originalmente el poder constituyente o en su caso el poder reformador de distribuir competencias en el texto constitucional, para dárselo al órgano legislativo federal y que sea éste el que lo decida en múltiples materias. Al no estar contempladas en la Constitución original este tipo de instrumentos, en realidad se trata de un invento que queda plasmado en la Constitución y por tanto adquiere total validez, sin que exista precepto alguno que de alguna manera establezca algún tipo de límite o control para este tipo de leyes, como pudiera ser el exigir que este tipo de legislación fuera aprobada también por alguna mayoría calificada. Si se toma en cuenta que el Ejecutivo Federal cuenta con las mayorías necesarias para aprobar legislación ordinaria, esta leyes, que distribuyen competencias entre todos los órdenes de gobierno son aprobadas como cualquier ley del ámbito federal ${ }^{22}$.

De la misma manera, la tendencia de nacionalizar leyes y ámbitos competenciales también surgió con la reforma constitucional al artículo 73 en su fracción XXI que posibilitó al Congreso de la Unión a expedir un Código Nacional de Procedimientos Penales a propósito de la reforma constitucional aprobada en junio de 2008 que estableció la transformación del sistema penal existente en uno de corte adversarial y acusatorio. Bajo el argumento defendido por especialistas de la necesidad de iniciar un proceso de unificación legislativa, y con ello establecer un mismo tipo de juicios penal para todo el país, se abrió el camino para que diversas materias legislativas abandonen el camino de competencias dual y busquen la uniformidad. El debate en realidad se debería de volver a presentar sobre la conveniencia o no del sistema federal de organización. A pesar de los argumentos que se puedan encontrar en casos específicos de falas en los ordenamientos estatales, creo que el país se ha beneficiado de poder explotar su diversidad y posibilidad de innovación legislativa.

Una buena cantidad de las últimas reformas constitucionales ha acarreado la creación (o transformación en algunos casos) de órganos constitucionales autónomos. Este fenómeno haya su explicación original, nuevamente en las demandas y negociaciones con los partidos políticos que posibilitaron las reformas, pues en muchos casos los partidos de oposición

22 Ver a Serna de la Garza, José María, El sistema federal mexicano. Un análisis jurídico, México, D.F.: UNAM- Insituto de Investigaciones Jurídicas, 2008, quien también hace reflexiones en este sentido. 
Esta obra forma parte del acervo de la Biblioteca Jurídica Virtual del Instituto de Investigaciones Jurídicas de la UNAM

ponían como condición al gobierno y su partido, que los órganos encargados de implementar las reformas fueran autónomos de cualquier influencia del gobierno priista o mas aún, si los órganos en cuestión contaban con órganos de dirección colegiados los partidos pedía este modelo para entonces proceder a negociar la integración de estos cuerpos por cuotas. El problema radica en que la enorme lista de órganos autónomos el único elemento en común es justamente su autonomía constitucional. Cada órgano cuenta con una naturaleza y funciones distinta, algunos son reguladores, otros son operativos, otros mas tiene facultades sancionatorias; cada uno cuenta con órganos de dirección y formas de nombramiento o integración distintos, y finalmente; lo que resulta preocupante, es que al salir del ámbito de poderes constituidos en los órdenes de gobierno constitucionales, muchos no tienen mecanismos de control, fiscalización o supervisión o los que tienen son internos dejándolos en una situación de debilidad para evaluar su desempeño.

\section{CONCLUSiones}

El panorama que nos arroja el análisis del proceso de reforma constitucional en México presenta conclusiones contundentes. Al analizar las motivaciones que se encuentran en el origen de las últimas reformas, constatamos la existencia de un presidencialismo reforzado que utiliza un discurso progresista y democrático, pero que en realidad establece procedimientos de enorme centralización (nacionalización) y control político, por arriba de los mecanismos constitucionales y los intereses de las mayorías, subordinando estos a las fuerzas políticas y sus intereses coyunturales a través de negociaciones e intercambios.

La reforma constitucional no detona espacios de deliberación y votación de mayorías calificadas de representantes políticos, pues el sistema político-electoral y de partidos opera con mayor contundencia sobre los representantes parlamentarios a través de la organización y disciplina partidista. Por tanto, no existen auténticos espacios de deliberación y argumentación parlamentaria sobre las razones, conveniencias, ventajas y desventajas de las modificaciones constitucionales. Todo es pactado fuera del debate público entre el ejecutivo federal y las cabezas de los principales partidos.

El resultado del exagerado uso de la reforma constitucional, o del hiperreformismo es una constitución laxa, desordenada, que no cumple con sus funciones normativas, que no provee de un marco de pautas que sean fácil y espontáneamente observadas por la ciudadanía, como tampoco pautas competenciales claras para las instituciones. En particular, los jueces, como 
Esta obra forma parte del acervo de la Biblioteca Jurídica Virtual del Instituto de Investigaciones Jurídicas de la UNAM

encargados de hacer una lectura ordenada y sistemática de la constitución, no pueden hacerlo al no haber estabilidad en la norma constitucional. De la misma manera, la Constitución no da claridad sobre sus contenidos para poder generar una cultura participativa y demandante que exija el cumplimiento de las normas y una rendición de cuentas a partir de estas. Estas carencias dejan el campo abierto a los espacios de impunidad, corrupción y crisis institucional.

Ante esta realidad, es necesario reinventar nuestro constitucionalismo, como la forma de reinventar nuestra estructura y vida social. Para ello, podemos plantear algunas ideas, con el objetivo de iniciar un debate al respecto. La primera tiene que ver con limitar la válvula de cambio constitucional, a partir del fortalecimiento de nuestro tribunal constitucional para que en el corto plazo vigile y sobretodo limite la función de reforma o modificación constitucional en tres supuestos:

a)Cuando la reforma no cumpla con la integración de voluntades auténticamente representativas (rigidez constitucional)

b)Cuando las reformas rompan la estructura constitucional fundamental y sus principios de república, representativa, laica, federal y democrática;

c) Cuando la reforma vulnere derechos fundamentales.

Asimismo, en un mediano y largo plazo, deberíamos intentar ya no limitar, sino cerrar la válvula del cambio a través de la modificación del proceso de reforma, agregando límites y medios de control democrático (como el plebiscito), para devolverle su carácter rígido y por ende el valor de norma suprema.

En ese sentido también sería importante dejar fuera al Ejecutivo federal de la posibilidad de iniciar o de influir en modo alguno en el proceso de reforma constitucional. Por último, sería muy importante cambiar el tipo de contenidos que yacen en el texto constitucional a partir de una reordenación de los contenidos, o bien a través de una nueva constitucionalidad. 
Esta obra forma parte del acervo de la Biblioteca Jurídica Virtual del Instituto de Investigaciones Jurídicas de la UNAM

\title{
LA DESNATURALIZACIÓN DE LOS ARTÍCULOS TRANSITORIOS EN LA REFORMA CONSTITUGIONAL POLÍTICO-ELEGTORAL DE 2014
}

\author{
Oswaldo CHACÓn Rojas*
}

\begin{abstract}
SUMARIO: I. Introducción. II. Naturaleza y relevancia de los Artículos transitorios en la Constitución. III. El posible abuso de artículos transitorios. IV. El uso de artículos transitorios en la reforma político electoral de 2014. V. Efectos del abuso de los artículos transitorios. VI. Conclusiones.
\end{abstract}

\section{INTRODUCGIÓN}

En este texto se aborda el uso y abuso que el Poder Constituyente ha hecho de los artículos transitorios en últimas reformas constitucionales. Se trata de uno de los temas de mayor actualidad y relevancia en el Derecho Constitucional mexicano, en virtud de que aspectos fundamentales de recientes reformas (llamadas estructurales), como la energética o la de telecomunicaciones, han sido erróneamente establecidos en artículos de esta naturaleza. La falta de una adecuada técnica legislativa bien pudo obedecer a cierto desconocimiento de la misma por parte de la Legislatura que procesó el Pacto por México que motivó las reformas. Tampoco podemos descartar que los errores obedezcan mas bien a razones políticas derivadas del interés por parte de los partidos mayoritarios que las aprobaron, de asegurar que las reglas acordadas no sean fácilmente acotadas o reorientadas en el desarrollo de las regulaciones respectivas por una mayoría simple donde ellos no sean tomados en cuenta (recordemos que el Congreso se integra por una mayoría simple del partido en el gobierno con aliados como el PVEM o Nueva

* Profesor-Investigador de la Facultad de Derecho de la Universidad Autónoma de Chiapas. 
Esta obra forma parte del acervo de la Biblioteca Jurídica Virtual del Instituto de Investigaciones Jurídicas de la UNAM

Alianza que es suficiente para aprobar las leyes que se derivan de las reformas constitucionales, sin necesidad de los votos de los principales partidos opositores que participaron en su aprobación, como PRD o PAN). Pero independientemente de las razones, la utilización de dichos artículos para detallar en exceso lo dispuesto en el texto constitucional y desarrollar aspectos fundamentales de las reformas nos obliga a responder distintos cuestionamientos: ¿Esto es constitucional? ¿Pueden dichos artículos contener aspectos sustantivos e incluso regulatorios del texto constitucional o deberían reducir su función a aspectos accesorios de temporalidad o de vigencia de las normas? ¿Pueden estos artículos ser inconstitucionales y, por lo tanto, ser recurribles ante la Suprema Corte de Justicia de la Nación? Estos y otros cuestionamientos nos plantea la relevancia que han adquirido este tipo de artículos en las llamadas reformas estructurales y sobre las cuales buscamos abonar al debate y a la reflexión. En especifico, ahondaremos el caso de la reforma político electoral publicada el 10 de febrero de 2014, en la que presumiblemente se utilizaron artículos transitorios para detallar en exceso lo dispuesto en el texto constitucional, regular diversos aspectos suplantando las tareas del legislador e, incuso, contradecir lo desarrollado en el propio artículo 41 constitucional materia de la reforma.

\section{NATURALEZA Y RELEVANGIA DE LOS ARTÍCULOS TRANSITORIOS EN LA CONSTITUCIÓN}

Mucho se ha hablado los últimos años respecto a la función o lo que debería ser la función de los artículos transitorios constitucionales, sobre todo a raíz del rol protagónico que han jugado en reformas recientes como la energética, en telecomunicaciones o la político electoral. Aspectos trascendentales de dichas reformas han sido desarrolladas en sus artículos transitorios, lo que ha llevado a preguntarnos sobre la constitucionalidad de esos actos, o sobre las consecuencias jurídicas de los mismos.

La discusión sobre los artículos transitorios de la Constitución no es reciente. Desde hace tiempo algunos autores han venido hablando de un Derecho transitorio, como Elisur Arteaga, para quien éste se trata de «conjunto de normas que regulan los conflictos intertemporales derivados de la eficacia derogatoria de las propias leyes» ${ }^{1}$. Dentro de este segmento, destaca el derecho constitucional transitorio pues en muchas ocasiones implica el

1 Arteaga Nava, Elisur, Derecho Constitucionaly Reformas Constitucionales http:/ /www.ordenjuridico.gob.mx/Constitucion/reformas.php 
Esta obra forma parte del acervo de la Biblioteca Jurídica Virtual del Instituto de Investigaciones Jurídicas de la UNAM

paso de una situación cualquiera a un nuevo régimen, por lo que su contenido resulta fundamental para mantener el orden.

En las reflexiones en torno a este articulado es importante considerar que si hablamos en particular de artículos transitorios en la Constitución y no de los artículos de la misma en general, es porque a pesar de que las normas jurídicas poseen una estructura lógica común, es posible elaborar diferentes clasificaciones, dependiendo de su función en el derecho, por lo que se puede decir que existen distintos tipos de normas. Así, por ejemplo, para Hart es propio del derecho no solamente prescribir conductas (normas primarias), sino también regularse a sí mismo, por lo que contiene normas secundarias que se refieren al proceso de creación y aplicación de las normas primarias². Dentro de esta segunda clase de normas, Hart define a la regla de reconocimiento, que permite determinar las normas que pertenecen al sistema, la regla de cambio, fundamental en virtud de la dinámica del derecho y la regla de adjudicación que establece los órganos y procedimientos de aplicación. Esta distinción permite separar los tipos de reglas, según su función en el sistema, lo cual, sin embargo, no implica que su estructura lógica sea distinta.

A partir de esta clasificación, parecería correcto sostener que en virtud de su naturaleza los artículos transitorios son normas que se refieren a otras normas, se podría decir que corresponden al tercer tipo de normas secundarias relativas a la adjudicación, ya que a pesar de que producen un cambio en el orden jurídico, son disposiciones jurídicas cuyo objeto es determinar el modo de aplicación de otras normas. Sin embargo, considerando la estructura de las normas, el sujeto normativo no son las normas mismas, aun cuando se determine su vigencia, sino las autoridades que las han de aplicar. Las normas son el objeto respecto del cual se realiza la acción, son un elemento del supuesto, pero no el sujeto a quien se dirige la norma.

Las distinciones anteriores tienen como aspecto relevante evidenciar que las funciones de las normas jurídicas son distintas, pues aunque regulen conductas, ya sean actos, acciones o estados de cosas, se pueden diferenciar en virtud del sujeto a quienes se dirigen, así como por su objeto y eficacia. Así, se podría decir que existe un tipo de reglas que tienen como función regular las conductas de los individuos, y otras que se dirigen a las autoridades. Este segundo grupo puede subdividirse en aquellas cuya función es la realización de actos normativos, ya sea de introducción o de eliminación de las normas, atribuir competencias y determinar el modo de aplicación de otras normas. De modo que por su función es posible distinguir las normas

2 Hart, H. L., El concepto de derecho, Buenos Aires, Abeledo Perrot, 1992, pp. 99 y ss. 
Esta obra forma parte del acervo de la Biblioteca Jurídica Virtual del Instituto de Investigaciones Jurídicas de la UNAM

derogatorias, de las que establecen la vigencia o reglas de aplicación temporal de otras normas.

Lo anterior no implica que estemos frente a normas de distinta categoría, o que ello implique un tratamiento desigual. Los artículos transitorios son considerados normas jurídicas; en sentido estricto, dado que regulan conductas relativas a la aplicación de otras normas se dirigen a las autoridades y su objeto consiste en determinar la vigencia o modo de aplicación de las normas expedidas. Aunque la derogación por acto expreso es posible, las normas derogatorias normalmente se encuentran previstas en los transitorios de alguna disposición.

De su denominación se infiere que la función de estos artículos es, en principio, temporal y sirven para regular los procesos de cambio en el sistema jurídico. Su naturaleza jurídica se define por su función que se refiere a la aplicabilidad de otras normas, ya sea al señalar la entrada en vigor de una disposición o al derogarla. El artículo transitorio pierde su eficacia una vez que ha cumplido su cometido, por ello es que no puede establecer prescripciones genéricas con carácter vinculante a los particulares. Por decirlo de alguna manera, son accesorios, pero no solamente eso, sino que a diferencia del resto de las normas jurídicas cuya vigencia en principio es indefinida, a menos que se estipule lo contrario en alguna disposición transitoria, la relevancia de la vigencia de estos artículos depende de su función, por lo que podría ser considerada como temporal. Por ejemplo, en el caso de las normas derogatorias previstas en un artículo transitorio una vez cumplida su función, la norma a que se refiere queda derogada definitivamente, por lo que si la norma derogatoria perdiera su vigencia, no se produciría ningún efecto respecto de la que ya había sido derogada, es como si una vez realizados sus efectos su vigencia fuese irrelevante.

Los artículos transitorios no solamente forman parte del sistema jurídico, sino que también comparten esta estructura normativa, por lo que desde el punto de vista de su estructura son normas jurídicas en sentido estricto, regulan los actos relacionados con la aplicación de otras normas y la establecen como obligatoria, prohibida o permitida. La diferencia entre los artículos transitorios y otro tipo de normas radica en dos aspectos importantes, por una parte en el sujeto normativo (a quien se dirige la norma), ya que normalmente se dirigen a las autoridades aplicadoras sin establecer obligaciones a los particulares, y por la otra, por su objeto, puesto que solamente pueden referirse a la vigencia o modo de aplicación de las normas que se expiden o derogan. En virtud del cambio que se produce en el sistema jurídico, regulan el tránsito de un orden jurídico a otro, pero la norma es denominada transitoria en razón de su función, no de su estructura. 
Esta obra forma parte del acervo de la Biblioteca Jurídica Virtual del Instituto de Investigaciones Jurídicas de la UNAM

Además de las normas que prevén la vigencia de una nueva norma existe otro tipo de artículo transitorio denominado normas derogatorias, cuyo objeto es poner fin a la vigencia de una o varias normas y en ocasiones autorizar su aplicación temporal previendo las reglas correspondientes, por lo que durante un lapso de tiempo coexistirán en el orden jurídico diferentes normas que regulan la misma materia sin incurrir en conflicto, pues se aplicarán diferenciadamente, según las circunstancias prescritas. La ultraactividad de una norma derogada es viable porque la norma derogada no ha dejado de pertenecer al sistema. Generalmente la ultra-actividad o supervivencia temporal de las normas derogadas es permitida para su aplicación a casos pendientes de resolución para evitar la vulneración de derechos adquiridos ${ }^{3}$.

Otro aspecto especial de los artículos transitorios es que carecen de autonomía, es decir, solamente pueden existir en vinculación con otras disposiciones normativas. No existe un derecho transitorio autónomo que exista por si y aplicable a todo tipo de constituciones. Por lo consiguiente, los artículos transitorios contienen normas incompletas. ya que para su total comprensión es necesario estudiarlos en relación con otra norma ${ }^{4}$.

En resumen, los Articulos transitorios se caracterizan por: 1) Existir por que están vinculadas a otras disposiciones normativas 2) carecen de autonomía 3)no regulan la conducta de los obligados por las normas principales si no de las autoridades aplacadoras de la norma general que refieren 4) su función es temporal. En consecuencia, de conformidad con su naturaleza se pueden identificar tres clases de artículos transitorios ${ }^{5}$ :

1) Los que determinan la vigencia de una norma:

Estableciendo la entrada en vigor o vigencia temporal de las disposiciones a que se refiere a partir del momento de la promulgación o publicación de la norma. La eficacia de estos artículos transitorios es inmediata, por lo que su vigencia podría ser temporal, pues su función se agota al entrar en vigor la norma a que hacen referencia.

2) Los que establecen la derogación de una o varias disposiciones jurídicas, así ponen fin a su vigencia con lo cual su función se agota, ya que las normas derogadas no pueden recuperar su vigencia.

3 Huerta Ochoa, Carla, "Artículos transitorios y derogación", Boletín Mexicano de Derecho Comparado, vol. XXX núm. 102, UNAM, septiembre-diciembre, 2001, pp. 811-840.

4 Larenz, Karl, Metodología de la Ciencia del Derecho, Ed. Ariel Barcelona, 1980

5 Cfrr Saenz Arroyo, Jose y otros, Técnica Legislativa, Ed Porrúa, México, 1988 
Esta obra forma parte del acervo de la Biblioteca Jurídica Virtual del Instituto de Investigaciones Jurídicas de la UNAM

3) Los que establecen un mandato al legislador, independientemente de que esté sujeto a plazo o de que se prevea una sanción en caso de infracción, la vigencia de estos artículos depende del cumplimiento de la condición prevista.

En relación con las normas que determinan la vigencia de otras normas, el primer y segundo tipo mencionados, ya que también las normas derogatorias se refieren a la vigencia, el sujeto normativo de las mismas es la autoridad que las debe aplicar. El tercer tipo, en cambio, se dirige al legislador o autoridad competente para emitir las disposiciones necesarias para la debida instrumentación de la norma, se trata normalmente de los reglamentos de una ley.

\section{EL POSIBLE ABUSO DE ARTÍ́CULOS TRANSITORIOS}

Como se ha afirmado, los fines de los artículos transitorios constitucionales se reducen a determinar la vigencia de una norma; derogar una o varias disposiciones jurídicas poniendo fin a su vigencia o; establecer un mandato al legislador, independientemente de que esté sujeto a plazo o de que se prevea una sanción en caso de infracción. Cuando el contenido de los artículos transitorios es contrario o va mas allá de estos fines, podemos afirmar que se esta haciendo un mal uso o abuso de éstos.

Confundir la función de los transitorios con la del texto constitucional puede conducir al abuso, que además no ha sido excepcional en nuestro país, prácticas como por ejemplo, la de recurrir a una mención en un artículo transitorio para reglamentarlo. En ocasiones ha bastado una palabra para que el Poder Ejecutivo se arrogara la potestad para reglamentar algo que no se encontraba previsto en ninguna ley, expidiendo así reglamentos viciados de ilegalidad, en lugar de proponer al Poder Legislativo las reformas pertinentes.

Lamentablemente este error de técnica legislativa que abusa de artículos transitorios al pretender regular el texto constitucional y que adquieren carácter de permanentes, ha sido una practica común en las recientes reformas estructurales, en las cuales éstos se han utilizado para definir cuestiones trascendentales como es el caso de los lineamientos sobre tipos de contratación, las atribuciones asignadas a diversas dependencias y la conversión de Pemex y la CFE en "empresas productivas del Estado". Evidentemente este régimen transitorio resulta absurdo a todas luces, puesto que aspira a convertirse en permanentes, al tratar de regular determinadas disposicio- 
Esta obra forma parte del acervo de la Biblioteca Jurídica Virtual del Instituto de Investigaciones Jurídicas de la UNAM

nes constitucionales, en lugar de enfocarse a definir exclusivamente su temporalidad, su ámbito de aplicación, los sujetos normativos, las autoridades responsables de aplicarla, el lugar y tiempo a que se hace referencia en la prescripción.

Por otra parte, estas reformas como en materia educativa, de competencia, de telecomunicaciones, político-electoral y de transparencia, son detalladas en exceso, extensas de manera innecesaria lo que genera malas leyes. Se ha llegado al extremo de contemplar en dichos artículos todo tipo de aspectos, no importando su rango y categoría. El Poder Constituyente suele incluir en dichos apartados todas las disposiciones que simplemente olvidó mencionar dentro de los artículos "definitivos". Pero los artículos transitorios constitucionales no sirven para todo. No podemos perder de vista que al tratarse de disposiciones constitucionales, deben coadyuvar a establecer la manera en que se crearan las normas: no deciden. ni deben decidir qué debe ser establecido por las normas. A la idea de Sartori, estas disposiciones no debe contener matices personales ni ideologías, ya que de otra forma se estaría limitando la libertad de los individuos ${ }^{6}$. La Constitución no debe, por tanto incluir disposiciones transitorias en su parte orgánica, para eso existe un lugar especifico dentro del apartado de los "Artículos Transitorios" y éstos deben de contener únicamente normas para regular la temporalidad de la norma, y no ideologizar.

Además, en ocasiones estos artículos son redactados con términos contrapuestos, lo que abre paso a la ambigüedad y la discrecionalidad en la aplicación. Ésta es una práctica que también se ha vuelto común en el derecho mexicano, lo cual es muy criticable, ya que puede producir confusión y violaciones de derechos.

\section{EL USO DE ARTÍCULOS TRANSITORIOS EN LA REFORMA POLÍTICO ELECTORAL DE 2014}

El 10 de febrero de 2014 fue publicado en el Diario Oficial de la Federación el DECRETO por el que se reforman, adicionan y derogan diversas disposiciones de la Constitución Política de los Estados Unidos Mexicanos, en materia político-electoral ${ }^{7}$. Se trató de una reforma extensa y de gran cala-

6 Sartori, Giovanni, Ingeniería constitucional comparada. Una investigación de estructuras, incentivos y resultados, 2a. ed., México, Fondo de Cultura Económica, 2001, p. 247.

7 Se reformaron los párrafos segundo y cuarto del apartado A del artículo 26; la fracción VII del párrafo vigésimo tercero del artículo 28; el primer párrafo del artículo 29; la fracción VII y los apartados 4o. y 6o. de la fracción VIII del artículo 35; la base I en sus párrafos 
Esta obra forma parte del acervo de la Biblioteca Jurídica Virtual del Instituto de Investigaciones Jurídicas de la UNAM

do, en la misma ruta de las ultimas reformas en la materia caracterizadas por su notoria sobrerregulación. Solo el artículo 41 constitucional contiene más de 4 mil palabras y delinea de forma detallada muchas reglas electorales - por ejemplo, la distribución de tiempo en radio y TV para partidos políticos. Esta reforma no fue la elección, e incluyo nuevas prohibiciones y sanciones - por ejemplo, causales para anular elecciones, amplias regulaciones en materia de fiscalización electoral, procedimientos sancionadores, reglas de equidad, coaliciones entre otras. Detrás de esta tendencia en México - a veces obsesiva - para sobrerregular la materia electoral, subyace una ingenua creencia de que la norma puede cambiar la realidad, aun cuando la experiencia muestra que las amenazas de castigo rara vez desincentivan el mal comportamiento ${ }^{8}$.

inicial y segundo, el tercer párrafo de la base II, la base III en su párrafo inicial, el apartado A en su párrafo inicial e incisos a), c), e) y g) y en su segundo párrafo, el apartado B en su primer párrafo e inciso c) y su segundo párrafo, el apartado $\mathrm{C}$ en su primer párrafo y el apartado D, la base IV en su párrafo inicial y la base V del artículo 41; la fracción II del artículo 54; el segundo párrafo de la fracción $\mathrm{V}$ del artículo 55; el artículo 59; el primer párrafo del artículo 65; el segundo párrafo del artículo 69, el inciso a) de la fracción XXI del artículo 73; el tercer párrafo de la fracción IV del artículo 74; la fracción II del artículo 76; la fracción VI del artículo 82; el artículo 83; el segundo párrafo del artículo 84; la fracción IX del artículo 89; el segundo párrafo del artículo 93; la fracción VI del artículo 95; las fracciones VII y VIII del artículo 99; el apartado A del artículo 102; los incisos c) y f) del segundo párrafo de la fracción II y la fracción III del artículo 105; el segundo párrafo de la fracción V, el segundo párrafo de la fracción VIII, el primer y tercer párrafos de la fracción XIII y la fracción XV del artículo 107; el primer párrafo del artículo 110; el primer párrafo del artículo 111; el encabezado y el segundo párrafo de la fracción I del artículo 115; los párrafos segundo y tercero de la fracción II, el primer párrafo y los incisos a), b), c), d), h), j) y k) de la fracción IV del artículo 116; el segundo párrafo del artículo 119; la fracción III de la BASE PRIMERA del apartado $\mathrm{C}$ del artículo 122; se adicionan un apartado $\mathrm{C}$ al artículo 26; un cuarto párrafo a la base I, y un tercer, cuarto y quinto párrafos a la base VI del artículo 41; un tercer párrafo al artículo 69; la fracción XXIX-U al artículo 73; las fracciones III y VII al artículo 74; las fracciones XI y XIII, recorriéndose la subsecuente en su orden, al artículo 76; un segundo y tercer párrafos a la fracción II y la fracción XVII al artículo 89; los párrafos tercero y cuarto al artículo 90; la fracción IX, recorriéndose la subsecuente en su orden, al artículo 99; un inciso i) al segundo párrafo de la fracción II del artículo 105; un segundo párrafo al inciso f) y un inciso n), recorriéndose los subsecuentes en su orden a la fracción IV, así como una fracción IX al artículo 116; y se deroga la fracción V del artículo 78, de la Constitución Política de los Estados Unidos Mexicanos.

8 En la década pasada el IFE impuso multas record a algunos partidos - 1,000 millones de pesos al PRI por el caso Pemexgate y 560 millones al PAN y el Partido Verde por el caso Amigos de Fox, ambas en 2003 - sin embargo, esas sanciones no parecen haber cambiado las tácticas de financiamiento de los partidos. Lo cierto es que sobrerregular y establecer castigos para motivar el buen comportamiento es parte de una ilusión normativa porque lo importante para prevenir el mal comportamiento no es el número de sanciones sino la probabilidad de ser detectado, procesado y sentenciado. 
Esta obra forma parte del acervo de la Biblioteca Jurídica Virtual del Instituto de Investigaciones Jurídicas de la UNAM

La sobrerregulación se extendió a los artículos transitorios, en los cuales se determinó que las entidades del país tenían hasta el 30 de junio de 2014 para adaptar sus legislaciones locales - tanto su constitución como sus normas secundarias - y definir las pocas reglas que todavía pueden de forma autónoma, entre ellas la regulación de las candidaturas independientes, el voto en el extranjero, los procedimientos sancionadores, las modalidades de las coaliciones y los debates entre los candidatos locales.

En los transitorios de la reforma se fue mas allá del propósito derogatorio y accesorio de los mismos. En el Segundo transitorio del decreto del 10 de febrero pasado, el Congreso de la Unión se impuso a sí mismo el plazo límite del próximo 30 de abril para expedir tres leyes generales: la de procedimientos electorales, que lo será también de instituciones en la materia; de partidos políticos, y para delitos electorales. Y en el mismo articulo, el Poder Constituyente trata de orientar al legislador en su tarea de realización de estas leyes. Esto generó que el transitorio II sea un artículo excesivamente largo y detallado, en los cuales el Constituyente no se reduce a exponer los ejes que deberá considerar el legislador en la realización de las leyes generales, sino que claramente adelanta ciertas regulaciones.

En efecto, basta ver el enorme desglose del transitorio segundo para advertir que se denota un evidente interés del legislador por regular en los mismos las disposiciones constitucionales de la reforma, lo cual no deja de ser un contrasentido, además que con ello, el Poder constituyente suplanta las funciones del legislador y, finalmente, el excesivo nivel de detalle además de constituir un error de técnica, genera condiciones para incurrir en contradicciones.

Las leyes a que hace referencia este transitorio son de tipo "general" porque delimitan las facultades de las autoridades federales, estatales y municipales en materia electoral; el anterior Código Federal de Instituciones y Procedimientos Electorales (COFIPE), como su nombre lo indica, solo establecía normas federales y los estados las suyas propias. Las leyes generales son aquellas que pueden incidir válidamente en todos los órdenes jurídicos parciales que integran al Estado Mexicano. Es decir, las leyes generales corresponden a aquellas respecto a las cuales el Constituyente o el Poder Revisor de la Constitución ha renunciado expresamente a su potestad distribuidora de atribuciones entre las entidades políticas que integran el Estado Mexicano, lo cual se traduce en una excepción al principio establecido por el artículo 124 constitucional. ${ }^{9}$ La labor del constituyente

9 Pero resulta que el Poder Revisor no renunció "a su potestad distribuidora de atribuciones entre las entidades políticas que integran el Estado Mexicano" -en este caso la Federa- 
Esta obra forma parte del acervo de la Biblioteca Jurídica Virtual del Instituto de Investigaciones Jurídicas de la UNAM

debe reducirse a establecer en la norma suprema los ejes o factores que el legislador ordinario debe tomar en cuenta en la realización de las leyes. En este caso, el poder constituyente obliga a legislador a que la ley general que regule los partidos políticos nacionales y locales, contemple: a) Las normas, plazos y requisitos para su registro legal y su intervención en los procesos electorales federales y locales; b) Los derechos y obligaciones de sus militantes y la garantía de acceso a los órganos imparciales de justicia intrapartidaria; c) Los lineamientos básicos para la integración de sus órganos directivos; la postulación de sus candidatos y, en general, la conducción de sus actividades de forma democrática; así como la transparencia en el uso de los recursos; d) Los contenidos mínimos de sus documentos básicos; e) Los procedimientos y las sanciones aplicables al incumplimiento de sus obligaciones; f) El sistema de participación electoral de los partidos políticos a través de la figura de coaliciones, así como un g) Un sistema de fiscalización sobre el origen y destino de los recursos con los que cuenten los partidos políticos, las coaliciones y los candidatos.

Sin embargo, el constituyente decide ir mas allá y en el caso de las coaliciones y las nuevas reglas de fiscalización adelanta regulaciones, suplantando con ello la tarea del legislador ordinario, señalando:

1. Se establecerá un sistema uniforme de coaliciones para los procesos electorales federales y locales;

2. Se podrá solicitar su registro hasta la fecha en que inicie la etapa de precampañas;

3. La ley diferenciará entre coaliciones totales, parciales y flexibles. Por coalición total se entenderá la que establezcan los partidos políticos para postular a la totalidad de los candidatos en un mismo proceso electoral federal o local, bajo una misma plataforma electoral. Por coalición parcial se entenderá la que establezcan los partidos políticos para postular al menos el cincuenta por ciento de las candidaturas en un mismo proceso electoral federal o local, bajo una misma plataforma. Por coalición flexible se entenderá la que establezcan los partidos políticos para postular al menos el veinticinco por ciento de las candidaturas en un mismo proceso electoral federal o local, bajo una misma plataforma electoral;

ción, los estados y el DF- sino que explícitamente asignó atribuciones al INE, para el ámbito federal y local, y a los institutos electorales locales, en sus respectivos ámbitos territoriales; en consecuencia, la ley general debería ceñirse a reglamentar la distribución de competencias ya establecida en los artículos 41 y 116 de la Constitución. 
Esta obra forma parte del acervo de la Biblioteca Jurídica Virtual del Instituto de Investigaciones Jurídicas de la UNAM

4. Las reglas conforme a las cuales aparecerán sus emblemas en las boletas electorales y las modalidades del escrutinio y cómputo de los votos;

En esta misma lógica de exceso regulatorio, se determina en el transitorio que el sistema de fiscalización sobre el origen y destino de los recursos con los que cuenten los partidos políticos, las coaliciones y los candidatos, deberá contener:

1. Las facultades y procedimientos para que la fiscalización de los ingresos y egresos de los partidos políticos, las coaliciones y los candidatos se realice de forma expedita y oportuna durante la campaña electoral;

2. Los lineamientos homogéneos de contabilidad, la cual deberá ser pública y de acceso por medios electrónicos;

3. Los mecanismos por los cuales los partidos políticos, las coaliciones y las candidaturas independientes deberán notificar al órgano de fiscalización del Instituto Nacional Electoral, la información sobre los contratos que celebren durante las campañas o los procesos electorales, incluyendo la de carácter financiero y la relativa al gasto y condiciones de ejecución de los instrumentos celebrados. Tales notificaciones deberán realizarse previamente a la entrega de los bienes o la prestación de los servicios de que se trate;

4. Las facultades del Instituto Nacional Electoral para comprobar el contenido de los avisos previos de contratación a los que se refiere el numeral anterior;

5. Los lineamientos para asegurar la máxima publicidad de los registros y movimientos contables, avisos previos de contratación y requerimientos de validación de contrataciones emitidos por la autoridad electoral;

6. La facultad de los partidos políticos de optar por realizar todos los pagos relativos a sus actividades y campañas electorales, por conducto del Instituto Nacional Electoral, en los términos que el mismo Instituto establezca mediante disposiciones de carácter general;

7. La facultad de los partidos políticos de optar por realizar todos los pagos relativos a la contratación de publicidad exterior, por conducto del Instituto Nacional Electoral, y

8. Las sanciones que deban imponerse por el incumplimiento de sus obligaciones. 
Esta obra forma parte del acervo de la Biblioteca Jurídica Virtual del Instituto de Investigaciones Jurídicas de la UNAM

$\mathrm{Al}$ detallar el Poder Constituyente en exceso los ejes previstos para la elaboración de la ley, termina reduciendo considerablemente la tarea del legislador, el cual en esta situación no tiene mas remedio que dedicarse a organizar las regulaciones ya determinadas, cubrir posibles "lagunas", o, en su caso, resolver posibles contradicciones ${ }^{10}$. Esta especie de "vicios" en la técnica legislativa empleada se deriva del hecho que la autoridad expide el cuerpo normativo y los artículos transitorios siguiendo el mismo procedimiento, por lo que en ocasiones el legislador, considerando que forman una unidad, incluyen en los artículos transitorios la regulación de conductas. Sin embargo, en virtud de la función de los artículos transitorios, esto no puede ser así, pues aun cuando su modificación o derogación efectivamente tiene

10 El afán regulatorio y el exceso de detalles también se observa cuando en el transitorio se obliga al Poder Revisor que en la ley general que regule los procedimientos electorales se contemple:

a) La celebración de elecciones federales y locales el primer domingo de junio del año que corresponda, en los términos de esta Constitución, a partir del 2015, salvo aquellas que se verifiquen en 2018, las cuales se llevarán a cabo el primer domingo de julio;

b) Los mecanismos de coordinación entre los órganos del Ejecutivo Federal en materia de inteligencia financiera y el Instituto Nacional Electoral, que permitan reportar a éste las disposiciones en efectivo que realice cualquier órgano o dependencia de la Federación, de las entidades federativas y de los municipios durante cualquier proceso electoral, cuando tales operaciones se consideren relevantes o inusuales de conformidad con los ordenamientos aplicables;

c) Las reglas aplicables para transparentar el financiamiento, la metodología y los resultados de las encuestas que se difundan, relativas a las preferencias electorales, así como las fechas límite para llevar a cabo su difusión;

d) Los términos en que habrán de realizarse debates de carácter obligatorio entre candidatos, organizados por las autoridades electorales; y las reglas aplicables al ejercicio de la libertad de los medios de comunicación para organizar y difundir debates entre candidatos a cualquier cargo de elección popular. La negativa a participar de cualquiera de los candidatos en ningún caso será motivo para la cancelación o prohibición del debate respectivo. La realización o difusión de debates en radio y televisión, salvo prueba en contrario, no se considerará como contratación ilegal de tiempos o como propaganda encubierta;

e) Las modalidades y plazos de entrega de los materiales de propaganda electoral para efectos de su difusión en los tiempos de radio y televisión;

f) Las sanciones aplicables a la promoción de denuncias frívolas. Para tales efectos se entenderá como denuncia frívola aquella que se promueva respecto a hechos que no se encuentren soportados en ningún medio de prueba o que no puedan actualizar el supuesto jurídico específico en que se sustente la queja o denuncia;

g) La regulación de la propaganda electoral, debiendo establecer que los artículos promocionales utilitarios sólo podrán ser elaborados con material textil;

h) Las reglas para garantizar la paridad entre géneros en candidaturas a legisladores federales y locales, y

i) Las reglas, plazos, instancias y etapas procesales para sancionar violaciones en los procedimientos electorales. 
Esta obra forma parte del acervo de la Biblioteca Jurídica Virtual del Instituto de Investigaciones Jurídicas de la UNAM

que verificarse por el mismo procedimiento y emanar de la misma autoridad, las prescripciones dirigidas a los particulares (en este caso los partidos políticos) deben encontrarse solamente en el cuerpo normativo, ya que de lo contrario la autoridad pudiera estar generando nuevas o diferentes obligaciones con el riesgo de promover su falta de claridad afectando el principio de certeza o seguridad jurídica, o bien, se corre el riesgo de restringir en los artículos transitorios los derechos previstos en el texto normativo. En efecto, establecer obligaciones a los particulares (partidos políticos) en los artículos transitorios pueden convertirse en una práctica contraria a la seguridad jurídica, sobre todo porque su función de producir el tránsito de una legislación a otra, es temporal. Además, a consecuencia de su propia denominación no son tomados en cuenta sino inmediatamente después de su publicación, después caen en el olvido.

Otro riesgo generado por el exceso regulatorio en los artículos transitorios, es que se puede incurrir en contradicciones respecto a lo establecido en el texto constitucional. Esto es lo que se observa, por ejemplo, en el Transitorio Octavo, pues su contenido claramente contradice lo establecido en el articulo 41 del texto constitucional, pues determina: que "una vez integrado el Instituto Nacional Electoral y a partir de que entren en vigor las normas previstas en el Transitorio Segundo anterior, las funciones correspondientes a la capacitación electoral, así como la ubicación de las casillas y la designación de funcionarios de la mesa directiva, en los procesos electorales locales, se entenderán delegadas a los organismos públicos locales". Lo anterior a pesar que en el Apartado B del artículo 41 del texto constitucional reformado establece que esas funciones corresponden al Instituto Nacional Electoral ${ }^{11}$. Por ello, aun y cuando el mismo transitorio contemple la posibilidad que el Instituto Nacional Electoral pueda reasumir dichas funciones, por mayoría del Consejo General, no se resuelve la abierta contradicción

11 Apartado B. Corresponde al Instituto Nacional Electoral en los términos que establecen esta Constitución y las leyes:... a) Para los procesos electorales federales y locales:

1. La capacitación electoral;

2. La geografía electoral, así como el diseño y determinación de los distritos electorales y división del territorio en secciones electorales;

3. El padrón y la lista de electores;

4. La ubicación de las casillas y la designación de los funcionarios de sus mesas directivas;

5. Las reglas, lineamientos, criterios y formatos en materia de resultados preliminares; encuestas o sondeos de opinión; observación electoral; conteos rápidos; impresión de documentos y producción de materiales electorales;

6. La fiscalización de los ingresos y egresos de los partidos políticos y candidatos, y

7. Las demás que determine la ley. 
Esta obra forma parte del acervo de la Biblioteca Jurídica Virtual del Instituto de Investigaciones Jurídicas de la UNAM

en que incurre esta disposición por la delegación de funciones a órganos distintos.

\section{EFECTOS DEL ABUSO DE LOS ARTÍCULOS TRANSITORIOS}

El análisis de los alcances de los artículos transitorios en las reformas constitucionales no es menor si reconocemos que no solo en la materia político electoral, sino también en otras como en telecomunicaciones o en el energético, fue precisamente en el régimen transitorio en el que se recogieron algunos de los cambios sustantivos más importantes. Si en dicho articulado se presentan contradicciones o excesos estamos obligados a discutir si se puede recurrir su inconstitucionalidad.

En principio hay que reconocer que la posibilidad de hacer una distinción entre diversos tipos de normas no implica la negación del carácter prescriptivo de los artículos transitorios, no solamente en virtud de su pertenencia al sistema jurídico, sino porque a pesar de ser reglas de aplicación que se refieren a otras normas, establecen obligaciones para los órganos aplicadores. De modo que al prever un deber ser en el supuesto que regulan, tienen que ser consideradas como normas y su contravención puede acarrear diversas consecuencias jurídicas.

En efecto, parece lógico que si los artículos transitorios son accesorios, y su contenido es limitado, no se puede decir que formen parte del texto normativo ni que sean impugnables, ya que no establecen derechos ni obligaciones a los particulares. Pero como se mencionó previamente, esto se debe a que su función no es regular las conductas de los particulares, sino simplemente prever reglas relativas a la vigencia de la norma que se expide, por lo que en caso de establecer contenidos contrarios al cuerpo normativo al que pertenecen serían impugnables.

Por otra parte, como los artículos transitorios establecen obligaciones para la autoridad, en caso de que las autoridades aplicadoras contravinieran lo dispuesto en dichas normas, sus actos también serían recurribles. Son normas con carácter obligatorio, por lo que en caso de una infracción a lo prescrito o de una indebida aplicación o interpretación de éstas, su aplicación es impugnable por el afectado y la autoridad aplicadora puede resultar responsable administrativa o judicialmente, ya que la aplicación de una norma derogada o que no ha entrado en vigor, vicia el acto y lo hace anulable.

Ahora bien, el hecho de que dichas disposiciones se encuentren en la Constitución, nos obliga a recordar que ésta es un parámetro de validez de 
Esta obra forma parte del acervo de la Biblioteca Jurídica Virtual del Instituto de Investigaciones Jurídicas de la UNAM

las normas secundarias que incluye - en paridad de rango y, por lo mismo, con la misma relevancia normativa - al cuerpo constitucional (por ejemplo, al contenido del artículo 41), a los tratados internacionales en derechos humanos (por ejemplo a la Convención Americana de los Derechos Humanos), pero también los intrincados artículos transitorios de la propia Constitución. Esto último es muy importante: los transitorios son disposiciones constitucionales cuyas normas son parámetro de validez de todas las normas contenidas en leyes infraconstitucionales, y de este reconocimiento a su rango depende también su posible impugnabilidad.

La inconstitucionalidad de artículos transitorios puede obedecer a distintas causas. La más común y evidente es cuando contiene disposiciones que contradicen lo que la propia constitución establece. Ese contraste puede verificarse de diferentes maneras. Por ejemplo, cuando la Constitución reserva una facultad para una autoridad determinada (por ejemplo, el Instituto Federal de Telecomunicaciones) y la ley la traslada a otra instancia (por ejemplo, a la Secretaría de Gobernación). Tal es el caso que nos ocupa, donde el octavo transitorio claramente contradice lo dispuesto en el Apartado B del articulo 41 constitucional. Algo similar sucede cuando la Constitución otorga una potestad precisa a un órgano autónomo y la ley pretende restringirla. En este último caso, la ley no está regulando sino conculcando una facultad constitucional.

Otra causa posible que no proviene del exceso sino del silencio: cuando el legislador es omiso en su obligación reglamentaria. Por ejemplo, cuando al no legislar en materia de derecho de réplica, los legisladores impiden que la Constitución surta efectos.

Como vemos, un articulo transitorio puede ser inconstitucional por diversas causas, sin embargo, no lo puede ser meramente por contemplar un error de técnica legislativa. En efecto, en nuestro país los errores de técnica legislativa no se encuentran constitucionalizados, por lo que no son sujetos de control constitucional. La jurisdicción constitucional solamente puede valorar el abuso de artículos transitorios en correlación con otros preceptos constitucionales: el control sólo será ejercible en la medida en que derechos fundamentales o preceptos constitucionales (como la seguridad jurídica) sean vulnerados ulteriormente por esos errores de técnica y, además, esta vulneración deberá ser patente y clara. Esto es, a diferencia de otros ordenamientos como Colombia o Austria donde se pueden controlar los defectos de técnica legislativa, en México se deben buscar hipótesis concretas donde la vulneración de la técnica produzca la vulneración del derecho. 
Esta obra forma parte del acervo de la Biblioteca Jurídica Virtual del Instituto de Investigaciones Jurídicas de la UNAM

De acuerdo a Mauro Rivera, en el derecho comparado, varios tribunales han emitido pronunciamientos en los que se han analizado defectos de técnica legislativa. En Italia en el año 2007, la Corte Costituzionale analizó la técnica legislativa de la Ley de Finanzas de 2006, argumentando que su escases hacía ininteligible la norma ${ }^{12}$. En España, el Tribunal Constitucional se ha pronunciado también varias veces sobre técnica legislativa, encontrando nexos entre la técnica legislativa y el principio de seguridad jurídica tutelado por la Constitución española ${ }^{13}$. El criterio del TC ha sido que los errores en la técnica legislativa no se traducen, necesariamente, en vicios de inconstitucionalidad, sino que debe analizarse la gravedad de estos vicios, el perjuicio en la seguridad jurídica, etc. De tal suerte, para la constitucionalidad de la ley es irrelevante la inintelegibilidad de algunos de sus preceptos, la catalogación errónea de un precepto (catalogándolo como transitorio), omisiones, terminología imprecisa, etc. La propia STC 46/1990, fijó el único caso de un defecto de técnica legislativa que trasciende per se: los juegos exagerados de remisiones que generan situaciones objetivamente confusas.

Ahora bien, el hecho de que en México no exista una constitucionalización de directrices de técnica legislativa no ha evitado algunos pronunciamientos jurisdiccionales que hayan versado sobre técnica legislativa o la hayan empleado entre sus consideraciones. Dentro del ordenamiento jurídico mexicano, el Poder Judicial Federal se ha pronunciado en algunas ocasiones (normalmente en la forma de obiter dicta) sobre técnica legislativa. Una amplia mayoría de estos pronunciamientos, lógicamente, se han hecho por parte de los Tribunales Colegiados de Circuito. Sin embargo, inclusive la Suprema Corte de Justicia ha analizado defectos de técnica legislativa. La misma característica de obiter dicta ha hecho que estos pronunciamientos sobre técnica legislativa no sean materia de tesis jurisprudenciales, sino que formen parte de las consideraciones o argumentos de tesis aisladas.

El criterio que se ha venido sosteniendo es que una falta de técnica legislativa puede acarrear la inconstitucionalidad de una ley dependiendo de la gravedad de la falta. ${ }^{14}$ Una primer toma de posición se dio en 1947 dentro del amparo 6728/47 donde la Segunda Sala de la SCJN sostuvo (por unanimidad) respecto a normas impugnadas por la vía del amparo

12 Cfr. Rivera León, Mauro Arturo y Fabian Constantino Martínez, Cuando la forma es fondo. Estudios de Tecnica Legislativa y Legilinguistica, IIJ UNAM- Editorial Flores, 2015.

13 STC 46/1990, FJ4: "la exigencia del 9.3 relativa al principio de seguridad jurídica implica que el legislador debe perseguir la claridad y no la confusión normativa...".

14 Carbonell, Miguel, "Los objetos de las leyes, los reenvíos legislativos y las derogaciones tácitas: notas de técnica legislativa", Boletín Mexicano de Derecho Comparado, México, vol. 30, núm. 89, mayo-agosto, 1997, p. 446. 
Esta obra forma parte del acervo de la Biblioteca Jurídica Virtual del Instituto de Investigaciones Jurídicas de la UNAM

que la concurrencia de defecto de técnica en las leyes, no las hacen por sí mismas inconstitucionales, pero en cambio, sí se impone otorgar el amparo porque además de las graves imperfecciones técnicas de las leyes su inconstitucionalidad es evidente. ${ }^{15} \mathrm{Es}$ decir, la propia corte consideraba que la falta de técnica legislativa no era per se causal de inconstitucionalidad, sino que debía ir aparejada a una violación sustantiva de preceptos constitucionales. Este criterio resultaria relevante en 1974 tras la conocida costumbre de ciertos ordenamientos estatales de establecer impuestos dentro de los artículos transitorios de una ley. Aquí, la corte integrará jurisprudencia por reiteración en los amparos en revisión 239/84, 8993/83, 3524/84, 9622/83 y 7876/83. Se afirmaba que este tipo de disposición podría, en todo caso, constituir un defecto de técnica legislativa el incluir en los artículos transitorios un impuesto específico, pero ello no determina la inconstitucionalidad de la ley. ${ }^{16}$

Este criterio, que se antoja bastante formalista, fue utilizado de nueva cuenta en la resolución de sendos amparos en revisión (1209/2005, $1272 / 2005$ y $1967 / 2005$ ), cuyo criterio fue consagrado en tesis aislada en abril de 2006. Se sostuvo que la técnica legislativa empleada en el establecimiento del tributo no podía per se significar la inconstitucionalidad de dicha disposición transitoria, sino que debía acompañarse por la ausencia de alguno de los elementos esenciales del tributo. Los Tribunales Colegiados, desde su creación en 1951, han emitido también diversos pronunciamientos sobre técnica legislativa, del mismo tenor que la propia SCJN: restrictivos, favorables a la legislación vigente y en la forma de consideraciones auxiliares.

Puede constatarse que no se han emitido pronunciamientos de carácter general teniendo como materia única la técnica legislativa. Sin embargo, derivado de distintas resoluciones puede trazarse un criterio mexicano; a saber, que la técnica legislativa no configura per se un objeto de control jurisdiccional a menos que estas deficiencias impliquen violaciones a otros preceptos constitucionales. La corte y los Tribunales Colegiados han sido bastante cuidadosos en no imponer requisitos ulteriores, ni sobre el titulado, la subdivisión de artículos o el contenido material permisible en los artículos transitorios. Sin embargo, a modo de obiter dicta sí han sostenido que parece idóneo subdividir artículos largos, evitar el casuismo, no establecer tributos

15 Tomo XCVIII, página 1053. Amparo 6137/48. "Productos Myrna", S.A. 8 de noviembre de 1948. Unanimidad de cuatro votos. La publicación no menciona el nombre del ponente (Núm. IUS 320223).

16 Séptima Época, Pleno, Semanario Fudicial de la Federación, 205-216 Prime- ra Parte, Jurisprudencia Constitucional/Administrativa. (Núm. IUS 232149); Infor- me 1986, Primera Parte, Pleno, tesis 8, página 646. Apéndice 1917-1995, Tomo I, Primera Parte, tesis 153, página 155. 
Esta obra forma parte del acervo de la Biblioteca Jurídica Virtual del Instituto de Investigaciones Jurídicas de la UNAM

en normas no tributarias o en artículos transitorios, tener cuidado con la redacción y sintaxis normativa, etc. El desacato de estas recomendaciones, empero, no produce la inconstitucionalidad de la norma ${ }^{17}$.

Luego entonces, en el caso que nos ocupa, los excesos regulatorios en los articulos transitorios de la reforma politico electoral, solo podran ser recurribles en la medida en que èstos vulneren principios o derechos constitucionales. El objeto impugnable no pueden ser por tanto meramente los errores de tecnica legislativa. Ir mas alla de su naturaleza de los transitorios podría, en todo caso, constituir un defecto de técnica legislativa, pero ello no determina su inconstitucionalidad.

A pesar del criterio sostenido por la jurisdicción mexicana, creemos que deberian existir regulaciones obligatorias que limiten y controlen la técnica usada por los legisladores. Conductas por parte del legislador, como las que hemos descrito, no sólo vulneran aspectos menores de la técnica legislativa, sino la seguridad jurídica o la garantía de exacta aplicación de la ley. Pero mientras eso sucede, la única posibilidad de recurrir la supuesta inconstitucionalidad de un articulo transitorio constitucional a través de los instrumentos reconocidos en la propia norma como el juicio de amparo, la acción de inconstitucionalidad, o en algunos supuestos la controversia constitucional, continuara dependiendo de la acreditación de violaciones a otras disposiciones constitucionales en su contenido.

\section{GONCLUSIONES}

Como se ha podido apreciar el derecho transitorio es una materia muy poco estudiada. En virtud de la creciente relevancia de los artículos transitorios, y considerando que no son pocos los problemas que una mala técnica legislativa puede causar, resulta indispensable no solamente estudiarlos, sino establecer límites al legislador, vigilar su contenido y verificar atentamente su elaboración y aplicación posterior. Estas tareas corresponden principalmente a la doctrina y a la jurisprudencia.

17 Se reconocen las deficiencias de técnica legislativa pero se defiende la constitucionalidad de la norma sin realizar un análisis más profundo acerca de la gravedad de la vulneración. Las resoluciones en materia tributaria y penal pueden atestiguar un buen ejemplo de ello. Bajo el criterio de la corte, es constitucional imponer un tributo en una disposición transitoria, inclusive sin necesidad de que ésta norma sea de naturaleza tributaria (aun cuando se reconozca el defecto en dicha técnica legislativa). Esta última pregunta parecería — y deberíaser respondida en un sentido negativo. Empero, aisladamente se ha considerado como constitucional introducir preceptos verdaderamente sustantivos en artículos transitorios. 
Esta obra forma parte del acervo de la Biblioteca Jurídica Virtual del Instituto de Investigaciones Jurídicas de la UNAM

El uso contrario de los artículos transitorios o el abuso de ellos, puede abrir la posibilidad de errores en la implemetacion, contradicciones, problemas de interpretación e, incluso, la posibilidad de generar litigios. Lo anterior debería ser un incentivo para que los legisladores hagan bien su tarea. El éxito de las reformas constitucionales no reside en su aprobación sino en su implementación y para que esto último sea posible hacen falta leyes claras, coherentes, estables y, sobre todo, constitucionales.

Cabe señalar que en ocasiones las coyunturas políticas dificultan la aprobación de reformas constitucionales acordes con el uso adecuado de artículos transitorios. Es el caso de la ultima legislatura federal mexicana, la cual pudo sacar adelante reformas de gran calado ofreciendo garantías a las minorías que en la aprobación de las leyes generales o secundarias no se alteraría el espíritu de dichas reformas. La exigencia de mayoría cualificada viene a ofrecer garantías a las minorías que una mayoría parlamentaria coyuntural no podrá alterar, aprovechando su momentánea ventaja, las reglas de procedimiento y las bases sobre las que se asienta la comunidad política. La Constitución se muestra así como un acuerdo básico, por encima de mayorías coyunturales, y que sólo puede reformarse si se reproduce ese acuerdo, que incluya a mayorías y minorías. Esta necesidad se hace más patente en la reforma constitucional de países federales, en los que la rigidez del procedimiento de reforma, busca salvaguardar los derechos de los estados o unidades federadas. Pero aun suponiendo que es valido el interés de los grupos parlamentarios opositores por adelantar regulaciones en el texto constitucional para evitar que el espíritu de las reformas sea orientado a senderos diferentes de los acordados, lo ideal seria que éstos confiaran el andamiaje institucional de control de la constitucionalidad.

En caso de no ser suficiente, en aras de ordenar la técnica legislativa constitucional bien podría atenderse propuestas como la de La Constitución Política de los Estados Unidos. Texto reordenado y consolidado, publicada por el Instituto de Investigaciones Jurídicas de la UNAM. En dicho documento, diversos investigadores han propuesto la eliminación de múltiples disposiciones reglamentarias en el texto constitucional que pasarían a una Ley de Desarrollo Constitucional. La propuesta implicaría sólo una reforma constitucional; la del artículo 69, para facultar al Congreso a expedir leyes para desarrollar el contenido de las normas constitucionales. En esa Ley de Desarrollo Constitucional quedarían aquellas disposiciones reglamentarias que, tras múltiples reformas, han quedado plasmadas en la Constitución. Minucias, detalles y hasta candados, como la distribución de los tiempos oficiales 
Esta obra forma parte del acervo de la Biblioteca Jurídica Virtual del Instituto de Investigaciones Jurídicas de la UNAM

durante precampañas y campañas electorales -que actualmente se estipulan con horas y minutos en la Constitución- irían a dar a esa ley.

De cualquier manera, sea cual sea la ruta elegida para corregir errores de técnica legislativa, debe hacerse sin perder de vista que el protagonismo jurídico en una democracia constitucional debe ser de los legisladores pero, para que ello sea posible y no llegue la hora de los jueces, los primeros deben hacer bien su tarea. 
Esta obra forma parte del acervo de la Biblioteca Jurídica Virtual del Instituto de Investigaciones Jurídicas de la UNAM

\title{
EL GASO ESPAÑOL. LA CRISIS DEL RÉGIMEN DE 1978 Y LAS POSIBILIDADES DE UNA REFORMA CONSTITUCIONAL (UN ANÁLISIS SOCIOPOLÍTICO DESDE LA PERSPECTIVA DE LA INTELIGENGIA EMOGIONAL)
}

\author{
Javier Esteban GUINEA*
}

\begin{abstract}
SUMARIO: I. Nota introductoria. II. Constitución y régimen político. III. El mito fundacional de la democracia española: La Transición. IV. Causas de la inestabilidad institucional. V. La naturaleza oligárquica de la política en España. VI. La aparición de una nueva de la pulsión política. VII. Epílogo desde una España impotente.
\end{abstract}

\section{NOTA INTRODUCTORIA}

Quiero agradecer, en primer lugar, la invitación que el Instituto de Investigaciones Jurídicas de la UNAM y la Facultad de Derecho de la Universidad Autónoma de San Luis Potosí, por conducto de los coordinadores de este Congreso, Doctores José María Serna e Isidro de los Santos Olivo, respectivamente, me han brindado para asistir como participante a este VII Congreso Nacional de Derecho Constitucional en México, precisamente en el año que antecede al centenario de la Constitución Mexicana de 1917.

Lo hago consciente de la oportunidad generosa que ha dado México a todos los españoles que a lo largo de los siglos XIX Y XX han tenido que abandonar el país en difíciles condiciones personales y políticas. Y lo hago sabiendo que esta tierra es una tierra de exilio; una tierra de libertad para los españoles rebeldes. Y también lo hago sabiendo de que en estos momentos no hace falta exiliarse de España, aunque no resulte nada fácil plantear

* Profesor de Derecho Constitucional de la Universidad Camilo José Cela, Madrid, España. 
Esta obra forma parte del acervo de la Biblioteca Jurídica Virtual del Instituto de Investigaciones Jurídicas de la UNAM

una crítica rigurosa y completa de nuestro sistema sin ser calificado como antisistema o populista por los censores oficiales.

Dicho esto, agradezco a México su generosidad con aquellos conciudadanos españoles que encontraron un hogar en esta patria. Espero, de igual modo, estar a la altura de las circunstancias en esta labor de responder a la pregunta que mi anfitrión me hizo hace dos meses, que es la pregunta que muchos ciudadanos del mundo se han hecho en los últimos años, después de asistir a los sucesos que desde las protestas masivas del 15 M del año 2011 están sucediendo allá en España. ¿Qué está pasado en España? ¿Estamos ante una crisis constitucional o de régimen político? ¿Qué está sucediendo en Cataluña?

El texto presente recoge la ponencia presentada en este congreso, además de un epílogo que actualiza el trabajo realizado.

\section{CONSTITUCIÓN Y RÉGIMEN POLÍTICO}

Creo que es sumamente importante que los constitucionalistas no perdamos la perspectiva de que toda Constitución, además de ser la norma fundamental y fuente de fuentes del ordenamiento es siempre una superestructura jurídica que responde a diversos intereses y realidades sociológicas. Obviarlo nos llevaría a una forma de fetichismo constitucional que no creo que debamos permitirnos ni siquiera entre expertos.

La distinción entre Constitución y régimen político es una herramienta de análisis que no podemos desperdiciar en estos momentos para analizar la crisis del modelo constitucional español de 1978 o la necesidad de una reforma constitucional en México.

La idea predominante de los siglos XVIII y XIX era que la Constitución traducía en normas jurídicas el régimen político, pero los cambios económicos y sociales nos demuestran que muchas veces la Constitución puede llegar a ser una fachada del poder, y que el verdadero poder puede situarse detrás de la Constitución. El riesgo de que nuestras sociedades se transformen en un futuro en sociedades posdemocráticas no puede quedar descartado y debe mantenernos alerta.

El profesor Karl Lowenstein nos enseñó que una constitución puede tener una naturaleza meramente nominal cuando no regula completamente un proceso político o incluso llegar a ser una constitución semántica cuando disfraza una situación de poder de hecho. Si yo dijera - utilizado los términos de Lowenstein- que la Constitución española es una pseudoconstitución estaría faltando a la verdad por cuanto la Constitución española es una nor- 
Esta obra forma parte del acervo de la Biblioteca Jurídica Virtual del Instituto de Investigaciones Jurídicas de la UNAM

ma que establece y hace posible la defensa de los derechos fundamentales y el Estado de Derecho.

Sin embargo, la Constitución española carece de una verdadera separación de poderes y dista mucho de establecer un sistema verdaderamente representativo, como luego veremos. Su desarrollo ha implicado una grave crisis institucional, moral y económica sin precedentes desde la muerte del dictador. Y tal y como proclamaba en su artículo 17 La Declaración de los derechos del hombre y del ciudadano de 1789, aquellas sociedades que no determinan la separación de poderes, carecen de constitución. No es que España carezca de una Constitución, pero bueno es recordar este artículo para, desde la modestia, hacernos conscientes del larguísimo camino que queda por recorrer a la democracia en España.

Las Constituciones suelen situar su mito fundacional en un poder constituyente popular, en un contrato social. Pero ocurre, a menudo, que si su sistema no es verdaderamente representativo y los poderes del Estado no están verdaderamente separados se produce un secuestro progresivo de la soberanía. El poder originario es sustituido en muchas ocasiones por una oligarquía a través de mecanismos de manipulación de la representación popular.

\section{EL MITO FUNDACIONAL DE LA DEMOCRACIA ESPAÑOLA: LA TRANSICIÓN}

Me gustaría comenzar haciendo algo de memoria y analizar el mito fundacional de la democracia en España. Me refiero a aquel momento conocido como la Transición; la Transición con mayúsculas. Sin duda un gran momento en que España recuperó las libertades civiles y los derechos fundamentales, tras casi cuarenta años de dictadura, pero también un fabuloso mito que sostiene que España es una democracia avanzada sin serlo. La mejor definición de mito que conozco me la dio el dramaturgo Fernando Arrabal: el mito es una mentira necesaria. ¿Pero acaso sigue siendo hoy el mito de la Transición española una mentira necesaria?

Para responder a esta cuestión les invito a acompañarme en este viaje en el tiempo. Estamos a principios de los años setenta del siglo pasado. El Franquismo era un régimen político personal que se agotaba con el declinar del dictador. Franco era ante todo Franquista. Por eso el Franquismo se fue adaptando a la historia. El franquismo comenzó siendo fascista cuando necesitó ganar la guerra con la participación del Eje, pero se mostró nacional católico - esa era su verdadera esencia- cuando había que ser occidental y 
Esta obra forma parte del acervo de la Biblioteca Jurídica Virtual del Instituto de Investigaciones Jurídicas de la UNAM

anticomunista... y luego se fue moderando hasta llegar a ser un régimen autoritario con una económica liberal, como lo fue el pinochetismo o lo es hoy China, por ejemplo.

El drama humano de la guerra civil y la represión ulterior fue brutal. Entre víctimas y exiliados supuso la desaparición de un millón de compatriotas; los represaliados directamente fueron más del veinte por ciento de la población. Esta es una historia que ustedes conocen bien en México porque recibieron a muchos exiliados. El coste emocional de aquella contienda es un factor a tener en cuenta todavía hoy, como veremos más adelante. De algún modo, la guerra civil supuso un trauma en el inconsciente colectivo en España que sigue influyendo sobre nuestra política, como veremos más adelante.

El coste económico de la contienda y el posterior bloqueo mantuvo a España en una penuria que recuerda los peores siglos de nuestra decadencia. Desde 1936 a 1955 el PIB real español no se recuperó del efecto de la guerra. Pasamos un infierno de veinte años de posguerra económica.

A finales de los años cincuenta el régimen de Franco consiguió romper el bloqueo con los acuerdos militares para la cesión de bases a los Estados Unidos, potencia necesitada de alianzas geopolíticas firmes contra el comunismo. El turismo, y las divisas que mandaban los emigrantes ayudaron también a propiciar el cambio socio-político y cultural del franquismo durante los años sesenta.

Franco, sabedor de su papel en la historia, decidió restaurar la Monarquía en la figura de Juan Carlos de Borbón. Franco sabía que el joven rey instauraría una monarquía parlamentaria y retomaría la senda de la historia de España. El dictador no era ningún tonto. Y pensaba que hasta cierto punto esta y no otra era su más alta meta histórica, tras haber salvado a España del comunismo. Todo en consonancia con un arquetipo entre el hombre providencial y el dictador romano. Todo ello dio lugar a desarrollar la Ley de sucesión en la jefatura del Estado del Reino de España. Franco esperaba que su sucesión se hiciera de un modo mucho más controlado, pero estaba resignado a la misma. Hoy se olvida este hecho, pero el rey fue nombrado sucesor por las Cortes de Franco, lo que no significa que luego no capitanease con éxito la lucha por las libertades, que era la misma lucha por su supervivencia política, pero esa es una historia mucho más conocida.

Conforme Franco envejecía, solo una minoría de personas poco perspicaces creía en la continuidad del franquismo. Sin embargo, el franquismo sociológico era un hecho indiscutible. La economía intervencionista y autárquica de los años cuarenta y cincuenta había dado paso a la economía 
Esta obra forma parte del acervo de la Biblioteca Jurídica Virtual del Instituto de Investigaciones Jurídicas de la UNAM

de mercado planificada y el desarrollo de los sesenta había transformado el país en la novena economía del planeta, con crecimientos anuales del 6,4 $\%$ del PIB durante más de una década. A principios de los años setenta, la Comunidad europea firmó un tratado preferencial con España.

El desarrollo generó y permitió unas tasas de crecimiento que dieron lugar al llamado milagro español. La nueva clase media, que nunca había tenido España, se hizo dominante, se pusieron las bases del estado social y la seguridad social se organizó. Al mismo tiempo se desarrolló una industria considerable en sectores básicos que proveía de bienes de consumo una sociedad en desarrollo.

Por entonces, el problema que preocupaba a la población era mejorar sus condiciones de vida y salir de la subsistencia. La mayoría de la población seguía aquel consejo cínico de Franco, que solía sorprender a las gentes que le rodeaban con una frase enigmática: usted haga como yo y no se meta en política. Por entonces las fuerzas políticas se dividían entre aquellas de dentro del régimen y aquellas de fuera del mismo.

Entre las fuerzas políticas franquistas se encontraban los reformistas y los continuistas. Los continuistas del régimen eran aquellos que pensaban que el Franquismo debía continuar aun sin Franco. Eran conocidos como el búnquer y tenían realmente pocas luces. Entre ellos se encontraban unos pocos tradicionalistas, francofalangistas y sobre todo militares del ejército franquista. El pilar del franquismo era el ejército nacional. Los reformistas del régimen eran aquellos franquistas que habían entendido que el régimen se acababa con Franco. Habían entendido que la presión Internacional y el crecimiento de la clase media nos llevarían de nuevo a la democracia. Entre ellos había falangistas moderados (como Suárez), monárquicos, tecnócratas, seudoliberales, democristianos y conservadores (como Fraga). Los reformistas franquistas, como era de esperar, serían los vencedores de las primeras elecciones ${ }^{1}$, con un ex falangista a la cabeza: Adolfo Suárez.

Las fuerzas anti-franquistas estaban entonces en la clandestinidad o el exilio y en posición de una larga derrota total. Estas fuerzas se dividían entre fuerzas políticas moderadas y rupturistas. Los Partidos Políticos eran ilegales y el más importante entonces era el Partido Comunista, que acaparaba las simpatías de muchos opositores. En aquel momento, les recuerdo, medio mundo era comunista. Pero el grupo de la oposición que contaba

1 Fuente: Ministerio del Interior de España: http://wrere.infoelectoral.mires/min/busquedaAvanzadaAction. html; jessionid =26B6DC6C2FC8153064C2A80DB548BAC9. app1?vuelta $=1$ Ecod TipoEleccion $=2 E^{2}$ codPeriodo $=197706 \mathcal{E}^{2}$ codEstado $=99 \mathcal{E}^{2} \operatorname{cod}$ Comunidad $=0$ E codProvincia $=0 \mathcal{E}^{2} \mathrm{cod} \mathrm{Mu}$ nicipio $=0$ \& codDistrito $=0$ \& codSeccion $=0$ \& codMes $a=0$ 
Esta obra forma parte del acervo de la Biblioteca Jurídica Virtual del Instituto de Investigaciones Jurídicas de la UNAM

con más apoyos geopolíticos y financieros era el Partido Socialista Obrero Español (PSOE), cuyas cabezas pensantes renegaban del radicalismo de un sector importante del socialismo histórico español. Había otros partidos de extrema izquierda y había, claro está, fuerzas nacionalistas catalanas y vascas. El franquismo, recordémoslo, había acabado con los estatutos de autonomía y había limitado el uso de las lenguas maternas al ámbito familiar. La España plural dio paso después de la Guerra Civil a un centralismo sin precedentes en nuestra historia, pero la historia es tozuda y la cuestión territorial ha vuelto a presentarse como una cuestión terminal en España, como veremos más tarde.

Entre todos estos partidos de la Oposición había dos sectores: Los partidos que querían pactar con las fuerzas reformistas del Franquismo y los que abogaban por la ruptura. Los partidarios de la ruptura, junto a otros movimientos civiles, constituyeron la Junta democrática, que sería abandonada poco a poco por todos los partidos. A la cabeza de la misma estuvo el pensador demócrata Antonio García Trevijano, uno de los perdedores de la Transición.

El problema en aquellos momentos es que el garante del Franquismo iba a ser el ejército, y éste no iba a permitir ninguna ruptura sin ejercer una feroz represión si fuera necesario. El franquismo controlaba la situación y decidió encauzar el cambio político desde dentro. El control de la sociedad por parte del poder era casi absoluto. Y poco a poco, como era de esperar, los moderados de fuera fueron pactando con los reformistas de dentro. Era evidente que no tenían fuerza ni quizá valor para intentar otra cosa.

Por aquel entonces ocurrió algo inesperado; como diría Maquiavelo ocurrió un acontecimiento. En Portugal estalló la Revolución de los Claveles ${ }^{2}$ (1974) y la NATO y los Estados Unidos y Alemania Federal temieron que aquella revolución tiñera de rojo la península ibérica y la colocará en manos del bloque soviético. Este hecho contribuyó a que las fuerza reformistas del franquismo pudieran imponer su criterio a la oposición. Las Cortes franquistas aprobaron casi sin fisuras una Ley para la Reforma Política ${ }^{3}$ (1977) que encauzó el proceso de cambio pacífico hacia el nuevo orden

2 Es el nombre dado al levantamiento militar de izquierdas del 25 de abril de 1974 que provocó la caída en Portugal de la dictadura salazarista. Esta dictadura dominaba el país desde 1926 .

3 La Ley 1/1977, de 4 de enero, para la Reforma Política fue aprobada el 18 de noviem-

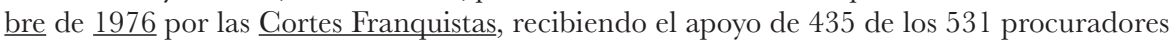
(81\% a favor), y sometida a referéndum el 15 de diciembre de 1976, con una participación del $77 \%$ del censo y un 94,17\% de votos a favor. Tenía el carácter de Ley Fundamental, siendo la última de las Leyes Fundamentales del Reino del franquismo. 
Esta obra forma parte del acervo de la Biblioteca Jurídica Virtual del Instituto de Investigaciones Jurídicas de la UNAM

preparando el terreno a nuestra Constitución de 1978. Hay que recordar que aquella Ley fue apoyada mayoritariamente por los electores, pese a que la oposición pidió el voto contrario. Su cerebro fue Torcuato Fernández Miranda, verdadero cerebro de la Transición.

Debemos pensar que durante el tardofranquismo una mayoría de la población no quería problemas, como suele ocurrir en cualquier régimen autoritario consolidado. Los que se manifestaban abiertamente contra el régimen no eran ni mucho menos la mayoría. La tenaz represión y la educación franquista eran hegemónicas. Sus partidarios eran numerosos y controlaban el país desde hacía décadas a golpe de represión, adoctrinamiento y políticas sociales básicas.

Aquella Ley para la Reforma Política, que actúo como un auténtico corsé constitucional para la futura constitución de 1978, estableció los límites de nuestro actual régimen político. En pocas palabras, lo que aquella Ley propiciaba podría resumirse así: España recuperaría las libertades civiles y políticas en una monarquía parlamentaria con dos cámaras que serían elegidas por las provincias, primando el voto agrario. Este diseño respondía a los intereses políticos, económicos y financieros que clamaban por el desarrollo pacífico y por la entrada en la Comunidad Europea, pues lógicamente la Comunidad Europea exigía a España que recobrase las libertades. Pero como tantas veces ocurre, las cosas importantes no estaban escritas en aquella Ley. Y esas cosas importantes eran que España abrazaría definitivamente una economía capitalista privatizando sectores estratégicos y se integraría en la OTAN. El aislacionismo o falsa neutralidad franquista tenía los días contados.

La única institución que podría negarse al cambio era el ejército, más que nada por miedo a represalias y a juicios por la represión en la que había participado durante el franquismo. Pero la cabeza pensante de aquel ejército franquista saltó por los aires hasta la superar la altura de un edificio madrileño. El almirante Luis Carrero Blanco fue asesinado por ETA, aunque detrás de aquel impresionante atentado de ETA muchos piensan que había alguien más. La organización terrorista pudo no estar sola en la preparación de aquel atentado.

Si la Ley para la Reforma política encauzó el proceso constituyente, se hacía necesario que el resultado de las primeras elecciones fuera el adecuado para que todo estuviera controlado. El pueblo votó en aquellas elecciones de 1977 entre una cantidad de opciones considerable, pero solo algunas contaban con los apoyos económicos y mediáticos necesarios. Por si acaso, la Ley electoral preveía una mayor representación de los territorios más 
Esta obra forma parte del acervo de la Biblioteca Jurídica Virtual del Instituto de Investigaciones Jurídicas de la UNAM

conservadores. El partido de los reformistas franquistas, la UCD, ganó con 164 escaños. En segundo lugar se colocó el Partido Socialista Obrero Español con 118 escaños, que era la principal fuerza pactista de la oposición al franquismo. Estos dos partidos quedaron muy lejos de la tercera y cuarta fuerza, el Partido Comunista con 20 escaños y los franquistas moderados de Alianza Popular con 16 escaños. Con estos mimbres se hizo la Constitución. Mirando atrás este periodo de nuestra historia uno se pregunta si las cosas no suceden siempre cuando tienen que suceder y como tienen que suceder... como dijo Shakespeare.

Pasado el tiempo, todavía no ha comenzado a estudiarse con rigor la Transición española. Para muchos colegas, el mito fundacional de la democracia española es un dogma indiscutible. Se comprende. Sus intereses crecieron con la ilusión de la libertad. Se creó la asignatura de Derecho Constitucional, se renovaron las cátedras... Me estoy refiriendo a la generación que hoy tiene de sesenta años en adelante. Pero sin duda los españoles que hoy tienen treinta años piensan de otra manera.

Si bien es cierto que el recobro de las libertades políticas y sobre todo personales es todavía motivo de alegría y celebración para los mayores, hoy una amplia mayoría de los jóvenes españoles han dejado de creer en sus políticos. De esta manera se ha empezado a criticar aquel periodo como la causa de los problemas actuales.

Por aquel entonces, en el diseñado proceso constituyente, ninguno de los partidos con representación mayoritaria se permitió discutir la posibilidad de que la forma de Estado del nuevo régimen fuera la república. Tampoco se plantearon que la democracia fuera presidencialista en lugar de parlamentaria. Nadie planteó una verdadera y útil separación de poderes del Estado. No se estableció una forma de organización territorial firme sino abierta, lo que provocaría a la larga la crisis de unidad nacional que ahora se manifiesta en Cataluña. Nadie puso en duda entonces la indisoluble unidad del Estado. Está claro que la Constitución se discutió dentro de unos límites pactados por los dos grandes partidos. Los españoles habían inventado su propio Consenso: Un acuerdo no escrito que daría a España décadas de estabilidad pero que recortaría las posibilidades de la libertad política constituyente.

El secreto de nuestro régimen político, ya lo hemos apuntado, se llama Consenso. El Consenso ${ }^{4}$ fue el pacto no escrito que permitió la llegada de la

4 Según la definición de la Real Academia de la Lengua Española, el término Consenso deriva del latín Consensus y se refiere al acuerdo entre todos los miembros de un grupo o entre varios grupos. 
Esta obra forma parte del acervo de la Biblioteca Jurídica Virtual del Instituto de Investigaciones Jurídicas de la UNAM

democracia parlamentaria. Este pacto creció al amparo del natural deseo de reconciliación y por eso favoreció el olvido de los hechos que sucedieron en la Guerra Civil y durante la dictadura. La sociedad necesitaba reconciliarse y por eso el olvido sustituyo al perdón, pues el verdadero perdón no es fácil de alcanzar y requiere voluntad de ambas partes, reconocimiento y justicia.

De algún modo, el trauma de la guerra civil mueve la primera emoción objeto de esta investigación. La primera emoción que hizo posible la Transición fue el miedo. La segunda, la alegría. En el arco entre ambas emociones se movió la libido política ${ }^{5}$ del pueblo español desde 1975 hasta 1982. En medio quedó enterrada durante algunas décadas la emoción destructiva de la rabia. Sin duda el tardofranquismo propició una forma de reconciliación desde el dominio de una España sobre la otra. Muchas familias tenían familiares en ambos bandos de la guerra, lo que propiciaría el reencuentro personal, pero el régimen no dejó de comportarse como un régimen vencedor y vengador hasta el final de sus días, pese a la monserga de la reconciliación oficial y el buen hacer de muchas personas a título particular.

De algún modo, los que propiciaron la Transición desde dentro realizaron un ejercicio de conciencia histórica. El hecho es que media España, menos ETA militar, se liberó la rabia con la muerte de Franco. Esa rabia etarra hizo posible que ETA siguiera matando a mil españoles aunque Franco hubiera ya muerto. La emoción de la rabia, que es la que hoy ha cambiado el panorama político no emergerá en la sociedad española hasta el año 2011. Tardará unos treinta años en aparecer. Ya veremos cómo reaparecerá eso que Manuel Machado llamaba la España de la rabia y de la idea ${ }^{6}$. Pero no adelantemos acontecimientos.

Es cierto que la mayoría de los ciudadanos votaron la Constitución en 1978 con alegría y que con ella recobraron sus libertades personales, aunque la democracia política fuera bastante imperfecta, como luego veremos. Aquella Constitución se blindó. Las posibilidades de reforma constitucional, al contrario de lo que sucede en su país, requieren un acuerdo difícilmente alcanzable por las fuerzas políticas presentes y futuras. Esta rigidez constitucional es uno de los problemas más serios que enfrenta hoy España. ¿Por qué se blindó de esta manera nuestra Constitución? Los llamados padres de la Constitución temieron que el partidismo podía volver a colocar a

5 Cuando empleo el término de libido política me estoy refiriendo a la energía psíquica política, no al eros del poder.

6 Como escribe Antonio Machado en su poema El Mañana efimero: Mas otra España nace/ la España del cincel y de la maza, / con esa eterna juventud que se hace/ del pasado macizo de la raza. / Una España implacable y redentora, / España que alborea / con un hacha en la mano vengadora, /España de la rabia y de la idea. 
Esta obra forma parte del acervo de la Biblioteca Jurídica Virtual del Instituto de Investigaciones Jurídicas de la UNAM

España en una división permanente e irreconciliable, y por eso se estableció un sistema de reforma que requiere un consenso muy notable. Piensen que para reformar la Constitución española en sus partes fundamentales, de acuerdo con el artículo $168^{7}$ de nuestra Ley Fundamental es necesaria la aprobación por dos tercios de cada una de las Cámaras, la disolución de las Cortes y la convocatoria de nuevas elecciones. Después, las nuevas cámaras deberán ratificar la decisión de modificar la Constitución y posteriormente procederán a redactar la nueva Constitución, que debe ser aprobada de nuevo por dos tercios de cada Cámara. El texto modificado deberá ser sometido a referéndum para su aprobación final.

A ustedes, que tienen una de las constituciones más flexibles del mundo esto les parecerá extraño. Pero el hecho es que en España tenemos una constitución rígida, y el problema de lo rígido es que tiende a romperse en lugar de adaptarse. Aunque en aquellos tiempos, ciertamente, nadie pensaba en cambiar la Constitución.

España sobrevivió a la crisis de 1973 (la llamada crisis del petróleo llegó a España unos años más tarde) con los pactos de la Moncloa. Aunque la tasa de paro se disparó hasta casi tres millones de personas, la sociedad aguantó con ilusión ese cambio de régimen. A mediados de los años 80, la entrada en la Unión Europea supuso más desarrollo, aunque también un profundo cambio estructural en nuestra producción que determinaría la futura dependencia y servidumbre exterior de España. España ha pasado de ser un país industrializado a ser un país de servicios. Pese a estos cambios, durante los años 80, pasado lo peor de aquella crisis, España recuperó el tono y logró una buena posición internacional. Por entonces los países emergentes no eran todavía una gran competencia, Europa era un club selecto y España se benefició de los fondos de desarrollo estructural y de otros fondos europeos, pero nuestra industria fue desmantelada poco a poco, inexorablemente. Lo que en principio se vivió como una fiesta -la moneda única- acabaría haciendo subir los precios desmesuradamente. La presión fiscal comenzó a subir y desde entonces no ha dejado de hacerlo. El gasto público se disparó. Pasamos de tener setecientos mil funcionarios en

7 Art. 168. 1. Cuando se propusiere la revisión total de la Constitución o una parcial que afecte al Título preliminar, al Capítulo segundo, Sección primera del Título I, o al Título II, se procederá a la aprobación del principio por mayoría de dos tercios de cada Cámara, y a la disolución inmediata de las Cortes. 2. Las Cámaras elegidas deberán ratificar la decisión y proceder al estudio del nuevo texto constitucional, que deberá ser aprobado por mayoría de dos tercios de ambas Cámaras. 3. Aprobada la reforma por las Cortes Generales, será sometida a referéndum para su ratificación. 
Esta obra forma parte del acervo de la Biblioteca Jurídica Virtual del Instituto de Investigaciones Jurídicas de la UNAM

1975 a más de tres millones en la actualidad para servir a una población que ha crecido solamente un $25 \%$.

En el orden político, los años ochenta supusieron el fin de la Transición y la consolidación del régimen. Otro acontecimiento propició esa consolidación. En 1981 el sector golpista del ejército fue definitivamente desmantelado tras la intentona del teniente coronel Tejero, que tomó el hemiciclo unas horas y se retiró al no encontrar apoyos ni alcanzar un acuerdo con el general Armada para un gobierno de concentración nacional que incluiría a las grandes fuerzas políticas para solucionar el problema del terrorismo y el separatismo. Después de aquel esperpento ${ }^{8}$, el partido socialista (la izquierda) gobernó por fin tras cuatro décadas fuera del poder en España. Así se cerró la Transición. Monarquía parlamentaria y socialdemocracia. Curioso equilibrio, genial equilibrio histórico. Europa, entonces fuerte, empujaba a España por la senda de la felicidad.

\section{CAUSAS DE LA INESTABILIDAD INSTITUCIONAL}

¿Qué es lo que ha pasado entonces para que las cosas comenzaran a resquebrajarse y España perdiera su estabilidad institucional?

España ha tenido que soportar dos crisis económicas desde la instauración de la democracia. La primera nació con ella y ya hemos visto como se encauzó. La segunda comenzó en el año 2007 y todavía la arrastramos. Esta segunda crisis llegó después de años de crecimiento sostenido, pero también de profundos cambios estructurales en la economía española. En 1975 el producto interior bruto industrial superaba el 33\% del PIB; hoy se sitúa en el 13\%. La integración en la Unión Europea ha supuesto el desmantelamiento de la industria nacional. La competencia con la industria europea era complicada por diversas cuestiones y partía de una pésima negociación. La globalización en la que han entrado los mercados a finales de los años 90 ha supuesto otro gran problema para los productores españoles. El crecimiento económico español de mediados de los años 90 ya estaba basado en los servicios y la construcción. La crisis de mediados de los años 2000 supuso el pinchazo de la llamada burbuja inmobiliaria. Este sector suponía alrededor del $11 \%$ del producto interior bruto, lo que ha hecho que la crisis haya atacado con especial virulencia a España.

8 Género literario que se caracteriza por la presentación de una realidad deformada y grotesca y la degradación de los valores consagrados a una situación ridícula. 
Esta obra forma parte del acervo de la Biblioteca Jurídica Virtual del Instituto de Investigaciones Jurídicas de la UNAM

Hasta la llegada de esta crisis a Europa la percepción que tenía la ciudadanía del sistema político español era sostenible. Pese a los continuos casos de corrupción estructural en los dos grandes partidos y de los partidos nacionalistas, la población vivía ajena a los mismos. La despolitización en España era muy notable. El régimen era estable y el sanguinario terrorismo de ETA fue apagándose poco a poco. Los intentos políticos de independencia en el País Vasco fueron atajados sin más problema en las Cortes. Los largos mandatos socialdemócratas de los años ochenta y noventa resultaron ser un bálsamo para casi toda la población, que veía con pereza la llegada de la nueva derecha. Después, hartos de corrupción, se produjo la alternancia que debía perfeccionar el régimen. En 1996 ganó la derecha y continúo la relativa modernidad de Aznar. Pero el atentado del 11 M de 2004 y la manipulación de la información que realizó el Gobierno del Partido Popular supuso la vuelta del partido socialista...

La grave crisis de 2008 vendría a cambiar totalmente el panorama. En dos años se destruyeron más de tres millones de empleos, el poder adquisitivo de la clase media se redujo en cinco años un 20\%. El PIB cayó en cuatro años casi un $10 \%{ }^{9}$ Los parados superaron los seis millones según las estadísticas oficiales ${ }^{10}$. El paro se extendió a más del $50 \%{ }^{11}$ de la población juvenil. Por primera vez en muchos años y desde la guerra, la sociedad fue consciente de que los hijos vivirían peor que sus padres. Esos hijos que constituían el futuro de la generación mejor preparada de la historia de España estaban -y por ahora están- condenados al paro, al subempleo y a la emigración. Esta misma toma de conciencia de lo que ha supuesto la desregulación del capitalismo y la consecuente crisis fundamenta la obra El Capital del Siglo XXI. Para Thomas Piketty, la creciente desigualdad en todo el mundo ha colocado a los debates intelectuales y políticos sobre la distribución de la riqueza en el centro del tablero. España no es ajena a este fenómeno, que además tiene fuertes tintes generacionales.

Volvamos a leer sobre los hechos históricos. El movimiento de las plazas en España, el famoso $15 \mathrm{M}$, supuso un toque de atención muy serio que las instituciones se permitieron no atender entonces pero que ha calado hondamente en la sociedad española. El Movimiento 15-M, también llama-

9 Datos oficiales del Instituto Nacional de Estadística. http://wrerr.ine.es/prensa/pib_tabla_cne.htm

10 Datos oficiales del Instituto Nacional de Estadística http://wrere.ine.es/prensa/epa_tabla. htm

11 Datos oficiales del Instituto Nacional de Estadística http://wrere.ine.es/ss/Satellite?L=es_

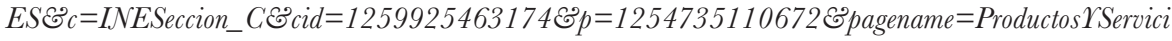
os\%2FPYSLayoutEparam $3=1259924822888$ 
Esta obra forma parte del acervo de la Biblioteca Jurídica Virtual del Instituto de Investigaciones Jurídicas de la UNAM

do movimiento de los indignados, fue un movimiento ciudadano formado a raíz de la manifestación del 15 de mayo de 2011. Pero ese movimiento fue sobre todo la expresión de la emergencia de una nueva clase: el precariado ${ }^{12}$. Junto a esa clase emergió la consciencia del underground español. La sospecha que se hizo visible en el imaginario español es que el mito fundacional de nuestra democracia escondía una férrea y corrupta oligarquía. Las masas juveniles entonaron entonces aquella consigna que recorrió el mundo: lo llaman democracia y no lo es.

Durante la última legislatura (2011-2015), las contradicciones del proyecto constitucional de 1978 han aflorado con virulencia, precisamente cuando se ha constatado el empobrecimiento de una parte considerable de la población, el aumento de la tasa del desempleo y un crecimiento de las desigualdades sociales y la inseguridad sin precedentes desde los años cuarenta. Todo ello ha provocado incertidumbre, sufrimiento y fractura social. Esta incertidumbre se ha transformado en dos emociones: el miedo y la rabia, que han venido a sustituir en el inconsciente pulsional español al miedo y la alegría, pilares emocionales del sistema constitucional de 1978.

Del mismo modo, hoy constatamos que la crisis económica y emocional que viene soportando España desde 2008 ha generado una crisis política sin precedentes desde el establecimiento de la democracia. Hay 2,5 millones de familias por debajo del umbral de la pobreza. El 1\% de personas más ricas acaparan el $20 \%$ de la riqueza nacional ${ }^{13}$. La destrucción de la clase media es un hecho. Y como suele ocurrir, cuando la clase media está en riesgo, las cosas se ponen complicadas para los de arriba. Nos encontramos inmersos en una crisis que se ha visto amplificada por los efectos económicos y el padecimiento por parte de la población de una injusta administración de los intereses generales. La tasa de corrupción ha subido 25 puestos en el pódium de los países más corruptos, solo comparable con Italia, dentro de Europa $^{14}$.

Todo este fenómeno tiene, claro está, una lectura económica, pero también tiene una lectura de orden psicopolítico que a menudo se olvida.

12 En su libro El precariado. Una nueva clase social, Guy Standing introduce este concepto. Por precariado nos referimos a la nueva clase masiva caracterizada por la inseguridad y creciente desigualdad. Esta clase se habría convertido en un factor de inestabilidad y cambio social.

13 Datos oficiales del Instituto Nacional de Estadística. http://wrwreine.es/prensa/ np844.pdf

14 Datos de Transparencia Internacional. http://transparencia.org.es/ipc-2015/ 
Esta obra forma parte del acervo de la Biblioteca Jurídica Virtual del Instituto de Investigaciones Jurídicas de la UNAM

\section{LA NATURALEZA OLIGÁRQUICA DE LA POLÍTICA EN ESPAÑA}

Enseñamos a nuestros alumnos algo que a veces nos permitimos olvidar: La Constitución posee un contenido jurídico enunciativo. Sin embargo, el régimen político supone unos hechos de poder real nutridos de contenidos sociales, económicos, emocionales, culturales, etc. Estos hechos determinan la realidad política, social, moral y económica de un país. Para conocer la naturaleza de un Régimen Político debemos preguntarnos: ¿Quién gobierna? ¿Por qué gobierna? ¿De qué manera gobierna? ¿Qué es lo que gobierna? ¿Para qué gobierna?

Para contestar a estas preguntas no es suficiente recurrir a la Constitución y debemos estar atentos a otras fuentes de información: Al conjunto de normas del país, especialmente leyes orgánicas y reglamentos. A la práctica constitucional y a los usos y desusos constitucionales. A las fuerzas operantes (partidos políticos). Al sistema económico imperante. A los poderes fácticos. Al estado emocional de la población. A la interpretación de la realidad que producen la opinión publicada. Pero sobre todo debemos estar atentos al mecanismo propio del poder y su relación con otros poderes no estatales.

España ha dejado de ser soberana en su política financiera, como consecuencia de su integración en la Unión Europea. Eso significa que una parte considerable del poder sobre cuestiones fundamentales viene determinada desde instancias europeas. Más aún cuando la tasa de endeudamiento del país hoy casi supera la barrera del 100\% del PIB anual ${ }^{15}$. Es decir, debemos todo lo que producimos en un año.

Para poder pagar la enorme deuda, y para poder pagar una administración que sigue generando endeudamiento, necesitamos préstamos exteriores. El problema es que quienes prestan, y más si son nuestros socios europeos, quieren garantías de devolución. Ese es el problema mayor de España en estos momentos. Esa deuda impide y limita las políticas de desarrollo del tejido empresarial básico que es el único que puede hacer crecer a una nación y desde el crecimiento propiciar políticas de igualdad. Y la pregunta que ahora tenemos que hacernos es cómo hemos llegado a este estado de ruina. Y la repuesta es que la clase política ha actuado generando una pesada clientela y propiciando una política de gastos y costes que no responde al interés general. Lo cierto es que las grandes empresas han sido las beneficiadas de una política de precios carísimos en sectores estratégicos y de contrataciones públicas desmesuradas. Lo lamentable es que cientos

15 Datos oficiales del Instituto Nacional de Estadística. http://wrew.ine.es/dynt3/FMI/es/ 
Esta obra forma parte del acervo de la Biblioteca Jurídica Virtual del Instituto de Investigaciones Jurídicas de la UNAM

de miles de clientes políticos han saqueado las arcas públicas durante estos últimos cuarenta años.

Pero si acudimos a la perspectiva del análisis político veremos que estos hechos tienen su preciso origen en una pérdida de control sobre la clase política, que cumple así lo que Michels llamaba la ley de hierro de las oligarquías. Toda organización tiende a hacer un fin de sí misma y de sus intereses rompiendo el principio de representación. En España, la irretroactividad de la elección de representantes es un hecho. Los miembros del Congreso y del Senado en España una vez elegidos no se deben a sus electores sino a las máquinas burocráticas de los partidos que les ponen en las listas y que sirven a sus propios intereses. Por eso el grito del $15 \mathrm{M}$ se resumía en pocas palabras: que no, que no, que no nos representan. Lo llaman democracia y no lo es...

A esta quiebra del sistema de representación se une la falta de una verdadera separación de poderes que ha permitido que gran parte de las decisiones políticas de las últimas décadas haya tenido una finalidad oligárquica y no democrática.

La caricatura de una clase política oligárquica al servicio de una clase económica (una casta) es una de las imagos más recurrentes del populismo de todos los tiempos. En cierta forma, el populismo y el nuevo populismo europeo de derechas o de izquierdas es un movimiento que viene a responder a los temores de una población que padece la incertidumbre y el desclasamiento y que en consecuencia ha dejado de creer y de sentirse representada por las instituciones. Las soluciones del populismo son la mayoría de las veces inaplicables, pero sus críticas suelen ser agudas y expresan el deseo profundo de la población de encontrar responsables o chivos expiatorios para sus desgracias causadas por el mal gobierno. Digamos que el populismo no es la causa del malestar sino la consecuencia del malestar. Es cierto que muchas veces, la reconstrucción de una identidad en medio del caos globalizador encuentra su sombra en la condena del otro: el diferente, el inmigrante, el poderoso o el débil. Estos fenómenos crecen en toda Europa de un modo estable y por ahora imparable. En el caso de la Europa del sur estos movimientos tienden a la izquierda (España y Grecia) pero en el resto de Europa son de derecha radical. En el caso de Italia y España, se dan además formas de populismos subnacionales o separatistas, que hacen del Estado central su particular enemigo. En estos tiempos, parafraseando a Marx, podemos decir que un fantasma recorre Europa: El populismo.

La forma de gobierno, siguiente punto en el análisis del régimen político nos lleva a otra cuestión. La división formal de poderes del Estado no significa que los poderes estén verdaderamente separados en España. 
Esta obra forma parte del acervo de la Biblioteca Jurídica Virtual del Instituto de Investigaciones Jurídicas de la UNAM

En España elegimos a aquellos que previamente ha designado la cúpula del partido, lo que significa que los diputados y senadores se deben más a sus organizaciones que a sus electores. Por otra parte, la misma cúpula del partido gobernante manda en el poder Ejecutivo y en el Legislativo si tiene mayoría para ello. Ambos poderes además influyen en el judicial a través de los nombramientos del Fiscal General del Estado, el nombramiento de algunos miembros del Consejo General del Poder Judicial y de los miembros del Tribunal Constitucional. No es que quienes sirven profesional y no políticamente al Poder Judicial no sean independientes. La moral de los jueces y de las fuerzas de seguridad a su servicio suele ser bastante ejemplar, pero lo cierto es que los grandes casos de corrupción sistemática de los grandes partidos tardan años en salir a la luz contra viento y marea y que el Poder Judicial pierde la eficacia que debería tener como contrapoder. El nombramiento en España del Fiscal General del Estado por el ejecutivo es insólito y poco adecuado para una democracia. Su influencia en el principio acusador puede ser notable. Podemos por tanto concluir que en nuestra Constitución hay independencia formal de los poderes, pero no verdadera separación de poderes.

La corrupción de la clase política y la misma clase política se ha convertido en el segundo motivo de preocupación para los españoles. Las encuestas del CIS revelan que la ciudadanía concibe que la corrupción es sistémica en España y su segundo problema, puesto que el tercero son directamente los políticos ${ }^{16}$. De hecho, la corrupción está institucionalizada en España. La corrupción como pecado a redimir forma parte de la psique católica y de nuestra estructura política. La unidad de facto de los poderes fortalece la sensación de impunidad con la que la criminalidad política organizada lleva décadas actuando. Este término de criminalidad política organizada me parece esencial a la hora de analizar lo que está ocurriendo en todo el planeta.

Podemos preguntarnos: ¿Es la corrupción algo sistémico en el régimen político español? Podemos decir que lo es en la medida en que hace posible el pago de favores de las empresas y bancos a las instituciones. Su relación con la delincuencia y el blanqueo de capitales no ha sido bien estudiada, pero existe, pues pocas empresas pueden generar el dinero negro que hoy requiere la corrupción política.

La politización del Tribunal Constitucional supone otro de los grandes escollos institucionales en España. La politización del supremo intérprete de la Constitución ha permitido bloqueos, retrasos y en general una orien-

16 Datos oficiales del Centro de Investigaciones Sociológicas. http://wrerr.cis.es/cis/export/ sites/default/-Archivos/Indicadores/documentos_html/TresProblemas.html 
Esta obra forma parte del acervo de la Biblioteca Jurídica Virtual del Instituto de Investigaciones Jurídicas de la UNAM

tación clara de sus miembros, muchos de los cuales no disimulan sus simpatías o incluso militancias. Un sainete jurídico político. Aunque el Tribunal Constitucional funciona satisfactoriamente en la defensa e interpretación de los derechos fundamentales, su labor como intérprete político deja mucho que desear y debería ser corregida cuanto antes. El caso más grave se produjo con el bloqueo y retraso de cuatro años en la sentencia sobre el recurso de constitucionalidad del Estatuto catalán, lo que supuso que el Estatuto fuera corregido solo después de años de vigencia, lo que implicó una reacción de la opinión en Cataluña que hizo posible que los separatistas se multiplicaran, como los peces y los panes del maná constitucional, por cinco en dos años ${ }^{17}$. La relación entre Cataluña y Madrid nunca ha sido sencilla y hay que conllevarla como decía Ortega, pero el separatismo de amplias capas de la población coincide con la crisis institucional de España y posiblemente cesaría si se pudieran encontrar soluciones para todo el Estado. A la cabeza de esas soluciones, a la cabeza de la regeneración de España deberían estar los catalanes. Sin ellos, sin entender la pluralidad y unidad del Estado, no podremos sobrevivir como nación.

Pero sigamos con el análisis de la crisis institucional, esta vez mirando al modelo electoral. Si los españoles pudiéramos elegir directamente al presidente del Gobierno el problema del separatismo catalán sería mucho menor. Se suele pensar que el problema del separatismo es consecuencia de que el Estado no ha fijado claramente el límite de las competencias de las Comunidades Autónomas. Lo cierto es que ha sido la necesidad de contar con los votos nacionalistas para investir presidentes en el parlamento por parte de los dos grande partidos lo que ha propiciado un traspaso de competencias sin límites reales. La Constitución ha dejado de cumplirse demasiadas veces en Cataluña. La educación nacionalista y la hegemonía de estas ideas han hecho el resto. Pero el problema catalán, la llamada independencia no es el primer problema que preocupa a la ciudadanía de

17 La sentencia del Tribunal Constitucional sobre el Estatuto de Cataluña de 2006 fue hecha pública el 28 de junio de 2010, cuatro años después de la presentación del recurso de inconstitucionalidad interpuesto por el Partido Popular el 31 de julio de 2006 sobre 114 de los 223 artículos del Estatuto de Autonomía de Cataluña de 2006, refrendado por los catalanes en el referéndum celebrado el 18 de junio de 2006.

El Tribunal Constitucional por ocho votos contra dos declaró inconstitucionales 14 artículos y sujetos a la interpretación del tribunal otros 27 (por seis votos contra cuatro). Además el tribunal estimó que "carecen de eficacia jurídica” las referencias que se hacen en el preámbulo del Estatuto a Cataluña como nación y a la realidad nacional de Cataluña. El texto completo del fallo y los cinco votos particulares que la acompañan se conocieron el 9 de julio de 2010 , un día antes de la celebración en Barcelona de la manifestación de rechazo a la sentencia bajo el lema "Som una nació. Nosaltres decidim" ('Somos una nación. Nosotros decidimos'). 
Esta obra forma parte del acervo de la Biblioteca Jurídica Virtual del Instituto de Investigaciones Jurídicas de la UNAM

Cataluña y se sitúa muy lejos de problemas como el paro. Sólo a un $14 \%$ de catalanes confiesan estar preocupados por la independencia, de acuerdo con las últimas encuestas del Centro de Investigaciones Sociológicas. Eso demuestra la naturaleza oligárquica de los cabecillas separatistas, hechos de la misma madera que los del resto de España. Lo que pasa es que los dirigentes nacionalistas siguen explotando dos emociones que a veces sabe combinar muy bien el nacionalismo populista: la rabia y la alegría o ilusión en establecer un nuevo proyecto nacional. ¿Vamos al fondo real del asunto? Cataluña no puede separarse de España porque ningún estado importante de Europa está dispuesto a permitir esa dinámica. Muchos tienen sus problemas y nadie quiere que su estado se divida y que el ejemplo español se extienda. Tras el ideal de la independencia se esconde el complejo de inferioridad por ser españoles de muchos habitantes del norte de España pero también la pulsión de rabia y el encuentro de un culpable de su situación: España. Por mucho que se apele al memorial de agravios históricos (muchos de ellos trágicos y reales pero similares a los de los demás españoles) después de treinta años de hegemonía cultural nacionalista, los independentistas no son todavía mayoría clara. El problema es que la escuela y el tiempo corren a favor de su hegemonía cultural identitaria.

Debemos reconocer que la oligarquía catalana fue sumamente hábil para desviar la pulsión que llevo a las manifestaciones a rodear el Parlament del que tuvieron que huir sus diputados en helicóptero. Desvió aquellas protestas que siguieron al $15 \mathrm{M}$ en Junio de 2011 contra el Estado español. En unos meses toda la rabia se dirigió contra el chivo expiatorio de España. Otra forma de populismo nacionalista. El nacionalismo lleva años corrompido en su gestión de gobierno pero ha sabido crear un enemigo mayor con ayuda de la inflexibilidad y el tancredismo ${ }^{18}$ de Madrid. Hay que recordar que en una Cataluña independiente los responsables actuales de la ruina de Cataluña no serían juzgados.

\section{LA APARICIÓN DE UNA NUEVA PULSIÓN POLÍTICA}

Cuando se produjeron las manifestaciones masivas del $15 \mathrm{M}$ de 2011 una gran parte de la población española se identificó con las reivindicaciones de

18 Relativo al comportamiento de don Tancredo, un personaje cómico de algunos festejos rurales españoles que se queda inmóvil en medio de la plaza, sobre un cajón, esperando que no le pille el toro. 
Esta obra forma parte del acervo de la Biblioteca Jurídica Virtual del Instituto de Investigaciones Jurídicas de la UNAM

las mismas ${ }^{19}$. Su aspecto juvenil puso de manifiesto que el reloj biológico del régimen avanzaba y que nuestro sistema constitucional iniciaba su declive. Las protestas masivas que dieron lugar al movimiento del 15- M fueron alimentadas por el despertar de una conciencia ciudadana que, de acuerdo con los estudios de opinión del Centro de Investigaciones Sociológicas (CIS) evidencian la desconfianza de la mayoría de la población en el sistema y sus gestores. Las protestas de los años 11 y 12 fueron liberadoras pasajeras de las emociones pero no supusieron un cambio de estatus político ni una solución a los problemas de los ciudadanos.

Por entonces, las fuerzas parlamentarias hegemónicas animaron con ciertas dotes de cinismo a los representantes del $15 \mathrm{M}$ a que se presentaran a unas elecciones, lo que entonces resultaba imposible. Tras aquel movimiento ciudadano, un grupo de activistas y politólogos - muchos de ellos antiguos militantes de las juventudes comunistas- decidió ponerse a organizar el movimiento en facultades y barrios y en los medios de comunicación, abandonando un estado de movilización callejera que fue agotándose poco a poco al no obtener resultados revolucionarios ni aportar soluciones políticas.

Los medios de comunicación se han hecho eco reciente de una noticia que dice que el germen de Podemos fue incubado por el Centro de Estudios Políticos y Sociales (CEPS), fundación financiada por el régimen bolivariano ${ }^{20}$. Pero este solo dato no explica el éxito mediático y político de este grupo, que supo conectar con el deseo de cambio y la rabia de millones de españoles. Este mismo grupo de politólogos (entre los que destacan Juan Carlos Monedero, Pablo Iglesias e Iñigo Errejón) sabía que la movilización del 15 M no era una movilización ideológica sino generacional y transversal. Podemos, un partido-movimiento, supo utilizar el carisma de Pablo Iglesias y el apoyo que ciertas cadenas de televisión le prestaron, bien por interés propio (audiencia) o bien por el interés del partido de Gobierno y sus medios afines por dividir a la izquierda española. El caso es que Podemos dio el salto en las elecciones al parlamento europeo.

La sorpresa electoral de las elecciones europeas ${ }^{21}$ del año 2014 vino a constatar la desafección del electorado con los dos grandes partidos herederos de la Transición. Estas dos opciones, que normalmente recogían el $75-80 \%$ de los sufragios se quedaron en un $49 \%$ de los votos. Una verdadera debacle en el sistema de partidos tradicional. A partir de ese momento,

19 Datos oficiales del Centro de Investigaciones Sociológicas http://datos.cis.es/pdf/ Es2905mar A.pdf

20 http://politica.elpais.com/politica/2014/06/17/actualidad/1403039351_862188.html

21 http://elecciones.mir.es/resultados2014/99PE/DPE99999TO.htm 
Esta obra forma parte del acervo de la Biblioteca Jurídica Virtual del Instituto de Investigaciones Jurídicas de la UNAM

Podemos comenzó a subir en las encuestas, colocándose en la primera posición durante muchos meses en el último año. El apoyo de muchos medios de comunicación supuso que este grupo amenazara la posición hegemónica del Partido Socialista en la izquierda. Pero de igual manera que Podemos se benefició de su apoyo mediático, llegado el momento, padeció una campaña de desprestigio y una investigación considerable por parte de algunos medios, que consideran el crecimiento de Podemos un verdadero peligro para el sistema. Muchos políticos de la vieja guardia de la Transición han alertado de lo que implicaría el triunfo del partido populista de izquierdas.

Podemos, sea cual sea su recorrido futuro, ha removido los cimientos de la democracia en España. Al principio acertó a mostrarse como un fuerza transversal, pero la transversalidad de podemos se truncó cuando muchos votantes del centro y centro derecha decidieron buscar otra alternativa al Partido Popular y los medios de comunicación pusieron el foco en un partido llamado Ciudadanos, que hasta entonces era una opción antinacionalista de centro en Cataluña. Este partido antinacionalista nació en Cataluña pero se ha extendido por todo el Estado.

Así como Podemos se nutre de la poderosa emoción de la rabia para llegar a la ilusión del cambio, Ciudadanos ha encarnado el sentido común, que no es precisamente una emoción, tratando de generar una emoción de alegría e ilusión entre sus electores, una alegría que conecta con la memoria de la Transición e intenta establecer un puente inter generacional.

En este mapa de emociones políticas, el Partido Popular ha manifestado desde sus primeros tiempos (Alianza Popular) la emoción del miedo al cambio. Se puede decir que es una formación dinámicamente reaccionaria y precisamente por eso trata de retroalimentarse con la dinámica revolucionaria Podemos. Del mismo modo, el escenario ideal para podemos es encarnar la primera fuerza de la oposición que gestione la rabia contra el Partido Popular. Las opciones menos viscerales, como Ciudadanos y el PSOE han tenido más problemas para movilizar electores. Desde un punto de vista emocional se comprende el pacto que desde hace unos meses han establecido el PSOE y Giudadanos, fuerzas que no se inclinan ni por el miedo conservador ni por la rabia rupturista, sino por la reforma constitucional moderada.

¿Qué ha sucedido en la izquierda? Digamos que los electores del PSOE han basculado entre la tristeza o la desesperanza y la rabia, por eso gran parte de ellos se han ido a Podemos, pero otra parte ha quedado paralizada o convencida de que la indignación escenificada por su líder Sánchez conecta con la indignación de la sociedad. Aunque el instinto de conserva- 
Esta obra forma parte del acervo de la Biblioteca Jurídica Virtual del Instituto de Investigaciones Jurídicas de la UNAM

ción (nostalgia) ha permitido al PSOE no perder la primera posición de la izquierda en los feudos agrarios y en los pequeños municipios, la tendencia parecía indicar que sería superado por Podemos, si esta organización es capaz de unificarse con otras fuerzas periféricas.

Con estos mimbres emocionales los electores decidieron decir basta al viejo estatus bipartidista. Los resultados de las elecciones generales del $2015^{22}$ no dejan lugar a dudas. El régimen ha entrado en crisis y se manifiesta una voluntad de un profundo cambio institucional. Pero ese cambio no tiene a día de hoy fuerza suficiente para llevarse a cabo.

Los viejos partidos españoles han pasado de representar al $80 \%$ de los electores españoles a poco más o menos la mitad de los votantes, siendo más acusado este fenómeno creciente en los grandes núcleos urbanos y entre la población joven. La corrupción sistémica y la precariedad de las condiciones de vida ha supuesto un desgaste de las instituciones y ha afectado a los corrompidos partidos tradicionales (PP y PSOE) llegando a dañar seriamente la imagen de la Corona española, lo que ha provocado la reciente abdicación del rey Juan Carlos I.

Ante la evidencia de los cambios políticos operados desde las pasadas elecciones generales, la opinión publicada, la ciudadanía, los partidos y los expertos en derecho constitucional se dividen en tres grandes bloques.

En primer lugar está el bloque de quienes piensan que no es necesaria una reforma constitucional en profundidad (fuerza conservadora que vehicula el miedo). El Partido Popular, con 123 escaños, posee los votos para ejercer de minoría de bloqueo constitucional. 1/3 de la cámara

En medio se sitúa el bloque de los que sostienen que es necesaria una reforma constitucional que afecte en mayor o menor medida a partes esenciales de la Constitución: sistema electoral, estructura territorial, división de poderes y derechos sociales fundamentales (fuerzas reformistas que intentan sin demasiado éxito la racionalización del problema). PSOE y Ciudadanos suman 130 diputados.

Por último, encontramos el bloque de aquellos que se inclinan por la necesidad de dar paso a un nuevo proceso constituyente donde todo sea discutible y discutido, incluida la forma de Estado y la posible autodeterminación de distintas comunidades autónomas (fuerzas rupturistas y separatistas que conectan con la rabia de la población). Podemos, junto a partidos separatistas catalanistas y vascos suma 96 escaños.

España, fiel a su tradición, después de casi cuarenta años de progreso y estabilidad, afronta un proceso de inestabilidad en el que emergen

22 https://resultadosgenerales2015.interiores/congreso/\#/ES201512-CON-ES/ES 
Esta obra forma parte del acervo de la Biblioteca Jurídica Virtual del Instituto de Investigaciones Jurídicas de la UNAM

las viejas pulsiones españolas motivadas por la incertidumbre y la precariedad y las inquietudes generadas, que basculan, como hemos visto, entre las emociones del miedo y la rabia. El daño económico a la clase media ha supuesto el despertar de tres viejos fantasmas del inconsciente colectivo español: el espectro de las "dos Españas", la reaparición de la lucha de clases en versión populista y la vieja tendencia disgregadora que amenaza la unidad nacional.

Se ha dicho que la crisis española, si no se encauza correctamente, podría provocar un Estado fallido. Es cierto que los agentes económicos y políticos estabilizadores de la Unión Europea hasta el momento se han mostrado eficaces a la hora de contener esta crisis del estado social y nacional en otros lugares como en Grecia, pero sin solucionar los sufrimientos de la gente. Precisamente por eso ese nuevo fantasma del populismo recorre Europa.

\section{EPÍLOGO DESDE UNA ESPAÑA ${ }^{23}$ IMPOTENTE}

Los nuevos resultados electorales, la aparición de dos nuevos partidos (Podemos y Ciudadanos) no tiene precedentes. De un lado muestra una nueva pulsión regeneradora y de otro muestra la impotencia parlamentaria para hacer frente a la grave situación que atraviesa nuestro país. La fragmentación del voto complica la gobernabilidad del país, ya de por sí difícil por la existencia de partidos separatistas en Cataluña, Galicia y País Vasco.

En este escenario, se evidencia el desgaste del régimen político de 1978 y se señala la necesidad de cambios institucionales profundos que pasan por reformular la Constitución Española de 1978, limitada en su origen por la imposibilidad de establecer un verdadero proceso constituyente. Pero la Constitución española, como hemos visto, es sumamente rígida y la reforma de sus partes esenciales exige un consenso y unas cualificadas mayorías parlamentarias que no son posibles en este momento dado el estado emocional de los dirigentes políticos y la división de fuerzas. El parlamentarismo ha mostrado su peor cara: la inestabilidad y e impotencia para formar gobierno.

Hoy los ciudadanos observan deprimidos como los egoísmos de partido (ajenos a los problemas en España) impiden ponerse de acuerdo para formar Gobierno. El sistema parlamentario y el artículo 99 de nuestra Consti-

23 Este trabajo ha sido actualizado con el análisis de aquello sucedido desde febrero hasta el 14 de abril de 2016. 
Esta obra forma parte del acervo de la Biblioteca Jurídica Virtual del Instituto de Investigaciones Jurídicas de la UNAM

tución ${ }^{24}$ exige en España una mayoría que no existe en estos momentos para investir al presidente del Gobierno. El espectáculo bochornoso que están dando los líderes ha desgastado a casi todas las fuerzas, con la excepción del partido Ciudadanos y quizá el PSOE, que han sido quienes en apariencia han tratado de pactar.

Pero los problemas que ha de enfrentar España superan ya la vieja política nacional. Gobierne quien gobierne deberá obedecer los requerimientos económicos de la Comisión Europea para recortar el déficit y deberá afrontar la necesaria creación de empleo favoreciendo a la pequeña y mediana empresa. Sin esas medidas, España está abocada a la quiebra y la pobreza, sea el gobierno de izquierdas o de derechas.

El mecanismo fáctico del Consenso que hizo posible una Transición controlada a la democracia fue viable por el acuerdo interesado entre vencedores y vencidos de la guerra civil. Sin embargo, hoy por hoy, no hay nada que haga mirar a los partidos más allá de sus alicortos intereses y sus particulares emociones primarias e intereses oligárquicos. Esto reproduce un alejamiento entre electores y elegidos que facilita la persistencia de una opción populista, pero incluso esa opción tiende a desgastarse al no ser capaz de conseguir lo que pregona y al dar muestras de frivolidad parlamentaria. Los ciudadanos esperan mucho de quien promete mucho y no ven con buenos ojos los juegos parlamentarios de una fuerza que pregona un cambio de régimen.

Desde que terminé esta conferencia, a mi llegada a España, constato que una nueva emoción ha hecho su aparición en el escenario. Las expectativas creadas por la aparición de los nuevos partidos se han visto defrauda-

24 El artículo 99 de nuestra Constitución establece:

1. Después de cada renovación del Congreso de los Diputados, y en los demás supuestos constitucionales en que así proceda, el Rey, previa consulta con los representantes designados por los grupos políticos con representación parlamentaria, y a través del Presidente del Congreso, propondrá un candidato a la Presidencia del Gobierno.

2. El candidato propuesto conforme a lo previsto en el apartado anterior expondrá ante el Congreso de los Diputados el programa político del Gobierno que pretenda formar y solicitará la confianza de la Cámara.

3. Si el Congreso de los Diputados, por el voto de la mayoría absoluta de sus miembros, otorgare su confianza a dicho candidato, el Rey le nombrará Presidente. De no alcanzarse dicha mayoría, se someterá la misma propuesta a nueva votación cuarenta y ocho horas después de la anterior, y la confianza se entenderá otorgada si obtuviere la mayoría simple.

4. Si efectuadas las citadas votaciones no se otorgase la confianza para la investidura, se tramitarán sucesivas propuestas en la forma prevista en los apartados anteriores.

5. Si transcurrido el plazo de dos meses, a partir de la primera votación de investidura, ningún candidato hubiere obtenido la confianza del Congreso, el Rey disolverá ambas Cámaras y convocará nuevas elecciones con el refrendo del Presidente del Congreso. 
Esta obra forma parte del acervo de la Biblioteca Jurídica Virtual del Instituto de Investigaciones Jurídicas de la UNAM

das en pocos meses. Tras meses de gallinero parlamentario y de ubicuidad mediática, los partidos no consiguen ponerse de acuerdo y se manifiestan como un problema y no como una solución. Los ciudadanos han sufrido un proceso de desgaste y en ellos asoma una sensación de hartazgo y tristeza. A niveles inconscientes, muchos de ellos comienzan a sentir verdadero asco y alejamiento del proceso parlamentario de estos meses, donde ningún partido ha conseguido convencer y donde se ha practicado una forma de hipocresía institucional nueva en nuestro país.

Se constata así el agotamiento del régimen del 78, pero también se constata la incapacidad para generar la ilusión y la potencia suficiente para generar un cambio acorde a los intereses de la sociedad. Estamos pues ante una profunda crisis de imaginarios y un agotamiento de las emociones políticas. España ante la incertidumbre. 
Esta obra forma parte del acervo de la Biblioteca Jurídica Virtual del Instituto de Investigaciones Jurídicas de la UNAM

\section{LA DIALÉGTICA GAMBIO-PERMANENGIA CONSTITUGIONAL: A PROPÓSITO DEL ANTEPROYECTO DE TEXTO REORDENADO Y GONSOLIDADO DE LA GONSTITUCIÓN POLÍTICA DE LOS ESTADOS UNIDOS MEXICANOS*}

Imer B. FLORES**

$[\mathrm{N}]$ inguna sociedad puede hacer una constitución perpetua, e inclusive un derecho perpetuo. La tierra pertenece a la generación viviente.

Thomas JEFFERSON (1789)

[N]ingún pueblo debe ser impedido para que se dé a sí mismo la constitución que bien le parezca.

Immanuel KANT (1798)

* Versión revisada de la ponencia presentada en la Mesa I. La reordenación y consolidación del texto de la Constitución mexicana de 1917, Tema III. La Dialéctica PermanenciaCambio Constitucional. Las opciones a futuro, VII Congreso Nacional de Derecho Constitucional, Facultad de Derecho de la Universidad Autónoma de San Luis Potosí (UASLP), Instituto Iberoamericano de Derecho Constitucional (IIDC), e Instituto de Investigaciones Jurídicas de la Universidad Nacional Autónoma de México (UNAM), en San Luis Potosí, San Luis Potosí (México), el 5 de febrero de 2016.

** Investigador, Instituto de Investigaciones Jurídicas, UNAM; Profesor, Facultad de Derecho, UNAM; Tutor, Posgrado en Derecho, UNAM; reconocimientos PRIDE D y SNI III. Correo electrónico:imer@unam.mx. Twitter: @imerbflores. El autor agradece a Isidro de los Santos, José María Serna de la Garza, y Diego Valadés la invitación para participar en el Congreso; y a José Luis Caballero Ochoa y a César de J. Molina Suárez, por compartir la mesa y, por supuesto, sus comentarios y observaciones, así como los de Jaime Cárdenas Gracia, Héctor Fix-Fierro, José Gamas Torruco, Carla Huerta, Francisco A. Ibarra Palafox, Francisco José Paoli Bolio, Pedro Salazar, y Salvador Valencia Carmona. 
Esta obra forma parte del acervo de la Biblioteca Jurídica Virtual del Instituto de Investigaciones Jurídicas de la UNAM

SUMARIO: I. Introducción. II. Constitución: actividad/proceso y producto/ resultado. III. Teoría y práctica de la dialéctica cambio-permanencia constitucional. IV. Los alcances y las limitaciones de la dinámica actual vía reformas parciales. V. Las alternativas en el futuro. VI. La revisión técnicojuridica vía reordenación y consolidación. VII. Conclusión.

\section{INTRODUCGIÓN}

Conmemorar el nonagésimo noveno aniversario de la Constitución de 1917 y el centésimo quincuagésimo noveno de la Constitución de 1857 ofrece la ocasión propicia para reflexionar no solamente sobre la dialéctica cambiopermanencia constitucional sino además sobre las alternativas en el futuro próximo, con especial referencia al Anteproyecto de texto reordenado y consolidado de la Constitución Política de los Estados Unidos Mexicanos. ${ }^{1}$

Así, comenzamos con un estudio no sólo sobre la naturaleza de la Constitución, a partir de su ambigüedad como actividad/proceso y producto/resultado, y de la dialéctica entre cambio-permanencia constitucional, sino también sobre los alcances y las limitaciones de la dinámica actual vía reformas parciales; continuamos con un examen de las alternativas en el futuro, con especial referencia a la revisión técnico-jurídica vía la reordenación y consolidación del texto constitucional; y concluimos con una especulación final.

\section{CONSTITUGIÓN: ACTIVIDAD/PROCESO Y PRODUCTO/RESULTADO}

La palabra ‘constitución’ está afectada por la ambigüedad actividad/proceso y/o producto resultado, pues cualquier diccionario la define como la "acción y efecto de constituir"; y 'constituir', a su vez, como "formar, componer, ser parte o elemento esencial de un todo" o "fundar, establecer u ordenar". Cabe aclarar que usamos el mismo término 'constitución' para referirnos tanto a una acción como a un efecto, i.e. el efecto de haber realizado dicha acción. El término 'constitución' sugiere dos cosas diferentes pero estrechamente relacionadas entre sí:

1 Vid. Héctor Fix-Fierro y Diego Valadés (coords.), Constitución Política de los Estados Unidos Mexicanos: Texto reordenado y consolidado. Ley de Desarrollo Constitucional. Anteproyecto, México, Instituto de Investigaciones Jurídicas, Universidad Nacional Autónoma de México, Instituto Iberoamericano de Derecho Constitucional, Senado de la República, Cámara de Diputados. LXIII Legislatura, Centro de Estudios de Derecho e Investigaciones Parlamentarias, 2016. 
Esta obra forma parte del acervo de la Biblioteca Jurídica Virtual del Instituto de Investigaciones Jurídicas de la UNAM

1) Actividad/proceso = el acto mismo de constituir; $y$

2) Producto $/$ resultado $=$ el efecto de haber constituido.

A partir de dicha ambigüedad, podemos sugerir que la constitución como actividad/proceso es lo que está por ser constituido --y hasta re-constituido-- y como producto/resultado es lo que está ya constituido --y hasta re-constituido--. De lo anterior se desprende que es una especie de espejo doble que refleja a la vez: dónde estamos y a dónde vamos, quiénes somos y quiénes queremos ser, qué tenemos y qué aspiramos a tener.

Por lo anterior, la constitución puede ser entendida como un programa o proyecto normativo de corto y de largo plazo. Baste evocar: 1) a Thomas Jefferson, para quien "La constitución y las leyes de sus predecesores se extinguen entonces en el curso natural con quienes les dieron existencia... Entonces cada constitución, cada ley, expira naturalmente al término de 19 años. Si es aplicada por más tiempo, es un acto de fuerza, y no de derecho."2 Y, 2) a John Marshall, para quien "una constitución no participa de la prolijidad de un código legal... una constitución pretende perdurar por las eras venideras, y, consecuentemente, debe ser adaptada a las varias crisis de las relaciones humanas."

Es conveniente abrir un breve paréntesis para recordar que Jefferson, a la sazón embajador estadounidense en Francia, en la carta dirigida a James Madison, adelantaría el principio "La tierra siempre pertenece a los vivos, y no a los muertos", ${ }^{4}$ al ser el primero en preguntar: "Si acaso una generación tiene el derecho a vincular a otra"; ${ }^{5}$, en responder: ${ }^{6}$

2 Thomas Jefferson, "Letter to James Madison" (Paris, September 6, 1789) en Merrill D. Peterson (ed.), The Portable Thomas Fefferson, Kingsport, Tennessee, Penguin Books, 1977, p. 449: "The constitution and the laws of their predecessors [are] extinguished then in their natural course with those who gave them being... Every constitution then, and every law, naturally expires at the end of 19 years. If it be enforced longer, it is an act of force, and not of right." (la traducción es nuestra.)

3 McCulloch v. Maryland, 17 U.S. 316, 407, 415 (1819): "A constitution does not partake of the prolixity of a legal code... a constitution, intended to endure for ages to come, and, consequently, to be adapted to the various crises of human affairs." (La traducción es nuestra.)

4 Jefferson, "Letter to James Madison", cit. en la nota 2, Ibid., p. 450: "[T] he earth belongs to the living, and not to the dead." (La traducción es nuestra.)

5 Ibid., p. 445: "The question Whether one generation of men has a right to bind another, seems never to have been started either on this or our side of the water." (La traducción es nuestra.)

$6 \quad$ Ibid., p. 449: "[N]o society can make a perpetual constitution, or even a perpetual law. The earth belongs always to the living generation. They may manage it then, and what proceeds from it, as they please, during their usufruct. They are masters too of their own persons, and consequently may govern them as they please." (La traducción es nuestra.) 
Esta obra forma parte del acervo de la Biblioteca Jurídica Virtual del Instituto de Investigaciones Jurídicas de la UNAM

$[\mathrm{N}]$ inguna sociedad puede hacer una constitución perpetua, e inclusive un derecho perpetuo. La tierra pertenece a la generación viviente. Ellos pueden entonces administrarla, y lo que procede de ella, como les plazca, durante su usufructo. Ellos son los arquitectos de sus personas, y consecuentemente pueden gobernarse a sí mismos como les plazca.

Por su parte, Immanuel Kant haría suyos estos conceptos, cuando al responder a la pregunta de "Si el género humano se halla en progreso constante hacia mejor" concluye: "[N] ingún pueblo debe ser impedido para que se dé a sí mismo la constitución que bien le parezca". ${ }^{7}$

Coincidencia o no: un estudio reciente de Zachary Elkins, Tom Ginsburg y James Melton, publicado en 2009, titulado "The Endurance of National Constitutions", en el marco del "Comparing Constitutions Project", ha venido a confirmar la intuición jeffersoniana de que la vida promedio de las constituciones es de 20 años (una generación) y el imperativo kantiano. ${ }^{8}$

No obstante, en la actualidad hay al menos una decena de constituciones que han perdurado más de un siglo (o están muy próximas a su primer centenario como la mexicana de 1917) (ver tabla 1):

\begin{tabular}{|c|c|c|}
\hline \multicolumn{3}{|c|}{ Tabla 1. } \\
\hline 1. & 1600 & San Marino \\
\hline 2. & $1788-1791$ & Estados Unidos de América \\
\hline 3. & 1814 & Noruega \\
\hline 4. & 1815 & Países Bajos \\
\hline 5. & 1831 & Bélgica \\
\hline 6. & 1849 & Dinamarca \\
\hline 7. & 1853 & Argentina \\
\hline 8. & 1857 & México \\
\hline 9. & 1868 & Luxemburgo \\
\hline 10. & 1875 & Tonga \\
\hline 11 & 1901 & Australia \\
\hline 12. & 1917 & México \\
\hline
\end{tabular}

Como se puede apreciar, incluimos a la Constitución mexicana tanto en el $8^{\circ}$ como en el $12^{\circ}$ lugar. La explicación es simple: La Constitución de

7 Immanuel Kant, "Si el género humano se halla en progreso constante hacia mejor", en Filosofia de la historia, trad. Eugenio Ímaz, México, Fondo de Cultura Económica, 1979, p. 106. (Publicación original: 1798)

8 Vid. Zachary Elkins et al., The Endurance of National Constitutions, New York, Cambridge University Press, 2009. 
Esta obra forma parte del acervo de la Biblioteca Jurídica Virtual del Instituto de Investigaciones Jurídicas de la UNAM

1917 fue la resultante de una reforma total a la Constitución de 1857, tal y como lo consagra su rubro "Constitución Política de los Estados Unidos Mexicanos, que reforma la del 5 de febrero de 1857" y como tal puede ser concebida como la misma Constitución de 1857, pero reformada en 1917.9 No obstante, como la reforma total de 1917 implicó una revisión integral a la de 1857 puede ser entendida como una nueva Constitución. ${ }^{10}$ (Nótese que en este último caso, no deberíamos contabilizar la de 1857 y, en consecuencia, al suprimir la misma y al recorrer la numeración, la de 1917 ocuparía el $11^{\circ}$ lugar entre las constituciones más longevas del mundo.)

Ahora bien, en el estudio citado, los autores explican la longevidad de las constituciones, a partir de la correlación entre tres principios: 1) adaptabilidad / flexibilidad; 2) inclusividad; y 3) gobernabilidad. En este orden de ideas, nos gustaría insistir que la Constitución como programa o proyecto normativo no es sino un experimento, como diría Oliver Wendell Holmes Jr.: "Nuestra Constitución... es un experimento, como toda la vida es un experimento." 11 De igual forma, la Constitución como toda obra humana no está acabada ni es perfecta sino que está inacabada y es perfectible. ${ }^{12}$

9 Algo parecido sucede con la Constitución de la República de la Argentina de 1853, misma que ha sido reformada en varias ocasiones, incluida la más reciente de 1994.

10 Vid. Imer B. Flores, "La Constitución de 1857 y sus reformas: A 150 años de su promulgación", en Diego Valadés y Miguel Carbonell (eds.), El proceso constituyente mexicano. A 150 años de la Constitución de 1857 y a 90 años de la Constitución de 1917, México, Instituto de Investigaciones Jurídicas, Universidad Nacional Autónoma de México, 2007, p. 286; y "El legado histórico-jurídico de la Constitución de 1857 y de sus reformas: reforma, restauración y revolución”, en Margarita Moreno-Bonett y Martha López Castillo (coords.), La Constitución de 1857. Historia y legado. Edición conmemorativa del bicentenario de la independencia y del centenario de la revolución mexicana (1810-1910), México, Facultad de Filosofía y Letras, Universidad Nacional Autónoma de México, y Recinto Parlamentario de la Secretaría de Hacienda y Crédito Público, 2009, p. 365.

11 Abrams v. United States, 250 U.S. 616, 630 (1919): "Our Constitution... is an experiment, as all life is an experiment."

12 Vid. Antonio Martínez Báez, "La constitución: Obra humana. Inacabada y perfectible", en Obras. Vol. I Obras político-constitucionales, México, Universidad Nacional Autónoma de México, 1994, pp. 67-70. (Título y publicación original: "Las lagunas de la Constitución", Excélsior, 4 de febrero de 1967.) Vid. también Sanford Levinson, "Introduction: Imperfection and Amendability", en Sanford Levinson (ed.), Responding to Imperfection. The Theory and Practice of Constitutional Amendment, Princeton, Princeton University Press, 1995, pp. 3-11; John Ferejohn, "Review: The Politics of Imperfection: The Amendment of Constitutions", Law E Social Inquiry, Vol. 22, No. 2 (Spring), 1997, pp. 501-530; James E. Fleming, Fidelity to Our Imperfect Constitution. For Moral Readings and Against Originalisms, Oxford, Oxford University Press, 2015; e Imer B. Flores, "On James E. Fleming's Fidelity to Our Imperfect Constitution: Intelligent or Unintelligent Fidelity?” disponible en: http://papers.ssrn.com/sol3/papers. cfm?abstract id $=2758438$. 
Esta obra forma parte del acervo de la Biblioteca Jurídica Virtual del Instituto de Investigaciones Jurídicas de la UNAM

Así, al reconocer que la Constitución no está acabada ni es perfecta sino inacabada y perfectible, resulta que es necesario adaptarla a la cambiante realidad, ya sea mediante enmiendas y reformas, así como por medio de interpretaciones, caracterizadas por ser más o menos incluyentes (o inclusivas) de los acuerdos políticos, pero sin poner en riesgo su gobernabilidad (o viabilidad).

\section{TEORÍA Y PRÁGTICA DE LA DIALÉGTICA CAMBIO-PERMANENCIA CONSTITUCIONAL}

El reto es conciliar lo aparentemente irreconciliable: el cambio y la permanencia, i.e. un cambio con permanencia (léase evolución), el cual es dialécticamente superior, como diría Kant, ${ }^{13}$ a las otras dos alternativas: un cambio sin permanencia (léase revolución); y peor aún a una permanencia sin cambio (léase simulación o "gatopardismo", i.e. la apariencia de cambio pero todo permanece tal cual, como en El gato pardo de Giuseppe Tomasi, Duque de Palma y príncipe de Lampedusa). ${ }^{14}$

El locus clásico lo constituye la celebérrima polémica entre dos filósofos pre-socráticos, Heráclito de Éfeso y Parménides de Elea, quienes representan las tesis opuestas del cambio y de la permanencia, respectivamente. Así, para el primero "Lo único constante y perpetuo es el movimiento", y para el segundo "El ser es uno, continuo y eterno". De esta guisa, el efesio explica el cambio: "es imposible bañarse dos veces en el mismo río." Por su parte, el eleático ilustra la permanencia: "la realidad del ser es única (por consiguiente, eterna)... la eternidad del ser y la imposibilidad del cambio lo sitúan en un constante presente." 15

No obstante, en la literatura jurídica, lo anterior no parece ser sino un pseudo-problema, pues diferentes autores, tales como Benjamin Cardozo y Roscoe Pound, han advertido no solamente sobre la existencia de dos nece-

13 Vid. Kant, "Si el género humano se halla en progreso constante hacia mejor", cit. en la nota 7, p. 116: "[P] ara lo cual sería necesario que el Estado se reformase a sí mismo de tiempo en tiempo y, ensayando la evolución en lugar de la revolución, progresara de continuo hacia mejor."

14 Vid. Imer B. Flores, "Heráclito vis-à-vis Parménides: Cambio y permanencia como la principal función del derecho en una democracia incipiente", en Luis J. Molina Piñeiro et al. (coords.), Funciones del derecho en las democracias incipientes. El caso de México, México, Porrúa y Facultad de Derecho, Universidad Nacional Autónoma de México, 2005, pp. 168-169.

15 Federico Ferro Gay, Los filósofos presocráticos. De Homero a Demócrito, México, Secretaría de Educación Pública, 1987, pp. 73, 82 y 95. Vid. Flores, "Heráclito vis-à-vis Parménides...", cit. en la nota 14, pp. 149-150. 
Esta obra forma parte del acervo de la Biblioteca Jurídica Virtual del Instituto de Investigaciones Jurídicas de la UNAM

sidades: la de cambio (o adaptabilidad) y la de permanencia (o estabilidad), sino además sobre la importancia de reconciliar ambas. ${ }^{16}$

Para explicitar la posibilidad de reconciliar ambas recurrimos a la metáfora del "árbol viviente". Dicha metáfora, por una parte, puede ser rastreada hasta John Stuart Mill: "La naturaleza humana no es una máquina que se construye según un modelo y dispuesta a hacer exactamente el trabajo que le sea prescrito, sino un árbol que necesita crecer y desarrollarse por todos lados, según las tendencias de sus fuerzas interiores, que hacen de él una cosa viva." 17 Y, por la otra, ha sido popularizada tanto por la práctica de algunas Cortes Supremas (como la canadiense) como por la teoría de Wilfrid J. Waluchow: ${ }^{18}$

La concepción del árbol viviente conecta las dos aproximaciones [i.e. estabilidad y adaptabilidad] en una clase de entendimiento de derecho común de las Declaraciones de Derechos --una que busca combinar la estabilidad relativa del derecho escrito atrincherado y la adaptabilidad relativa del derecho común.

Waluchow sigue a H.L.A. Hart, quien ha distinguido - al interior de sus reglas secundarias - entre las reglas de cambio (o de legislación, en un

16 Vid. Benjamin Cardozo, The Nature of the Fudicial Process, New Haven, Yale University Press, 1921 (hay versión en español: La función judicial, trad. Victoria Cisneros y Leonel Pereznieto Castro, Atizapán de Zaragoza, Pereznieto editores, 1996); y The Growth of the Law, New Haven, Yale University Press, 1924; y Roscoe Pound, Interpretations of Legal History, New York, The Macmillan Co., 1923 (hay reimpresión: Cambridge, Massachusetts, Harvard University Press, 1946; y edición electrónica: 2014); y Law Finding Through Experience and Reason, Athens, University of Georgia Press, 1960.

17 John Stuart Mill, On Liberty, Indianapolis, Hackett, 1978, pp. 56-57: "Human nature is not a machine to be built after a model, and set to do exactly the work prescribed for it, but a tree, which requires to grow and develop itself on all sides, according to the tendency of the inward forces which make it a living thing." (Publicación original: 1859; y hay versión en español: Sobre la libertad, trad. Pablo de Azcárate, Madrid, Alianza editorial, 1970, p. 130.)

18 W.J. Waluchow, A Common Law Theory of Fudicial Review. The Living Tree, Cambridge, Cambridge University Press, 2007, p. 183: "The living tree conception brings these two approaches [i.e. fixity and adaptability] together into a kind of common law understanding of Charters - one that seeks to combine both the relative fixity of entrenched written law and the relative adaptability characteristic of the common law." (La traducción es nuestra.) (Hay versión en español: Una teoría del control judicial de constitucionalidad basada en el common law. Un árbol vivo, trad. Pablo de Lora, Madrid, Marcial Pons, 2009, p. 269: "La concepción basada en el árbol vivo aúna estas dos aproximaciones en una suerte de concepción de las Declaraciones de Derechos basadas en el common law --una visión que busca combinar tanto la relativa fijeza del derecho escrito y atrincherado cuanto la relativa adaptabilidad característica del common law--.") Vid. Imer B. Flores, "The Living Tree Constitutionalism: Fixity and Flexibility", Problema. Anuario de Filosofia y Teoría del Derecho, No. 3, 2009, pp. 37-74. 
Esta obra forma parte del acervo de la Biblioteca Jurídica Virtual del Instituto de Investigaciones Jurídicas de la UNAM

sentido amplio) y las reglas de adjudicación. ${ }^{19}$ Así, podemos identificar dos grandes tipos de cambio constitucional:

1)Cambio constitucional vía legislación (léase enmiendas, reformas y hasta una nueva Constitución); y

2)Cambio constitucional vía adjudicación (léase cambios en los criterios o precedentes de interpretación).

\section{Cambio constitucional vía legislación (léase enmiendas, reformas y hasta una nueva Constitución)}

En menos de cien años, en México, se han promulgado 227 Decretos de reforma a la Constitución, contabilizada la publicada en el Diario Oficial de la Federación (DOF), del 29 de enero de 2016, en materia de Reforma Política de la Ciudad de México, como la más reciente. Lo anterior da lugar a 2.29 reformas por año. Aclaro que preferimos contar las reformas a partir del número de Decretos de reforma y no del número de artículos reformados. La razón es simple: muchas veces un solo decreto implica que el cambio de terminología se replica en varias decenas de artículos sin que haya una transformación mayor, como por ejemplo con el misma modificación de Distrito Federal a Ciudad de México.

El Decreto 114, el cual está exactamente a la mitad, fue publicado en el DOF del 10 de agosto de 1987, junto a los Decretos del 113 al 116. Como se puede apreciar prácticamente la mitad de Decretos fueron promulgados en los primeros 70 años de vigencia de la Constitución de 1917 y la otra mitad en los últimos 29 años. De igual forma, 65 Decretos fueron publicados en los primeros 50 años, a razón de 1.3 Decretos por año (o casi 4 Decretos en 3 años); y 162 en los restantes 49 años, a razón de 3.3 Decretos por año

19 Vid. H.L.A. Hart, The Concept of Law, Oxford, Oxford University Press, 1961. (Hay versión en español: El concepto del derecho, trad. Genaro R. Carrió, Buenos Aires, Abeledo Perrot, 1963.) (Hay 2a ed. con "Postscript", Oxford, Oxford University Press, 1994; y versión en español: Post scríptum al concepto del derecho, trad. Rolando Tamayo y Salmorán, México, Universidad Nacional Autónoma de México, 2000.) Vid. también W.J. Waluchow, Inclusive Legal Positivism, Oxford, Oxford University Press, 1994 (hay versión en español: Positivismo jurídico incluyente, trad. Marcela S. Gil y Romina Tesone, y rev. tec. Hugo Zuleta, Madrid, Marcial Pons, 2007); e Imer B. Flores, "The Quest for Legisprudence: Constitutionalism v. Legalism”, en Luc J. Wintgens (ed.), The Theory and Practice of Legislation: Essays on Legisprudence, Aldershot, Ashgate, 2005, pp. 26-52; "Legisprudence: The Forms and Limits of Legislation", Problema. Anuario de Filosofia y Teoría del Derecho, No. 1, 2007, pp. 247-266; y "Legisprudence: The Role and Rationality of Legislators --vis-à-vis Judges-- towards the Realization of Justice", Mexican Law Review, New Series, Vol. 1, No. 2, 2009, pp. 91-110. 
Esta obra forma parte del acervo de la Biblioteca Jurídica Virtual del Instituto de Investigaciones Jurídicas de la UNAM

(o casi 10 Decretos en 3 años), i.e. alrededor de 6 Decretos más en el mismo período. Lo anterior sugiere que la dialéctica cambio-permanencia se ha visto acelerada en los últimos años.

\section{Cambio constitucional vía adjudicación (léase cambios} en los criterios o precedentes de interpretación)

Como ya vimos, también es posible el cambio constitucional por la vía de la adjudicación, es decir al cambiar el criterio o precedente de interpretación. Dicho fenómeno es caracterizado en la doctrina como "mutación constitucional". ${ }^{20}$ En el caso mexicano, vale la pena mencionar las diferentes interpretaciones que se la han dado al artículo 133 de la Constitución general de la República, ya sea para:

A. Establecer el "monopolio indebido" de la Suprema Corte de Justicia de la Nación para interpretar la Constitución general de la República; y

B. Estipular los términos de la jerarquía normativa de leyes y tratados.

Antes de continuar, es oportuno recordar los términos originales de dicho artículo:

Artículo 133.- Esta Constitución, las Leyes del Congreso de la Unión que emanen de ella, y todos los tratados hechos y que se hicieren por el Presidente de la República, con aprobación del Congreso, serán la ley suprema de toda la Unión. Los jueces de cada Estado se arreglarán a dicha Constitución, Leyes y Tratados, a pesar de las disposiciones en contrario que pueda haber en las constituciones o leyes de los Estados.

Con posterioridad el mismo numeral fue objeto de sendos Decretos de reforma: primero, el Decreto 16, publicado en el DOF, del 18 de enero de 1934, para modificar no solamente la redacción sino además los términos de la celebración de los tratados, de aprobación del "Congreso" (léase ambas cámaras) a del "Senado" (léase una sola cámara):

Artículo 133. Esta Constitución, las Leyes del Congreso de la Unión que emanen de ella y todos los Tratados que estén de acuerdo con la misma, celebrados y que se celebren por el Presidente de la República, con aprobación del Senado, serán la Ley Suprema de toda la Unión. Los jueces de cada Estado se arre-

20 Vid. José Afonso Da Silva, "Mutaciones constitucionales", Cuestiones Constitucionales. Revista Mexicana de Derecho Constitucional, No. 1, julio-diciembre, 1999, pp. 3-24. 
Esta obra forma parte del acervo de la Biblioteca Jurídica Virtual del Instituto de Investigaciones Jurídicas de la UNAM

glarán a dicha Constitución, leyes y tratados, a pesar de las disposiciones en contrario que pueda haber en las Constituciones o leyes de los Estados.

Y, más recientemente, con el ya citado Decreto 227, para modificar los términos de cada "Estado" a cada "entidad federativa" y quedar hasta este momento:

Artículo 133.- Esta Constitución, las Leyes del Congreso de la Unión que emanen de ella y todos los Tratados que estén de acuerdo con la misma, celebrados y que se celebren por el Presidente de la República, con aprobación del Senado, serán la Ley Suprema de toda la Unión. Los jueces de cada entidad federativa se arreglarán a dicha Constitución, leyes y tratados, a pesar de las disposiciones en contrario que pueda haber en las Constituciones o leyes de los Estados.

\section{A. Establecer el "monopolio indebido" de la Suprema Corte de Fusticia de la Nación para interpretar la Constitución general de la República}

Desde un comienzo, a la Suprema Corte de Justicia de la Nación le correspondieron las funciones de control de constitucionalidad, en lo que da lugar a un modelo de control concentrado, pero resulta que la segunda parte del artículo 133 dejaba abierta la posibilidad de un modelo de control difuso por parte de los jueces locales; y, en consecuencia, el sistema mexicano podría ser caracterizado como un modelo de control híbrido o mixto, i.e. concentrado en unos casos y difuso en otros.

No obstante, a principios de la década de los 1940's, la entonces Segunda Sala de la Suprema Corte de Justicia de la Nación, al conocer el Amparo 4072-1941/2a a partir del proyecto de sentencia elaborado por Gabino Fraga, ministro presidente de dicha Sala, y al responder a la pregunta $\dot{i}$ Pueden conocer de problemas de constitucionalidad de leyes, autoridades distintas del Poder Judicial de la Federación?, resolvió que dicha atribución era exclusiva del Poder Judicial Federal y que la única vía era el amparo.

El proyecto de sentencia fue publicado ${ }^{21}$ en la Revista de la Escuela Nacional de Furisprudencia, ahora Facultad de Derecho, de la Universidad Nacional Autónoma de México, y sería seriamente criticado y cuestionado, en el número subsiguiente de la misma revista, por los profesores Antonio Mar-

21 Vid. Gabino Fraga, “¿Pueden conocer de problemas de Constitucionalidad de Leyes, autoridades distintas del Poder Judicial de la Federación?”, Revista de la Escuela Nacional de Furisprudencia, Tomo IV, Nos. 13-14, enero-junio, 1942, pp. 131-147. 
Esta obra forma parte del acervo de la Biblioteca Jurídica Virtual del Instituto de Investigaciones Jurídicas de la UNAM

tínez Báez ${ }^{22}$ y Antonio Carrillo Flores. ${ }^{23}$ El primero anota "Es infundada y abiertamente contraria a los textos y a los principios constitucionales la tesis que... atribuye al Poder Judicial de la Federación competencia exclusiva para conocer la regularidad de fondo o constitucionalidad de las leyes ordinarias"; ${ }^{24}$ en tanto que el segundo apunta "el deber de un órgano cualquiera de la autoridad para obedecer los textos constitucionales y desentenderse de la ley secundaria que los quebrante, no es dudoso. ${ }^{25}$

\section{B. Estipular los términos de la jerarquía normativa de leyes y tratados ${ }^{26}$}

Como es sabido: en 1992, antes de la reforma constitucional y legal en materia de administración de justicia de 1994-1995, la Suprema Corte, con el voto de los 18 ministros presentes del total de 21, decidió de manera unánime que leyes y tratados "ocupan, ambos, el rango inmediatamente inferior a la Constitución en la jerarquía de norma" y que al tener "la misma jerarquía, el tratado internacional no puede ser criterio para determinar la constitucionalidad de una ley ni viceversa." ${ }^{27}$

Con posterioridad, en 1999, después de la mencionada reforma de 1994-1995, este criterio fue revisado y abandonado por la propia Corte, al ser sustituido también de modo unánime, por el voto de los 10 ministros presentes del total de 11, quienes decidieron que "los tratados internacionales se encuentran en un segundo plano inmediatamente debajo de la ley fundamental y por encima del derecho federal y el local" y que en consecuencia el tratado internacional sí puede ser criterio para determinar la constitucionalidad de una ley, pero no a la inversa. ${ }^{28}$

22 Vid. Antonio Martínez Báez, "El indebido monopolio del Poder Judicial de la Federación para conocer de la inconstitucionalidad de leyes", Revista de la Escuela Nacional de furisprudencia, Tomo IV, No. 15, julio-septiembre, 1942, pp. 243-253.

23 Vid. Antonio Carrillo Flores, "El ejecutivo y las leyes inconstitucionales", Revista de la Escuela Nacional de Furisprudencia, Tomo IV, No. 15, julio-septiembre, 1942, pp. 255-266.

24 Martínez Báez, cit. en la nota 22, p. 252.

25 Carrillo Flores, cit. en la nota 23, p. 256.

26 Vid. Imer B. Flores, "Sobre la jerarquía normativa de leyes y tratados: A propósito de la (eventual) revisión de una tesis", Cuestiones Constitucionales. Revista Mexicana de Derecho Constitucional, No. 13, julio-diciembre, 2005, pp. 235-249.

27 "Leyes y tratados internacionales, tienen la misma jerarquía normativa", Seminario Fudicial de la Federación, México, 8 época, t. LX, No. 205,596, P. C/1992, diciembre, p. 27.

28 "Tratados internacionales. Se ubican jerárquicamente por encima de las leyes federales y en segundo plano respecto de la Constitución federal", Seminario fudicial de la Federación, México, 9a época, t. X, No. 192,867, P. LXXVII/1999, noviembre, 1999, p. 46. 
Esta obra forma parte del acervo de la Biblioteca Jurídica Virtual del Instituto de Investigaciones Jurídicas de la UNAM

\section{LOS ALCANCES Y LAS LIMITACIONES}

\section{DE LA DINÁMICA ACTUAL VÍA REFORMAS PARGIALES}

Si bien los 227 Decretos de reforma a la Constitución general de la República en 99 años, a sazón de 2.29 reformas por año, parecen sugerir que hemos adaptado con éxito la Constitución a la cambiante realidad nacional, al actualizar y hasta modernizar sus contenidos, resulta que las reformas parciales por sí mismas no garantizan una dialéctica exitosa. De entrada habría que destacar que no solamente se ha acelerado la dinámica del cambio vía reformas parciales en los últimos 35 años desde 1982 sino además ha aumentado la extensión de la Constitución al grado de haber triplicado el texto en menos de cien años. Lo anterior implica un problema doble: la inflación legislativa (problema cuantitativo) y la deflación legislativa (problema cualitativo), caracterizada por la inclusión, por un lado, de una infinidad de reformas, algunas quizás no estrictamente necesarias, y, por el otro, de una inmensidad de legislación secundaria con rango constitucional. ${ }^{29}$

En cuanto a la extensión de las constituciones, resulta que la más extensa del mundo es la de la India, con 444 artículos, 118 enmiendas y 117,369 palabras, y la menos es la de los Estados Unidos de América, con 7 artículos, 27 enmiendas y 4,400 palabras. Por su parte, la carta magna de 1917 comenzó con 136 artículos y 16 disposiciones transitorias y 22,251 palabras. Para el año 2000, en poco más de ochenta años, había duplicado casi su extensión original hasta llegar a 42,802 palabras; y para el año 2015, en menos de 20 años, ha triplicado su extensión original para llegar a 66,073 palabras.

Si bien, la tendencia del llamado "nuevo constitucionalismo latinoamericano", a partir de la promulgación de las Constituciones de Brasil (1988), Colombia (1991), Venezuela (1999), Ecuador (2008) y Bolivia (2009), ha sido la de contar con textos bastante extensos que se caracterizan por ser muy detallados y por tener entre 40,000 y 50,000 palabras, la racional es y ha sido muy diferente. Conviene explicitar que dichas constituciones al requerir del apoyo popular e incluso al estar sometidas a refrendos, tenían que consagrar en el texto algunas "conquistas" para ser atractivas al pueblo, ya que su "propósito es que el pueblo, en el ejercicio de su poder constituyente, enuncie con toda claridad las normas que deben observar los poderes constituidos, incluyendo los órganos de control de constitucionalidad." 30

29 Vid. Flores, "The Quest for Legisprudence...", cit. en la nota 19, p. 32.

30 Héctor Fix-Fierro y Diego Valadés, "Hacia la reordenación y consolidación del texto de la Constitución Política de los Estados Unidos Mexicanos de 1917. Estudio Introductorio", en loc. cit. en la nota 1, p. 6. 
Esta obra forma parte del acervo de la Biblioteca Jurídica Virtual del Instituto de Investigaciones Jurídicas de la UNAM

Sin embargo, en el caso de México, la explicación no es necesariamente la misma. Podemos aventurar algunas hipótesis, las cuales no se excluyen ni se implican: (1) amplitud, (2) acuciosidad / minuciosidad, y (3) multiplicidad de las reformas.

En primera instancia, las reformas antes dependían de la voluntad más o menos unilateral del presidente de la República, quien podría ajustar la Constitución a su estilo personal de gobernar, al contar con el apoyo de su partido político, del cual es el líder nato, y de la mayoría calificada de dos terceras partes en ambas cámaras del Congreso de la Unión para introducir tales adiciones o modificaciones; y ahora, ante el fenómeno de los gobiernos divididos, a partir de 1997, dependen de los acuerdos más o menos amplios con y entre los partidos políticos nacionales.

En segundo lugar, los partidos políticos han tendido a poner los acuerdos por escrito y "elevarlos a rango constitucional", al incluir los detalles puntuales de los mismos, "a fin de protegerlos frente a las mayorías legislativas ordinarias y evitar también la posible impugnación de su constitucionalidad ante los tribunales." ${ }^{31}$ Esta tendencia se ha incrementado, sobre todo

31 Id. Como se puede apreciar, lo anterior obedece a la "desconfianza" prevaleciente entre los diferentes actores políticos y a la idea falaz de que es posible "vacunar" las reformas ante una eventual inconstitucionalidad. Al respecto, nos hemos pronunciado sobre la posibilidad de controlar la constitucionalidad, inclusive de las reformas a la constitución. Vid. Imer B. Flores, "Sobre las formas y los límites de la legislación: A propósito de la constitucionalidad de una reforma constitucional", en Diego Valadés y Miguel Carbonell (eds.), El estado constitucional contemporáneo. Culturas y sistemas jurídicos comparados, Tomo I, México, Instituto de Investigaciones Jurídicas, 2006, pp. 271-292; "Sobre la (in)constitucionalidad de «reformas constitucionales»: A propósito de los casos de Chiapas, Michoacán y Oaxaca”, Cuestiones Constitucionales. Revista Mexicana de Derecho Constitucional, No. 17, julio-diciembre, 2007, pp. 259-280; "Sobre los límites de las reformas constitucionales: A propósito de tres acciones de inconstitucionalidad recientes", en Eduardo Ferrer Mac-Gregor y Arturo Zaldívar Lelo de Larrea (eds.), La ciencia del derecho procesal constitucional. Estudios en Homenaje a Héctor Fix-Zamudio en sus cincuenta años como investigador del derecho. T. VIII Procesos Constitucionales Orgánicos, México, Instituto de Investigaciones Jurídicas, Universidad Nacional Autónoma de México, 2008, pp. 831-856; "El problema de los límites de las «reformas constitucionales» y el control de su constitucionalidad", en Jesús Córdova Schaefer (coord.), Teoría General del Derecho Constitucional, Lima, Ediciones Caballero Bustamante, 2009, pp. 457-493; "Estado de derecho y legislación: El problema de la regla de la mayoría", en Jaime Labastida y Violeta Aréchiga (eds), Identidad y Diferencia, Volumen I, La politica y la Cultura, México, Siglo XXI, 2010, pp. 148-163; "Sobre la reforma a la constitución y su control: a propósito de las implicaciones y limitaciones del amparo 186/2008”, en César Astudillo y Lorenzo Córdova (coords.), Reforma y control de la constitución. Implicaciones y límites, México, Instituto de Investigaciones Jurídicas, UNAM, 2011, pp. 127-143; y "La constitución del principio democrático (vis-à-vis el gobierno de la mayoría)", Mesa I. Sistemas electorales y principios constitucionales. VIII Congreso Mundial de la Asociación Internacional de Derecho Constitucional, México, Tribunal Electoral del Poder Judicial de la Federación, 2012, pp. 112-131. 
Esta obra forma parte del acervo de la Biblioteca Jurídica Virtual del Instituto de Investigaciones Jurídicas de la UNAM

después de la aprobación de la reforma a la Constitución, en materia político-electoral, publicada en el DOF del 22 de agosto de 1996, la cual requirió de un amplio consenso, pues el partido en el gobierno no contaba por sí solo con la mayoría calificada de dos terceras partes requerida en la Cámara de Diputados, pero para la aprobación de la legislación secundaria bastó con el apoyo del partido oficial, el cual contaba por sí solo con la mayoría simple. De igual forma, dichos acuerdos por su misma naturaleza reglamentaria no son permanentes, sino que están sujetos a una revisión constante, como ha sucedido con la misma materia político-electoral, la cual ha sido objeto de diferentes reformas constitucionales posteriores en 2007, 2014 (en dos ocasiones), 2015, y 2016 (en dos ocasiones, en la primera parte del año).

En tercer término, los actores políticos, incluidos los diferentes partidos y hasta grupos o sectores al interior de los mismos, han favorecido una dinámica no competitiva sino colaborativa, del tipo quid pro quo, es decir "esto por aquello", también conocida como de log-rolling o "intercambio" de reformas, esto es de reforma por reforma, ya sea en todo o en parte(s). Como muestra un par de botones: por una parte, la reforma a la Constitución, en materia de seguridad y justicia, publicada en el DOF del 18 de junio de 2008, fue el producto de un intercambio entre quienes querían imponer su "mano dura" en materia de seguridad, de un lado, y quienes aprovecharon para incorporar aspectos garantistas en materia de justicia, del otro, y por lo mismo contiene una fuerte tensión y hasta contradicciones entre las dos partes. Por otra parte, la controvertida reforma a la Constitución, en materia político-electoral, publicada en el DOF del 10 de febrero de 2014, fue claramente parte de un paquete de reformas en las cuales destacaba la reforma a la Constitución en materia energética, publicada en el DOF del 20 de diciembre de 2013. Así mismo, dentro de la reforma en materia políticoelectoral las legisladoras mujeres de los diferentes partidos representados tanto en la Cámara de Diputados como en la de Senadores aprovecharon la coyuntura para condicionar sus votos, siempre y cuando se consagrara a rango constitucional el principio de paridad de género en la postulación de candidatos a los cargos de legisladores tanto federales como locales. ${ }^{32}$

32 Vid. Imer B. Flores, "El problema del principio de paridad de género en materia electoral: ¿de punto de partida a punto de llegada?, Documento de trabajo, No. 189, México, Instituto de Investigaciones Jurídicas, UNAM, (diciembre) 2015. Hay versión revisada en: Revista Mexicana de Derecho Electoral, No. 9, enero-junio, 2016, disponible en versión electrónica en: http://www2.juridicas.unam.mx/2016/04/04/el-problema-del-principio-de-la-paridad-de-genero-enmateria-electoral-de-punto-de-partida-a-punto-de-llegada/ (página consultada el 06/06/16). 
Esta obra forma parte del acervo de la Biblioteca Jurídica Virtual del Instituto de Investigaciones Jurídicas de la UNAM

De esta dinámica derivan algunos problemas adicionales de técnica jurídico-constitucional, tales como: ${ }^{33}$

1. Redundancias y reiteración: por ejemplo, la prohibición de los ministros de los cultos religiosos para ocupar cargos públicos está repetida en varios artículos, cuando bastaría con incluir la prohibición en el artículo 130.

2. Inconsistencias terminológicas y variabilidad: por ejemplo, el uso tanto de los "derechos humanos" como de sus respectivas "garantías" se ha ido uniformando en reformas diferentes y sucesivas ${ }^{34}$ pero el artículo 18 alude todavía tanto a los "derechos fundamentales" como a los "derechos humanos".

3. Disparidad en el alcance y en la profundidad de la regulación: por ejemplo, el trato que se le dan a los diferentes órganos constitucionales autónomos es muy distinto: A) una mención en una fracción de un artículo para las Universidades e instituciones de educación superior que gozan de autonomía (artículo $3^{\circ}$ ); B) unos cuantos párrafos en un artículo para el ahora Instituto Nacional de Acceso a la Información y Protección de Datos Personales, otrora Instituto Federal de Acceso a la Información (artículo 6); C) unos cuantos párrafos en un mismo artículo para el Banco de México, la Comisión Federal de Competencia Económica, el Consejo Nacional de Evaluación de la Política de Desarrollo Social, el Instituto Federal de Telecomunicaciones, y el Instituto Nacional para la Evaluación de la Educación (artículo 28); y D) varios párrafos en un mismo artículo para el ahora Instituto Nacional Electoral, otrora Instituto Federal Electoral (artículo 41).

4. Falta de orden y de sistematicidad: por ejemplo, el mismo artículo 41, el cual reglamenta la materia electoral, regula no solamente las elecciones y las autoridades electorales, sino además los partidos políticos,

33 Cfr. Fix-Fierro y Valadés, "Hacia la reordenación y consolidación del texto de la Constitución...", cit. en la nota 30, pp. 8-12.

34 Sobre todo a partir de la reforma a la Constitución en materia de derechos humanos, publicada en el DOF del 10 de junio de 2011, y de la reforma a la Constitución en materia política, publicada en el DOF del 9 de agosto de 2012, la cual dejó atrás las llamadas "prerrogativas" del ciudadano para reconocerlos como verdaderos "d-e-r-e-c-h-o-s" (con todas sus letras) y, en consecuencia, reglamentar las candidaturas de libre postulación. Vid. Imer B. Flores, "El problema de las candidaturas a-partidistas, independientes o sin partido", en John M. Ackerman (ed.), Nuevos escenarios del derecho electoral: Los retos de la reforma de 2007-2008, México, Instituto de Investigaciones Jurídicas, Universidad Nacional Autónoma de México, 2009, pp. 233-262. 
Esta obra forma parte del acervo de la Biblioteca Jurídica Virtual del Instituto de Investigaciones Jurídicas de la UNAM

así como los mecanismos de participación ciudadana, tales como la consulta popular.

5. Deficiencias en la ubicación de las disposiciones constitucionales: por ejemplo, el artículo 102, el cual está insertado en el Título Tercero, Capítulo IV del Poder Judicial, consagra en el apartado A. la figura del Ministerio Público, y contempla en el apartado B. la Comisión Nacional de Derechos Humanos.

6. Desactualización del texto: por ejemplo, la reforma a la Constitución general de la República, en materia de reforma política de la Ciudad de México, publicada en el DOF del 29 de enero de 2016, dio lugar a la "Ciudad de México" y a infinidad de actualizaciones, pero en la fracción XXIX-W, del artículo 73, todavía hace referencia al "Distrito Federal".

7. Naturaleza reglamentaría de varias disposiciones contenidas en la Constitución: por ejemplo, el ya multicitado artículo 41 reglamenta la materia electoral a tal detalle que cuenta ya con 4,065 palabras, casi la misma extensión que toda la Constitución estadounidense.

Aunado a lo anterior, por tratarse de un Estado con una organización federal con autoridades tanto centrales, federales o nacionales como estatales o locales, gran parte de las reformas a la Constitución general de la República se reproducen en las 32 Constituciones de las entidades federativas y en ellas se repiten exponencialmente los mismos errores de técnica jurídico-constitucional.

\section{LAS ALTERNATIVAS EN EL FUTURO}

Comienzo este apartado con una doble aclaración o caveat: no considero que el camino de las reformas parciales sea el adecuado y creo que es necesaria una reforma total con independencia del nombre que le den. $\mathrm{Al}$ respecto, enjuicio que con el marco constitucional vigente es posible hacer una reforma total, como en su momento se hizo con la Carta Magna de 1857, para pasar a la de 1917. De igual forma, estimo que se necesita de al menos una reforma parcial para contemplar expresamente la posibilidad de convocar a un Congreso Constituyente, sin descartar que a partir de una interpretación extensiva del artículo 39 sea posible hacerlo.

Aclaro que en mi opinión no basta con cambiar la Constitución o normatividad para cambiar la realidad y lo que necesitamos es una nueva cons- 
Esta obra forma parte del acervo de la Biblioteca Jurídica Virtual del Instituto de Investigaciones Jurídicas de la UNAM

titucionalidad o normalidad. ${ }^{35}$ La cual debe ir acompañada de un acto refundacional, el cual implique una especie de "borrón y cuenta nueva..." Adelanto que no es algo meramente cultural sino institucional, al depender de los incentivos adecuados.

Acto seguido, revisamos brevemente las alternativas:

1) Continuidad de la dinámica, seguir con el mismo patrón hasta ser la Constitución más extensa (sextuplicar el texto original).

2) Discontinuidad de la dinámica, detener el patrón y para tal efecto:

A. Declarar una moratoria, tregua o veda para no realizar por algún tiempo más reformas parciales;

B. Cambiar el procedimiento de la reforma a la Constitución para dificultarlo con la idea de hacerla más rígida o menos flexible, ${ }^{36}$ ya sea al requerir:

a) la autorización del contenido de la reforma por una Comisión de Redacción y Estilo por Letrados y/o por un control previo de constitucionalidad;

b) la aprobación en dos legislaturas consecutivas y/o en una sesión del Congreso general; y

c) la ratificación ya no por mayoría simple sino calificada de $2 / 3$ partes de las legislaturas de las entidades federativas (de 17 a 22) y/o por un refrendo constitucional-popular en la próxima elección general; y

C. Reformar la Constitución para incluir expresamente la posibilidad de convocar a Congreso Constituyente y en su caso convocar al mismo;

Aunado a lo anterior:

D. Realizar una revisión integral a la Constitución, ya sea:

a. Vía la convocatoria a un congreso constituyente;

b. Vía la reforma total por parte del órgano o poder revisor; y

c. Vía la reordenación y consolidación del texto.

\section{LA REVISIÓN TÉGNICO-JURÍDICA VÍA REORDENACIÓN Y CONSOLIDACIÓN}

El anteproyecto de texto reordenado y consolidado retoma las diferentes experiencias de derecho constitucional comparado, entre las cuales destaca

35 AA.VV., Hacia una nueva constitucionalidad, México, Universidad Nacional Autónoma de México, 1999.

36 Vid. James Bryce, "Flexible and Rigid Constitutions", in Constitutions, New York, Oxford University Press, 1901, pp. 3-94 (hay versión en español: Constituciones flexibles y constituciones rígidas, Madrid, Centro de Estudios Constitucionales, 2015). 
Esta obra forma parte del acervo de la Biblioteca Jurídica Virtual del Instituto de Investigaciones Jurídicas de la UNAM

el caso de la Constitución de la Confederación Helvética (Suiza) de 19992000, la cual fue el producto de un proceso de revisión que comenzó en 1987 y duró poco más de una década. Dicho proyecto tenía el objetivo de poner al día el derecho constitucional vigente, escrito y no escrito, presentarlo de forma comprensible, ordenado sistemáticamente, así como de unificar el lenguaje y la densidad normativa de los preceptos constitucionales. ${ }^{37}$

De tal forma, para el caso mexicano, la idea es que sea la misma Constitución "pues no se alteran las decisiones políticas y jurídicas que contiene, aunque puedan considerarse inconvenientes o erróneas, ni se introducen cambios que podrían resultar necesarios o favorables, sino que solamente se revisa y optimiza el texto vigente del momento." ${ }^{38}$ La ventaja principal de una revisión técnica es que no afecta las decisiones políticas fundamentales ni altera los contenidos al limitarse a reordenarlos y consolidarlos, al reubicar algunas disposiciones y al depurar sus contenidos, así como al mantener el número total de artículos (136) e inclusive respetar la ubicación de algunos numerales icónicos (artículos $3^{\circ}, 27$ y 130). No obstante, la desventaja es que en principio no realiza ningún tipo de ajuste ni mucho menos resuelve las tensiones existentes en sus contenidos. Para muestra baste mencionar la tendencia centralista en clara contraposición a la naturaleza federalista consagrada en el artículo 40:

Es voluntad del pueblo mexicano constituirse en una República representativa, democrática, laica y federal, compuesta por Estados libres y soberanos en todo lo concerniente a su régimen interior, y por la Ciudad de México, unidos en una federación establecida según los principios de esta ley fundamental.

Ahora bien, las únicas adiciones significativas son: 1) la inclusión de un "Preámbulo"; y 2) la incorporación de las "leyes de desarrollo constitucional". De un lado, el Preámbulo propuesto es: ${ }^{39}$

Esta Constitución expresa la voluntad del Pueblo Mexicano de instituir un Estado de Derecho democrático, social y laico, organizado como república representativa y federal, con base en los principios de soberanía, libertad, justicia, igualdad, equidad, dignidad y seguridad jurídica; que haga posible una sociedad plural, educada, sana, con bienestar y sin exclusiones; que en el ámbito interno y en las relaciones internacionales auspicie el desarrollo y

37 Vid. Fix-Fierro y Valadés, "Hacia la reordenación y consolidación del texto de la Constitución...", cit. en la nota 30, p. 7.

38 Ibid., p. 13.

39 Ibid., p. 31. 
Esta obra forma parte del acervo de la Biblioteca Jurídica Virtual del Instituto de Investigaciones Jurídicas de la UNAM

la garantía de los derechos humanos, la paz y la solidaridad entre todos los pueblos.

Del otro, las leyes de desarrollo constitucional, las cuales pueden ser concebidas como leyes constitucionales, leyes reglamentarias e inclusive como leyes orgánicas, sirven al propósito de depurar los contenidos para dejar la materia estrictamente constitucional en el texto de la Constitución y pasar la reglamentación de la misma a tales leyes.

Para concluir este apartado solamente resta aludir al hecho de que se trata de depurar la Constitución con la idea de que sea la misma, aun cuando no se descarta que pueda darse lugar a una nueva lectura de la Constitución y por consiguiente a nuevas interpretaciones del texto mismo. Lo anterior da lugar a la aparente paradoja de una nueva vieja Constitución, la cual retoma el pasado y presente, pero recobra su viabilidad en el futuro inmediato. Sin embargo, por la misma naturaleza del anteproyecto el esfuerzo se queda un tanto corto, pero es ciertamente un paso obligado para dar lugar no solamente a un nuevo texto constitucional reordenado y consolidado sino además a una nueva constitucionalidad.

\section{CONCLUSIÓN}

Para finalizar nada más no resta especular que en caso de continuar con la dinámica actual vía reformas parciales la extensión de la Constitución se va a sextuplicar en los años próximos. Con lo cual se van a acentuar aun más los problemas cuantitativos y cualitativos de inflación y de deflación legislativa, así como de técnica jurídico-constitucional. Si bien, con la reordenación y consolidación del texto, la cual implica la incorporación de las leyes de desarrollo constitucional, con independencia del nombre que se les ponga, se corrige en parte algunos de estos problemas, la misma resultaría a la larga insuficiente. Por el contrario, para romper con dicha dinámica de una vez por todas es y va a ser necesario, un acto re-constitutivo o refundacional al realizar una revisión integral a la Constitución, ya sea vía un congreso constituyente o vía una reforma total por el órgano o poder revisor, pero ciertamente el reto es y va a ser en cualquier caso instaurar una nueva constitucionalidad, i.e. una nueva cultura constitucional. 
Esta obra forma parte del acervo de la Biblioteca Jurídica Virtual del Instituto de Investigaciones Jurídicas de la UNAM

\author{
EL CAMBIO CONSTITUCIONAL \\ EN AMÉRICA LATINA. (NOTA \\ SOBRE UN FENÓMENO REGURRENTE \\ DE LAS ÚLTIMAS DÉGADAS)
}

Domingo García BeLAUnde

\begin{abstract}
SuMARIO: I. Preliminar. II. Algunos casos singulares. III. Más sobre lo mismo. IV. Precisiones previas. V. Cambios "menores" en el texto constitucional. VI. La mutación y sus alcances. VII. Consideraciones finales.
\end{abstract}

\title{
I. PRELIMINAR
}

Lo primero que hay que dejar en claro y para estos fines, es qué entendemos por "cambio constitucional" y cuáles son sus modalidades. Esto por cuanto si bien el concepto "cambio" tiene un uso muy extendido, se emplea en varios sentidos, es multívoco y puede tener otros alcances en otros idiomas. Así pues, precisemos que con ello nos referimos aquí a un fenómeno que significa que alteramos la Constitución totalmente, para que ella denote o exprese otra realidad u otros fines o designios políticos o económicos, pues de no ser así no tendría sentido hacerlo. Otra posibilidad es hacerlo solo parcialmente, pero incidiendo en lo básico, de manera tal que dicho cambio, aun cuando solo sea parcial, termine afectando el espíritu del texto mismo. Se trataría, pues, de un cambio total, sea porque formalmente se sustituya un texto por otro, sea porque las modificaciones son de tal extensión y envergadura que el espíritu del texto fundamental deviene en otro (como es, por ejemplo, la Constitución chilena de 1980, de construcción mañosa pero con fines autoritarios que en 2005 varió sustancialmente su sentido básico, lo que no ha impedido que muchos, como se observa con el nuevo gobierno de la Bachelet, intenten cambiarla ya que, según afirman, tiene un vicio de origen que es insalvable. Esto es un punto de vista político bastante discutible, más aún cuando los hechos terminan legitimando lo existente, o como decían los escolásticos, creando una legitimidad de ejercicio). 
Esta obra forma parte del acervo de la Biblioteca Jurídica Virtual del Instituto de Investigaciones Jurídicas de la UNAM

Lo segundo que hay que aclarar es que este cambio puede hacerse básicamente de dos maneras: i) respetando la legalidad preestablecida o ii) rompiendo con ella. En términos gruesos diríamos que en un caso se llega a una nueva Constitución por común acuerdo y respetando la legalidad previa. En otro, se parte de cero, es decir, de un acto de voluntad que generalmente se lleva a cabo por la fuerza, es decir, por la voluntad de los que están en el poder o de los que quieren adueñarse de él. En el primer caso, el cambio podría decirse que está previsto y es anunciado: en el segundo no.

Hay por último cambios que formalmente guardan las apariencias y se desenvuelven de acuerdo con ellas, pero poco a poco las van despojando de sentido, de manera tal que lo que empieza en forma comedida, termina siendo un fraude a la Constitución que sigue en la vitrina, pero que tiene en paralelo una normatividad que la desconoce. Históricamente son conocidos los casos de Hitler y Mussolini. El primero llegó a ser Canciller (o sea, Primer Ministro) bajo la democrática Constitución de Weimar en 1933 y teniendo como presidente a Hindenburg. Pero muerto Hindenburg en 1934, empezó a construir una legalidad al margen o en contra de la Constitución, la cual seguía vigente en teoría. Mussolini llegó a igual cargo luego de la Marcha sobre Roma en 1922 y fue el rey Víctor Manuel III el que lo autorizó o en todo caso no impidió y además permitió que llevase a cabo todos los desmanes que luego hizo, sin respetar al Estatuto Albertino de 1848 que estaba en vigor en aquella época. En ambos casos, tanto Alemania como Italia, tuvieron luego de finalizada la Segunda Guerra Mundial un gran vuelco en su trayectoria vital, que dio origen a las constituciones con las cuales todavía viven, si bien con reformas, mutaciones e interpretaciones constitucionales. La italiana de 1948 y la alemana de 1949(en realidad Ley Fundamental, pues el país estaba dividido y partido en dos, pero esto no ha cambiado luego de la reunificación alemana en 1991). Y como consecuencia de la derrota y aniquilamiento del país, que en el caso de Alemania tuvo como vigilante del proceso constituyente a los ejércitos aliados de ocupación. $\mathrm{O}$ de la caída de Mussolini en el caso de Italia y la posterior eliminación de la monarquía mediante un referéndum dudoso pero legitimado por el tiempo. En Alemania existía un sistema parlamentario con un jefe de gobierno que era denominado como Canciller. En Italia era una monarquía constitucional de tipo parlamentario en manos de la familia Saboya, que terminó eliminada y proscrita al finalizar la guerra. Y reemplazada por la república.

Algo distinto es el caso de los países que siendo colonias, protectorados o similares, rompen con la metrópoli, se independizan y se dan su propia legalidad. Es el caso de la revolución hispanoamericana que se inicia en 1810 
Esta obra forma parte del acervo de la Biblioteca Jurídica Virtual del Instituto de Investigaciones Jurídicas de la UNAM

y culmina por así decirlo en 1824, en movimiento inédito solo precedido por las que habían sido colonias británicas en Norteamérica. Y que siendo algo aislado y sorprendente, se generalizó a partir de la década de 1960, por el fenómeno conocido como descolonización sobre todo en el África, al cual ayudó mucho el testimonio célebre de Frantz Fanon: "Los condenados de la tierra". En estos casos, se trató del nacimiento de nuevos países, con territorio propio y que por tanto rompían los lazos que los unían con los imperios de los que dependían y empiezan su andadura independiente. Pero es indudable que se trata de fenómenos históricos especiales que no se repiten (como fue el proceso especial de la India en 1947). Y que hay que situarlos en el tiempo. Uno, inédito y peculiar que se da en América, primero a fines del siglo XVIII y en la parte norte del continente. Y luego a principios del XIX en el territorio de dominio hispano, del cual hay que separar el Brasil, por su peculiar trayectoria histórica (monarquía independiente desde 1822 y sin disparar un tiro, la proclamación de la República en 1889).

Los cambios son medidas que deben o pueden darse, pero no son indispensables. Y si bien es un hecho que los textos envejecen, es cierto por otro lado que una sabia y atenta actualización de ellos puede perfectamente mantener vigente un texto más allá de sus propósitos iniciales. En América tenemos el caso paradigmático de los Estados Unidos, con la misma carta desde 1787, muy propia de la familia jurídica en el cual se encuentra. Y en el área de predominio romanista, contamos con la constitución mexicana de 1917 y la argentina de 1853-1860, con numerosos cambios en el caso de la primera, y con pocos en el caso de la segunda, pero que siguen vigentes. Y sin olvidarnos de Colombia, que tuvo la misma constitución por un muy largo período: 1886-1991.Por tanto, el que los cambios sean necesarios y que siempre haya que cambiar, es una realidad que no tiene una sola solución, sino varias que además están vinculadas al entorno. Todo depende de la forma cómo se enfoquen las situaciones de agitación y ruptura que puedan presentarse.

\section{AlgunOS CASOS SINGULARES}

Veamos esto con más detalle. En cuanto a los Estados Unidos, si bien es cierto que el texto se mantiene básicamente el mismo y solo ha tenido en su larga vigencia 27 enmiendas formales, ha sido continuamente interpretado a nivel jurisprudencial, lo que explica que se mantenga hasta ahora. Pero no hay que olvidar que al margen de la Constitución federal, los cincuenta estados de la Unión tiene cada uno su propia constitución, que son además 
Esta obra forma parte del acervo de la Biblioteca Jurídica Virtual del Instituto de Investigaciones Jurídicas de la UNAM

textos largos, detallados y que se modifican con frecuencia y que por cierto tienen un alcance limitado al ámbito territorial en el cual opera. Lo cual nos lleva a la conclusión de que en el día a día, el ciudadano norteamericano se rige por la Constitución de su Estado, si bien en los grandes temas, lo que a la larga interesa es la constitución federal y su interpretación por la Corte Suprema, en especial en materias tales como derechos fundamentales, distribución de poderes, política exterior y aspectos comerciales.

Un caso especial de cambio constitucional que podría decirse que es sui generis, es el que ha sucedido en México y que precisamente es materia de análisis por los distinguidos colegas que participan en este evento. Y es que la vigente Constitución aprobada en 1917 y próxima a cumplir un siglo de vigencia, ha tenido 642 cambios a través de 225 decretos de reforma constitucional, considerados hasta julio de 2015. De los 136 artículos que la conforman desde su inicio, solo 27 han permanecido intocados; es decir solo permanece en su forma original el $19.85 \%$ de su texto (según información que se desprende de las investigaciones de José María Soberanes Díez). Es decir, ha habido continuas reformas con cierta periodicidad que han dejado prácticamente atrás el modelo político originario - no en su totalidad por cierto - y se han acomodado a los tiempos, permitiendo que exista una normalidad constitucional desde fines de la década de 1920,más allá de las imperfecciones existentes o de la presencia hegemónica de un solo partido durante largo tiempo.Y precisamente, como tales enmiendas han acabado por hacer un texto caótico y poco manejable, es que un grupo de juristas encabezado por Diego Valadés y Héctor Fix-Fierro han reelaborado la Constitución vigente, manteniendo por cierto su texto, pero armonizándolo y haciéndolo más inteligible con propuestas ingeniosas, lo cual ha tenido una buena acogida en la clase política mexicana, consciente de que las numerosas reformas efectuadas en los últimos treinta años, al margen de su bondad, han tenido una mala arquitectura y peor armado. Tal documento tiene el nombre de "Texto reordenado y consolidado" y acaba de ser publicado esperando que tenga una buena acogida.

Y en la Argentina ha pasado algo curioso. Durante la época de Perón y mediante todo un procedimiento regular, se discutió y aprobó la Constitución de 1949 que, por razones obvias, era mucho mejor que la anterior, por lo menos en cuanto a estructura formal y contenidos modernos. Pero Perón fue derrocado en 1955 y el gobierno militar que lo remplazó hizo dos cosas: lo primero fue dejar sin efecto la Constitución peronista de 1949 y poner nuevamente en vigencia la de 1853. Y lo segundo convocar una asamblea 
Esta obra forma parte del acervo de la Biblioteca Jurídica Virtual del Instituto de Investigaciones Jurídicas de la UNAM

especial para hacer ciertos cambios constitucionales que se concretaron en 1957 y que se han mantenido en el tiempo.

Un caso especial lo constituye el Perú, del cual vamos a decir algo, pero solo en relación con el siglo XX, período en el cual han estado vigentes las siguientes constituciones: 1920, 1933, 1979 y 1993. Curiosamente todas ellas nacieron de golpes de Estado. La primera fue consecuencia de un período electoral complicado en 1919, en la cual con apoyo militar uno de los candidatos depuso al presidente en funciones y para justificarse convocó un plebiscito e instaló una Asamblea Nacional que dictó la Constitución de 1920, que sirvió para justificar el gobierno de once años que inauguró el golpista, Augusto B. Leguía. En 1930, fue derrocado y se convocó a un Congreso Constituyente que discutió y aprobó la Constitución de 1933, que tuvo larga duración. Con el gobierno militar autoritario de doce años (1968-1980) se ideó una salida hacia la democracia mediante una Asamblea Constituyente que funcionó en el período 1978-1979 y que aprobó la Constitución de 1979, que entró en vigencia en 1980. Años más tarde, siendo Fujimori presidente constitucional y al no tener mayoría parlamentaria, dio un auto-golpe disolviendo el Congreso y las principales instituciones políticas del país (5 de abril de 1992). Pero presionado por la opinión pública nacional e internacional, convocó a un Congreso Constituyente para sus propios fines y así nació la Constitución de 1993, con rasgos autoritarios que han sido pulidos y enmendados y que rige hasta ahora. En el siglo XX, el Perú ha tenido pues cuatro constituciones - la última de las cuales sigue en vigor - y todas han nacido de hechos de fuerza, sin ningún respaldo legal o constitucional previo. Es un caso nítido y quizá extremo de lo que es un cambio constitucional propiamente dicho, y que ha sido legitimado por la práctica política.

\section{MÁS SOBRE LO MISMO}

Pero hay cambios que se hacen desde una legalidad previa, si bien con ciertos forcejeos, como en Colombia con su Constitución de 1991, Bolivia con su Constitución de 2009 y Venezuela con la Constitución de 1999.Lo que sucede es que muchas veces en su recorrido pierden la legitimidad de origen o quizá debido a ello, es que intentan subvertirla desde adentro o usarla para sus propios fines (como Evo Morales en Bolivia, Chávez y Maduro en Venezuela, Ortega en Nicaragua, Correa en Ecuador, entre otros). Es decir, la figura del iluminado y hombre providencial acecha a nuestros políticos y eso explica que haya renacido la pasión por las reelecciones indefinidas, 
Esta obra forma parte del acervo de la Biblioteca Jurídica Virtual del Instituto de Investigaciones Jurídicas de la UNAM

que creíamos superadas hacía tiempo. De ahí que siendo el poder una tentación casi irresistible, es bueno que la democracia instituya la alternancia y el freno de las reelecciones, que en los países presidencialistas como son los nuestros, esto se ha prohibido desde siempre, pero que hoy renace con fuerza y aparece debilitado como principio. Y es que la permanencia en el poder es algo así como la fruta prohibida en el Edén, que atrae en forma casi irresistible y que solo puede ser detenida cuando desde el exterior hay topes que la bloquean (caso Uribe en Colombia y Evo Morales en Bolivia). La historia del siglo XIX está llena de estos ejemplos y personajes que tuvieron sanas intenciones y que sin lugar a dudas pensaron lo mejor para su país, pero atrapados por su ambición, gobernaron en forma autoritaria y sin control (Juan Manuel de Rosas en la Argentina, el doctor Francia en Paraguay, Porfirio Díaz, en México,etc).Y tan providenciales se sienten que por lo general no salen del poder en forma pacífica, sino echados de diversa manera, a veces brutalmente, otras en forma más negociada (como fue el caso de Porfirio Díaz en 1911).

Un caso especial de disfraz constitucional y con ribetes de sainete, lo constituye el caso de Cuba. Los rebeldes capitaneados por Fidel Castro derribaron a la dictadura de Batista en medio del aplauso del continente (enero de 1959). Pero Castro resultó no solo providencial sino mesiánico aparte de megalómano. Luego de algunas cuantas medidas de impacto popular y de gestos simpáticos, se enroló como apéndice de la otrora existente Unión Soviética y aplicó el comunismo en todos sus niveles y solo sobrevivió gracias a la ayuda permanente que le proporcionó la potencia soviética. Durante esos años, Cuba fue en realidad una isla física e intelectual y una franca dictadura. En 1992 tras la caída de la Unión Soviética, se cortó el inmenso subsidio diario que recibía, y tuvo que acomodarse para no morir asfixiada y recurrió para eso al turismo y a nuevas restricciones. Es indudable que Cuba no es ya la puerta trasera de los Estados Unidos ni un país de deshechos, pues se ha avanzado bastante en varios campos. Pero a nivel de democracia, de tolerancia política, de alternancia en el poder, esto no existe. Su todavía vigente Constitución de 1976, no es más que un documento virtual sin ninguna aplicación, pues quien manda es una camarilla que dice representar al partido comunista, el único existente en la Isla. Con el retiro de Fidel Castro por los achaques de la edad, lo remplazó su hermano Raúl, que en el fondo es más de lo mismo, pero con aparente ánimo de cambiar las cosas. De hecho, se han liberado algunos controles, existe un turismo bien tratado, se ha logrado atraer inversión extranjera - no norteamericana, si bien esto puede concretarse en un futuro - y se ha permitido el crecimien- 
Esta obra forma parte del acervo de la Biblioteca Jurídica Virtual del Instituto de Investigaciones Jurídicas de la UNAM

to del sector privado en pequeños sectores. Todo apunta pues a que la Isla se irá abriendo poco a poco a los nuevos aires que la encontraran nueva, sin lugar a dudas, muy cambiada pero sin dictadura. Si bien esto, al parecer, demorará. Hablar de cambios constitucionales en la Cuba de hoy es imposible, pues lo que cambia, si es que hay cambios, son los personajes, no las políticas ni las libertades que siguen ausentes y perseguidos o arrinconados los disidentes.

\section{PREGisiones PREVIAS}

Todos lo anterior, así como los ejemplos puestos, estén referidos al "cambio constitucional" en sentido estricto, o sea, en sentido fuerte o quizá en forma más acentuada. Pero existen otros tipos de cambios que han sido muy estudiados y sobre los cuales no existe una doctrina pacífica. Son, si se quiere, cambios en sentido débil, no directos sino indirectos, que no deben ser ignorados y que calificamos así en forma provisoria. Sobre ello haremos una referencia en forma genérica, anotando su importancia y sindicándolos como formas "menores" de llevar a cabo un cambio constitucional.

\section{CAMBIOS "MENORES" EN EL TEXTO CONSTITUCIONAL}

Intentando una clasificación que, como siempre es convencional, podríamos decir que el cambio constitucional en sentido débil o menor podría darse de diversas maneras, de las que señalamos algunas:

a) interpretación, que llevan a cabo los órganos jurisdiccionales (jueces, cortes o tribunales constitucionales)

b) mutaciones, fenómeno consistente en mantener el texto o la letra, pero dándole una significación distinta. Tiene cierto parentesco con la interpretación, pero se diferencia de ella pues esta siempre resulta añadiendo algo consciente o inconscientemente, mientras que la mutación no toca la letra sino que le da un sentido distinto o nuevo a lo que ya existe.

c) reforma, que es cuando alguna parte de la constitución se modifica por las vías formales. Normalmente las reformas tienden a ser parciales, y además siempre son complicadas. Una reforma total, en espíritu y letra no solo es difícil sino poco frecuente, y ya nos hemos 
Esta obra forma parte del acervo de la Biblioteca Jurídica Virtual del Instituto de Investigaciones Jurídicas de la UNAM

referido a ello. Aquí nos circunscribimos a la reforma parcial, que es un cambio, pero en dimensión más acotada.

Estos tres temas son todos ellos problemáticos y requieren cierta calma y extensión para desarrollarlos, que hemos realizado en otra parte, por lo que aquí nos detendremos únicamente en el de la "mutación" y en forma por demás breve y libre, siguiendo un reciente trabajo de Francisco Fernández Segado.

\section{LA MUTACIÓN Y SUS ALGANCES}

El término "mutación" fue introducido en el mundo hispánico por Manuel García Pelayo en su conocido manual "Derecho Constitucional Comparado" aparecido por vez primera en 1950. El concepto fue elaborado, si bien no muy técnicamente, por Paul Laband, a quien se sindica como el fundador de la moderna doctrina juspublicista alemana a mediados del siglo XIX y precisado sobre todo por Jellinek. Pero quien le da amplio uso y respaldo y logra su general aceptación es el jurista chino que estudió en Alemania, Hsü Dau-Lin, en la década del treinta del siglo pasado. Y desde entonces no ha hecho más que progresar logrando ingresar en nuestro mundo, como ya se adelantó, en la década de 1950.

Lo que distingue a la "mutación" de los otros cambios, es la sutileza con la que actúa. Esto es, mientras que la interpretación tiene en principio límites o en todo caso limitante - pues se sabe y se dice lo que se va a hacer - en la mutación las palabras del texto siguen teniendo las mismas letras, pero se les da otro significado. Es el caso singular de la Constitución norteamericana de 1787 y ello ocurre con frecuencia, en parte por la antigüedad de los textos, por la vaguedad de los términos empleados, porque las palabras con los años y en general con el transcurso del tiempo, adquieren otros usos. En el ejemplo norteamericano, precisamente por esto, es que se puede confundir "mutación" con "interpretación", como se aprecia en el concepto de "igualdad" que en un principio negó derechos a los negros, luego a fines del siglo XIX se los reconoció pero para ejercerlos en forma separada y recién a mediados del siglo XX se generaliza, si bien es cierto que también medió la existencia de la llamada Ley de Derechos Civiles firmada por el presidente Johnson.

En los países de tradición romanista, la mutación es más difícil, pues en general y pese a cierta vaguedad en la redacción, hay una mayor precisión en los términos y sobre todo mayor extensión en los contenidos, pero esto no 
Esta obra forma parte del acervo de la Biblioteca Jurídica Virtual del Instituto de Investigaciones Jurídicas de la UNAM

lo impide que suceda. En el caso de la experiencia jurisprudencial peruana, el Tribunal Constitucional ha elaborado - o mejor dicho reformulado sobre bases mal conocidas - una supuesta "autonomía procesal" que les permite hacer cosas que normalmente estarían vedadas a un ente de tal nivel. Lo que es totalmente distinto a la tipología de sentencias que ha elaborado la jurisprudencia italiana y que son bien conocidas (sentencias exhortativas, manipulativas, aditivas, etc.).

\section{CONSIDERACIONES FINALES}

Ahora bien, los cambios constitucionales sean los mayores o los de orden menor y más acotado (reforma parcial, interpretación y mutación) responden siempre a una intención política vinculada con la gobernabilidad y muchas veces con la capacidad o mejor, incapacidad de la clase política para adaptarse a las situaciones. Esto de hecho no ha pasado desapercibido para la doctrina constitucional, si bien ha preocupado más, recientemente, a los politólogos (así, Gabriel L. Negretto). Y muchas veces de la mano con deseos políticos de perpetuarse en el poder mediante cambios en la duración de los períodos presidenciales que se han vuelto recurrentes en nuestra América en las últimas décadas. Lo que sí es claro, es que por más esmero que ponga un legislador o un constituyente, la vida real y el futuro le presentará nuevas situaciones y nuevas exigencias que habrá que afrontar: cómo hacerlas es el gran problema. Eso depende de la clase política, del entorno regional y sobre todo del momento ideológico.

Lo que sí debe quedar claro es que las reformas parciales, las mutaciones y las interpretaciones son siempre inevitables y en veces necesarias. Problema pendiente y sin respuesta inmediata es cómo y cuándo hacerlo. 
Esta obra forma parte del acervo de la Biblioteca Jurídica Virtual del Instituto de Investigaciones Jurídicas de la UNAM

\section{TEORÍA Y PRÁCTICA DEL CAMBIO CONSTITUCIONAL EN MÉXICO}

\section{María del Pilar HeRnándeZ*}

La imagen de la sociedad como un todo homogéneo donde existen intereses comunes, se sustituye por la versión hobbesiana de confrontación y lucha entre intereses irreconciliables.

Pedro DE VEGA

En torno a la legitimidad constitucional

Sumario: I. Prolegómenos desde la teoría de la constitución: poder constituyente y reforma constitucional. II. El cambio constitucional desde la teoría de la constitución III. El cambio constitucional desde la ciencia politica. IV. La reforma constitucional en México. V. Bordando sobre lo bordado: reforma integral o nueva constitución. VI. Fuentes de consulta.

\section{PROLEGÓMENOS DESDE LA TEORÍA}

\section{DE LA CONSTITUCIÓN: PODER GONSTITUYENTE Y REFORMA CONSTITUCIONAL}

A partir de la conformación del Estado Constitucional, la concepción de la soberanía popular, genera nuevos esquemas de comprensión con relación al desarrollo del proceso constituyente ${ }^{1}$ (Verfassunggebung), las cuales tratan

* Investigadora Titular C, definitiva TC, Instituto de Investigaciones Jurídicas, Universidad Nacional Autónoma de México, correo institucional:mphm@unam.mx

1 Nos referimos a la determinación de la soberanía popular, como base legitimadora del poder constituyente, tanto del originario, como derivado. 
Esta obra forma parte del acervo de la Biblioteca Jurídica Virtual del Instituto de Investigaciones Jurídicas de la UNAM

de identificar en cada momento o etapas de Éste, ${ }^{2}$ la legitimación, procedimiento y limites que le corresponden.

\section{a)Poder constituyente}

La cadena lógica de vigencia de una nueva constitución parte del documento fundamental que, inmediatamente antes, estuvo en vigor y así retrospectivamente hasta llegar a la constitución fundante que ubica su fuente de creación y legitimidad en la soberanía del pueblo, única y originaria de la cual emana todo poder y que, ya en la Constitución sancionada deviene en la supremacía que la caracteriza.

Soberanía popular concebida tanto en el pensamiento de Jean Bodin como en el de Juan Jacobo Rousseau ejerciéndose, en consecuencia, bien de manera directa, ya a través de mecanismos de representación, típicos de los sistemas político-constitucionales actuales.

La otra forma en que tiene origen una constitución es a través de la revolución, esto es, del rompimiento violento de los fundamentos constitucionales de un estado a través de las armas y de la fuerza; quedan excluidos del concepto las rebeliones, los motines y los cuartelazos. ${ }^{3}$ Este tipo de formación constitucional se basa en el consenso suscitado en el nuevo orden instaurado, quizá en este momento sin adjetivarlo como constitucional y que, a partir de los Acuerdos de la Moncloa y su concreción en la Constitución Española vigente, determinó una nueva modalidad de advenir a una nueva constitución: transicional de consenso.

$\mathrm{Al}$ efecto de aclararnos cabe hacer el siguiente planteamiento: ¿Quién detenta el poder soberano del pueblo? ${ }^{4}$

Traemos en este momento a colación las palabras de Juan Jacobo Rousseau, a saber:

2 El termino etapas nge como sinónimo de las clases de poder constituyente, basándose en la determinación de Vanossi sobre los diferentes momentos en que se puede suscitar. Cfr. Vanossi, Jorge Reinaldo, Estudios de teoría constitucional, México, UNAM-IIJ, 2002, p. 241.

3 Sobre el particular se ha debatido en torno a si el artículo 136 de la Constitución mexicana, da fundamento a este tipo de cuestiones, hago el planteamiento no obstante no estar de acuerdo con esta postura, sobre todo porque el artículo 136 estipula su reinstauración cuando el orden se restablezca.

4 El constitucionalista ha olvidado aquellas palabras plasmadas en el artículo $4^{\circ}$ de la Constitución de Apatzingán de 1814: "La sociedad tiene derecho incontestable a establecer el gobierno que más le convenga, modificarlo y abolirlo totalmente cuando su felicidad lo requiera". 
Esta obra forma parte del acervo de la Biblioteca Jurídica Virtual del Instituto de Investigaciones Jurídicas de la UNAM

...es contrario a la naturaleza del cuerpo político imponerse leyes que no puede revocar; pero que no es ni contra la naturaleza ni contra la razón que no puede revocar esas leyes sino con la misma solemnidad con que la estableción

Dicho lo anterior resulta más fácil abordar el tema.

El poder constituyente del pueblo como uno de los atributos de la soberanía, se torna en la base misma del constitucionalismo, en general, y del mexicano, en particular. Podríamos traducir el concepto de soberanía, como la primera y fundamental decisión de nuestro ser constitucional, concepto que puede ser resumido en su devenir como la lucha del hombre y de los pueblos para constituirse en dueños de su propio destino.

Básicamente en el marco del Estado de derecho ${ }^{6}$ la cuestión que se debate es la titularidad de ese poder soberano, por mejor decir, dentro del sistema representativo se cuestiona quién detenta el poder de representación, la respuesta que ha sido más socorrida es en el sentido de que en un sistema de tal naturaleza las voluntades se confunden, así, la voluntad del pueblo reside en su representación.

Es sabido que el pueblo deposita o transfiere parte de su soberanía en sus representantes al efecto de organizarse y de que se constituya todo un sistema orgánico, a tal efecto el momento de creación prístino de todo el sistema constitucional recae en llamado Poder Constituyente que deviene en un Congreso Constituyente originario integrado, como ya se ha apuntado, por representantes del propio pueblo; de este congreso constituyente originario deriva, a su vez, una asamblea proyectista, integrada por miembros escogidos del propio Congreso y encargado de elaborar un proyecto de Constitución que, debatido, dará origen a la nueva carta fundamental.

La conformación y en sí mismo el poder constituyente originario se caracteriza por dos notas esenciales, a saber: en cuanto órgano especialmente creado y, segundo, en cuanto a su función teleológica: expedir una nueva Constitución.

5 Citado por Cueva, Mario de la, Teoría de la Constitución, México, Porrúa, 1982, p. 125.

6 Al decir de Elías Días, el Estado de Derecho presenta como características básicas e indispensables:

a) Imperio de la ley: ley como expresión de la voluntad general.

b) División de poderes: legislativo, ejecutivo y judicial.

c) Legalidad de la Administración: actuación según ley y suficiente control judicial.

d) Derechos y libertades fundamentales: garantía jurídico-formal y efectiva realización material.

Cfr. Díaz, Elías, Estado de Derecho y sociedad democrática; 8ª ed., Madrid, Taurus, 1986, p.89. 
Esta obra forma parte del acervo de la Biblioteca Jurídica Virtual del Instituto de Investigaciones Jurídicas de la UNAM

Aunado a lo anterior, el poder constituyente se denota por el tipo de limitaciones reales o extrajurídicas que posee, esto es, el constituyente originario en su función primigenia se encuentra con elementos fundantes a respetar, particularmente los ideológicos (consistentes en creencias o valores que se encuentran en la superestructura social) y los estructurales (que conforman el ámbito social subyacente). Es importante advertir que esta limitaciones reales o extrajurídicas no solo afectan al poder constituyente originario, sino también al derivado o permanente.

Estos límites no son condiciones jurídicas, ni asumen formas como tales, pero su presencia e importancia son incuestionables en cualquier regulación constitucional que se considere adecuada, principalmente si la idea es referirse a una reforma de Estado, ya que como menciona Allan Brewer, toda reforma de Estado implica siempre, una reforma constitucional; pero no toda reforma constitucional conlleva una reforma de Estado. ${ }^{7}$

Finalmente, cabe señalar que en su labor constitutiva, el constituyente originario le da contenido a la Constitución en tanto conjunto de normas contenedoras de valores, principios y reglas, así:

1. Creación, organización y atribución de competencias de los órganos constitucionales, trátese de los de potestad originaria -Legislativo, Ejecutivo y Judicial-- ya de los más contemporáneos como lo son los constitucionales autónomos o de relevancia constitucional;

2. La determinación de la forma de Estado, en sus modelos primigenios de compuestos o simples - confederación, estado unitario o federación - en sus nuevas modalidades como lo son la autonómica o regional;

3. La determinación de un sistema de gobierno, trátese del Parlamentario o Presidencial, o cualesquiera de sus modalidades de semiparlamentaria o semipresidencial;

4. La determinación del catálogo de derechos fundamentales y sus garantías;

5. Los mecanismos de actualización de la fuerza normativa de la Constitución (die normative Kraft der Verfassung) ${ }^{8}$, bien trátese del mecanismo

7 Brewer Carías, Allan R., "El proceso constituyente y la fallida reforma del Estado en Venezuela", Estrategias y propuestas para la reforma del Estado, México, UNAM-IIJ, 2002, p. 26.

8 Hernández, María del Pilar, "La fuerza normativa de la Constitución”, Problemas actuales del derecho constitucional. Estudios en homenaje a forge Carpizo, México, IIJ/UNAM, 2008, pp. 187-192. 
Esta obra forma parte del acervo de la Biblioteca Jurídica Virtual del Instituto de Investigaciones Jurídicas de la UNAM

formal por excelencia que es la reforma constitucional, ya se trate de un de los mecanismos informales como lo es la interpretación constitucional; y

6. Las garantías procesales de defensa de la Constitución.

\section{b) La reforma constitucional}

Desde la consideración de la teoría de la constitución, los procedimientos de actualización de los contenidos de la constitución, como hemos apuntados líneas arriba, son de naturaleza formal e informal. El único procedimiento de carácter formal es la reforma constitucional; son de índole informal tanto la interpretación como la mutación constitucional (Verfassungswandlung), considerando en ésta a las convenciones constitucionales.

$\mathrm{Al}$ decir de Alfonso da Silva ${ }^{9}$ :

Mutaciones constitucionales son los cambios no formales que operan en el correr de la historia de una Constitución, sin alterar el enunciado formal, sin cambiar la letra del texto. Según la doctrina tradicional, esto se da por la fuerza de la modificación de las tradiciones, de la adecuación político social, de las costumbres, de la alteración empírica y sociológica, por la interpretación y por el ordenamiento de estatutos que afectan la estructura orgánica del Estado

Vale precisar que cualquiera de los procedimientos informales deben pasar, indefectiblemente, por el tamiz de la reforma constitucional.

Corresponde a uno de los poderes constituidos erigirse en poder revisor de la constitución, con una integración y procedimiento especial, y por tanto, trascendente a la falaz inmutabilidad temporal del propio documento fundacional de cualesquier estado, argumento que contradice, ab esentia, la naturaleza misma de la Constitución producto de los diversos contextos socio-históricos de los que es consecuencia y de los cuales debe ser regulador a riesgo de generar una dislocación entre las estructuras sociales e institucionales y el vaciamiento mismo de la Constitución, rindiendo de ella una mera constitución nominal.

Este poder constituyente de reforma o reformador - derivado o permanente - asume una competencia excepcional: es al único órgano al que le es dable modificar o redistribuir las competencias ordinarias del Estado, abar-

9 Silva, Alfonso da, "Mutaciones constitucionales" (Traducción del portugués de María del Pilar Hernández), Cuestiones constitucionales, Revista mexicana de derecho constitucional, $\mathcal{N}^{\circ} 1$, México, IIJ/UNAM, julio-diciembre de 1999, pp. 7-8. 
Esta obra forma parte del acervo de la Biblioteca Jurídica Virtual del Instituto de Investigaciones Jurídicas de la UNAM

cando tanto la hipótesis de la reforma total como la de la enmienda parcial de la constitución escrita, sin perjuicio del carácter polémico que envuelve la posibilidad de una reforma total y sustantiva a la constitución, incluidas, como sucedió en 1992 en nuestro ordenamiento constitucional patrio, con las denominadas decisiones políticas fundamentales (la propiedad del agro y las relaciones estado-iglesia).

El poder constituyente permanente se encuentra en un grado jerárquico intermedio entre el constituyente originario y los poderes constituidos. Es el poder constituyente originario el que se enfrenta al acto creador de órganos y competencias, y son los poderes constituidos a los que les corresponde concretar no sólo los actos de gobierno sino, además, aquella parte de la voluntad popular que legitima al propio Estado en su devenir histórico.

Dentro de los estados nacionales consolidados, paulatina y progresivamente, desde el siglo XVIII hasta el pasado XX, de los cuales el nuestro forma parte, se determina en sus respectivas constituciones un procedimiento especial de reforma respecto del contenido de una norma de rango constitucional, procedimiento que, en aras de su trascendencia respecto del orden jurídico total, ha de ser realizado también por un órgano de carácter especial que, como hemos apuntado líneas arriba, es el poder revisor de la constitución.

Este procedimiento agravado de reforma - propio de las constituciones estáticas, sólidas o cristalizadas, en definitiva rígidas, conforme a la clasificación de James Bryce - ${ }^{10}$ es el sustento, justamente, del carácter supralegal de la constitución, ${ }^{11}$ al ubicar a ésta en una esfera superior jerárquica de las demás normas del ordenamiento (supremacía constitucional) y vigilar continuamente su fundamentalidad.

De esta manera, la rigidez constitucional, como la especialidad del procedimiento agravado de reforma constitucional, ha adquirido distintos modos en el derecho comparado, donde algunos ordenamientos exigen la participación del pueblo mediante referéndum, en otros se requiere mayoras calificadas del parlamento, en otro se precisa la intervención de dos legislaturas sucesivas e incluso hay supuestos en que se confía, la reforma, a una Asamblea creada ad hoc.

10 Bryce, James, Constituciones flexibles y constituciones rígidas, Madrid, Instituto de Estudios Políticos, 1952, pp. 75.

11 Manuel Aragón determina la diferencia entre supremacía política de la constitución de su supremacía legal, donde esta última se le denomina supralegalidad. Cfr. Aragón Reyes, Manuel, Estudios de Derecho Constitucional, Madrid, Centro de Estudios Políticos y Constitucionales de Madrid, 1998, p. 245. 
Esta obra forma parte del acervo de la Biblioteca Jurídica Virtual del Instituto de Investigaciones Jurídicas de la UNAM

Por lo que hace al procedimiento ordinario de reforma, en relación a las denominadas constituciones cambiantes o fluidas, también denominadas flexibles, es sabido desde el análisis de Bryce que no requieren de la erección de un órgano especial ni, en consecuencia, un procedimiento especial.

El genio de Bryce llegó a dilucidar, a través de su análisis de la Constitución de la República de África del Sur (Transvaal) ${ }^{12}$, que las constituciones de iure podían ser clasificadas como rígidas, pero de facto eran reformadas como flexibles ${ }^{13}$. Inopinadamente, como veremos en el parágrafo 5, "De la práctica del cambio constitucional en México", es el caso prototípico de nuestra constitución general, en gran medida una mera constitución nominal.

\section{EL CAMBIO GONSTITUGIONAL DESDE LA TEORÍA DE LA CONSTITUGIÓN}

Admitida por la teoría de la constitución la naturaleza mutable del documento fundante mismo en tanto reflejo de la realidad socio histórica y cultural, la misma teoría ha aceptado, inopinadamente, que cambio constitucional es igual a reforma constitucional, id. est., opera el cambio desde el nivel formal de la adecuación de las normas constitutivas del estado a las realidades subyacentes a ese estado, entendiendo de la Constitución es un reflejo de la realidad, pero no solamente esto ya que al mismo tiempo, ella conforma la realidad, constituyéndose, en su fuente originaria.

El conflicto entre la dinámica constitucional y la Constitución, condensada en la fórmula clásica derecho constitucional versus realidad constitucional, justificaría, en honor a esta última, el reconocimiento de la "fuerza normativa de los hechos", indefectible fuente del derecho. ${ }^{14}$

Reforma constitucional como cambio, implica el reconocimiento de la función de la Constitución, asegurar la formación de la unidad política y la organización de los poderes, todos los poderes, la organización de la vida económica y social.

La Constitución en tanto estructura dinámica y programática, salvaguarda el mantenimiento de su fuerza normativa, a través de su historicidad y de la posibilidad de su evolución.

12 Provincia de Sudáfrica desde 1910 hasta 1994 con capital en Pretoria que hoy en día ya no existe.

13 Bryce, op. cit., p. 96.

14 Jellinek, George, Teoría del Estado, 2a . ed., (Tr. Fernando de los Rios Urruti), Bueno Aires, Albatros, 1943, p. 283; Schmitt, Carl., Teoría dela Constitución (trad. De Francisco Riebro Ayala), Madrid, Alianza Editorial, 1982, p. 41. 
Esta obra forma parte del acervo de la Biblioteca Jurídica Virtual del Instituto de Investigaciones Jurídicas de la UNAM

Desde esa teoría del derecho constitucional, de la Constitución, en palabras de Jellinek, Burdeau Schmitt, entre otros, es entendida la reforma constitucional como cambio, uno que ha de tener en consideración alternativas constitucionales que atiendan, posibilitado que la Constitución se adapte a las condiciones histórico sociales, "los principios fundamentales deber ser suficientemente elásticos para acompañar al 'metabolismo social' y posibilitar la revisión constitucional coherente a las mutaciones constitucionales ${ }^{15}$."

El círculo vicioso que envuelve nuestros tiempos en la generación de denominaciones que en apariencia denotan el contenido de la reforma constitucional bajo la novedosa expresión "cambio constitucional", nos hacen olvidar que, en la más acrisolada posición de nuestra teoría de derecho público, la teoría de la constitución es, al mismo tiempo, teoría de su praxis.

Inmutabilidad y atemporalidad constitucionales son categorías proscritas de la teoría de la constitución.

No ignoro la necesaria complementariedad que la inter y multidisciplinariedad metódica marca a nuestros estudios, a los del derecho constitucional me refiero, que ciencia política, teoría del estado y derecho internacional han marcado desde siempre nuestra disciplina. Y ello me parece, reitero, metódicamente necesario.

Qué duda cabe que la ciencia política nos permite a los constitucionalistas focalizar mejor los análisis y generar, indiscutiblemente, prospectivas más coherentes, ello es así como, cuando ha menester, el echar manos de otras disciplinas más cuantitativas, pero ello en forma alguna, estoy convencida, autoriza a la perversión del uso categorial al cual estamos sujetos.

La expresión "cambio constitucional" es novedosa sí, si ella predica, como se deduce de un politólogo como lo es Gabriel Negretto, que vas más allá de lo que el concepto de reforma constitucional, entendida como cambio, hasta hoy predica.

Cambio constitucional desde la teoría de la constitución y de la ciencia política tienen un punto de contacto: cuando analizan la realidad sociohistórica --coyuntural y fáctica-- que impele, como fuerza viva de la propia praxis constitucional, a la reforma.

Pero se apartan diametralmente, cuando es el concepto de cambio constitucional, al menos el de Negretto, va más allá analizando los efectos que en la institucionalidad se determina como eficiente o deficientemente operativa.

15 Gomes Canotilho. José Joaquim, Direito Constitucional, Coimbra, Almedina, 1980, pp. $19-20$. 
Esta obra forma parte del acervo de la Biblioteca Jurídica Virtual del Instituto de Investigaciones Jurídicas de la UNAM

La teoría de la constitución ha comprendido esos efectos, no precisamente a trapes del concepto de reforma constitucional, esa es en el plano formal, cuando mediante el concepto de fuerza normativa de la constitución (die normative Kraft der Verfassung) irradia e implica a los participantes mismos de la vida constitucional comprometidos en concretar en la vivencia misma de la constitución a través de la praxis constitucional, así, se expresa la otra dimensión: Constitución in action.

Concebida así, Constitución y reforma constitucional justifican las mutaciones constitucionales y la vitalidad misma de la constitución a través de la reforma a través de la naturaleza y función de la Constitución: factum brutus non est constitutionem.

\section{El CAMBIO CONSTITUCiONAL DESDE LA CIENCIA POLÍTICA}

La literatura en materia de reforma constitucional evidencia el cambio lexical de algunos autores ${ }^{16}$ por la expresión "cambio constitucional", baste recordar el escrito del ya citado Alfonso da Silva que data del año de 1999 y, en el ámbito mexicano, Salvador Valencia Carmona ${ }^{17}$ quien, por cierto, en su escrito Constitución y Reforma constitucional en México, alude a la denominada "teoría del cambio constitucional" la cual, conforme a su dicho: [explica las] "... vicisitudes que surgen en el transcurso de la vigencia de una Constitución ... esta teoría comprende los diferentes incidentes y accidentes que puede sufrir una Constitución durante su vigencia, que son, principalmente, los siguientes: reforma constitucional, mutación constitucional, suspensión, quebrantamiento y supresión de la Constitución.

Valencia Carmona no indica quién o quiénes inician y se inscriben en tal teoría, ya que, de su propia definición es evidente que se está refiriendo a la reforma constitucional en tanto cambio formal, las otras como cambios informales propios de la realidad histórica social que subyace a cualesquier constitución y que hemos tratado líneas arriba.

La ciencia política en materia de poder constituyente y reforma constitucional, también ha utilizado "cambio constitucional" que mantenía una posición pacífica y contestes con la ya expuesta y propia de la teoría de la constitución que, incluso, mantuvieron la idea de la pretensión de perdurabilidad del documento constitucional por sus creadores de cara a la

16 Arendt, Hannah, On Revolution. NuevaYork, Penguin Books, 1990.

17 Ackerman, Bruce, We the People. Transformations. Cambridge/London, Harvard University Press, 1988. 
Esta obra forma parte del acervo de la Biblioteca Jurídica Virtual del Instituto de Investigaciones Jurídicas de la UNAM

frecuencia con que se suceden cambios constitucionales profundos que los órdenes jurídicos experimentan, muy a menudo impulsados para satisfacer los intereses de corto plazo de actores políticos poderosos, México como la mayor parte de los países de la región, como lo analiza Negretto, adolecen del mismo mal.

A casi tres décadas de aquellos escritos la expresión, pese al escepticismo o el desprecio que algunos constitucionalistas que con mohines o palabras me lo han hecho saber, ha adquirido un evidente matiz politológico virtud los escritos de Gabriel Negretto a partir de 2009 con su artículo Paradojas de la reforma constitucional en América Latina, que si bien en su escrito realiza un planteo por demás similar al que realizamos desde la teoría constitucional, $i d$., est, cambio es igual a reforma de ahí, incluso, el título de la colaboración a la publicación periódica Fournal of Democracy.

En su artículo La política del cambio constitucional en América Latina de 2013, Negretto elabora una teoría que, dicho por el mismo, es dual, dando cuenta de la insuficiencia de la ciencia política de cara a las explicaciones del estudio e las instituciones políticas y, por tanto, del concepto mismo de cambio constitucional como sinónimo de reforma constitucional a las cuales, sea una u otra denominación, "... la adopción de nuevas estructuras constitucionales está determinada por el funcionamiento pasado del régimen constitucional y por los intereses partidistas y el poder relativo de los actores políticos reformistas en el momento del cambio."

La teoría en dos niveles se ancla en tres variables explicativas, a saber: el desempeño de las estructuras constitucionales vigentes, el poder relativo que los reformadores pueden ejercer en el proceso de selección institucional, y la incertidumbre electoral. Esto quiere decir que, más allá del interés cooperativo por sancionar una constitución eficiente, al ser fieles a sus intereses partidarios, los constituyentes están sesgados respecto de qué diseño prefieren, ya que siempre estarán inclinados a seleccionar el que les ofrezca mayores beneficios. Es por esto que los recursos de poder son fundamentales en este argumento, porque tienen la capacidad concreta de influir en el diseño final.

El punto de divergencia de la categoría reforma constitucional a la de cambio constitucional, mutada en contenido en la literatura Negrettiana, la mara la utilización metodológica empirista que le conducen a resultados impecables e incuestionables respecto de la forma como los intereses partidistas y el poder relativo de los actores políticos involucrados en procesos de cambio constitucional impactan las decisiones sobre la adopción de nuevas instituciones políticas. 
Esta obra forma parte del acervo de la Biblioteca Jurídica Virtual del Instituto de Investigaciones Jurídicas de la UNAM

En efecto, aquello que el "constitucionalista" calla por sabido, en los análisis de Negretto se explicita con la dosis de realismo que recuerda que los teóricos de la constitución, devienen los grandes legitimadores del poder, por convicción, por interés, por indolencia o por extrema ignorancia. Los casos se encuentran en los anales de la historia.

La categoría cambio constitucional de Negretto sí considera lo que para el constitucionalista subyace en reflexión: el contexto socio histórico y las razones (argumentos) determinantes en la adopción de ciertas instituciones y no de otras, lo que complementa con los efectos de largo plazo que ellas despliegan, propio de los análisis politológicos más recurrentes.

El análisis de tres instituciones pilares del estado democrático de derecho son puntuales, así; la presidencia, los pesos y contrapesos entre el legislativo y el ejecutivo y el diseño electoral son paradigmáticas en el análisis, sumada a éste el concepto de incertidumbre electoral que, en definitiva, da la nota distintiva a la categoría cambio constitucional, sobre todo de cara a la negociaciones a las cuales arriban los partidos políticos que rediseñan aquéllas y elaboran éstas, con un margen de especulación de los que a futuros será su situación de cara a los resultados electorales y su posición en nuevas negociaciones en lo individual como en lo partidario. En líneas generales, los partidos firmes van a preferir reglas electorales más restrictivas, reglas de reelección más laxas, y una distribución de poderes en favor del ejecutivo. En cambio, los partidos electoralmente más débiles van a ejercer presión por lograr instituciones más inclusivas como mayoría absoluta para elegir al Presidente, no reelección, y mayor poder para el legislativo.

Por último cabe señalar que la teoría de Gabriel Negretto surge de y explica a. los estados latinoamericanos y, hasta ahora, ha mostrado esa capacidad explicativa propia del politólogo que, indefectiblemente vuelve a tener su punto de convergencia en el procedimiento formal por excelencia del texto constitucional: la reforma.

\section{LA REFORMA CONSTITUCIONAL EN MÉXICO}

México ha incorporado en el devenir de la historia patria el procedimiento y el órgano constituido legitimado para verificar las modificaciones a la Constitución Política Nacional, en diferentes artículos de las también diferentes constituciones históricas de 1824 a la vigente 1917; inscribiendo dicha facultad en el artículo 135, que a la letra determina: 
Esta obra forma parte del acervo de la Biblioteca Jurídica Virtual del Instituto de Investigaciones Jurídicas de la UNAM

Artículo 135. La presente Constitución puede ser adicionada o reformada. Para que las adiciones o reformas lleguen a ser parte de la misma, se requiere que el Congreso de la Unión, por voto de las dos terceras partes de los individuos presentes, acuerde las reformas o adiciones, y que estas sean aprobadas por la mayoría de las legislaturas de los Estados.

El Congreso de la Unión o la Comisión Permanente en su caso, harán el cómputo de los votos de las Legislaturas y la declaración de haber sido aprobadas las adiciones o reformas.

Vale indicar que conforme a la página de la Cámara de Diputados ${ }^{18}$ hasta 2016 se suma el número de 684 reformas a los artículos del $1^{\circ}$ al 136 , a los diversos transitorios 9, a artículos transitorios de Decretos de Reforma 4, que en total suman 697 cambios constitucionales formales.

El precepto y la constitución son omisos respecto de ciertos aspectos que dan completitud al precepto transcrito, en razón de que en ningún artículo se hace alusión a quiénes están facultados para iniciar un reformas constitucional $^{19}$, no obstante y en razón de la aceptada traspolación que

18 http://wrew.diputados.gob.mx/LeyesBiblio/ref/cpeum_art.htm

19 PODER REFORMADOR DE LA GONSTITUCión. El PROGEDIMIENTO REFORMATORIO RELATIVO EMANADO DE ESTE ÓRGANO CON FACULTADES LIMITADAS, ES SUSCEPTIBLE DE CONTROL GONSTITUCIONAL.

No puede identificarse al Poder Reformador de la Constitución con el Poder Constituyente, debido a que la propia Norma Fundamental establece ciertos límites al primero, los cuales deben cumplirse para respetar el principio jurídico de supremacía constitucional, pues de lo contrario se daría prevalencia únicamente al principio político de soberanía popular -los mencionados principios deben coexistir siempre que se asocien adecuadamente con los momentos históricos y con el tipo de ejercicio que se trate-. El Poder Constituyente, soberano, ilimitado, no puede quedar encerrado dentro del ordenamiento constitucional. La historia ha demostrado que todos los intentos de organización jurídica del Poder Constituyente, en el mejor de los casos, han servido sólo para privar al pueblo de sus facultades soberanas, a favor de otras instancias u otros órganos estatales. Se considera que ese poder ilimitado se ejerce, de acuerdo con su propia naturaleza, como fuerza externa al sistema, por lo que siempre y en todo momento podrá reformar a la Constitución existente o establecer una nueva, pero su actuación no podrá explicarse en términos jurídicos, sino por las vías de hecho, esto es, mediante un proceso revolucionario. En cambio, ningún poder constituido puede extraerse de la órbita en que la Constitución sitúa su esfera de competencias; por ello es que resulta inaceptable la pretensión de convertir al Poder Constituyente en el Poder Reformador -ordenado y regulado en la Constitución- como la aspiración contraria de hacer del Poder de Revisión un auténtico y soberano Poder Constituyente. El Poder Reformador es un órgano regulado y ordenado en el texto constitucional, pues es en él donde se basa su competencia. Aun cuando se acepte que la competencia para reformar la Constitución no es una competencia normal, sino una facultad extraordinaria o, si se quiere, una "competencia de competencias", ello no implica que se identifique, sin más, la facultad extraordinaria con el Poder Soberano. Claramente se trata de conceptos que no son idénticos, pues el Poder de Revisión 
Esta obra forma parte del acervo de la Biblioteca Jurídica Virtual del Instituto de Investigaciones Jurídicas de la UNAM

en materia de reforma constitucional se ha realizado respecto del procedimiento de formación de las leyes y decretos, tanto en lo relativo a fase de iniciativa como de promulgación, asimilándose así a la Constitución en su carácter de ley lato sensu.

De hecho tal aplicación supletoria se realiza atendiendo al hecho que la reforma constitucional se realiza, siempre e indefectiblemente, mediante decreto así, atendiendo que el 71 alude al tal hecho es el mecanismo utilizado. Vale reiterar que el 135 como tal no contiene un procedimiento de reforma constitucional.

Al hilo discursivo, tendrán la facultad de iniciar una reforma constitucional, conforme al artículo 71 constitucional:

\section{Al Presidente de la República;}

II. A los Diputados y Senadores al Congreso de la Unión;

III. A las Legislaturas de los Estados y de la Ciudad de México ${ }^{20}$; y

IV. A los ciudadanos en un número equivalente, por lo menos, al cero punto trece por ciento de la lista nominal de electores, en los términos que señalen las leyes.

nunca podrá tener otro fundamento que no sea la propia Constitución; de manera contraria, el Poder Constituyente, como poder soberano, es previo e independiente del ordenamiento. En consecuencia, es claro que solamente considerando al Poder Reformador como un poder constituido y limitado, la estructura de la organización constitucional democrática mantiene su coherencia y cobra sentido el principio jurídico de supremacía constitucional, ya que así ningún poder organizado y regulado por la Constitución puede ubicarse encima de ella. Sólo de este modo puede hablarse propiamente de una capacidad de la norma fundamental para controlar sus propios procesos de transformación. Con ello, la Constitución se presenta como auténtica lex superior y la reforma constitucional puede interpretarse como una verdadera operación jurídica. De todo lo anterior se concluye que si el Poder Reformador es un órgano complejo limitado y sujeto necesariamente a las normas de competencia establecidas en el texto constitucional, entonces es jurídica y constitucionalmente posible admitir que un Estado Constitucional debe prever medios de control sobre aquellos actos reformatorios que se aparten de las reglas constitucionales. Es decir, derivado de una interpretación del artículo 135 de la Constitución Política de los Estados Unidos Mexicanos, cabe la posibilidad de ejercer medios de control constitucional contra la eventual actuación violatoria de las normas del procedimiento reformatorio.

Amparo en revisión 186/2008. Centro Empresarial de Jalisco, Sindicato Patronal. 29 de septiembre de 2008. Mayoría de seis votos. Disidentes: Margarita Beatriz Luna Ramos, José Fernando Franco González Salas, José de Jesús Gudiño Pelayo y Sergio A. Valls Hernández. Ausente: Mariano Azuela Güitrón. Ponente: José Ramón Cossío Díaz. Secretario: Roberto Lara Chagoyán.

El Tribunal Pleno, el tres de noviembre en curso, aprobó, con el número LXXV/2009, la tesis aislada que antecede. México, Distrito Federal, a tres de noviembre de dos mil nueve.

20 Reforma publicada en el Diario Oficial de la Federación, 01 de enero de 2016. 
Esta obra forma parte del acervo de la Biblioteca Jurídica Virtual del Instituto de Investigaciones Jurídicas de la UNAM

El trámite de discusión, en tanto facultad que tiene el Congreso y que se denotan como exclusivas y que se ejercen de manera separada pero sucesiva, será el establecido en el 72 constitucional, que además consagra en favor del titular del ejecutivo federal (inciso c) el derecho de veto, el cual en el presente caso (reforma constitucional) no se puede hacer valer. Esto resulta lógico pues el órgano que está conociendo, Constituyente permanente, tal como lo hemos asentado, se encuentra por encima de los poderes constituidos y sin lugar a dudas el Ejecutivo es uno de ellos, en consecuencia, jamás podrá hacer uso de su veto.

Tal interpretación, de cara a la expresada por nuestro tribunal pleno de la Suprema Corte de Justicia de la Nación, pudiese resultar contradictorio si atendemos a la tesis 1a. LXXXVII/2009, publicada en Semanario Judicial de la Federación, Tomo XXIX, Mayo de 2009, visible a fojas $851^{21}$, que a la letra determina:

DERECHO DE VETO. Al NO EXISTIR ALGÚN PRECEPTO CONSTITUCIONAL QUE LIMITE SU EJERCICIO EN GUANTO AL CONTENIDO, EL TITULAR DEL PODER EJEGUTIVO PUEDE REALIZAR LIBREMENTE SUS OBSERVACIONES A GUALQUIER PROYEGTO DE LEY O DEGRETO.

El derecho de veto consiste en la facultad conferida al titular del Poder Ejecutivo para realizar libremente observaciones a cualquier proyecto de ley o decreto emitido por el Legislativo, con la única limitante de que lo haga dentro de los primeros diez días contados a partir de que recibió el documento respectivo y, en su caso, en razón de la materia con que éste se vincule, pero sin que se advierta alguna disposición constitucional que limite el ejercicio de este derecho en cuanto a su contenido; de ahí que se presuponga la libertad que el Constituyente Permanente le ha conferido al Ejecutivo para ejercerlo, derivado de su carácter eminentemente político. En ese sentido, se concluye que el titular del Poder Ejecutivo puede realizar libremente sus observaciones a cualquier proyecto de ley o decreto, en virtud de que la interpretación efectuada en el escrito que las contiene no puede reputarse jurídica, sino política, ya que no se sustenta necesariamente en motivos de derecho, sino de oportunidad, referidos a intereses económicos, sociales, políticos, etcétera, es decir, bajo argumentos y razones políticas, y no sujetas a un método jurídico, pues sólo así el derecho de veto representa un mecanismo de control político de poderes cuyo objeto es mantener el equilibrio entre ellos, al presuponer una limitación del poder por el poder mismo,

21 Controversia constitucional 148/2008. Poder Legislativo del Estado de Nuevo León. 11 de marzo de 2009. Cinco votos. Ponente: Sergio A. Valls Hernández. Secretaria: Laura García Velasco. 
Esta obra forma parte del acervo de la Biblioteca Jurídica Virtual del Instituto de Investigaciones Jurídicas de la UNAM

representando su ejercicio el principal contrapeso que posee el Poder Ejecutivo para frenar el exceso en el ejercicio de las funciones del Legislativo.

Por otro lado en el procedimiento de reforma se sigue la prescripción del 72, inciso h) que a la letra determina:

H. La formación de las leyes y decretos puede comenzar indistintamente en cualquiera en cualquiera de las dos Cámaras, con excepción de los proyectos que versaren sobre empréstitos, contribuciones o impuestos, o sobre reclutamiento de tropas, todos los cuales deberán discutirse primero en la Cámara de Diputados.

El que inicie la discusión en la Cámara de Diputados en tratándose de los temas aludidos, consideramos que resulta conveniente toda vez que son aspectos de la vida social e institucional que inciden más en la vida del pueblo y en razón de que es la Cámara de Diputados la que tradicionalmente se ha considerado la representante del pueblo que mejor que las discusiones tengan inicio en tal sede.

Por lo que hace a la aprobación por las legislaturas locales, el 135 constitucional determina una mayoría simple por parte de aquellas para que se considere aprobada la reforma sometida al Constituyente permanente.

Finalmente, por lo que se refiere a la promulgación, se sigue lo establecido por el artículo 89, fracción I, siendo el titular del Ejecutivo Federal a quien corresponde tal facultad de promulgación.

Como podemos apreciar el artículo 135, no es en exclusiva el que prevé el procedimiento de reforma constitucional, sino que éste se encuentra involucrado en otro procedimiento que es el de formación de leyes, de ahí que en ocasiones se tenga tan poco cuidado en las apreciaciones que respecto de la norma Constitucional podamos tener.

Lo anterior (la falta de cuidado en la reforma constitucional), no solo sucede con relación al procedimiento constitucional de reforma, sino también dentro del ámbito material, donde en ocasiones, las propias reformas atentan contra los principios constitucionales, principalmente en relación a los limites que consolidan las famosas cláusulas de intangibilidad o cláusulas pétreas.

Como sabemos, en México no existen límites expresos, ya que la Constitución no determina en ningún artículo en que materias o principios no puede ser reformada, por ende, tampoco contiene límites implícitos; ${ }^{22} \sin$

22 Determinados en la Constitución, pero interpretados por la doctrina y/o la jurisprudencia. 
Esta obra forma parte del acervo de la Biblioteca Jurídica Virtual del Instituto de Investigaciones Jurídicas de la UNAM

embargo, existen varios doctrinarios que concuerdan en la existencia de limites inmanentes, que no son respetados, ${ }^{23}$ entre ellos Jorge Carpizo, ${ }^{24}$ Luis Felipe Canudas, ${ }^{25}$ Valencia Carmona; ${ }^{26}$ y, por último, Mario de la Cueva, quien menciona:

El procedimiento de reforma parcial, como es el artículo 135, sólo puede conducir a modificaciones concretas, pero nunca al cambio de los principios fundamentales. De este modo el poder reformador de la Constitución debe detenerse ante los principios que contribuyen a la integración del estilo de vida política del pueblo. ${ }^{27}$

Por tal razón, nos adherimos a la postura de Haberle, ${ }^{28}$ cuando determina que toda reforma constitucional, debe considera lo "políticamente significativo", ya que de otra manera solo hablamos de una reforma constitucional inservible, generando un número de reformas constitucionales exorbitante.

Lo anterior, nos permite reflexionar en el caso mexicano (donde se han realizado aproximadamente 700 reformas constitucionales), las siguientes interrogantes:

¿La constitución de 1917 sigue siendo la misma constitución después de las innumerables reformas (adiciones y supresiones) que ha sufrido, entre los cuales podemos indicar un principio y una decisión políticas fundamentales?

¿Sigue siendo útil aprender y enseñar la clasificación que Bryce ${ }^{29}$ heredó a la doctrina constitucional, respecto de las diferencias que guardan las constituciones rígidas y flexibles, clasificación que a servido tristemente para adjetivar a la nuestra como rígida?

23 Aquellos contenidos por una interpretación doctrinal o jurisprudencial, aunque no se encuentren en el texto constitucional.

24 Carpizo, Jorge, La Constitución Mexicana de 1917, México, UNAM, 1979, p.131.

25 Canudas, Luis Felipe, "Irreformabilidad de las constituciones políticas de la Constitución”, en Revista de Jurisprudencia, México, núm. 20, pp.107-108.

26 Valencia Carmona, Salvador y Héctor FIX ZAMUDIO, Derecho Constitucional Mexicano y Comparado, México, Porrúa, 2000, p. 44

27 De la Cueva, Mario, La idea del Estado, México, Fondo de Cultura Económica, Cuarta edición, 1996, p. 345.

28 Haberle, Peter, El Estado constitucional, México, UNAM-IIJ, 2001, p. 131.

29 Recordemos que a través de metáforas Bryce caracteriza a las constituciones que él denomina "antiguas" (las que tienen su origen en los países de common law) y las "modernas" (las que tienen su origen en el siglo XVIII). 
Esta obra forma parte del acervo de la Biblioteca Jurídica Virtual del Instituto de Investigaciones Jurídicas de la UNAM

La Constitución válida sólo es aquella que no sólo guarda el contenido determinado para aquellas que Karl Loewenstein considera como normativa, sino que, además debe necesariamente que estar acorde con la realidad, y en este aspecto coincidimos con el constitucionalista Gomes Canotilho al decir que una constitución no sólo debe de haber satisfecho el aspecto de la legalidad (conformidad con los procesos constitucionalmente establecidos) sino, además:

...también el de la "legitimidad constitucional como "validación social" corespondencia con los criterios de justicia, con los valores, ideas sociales e imperativos enraizados en el mundo social". 30

\section{BORDANDO SOBRE LO BORDADO: REFORMA INTEGRAL O NUEVA GONSTITUCIÓN}

Antes de pasar a las propuestas puntuales, cabe hacer mención de un hecho contundente, el día de hoy no estaríamos aquí congregados reflexionando en torno a la reforma constitucional u obsolescencia de la actual y, consecuentemente, de la necesidad de una nueva Constitución de no darse dos hechos contundentes, primero, el advenimiento del centenario de la Constitución de '17 y, segundo, la propuesta de constitución reordenada y consolidada de los doctores Valades y Fix Fierro, trabajo meritorio por donde se aprecie y que, en aras de los trabajos reiniciados en el Senado - en una comisión especial encabezada por Raúl Cervantes, que fueran anunciado en diciembre de 2015 y, como hemos anotado, reiniciado en febrero de este 2016 - estoy segura que será de mucha orientación.

Creo que para dar una respuesta coherente se debe determinar:

1. Quién o quiénes son los legitimados para expedir una nueva Constitución, y

2. A través de qué mecanismos.

Respecto a la cuestión de la reforma, es necesario precisar que para quien esto escribe no vale la llamada reforma constitucional integral, particularmente porque se incurriría en omisiones y errores sistemático-constitucionales, ya por demás evidentes en nuestra Constitución.

30 Gomes Canotilho, José Joaquin, Direito Constitucional, Coimbra, Almedina, 1980, pp. 185-186. (Traducción nuestra). 
Esta obra forma parte del acervo de la Biblioteca Jurídica Virtual del Instituto de Investigaciones Jurídicas de la UNAM

Por otra parte y echa la anterior salvedad, considero que no hay punto de debate alguno, pues hasta ahora y tal como lo hemos visto, sirve la traspolación del esquema de procedimiento de formación de las leyes al ámbito de la reforma constitucional.

En cuanto a la probabilidad de crear una nueva Constitución, desde mi punto de vista el problema se resuelve:

Primero. A través del concepto de soberanía,

Entre las formas de dar origen a una Constitución, según Bryce, están dos que nos son ad hoc a este comentario, a saber: primero, aquellas en la cual "una nación puede, por sí misma, crearlas cuando han renunciado a su antigua forma de gobierno o se ha libertado de ella y desea crear otra enteramente de novo" y, segundo, aquellas que "pueden crearse estrechando los lazos existentes con la autoridad entre varias comunidades autónomas. Cuando los peligros anteriores o los intereses económicos han conducido a estas comunidades a desar una unión más íntima que la creada por los tratados o acuerdos federales, las comunidades pueden constituirse en nación, con un gobierno acordado con un instrumento que las mantendrá unidas y se encargará de que actúen como cuerpo único"31.

Con independencia que nos encontremos dentro de una democracia representativa, ya que aquélla reside esencial y originariamente en el pueblo y el pueblo puede pedir que se convoque a un nuevo Congreso Constituyente originario para que se elabore una nueva Constitución.

¿Quién estaría facultado para realizar la convocatoria? Ya que no nos encontramos ante una situación de ruptura constitucional sino de la canalización a través de los representantes legítimos, el único legitimado para hacer la convocatoria a un nuevo Congreso Constituyente sería el Poder Legislativo.

Segundo. Si se opta por la reforma constitucional ésta sólo es posible si se realiza para insertar mecanismos de democracia directa como lo son el plebiscito y el referéndum. Desde luego, este procedimiento es tardado pero, sin lugar a dudas, se determina dentro del marco de legalidad y legitimidad que se consagra en nuestro ordenamiento jurídico.

Estoy cierta de que este siglo, al igual que sucedió con el anterior, se ve plasmado de acontecimientos que rompen con todos los paradigmas, con estructuras, y se ve convulsionado en sus cimientos de tal esquema no escapa nuestro país, pero aquí y ahora, más que nunca, lo que se requiere es el respeto a la dignidad de los que conformamos y damos vida a esta sociedad

31 Bryce, op. cit., pp. 102-104. 
Esta obra forma parte del acervo de la Biblioteca Jurídica Virtual del Instituto de Investigaciones Jurídicas de la UNAM

mexicana, la revolución como la resistencia civil sólo conducen a la irracionalidad del poder.

Finalmente sólo nos resta hacer dos reflexiones:

Primera. La labor de los constitucionalistas si bien no se mueve al impulso de los vientos fácticos de la sociedad, ha de ser congruente con ella en la medida que es ahí en donde se encuentra inserto y comprometido, considerando en todo momento que los principios constitucionales y la Constitución son vivos y dinámicos, que las normas que conforman a esa Constitución son lo suficientemente elásticas para no unidimensionalizar el tejido social y esclerotizarlo.

La norma, particularmente la constitucional, y de esto tengo firme convicción, no ha perdido sus caracteres de general y abstracta, siempre y cuando se reconozca que es necesario que dicha norma sea congruente con la realidad que se vive, que ser y deber ser son elementos indisolubles, que principios y decisiones políticas fundamentales permanezcan, bajo condición de dar el cauce necesario a la actuación del Estado. Que tenga legitimidad en tanto validación social.

Sólo bajo el análisis sociojurídico e interdisciplinario de los fenómenos identificados puede darse una explicación a la crisis política que se da, no sólo en el seno los colectivos tradicionales y la puesta en emergencia de lo que Claus Offe llama nuevos movimientos sociales, sino en instituciones que dan coherencia al actuar social, entiéndase partidos políticos, gobernabilidad, legitimidad, legalidad, llegándose incluso a determinar los parámetros de unidad y orden político que debe subyacer al interior de un Estado. En la medida que se ponga en marcha tal análisis podrá entenderse, también, la crisis por la que pasa la fuerza y validez de la Constitución, tanto en su vertiente interna, en donde juegan factores domésticos y particulares de cada sistema, así como en su vertiente externa, esto es, de orden jurídico supranacional, en donde, qué duda cabe, se da un replanteamiento integral sobre la relativización de la función de la Constitución, específicamente, de la función de coherente unidad operativizada a través de los órganos constitucionalmente legitimados.

\section{FUENTES DE CONSULTA}

Ackerman, Bruce, We the People. Transformations. Cambridge/London, Harvard University Press, 1988.

Alonso García, Enrique, La interpretación de la Constitución, Madrid, Centro de Estudios Constitucionales, 1984. 
Esta obra forma parte del acervo de la Biblioteca Jurídica Virtual del Instituto de Investigaciones Jurídicas de la UNAM

Aragón Reyes, Manuel, Estudios de Derecho Constitucional, Madrid, Centro de Estudios Políticos y Constitucionales de Madrid, 1998.

ARendt, Hannah, On Revolution. NuevaYork:, Penguin Books, 1990.

BARcelona, Pietro, L'uso alternative del diritto, Roma, Bari, 1973.

BREWER Carías, Allan R., "El proceso constituyente y la fallida reforma del Estado en Venezuela", en Estrategias y propuestas para la reforma del Estado, México, UNAM-IIJ, 2002.

BRYCE, James, Constituciones flexibles y constituciones rígidas, Madrid, Instituto de Estudios Políticos, 1952.

BuRdeAu, George, "Une survivance: la notion de Constitution", L'evolution du Droit Public, Études en I'honeur d'Archille Mestre, París, 1956.

CANUDAS, Luis Felipe, "Irreformabilidad de las constituciones políticas de la Constitución”, en Revista de Jurisprudencia, México, núm. 20, pp.107-108.

Carbonnier, Jean, Sociología jurídica, Madrid, Tecnos, 1977.

Carpizo, Jorge, La Constitución Mexicana de 1917, México, UNAM, 1979.

Cueva, Mario de la, Teoría de la Constitución, México, Porrúa, 1982.

De la Cueva, Mario, La idea del Estado, México, Fondo de Cultura Económica, Cuarta edición, 1996.

DíAz, Elías, Estado de Derecho y sociedad democrática; 8a ed., Madrid, Taurus, 1986.

FORSTHOFF, E., "Problemas constitucionales del Estado social", El Estado social (trad. José Puente Egido), Madrid, Centro de Estudios Constitucionales, 1986.

Forsthoff, E., Stato de diritto in transformazione (trad. al italiano de Carlo Almirante), Milán, Giuffrè Editore, 1973.

Gomes Canotilho. José Joaquim, Direito Constitucional, Coimbra, Almedina, 1980.

HABerle, Peter, El Estado constitucional, México, UNAM-IIJ, 2001.

Hernández, María del Pilar, "La fuerza normativa de la Constitución", Problemas actuales del derecho constitucional. Estudios en homenaje a Jorge Carpizo, México, IIJ/UNAM, 2008.

Hesse, K., Escritos de derecho constitucional (trad. Pedro Cruz Villalón), Madrid, Centro de Estudios Constitucionales, 1983.

JellineK, G., Teoría del Estado, 2ª Ed. (trad. Fernando de los Ríos Urruti), buenos Aires, Albatros, 1943.

SchmitT, G., Teoría de la constitución (trad. De Francisco Riebro Ayala), Madrid, Alianza Editorial, 1982. 
Esta obra forma parte del acervo de la Biblioteca Jurídica Virtual del Instituto de Investigaciones Jurídicas de la UNAM

JellineK, George, Teoría del Estado, 2a . ed., (Tr. Fernando de los Rios Urruti), Bueno Aires, Albatros, 1943.

Lassalle, Ferdinand, ¿Qué es la Constitución?, 2ª Ed., México, Ariel, 1976.

MAILLE, M., L'état du droit. Introduction à une critique du droit constitutionnel, Grenoble, 1978.

SchmitT, Carl., Teoría dela Constitución, trad. De Francisco Riebro Ayala), Madrid, Alianza Editorial, 1982.

SiLvA, Alfonso da, "Mutaciones constitucionales" (Traducción del portugués de María del Pilar Hernández), Cuestiones constitucionales, Revista mexicana de derecho constitucional, $\mathcal{N}^{\circ} 1$, México, IIJ/UNAM, julio-diciembre de 1999.

SMED, R., Constitución y derecho constitucional (trad. José Ma. Beneyto Pérez), Madrid, Centro de Estudios Constitucionales, 1985.

VALEncia Carmona, Salvador y Héctor FIX ZAMUDIO, Derecho Constitucional Mexicano y Comparado, México, Porrúa, 2000.

VANOSSI, Jorge Reinaldo, Estudios de teoría constitucional, México, UNAM-IIJ, 2002.

ZippelLiUs, Reinhold, Teoría general del Estado (Ciencia de la política), México, UNAM, 1985. 
Esta obra forma parte del acervo de la Biblioteca Jurídica Virtual del Instituto de Investigaciones Jurídicas de la UNAM

\section{LA FORMA DE LA NORMA. REFLEXIÓN SOBRE EL CARÁCTER REGLAMENTARIO DE ALGUNAS DISPOSICIONES CONSTITUCIONALES}

Carla Huerta*

SUMARIO: I. Introducción. II. El contexto de la regulación constitucional. III. El objeto de análisis: la Constitución. IV. Particularidades de la Constitución como norma. V. La materia constitucional. VI. Reflexiones finales.

\section{INTRODUCCIÓN}

La pregunta sobre la forma de la norma constitucional no es ociosa, en la actualidad discutir sobre la manera en que deben ser redactadas las disposiciones constitucionales es de gran relevancia. La técnica legislativa, como disciplina, ha sido desarrollada ampliamente en torno a la elaboración de leyes y reglamentos, pero poco se dice sobre la norma constitucional. No obstante, en su carácter de norma general y abstracta, mucho de lo desarrollado por la teoría y la técnica de la legislación, en la medida en que éstas se entiendan como los medios para elaboración de normas ${ }^{1}$ podría ser aplicado a la Constitución.

Para poder plantear los problemas que surgen de la regulación detallada de algunas disposiciones constitucionales es preciso señalar que el objetivo del presente ensayo no es el de hacer un análisis descriptivo del derecho mexicano, sino por el contrario se pretende que sea principalmente normativo. Tampoco se trata de discutir la estructura de los enunciados normativos constitucionales, sino más bien de evaluarlos desde el punto de vista material. Para abordar el tema sobre la forma adecuada o más conveniente

* Investigadora del Instituto de Investigaciones Jurídicas de la UNAM.

1 Cffr. Aguiló Regla, Josep, “Técnica legislativa y documentación automática de legislación", en Elementos de técnica legislativa, Carbonell, Pedroza de la Llave coords., UNAM, México, 2000, pp. 245- 248. 
Esta obra forma parte del acervo de la Biblioteca Jurídica Virtual del Instituto de Investigaciones Jurídicas de la UNAM

de las normas constitucionales, en este caso más bien en relación a su generalidad o especificidad, es preciso partir de la pregunta sobre la naturaleza de la Constitución que cuestiona si ésta tiene un carácter especial, en otras palabras, es preciso saber qué tipo de norma es.

La respuesta viene dada en primera instancia por su carácter de norma fundamental y primera norma del sistema jurídico que regula la producción normativa ${ }^{2}$, así como su supremacía, cualidad que le es reconocida por su especial naturaleza como expresión originaria de la voluntad fundacional de un pueblo y el especial procedimiento que se lleva a cabo para su otorgamiento.

Las preguntas a partir de las cuáles se plantea la reflexión son las siguientes: Primero, ¿cómo debe ser la Constitución?, por lo que cabe preguntar de manera más específica: ¿Cómo debe ser un precepto constitucional? Si bien es cierto que por una parte esta última pregunta se refiere a la estructura de la norma, la idea es más bien analizar primero sus propiedades, principalmente las de generalidad y abstracción, aunque también se aborda la temática de su contenido en la medida en que se puede discutir cuáles son las materias que deben ser reguladas en la Constitución y con qué detalle. Esto lleva a preguntarse ¿qué debe incluir una disposición constitucional para satisfacer los fines para los cuales la norma es emitida? Estas cuestiones requieren que se consideren diversos aspectos de la teoría general del derecho.

Segundo, desde la perspectiva de la teoría del derecho constitucional vale la pena cuestionarse ¿qué es materia propiamente constitucional? Si es que se puede hablar de algo así. ¿Qué tipo de cuestiones corresponde considerar al Constituyente de manera primordial o exclusiva para establecer el marco conforme al cual se realice el desarrollo posterior que corresponde al legislador? Esto lleva a la necesidad de retomar la pregunta sobre ¿qué es una Constitución? Identificar las propiedades relevantes del concepto de Constitución tiene por objeto entender su especial naturaleza para: 1. Reflexionar sobre los contenidos de la Constitución, y 2. Decidir si hay materias que deben ser reguladas con mayor precisión y cuáles.

Finalmente, vale la pena mencionar que uno de los aspectos más interesantes de este problema de la reglamentación de preceptos constitucionales es que la sobrerregulación ha alcanzado disposiciones que no forman parte del texto constitucional en sentido estricto. Los artículos transitorios de ca-

2 Kelsen menciona en reiteradas ocasiones que es una peculiaridad del derecho regular su propia producción, Kelsen, Hans, Teoría pura del derecho, (segunda edición), trad. de Roberto J. Vernengo, Porrúa, México, 2000, p. 232. 
Esta obra forma parte del acervo de la Biblioteca Jurídica Virtual del Instituto de Investigaciones Jurídicas de la UNAM

rácter reglamentario, que por sus contenidos transgreden la función de los mismos, también deben ser analizados con detenimiento. Aunque éste no será un tema que se aborde en este ensayo.

\section{EL CONTEXTO DE LA REGULAGIÓN GONSTITUCIONAL}

Diversas cuestiones han de considerarse en la elaboración y reforma de una Constitución, entre otras cosas, su naturaleza de norma, su función en el sistema jurídico, el lenguaje mediante el cual se expresa, la finalidad con la que es emitida así como los objetivos a lograr. El punto de partida del análisis es un concepto de derecho que supone la comprensión de su funcionamiento como un sistema dinámico que regula su propia modificación mediante la previsión de ciertas reglas de introducción y eliminación de las normas. ${ }^{3}$

La transformación del sistema se lleva a cabo mediante la realización de actos normativos ya sea por la introducción o eliminación de una norma. Así se produce una modificación del sistema jurídico por la creación de una norma a través de actos de promulgación o de adición por ejemplo ${ }^{4}$, o por su eliminación mediante un acto de derogación cuando además de suprimir la norma se produce un cambio en el conjunto de las normas aplicables ${ }^{5}$. Esto último es especialmente relevante para la aplicación de la Constitución, pues cada reforma, adición o derogación de una disposición constitucional puede producir la modificación del sentido de otras disposiciones constitucionales, porque la Constitución opera como un sistema ${ }^{6}$.

Bulygin señala que en relación con las normas jurídicas se pueden presentar tres tipos de problemas distintos: 1. los axiológicos, que se refieren

3 Alchourrón y Bulygin en Sobre la existencia de las normas jurídicas, Distribuciones Fontamara, S.A., México 1997, pp. 62, 63.

4 El sentido de "creación del derecho" es muy amplio en Kelsen e incluye los actos de promulgación, reforma y abrogación de las normas pues cada uno se realiza mediante un acto normativo. Kelsen, Hans, Teoría general del derecho y del Estado, trad. de Eduardo García Máynez, UNAM, México, 1988, p. 147.

5 Para Alchourrón los cambios en un sistema jurídico son consecuencia de su expansión, contracción o revisión. La primera se produce cuando se agregan normas al sistema, al menos una, la contracción al eliminarlas, y la revisión ocurre cuando se elimina una norma y posteriormente se agrega otra incompatible con la norma eliminada, la revisión sería así la expansión de una contracción. Alchourrón, Carlos, "Conflicts of Norms and the Revision of Normative Systems", Law and Philosophy, vol. 10, iss. 4, 1991, Kluwer, Netherlands, p. 425.

6 Solamente la concepción de la Constitución como sistema puede explicar las relaciones que se producen entre las normas que la conforman. Cfr., Huerta, Carla, Teoría del derecho. Cuestiones relevantes, Instituto de Investigaciones Jurídicas, UNAM, México, 2009, p. 262. 
Esta obra forma parte del acervo de la Biblioteca Jurídica Virtual del Instituto de Investigaciones Jurídicas de la UNAM

principalmente a cuestiones de equidad y justicia, 2. los problemas lingüísticos que están relacionados con la vaguedad (sintáctica y semántica) y la ambigüedad (ya sea actual o potencial), tanto de los conceptos jurídicos como de los enunciados normativos, y 3. los problemas que él denomina lógicos o conceptuales, como son el sistemático y el dinámico, y que derivan de la propia naturaleza del derecho. ${ }^{7}$ Por lo que a la forma de la norma se refiere, en relación con los actos de creación normativa son de especial interés los problemas lingüísticos y los lógicos.

Los problemas dinámicos se encuentran asociados al objeto que regulan las normas: las conductas que son cambiantes, así como al hecho que las normas en su calidad de elementos primarios del sistema se relacionan entre sí y forman una unidad que se ordena conforme a ciertos criterios determinados por el propio sistema. Asumir que el derecho opera como un sistema implica aceptar ciertas propiedades formales del sistema como son la completitud, la coherencia, la consistencia y la independencia que determinan la forma en que las normas que lo integran se relacionan ${ }^{8}$. Estas "propiedades" operan como criterios de desarrollo e interpretación del derecho y podrían considerarse como un deber racional para la autoridad normativa y aplicadora ${ }^{9}$.

Estos problemas resultan del proceso de creación y eliminación de las normas, en términos de Bulygin de los actos de promulgación y derogación. ${ }^{10}$ Es por ello que es conveniente tener un conocimiento adecuado de la estructura y funcionamiento del sistema jurídico, así como de sus presupuestos operativos al evaluar la inclusión, modificación o eliminación de una determinada disposición en la Constitución. Todo acto normativo produce una transformación del sistema jurídico, especialmente relevantes son los que se realizan a la Constitución por su posición en el sistema jurídico,

7 Bulygin Eugenio, “Teoría y técnica de la legislación”, Análisis lógico y derecho, Centro de Estudios Constitucionales, Madrid, 1991, pp. 411, 412.

8 Cr. Huerta, Carla, Conflictos normativos, segunda edición, UNAM, México, 2007, pp. 130-135. Alchourrón y Bulygin hablan de la completitud, la coherencia y la independencia como propiedades estructurales de los sistemas normativos, Introducción a la metodología de las ciencias jurídicas y sociales, Editorial Astrea, Buenos Aires, 1993, pp. 100-102.

9 Ya Savigny sugería que en la aplicación y creación del derecho era precisa su comprensión lógica y sistemática. Como dice Larenz, es característico en Savigny el método el sistemático que intenta comprender la totalidad de las normas jurídicas como un todo coherente, y que para él se tenía que combinar con el método histórico. Vid Larenz, Karl, Metodología de la ciencia del derecho, trad. Marcelino Rodríguez Molinero, Ariel, Barcelona, 1994 p. 38.

10 Bulygin, op.cit, nota 7, p. 419. 
Esta obra forma parte del acervo de la Biblioteca Jurídica Virtual del Instituto de Investigaciones Jurídicas de la UNAM

ya que cada reforma repercute en las normas subordinadas a ella ${ }^{11}$. Esto se debe a que en el derecho, entendido como sistema, las normas jurídicas se encuentran relacionadas unas con otras conforme a los criterios del propio sistema.

Los problemas lingüísticos derivan del lenguaje natural en el que el derecho es expresado de modo que los enunciados normativos pueden estar afectados por cualquier tipo de problema lingüístico como son la oscuridad, la vaguedad o la ambigüedad. La falta de claridad y precisión en la elaboración de una norma da lugar a problemas de aplicación que pueden causar problemas de índole jurídica o sumarse a ellos, sobre todo por la cantidad de conceptos técnicos que se utilizan en el derecho por ser el derecho un lenguaje especial cuya función es expresar conductas debidas ${ }^{12}$.

Este tipo de problemas pueden parecer menores al lado de los de orden lógico ya que puede realizarse un control previo a la expedición de la norma y recurrirse a expertos para evitarlos ${ }^{13}$. Aunque se trate de un problema salvable, el uso inadecuado de las reglas del lenguaje jurídico, que parte del lenguaje natural como señala María Bono, genera conflictos que impiden que se cumplan los fines de "accesibilidad, claridad y precisión" propios de la racionalidad lingüística ${ }^{14}$. Es por ello que Bulygin sostiene que es preciso separar la función política de la sanción legislativa de la de la elaboración técnica del proyecto de ley, lo cual se puede lograr encomendando la labor a técnicos especializados ${ }^{15}$.

Esta estrecha relación entre el lenguaje y el derecho hace indispensable que la actividad normativa sea realizada con especial atención, ya que los enunciados normativos que conforman el lenguaje jurídico tienen un carácter prescriptivo. Cabe aclarar que aquí se adopta una definición semántica

11 Lo que permanece invariable según Alchourrón y Bulygin son los criterios de identificación del sistema que permiten hablar del mismo sistema. En términos de derecho positivo este criterio sería la Constitución, op. cit., nota 3, pp. 61-63.

12 Si un enunciado normativo no es claro será preciso interpretarlo, y como dice Guastini si la interpretación es entendida como atribución de significado, entonces es presupuesto de los actos de aplicación, Guastini, Riccardo, Estudios sobre la interpretación jurídica, trad. de Gascón y Carbonell, Instituto de Investigaciones Jurídicas, UNAM, México, 1999, p. 5.

13 Como apoyarse en una comisión de estilo, como se hizo antes de la expedición de la Constitución de 1857, cuyo objeto sería la revisión por expertos en el idioma, además de juristas para supervisar la redacción y el lenguaje técnico. Aunque muy rápidamente en 1917 también se sometió a revisión el texto reformado de la Constitución.

14 Cfr. Bono, María, "La racionalidad lingüística en la producción legislativa", en Elementos de técnica legislativa, Carbonell, Pedroza de la Llave coords., Instituto de Investigaciones Jurídicas, UNAM, México, 2000, p. 192.

15 Bulygin, op.cit, nota 7, p. 423. 
Esta obra forma parte del acervo de la Biblioteca Jurídica Virtual del Instituto de Investigaciones Jurídicas de la UNAM

de norma, de modo que la norma es el significado del enunciado normativo que es el emitido por el legislador (l.s.). Según Wróblewski, el lenguaje jurídico como lenguaje del deber ser en el que se formulan los textos normativos se distingue del lenguaje ordinario en los niveles semántico y pragmático, más no en el sintáctico. ${ }^{16}$ La forma del enunciado ha de conformarse por lo tanto a las reglas de la gramática del lenguaje en el que se redactan, aunque puede variar un poco en el estilo que es propio del derecho.

No obstante, al enunciado normativo en sí corresponde una estructura propia que la teoría general de las normas ha establecido que se integra por tres elementos: supuesto de hecho, cópula y sanción o consecuencia jurídica. Cuando no es dada, esta forma ideal del enunciado normativo ${ }^{17}$ ha de ser identificada o reconstruida mediante interpretación por el órgano que aplica o desarrolla una disposición jurídica. La falta de alguno de estos elementos es una deficiencia técnica imputable al legislador y la consecuencia es la imposibilidad de satisfacer la norma, así como de exigir su cumplimiento. Un ejemplo claro en la Constitución es la omisión legislativa, en México es evidente que el incumplimiento de un mandato al legislador carece de consecuencias ${ }^{18}$.

Esto nos lleva a reflexionar sobre su formulación. Las normas entendidas como reglas de conducta de observancia obligatoria, han de contar con un supuesto de hecho o hipótesis normativa que se define como abstracción de la realidad regulada. Este elemento de la norma es en el que se puede identificar unas de las propiedades más importantes que caracterizan a los enunciados normativos: la abstracción y generalidad, las cuales producen otras formas de ambigüedad y vaguedad que se suman a las de las palabras utilizadas. No obstante, son estas propiedades las que permiten mediante la realización de una operación intelectual elaborar supuestos de hecho independientes de la realidad observada que se pretende transformar mediante la regulación.

16 Wróblewski, Jerzy, Sentido y hecho en el derecho, trad. de Francisco Javier Ezquiaga Ganuzas, Distribuciones Fontamara, México, 2001, p. 177.

17 Vid por ejemplo, Kelsen, Hans, Teoría pura del derecho, (primera edición), México, Editora Nacional, 1981, p. 48, o bien, Schreiber, Rupert, Die Geltung von Rechtsnormen, BerlínHeidelberg-Nueva York, Springer Verlag, 1966, pp. 9 y ss.

18 El concepto de "omisión legislativa" tiene varias acepciones, pero en general se refiere a la inactividad o negligencia por parte del legislador para elaborar una ley ya por mandato expreso o en función de las competencias atribuidas por la Constitución. El problema está en que como dice Morón Urbina, en la mayoría de los casos, la omisión legislativa carece de "remedio jurídico eficaz". Cfr. Morón Urbina, Juan Carlos, "La omisión legislativa inconstitucional y su tratamiento jurídico", Revista Peruana de Derecho Constitucional, n 1, Lima, 1999, p. 452. 
Esta obra forma parte del acervo de la Biblioteca Jurídica Virtual del Instituto de Investigaciones Jurídicas de la UNAM

Dado que la Constitución es una norma de un tipo especial, no solamente por su carácter de norma suprema del sistema jurídico, sino también por su función delimitadora de la creación de normas, sus disposiciones son las normas más generales y abstractas del orden jurídico ya que a partir de estas normas se desarrolla el sistema jurídico, y así es conveniente que sea pues esto hace posible su interpretación, y esta flexibilidad de sentido refuerza su permanencia. Además, como señala Aragón la capacidad evolutiva de una Constitución es una cualidad importante del constitucionalismo que reside en la "capacidad que poseen los textos para adaptarse a circunstancias cambiantes, a través de la interpretación, sin transformar la redacción originaria" ${ }^{19}$ y esto solamente es posible en la medida en que sus supuestos sean generales y abstractos.

Finalmente, si bien es cierto que la dinámica es una propiedad distintiva del derecho es conveniente adaptar la Constitución solamente cuando no sea posible interpretarla de otra manera, pues es importante mantener el equilibrio entre transformación y permanencia si las normas han de cumplir su función de guías de conducta y el derecho ha de operar como herramienta de conformación social como decía Kelsen ${ }^{20}$. De modo que la autoridad facultada para modificar y desarrollar el sistema jurídico tiene que balancear la dinámica propia del derecho con la permanencia constitucional para fortalecer su posición como norma fundamental y su vigencia ${ }^{21}$.

\section{EL OBJETO DE ANÁLISIS: LA CONSTITUCIÓN}

Aquí retomamos la cuestión sobre la precisión con la que han de ser redactas las disposiciones constitucionales, para ello me parece importante repensar qué es una Constitución, algo que aunque hoy en día podría parecer evidente, no lo es tanto. Identificar las propiedades relevantes del concepto de

19 Aragón Reyes, Manuel, "Dos problemas falsos y uno verdadero: "neoconstitucionalismo", "garantismo" y aplicación judicial de la Constitución", en Estado constitucional, derechos humanos, justicia y vida universitaria. Estudios en homenaje a forge Carpizo, Carbonell, Fix-Fierro, González Pérez, Valadés coords., Tomo IV, vol. 1, Instituto de Investigaciones Jurídicas, UNAM, México, 2015, p. 96.

20 El elemento central para Kelsen es la coercibilidad, por eso señala que: "The specific technique of the law -the technique of indirect motivation- consists in the very fact that it attaches to certain conditions certain coercive measures as consequences", Kelsen, Hans, "Law as a Specific Social Technique", University of Chicago Law Review, vol. 9, iss. 1, p. 87.

21 Por lo que a la permanencia de la Constitución y al proceso de reforma constitucional desde la perspectiva material, como dinámica de los contenidos constitucionales, se refiere vid Huerta, op. cit., nota 6, pp. 72-76. 
Esta obra forma parte del acervo de la Biblioteca Jurídica Virtual del Instituto de Investigaciones Jurídicas de la UNAM

Constitución tiene por objeto entender su especial naturaleza para reflexionar sobre los contenidos de la Constitución y cómo deben ser regulados.

Primero hay que aclarar que como punto de partida se han de considerar tres aspectos: el carácter de norma jurídica de la Constitución, su posición y su función en el sistema jurídico. Considerar a la Constitución como norma implica principalmente reconocer que produce efectos jurídicos y que su cumplimiento es obligatorio y por lo tanto, exigible. El derecho se distingue de otros tipos de normatividad porque regula su propia creación y esto debe hacerse en la norma superior ${ }^{22}$. Así, la Constitución regula la producción normativa de modo que funda y conforma el sistema jurídico por lo que su fuerza y eficacia normativas derivan de su posición en el sistema jurídico ${ }^{23}$ que por lo mismo tiene que ser la suprema. De tal forma que como primera norma del sistema regula los procedimientos de creación y de su conformidad con ella derivan cadenas de validez de las normas como sostenía Kelsen.

La supremacía de la Constitución sin embargo, además de a su posición en el sistema jurídico, hace referencia a su eficacia y su fuerza derogatoria que indican la forma en que opera como norma jurídica, que es de manera directa, y en ello radica su normatividad ${ }^{24}$. Esto significa por una parte, que los órganos competentes que deben aplicar el orden jurídico están obligados a aplicar directamente las normas constitucionales, pues los derechos previstos en la Constitución son inmediatamente operativos, aun sin desarrollo legislativo. El principio de eficacia directa de la Constitución no opera de la misma manera respecto de todas las normas constitucionales, aunque por supuesto es aplicable a los derechos que son exigibles de manera inmediata. En cambio, el ejercicio de competencias, así como los procedimientos de creación y aplicación de las normas con frecuencia requieren de ser precisados en las leyes en términos generales y pormenorizados en los reglamentos respectivos.

22 Kelsen sostiene que el orden jurídico es un sistema de normas generales e individualizadas "entrelazadas entre sí de acuerdo con el principio de que el derecho regula su propia creación". Kelsen, op.cit, nota 4, p 156.

23 Su fuerza es determinada por los criterios de jerarquía y distribución de materias, vid. De Otto, Ignacio, Derecho Constitucional. Sistema de fuentes, 2da. edición, Barcelona, Editorial Ariel, 1989, pp. 88-91.

24 Para Wróblewski la discusión sobre la normatividad de la Constitución solamente es significativa si por normatividad se entiende que las disposiciones constitucionales regulan directa o indirectamente la conducta humana. Wróblewski, Jerzy, Constitución y teoría general de la interpretación jurídica, trad. de Arantxa Azurza, Civitas, Madrid, 1988, Civitas, 1985, pp. 103, 104. 
Esta obra forma parte del acervo de la Biblioteca Jurídica Virtual del Instituto de Investigaciones Jurídicas de la UNAM

Esta eficacia directa de la Constitución deriva de su posición jerárquica en el sistema jurídico como norma suprema del mismo, que se aplica también a las relaciones jurídicas según el principio de jerarquía normativa, porque se entiende que esta superioridad significa que la Constitución no es un mandato al legislador, sino una norma a aplicar. Por otra parte, significa además que en caso de conflicto con disposiciones secundarias del orden jurídico prevalece la Constitución aun cuando sus preceptos solamente sean generales. El desarrollo puntual de disposiciones constitucionales podría tener un efecto sustitutorio de la legislación secundaria, y en dicho caso si se expidieran las leyes secundarias no se producirían conflictos siempre y cuando el legislador ordinario fuese cuidadoso al reproducir las normas constitucionales en la ley ${ }^{25}$.

De modo que siguiendo a Kelsen si la Constitución se define por su jerarquía y función, y dado que su carácter de norma jurídica es un "deber ser", entonces su función es regular conductas de manera directiva ${ }^{26}$. Si su objeto es regular conductas y sus disposiciones son prescriptivas, entonces las declaraciones y explicaciones no pueden ser parte de su contenido. A la Constitución le compete establecer los órganos encargados de la creación de normas generales y determinar el procedimiento correspondiente. Pero además para Kelsen, la "Constitución en sentido material, puede determinar no solamente los órganos del proceso legislativo, sino también, hasta cierto grado, el contenido de leyes futuras" ${ }^{27}$. Pero solo en cierto grado, no de manera absoluta, pues no es su función determinar todo el sistema jurídico.

Dado que la Constitución como primera norma positiva establece órganos, procedimientos y contenidos como sostenía Kelsen, al determinar los contenidos prescritos o excluidos para la creación de normas inferiores válidas, estas reglas operan como criterios de su desarrollo válido. Por lo que el legislador ordinario debe sujetarse a lo previsto en la Constitución, pues el modelo jerárquico se sustenta en los valores de orden, estabilidad, seguridad y responsabilidad. Así entendida, la Constitución funciona como el sistema de significaciones jurídicas que determina los significados de las demás normas del sistema. Pero la Constitución no puede determinar en todos los sentidos el acto mediante el cual es aplicada, por lo que siempre

25 Esto sin embargo, genera un problema de redundancia, pues habría dos enunciados normativos idénticos regulando el mismo supuesto, vid Huerta, op.cit, nota 6, pp. 20, 21.

26 Cfr. Kelsen, op.cit, nota 2, pp. 18, 19, 232, 234.

27 Kelsen, op.cit, nota 4, p. 148. Según Kelsen la Constitución puede prescribir o excluir ciertos contenidos, en su opinión, es más eficaz "excluir por la Constitución leyes de determinados contenidos", op.cit, nota 2, p. 234. 
Esta obra forma parte del acervo de la Biblioteca Jurídica Virtual del Instituto de Investigaciones Jurídicas de la UNAM

subsiste un espacio para la discrecionalidad ${ }^{28}$. Este margen para el desarrollo es deseable, pues la intención no es que todo se encuentre previsto en la Constitución, ni siquiera es posible. Es más, como bien señala Bulygin, "el legislador no tiene que prever todas las circunstancias posibles que pueden presentarse" y añade: "cosa que sería ciertamente imposible para el legislador humano" 29 .

La Constitución es el marco de referencia para el desarrollo y aplicación de las normas del sistema jurídico, no la totalidad, su función no es preverlo todo. Es más si los contenidos son específicos, el legislador no puede desarrollar el derecho sino transcribir solamente, es casi como remitir la regulación al poder Ejecutivo para reglamentar lo necesario para su aplicación, con lo que se pierde un mecanismo de control y equilibrio. Si los supuestos se cierran se impide la configuración posterior por el legislador que es indispensable en casos como los que requieren un margen de decisión. Precisar las normas es anclarlas en el presente negando el futuro al imposibilitar su adaptación por medios distintos a la reforma.

Según Hesse la Constitución tiene un carácter amplio y abierto, regula de manera general, lo importante y lo que necesita determinación, la concretización de lo demás dice que se "confía" al resto del orden jurídico puesto que "la Constitución no codifica". En su opinión, hay que aceptar que "las normas de la Constitución no son completas ni perfectas", es más para Hesse "la Constitución debe permanecer incompleta e inacabada"30. En otras palabras, la Constitución debe lograr cierto equilibrio entre la "precisión" que es necesaria para la claridad y comprensión del significado de las normas y la indeterminación que hace posible la adaptación de la Constitución mediante la interpretación.

En la medida en que los enunciados normativos son indeterminados, pueden ser considerados como marcos abiertos a la interpretación como decía Kelsen ${ }^{31}$. Por lo que a su formulación se refiere, se pueden producir distintas formas de indeterminación y pueden ser de orden semántico, sintáctico o pragmático, que corresponden a distintos planos de análisis del lenguaje. Por su posición en el sistema, la Constitución es la norma cuyos contenidos ofrecen por su generalidad y abstracción la mayor indetermina-

28 Kelsen, op.cit, nota 2, p. 350.

29 Bulygin, op.cit, nota 7, p. 415

30 Hesse, Konrad, Escritos de derecho constitucional, trad. de Pedro Cruz Villalón, Centro de Estudios Constitucionales, Madrid, 1992, pp. 17, 18 y 34.

31 Kelsen, Hans, Teoría pura del derecho, traducción de Moisés Nilve de la edición francesa de 1953, pp. 167 y ss. 
Esta obra forma parte del acervo de la Biblioteca Jurídica Virtual del Instituto de Investigaciones Jurídicas de la UNAM

ción. Si se atiende a la distinción hecha por Kelsen a partir del acto de voluntad que la produce, entonces se puede hablar de dos tipos de indeterminación: la intencional y la no intencional ${ }^{32}$. La no intencional puede resultar de una mala formulación lingüística, una pobre técnica legislativa o de la incertidumbre que produce la existencia de una pluralidad de normas que regulan el mismo supuesto, esto evidentemente no es deseable.

La intencional en el caso del Constituyente se manifiesta en la formulación de normas generales que hacen posible el trabajo conceptual y permiten un margen de interpretación que se concreta en el acto de aplicación de la norma. Cuando es intencional tiene por objeto configurar y proteger el ámbito mínimo de derechos y libertades permitiendo el desarrollo posterior al legislador, o bien, abrir a la interpretación sus previsiones generales para que abarquen la mayor cantidad de supuestos posibles. La generalidad y abstracción pueden producir ambigüedades, pero esto no tiene que percibirse como algo negativo pues hace posible la duración de la norma, y esta permanencia produce una estabilidad que refuerza su normatividad. De esta manera se hace posible una forma de adecuación más flexible que por vía de reforma constitucional. Este tipo de indeterminación, es parte de la versatilidad necesaria en el derecho.

La función de la Constitución es compleja y variable como señalan Hamon y Troper, quienes distinguen las funciones jurídicas de las políticas ${ }^{33}$. No obstante se puede decir que como norma jurídica suprema del sistema jurídico su función es regular y limitar el ejercicio del poder para garantizar la libertad mediante la previsión de controles. Para poder lograrlo es imprescindible su permanencia a pesar de la dinámica del derecho, la reglamentación de sus preceptos la hace rígida por lo que podría no llegar a afianzar su normatividad o incluso perder rápidamente su vigencia. Si no tiene una cierta estabilidad, la Constitución no puede posibilitar ni garantizar el funcionamiento de un Estado ${ }^{34}$.

Por eso debe ser distinta a la ley no solamente en el rango sino también en sus contenidos, pues si bien la jerarquía es definitoria de la Constitución como norma porque la posición que ocupa en el sistema jurídico la distin-

32 Kelsen, op.cit, nota 2, p. 350.

33 Desde el punto de vista jurídico consideran una triple función de la Constitución: fundamentar la validez del sistema jurídico, determinar las modalidades de designación de gobernantes y sus competencias y enunciar principios que justifiquen las reglas positivas y su ulterior interpretación. Hamon, Francis y Michel Troper, Droit Constitutionel, 28 a ed., L.G.D.J., Paris, 2013, pp. 44, 45.

34 Cfr. Huerta, Carla, Mecanismos constitucionales para el control del poder, $3^{\text {a }}$. edición, Instituto de Investigaciones Jurídicas, UNAM, México, 2010, p. 59. 
Esta obra forma parte del acervo de la Biblioteca Jurídica Virtual del Instituto de Investigaciones Jurídicas de la UNAM

gue de otras normas, se distingue de otras fuentes ${ }^{35}$ primordialmente por su contenido: regula la dinámica jurídica y los destinatarios de estas disposiciones son los órganos que crean y aplican normas ${ }^{36}$. Esto significa que tiene que haber una diferencia entre Constitución y ley no solamente en la forma que adopta, sino también en los contenidos que regula.

En resumen, la regulación detallada equipara la Constitución a la ley lo que menoscaba su supremacía, principalmente en sentido material pues aunque el proceso de elaboración y reforma de la Constitución sea distinto ${ }^{37}$, la forma de la norma no permitiría distinguir la cualidad fundamental de sus prescripciones al ser iguales y la distinción formal entre norma constitucional y ley ordinaria se tornaría irrelevante. Esto no es conveniente porque la Constitución debe preservar su supremacía jurídica frente a las leyes, distinguirse de ellas, no sólo formalmente sino también materialmente, pues como señala Aragón, el rango de la Constitución es inseparable de su contenido ${ }^{38}$. Es más, el desarrollo detallado de preceptos constitucionales hace superfluo el trabajo del legislador ordinario, puesto que de esta manera el Constituyente permanente substituye en sus funciones al legislador y materialmente invade su esfera de competencia.

\section{PARTIGULARIDADES DE LA CONSTITUCión COMO NORMA}

El derecho regula su propia creación, esta es una de sus notas distintivas, razón por la cual según Kelsen, el derecho se caracteriza por dos tipos de acciones: la creación y la aplicación de normas ${ }^{39}$. En un sistema jerárquico todo acto de creación, excepto el del Constituyente originario, es un acto

35 Para Ignacio de Otto las fuentes son los actos a los que el derecho positivo confiere la virtualidad de crear una norma. De Otto, op.cit, nota 23, p. 70.

36 Según Rolando Tamayo la Constitución, como parte del discurso prescriptivo, se dirige a los órganos que deben aplicarla. Tamayo, Rolando, "Interpretación constitucional, La falacia de la interpretación cualitativa", en Vázquez, Rodolfo, (compil.) Interpretación jurídica y decisión judicial, Fontamara, México, 1998, Doctrina Jurídica Contemporánea nº 4, p. 115.

37 La supralegalidad es para Aragón la garantía jurídica de la supremacía constitucional y no es una propiedad meramente formal que deriva de su procedencia de una fuente superior a la del derecho ordinario, sino sobre todo de sentido material. Aragón, Manuel, "Sobre las nociones de supremacía y supralegalidad constitucional", en Revista de Estudios Políticos, no. 50, marzo-abril 1986, Centro de Estudios Constitucionales, p. 23.

38 Aragón, Ibidem, p. 22.

39 Para Kelsen la "creación del derecho es siempre aplicación del mismo." Aunque en su opinión, "normalmente cada acto es al propio tiempo creador y aplicador del derecho" excepto los casos limítrofes, op.cit, nota 4, p. 157. 
Esta obra forma parte del acervo de la Biblioteca Jurídica Virtual del Instituto de Investigaciones Jurídicas de la UNAM

de aplicación. El legislador ordinario es el primer intérprete de la Constitución ${ }^{40}$, pues debe conformarse a ella para la elaboración de las leyes, ya que una ley solamente puede ser considerada norma jurídica, ser obligatoria y servir de fundamento a otras normas, si ha sido adoptada conforme a la Constitución ${ }^{41}$. Es por ello que su labor creadora tiene una doble relevancia: desarrollar y precisar los contenidos de la Constitución, y realizar un trabajo coherente que evite en la medida de lo posible la necesidad de la interpretación, pero si las disposiciones son reglamentarias ni interpretación ni desarrollo son posibles.

Como ya se mencionó, la Constitución en virtud de su rango y función permanece_indeterminada, y regula sólo de manera general la forma en que debe ser aplicada, por lo que deja un cierto espacio de discrecionalidad al órgano creador de normas secundarias y al intérprete ${ }^{42}$. El carácter de marco abierto de los enunciados normativos debe ser llenado a través del acto interpretativo ${ }^{43}$. El origen de la incertidumbre sobre el significado y alcance de las normas jurídicas se encuentra en primer lugar en el órgano redactor de la norma, que en el caso que nos ocupa es el Constituyente. Pero esto no necesariamente es un defecto pues la indeterminación puede ser intencional y tener un propósito funcional.

Es por ello que sería conveniente que para hacerla eficaz la actividad normativa del Constituyente se guiara por el modelo del "legislador racional" que presume que la actuación del legislador es la de un sujeto individual, permanente, único y razonable que conoce el sistema jurídico en su totalidad. ${ }^{44}$ Este modelo supone que el legislador conoce todas las circunstancias, debe ser coherente, consistente y además justo. Según Nino este modelo es utilizado por los juristas aunque "poco tiene que ver con el legislador de carne y hueso que sanciona leyes"45. Así el legislador racional es omnicomprensivo, en el sentido de que no deja ninguna situación jurídica

40 Para Kelsen, hay interpretación constitucional "en tanto corresponda aplicarla, mediante el procedimiento legislativo", op.cit, nota 2, p. 349.

41 Cfr. Hamon y Troper, op.cit, nota 33, p. 45.

42 La discrecionalidad es una potestad regulada, por lo que no debe confundirse con la arbitrariedad, su ejercicio es un acto de poder limitado. Vid Huerta, Carla, "Discrecionalidad y legalidad: tensión en la aplicación del derecho", Disertaciones de filosofía del derecho, Fernández Ruíz coord., UNAM, México, 2013, p. 17.

43 Kelsen, op.cit, nota 2, pp. 349-352.

44 Sobre el tema vid, Esquiaga, Francisco Javier, "Argumentos interpretativos y el postulado del legislador racional” en Vázquez, Rodolfo, (compil.) Interpretación jurídica y decisión judicial, Fontamara, México, 1998, Doctrina Jurídica Contemporánea nº 4, pp. 157- 186.

45 Nino, Carlos, Consideraciones sobre la dogmática jurídica, UNAM, México, 1989, p. 85. 
Esta obra forma parte del acervo de la Biblioteca Jurídica Virtual del Instituto de Investigaciones Jurídicas de la UNAM

sin regular, finalista porque tiene un objetivo, no es redundante, es operativo pues solamente emite normas que serán aplicadas, preciso en la utilización del lenguaje que además es perfecta, y su única función es legislar. ${ }^{46}$ Este modelo ha de ser tomado con cautela. como guía de la acción normativa racional, no como una descripción de la realidad. En el caso de México, parece que el legislador solamente tiene una pretensión afín a este modelo que es la de ser omnicomprensivo, ya que intenta legislar sobre todo lo que se le ocurre, aunque es evidente que jamás se podrían prever todas las situaciones posibles ${ }^{47}$.

La labor constitucional debe por lo tanto, partir siempre de la hipótesis de un legislador constituyente no redundante, de la idea de que el enunciado normativo no es superfluo, ni repetitivo, sino un enunciado que por sí solo, o en conexión con otros prevé derechos u obligaciones. De modo que como presupuesto de elaboración e interpretación de las normas ha de tomarse en cuenta que la Constitución se conforma por una serie de normas no independientes, entendidas en el sentido de Kelsen ${ }^{48}$, por lo que en virtud de la vinculación e interrelación de los enunciados normativos en términos de la unidad del sistema jurídico. la estructura de la norma puede integrarse mediante la complementación de diversos enunciados normativos ${ }^{49}$.

Así, el método sistemático de interpretación hace posible vincular diversos enunciados para integrar la norma y atribuirle significado mediante la combinación de algunos elementos o partes de los enunciados normativos para formar una norma completa, como dice Guastini. ${ }^{50}$ Razón por la cual no es necesario repetir una y otra vez en un cuerpo normativo, menos aún en la Constitución, los enunciados normativos completos una y otra vez. Es más los supuestos constitucionales no pueden ser interpretados de manera aislada, sino relacionándolos con los demás supuestos de la Constitución ya

46 Ibidem, pp.85-86.

47 En algún momento pudo ser el objetivo de los procesos de codificación francés y alemán que dieron lugar a los códigos civiles de 1804 y 1900 respectivamente, pero intentar considerar todas las situaciones posibles no hubiera permitido concluir los trabajos legislativos.

48 A diferencia de las normas no independientes, las normas independientes prevén la sanción coactiva en el mismo enunciado que el supuesto de hecho. Kelsen, op.cit, nota 2, pp. $67-70$.

49 Las relaciones entre los supuestos de hecho son de distintos tipos, Schreier habla de dependencia, fusión y compatibilidad, y aunque en su libro utiliza el término "hecho jurídico", aclara que lo usa en el sentido de supuesto o hipótesis jurídica. Schreier, Fritz, Conceptos y formas fundamentales del derecho, trad. de Eduardo García Máynez, Ediciones Coyoacán, México, 2010, pp. 121-169.

50 Guastini, op.cit, nota 12, p. 44. 
Esta obra forma parte del acervo de la Biblioteca Jurídica Virtual del Instituto de Investigaciones Jurídicas de la UNAM

que ésta forma una unidad, por lo que deben ser interpretados de manera sistemática y coherente.

De modo que es posible sostener que el "legislador racional" como presupuesto teórico puede servir al Constituyente como premisa (ideal) de la tarea normativa, que a la vez opere como mecanismo de control preventivo de las normas, y como presupuesto de interpretación para la reforma de la Constitución. El objetivo principal de recurrir a este modelo es el de optimizar la aplicación de las normas constitucionales para incrementar su eficacia y por consiguiente la permanencia de la Constitución misma. Trabajar con este modelo podría operar como una presunción a favor del órgano reformador de la Constitución que contribuiría a hacer una interpretación razonable y congruente de sus normas.

Dada la función y rango de la Constitución debe existir claridad ${ }^{51}$ y certeza en el texto constitucional para poder cumplir con su función directiva, el cual debe adecuarse a la realidad que regula y procurar mantener su permanencia para preservar su fuerza normativa. Aunque esto pueda parecer contradictorio, refleja más bien la tensión que se produce entre cambio y permanencia que resulta de la naturaleza dinámica del derecho ${ }^{52}$. Para reforzar la permanencia de la Constitución sus disposiciones han de ser generales y abstractas con lo cual se hace posible su interpretación y por ende, el cambio vía mutación. Solamente cuando no es posible otra interpretación entonces procede la reforma en los términos previstos por la propia Constitución.

Los enunciados normativos de la Constitución, así como los que forman parte de una reforma o adición a la misma, pueden ser interpretados si son amplios y abiertos, al igual que los artículos transitorios de las mismas, aun cuando no forman parte del texto constitucional (s.s.). La interpretación constitucional se identifica por su objeto, una Constitución ${ }^{53}$, y según Wróblewski tiene cuatro peculiaridades: la variedad de las reglas constitucionales, ${ }^{54}$ las características de los términos utilizados en su for-

51 Aunque como señala Guastini la claridad resulta de la interpretación, es conveniente que los enunciados normativos sean simples y bien redactados para evitar la obscuridad. Ibidem, pp. 7, 8.

52 Sobre la tensión mencionada entre modificación y permanencia vid Huerta, Carla, "La fuerza normativa de la Constitución. Tensión entre aplicación y reforma constitucional", en Estado Constitucional, derechos humanos, justicia y vida universitaria, homenaje a Jorge Carpizo, UNAM, México, 2015, pp. 19-48.

53 Wróblewski, op. cit, nota 24, p. 33.

54 Wróblewski considera a las reglas de conducta en sentido estricto, las reglas de organización, las reglas teleológicas y las reglas directivas como tipos de normas constitucionales. Ibidem, pp. 104-106. 
Esta obra forma parte del acervo de la Biblioteca Jurídica Virtual del Instituto de Investigaciones Jurídicas de la UNAM

mulación ${ }^{55}$, la aplicabilidad de las normas constitucionales, y el carácter político de la interpretación constitucional. ${ }^{56}$ Esto aunado a su posición y función en el sistema jurídico hacen de la interpretación constitucional un proceso especial.

Por la complejidad normativa de la Constitución la amplitud y apertura son propiedades deseables de sus disposiciones para hacer posible no solamente su adaptación mediante interpretación, sino también la pluralidad. El procedimiento que se conoce en la teoría del derecho constitucional como "mutación constitucional" se refiere solamente a la concretización del contenido de la norma constitucional ${ }^{57}$ y su efecto es el de cambiar la norma constitucional mediante la atribución de un significado distinto sin que se modifique el texto que enuncia la norma..$^{58}$ La mutación sin embargo, se limita a aclarar, completar o adaptar el significado de un precepto constitucional, no puede incluir algo diferente pues se encuentra limitada por su propia formulación.

La mutación es un proceso que fortalece la normatividad de la Constitución que refleja la capacidad evolutiva y de actualización y adaptación del derecho a una realidad cambiante. Para Hesse es la única solución para hacer posible mantener las funciones de racionalización, estabilización y limitación del poder de la Constitución ${ }^{59}$. Pero como ya se mencionó, las disposiciones constitucionales en su calidad de lenguaje escrito, tienen un potencial interpretativo limitado. Es por ello que Hesse señala que: "donde la posibilidad lógica del texto de la norma termina o donde una determinada mutación constitucional aparecería en clara contradicción con el texto de la norma, concluyen las posibilidades de interpretación de la norma y, con ello, las posibilidades de una mutación constitucional" 60 .

En virtud de sus supuestos cerrados una Constitución reglamentaria no permite la interpretación, por lo que no da lugar a la mutación y se cierra así no sólo al desarrollo legislativo sino al judicial también, limitando así su capacidad de adaptación. Esto es contrario a la propia naturaleza de la Constitución y a su función, la posibilidad de adaptación por medios menos rígidos que la reforma constitucional es necesaria, y como dice Guastini,

55 Por lo que a los términos se refiere señala que en el lenguaje legal se distinguen los términos valorativos, los semi-descriptivos y los descriptivos. Ibidem, pp. 102, 103.

56 Ibidem, pp. $111,112$.

57 Hesse, op. cit, nota 30, p. 24.

58 Sánchez, Urrutia, "Mutación constitucional y fuerza normativa de la Constitución", REDC, n 58, 2000 , p.134.

59 Hesse, op. cit, nota 30, p. 102.

60 Ibidem, pp. 101, 102. 
Esta obra forma parte del acervo de la Biblioteca Jurídica Virtual del Instituto de Investigaciones Jurídicas de la UNAM

una interpretación evolutiva permite atribuir al texto constitucional un significado distinto del histórico ${ }^{61}$, lo cual es especialmente relevante en el caso de Constituciones de larga vigencia.

\section{LA MATERIA GONSTITUCIONAL}

En este apartado se aborda la cuestión relativa a los contenidos constitucionales, es decir, a las materias que ameritan ser previstas en la norma suprema por su relevancia, a aquello que se puede considerar como materia constitucional ${ }^{62} \mathrm{xxx}$. Sobre todo para que se reconsidere la práctica ya añeja de elevar a rango constitucional cualquier cuestión o materia con la idea de evitar que el legislador pueda disponer de la Constitución por indiscriminadamente, sin considerar su carácter fundamental. Para referirnos a este tipo de contenidos que por su naturaleza deben estar previstos en la Constitución, se hará referencia a los conceptos de "reserva constitucional" y materia constitucional.

Como ya se mencionó, los contenidos propios de la Constitución están determinados por su naturaleza y función, vale la pena recordar además, que la Constitución tiene un doble carácter como origen jurídico del poder y límite del mismo ${ }^{63}$, por lo que le corresponde establecer la estructura del sistema estatal y controles del poder político. En ese sentido, si la finalidad de una Constitución es limitar el poder como dice Loewenstein ${ }^{64}$, entonces es materia constitucional prever un sistema de reglas fijas que limitan su ejercicio para que pueda operar como dispositivo de control del proceso del poder $^{65}$.

Para Hesse la Constitución debe determinar los fundamentos del orden de la comunidad y la estructura estatal, así como los procedimientos

61 Guastini, op. cit, nota 12, pp. 84-87.

62 Guastini señala que "se llaman materialmente constitucionales las normas "fundamentales" -en uno u otro sentido- de un ordenamiento jurídico" y que la materia constitucional es el "conjunto de objetos que son regulados por tales normas, de tal forma que el criterio de identificación no es meramente formal. Guastini, Riccardo, Estudios de teoría constitucional, Fontamara-UNAM, México, 2001, pp. 33, 34.

63 Vid Tamayo y Salmorán, Rolando, Introducción al estudio de la Constitución, 2da. edición, UNAM, México 1986, p. 294.

64 Loewenstein, Karl, Teoría de la Constitución, trad. de Alfredo Gallego Anabitarte, Ariel, Barcelona, 1986, p. 36.

65 Las reglas previstas en la Constitución mexicana como medios de control interorgánicos son analizados en los capítulos V a VII de la obra Mecanismos constitucionales para el control del poder, Huerta, op. cit., nota 34, pp. 117-175. 
Esta obra forma parte del acervo de la Biblioteca Jurídica Virtual del Instituto de Investigaciones Jurídicas de la UNAM

mediante los cuales han de tomarse las decisiones que en la norma fundamental se dejaron abiertas; asimismo ha de establecer el sistema de competencias y determinar los procesos de resolución de conflictos ${ }^{66}$. Esta lista muestra de alguna manera la amplitud del objeto de la Constitución, en opinión de Aragón ha de regular además de normas estructurales (organizativas o procedimentales), normas materiales (de derechos fundamentales) y garantías institucionales, mandatos al legislador y normas de competencia entre otras ${ }^{67}$.

Desde el punto de vista de su contenido mínimo hay que tomar en cuenta la estructura de la Constitución en su calidad de norma suprema, la cual se integra hoy en día por los derechos fundamentales, la división del poder y el control de la constitucionalidad. Estos ejes básicos se acompañan de la regulación de tres materias complementarias que son el modelo económico, los procesos de participación en la toma de decisiones y el sistema de fuentes ${ }^{68}$. Los dos primeros ejes no solamente por estar previstos en la Declaración de Derechos del Hombre y el Ciudadano de 1789, sino sobre todo porque están relacionados con lo que se considera como el sentido genuino de la Constitución, esto es, "como norma jurídica fundamental que, garantizando los derechos de los ciudadanos, organiza el Estado de tal forma que garantiza también la democracia" 69 .

Estos elementos se encuentran en el núcleo de los contenidos debidos de la Constitución. En cuanto al tercer eje, su relevancia actual es innegable, pues como el mismo Aragón señala: "sin la justicia constitucional, la Constitución no puede existir, ya que sería una hoja en blanco que el legislador podría llenar a su capricho"70. A esto mismo se refiere Carl Schmitt cuando sostiene que uno de los elementos de la Constitución de un Estado es la protección a la libertad individual frente al Estado ${ }^{71}$, y junto a este elemento jurídico considera también como fundamental, el elemento político del que procede la forma de gobierno.

En la Constitución, en virtud de su carácter de fuente primaria, se deben prever los contenidos más relevantes, aquellos que se consideren como fundamentales a efectos de impedir su limitación y poder controlar su de-

66 Hesse, op. cit, nota 30, p. 19.

67 Aragón, op. cit, nota 19, pp. 100, 101.

68 Huerta, op. cit, nota 6, pp. 58-60.

69 Cfr. Aragón, op. cit, nota 19, p. 97.

70 Ibidem, p. 103.

71 Schmitt, Carl, Teoría de la Constitución, versión española de Francisco Ayala, Alianza Editorial, S.A., Madrid 1982, p. 139. 
Esta obra forma parte del acervo de la Biblioteca Jurídica Virtual del Instituto de Investigaciones Jurídicas de la UNAM

sarrollo y realización. Es por ello que para Aragón es preciso que la norma suprema cuente con "instrumentos jurídicos que garanticen la aplicación de la Constitución, y éstos no son otros que los propios del control judicial, mediante la aplicación de las normas constitucionales por los tribunales ordinarios o bien, también, mediante la creación de unos tribunales específicos: los tribunales constitucionales". Para él, las garantías jurídicas solamente son efectivas cuando están aseguradas por controles jurisdiccionales ${ }^{72}$.

Habiendo establecido que uno de los aspectos distintivos de la Constitución es que regula la producción de las normas jurídicas y que de ella depende el principio mismo de creación normativa, conforme al modelo jerárquico, de la norma fundamental desciende por grados el resto del orden jurídico $^{73}$. Por consiguiente, la regulación de las fuentes es materia constitucional. Es por ello que de Otto la considera "fuente acerca de las fuentes", para él la Constitución condiciona toda la creación del derecho y la regulación de las fuentes es "contenido obligado de la Constitución"74.

De modo que en relación con el sistema de fuentes se deben prever en la Constitución las reglas generales de competencia de creación normativa y de procedimiento, así como los contenidos debidos mínimos y excluidos de la regulación. Pues como bien dice Kelsen, la "Constitución en sentido material está constituida por los preceptos que regulan la creación de normas jurídicas generales y, especialmente la creación de leyes" ${ }^{\prime 75}$, por lo que también puede regular de manera genérica los contenidos a desarrollar por las leyes. Pero no le corresponde a la Constitución regular al detalle todos los procedimientos creación y de aplicación de las normas, esto corresponde en primer lugar al legislador ordinario que debe sentar las bases para el ejercicio de las competencias y los derechos previstos en la Constitución, y en segundo lugar al poder Ejecutivo que ha de especificar los procedimientos previstos en la ley. En este proceso de particularización de las normas realizado a partir de una distribución de potestades normativas se hace posible constitucionalizar el derecho, para que llegue a todas las disposiciones del sistema, y como dice Aragón "hacer que la Constitución, "como derecho", rija"76.

72 Aragón, op. cit, nota 19, p. 94.

73 La explicación del derecho como un sistema de normas organizado jerárquicamente es una de las más destacadas aportaciones de Kelsen, denominada por él como Stufenbautheorie, que sostiene que a partir de la Constitución se construye el sistema jurídico de manera escalonada, por lo que también se configura como parámetro de validez de las normas jurídicas, op. cit, nota 2, pp. 232-284.

\footnotetext{
74 De Otto, op. cit, nota 23, pp. 82, 83

75 Kelsen, op. cit, nota 4.

76 Op. cit, nota 19, p. 95.
} 
Esta obra forma parte del acervo de la Biblioteca Jurídica Virtual del Instituto de Investigaciones Jurídicas de la UNAM

Otra cuestión a reflexionar es si hay materias exclusivas de la Constitución, algo que se pudiera llamar "reserva constitucional", un tema que me interesa desde hace tiempo ${ }^{77}$. La reserva constitucional tiene por objeto prever límites de materia a las leyes ordinarias por lo que ciertas materias se reservan a fuentes constitucionales ${ }^{78}$. La reserva constitucional tiene el mismo efecto que la reserva de ley, término más común en la doctrina, que se refiere a las limitaciones de contenido a regular que se establecen a cierto tipo de fuente. ${ }^{79}$ La reserva constitucional constituye un límite al poder Legislativo que se fundamenta en la naturaleza de la materia a regular, ya que se trata de una decisión tomada por el Constituyente que tiene por efecto sustraer ciertas materias fundamentales de la potestad de órganos normativos inferiores.

En términos generales es materia constitucional: la delimitación de los derechos y libertades fundamentales, la organización del Estado y el gobierno, el control de la constitucionalidad, la regulación de las fuentes del derecho y la reforma constitucional. La limitación o excepción a lo previsto en estas materias en la Constitución debe ser prevista expresamente en los preceptos constitucionales que la regulen. De estos temas cualquier parte específica puede ser reservada, dicha decisión depende no tanto de la naturaleza de la materia como del contexto político, social y cultural en que el órgano constituyente la realice.

Una limitación regulada en una disposición jerárquicamente subordinada a la norma fundamental sería inconstitucional, pues contravendría sus contenidos. Estas limitaciones o restricciones al ejercicio de derechos deben precisarse puntualmente, pues la delimitación de un derecho incide negativamente en la esfera de libertad del individuo, afectando su autonomía. De igual forma cualquier acto de intervención de la autoridad que pueda implicar un daño o menoscabo en los derechos de las personas debe precisarse $^{80}$. Las competencias deben ser expresas y detalladas, especialmente las

77 El tema lo abordé por primera vez en el artículo "Las Normas Oficiales Mexicanas en el ordenamiento jurídico mexicano", Boletín Mexicano de Derecho Comparado, n 92 , Instituto de Investigaciones Jurídicas, UNAM, México, 1998, pp. 372-376, y lo retomé recientemente en "La fuerza normativa de la Constitución. Tensión entre aplicación y reforma constitucional", en op. cit, nota 52, 2015, pp. 30-34.

78 Dependiendo de lo previsto en la propia Constitución puede ser reservada a la Constitución misma o a leyes constitucionales. Pizzorusso, Alessandro, Lecciones de derecho constitucional, trad. de Javier Jiménez Campo, vol. II, Centro de Estudios Constitucionales, Madrid, 1984, p. 250

79 La reserva de ley es una previsión hecha ya sea en la Constitución o en la ley, para determinar las materias que deben ser reguladas por la "ley", lo que a su vez impide su regulación por medio de otro tipo de disposiciones de rango inferior. Pizzorusso, ibidem, p. 160.

80 En este sentido, según la Suprema Corte de Justicia de la Nación si la autoridad ha de producir una afectación de la persona, sus posesiones o sus derechos "deberá ajustarse a los 
Esta obra forma parte del acervo de la Biblioteca Jurídica Virtual del Instituto de Investigaciones Jurídicas de la UNAM

relacionadas con facultades sancionatorias que pueden afectar la libertad o el patrimonio de las personas, los procedimientos en cambio pueden ser formulados de manera más general aunque deben incluir aquellos elementos que constituyan derechos o garantías procedimentales.

El desarrollo por ley de una disposición constitucional se hace conforme al principio de competencia expresa atribuida al poder Legislativo, o bien, mediante un mandato al legislador, y los contenidos están delimitados por la propia Constitución. El mandato al legislador ${ }^{81}$ es un tipo de norma cuya función radica en prever una obligación para el poder Legislativo de regular la materia que el Constituyente determina expresamente, ya sea en la Constitución o en alguno de sus artículos transitorios. Además de un mandato, estas disposiciones tienen el carácter de norma de distribución competencial, y se pueden entender como una reserva de ley, excepto cuando es previsto en un artículo transitorio.

Por lo que a la conveniencia de elaborar supuestos constitucionales generales se refiere, Pizzorusso señala que es un límite positivo de la legislación ordinaria que "las normas constitucionales prevén como obligatorias ciertas intervenciones del legislador", tales como los mandatos mencionados, pues son "intervenciones legislativas constitucionalmente debidas" 22 que carecerían de sentido si la norma constitucional regula la materia exhaustivamente, aunque se pueden prever ciertas limitaciones de contenido de la ley en la norma constitucional.

El propósito de prever un mandato al legislador es que el poder Legislativo desarrolle lo que la Constitución solamente menciona o delimita en términos generales. El mandato se fundamenta no solamente en la representatividad del órgano y en el principio democrático que legitima su actuación, sino también en un principio de confianza. El mandato al legislador es de alguna forma una remisión de la potestad normadora de ciertos contenidos que establece una obligación de desarrollo conforme a la Constitución dentro de un plazo razonable, cuando no se prevé un plazo específico ${ }^{83}$. Estas

procedimientos previamente establecidos en la Constitución Política de los Estados Unidos Mexicanos y las leyes secundarias", Suprema Corte de Justicia de la Nación. Las Garantías de Seguridad Jurídica, Colección Garantías Individuales, SCJN, México, 2003, p. 9.

81 Scheuner explica en su clasificación que los mandatos al legislador son normas que se configuran como órdenes para el desarrollo de un determinado precepto constitucional por parte del legislador, "Staatszielbestimmungen" en Festschrift für Forsthoff, von Schnur (ed.), München, 1972, pp. 325 y ss.

82 Pizzorusso, op. cit., nota 78 p. 254.

83 El principio de interpretación conforme obliga a tribunales y órganos judiciales y administrativos a interpretar la Constitución en cualquier momento de su aplicación en el 
Esta obra forma parte del acervo de la Biblioteca Jurídica Virtual del Instituto de Investigaciones Jurídicas de la UNAM

disposiciones pueden ser problemáticas cuando no prevén una sanción para el caso de incumplimiento si las normas no se expiden. El problema de ineficacia de dichas normas se agrava por la falta de voluntad política para exigir responsabilidad a los legisladores.

Las disposiciones constitucionales reglamentarias dan al poder Legislativo la impresión de que puede postergar su deber de desarrollo sin que se produzca mayor afectación, lo cual es falso independientemente de la eficacia directa que las disposiciones constitucionales pueden tener. Sobre todo porque si se incluyó un mandato al legislador es porque el Constituyente consideró que hay materia a desarrollar y que esto debe hacerse por el legislador ordinario, de ahí el mandato. Regular de manera precisa un precepto e incluir un mandato al legislador es una clara indicación de falta de confianza no solamente en el legislador, sino también en el poder Judicial, en su capacidad para controlar al legislador en la realización de su función de desarrollo del precepto.

Parece que la reglamentación de la Constitución se realiza para limitar al legislador y evitar que sometan a negociación ciertos temas por temor al cabildeo y la corrupción en virtud de los intereses en juego, pero con ello se impide que se aborde novedosamente materias que quedan "reservadas" a la potestad exclusiva del Constituyente. En otras palabras, impide a la ley la regulación de la materia por disposición constitucional.

Finalmente, el hecho de que las disposiciones constitucionales sean normas jurídicas generales provee seguridad jurídica y esto tiene por efecto que las decisiones de los tribunales sean en cierta medida previsibles. Para Kelsen esta generalidad es expresión del Estado de derecho que se puede identificar con el principio de seguridad jurídica ${ }^{84}$. Para los sistemas jurídicos de tradición civilista la certeza es un valor de especial relevancia, y dado que su principal función es el control de la discrecionalidad de los jueces, para que esto sea posible la legislación debe ser completa, coherente y clara.

\section{REFLEXIONES FINALES}

La Constitución es una norma jurídica, su función no es hacer declaraciones de intención ni satisfacer intereses producto de negociaciones políticas

sentido de sus reglas y principios en virtud de su supremacía y su función en la determinación del sistema de fuentes y de la validez del sistema jurídico. García de Enterría, Eduardo, La Constitución como norma y el Tribunal Constitucional, tercera edición, Givitas, Madrid, 1991, p. 95.

84 Kelsen, op. cit., nota 2, p. 260. 
Esta obra forma parte del acervo de la Biblioteca Jurídica Virtual del Instituto de Investigaciones Jurídicas de la UNAM

coyunturales, sino conformar un Estado y garantizar los derechos fundamentales de las personas. Sus previsiones deben ser realistas, no solamente en el sentido de que sean expedidas para resolver un problema real, sino también que su satisfacción sea viable. Solamente así es posible hablar de seguridad jurídica, entendida como valor del Estado de derecho que se manifiesta en exigencias objetivas en términos de normas jurídicas formuladas adecuadamente, así como en relación con el cumplimiento del derecho por sus destinatarios y por los órganos de aplicación. Pues como bien decía Lasalle: "de nada sirve lo que se escriba en una hoja de papel, si no se ajusta a la realidad" ${ }^{85}$. Los buenos deseos y la regulación excesiva de órganos y procedimientos afectan la eficacia de la Constitución y en esa medida su normatividad también.

En el proceso de creación y modificación de las normas constitucionales se debe tener en cuenta el carácter estructural y jerárquico del sistema jurídico, así como la relación entre las normas que lo integran para poder determinar el detalle con el que un precepto ha de ser elaborado. En la Constitución se prevén las reglas conforme a las cuales son creadas las normas jurídicas que integran el sistema jurídico, por lo que sus preceptos han de ser claros y concisos, comprensibles a fin de facilitar su desarrollo y aplicación. Pues como dice Aragón, el verdadero problema es la aplicación judicial de la Constitución porque de ello depende la eficacia de la propia Constitución ${ }^{86}$, y si la norma constitucional no es clara y coherente, sino confusa, prolija y redundante no puede ser eficaz ni cumplir su función regulativa $^{87}$.

Así mismo, las denominadas propiedades formales del sistema jurídico, en su calidad de ideales racionales más que de propiedades reales ${ }^{88}$, deben ser tomadas en cuenta al crear una norma, la cual debe ser coherente con el resto del sistema jurídico, no debe entrar en contradicción con otras normas ni ser redundante, pero sobre todo, se debe procurar que el significado atribuido se incorpore racional y congruentemente al sistema jurídico. La forma de la norma es dada por el redactor en primera instancia, en segundo lugar por el intérprete y finalmente por quien la aplica ${ }^{89}$, aunque estas

85 Lasalle, Ferdinand, ¿Qué es una Constitución?, Ediciones Coyoacán, México, 2009, p. 72.

86 Aragón, op. cit, nota 19, p. 83.

87 La falta de claridad afecta la operatividad del derecho, pues como Alchourrón señala, el derecho tiene dos funciones prácticas: evaluar acciones humanas y guiar la conducta de las personas, op. cit, nota 5, p. 413.

88 Alchourrón y Bulygin, op. cit, nota 8, p. 102.

89 Como señala Jellinek el legislador le da sentido a los preceptos constitucionales, por lo que puede producir una mutación constitucional, así de modo subrepticio las disposiciones 
Esta obra forma parte del acervo de la Biblioteca Jurídica Virtual del Instituto de Investigaciones Jurídicas de la UNAM

últimas dos cualidades pueden sin embargo coincidir en un solo sujeto u órgano, no necesariamente siempre es así. El sentido de un enunciado normativo en cambio, es determinado por el intérprete en función de lo dispuesto por el propio derecho, la teoría del derecho y la jurisprudencia.

Aunque por su posición predomine sobre el resto del sistema jurídico y se configure como elemento determinante para su desarrollo, esto no significa que se tenga que prever todo en la Constitución. Es más la completitud como propiedad del sistema jurídico como señala Bulygin "no es producto de necesidad lógica o de una armonía preestablecida, sino del esfuerzo y la capacidad técnica del legislador"90, lo cual no implica que sea obligación exclusiva del Constituyente.

La Constitución como norma jurídica suprema cuando es jurisdiccionalmente aplicada garantiza la limitación del poder, y mientras más específicas sean las disposiciones constitucionales serán más restrictivas de las competencias de la autoridad, pero también de los derechos, y mientras lo primero es conveniente, lo último no es deseable. El órgano constituyente no debe sustituir ni desplazar al legislador, menos aún sobrerregular las materias de las que se ocupa, debería más bien regular con mesura para establecer el marco que al legislador ordinario corresponde desarrollar y adaptar en su caso. Por lo mismo, de ninguna manera debe contener planes o programas, ese tipo de decisiones requieren de flexibilidad por eso su elaboración corresponde al poder Ejecutivo

En la actualidad en México la cualidad de norma jurídica de la Constitución vigente ha sido menoscabada por diversos factores, uno de ellos es la concepción generalizada en la cultura (o falta de cultura) constitucional que está en el imaginario popular sobre todo de políticos y partidos, pero también en la de individuos y agrupaciones privadas, de que basta poner algo en la Constitución para solucionar un problema ${ }^{91}$. Esta percepción mistificada de la Constitución, aunada a la desconfianza en el legislador ordinario hace que se intente incluir cualquier cosa en la Constitución. Ese

constitucionales adquieren poco a poco, un significado distinto, al igual que se puede hacer por la práctica administrativa y los tribunales en el ámbito de sus competencias. Jellinek, Georg, Reforma y mutación de la Constitución, trad. de Christian Förster, Centro de Estudios Constitucionales, Madrid, 1991, pp. 15, 16.

90 Bulygin, op. cit, nota 7, p. 417.

91 En ese mismo sentido es que Marín Díaz señala que "conviene tener presente que existe una diferencia sutil entre la codificación de la Constitución como objeto de veneración social y su verdadera concretización como práctica social". Martín Díaz y Díaz. Ensayos sobre la propiedad, Antonio Azuela compilador, Instituto de Investigaciones Jurídicas, UNAM, México, 2014, p. 14. 
Esta obra forma parte del acervo de la Biblioteca Jurídica Virtual del Instituto de Investigaciones Jurídicas de la UNAM

"romanticismo normativo" es una tendencia basada en una idea imprecisa de justicia, así como en esa falsa idea de que el derecho cambia ipso iure la realidad. Es indispensable un cambio en la percepción de la Constitución, la formación de una auténtica cultura jurídica, no sólo para expertos, sino para la población en general, lo cual requiere de una educación constitucional que motive a tomar en serio la Constitución

Es por ello que hay que cuestionar la necesidad de una reforma, del detalle con que se regula un tema, de las instituciones que se incluyen. La desconfianza en poder Legislativo es un argumento débil que no justifica elaborar reformas constitucionales detalladas. Sobre todo en casos como el de México en que el Congreso de la Unión es el órgano que reforma la Constitución en la primera fase del procedimiento, y en la práctica los órganos legisladores de las entidades federativas que realizan la segunda fase, nunca se oponen, es más, la mayoría que se requiere para la aprobación de la reforma en general es negociada previamente, por lo que no tiene sentido elaborar artículos de carácter reglamentario.

Al reglamentar disposiciones constitucionales, el Constituyente pretende vincular al poder Legislativo futuro a sus decisiones con lo que limita la posibilidad de una actualización flexible del derecho, como si tuviese la última palabra, lo peor es que ni siquiera puede asegurar la permanencia de la institución, como se puede observar claramente en materia electoral ${ }^{92}$. La reglamentación nos hace prisioneros, impide la conformación de instituciones durables, y atenta contra la estabilidad y la seguridad jurídica, en ocasiones incluso contra la libertad y autonomía de las personas. Es por ello que hay que buscar un equilibrio entre lo pétreo y lo efimero, demasiado cambio afecta su normatividad tanto como una rigidez absoluta. Un derecho en constante transformación no puede lograr los cambios proyectados al diseñar las normas, ni cumple su función regulativa. Moreso ${ }^{93}$ advierte que si las disposiciones constitucionales se cambian constantemente no logran fijar su sentido, ni modificar los patrones de conducta por lo que no pueden llegar a ser eficaces.

92 Ost atinadamente dice que "el tiempo determina la fuerza instituyente del derecho", no es posible detener el tiempo con las normas jurídicas, pues como decía Portalis: "los códigos del pueblo se hacen con el tiempo", lo mismo se puede decir de la Constitución; hay que confiar en el legislador y en los otros poderes para dar vida a las disposiciones constitucionales. Ost, François, El tiempo del derecho, trad. de María Guadalupe Benítez Toriello, Siglo XXI, México, 2005, pp. 12, 231 y 232.

93 Moreso, José Juan, La indeterminación del derecho y la interpretación de la Constitución, Centro de Estudios Políticos y Constitucionales, Madrid, 1998, p. 180. 
Esta obra forma parte del acervo de la Biblioteca Jurídica Virtual del Instituto de Investigaciones Jurídicas de la UNAM

Para que la Constitución pueda cumplir su función es preciso que tenga fuerza normativa, la cual depende de su permanencia que se sustenta en instituciones que realizan actos de control que son presupuesto de su eficacia. La relación entre permanencia y reforma es dialéctica y precisa encontrar un equilibrio. Si se continúa reformando la Constitución mexicana incesantemente se podrá decir del derecho positivo lo mismo que decía Kirchmann del análisis dogmático, se hará contingente y la labor de los órganos constituyente y legislativo terminará por convertirse en "basura"94.

Es cierto que la Constitución debe reflejar la realidad, no puede ser una simple hoja de papel, pero la dinámica del derecho debe ser racionalizada, y no puede pretender incluirlo todo, no debe intentar amarrar al legislador como a Ulises al mástil, para que nada pueda hacer cuando escuche las voces del pueblo, el canto desesperado de unos ciudadanos que nadie escucha.

94 Según Kirchmann el objeto de la ley positiva hace del objeto de la ciencia algo casual y contingente, y "en cuanto la ciencia hace de lo contingente su objeto, ella misma se hace contingencia; tres palabras rectificadoras del legislador y bibliotecas enteras se convierten en basura". Kirchmann, Julius, Hermann von, La jurisprudencia no es ciencia, Instituto de Estudios Políticos, Madrid, 1949, p. 54. 
Esta obra forma parte del acervo de la Biblioteca Jurídica Virtual del Instituto de Investigaciones Jurídicas de la UNAM

\title{
DESAFÍOS EN LA INSTRUMENTACIÓN DE UNA REFORMA CONSTITUCIONAL DE GLAROSGUROS EN MATERIA ELEGTORAL
}

\author{
Saúl Mandujano Rubio*
}

\begin{abstract}
SUMARIO: I. Introducción. II. Entre lo mesurado y lo excesivo en la facultad de atracción a cargo del Instituto Nacional Electoral. III. La atribución del Instituto Nacional para emitir acuerdos vinculantes de carácter regulatorio y el principio de jerarquía normativa. IV. Análisis y disyuntiva del modelo dual de solución de controversias en materia de propaganda político-electoral. V. Nuevas causales de nulidad de la elección y la excesiva litigiosidad de los comicios. VI. Consideraciones finales. VII. Referencias consultadas.
\end{abstract}

\section{INTRODUCCIÓN}

Como sucede con otras reformas constitucionales, la que fue aprobada en el año 2014 en materia político-electoral, es producto de un pacto entre los actores políticos. Cada elección presidencial se traduce en un reclamo para introducir cambios en la normativa electoral. Sugeridas por los derrotados en la contienda, las modificaciones en muchos casos solo revelan la inquietud de revertir un futuro revés electoral, sin atacar de raíz las malas prácticas de la competencia.

Ordenamiento que plasma el acuerdo en el que se fundamentan la sociedad política y su organización estatal, la supremacía de la Constitución también se explica porque exige procedimientos de elaboración y mayores requisitos de cambio que los adoptados para el resto del sistema normativo.

* Licenciado en Derecho por la UNAM (Campus Acatlán); Maestro en Derecho electoral por el Instituto de Investigaciones y Capacitación Electoral del Tribunal Electoral del Poder Judicial del Estado de Jalisco. Profesor de Carrera Definitivo en la UNAM (Campus Acatlán) en el área de derecho internacional. 
Esta obra forma parte del acervo de la Biblioteca Jurídica Virtual del Instituto de Investigaciones Jurídicas de la UNAM

Por esa razón, las primeras constituciones preveían plazos muy largos antes de que pudieran reformarse. Esa excesiva rigidez desapareció y en el año de 1857 se adoptó el sistema de reforma todavía en vigor que facilitó cambiar la Constitución para no cambiar la Constitución.

Un número elevado de reformas constitucionales revela que nos hemos ido al extremo opuesto. Son tantas, tan frecuentes y barrocas que la norma suprema se fue desfigurando. La inestabilidad del texto tiene repercusiones negativas para el conjunto de las instituciones, pues una base jurídica insegura y volátil no puede darles un soporte estable. Una Constitución fugaz genera un poder impredecible en el que no se puede confiar. De continuar por la pendiente que llevamos la Constitución se volverá inservible y nos lanzará al vacío de la anomia. ${ }^{1}$

Debido al cúmulo de cambios, además de su amplitud, el texto constitucional se ha vuelto más complejo. Abundan reformas con alto grado de detalle, propias de una ley o de un reglamento. Se advierten en su contenido artículos de extensión considerable que ponen en entredicho la sistematicidad del marco constitucional. Por citar un ejemplo en materia electoral, el artículo 41, pasó de 65 a 1,297 palabras.

En los últimos años puede haber, y seguramente ha habido buenas razones para realizar tantas reformas constitucionales, pero lo cierto es que ese proceso no permite avanzar en la construcción de un país de leyes y en la puntual observancia de sus normas supremas. Existe de todo, reformas de poca monta o casi insignificantes, hasta otras que han intentado cambiar una realidad previa que ya no generaba los consensos necesarios para conservarla. ${ }^{2}$

Se supone que una configuración distinta de las fuerzas políticas puede generar avances en el proceso de democratización, de hecho ha ocurrido así en diversas ocasiones, sin embargo no sucede de la misma manera cuando una reforma constitucional se compromete solo para asegurar el acompañamiento de otra fuerza política en la aprobación de reformas estructurales. La más reciente reforma electoral resulta, debido a eso, una reforma de claroscuros. Parte de su contenido favorece la excesiva litigiosidad de los comicios y acusa una elevada tendencia prohibicionista.

1 Valadés, Diego. “Qué hacer con la Constitución?”. Reforma, México, 2 de febrero de 2016, [fecha de consulta: 10 de marzo 2016]. Disponible en: wrere.reforma.com/aplicaciones/editoriales/editorial.aspx?id=81220

2 Carbonell, Miguel, "Verborrea e incultura constitucional". Revista Nexos [en línea]: 1 de febrero de 2012, [fecha de consulta: 11 de marzo 2016]. Disponible en: http://wrewenexos.com. $\underline{m x / ? p=14673}$ 
Esta obra forma parte del acervo de la Biblioteca Jurídica Virtual del Instituto de Investigaciones Jurídicas de la UNAM

Materia regulada de forma excesiva en la Constitución, en el ámbito electoral se llega al extremo de incorporar al texto constitucional un elevado número de disposiciones reglamentarias. Por esa razón, comparto la inquietud de académicos del Instituto de Investigaciones Jurídicas de la UNAM de realizar un ejercicio que compacte y reordene el texto de la norma suprema, eso mismo debe ocurrir en el ámbito electoral.

Acorde con lo anterior, en el presente trabajo se abordarán aquellos aspectos de la más reciente reforma constitucional en materia político-electoral que significan grandes retos en su instrumentación. Después de la elección concurrente del año 2015, en el terreno operativo se advierten áreas de oportunidad que ameritan ajustarse. Por esa razón, sin dejar de señalar los temas acertados de la reforma, se pondrá especial énfasis en el desafío que representan algunos aspectos en la construcción de un Sistema Nacional Electoral.

\section{ENTRE LO MESURADO Y LO EXCESIVO \\ EN LA FACULTAD DE ATRACGIÓN A GARGO \\ DEL INSTITUTO NAGiONAL ELEGTORAL}

Previo a la conclusión del proceso electoral federal de 2012 ya se habían presentado en la Cámara de Diputados 69 iniciativas con propuestas de modificación al artículo 41 constitucional y a diversos preceptos del Código Federal de Instituciones y Procedimientos Electorales. Dentro del Pacto por México, suscrito por el Ejecutivo Federal y los presidentes de los partidos Acción Nacional, de la Revolución Democrática y Revolucionario Institucional, los compromisos 89 y 90 fueron centrales para materializar la reforma político-electoral. Por un lado, se pretendió establecer un marco jurídico estable y claro para la actuación de los partidos políticos en tiempos electorales y no electorales; por otro, crear una autoridad electoral de carácter nacional y una legislación única que se ocupe tanto de las elecciones federales, como de las estatales y municipales. ${ }^{3}$

Respecto a la reforma política se incorporó la facultad del Presidente de la República de optar por construir un gobierno de coalición con la anuencia de uno o más partidos diferentes al suyo, en ese caso, los nombramientos que haga de los Secretarios de Estado tendrán que ser ratificados por el

3 Valdés Zurita, Leonardo y González Suárez, Patricia, "Elementos para el análisis de la reforma electoral de 2014". Revista Mexicana de Derecho Electoral, UNAM- Instituto de Investigaciones Jurídicas. (6): 221, Julio- Diciembre 2014. 
Esta obra forma parte del acervo de la Biblioteca Jurídica Virtual del Instituto de Investigaciones Jurídicas de la UNAM

Congreso de la Unión. Ajustando la reelección consecutiva de legisladores al interés y conveniencia de los partidos políticos, los Senadores podrán ser reelectos hasta por dos periodos y los Diputados hasta por cuatro, sumando en ambos casos 12 años en el ejercicio del cargo. Con el fin de generar una transmisión más dinámica entre la fecha de la elección, la declaratoria de Presidente electo y la protesta del nuevo titular del Poder Ejecutivo Federal, se adelanta la toma de posesión al $1^{\circ}$ de octubre.

Otro cambio de naturaleza política es el relativo a la creación de una Fiscalía General de la República como órgano autónomo, con personalidad jurídica y patrimonio propios, ya no dependiente del Ejecutivo Federal. También lo es otorgar autonomía constitucional al Consejo Nacional de Evaluación de la Política de Desarrollo Social (CONEVAL), cambio que impacta de manera sustancial en el objeto y la competencia que le corresponde. Con dosis de acierto, la modificación constitucional en el terreno político resulta, en principio, afortunada.

Pasando al terreno de lo electoral, la reforma constitucional de 2014 aumenta al 3 por ciento el umbral para mantener el registro como partido político, se apuesta por asegurar la suficiente representatividad pero al mismo tiempo propicia la reducción de la pluralidad. Gracias a la reforma los partidos deben ahora garantizar la paridad de género en las candidaturas a los órganos legislativos, tema que avanzó de manera significativa para la integración de los ayuntamientos. Aun incorporadas con anterioridad, la reforma al artículo 41 asegura los derechos y prerrogativas de los candidatos independientes. Se agregan nuevas causales para la nulidad de las elecciones, acicate adicional para la impugnación infundada de los comicios.

Sin duda el tema más relevante para el propósito de este trabajo es el relativo a la construcción de un Sistema Nacional Electoral, integrado por el Instituto Nacional Electoral y los organismos públicos locales. Al hacer un análisis de las ventajas y desventajas de la creación de un órgano nacional, las Comisiones Unidas del Senado concluyeron que el actuar de los órganos electorales locales puede reforzarse con la intervención del Instituto Nacional Electoral (INE) en algunas de sus atribuciones. Se estima que para cumplir con los fines de imparcialidad, transparencia, independencia, integridad, eficacia y efectividad, vocación de servicio y profesionalismo en los órganos electorales locales, no es pertinente su desaparición, sino establecer la homologación de algunos aspectos. ${ }^{4}$

4 Dictamen de las Comisiones Unidas de Puntos Constitucionales; de Gobernación; de Reforma del Estado; de Estudios Legislativos, Primera y de Estudios Legislativos, Segunda, en relación con las iniciativas con proyecto de decreto por el que se reforman y adicionan 
Esta obra forma parte del acervo de la Biblioteca Jurídica Virtual del Instituto de Investigaciones Jurídicas de la UNAM

Desde el momento en que se llevó a cabo la reforma constitucional, se modificó el quehacer de la autoridad electoral. Entre las nuevas funciones del INE se establecieron tres novedosas formas de interacción con los organismos públicos locales electorales; la facultad de asunción, la de atracción y la de delegación. Estas atribuciones dieron al INE facultades por encima de las autoridades locales para la organización de las elecciones en dicho ámbito. Por esa razón, los organismos locales deben cumplir determinados lineamientos emitidos por el INE, durante la organización y desarrollo de las elecciones estatales. ${ }^{5}$

Con fundamento en el inciso a) del Apartado C, de la Base V del artículo 41 constitucional, el artículo 120 de la Ley General de Instituciones y Procedimientos Electorales (LGIPE) dispone que por asunción se entiende la atribución del INE de asumir directamente la realización de todas las actividades propias de la función electoral que corresponden a los organismos públicos locales. Sin carácter discrecional, esta atribución solo podrá ejercerse en condiciones específicas y a petición fundada y motivada ante el INE, de al menos cuatro de sus consejeros o de la mayoría del consejo del Organismo Público Local.

Mediante procedimientos especiales que deberá instaurar la Secretaría Ejecutiva del INE, el Consejo General resolverá el proyecto de resolución que someta la Secretaría antes de que inicie el proceso local correspondiente, valorando los elementos que afecten alguno o varios de los principios constitucionales que dieron motivo a la solicitud de la asunción. La resolución se aprobará, en su caso, al menos por la mayoría de ocho votos de los Consejeros Electorales con derecho a voto y podrá recurrirse ante la Sala Superior del Tribunal Electoral del Poder Judicial de la Federación. Una vez iniciado el proceso electoral local, no podrá instaurarse el procedimiento de asunción. ${ }^{6}$

diversos artículos de la Constitución Política de los Estados Unidos Mexicanos en materia político-electoral, Gaceta del Senado, México, Senado de la República (LXII Legislatura), 2 de diciembre de 2013, p. 124, [fecha de consulta: 17 de marzo de 2016]. Disponible en: http:// wrere.senado.gob.mx/comisiones/puntos_constitucionales/docs/dictamen_031213.pdf

5 Sánchez Gutiérrez, Arturo y Vives Segl, Horacio, "Las nuevas atribuciones del INE al interior de las elecciones locales". Revista Mexicana de Derecho Electoral, UNAM- Instituto de Investigaciones Jurídicas. (6): 151, Julio- Diciembre 2014.

6 Mediante resolución de fecha veintidós de octubre de 2015, dictada en el juicio de revisión constitucional y juicio para la protección de los derechos político-electorales del ciudadano, identificados respectivamente con el número de expediente SUP-JRC-678/2015 y SUP-JDC-1272/2015 acumulados, la Sala Superior del Tribunal Electoral del Poder Judicial de la Federación sentó el precedente de una asunción de naturaleza jurisdiccional. Al declarar la nulidad de la elección de Gobernador del Estado de Colima, realizada el siete de junio, 
Esta obra forma parte del acervo de la Biblioteca Jurídica Virtual del Instituto de Investigaciones Jurídicas de la UNAM

Con la aprobación de la mayoría de votos de su consejo general, los Organismos Públicos Locales podrán solicitar al INE la asunción parcial de alguna actividad propia de la función electoral que les corresponde. El INE resolverá por mayoría de cuando menos ocho votos. En este caso, la solicitud puede presentarse en cualquier momento del proceso electoral de que se trate y solo tendrá efectos durante el mismo.

En cuanto a la facultad de atracción, cuando su trascendencia así lo determine o para sentar un criterio de interpretación, el INE tiene la atribución de atraer a su conocimiento cualquier asunto que sea de la competencia de los Organismos Públicos Locales. De ejercicio excepcional, siguiendo un procedimiento similar al de la asunción, la petición de atracción se justifica si el asunto es trascendente y reviste un interés superlativo reflejado en la gravedad del tema, es decir, en la posible afectación o alteración del desarrollo del proceso electoral o de los principios que rigen la función electoral local. Esta petición puede presentarse en cualquier momento, sin importar que el proceso electoral ya hubiere comenzado.

$\mathrm{Al}$ ejercer la atracción para sentar un criterio de interpretación, el INE debe valorar el carácter novedoso o excepcional del tema a tratar. Debido a la importancia de fijar un criterio jurídico para casos futuros o la complejidad sistemática de los mismos, es necesario tener en cuenta el alcance que la resolución pueda producir tanto para la sociedad en general, como para la función electoral local.

Por regla general, para el ejercicio de la facultad de atracción se han establecido dos tipos de requisitos, cualitativos y cuantitativos. Los primeros consisten en que el caso revista intrínsecamente importancia e interés superior, tanto jurídico como extrajurídico. Los segundos están relacionados con lo trascendente o novedoso del caso, a tal grado que del mismo pueda desprenderse la fijación de criterios jurídicos para situaciones futuras y complejas. Por supuesto, el ejercicio de la atribución a cargo del INE debe ceñirse a las reglas previstas tanto en la Constitución como en las leyes aplicables en materia electoral.

Acotada la facultad, no es posible que a través de su ejercicio se emitan criterios generales que sustituyan las reglas previstas en los estados. Dado que la formulación de criterios interpretativos debe encaminarse a armoni-

en el resolutivo séptimo de la sentencia se instruye al INE para que proceda a organizar la elección extraordinaria, al actualizarse los supuestos previstos en el artículo 121, párrafo 2, inciso b) de la LGIPE, relativos a que no existen condiciones políticas idóneas, por injerencia o intromisión comprobable de alguno de los poderes públicos en la entidad federativa que afecten indebidamente la organización del proceso electoral a cargo del Organismo Público Local, al no poderse realizar todas las etapas del proceso electoral con imparcialidad. 
Esta obra forma parte del acervo de la Biblioteca Jurídica Virtual del Instituto de Investigaciones Jurídicas de la UNAM

zar los sistemas para la coexistencia de normas, no es correcto suplantar las reglas diseñadas en los distintos sistemas jurídicos establecidos por los órganos legislativos estatales, pues ello equivaldría a ejercer una especie de control de constitucionalidad indirecto para el cual no está facultado el Consejo General del INE. ${ }^{7}$

Mediante un criterio mayoritario, la Sala Superior del Tribunal Electoral del Poder Judicial de la Federación sostiene que cuando el Consejo General del INE ejerce la facultad de atracción, no se encuentra en condiciones de confrontar directamente las reglas previstas en las distintas legislaciones electorales con el bloque de constitucionalidad, pues esa atribución se encuentra reservada para la Suprema Corte de Justicia de la Nación al resolver las acciones de inconstitucionalidad. Tampoco está en condiciones de cambiar las reglas, aun si advierte que uno de los modelos implementados en las entidades federativas omite regular de manera expresa alguna medida establecida por otro legislador local o por el federal, pues el ejercicio de la facultad de atracción solo está diseñado, si por la relevancia del asunto, es necesario sentar un criterio de interpretación, es decir, definir el sentido o determinar el alcance de una regla, tomando en consideración los precedentes jurisdiccionales.

Existe exceso en el ejercicio de la facultad de atracción, si el Consejo General del INE en lugar de sentar criterios interpretativos tendentes a armonizar la coexistencia de reglas establecidas en las legislaciones electorales locales, emite criterios generales que dejan sin efecto dichas reglas, vulnerando con ello la libertad de configuración legislativa a cargo de los congresos locales. Es inadmisible que a través del ejercicio de la facultad de atracción, el Consejo General emita reglas generales que sustituyan las previstas en las entidades federativas, pues así se vulnera la libertad configurativa de los estados. ${ }^{8}$

Otra atribución del INE es la delegación de funciones en los Organismos Públicos Locales. En su ejercicio el Consejo General deberá considerar la evaluación positiva de las capacidades profesionales, técnicas, humanas y materiales del Organismo Público Local, para cumplir con eficiencia la función. La delegación se realizará antes del inicio del proceso local correspondiente y requerirá el voto de al menos ocho Consejeros Electorales. Finalizado el proceso electoral de que se trate, cesarán los efectos de la delegación.

7 Sentencia de la Sala Superior del Tribunal Electoral del Poder Judicial de la Federación, identificado con la clave SUP-RAP-103/2016 y acumulados, de fecha 10 de marzo de 2015 , pp. 22 y 23.

$8 \quad$ Ibid., p. 36. 
Esta obra forma parte del acervo de la Biblioteca Jurídica Virtual del Instituto de Investigaciones Jurídicas de la UNAM

Como todo acuerdo del Consejo General, se deberá fundar y motivar el uso de esta atribución. La delegación de facultades se realizará de forma específica en cada caso para un Organismo Público Local determinado. En dicho supuesto, los Organismo Públicos favorecidos deberán ejercitar las facultades delegadas sujetándose a la previsto en la LGIPE, la Ley General de Partidos Políticos, los lineamientos, acuerdos generales, normas técnicas y demás disposiciones que emita el Consejo General. El INE podrá reasumir la función delegada antes de que finalice el proceso electoral respectivo, siempre y cuando se apruebe por la misma mayoría de ocho votos.

De diferentes maneras y en distintas ocasiones, se ha dicho que la nueva ingeniería institucional implica una redistribución de atribuciones entre las autoridades electorales, que busca garantizar la homogeneidad y estandarización en la aplicación de las reglas democráticas en todos los ámbitos políticos del país. También se ha sostenido que en la conformación de un Sistema Nacional Electoral, como autoridad rectora, el INE debe mantener una estrecha y bien aceitada relación interinstitucional con los Organismos Públicos Locales Electorales (OPLES), pues precisamente con el objeto de contar con normas y procedimientos homogéneos, se dio paso a un entramado de competencia concurrente y compartida. Bajo esa óptica debe verse al INE como una autoridad coordinadora y vinculante que aplicará la reforma electoral para consolidar a los órganos públicos locales.

Debido a que las leyes electorales de las entidades federativas establecen una diversidad de procedimientos en distintos temas, mediante la facultad de atracción el INE ha procurado definir un mínimo de criterios que homologuen las disposiciones y encaminen hacia una regulación unificada que asegure el cumplimiento de los valores y principios que rigen la materia electoral desde la Constitución Federal. Labor nada sencilla, esta tarea compromete a un análisis detallado de las treinta y dos legislaciones electorales estatales.

En ese tenor, con el fin de fijar directrices para la designación de Consejeros Electorales Distritales y Municipales, el INE emitió unos lineamientos cuyo propósito es ajustar el procedimiento de selección y designación respectivo. A través de ellos se pretende enfatizar y garantizar la responsabilidad que corresponde a esta clase de servidores electorales al momento de desempeñar su encargo. En la parte considerativa del acuerdo de mérito se destaca que la intención es la profesionalización en la organización de los procesos electorales locales. ${ }^{9}$

9 Instituto Nacional Electoral, "Acuerdo del Consejo General del Instituto Nacional Electoral por el que se ejerce la facultad de atracción y se aprueban los Lineamientos para la designación de los Consejeros Electorales Distritales y Municipales, asi como de los Servidores Públicos Titulares de las Áreas Ejecutivas de 
Esta obra forma parte del acervo de la Biblioteca Jurídica Virtual del Instituto de Investigaciones Jurídicas de la UNAM

Razonable en principio, los lineamientos tienen por objeto establecer los criterios y procedimientos a los que deberán ajustarse los OPLES en la designación de los Consejeros Electorales Distritales y Municipales. Acorde a su texto, se considera en el procedimiento la valoración curricular y la entrevista a los aspirantes que se estimen idóneos, por una comisión o comisiones de consejeros electorales del órgano superior de dirección. Para la valoración y entrevistas se deben tomar en cuenta criterios que garanticen la imparcialidad, independencia y profesionalismo de los aspirantes, quienes previamente debieron manifestar por escrito las razones por las que aspira a ser designado. En la designación habrá de tomarse como mínimo los siguientes criterios: compromiso democrático; paridad de género; prestigio público y profesional; pluralidad cultural de la entidad; conocimiento de la materia electoral y participación comunitaria o ciudadana. ${ }^{10}$

Aun siendo aceptable la justificación, instrumentar en la práctica estos lineamientos coloca a los OPLES en una dinámica muy compleja. Por un lado, el perfil de los aspirantes en una entidad tan dispersa como el Estado de México obliga a considerar la heterogeneidad del perfil, moviéndose en extremos opuestos. Desde un aceptable nivel de escolaridad a otro poco favorecido. Por otro lado, insistiendo en el caso del Estado de México, integrar 170 órganos desconcentrados, con 12 consejeros electorales cada uno, de los cuales 6 son propietarios y 6 suplentes, genera un universo probable de miles de aspirantes a entrevistar para estar en posibilidad de designar a 2,040 consejeros. Como puede advertirse la actividad demanda un esfuerzo operativo considerable.

Plausible el trabajo del INE de armonizar el marco normativo de las entidades federativas, el ejercicio de la facultad de atracción puede transitar entre lo mesurado y lo excesivo. Razonable como en el supuesto anterior, deja de serlo si con el pretexto de definir criterios interpretativos se emiten reglas generales de carácter vinculante, a través de las cuales se instrumentan acciones afirmativas, como sucedió en el tema de género, dirigidas a impulsar el registro de un mayor número de mujeres a cargos de elección popular, sin ocuparse de hacer un análisis particularizado de cada entidad ni de analizar el contexto histórico, socio-político y cultural que condujo a cada uno de los poderes legislativos de los estados a adoptar las medidas

Dirección de los Organismo Públicos Locales Electorales. INE/CG865/2015”, Sesión Extraordinaria del Consejo General del 9 de octubre de 2015.

10 Instituto Nacional Electoral, "Lineamientos para la designación de los Consejeros Electorales Distritales y Municipales, así como de los Servidores Públicos Titulares de las Áreas Ejecutivas de Dirección de los Organismos Públicos Locales Electorales". Anexo del Acuerdo INE/CG865/2015, Sesión Extraordinaria del Consejo General del 9 de octubre de 2015. 
Esta obra forma parte del acervo de la Biblioteca Jurídica Virtual del Instituto de Investigaciones Jurídicas de la UNAM

tendentes a cumplir su obligación constitucional de garantizar la paridad de género. ${ }^{11}$

Mesurado y válido es el ejercicio de la facultad de atracción cuando la labor interpretativa del INE logra la coexistencia de las normas estatales, sin vulnerar la libertad de configuración legislativa de las entidades federativas. No parece admisible que mediante el ejercicio de dicha facultad, el Consejo General emita reglas generales que sustituyan a las previstas en los estados.

\section{LA ATRIBUGIÓN DEL INSTITUTO NACIONAL ELECTORAL PARA EMITIR ACUERDOS VINCULANTES DE CARÁCTER REGULATORIO Y EL PRINCIPIO DE JERARQUÍA NORMATIVA}

Dispone el numeral 1, inciso a), del artículo 104 de la LGIPE, que a los Organismos Públicos Locales les corresponde aplicar las disposiciones generales, reglas, lineamientos, criterios y formatos que, en ejercicio de las facultades que le confiere la Constitución y esta ley, establezca el INE. Es decir, el Consejo General de ese instituto posee la facultad para emitir acuerdos generales vinculantes respecto a los OPLES.

Como puede advertirse, esta atribución enviste al INE de una jerarquía superior a la de los OPLES. Si bien es una jerarquía que habrá de entenderse como de "primero entre pares", los OPLES deben trabajar y definirse en función de una rectoría del INE, empezando por el hecho de que los integrantes del órgano superior de dirección a nivel local, con voz y voto en el Consejo, son nombrados por el Consejo General del INE, lo cual abona a la sensación de cierto predominio del INE sobre los OPLES, impresión que se refuerza con el ejercicio de la facultad de atracción a cargo de dicho instituto. ${ }^{12}$

Según se desprende del precepto citado de la LGIPE, los Organismos Públicos Locales deben atender las reglas, lineamientos, criterios y formatos que emita el Consejo General del INE. Bajo ese esquema, el universo normativo que rige la función electoral es interminable. Entre 2014 y lo que va del 2016, el Consejo General del INE ha celebrado más de 100 sesiones extraordinarias y emitido cerca de 1,500 acuerdos, muchos de los cuales

11 Sentencia de la Sala Superior del Tribunal Electoral del Poder Judicial de la Federación, op. cit., p. 33.

12 Sánchez Gutiérrez, Arturo y Vives Segl, Horacio, op. cit, p. 149. 
Esta obra forma parte del acervo de la Biblioteca Jurídica Virtual del Instituto de Investigaciones Jurídicas de la UNAM

expiden reglamentos, lineamientos y criterios que regulan la actividad de los OPLES.

Frente a un cúmulo exorbitante de reglas, no es labor sencilla lograr la armonía en la coexistencia de una gran diversidad de disposiciones reglamentarias. Al ejercer la facultad de atracción, el INE realiza un trabajo de homologación intentando aproximar el contenido de las leyes electorales de las entidades federativas. Con base en el artículo 104 de la LGIPE, de presentarse una incompatibilidad entre lo dispuesto por una norma local y algún lineamiento o reglamento expedido por el INE, predomina este último suscitando la inaplicación de la disposición estatal, circunstancia que dota de nuevo sentido al principio de jerarquía normativa. En tal supuesto, los lineamientos o reglamentos del INE prevalecen sobre las leyes expedidas por las legislaturas estatales.

A modo de referencia, al expedir el INE el Reglamento de Radio y Televisión en Materia Electoral, se dispone en su artículo 13 que dentro de cada proceso electoral local, los partidos políticos accederán a sus prerrogativas de radio y televisión en un periodo único y conjunto para precampañas. Independientemente del número de precampañas por tipo de elección que prevea cada legislación local, el INE administrará los tiempos del Estado que correspondan a los partidos para sus precampañas durante un periodo único, el cual no podrá exceder de los plazos máximos que señala la Constitución. En caso de que las legislaciones locales prevean la celebración de precampañas tanto para gobernador/a como para diputados/as o ayuntamientos, en periodos de diferente duración, esta quedará comprendida dentro de un periodo único de acceso a tiempos en radio y televisión. ${ }^{13}$

De acuerdo a lo previsto por el artículo 246 del Código Electoral del Estado de México, la duración máxima de las precampañas para las elecciones de Gobernador, diputados e integrantes de los ayuntamientos no podrá ser mayor a las dos terceras partes de la duración de las campañas, y deberán concluirse antes del vigésimo quinto día previo al del inicio del plazo para el registro de las candidaturas ante el órgano electoral respectivo.

Conforme a lo descrito, en el proceso electoral local 2015 para la elección de diputados y ayuntamientos en el Estado de México, la duración de las precampañas fue de 23 días en cada elección. Dado que la fecha de registro de las candidaturas no coincide para la elección de diputados y de ayuntamientos, dar cumplimiento a lo ordenado por el Reglamento de Radio y Televisión en Materia Electoral, en el sentido de ajustar a un periodo

13 Instituto Nacional Electoral, "Reglamento de Radio y Televisión en Materia Electoral. INE/ CG267/2014”, Sesión Extraordinaria del 19 de noviembre de 2014. 
Esta obra forma parte del acervo de la Biblioteca Jurídica Virtual del Instituto de Investigaciones Jurídicas de la UNAM

único la prerrogativa de acceso a la radio y la televisión, implicó que los partidos vieran disminuida dicha prerrogativa a solo 21 días de los 23 que dura la precampaña. Es decir, atender al periodo único ordenado por el Reglamento del INE, conlleva en cierto modo a disminuir la prerrogativa de los partidos políticos.

Un enfoque tradicional del principio de jerarquía normativa, basado en lo previsto por el artículo 133 constitucional, determina que las leyes locales se encuentran en un plano inferior a la Constitución, las leyes del Congreso de la Unión que emanen de ella y todos los tratados que estén de acuerdo con la misma. Como la LGIPE es una ley general y tiene preeminencia sobre la legislación electoral de los estados, al ordenar en su artículo 104 que los Organismos Públicos Locales deberán aplicar las disposiciones generales, reglas, lineamientos y criterios que establezca el INE, deconstruye el principio de jerarquía normativa y coloca a los reglamentos y lineamientos del INE por encima de las leyes estatales. De ahí que a pesar de las disposiciones en contrario, la autoridad electoral local aplicará los reglamentos del INE aun cuando dicha aplicación restrinja el goce de una prerrogativa a favor de los partidos políticos otorgada por su normativa estatal.

Situación similar ocurre en otros temas como el referido al registro de un partido político local. Al emitir los Lineamientos para el ejercicio del derecho que tienen los otrora Partidos Políticos Nacionales para optar por el registro como Partido Político Local establecido en el artículo 95, párrafo 5 de la Ley General de Partidos Políticos, el INE impone un procedimiento único que deberán observar los Organismo Públicos Locales al resolver las solicitudes sobre el particular, a pesar de lo dispuesto en la normativa local.

$\mathrm{Al}$ ejercer la facultad de atracción respecto al registro de los otrora Partidos Políticos Nacionales como partidos políticos locales, con el fin de fijar criterios de interpretación que orienten a los Organismos Públicos locales en la materia, el INE define el procedimiento único que habrá de seguirse por la autoridad estatal competente para otorgar el registro a un partido local. Con fundamento en el precepto de la Ley General de Partidos Políticos, si un Partido Político Nacional pierde su registro por no haber alcanzado el porcentaje mínimo de votación en el último proceso electoral ordinario federal, podrá optar por el registro como partido político local, en la o las entidades federativas en cuya elección inmediata anterior hubiere obtenido por lo menos el tres por ciento de la votación válida emitida y hubiere postulado candidatos propios en al menos la mitad de los municipios y Distritos, condición con la cual se le tendrá por cumplido y acreditado el requisito del número mínimo de militantes con que debe contar. 
Esta obra forma parte del acervo de la Biblioteca Jurídica Virtual del Instituto de Investigaciones Jurídicas de la UNAM

De manera correcta, se determina que los Partidos Políticos Nacionales se sujetarán a un procedimiento extraordinario para obtener el registro como partido político local, de pretender sujetarlos al mismo procedimiento que sigue una organización que busca obtener su registro como partido político local, sería conculcar el derecho del partido político a participar en los procesos electorales que han dado inicio o están por iniciar, así como el derecho de los ciudadanos a asociarse y participar activamente en la vida política nacional. Dado que el acuerdo respectivo fue aprobado el día 6 de noviembre de 2014, para entonces en varias entidades federativas el Partido del Trabajo ya se encontraba en trámites con el fin de obtener el registro como partido político local, circunstancia que orilló a las autoridades electorales estatales a sobreseer la solicitud y exigir una nueva petición que se sujetara al procedimiento único dispuesto por el INE. ${ }^{14}$

La facultad que posee el Consejo General del INE para emitir acuerdos generales vinculantes, le permite definir nuevas reglas que sustituyen las disposiciones y el modelo de procedimientos previsto en las entidades federativas, circunstancia que como sostiene la Sala Superior del TEPJF puede vulnerar la libertad configurativa de los estados, sin embargo, dado que la atribución del INE tiene asidero en la LGIPE las autoridades electorales locales se sujetan a las reglas, lineamientos y criterios que la autoridad nacional emite. Ahora bien, el esfuerzo de homologar la normativa electoral que realiza el INE ha contribuido a la excesiva regulación en la materia electoral, aspecto que abona poco a su sistematicidad.

\section{ANÁLISIS Y DISYUNTIVA DEL MODELO \\ DUAL DE SOLUGIÓN DE CONTROVERSIAS EN MATERIA DE PROPAGANDA POLÍTICO-ELECTORAL}

Con la reforma constitucional de 2014, se introdujo la implementación de un modelo dual de solución de controversias en materia político-electoral, en el que se mandata a cargo del INE la instrucción de los procedimientos especiales sancionadores y a la Sala Regional Especializada del TEPJF la solución de las controversias. Dichas sentencias podrán recurrirse ante la Sala Superior del propio Tribunal, quien resolverá de forma inatacable.

14 Instituto Nacional Electoral, "Acuerdo del Consejo General del Instituto Nacional Electoral por el que se ejerce la facultad de atracción y se aprueban los Lineamientos para el ejercicio del derecho que tienen los otrora Partidos Políticos Nacionales para optar por el registro como Partido Político Local, establecido en el artículo 95, párrafo 5 de la Ley General de Partidos Políticos. INE/CG939/2015”, Sesión extraordinaria del 7 de noviembre de 2015. 
Esta obra forma parte del acervo de la Biblioteca Jurídica Virtual del Instituto de Investigaciones Jurídicas de la UNAM

Se trata de uno de los cambios más controvertidos de la reforma, pues a escasos meses de su instrumentación dio lugar a diversos cuestionamientos que llevan a pensar en su reconfiguración. El nuevo esquema ha tenido que afrontar dilemas relacionados con posibles violaciones a derechos fundamentales, como la libertad de expresión, el derecho a la información, la calumnia electoral, el derecho a la intimidad y la sobreexposición mediática, entre otros. ${ }^{15}$

A diferencia del procedimiento especial sancionador anterior, en la reingeniería constitucional y legal del año 2014 se estableció que la autoridad administrativa habrá de continuar investigando e integrando los expedientes, mientras que la Sala Regional Especializada quedó facultada para determinar si, con la investigación realizada, procede imponer una sanción. De acuerdo con el esquema, corresponde al INE recibir la denuncia por presuntas violaciones al modelo de comunicación política, la Unidad Técnica de lo Contencioso Electoral tendrá solo 24 horas para admitirla o desecharla. Si al examinar las pruebas aportadas, la Unidad Técnica considera necesaria la adopción de medidas cautelares, las propondrá a la Comisión de Quejas y Denuncias. Admitida la denuncia se emplazará a las partes para que comparezcan a una audiencia de pruebas y alegatos dentro de las 48 horas siguientes. Celebrada la audiencia se turnará de forma inmediata el expediente completo a la Sala Regional Especializada, quien contará con un plazo de 48 horas para elaborar el proyecto de sentencia. La Sala tendrá, a su vez, 24 horas para resolver en sesión pública.

Dado que es facultad de la Comisión de Quejas y Denuncias del INE determinar la procedencia y aplicación de las medidas cautelares, esa decisión es apelable ante la Sala Superior del TEPJF. De tal manera, en virtud de la brevedad de los plazos que corren a la Sala Especializada para resolver la controversia, puede ocurrir que la Sala Superior emita la resolución al recurso de apelación en fecha posterior a la sentencia de la Sala Especializada, es decir, primero se decide el fondo de la controversia antes de la medida cautelar. Por otro lado, también sucede que al resolver la impugnación de la medida cautelar, la Sala Superior anticipa el criterio y fija la postura sobre el posible recurso de revisión que se interponga contra la sentencia de la Sala Especializada. Dicho de otra forma, al decidir sobre la medida cautelar la Sala Superior se asoma al fondo de la controversia y podría marcarle rumbo

15 Alanís Figueroa, María del Carmen, "Fundamentos y aplicaciones del procedimiento especial sancionador en materia electoral", México, Instituto Electoral del Estado de México, Serie Breviarios de Cultura Política Democrática (25), 2015. p. 93. 
Esta obra forma parte del acervo de la Biblioteca Jurídica Virtual del Instituto de Investigaciones Jurídicas de la UNAM

a la determinación de la Sala Especializada, colocando a esta en incómoda situación.

Mientras el procedimiento especial sancionador se gestó en el pasado como un modelo uniinstancial de solución de controversias, claramente recurrible por la vía jurisdiccional, su diseño actual lo transforma en un modelo dual que suscita la concurrencia de distintas autoridades al tramitar la queja. Están involucradas de manera simultánea la Unidad Técnica de lo Contencioso Electoral y la Comisión de Quejas y Denuncias del INE, así como la Sala Especializada y la Sala Superior del TEPJF.

Esa circunstancia puede dar lugar a situaciones poco congruentes, tal vez la Comisión de Quejas y Denuncias del INE considere procedente la medida cautelar y determine el retiro de un promocional de los medios de comunicación, por estimar que fue excesivo el ejercicio de la libertad de expresión. Como la decisión es recurrible ante la Sala Superior, podría quedar firme la medida sin que para la Sala Especializada exista motivo de sanción. El criterio jurisdiccional sobre el ejercicio de la libertad de expresión llega a tener una connotación distinta de la óptica que orienta a la instancia administrativa, siendo más permisivo el umbral que fija el tribunal.

Desde la perspectiva garantista y convencional de los derechos humanos, para determinar la existencia o inexistencia de mensajes calumniosos es necesario, previo a la valoración de la protección constitucional de las expresiones realizadas, elaborar un esquema doctrinal y conceptual que permita dilucidar los límites de la libertad de expresión en el contexto específicamente electoral, destacando que el ámbito de la crítica aceptable se extiende en el curso de los debates políticos durante las campañas electorales o cuando versen sobre cuestiones de interés público. ${ }^{16}$ Esa labor, propia de un órgano jurisdiccional suele escapar de la órbita en que se mueve la instancia administrativa, pues es más limitada o reducida la intensidad que le corresponde a esta última en el control constitucional y convencional del ejercicio de la libertad de expresión

Si toda sociedad democrática demanda la posibilidad de manifestar ideas y opiniones que permitan hacer llegar a la ciudadanía la información necesaria para ejercer el voto, el fin último del procedimiento especial sancionador dista mucho de ser únicamente la imposición de sanciones para quien incumpla con las reglas de comunicación política, debe servir también

16 Gómez García, Iván y Hernández Toledo, Carlos, "Libertad de expresión en materia político electoral. Análisis de la calumnia en las sentencias de la Sala Especializada”. En: Coello Garcés, Clicerio; De la Mata Pizaña, Felipe y Villafuerte Coello, Gabriela (Coords.), Procedimiento Especial Sancionador en la fusticia Electoral, México: Tirant lo Blanch, 2015, p. 77. 
Esta obra forma parte del acervo de la Biblioteca Jurídica Virtual del Instituto de Investigaciones Jurídicas de la UNAM

para preservar un conjunto de normas adoptadas a fin de que se transmitan por cualquier vía los mensajes políticos de los interesados en la contienda electoral, de tal forma que a través de dicha tutela se cuiden los principios rectores de toda elección. ${ }^{17}$ Acorde con lo anterior, la facultad de establecer y determinar las medidas cautelares debe corresponder a la Sala Regional Especializada, finalmente la Sala Superior tiene competencia para revisar esa determinación, asegurando la existencia de una segunda instancia.

Toda vez que la naturaleza administrativa sancionadora de este procedimiento convierte a la autoridad resolutora en una institución sujeta a presiones importantes de los actores políticos y de los medios de comunicación, lo correcto es retirársela a la Comisión de Quejas y Denuncias del INE, depositándola en la Sala Especializada, órgano jurisdiccional que respecto a la libertad de expresión tiene mayor margen de interpretación y cuenta con la ventaja de resolver sin la presencia de los representantes de los partidos políticos.

Corregir el diseño del procedimiento especial sancionador amerita revisar la excesiva brevedad de los plazos e incorporar a la Sala Regional Especializada de forma preponderante en la integración del expediente respectivo. Otorgarle a esta Sala la facultad de establecer las medidas cautelares, pospone de manera correcta que la Sala Superior se asome de forma anticipada a la controversia. Después de todo, dictar una medida cautelar anticipa una mirada al fondo de la controversia pues se determinan con base en la apariencia del buen derecho, facultad que debe corresponder a la autoridad resolutora.

\section{Nuevas CaUSALES DE NULIDAD DE La ELEGCiÓN Y LA EXCESIVA LITIGIOSIDAD DE LOS COMICIOS}

Es común que al término de una elección presidencial se ponga a discusión su régimen constitucional y legal. En distintas ocasiones se ha pretendido atajar las derrotas electorales incorporando nuevas causales que permitan anular un resultado adverso. Así sucedió con la reciente reforma constitucional de 2014, los perdedores de la contienda se enojaron por la derrota y tuvieron la "brillante" idea de ampliar los supuestos de nulidad de una elección.

No es buena opción aumentar las causales de nulidad de una elección, una reforma electoral en ese sentido solo anticipa lo que serán las futuras

17 Alanís Figueroa, María del Carmen, op, cit., p. 94. 
Esta obra forma parte del acervo de la Biblioteca Jurídica Virtual del Instituto de Investigaciones Jurídicas de la UNAM

controversias y la nueva fuente de discusión y malestar en la competencia electoral. Suponer que el texto parte de un propósito disuasivo, queriendo desalentar prácticas irregulares, no consigue que los actores políticos se abstengan de los malos hábitos ya arraigados en su modo de entender la contienda. Agregar causas de nulidad incentiva la cultura de la impugnación y no abona a la aceptabilidad de la derrota.

Propiciar el cuestionamiento sistemático de los resultados electorales dinamita la legitimidad de los comicios y contribuye a eludir la responsabilidad del fracaso, los partidos políticos quieren de ese modo anticipar el remedio legal a las prácticas irregulares que presumiblemente le dan el triunfo al oponente. Desde la elección presidencial del año 2006, se puso a debate la descripción casuística de nuevas causas de nulidad de las elecciones federales. Entonces fueron incorporadas a la Ley General del Sistema de Medios de Impugnación en Materia Electoral (LGSMIME) causas expresas para anular la elección de Presidente de los Estados Unidos Mexicanos: i) Cuando alguna o algunas de las causales de nulidad de la votación recibida en casilla se acrediten en por lo menos el veinticinco por ciento de las casillas instaladas; ii) Cuando no se instale el veinticinco por ciento de las casillas y consecuentemente la votación no hubiere sido recibida; iii) Cuando el candidato ganador de la elección resulte inelegible. ${ }^{18}$

Derivado de la reforma constitucional de 2014, se incorporó a la Base VI del artículo 41, que la ley establecerá el sistema de nulidades de las elecciones federales o locales por violaciones graves, dolosas y determinantes en los siguientes casos: a) Se exceda el gasto de campaña en un cinco por ciento del monto total autorizado; b) Se compre o adquiera cobertura informativa o tiempos en radio y televisión, fuera de los supuestos previstos en la ley; c) Se reciban o utilicen recursos de procedencia ilícita o recursos públicos en las campañas. Dichas violaciones deberán acreditarse de manera objetiva y material. Se presumirá que son determinantes cuando la diferencia de la votación obtenida entre el primero y el segundo lugar sea menor al cinco por ciento.

Además de las causas específicas de nulidad ya señaladas, al modificarse en el año 2014 la LGSMIME, se refrendó en el artículo 78 bis la causal genérica de nulidad de las elecciones federales y locales, cuando se acrediten

18 A partir de la reforma constitucional y legal de 2007-2008, se incorporó a la LGSMIME el artículo 77 Bis. Las causas expresas de nulidad de la elección presidencial no fueron agregadas al texto constitucional, siguiendo la lógica de que en el ordenamiento secundario se establecen las causales de nulidad de una elección de diputados de mayoría relativa y de senadores en una entidad federativa. De manera correcta, es en una ley general donde deben precisarse los supuestos de nulidad de una elección. 
Esta obra forma parte del acervo de la Biblioteca Jurídica Virtual del Instituto de Investigaciones Jurídicas de la UNAM

violaciones graves, dolosas y determinantes. Corrigiendo una aparente omisión legislativa del año 2008, se describe ahora que por violaciones graves se entenderán aquellas conductas irregulares que produzcan una afectación sustancial a los principios constitucionales en la materia y pongan en peligro el proceso electoral y sus resultados.

Similar en su contenido, el artículo 78 de la LGSMIME ya dispone que las Salas del Tribunal Electoral podrán declarar la nulidad de una elección de diputados o senadores cuando se hayan cometido en forma generalizada violaciones sustanciales en la jornada electoral, en el distrito o entidad de que se trate, siempre que se encuentren plenamente acreditadas y se demuestre que las mismas fueron determinantes para el resultado de la elección, salvo que las irregularidades sean imputables a los partidos promoventes o sus candidatos. Puede advertirse así, en estricto sentido, que el nuevo artículo 78 bis extiende la causal genérica a todas las elecciones federales o locales y a otras etapas del proceso electoral, extensión innecesaria cuando se apoyan en el mismo fundamento, es decir, la violación a principios constitucionales.

Si bien el artículo 78 bis incorpora el significado de violación grave, el mismo se encuentra implícito en la construcción jurisdiccional de la causal de nulidad por violación a los principios constitucionales. En efecto, como resultado de una interpretación del TEPJF, aquellas conductas que puedan implicar violaciones graves a los principios que rigen las elecciones y pongan en duda la certeza de los resultados obtenidos, darán lugar a decretar la nulidad de la elección. Para que sea considerada valida cualquier elección deben observarse los principios constitucionales y legales que las regulan. Se trata de respetar los elementos fundamentales de una elección democrática, cuyo cumplimiento es imprescindible para que una elección se considere producto del ejercicio popular de la soberanía, dentro del sistema jurídicopolítico construido en la norma suprema y en las leyes electorales elevadas a rango constitucional. ${ }^{19}$

Heredera de la causal abstracta de nulidad de una elección, la violación a los principios constitucionales representa la causal genérica por excelencia. En ella se recoge que la existencia de irregularidades ocurridas en un proceso electoral, contrarias a una disposición constitucional, son capaces de afectar o viciar en forma grave y determinante el proceso comicial res-

19 Sala Superior del Tribunal Electoral del Poder Judicial de la Federación, "Tesis X/2001. Elecciones. Principios constitucionales y legales que se deben observar para que cualquier tipo de elección sea considerada valida", Fusticia Electoral, Tribunal Electoral del Poder Judicial de la Federación. (5): 63-64, 2002. 
Esta obra forma parte del acervo de la Biblioteca Jurídica Virtual del Instituto de Investigaciones Jurídicas de la UNAM

pectivo, conduciendo a la invalidez de la elección por ser contraria a la norma suprema.

Agregar causales específicas de nulidad de una elección es una mala ocurrencia y un remedio inadecuado que no pone fin a las malas prácticas electorales. Si ya se contempla la nulidad de la elección por violación a los principios constitucionales, caben en ella una infinidad de supuestos siempre que signifiquen violaciones sustanciales y determinantes. Por supuesto, es también una pésima idea incorporar causales de nulidad en el texto constitucional, hacerlo de esa forma atenta a la sistematicidad que debe tener la norma suprema y la vuelve excesivamente reglamentaria.

\section{CONSIDERAGIONES FINALES}

Primera. Reforma de claroscuros, las modificaciones constitucionales y legales de 2014 en materia electoral ha dado lugar a una indeseable dispersión normativa. Las adecuaciones de las leyes electorales locales al marco normativo de ámbito nacional propician una gran cantidad de conflictos y acusan serios problemas de armonización en las reglas.

Segunda. Parte del contenido de la reforma constitucional y legal en materia electoral favorece la excesiva litigiosidad de los comicios y acusa una elevada tendencia prohibicionista.

Tercera. Entre lo mesurado y lo excesivo, cuando el Consejo General del INE ejerce la facultad de atracción, no se encuentra en condiciones de confrontar directamente las reglas previstas en las distintas legislaciones electorales con el bloque de constitucionalidad, esa atribución está reservada para la Suprema Corte de Justicia al resolver las acciones de inconstitucionalidad.

Cuarta. Dando nuevo sentido y alcance al principio de jerarquía normativa, con base en el artículo 104 de la LGIPE, de presentarse una incompatibilidad entre lo dispuesto por una norma local y algún lineamiento o reglamento expedido por el INE, predomina este último suscitando la inaplicación de la disposición estatal. En tal supuesto, los lineamientos o reglamentos del INE prevalecen sobre las leyes expedidas por las legislaturas locales.

Quinta. Mientras el procedimiento especial sancionador se gestó en el pasado como un modelo uniinstancial de solución de controversias, su diseño actual lo transforma en un modelo dual que suscita la concurrencia de distintas autoridades al tramitar la queja. Esa circunstancia da lugar a situaciones poco congruentes. Debe corregirse su diseño y revisar la excesiva 
Esta obra forma parte del acervo de la Biblioteca Jurídica Virtual del Instituto de Investigaciones Jurídicas de la UNAM

brevedad de los plazos para resolver, otorgándole a la Sala Regional Especializada la facultad de establecer las medidas cautelares.

Sexta. El nuevo texto del artículo 41 constitucional contiene contradicciones con el artículo 116, haber colocado en la Constitución nuevas causas de nulidad de una elección no solo es un despropósito, es una inconveniente forma de entender el contenido y los límites del texto constitucional, es sobre todo una invitación al litigio generalizado, al conflicto perpetuo. ${ }^{20}$

Séptima. Un número elevado de reformas constitucionales revela que nos hemos ido al extremo opuesto. Son tantas, tan frecuentes y barrocas que la norma suprema se fue desfigurando. La excesiva regulación en materia electoral no abona a la sistematicidad constitucional y se ha vuelto en exceso reglamentaria. Por ello se justifica un ejercicio que compacte y reordene el texto de la norma suprema.

\section{REFERENCIAS CONSULTADAS}

Bibliografia:

ALANÍS Figueroa, María del Carmen, "Fundamentos y aplicaciones del procedimiento especial sancionador en materia electoral", México, Instituto Electoral del Estado de México, Serie Breviarios de Cultura Política Democrática (25), 2015.

COELLO Garcés, Clicerio; DE LA MATA Pizaña, Felipe y VILLAFUERTE Coello, Gabriela (Coords.), "Procedimiento Especial Sancionador en la Fusticia Electoral", México, Tirant lo Blanch, 2015.

Hemerografía:

ALGOGER V., Jorge, "El ciclo de las reformas electorales en México". Revista Mexicana de Derecho Electoral, UNAM- Instituto de Investigaciones Jurídicas. (6), Julio- Diciembre 2014.

CARBONELL, Miguel, "Verborrea e incultura constitucional". Revista Nexos [en línea]: 1 de febrero de 2012. Disponible en: http://wrere.nexos.com. $m x /: p=14673$

SÁNCHEZ Gutiérrez, Arturo y VIVES Segl, Horacio, "Las nuevas atribuciones del INE al interior de las elecciones locales". Revista Mexicana de Derecho Electoral, UNAM- Instituto de Investigaciones Jurídicas. (6), Julio- Diciembre 2014.

20 Alcocer V., Jorge, "El ciclo de las reformas electorales en México". Revista Mexicana de Derecho Electoral, UNAM- Instituto de Investigaciones Jurídicas. (6): 137, Julio- Diciembre 2014. 
Esta obra forma parte del acervo de la Biblioteca Jurídica Virtual del Instituto de Investigaciones Jurídicas de la UNAM

SALA Superior del Tribunal Electoral del Poder Judicial de la Federación, "Tesis X/2001. Elecciones. Principios constitucionales y legales que se deben observar para que cualquier tipo de elección sea considerada valida", Justicia Electoral, Tribunal Electoral del Poder Judicial de la Federación. (5), 2002.

VALADÉS, Diego. "Qué hacer con la Constitución?". Reforma, México, 2 de febrero de 2016. Disponible en: wrere.reforma.com/aplicaciones/editoriales/editorial.aspx:id $=81220$

VALDÉS Zurita, Leonardo y GONZÁLEZ Suárez, Patricia, "Elementos para el análisis de la reforma electoral de 2014". Revista Mexicana de Derecho Electoral, UNAM- Instituto de Investigaciones Jurídicas. (6), Julio- Diciembre 2014.

\section{Sentencias y documentos oficiales:}

Dictamen de las Comisiones Unidas de Puntos Constitucionales; de Gobernación; de Reforma del Estado; de Estudios Legislativos, Primera y de Estudios Legislativos, Segunda, en relación con las iniciativas con proyecto de decreto por el que se reforman y adicionan diversos artículos de la Constitución Política de los Estados Unidos Mexicanos en materia político-electoral, Gaceta del Senado, México, Senado de la República (LXII Legislatura), 2 de diciembre de 2013, [fecha de consulta: 17 de marzo de 2016]. Disponible en: http://wrere.senado.gob.mx/comisiones/puntos_constitucionales/docs/dictamen_031213.pdf

INSTITUTO Nacional Electoral, "Acuerdo del Consejo General del Instituto Nacional Electoral por el que se ejerce la facultad de atracción y se aprueban los Lineamientos para la designación de los Consejeros Electorales Distritales y Municipales, así como de los Servidores Públicos Titulares de las Áreas Ejecutivas de Dirección de los Organismo Públicos Locales Electorales. INE/CG865/2015”, Sesión Extraordinaria del Consejo General del 9 de octubre de 2015

INSTITUTO Nacional Electoral, "Acuerdo del Consejo General del Instituto Nacional Electoral por el que se ejerce la facultad de atracción y se aprueban los Lineamientos para el ejercicio del derecho que tienen los otrora Partidos Politicos Nacionales para optar por el registro como Partido Político Local, establecido en el artículo 95, párrafo 5 de la Ley General de Partidos Políticos. INE/CG939/2015”, Sesión extraordinaria del 7 de noviembre de 2015.

INSTITUTO Nacional Electoral, "Lineamientos para la designación de los Consejeros Electorales Distritales y Municipales, así como de los Servidores Públicos Titulares de las Áreas Ejecutivas de Dirección de los Organismos Públicos Locales Electorales". Anexo del Acuerdo INE/CG865/2015, Sesión Extraordinaria del Consejo General del 9 de octubre de 2015. 
Esta obra forma parte del acervo de la Biblioteca Jurídica Virtual del Instituto de Investigaciones Jurídicas de la UNAM

INSTITUTO Nacional Electoral, "Reglamento de Radio y Televisión en Materia Electoral. INE/CG267/2014", Sesión Extraordinaria del 19 de noviembre de 2014.

Sentencia de la Sala Superior del Tribunal Electoral del Poder Judicial de la Federación, identificado con la clave SUP-JRC-678/2015 y SUPJDC-1272/2015 acumulados, de fecha 22 de octubre de 2015.

Sentencia de la Sala Superior del Tribunal Electoral del Poder Judicial de la Federación, identificado con la clave SUP-RAP-103/2016 y acumulados, de fecha 10 de marzo de 2015. 
Esta obra forma parte del acervo de la Biblioteca Jurídica Virtual del Instituto de Investigaciones Jurídicas de la UNAM

\title{
LA NECESIDAD DE ESQUEMATIZAR EL CONTENIDO DE LOS DEREGHOS HUMANOS DE LA CONSTITUCIÓN MEXICANA DE 1917
}

\section{Sergio Arnoldo MORÁn NAVARRO*}

\begin{abstract}
SUMARIO: I. Introducción. II. El contenido de los Derechos Humanos en la Constitución mexicana. III. Los modelos constitucionales en la regulación de las libertades. IV. Delimitación de libertades, contenido esencial y proporcionalidad. V. Algunas consideraciones. VI. Literatura Consultada.
\end{abstract}

\section{INTRODUCCIÓN}

El pasado 31 de enero del presente, el doctor Diego Valadés propuso ante los medios de comunicación nacionales, la necesidad de reescribir la Constitución mexicana de 1917, dentro de las razones externadas, al menos, señala dos graves problemas: un déficit notable en el cumplimiento de sus funciones, y un alejamiento de su esencia original provocado por las constantes reformas. ${ }^{1}$

Agregando que, "La Constitución de 1917 fue el producto de la identificación de las demandas y las expectativas sociales, y por eso tuvo un contenido eminentemente social, porque resolvía las inquietudes de campesinos, y ya de obreros. En esa Constitución, el protagonista era el pueblo, por decirlo no en términos políticos ni demagógicos, sino estrictamente conceptuales, como se podría decir basándose en Rousseau. De eso hablaban la Constitución Francesa, y la de Estados Unidos; es decir, las constitucio-

* Doctor en Derecho por la Universidad Complutense de Madrid, España; Profesor Titular de la Universidad Autónoma de Nayarit, México; integrante del Sistema Nacional de Investigadores, nivel I, del Consejo Nacional de Ciencia y Tecnología.

1 Valadés, Diego, "Reescribir la Constitución" en Periódico Reforma, publicado el 31 de enero de 2016. 
Esta obra forma parte del acervo de la Biblioteca Jurídica Virtual del Instituto de Investigaciones Jurídicas de la UNAM

nes son del pueblo, porque el pueblo somos todos. Esto cambió, y luego la Constitución se convirtió en un instrumento de los gobernantes, pero con un giro adicional: ahora las constituciones también son el instrumento de la clase política internacional y, entonces, nos encontramos que, en los últimos años, se hablaba más de la reforma constitucional mexicana en Wall Street que en México". ${ }^{2}$

Ante este escenario, la clase política nacional, también ha propuesto la necesidad de inclusive, crear una nueva constitución. Así, representantes de la izquierda mexicana, como el ex candidato a la Presidencia de la República Cuauhtémoc Cárdenas y el senador Alejandro Encinas, ambos ex perredistas, el pasado 3 de octubre del año 2015, lanzaron la convocatoria para construir un nuevo proyecto de nación, en el que se discutieran los problemas que afectan a la sociedad y las posibles vías para resolverlos, argumentando que, "la edificación de un país modelado de manera muy distinta del actual, que cuente con una nueva Constitución y que ésta sea, al mismo tiempo, estación de llegada y plataforma de lanzamiento de los cambios que hagan de México una nación soberana, de iguales, de justicia, y democrática". ${ }^{3} \mathrm{Al}$ respecto, otro de los representantes de la izquierda, como lo es Porfirio Muñoz Ledo, el otro líder histórico de la Corriente Democrática de 1988, estuvo de acuerdo con la propuesta, señalando que la Constitución de 1917 sólo es un referente histórico, al punto que, agregó, ha sido traicionada y en la víspera de los cien años, debería realizarse una revisión integral en su contenido, para refundar la República.

Este escenario próximo del centenario de la Constitución mexicana, nos debe permitir, en un primero momento, revisar las bases que dieron origen a esta gran nación, con la finalidad de determinar la vigencia de los ideales que se vieron plasmados en nuestra Carta Magna. Pero también, debemos visualizar la posibilidad que tiene nuestro México, de replantear la estructura bajo el cual se ha organizado el poder del Estado, es decir, cuestionar la pertinencia de continuar con el modelo presidencialista que tenemos, o valorar la implementación de un modelo alterno, como lo puede ser el sistema parlamentarista o semiparlamentarista; así como también ponderar, el funcionamiento del sistema de justicia nacional, en el esquema bajo el cual se encuentra el máximo tribunal del país, o en su caso, determinar la separación de la defensa de la constitución en la creación de un Tribunal Constitucional, por citar algunos ejemplos.

\footnotetext{
2 Ídem.

3 Consultado en la página oficial de Ciudadanos en Red http://ciudadanosenred.com.mx/ noticia/reescribir-la-constitucion/, el 5 de febrero de 2016.
} 
Esta obra forma parte del acervo de la Biblioteca Jurídica Virtual del Instituto de Investigaciones Jurídicas de la UNAM

Pero lo cierto es, que el presente trabajo representa, la oportunidad que se tiene, de organizar las bases en las cuales se sentaron las libertades que tendremos los mexicanos en esta nación, bajo un esquema distinto, en donde sea posible visualizar con la claridad debida, aquellos aspectos esenciales a cada uno de los derechos humanos que el Estado mexicano se ha comprometido a garantizar. Ya que la regulación actual, no permite que se conozca a plenitud, el sentido y alcance de cada uno de dichos derechos, dificultando con ello, que la sociedad entienda con plenitud, el Estado de Derecho que esta instaurado para la seguridad de sus libertades.

\section{EL CONTENIDO DE LOS DERECHOS Humanos EN La CONSTITUCiÓN MEXicana}

La estructura que se implementó para organizar el texto que se encuentra inmerso en cada uno de los preceptos que integran la Constitución Política de los Estados Unidos Mexicanos, es un tanto compleja, de ahí que quienes se adentran a conocer el contenido del mismo, encuentran una serie de irregularidades que lejos de facilitar su comprensión, generan una serie de confusiones que bien pueden propiciar un efecto contrario al deseado, es decir, que pierdan interés.

Así, en lo que respecta a las libertades de los mexicanos, encontramos un título especial dedicada a las mismas, al inicio del texto constitucional, "Título Primero, Capítulo I, De los Derechos Humanos y sus Garantías", y quienes tienen acceso al texto pensarán que, en este apartado, se encontrarán todas la libertades que el Estado mexicano se ha comprometido a cumplir y garantizar. Pero, haciendo una primera observación encontraremos que, en la doctrina, la noción de derechos humanos no encuentra necesariamente la aceptación de que los derechos humanos tengan que estar reconocidos para que un Estado deba cumplir con los mismos.

El segundo aspecto a valorar radica en que, de la noción de garantía, en el lenguaje moderno, se hace alusión a los mecanismos de defensa que tiene el Estado para proteger las libertades, y en este sentido, caeremos en cuenta que dentro de este apartado, no se contiene mecanismo alguno de defensa de la Constitución, por lo que, dicha denominación no encontrará sustento en la denominación, por lo que, el seguir utilizando en la denominación del Título I, Capítulo I, el calificativo de y sus garantías, no es adecuado.

Sin embargo, el problema mayor no radica en la inadecuada denominación del Título I, Capítulo I, sino en la ausencia de esquematización dentro del texto constitucional, y sobre todo, en el apartado de las libertades cono- 
Esta obra forma parte del acervo de la Biblioteca Jurídica Virtual del Instituto de Investigaciones Jurídicas de la UNAM

cidas como derechos humanos. Al entrar al análisis del artículo 1 del texto constitucional, nos encontramos con diferentes aspectos a ponderar. ${ }^{4}$ Del análisis del mismo, si preguntamos que contiene este precepto, tendremos la necesidad de tratar de encontrar una metodología que permita una análisis adecuado, por lo que, nos veremos en la necesidad de entender cada uno de los párrafos que integran el artículo primero. ${ }^{5}$

Inicialmente, debemos considerar que ha cambiado la noción tradicional que se tenía en el Estado mexicano de las Garantías Individuales, y que también cambió substancialmente la concepción de derechos que se podrán proteger, debido a que la noción que ha permeado en los sistemas jurídicos positivistas se sustenta en la noción de derechos fundamentales, ${ }^{6}$ más que en la de derechos humanos. ${ }^{7}$

4 Se trascribe a continuación el texto integro de dicho precepto:

"Artículo 1o. En los Estados Unidos Mexicanos todas las personas gozarán de los derechos humanos reconocidos en esta Constitución y en los tratados internacionales de los que el Estado Mexicano sea parte, así como de las garantías para su protección, cuyo ejercicio no podrá restringirse ni suspenderse, salvo en los casos y bajo las condiciones que esta Constitución establece.

Párrafo reformado DOF 10-06-2011

Las normas relativas a los derechos humanos se interpretarán de conformidad con esta Constitución y con los tratados internacionales de la materia favoreciendo en todo tiempo a las personas la protección más amplia.

Párrafo adicionado DOF 10-06-2011

Todas las autoridades, en el ámbito de sus competencias, tienen la obligación de promover, respetar, proteger y garantizar los derechos humanos de conformidad con los principios de universalidad, interdependencia, indivisibilidady progresividad. En consecuencia, el Estado deberá prevenir, investigar, sancionar y reparar las violaciones a los derechos humanos, en los términos que establezca la ley.

Párrafo adicionado DOF 10-06-2011

Está prohibida la esclavitud en los Estados Unidos Mexicanos. Los esclavos del extranjero que entren al territorio nacional alcanzarán, por este solo hecho, su libertad y la protección de las leyes.

Queda prohibida toda discriminación motivada por origen étnico o nacional, el género, la edad, las discapacidades, la condición social, las condiciones de salud, la religión, las opiniones, las preferencias sexuales, el estado civil o cualquier otra que atente contra la dignidad humana y tenga por objeto anular o menoscabar los derechos y libertades de las personas."

5 Sobre el alcance y consecuencias de las nuevas condiciones en materia de derechos humanos en el Estado mexicano, cfr. Moran Navarro, Sergio y Lomelí, Humberto, "La ampliación de los derechos protectores, la nueva realidad del Estado mexicano a raíz de la reforma constitucional de 10 de junio de 2011, en Contribuciones al Derecho Constitucional Serna de la Garza, José María (Coord.), ed. IIJ-UNAM, México, 2015.

6 Sobre los derechos fundamentales cfr. Alexy, Robert, Teoría de los Derechos Fundamentales, ed. Centro de Estudios Políticos y Constitucionales, Madrid 1993; también Ferrajoli, Luigui, Los Fundamentos de los Derechos Fundamentales, editorial Trotta, Madrid, 2001; véase también Carbonell, Miguel, Los derechos fundamentales en México, Cuarta Edición, ed. UNAM-CNDH, México, 2011.

7 Sobre los Derechos Humanos, cfr. Dworkin, Ronald, Los Derechos en serio, editorial Ariel, Barcelona, 1984; también Carpizo Jorge, Los Derechos Humanos: naturaleza, denominación 
Esta obra forma parte del acervo de la Biblioteca Jurídica Virtual del Instituto de Investigaciones Jurídicas de la UNAM

Ahora bien, si se pretende utilizar el concepto de garantías para definir los mecanismos que existirán para la protección de los mismos, el Estado mexicano ha adecuado el marco normativo con la expedición de una nueva Ley de Amparo, la cual, la cual además de proteger los derechos humanos reconocidos por la Constitución mexicana, también se pueden invocar ahora aquellos derechos humanos que se encuentran previstos en los tratados suscritos en los términos previstos por el artículo 133 de la Constitución General de la República en esta materia.

Sin embargo, en el análisis del propio párrafo primero del artículo primero, también se encuentra previsto el principio de interpretación constitucional conforme, o intepretación conforme a la constitución, al prever que, cuando en la Constitución mexicana se señale algún límite al ejericio de las libertades, restringiendo o suspendiendo las mismas, deberan estar de acuerdo a las condiciones previstas en el propio texto constitucional. ${ }^{8}$

Continuando analizando el artículo primero, ahora en su párrafo segundo, encontramos que se contiene otro principio, conocido en la doctrina como el principio pro persone ${ }^{9}$ que pretende garantizar, cuando la constitución y un tratado regulen una libertad, prevalezca aquella que garantice la protección más amplia.

Otra cuestión relevante deriva del análisis del párrafo tercero del artículo primero, ${ }^{10}$ que incluye en un primer momento, las obligaciones que tienen todas las autoridades mexicanas en el ámbito de su competencia y de acuerdo con la materia de derechos humanos, para después en el mismo párrafo tercero incorporar los principios en materia de derechos humanos

y características, en Revista Mexicana de Derecho Constitucional, número 25 julio-diciembre 2011, p. 4 y ss.

8 Da Silva, Firgilio Alfonso, "La interpretación conforme a la Constitución. Entre la trivialidad y la centralización judicial”, en Revista Mexicana de Derecho Constitucional, no. 12, también Ferrer Mac-Gregor, Eduardo, Interpretación conforme y control difuso de convencionalidad, en La reforma Constitucional en Derechos Humanos: un nuevo paradigma, Coordinada por Miguel Carbonell y Pedro Salazar, ed. IIJ-UNAM, México 2011, p. 358 y ss.

9 Sobre el principio pro persone, cfr. Caballero Ochoa, José Luis, La incorporación de los tratados internacionales sobre derechos humanos en España y México, Porrúa, México, 2009, pp. 62 y ss., también Caballero Ochoa, José Luis "La cláusula de interpretación conforme y el principio pro persone (artículo $1^{\circ}$ segundo párrafo de la Constitución", en La reforma Constitucional en Derechos Humanos: un nuevo paradigma, Coordinada por Miguel Carbonell y Pedro Salazar, ed. IIJ-UNAM, México 2011, p.103 y ss.

10 Carbonell, Miguel "Las obligaciones del Estado en el artículo $1^{\circ}$ de la Constitución Mexicana", en la obra La reforma Constitucional en Derechos Humanos: un nuevo paradigma, Coordinada por Miguel Carbonell y Pedro Salazar, ed. IIJ-UNAM, México 2011, p. 63 y ss. 
Esta obra forma parte del acervo de la Biblioteca Jurídica Virtual del Instituto de Investigaciones Jurídicas de la UNAM

y con posterioridad, nuevamente regresar y agregar más obligaciones para las autoridades mexicanas.

Por último, el cuarto párrafo del artículo primero, incorpora el principio de igualdad, es decir, el principio de no discriminación, en cualquiera de las diversas formas que existen de en las sociedades modernas, como base de toda sociedad democrática.

En este pequeño análisis del artículo primero, encontramos que, se tienen desde conceptos, principios, obligaciones, y demás aspectos que, ante la ausencia de una esquematización adecuada, puede generar problemas en la regulación que se requiera para los casos concretos que se vayan presentando, debido a que, el contenido del artículo primero es muy amplio, y con ello, dificulta su análisis y precisión.

Otro de los aspectos que contienen una complejidad similar, deriva de las condiciones que encontramos en la regulación de la libertad personal previstas en el artículo 16 de la Constitución mexicana. En un primer aspecto, debemos considerar, que este precepto, contiene en su primer párrafo, lo conocido en la doctrina como el principio de legalidad, ${ }^{11}$ que obliga a todas las autoridades, cuando realiza actos de molestia, a realizarlo bajo ciertas condiciones para considerar como válida su actuación, imponiendo que debe actuar por escrito, en donde deberá fundar y motivar su competencia y la causa legal de su proceder.

Luego, derivado de la reforma de 1 de junio de 2009, se incorporó un texto que corresponde con la protección de datos personales,${ }^{12}$ mismo que, según la tradición de la materia, debería formar parte de la materia de transparencia y acceso a la información pública, que se encuentra ubicada en el artículo 6, por constituir en esta instancia la que concentra la materia, inclusive, al punto que, en nuestra nación se cuenta con un Instituto Nacional de Transparencia, Acceso a la Información y Protección de Datos Personales, y por ende, el esquema constitucional debería estar concentrado en un solo precepto, y no disperso en varios.

11 Artículo 16. Párrafo primero "Nadie puede ser molestado en su persona, familia, domicilio, papeles o posesiones, sino en virtud de mandamiento escrito de la autoridad competente, que funde y motive la causa legal del procedimiento"...

12 Artículo 16. .. párrafo segundo "Toda persona tiene derecho a la protección de sus datos personales, al acceso, rectificación y cancelación de los mismos, así como a manifestar su oposición, en los términos que fije la ley, la cual establecerá los supuestos de excepción a los principios que rijan el tratamiento de datos, por razones de seguridad nacional, disposiciones de orden público, seguridad y salud públicas o para proteger los derechos de terceros"... 
Esta obra forma parte del acervo de la Biblioteca Jurídica Virtual del Instituto de Investigaciones Jurídicas de la UNAM

Siguiendo con el análisis del artículo 16 de la Constitución mexicana, el párrafo tercero, cuarto, quinto, sexto, séptimo y octavo, ${ }^{13}$ contienen la regulación de la libertad personal, previendo una serie de situaciones que deben ajustarse para su debido respeto y cumplimento, al imponer obligaciones tanto a las autoridades ministeriales como judiciales en su tratamiento. Pero al llegar al párrafo noveno, nos encontramos con una definición del tipo de delincuencia organizada, es decir, en la Constitución General de la República se han llegado a definir hasta tipos penales, cuestión que entendemos, debe dejarse para la legislación de la materia.

Con posterioridad, en este mismo artículo 16, encontramos aspectos que tienen que ver con la inviolabilidad del domicilio, con la regulación de

13 Artículo 16. Párrafos tercero y siguientes...

"No podrá librarse orden de aprehensión sino por la autoridad judicial y sin que preceda denuncia o querella de un hecho que la ley señale como delito, sancionado con pena privativa de libertad y obren datos que establezcan que se ha cometido ese hecho y que exista la probabilidad de que el indiciado lo cometió o participó en su comisión.

Párrafo reformado DOF 01-06-2009. Fe de erratas DOF 25-06-2009

La autoridad que ejecute una orden judicial de aprehensión, deberá poner al inculpado a disposición del juez, sin dilación alguna y bajo su más estricta responsabilidad. La contravención a lo anterior será sancionada por la ley penal

Cualquier persona puede detener al indiciado en el momento en que esté cometiendo un delito o inmediatamente después de haberlo cometido, poniéndolo sin demora a disposición de la autoridad más cercana y ésta con la misma prontitud, a la del Ministerio Público. Existirá un registro inmediato de la detención.

Sólo en casos urgentes, cuando se trate de delito grave así calificado por la ley y ante el riesgo fundado de que el indiciado pueda sustraerse a la acción de la justicia, siempre y cuando no se pueda ocurrir ante la autoridad judicial por razón de la hora, lugar o circunstancia, el Ministerio Público podrá, bajo su responsabilidad, ordenar su detención, fundando y expresando los indicios que motiven su proceder.

En casos de urgencia o flagrancia, el juez que reciba la consignación del detenido deberá inmediatamente ratificar la detención o decretar la libertad con las reservas de ley.

La autoridad judicial, a petición del Ministerio Público y tratándose de delitos de delincuencia organizada, podrá decretar el arraigo de una persona, con las modalidades de lugar y tiempo que la ley señale, sin que pueda exceder de cuarenta días, siempre que sea necesario para el éxito de la investigación, la protección de personas o bienes jurídicos, o cuando exista riesgo fundado de que el inculpado se sustraiga a la acción de la justicia. Este plazo podrá prorrogarse, siempre y cuando el Ministerio Público acredite que subsisten las causas que le dieron origen. En todo caso, la duración total del arraigo no podrá exceder los ochenta días.

Por delincuencia organizada se entiende una organización de hecho de tres o más personas, para cometer delitos en forma permanente o reiterada, en los términos de la ley de la materia.

Ningún indiciado podrá ser retenido por el Ministerio Público por más de cuarenta y ocho horas, plazo en que deberá ordenarse su libertad o ponérsele a disposición de la autoridad judicial; este plazo podrá duplicarse en aquellos casos que la ley prevea como delincuencia organizada. Todo abuso a lo anteriormente dispuesto será sancionado por la ley penal." 
los cateos, ${ }^{14}$ que agregado a las cuestiones previamente señaladas, nos deriva que, contienen disposiciones de diversa índole, y que complican aplicación, porque se encuentran inmersos aspectos que no son complementarios, sino que cuentan con una independencia que no permiten ubicar, de manera adecuada su regulación y vigencia.

14 Artículo 16 párrafo undécimo y siguientes:

"En toda orden de cateo, que sólo la autoridad judicial podrá expedir, a solicitud del Ministerio Público, se expresará el lugar que ha de inspeccionarse, la persona o personas que hayan de aprehenderse y los objetos que se buscan, a lo que únicamente debe limitarse la diligencia, levantándose al concluirla, un acta circunstanciada, en presencia de dos testigos propuestos por el ocupante del lugar cateado o en su ausencia o negativa, por la autoridad que practique la diligencia.

Las comunicaciones privadas son inviolables. La ley sancionará penalmente cualquier acto que atente contra la libertad y privacía de las mismas, excepto cuando sean aportadas de forma voluntaria por alguno de los particulares que participen en ellas. El juez valorará el alcance de éstas, siempre y cuando contengan información relacionada con la comisión de un delito. En ningún caso se admitirán comunicaciones que violen el deber de confidencialidad que establezca la ley.

Exclusivamente la autoridad judicial federal, a petición de la autoridad federal que faculte la ley o del titular del Ministerio Público de la entidad federativa correspondiente, podrá autorizar la intervención de cualquier comunicación privada. Para ello, la autoridad competente deberá fundar y motivar las causas legales de la solicitud, expresando además, el tipo de intervención, los sujetos de la misma y su duración. La autoridad judicial federal no podrá otorgar estas autorizaciones cuando se trate de materias de carácter electoral, fiscal, mercantil, civil, laboral o administrativo, ni en el caso de las comunicaciones del detenido con su defensor.

Los Poderes Judiciales contarán con jueces de control que resolverán, en forma inmediata, y por cualquier medio, las solicitudes de medidas cautelares, providencias precautorias y técnicas de investigación de la autoridad, que requieran control judicial, garantizando los derechos de los indiciados y de las víctimas u ofendidos. Deberá existir un registro fehaciente de todas las comunicaciones entre jueces y Ministerio Público y demás autoridades competentes.

Las intervenciones autorizadas se ajustarán a los requisitos y límites previstos en las leyes. Los resultados de las intervenciones que no cumplan con éstos, carecerán de todo valor probatorio.

La autoridad administrativa podrá practicar visitas domiciliarias únicamente para cerciorarse de que se han cumplido los reglamentos sanitarios y de policía; y exigir la exhibición de los libros y papeles indispensables para comprobar que se han acatado las disposiciones fiscales, sujetándose en estos casos, a las leyes respectivas y a las formalidades prescritas para los cateos.

La correspondencia que bajo cubierta circule por las estafetas estará libre de todo registro, y su violación será penada por la ley.

En tiempo de paz ningún miembro del Ejército podrá alojarse en casa particular contra la voluntad del dueño, ni imponer prestación alguna. En tiempo de guerra los militares podrán exigir alojamiento, bagajes, alimentos y otras prestaciones, en los términos que establezca la ley marcial correspondiente. 
Esta obra forma parte del acervo de la Biblioteca Jurídica Virtual del Instituto de Investigaciones Jurídicas de la UNAM

Por si fuera poco, dentro de este título primero, capítulo primero de la Constitución mexicana, encontramos preceptos en donde íntegramente no contiene derecho alguno, como lo es el previsto en el artículo 26, en donde es posible encontrar, aspectos que derivan de la rectoría económica del Estado, así como del Sistema Nacional de Estadística y Geografía y del Consejo Nacional de Evaluación de la Política de Desarrollo Social, cuyo contenido, nada tiene que ver con las libertades que debemos tener en esta nación.

Pero si esto no es suficiente, fuera del texto del capítulo primero, encontramos libertades reconocidas en otros preceptos constitucionales, como lo son las encontradas en los artículos 35, respecto a los derechos políticos, o los derechos laborales previstos en el artículo 123 de nuestra Carta Magna.

\section{LOS MODELOS CONSTITUCIONALES \\ EN LA REGULACIÓN DE LAS LIBERTADES}

En la tradición constitucional, las naciones han implementado dos modelos en el reconocimiento de las libertades. El primero de estos, deriva de la regulación general de las libertades, en las cuales, basta solo con señalar dentro del texto de alguno de los preceptos regulados en títulos y capítulos el contenido de los preceptos que corresponderían con el apartado de la constitución que se esta regulando.

Así, encontramos naciones como Italia, ${ }^{15}$ Francia $^{16}$ y México, ${ }^{17}$ por citar algunas de ellas, que incorporan en el contenido del texto de su constitución, aspectos relacionados con las libertades, los principios constitucionales o la organización del Estado, basados solo en la esquematización por títulos y capítulos.

El otro modelo, utilizado por naciones como Alemania ${ }^{18}$ y España, ${ }^{19}$ han incorporado en el contenido del texto constitucional, además de la organización por títulos y capítulos, una esquematización que permite identificar, en cada precepto, una identificación de cada uno de los contenidos que complementaran la figura prevista para cada apartado de sus constituciones, de tal forma que, en la aplicación al caso concreto del derecho reconocido o del principio invocado, es posible identificar desde el contenido

15 Constitución Italiana de 1947, actualizada marzo 2016.

16 Constitución Francesa de 1958, actualizada marzo 2016.

17 Constitución Política de los Estados Unidos Mexicanos de 1917, actualizada marzo 2016.

18 Ley Fundamental de Bonn de 1949, actualizada marzo 2016

19 Constitución española de 1978, actualizada marzo 2016. 
Esta obra forma parte del acervo de la Biblioteca Jurídica Virtual del Instituto de Investigaciones Jurídicas de la UNAM

esencial y hasta las condiciones adecuadas para la valoración en la aplicación del principio de proporcionalidad propuesto por Alexy.

El primero de los modelos permite la identificación de los aspectos generales que se pretenderán regular, sin embargo, en la precisión de los contenidos en ocasiones nos encontraremos con aspectos que no tienen relación con el título o el capitulo de referencia, o que inclusive, no deberían formar parte del texto constitucional, porque bien pudiera dejarse para su inclusión en la legislación ordinaria.

El segundo de los modelos, además de permitir la identificación de los aspectos generales previstos en los títulos y capítulos, propiciará también que se puedan ubicar con mayor facilidad los aspectos esenciales y necesarios para entender la figura prevista con mayor detenimiento y conocimiento, haciendo inclusive mas sencilla su identificación al momento de resolver el caso concreto, en caso de así requerirse.

\section{DELIMITACiÓN DE LIBERTADES, CONTENIDO ESENCIAL Y PROPORCIONALIDAD}

Entender la complejidad de la relación que existe en el texto constitucional de los principios y derechos, no es una tarea sencilla, debido a que, de manera constante, encontraremos escenarios en donde, colisionarán innevitablemente dichos derechos o principios. Así, veremos que de manera constante nos encontraremos en situaciones en donde la solución al caso concreto no es simple, sino que por el contrario, determinar, que es lo que debe prevalecer, será una tarea compleja, y para ello, es necesario utilizar el contenido esencial y el principio de proporcionalidad. ${ }^{20}$

El principio de proporcionalidad, en la doctrina, también conocido como postulado de proporcionalidad o como principio de prohibición de exceso, ${ }^{21}$ cuenta con dos teorías en su aplicación, la teoría relativa y la absoluta. En lo que respecta a la teoría relativa, es relevante desde el momento

20 Sobre el principio de proporcionalidad, cfr. Moran Navarro, Sergio y Bahena, Alma, "Una perspectiva del principio de proporcionalidad en México", en Derecho, Sociedady fusticia, Una visión plural, coordinado por Pedro Antonio Enríquez López e Irina Graciela Cervantes Bravo, publicado por el Poder Judicial del Estado de Nayarit, 2014.

21 Nogueira Alcalá, Humberto, "El uso del postulado de proporcionalidad en la jurisprudencia de la Corte Interamericana de Derechos Humanos sobre libertad de expresión", en Estudios Constitucionales, Chile, Centro de Estudios Constitucionales de Chile, Universidad de Talca, Año 9, $\mathrm{N}^{\mathrm{o}}$ 1, 2011, p. 120. 
Esta obra forma parte del acervo de la Biblioteca Jurídica Virtual del Instituto de Investigaciones Jurídicas de la UNAM

en que pueda adoptar el contenido esencial de los derechos humanos, ${ }^{22}$ en la cual, reconoce que los derechos fundamentales no son ilimitados, y en consecuencia, se pueden afectar, en la medida misma que no afecte o vulnere el núcleo esencial ${ }^{23}$ o contenido mínimo del derecho fundamental, y con ello, evitar el vaciamiento o la desconstitucionalización ${ }^{24}$ del derecho.

Por su parte, la teoría absoluta, su concepción es más amplia, debido a que, procura conocer el contenido esencial del derecho fundamental no solo para el caso concreto, sino "de una vez para todas" 25 las ocasiones necesarias, de tal forma que, identifica el núcleo o la esfera de lo indecidible ${ }^{26}$ por parte de cualquier autoridad, ante cualquier posibilidad de, y se puedan determinar los elementos que no están disponibles para el juzgador en ningún caso.

En la resolución de casos difíciles, el principio de proporcionalidad se ha constituido en la herramienta argumentativa más importante para resolver los conflictos de colisiones entre dos o más derechos o principios constitucionales, utilizando diversas técnicas argumentativas. Dentro de las cuales, se destacan: el principio de proporcionalidad, el de ponderación, la razonabilidad, la maximización de los efectos normativos de los derechos fundamentales, también el efecto irradiación, así como la proyección horizontal de los derechos (drittwirkung), el principio pro persona, por citar algunos. ${ }^{27}$

En particular, el principio de proporcionalidad es importante, al grado tal, que destacados jurístas han propuesto diversas teorías que pretenden, en mayor medida, dotar de racionalidad las resoluciones jurisdiccionales, con el objetivo de alzanzar, una mayor transparencia en los argumentos que permitan decidir los casos difícilies, al momento de pronunciarse sobre el sentido y valor que deberán tener los preceptos constitucionales al resolver

22 Criterio emitido por el Pleno de la Suprema Corte de Justicia de la Nación en la tesis aislada número P. XII/2011, de rubro "CONFLICTOS QUE INVOLUCRAN DERECHOS FUNDAMENTALES. SU RESOLUCIÓN JURÍDICA”, correspondiente a la 9a. Época; S.J.F. y su Gaceta; Tomo XXXIV, agosto de 2011, p. 23.

23 Véase Häberle, Peter, La garantía del contenido esencial de los derechos fundamentales en la Ley Fundamental de Bonn, Brage, Joaquín (trad.), Madrid, Dykinson, 2003.

24 Silva García, Fernando, Deber de ponderación y principio de proporcionalidad, México, Porrúa, 2012, pp. 15-28.

25 Ibídem, p. 20.

26 Véase Ferrajoli, Luigi, "El constitucionalismo garantista. Entre Paleo-iuspositivismo y Neo-iusnaturalismo", en DOXA. Cuadernos de Filosofia del Derecho, No. 34, 2011, ISSN: 02148676, pp. 321, disponible en: http://es.scribd.com/doc/93126554/Ferrajoli-DOXA34-Respuesta

27 Carbonell, Miguel (coord.), Argumentación furídica. El juicio de ponderación y el principio de proporcionalidad, México, Porrúa-UNAM, $2^{a}$ edición, 2012, p. XII. 
Esta obra forma parte del acervo de la Biblioteca Jurídica Virtual del Instituto de Investigaciones Jurídicas de la UNAM

el caso concreto, y brindando así, una mayor transparencia en el ejericio de la jurisdicción constitucional. ${ }^{28}$

$\mathrm{Al}$ respecto, Carbonell menciona que "... se trata de una técnica de interpretación cuyo objetivo es tutelarlos (los derechos) de mejor manera, expandiendo tanto como sea posible su ámbito de protección, pero haciendo que todos los derechos sean compatibles entre ellos, en la medida en que sea posible. De hecho, el principio de proporcionalidad constituye hoy en día quizá el más conocido y el más recurrente "limite de los limites" a los derechos fundamentales y en esa medida supone una barrera frente a intromisiones indebidas en el ámbito de los propios derechos. ${ }^{\prime 29}$

Hecho lo anterior, regresamos al analisis del artículo primero, en el cual nos referimos al párrafo segundo, que contiene el principio pro persone, que pretende garantizar, cuando la constitución y un tratado regulen una libertad, garantizar la protección más amplia de ese derecho, vemos que, esta disposición se confronta abiertamente con el párrafo primero última parte del mismo artículo primero, ya que el citado párrafo consagra el principio de interpretación conforme a la constitución, e impone la obligación de hacer valer las limitaciones establecidas en el texto constitucional.

Este escenario propició, que la Suprema Corte de Justicia de la Nación, emitiera la jurisprudencia por contradicción de tesis 293/2011, ${ }^{30}$ en dos as-

28 Cfr. Zagrebelsky, Gustavo, El derecho dúctil. Ley, derechos, justicia, Madrid, Trotta, 8 a edición, 2008, pp. 109-130. Dworkin, Ronald, Los derechos en serio, Barcelona, Ariel, (1984), $7^{\text {a }}$ reimpresión, 2009, pp. 146 y ss. Bernal Pulido, Carlos, "La Racionalidad de la Ponderación" y "El principio de proporcionalidad de la legislación penal", en ibídem, pp. 27-49 y 189-218. Prieto Sanchís, Luis, "Neoconstitucionalismo y ponderación judicial", en Carbonell, Miguel (ed.), Neoconstitucionalismo(s), Trotta, $2^{a}$ edición, Madrid, 2005, pp. 123-158. Clericó, Laura, "El examen de proporcionalidad: entre el exceso por acción y la insuficiencia por omisión o defecto", en Carbonell, Miguel (ed.), El principio de proporcionalidad y la interpretación constitucional, Ministerio de Justicia y Derechos Humanos, Ecuador, Quito, 2008, pp. 125-174. Entre otros.

29 Carbonell, Miguel, "Nuevas formas de proteger los Derechos Fundamentales", en Carbonell, Miguel (Coord.), El principio de proporcionalidad y la protección y la interpretación constitucional, Ministerio de Justicia y Derechos Humanos, Ecuador, Quito, 2008, p. 8.

30 De los antecedentes de los criterios que propiciaron la presente jurisprudencia por contradicción de tesis 293/2011, encontramos que el 24 de junio de 2011 en la Oficina de Certificación Judicial y Correspondencia de la Suprema Corte de Justicia de la Nación (en adelante SCJN), se denunció la posible contradicción de tesis entre los criterios sostenidos por el Primer Tribunal Colegiado en Materias Administrativa y de Trabajo del Décimo Primer Circuito y por el Séptimo Tribunal Colegiado en Materia Civil del Primer Circuito. Que se registró bajo el número 293/2011, el Presidente del Alto Tribunal ordenó el envío del asunto a la Primera Sala de la SCJN, bajo la Ponencia del Ministro Arturo Zaldívar Lelo de Larrea para la elaboración del proyecto de resolución correspondiente. En virtud de la trascendencia del tema que se analizaba, la Primera Sala de la SGJN determinó enviar el asunto al Tribunal Pleno, para su discusión y resolución. 
Esta obra forma parte del acervo de la Biblioteca Jurídica Virtual del Instituto de Investigaciones Jurídicas de la UNAM

pectos, aunque el relevante para el presente punto corresponde a la Posición jerárquica de los tratados internacionales en materia de derechos humanos frente a la Constitución. Al establecer que "de la interpretación literal, sistemática y originalista del contenido de las reformas constitucionales de 6 y 10 de junio de 2011, se desprende que las normas de derechos humanos, independientemente de su fuente, no se relacionan en términos jerárquicos, sin embargo, cuando la Constitución establezca una restricción expresa al ejercicio de los derechos humanos, se deberá estar a lo que indica la norma constitucional. En este sentido, los derechos humanos, con independencia de su fuente, constituyen el parámetro de control de regularidad constitucional, conforme al cual debe analizarse la validez de todas las normas y actos de autoridad que forman parte del ordenamiento jurídico mexicano."

Este tipo de conflictos, es decir, cuando existe colisión de derechos o principios que se ubican jerárquicamente al mismo nivel, han encontrado en la doctrina una solución adecuada, utilizando en un primer término la identificación del contenido esencial de los derechos en conflicto utilizado por el Tribunal Constitucional Alemán y expuestos adecuadamente por Haberle, mismos que se complementan al utilizar el principio de proporcionalidad propuesto por Robert Alexy en la solución de los mismos. Pero hacerlo en los términos adoptados en la tesis 293/2011 por el máximo tribunal de esta nación, es decir, por la Suprema Corte de Justicia de la Nación, creo que ha sido precipitado, debido a que, el ejercicio exigía una mayor complejidad en su análisis, en la identificación de los elementos en juego, en las razones que deberían utilizarse para hacer valer un principio sobre el otro, pero creo que tanto los elementos que emitieron los tribunales que propiciaron la contradicción de tesis, no eran sobre casos similares, sino que se trataban de asuntos de diferente índole, y en la solución de los mismos, aún de manera diversa, bien pudieron seguir rumbos diferentes, sin que necesariamente se contradijeran.

\section{Algunas CONSIDERACiONES}

Como hemos visto, el esquema previsto en el texto constitucional para la regulación de las libertades, cumple con el mínimo que requiere una nación en el reconocimiento de los derechos humanos que tiene toda persona, por el simple hecho de ser persona.

Sin embargo, dicho esquema, no siempre logra delimitar el sentido y alcance que tiene consigo cada libertad, debido a que, de manera natural, al no estar previsto una organización dentro del contenido de cada precepto que contiene el reconocimiento de los derechos humanos, también se mez- 
Esta obra forma parte del acervo de la Biblioteca Jurídica Virtual del Instituto de Investigaciones Jurídicas de la UNAM

clan aspectos que tienen que ver con el funcionamiento de las instituciones del Estado, o inclusive, con otros derechos, pudiendo provocar una falta de precisión en la identificación de aquellos aspectos que son esenciales a las libertades que se han reconocido.

En otras naciones, existe una esquematización más precisa dentro de cada precepto que integra el texto constitucional, de tal forma que, es posible, identificar plenamente el contenido de cada libertad, y con ello, es posible que, en la solución del caso concreto, se puedan utilizar todas las herramientas necesarias para su adecuado cumplimiento.

La esquematización de las libertades, permite utilizar, a través del principio de proporcionalidad y el contenido esencial de los derechos y principios, de aquellos elementos que permitirán identificar de manera adecuada, todas las condiciones previstas para entender y comprender el sentido y alcance de las libertades en juego, máxime cuando dentro de las mismas, por la naturaleza de los asuntos, colisionan.

Bien sea con la propuesta de reescribir la Constitución, realizar una reforma integral a la misma, e inclusive, valorando la creación de una nueva constitución, lo cierto es que, en el reconocimiento de las libertades, se requiere que se implemente un modelo que permita identificar en el contenido del texto, aquellos aspectos que son inherentes a las libertades que tenemos en esta nación, y la necesidad de esquematizar el contenido de los derechos, debe ser tomada como una apremiante necesidad en el reconocimiento de las libertades en nuestra constitución.

\section{LiTERATURA CONSULTADA}

\section{Bibliografia:}

Alexy, Robert, Teoría de los Derechos Fundamentales, ed. Centro de Estudios Políticos y Constitucionales, Madrid 1993;

CABALlero Ochoa, José Luis, La incorporación de los tratados internacionales sobre derechos humanos en España y México, Porrúa, México, 2009, pp. 62 y ss.

CABALLERO Ochoa, José Luis "La cláusula de interpretación conforme y el principio pro persone (artículo $1^{\circ}$ segundo párrafo de la Constitución", en La reforma Constitucional en Derechos Humanos: un nuevo paradigma, Coordinada por Miguel Carbonell y Pedro Salazar, ed. IIJ-UNAM, México 2011, p. 103 y ss. 
Esta obra forma parte del acervo de la Biblioteca Jurídica Virtual del Instituto de Investigaciones Jurídicas de la UNAM

Carbonelt, Miguel "Las obligaciones del Estado en el artículo $1^{\circ}$ de la Constitución Mexicana", en la obra La reforma Constitucional en Derechos Humanos: un nuevo paradigma, Coordinada por Miguel Carbonell y Pedro Salazar, ed. IIJ-UNAM, México 2011, p. 63 y ss.

Carbonell, Miguel, Los derechos fundamentales en México, Cuarta Edición, ed. UNAM-GNDH, México, 2011.

Carbonelt, Miguel, "Nuevas formas de proteger los Derechos Fundamentales", en Carbonell, Miguel (Coord.), El principio de proporcionalidad y la protección y la interpretación constitucional, Ministerio de Justicia y Derechos Humanos, Ecuador, Quito, 2008, p. 8.

Carbonell, Miguel (coord.), Argumentación Furídica. El juicio de ponderación y el principio de proporcionalidad, México, Porrúa-UNAM, 2ª edición, 2012, p. XII.

CLERICó, Laura, "El examen de proporcionalidad: entre el exceso por acción y la insuficiencia por omisión o defecto", en Carbonell, Miguel (ed.), El principio de proporcionalidad y la interpretación constitucional, Ministerio de Justicia y Derechos Humanos, Ecuador, Quito, 2008, pp. 125-174. Entre otros.

DwORKIN, Ronald, Los Derechos en serio, editorial Ariel, Barcelona, 1984;

FERRAJOLI, Luigi, "El constitucionalismo garantista. Entre Paleo-iuspositivismo y Neo-iusnaturalismo", en DOXA. Cuadernos de Filosofia del Derecho, No. 34, 2011, ISSN: 0214-8676, pp. 321, disponible en: http://es.scribd. com/doc/93126554/Ferrajoli-DOXA34-Respuesta

Ferrajoli, Luigui, Los Fundamentos de los Derechos Fundamentales, editorial Trotta, Madrid, 2001;

FERRER Mac-Gregor, Eduardo, Interpretación conforme y control difuso de convencionalidad, en La reforma Constitucional en Derechos Humanos: un nuevo paradigma, Coordinada por Miguel Carbonell y Pedro Salazar, ed. IIJ-UNAM, México 2011, p. 358 y ss.

HÄBERLE, Peter, La garantía del contenido esencial de los derechos fundamentales en la Ley Fundamental de Bonn, Brage, Joaquín (trad.), Madrid, Dykinson, 2003.

MORÁn Navarro, Sergio y Bahena, Alma, "Una perspectiva del principio de proporcionalidad en México", en Derecho, Sociedady fusticia, Una visión plural, coordinado por Pedro Antonio Enríquez López e Irina Graciela Cervantes Bravo, publicado por el Poder Judicial del Estado de Nayarit, 2014.

MORÁn Navarro, Sergio y Lomelí, Humberto, "La ampliación de los derechos protectores, la nueva realidad del Estado mexicano a raíz de la reforma constitucional de 10 de junio de 2011, en Contribuciones al Derecho 
Esta obra forma parte del acervo de la Biblioteca Jurídica Virtual del Instituto de Investigaciones Jurídicas de la UNAM

Constitucional Serna de la Garza, José María (Coord.), ed. IIJ-UNAM, México, 2015.

NogUeIRA Alcalá, Humberto, "El uso del postulado de proporcionalidad en la jurisprudencia de la Corte Interamericana de Derechos Humanos sobre libertad de expresión", en Estudios Constitucionales, Chile, Centro de Estudios Constitucionales de Chile, Universidad de Talca, Año 9, $\mathrm{N}^{\circ}$ 1, 2011, p. 120.

PRIETO Sanchís, Luis, "Neoconstitucionalismo y ponderación judicial", en Carbonell, Miguel (ed.), Neoconstitucionalismo(s), Trotta, $2^{a}$ edición, Madrid, 2005, pp. 123-158.

Silva García, Fernando, Deber de ponderación y principio de proporcionalidad, México, Porrúa, 2012, pp. 15-28.

Zagrebelsky, Gustavo, El derecho dúctil. Ley, derechos, justicia, Madrid, Trotta, $8^{a}$ edición, 2008, pp. 109-130.

\section{Hemerografia:}

CARPIZO Jorge, Los Derechos Humanos: naturaleza, denominación y características, en Revista Mexicana de Derecho Constitucional, número 25 julio-diciembre 2011, p. 4 y ss.

DA Silva, Firgilio Alfonso, "La interpretación conforme a la Constitución. Entre la trivialidad y la centralización judicial", en Revista Mexicana de Derecho Constitucional, no. 12,

\section{Normas furídicas:}

Constitución Política de los Estados Unidos Mexicanos de 1917, actualizada marzo 2016.

CONSTITUCión española de 1978, actualizada marzo 2016.

Constitución de la República Francesa de 1958, actualizada marzo 2016.

Constitución de la República Italiana de 1947, actualizada marzo 2016.

LEY Fundamental de Bonn de 1949, actualizada marzo 2016

Jurisprudencias y tesis aisladas:

Criterio emitido por el Pleno de la Suprema Corte de Justicia de la Nación en la tesis aislada número P. XII/2011, de rubro "CONFLICTOS QUE INVOLUGRAN DEREGHOS FUNDAMENTALES. SU RESOLU- 
CIÓN JURÍDICA", correspondiente a la 9a. Época; S.J.F. y su Gaceta; Tomo XXXIV, agosto de 2011, p. 23.

JURISPRUDENCIA por contradicción de tesis 293/2011, encontramos que el 24 de junio de 2011 en la Oficina de Certificación Judicial y Correspondencia de la Suprema Corte de Justicia de la Nación (en adelante SCJN), se denunció la posible contradicción de tesis entre los criterios sostenidos por el Primer Tribunal Colegiado en Materias Administrativa y de Trabajo del Décimo Primer Circuito y por el Séptimo Tribunal Colegiado en Materia Civil del Primer Circuito. 
Esta obra forma parte del acervo de la Biblioteca Jurídica Virtual del Instituto de Investigaciones Jurídicas de la UNAM

\title{
EL DISEÑO DE LA REFORMA GONSTITUGIONAL EN MÉXICO
}

\author{
Marina del Pilar OLMEdA GARCíA*
}

\begin{abstract}
SUMARIO: I. Planteamiento. II. Breve panorama de la evolución constitucional. III. Una visión de las reformas constitucionales 1917-2016. IV. Procedimiento de reforma constitucional. V. Consideraciones finales. VI. Bibliografia.
\end{abstract}

\section{Planteamiento}

La Constitución Mexicana de 1917 es una de las más longevas del mundo. En el mundo, la mayoría de las Constituciones vigentes son posteriores a la Segunda Guerra Mundial y buen número de ellas fueron expedidas después de la caída del Muro de Berlín en 1989. En América Latina, los países integrantes de la región en su mayoría han promulgado un texto constitucional después de 1978, a excepción de Costa Rica, México, Panamá y Uruguay. En estas circunstancias, la celebración de este Congreso Nacional de Derecho Constitucional representa un excelente momento y espacio para reflexionar sobre nuestra Ley Fundamental, tanto sobre su longevidad excepcional, como sobre la teoría, práctica y procedimiento de la reforma constitucional; a partir de su examen crítico, como bien se titula esta mesa, realizar un intento de balance de estas reformas, sus problemas y dilemas, y proponer orientaciones para ordenar posibles caminos de solución.

* Doctora en Educación, por la Universidad Iberoamericana y Estudios de Doctorado en Derecho Constitucional por la Universidad de Castilla La Mancha; Profesora - Investigadora de la Universidad Autónoma de Baja California, México; Integrante del Sistema Nacional de Investigadores; SNI-ll; del Instituto Iberoamericano de Derecho Constitucional; de la Asociación Internacional de Derecho Administrativo y de las Redes Mexicanas e Internacional de Posgrado en Derecho; Es Autora de diversos libros entre ellos: Ética Profesional; Historia de las Instituciones Jurídicas y Evolución de la Constitución de Baja California. 
Esta obra forma parte del acervo de la Biblioteca Jurídica Virtual del Instituto de Investigaciones Jurídicas de la UNAM

Al día 29 de enero de 2016, el texto de la Constitución de 1917 ha sido objeto de 697 modificaciones, a través de 227 decretos de reforma, lo que ha dado lugar a un incremento, o como dicen algunos "ensanchado", "aumentado", "crecido" o "engordado" el texto constitucional aproximadamente en un $150 \%$ en relación con su texto original; es decir de 21,381 palabras a 66,000. A este respecto, el Doctor Jorge Carpizo explica "el número de las reformas es indicativo, y expresa una realidad; si sólo nos quedáramos con este dato no sería posible captar toda la problemática y profundidad que encierra el asunto de la reforma constitucional en México" ${ }^{1}$. El Doctor Diego Valadés, otro de los académicos que más ha estudiado este tema, afirma que, las reformas "se han convertido en una Constitución para especialistas y no para beneficio de la ciudadanía (...) y una Constitución por definición es una norma para ciudadanos"2. Al referirse también a las reformas constitucionales, Pedro Salazar sostiene que, "las reformas constitucionales nos anuncian que, en México, la Constitución no es un instrumento eficiente para regular y encauzar las relaciones entre los poderes y entre éstos y los gobernados, sino que, en los hechos, es un utensilio a disposición de los poderosos que lo moldean a su capricho"3.

En efecto, la cantidad de reformas que ha sufrido el texto constitucional original y el alcance de muchas de ellas, suscita varias preguntas: ¿Qué consecuencias tienen tantos cambios? y ¿Cuáles son los alcances del procedimiento de reforma constitucional? Habrá que agregar a estas preguntas, las observaciones de sintaxis, de sistemática y de técnica jurídica. La Constitución mexicana cambia mucho y mayormente por los mismos lados, cambia abruptamente aunque es longeva, cambia a pesar de que lo inhiba su diseño y procedimiento constitucional, todo esto es digno de reflexión y estudio.

\section{BREVE PANORAMA DE LA EVOLUGIÓN CONSTITUCIONAL}

Se parte, de que los impulsores de la lucha por la independencia, del movimiento de reforma y de la revolución mexicana tuvieron entre sus finalidades el que México se constituyera como un Estado de Derecho, en el que el

1 Carpizo, Jorge, "La reforma constitucional en México: procedimiento y realidad", Revista Mexicana de Derecho Comparado, México, UNAM, Instituto de Investigaciones Jurídicas, 2011, p. 575.

2 Valadés, Diego, Las funciones de la reforma Constitucional, en Valadés, Diego, y Carbonell, Miguel, (coords), El proceso constituyente mexicano. A 150 años de la constitución de 1857 y 90 de la constitución de 1917, México, UNAM, Instituto de Investigaciones Jurídicas, 2007, p. 819.

3 Salazar, Pedro, "Las demasiadas autonomías", Revista Nexos, México, Número 434, 2014, pp. 46-47. 
Esta obra forma parte del acervo de la Biblioteca Jurídica Virtual del Instituto de Investigaciones Jurídicas de la UNAM

poder se subordinara al Derecho. Esta finalidad es una tarea que no se agota con la promulgación de los textos constitucionales, sino que por el contrario es un proceso normativo que se proyecta a través del tiempo, y que se vertebra con la creación de leyes, reglamentos, decretos, acuerdos y demás disposiciones que en su conjunto integran el sistema jurídico de una nación.

La evolución del ordenamiento constitucional para calificar a México como un Estado de Derecho, se desarrolló a la par de pugnas políticas entre los grupos de poder: entre republicanos y monarquistas al conformar la vida independiente a principios del siglo XIX; por las disputas entre federalistas y centralistas en el nacimiento de la vida independiente; por las luchas entre liberales y conservadores en la segunda mitad del mencionado siglo XIX; por la resistencia contra las fuerzas invasoras del exterior; a través, también de la resistencia de los revolucionarios contra porfiristas y golpistas huertistas, así como los enfrentamientos que sostuvieron entre si los diversos grupos revolucionarios en el marco de la revolución social del siglo XX. Esta última etapa, bajo las presiones internacionales que se ejercieron sobre México con motivo de la Primera Guerra Mundial.

Así, del análisis de nuestra evolución constitucional se observa que hemos transitado: de la monarquía, a la república; del centralismo, al federalismo; del confesionalismo, al laicismo; del abuso personal, al poder de la autoridad; del desprecio por los derechos, al reconocimiento constitucional como derechos humanos; de la represión sistemática, a las reivindicaciones sociales como derechos sociales; de un régimen político basado en prerrogativas políticas de clase mediante fueros y privilegios, a la consideración de que la Ley debe ser igual para todos; se transitó también, de un sistema político electoral de elecciones indirectas, a un sistema configurado por elecciones directas.

Como resultado de este proceso, se puede afirmar que las generaciones de mexicanos de los movimientos de independencia, de la revolución liberal, de la reforma y de la revolución social determinaron las decisiones jurídicas-políticas fundamentales de nuestro régimen constitucional vigente; que como la propia Constitución lo define, como un sistema: republicano, representativo, democrático, laico y federal. En su organización destacan los principios de la soberanía del pueblo, separación y colaboración de poderes, separación de la iglesia y el estado, la composición de estados libres y soberanos en su régimen interior unidos en una federación, y en donde los derechos humanos precisan el reconocimiento de los principios inherentes a la naturaleza humana.

La evolución constitucional permite afirmar, que la definición constitucional de México se inicia con la promulgación de la Constitución de Apatzingán del 22 de octubre de 1814; se confirma con el Acta Constitutiva 
Esta obra forma parte del acervo de la Biblioteca Jurídica Virtual del Instituto de Investigaciones Jurídicas de la UNAM

de la Federación Mexicana del 31 de enero de 1824 y la Constitución Federal del 4 de octubre del mismo año; le siguen la Constitución Centralista integrada por las siete Leyes de 1836, las Bases Orgánicas de la República Mexicana de 1843, el Acta Constitutiva y de Reforma de 28 de mayo de 1847 que restableció el federalismo. Se cierra este proceso con la Constitución federal del 5 de febrero de 1857 y la vigente Constitución política de los Estados Unidos Mexicanos promulgada también un 5 de febrero de 1917.

Así, el examen del proceso constitucional mexicano a través de las decisiones jurídicas-políticas fundamentales que cada Ley suprema determinó, nos lleva a afirmar que la Constitución de Apatzingán tuvo como principal propósito el definir el perfil político de la nación mexicana, con la finalidad de fortalecer el movimiento independentista; se identifica también que las dos Constituciones centralistas fueron un paréntesis en la historia constitucional de México, y se acredita que el Acta Constitutiva y Reformas de 1847 restableció y actualizó la vigencia de la Constitución de 1824. Este examen nos lleva a afirmar, que las tres Constituciones fundamentales y fundacionales que la nación mexicana ha adoptado y positivizado, son: La Constitución de 1824, la que conjuntamente con el Acta Constitutiva y de Reformas de 1847, vertebró el sistema federal; se suma la Constitución de 1857, que integrada con las leyes de Reforma 1859-1863, delinea los principios configurativos del Estado laico, para cerrar con la Constitución de 1917, que fortaleció el reconocimiento de los derechos humanos, delimitó los derechos sociales y los principios fundamentales de la democracia social mexicana.

El análisis de esta evolución, demuestra lógicamente que cada una de estas Constituciones fue la expresión normativa de las ideas prevalecientes en su tiempo y poseen su propia unidad, a su vez cada una le fue aportando a las otras las decisiones jurídicas fundamentales. De la Constitución de 1824, sus principios y valores fueron recogidos y ampliados en la Constitución de 1857 y éstos a su vez fueron enriquecidos en la Constitución de 1917.

Ahora, el centro del debate es el análisis de lo que ha acontecido con el texto constitucional a partir de la promulgación de la Ley fundamental de 1917. Se entiende, que a través del cúmulo de reformas se ha intentado encontrar fórmulas, que permitan transitar de un sistema democrático representativo formal, a otro participativo real; de un sistema político de cacicazgos, a un régimen de partidos políticos; de la presencia hegemónica de un partido político, a un régimen político de conformación plural; de un sistema de elecciones organizadas por el estado, a un sistema electoral conducido por órganos ciudadanos. Las reformas constitucionales, entendemos que tienen como finalidad justificante la búsqueda de esos objetivos, en un encuentro, reencuentro y desencuentro de principios, valores, procedimientos y fórmulas que han nutrido la vida política nacional. 
Esta obra forma parte del acervo de la Biblioteca Jurídica Virtual del Instituto de Investigaciones Jurídicas de la UNAM

\section{UNA VISIÓN DE LAS REFORMAS CONSTITUCIONALES 1917-2016}

La Constitución mexicana de 1917 cumplió este 5 de febrero una vigencia histórica de 99 años, que supera con mucho la vigencia que tuvieron la suma de todas las Constituciones anteriores, las que en su conjunto tuvieron una vigencia sumada menor. Se considera que la razón que explica la longevidad de nuestra Constitución de 1917, es que en ella quedaron integradas las decisiones jurídicas-políticas fundamentales, e ideales expresados en los movimientos sociopolíticos del siglo XIX. Este proceso evolutivo, se vio complementado y enriquecido con las decisiones fundamentales, que se expresaron durante la revolución mexicana del siglo XX.

Otro factor que ha contribuido a la longevidad de la Constitución, es el hecho innegable de su evolución permanente, a través de la actividad legislativa del poder constitucional reformador, quien ha incorporado cambios conforme al desarrollo histórico nacional, mediante el procedimiento que determina la propia Ley Fundamental en el artículo 135 constitucional.

El proceso reformatorio de la Constitución de 1917 inició el 8 julio de 1921, de esta fecha, al 30 de enero de 2016, se han promulgado 227 decretos de reforma que suman 697 reformas. Han sido modificados también cuatro enunciados de sus títulos, capítulos y sus artículos transitorios han experimentado 12 reformas, 8 con la modificación del texto original de la Constitución de 1917 y 4 más que han modificado artículos transitorios de tres decretos de reforma constitucional. Los artículos más modificados son en orden por precepto, corresponden a:

\section{TABLA 1. LOS ARTÍCULOS MÁS MODIFICADOs ${ }^{4}$}

\begin{tabular}{|c|c|c|c|c|}
\hline Artículo & Número de Reformas & Fe de erratas & Aclaraciones & Total \\
\hline 40 & 14 & 1 & O & 15 \\
\hline 27 & 20 & 1 & 0 & 21 \\
\hline 73 & 76 & 3 & 1 & 80 \\
\hline 74 & 17 & 1 & 0 & 18 \\
\hline 79 & 15 & 0 & 1 & 16 \\
\hline 89 & 18 & 0 & 2 & 20 \\
\hline 94 & 12 & 1 & 0 & 13 \\
\hline 97 & 10 & 1 & 0 & 11 \\
\hline 107 & 16 & 2 & 0 & 18 \\
\hline 115 & 15 & 0 & 0 & 15 \\
\hline 123 & 26 & 3 & 0 & 29 \\
\hline
\end{tabular}

4 Cámara de Diputados, México, http://wrere.diputados.gob.mx/LeyesBiblio/ref/cpeum_art. htm, consultado el 29 de enero de 2016. 
Esta obra forma parte del acervo de la Biblioteca Jurídica Virtual del Instituto de Investigaciones Jurídicas de la UNAM

En la revisión realizada, por número de artículos, las reformas se han concentrado dramáticamente en algunos preceptos, el artículo más reformado resulta ser el 73 que suma 76 modificaciones y adiciones, que significa más de una reforma cada año y medio; el artículo 123 constitucional ha tenido 26 reformas y se modifica en promedio cada 3 años; el artículo 27 constitucional ha tenido 20 reformas y se modifica en promedio cada 4 años. En suma, de los 136 preceptos que integran nuestra Constitución, sólo 10 artículos concentran el 36\% de todas las reformas constitucionales en sus 99 años de vigencia ${ }^{5}$. Cabe considerar que cada una de las modificaciones que originan las reformas es importante por sí misma, por su naturaleza constitucional.

El análisis de las reformas constitucionales realizadas por período presidencial, quedan agrupadas cronológicamente en los siguientes términos:

\section{TABLA 2. REFORMAS CONSTITUCIONALES}

EFECTUADAS EN CADA PERIODO PRESIDENCIAL ${ }^{6}$

\begin{tabular}{|c|c|c|c|c|c|}
\hline Presidente & Periodo & $\begin{array}{c}\text { Número } \\
\text { de decretos } \\
\text { de Reforma }\end{array}$ & $\begin{array}{c}\text { Número de } \\
\text { reformas }\end{array}$ & $\begin{array}{c}\text { Reformas al } \\
\text { articulado }\end{array}$ & $\begin{array}{c}\text { Reformas } \\
\text { a artículos } \\
\text { transitorios }\end{array}$ \\
\hline $\begin{array}{c}\text { Álvaro } \\
\text { Obregón }\end{array}$ & $1920-1924$ & 2 & 8 & 7 & 1 \\
\hline $\begin{array}{c}\text { Plutarco } \\
\text { Elías Calles }\end{array}$ & $1924-1928$ & 5 & 18 & 18 & 0 \\
\hline $\begin{array}{c}\text { Emilio } \\
\text { Portes Gil }\end{array}$ & $1928-1930$ & 1 & 2 & 2 & 0 \\
\hline $\begin{array}{c}\text { Pascual } \\
\text { Ortiz Rubio }\end{array}$ & $1930-1932$ & 2 & 4 & 4 & 0 \\
\hline $\begin{array}{c}\text { Abelardo R. } \\
\text { Rodríguez }\end{array}$ & $1932-1934$ & 9 & 22 & 22 & 0 \\
\hline $\begin{array}{c}\text { Lázaro } \\
\text { Cárdenas del } \\
\text { Río }\end{array}$ & $1934-1940$ & 10 & 15 & 15 & 0 \\
\hline
\end{tabular}

5 Suprema Corte de Justicia de la Nación, Constitución Politica de los Estados Unidos Mexicanos, que reforma la de 5 de febrero de 1857 (compilación cronológica de sus modificaciones), México, https://wrewe.scjn.gob.mx/normativa/analisis_reformas/paginas/titulo_primero.aspx, consultado el 29 de enero de 2016.

6 Cámara de Diputados Reformas Constitucionales en Orden Cronológico, México: http://wrwr. diputados.gob.mx/LeyesBiblio/ref/cpeum_crono.htm, consultado el 29 de enero de 2016. 
Esta obra forma parte del acervo de la Biblioteca Jurídica Virtual del Instituto de Investigaciones Jurídicas de la UNAM www.juridicas.unam.mx https://biblio.juridicas.unam.mx/bjv

Libro completo en: https://goo.gl/8cEQmT

EL DISEÑO DE LA REFORMA CONSTITUGIONAL EN MÉXICO

\begin{tabular}{|c|c|c|c|c|c|}
\hline Presidente & Periodo & $\begin{array}{c}\text { Número de } \\
\text { decretos de } \\
\text { Reforma }\end{array}$ & $\begin{array}{l}\text { Número de } \\
\text { reformas }\end{array}$ & $\begin{array}{l}\text { Reformas al } \\
\text { articulado }\end{array}$ & $\begin{array}{l}\text { Reformas } \\
\text { a articulos } \\
\text { transitorios }\end{array}$ \\
\hline $\begin{array}{l}\text { Manuel } \\
\text { Ávila } \\
\text { Camacho } \\
\end{array}$ & $1940-1946$ & 10 & 18 & 18 & 0 \\
\hline $\begin{array}{l}\text { Miguel } \\
\text { Alemán } \\
\text { Valdés }\end{array}$ & 1946-1952 & 13 & 20 & 20 & 0 \\
\hline $\begin{array}{l}\text { Adolfo Ruíz } \\
\text { Cortines }\end{array}$ & 1952-1958 & 1 & 2 & 2 & 0 \\
\hline $\begin{array}{l}\text { Adolfo } \\
\text { López } \\
\text { Mateos }\end{array}$ & 1958-1964 & 8 & 11 & 11 & 0 \\
\hline $\begin{array}{c}\text { Gustavo } \\
\text { Díaz Ordaz }\end{array}$ & $1964-1970$ & 8 & 19 & 19 & 0 \\
\hline $\begin{array}{c}\text { Luis } \\
\text { Echeverría } \\
\text { Álvarez }\end{array}$ & $1970-1976$ & 15 & 40 & 40 & 0 \\
\hline $\begin{array}{c}\text { José López } \\
\text { Portillo y } \\
\text { Pacheco }\end{array}$ & 1976-1982 & 14 & 34 & 34 & 0 \\
\hline $\begin{array}{l}\text { Miguel de } \\
\text { la Madrid } \\
\text { Hurtado }\end{array}$ & 1982-1988 & 21 & 66 & 62 & 4 \\
\hline $\begin{array}{c}\text { Carlos } \\
\text { Salinas de } \\
\text { Gortari } \\
\end{array}$ & 1988-1994 & 15 & 55 & 51 & 4 \\
\hline $\begin{array}{l}\text { Ernesto } \\
\text { Zedillo } \\
\text { Ponce de } \\
\text { León }\end{array}$ & $1994-2000$ & 18 & 77 & 76 & 1 \\
\hline $\begin{array}{c}\text { Vicente Fox } \\
\text { Quezada }\end{array}$ & $2000-2006$ & 17 & 31 & 30 & 1 \\
\hline $\begin{array}{c}\text { Felipe } \\
\text { Calderón } \\
\text { Hinojosa }\end{array}$ & 2006-2012 & 37 & 110 & 58 & 2 \\
\hline $\begin{array}{c}\text { Enrique } \\
\text { Peña Nieto }\end{array}$ & 2012- & 21 & 145 & & \\
\hline Total & & 227 & 697 & 489 & 13 \\
\hline
\end{tabular}


Esta obra forma parte del acervo de la Biblioteca Jurídica Virtual del Instituto de Investigaciones Jurídicas de la UNAM

Por períodos presidenciales, en promedio cada presidente promulgó 16.38 reformas. Este promedio creció notablemente a partir de 1982, durante la presidencia de Miguel de la Madrid Hurtado, que se cuadruplicó para alcanzar el 57.8, es decir casi 60 reformas por periodo presidencial ${ }^{7}$. Felipe Calderón Hinojosa es el presidente que más reformas ha aprobado, 110; se posiciona después Ernesto Zedillo Ponce de León con 77 reformas y continua Miguel de la Madrid Hurtado con 66 reformas $^{8}$. Durante la presidencia actual de Enrique Peña Nieto, se han efectuado 145 reformas Constitucionales.

Se encuentra así, que la Constitución mexicana promulgada en 1917 queda muy poco; el $80 \%$ de sus artículos originales han sido modificados o adicionados en un promedio de 5 veces cada uno. Se afirma, que "es una Constitución que ha sido modificada dos veces más que cualquier otra Constitución democrática del mundo(...) mientras que el promedio de reformas constitucionales en países democráticos estables es de 5.8 por año de 1993 al 2002, en México este promedio ha sido de 11.6"9.

La Constitución mexicana es la más antigua de las Constituciones en vigor de América Latina, es una Constitución casi centenaria, que ha presidido una evolución sociopolítica económica y cultural impresionante, aunque es la que ha tenido mayores reformas, "una vez cada dos meses, el doble que en Colombia, cuatro veces más que en Chile, y al menos ocho veces más que en Uruguay, Argentina y Bolivia"10.

Otra consideración que debe ser integrada a este análisis, para valorar las reformas, es el período en el que se decide realizarlas. Se identifica que el órgano legislativo decide aprobar mayor número de reformas al final de su período, lo que se demuestra con el hecho de que del total de reformas constitucionales, 114 de ellas han sido aprobadas en el mes de diciembre, y 96 en el mes de agosto, lo que representa que el 37\% de todas las reformas constitucionales han sido aprobadas en estos dos meses del año. Por el

7 Congreso de la Unión, México, http: //wrere.congreso.gob.mx; UNAM, Instituto de Investigaciones Jurídicas, México, http://wrere.juridicas.unam.mx/, consultado el 29 de enero de 2016. Para el conteo de las reformas se tomó en cuenta el artículo completo y no cuántos párrafos del mismo se alteraron en la misma ocasión.

8 Congreso de la Unión, http://wrere.congreso.gob.mx/, consultado el 29 de enero de 2016. Para el conteo de las reformas se tomó en cuenta el artículo completo y no cuántos párrafos del mismo se alteraron en la misma ocasión.

9 Lorenz, Astrid, "How to Measure Constitutional Rigidity. Four Concepts and Two Alternatives", Periódico Fournal of Theoretical Politics, Estados Unidos, 17.3, 2005, pp. 339-361.

10 Nolte, Detlef, Reformas constitucionales en América Latina, http://wrwroacademia. edu/7022280/Reformas_Constitucionales_en_Am\%C3\%A9rica_Latina, consultado el 4 de enero de 2016. 
Esta obra forma parte del acervo de la Biblioteca Jurídica Virtual del Instituto de Investigaciones Jurídicas de la UNAM

contrario, en mayo y enero casi no se observa reformas constitucionales, solo 8 veces en mayo y desde hacía 22 años no se había aprobado ninguna en enero, hasta la de este año 2016 la relativa a la Ciudad de México, con su definición como entidad federativa ${ }^{11}$. No obstante, debe ser considerado en esta observación, los ciclos de las sesiones ordinarias del Congreso de la Unión, que van de agosto a diciembre y de febrero a abril.

Las opiniones doctrinales respecto a las reformas constitucionales puede agruparse en tres corrientes, las que se categorizan como: gradualista, radical y ecléctica. La corriente gradualista propone que la Constitución se reforme cada vez que sea necesario; la corriente radical por su parte, postula que se convoque a un nuevo congreso constituyente y la posición ecléctica, que propone la necesidad de instrumentar una reforma constitucional de gran aliento, a partir de la condición previa de una revisión profunda con el propósito de distinguir aquellas reformas que fueron sólo programas de gobierno, de las que dieron lugar a instituciones de gran aliento al régimen Constitucional.

En la corriente gradualista puede ubicarse como uno de sus principales exponentes a Jesús Reyes Heroles, quien sostuvo que "la intolerancia sería el camino seguro para volver al México bronco y violento" afirmó que el "gradualismo", es un "método que nos ha permitido alcanzar metas firmes sin exponer al país a fuertes retrocesos por avances deslumbrantes" ${ }^{12}$. Con sustento en esta tesis impulsó la famosa reforma política de 1977. En esta misma corriente gradualista se ubica a Diego Valadés, quien explica que el procedimiento de las modificaciones progresivas tiene múltiples ventajas:

"Ninguna reforma es la última; toda reforma admite la prueba del ensayo y del error; quedan abiertas nuevas opciones; el tramo entre lo deseable y lo posible se acorta; mantienen su vigencia las saludables expectativas de mejoría, o por lo menos de cambios, se matiza el inmediatismo y se programan y encauzan los nuevos estilos. Todo eso se consigna como parte de lo positivo de las reformas sucesivas. Pero también hay desventajas; insatisfacción perenne; inestabilidad de las instituciones; percepción generalizada de indefinición y transitoriedad; rutinización del debate y agotamiento argumental, con el consiguiente riesgo de abandonar los términos aún de lo ya acordado"13.

11 Cámara de Diputados México, Reformas Constitucionales por Periodo Presidencial, http:// wrere.diputados.gob.mx/LeyesBiblio/ref/cpeum_per.htm, consultado el 29 de enero de 2016.

12 Reyes Heroles, Jesús, Discurso pronunciado en la ceremonia connmemorativa del 150 aniversario CL de la suscripción de la Constitución federal de 1824, en Discursos políticos, México, Comisión Nacional Editorial, 1975.

13 Valadés, Diego, Constitucionalismo y Reforma Constitucional en México, UNAM, Instituto de Investigaciones Jurídicas, Ed. Flores, 2004, p. 199. 
Esta obra forma parte del acervo de la Biblioteca Jurídica Virtual del Instituto de Investigaciones Jurídicas de la UNAM

La segunda corriente calificada como radical, postula que muchas de las reformas han tenido por objeto apoyar la realización de un programa de gobierno, y que cuando el gobierno en turno termina su encargo, la nueva normatividad pierde su interés aplicativo. Los partidarios de esta corriente proponen que la Constitución requiere de muchos cambios y muy profundos y que estos no pueden ser abordados a través del mecanismo previsto en el artículo 135, por lo que se requiere convocar a un nuevo congreso constituyente. Entre los principales expositores de esta corriente se encuentra Porfirio Muñoz Ledo, quién en el 2003 comentó con amplitud el resultado de un estudio del programa de las Naciones Unidas para el Desarrollo PNUD, sobre el desarrollo de las democracias en América Latina, entre cuyas conclusiones fundamentales figuraba el que "las autoridades públicas de la región habían perdido capacidad para conducir los procesos políticos y económicos e incluso para mantener su jurisdicción sobre el territorio"14. En esta misma corriente, Jaime Cárdenas sostiene que:

"La Constitución de 1917 fue impuesta, no fue nunca un producto de consenso entre las fuerzas políticas. Organizó el poder público a favor del ejecutivo... Muchos de sus derechos fundamentales carecen de garantías efectivas, principalmente en el caso de los Derechos Sociales. Las reglas constitucionales se instrumentalizaron a favor de un aparato o sistema de dominación política y hacia un modelo económico, nacionalista, sin apertura al exterior. No fue una constitución normativa, contuvo los programas políticos de los presidentes en turno, y en fin no ha sido una norma directamente aplicable ni ha prohijado un régimen democrático" 15 .

En la tercera corriente que puede calificarse como ecléctica, se agrupan destacados juristas entre los que se encuentran Jorge Carpizo, Héctor Fix Zamudio, Diego Valadés y Salvador Valencia Carmona, quienes con investigaciones profundas de décadas de estudio, han aportado importantes recomendaciones sobre este tema, de las que puede resumirse: El doctor Jorge Carpizo en múltiples trabajos sobre la reforma constitucional en México, su procedimiento y realidad, analiza el proceso de reformas a la Constitución, en los que afirma que "aun cuando el procedimiento de reformas establecido por la Constitución de 1917 es formalmente rígido, en la práctica ha

14 Muñoz Ledo, Porfirio, "Los dilemas de la reforma“, Periódico El Universal, 31 de enero de 2005.

15 Cárdenas Gracia, Jaime, “ ¿Qué es la Constitución mexicana, por qué y para que reformarla?", Furídica Anuario del departamento de derecho de la Universidad Iberoamericana, México, No. 32, año 2002, p. 231. 
Esta obra forma parte del acervo de la Biblioteca Jurídica Virtual del Instituto de Investigaciones Jurídicas de la UNAM

resultado bastante flexible"16. El doctor Héctor Fix Zamudio y Salvador Valencia Carmona sostienen que:

\begin{abstract}
"Resulta alarmante el número de reformas que se le han hecho a la Constitución, fenómeno que se ha visto agravado por el hecho de que algunas reformas han sido reiterativas, otras discordantes, y muchas han sido procesadas con escasa técnica legislativa, pudiéndose observar que el error más frecuente de este tipo radica en que a través de los procesos de reforma constitucional se le han incorporado a la Constitución preceptos excesivamente reglamentarios que no son sustantivamente de carácter constitucional... que por presiones coyunturales de diversos grupos sociales y políticos, se elevan a rango fundamental" 17 .
\end{abstract}

Para cerrar este apartado, cabe afirmar que muchas de las reformas instrumentadas por el Poder Constitucional Reformador, pueden ser evaluadas con signo positivo, un buen número de autores así lo consideran, entre ellos Héctor Fix-Zamudio y Salvador Valencia Carmona ${ }^{18}$, José Gamas Torru$\mathrm{Co}^{19}$ y Jorge Madrazo ${ }^{20}$. Algunas reformas a la Constitución le han proveído un nuevo aliento a las instituciones democráticas y republicanas y otras han dado lugar a que se integren constitucionalmente figuras jurídicas ideadas por el constitucionalismo, como la de algunos organismos constitucionales autónomos. Este accionar ciertamente ha enriquecido el andamiaje jurídico propio de un país que pretende erigirse como un Estado de Derecho, lo que ha permitido la adaptabilidad, gobernabilidad y estabilidad.

Se califican también reformas constitucionales de efectos negativos, que han afectado la función y eficacia jurídica y política de la Constitución. En-

16 Carpizo, Jorge, "La reforma constitucional en..., op. cit.

17 Fix Zamudio, Héctor y Valencia Carmona, Salvador, Derecho Constitucional Mexicano y comparado, México, Porrúa, 2013, pp. 122-124.

18 Carpizo, Jorge, "La reforma constitucional en...", cit., pp. 580-582. Fix-Zamudio, Héctor y Valencia Carmona, Salvador, op. cit., pp. 116 y 117, quienes escribieron que las reformas en principio han sido provechosas, han enriquecido el orden constitucional y lo han actualizado, aunque en múltiples ocasiones fueron innecesarias.

19 Gamas Torruco, José, Derecho constitucional mexicano, México, Porrúa-UNAM, Instituto de Investigaciones Jurídicas, 2001, pp. 583 y 584, quien opina que tan indiscutible es su abundancia y frecuencia "como la pertinencia de muchas de ellas dada la necesidad de asegurar normas exigidas por una evolución social particularmente dinámica”.

20 Madrazo, Jorge, Reflexiones constitucionales, México, Porrúa, 1994, pp. 190 y 191, explica que muchas de las reformas han respondido a la idea original de 1917 del ahora denominado Estado social de derecho y a las exigencias de dirección económica y social por construir y perfeccionar dicho Estado, aunque manifiesta su preocupación por el número creciente de reformas. 
Esta obra forma parte del acervo de la Biblioteca Jurídica Virtual del Instituto de Investigaciones Jurídicas de la UNAM

tre los autores de esta opinión se encuentran Felipe Tena Ramírez ${ }^{21}$, Ignacio Burgoa $^{22}$, Miguel Carbonell23 y José Barragán Barragán²4.

Otras reformas constitucionales se han calificado como ociosas, "ya que en ocasiones se ha puesto en movimiento el complicado procedimiento de reforma constitucional para sustituir un término cuyo significado ya había sido debidamente aclarado a través de la doctrina y/o la jurisprudencia"25. Manuel González Oropesa, citado por Javier Patiño Camarena, sostiene que "a distancia, nuestra Constitución luce como la vio Carranza en 1915, transformada, reformada, y cambiada, por lo que coincidiría con Palavichini que consideraba que la Constitución de 1857 era mejor cuando fue promulgada que con posterioridad, debido a lo mal intencionado de sus constantes reformas". ${ }^{26}$

El doctor Diego Valadés es uno de los tratadistas que más ha estudiado este tema, desde hace cuarenta años afirmó que "la mayoría de las reformas no contienen aspectos innovadores, que son los únicos que deben ser tomados en cuenta. Que los otros aspectos actualizadores, explicativos y correctivos se deberían lograr a través de leyes reglamentarias, orgánicas o sociales,

21 Tena Ramírez, Felipe, Derecho constitucional mexicano, México, Porrúa, 2010, pp. 61 y 62, sostiene que el actual procedimiento reformatorio propicia el número excesivo de modificaciones, creándose la proliferación de aquéllas, que por frecuentes y, a veces, desarticuladas, transformaron a la ley fundamental en un Código inestable.

22 Burgoa, Ignacio, Derecho constitucional mexicano, México, Porrúa, 2009, pp. 373 y 378 , reconoce que algunas reformas han sido necesarias, otras útiles y las demás incongruentes con los principios fundamentales de la ley suprema, que el Congreso las ha aprobado por obsecuencia y servilismo hacia su impulsor el presidente de la República; los legisladores han carecido de conciencia cívica, dignidad y patriotismo, al mismo tiempo que el artículo $135 \mathrm{c}$. no protege a la Constitución de caprichosas, irreflexivas y atentatorias alteraciones.

23 Carbonell, Miguel, La Constitución pendiente, Agenda mínima de reformas constitucionales, México, UNAM, Instituto de Investigaciones Jurídicas, 2004, p. 14, y Constitución, reforma constitucional y fuentes del Derecho en México, pp. 252 y 253, considera que la reforma constitucional ha introducido a la ley fundamental intereses coyunturales o la visión del presidente de la República sobre qué debe contener la Constitución, aunque admite que no siempre ha sido así, como fue el caso de las reformas de las décadas de 1940 y 1950 relacionadas con el desarrollo industrial.

24 Barragán Barragán, José, El poder revisor y el sentido originario de la Constitución, en varios autores, El significado actual de la Constitución, México, UNAM, Instituto de Investigaciones Jurídicas, 1998, p. 66, manifiesta que el órgano revisor de la Constitución ha cometido excesos, en virtud de que ha modificado materias que pertenecen a la forma de gobierno, materia que el pueblo se ha reservado a su favor.

25 Patiño Camarena, Javier, Constitucionalismo y Reforma Constitucional, México, UNAM, Instituto de Investigaciones Jurídicas, Ed. Flores, p. 191.

26 Ibidem, p. 201. 
Esta obra forma parte del acervo de la Biblioteca Jurídica Virtual del Instituto de Investigaciones Jurídicas de la UNAM

la costumbre o los principios generales del derecho internacional"27. Desde entonces propuso la iniciativa popular y el referendo para las reformas constitucionales. Diez años después el mismo autor afirmó que las sucesivas reformas constitucionales son el instrumento "para refrenar un tanto, o para encausar en lo posible, la acción de los gobernantes" ${ }^{28}$. Ahora el doctor Valadés, casi después de cuarenta años de la primera referencia citada, en una conferencia con los universitarios de Baja California, afirmó:

Trun="hemos hecho muchos cambios pero no hemos variado la estructura del poder, los cambios han sido para ser más complejo e inaccesible el texto constitucional, pero no para hacer más diáfano y más accesible el sistema constitucional en lo que respecta a la estructura del poder (...) todos estos problemas que se han venido acumulando en la Constitución están dando un claro déficit de ingobernabilidad en el país”29.

\section{PROGEDIMIENTO DE REFORMA GONSTITUCIONAL}

Para explicar el proceso de reforma constitucional se ha desarrollado la "teoría del cambio constitucional"; esta teoría aborda las vicisitudes y circunstancias de la Constitución durante su vigencia. El doctor Héctor Fix Zamudio integra en esta teoría lo que él llama "incidentes y accidentes" que puede sufrir la Constitución y que adjetivisa como "la reforma constitucional, mutación constitucional, suspensión, quebrantamiento y supresión de la Constitución" 30 .

Respecto al procedimiento de reforma, éste se determinó en la Constitución de 1917 en el artículo 135. El Diario de debates, reporta que en el Congreso Constituyente de la Ley Fundamental mexicana, este tema no suscitó discusión alguna, por lo que el Congreso se limitó a ratificar el sistema de reformas de la Constitución de 1857. En este sentido, en el artículo 135 constitucional aprobado en 1917 se reiteraron las bases para estructurar al Poder Constitucional Reformador a través de la actividad concertada del Con-

27 Valadés, Diego, Problemas de la reforma constitucional en el sistema mexicano, Los cambios constitucionales, México, UNAM, Instituto de Investigaciones Jurídicas, 1977, pp. 206 - 207.

28 Valadés, Diego, La Constitución reformada, UNAM, Instituto de Investigaciones Jurídicas, México, 1987, p. 19.

29 Valadés, Diego, Una nueva constitución o renovar la vigente, Conferencia, México, Periódico Z, 15-21 de marzo 2013.

30 Valencia Carmona, Salvador, Constitución y Reforma Constitucional en México, México, UNAM, Instituto de Investigaciones Jurídicas, 1998, p. 685. 
Esta obra forma parte del acervo de la Biblioteca Jurídica Virtual del Instituto de Investigaciones Jurídicas de la UNAM

greso de la Unión y de las Legislaturas de los Estados, con la siguiente redacción original:

Artículo 135. "La presente Constitución puede ser adicionada o reformada. Para que las adiciones o reformas lleguen a ser parte de la misma se requiere que el Congreso de la Unión, por el voto de las dos terceras partes de los individuos presentes, acuerde las reformas o adiciones, y que éstas sean aprobadas por la mayoría de las Legislaturas de los Estados. El Congreso de la Unión hará el cómputo de los votos de las legislaturas y la declaración de haber sido aprobadas las adiciones o reformas".

Este precepto constitucional permaneció con su texto original durante cerca de cinco décadas, y consecuentemente se estuvo aplicando el mismo procedimiento de reforma constitucional durante este periodo. Es hasta el año de 1966 que se reforma este artículo 135, con la adición de un segundo párrafo, para precisar en el mismo que, "el Congreso de la Unión o la Comisión Permanente en su caso, harán el cómputo de los votos de la Legislaturas locales y la declaración de haber sido aprobadas las adiciones o reformas".

La exigencia de que las reformas o adiciones a la Constitución deben ser aprobadas, en primer término, por el Congreso de la Unión, y con posterioridad por las Legislaturas de los estados, se formuló por primera vez en la Constitución de 1857. El requisito de que las reformas o adiciones requieran ser aprobadas tanto por el Congreso de la Unión, como por la mayoría de las Legislaturas de los Estados, responde al propósito de preservar el "pacto federal" y garantizar el que cuando se modifiquen los términos de la Constitución, se decida tanto por la federación, como por las entidades federativas, las que tienen la potestad de vigilar que prevalezca el reparto de competencias. A este respecto, el doctor Jorge Carpizo explica que el artículo 135 Constitucional:

"está estrechamente relacionado con el sistema federal y es una de sus defensas y protecciones en un doble sentido. Por una parte, las entidades federativas al intervenir en el procedimiento están garantizando su existencia y la del propio sistema federal (...) por otra, es una garantía de que la federación no va ver mermada sus competencias a grado tal que se afecte la unidad del estado y su correcto funcionamiento" 31 .

31 Carpizo, Jorge, Estudios constitucionales, México, Porrúa-UNAM, Instituto de investigaciones jurídicas, 2003, p. 576. 
Esta obra forma parte del acervo de la Biblioteca Jurídica Virtual del Instituto de Investigaciones Jurídicas de la UNAM

Cabe destacar, que la exigencia de la participación en toda reforma constitucional de los órganos legislativos federal y locales, obedece también a que en todo estado social y democrático de derecho, en materia de reformas a la Ley Fundamental, se requiere idear un mecanismo que trascienda a los poderes constituidos, pues estos por su propia naturaleza, no pueden alterar en ningún caso y por ningún motivo, los términos de su representación, ni a la Ley que los crea y organiza. Es decir, el órgano autorizado para reformar la Ley fundamental no está conformado de la legislatura federal y de las legislaturas de las entidades federativas, se trata de un órgano que responde a naturaleza diferente, porque su obra se convierte en parte de la Constitución, con la misma jerarquía a la que decidió el poder constituyente. En México, como en casi todas las Constituciones del mundo, este órgano no tiene un nombre en la Constitución, sino que es la doctrina o la jurisprudencia las que se lo han asignado con los calificativos de "Poder reformador", "Poder modificador", "Poder constituyente instituído". El maestro Felipe Tena Ramírez lo denomina como "Poder constituyente permanente" en consideración a que su función es constituyente porque participa de la función soberana al adicionar o reformar la obra del poder originario o constituyente" ${ }^{32}$. El doctor Jorge Carpizo se adhiere a la denominación "órgano revisor de la Constitución" porque "no es un poder constituyente sino constituido en la Constitución, en tal razón posee las características y límites de cualquier poder constituido"33.

Este procedimiento de reforma constitucional establecido en el artículo 135 califica a nuestra Constitución como rígida, al contrario de las flexibles. Es decir, es un procedimiento rígido en cuanto a que es más exigente o complicado para reformar la norma constitucional, que el que se exige para reformar la norma ordinaria. En esta forma se preserva la supremacía constitucional y la estabilidad que toda Ley fundamental debe poseer, para dar respuesta a la necesaria adecuación de la realidad cambiante.

Respecto a quienes tienen facultad de iniciativa para reformar la Constitución, el artículo 135 constitucional no lo determina, por lo que al no establecerse una regla específica para este fin habrá que remitirse a la regla general establecida en el artículo 71 de la Ley fundamental, que a la letra expresa: El derecho de iniciar leyes o decretos compete:

I. Al presidente de la república;

II. A los diputados y senadores al congreso de la unión; (modificada por la reimpresión de la Constitución, publicada en el diario oficial de la federación el 6 de octubre de 1986).

\footnotetext{
32 Tena Ramírez, Felipe, op. cit., p. 46.

33 Carpizo, Jorge, Estudios constitucionales..., cit., p. 578.
} 
Esta obra forma parte del acervo de la Biblioteca Jurídica Virtual del Instituto de Investigaciones Jurídicas de la UNAM

III. A las legislaturas de los estados; y

IV. A los ciudadanos en un número equivalente, por lo menos, al cero punto treceporcientodelalistanominaldeelectores, enlostérminosqueseñalenlasleyes. (Adicionado mediante decreto publicado en el diario oficial de la federación el 9 de agosto de 2012).

La Ley del congreso determinara el trámite que deba darse a las iniciativas. (Reformado mediante decreto publicado en el diario oficial de la federación el 9 de agosto de 2012).

Para la tramitación de la iniciativa de reforma, debe seguirse el procedimiento del artículo 72 constitucional, es decir se examina y discute la iniciativa en el Congreso de la Unión, participando cada Cámara en forma separada y sucesiva.

Una pregunta que se plantea al procedimiento es ¿con qué mayoría deben las entidades federativas aprobar el proyecto que envía el Congreso de la Unión?, el artículo 135 constitucional no exige una mayoría determinada a las legislaturas locales, por lo que deberá estarse a lo que las propias Constituciones locales determinen.

El Doctor Héctor Fix-Zamudio ha propuesto, como solución a los problemas de la reforma Constitucional "profusa y desmedida", integrar a nivel constitucional ordenamientos "intermedios" entre las normas fundamentales y las disposiciones que conforman a la legislación ordinaria. Que a través de este tipo de ordenamientos se canalicen muchas de las reformas de carácter reglamentario, que actualmente se le hacen a la Constitución, que alargan su texto y provocan inestabilidad de la misma, ya que por los detalles que regulan, propician la necesidad de reformarlas de manera constante. "Para hacer uso de este tipo de leyes se requiere establecer constitucionalmente el procedimiento específico que se deberá observar en su aprobación, modificación o derogación, procedimiento que deberá ser de mayor dificultad que el que se exige para reformar a las leyes ordinarias, pero con menores exigencias que las exigidas para reformar las normas constitucionales"34.

Por su parte, Jorge Madrazo propone que la Constitución mexicana puede ser modificada siguiendo el criterio del sistema venezolano, o conforme a dos procedimientos diferentes: uno como "enmienda constitucional" y otro como "reforma constitucional". La enmienda constitucional se puede utilizar para modificar los preceptos constitucionales que son de naturaleza reglamentaria, procedimental o de orden secundario. La reforma Constitu-

34 Fix Zamudio, Héctor y Valencia Carmona, Salvador, op. cit., p. 127. 
Esta obra forma parte del acervo de la Biblioteca Jurídica Virtual del Instituto de Investigaciones Jurídicas de la UNAM

cional se reservaría para modificar los principios verdaderamente substanciales de la Constitucion ${ }^{35}$.

El doctor Carpizo, en diversos estudios expuso con énfasis que, "no es deseable ni conveniente que continúe el torrente de reformas constitucionales que se han observado los últimos años" y con el objetivo de acabar con esta práctica, plantea tres propuestas: 1. La introducción de verdaderas leyes constitucionales orgánicas; 2. Una revisión general de carácter gramatical y técnico al texto constitucional; 3 . La introducción de la iniciativa popular y el referendo al procedimiento de la reforma constitucional ${ }^{36}$.

En un estudio colaborativo del Instituto de Investigaciones Jurídicas de la UNAM, coordinado por los doctores Héctor Fix-Fierro y Diego Valadés, con la participación de los investigadores Daniel Barceló, Eduardo Ferrer Mac-Gregor, Pedro Salazar Ugarte y José María de la Serna Garza, se plantea una propuesta muy acabada y concreta para reordenar primero, y consolidar después el texto vigente de la Constitución de 1917, con la explicación de los criterios y pasos esenciales, a través de un texto comparativo ${ }^{37}$. En este estudio se concluye que "el texto que resulte del ejercicio de reordenación y consolidación que se propone será la misma Constitución vigente, pues no se alteran las decisiones jurídicas y políticas que contiene, aunque puedan considerarse inconvenientes o erróneas, ni se introducen cambios que podrían resultar necesarios o favorables, sino que solamente se revisa y optimiza el texto vigente del momento" ${ }^{* 38}$.

En este mismo estudio para la reordenación y consolidación del texto constitucional, en el apartado IV de criterios y metodología se propone también, " respetar el número total de artículos del texto (136), sin agregar ni disminuirlo, bajo la convicción de que es posible redistribuir todas las materias reguladas, de manera más equilibrada, en el articulado existente... resulta convincente respetar la ubicación actual de los artículos emblemáticos de la Constitución, aunque pudiera no ser la óptima desde el punto de vista técnico ${ }^{* 39}$. Los demás artículos se explica que pueden ser objeto de reubicación y que los cambios de ubicación son relativamente menores, por lo que se respeta mayormente la colocación actual de la mayoría de ellos.

35 Madrazo, Jorge, op. cit., p. 63.

36 Patiño Camarena, Javier, op cit., p. 208.

37 Fix-Fierro, Héctor y Valadés, Diego (coords.), Constitución Política de los Estados Unidos Mexicanos. Texto reordenado y consolidado. Anteproyecto, México, UNAM, Instituto de Investigaciones Jurídicas, http://www.juridicas.unam.mx/novedades/estudio_ldc.pdf, consultado el 1 marzo de 2016.

38 Ibidem, p. 14.

39 Idem. 
Esta obra forma parte del acervo de la Biblioteca Jurídica Virtual del Instituto de Investigaciones Jurídicas de la UNAM

Continúa la investigación referenciada en el mismo apartado IV con el punto 2, en el que se explica que, "la reordenación implica reubicar las disposiciones constitucionales en el artículo, apartado, fracción o párrafo que resulte más conveniente desde el punto de vista sistemático o técnico, sin alterar su redacción salvo para corregir errores evidentes" ${ }^{*}$. En el punto 3 sobre la consolidación, se explican los criterios para: "mejorar la puntuación y la redacción; en algunos casos se sintetiza el contenido, suprimiéndose redundancias e inconsistencias; se articula la redacción de los párrafos reordenados; se mejora la presentación sistemática, en apartados, fracciones e incisos; y, finalmente, se traslada el contenido de las partes que se han considerado -reglamentarias- a la Ley de Desarrollo Constitucional”" ${ }^{2}$.

En adhesión con la investigación comentada, se coincide con la propuesta de reordenación y consolidación del texto constitucional que plantea el grupo de investigadores del Instituto de Investigaciones Jurídicas de la UNAM, así como la medida "concomitante y necesaria" de una Ley de Desarrollo Constitucional.

\section{CONSIDERACIONES FINALES}

- La Constitución es un ente vivo, en proceso incesante de transformación, es la suprema voluntad de un pueblo sobre sí mismo, para darse una organización política y un sistema jurídico, en cuya manifestación se declaran y establecen los principios jurídicos y políticos que rigen la vida de una nación.

Las Constituciones aspiran a ser democráticas, este principio es una verdad indiscutible desde que, como bien lo dice el doctor Héctor Fix Zamudio "se impuso la tesis de la soberanía del pueblo"42. Es el pueblo, en efecto quien en el ámbito de su soberanía, asume la facultad de expedir su propia Constitución. Este dogma de la filosofía jurídica-política, otorga el reconocimiento al pueblo, como autoridad suprema de la vida de una nación.

- Por su naturaleza, la Constitución es una obra perdurable. El concepto de Constitución tiene implícita la idea de estabilidad, raigambre, permanencia, consistencia, firmeza, seguridad, entre otros

\footnotetext{
40 Idem.

41 Ibidem, p. 15.

42 Fix Zamudio, Héctor y Valencia Carmona Salvador, op. cit., p. 125.
} 
Esta obra forma parte del acervo de la Biblioteca Jurídica Virtual del Instituto de Investigaciones Jurídicas de la UNAM

adjetivos necesarios para integrar este concepto, como elemento definidor. Incluso, se ha ido al extremo de Constituciones, que han omitido cláusulas de revisión, o que hicieron imposible cualquier modificación. Frente a este criterio, se postuló la idea de la adaptabilidad, de la dinámica constitucional como el derecho que tiene la sociedad de revisar, de examinar, de reformar y en última instancia de cambiar su Constitución. En estos dos extremos se mueve el péndulo de la estática y la dinámica constitucional, márgenes en los que debe buscarse el equilibrio, dicen algunos, el justo medio aristotélico.

- La Constitución por su naturaleza democrática debe generarse en procedimientos que permitan intervenir al pueblo, titular del poder constituyente, esta tarea se le encarga al órgano constituyente, integrado por representantes populares encargados de crear la Constitución. No obstante, este órgano constituyente no siempre es democrático, en la práctica hay Constituciones a voluntad del hombre fuerte en turno, o con aplicación de procedimientos autocráticos.

- En un Estado de Derecho, la reforma constitucional es una institución inevitable y necesaria para mantener acorde el orden normativo a la realidad social imperante. Esta institución es entendida como la actividad normativa que cambia el texto fundamental, mediante el cual se modifica, suprime o sustituye un precepto por otro o se revisa el orden constitucional en general. En derecho comparado y en la tendencia general de las Constituciones del mundo, una característica es su rigidez, toda vez que de la solemnidad y procedimiento especial que adopte el texto fundamental para revisarse, depende que se generen garantías de fortaleza y estabilidad para el derecho y el régimen jurídico.

- Las Constituciones mexicanas han instituido sistemas diferentes de reforma. En la Constitución de 1917 se determinó en el texto constitucional en el artículo 135. El Diario de debates reporta, que en el Congreso Constituyente de la Ley Fundamental mexicana, este tema no suscitó discusión alguna, por lo que el Congreso se limitó a ratificar el sistema de reformas de la Constitución de 1857. En este sentido, en el artículo 135 constitucional aprobado en 1917 se reiteraron las bases para estructurar al Poder Constitucional Reformador a través de la actividad concertada del Congreso de la Unión y de las Legislaturas de los Estados. 
Esta obra forma parte del acervo de la Biblioteca Jurídica Virtual del Instituto de Investigaciones Jurídicas de la UNAM

- El balance que se formula del número y circunstancias en que se realizan las reformas constitucionales, desde una perspectiva cuantitativa se puede afirmar, que las reformas han sido muy abundantes, con un número impresionante y tal vez demasiadas. Y desde una perspectiva cualitativa, intentando la mayor objetividad encontramos de todo, positivas, negativas y algunas superfluas e innecesarias.

- Se hace necesario, por lo tanto, realizar una reforma constitucional, a la que la doctrina llama o califica como "de gran aliento", que exige: una profunda revisión crítica, sistemática por "bloques constitucionales" 43 , a la que la doctrina también llama "bloques de constitucionalidad" 44 , que permitan el mayor conocimiento y profundidad, de los diferentes elementos o piezas del conjunto que conforman una unidad o subsistema constitucional. Se debe también en este proceso, distinguir en cada uno de los subsistemas lo esencial de lo reglamentario, para conservar los principios fundamentales en la Constitución y pasar a través de una ley que algunos proponen llamarse "leyes constitucionales u orgánicas" 45 , "leyes orgánicas"46, "leyes constitucionales" 47 o "leyes de desarrollo constitucional" 48 y darle racionalidad a los aspectos reglamentarios, para que la sociedad mexicana tenga la posibilidad de entender su Constitución.

- La existencia de una Ley de Desarrollo Constitucional, inhibiría la necesidad de estar reformando la Constitución con frecuencia, en aspectos reglamentarios o procedimentales, que no deben ser parte de su texto. En esta forma, la reforma constitucional deja de ser un ejercicio constante e innecesario.

43 Bidart Campos, German, El derecho de la Constitución su fuerza normativa, México, Ed. UNAM, 2003, p. 269.

44 Favoreu, Louis, El bloque de la constitucionalidad, simposio franco-español de Derecho Constitucional, Universidad de Sevilla, Guadernos civitas, 1991, p. 22.

45 Carpizo, Jorge, La reforma constitucional en México..., cit., p. 587 y 588.

46 Fix-Zamudio, Héctor y Valencia Carmona, Salvador, op. cit., p. 126.

47 Patiño Camarena, Javier, op. cit., p. 218.

48 Fix-Fierro, Héctor y Valadés, Diego (coords.), op. cit. 
Esta obra forma parte del acervo de la Biblioteca Jurídica Virtual del Instituto de Investigaciones Jurídicas de la UNAM

\section{BIBLIOGRAFÍA}

BARRAGÁn BARRAGÁn, José, El poder revisor y el sentido originario de la Constitución, en varios autores, El significado actual de la Constitución, México, UNAM, Instituto de Investigaciones Jurídicas, 1998

Bidart Gampos, German, El derecho de la Constitución su fuerza normativa, México, Ed. UNAM, 2003.

CÁMARA DE DiPuTAdos, México, http://wrere.diputados.gob.mx/LeyesBiblio/ref/ cpeum_per.htm, consultado el 29 de enero de 2016.

putados.gob.mx/LeyesBiblio/ref/cpeum_crono.htm, consultado el 29 de enero de 2016.

CÁmaRa De DiPUtados, Reformas Constitucionales por Periodo Presidencial, México, http://wwre.diputados.gob.mx/LeyesBiblio/ref/cpeum_per.htm, consultado el 29 de enero de 2016.

Carbonell, Miguel, Constitución, reforma constitucional y fuentes del Derecho en México, México, UNAM, Instituto de Investigaciones Jurídicas, 2004.

- La Constitución pendiente, Agenda minima de reformas constitucionales, México, UNAM, Instituto de Investigaciones Jurídicas, 2004.

CÁRdenas Gracia, Jaime, “ ¿Qué es la Constitución mexicana, por qué y para reformarla?", Furídica Anuario del departamento de derecho de la Universidad Iberoamericana, México, No. 32, año 2002.

CARPIZO, Jorge, Estudios constitucionales, México, Porrúa- UNAM, Instituto de investigaciones jurídicas, 2003.

-, "La reforma constitucional en México: procedimiento y realidad", Revista Mexicana de Derecho Comparado, año XLIV, núm. 13, mayo - agosto del 2011.

CONGReso DE LA UNIÓN, México, http://wrerr.congreso.gob.mx/, consultado el 29 de enero de 2016.

FAVOREU, Louis, El bloque de la constitucionalidad, simposio franco-español de Derecho Constitucional, Universidad de Sevilla, Guadernos civitas, 1991.

FiX-Fierro, Héctor y Valadés, Diego (coords.), Constitución Política de los Estados Unidos Mexicanos. Texto reordenado y consolidado. Anteproyecto, México, UNAM, Instituto de Investigaciones Jurídicas, http://wrere.juridicas.unam. $m x /$ novedades/estudio_ldc.pdf, consultado el 1 marzo de 2016.

Fix-Zamudio, Héctor y Valencia Carmona, Salvador, Derecho Constitucional Mexicano y comparado, México, Porrúa, 2013. 
Esta obra forma parte del acervo de la Biblioteca Jurídica Virtual del Instituto de Investigaciones Jurídicas de la UNAM

Gamas Torruco, José, Derecho constitucional mexicano, México, PorrúaUNAM, Instituto de Investigaciones Jurídicas, 2001.

Lorenz, Astrid, "How to Measure Constitutional Rigidity. Four Concepts and Two Alternatives", Periódico Fournal of Theoretical Politics, Estados Unidos, 17.3, 2005.

MADRAZO, Jorge, Reflexiones constitucionales, México, Porrúa, 1994.

Muñoz Ledo, Porfirio, "Los dilemas de la reforma", Periódico El Universal, 31 de enero de 2005.

NolTe, Detlef, Reformas constitucionales en América Latina, http://wrere.academia. edu/7022280/Reformas_Constitucionales_en_Am\%C3\%A9rica_Latina, consultado el 4 de enero de 2016.

Patiño Camarena, Javier, Constitucionalismo y Reforma Constitucional en México, UNAM, Instituto de Investigaciones Jurídicas, Ed. Flores, 2004.

Reyes Heroles, Jesús, Discurso pronunciado en la ceremonia connmemorativa del 150 aniversario CL de la suscripción de la Constitución federal de 1824, en Discursos políticos, México, Comisión Nacional Editorial, 1975.

Salazar, Pedro, "Las demasiadas autonomías", Revista Nexos, México, Número 434, 2014.

Suprema Corte de Justiaia de la Nación, Constitución Política de los Estados Unidos Mexicanos, que reforma la de 5 de febrero de 1857 (compilación cronológica de sus modificaciones), México, https://wwre.scjn.gob.mx/normativa/analisis_reformas/paginas/titulo_primero.aspx, consultado el 29 de enero de 2016.

Tena Ramírez, Felipe, Derecho constitucional mexicano, México, Porrúa, 2010.

VALADÉS, Diego, Constitucionalismo y Reforma Constitucional en México, UNAM Instituto de Investigaciones Jurídicas, Ed. Flores, 2004.

, La Constitución reformada, UNAM, Instituto de Investigaciones Jurídicas, México, 1987.

, Las funciones de la reforma Constitucional, en Valadés, Diego, y Carbonell, Miguel, (coords), El proceso constituyente mexicano. A 150 años de la constitución de 1857 y 90 de la constitución de 1917, México, UNAM, Instituto de Investigaciones Jurídicas, 2007.

, Problemas de la reforma constitucional en el sistema mexicano, Los cambios constitucionales, México, UNAM, Instituto de Investigaciones Jurídicas, 1977.

, Una nueva constitución o renovar la vigente, Conferencia, Tijuana, Baja California, México, Periódico Z, 15-21 de marzo 2013.

Valencia Carmona, Salvador, Constitución y Reforma Constitucional en México, México, UNAM, Instituto de Investigaciones Jurídicas, 1998. 
Esta obra forma parte del acervo de la Biblioteca Jurídica Virtual del Instituto de Investigaciones Jurídicas de la UNAM

\title{
¿REFORMA, MUTACIÓN O ENMIENDA CONSTITUCIONAL?
}

\author{
José F. Palomino Manchego*
}

"Una reforma de la Constitución debe exigir un prius inexcusable de un consenso político equiparable al alcanzado en el momento constituyente".

Francisco FERNÁNDEZ SEGADO

SUMARIO: I. Planteamiento del problema: planteamiento del problema: ${ }_{i}$ reforma total o revisión total de la constitucion?. II. El poder constituyente como presupuesto inicial. III. Segundo presupuesto: la fuerza normativa de la constitucion. IV. Constitución en sentido material y constitución en sentido formal. V. La posicion de Domingo García Belaunde. VI. Conclusiones provisionales. VII. Apéndice. La reciente reforma constitucional en cuba del 26 de junio de 2002 (un caso singular).

\section{Planteamiento Del PROBlema: ¿REFORMA TOTAL O REVISIÓN TOTAL DE LA CONSTITUCIÓN?}

Ante todo, es útil indicar que la actual situación política se ve plenamente identificada con el tema de la reforma constitucional. El mejor ejemplo que

* Profesor de Derecho Constitucional y Teoría del Derecho de las universidades Nacional Mayor de San Marcos, de Lima y de la Academia de la Magistratura. Profesor de Filosofía del Derecho de la Universidad Femenina del Sagrado Corazón. Secretario Ejecutivo del Instituto Iberoamericano de Derecho Constitucional (Sección Peruana). Diplomado en Defensa Nacional por el Ministerio de Defensa de España.

Como en anteriores ocasiones, tengo un deber de gratitud hacia Domingo García Belaunde, Javier Tajadura Tejada, Luis Sáenz Dávalos y Edgar Carpio Marcos, por sus valiosas observaciones, sugerencias y material bibliográfico que me han proporcionado en su día. 
Esta obra forma parte del acervo de la Biblioteca Jurídica Virtual del Instituto de Investigaciones Jurídicas de la UNAM

se puede traer a colación es la Ley $\mathrm{N}^{\mathrm{0}} 27600$ (El Peruano, 16 de diciembre de 2001). Su artículo 2 apunta literalmente lo siguiente:

“...

La Comisión de Constitución, Reglamento y Acusaciones constitucionales, propondrá un proyecto de reforma total de la Constitución, tomando en cuenta la Constitución histórica del Perú, y en particular el texto de la Constitución de 1979. Tras su aprobación por el Congreso será sometido a referéndum. De ser aprobada, quedará abrogada la Constitución de 1993...”. ${ }^{1}$

De otro lado, la opinión pública (sociedad civil), cuyo poder de decisión es cada día más notorio, también ha dejado sentir su voz a tenor de los siguientes comentarios:

¿Cómo debe hacerse la reforma constitucional?²

Algunos extractos de nuestro foro:

— "Que no cambien la Constitución actual".

- "Debemos tender hacia una carta más liberal".

- "Debería volverse a la Constitución de 1979 y a partir de ella hacer la reforma".

— “Que siga como está. ¿Para qué cambiarla?”.

1 Para el caso peruano hasta la Constitución de 1979, vid. Domingo García Belaunde: “¿Reforma constitucional?”, en AA.VV. La Constitución diez años después, Constitución y Sociedad-Fundación Friedrich Naumann, Lima, 1989, págs. 337-358. Del mismo autor, teniendo al frente la situación actual, vid. "Sobre la reforma constitucional y sus problemas", en AA.VV. Propuestas de reforma constitucional, Universidad Católica de Santa María, Arequipa, 2002, págs. 15-34. Ahora, vuelto a publicarse debidamente corregido en la presente Revista Aequum et Bonum. Además, vid. Humberto Henríquez Franco: Naturaleza y técnicas de la reforma constitucional, tesis para optar el grado de magíster en Derecho con mención en Derecho Constitucional, Pontificia Universidad Católica del Perú, Lima, 1999; y Alberto Villacorta Michelena: Los límites de la reforma constitucional, Editorial Grijley, Lima, 2003. Antecede Prólogo de Javier Valle-Riestra.

2 Las opiniones se han tomado de "El Comercio", 4 de enero de 2002. Acerca de la reforma constitucional me he ocupado también en el Prólogo al libro de Gerardo Eto Cruz: Estudios de Derecho Constitucional, Universidad Nacional de Trujillo-Biblioteca Peruana de Derecho Constitucional, Trujillo, 2002, págs. I-XXIV. De igual forma, se ha publicado como artículo con el siguiente título: "Gerardo Eto Cruz y el Derecho Constitucional (Algunas notas a propósito de su reciente libro)”, en la Revista Jurídica del Perú, Año LII, n 31, febrero, Trujillo, 2002, págs. 143-156. Ahí pongo de relieve los importantes aportes de Peter Häberle en lo que concierne al "poder constituyente del pueblo" y al amplio espectro de posibles soluciones político-constitucionales. 
Esta obra forma parte del acervo de la Biblioteca Jurídica Virtual del Instituto de Investigaciones Jurídicas de la UNAM

- "Tiene que hacerse de modo ordenado, tomando como base la actual Constitución y, a partir de ella, promover un debate sobre los puntos fundamentales".

— "Bajo los mismos criterios que se siguió en 1993 para que el país progrese, y no se quede estancado como en 1979".

- "Antes que nada el Gobierno y los partidos tienen que ponerse de acuerdo sobre una agenda básica de reforma. ¿Qué país queremos para nuestros hijos y qué ámbitos debemos atender prioritariamente?".

— "La reforma constitucional que se piensa hacer en el Congreso debe incluir la prohibición a perpetuidad de la reelección presidencial".

- "Debe hacerse sin alterar la estabilidad nacional ni espantar las inversiones".

— "No debe incluir la obligatoriedad del sufragio. Eso debe ser parte de la democracia".

- "Debe considerar el problema social, respetar los principios constitucionales y los derechos de la persona y la sociedad. Debe imponer severas sanciones a los presidentes, ministros y congresistas que delincan y se burlen de la voluntad popular".

- "Tiene que haber un Congreso Constituyente elegido por el pueblo".

- "La reforma debe realizarse bajo los conceptos de representatividad, para lo cual debe perfeccionarse los mecanismos de participación popular".

De lo expuesto se desprende que las opiniones van y vienen sin medir las consecuencias que acarrea una reforma de la Constitución mediante el proceso constituyente (Verfassunggebung). En las páginas que siguen veremos algunos aspectos relacionados con el tema, básicamente pensando en la dogmática o teoría constitucional que es, sin duda alguna, el mejor recetario y soporte para desarrollar una verdadera reforma constitucional, y su diferencia con la mutación y la enmienda constitucional. ${ }^{3}$ Así, la Constitución como norma mantiene la supremacía del ordenamiento jurídico, es decir,

3 Según el Diccionario de la Lengua Española, 22"ava . edición, Madrid, 2001, el vocablo "Reforma" equivale a acción y efecto de reformar o reformarse. "Reformar" significa volver a formar, rehacer, modificar algo, por lo general con la intención de mejorarlo. Mientras que "Mutación" significa acción y efecto de mudar o mudarse. Finalmente, "Enmienda" equivale a acción y efecto de enmendar, propuesta de variante, adición o reemplazo de un proyecto, dictamen, o informe o documento análogo. 
Esta obra forma parte del acervo de la Biblioteca Jurídica Virtual del Instituto de Investigaciones Jurídicas de la UNAM

sobre el resto de las fuentes del Derecho ${ }^{4}$ o de las normas infraconstitucionales. En esa línea de principio, técnicamente la supremacía de la Constitución se complementa con el instituto de la rigidez constitucional ${ }^{5}$ que supone que la Constitución establece sus propios procedimientos de reforma, diferenciándose así de las fuentes legales e impidiendo que la modificación de sus preceptos pueda ser llevada a cabo por el legislador. Es más, la Constitución se agota en el acto constituyente. ${ }^{6} \mathrm{~A}$ tenor de tales ideas podemos plantear la interrogante: ¿¿reforma? o ¿revisión? total de la Constitución.

De igual manera, tema político y de viva actualidad es el que ahora nos proponemos desarrollar: la reforma constitucional. En fecha reciente mucho se ha dicho y poco se ha comprendido sobre la materia, en especial por los operadores políticos. En tal sentido, conviene decir algo al respecto como una contribución al debate alturado y académico, y que sirva como material de trabajo, al igual que otros ensayos que vienen per se aportando lo suyo. Por consiguiente, lo cierto es que la reforma constitucional es actualmente un problema político, pero que merece indudablemente desde sus raíces una solución jurídica. ${ }^{7}$

Como anota Balaguer Callejón, con evidente acierto: "Sobre la reforma constitucional confluyen las tensiones más intensas del sistema constitucional. Esta acumulación de tensiones es lógica si se tiene en cuenta que la reforma no es solo un mecanismo técnico de modificación de la Constitución sino también la vía por la que el poder constituyente se integra en el orden constitucional. Un poder constituyente sometido a normas justamente por

4 Sobre este punto vid. el libro de Miguel Carbonell de tan superlativo mérito: Constitución, reforma constitucional y fuentes del Derecho en México, 2a . edición, Editorial Porrúa-UNAM, México, D.F., 1999.

$5 \mathrm{Al}$ respecto, vid. Pablo Lucas Verdú: "Naturaleza, contenido y consecuencias de la rigidez constitucional", en Homenaje a D. Nicolás Pérez Serrano, t. II, Instituto Editorial Reus, Madrid, 1959, págs. 107-132. Su lectura me ha aclarado muchas dudas. Más de pronto, vid. Alessandro Pace y Joaquín Varela: La rigidez de las constituciones escritas, Centro de Estudios Constitucionales, Madrid, 1995.

6 Cfr. Francisco Balaguer Callejón (Coordinador): Derecho Constitucional, vol. I, Editorial Tecnos, S.A., Madrid, 1999, pág. 109.

7 Inspirado en la doctrina italiana nos dice Carlos de Cabo Martín que: "La relación de Tiempo y el Derecho es una relación compleja que trata en su globalidad de responder a la contradicción que en todos los ámbitos plantea el transcurso del tiempo como es el de la permanencia-cambio y que en el Derecho suscita las cuestiones de vigencia, eficacia y seguridad jurídicas. Y es también y sobre todo una relación compleja porque es de doble dirección en cuanto comprende la del Tiempo en el Derecho y la del Derecho en el Tiempo". Todas estas singularidades tienen su proyección específica en la reforma constitucional. Cffr. su libro La reforma constitucional, Editorial Trotta, S.A., Madrid, 2003. 
Esta obra forma parte del acervo de la Biblioteca Jurídica Virtual del Instituto de Investigaciones Jurídicas de la UNAM

medio de la regulación constitucional de la reforma, pero que no deja por ello de evocar a los agentes políticos con capacidad para reestructurar el marco de convivencia social que la Constitución supone. De ese modo, la reforma constitucional adquiere una doble naturaleza por cuanto expresa y limita a la vez al poder constituyente". ${ }^{8}$

\section{EL PODER CONSTITUYENTE COMO PRESUPUESTO INICIAL}

Discurramos brevemente sobre el poder constituyente. Lo primero que hay que analizar es ¿Cuál es el significado y alcance del poder constituyente (pouvoir constituens)? ¿Es lo mismo que el poder político? ¿Se le puede encuadrar y definir como poder jurídico y limitado? Pérez Serrano con su maestría habitual nos decía lo siguiente: "En realidad, si atendemos a su pura y esencial significación, habremos de entender que es 'constituyente' el poder que 'constituye'. De lo cual cabe derivar dos consecuencias: $1^{\mathrm{a}}$. Que ha existido poder constituyente en todo tiempo, pues siempre ha habido en la comunidad política un poder que la organice, le dé estructura, le imprima su peculiar fisonomía específica dentro del género Estado y 2a . Que sólo merece el nombre de 'constituyente' el poder que verdadera y cumplidamente realiza esta misión, aunque no esté jurídicamente prefigurado para acometerla y, por el contrario, no tiene derecho al título el poder que por más que este calificativo se designe fracasa en su empeño de constituir". ${ }^{9}$

8 Cfr. el trabajo del catedrático granadino Francisco Balaguer Callejón: "El status constitucional de la reforma y la fragmentación del poder constituyente" en AA.VV. La democracia constitucional. Estudios en homenaje al Profesor Francisco Rubio Llorente, vol. I, Congreso de los Diputados, Tribunal Constitucional, Universidad Complutense de Madrid, Fundación Ortega y Gasset, Centro de Estudios Políticos y Constitucionales, Madrid, 2002, pág. 122.

9 Cfr. Nicolás Pérez Serrano: El poder constituyente, Real Academia de Ciencias Morales y Políticas, Madrid, 1947, pág.11. En la doctrina nacional recientemente ha visto la luz el ensayo de Aníbal Torres Vásquez: "El poder constituyente", en la Revista del Foro, Año MMIII, no 1, junio, Lima, 2003, págs. 9-18. Apoyado en los clásicos, según el autor, con quien guardamos un respeto mutuo, el poder constituyente originario comprende la potestad de dictaminar la primera Constitución o de reformar o de sustituir la existente por otra. Emana directamente del pueblo, no está instituida por alguna Constitución precedente, por lo que no está sometido a reglas anteriores. Se caracteriza por ser originario, supremo, soberano, extraordinario, ilimitado y autónomo. Mientras que el poder constituyente derivado o constituido - agrega Torres Vásquez - denominado también poder revisor o poder constituyente permanente o instituido, comprende la potestad de reformar, haciendo modificaciones, supresiones o adiciones a preceptos no esenciales de la Constitución, conforme a lo previsto en el mismo texto. 
Esta obra forma parte del acervo de la Biblioteca Jurídica Virtual del Instituto de Investigaciones Jurídicas de la UNAM

La posibilidad de formular una tipología de los conceptos de poder constituyente (que según Carl Schmitt es "voluntad positiva") arranca de la comprobación de que la teoría constitucional utiliza aquella expresión con variadas direcciones, las más de las veces en un notorio emparentamiento o connotación con posiciones ideológicas muy definidas o compromisos con afirmaciones dogmáticas y apriorísticas pertenecientes a diversas "escuelas" o tendencias jurídico-políticas. En tal sentido, el punto de arranque lo encontramos en la doctrina expuesta por el abate Emmanuel Sieyès (17481836) con su panfleto: ¿Qué es el Tercer Estado? ${ }^{30}$, escrito en plena Revolución francesa: el pouvoir constituant de la Nación. ${ }^{11}$ Conceptualizando, el poder constituyente es la voluntad política cuya fuerza o autoridad es capaz de adoptar la concreta decisión de conjunto sobre modo y forma de la existencia política, determinando así la propia existencia de la unidad política como un todo. ${ }^{12}$

Y como bien apunta Eto Cruz: "El poder constituyente, como desarrollo teórico, es un archipiélago que nutre distintas aristas del amplio e intrincado territorio del constitucionalismo contemporáneo. Así - añade Eto Cruz- el poder constituyente tiene múltiples conexiones con otros dominios, que en líneas generales son: a) el origen fundacional del Estado; $b$ ) en la reforma de la Constitución, y con él, en el tema de las mutaciones constitucionales; c) guarda conexidad, además, con el tema de la interpretación constitucional, y con el propio fundamento de la defensa de la Constitución; d) igualmente se vincula con el complejo tema de la soberanía; y e) su vinculación estrecha con la transición política". ${ }^{13}$

10 Vid., especialmente: Escritos políticos de Sieyès, Cronología, Orientación bibliográfica, Introducción y Estudio preliminar de David Pantoja Morán, Fondo de Cultura Económica, México, D.F., 1993. También, Emmanuel Sieyès: ¿Qué es el Tercer Estado?, traducción del francés, introducción y notas de Francisco Ayala, Aguilar S.A., de ediciones, Madrid, 1973.

11 Para mayor amplitud, vid. los argumentos finamente tallados de Jorge Reinaldo A. Vanossi: Teoría Constitucional (Teoría constituyente), t. I, $2^{\text {a }}$. edición, actualizada con la colaboración de Alberto Ricardo Dalla Vía, Ediciones Depalma, Buenos Aires, 2000, pág. 5. Antecede Prólogo de Adolfo R. Rouzaut. Del mismo autor, vid. su libro Estudios de teoría constitucional, UNAM, México, D.F., 2002. Antecede Explicación Preliminar del constitucionalista mexicano Diego Valadés.

12 El concepto en mención proviene de Carl Schmitt: Teoría de la Constitución, traducción del alemán de Francisco Ayala, Editorial Revista de Derecho Privado, Madrid, 1934, pág. 86.

13 Así lo explica en el Estudio preliminar al libro de Sigifredo Orbegoso Venegas: Poder Constituyente y otros ensayos, Editora Normas Legales, Trujillo, 2002, págs. 41-42. Resulta también de utilidad el ensayo del referido profesor de Trujillo, cuyo título es "El poder constituyente" (págs. 63-103), donde plantea tesis interesantes. 
Esta obra forma parte del acervo de la Biblioteca Jurídica Virtual del Instituto de Investigaciones Jurídicas de la UNAM

\section{SEGUNDO PRESUPUESTO: LA FUERZA NORMATIVA DE LA CONSTITUCIÓN}

Para abordar el tema de la reforma constitucional al igual que el de la interpretación constitucional, ${ }^{14}$ es preciso partir de una premisa fundamental, que sin lugar a dudas tiene el reconocimiento del valor normativo que posee una Constitución, o lo que es lo mismo, el papel que esta última cumple en cuanto norma jurídica. ${ }^{15}$ En efecto, no tendría ningún sentido que se postule una tarea interpretativa de parte de los operadores del Derecho si previamente no se define el valor y los caracteres que se aparejan respecto de aquel instrumento, que precisamente se desea interpretar. Cabe recordar que la Constitución es o representa la norma jurídica fundamental, la primera de las expresiones normativas que tiene un país.

A fin de cuentas, esta norma suele estar tamizada de solemnidad y convencionalismo, pero es oportuno precisar, porque así lo impone el Derecho Constitucional, las razones del por qué se invoca tan especial como significativa característica. Como se sabe, la Constitución es ante todo una norma, porque su contenido vincula o pretende vincular jurídicamente tanto a los detentados del poder estatal como a los destinatarios del mismo. Tiene por tanto, una orientación eminentemente bilateral, como por lo demás lo suelen proclamar todos o la mayor parte de manuales de Derecho Constitucional. ${ }^{16}$ La razón de ese valor normativo tiene, sin embargo, variantes que están más allá de la simple articulación formal del ordenamiento jurídico, ${ }^{17}$

14 A propósito, vid. Joachim Lege: “¿Reforma de la Constitución o interpretación constitucional? El debate metodológico en torno a la supresión del Senado bávaro", en Cuestiones constitucionales, Revista Mexicana de Derecho Constitucional, $n^{\circ}$ 9, julio-diciembre, México, D.F., 2003, págs. 187-199, Según el autor, la sentencia del Tribunal Constitucional bávaro permite reflexionar sobre la delimitación entre derecho y política constitucionales. Y con la decisión que adoptó dicho Tribunal Constitucional se debilita al Estado constitucional, por cuanto se pierde la función estabilizadora, racionalizadora y garante de la libertad de la Constitución escrita.

15 Para un planteamiento general, vid. Eduardo García de Enterría: La Constitución como norma y el Tribunal Constitucional, 3ª . edición, Editorial Civitas, Madrid, 1985; y Germán J. Bidart Campos: El derecho de la Constitución y su fuerza normativa, Ediar, Buenos Aires, 1995, in toto. Ambos autores se han ocupado profesionalmente del tema.

16 La idea de bilateralidad de la norma constitucional ha sido desde siempre o por lo menos desde la aparición de nuestra materia, premisa básica a considerar en cualquier análisis constitucional. La doctrina suele considerar dos partes o sectores clásicos en toda Constitución, una parte dogmática y una parte orgánica. La bilateralidad no es una mera configuración dogmática, sino una auténtica expresión del sentido de toda norma constitucional.

17 Bien ilustrativa a este respecto es la opinión de Hans Kelsen: Teoría pura del Derecho, $5^{\text {a }}$. edición, traducción de la $2^{a}$. edición en alemán por Roberto J. Vernengo, UNAM, México, D.F., 1986, págs. 205 y sgts. 
Esta obra forma parte del acervo de la Biblioteca Jurídica Virtual del Instituto de Investigaciones Jurídicas de la UNAM

pues la supremacía que con ordinaria frecuencia se predica de la Constitución sólo se justifica si se repara tanto en su origen y contenido, como en el papel o rol que le corresponde cumplir en el mundo del Derecho.

Por el primero de estos factores, es decir, por el relativo a su origen, una Constitución es distinta de cualquier otra, en la medida en que aquella es producto o resultado no de la voluntad de los poderes constituidos u ordinarios, sino de la voluntad del poder constituyente creador por excelencia y único, extraordinario e ilimitado por naturaleza. En la medida en que la Constitución es resultado de la intención popular, depositada en el poder soberano que la representa, su significado es mucho más relevante que el de cualquier otra expresión jurídica. Y sin equívoco alguno, ninguna otra norma por consiguiente, puede equiparársele. Pues, toda expresión del Derecho que no tenga su nacimiento en la voluntad constituyente carece de los mismos supuestos de legitimidad que acompañan a una Constitución.

Por el segundo de los factores enunciados, es distinta una Constitución, porque su contenido, a diferencia del correspondiente a cualquier otro tipo de norma, pretende la regulación del poder en cuanto elemento fundamental del Estado. Bajo dicho supuesto, tal ordenación, se suele traducir en tres aspectos: a) organización, b) limitación y c) justificación. Mientras que la idea de organización se refiere a la configuración funcional de los órganos entre los cuales se distribuye el Estado, y la de limitación al reconocimiento de derechos fundamentales como esferas de libertad reconocidas sobre los individuos y respecto de las cuales el poder no puede penetrar o cometer excesos; la de justificación, por su parte, se vincula a los objetivos que el poder se traza como obligaciones o programas a cumplir. Cualquier norma fundamental estructura pues su contenido bajo esa configuración trialista y es difícil, por lo menos hoy en día, prescindir de cualquiera de los elementos de la misma. ${ }^{18}$

Pero aún más: el último factor que permite justificar la razón de supremacía que acompaña a una norma fundamental y la consecuencia de su carácter normativo, es el del papel o rol que le corresponde cumplir. A ese nivel, la Constitución se identifica como la primera de las fuentes del Derecho, y fuente no sólo en términos formales sino también materiales. ${ }^{19}$

18 El contenido de la Constitución enfocado desde la perspectiva de las tres variantes aquí señaladas, lo encontramos explicitado en Eduardo García de Enterría: La Constitución como norma y el Tribunal Constitucional, citado, pág. 49; y en Germán J. Bidart Campos: El derecho de la Constitución y su fuerza normativa, citado, págs. 96-103, 139 y sgts.

19 Por su valor docente, $c f r$. Eduardo García de Enterría: La Constitución como norma jurídica y el Tribunal Constitucional, citado, págs. 49-50; Dieter Grimm: "La Constitución como fuente del Derecho", en A. Baratta, D. Grimm, F. Rubio Llorente: Las fuentes del Derecho, Anuario 
Esta obra forma parte del acervo de la Biblioteca Jurídica Virtual del Instituto de Investigaciones Jurídicas de la UNAM

Se dice que es fuente formal en la medida en que establece el modus operandi en la creación del Derecho o el modo como nacen o se generan las diversas expresiones normativas. Quiere decir, en términos generales, quiénes son los órganos legitimados para crear Derecho (Congreso, Poder Ejecutivo, Poder Judicial, etc.), la estructura que poseen (unicameral para el caso del Congreso, bilateral para el caso del órgano Ejecutivo, plural para el caso del órgano Judicial y sus instancias, etc.), la competencia que se les reconoce (leyes para el órgano Legislativo, decretos para el órgano Ejecutivo, jurisprudencia para el órgano Judicial, etc.) y, el procedimiento específico en la elaboración del derecho (votaciones por mayorías simples, absolutas o calificadas en el caso del Congreso, decisiones o acuerdos en el caso del Ejecutivo, debido proceso formal en el caso de la Judicatura, etc.)

Empero, se dice que es también fuente material, en la medida en que la Constitución, no obstante habilitar la creación del Derecho en todas las direcciones, representa a su vez el parámetro de validez jurídica del resto de normas integrantes del ordenamiento, de modo tal que ninguna otra expresión normativa, ninguna otra manifestación jurídica, podrá sustraerse del contexto marcado por la norma fundamental y, por el contrario sólo será válida una norma o cualquier otra expresión del Derecho en la medida en que no se salga de los cauces marcados por la Constitución.

Como lo ha subrayado Carlos Sánchez Viamonte: “... el círculo máximo trazado por el poder constituyente con el nombre de Constitución, traza la órbita de la juridicidad, cuyo ordenamiento debe abstenerse dentro de dicha órbita y condicionada por ella. La sola existencia de una Constitución basta para afirmar que el Estado de Derecho creado por ella, excluye todo el Derecho que no nazca de ella explícita o implícitamente, porque ninguna manifestación de voluntad colectiva o personal, de autoridad o de libertad es apta para crear Derecho que, de una o de otra manera, no tenga su origen en la voluntad constituyente expresada a través de la Constitución". ${ }^{20}$

Son en consecuencia, estas razones de origen, contenido y función, y no argumentaciones meramente formalistas, las que han permitido edificar la teoría de la supremacía constitucional, y por consiguiente, la correlativa ne-

de la Facultad de Derecho de Lleida, Barcelona, 1983, págs. 13 y sgts.; Javier Pérez Royo: Las fuentes del Derecho, Editorial Tecnos, S.A., Madrid, 1985, págs. 27 y sgts.; Ignacio de Otto Pardo: Derecho Constitucional. Sistema de fuentes, $2^{a}$. reimpresión, Editorial Ariel, S.A., Barcelona, 1991, págs. 82 y sgts.

20 Cfr. Carlos Sánchez Viamonte: El constitucionalismo y sus problemas, Ediar, Buenos Aires, 1957, pág. 54. Del mismo autor: El poder constituyente. Origen y formación del constitucionalismo universal y especialmente argentino, Editorial Bibliográfica Argentina, Buenos Aires, 1957, in toto. 
Esta obra forma parte del acervo de la Biblioteca Jurídica Virtual del Instituto de Investigaciones Jurídicas de la UNAM

cesidad de predicar su carácter indiscutiblemente normativo al interior del mundo jurídico. ${ }^{21}$

Ahora bien, la primera y elemental manifestación del carácter normativo de la Constitución viene representada sin lugar a dudas, por el hecho de su aplicabilidad. En la medida en que una Constitución se aplica, puede predicarse de ella su valor normativo como premisa fundamental. ${ }^{22}$ Tal es pues la regla general con la que se suele operar en la normativa constitucional y a la que, por supuesto, los operadores del Derecho le deben escrupulosa observación. ${ }^{23}$

Sin embargo, esto que a primera vista resulta incontrovertible, requiere ciertas precisiones adicionales, pues aunque nadie niega tal postulado, debe reconocerse que la consabida normatividad de la Constitución no supone tampoco que la aplicabilidad que le acompaña como consecuencia elemental opere o se manifieste de modo inmediato en todos los casos y en todas las circunstancias. Dicho de otro modo, el que se predique la aplicación de una norma fundamental, no sugiere que tal condición funcione inmediatamente y de manera uniforme en todas las hipótesis.

Con alguna razón se ha postulado desde hace buen tiempo que a toda Constitución le acompañan peculiaridades especiales. ${ }^{24}$ Mientras que unas se manifiestan hacia afuera, es decir, frente a otras normas jurídicas y en ese sentido se habla de peculiaridades "de" la norma constitucional, otras, por el contrario, se manifiestan al interior de los mismos dispositivos que la integran, hablándose en tal sentido de peculiaridades "en" las normas constitucionales.

Pues bien, cuando hablamos de estas últimas, nos estamos refiriendo al problema arriba descrito. Todas las normas constitucionales se aplican, pero no todas ellas de la misma forma. Así las cosas, un dispositivo que por ejemplo tiene que ver con el reconocimiento de una libertad individual no es aplicado de manera semejante a uno que, en cambio, tenga que ver con el

21 Por cierto, buena parte de estas razones fueron esbozadas por el histórico juez John Marshall (1755-1835) desde el momento mismo en que se sentaron las bases del principio de supremacía constitucional durante la secuela del célebre leading case Marbury vs. Madison (1803). Vid. el texto completo en Revista Mexicana de Derecho Público, vol. I, nº 3, México, D.F., 1943, págs. 317 y sgts.

22 Para tal fin, me remito a Eduardo García de Enterría: La Constitución como norma y el Tribunal Constitucional, citado, págs. 63 y sgts.; Germán J. Bidart Campos: El derecho de la Constitución y su fuerza normativa, citado, págs. 19 y sgts.; Ignacio de Otto Pardo: Derecho Constitucional. Sistema de fuentes, citado, págs. 76 y sgts., y Javier Pérez Royo: Curso de Derecho Constitucional, $7^{\mathrm{a}}$. edición, Marcial Pons, Ediciones Jurídicas y Sociales, S.A., Madrid, 2000, págs. 45 y sgts.

23 En esa línea explicativa, vid. Germán J. Bidart Campos: El derecho de la Constitución y su fuerza normativa, citado, págs. 88-89.

24 Cfr. Alejandro Nieto: "Peculiaridades jurídicas de la norma constitucional", en Revista de Administración Pública, nº 100-102, enero-diciembre, Madrid, 1983, págs. 371 y sgts. 
Esta obra forma parte del acervo de la Biblioteca Jurídica Virtual del Instituto de Investigaciones Jurídicas de la UNAM

principio de pluralismo económico. Si bien el carácter normativo de ambos no puede ser colocado en tela de juicio, sus alcances operacionales difieren notoria o sustancialmente. Justo porque no todas las normas constitucionales son semejantes, la doctrina postula la existencia de dos géneros principales al interior de la Constitución: a) normas operativas y b) normas programáticas. ${ }^{25}$

Mientras que para las primeras, el nivel de aplicación es directo o inmediato, en las segundas varía el mismo en función de determinados supuestos, siendo por tanto semidirecto o mediato. Las normas operativas suelen asociarse a los derechos de tipo individual y político y a la mayor parte de los dispositivos concernientes con el funcionamiento orgánico del Estado, mientras que las normas programáticas suelen referirse a los derechos sociales, económicos y culturales, así como al conjunto de obligaciones cuya responsabilidad queda sujeta al cumplimiento del Estado y sus órganos de poder.

En esa medida, y si para las primeras no existe dificultad de aplicación, pues su cumplimiento sólo depende de la voluntad de los titulares de dichas normas sin que pueda anteponerse ningún tipo de requisito previo, con las segundas el grado de aplicación se encuentra condicionado desde que para su puesta en ejecución se hace necesario, preliminarmente, la creación de ciertas condiciones, las que por otra parte, o pueden ser técnicas (legislativas por ejemplo, cuando se trata de desarrollar un precepto, o administrativas cuando se trata de reglamentar o ejecutar un mandato, etc.) o pueden ser, eminentemente políticas o discrecionales (cuando de lo que se trata es de crear contextos materiales o socioeconómicos que habiliten la operatividad de una norma considerada programática).

Como quiera que con las normas operativas no existe mayor problema normativo, pues por principio se aplican íntegramente o en su totalidad, y como se dijo de modo directo, conviene precisar que con las normas programáticas, los niveles de aplicación, pueden operar hasta en cuatro variantes:

a) En la medida en que una norma programática se encuentra contenida en la Constitución y goza por ende de la supremacía innata que a ésta le acompaña, puede anteponerse, y en ese sentido aplicarse, sobre normas de inferior jerarquía que la desconozcan o vulneren. ${ }^{26}$

25 Un planteamiento general lo encontramos en Rolando E. Pina: Cláusulas constitucionales operativas y programáticas, Editorial Astrea, Buenos Aires, 1973, págs. 13 y sgts. Néstor Pedro Sagüés: Elementos de Derecho Constitucional, t. I, Ediar, Buenos Aires, 1997, págs. 92 y sgts.; y Germán J. Bidart Campos: El derecho de la Constitución y su fuerza normativa, citado, págs. 222 y sgts.

$26 \mathrm{Al}$ respecto, vid. Eduardo García de Enterría: La Constitución como norma y el Tribunal Constitucional, citado, págs. 68-71; e Ignacio de Otto Pardo: Derecho Constitucional, citado, págs. 77 y sgts. 
Esta obra forma parte del acervo de la Biblioteca Jurídica Virtual del Instituto de Investigaciones Jurídicas de la UNAM

b)En la medida en que una norma programática puede ser ejercitada por específicos titulares en específicos casos (lo que acontece por ejemplo respecto del derecho al trabajo, y el goce que del mismo atributo pueden tener algunas personas en particular) frente a la hipótesis de su transgresión -mediante actos u omisiones- cabe la tutela y por tanto, la aplicación de la misma. ${ }^{27}$

c)En la medida en que la norma programática forma parte del contenido material de la Constitución, su contenido sirve como parámetro interpretativo de toda decisión jurisdiccional, y en ese sentido también es aplicable. ${ }^{28}$

d) En la medida en que no todas las normas programáticas son iguales, prescindiendo de aquellas de naturaleza eminentemente política o discrecional, las que sólo requieren de condiciones técnicas, sí pueden resultar exigibles y en tal sentido aplicable, ante los órganos que conocen de la jurisdicción constitucional.

A los efectos de nuestro estudio, el valor normativo de la Constitución se da por el reconocimiento que es una norma jurídica fundamental, proveniente de la intención popular, a través del poder constituyente. Es una de las primeras expresiones jurídicas normativas que busca vincular al Estado con los ciudadanos, para regular el poder del mismo. Muy en línea con lo anterior, la Constitución (norma normarum) es considerada como la primera fuente de Derecho, cuyas normas son aplicables, pero no todas de la misma forma.

\section{CONSTITUGION EN SENTIDO MATERIAL Y CONSTITUCION EN SENTIDO FORMAL}

Prescindiendo de la múltiple tipología y de la variadísima clasificación de "las constituciones"29 a que conduce intrínsecamente la doctrina, podemos sostener que las numerosas y disímiles ideas que se han expuesto sobre este concepto pueden subsumirse en dos tipos genéricos: a) en sentido material (la Constitución real, ontológica, teleológica, socialy deontológica) y b) en sentido jurídicopositiva. ${ }^{30}$

27 Cfr. Rolando E. Pina: Cláusulas constitucionales operativas y programáticas, citado, págs. 63 y sgts.

28 Cfr. Eduardo García de Enterría: La Constitución como norma y el Tribunal Constitucional, citado, págs. 68-71; Ignacio de Otto Pardo: Derecho Constitucional, citado, págs. 77 y sgts.

29 Modélico y de gran predicamento resulta el libro de James Bryce: Constituciones flexibles y constituciones rígidas, Centro de Estudios Constitucionales, Madrid, 1988. Antecede Estudio preliminar de Pablo Lucas Verdú.

30 Aquí seguimos el lúcido planteamiento de Ignacio Burgoa: Derecho Constitucional Mexicano, Editorial Porrúa, México, D.F., 1999, págs. 320 y sgtes. 
Esta obra forma parte del acervo de la Biblioteca Jurídica Virtual del Instituto de Investigaciones Jurídicas de la UNAM

\section{A. Constitución en sentido material (mutación constitucional)}

En lo tocante al primer tipo, se implica en el ser de un pueblo, en su existencia social dentro del devenir histórico. A su vez, presenta diversos aspectos reales, como el económico, el político y primordialmente, el cultural (elemento ontológico); así como en el desiderátum o tendencia para mantener, mejorar o cambiar dichos aspectos (elemento deontológico o "querer ser"). Este tipo de Constitución se da en la vida misma de un pueblo como condición sine qua non de su identidad (Constitución real), así como en su propia finalidad (Constitución teleológica), con abstracción de toda estructura jurídica.

Huelga comentar, por tanto, que el término y el concepto de Constitución real fueron empleados en el siglo XIX por el socialista Ferdinand Lassalle (1825-1864) ${ }^{31}$ para designar la estructura ontológica misma de un pueblo, es decir, su ser y su modo de ser. "Una Constitución real y efectiva la tienen y la han tenido siempre todos los países", afirmaba Lassalle, agregando que: "Del mismo modo y por la misma ley de necesidad de todo cuerpo tiene una Constitución, su propia Constitución, buena o mala, estructurada de un modo o de otro, todo país tiene, necesariamente, una Constitución real y efectiva, pues no se concibe país alguno en que no imperen determinados factores reales de poder, cualesquiera que ellos sean".

Así, y sólo así, la presencia necesaria, esencial, innegable, sine qua non, de la Constitución real de un pueblo, que expresa la "quididad" (del latín quidditas, esencia, razón, porqué de una cosa) misma de éste, no puede inadvertirse, y tan es así que la doctrina, con diferentes denominaciones, se ha referido a ella. Por lo que concierne a lo que se llama Constitución teleológica, ésta no tiene una dimensión óntica como ser y modo de ser de un pueblo, sino que denota el conjunto de aspiraciones o fines que a éste se adscribe en sus diferentes aspectos vitales, implicando su querer ser. Desde este punto de vista, la Constitución teleológica responde a lo que el pueblo "quiere" y "debe" ser, a lo que se "quiere" que el pueblo sea o "deba" ser. Este "querer" y "deber" ser no extrañan meras construcciones especulativas o concepciones ideológicas, sino tendencias que desarrollan los factores reales de poder, como denominaba Lassalle al conjunto de fuerzas de diferentes especies que necesariamente actúan en el seno de toda sociedad.

De ello se concluye que la Constitución teleológica no consiste sino en los objetivos de la Constitución real, demarcados, sustantivados y condicionados por dichos factores. En la Constitución real, según se habrá observado,

31 Vid. el libro clásico de Ferdinand Lassalle: ¿Qué es una Constitución?, traducción del alemán por Wenceslao Roces, Editorial Ariel, S.A., Barcelona, 1984, págs. 77 y sgts 
Esta obra forma parte del acervo de la Biblioteca Jurídica Virtual del Instituto de Investigaciones Jurídicas de la UNAM

se encuentra la vasta problemática de un pueblo como resultante de una múltiple gama de circunstancias y elementos que también, obviamente, se localizan en ella. Por su parte, en la Constitución teleológica se comprenden las soluciones que a dicha problemática pretenden dar los factores reales de poder desde distintos puntos de vista, tales como el político, el cultural o el socioeconómico principalmente.

Ambas especies de "Constitución" son prejurídicas y metajurídicas en su existencia prístina, o sea, existen en la dimensión ontológica y teleológica del pueblo mismo como unidad real independiente de su organización jurídica o incluso sin esta organización. En otras palabras, dichas constituciones no son jurídicas, aunque sean o deban ser el contenido de las jurídicas, a las cuales nos referimos enseguida. A la vista de lo expresado más arriba, son constituciones que aceptan las mutaciones constitucionales.

Hemos de dirigir ahora una mirada general de conjunto a la mutación de la Constitución. Por de pronto, la mutación constitucional (Verfassungswandlung) constituye una modificación no formal -sin modificación expresa del texto de la Constitución, alude Häberle- del ordenamiento constitucional, es decir, el cambio operado en el mismo sin seguir procedimiento más agravado y difícil establecido para la reforma de la Constitución, tal como enseña Pedro de Vega. ${ }^{32}$ De ahí pues la diferencia entre reforma constitucional (Verfassungsänderung) y mutación constitucional. La primera es la modificación de los textos constitucionales producidas por acciones voluntarias dice Jellinek, siguiendo a Paul Laband- e intencionadas; la segunda es la modificación que deja indemne su texto sin cambiarlo formalmente - añade Jellinek- que se produce por hechos que no tienen que ir acompañados por la intención, o conciencia, de tal mutación. ${ }^{33}$

Sin embargo, la nueva doctrina del Derecho Público donde la mutación constitucional es ya un concepto corriente, la caracteriza principalmente como desvalorización y corrosión de las normas jurídicas de las institucio-

32 Vid. a este respecto, Pedro de Vega: La reforma constitucional y la problemática del poder constituyente, $1^{\mathrm{a}}$. reimpresión, Editorial Tecnos, S.A., Madrid, 1988, págs. 179 y sgts. Obra capital e importante para entender el tema abordado.

33 Vid. Georg Jellinek: Reforma y mutación de la Constitución, traducción del alemán de Christian Förster, revisada y Estudio preliminar de Pablo Lucas Verdú, Centro de Estudios Constitucionales, Madrid, 1991, pág. 7. En igual sentido, Néstor Pedro Sagüés: "Los jueces y la interpretación constitucional mutativa", en su libro La interpretación judicial de la Constitución, Editorial Depalma, Buenos Aires, 1998, págs. 51-81. 
Esta obra forma parte del acervo de la Biblioteca Jurídica Virtual del Instituto de Investigaciones Jurídicas de la UNAM

nes afectadas..$^{34}$ En tal sentido, como anota Hsü Dau-Lin, resulta usual distinguir cuatro clases de mutación de la Constitución: ${ }^{35}$

a) Mutación de la Constitución mediante una práctica estatal que no viola formalmente la Constitución. En tal caso se ignora un artículo concreto de la Constitución o se contradice cierta prescripción constitucional, pues se trata de relaciones jurídicas que todavía no se regulan por un precepto constitucional. Ejm., la iniciativa imperial en el viejo Reich alemán.

b) Mutación de la Constitución mediante la imposibilidad de ejercer ciertos derechos estatuidos constitucionalmente. El derecho que atribuyen los artículos constitucionales a ciertos sujetos pierde ante la imposibilidad de ejercerlos, de modo que esos artículos de la Constitución ahora ya no corresponden a la realidad jurídica. Ejm., el derecho de disolución de la Cámara de Diputados por el Presidente de la República francesa, a tenor del artículo 5 de la Ley Constitucional del 25 de febrero de 1875. Desde su origen se aplicó una sola vez, por el mariscal Mac Mahon, en el año de 1887, y al cabo lo pagó con su dimisión. Desde entonces el derecho de disolución jamás se aplicó.

c) Mutación de la Constitución mediante una práctica estatal contradictoria con la Constitución, sea por la llamada reforma material de la Constitución, sea por la legislación ordinaria, sea por los reglamentos de los órganos estatales superiores o por su práctica efectiva. Ejm., el artículo 49 de la Constitución del Reich que atribuye al Presidente el derecho incondicional de indulto y gracia en todo el Reich. No se regula una limitación en ciertos casos penales. No obstante, el artículo 13 de la ley sobre el Tribunal Supremo de 9 de julio de 1921 estatuye que el Presidente del Reich necesita la aprobación del Reichstag para indultar a un condenado por dicho Tribunal.

d) Mutación de la Constitución mediante su interpretación, particularmente cuando los preceptos constitucionales sólo se interpretan según consideraciones y necesidades que cambian con el tiempo sin atender particularmente al texto fijo de la Constitución, o sin que se considere el sentido originario que dio el constituyente a las normas constitucionales en cuestión. Ejm., el artículo 4 de la Constitución de Prusia del 5 de diciembre de 1848 establecía, también más tarde en su forma revisada del 31 de enero de 1850: "Todos los prusianos son iguales ante la ley. No hay privilegios estamentales ni de rangos". El texto de la norma correspondía plenamente al sentido origi-

34 Así lo reconoce Hsü Dau-Lin: Mutación de la Constitución, traducción del alemán de Pablo Lucas Verdú y Christian Förster, Instituto Vasco de Administración Pública, Oñati, 1998, pág. 29. Agradezco al profesor salmantino Lucas Verdú por haberme obsequiado dicha obra en una de las visitas que le hice a su hogar. Su magnífico Estudio preliminar que antecede al libro es iluminador para entender este tema poco trajinado.

35 Aquí seguimos a Hsü Dau-Lin, quien fue discípulo de Rudolf Smend: Mutación de la Constitución, citado, págs. 31 y sgts. La obra fue originalmente escrita en 1932. 
Esta obra forma parte del acervo de la Biblioteca Jurídica Virtual del Instituto de Investigaciones Jurídicas de la UNAM

nario de la garantía de la libertad propia del individualismo del tiempo sobre cuya vinculación jurídica directa no pueden caber serias dudas. Sin embargo, en la práctica este precepto se interpretó con muchas restricciones, y como tal, en la práctica no tuvo alcance jurídico.

\section{B. Constitucion en sentido formal (reforma y enmienda constitucional)}

La Constitución jurídico-positiva se traduce en un conjunto de derechos básicos y supremos cuyo contenido puede o no reflejar la Constitución real y teleológica. Es dicha Constitución, en su primariedad histórica, la que da origen al Estado. En la primera hipótesis que se acaba de señalar, la vinculación entre la Constitución real y teleológica, por un lado, y la Constitución jurídico-positiva, por el otro, es indudable, en cuanto que ésta no es sino la forma normativa de la materia normada, que es aquélla.

En la segunda hipótesis no hay adecuación entre ambas, en el sentido de que la Constitución real y teleológica no se convierte en el substratum de la Constitución jurídico-positiva, o sea, que una y otra se oponen o difieren, circunstancia que históricamente ha provocado la ruptura del orden social, político y económico establecido normativamente. De esto se infiere que la vinculación entraña la legitimidad o autenticidad de una Constitución jurídico-positiva y la inadecuación, su ilegitimidad o su carácter obsoleto, ya que o se impone a la Constitución real o no responde a la Constitución teleológica de un pueblo.

Conforme a la lógica jurídica, toda Constitución positiva debe ser el elemento normativo en que trascienden las potestades de autodeterminación y autolimitación de la soberanía popular, las mismas que traducen el poder constituyente (mediante el principio político democrático). En efecto la autodeterminación del pueblo se manifiesta en la existencia de un orden jurídico, que por sí solo excluye la idea de arbitrariedad. El Derecho, pues, en relación con el concepto de poder soberano, se sustenta como el medio de realización normativa de la capacidad autodeterminativa.

Ahora bien, la autodeterminación, lo mismo que la autolimitación, pueden operar por el Derecho positivo en forma directa o indirecta o, mejor dicho, originaria o derivada. En efecto, el orden jurídico de un Estado que implica uno de los elementos de su sustantividad, comprende todo un régimen normativo que suele clasificarse en dos grandes grupos o categorías o disposiciones de Derecho: a) las constitucionales, que forman un todo preceptivo llamado Constitución en sentido jurídico-positivo y b) las secundarias, emanadas de ésta, que a su vez se subdividen en varios cuerpos legales de diversa índole, a saber: sustantivas, orgánicas, adjetivas, locales, etc. 
Esta obra forma parte del acervo de la Biblioteca Jurídica Virtual del Instituto de Investigaciones Jurídicas de la UNAM

Pues bien, es la Constitución la que directa y primordialmente objetiva y actualiza las facultades de autodeterminación y autolimitación de la soberanía popular, por lo que recibe también el nombre de Ley fundamental. Se basan en la calificación, organización y funcionamiento del gobierno del Estado o del pueblo (autodeterminación) y establece las normas que encauzan el poder soberano (autolimitación). La Constitución consigna, en primer término, derechos públicos subjetivos que el gobernado puede oponer al poder público estatal; y en segundo lugar, establece competencias expresas y determinadas, como condición sine qua non de la actuación de los órganos de gobierno. Esta tipología de Constitución es la que acepta la reforma y la enmienda constitucional.

Por lo que respecta a la enmienda constitucional hemos de significar que es una vieja práctica que emplea la Constitución norteamericana de 1787, en actual vigencia, y que precisamente tiene 27 enmiendas a la fecha, las mismas que se incluyen al final de su texto, y no dentro del propio cuerpo constitucional.

Los Estados Unidos ofrecen un ejemplo típico - recuerda el maestro Adolfo G. Posada- de cómo se produce, evolutiva y expresamente a la vez, una transformación constitucional por obra de la acción interpretativa de la jurisprudencia, tan poderosamente iniciada por el juez Marshall, y de los hombres de Estado, como Hamilton, Jackson, Wilson..., y especial y principalmente merced al cambio de potencialidad de los elementos políticos y sociales con sus órganos los partidos y los grupos representativos de los intereses colectivos. ${ }^{36}$

El artículo 5 de la Constitución norteamericana señala: "El Congreso, siempre que dos tercios de ambas Cámaras lo consideren necesario, propondrá enmiendas a esta Constitución o, a pedido de las Legislaturas de dos tercios de los diversos Estados, convocará a una convención para proponer enmiendas, las cuales en ambos casos serán válidas para todos los fines y propósitos de esta Constitución, cuando sean ratificadas por las Legislaturas de las tres cuartas partes de los diversos Estados, o convenciones reunidas en tres cuartas partes de los mismos, según uno u otro modo de ratificación haya sido propuesto al Congreso; ello siempre que antes del año mil ochocientos ocho no se haga ninguna enmienda que de cualquier manera afectara las cláusulas primera y cuarta de la novena sección del artículo primero

36 Vid., en tal sentido, el libro clásico de Adolfo G. Posada: La reforma constitucional, Librería General de Victoriano Suárez, Madrid, 1931, pág. 11. 
Esta obra forma parte del acervo de la Biblioteca Jurídica Virtual del Instituto de Investigaciones Jurídicas de la UNAM

y que ningún Estado, sin su consentimiento, sea privado de la igualdad de sufragio en el Senado". ${ }^{37}$

Es, sin embargo, la actual Constitución de Venezuela, aprobada mediante el refrendo constituyente, a los 15 días del mes de diciembre de 1999, la que establece claramente la diferencia entre enmienda constitucional y reforma constitucional. $\mathrm{Al}$ respecto, el artículo 340 apunta lo siguiente: "La enmienda tiene por objeto la adición o modificación de uno o varios artículos de esta Constitución, sin alterar su estructura fundamental". A su turno, el artículo 342 prescribe: "La reforma constitucional tiene por objeto una revisión parcial de esta Constitución y la sustitución de una o varias de sus normas que no modifiquen la estructura y principios fundamentales del texto constitucional".

\section{La Posición de Domingo García Belaunde}

Como es de conocimiento público, el 26 de mayo de 2001 el Poder Ejecutivo nombró una Comisión de Estudios de las Bases de la Reforma Constitucional, que instalada el 6 de junio, terminó sus labores el 16 de julio. Dicha Comisión, compuesta de 28 miembros, debatió largamente todos los temas de la agenda, los que fueron finalmente aprobados por consenso y en mayoría. El último tema, relativo al procedimiento de reforma constitucional, corrió a cargo de Domingo García Belaunde, y fue presentado al seno de la Comisión, y que luego de ser debatido, se aprobó con algunas enmiendas, que en realidad no cambian el sentido básico de la propuesta (y así figura en el informe oficial publicado por el Ministerio de Justicia). El proyecto original había quedado inédito en los archivos, y por eso es que ahora se publica con la autorización del autor para difundirlo con fines estrictamente académicos. Tiene el tenor literal que sigue:

\section{PROCEDIMIENTOS PARA UNA REFORMA CONSTITUCIONAL}

- La Comisión ha estimado conveniente presentar un conjunto de posibilidades para la reforma constitucional, teniendo como base la Constitución de 1979, pero a su vez aceptando como realidad que el país desde 1993 se rige por la Constitución sancionada ese año, no obstante encontrarse totalmente deslegitimada.

37 Sobre el tema, vid. C. Herman Pritchett: La Constitución americana, Tipográfica Editora Argentina S.A., Buenos Aires, 1965, págs. 49-61. 
Esta obra forma parte del acervo de la Biblioteca Jurídica Virtual del Instituto de Investigaciones Jurídicas de la UNAM

- Por eso plantea algunos caminos a seguir, que sin ánimo exhaustivo, podemos enumerar de la siguiente manera.

\section{Primera alternativa}

Lo primero que debe aceptar el Congreso de la República, de ser posible en el mismo mes de agosto del año en curso, es declarar la nulidad de la Constitución de 1993, y poner en vigencia la de 1979. Los argumentos que sustentan esta medida, son las siguientes:

- El artículo 307 de la Constitución de 1979, en cuanto estipula que dicha Carta no perderá vigencia en ningún caso, y que todos están obligados a restablecerla, tan pronto sea posible.

- El que la Constitución de 1993 fue aprobada por un Congreso Constituyente Democrático fruto de un golpe de Estado y en dependencia de un gobierno autoritario y corrupto, como los hechos posteriores lo han confirmado.

- Que adicionalmente, la Constitución de 1993 fue aprobada en un debate parlamentario controlado y no libre, y ratificado por un referéndum que se realizó sin ninguna seguridad ni garantía en sus resultados, y con un propósito fraudulento.

- Que la Constitución de 1993 sólo ha servido como un instrumento de la dictadura, pues ha sido vaciada de contenido, incumplida en los pocos preceptos novedosos y democráticos que fueron incorporados, y adicionalmente, ha servido para proteger actos de corrupción y de violación de los derechos humanos, perdiendo así cualquier eventual legitimidad que pudiera haber tenido o que hubiera aspirado a tener (si bien no tuvo legitimidad de origen, bien pudo tener legitimidad de ejercicio, de la que también careció).

Sin embargo, en el mismo acto, deben aclararse convalidadas todas las acciones, nombramientos, compromisos, etc., que hayan sido hechas bajo su imperio, incluyendo aspectos tributarios, financieros, administrativos, judiciales, etc., con independencia a su revisión futura, en caso de que el tiempo transcurrido y las leyes correspondientes, así lo configuren y posibiliten.

Expresamente debe señalarse que:

- Se mantienen los derechos humanos aprobados por los tratados internacionales de la materia, y ratificados por el Perú. 
Esta obra forma parte del acervo de la Biblioteca Jurídica Virtual del Instituto de Investigaciones Jurídicas de la UNAM

- Se deja en suspenso la parte relativa a los aspectos laborales, de seguridad social, salud y bienestar, y régimen agrario.

- La institución del Defensor del Pueblo debe mantenerse como tal, con sus atribuciones.

- El actual Congreso de la República pasa a llamarse Cámara de Diputados.

- Debe mantenerse el nombre del Tribunal Constitucional, con sus miembros y competencias actuales, hasta que sea renovado totalmente.

- Se convoca a elecciones para una Asamblea Constituyente de 80 miembros, para que en el plazo de seis meses introduzca en la Constitución de 1979, los cambios que correspondan. Al término de su mandato, de los 80 constituyentes, 45 pasarán a formar el Senado (por sorteo), y los 35 restantes se incrementarán a la Cámara de Diputados, que de esta manera tendrá un total de 115 miembros.

- Se establece que la ONPE es parte integrante del Jurado Nacional de Elecciones. En igual sentido, lo es el RENIEC. Ambos dependerán del Jurado, en tanto se hagan las reformas correspondientes.

- Los cambios efectuados serán sancionados por un referéndum posterior.

- Se mantienen las prerrogativas del Consejo Nacional de la Magistratura en lo que se refiere a la ratificación.

- Se establecerán las disposiciones transitorias que sean necesarias.

\section{Segunda alternativa}

Utilizar los propios medios que la actual Constitución señala en su artículo 206, y mediante ella, proceder a la modificación constitucional en todo aquello que se considere pertinente. Utilizando este mecanismo, pueden introducirse las modificaciones que correspondan y se puede tener como resultado una Constitución de 1993 actualizada, mejorada sustancialmente y sobre todo, legitimada. Con todo, queda el problema de mantener su estructura y sobre todo los nombres de los que usurparon funciones y que aparecen como firmantes del documento, así como quien lo promulgó, lo cual no es lo más recomendable. Es cierto que para efectos prácticos se trata de un nuevo texto democrático y legítimo, pero queda la impronta autoritaria, que no es lo más adecuado. 
Esta obra forma parte del acervo de la Biblioteca Jurídica Virtual del Instituto de Investigaciones Jurídicas de la UNAM

\section{Tercera alternativa}

Utilizar los mecanismos que la actual Constitución de 1993 prevé para la reforma constitucional, teniendo en cuenta lo siguiente:

- Introducir una reforma total incorporando la Constitución de 1979, aprobando esta decisión en dos legislaturas ordinarias sucesivas o en una, y ulterior ratificación en referéndum.

- Simultáneamente, introducir las reformas de actualización a la Carta de 1979, con las correspondientes disposiciones transitorias, estableciendo los plazos correspondientes.

\section{Cuarta alternativa}

Aprobar una ley de referéndum para consultar al pueblo si quiere retornar a la Constitución de 1979 y, en su caso, convocar a una Asamblea Constituyente para que reforme, actualice y ponga en práctica dicha Constitución.

\section{Quinta alternativa}

Aprobar una ley de referéndum para que el pueblo decida si quiere que se apruebe una nueva Constitución que recoja lo mejor de la tradición histórica del Perú. De ser el caso, sería convocada una Asamblea Constituyente expresamente para ello.

Lima, agosto de 2001.

\section{Conclusiones PROVisionales}

A la vista de lo que venimos diciendo, y tomando como norte los dictados constitucionales, importa señalar, amén de otras, las siguientes conclusiones:

1. Desde un punto de vista sistemático, no quepa duda alguna que la técnica de la reforma constitucional (como concepto derivado del de Constitución, decía Carl Schmitt) es un ejercicio más de la democracia representativa, en la inteligencia que los actores políticos 
Esta obra forma parte del acervo de la Biblioteca Jurídica Virtual del Instituto de Investigaciones Jurídicas de la UNAM

(parlamentarios, constituyentes) respeten el sentido y la voluntad de la norma y de la realidad constitucional.

2. El modus operandi de la reforma constitucional, como un procedimiento normativamente regulado, adapta el texto constitucional a la cambiante dinámica realidad política, producto de la actividad de los agentes sociales (como únicos depositarios de la soberanía nacional) a través de la Constitución material. Por ello, la iniciativa de la reforma debe respetar el sentir del poder constituyente originario, y de sus manifestaciones de voluntad.

3. El mecanismo de la reforma constitucional ${ }^{38}$ se propone desarrollar un balance permanente y positivo entre las necesidades de una verdadera estabilidad jurídico-constitucional y los permanentes requerimientos de cambio político. Para ello se debe tener presente que la norma constitucional no nace in vitro, sino al fluir de las exigencias de la comunidad política, quien ostenta la legitimidad democrática.

4. También resulta preciso señalar que la Constitución, en tanto es Ley suprema, incluye dentro de su seno las vigas maestras del ordenamiento jurídico, y sobre este edificio tendrá que construirse el tan ansiado Estado Constitucional. Y si la reforma constitucional, en el orden práctico, no ha respetado -error antidemocrático- el mecanismo a seguir, dicha Constitución está sentenciada a desaparecer.

5. La reforma constitucional ${ }^{39}$ no puede obviar el proceso de mundialización de las ideas democráticas y las transformaciones (una suerte de eclosión dirá Néstor Pedro Sagüés) del Derecho Constitucional, el cambio político y la revertebración del orden constitucional y que se pueden traducir en los siguientes aspectos: a) la globalización, b) la apertura de fronteras, c) la relativización de los términos "Constitución” y "soberanía”, d) el despegue del Derecho Internacional de los

38 Según Carl Schmitt, lo cual nos parece acertadísimo, la palabra "reforma constitucional" (revisión) es inexacta porque no se trata de reformas de la Constitución misma, sino tan sólo de las determinaciones legal-constitucionales. Sin embargo, recomienda conveniente consignar la expresión por ser usual hoy.

39 Una visión completa y exhaustiva se puede consultar en Javier Pérez Royo: La reforma de la Constitución, Publicaciones del Congreso de los Diputados, Madrid, 1987. Del mismo autor se puede revisar los comentarios que realiza a los artículos 166, 167, 168 y 169 de la Constitución de España de 1978, en Oscar Alzaga Villaamil: Comentarios a la Constitución española de 1978, t. XII, Cortes Generales-Editoriales de Derecho Reunidas, Madrid, 1999, págs. 413-513. También, vid. Pablo Pérez Tremps: "El alcance jurídico y político de la primera reforma constitucional en España", en AA.VV. Homenaje a Joaquín Tomás Villarroya, t. II, Generalitat Valenciana, Valencia, 2000, págs. 873-888, en especial el desarrollo de la función que le tocó desempeñar al Tribunal Constitucional en su día. 
Esta obra forma parte del acervo de la Biblioteca Jurídica Virtual del Instituto de Investigaciones Jurídicas de la UNAM

derechos humanos, y como tal, el reconocimiento y cumplimiento de los Estados-parte de los tratados, pactos, protocolos, convenciones o instrumentos donde se reafirman en definitiva, el principio de dignidad de la persona humana como el valor moral más importante que tiene el hombre, y e) la función creadora del juez constitucional, sobre la base de la actividad jurisdiccional que le toca desarrollar, mediante la integración y la creación (iuris dictio) del Derecho.

6. En buena medida, el principio democrático de la participación popular como basamento en los procesos de reforma constitucional, mejor dicho, la participación del pueblo (como titular del poder constituyente) es fundamental, ora en el momento de la iniciativa, ora en el momento de la ratificación a través del referéndum, sin trastocar el entramado organizativo.

7. Finalmente, parafraseando a José Ortega y Gasset: "Si las constituciones deben ser como el galgo, o sea piel y huesos, ¿a qué llenarlas de tejido adiposo?". Tal aserto es válido al momento de llevar adelante el procedimiento de la reforma constitucional, y como consecuencia de ello afianzarse el sentimiento constitucional (Verfassungsgefühl).

\section{APÉNDICE. LA RECIENTE REFORMA GONSTITUCIONAL EN GUBA DEL 26 DE JUNIO DE 2002 (UN CASO SINGULAR) ${ }^{40}$}

Un caso bastante especial es el que nos ofrece el modelo de reforma adoptado por Cuba no hace sino unos pocos meses. En efecto, una rápida ojeada de los contenidos que se propugna a través de la consabida Ley de Reforma nos permite apreciar que dicho país ha incorporado a sus técnicas reformatorias las llamadas cláusulas pétreas o de intangibilidad, disposiciones que como bien se sabe, apuntan a garantizar un estado de invulnerabilidad o irreversibilidad en los contenidos constitucionales. Prueba irrefutable de que dicho esquema es adoptado por el modelo en mención se corrobora desde la sola

40 Acerca de los textos constitucionales en el devenir de su historia, vid. Andrés $\mathbf{M}^{\mathrm{a}}$. Lazcano y Mazón: Las constituciones de Cuba, Ediciones Cultura Hispánica, Madrid, 1952. Antecede Prólogo de Manuel Fraga Iribarne; y Constituciones cubanas desde 1812 hasta nuestros días, edición e introducción de Leonel-Antonio de la Cuesta y recopilación bibliográfica de Rolando Armando Alum Linera, Ediciones Exilio, New York, 1974. La Constitución de 1901 se puede consultar también en Constituciones de Europa y América, t. II, selección de textos vigentes, traducción y notas de Nicolás Pérez Serrano y Carlos González Posada, Librería General de Victoriano Suárez, Madrid, 1927, págs. 39-75. Antecede Estudio preliminar de Adolfo G. Posada. 
Esta obra forma parte del acervo de la Biblioteca Jurídica Virtual del Instituto de Investigaciones Jurídicas de la UNAM

supresión a toda referencia de las llamadas reformas totales o parciales originalmente reconocidas como opciones modificatorias en el texto primigenio del artículo 137 de la Constitución cubana y su sustitución por un texto genérico, que a pesar de reconocer la capacidad reformatoria, la somete a evidentes condicionamientos.

Si cabe hablar así para el nuevo texto, queda claro que si bien la Constitución puede ser reformada por la Asamblea Nacional del Poder Popular mediante acuerdo adoptado, en votación nominal, por una mayoría no inferior a las dos terceras partes del número total de sus integrantes, tal procedimiento de ninguna forma puede recaer sobre el sistema político, económico y social, cuyo carácter irrevocable ha quedado establecido en el artículo 3 del Capítulo I. Dicho sea de paso, tampoco y por otra parte se puede aventurar una reforma cuando ésta pretenda desconocer la prohibición de negociar acuerdos bajo agresión, amenaza o coerción de una potencia extranjera.

Que, como complemento a lo dicho, la Ley de Reforma haya establecido que: "El socialismo y el sistema político y social revolucionario... probado por años de heroica resistencia frente a las agresiones de todo tipo y la guerra económica de los gobiernos de la potencia imperialista más poderosa que ha existido... es irrevocable, y Cuba no volverá jamás al capitalismo" (adición al texto del artículo 3) o que: "Las relaciones económicas, diplomáticas y políticas con cualquier Estado no podrán ser jamás negociadas bajo agresión, amenaza o coerción de una potencia extranjera" (adición al texto del artículo 11); no hace sino reflejar, al margen del calibrado matiz ideológico (explicado por lo demás, dadas las peculiares características gubernamentales de dicho país) una férrea voluntad de dotar a la Constitución cubana de mecanismos que aseguren su pervivencia de fondo por encima de eventuales procedimientos de modificación futura.

$\mathrm{Si}$, en todo caso, la opción acogida no es practicable - engañosa, por tanto, sino errónea- dependerá en buena medida no sólo de la existencia de mecanismos jurídicos complementarios (un eventual control constitucional de las reformas, hasta hoy inexistente en dicho país) sino de la propia concepción de soberanía popular que a futuro se maneje. Sin embargo eso es algo en lo que por ahora no se puede hacer mayores especulaciones, salvo las que aparecen objetivamente en el documento examinado.

He aquí el texto:

LEY DE REFORMA GONSTITUGiONAL DE GUBA DEL 26 DE JUNIO DE 2002

Ricardo Alarcón de Quesada, presidente de la Asamblea Nacional del Poder Popular 
Esta obra forma parte del acervo de la Biblioteca Jurídica Virtual del Instituto de Investigaciones Jurídicas de la UNAM

HAGO SABER: que la Asamblea Nacional del Poder Popular en Sesión Extraordinaria celebrada el día 26 del mes de junio del 2002, en votación nominal, conforme a las reglas que establece en su Capítulo XV, Artículo 137, la Constitución de la República, adoptó por unanimidad el Acuerdo No. - mediante el cual habilitó la siguiente Ley de Reforma Constitucional:

POR CUANTO: El pueblo de Cuba, titular del poder soberano del Estado y por ende del poder constituyente de la nación, que se traduce en la Constitución vigente cuyo anteproyecto original, discutido y analizado por millones de personas que aportaron sus ideas y modificaciones al texto presentado, posteriormente aprobada en referendo nacional mediante el voto libre, directo y secreto del $97,7 \%$ de los electores que acudieron a las urnas y proclamada el 24 de febrero de 1976.

POR GUANTO: El pueblo de Cuba, en un proceso plebiscitario popular, puesto de manifiesto en la Asamblea Extraordinaria de las direcciones nacionales de las organizaciones de masas, actos y marchas a todo lo largo y ancho del país, donde participaron más de nueve millones de personas y luego mediante la firma pública y voluntaria de 8198237 de electores, han solicitado a la Asamblea Nacional del Poder Popular reformar la Constitución de la República.

POR TANTO: La Asamblea Nacional del Poder Popular, expresando la voluntad del pueblo de Cuba y en uso de la potestad que le confiere el Artículo 70 y en correspondencia con el inciso a) del Artículo 75 y el Artículo 137, todos de la Constitución de la República, acuerda la siguiente:

LEY DE REFORMA CONSTITUCIONAL

Artículo 1: Se modifica el Capítulo I, Fundamentos Políticos, Sociales y Económicos del Estado del modo que sigue:

a) Adicionar un párrafo al final del Artículo 3.

b) Adicionar un párrafo al final del Artículo 11.

Los que quedan redactados de la forma siguiente:

Artículo 3.- En la República de Cuba la soberanía reside en el pueblo, del cual dimana todo el poder del Estado. Ese poder es ejercido directamente o por medio de las Asambleas del Poder Popular y demás órganos del Estado que de ellas se derivan, en la forma y según las normas fijadas por la Constitución y las leyes.

Ricardo Alarcón leyó el proyecto que fue aprobado en la sesión extraordinaria.

Todos los ciudadanos tienen el derecho de combatir por todos los medios, incluyendo la lucha armada, cuando no fuera posible otro recurso, 
Esta obra forma parte del acervo de la Biblioteca Jurídica Virtual del Instituto de Investigaciones Jurídicas de la UNAM

contra cualquiera que intente derribar el orden político, social y económico establecido por esta Constitución.

El socialismo y el sistema político y social revolucionario establecido en esta Constitución, probado por años de heroica resistencia frente a las agresiones de todo tipo y la guerra económica de los gobiernos de la potencia imperialista más poderosa que ha existido y habiendo demostrado su capacidad de transformar el país y crear una sociedad enteramente nueva y justa, es irrevocable, y Cuba no volverá jamás al capitalismo.

Artículo 11.- El Estado ejerce su soberanía:

a) sobre todo el territorio nacional, integrado por la Isla de Cuba, la Isla de la Juventud, las demás islas y cayos adyacentes, las aguas interiores y el mar territorial en la extensión que fija la ley y el espacio aéreo que sobre éstos se extiende;

b) sobre el medio ambiente y los recursos naturales del país;

c) sobre los recursos naturales, tanto vivos como no vivos, de las aguas, el lecho y el subsuelo de la zona económica marítima de la República, en la extensión que fija la ley, conforme a la práctica internacional.

La República de Cuba repudia y considera ilegales y nulos los tratados, pactos o concesiones concertados en condiciones de desigualdad o que desconocen o disminuyen su soberanía y su integridad territorial.

Las relaciones económicas, diplomáticas y políticas con cualquier otro Estado no podrán ser jamás negociadas bajo agresión, amenaza o coerción de una potencia extranjera.

Artículo 2: Se modifica el Capítulo XV, Reforma Constitucional, en la forma siguiente:

a) Suprimir en el Artículo 137, primer párrafo, las palabras: “...total o parcialmente...” y en el segundo párrafo, las palabras: “...es total o...”.

b) Adicionar al final del primer párrafo del Artículo 137: “...excepto en lo que se refiere al sistema político, económico y social, cuyo carácter irrevocable lo establece el Artículo 3 del Capítulo I, y la prohibición de negociar acuerdos bajo agresión, amenaza o coerción de una potencia extranjera".

El cual queda redactado de la manera que sigue:

Artículo 137.- Esta Constitución solo puede ser reformada por la Asamblea Nacional del Poder Popular mediante acuerdo adoptado, en votación nominal, por una mayoría no inferior a las dos terceras partes del número total de sus integrantes, excepto en lo que se refiere al sistema político, económico y social, cuyo carácter irrevocable lo establece el Artículo 3 del Capítulo I, y la prohibición de negociar acuerdos bajo agresión, amenaza o coerción de una potencia extranjera. 
Esta obra forma parte del acervo de la Biblioteca Jurídica Virtual del Instituto de Investigaciones Jurídicas de la UNAM

Si la reforma se refiere a la integración y facultades de la Asamblea Nacional del Poder Popular o de su Consejo de Estado o a derechos y deberes consagrados en la Constitución, requiere, además, la ratificación por el voto favorable de la mayoría de los ciudadanos con derecho electoral, en referendo convocado al efecto por la propia Asamblea.

Artículo 3 : Adicionar al final del texto constitucional, luego del Capítulo XV, Artículo 137, una Disposición Especial, que exprese lo siguiente:

DISPOSICIÓN ESPECIAL.- El pueblo de Cuba, casi en su totalidad, expresó entre los días 15 y 18 del mes de junio del 2002, su más decidido apoyo al proyecto de reforma constitucional propuesto por las organizaciones de masas en asamblea extraordinaria de todas sus direcciones nacionales que había tenido lugar el día 10 del propio mes de junio, en el cual se ratifica en todas sus partes la Constitución de la República y se propone que el carácter socialista y el sistema político y social contenido en ella sean declarados irrevocables, como digna y categórica respuesta a las exigencias y amenazas del gobierno imperialista de Estados Unidos el 20 de mayo del 2002.

Todo lo cual fue aprobado por unanimidad, mediante el Acuerdo No. - adoptado en sesión extraordinaria de la V Legislatura, celebrada los días 24, 25 y 26 del mes de junio del 2002.

\section{DISPOSICIONES FINALES}

PRIMERA: Teniendo en cuenta las modificaciones realizadas por esta Ley de Reforma Constitucional, corríjase en lo pertinente e imprímase íntegramente en un solo texto con carácter oficial la Constitución de la República de Cuba con las reformas aquí aprobadas y en el correspondiente texto único consígnese las fechas y demás datos de la presente Reforma.

SEGUNDA: Se derogan cuantas disposiciones legales se opongan al cumplimiento de lo establecido en la presente Ley.

TERCERA: Esta Ley de Reforma Constitucional comenzará a regir a partir de la fecha de su publicación en la Gaceta Oficial de la República.

Dada en la Sala de Sesiones de la Asamblea Nacional del Poder Popular, Palacio de las Convenciones, Ciudad de La Habana, a los 26 días del mes de junio del 2002, "Año de los Héroes Prisioneros del imperio". 
Esta obra forma parte del acervo de la Biblioteca Jurídica Virtual del Instituto de Investigaciones Jurídicas de la UNAM

\title{
¿NUEVA GONSTITUGIÓN PARA MÉXICO?
}

\author{
Francisco José PAOLI BOLIO*
}

\begin{abstract}
SuMARIO: I. Opiniones divididas sobre una nueva Constitución. II. Situación de México a casi 100 años de 1917. III. Referendum constitucional, constituyente y nueva Constitución.
\end{abstract}

\section{OPINIONES DIVIDIDAS SOBRE UNA NUEVA CONSTITUCIÓN}

A punto de celebrar el centenario de la Constitución que fue puesta en vigor el 5 de febrero de 1917, miles de ciudadanos nos preguntamos si esa Ley Fundamental sigue vigente, o requiere una revisión integral que nos conduzca a una nueva. Las opiniones están divididas y me temo que son más los que opinan que la Constitución de 1917 no debe ser sustituida por otra, lo que no quiere decir que se oponen a que sea revisada integralmente. Porque se le han hecho en estos 99 años, más de seiscientas reformas ${ }^{1}$, que la han transformado sustancialmente. No pocos piensan que tantas reformas, muchas de ellas inconexas, la han deformado y planteado normas que se contradicen con otras; que actualmente tenemos una Constitución contrahecha. Hay quienes piensan que con varios de los cambios e interpretaciones de la Suprema Corte, más el papel que han jugado las leyes generales que son válidas en todo el territorio nacional, lo que tenemos virtualmente es una nueva Constitución². Otros más consideran que aunque les parece positiva la idea hacerle una revisión y cambio integral, esto será imposible, ya

* Investigador del Instituto de Investigaciones Jurídicas de la UNAM.

1 En la ponencia que presentó en el Congreso el Dr. Héctor Fix Fierro, reportó que se le había hecho hasta principios de Febrero de 2016, 696 reformas. Además informó que una tercera parte de ellas se habían hecho en los dos últimos períodos de gobierno, es decir en 9 años.

2 Esto sostuvo Sergio López Ayllón, en su ponencia. 
Esta obra forma parte del acervo de la Biblioteca Jurídica Virtual del Instituto de Investigaciones Jurídicas de la UNAM

que las distintas fuerzas políticas y factores reales de poder ${ }^{3}$ no se pondrán de acuerdo. Hay también que temen que algunas reivindicaciones fundamentales, como los derechos de los trabajadores y campesinos, logradas en la Constitución del '17, podrían cancelarse en una nueva Constitución, por lo cual prefieren no tocar la vigente, aún sabiendo de todas las contradicciones que contiene y sus carencias o insuficiencias para defender los derechos humanos y los derechos políticos en nuestros días.

Hay pues, una fuerte interrogante en diversos sectores de la sociedad mexicana que dudan de la viabilidad de una reforma integral de la Constitución, aunque por distintas razones.

En este contexto contradictorio, se nos presenta el trabajo académico preparado por los doctores Diego Valadés y Héctor Fix Fierro, Constitución Política de los Estados Unidos Mexicanos, Texto reordenado y consolidado. En él se propone de manera inteligente y fundamentada, una vía para hacer esa revisión integral y sistemática, que nos conduzca a un texto en el que se eviten disposiciones que aparecen más de una vez, actualizar las referencias que se hacen algunos órganos que han cambiado de nombre, enviar a Leyes de Desarrollo Constitucional, los artículos que tienen largas disposiciones de carácter reglamentario, además de reordenar las normas reubicándolas en el artículo, apartado, fracción o párrafo que resulte más conveniente desde un punto de vista sistemático y técnico, sin alterar su redacción y finalmente consolidar el texto.

El trabajo de Diego Valadés y Héctor Fix Fierro ha sido expuesto y comentado en distintas mesas, por lo que yo haré sólo algunos comentarios al respecto:

1.1 No sé si los autores lo hicieron ante el cúmulo de dificultades y oposiciones para hacer un cambio integral de la Constitución, a través de un constituyente. A mí me parece que puede ser visto como un trabajo que abre sutilmente el camino para un constituyente. Esto sólo puede ocurrir si la situación social, económica y política, nos lleva a una crisis precipitante del sistema político.

1.2 Es a mi juicio un trabajo preparatorio serio y detallado, que considera y asume las reivindicaciones, derechos, criterios y directivas fundamentales que constituciones mexicanas anteriores han hecho, lo que me parece muy valioso, porque como dice Zagrebelsky "La historia constitucional es cambio, es contingencia política, es acumulación de la experiencia del pasado en el presente, es realidad social, es relación entre el pasado y el futuro, es

3 Así los llamó Ferdinand Lassalle en el siglo XIX. 
Esta obra forma parte del acervo de la Biblioteca Jurídica Virtual del Instituto de Investigaciones Jurídicas de la UNAM

movimiento de sujetos a priori indefinibles, es imprevisibilidad de problemas y espontaneidad de soluciones." Porque muchos ciudadanos y buen número de juristas, consideramos que no se debe prescindir de nuestro pasado constitucional, por defectuosas que hubieran sido nuestras Leyes fundamentales. Es necesario reconsiderarlas, para mantener no pocos de sus elementos si calculamos que nos pueden servir para lidiar con el futuro. También nos muestran en su trabajo estos dos investigadores del derecho que tenemos que filtrarlas, actualizarlas y quitarles el peso muerto que podamos advertir, así como derogar las normas que sean claramente obsoletas, evitar las repeticiones y darles sentido contemporáneo y proyección al futuro.

1.3 La presentación del trabajo como un estudio académico, solo acepta objeciones en esa dimensión, lo cual me parece una buena táctica. Pero como es fácil interpretar que el trabajo también tiene una intención política: abrir la puerta para hacer una Constitución moderna, con una estructura coherente y normas planteadas sistemáticamente, que recoja los derechos humanos de primera, segunda y tercera generación, mantenga la división de poderes y agregue posibilidades de colaboración entre órganos de las esferas ejecutiva y legislativa, establezca claramente principios y criterios para organizar y conducir la economía, la sociedad y la lucha por el poder refuerce la defensa de las personas y sus comunidades más básicas como son las familias y las escuelas. Si esto es como yo imagino un movimiento táctico que tiene por detrás una estrategia de cambio constitucional mayor, me parece que el planteamiento que sigue, es el del planteamiento abierto para preparar una nueva Constitución. Y en ese paso, no puede brincarse el establecimiento de un constituyente electo por los ciudadanos, con el abierto propósito para hacer esos cambios. Porque ciertamente las normas tienen un sentido que se explica por las circunstancias en las que se crea. Y es claro para todos que esas no son las que tuvieron los constituyentes de 1857, ni las 1917, ni las de muchas de las reformas posteriores. Las reformas constitucionales de 2011 , que reivindican los derechos humanos, serían claramente algunas de las que deberán inscribirse en una nueva Constitución.

1.4 Los juristas Valadés y Fix Fierro, agregan en su muy completo ejercicio académico, la conveniente existencia y utilización de Leyes de Desarrollo Constitucional, para incorporar disposiciones de tipo reglamentario que se encuentran inadecuadamente en la CPEUM actual. Esta es una propuesta clave de técnica jurídica, que puede, y a mi juicio debe, llevar a cabo el actual poder reformador de la Constitución. 
Esta obra forma parte del acervo de la Biblioteca Jurídica Virtual del Instituto de Investigaciones Jurídicas de la UNAM

\section{SituAaión DE MÉXICO A CASI 100 AÑOS DE 1917}

El Estado mexicano vive el momento más corrupto de su historia. Por todos lados surgen evidencias o indicios de esa descomposición metastásica, que llega masivamente a todos los niveles de la administración pública, y que también es propiciada desde muchos ámbitos de la actividad privada, para obtener de manera indebida, contratos, permisos, concesiones, exenciones y privilegios que otorga el Estado. Esta situación en la que un día sí y otro también aparecen huellas de conflictos de interés, que son sepultados o velados, por las propias instancias de la administración pública y de la administración de justicia que debieran denunciarlos y sancionarlos.

La mayor parte de las personas en México no confía en buena parte de sus instituciones, públicas y privadas, como han mostrado diversos sondeos nacionales e internacionales. Las instituciones públicas se han debilitado mucho, especialmente las encargadas de perseguir a los delincuentes y administrar justicia. Todos los días aparecen en los medios informativos, indicios y hasta pruebas de que, tanto dichas instituciones como la administración pública en sus tres órdenes o niveles, son incapaces de cumplir cabalmente con su cometido. También tenemos claro los mexicanos que si no se entrega dinero o bienes a los funcionarios y empleados públicos, los asuntos no caminan. Por otra parte, las grandes empresas y sindicatos de entidades públicas, disfrutan de un tratamiento de excepción y no les cobran los impuestos o derechos que debieran, de acuerdo con la ley, o bien, se les devuelven millones de pesos de impuestos que cubrieron, pero que, poco tiempo después, les retornan. El Estado en este largo y progresivo proceso de corrupción, ha ido creando regímenes de excepción que protegen a personas y grupos privilegiados, con el consecuente descuido y abandono de los asalariados y las pequeñas y medianas empresas.

Las condiciones en las que vivimos los habitantes de México es tan grave, tan inquietante, tan desesperada en muchos casos, que me atrevo a sostener que están "madurando los tiempos", para proponer un cambio integral de la Constitución Política, que permita recrear confianza, con nuevas instituciones desde las que se puedan atacar de raíz los problemas más graves que está padeciendo nuestra sociedad. Se que la creación de una nueva Ley Fundamental que oriente con un nuevo espíritu -como podría decir Montesquieu- la vida social, económica, política y cultural del país, no es suficiente para resolver la crisis por la que atravesamos. Que deben cambiarse muchas cosas en las relaciones económicas y sociales, en la cultura, en el sistema educativo, en la administración de justicia, en el sistema 
Esta obra forma parte del acervo de la Biblioteca Jurídica Virtual del Instituto de Investigaciones Jurídicas de la UNAM

de seguridad pública, en las relaciones que sostenemos con diversos países; particularmente con Estados Unidos de América, país con quien tenemos el mayor intercambio comercial, y al que migra la mayor parte de los mexicanos; y también el mercado más grande de fármacos, de armas y de personas del planeta, que estimula la existencia de un crimen organizado que se ha potenciado enormemente y que pone en jaque, diariamente, a los tres órdenes de gobierno, penetra las policías, compra jueces, oficiales de las fuerzas armadas, lava dinero utilizando a un gran número de empresarios nacionales y de otros países, promueve nombramientos de funcionarios en los tres órdenes de gobierno, impulsa candidatos a puestos de elección popular y cuenta con medios de transporte terrestre, aéreo y marítimo, de comunicación e inteligencia; y dispone de una tremenda capacidad de fuego con la que enfrenta cotidianamente a nuestras fuerzas armadas y amedrenta a nuestra población.

Tal vez la situación en la que vivimos no sea todavía tan crítica como la que provoca una revolución. No es la situación de principios de los años cincuenta en el siglo XIX cuando se restableció la Constitución federal de 1824 y se convocó a un constituyente que elaboró la gran Constitución demoliberal mexicana. No se si la lucha armada que tuvimos entre 1910 y 1915, que dio lugar a la convocatoria para hacer una constitución nueva en 1916, era una situación más grave o igual de grave que la que estamos viviendo. Pero si sé que tenemos más de cien mil muertos y desaparecidos, que la mitad de los mexicanos viven en distintas dimensiones de pobreza; que la que experimentamos es suficientemente grave como para dar una sacudida a las instituciones, convocando a un constituyente que las transforme y, sobre todo, que convoque el renacimiento de la confianza ciudadana como lo hizo el Constituyente de 1916-1917 en Querétaro.

También estoy convencido de que estas convocatorias no pueden ser hechas por un ejercicio técnico. Se que para un buen número de personas, no hemos alcanzado el nivel más alto de crisis que plantee en forma muy clara la necesidad de transformación de las instituciones con las que hoy vivimos. Esta claro que muchas de ellas no funcionan para lo que fueron creadas o funcionan mal, porque han sido obstruidas por la corrupción y manipuladas por los poderes fácticos, nacionales e internacionales, pero que también han sido bloquedas porque no están diseñadas para conducir la vida social, económica y política que se mueve en una pluralidad muy amplia y que exige la creación de órganos del Estado con capacidad para incluir a la pluralidad de comunidades, empresas, esfuerzos educativos, atender sus demandas y promover los proyectos científicos y tecnológicos que impulsen el progreso 
Esta obra forma parte del acervo de la Biblioteca Jurídica Virtual del Instituto de Investigaciones Jurídicas de la UNAM

general de los mexicanos. Para esto si es muy útil el ejercicio académico que han hecho juristas como Valadés y Fix Fierro.

Aún sabiendo que es muy difícil arribar a una nueva Constitución con las características descritas, me atrevo a proponer esa empresa pública fundamental, como lo han hecho otros. Esta puede ser una de las medidas que todavía está en nuestras manos y que puede inspirar al pueblo de México, a caminar con más confianza hacia las metas que le proponga un conjunto de constituyentes de alta calidad moral. Ellos deben analizar la situación actual, debatir entre sí y formular la propuesta de nueva Norma Suprema para la nación mexicana. No sería una medida suficiente para salir de la crisis como he sostenido antes, pero puede permitirnos abrir un nuevo camino de progreso realizado en paz, dentro de un Estado de derecho, que es una de nuestras mayores carencias.

También es importante hacer notar que una reforma integral de la Constitución, puede hacerse con menos dificultades en un momento en que la crisis no es todavía tan rotunda, en un momento en que las instituciones no se han llegado al total desprestigio y la total impotencia.

Así pues, ante esta situación tan grave me atrevo a proponer la preparación de una nueva Constitución Política, que surja de una revisión integral de la actual. Esto ocurrió en 1916, cuando Venustiano Carranza y su equipo de gobierno propuso al país la formación de un Constituyente y presentó a éste un proyecto de Constitución que partía de postulados hechos en la anterior de 1857, en cuyo nombre se levantó en armas. El Primer Jefe del Ejército Constitucionalista, no tenía la intención de que se hiciera una Norma Fundamental, en la que se incorporaran los derechos de los trabajadores del campo y de la ciudad, ni algunos otros. Pero los constituyentes que venían de los campos revolucionarios, se impusieron al grupo conservador y lograron una Constitución que ha sido ejemplo para muchas naciones.

\section{REFERÉNDUM CONSTITUCIONAL, CONSTITUYENTE Y NUEva CONSTITUCiÓN}

Argumento brevemente ahora varios puntos que explican un poco más esta propuesta:

3.1 Una nueva Constitución puede provocar un cambio amplio en la sociedad y el Estado mexicanos. También puede promover el entusiasmo social para superar la angustiosa situación en la que vivimos, tras una etapa larga de violencia sangrienta, miles de muertos y desaparecidos y ha ocurrido en la práctica, materialmente, la destrucción de muchas instituciones 
Esta obra forma parte del acervo de la Biblioteca Jurídica Virtual del Instituto de Investigaciones Jurídicas de la UNAM

públicas que estaban diseñadas para lograr el bien común, y se han reconvertido regresivamente en protectoras de intereses parciales.

3.2 Preparar una nueva Constitución de la República y que en ella se establezca una nueva forma de gobierno. Una que sustituya al desgastado y monopólico sistema presidencialista, por otro más cooperativo en el que distintas fuerzas de la sociedad se empoderen, participen más ampliamente en la deliberación y se hagan cargo de las decisiones las decisiones fundamentales. Estas fuerzas positivas pueden fomentar la producción amplia de bienes y servicios básicos para el desarrollo de la vida humana en forma digna y promover la distribución más equitativa de la riqueza. En los tiempos que corren la han impulsado algunos lideres sociales como Javier Sicilia, el obispo Raúl Vera y un conjunto de constitucionalistas que ven en una nueva Carta Fundamental, la unificación de un país disperso y la reconstrucción de un tejido social solidario, que se ha destruido en gran medida.

3.3 Insisto ahora en la medida siguiendo el camino de una reforma a la CPEUM, que parta de la realización de un referendo en el que la ciudadanía decida si se hace una revisión integral de esa norma fundamental. Si ese referendo aprueba por mayoría absoluta la revisión completa de la Norma Fundamental, se podría convocar a la elección de un constituyente originario. No se si se pueda determinar que los "tiempos están maduros" para hacer un cambio mayor a la Constitución, como sugiere el jurista de profundidad como Gustavo Zagrebelsky. Se trata de una interpretación sobre si hemos alcanzado la madurez de los tiempos que nos abra la puerta a los cambios profundos que requiere nuestro sistema político y nuestra golpeada sociedad. Mi propuesta tiene como motivación la confianza, utópica si ustedes quieren, de que el referendo constitucional, permitiría a la ciudadanía activarse y pensar bien si decide o no la promoción de un constituyente, con un mandato expreso para debatir sobre una nueva Constitución.

3.4 El Constituyente debiera ser electo por los ciudadanos en forma directa y funcionar por un período breve de no más de seis meses, sus integrantes no recibirían dietas pingues como las que tienen actualmente nuestros legisladores, sino que trabajarían con remuneraciones modestas como las que puede recibir un trabajador calificado; y tendrían que ser electos a partir de candidaturas independientes, entre personas que reúnan requisitos de alta calidad moral y prestigio como buenos ciudadanos ${ }^{4}$. Considero que los partidos políticos como tales no debieran participar como tales en la elección de los constituyentes, aunque los integrantes de los partidos, en

4 Me lleva a esta propuesta el enorme desprestigio en el que han caído los partidos políticos. 
Esta obra forma parte del acervo de la Biblioteca Jurídica Virtual del Instituto de Investigaciones Jurídicas de la UNAM

tanto ciudadanos, podrían y deberían participar. La campañas se desarrollarían fundamentalmente con debates que se tendrían en los medios masivos de información en tiempos de Estado y en medios públicos. Los debates podrían desarrollarse previamente por dos meses en un período preconstituyente en las entidades federativas, para que los ciudadanos residentes en ellas pudieran tener elementos para elegir a los diputados constituyentes de cada una.

3.5 Propongo que se diseñe un constituyente pequeño de ciento cincuenta integrantes ${ }^{5}$. Las asambleas demasiado amplias no son propicias ni para la deliberación ni para llegar a acuerdos después de los debates, tanto en comisiones, como en el pleno.

3.6 Deliberar sobre una nueva Constitución y prepararla, puede permitir que se vislumbren salidas a los problemas graves que padecemos, se estimulen fórmulas para el crecimiento económico, para instituir nuevos sistemas: educativo, de salud, de partidos y de justicia, creando estímulos para la participación ciudadana, la auditoría social y la creación de un sistema eficaz de rendición de cuentas.

3.7 Coincido con la propuesta de Jaime Cárdenas, planteada en su ensayo publicado en la revista Cuestiones Constitucionales 6 , "El procedimiento para la revisión integral de la Constitución de 1917". Para precisar, coincido en el sentido de que además del referéndum previo al Constituyente, deberá hacerse otro una vez aprobado el proyecto por el legislador, para confirmar su entrada en vigor y todo ello hecho bajo el principio de que el pueblo tiene en todo tiempo el derecho de darse su Norma Suprema y su gobierno. Este proceso constituyente, autorizado por una reforma constitucional que apruebe el referendo constitucional, será seguido por un proceso instituyente integral, y podría llevarse a cabo entre abril y septiembre del año 2017, para estar en condiciones de promulgar la nueva Constitución hacia el mes de noviembre de ese año. Empezaríamos 2018 con un nuevo marco jurídico moderno y tendríamos la realización de unas elecciones generales que nos dotaran de nuevas autoridades y nuevas posibilidades de desarrollo.

5 Sugiero un criterio para elegir un pequeño constituyente, basado en población representada, donde se elegiría un candidato por cada dos distritos electorales. Esto daría la cifra de 150 constituyentes.

$6 \quad N^{\circ} 12$, del año 2011. Suscribo en buena medida la propuesta de Jaime Cárdenas. Difiero en algunas cosas, como la del número de constituyentes. También en la participación de los partidos en su elección, porque entre otras instituciones, los partidos y su financiamiento, tienen que ser definidos de una manera distinta en la nueva Constitución. 
Esta obra forma parte del acervo de la Biblioteca Jurídica Virtual del Instituto de Investigaciones Jurídicas de la UNAM

\title{
LAS INEFICACIAS LEGALES Y POLÍTICAS DEL HÍPER-REFORMISMO CONSTITUGIONAL MEXICANO
}

\author{
Francisca POU GIMÉNEZ*
}

\begin{abstract}
SUMARIO: I. Introducción. II. Conceptualización de las ineficacias jurídicas y politicas. III. Las ineficacias jurídicas de la constitución mexicana. IV. Las ineficacias políticas de la Constitución mexicana. V. Lo que hay por delante. VI. Referencias bibliográficas.
\end{abstract}

\section{INTRODUCGIÓN}

Me da gusto presentar en este foro trabajo mío reciente, todavía en desarrollo, que explora las relaciones entre patrones de cambio constitucional y la noción de eficacia (o ineficacia) constitucional. Como sabemos, la Constitución mexicana del 1917 se caracteriza tanto por ser una de las más longevas del mundo, como por haber sido sometida a un proceso de incesantes reformas - graduales, incrementales, de muy distinto contenido y alcance, pero con un impacto conjunto enorme- - Y como han destacado Casar y Marván ${ }^{1}$, el reformismo constitucional mexicano no sólo no se detiene, sino que se intensifica todavía a partir de los años 90 con la llegada del pluralismo político a nuestras cámaras de representación política. En un seminario reciente que hicimos sobre este mismo tema en la UNAM, Andrea PozasLoyo propuso llamar a este patrón "híper-reformismo" y yo adopto esta expresión en el análisis que nos ocupa. Tras más de 600 episodios (IIJ-UNAM 2015), este proceso de híper-reforma ha desembocado en un texto muy ex-

* ITAM, Ciudad de México; ponencia presentada en el VII Congreso Nacional de Derecho Constitucional, celebrado en San Luis Potosí del 3 al 5 de febrero de 2015. Agradezco a la Universidad Autónoma de San Luis Potosí, al Instituto de Investigaciones Jurídicas de la UNAM y al Instituto Iberoamericano de Derecho Constitucional la oportunidad de presentar mi trabajo en dicho foro.

1 Casar, María Amparo y Marván, Ignacio (coords.), Reformar sin mayorías. La dinámica del cambio constitucional en México (1997-2012), México, Taurus, 2014, pp. 13-85. 
Esta obra forma parte del acervo de la Biblioteca Jurídica Virtual del Instituto de Investigaciones Jurídicas de la UNAM

tenso, muy complejo, con grandes porciones de regulación extremadamente detallada - del tipo de la que esperaríamos encontrar en un código, no en una constitución - y con previsiones que en muchas ocasiones no guardan la necesaria relación de coherencia, ni desde la perspectiva técnica ni desde la perspectiva sustantiva². Nuestra Constitución de 1917 es, en definitiva, un texto muy sobredimensionado y de muy difícil manejo.

Sin embargo, qué relación tenga este proceso híper-reformista y el texto resultante con la eficacia o la ineficacia de nuestra Constitución del 2016 es una pregunta bastante más específica que no puede abordarse de manera sencilla, pues exige partir de una idea más o menos decantada de lo que uno entiende por "eficacia de la Constitución", y esta decantación tampoco resulta fácil. A mi juicio, parece intuitivamente adecuado partir de la base de que conviene imaginar el concepto de "eficacia constitucional" como un concepto relativamente delgado, que nos permita afirmar, por ejemplo, que una Constitución es eficaz incluso si no tenemos razones para considerarla una constitución suficientemente buena a la luz de ciertos ideales sustantivo-morales. Pero más allá de eso, la construcción de la noción de "eficacia constitucional" se hace extremadamente complicada por las inacabables discusiones que, como se sabe, existen en torno a qué debemos entender por "Constitución" y por los desafíos que plantea la tarea de intentar aterrizar una noción sólida y útil de "eficacia" constitucional ${ }^{3}$

\section{GONGEPTUALIZAGiÓN}

DE LAS INEFICACIAS JURÍDICAS Y POLÍTICAS

Sobre ese trasfondo, en el trabajo tomo la opción de entender "Constitución" como texto supremo con determinada posición jerárquica en el ordenamiento - lo que algunos politólogos han llamado "big C", en oposición a la concepción de Constitución como "small c" que cubriría todas las normas que se ocupan de regular el funcionamiento básico del aparato estatal y sus relaciones con los ciudadanos, aunque para abarcarlas haya que ir fuera y más allá de la Constitución-texto, de la Constitución en ma-

2 Véase Pou Giménez, Francisca, "Las reformas en materia de derechos fundamentales”, en Casar, María Amparo y Marván, Ignacio (coords.), Reformar sin mayorías. La dinámica del cambio constitucional en México, México, Taurus, 2014, pp. 87-137, y Pou Giménez, Francisca, "Constitucionalismo Viejo, nuevo y desatado", en Bonilla, Daniel (ed.), El constitucionalismo en el continente americano, Bogotá, Colombia, Siglo del Hombre Editores (en prensa, 2016).

3 Pozas-Loyo, Andrea, "What constitutional efficacy is not", manuscrito no publicado en poder de la autora, 2015. 
Esta obra forma parte del acervo de la Biblioteca Jurídica Virtual del Instituto de Investigaciones Jurídicas de la UNAM

yúscula ${ }^{4}$ - y construyo una aproximación funcional a la noción de eficacia, en cuyo contexto una Constitución eficaz es una Constitución capaz de desempeñar ciertas funciones jurídicas y políticas básicas. Y distingo dos grandes vertientes de eficacia: la eficacia jurídica y la eficacia política, según nos refiramos a funciones desempeñadas en el contexto del sistema jurídico o en el contexto del sistema político - entendidos como realidades conceptualmente distinguibles, aunque necesariamente imbricadas en el plano de su funcionamiento empírico-.

La noción de eficacia jurídica de la Constitución apela a la idea de que la Constitución es capaz de proporcionar una orientación fundamental acerca de cuáles son las reglas de reconocimiento, cambio y adjudicación que permiten el funcionamiento regular del sistema jurídico como sistema de regulación social distintivo. Desde esta perspectiva, es muy importante entender que el derecho no es un sistema normativo estático - como lo puede ser la moral - sino un sistema dinámico intrínsecamente preocupado no sólo por fijar estándares sustantivos que nos orientan acerca de lo que está prohibido, autorizado u ordenado, sino también por crear los medios para la ejecución, desarrollo, o cumplimiento de este programa sustantivo. De algún modo, el derecho está siempre intrínsecamente preocupado por la espada de Damocles de su potencial ineficacia. Por ello el derecho configura una maquinaria compleja de motivaciones de distinto tipo que prefigura la incidencia en la realidad de las bases sustantivas que lo fundamentan. La Constitución debe contener los aspectos fundamentales de este esquema. Sus previsiones, desde el texto mismo, deben ser capaces de dar a las personas "razones para la acción" 5 y organizar el avance o garantía y cumplimiento del programa sustantivo mediante la acción del poder legislativo, el poder ejecutivo, el poder judicial, las otras estructuras orgánicas que hoy día incluyen los aparatos estatales, y los ciudadanos.

La eficacia política de la Constitución exige que la Constitución sea capaz de organizar la conversación democrática en una sociedad. La democracia constitucional no es un sistema en el que se está discutiendo todo en todo momento. La Constitución marca (o debe marcar) puntos de equilibrio entre las decisiones del pasado, del presente y del futuro; entre las decisiones que competen a todas y cada una de las personas en lo individual, a los grupos en que se integran, a las mayorías políticas; entre el ámbito de lo decidible y lo indecidible, por decirlo invocando la expresión famosa de Fe-

\footnotetext{
4 Elkins, Zachary; Ginsburg, Tom y Melton, James, The Endurance of National Constitutions, Cambridge, MA, Cambridge University Press, 2009.

5 Raz, Joseph, Practical Reason and Norms, Oxford, Oxford University Press, 1999.
} 
Esta obra forma parte del acervo de la Biblioteca Jurídica Virtual del Instituto de Investigaciones Jurídicas de la UNAM

rrajoli ${ }^{6}$. La Constitución decanta también el tipo de asuntos que exigen una discusión democrática más intensa (y para su tratamiento exige mayorías absolutas o calificadas) o más extensas (y requiere la concurrencia de varias mayorías de cuerpos legislativos distintos, o de instituciones mayoritarias y no mayoritarias, o de una consulta a la población mediante referéndum, por ejemplo) o más extendidas en el tiempo (y requiere la consideración repetida de ciertos asuntos antes de que las decisiones puedan adoptarse). Por supuesto ninguno de estos puntos de división o inflexión quedan nítidamente definidos, porque la Constitución plantea siempre desafíos interpretativos importantes, sino que se genera un debate acerca de dónde exactamente se sitúa cada uno de ellos - debate que acaba siendo parte importante de la misma conversación política presidida y organizada desde la Constitución-. La Constitución, entonces, ordena el debate político tanto acerca de las implicaciones de su contenido como acerca de su propia configuración como vehículo y estructura de toma de decisiones, siempre que consiga que los ciudadanos se identifiquen con ella en cuanto a estructura y en cuanto a "mapa" de los confines de lo político - lo cual constituye, también, una manifestación poderosísima de eficacia constitucional-.

Por tanto, dicho en términos sintéticos, la Constitución eficaz es aquella capaz de dar orientación básica a ciudadanos y autoridades públicas acerca de cuáles son las reglas del "juego del derecho" —en oposición a las reglas de la fuerza, o del dinero, por ejemplo - y cuáles son las reglas del "juego de la democracia" - en oposición a las del autoritarismo o la arbitrariedaden una sociedad en particular.

\section{LAS INEFICACIAS JURÍDICAS DE LA CONSTITUCIÓN MEXICANA}

A la vista del esquema analítico anterior, mi trabajo concluye que el híperreformismo mexicano no presenta buen aspecto. Esta Constitución nuestra que, como ha sido recordado en este foro, en algún momento fue pionera y ejemplar en el ámbito mundial, en estos momentos parece enfrentar importantes dificultades.

En el plano de las ineficacias jurídicas, hay que empezar por destacar que la Constitución enfrenta agudos problemas para funcionar como un sistema de motivación de conductas (cuyas piezas otorguen a los individuos razones excluyentes o perentorias para la acción) por motivos que tienen

6 Ferrajoli, Luigi, Democracia y garantismo, ed. de Miguel Carbonell, Madrid, Trotta, 2008. 
Esta obra forma parte del acervo de la Biblioteca Jurídica Virtual del Instituto de Investigaciones Jurídicas de la UNAM

que ver con dificultades de mera ininteligibilidad del texto. Para saber en qué condiciones es constitucional una detención, por ejemplo, el lector de la Constitución tiene que adentrarse en las densísimas previsiones del artículo 16, muchas de las cuales utilizan palabras que le resultan del todo opacas, omitir las que parecen referirse a temas distintos, continuar con la lectura del artículo 17, donde se habla de otra cosa, para llegar al artículo 18, donde de nuevo encuentra previsiones que se refieren al tema. Pero haría mal en desconocer, además, que uno de los artículos transitorios de la Constitución provee que el arraigo (arresto domiciliario bajo tutela del Ministerio Público, antes de que existan cargos penales contra uno), además de poder ser decretado en la hipótesis prevista en el artículo 16 (sospechas de comisión de hechos relacionados con delincuencia organizada), puede ser extendido por el legislador federal a todos los delitos graves. La cantidad de datos y previsiones que es necesario aclarar y tratar de entender para saber quién puede detener a una persona, por qué causas, en qué circunstancias, ante qué autoridades, por cuánto tiempo, en vistas a que el juez tome qué determinaciones, etcétera, es inmenso y presenta desafíos incluso para los abogados más especializados. Y por supuesto, no tener claro algo tan básico como cuáles son las condiciones constitucionales de la detención es estar preparado para tolerar la arbitrariedad en un punto esencial para la existencia de un estado de derecho.

Para saber cuál es el modelo constitucional de regulación de la economía, por su parte - y por poner otro ejemplo - el ciudadano se dirigirá probablemente a los artículos 25 a 28 de la Carta Magna, que en conjunto suman la asombrosa cantidad de 8,551 palabras (más del doble de las que tiene esta ponencia), y después deberá tratar de desentrañar qué implican, en ese ámbito, las numerosísimas previsiones sobre regulación de la competencia y telecomunicaciones y otros aspectos económicos incluidas en los artículos transitorios y, algunas, en el texto del artículo 6 - que contiene regulación relativa a la libertad de expresión y el derecho a la información pero incluye previsiones sobre medios de comunicación, comunicaciones y telecomunicaciones - En definitiva: el desorden, el barroquismo expresivo, la extensión y el lenguaje excesivamente técnico, habitualmente oscuro, de la Constitución del 2016, hace muy difícil desprender de ella razones claras para la acción.

Ello plantea o multiplica las dificultades que el texto ofrece a nivel de aplicación o ejecución legislativa y ejecutiva. El desarrollo legislativo de la Constitución parte siempre en México, por lo que acabamos de decir, de líneas fundantes poco claras, y a menudo exige operar al mismo tiempo 
Esta obra forma parte del acervo de la Biblioteca Jurídica Virtual del Instituto de Investigaciones Jurídicas de la UNAM

sobre el texto de las leyes y sobre el texto mismo de la Constitución (porque la Constitución contiene aspectos regulativos que suelen quedar implicados cuando uno intenta diseñar regulaciones y políticas públicas sobre su base). Las responsabilidades ejecutivas y legislativas que deben emprenderse sobre la base de la Constitución, entonces, tienen un grado de complejidad alto y no será nunca fácil establecer la continuidad que guarden con las previsiones dentro de cuyo marco deben permanecer.

A nivel de garantía judicial, las cosas son todavía más complicadas. Los jueces contemporáneos tienen, como es sabido, una responsabilidad en la generación de normatividad que es mucho más alta que en cualquier otro momento histórico. El derecho contemporáneo deja menos cosas resultas a nivel legislativo y los jueces, que deben proyectar las consecuencias jurídicas de los derechos fundamentales en casos concretos, construyen soluciones jurídicas a partir de los materiales que les parecen aplicables. Los jueces tienen, además, una responsabilidad central en la reconstrucción de la unidad del sistema jurídico, lo cual implica emprender la tarea de elaborar colectivamente - en particular para el caso de los jueces de las cortes supremas o constitucionales que coronan el sistema- ejercicios en los que trate de plasmarse el significado global de la Constitución. En todos los sistemas jurídicos, esta tarea resulta complejizada por la multitud de maneras en que una Constitución puede ser interpretada. El acalorado debate que se desarrolla en todos los países sobre la interpretación de unas u otras previsiones constitucionales, así como la existencia de bibliotecas enteras llenas de reflexión teórica sobre el tema de la interpretación dan fe del desafio que representa involucrarse en ellas desde los tribunales con miras a producir razonamientos jurídicos justificados, revestidos de autoridad y respaldados por la coacción estatal.

Sobre la base de una Constitución como la mexicana del 2016, en su perpetuamente cambiante destino, la dificultad de estas tareas interpretativas se multiplica exponencialmente. En algunas ocasiones - como demuestra la cantidad de horas y esfuerzos que ha dedicado la Corte Suprema a tratar de reconstruir el sistema de fuentes en el área de la Constitución de los derechos después de la reforma de junio de $2011^{7}$ - las tensiones e in-

7 Véase, al respecto, Silva García, Fernando (2014): "Derechos humanos y restricciones constitucionales: ¿reforma constitucional del futuro vs. interpretación constitucional del pasado? (Comentario a la CT 293/2011 del Pleno de la SCJN)", Cuestiones Constitucionales, Revista mexicana de Derecho Constitucional, México, No. 30, enero-julio de 2014; Sánchez Gil, Rubén "Notas sobre la Contradicción de tesis 293/2011", Revista Iberoamericana de Derecho Procesal Constitucional, No. 21, enero-junio de 2014; y Pou Giménez, Francisca "Lo que quisiera que la Suprema Corte hiciera por mí: lealtad constitucional y justicia dialógica en la aplicación 
Esta obra forma parte del acervo de la Biblioteca Jurídica Virtual del Instituto de Investigaciones Jurídicas de la UNAM

coherencias internas ofrecen dificultades no ya solo para determinar lo que la Constitución significa, sino lo que la Constitución es - esto es: existen enormes dificultades para determinar no ya qué significan e implican sus previsiones, sino qué debe contar como "norma constitucional" y qué no-. La Constitución, en conclusión, es muy imperfecta como pieza (fundante y central) de maquinaria legal.

\section{LAS INEFICACIAS POLÍTICAS \\ DE LA CONSTITUCIÓN MEXICANA}

En el plano de las ineficacias políticas, hay también un amplísimo abanico de cosas por comentar. En general, la heterogeneidad y la falta de estructura y claridad del texto proyectan la sensación de que todo es susceptible de ser discutido en cualquier momento. Se renuncia así en México a las ventajas de la "división intergeneracional del trabajo" que la Constitución de algún modo opera ${ }^{8}$. En lugar de experimentar la liberación que representa que ciertas cosas se reciban ya decididas (e incluidas en la Constitución) desde el pasado y que no haya que dedicar tiempo y esfuerzo en pensar cómo emprenderlas - salvo circunstancias especiales -, con la consiguiente posibilidad de poder encauzar todas las energías a la discusión y gestión pública de otras, en México todo parece estar y al mismo tiempo poder desaparecer en cualquier momento. La configuración del texto hace difícil saber qué cosas parecen ser más fundamentales y merecen ser más estables que otras. Ello mismo dificulta enormemente que la ciudadanía pida cuentas a los legisladores sobre la base de la Constitución. Como es sabido, la democracia se define no sólo por ser un sistema en el que el ingreso a ciertas posiciones de autoridad deriva directa o indirectamente de la voluntad popular expresada mediante el voto, sino por ser un sistema en el que estas autoridades escogidas están permanentemente sujetas al escrutinio y la crítica de la ciudadanía. En México, es difícil impulsar estos ejercicios de "accountability" o dación de cuentas sobre la base de la Constitución y es difícil, por consiguiente, empezar siquiera a asentar esta segunda dimensión importantísima de la democracia.

de la 293/2011”, en Sánchez Gil, Rubén y Caballero, José Luis (eds.), Derechos constitucionales e internacionales. Perspectivas, retos y debates, México, Tirant lo Blanch (en prensa).

8 Holmes, Stephen, "El pre-compromiso y la paradoja dela democracia", en Elster, Jon and Slagstad, Rune (eds.), Constitución y democracia, México, Fondo de Cultura Económica, 1988. 
Esta obra forma parte del acervo de la Biblioteca Jurídica Virtual del Instituto de Investigaciones Jurídicas de la UNAM

Otro efecto político de la Constitución que vale la pena identificar es, a mi juicio, el sobre-empoderamiento de los jueces. La heterogeneidad y complejidad del texto constitucional los empodera enormemente porque pueden presentar casi cualquier conclusión como una derivación no irracional de lo que dice el texto constitucional. Y de nuevo, el material que hace posible esto dificulta, por los mismos motivos, un ejercicio ciudadano fuerte de supervisión de la actividad de los jueces. Como la Constitución cambia tanto, además, los tribunales no tienen incentivos, a mi juicio, para invertir tiempo esfuerzo en construir doctrinas jurídicas lo más justificadas posibles, pues saben que la base normativa sobre la que se asientan seguramente cambiará pronto. Y la academia, tampoco tiene incentivos para desarrollar análisis muy exigentes de esas doctrinas judiciales, porque por las mismas razones están destinadas a cambiar pronto... A lo largo de toda la cadena, la impermanencia constitucional genera efectos claramente inclinados en la dirección contraria a la profundización de prácticas que son importantes para la profundización de la democracia.

¿Será, sin embargo, que los momentos políticos generados por los reiterados episodios de reforma proveen en sí mismos suficientes espacios para el desarrollo de un debate político democrático vibrante en torno al contenido de la Constitución? Dada la dinámica política que marca la presentación, discusión y aprobación de las reformas - que fluye sin mayor problema, a pesar de que la fórmula del artículo 135 exige la concurrencia del 2/3 de los miembros presentes de ambas cámaras y la aprobación por la mitad de las legislaturas estatales - desgraciadamente no es así. El proceso de aprobación de reformas en México se aleja en casi todos los aspectos relevantes del tipo de proceso púbico que Ackerman llama "política constitucional" en oposición a la "política ordinaria" - un proceso distintivo singularizado por sus altos niveles de inclusión, participación, deliberación y un especial espíritu de motivación por los asuntos públicos ${ }^{9}$ - Reformar la Constitución en México es legislar por (apenas) otros medios. Las reformas constitucionales son, por ejemplo, tan fácilmente objeto de lobby político como la legislación ordinaria, y a veces la opinión pública "descubre" determinada reforma cuando ya ha sido aprobada. De tanto en tanto, algunos cambios adquieren un perfil más alto - pero justo del mismo modo que algunos proyectos legislativos generan más debate de vez en cuando-. Por supuesto que podríamos considerar que, entonces, hay una ventaja en términos democráticos porque las generaciones presentes tienen en México a la Constitución más en sus manos que lo que suele ocurrir: existiría por consiguiente menos tiranía del pasado sobre el presente.

9 Ackerman, Bruce, We the People, Cambridge, MA, The Belknap Press, Harvard University Press, 1993. 
Esta obra forma parte del acervo de la Biblioteca Jurídica Virtual del Instituto de Investigaciones Jurídicas de la UNAM

Por las mismas razones, sin embargo, el presente cuyas decisiones constriñen (en alguna medida) el futuro no fundamenta su actuar en razones o procedimientos particularmente valiosos. Quizá no hay nada intrínsecamente malo en tener constitucionalismo por medios ordinarios, pero si el sistema político ordinario opera menos que aceptablemente - como se puede argumentar que ocurre en México - no hay motivos para albergar esperanzas respecto de una eventual textura democrática especial de la Constitución.

Como subrayan Elkins et al. ${ }^{10}$ la durabilidad, estabilidad o permanencia de la Constitución - esto es, su grado de rigidez efectiva- puede generar efectos positivos en el sistema político, como el desarrollo de hábitos de obediencia, el refuerzo de los efectos del pre-compromiso en las autoridades públicas (quienes pasan a verse efectivamente constreñidas por reglas que están pensadas y puestas para limitarlos); la posibilidad de gestionar con mayor efectividad los tiempos y los procesos de la política; el desarrollo de instituciones auxiliares que ayudan a cumplir los mandatos constitucionales (algo imposible si la constitución está cambiando todo el tiempo); el progresivo desarrollo del sentimiento de pertenencia a un demos articulado en torno al texto constitucional; el incremento de la previsibilidad, que puede favorecer el desarrollo económico; o los beneficios asociados a tener una "división del trabajo" que empodera a las mayorías políticas del presente al liberarlas de la necesidad de encarar algunos asuntos (que la constitución presenta como pre-decididas en el pasado). En México, resulta claro que ninguna de estas potenciales ventajas se cosecha.

Por los motivos señalados, parece que no queda más remedio que concluir que, tanto por sus rasgos de contenido como por el hecho de estar cambiando continuamente, nuestra constitución del 2016 no parece estar desconectada de las dificultades que actualmente enfrentamos - después de treinta años de haber empezado el camino - para construir un verdadero estado de derecho y para consolidar nuestra inmensamente debilitada democracia. No es que no estemos consiguiendo profundizar o consolidar ciertos procesos a pesar de lo que la Constitución dice, sino que lo que la Constitución dice y contiene se erige en una de las causas por las cuales no lo conseguimos.

\section{LO QUE HAY POR DELANTE}

Por desgracia, el diagnóstico anterior parece arrojarnos a lo que algunos de los participantes en este foro han llamado un escenario de "catastrofismo". Y lo primero que debemos preguntarnos es si no estará entonces im-

10 Elkins, Zachary; Ginsburg, Tom y Melton, James, op. cit., pp. 12-35. 
Esta obra forma parte del acervo de la Biblioteca Jurídica Virtual del Instituto de Investigaciones Jurídicas de la UNAM

pregnado por algo que es bien importante detectar cuando uno hace teoría constitucional y evaluaciones de la realidad sobre su base: si no estará este diagnóstico fundamentado en premisas empíricas y conceptuales sesgadas ab initio, cuyo uso está destinado, por tanto, a proyectar evaluaciones naturalmente peores en ciertos escenarios y naturalmente mejores en otros.

Como han señalado brillantemente varios autores ${ }^{11}$, es muy importante no suscribir sin darnos cuenta narrativas de "fracaso constitucional" basadas con frecuencia en premisas asimétricas sobre el valor de las reglas y las instituciones en unas y otras partes del mundo, que reflejan una economía política del conocimiento jurídico no neutral, y que muestran al constitucionalismo del Sur como "naturalmente" defectuoso y pobre. La discusión teórica sobre reforma constitucional, por ejemplo, parece tomar como "casos naturales" de referencia el constitucionalismo de países del norte como Estados Unidos, España o Alemania, cuando en realidad, contemplados desde una perspectiva comparada, habría que calificarlos más bien de instancias de "hipo-reformismo" - en particular el caso de Estados Unidos.

Pero a mi juicio, incluso si hiciéramos justicia a este reclamo y nos comprometiéramos a construir una vara de medir más equitativamente permeada por las experiencias mayoritarias en el mundo, todavía tendríamos que concluir que la Constitución mexicana del 2016 genera injustificadas ineficacias legales y políticas y opera como un instrumento que dificulta más que facilita la conseción de los objetivos de la Constitución. Por mucho que podamos concluir que la imagen prevaleciente de las dinámicas de reforma debe modificarse para acoger como casos estándar casos que ahora siguen percibiéndose como de reforma muy frecuente, el escenario mexicano actual seguiría dando pie para hablar de híper-reformismo.

La comunidad ciudadana y académica mexicana está empezando a tomar consciencia de esto y por fin se está abriendo un debate acerca de qué caminos podrían explorarse. Entre ellas se cuenta la elaboración de una Constitución nueva, pero también la novedosa propuesta de un grupo de profesores de la UNAM que abogan por una reordenación profunda del texto, complementada por el traslado de varios de sus bloques de previsiones a una nueva fuente jurídica: las leyes de desarrollo constitucional ${ }^{12}$. Cuál sea la viabilidad y deseabilidad de estas propuestas, y cuáles otras valdría la

11 Véase Bonilla Maldonado, Daniel, "La economía política del conocimiento jurídico". Revista de Estudos Empiricos em Direito / Brazilian Fournal of Empirical Legal Studies, Brasil, vol. 2, n. 1, enero 2015, y Esquirol, Jorge, Las ficciones del derecho latinoamericano, Bogotá, Universidad de los Andes, Siglo del Hombre Editores, 2014.

12 IIJ-UNAM, "Constitución Política de los Estados Unidos Mexicanos. Texto reordenado y consolidado", Diego Valadés y Héctor Fix Fierro (coords), México, UNAM, 2015 
Esta obra forma parte del acervo de la Biblioteca Jurídica Virtual del Instituto de Investigaciones Jurídicas de la UNAM

pena ponderar son, sin embargo, preguntas cuyo abordaje dejaremos para otras mesas de este congreso.

\section{REFERENCIAS BIBLIOGRÁFICAS}

Ackerman, Bruce, We the People, Cambridge, MA, The Belknap Press, Harvard University Press, 1993.

Bonilla Maldonado, Daniel, "La economía política del conocimiento jurídico". Revista de Estudos Empíricos em Direito / Brazilian Fournal of Empirical Legal Studies, Brasil, vol. 2, n. 1, enero 2015.

CASAR, María Amparo y MARVÁN, Ignacio (coords.), Reformar sin mayorías. La dinámica del cambio constitucional en México (1997-2012), México, Taurus, 2014.

ELKins, Zachary; Ginsburg, Tom y Melton, James, The Endurance of National Constitutions, Cambridge, MA, Cambridge University Press, 2009.

ESQUIROL, Jorge, Las ficciones del derecho latinoamericano, Bogotá, Universidad de los Andes, Siglo del Hombre Editores, 2014.

Ferrajoli, Luigi, Democracia y garantismo, edición de Miguel Carbonell, Madrid, Trotta, 2010.

HoLMES, Stephen, "El pre-compromiso y la paradoja dela democracia", en Elster, Jon and Slagstad, Rune (eds.), Constitución y democracia, México, Fondo de Cultura Económica, 1988.

IIJ-UNAM, "Constitución Política de los Estados Unidos Mexicanos. Texto reordenado y consolidado", Diego Valadés y Héctor Fix Fierro (coords), México, UNAM, 2015.

POU GIMÉNEZ, Francisca, "Las reformas en materia de derechos fundamentales", en Casar, María Amparo y Marván, Ignacio (coords.), Reformar sin mayorías. La dinámica del cambio constitucional en México, México, Taurus, 2014, pp. 87-137.

, "Constitucionalismo Viejo, nuevo y desatado", en Bonilla, Daniel (ed.), El constitucionalismo en el continente americano, Bogotá, Colombia, Siglo del Hombre Editores (en prensa, 2016).

- "Lo que quisiera que la Suprema Corte hiciera por mí: lealtad constitucional y justicia dialógica en la aplicación de la 293/201 1”, en Sánchez Gil, Rubén y Caballero, José Luis (eds.), Derechos constitucionales e internacionales. Perspectivas, retos y debates, México, Tirant lo Blanch (en prensa, 2016.

POZAS-LOYO, Andrea, "What constitutional efficacy is not", Manuscrito no publicado en poder de la autora, 2015. 
Esta obra forma parte del acervo de la Biblioteca Jurídica Virtual del Instituto de Investigaciones Jurídicas de la UNAM

RAZ, Joseph, Practical Reason and Norms, Oxford, Oxford University Press, 1999.

SÁnchez GIL, Rubén "Notas sobre la Contradicción de tesis 293/2011", Revista Iberoamericana de Derecho Procesal Constitucional, No. 21, enero-junio de 2014.

SILVA GARCíA, Fernando, "Derechos humanos y restricciones constitucionales: ¿reforma constitucional del futuro vs. interpretación constitucional del pasado? (Comentario a la CT 293/2011 del Pleno de la SCJN)", Cuestiones Constitucionales, Revista mexicana de Derecho Constitucional, México, No. 30, enero-julio de 2014. 
Esta obra forma parte del acervo de la Biblioteca Jurídica Virtual del Instituto de Investigaciones Jurídicas de la UNAM

\title{
EL PROCEDIMIENTO DE LA REFORMA GONSTITUGIONAL: UN EXAMEN GRÍTICO
}

\author{
Andrea PozAs LOYO*
}

\begin{abstract}
SUMARIO: I. Introducción. II. Tres perspectivas para el análisis integral del proceso de reforma. III. La perspectiva desde el derecho comparado y la teoría normativa: la instancia del referéndum en México.
\end{abstract}

\section{INTRODUCGIÓN}

Es difícil exagerar la importancia del procedimiento de reforma constitucional, como afirma Amar su centralidad es indiscutible pues en él se delinean las condiciones bajo las cuales el resto de las normas constituciones pueden transformarse legalmente. ${ }^{1}$ En esta misma línea Albert afirma en un reciente artículo: "no hay en una constitución reglas más importantes que las que gobiernan su reforma" pues abren la puerta al cambio de toda la constitución. ${ }^{2}$ Por ello su análisis crítico es fundamental para la comprensión y mejoramiento de la dinámica de cambio constitucional de cualquier país. Este análisis adquiere particular urgencia en nuestro país ya que en las últimas tres décadas se han caracterizado por un patrón de "hiper-reformismo" que ha generado no solo un texto largo, técnicamente deficiente y extremadamente dificil, ${ }^{3}$ sino también ha producido importantes ineficacias. ${ }^{4}$

* Investigadora del Instituto de Investigaciones Jurídicas de la UNAM.

1 Akhil Reed Amar, The Consent of the Governed: Constitutional Amendment Outside Article V, 94 COLUM. L. REV. 1994.

2 Richard Albert, "Amending constitutional amendment rules", $I \bullet C O N$ Vol. 13 No. 3, 2015.

3 Valadés Diego y Fix-Fierro Héctor, "Estudio introductorio" en La Constitución Reordenada y Consolidada disponible en: http://www2.juridicas.unam.mx/constitucion-reordenadaconsolidada//

4 Francisca Pou "Hyper-reformism and constitutional inefficacies in Mexico" artículo presentado en el Seminario Internacional de Cambio y Eficacia Constitucionales IIJUNAM, noviembre 2015. 
Esta obra forma parte del acervo de la Biblioteca Jurídica Virtual del Instituto de Investigaciones Jurídicas de la UNAM

En esta ponencia quiero defender que un análisis crítico integral del procedimiento de reforma requiere al menos de tres perspectivas complementarias. Mientras dos de estas perspectivas han tendido un desarrollo importante en México, la tercera ha tenido una presencia menor en nuestras discusiones. Esta tercera perspectiva propone un análisis normativo de los procedimientos de reforma a la luz del derecho constitucional comparado. ${ }^{5}$ Iniciaré con una muy breve descripción de las dos primeras perspectivas, para después introducir la tercera perspectiva y mostrar cómo complementa a las otras dos y cómo las tres hacen posible un análisis crítico integral del proceso de reforma.

\section{TRES PERSPECTIVAS PARA EL ANÁLISIS}

INTEGRAL DEL PROCESO DE REFORMA

La primera perspectiva nos arroja un análisis puramente jurídico del procedimiento de reforma. Bajo esta perspectiva, se han señalado los múltiples vacíos del procedimiento de la reforma en México y sus consecuencias. Se ha señalado por ejemplo, que no establece quién tiene la facultad de iniciativa para la reforma constitucional, o que no establece con qué mayoría deben las legislaturas de las entidades federativas aprobar el proyecto de reforma. De igual manera, bajo esta primera perspectiva se ha debatido por ejemplo si el Congreso de la Unión, o durante los recesos de aquel, la Comisión Permanente, pueden verificar que las legislaturas locales hayan seguido el procedimiento. Este tipo de análisis crítico puramente jurídico del procedimiento, constituye el punto de partida de las otras dos perspectivas y como ustedes saben ha tenido una larga y rica trayectoria en nuestro país. ${ }^{6}$

Una segunda perspectiva crítica del procedimiento de la reforma constitucional incorpora al análisis de jure consideraciones de facto. En particular incorpora cómo los preceptos de jure se han corporeizado dada la dinámica política y social de un determinado país. Por ejemplo, bajo esta perspectiva

5 E.g. ver: Richard Albert, "The Structure of Constitutional Amendment Rules Richard Albert”, Boston College Law School Faculty Papers, 2014.

6 Ver por ejemplo: Valadés, Diego. "Problemas de la reforma constitucional en el sistema mexica- no", en varios autores, Los cambios constitucionales, México, UNAM, Instituto de Investigaciones Jurídicas, 1977. Carpizo, Jorge "La Reforma constitucional en México. Procedimiento y realidad." Boletín Mexicano de Derecho Comparado (México, IIJ-UNAM), nueva serie, año XLIV, 2011. Carpizo, Jorge y Carbonell, Miguel, Derecho constitucional, 6a. ed., México, Porrúa-UNAM, Instituto de Investigaciones Jurídicas, 2009. Carbonell, Miguel, "Notas sobre la reforma constitucional en México", Revista de la Facultad de Derecho de México, México, UNAM, t. LVI, núm. 245, 2006. 
Esta obra forma parte del acervo de la Biblioteca Jurídica Virtual del Instituto de Investigaciones Jurídicas de la UNAM

se puede analizar en México el papel que las legislaturas locales han jugado en los procesos de reforma constitucional y mostrar cómo, a pesar de que de jure tienen poder de veto, de facto no han ejercido este poder. Un análisis como éste tendría que incluir una explicación de la dinámica política entre la Federación, los partidos políticos y las legislaturas locales. Un tema que ha sido estudiado partiendo de este enfoque es la relación entre la tasa de reforma, el unipartidismo hegemónico y el subsecuente pluralismo político. ${ }^{7}$ Así esta segunda perspectiva tiene una vocación no solo normativa sino también explicativa y por tanto necesariamente incorpora investigación empírica.

Finalmente, existe una tercera perspectiva sobre la que quiero llamar la atención el día de hoy. Esta perspectiva ha sido menos desarrollada en nuestro país, pero creo que puede ser fructífera y complementar a los otros dos enfoques en la muy importante tarea del análisis crítico del proceso de reforma constitucional en México. Esta perspectiva busca dar claves para un análisis normativo de los procedimientos de reforma a la luz del derecho constitucional comparado y la teoría democrática, se encuentra de manera más o menos articulada en literatura internacional de constitucionalismo comparado contemporáneo y es una tarea pendiente en México.

Para dar una primera caracterización de esta tercera perspectiva vale la pena contrastarla con las dos primeras. Como he dicho, la primera perspectiva ha generado un sólido conocimiento jurídico del procedimiento de reforma en la Constitución Mexicana y ha permitido un análisis crítico de sus debilidades específicas. A su vez la segunda perspectiva, genera explicaciones sobre las determinantes políticas y sociales de la reforma constitucional, y su contrastación con el procedimiento de jure da una pauta para una crítica normativa cimentada en la realidad socio-política y cómo ésta corporeiza el procedimiento constitucional. Así siguiendo nuestro ejemplo anterior, se puede contrastar la vocación federalista del procedimiento de reforma en México con la realidad de política de un proceso de reforma donde las legislaturas locales han jugado un papel secundario. Hay que notar que sin el análisis jurídico no es viable el análisis socio-político, y que al mismo tiempo la segunda perspectiva complementa a la primera pues nos lleva del texto a la realidad.

Si bien estas dos perspectivas nos dan conocimiento necesario para emprender cualquier análisis crítico serio del procedimiento de reforma en México, nos quedan a deber en dos cuestiones importantes: En primer lu-

7 E.g. M. Amparo Casar e Ignacio Marván, Reformar sin mayorías: La dinámica del cambio constitucional en México 1997-2012, Taurus.2014. 
Esta obra forma parte del acervo de la Biblioteca Jurídica Virtual del Instituto de Investigaciones Jurídicas de la UNAM

gar, no nos dan criterios evaluativos generales que nos permitan una crítica, por así decirlo, exógena a nuestro procedimiento de reforma. La primera perspectiva analiza el procedimiento y sus limitaciones, mientras que la segunda nos muestra cómo y porqué este procedimiento de jure genera, dadas las condiciones políticas y sociales, cierto patrón de cambio constitucional, pero ambas lo hacen sin salir del ámbito nacional y por tanto sus conclusiones normativas son circunscritas. Para darle mayor solidez teórica a nuestras conclusiones sería importante vincularlas a la teoría democrática y al constitucionalismo que son los cimientos normativos de nuestro sistema constitucional.

En segundo lugar, estas dos primeras perspectivas no presentan alternativas que incorporen el conocimiento acumulado de las experiencias internacionales para enfrentar las deficiencias que nuestro procedimiento tiene. El carácter internacional del constitucionalismo contemporáneo es patente, nuestro sistema constitucional reconoce la centralidad del derecho internacional, nuestros análisis no se deben quedar atrás, es indispensable incorporar la perspectiva comparada al estudio crítico del procedimiento de reforma constitucional: ésta es la propuesta de la tercera perspectiva. Como he dicho esta perspectiva a sido poco desarrollada. En lo que queda de mi exposición daré un bosquejo de cómo podría proceder este tipo de análisis crítico a nuestro procedimiento de reforma y cómo complementaría y sería complementada por las otras dos perspectivas.

\section{LA PERSPECTIVA DESDE EL DERECHO COMPARADO Y LA TEORÍA NORMATIVA: LA INSTANCIA DEL REFERÉNDUM EN MÉXICO}

Como Richard Albert ${ }^{8}$ afirma, la literatura ha identificado al menos 8 funciones que las reglas formales de reforma cumplen en las constituciones democráticas:

1. Detallan el procedimiento de cambio de la constitución escrita

2. Distinguen entre texto constitucional y ley ordinaria

3. Establecen qué no es sujeto de cambio por medio de una reforma constitucional

4. Expresan valores constitucionales. Por ejemplo, mediante diferentes niveles de rigidez para distintas partes de la constitución señalan

8 Richard Albert, 2014 op.cit. 
Esta obra forma parte del acervo de la Biblioteca Jurídica Virtual del Instituto de Investigaciones Jurídicas de la UNAM

las normas constitucionales que se consideran más fundamentales o identitarias.

5. Canalizan la voluntad popular en el diálogo institucional

6. Promueven la deliberación acerca de significado de la constitución

7. Dan forma y codeterminan la dinámica del cambio constitucional incluyendo la interpretación y lo que la literatura llama cambios constitucionales informales.

8. Expresan la relación dual del constitucionalismo democrático vis-ávis los representantes: por un lado los autorizan a alterarla constitucional bajo condiciones excepcionales, al tiempo que limitan cómo y qué actores pueden realizar estos cambios.

Ahora bien, estas funciones, que se derivan teóricamente del constitucionalismo democrático, y empíricamente del derecho comparado de las democracias con constituciones codificadas, pueden ser utilizadas como criterios evaluativos exógenos generales para los procedimientos de reforma.

Así, en el caso de México podríamos preguntarnos por ejemplo, en qué medida nuestro procedimiento cumple con la función central de canalizar la voluntad popular en el diálogo institucional. Para hacer esta evaluación podríamos servirnos de las dos primeras perspectivas que discutí al inicio de mi ponencia. Podríamos constatar desde el análisis jurídico que el procedimiento no da una vía formal a la participación de la ciudadanía en el procedimiento de reforma, y desde un análisis político-jurídico podríamos mostrar que si bien algunas organizaciones de la sociedad civil han jugado un papel relevante en algunas reformas constitucionales, este no ha sido siempre el caso y las organizaciones y grupos de interés involucrados difícilmente pueden considerarse representativos de la ciudadanía en su conjunto. Así, partiendo un criterio exógeno que se fundamenta en la teoría democrática y sirviéndonos del conocimiento jurídico y socio-político del cambio constitucional en México, podríamos concluir que tenemos un déficit democrático importante.

Ahora bien, teniendo este diagnóstico podríamos recurrir al derecho constitucional comparado y preguntarnos qué procedimientos han sido utilizados para cumplir con la función de canalización de la voluntad popular en las constituciones democráticas internacionales. Podríamos estudiar las muy diversas formas que adquiere la participación de la ciudadanía en los procedimientos de reforma mediante iniciativas populares por un lado y referéndums por el otro. Por ejemplo, los referéndums pueden incorporarse como un paso necesario o como un paso condicionado que puede ser activado bajo ciertas circunstancias, este es el caso español que lo establece 
Esta obra forma parte del acervo de la Biblioteca Jurídica Virtual del Instituto de Investigaciones Jurídicas de la UNAM

como un paso final si una décima parte de alguna de las dos cámaras así lo piden. Una ventaja no menor de el análisis comparado de las muy diversas opciones institucionales es que nos inoculan de prejuicios generalizadores que plantean la introducción del referéndum términos maniqueos: o como la salvación o como perdición. El estudio de las muy diferentes formas institucionales que tiene el referéndum (y otras formas de participación ciudadana) en las constituciones del mundo nos recuerda que las diferencias institucionales tienen consecuencias y que difícilmente se puede decir que el referéndum sea siempre negativo o positivo.

Adicionalmente, el estudio comparado nos muestra que tendríamos también que analizar cómo se integran estas figuras al procedimiento en su conjunto, si se incluyen como parte de una regla única para reformar todos los artículos (lo que se conoce como el modelo comprensivo de vía única), como parte de un conjunto de procedimientos alternativos para reformar todos los artículos (modelo comprensivo de vías múltiples), como parte de una vía única para reformar solo algunos artículos (restringuido de vía única) y así sucesivamente con los 6 modelos en que se puede ordenar el marco procedimiento de reforma constitucional. ${ }^{9}$

Finalmente, tras un estudio de las diversas opciones que el derecho constitucional comparado pone sobre la mesa, tendríamos que volver al conocimiento jurídico-político de nuestro país para analizar cómo las diversas alternativas podrían funcionar dada las dinámicas jurídico- políticas de nuestro país y dadas las características de nuestra constitución. Así podríamos reflexionar por ejemplo, sobre las posibles consecuencias negativas que tendría la integración del referéndum como paso necesario para cualquier reforma constitucional dado el carácter reglamentario de muchos de nuestros artículos. De este modo podríamos pensar que para introducir el referéndum de manera funcional tendríamos que incorporarla en un modelo restringido de vía única como el que está presente en el proyecto de leyes de desarrollo constitucional propuesta por el Dr. Valdés y el Dr. Héctor Fix Fierro.

En conclusión mi muy acotada propuesta es la integración al debate del análisis crítico de nuestro proceso de reforma, la perspectiva que integra conocimiento del derecho comparado y criterios normativos exógenos cimentados en la teoría democrática y el constitucionalismo para complementar el análisis jurídico y socio-jurídico de nuestro procedimiento.

\footnotetext{
9 Ver Alberts op.cit.
} 
Esta obra forma parte del acervo de la Biblioteca Jurídica Virtual del Instituto de Investigaciones Jurídicas de la UNAM

\title{
LA CONSTITUCIÓN EN PIEZAS: ASISTEMATICIDADES Y REFORMA CONSTITUGIONAL
}

\author{
Mauro Arturo RIVERA LEÓN*
}

SumARIO: I. La Constitución que nació reformada. II. Asistematicidades en la Constitución. III. Atendiendo a los problemas del texto. IV. Conclusiones. IV. Bibliografia.

\section{LA CONSTITUGIÓN QUE NACIÓ REFORMADA}

La reforma constitucional se encuentra indisolublemente ligada a la Constitución de Querétaro de 1917. La Constitución no sólo ha sido reformada, nació reformada. El texto original reza "Constitución política de los Estados Unidos Mexicanos que reforma a la de 5 de febrero de 1857". No es, en sentido estricto una reforma ${ }^{1}$. Es un texto vivo y propio. Sin embargo, conserva en su título autodefinitorio la expresión semántica que, en forma de profecía, vendrá a realizarse a lo largo de noventa y nueve años de vida constitucional.

Es cierto, nuestra Constitución no es una simple reforma pero actualmente se ha transformado y redefinido en base a sus enmiendas. Las reformas se han vuelto inseparables del texto y el texto mismo despierta cuestionamientos sobre su identidad. A lo largo de casi cien años de vida constitucional tenemos más de 600 reformas al articulado a través de 227 decretos de reforma constitucional a día 28 de marzo de 2016.

* Doctor en Derecho por la Universidad Complutense de Madrid. Actualmente labora en la Suprema Corte de Justicia de la Nación adscrito a la Ponencia del Ministro José Ramón Cossío Díaz.

1 Rabasa, Emilio O., El pensamiento político y social del constituyente de 1916-1917, México, IIJ-UNAM, 1996, p. 39. 
Esta obra forma parte del acervo de la Biblioteca Jurídica Virtual del Instituto de Investigaciones Jurídicas de la UNAM

Sólo los primeros cuatro años (una muestra irrefutable de lo complejo y convulso de nuestra vida política en aquel entonces) se vieron libres de la avalancha reformista que con posterioridad ha caracterizado a un texto que, tras semejante cantidad de cambios que han duplicado su extensión, sabemos es Constitución mexicana, más no si efectivamente es aquella promulgada en 1917.

Nuestro artículo correspondiente a la reforma constitucional es una herencia de la Constitución de 1857 que lo recogía en términos similares.

Actualmente el artículo 135 prevé el procedimiento de reforma constitucional en los siguientes términos:

Artículo 135: La presente Constitución puede ser adicionada o reformada. Para que las adiciones o reformas lleguen a ser parte de la misma, se requiere que el Congreso de la Unión, por el voto de las dos terceras partes de los individuos presentes, acuerden las reformas o adiciones, y que éstas sean aprobadas por la mayoría de las legislaturas de los Estados y de la Ciudad de México.

El Congreso de la Unión o la Comisión Permanente, en su caso, harán el cómputo de los votos de las legislaturas y la declaración de haber sido aprobadas las adiciones o reformas.

Como puede apreciarse, sin perjuicio de objeciones puntuales, no podemos afirmar que tenemos un procedimiento de reforma constitucional excesivamente flexible o que carezca de requisitos. La nuestra es una Constitución rígida ${ }^{2}$. Se requiere de una mayoría agravada y la ulterior aprobación de las Entidades Federativas para modificar su texto. Ha sido la dinámica política y no la flexibilidad del procedimiento la que ha generado un constante ritmo de reformas constitucionales muchas veces superfluas e innecesarias ${ }^{3}$.

Sólo 22 artículos del texto constitucional permanecen sin reforma y el propio artículo 135, por cierto, no es uno de ellos (ha tenido reformas en 1966 y $2016^{4}$ ). Ello implica que el $83.8 \%$ del articulado constitucional ha sido reformado. Como se ha señalado anteriormente, de las 22,028 pala-

2 La distinción clásica proviene de BRYCE, James, Constituciones flexibles y Constituciones rígidas, Madrid, Centro de Estudios Políticos, 1962.

3 Carpizo, Jorge, "La reforma constitucional en México. Procedimiento y realidad", Boletín Mexicano de Derecho Comparado, México, nueva serie, año XLIV, núm. 131, mayo-agosto de 2011 , p. 580.

4 En la doctrina se ha dado cierto debate sobre la posibilidad jurídica de reformar el artículo que establece la reforma constitucional. Véase Ross, Alf, El concepto de validez y otros ensayos, México, Fontamara, 1993, págs. 80 y 81. Una reseña de la discusión subsecuente se ofrece en Henríquez, Miriam y Lamberth, Jorge, “`Son válidas las modificaciones al capítulo 
Esta obra forma parte del acervo de la Biblioteca Jurídica Virtual del Instituto de Investigaciones Jurídicas de la UNAM

bras originales del texto hemos aumentado a 60,461, lo que significa directamente un aumento de más del $1705 \%$.

En el sexenio presidencial pasado (2012-2016), tuvimos 38 reformas constitucionales, lo que nos da un ritmo de 6.33 reformas constitucionales por año. En el transcurso del sexenio presente, tenemos 22 reformas constitucionales en los primeros 3 años con cuatro meses del periodo correspondiente. Ello implica un promedio aproximado de 5 reformas constitucionales por año.

El ritmo elevado de reformas parece alcanzar cierta estabilidad y ha pasado de la tendencia creciente al franco cambio constitucional cada dos meses. Esta "estabilización" en los últimos años es paradójica y probablemente condicionada por la realidad fáctica. No parece que sea posible modificar más la Constitución en menos tiempo.

La nuestra es la Constitución que no cesa. La Constitución de la reforma perpetua. Si en el pensamiento de Condorcet se debatía la legitimidad de atar a generaciones futuras con una Constitución redactada en el pasado, en México el debate - por lo menos desde la óptica de la democracia representativa- carece de relevancia porque el derecho de las nuevas generaciones a la revisión constitucional es un derecho en constante ejercicio ${ }^{6}$.

¿Cuáles son las causas de esta particular dinámica? Anteriormente me he pronunciado en el sentido de que existen cuatro causas conexas que han generado conjuntamente esta dinámica reformista: a) en menor medida, la hegemonía de un partido político en la etapa pre-transitoria; b) una concepción política de la Constitución; c) artículos reglamentarios con alto grado de detallismo y, finalmente, d) una dinámica de centralización de facultades $^{7}$. Empero este artículo no pretende ser un estudio específico del procedimiento de reforma constitucional ni un análisis de las causas subyacentes a un ritmo de reformas tan elevado.

Me interesa, más bien, analizar el efecto que han tenido las constantes reformas en la sistematicidad del texto constitucional. En la siguien-

de reforma constitucional? Una reflexión sobre la autorreferencia normativa de Alf Ross y sus detractores", Estudios Constitucionales, Talca, año 13, núm. 2, 2015, págs. 158-162.

5 Soberanes, José María, Análisis formal de las reformas constitucionales, México, IIJ-UNAM, 2015, p. 3.

6 Un debate similar se da respecto a la existencia de límites materiales a la reforma constitucional. Cfr. Aragón, Manuel, Constitución, democracia y control, México, IIJ-UNAM, 2002, p. 19.

7 Rivera León, Mauro Arturo, "De la rigidez teórica a la flexibilidad material: un análisis del procedimiento de reforma constitucional en México (1917-2012)", Revista Iberoamericana de Derecho Procesal Constitucional, México, núm. 20, Julio-Diciembre de 2013, págs. 171 y ss. 
Esta obra forma parte del acervo de la Biblioteca Jurídica Virtual del Instituto de Investigaciones Jurídicas de la UNAM

te sección, analizaré los tipos de asistematicidades que las reformas han producido en el texto. Posteriormente, entraré al estudio del proyecto de Constitución reordenada propuesto por el Prof. Valadés y el Prof. Fix Fierro para continuar realizando algunas consideraciones sobre la necesidad de incluir una técnica legislativa constitucional en el proceso de enmiendas al texto. Finalmente, ofrezco algunas conclusiones sobre la sistematicidad de la Constitución.

\section{ASISTEMATICIDADES EN LA CONSTITUCIÓN}

\section{La sistematicidad como concepto constitucional}

En el pensamiento constitucional moderno, una Constitución debe poseer ciertas características ideales sobre las que existe un cierto consenso como la estabilidad, un marco de delimitación competencial, un grado de flexibilidad interpretativa, inter alia. Uno de los conceptos que podríamos incluir en este análisis es el de sistematicidad. Una Constitución debe ser sistemática.

La sistematicidad alude directamente a la conformación de un sistema, es decir, su pertenencia a un conjunto de reglas o principios entrelazados cuya relación obedece a un orden lógico de reglas apreciables en el propio sistema. Si en el pensamiento científico la sistematicidad brinda racionalidad, coherencia e inteligibilidad, en el marco jurídico el concepto brinda una lógica interna dinámica inherente al sistema normativo. En la teoría constitucional, tal sistematicidad se ve reflejada en el ensamble natural de sus conceptos, en la coherencia de sus contenidos, en la complementariedad de sus preceptos.

Además de ello, el uso del vocablo en materia jurídica adquiere una fuerte connotación como método interpretativo que considera a las provisiones relevantes no como entes aislados incapaces de relacionarse con el resto del sistema jurídico, sino como partes coherentes de él cuyo engarce necesariamente debe tomarse en cuenta por el intérprete ${ }^{8}$.

En el caso mexicano, la Constitución es un sistema ${ }^{9}$ conformado, a su vez, por subsistemas menores propios de materias concretas. Ejemplo de

8 Ezquiaga, Javier, La argumentación en la justicia constitucional, Bogotá, Diké, p. 127.

9 La Suprema Corte ha aludido en diversas ocasiones al "Sistema Constitucional". Cito por número de registro Ius inter alia: 2009923, 2007339, 2006477, 2009923, 169128, 170881,173608 , etc. 
Esta obra forma parte del acervo de la Biblioteca Jurídica Virtual del Instituto de Investigaciones Jurídicas de la UNAM

ello es el sistema federal, el sistema de derechos humanos, sistema de responsabilidades administrativas ${ }^{10}$, sistema de justicia constitucional ${ }^{11}$, etc.

De tal suerte, el sistema constitucional se conforma por las diversas piezas tanto jurídicas (conceptos jurídicos contenidos) como materiales (preceptos y plasmaciones lingüísticas concretas). Forma y fondo. El resultado nos arroja una estructura que delimita un marco jurídico complementado por el derecho internacional.

Las piezas de la Constitución, sin embargo, no forman una figura predefinida con anterioridad. No existe una preconcepción previa a la que debamos ajustarnos. Una Constitución no es un rompecabezas que, siguiendo un molde definido, pueda nuevamente ser ensamblada en un tipo ideal. Cada Nación consagra en su Constitución distintas ideas y conceptos que considera determinantes en su devenir histórico y esenciales desde el punto de vista económico, social o político.

Aun cuando ciertos conceptos fundamentales como la división de poderes ${ }^{12}$ o la consagración de derechos fundamentales sean inherentes a las Constituciones democráticas, existe un considerable margen de divergencia. Además, cada Constitución puede usualmente ser modificada mediante un proceso concreto que permite actualizar el texto y plasmar las aspiraciones mayoritarias mediante mecanismos democráticos.

En este sentido, cada cambio, aunque sea menor, genera, por así decirlo, una nueva Constitución que se configura así misma en virtud de la nueva relación de sus piezas. La naturaleza sistemática de la Constitución nos da un nuevo texto en cada cambio concreto al generar una distinta interrelación de sus contornos no obstante este nuevo texto frecuentemente mantenga un espíritu similar.

A lo largo de los 99 años de vigencia de nuestra Constitución, la dinámica reformista a la que hemos hecho alusión con anterioridad, ha modificado nuestra Carta Magna con una intensidad inusitada y una profundidad poco usual en el derecho comparado. No resulta sorprendente que las constantes y apresuradas reformas hayan tenido una repercusión en la forma de un texto con problemas de coherencia interna, notoria falta de técnica legislativa y sistematicidad.

10 A ello se alude explícitamente en la tesis de número de Ius 2004098. Se ha hecho también alusión al sistema constitucional de partidos políticos (160941), sistema constitucional electoral (167025) etc.

11 Precisamente así ha titulado Pérez Tremps, uno de sus más conocidos estudios. Pérez Tremps, Pablo, Sistema de Fusticia Constitucional, Madrid, Cívitas, 2010.

12 Sobre el concepto véase in toto Vile, Maurice, Constitutionalism and Separation of Powers, Indianápolis, Liberty Fund, 1998. 
Esta obra forma parte del acervo de la Biblioteca Jurídica Virtual del Instituto de Investigaciones Jurídicas de la UNAM

Este estudio argumenta la existencia de, al menos, dos vertientes de asistematicidades en nuestra Constitución: a) asistematicidad material y b) asistematicidad jerárquica. La asistematicidad material hace referencia a la heterogeneidad de materias abordadas en un artículo o capítulo, así como la falta de un correcto desglose temático de los contenidos en la Constitución. Por otro lado, nuestro análisis afirma que el carácter excesivamente reglamentario de diversas disposiciones constitucionales constituye una falta de sistematicidad per se, al privar no a la Constitución, sino al sistema jurídico en su conjunto del orden inherente a la naturaleza de sus disposiciones. Analicemos con mayor detenimiento ambos tipos de asistematicidades.

\section{Asistematicidad material}

La heterogeneidad de materias abordadas por el articulado o capitulado de la Constitución se ha convertido en una verdadera constante en el texto. Las numerosas reformas han incrementado el texto constitucional a prácticamente el doble de su longitud original. Sin embargo, curiosamente han conservado con singular fervor el número original de los artículos. 136 artículos fueron promulgados en el texto de 1917 y, casi cien años después, 136 artículos permanecen.

Una regulación heterogénea no corresponde a una Constitución sistemática. Carece de orden en la disposición de sus contenidos y en el balance temático de los títulos. Por tanto, la falta de sistematicidad puede deberse tanto al contenido concreto del precepto (asistematicidad material pura) como a la ubicación de los mismos considerando las partes o capítulos de la Constitución (asistematicidad por ubicación).

\section{A. Asistematicidad material pura}

Sin duda, la diversidad de materias reguladas por artículos constitucionales dificulta la interpretación y lectura del texto ante la falta de un hilo conductor. Existen, en efecto, artículos que, pese a su constante reforman, han mantenido un cierto grado de homogeneidad. Ejemplo de ello lo constituye el artículo $3^{\circ}$ (educación), $18^{\circ}$ (sistema penal/penitenciario), $24^{\circ}$ (libertad religiosa), $30^{\circ}$ (nacionalidad), etc. Tales artículos han sido reformados en diversas ocasiones pero han conservado una unidad temática. Ello no implica que, por ejemplo, la técnica legislativa empleada en su reforma sea loable o que el grado regulativo ejercido no sea muy alto. Por el contra- 
Esta obra forma parte del acervo de la Biblioteca Jurídica Virtual del Instituto de Investigaciones Jurídicas de la UNAM

rio, frecuentemente la regulación hecha en tales artículos resulta excesiva o presenta graves defectos, sin por ello abandonar la homogeneidad de los contenidos.

Tomemos por ejemplo el artículo 73 constitucional que define las facultades del Congreso. Tal artículo tiene una unidad temática ejemplar aunque tenga una regulación casuística que innecesariamente especifique sobremanera las competencias legislativas de las Cámaras o centralice excesivamente nuestro régimen federal. Empero, tales defectos no alteran la homogeneidad de materias. Por tanto, ello no se traduce en la asistematicidad material a la que hacemos alusión en esta sección, en tanto existe homogeneidad temática.

Un ejemplo concreto de heterogeneidad lo constituye el artículo 4 que estatuye derechos dispares. Así, establece la igualdad del varón y la mujer ante la ley, el derecho a decidir el número de hijos, derecho a la alimentación nutritiva, derecho a la salud, derecho al medio ambiente sano, derecho al deporte, derecho a la vivienda digna, derecho a la identidad, el principio del interés superior de la niñez y derecho a la cultura.

\section{B. Asistematicidad material por ubicación}

Una forma distinta de producir una regulación asistemática se encuentra en el posicionamiento de los preceptos en las partes constitucionales, capítulos y títulos correspondientes. En este sentido, nuestra Constitución tiene una parte dogmática y una parte orgánica. En la teoría constitucional, la parte dogmática es la encargada de la regulación de los derechos mientras que la parte orgánica, como su nombre lo indica, establece el régimen competencial, los órganos estatales y su integración ${ }^{13}$. Además de ello, tenemos diversos capítulos y títulos que se consagran, por lo menos de forma idónea, a una materia en concreto. Por ejemplo, el primer capítulo "De los Derechos Humanos y sus Garantías" debe contener la unidad temática de regular derechos fundamentales y sus mecanismos de protección. Si estableciésemos dentro de este título la duración del periodo presidencial o la elección de jueces de distrito esto claramente se traduciría en una falta de sistematicidad.

13 Una clasificación presente en la doctrina. Cfr. Garrorena, Ángel, Derecho Constitucional: Teoría de la Constitución y Sistema de Fuentes, Madrid, Centro de Estudios Políticos y Constitucionales, 2014, p. 83. 
Esta obra forma parte del acervo de la Biblioteca Jurídica Virtual del Instituto de Investigaciones Jurídicas de la UNAM

En ocasiones, la homogeneidad temática del título es respetada escrupulosamente. Éste es el caso, por ejemplo, del Capítulo II "De los mexicanos" que sólo contiene disposiciones sobre nacionalidad, obligación de los mexicanos y prelación de empleos a favor de nacionales en ciertos casos. Sin embargo, cuando el artículo 26, ubicado dentro del capítulo relativo a los derechos humanos y sus garantías configura un órgano constitucional autónomo en materia de estadística y geografía, claramente ubica una disposición orgánica no relativa a derechos humanos en un título al que temáticamente no corresponde.

Algo parecido ocurre con el artículo 102 que no sólo establece las bases del Ministerio Público Federal, sino de las Comisiones de Derechos Humanos (Ombudsman). Ello genera una doble y curiosa asistematicidad. Por un lado, resulta claro que la regulación del Ministerio Público/Fiscalía en el mismo artículo que los organismos defensores de derechos humanos redunda en una clara falta de homogeneidad material pura por su regulación conjunta. Empero, por otro lado, tal regulación se establece directamente en un artículo ubicado en el título correspondiente al Poder Judicial. ¿Es el Ombudsman o la Fiscalía perteneciente al Poder Judicial o nos encontramos regulando una materia en un título al que claramente no pertenecen?

Ello ocurre con no poca frecuencia en nuestro texto constitucional propenso a regular en su parte dogmática preceptos que verdaderamente corresponderían a la parte orgánica. Siguiendo el análisis de Soberanes ${ }^{14}$, podemos señalar algunos ejemplos adicionales de ello: La organización del Instituto Nacional para la Evaluación de la Educación, organización del organismo responsable del derecho al acceso a la información pública, el establecimiento de un fideicomiso denominado "Fondo Mexicano del Petróleo para la Estabilización y el Desarrollo Social”, organización del Banco Central, organización de la Comisión Federal de Competencia Económica, etc.

En tal orden de ideas, la asistematicidad material no sólo se da como resultado directo de la heterogeneidad de materias reguladas, sino que también puede darse indirectamente por la ubicación de la disposición en una sección diversa. Es decir que, aun cuando el precepto en cuestión regule únicamente una materia, su ubicación en una sección dedicada al estudio de otra materia, se traduce en la asistematicidad de la disposición.

La conservación del número fijo de artículos y la práctica de evitar recorrer los numerales probablemente ha incidido en que se produzcan este tipo de asistematicidades. Si hubiésemos considerado crear nuevos títulos y capítulos específicos podríamos haber mantenido cierta homogeneidad.

14 Soberanes, José María, op. cit., p. 27. 
Esta obra forma parte del acervo de la Biblioteca Jurídica Virtual del Instituto de Investigaciones Jurídicas de la UNAM

Una clara muestra de ello son los denominados "órganos constitucionales autónomos". La continua creación de administraciones independientes vestidas con los ropajes de un órgano constitucional, se ha vuelto una práctica constante. Empero, su regulación no obedece a un patrón sistemático ni comparte una serie de características concretas que nos permitan inferir su tratamiento idéntico en igualdad de condiciones.

De tal suerte, podría crearse un título exclusivo a los órganos constitucionales autónomos que regulase sus características, condiciones financieras, capacidad reglamentaria y grado de autonomía de una forma homogénea delegando sus necesarias notas distintivas a los artículos específicos o abiertamente a una ley reglamentaria. En cambio, se ha optado por su regulación casuística en artículos distintos con lo que su configuración carece de toda homogeneidad temática.

\section{Asistematicidad jerárquica}

\section{A. La invasión de la normativa secundaria}

El segundo tipo de asistematicidad, como habíamos avanzado en líneas anteriores, corresponde a la asistematicidad jerárquica. Con ella designamos una asistematicidad trascendente, pues no hace referencia al texto en concreto sino al sistema jurídico en su conjunto.

En tal entendimiento, la naturaleza excesivamente reglamentaria de ciertas disposiciones de la Constitución le priva al orden jurídico de una adecuada distribución normativa.

Idealmente, tendríamos a un texto constitucional que enumera y desarrolla los principios básicos de ciertos derechos fundamentales y perfila los contornos de la división de poderes en su aspecto orgánico. En normativa secundaria, tendríamos un mayor desarrollo sobre el ejercicio de los derechos fundamentales y los aspectos organizativos puntuales de las instituciones enumeradas en la Constitución. Finalmente, los reglamentos establecerían los puntos menores restantes.

Sin embargo, el desarrollo constitucional mexicano sigue un camino diferente al del marco teórico mencionado con anterioridad. Una gran cantidad de preceptos en la Constitución regulan a un nivel inusitado las instituciones, órganos y los derechos fundamentales. Ello, en cierta medida, invade el ámbito competencial propio de las leyes secundarias e, inclusive, los reglamentos. No sólo genera una necesidad de constante reforma cons- 
Esta obra forma parte del acervo de la Biblioteca Jurídica Virtual del Instituto de Investigaciones Jurídicas de la UNAM

titucional, sino que desnaturaliza el propio texto cuyo articulado se ve preso del profundo detallismo de las reformas.

Un ejemplo de ello lo constituye el artículo 41 constitucional que actualmente cuenta con más de 40 párrafos. Este artículo regula los partidos políticos y la administración electoral a un nivel tan profundo que podemos hablar verdaderamente de una ley de partidos y de un Código Electoral inserto en la Constitución. Veámoslo con más detalles.

En el artículo 41 constitucional se regula los objetivos de los partidos políticos, su financiación dependiendo del tipo de campaña, las campañas internas, fiscalización, uso de los medios de comunicación social, etc. Además de ello, el artículo en comento regula la administración electoral por un Instituto Nacional, distribución competencial con los organismos electorales locales, propaganda política, estructura del Instituto Nacional Electoral, Servicio Civil Electoral y nulidad de elecciones.

En suma, regulamos en más de cuarenta párrafos lo que la mayoría de las Constituciones del mundo recogen en un par de líneas. El resultado, es un ordenamiento asistemático en que la cantidad de minutos que corresponde a los partidos políticos por concepto de propaganda no se encuentra establecida por un reglamento o una ley secundaria, sino por la propia Constitución. Tal profundidad no sólo es innecesaria sino que contribuye además a generar una dinámica de inestabilidad constitucional por la constante reforma de preceptos que podrían perfectamente establecerse en leyes reglamentarias.

Situación similar acontece respecto a derechos indígenas (art. 2), derecho agrario (art. 27), Tribunal Electoral (art. 99), juicio de amparo (art. 107), etc. En todos estos casos, inter alia, tenemos artículos de una longitud excesiva debido al alto nivel de detallismo que se utiliza en la regulación de la materia en concreto. Más que excepciones, la gran cantidad de reformas constitucionales, está convirtiendo a este tipo de artículos en una regla.

Curiosamente, esta práctica es igualmente nociva desde el punto de vista de la economía del lenguaje jurídico. Las normas secundarias, en lugar de poder desarrollar los preceptos constitucionales bajo los parámetros establecidos, en muchos casos deben previamente repetir en su articulado las disposiciones que la Constitución ha establecido.

Ello no sólo genera una duplicidad innecesaria, sino que abre un cuestionamiento legítimo sobre la naturaleza jurídica de artículos constitucionales insertos en normas secundarias por vía de transcripción. ¿Es posible ejercer control constitucional sobre estas normas cuando se apartan del texto? ¿Cuál es la divergencia que puede ser objeto de control? ¿La transcripción 
Esta obra forma parte del acervo de la Biblioteca Jurídica Virtual del Instituto de Investigaciones Jurídicas de la UNAM

debe ser literal? Aunque muchas de las interrogantes puedan parecer de una importancia relativamente menor, éste es un legítimo cuestionamiento sobre la idoneidad de la técnica legislativa constitucional.

\section{B. Asistematicidad de asistematicidades: paradojas regulatorias}

Hemos mencionado que la regulación que la Constitución hace en ciertos artículos genera una asistematicidad en virtud de la naturaleza reglamentaria de sus preceptos. Paradójicamente, es posible constatar también un tratamiento asistemático en esta naturaleza regulatoria.

Es decir que, a pesar de que la Constitución establece un nivel de detallismo profundo en una gran cantidad de sus preceptos, no ofrece idéntico tratamiento a figuras análogas, algo que el estudio de los profesores Valadés y Fierro mostró con claridad ${ }^{15}$.

Por ejemplo, en el propio artículo 28 constitucional la regulación que se hace del Banco de México es bastante más escueta que la del Instituto Federal de Telecomunicaciones. De igual forma, contrástese el extensísimo artículo 99 que regula al Tribunal Electoral del Poder Judicial de la Federación con las pinceladas que se ofrecen sobre justicia laboral (art. 123) o militar (art. 13) ${ }^{16}$.

Valadés y Fix argumentan que la disparidad en el alcance de la regulación es producto del momento en que las respectivas disposiciones se introdujeron. Es decir, producto de periodos con diferente ánimo de alcance regulatorio. Presumiblemente, el constituyente era menos propenso a la profundidad en la regulación que los actores políticos participantes en la reforma constitucional en la actualidad.

Tenemos, entonces, que ha sido una constante el aumento del espíritu detallista del legislador constitucional que pretende preverlo todo en la Carta Magna. Ello no es impedimento para que tal forma de reformar la Constitución nos arroje una fuerte asistematicidad entre figuras cuyos rasgos se encuentran completamente plasmados en la Carta Magna y otras figuras presumiblemente de similar importancia que sólo tienen delineados sus contornos.

La problemática es evidente. Si las palabras del texto constitucional tienen un peso ¿debe resultar significativo que una institución se encuentre

15 Valadés, Diego y Fix-Fierro, Héctor, Constitución Política de los Estados Unidos Mexicanos. Texto reordenado y consolidado, México, IIJ-UNAM, 2014, p. 11.

16 Ibid. 
Esta obra forma parte del acervo de la Biblioteca Jurídica Virtual del Instituto de Investigaciones Jurídicas de la UNAM

completamente detallada en el texto constitucional y otra no? ¿Debemos entender que tal divergencia tiene algún tipo de significado? Y, en todo caso, ¿Por qué si son instituciones de importancia similar el grado de libertad del legislador en un caso será mínimo mientras que en el otro podrá llegar a incidir en aspectos fundamentales de la figura jurídica? El resultado no sólo es un texto con regulación asistemática y dispar sino, en ocasiones, francamente arbitraria.

\section{ATENDIENDO A LOS PROBLEMAS DEL TEXTO}

\section{El proyecto de reordenación constitucional}

Recientemente (2014) los Profesores Diego Valadés y Héctor Fíx Fierro presentaron un complejo estudio de reordenación constitucional. En este esfuerzo académico, parten de la observación de la dinámica de la reforma constitucional que hemos mencionado con anterioridad para realizar un profundo diagnóstico del estado actual de la norma. Finalmente, realizan correcciones al texto partiendo de su reordenación y, en menor medida, reubicación de algunas disposiciones en una ley de desarrollo constitucional.

Vale la pena mencionar, si quiera de forma somera, el diagnóstico de los efectos en el texto constitucional del que parte el estudio en tanto coincide en varios puntos con lo que aquí hemos denominado "asistematicidades". El estudio afirma que existe en la Constitución 1) disposiciones duplicadas; 2) uso variable e inconsistente de terminología; 3) disparidad en el alcance y profundidad de la regulación; 4) desorden y falta de sistema en la materia regulada en los artículos constitucionales; 5) deficiente ubicación de las disposiciones constitucionales; 6) errores en la actualización del texto y, finalmente, 7) la existencia de artículos reglamentarios.

En este sentido, los defectos 4) y 5) corresponden respectivamente a lo que hemos denominado asistematicidad material pura y asistematicidad material por ubicación. Por otro lado, los defectos 7) y 3) aluden a lo que anteriormente denominamos asistematicidad jerárquica y su ulterior disparidad en el tratamiento de regulaciones.

Habiendo realizado un claro diagnóstico, el estudio reordena la Constitución partiendo de la premisa implícita de que el mantenimiento de las decisiones fundamentales es posible realizando ajustes de técnica legislativa en el texto y reubicando ciertas disposiciones. Además de ello, ante la gran 
Esta obra forma parte del acervo de la Biblioteca Jurídica Virtual del Instituto de Investigaciones Jurídicas de la UNAM

extensión del texto, se propone la creación de una ley de desarrollo constitucional (lo que en España se conoce como "Ley Orgánica).

Esta ley, sería aprobada por una mayoría de entidad superior a la requerida para la legislación ordinaria pero menor que la necesaria para una reforma constitucional. Su objetivo sería desarrollar los contenidos de la Constitución que actualmente se encuentran en el texto pero cuyo mantenimiento no es esencial. De tal suerte, se respetaría la voluntad política que constitucionalizó la medida en concreto pero, al mismo tiempo, se aligeraría el texto constitucional. En total, la reducción es cercana al 30\% ${ }^{17}$.

En resumen, la reordenación constitucional propuesta ataca a los defectos producidos por las constantes reformas y busca combatir también las asistematicidades que hemos diagnosticado con anterioridad desde un punto de vista realista con las posibilidades políticas de reforma. Varias de las correcciones sugeridas son materia propia de la técnica legislativa. En la siguiente sección estudiaremos su potencial impacto en el proceso de reformas constitucionales.

\section{Técnica legislativa constitucional}

Anteriormente, hemos hecho alusión al interesante proyecto de reordenación constitucional que incluía una reformulación del texto, reubicación de ciertos preceptos, corrección de defectos lingüísticos y la creación de una ley de desarrollo constitucional. La labor que los autores realizan no sólo es de diseño normativo sino también una labor de técnica legislativa. Ha quedado demostrado lo necesario de corregir lingǘstica y estructuralmente los contenidos de la Constitución. En este orden de ideas ¿Exige nuestra dinámica reformista el desarrollo de un sistema de técnica legislativa constitucional?

En nuestro libro Cuando la forma es fondo ${ }^{18}$, el Prof. Martínez Fabián y yo abríamos la interrogante respecto a si es necesario explorar un campo concreto conocido como técnica legislativa constitucional. De tal suerte, si las particularidades de la Constitución ${ }^{19}$ (supremacía y carácter de apertu-

17 Ibid., p. 18.

18 Rivera León, Mauro Arturo y Martínez Fabián, Constantino, Cuando la forma es fondo: estudios de técnica legislativa y legilinguiistica, México, IIJ-UNAM, 2015, p. 50.

19 Según Prieto Sanchís, estas particularidades en algunos casos "se derivan de la propia naturaleza del objeto normativo, y otras responden a la peculiar función de los órganos jurisdiccionales competentes o a las también especiales consecuencias que se atribuyen a sus decisiones". Prieto Sanchís, Luis, "Notas sobre interpretación constitucional", Revista 
Esta obra forma parte del acervo de la Biblioteca Jurídica Virtual del Instituto de Investigaciones Jurídicas de la UNAM

$\mathrm{ra}^{20}$ ) como norma fundante han justificado que ramas generales deriven en ramas específicas (como la interpretación constitucional ${ }^{21}$ ) ¿No es nuestra dinámica reformista un fuerte aliciente para el estudio de la propia técnica que debe regir en el texto?

En México la expresión "técnica legislativa constitucional" ha sido utilizada como giro lingǘstico ocasional por algunos autore ${ }^{22}$ cuando señalan defectos formales del texto sin que necesariamente se haga una referencia favorable a la creación de un sistema de técnica legislativa específico para la Constitución.

Sin embargo, la doctrina mexicana ha señalado en reiteradas ocasiones diversos defectos de técnica legislativa constitucional ${ }^{23}$ que han sido incluso atendidos a profundidad en el proyecto constitucional reordenado.

Considero, sin embargo, que la realidad política y el uso que los actores relevantes han dado a la reforma constitucional deben llevarnos a concluir que un tratamiento intuitivo de la técnica legislativa en la Constitución resulta insuficiente en el caso mexicano. Debemos, por tanto, institucionalizar la técnica legislativa constitucional para lograr un tratamiento sistemático del texto que se incorpore a la Constitución en virtud de las reformas y adiciones.

En la teoría general de la técnica legislativa existen dos grandes modelos, a saber, el modelo anglosajón y el modelo germánico ${ }^{24}$. Mientras que el modelo anglosajón confia la redacción de todos los proyectos de ley a un órgano específico con redactores especializados, el sistema germánico busca alcanzar la homogeneidad mediante cuestionarios, directrices y lineamientos que establezcan los parámetros que los redactores deben de seguir.

del Centro de Estudios Constitucionales, Madrid, núm. 9, Mayo-Agosto de 1991, p. 176. Sobre los principios diferenciadores en la interpretación constitucional, Duque, Román, Sistema de Fuentes de Derecho Constitucional y Técnica de Interpretación Constitucional, Homero, Caracas, 2014, págs. 181-183.

20 Garrorena, Ángel, op. cit., p. 85.

21 "La cuestión de si estas especialidades vienen a configurar un proceso cualitativamente distinto, o más bien sólo una diferencia de grado respecto al método de interpretación jurídica en general, es difícil de responder categóricamente". En este sentido DíAZ, Javier, "La interpretación constitucional y la jurisprudencia constitucional", Quid Iuris, México, núm. 6, 2008, p. 10.

22 Hernández Chong Cuy, María Amparo, Suprema Corte y controversias constitucionales: análisis de comportamiento judicial, México, Porrúa, 2012, págs. 424 y 425.

23 Por ejemplo, el errático sistema de numeración constitucional. SOBERANES, José María, Op. Cit., págs. 24 y ss.

24 García Escudero, Piedad, "Nociones de técnica legislativa para uso parlamentario", Asamblea: Revista parlamentaria de la Asamblea de Madrid, Madrid, núm. 13, diciembre 2006, p. 122 y ss. 
Esta obra forma parte del acervo de la Biblioteca Jurídica Virtual del Instituto de Investigaciones Jurídicas de la UNAM

¿Cuál de los modelos de técnica legislativa podríamos seguir en el establecimiento del sistema que aquí se discute? Para nuestro caso concreto (en materia constitucional) me parece que se podría seguir el modelo germánico creando un manual de técnica legislativa para el Congreso Federal que contenga una sección concreta sobre reforma constitucional o, más idealmente, la creación de un manual específico sobre técnica legislativa en la reforma constitucional.

En dicho manual, debería especificarse de forma indicativa cuál es la correcta numeración de los incisos, la recomendación sobre ejes temáticos de la Constitución (probable ubicación de nuevos contenidos), puntuación y uso consistente de terminología, recomendaciones sobre sobre la profundidad idónea de la regulación de figuras introducidas en el texto constitucional, entre otros aspectos.

En tanto manual, su seguimiento sería potestativo pero, sin duda, constituiría una fuerte guía constante para parlamentarios cuyos asesores no siempre tienen el nivel técnico recomendado para proponer reformas constitucionales bajo ciertos parámetros.

\section{Conclusiones}

A lo largo de este texto, hemos puesto sobre relieve el efecto negativo que ha tenido el constante ritmo de reformas constitucionales sobre la naturaleza sistemática de la Constitución. Por un lado, la asistematicidad material pura y la asistematicidad por ubicación han generado un articulado heterogéneo carente de unidad en sus contenidos. Por otro lado, la asistematicidad jerárquica priva al ordenamiento jurídico del orden inherente a la naturaleza de sus disposiciones. Ello se ve complementado ulteriormente por un tratamiento asistemático de este propio afán regulatorio.

Estos defectos se atienden frontalmente en el proyecto de reordenación constitucional de los profesores Valadés y Fierro, que tiene como gran mérito el mantenimiento de las decisiones fundamentales políticas pero con una corrección técnico-lingüística aparejada a la reducción de los contenidos debido a la ley de desarrollo constitucional.

Además de las anteriores consideraciones, nuestra peculiar dinámica, nos ha llevado también a proponer una verdadera sistematización de la técnica legislativa constitucional que nos ayude a mantener la coherencia interna y naturaleza sistemática de la Constitución.

De forma aislada, ambas propuestas resultan loables. Empero, es imprescindible no sólo limar los múltiples defectos del texto que ha ocasionado 
Esta obra forma parte del acervo de la Biblioteca Jurídica Virtual del Instituto de Investigaciones Jurídicas de la UNAM

la dinámica reformista, sino también detenerla, modificarla y dirigirla hacia un verdadero debate público sobre los contenidos esenciales y acuerdos fundamentales de nuestra Constitución.

Para ello, más que instrumentos normativos y mecanismos jurídicos, se requiere algo de mucho mayor complejidad, un cambio en la cultura jurídica. Es necesario un distinto entendimiento de la norma fundante por parte de los operadores políticos intervinientes en los procesos de reforma.

Nuestro sistema constitucional, habituado a las reformas hechas bajo el presupuesto de que la modificación normativa incide automáticamente en la realidad fáctica ha entrado en una dinámica constitucional nociva, que genera defectos técnicos en el texto poniendo en verdadero peligro a la fuerza normativa de nuestra Carta Magna. Los actores políticos deben tomar verdadera conciencia de los significados de una Constitución, de su fuerza jurídica

Esta dinámica debe detenerse. De lo contrario, seguiremos teniendo una Constitución reglamentaria y casuística, asistemática e inestable; seguiremos teniendo, en suma, más que un sistema constitucional, una Constitución en piezas.

\section{BiBLIOGRAFÍA}

ARAGÓn, Manuel, Constitución, democracia y control, México, IIJ-UNAM, 2002. BRYCE, James, Constituciones flexibles y Constituciones rígidas, Madrid, Centro de Estudios Políticos, 1962.

CARPIZO, Jorge, "La reforma constitucional en México. Procedimiento y realidad", Boletín Mexicano de Derecho Comparado, México, nueva serie, año XLIV, núm. 131, mayo-agosto de 2011.

DÍAZ, Javier, "La interpretación constitucional y la jurisprudencia constitucional", Quid Iuris, México, núm. 6, 2008.

EzQUiAgA, Javier, La argumentación en la justicia constitucional, Bogotá, Diké, 2008.

García Escudero, Piedad, "Nociones de técnica legislativa para uso parlamentario", Asamblea: Revista parlamentaria de la Asamblea de Madrid, Madrid, núm. 13, Diciembre de 2006.

Garrorena, Ángel, Derecho Constitucional: Teoría de la Constitución y Sistema de Fuentes, Madrid, Centro de Estudios Políticos y Constitucionales, 2014.

HENRÍQUez, Miriam y LAMBERTH, Jorge, “'Son válidas las modificaciones al capítulo de reforma constitucional? Una reflexión sobre la autorreferen- 
Esta obra forma parte del acervo de la Biblioteca Jurídica Virtual del Instituto de Investigaciones Jurídicas de la UNAM

cia normativa de Alf Ross y sus detractores", Estudios Constitucionales, Talca, año 13, núm. 2, 2015.

Hernández Chong Cuy, María Amparo, Suprema Corte y controversias constitucionales: análisis de comportamiento judicial, México, Porrúa, 2012.

Pérez Tremps, Pablo, Sistema de Justicia Constitucional, Madrid, Cívitas, 2010.

PrIETO SACHÍs, Luis, "Notas sobre interpretación constitucional", Revista del Centro de Estudios Constitucionales, Madrid, núm. 9, Mayo-Agosto de 1991.

RÁBASA, Emilio O., El pensamiento político y social del constituyente de 1916-1917, México, IIJ-UNAM, 1996.

Rivera LeÓn, Mauro Arturo y Martínez Fabián, Constantino, Cuando la forma es fondo: estudios de técnica legislativa y legilingüística, México, IIJ-UNAM, 2015.

Rivera León, Mauro Arturo, "De la rigidez teórica a la flexibilidad material: : un análisis del procedimiento de reforma constitucional en México (1917-2012)", Revista Iberoamericana de Derecho Procesal Constitucional, México, núm. 20, Julio-Diciembre de 2013.

Ross, Alf, El concepto de validez y otros ensayos, México, Fontamara, 1993.

DuQue, Román, Sistema de Fuentes de Derecho Constitucionaly Técnica de Interpretación Constitucional, Caracas, Homero, 2014.

Soberanes, José María, Análisis formal de las reformas constitucionales, México, IIJ-UNAM, 2015.

VAladés, Diego y FIX, Héctor, Constitución Política de los Estados Unidos Mexicanos. Texto reordenado y consolidado, México, IIJ-UNAM, 2014.

VALAdÉs, Diego, La Constitución reformada, México, IIJ-UNAM, 1987.

VILE, Maurice, Constitutionalism and Separation of Powers, Indianápolis, Liberty Fund, 1998. 
Esta obra forma parte del acervo de la Biblioteca Jurídica Virtual del Instituto de Investigaciones Jurídicas de la UNAM

\title{
LA CONSTITUGIÓN DE 1917, REFORMA DE LAS GONSTITUCIONES ESTATALES Y LAS NUEVAS CONSTITUCIONES DE GUERRERO Y DE LA CIUDAD DE MÉXICO*
}

\section{Marcial RODRÍGUEZ SALDAÑA**}

\begin{abstract}
SUMARIO: I. Introducción. II. La adecuación de las constituciones locales a la federal de 1917. III. La estructura actual de las Constituciones Locales. IV. Federalismo Centralista y reforma constitucional en los Estados. V. El control constitucional de las reformas a las constituciones de los Estados. VI. Contribuciones del Constitucionalismo Local. VII. El método de reforma en las Constituciones Estatales. VIII. La Nueva Constitución del Estado de Guerrero. IX. La nueva Constitución de la Ciudad de México y el centralismo. X. Conclusión y prospectiva de la reforma constitucional en los estados de la Federación. XI. Bibliografia.
\end{abstract}

\section{INTRODUCCIÓN}

La adopción del sistema federal mexicano, fue una de las decisiones fundamentales que aprobaron los primeros constituyentes de 1824 al incluir esta forma de gobierno en el artículo $4^{\circ}$., de nuestra primera carta fundamental. En la parte de la existencia de los órdenes normativos locales, dispuso en su artículo 161, fracción II referido a las obligaciones de los Estados, que estos deberían de publicar su Constitución por medio de los gobernadores. ${ }^{1}$

* Ponencia presentada en el VII Congreso Nacional de Derecho Constitucional, realizado del 3 al 5 de febrero del 2016, en la ciudad de San Luis Potosí, SLP, México.

** Rector de la Universidad Autónoma de Guerrero; Diplomado en Ciencia Política por la Universidad Sorbona de París I; Doctor en Derecho por la UNAM; miembro del Instituto Iberoamericano de Derecho Constitucional - sección mexicana- actualmente profesorinvestigador de la Unidad de Estudios de Posgrado e Investigación de la Universidad Autónoma de Guerrero

1 H. Cámara de Diputados del H. Congreso de la Unión, LIV Legislatura, Las Constituciones de México, La Constitución de 1824, México, 1989, pp. 77 y 93. 
Esta obra forma parte del acervo de la Biblioteca Jurídica Virtual del Instituto de Investigaciones Jurídicas de la UNAM

El modelo de organización federal instaurado en México en cuanto a la distribución de competencias contenidas en la Constitución Federal y en las Constituciones de los Estados, fue retomado de la décima enmienda a la Constitución de los Estados Unidos de América que consiste esencialmente en que los poderes que la Constitución no otorgue a los Poderes de la Federación ni prohíba a los Estados, quedan reservados a estos. ${ }^{2}$

Este sistema de reserva de poderes a los Estados de la federación fue confirmado en la Constituciones de 1857, (artículo 117) y en la vigente de 1917 (artículo 124).

Las sucesivas reformas al artículo 73 de la Constitución Política de los Estados Unidos Mexicanos de 1917, denotan una marcada concentración de facultades de los poderes federales respecto de las de los Estados. ${ }^{3}$

La Constitución de 1917 no previó en sus artículos transitorios ningún mandato para adecuar las Constituciones estatales al contenido del nuevo texto constitucional, esto se mandató en el decreto del 22 de marzo de ese año, expedido por Venustiano Carranza, el cual establecía que los Congresos de los Estados se constituirían en Congresos Constituyentes, y que señaló textualmente:

"Artículo $5^{\circ}$.- Las Legislaturas de los Estados que resulten de las elecciones próximas tendrán además del carácter de Constitucionales, el de Constituyentes, para sólo el efecto de implantar en las Constituciones locales, las reformas de la nueva Constitución General de la República en la parte que les concierna, y así se expresará en la convocatoria correspondiente.” ${ }^{4}$

Las Constituciones locales aprobadas después de la Federal de 1917, siguieron el mismo método de ésta en cuanto a que se trató de un proyecto de reformas a la Constitución de 1857, por ello, aun cuando a los órganos legislativos que las aprobaron se les denominó Congresos Constituyentes, los proyectos de las iniciativas fueron de reformas y adiciones a los textos vigentes.

A noventa y nueve años de vigencia de la Constitución de 1917 y a un año de cumplir su primer centenario, conviene revisar el desarrollo de las reformas a las Constituciones locales en relación con nuestra carta fundamental durante casi un siglo.

2 Padover, Saul K., The living U.S. Constitution, New American Library, New York, 1983, p. 68 .

3 Aarteaga Nava, Elisur, El sistema federal mexicano, Editorial Porrúa, México, 2013, p. 116.

4 Bolaños, G. B., (recopilador) Recopilación de leyes y decretos expedidos de enero a abril de 1917 , Imprenta de la Secretaría de Gobernación, México, s/a., P 47., vinculo electrónico wrere. sitios.scjn.gob.mx/constitucion1917.../4Enero-abril1917Recopilaci... 
Esta obra forma parte del acervo de la Biblioteca Jurídica Virtual del Instituto de Investigaciones Jurídicas de la UNAM

\section{LA ADEGUACIÓN DE LAS CONSTITUCIONES LOCALES A LA FEDERAL DE 1917}

La adecuación de las Constituciones de los estados a la CPEUM de 1917 fue paulatina conforme a las condiciones propias de cada entidad federativa, así tenemos que la primera Constitución en ser reformada fue la de Sonora el 29 de marzo de $1917^{5}$ y la última fue la de Morelos el 16 de noviembre de $1930 .{ }^{6}$ La transformación de los territorios que reconocía la Constitución de 1917 al constituirse como nuevos Estados trajo como consecuencia la aprobación de las constituciones de Quintana Roo el 12 de enero de 1975 y de Baja California Sur el 15 de enero de 1975.

\section{LA ESTRUCTURA DE CONSTITUCIONES LOCALES}

La Constitución de 1917 mantuvo en general el modelo de integrar en una primera parte las garantías individuales (hoy derechos humanos y sus garantías) y en una segunda la organización del Estado, tal y como se había aprobado en la Constitución de 1857, la cual en su parte inicial incorporó el concepto de los Derechos del Hombre y en una segunda la estructura del Estado, a diferencia de la Constitución de 1824 que no incluyó derechos fundamentales siguiendo el esquema original de la Constitución norteamericana antes de la aprobación de sus enmiendas.

La integración de Derechos Humanos de la Constitución de 1857 y de garantías individuales en la Constitución de 1917 siguió el modelo de la Constitución Francesa de 1791, la cual integró al texto la declaración de los Derechos del Hombre y del Ciudadano. ${ }^{7}$

Si tomamos como ejemplo la Constitución del Estado de México que se aprobó después de la Constitución de 1917, encontramos que estaba estructurada en libros, títulos y capítulos. El libro primero se refería al Estado de México en general, el título único del Estado de México como entidad Libre y Soberana; el segundo libro se refería a la organización política general del Estado de México, titulo primero, de la condición política de las personas, título segundo del gobierno del Estado donde incluía el poder legislativo, ejecutivo y judicial, el ministerio público y la responsabilidad de los servido-

5 Cfr. Cuadro de fechas de reformas a las constituciones locales de México, a partir de la Constitución de 1917, al final de este trabajo.

6 Cfr. García Rubí, Jorge Arturo, Historia constitucional de Estado de Morelos, pp. 242-244, versión electrónica, vínculo biblio.juridicas.unam.mx/libros $/ 1 / 8 / 20$.

7 Duverger, Maurice, Constitutions et documents politiques, editorial PUF, París, 1957, p. 17. 
Esta obra forma parte del acervo de la Biblioteca Jurídica Virtual del Instituto de Investigaciones Jurídicas de la UNAM

res públicos; el libro tercero se refería a la organización política de los municipios; el libro cuarto a las prevenciones generales de la Administración Pública, que incluía las bases de la organización de la hacienda pública, las bases de la organización del trabajo, bases de la legislación agraria, disposiciones sobre el enjuiciamiento civil, legislación sobre educación pública, escuelas especiales para indígenas; el libro quinto relativo a la permanencia de la Constitución, que incluía la reforma y la inviolabilidad de la Constitución, que daba un total de 235 artículos. $^{8}$

Desde que se publicó en 1988 el libro Derecho Constitucional Estatal del maestro Elisur Arteaga Nava ${ }^{9}$; el de Derecho Constitucional y Administrativo de la entidades federativas del Doctor Máximo N. Gámiz Parral en $1990^{10}$ y el Derecho Constitucional Estatal coordinado por Francisco José de Andrea Sánchez en el $2001^{11}$, la realidad del constitucionalismo local en México ha tenido significativas transformaciones.

En la actualidad las constituciones locales de México tienen una variedad en cuanto a su diseño.

Hay Constituciones que en su primer título se refieren al Estado y su territorio, soberanía, forma de gobierno, principios fundamentales, estableciendo que forman parte de los Estados Unidos Mexicanos, como es el caso de: Aguascalientes; Baja California; Baja California Sur (bajo la denominación de principios constitucionales); Campeche; Chiapas; Chihuahua; Coahuila; Durango; Estado de México, Guerrero (disposiciones preliminares); Hidalgo; Jalisco; Morelos (bajo la denominación de disposiciones preliminares en donde incluye los Derechos Humanos); Nayarit; Puebla, Quintana Roo (principios constitucionales) San Luis Potosí; Sinaloa; Tabasco; Tamaulipas; Tlaxcala y Veracruz.

Otras Constituciones contienen en su primer título a los Derechos Humanos, tales como las de: Colima; Durango; Guanajuato; Michoacán (como garantías individuales y sociales), Nuevo León (derechos del hombre) Oaxaca (incluido como principios constitucionales, Derechos Humanos y sus garantías), Querétaro; Sonora (dentro del título preliminar en el artículo $1^{\circ}$., como Derechos del Hombre); y Yucatán.

En caso de Aguascalientes dentro del primer capítulo relativo a declaraciones en su artículo $1^{\circ}$., se refiere a que forma parte de la federación y

8 Cfr. Constitución Política del Estado Libre y Soberano de México, publicada en la gaceta del gobierno el 10, 14 y 17 de noviembre de 1917 .

9 Arteaga Nava, Elisur, Derecho Constitucional Estatal, Editorial Porrúa, México, 1988.

10 Gámiz Parral, Máximo, Derecho Constitucional y Administrativo de las entidades federativas, Editorial UNAM, México, 1990.

11 Andrea Sánchez, Francisco de, Derecho Constitucional Estatal, Estudios históricos, legislativos y teórico-prácticos de los estados de la República mexicana, Editorial UNAM, México, 2001. 
Esta obra forma parte del acervo de la Biblioteca Jurídica Virtual del Instituto de Investigaciones Jurídicas de la UNAM

posteriormente en el $2^{\circ}$., se refiere a los Derechos Humanos, sin dedicar un capítulo propio.

La Constitución de Chihuahua en el título II incorpora los Derechos Humanos bajo la denominación de Derechos Fundamentales. ${ }^{12}$

En un segundo título y/o capítulo incluyen los Derechos Humanos las constituciones de: Baja California Sur; Chiapas; Chihuahua (bajo la denominación de Derechos Fundamentales); Coahuila, Estado de México, Guerrero; Hidalgo; Nayarit; Puebla; Quintana Roo; Sinaloa, Tabasco; Tlaxcala (de los derechos individuales); Veracruz y Zacatecas.

En el capítulo III Baja California los incorpora como garantías individuales, sociales y de la protección a los Derechos Humanos; Campeche y Jalisco como de los Derechos Humanos y sus garantías y Nayarit bajo la denominación de los habitantes y sus Derechos Humanos.

Tamaulipas no tiene un título o capítulo dedicado a los Derechos $\mathrm{Hu}$ manos, pero en su parte relativa a los habitantes y al Estado, capítulo V del título I reconoce un catálogo de derechos y las normas derivadas del artículo $1^{\circ}$ de la CPEUM.

Como podemos corroborar, el diseño general de las Constituciones locales mexicanas es muy diverso, en tanto que la mayoría todavía mantiene una estructura que pone en primer lugar al Estado, siguiendo el modelo norteamericano y de la Constitución de 1824 y otra parte aún minoría, ya incluye en primer término a los Derechos Humanos. ${ }^{13}$

\section{LA ESTRUCTURA ACTUAL}

DE LAS CONStituGiones LOCALES DE MÉxico

Los aspectos que contienen todas las Constituciones de los Estados de federación mexicana son los siguientes:

\section{- Organización del Estado: pertenencia a la federación, soberanía}

12 Periódico Oficial del Gobierno del Estado, de fecha 10 de septiembre de 1995. Este concepto lo desarrollan diversos tratadistas como: Alexy, Robert, Teoría de los Derechos Fundamentales, traducción de Carlos Bernal Pulido, Centro de Estudios Constitucionales, Madrid, 2014. 601 pp.; Ferrajoli, Luigi, Los fundamentos de los derechos fundamentales, traductores: Perfecto Andrés, Antonio de Cabo, Miguel Carbonell, Lorenzo Córdova, Marcos Criado y Gerardo Pisarello, Editorial Trotta, Madrid, 2001, 391 pp.; Fioravante, Mauricio, Los Derechos Fundamentales, traducción Manuel Martínez Neira, Editorial Trotta, Madrid, 1996, 165 pp.

13 Véase la estructura de las Constituciones estatales en los Estados Unidos de América en: Barceló Rojas, Daniel Armando, Introducción al Derecho Constitucional Estadounidense, Editorial UNAM, México, 2005, p. 75. 
Esta obra forma parte del acervo de la Biblioteca Jurídica Virtual del Instituto de Investigaciones Jurídicas de la UNAM

popular, régimen representativo, democrático; división de poderes; relación de municipios; habitantes; ciudadanos, derechos, obligaciones;

- Derechos Humanos: protección de los contenidos en la Constitución Federal y tratados internacionales; Comisiones Estatales de Defensa de los Derechos Humanos;

- Régimen democrático: principios rectores en materia electoral; partidos políticos; organización de elecciones; institutos electorales; tribunales electorales; medios de impugnación en materia electoral;

- Poder Legislativo: sistema mixto de representación por mayoría y proporcional; periodos de sesiones;

- Poder Ejecutivo: no reelección, seis años de mandato constitucional; requisitos para ocupar el cargo;

- Ministerio Público, bajo la denominación de Procuraduría General de Justicia o de Fiscalía General del Estado;

- Poder Judicial: inamovilidad; Consejos de la Judicatura; tribunales de justicia administrativa; sistema acusatorio penal;

- Órganos Superiores de Fiscalización;

- Institutos de Acceso a la Información Pública y Protección de Datos Personales;

- Municipios;

- Responsabilidad de Servidores Públicos;

- Reforma e inviolabilidad de la Constitución.

Existen en las Constituciones locales de México aspectos comunes con sus particularidades, como el número de periodos de sesiones de los congresos de los Estados: un periodo, Durango y Querétaro (sesión permanente durante el año); dos periodos, Baja California Sur; Campeche, Chiapas, Chihuahua, Colima, Coahuila, Guanajuato, Hidalgo, Jalisco, Morelos, Nayarit, Nuevo León, Oaxaca, Quintana Roo, SLP, Sinaloa, Sonora; Tabasco, Tamaulipas, Tlaxcala, Veracruz y Zacatecas; tres periodos, Baja california, Estado de México, Puebla y Yucatán.

Llaman la atención ciertos aspectos muy particulares de algunas Constituciones locales como los casos de: Quintana Roo, que describe con detalle los límites de cada municipio con sus vértices, rumbos, distancias y coordenadas; Baja california Sur y Oaxaca sus linderos y colindancias con cada Estado; que se destine el 2.5 por ciento, presupuesto del Estado a la Universidad Autónoma de Morelos.

Hay una variedad en cuanto al número de artículos de las Constituciones de los estados en México, así tenemos que la de menor número es la 
Esta obra forma parte del acervo de la Biblioteca Jurídica Virtual del Instituto de Investigaciones Jurídicas de la UNAM

de Querétaro con cuarenta artículos y la más extensa la de Chihuahua con doscientos tres. ${ }^{14}$

\section{Federalismo Gentralista Y REFORMA CONSTITUCIONAL EN LOS ESTADOS}

El contenido de las Constituciones locales actuales tiene un conjunto de aspectos que han provenido de reformas a la Constitución de 1917 y que han obligado a modificar las cartas constitucionales de los Estados, entre los cuales encontramos:

a) la existencia de Comisiones de Defensa de los Derechos Humanos: la obligación de respetar los Derechos Humanos contenidos en los tratados internacionales y los criterios de interpretación;

b) La igualdad de Derechos entre el hombre y la mujer;

c) La regulación de la vida democrática mediante los principios rectores en materia electoral; los partidos políticos; sistema de representación en los Congresos Locales de mayoría relativa y representación proporcional; institutos locales electorales y en algunos casos de participación ciudadana, cuyos integrantes son designados por el Consejo General del Instituto Nacional Electoral; medios de impugnación en materia electoral; tribunales electorales locales, cuyos miembros son designados por el Senado de la República;

d) La forma de gobierno republicana, federal, representativa, democrática y laica;

e) Tribunales Administrativos;

f) Órganos de acceso a la información pública y de protección de datos personales;

g) Órganos de fiscalización;

h) Inamovilidad de magistrados de los tribunales superiores de justicia;

i) Sistema penal acusatorio.

Estos contenidos se han incorporado a las Constituciones locales en México producto de mandatos precisos de las reformas a las Constitución Federal de 1917, los cuales denotan una gran influencia de los poderes centrales en las modificaciones que han tenido las Constituciones de los estados

14 Véase el cuadro al final de este artículo, sobre el número de artículos de cada Constitución Estatal. 
Esta obra forma parte del acervo de la Biblioteca Jurídica Virtual del Instituto de Investigaciones Jurídicas de la UNAM

de la federación durante la vigencia de nuestra actual Constitución, como ha ocurrido en los Estados Unidos de Norteamérica. ${ }^{15}$

\section{EL GONTROL GONSTITUGIONAL}

\section{DE LAS REFORMAS A LAS CONSTITUCIONES DE LOS ESTADOS}

Las Constituciones de los Estados no pueden contravenir normas de la Constitución Federal, es por ello que se creó un mecanismo de verificación para que las reformas que se hagan a las Constituciones locales puedan ser revisadas en cuanto a que si contravienen o no al texto constitucional federal, mediante la acción de inconstitucionalidad.

Es así que han existido diversas sentencias de la Suprema Corte de Justicia de la Nación, que han declarado inconstitucionales determinadas reformas a las Constituciones de algunos estados de la federación, entre algunas de ellas encontramos: los casos de las acciones de inconstitucionalidad 40 y 42 /2006, en Michoacán; 41 y 43/2006, en Oaxaca, y 49, 50 y 51/ 2006; mediante las cuales los diputados locales pretendían ampliar sus mandatos y el de los integrantes de los Ayuntamientos. ${ }^{16}$

La SCJN resolvió que los electores votaron por diputados locales y miembros de los Ayuntamientos por un periodo específico, y que ellos no podrían prorrogar su mandato para el que fueron electos, toda vez que contravenía el principio de gobierno republicano de renovación periódica del poder.

La acción de inconstitucionalidad dentro del expediente 52/2009, consistente en que el Constituyente Permanente del Estado de Aguascalientes había aprobado una reforma a su Constitución que establecía que el Tribunal Electoral del Estado sería un órgano temporal, y en ese periodo el Tribunal Superior de Justicia asumiría sus funciones, ante lo cual la SGJN resolvió que era inconstitucional dicha reforma en virtud de que el tribunal Electoral debería ser un órgano permanente.

Estos son solo algunos casos de los muchos que han existido, en donde la SGJN, han tenido que declarar inconstitucionales reformas a constitucio-

15 Véase los requerimientos federales para las Constituciones de los estados en estados Unidos, en: Tarr, Alan, Comprendiendo las constituciones estatales, traducción de Daniel Barceló, Editorial UNAM, México, 2009, pp. 61-81.

16 Cfr. Flores, Imer B., Sobre la (in) constitucionalidad de "reformas constitucionales: a propósito de los casos de Chiapas, Michoacán y Oaxaca, revista Cuestiones Constitucionales, del IIJ UNAM, número 17, año 2007. 
Esta obra forma parte del acervo de la Biblioteca Jurídica Virtual del Instituto de Investigaciones Jurídicas de la UNAM

nes de los estados de la federación que han contravenido principios y normas de la Constitución Federal de 1917.17

\section{CONTRIBUGIONES DEL CONSTITUGIONALISMO LOCAL}

A la par de esa incidencia obligatoria de los Poderes Federales en las reformas a las constituciones locales, han existido también aportaciones significativas de las entidades federativas aL constitucionalismo, entre las cuales encontramos:

a) En materia de cultura constitucional, tenemos la obligación de leer la Constitución Federal, Estatal y leyes electorales en el caso de Chihuahua desde la reforma del $1^{\circ}$ de octubre de 1994;

b) En reconocimiento a los derechos políticos de la mujer, toda vez que en Yucatán se les otorgó el derecho de votar en elecciones municipales y estatales desde 1923, en Chiapas y Tabasco en 1925, mientras que a nivel federal hasta 1947 en elecciones municipales y hasta 1953 en elecciones federales;

c) En cuanto al de método de reforma constitucional, a través del reformas integrales, en tanto que la Federal de 1917 ha seguido el de reformas parciales;

d) La obligación de enseñar en educación básica y superior en Chiapas, los derechos humanos contenidos en la CPEUM y en la Declaración Universal de Derechos Humanos de la ONU;

e) En la incorporación del concepto de Derechos Fundamentales en lugar de Derechos Humanos en la Constitución de Chihuahua; y las de Tabasco y Coahuila;

f) En materia de participación ciudadana, antes de que en la Constitución Federal de 1917 se incorporara la Consulta Popular y la Iniciativa ciudadana mediante la reforma del 10 de febrero del 2014, ha existido una gran ola de reformas que han integrado distintas formas de participación popular entre las que destacan el referéndum, el plebiscito, la iniciativa popular ${ }^{18}$ y la revocación de mandato entre otros

17 Véanse entre otras: Controversias Constitucionales 9/2001,11/2011; 51/2014; $35 / 2014$.

18 Cfr. Gamboa Montejano, Claudia y García San Vicente, María de la Luz, Democracia Directa, referéndum, Plebiscito e Iniciativa Popular, H. Cámara de Diputados LX Legislatura, México, 2006, p. 53. 
Esta obra forma parte del acervo de la Biblioteca Jurídica Virtual del Instituto de Investigaciones Jurídicas de la UNAM

estados en Chihuahua desde 1997, Baja California a partir del 2011 Oaxaca en el 2011 y Guerrero en 2014;

g) En la actividad legislativa existe la obligación de aprobar un Plan de Desarrollo Legislativo que deberá contener la Agenda Legislativa elaborado bajo los principios de economía funcional, eficiencia y democrático en el Congreso del Estado de Baja California (Artículo 38 ;

h) La participación del Congreso del Estado en formas de control de la Administración con matices parlamentarios, como lo es el caso de la Constitución de Aguascalientes en donde se faculta a la legislatura para citar al Gobernador para que informe (fracción XXX del artículo 27 de su Constitución; en Nuevo León se le atribuye al Congreso la Facultad de ratificar al Secretario de Finanzas y al Tesorero (fracción XXII del artículo 63 de su Constitución); y en Oaxaca la ratificación del Gabinete (fracción XXXIV del artículo 59 constitucional);

i) La obligación de voto de las dos terceras partes de los diputados locales presentes en la sesión para la aprobación de leyes en materia: Electoral, Derechos Humanos, Deuda Pública, Fiscalización Superior del Estado y Municipios, Penal, Ingresos del Estado y Municipios, presupuesto del Estado; Designación de integrantes de Organismos Públicos Autónomos; Comité estatal de Vinculación Hacendaria; Código Financiero para los municipios del Estado y Ley de Hacienda del Estado (P.O. 7 de febrero de 2014 de Coahuila, art. 62 bis);

j) Control de Constitucionalidad, ya sea por tribunales constitucionales, en donde el pleno del Tribunal Superior de Justicia asume esta función como en Chiapas, Coahuila, Nuevo León, Tabasco y Yucatán; salas de control constitucional dentro del Tribunal Superior de Justicia en los casos de: Chihuahua, Durango, Estado de México, Guerrero, Nayarit, Oaxaca, Tabasco;

k) Control previo de Constitucionalidad. Este modelo de control fue adoptado originalmente en Francia por el Consejo Constitucional Francés ${ }^{19}$, luego en España y se ha retomado en las constituciones locales de México en Yucatán desde el 17 de mayo del 2010, a pesar de la oposición del gobierno federal quien promovió una acción de inconstitucionalidad que fue resuelta por la SGNJ a favor de constitucionalidad y Nayarit;

19 Cfr. Avril, Pierre, Gicquel, Jean, Le Conseil Constitutionnel, Editorial Montchrestien, París, 1993, p. 90. 
Esta obra forma parte del acervo de la Biblioteca Jurídica Virtual del Instituto de Investigaciones Jurídicas de la UNAM

l) La figura de omisión legislativa en el caso de Chiapas, Campeche y Quintana Roo y en su noción de omisión normativa en Coahuila;

m) Diferente porcentaje respecto de la Constitución Federal, que establece el tres por ciento para el acceso de diputados de representación proporcional, como en los casos de los Estados de Chihuahua y Yucatán que exigen el 2\% y Nayarit el 1.5\%;

n) En el número de periodo ordinarios del Poder Legislativo, mientras que la Constitución Federal previene dos periodos ordinarios, en Durango y Querétaro tienen un periodo y tres periodos en Baja california, Estado de México, Puebla, y Yucatán;

o) Respecto de la reelección de legisladores, en tanto que la Constitución Federal admite hasta tres periodos adicionales para los diputados federales, hay constituciones locales que establecen periodos diferentes como las de: Aguascalientes, Colima, Chihuahua, Oaxaca, Quintana Roo y Tamaulipas un periodo;

p) Diversidad en cuanto a su sistema para la elección de miembros de los Ayuntamientos, toda vez que mientras la mayoría de constituciones locales previenen la elección total por el método de representación proporcional, varios estados han adoptado el sistema mixto de elección en distritos por mayoría relativa y con otra parte de representación proporcional, como en los casos de: Aguascalientes, Baja california Sur, Campeche, Chihuahua, Chiapas, Jalisco, Nuevo León; QRoo; Sonora;

q) El tiempo de función de los Regidores de 4 años en Tamaulipas y Veracruz;

Como podemos apreciar, son abundantes y significativas las aportaciones propias de las constituciones de los Estados federados de México al constitucionalismo.

\section{El MÉTODO DE REFORMA EN LAS CONSTITUCIONES ESTATALES}

Como hemos señalado, la modificación de las constituciones locales después de la aprobación de la Constitución de 1917, se hizo de la misma forma, a través de Congresos Constituyentes mediante iniciativas de reformas y adiciones y no de proyectos de nuevos textos constitucionales, aun cuando hayan modificado partes sustantivas de los mismos. Las reformas subsecuentes se fueron haciendo a través del procedimiento normal de iniciativas parciales que en general han dado como resultado textos muy desordenados 
Esta obra forma parte del acervo de la Biblioteca Jurídica Virtual del Instituto de Investigaciones Jurídicas de la UNAM

y poco coherentes en la sistemática constitucional. Así por ejemplo podemos señalar el caso de la Constitución de Coahuila que regula lo referente a la Comisión de Defensa de Derechos Humanos en su parte final dentro del último título que se refiere a la inviolabilidad y reforma de la Constitución, texto que no guarda ninguna relación temática; y así la mayoría de Constituciones locales siguen la misma estructura temáticamente desarticulada que ha tenido hasta ahora la Constitución de 1917. Sin embargo, algunas Constituciones locales han seguido un método de reformas que podríamos denominar integral, puesto que aún cuando no han sido aprobadas por Congresos Constituyentes locales, las iniciativas de modificación han reformado todo su articulado no sólo en la parte formal sino en sus contenidos. Este método de reforma integral se ha seguido en los caso de las Constituciones

del Estado de México en 1995²0, San Luis Potosí en 1996²1, Estado de Zacatecas en $1998^{22}$, Veracruz en $1999{ }^{23}$ y Guerrero en el 2014.24

20 Véase la exposición de motivos del proyecto de la iniciativa de decreto por la que se reforman, adicionan y derogan diversos libros, títulos, capítulos, secciones, artículos y fracciones de la Constitución Política del Estado Libre y Soberano de México del 27 de febrero de 1995, cuyo texto es el siguiente: "Como resultado de las sucesivas modificaciones, el texto constitucional, ha tenido cambios que se reflejan en el enunciado de títulos, secciones, artículos y fracciones derogados, artículos bis y con literal, lo que amerita su revisión integral para darle mayor orden, continuidad y sistematización.” P. 1.

$21\{$ N. de E. las adiciones y reformas aprobadas en el decreto 657 de la LIV legislatura, publicado en el P.o. del Estado el 20 de noviembre de 1996, modificó de manera sustancial prácticamente todo el texto que a la fecha tenia la Constitución, dando como resultado un texto diferente, debido a lo anterior es parte del nuevo texto a partir de 1996.

22 Véase la iniciativa de reformas y adiciones a la Constitución del Estado de Zacatecas DEL 22 de diciembre de 1997, "Al presentar su cuarto Informe de Gobierno, el Ejecutivo del Estado expresó que la distinta realidad en que vivimos los zacatecanos hacía no sólo aconsejable sino imprescindible promover una reforma integral a nuestra Ley Suprema, que fuese la expresión jurídica y política del modo de ser de nuestro pueblo y cauce para la edificación de una sociedad mejor que la actual". P. 3.

23 Véase la exposición de motivos de la iniciativa de Reforma Integral a la Constitución Política del Estado Libre y Soberano de Veracruz-Llave de 13 de septiembre de 1999, cuya parte del texto es el siguiente: “... la presente iniciativa de reforma integral a la Constitución Política del Estado Libre y Soberano de Veracruz-Llave sustenta un proyecto que significa por la compactación, supresión, modificación, adición y reordenamiento de Títulos, Capítulos Secciones y artículos de las partes dogmática y orgánica de nuestra Ley Suprema, p. XXVI.

24 Véase la iniciativa de decreto que reforma y adiciona integralmente diversas disposiciones de la Constitución Política del Estado Libre y Soberano de Guerrero, en su parte que dice: "La iniciativa de reforma Integral a la Constitución, constituye una propuesta progresista, moderna y de avanzada, que trasciende a la arquitectura del poder prevaleciente, y se inscribe dentro de las corrientes más representativas del pensamiento político-jurídico contemporáneo, p. 6. 
Esta obra forma parte del acervo de la Biblioteca Jurídica Virtual del Instituto de Investigaciones Jurídicas de la UNAM

En este contexto, en el Estado de Guerrero, se aprobó una reforma integral a su Constitución, que conviene exponer en sus aspectos fundamentales, para el conocimiento del constitucionalismo local mexicano.

\section{LA Nueva Constitución Del Estado DE GUeRrero}

La Constitución del Estado de Guerrero que adecuó las reformas y adiciones de la Constitución Federal de 1917, se publicó en el periódico oficial del Estado el 3, 10 y 17 de noviembre de 1917 y 5 de enero de 1918, y al igual que todas las constituciones locales tuvo múltiples reformas que hicieron un texto desarticulado, por citar un ejemplo, la Comisión Estatal de la Defensa de los Derechos Humanos fue incluida dentro del capítulo relativo al Poder Ejecutivo.

Durante los años 2011, 2012 y 2013 se realizaron foros de consulta sobre diversas temáticas relativas a la aprobación de un nuevo texto constitucional; una vez que se concluyó este proceso, junto con el Licenciado Porfirio Muñoz Ledo elaboramos un proyecto de reforma integral a la Constitución de Guerrero, vanguardista, el más avanzado del constitucionalismo, sin embargo, fue mutilado por abogados conservadores.

En proyecto modificado fue entregado al Congreso del Estado el 27 de octubre del 2012 y había el propósito de que con motivo del bicentenario de la instalación del primer Congreso de Anáhuac, el 13 de septiembre del 2013 se promulgara el decreto de reforma constitucional, sin embargo, la burocracia en el Poder Legislativo prolongó su aprobación y fue hasta el 29 de abril del 2014 que se publicó en el Periódico oficial del Gobierno del Estado.

Aún cuando se le hicieron cambios relevantes ala proyecto original, la nueva Constitución de Guerrero, mantuvo algunos avances y aportaciones muy importantes.

El método de reforma que se propuso fue el de Reforma Integral, con el objetivo de tener un texto constitucional sistemático

El proyecto original proponía incluir como primer título todo lo relativo a los de Derechos Humanos, sin embargo, en el Congreso del Estado modificaron el orden temático y parte de sus contenidos que como fueron aprobados al final fundamentalmente son los siguientes:

\section{Disposiciones Preliminares}

El título primero se denomina disposiciones preliminares, en donde se establece que el Estado de Guerrero forma parte de la federación y que se 
Esta obra forma parte del acervo de la Biblioteca Jurídica Virtual del Instituto de Investigaciones Jurídicas de la UNAM

constituye como un Estado de derecho democrático y social, siguiendo el ejemplo de la Constitución española de 1978 y de las Constitución de Tabasco.

Reafirma su calidad soberana en su régimen interior, la residencia de la soberanía en el pueblo; que la dignidad es la base de los derechos humanos individuales y colectivos de la persona; establece como valores superiores del orden jurídico, político y social, la libertad, la igualdad, la justicia social, la solidaridad, el pluralismo democrático e ideológico, el laicismo, el respeto a la diversidad y a la vida en todas sus manifestaciones; señala como deberes fundamentales del Estado promover el progreso social y económico, individual y colectivo, el desarrollo sustentable, la seguridad y la paz social, y el acceso de todos los guerrerenses a los asuntos públicos, y en la cultura, atendiendo siempre el principio de equidad; refiere que el principio precautorio constituirá la base del desarrollo económico y el deber del Estado de garantizar y proteger los derechos de la naturaleza (artículos $1^{\circ}$ y $2^{\circ}$ de la Constitución Política del Estado de Guerrero, CPEG).

\section{Derechos humanos y sus garantías}

El título segundo se refiere a los derechos humanos y sus garantías, en el cual retoma los principios contenidos en la CPEUM en cuanto a los que reconoce la misma y los instrumentos internacionales, la procedencia de la reparación del daño en caso de su violación, su eficacia directa y vinculación con todos los poderes públicos, la obligación para las autoridades del Estado de promover, respetar, proteger, defender y garantizar los derechos humanos con base en los principios de universalidad, interdependencia, indivisibilidad, progresividad y máxima protección, en cuya interpretación y aplicación deberá atenderse el sentido más favorable contenido en la CPEUM y en los ordenamientos internacionales (artículo 4 de la CEPEG).

Reconoce para toda persona individual y colectiva, la titularidad de derechos humanos, como mínimos los siguientes: a la vida y proscribe la pena de muerte; a la libertad y seguridad personal y colectiva; prohibición de ser privado o limitado de la libertad sin el debido proceso; prohibición de obtener y usar pruebas ilícitamente; de ser informado en forma inmediata en caso de detención, de sus derechos y causas de su detención, a no ser obligado a declarar y a contar con un abogado para su defensa; a ser indemnizada en caso de haber sido privada de la libertad y/o de ser sentenciado por error judicial; de acceso a la justicia por violación a derechos humanos; respeto a la integridad física, psíquica, moral, por lo que prohíbe 
Esta obra forma parte del acervo de la Biblioteca Jurídica Virtual del Instituto de Investigaciones Jurídicas de la UNAM

la tortura, las penas o tratos crueles, inhumanos o degradantes; de igualdad y no discriminación por ningún motivo; a la protección del matrimonio y la familia; a la erradicación de la violencia de género; derechos plenos a las niñas y niños; a la identidad, nombre propio y apellidos de sus progenitores o al de uno de ellos; a la propiedad y al uso de los bienes; a la libertad de convicciones éticas, de conciencia, religión, humanitarias o de naturaleza afines en lo individual como colectivo; a la libertad de expresión y de información, a buscar y recibir informaciones de todo tipo, al derecho de rectificación y respuesta; al libre acceso a registros, archivos, bancos de datos personales en posesión de entidades públicas o privadas, a requerir su actualización, rectificación, confidencialidad o supresión en caso de que restrinjan sus derechos; a decidir libremente sobre sus órganos, tejidos y células para destinarlos en donación o recibirlos en trasplante sin fines de lucro; acceder en condiciones de igualdad a empleos, comisiones y cargos públicos; a solicitar como ciudadanos su registro como candidatos independientes.

\section{Derechos económicos, sociales, culturales y ambientales}

La sección primera del capítulo dedicada a derechos humanos, se refiere a los derechos económicos, sociales, culturales y ambientales, entre los que se encuentran: al trabajo; a la educación y formación profesional; vivienda digna; a la salud integral; a la alimentación; al agua; a un medio ambiente sano; deber del Estado para garantizar la protección, conservación, restauración de los bienes ambientales y reparación del daño ambiental; de los grupos vulnerables de acceso a condiciones de bienestar e inclusión social; de las personas discapacitadas; migrantes dentro y fuera del territorio del estado; de las niñas y niños; a la no discriminación de mujeres embarazadas a acceso a la salud materna; de las víctimas de la violencia familiar, sexual, maltrato infantil y cualquier forma de esclavitud; a la recreación social, deportiva, cultural, sano esparcimiento para la integración y convivencia colectiva; y la obligación del para aprobar leyes y aplicar políticas publicas que garanticen los derechos sociales (fracciones I a IX del artículo 6 de la CPEG.)

\section{Derechos de los pueblos indígenas y afromexicanos}

La sección segunda de este mismo título II, está dedicada a los pueblos indígenas y afromexicanos, en la cual se admite la composición e identidad 
Esta obra forma parte del acervo de la Biblioteca Jurídica Virtual del Instituto de Investigaciones Jurídicas de la UNAM

multiétnica, plurilinguística y pluricultural de los pueblos originarios indígenas especialmente de los nahuas, mixtecos, tlapanecos y amuzgos y de las comunidades afromexicanas; a quienes les reconoce los derechos siguientes: libre determinación y autonomía; a decidir sus formas de convivencia, de organización social, económica, política y cultural; a aplicar sus propios sistemas normativos en la regulación y solución de sus conflictos internos; a elegir de acuerdo a sus procedimientos y practicas tradicionales a sus autoridades y representantes y a garantizar la participación de las mujeres en condiciones de equidad promoviendo su participación y liderazgo en los asuntos públicos; al acceso del uso y disfrute colectivo de sus tierras, territorios y recursos naturales, a la consulta y consentimiento previo libre e informado de la comunidad, en caso de afectación y en su caso a tener beneficios y productos; a preservar y enriquecer las lenguas conocimientos y toda su identidad cultural; al acceso pleno de la jurisdicción del Estado tomando en cuanta su usos, costumbres, cultura, asistidos por traductores, intérpretes y defensores; a la educación intercultural, lingüística, laica, gratuita y de calidad; a sistemas de becas; al acceso al primer empleo; a la enseñanza obligatoria de sus lenguas y del español; a que el estado genere políticas públicas; al reconocimiento y garantía de sus acciones de seguridad pública y prevención del delito, de su sistema de faltas cuyo seguimiento debe ser a través de la policía comunitaria o rural formadas por personas de su comunidad designados en asamblea popular o general, (artículos 8 a 14 de la CPEG).

Es esta parte, es muy importante destacar que las policías comunitarias en Guerrero tienen fundamento constitucional, ya que forman parte del sistema de seguridad pública en el Estado y se encuentra reglamentada su existencia en la ley 701 de Reconocimiento de Derechos y Cultura de los Pueblos y Comunidades Indígenas promulgada el 8 de abril del 2011.

\section{Derechos Politicos}

En el ámbito de los derechos políticos de los ciudadanos, además de los derechos normales de votar y ser electo, contiene los de: asociarse libre y pacíficamente para participar en los asuntos públicos del Estado; participar en los procesos de plebiscito, referéndum y revocación de mandato y demás instrumentos de participación ciudadana; presentar iniciativas de ley ante el Congreso del Estado; acceso a la información pública del Estado; ser preferido en igualdad de condiciones para desempeñar cualquier servicio público en el Estado; formular peticiones a las autoridades estatales; afiliarse de manera libre, individual e independiente a cualquier partido político; a exigir a 
Esta obra forma parte del acervo de la Biblioteca Jurídica Virtual del Instituto de Investigaciones Jurídicas de la UNAM

las autoridades que rindan cuentas de manera oportuna y que sus actos sean transparentes y públicos; a los guerrerenses que vivan fuera del Estado o del país se les garantiza el derecho a votar en las elecciones para gobernador y a ser votados como diputados migrantes, (artículo 19 de la CPEG), esto en razón de que se previene que el Congreso del Estado se integre también con un legislador local migrante, sin embargo, este derecho no se ejerció en el proceso electoral del año 2015, debido a que a pesar de ya estar reconocido en la Constitución, los propios diputados locales aprobaron una reforma para que esta disposición entre en vigor hasta el proceso electoral del 2018.

\section{Organización del Estado}

$\mathrm{Al}$ igual que las demás constituciones locales, la nueva Constitución de Guerrero contiene lo relativo a la forma de gobierno que proviene del artículo 40 de la Constitución Federal, que incluye la representación popular y participativa; al territorio; a los municipios que lo integran; los símbolos del Estado; a los partidos políticos y candidaturas independientes; al proceso electoral; a los poderes legislativo (que debe realizar dos periodos de sesiones ordinarios cada año), ejecutivo y judicial (que incluye el proceso penal acusatorio oral, con los derechos para una persona imputada, los derechos de la víctima o el ofendido) y un sistema de control constitucional (como ya existe en otras entidades federativas, aquí mediante una sala que forma parte del Tribunal Superior de Justicia, la cual aún no se ha instalado por falta de la legislación reglamentaria, (título IV, artículo 22 al 104).

\section{7. Órganos autónomos del Estado y de autonomía técnica}

Una de las reformas de la nueva Constitución de Guerrero, fue la de agrupar en un título propio a los órganos autónomos del Estado, al igual que lo han hecho entre otras constituciones locales como las de: Durango, Michoacán, Morelos, Oaxaca, Querétaro Tlaxcala, Veracruz y Yucatán.

El nuevo texto constitucional de Guerrero establece como garantías para los órganos autónomos la autonomía e independencia y los obliga a conducirse bajo los principios de: certeza, legalidad, imparcialidad, objetividad, eficiencia, racionalidad presupuestaria, profesionalismo, responsabilidad, transparencia, máxima responsabilidad y rendición de cuentas.

Las características comunes de los órganos autónomos consisten en: que son permanentes; tienen personalidad jurídica y patrimonio propio; 
Esta obra forma parte del acervo de la Biblioteca Jurídica Virtual del Instituto de Investigaciones Jurídicas de la UNAM

autonomía técnica, presupuestal, de gestión, organización, funcionamiento y de decisión; elaborar su propio proyecto de presupuesto; rendir informes financieros y cuenta pública al Congreso del Estado, sobre la aplicación de su presupuesto; comparecer ante el Congreso del Estado, por medio de su presidente; privilegiar la máxima publicidad y transparencia en su funcionamiento, deliberaciones y resoluciones; a establecer el servicio civil de carrera; sus actos y resoluciones serán sometidas a control jurisdiccional, salvo los de la Comisión Estatal de Defensa de los Derechos Humanos y del Instituto de Transparencia, Acceso a la Información y Protección de Datos Personales; un estatuto para sus integrantes, sujeción a responsabilidades política, penal, administrativa, civil; garantías de igualdad en el valor de su voto, salvo en el caso de voto de calidad, a postularse y a elegir a su titular o Presidente.

La nueva Constitución Política de Guerrero, reconoce como Órganos Autónomos del Estado a: la Comisión Estatal de Defensa de los Derechos Humanos; al Instituto de Transparencia, Acceso a la Información y Protección de Datos Personales; al Instituto Electoral y de Participación Ciudadana; al Tribunal Electoral del Estado; al Tribunal de lo Contencioso Administrativo; a la Fiscalía General del Estado; y a los Órganos con Autonomía Técnica, como instituciones adscritas a los poderes del Estado para coadyuvar en el mejor desempeño de sus funciones, los cuales son: la Auditoría General del Estado, vinculado al Congreso del Estado; Consejo de Políticas Públicas, dependiente del Poder Ejecutivo; el Consejo de la Judicatura, adscrito al Poder Judicial; y el Instituto de Defensoría Pública del Estado, dependiente del Consejo de la Judicatura (artículos 104 al 169 de la CPEG).

Como lo hacen las demás Constituciones estatales, la de Guerrero incluye al Municipio libre y a: la hacienda pública del estado, la hacienda municipal, la educación pública, las universidades e instituciones de educación superior, la responsabilidad de los servidores públicos; el servicio civil de carrera; y en su parte final lo relativo a la supremacía, reforma e inviolabilidad de la Constitución.

\section{Adecuación de la reforma Constitucional de Guerrero a la legislación reglamentaria.}

Para llevar a cabo las adecuaciones de las reformas de la Constitución del Estado de Guerrero a las leyes reglamentarias, se estableció un tercer artículo transitorio que mandataba a los diputados del Congreso Local a llevar a cabo dichas modificaciones en un plazo de dos años (al 29 de abril del 2016) el cual está por cumplirse, sin que los legisladores locales hayan 
Esta obra forma parte del acervo de la Biblioteca Jurídica Virtual del Instituto de Investigaciones Jurídicas de la UNAM

realizado dichas reformas, es por ello que recientemente acaban de aprobar un cambio a dicha disposición para prorrogar un año más dicho plazo.

En la parte de la aplicación de las leyes reglamentarias, se estableció en el artículo cuarto transitorio que en tanto no se hicieran las adecuaciones de las normas constitucionales, seguirían vigentes las disposiciones reglamentarias, en todo lo que no contraviniera a la nueva Constitución.

La nueva Constitución de Guerrero, que es la más reciente aprobada en las entidades federativas de país, constituye un avance en el constitucionalismo local, ya que fue producto de un amplio proceso de consulta; se utilizó un método de reforma integral que organiza y estructura mejor un texto constitucional; incorporó un amplio catalogo de derechos humanos, de los pueblos indígenas incluyendo sus policía comunitarias; la democracia participativa mediante el referéndum, el plebiscito, la iniciativa popular y la revocación de mandato; un título especial para los Órganos Autónomos del Estado y los de autonomía técnica, la obligatoriedad del servicio civil de carrera.

\section{LA nueva Constitución de la GiUdad DE MÉXICO Y EL CENTRALISMO}

Este 29 de enero del 2016, se publicaron en el Diario Oficial de la Federación, las reformas a la Constitución Federal de 1917, relativas a la transformación del anterior Distrito Federal, a una nueva entidad de la federación que es la Ciudad de México.

La reforma constitucional que crea la Ciudad de México, mantiene marcados rasgos de centralismo, ya que en la integración de la Asamblea Constituyente para la aprobación de su propia Constitución (a mas tardar el 31 de enero del 2017), los poderes federales habrán de designar a treinta y cuatro de cien integrantes, a saber, catorce senadores y catorce diputados federales, seis por el Presidente de la Republica, y el resto seis por el Jefe de Gobierno del Distrito Federal (artículo transitorio 7 incisos C, D y E de la reforma a la CPEUM)

Por otra parte, el sistema de elección de los miembros de la Asamblea Constituyente, que será sólo por representación proporcional, rompe con el sistema normal de elección de la Cámara Federal de Diputados y de los Congresos locales, que es el sistema mixto con predominante mayoritario.

Otra expresión de concentración de poder, la encontramos en la facultad del Presidente de la República para poder remover al servidor público que ejerza el mando directo de la fuerza pública por causas graves que de- 
Esta obra forma parte del acervo de la Biblioteca Jurídica Virtual del Instituto de Investigaciones Jurídicas de la UNAM

termine la ley que expida el Congreso de la Unión (párrafo sexto inciso B fracción XI del artículo 122 de la CPEM).

La reforma constitucional para la creación de la Ciudad de México previene mandatos precisos que deberá contener la nueva Constitución de esta entidad federativa, tales como: la forma de gobierno representativo, republicano, democrático y laico; establecer normas y garantías para la protección de los derechos humanos; el principio de sobre representación de no mas del 8\%; posibilidad de elección de diputados hasta por cuatro periodos; garantías a los grupos parlamentarios de acceso a los órganos de gobierno del Congreso local; que el titular de la entidad de fiscalización sea electo por las dos terceras partes de los miembros presentes de la legislatura por un periodo no menor a siete años; las facultades del jefe de gobierno y los requisitos para ocupar el cargo; la independencia de los magistrados y jueces del Poder Judicial, el periodo de su encargo y la posibilidad de reelección; las demarcaciones territoriales; integración, organización y facultades de las Alcaldías; número de concejales; la aprobación del presupuesto y su ejercicio por las Alcaldías; la elección consecutiva de Alcaldes y Concejales hasta por un periodo adicional; la competencia de las alcaldías; las bases para que la ley establezca los criterios o fórmulas de asignación de los presupuestos para las demarcaciones territoriales; requisitos de los Alcaldes y Concejales; los órganos autónomos que previene la Constitución Federal; las normas para la organización, funcionamiento y facultades del Tribunal de Justicia Administrativa; las reglas de la Constitución Federal en materia electoral; que las funciones de procuración de justicia en la Ciudad de México se realicen con base en los principios de autonomía, eficiencia, imparcialidad, legalidad, objetividad, profesionalismo, responsabilidad y respeto a los derechos humanos (artículo 122 de la CPEUM).

Los contenidos de la reforma al artículo 122 de la CPEUM, son demasiado descriptivos y extensos, toda vez que regulan aspectos a detalle que deberá integrar la nueva constitución de la Ciudad de México, entre ellos: el gasto de operación de la demarcación territorial y ajustar su gasto corriente a las normas y montos máximos, así como a los tabuladores desglosados de remuneraciones de los servidores públicos; las bases para que la ley correspondiente prevea los criterios o fórmulas para la asignación del presupuesto de las demarcaciones territoriales, el cual se compondrá, al menos, de los montos que conforme a la ley les correspondan por concepto de participaciones federales, impuestos locales que recaude la hacienda de la Ciudad de México e ingresos derivados de la prestación de servicios a su cargo; los 
Esta obra forma parte del acervo de la Biblioteca Jurídica Virtual del Instituto de Investigaciones Jurídicas de la UNAM

requisitos para ser Alcalde y Concejal: prohibición para las demarcaciones (Alcaldías) para contraer deuda.

No hay ninguna duda respecto de que las Constituciones de las entidades federadas deben adecuarse plenamente a lo dispuesto por la Constitución Federal, sin embargo, este cúmulo de mandatos de la Constitución Federal de 1917 hacia la nueva Constitución de la Ciudad de México, refleja en gran medida la excesiva injerencia de los poderes federales en las Constituciones locales.

La legislación que se ha aprobado por las sucesivas Asambleas Legislativas del anterior Distrito Federal, ha sido considerada como de mayor avance en el reconocimiento de las libertades (derecho a la libre procreación de hijos, interrupción del embarazo, derecho a contraer matrimonio a personas del mismo sexo) y derechos sociales (de los adultos, mayores, personas discapacitadas, madres solteras), por lo que se puede prefigurar que la Constitución de la nueva Ciudad de México, pueda ser de vanguardia en el concierto de las Constituciones de las demás entidades de la federación.

\section{CONCLUSIÓN Y PROSPEGTIVA \\ DE LA REFORMA GONSTITUCIONAL EN LOS ESTADOS DE LA FEDERACIÓN}

Como ha quedado demostrado a lo largo de esta exposición, los poderes federales mediante reformas al artículo 73 de la Constitución General de 1917, y de otros artículos constitucionales, han asumido progresivamente cada vez más facultades, haciéndolas explicitas, en detrimento de las reservadas originalmente a los estados, con ello se observa una tendencia que continuará y habrá de acentuarse en los años porvenir, como ya lo podemos apreciar con la iniciativa de la policía única (independientemente de su sentido de oportunidad o validez coyuntural); sin embargo, también en la medida de que haya más alternancia en los poderes estatales y mayor autonomía respecto de los poderes federales, podrán existir como ha ocurrido hasta ahora, muchas contribuciones del constitucionalismo local. 
Esta obra forma parte del acervo de la Biblioteca Jurídica Virtual del Instituto de Investigaciones Jurídicas de la UNAM

\begin{abstract}
ANEXO
TABla DE GONSTITUGiONES LOGALES, ESTADO, FECHA DE PROMULGACIÓN Y NÚMERO DE ARTÍCULOS
\end{abstract}

\begin{tabular}{|c|c|c|}
\hline Constitución & Fecha de promulgación & Número de artículos \\
\hline Aguascalientes & 9, 16, 23 de septiembre 1917 & 95 \\
\hline Baja California & 16 de agosto de 1953 & 113 \\
\hline $\begin{array}{l}\text { Baja California } \\
\text { Sur }\end{array}$ & 15 de enero 1975 & 167 \\
\hline Campeche & 5,7 y 10 julio 1917 & 132 \\
\hline Chiapas & 3 de febrero 1921 & 95 \\
\hline Chihuahua & $\begin{array}{l}25 \text { de mayo } 1921 \text {, Nueva } \\
\text { Constitución } 17 \text { de junio de } 1950\end{array}$ & 203 \\
\hline Coahuila & 19 de febrero de 1918 & 198 \\
\hline Colima & $\begin{array}{l}27,27 \text { de octubre, } 3,10,17 \text { y } 24 \text { de } \\
\text { noviembre de } 1917\end{array}$ & 151 \\
\hline Durango & 14 marzo 1918 & 183 \\
\hline $\begin{array}{l}\text { Estado de } \\
\text { México }\end{array}$ & 10, 14 y 17 de noviembre de 1917 & 149 \\
\hline Guanajuato & 18 octubre 1917 & 145 \\
\hline Guerrero & $\begin{array}{l}3,10 \text { y } 17 \text { de noviembre de } 1917 \text { y } 5 \\
\text { de enero de } 1918\end{array}$ & 199 \\
\hline Hidalgo & 1 de octubre de 1920 & 159 \\
\hline Jalisco & $\begin{array}{l}21,25 \text { y } 28 \text { de julio y } 1 \text { de agosto de } \\
1917\end{array}$ & 119 \\
\hline Michoacán & $\begin{array}{l}71014,1721,24 \text {, jueves } 28 \text {, de } \\
\text { febrero; } 3,7,1014 \text { de marzo de } \\
1918\end{array}$ & 165 \\
\hline Morelos & 16 de noviembre de 1930 & 151 \\
\hline Nayarit & $\begin{array}{l}17,21,24 \text { y } 28 \text { de febrero y } 3,7,10 \text { y } \\
14 \text { de marzo de } 1918 \text {. }\end{array}$ & 139 \\
\hline Nuevo León & 16 diciembre 1917 & 153 \\
\hline Oaxaca & 4 de abril 1922 & 142 \\
\hline Puebla & 2 de octubre de 1917 & 143 \\
\hline
\end{tabular}


Esta obra forma parte del acervo de la Biblioteca Jurídica Virtual del Instituto de Investigaciones Jurídicas de la UNAM

\begin{tabular}{|l|l|l|}
\hline \multicolumn{1}{|c|}{ Constitución } & \multicolumn{1}{|c|}{ Fecha de promulgación } & \multicolumn{1}{c|}{ Número de artículos } \\
\hline Querétaro & $\begin{array}{l}22 \text { y } 29 \text { de septiembre, } 6,13,20 \text { y } 27 \\
\text { de octubre y } 3 \text { noviembre } 1917\end{array}$ & 40 \\
\hline Quintana Roo & 12 de enero 1975 & 169 \\
\hline San Luis Potosí & $\begin{array}{l}2,5,9,12,16,19,23,26 \text { y } 30 \text { de } \\
\text { enero; } 2,6 \text { y } 9 \text { de febrero de } 1918 .\end{array}$ & 139 \\
\hline Sinaloa 159 & $\begin{array}{l}25 \text { de agosto de } 1917, \text { reformada por } \\
\text { plebiscito el } 22 \text { junio } 1922\end{array}$ & \\
\hline Sonora & 29 de marzo de 1917 & 165 \\
\hline Tabasco & 5 abril 1919 & 84 \\
\hline Tamaulipas & 5 de febrero de 1921 & 167 \\
\hline Tlaxcala & $\begin{array}{l}2,9,16,30 \text { de } 0 \text { ctubre, } 6 \text { y } 20 \text { de } \\
\text { noviembre, } 4 \text { y } 11 \text { diciembre } 1918\end{array}$ & 121 \\
\hline Veracruz & 25 septiembre 1917 & 84 \\
\hline Yucatán & 14 enero 1918 & 109 \\
\hline Zacatecas & 11 de julio 1998 & 167 \\
\hline
\end{tabular}

\section{BibliografíA}

ALLAM TARR, G., Comprendiendo las constituciones estatales, traducción de Daniel Barceló, Editorial UNAM, México, 2009, 353 pp.

ALEXY Robert, Teoría de los Derechos Fundamentales, traducción de Carlos Bernal Pulido, Centro de Estudios Constitucionales, Madrid, 2014. 601 pp.;

ARTEGA NAVA Elisur, El sistema federal mexicano, Editorial Porrúa, México, 2013, 283 pp.

ARTEGA NAVA Elisur, Derecho Constitucional Estatal, Editorial Porrúa, México, 1988, 444 pp.

AVRIL Pierre, GICQUEL Jean, Le Conseil Constitutionnel, Editorial Montchrestien, París, 1993, 156 pp.

BARGELÓ ROJAS, Daniel Armando, Introducción al Derecho Constitucional Estadounidense, Editorial UNAM, México, 2005, 197 pp.

BOLAÑOS G. B., (recopilador) Recopilación de leyes y decretos expedidos de enero a abril de 1917, Imprenta de la Secretaría de Gobernación, México, s/a., vinculo electrónico wrerr.sitios.scjn.gob.mx/constitucion1917.../4Enero-abril1917Recopilaci... 
Esta obra forma parte del acervo de la Biblioteca Jurídica Virtual del Instituto de Investigaciones Jurídicas de la UNAM

Constitución Política del Estado Libre y Soberano de México, publicada en la gaceta del gobierno el 10, 14 y 17 de noviembre de 1917.

DE ANDREA Francisco, Derecho Constitucional Estatal, Estudios históricos, legislativos y teórico-prácticos de los estados del la República mexicana, Editorial UNAM, México, 2001, 548, pp.

GAMBOA MONTEJANO Claudia y GARCIA SAN VICENTE, María de la Luz, Democracia Directa, referéndum, Plebiscito e Iniciativa Popular, H. Cámara de Diputados LX Legislatura, México, 2006,

GAMIZ PARRAL Máximo, Derecho Constitucionaly Administrativo de las entidades federativas, Editorial UNAM, México, 1990, 375 pp.

GARCIA RUBI Jorge Arturo, Historia constitucional de Estado de Morelos, pp. 242244, versión electrónica, vínculo biblio.juridicas.unam.mx/libros/1/8/20

DUVERGER Maurice, Constitutions et documents politiques, editorial PUF, París, 1957, 991 pp.

H. Cámara de Diputados del H. Congreso de la Unión, LIV Legislatura, Las Constituciones de México, La Constitución de 1824, México, 1989, 991 pp.

FERRAJOLI Luigi, Los fundamentos de los derechos fundamentales, traductores: Perfecto Andrés, Antonio de Cabo, Miguel Carbonell, Lorenzo Córdoba, Marcos Criado y Gerardo Pisarello, Editorial Trotta, Madrid, 2001, 391 pp.

FIORAVANTE Mauricio, Los Derechos Fundamentales, traducción Manuel Martínez Neira, Editorial Trotta, Madrid, 1996, 165 pp.

FLORES Imer B., Sobre la (in) constitucionalidad de "reformas constitucionales: a propósito de los casos de Chiapas, Michoacán y Oaxaca, revista Cuestiones Constitucionales, del IIJ UNAM, número 17, año 2007.

PADOVER Saul K., The living U.S. Constitution, New American Library, New York, 1983, $399 \mathrm{pp}$. 
Esta obra forma parte del acervo de la Biblioteca Jurídica Virtual del Instituto de Investigaciones Jurídicas de la UNAM

\title{
REVISIÓN DEL DISEÑO Y LA TÉGNICA CONSTITUGIONALES EN MÉXICO
}

\author{
Miguel Ángel RodRíGUEZ VÁzQUEZ*
}

\begin{abstract}
SUMARIO: I. Introducción. II. Aspectos teórico-conceptuales sobre la técnica y el diseño constitucionales. III. El uso de la técnica y el diseño constitucionales en el caso mexicano. IV. Conclusiones. V. Referencias Bibliográficas.
\end{abstract}

\section{INTRODUCGIÓN}

Un tema poco atendido en México por quienes tienen el poder de reformar el texto constitucional, ha sido el relativo a la técnica constitucional, basta realizar su lectura para demostrar dicha aseveración. Tan es así que el Instituto de Investigaciones Jurídicas de la Universidad Nacional Autónoma de México y el Instituto Iberoamericano de Derecho Constitucional, lo hacen explícito en el estudio académico que realizan de la Constitución Política de los Estados Unidos Mexicanos, de ahí que hayan generado un proyecto denominado: "Texto reordenado y consolidado", al que nos referiremos en este trabajo.

Lo anterior es ya un problema fuerte, pero si a ello le agregamos que en muchas de las ocasiones, los diseños contenidos en las reformas constitucionales han obedecido, entre otras razones, a intereses personales o de grupo con lo cual pretenden obtener provecho y mejorar la situación en que se encuentran sin tomar en cuenta a los demás grupos y en general a la comunidad, también a que se hacen por aspectos coyunturales sin visión de largo plazo y pierden

* Doctor en Derecho por la Universidad Nacional Autónoma de México. Catedrático e investigador de la Facultad de Derecho y Ciencias Políticas en la Universidad Juárez del Estado de Durango. Investigador Nivel I del Sistema Nacional de Investigadores. Miembro asociado de la Sección Mexicana del Instituto Iberoamericano de Derecho Constitucional. Magistrado en Retiro. 
Esta obra forma parte del acervo de la Biblioteca Jurídica Virtual del Instituto de Investigaciones Jurídicas de la UNAM

de vista que una Constitución pretende crear un orden que dé estabilidad por un periodo más o menos amplio, mientras las condiciones que le dieron origen no cambien sustancialmente, entonces, la situación se agrava.

Ante tal panorama, ahora que se acerca el aniversario número cien de la promulgación de nuestra Constitución vigente, es válido que nos preguntemos si es llegado el momento de crear una nueva o de realizar una reforma integral a la existente o como dice el proyecto antes citado, si solamente se establece un "Texto reordenado y consolidado". Obviamente, que en última instancia eso será tarea de quienes tienen el poder de hacerlo, ya sea desde el Congreso de la Unión y las legislaturas de los estados actuando como Poder Revisor de la Constitución, o bien, desde el seno de un congreso constituyente, pero eso no disminuye ni un ápice la responsabilidad que tenemos la ciudadanía de hacer valer nuestros derechos, tal como es el caso de expresar libremente nuestras opiniones y hacer las propuestas que consideremos que más nos benefician, al igual que el sector académico, quienes podemos y debemos tener influencia, sobre todo en el aspecto técnico, aunque no exclusivamente, para cuidar la sistematicidad de un texto como el que nos referimos. Entonces, es necesario que las modificaciones que se realicen a ciertas instituciones y procesos, se lleven a cabo con la técnica constitucional adecuada: que sean acordes a los valores que lo sustentan, que tengan claridad en los objetivos que persigan y los medios para alcanzarlos y no se constituyan en obstáculos para llevarlos a la práctica; que tengan coherencia y completitud; que el lenguaje que se emplee cumpla con las características de claridad y precisión, y sea acorde a la tradición política de que proviene y que se cuide el régimen transitorio para prever problemas de tipo jurídico que se puedan generar y así evitar que lleguen a judicializarse, además que no se desnaturalice su función y pretenda habilitar competencias que no se encuentran dentro del texto constitucional.

La pregunta de la que partimos en esta investigación la planteamos de la siguiente manera: iincide la falta de técnica constitucional, por ignorancia o por el mal uso que se hace de ella deliberadamente, en la eficacia de las reformas constitucionales? Desde aquí definimos nuestra postura y respondemos que sí, pues pasar por alto la técnica constitucional por ignorancia o a sabiendas de que se está haciendo un mal uso de ella sí repercute en el cumplimiento de la norma constitucional; de ahí que sea necesario remontarnos al diseño de la reforma constitucional o de sustitución de la Constitución y conocer los motivos que las originaron para saber qué resultados eran los esperados y por qué se pasó por alto la técnica constitucional. 
Esta obra forma parte del acervo de la Biblioteca Jurídica Virtual del Instituto de Investigaciones Jurídicas de la UNAM

El método que utilizaremos para demostrar la aseveración hecha, consiste en el análisis de casos en los que por diversos motivos se hace a un lado la técnica constitucional y se trastoca el fondo de la reforma constitucional, de ahí que afirmemos, parafraseando a Jesús Reyes Heroles, quien aseveró: "en política, la forma es fondo", también en lo constitucional, "la forma es fondo".

El trabajo se divide en tres partes: en la primera se aborda lo teóricoconceptual en cuanto a la técnica y los diseños constitucionales; en la segunda se propone una clasificación de los problemas que presenta la técnica constitucional y con base en ella se analiza, a través de la metodología de casos, lo que acontece en México, y, finalmente, se formulan las conclusiones en las que se resalta la importancia del uso adecuado de la técnica constitucional para que el resultado esperado al momento de hacer el diseño constitucional se logre y tenga eficacia en el mundo fáctico.

\section{ASPECTOS TEÓRICO-CONGEPTUALES SOBRE LA TÉGNICA Y EL DISEÑO CONSTITUGIONALES}

Técnica constitucional. Para empezar, conviene referirnos a lo que entendemos por "técnica constitucional", pues, por lo general, se alude a ella y se da por sentado que se tiene clara la comprensión de su significado y los alcances que tiene dicha expresión. Tiene razón José Roldán Xopa al afirmar: “Cuando los abogados reparamos en la 'técnica' legislativa o constitucional pareciera, en primer término, que ponemos por delante un prurito gremial por el que, cuando algo sale de lo que se estima 'lo adecuado', según los usos o costumbres o a las 'buenas prácticas', lo convertimos en nuestro blanco para tirarle."1

La palabra "técnica" tiene varios significados, según el Diccionario de la Lengua Española, entre ellos, los dos siguientes: "Perteneciente o relativo a las aplicaciones de las ciencia y las artes", así como "conjunto de procedimientos y recursos de que se sirve una ciencia o arte". ${ }^{2}$ Si nos vamos al terreno de lo jurídico se ha definido de la siguiente forma:

1 Roldán Xopa, José, “Crónicas de la reforma energética (II). La 'técnica' constitucional'. [En línea 18 de marzo de 2016]. Disponible en https://joseroldanxopa.wordpress. com/2014/01/05/cronicas-de-la-reforma-energetica-ii/.

2 Diccionario de la Lengua Española, Edición del tricentenario. [En línea, 18 de marzo de 2016]. Disponible en: die.rae.es/'id=ZlkyMDs. 
Esta obra forma parte del acervo de la Biblioteca Jurídica Virtual del Instituto de Investigaciones Jurídicas de la UNAM

Conjunto de los medios jurídicos (formulación de la norma, aplicación por lo práctico de la norma), que permite la realización del derecho con una finalidad determinada [...], la formulación de normas jurídicas y su aplicación a los casos concretos, puede también ser tecnificada, es decir, guiada por una serie de reglas - las reglas técnicas- que prescriben un conjunto de procedimientos especiales, cuya observancia permite un trabajo bien organizado y asegura resultados más fructíferos. ${ }^{3}$

En tal virtud, si tomamos elementos de esas definiciones consideramos que debemos ubicarla en una relación de medio a fin, tal como lo estima Néstor Pedro Sagüés, quien expone que la técnica "cumple así un rol servicial o instrumental respecto del método." 4

Ahora bien, en el terreno del Derecho Constitucional, por técnica constitucional entendemos, para efectos de este trabajo: una serie de reglas que son utilizadas para formular un texto constitucional o introducirle reformas asi como para su aplicación, con la finalidad de que sea claro, comprensible y sistematizado, con contenidos fundamentales congruentes con los objetivos fijados y con la pretensión de que incida en el terreno de lo fáctico.

En cuanto a la formulación del texto, en primer lugar, se debe tener un posicionamiento en cuanto a la concepción de lo que es una Constitución, contar con conocimientos suficientes sobre Teoría de la Constitución y conocer la realidad social del contexto en el que se expedirá la Ley Fundamental o será reformada, pues la técnica es muy clara al establecer que los objetivos se alcanzarán a través de los contenidos seleccionados, es decir, vigilar esa relación de medio a fin a la que hicimos referencia supra, además se tendrá en cuenta que son muy diferentes a los de una ley ordinaria, por lo que no se deben llevar al texto constitucional contenidos reglamentarios, sino solamente dejar lo fundamental. Daremos tres ejemplos al respecto.

El primero nos lo brinda el estudio que realizaron el Instituto de Investigaciones Jurídicas de la Universidad Nacional Autónoma de México y el Instituto Iberoamericano de Derecho Constitucional respecto al texto constitucional vigente, en el que advierte la existencia de múltiples disposiciones que son "propiamente reglamentarias" y señalan como casos especialmente notorios algunos de los contenidos de los artículos 2, 3, 20, 27, 28, 41, 79, 99, 105, 107, 115, 116, 122 y 123 constitucionales. El segundo ejemplo tiene que ver con el debate que se llevó a cabo en el Congreso Constituyente

3 Enciclopedia Furídica. [En línea 18 de marzo de 2016]. Disponible en http://wrere.enciclopedia-juridica.biz14.com/d/t\%C3\%A9cnica-jur\%C3\%ADdica/t\%C3\%A9cnica-jur\%C3\%ADdica. htm.

Sagüés, Néstor Pedro, Teoría de la Constitución, Buenos Aires, Astrea, 2004, p. 132. 
Esta obra forma parte del acervo de la Biblioteca Jurídica Virtual del Instituto de Investigaciones Jurídicas de la UNAM

de Querétaro, en el que se hizo mención de que hasta 1917 privaba una "rígida técnica constitucional", lo que interpretamos en el sentido de que se refería a que se apegaran a la idea generalizada de las partes que debería contener el texto constitucional, que no era otra que el acercarse a lo establecido por el artículo 16 de la Declaración de los Derechos del Hombre y del Ciudadano de 1789, que a la letra dice: "Toute societé dans laquelle la garantie des droits n'est pas assurée ni la séparation des pouvoir determinée, n’a point de Constitution", de ahí que si se agregara algo, como fue el caso mexicano al consagrar derechos sociales, se estaría rompiendo con esa técnica constitucional. El tercer ejemplo, lo dirigimos a lo mencionado por Mirkine-Guetzévitch, quien alude a "la técnica constitucional -de la Revolución Francesa-, como la inspiradora esencial del Derecho Constitucional moderno [... ${ }^{\prime},{ }^{5}$ al referirse al principio de unidad del Derecho Público que tuvo expresión a fines del siglo XVIII, como tendencia a incluir en el articulado lo que representaba problema en las relaciones de los Estados con elementos del ámbito internacional, tales como los tratados.

Agregamos lo siguiente, el contenido debe ser fijado en función de los objetivos que se persigan, de tal forma que esté presente el elemento teleológico, como pudiera ser, el establecimiento del "orden jurídico fundamental de la comunidad". ${ }^{6}$ Cabe mencionar lo que dice Atienza al respecto: "las técnicas tienen un carácter mucho más sectorial, no pretenden explicar un fenómeno, sino indicar cómo conseguir ciertos objetivos a partir de determinados conocimientos y, en consecuencia, utilizan o aplican saberes que, por tanto, cabe considerar como más básicos." 7

No obstante, la técnica constitucional no se agota en dicho tramo, sino que es menester cuidar la forma, pues en caso que no sea así, puede afectar al contenido, es decir, en un sistema de Constitución escrita, al redactar las disposiciones constitucionales es indispensable que se cuide el lenguaje que se va a utilizar, que sea claro y preciso, pues es un instrumento de comunicación que contiene un mensaje para los destinatarios de la norma, de tal manera que se debe evitar que haya ambigüedad y vaguedad, pues ello crea problemas en la interpretación y, por ende, en la aplicación de las normas. Podemos dar como ejemplo la crítica razonada a la reforma constitucional en

5 Guetzévich, Mirkine, Modernas tendencias del Derecho Constitucional, trad. de Sabino Álvarez Gendin, Madrid, Reus,

6 Böckenförde, Ernst Wolfang, Estudios sobre el Estado de Derecho y la democracia, trad. de Rafael de Agapito Serrano, Barcelona, Trotta, 2000, p. 159.

7 Atienza, Manuel, “Contribución para una teoría de la legislación”, en Carbonell, Miguel y Pedroza de la Llave, Susana Thalía, Elementos de técnica legislativa, México, Porrúa/ UNAM, 2010, p. 67. 
Esta obra forma parte del acervo de la Biblioteca Jurídica Virtual del Instituto de Investigaciones Jurídicas de la UNAM

materia energética que realizó Diego Valadés, quien consideró que se usaron términos ambiguos que permitían "hacer cualquier operación en el sector", ${ }^{8}$ y -agregamos- pudiera ser en detrimento de los intereses nacionales.

Como la Constitución se compone de normas jurídicas, y como bien lo dice Néstor Pedro Sagüés, se tiende a magnificar su dimensión normativa, se utiliza una "metodología normativa", ya que el método normológico se ocupa del establecimiento de la norma constitucional y de su funcionamiento, ${ }^{9}$ en tal virtud, se debe cuidar que al redactar el texto constitucional entendido como conjunto de normas jurídicas, haya sistematicidad lo que permitirá dar seguridad y previsibilidad a los destinatarios sobre las consecuencias de sus acciones, como resultado de la coherencia y completitud que debe observar. El problema que se puede suscitar, si ello no sucede así, es que se generen antinomias o existan lagunas dentro del texto constitucional.

Como parte de lo anterior se debe guardar un orden, en otras palabras, las disposiciones deben estar colocadas en el lugar que les corresponda de acuerdo a la naturaleza del diseño realizado que da origen a la norma constitucional; sin embargo, en la práctica legislativa observamos, como bien nos dice Diego Valadés, en relación con los artículos transitorios, "su objeto se agota en el tiempo," 10 de tal manera que se rompe con la técnica constitucional el establecer allí disposiciones que no tienen eficacia perentoria, puesto que su lugar es dentro del texto constitucional.

Por último, considero que al crear un texto constitucional se deben tomar en cuenta dos aspectos: la estabilidad y la flexibilidad. En cuanto a lo primero, en nuestro sistema constitucional conviene que siempre haya una cláusula que haga rígida la Constitución, pues como su contenido es valioso, no debe ser fácil cambiarlo por intereses coyunturales sobre todo de tipo político, pero sí debe ser lo suficientemente flexible para adecuarse a los cambios sociales y no quede petrificada.

8 Valadés, Diego, "La Constitución desfigurada", [En línea 18 de marzo de 2016]. Disponible en http://wwrerreforma.com/aplicacioneslibre/preacceso/articulo/default.aspx:id=18212 Eurl redirect=http://wrwre.reforma.com/aplicaciones/editoriales/editorial.aspx?id=18212.

$9 \quad$ El autor antes citado parte de la gestación de la norma constitucional para luego pasar a la formulación del texto constitucional, en donde es menester utilizar reglas de tipo técnico formal que "aluden a la presentación de la norma constitucional, tanto en su vocabulario y terminología, como en cuanto a su estilo, articulado y orden de tratamiento de los temas propios de una constitución. En todo caso, los valores jurídico-políticos que se pretenden salvar aquí son los de verdad [...], y seguridad [...]", Sagüés, Néstor Pedro, op cit., nota 4, p. 136.

10 Valadés, Diego, "La Constitución desfigurada", consultado en "La Constitución desfigurada", [En línea 18 de marzo de 2016]. Disponible en http://wrere.reforma.com/aplicacioneslibre/preacceso/articulo/default.aspx?id=18212 Eurlredirect=http://wrere.reforma.com/aplicaciones/ editoriales/editorial.aspx?id=18212. 
Esta obra forma parte del acervo de la Biblioteca Jurídica Virtual del Instituto de Investigaciones Jurídicas de la UNAM

En cuanto al funcionamiento de la Constitución, hacemos nuestra la exposición de Néstor Pedro Sagüés, quien menciona que comprende los siguientes elementos: la interpretación, la determinación, la integración y la aplicación. ${ }^{11}$

Esos elementos (técnicos) nos marcan un protocolo aceptado por la generalidad de la comunidad de constitucionalistas en un determinado contexto histórico, y nos servirá para realizar un correcto diseño de la norma constitucional, de la forma de su presentación y de su concreción en el texto constitucional. Lo antes expuesto concuerda en mayor o menor medida con lo expuesto por Linares Quintana, quien menciona en relación con la técnica constitucional que se debe cumplir con lo siguiente: adecuación a la realidad institucional, estabilidad, flexibilidad, fundamentalidad, prudencia y el lenguaje. ${ }^{12}$

Para completar el marco teórico-conceptual que nos servirá de base para hacer el análisis del caso mexicano en el tema que nos ocupa, nos referiremos a continuación al diseño constitucional.

Diseño constitucional. Para entender el funcionamiento de un sistema político debemos tener la comprensión de los diversos elementos que lo forman y las relaciones de interdependencia que existen los mismos. Las Constituciones, son parte de ellos y, actualmente, juegan un papel muy importante, habida cuenta que tratan de hacer racional el "proceso del poder" y de dar cauce a la dinámica en la que convergen diferentes expresiones, intereses y modelos de vida, es decir, pretenden ser variable independiente que moldeen lo económico, político, social y cultural de una sociedad, sin imponer una determinada forma de vida.

Lo anterior significa que aun cuando la Constitución es una creación social en la que se refleja en gran medida la conformación de la sociedad, su naturaleza normativa nos permite advertir que no se limita a ser una variable dependiente del ente social, sino que a través de regulaciones específicas esperan resultados exitosos en diferentes ámbitos de la vida social. Al respecto, Konrad Hesse expresó:

[...] La constitución jurídica viene condicionada por la realidad histórica. La Constitución no puede ignorar las circunstancias concretas de una época, de forma que su pretensión de vigencia sólo puede realizarse cuando toma en cuenta dichas circunstancias. Pero la Constitución jurídica no es sólo expre-

11 Sagüés, Néstor Pedro, op. cit., nota 4, pp. 144-228.

12 Linares Quintana, Segundo V., Tratado de la Ciencia del Derecho Constitucional, Buenos Aires, t. III, pp. $563-614$. 
Esta obra forma parte del acervo de la Biblioteca Jurídica Virtual del Instituto de Investigaciones Jurídicas de la UNAM

sión de la realidad de cada momento. Gracias a su carácter normativo ordena y conforma a su vez la realidad social y política. De esta coordinación relativa entre ser y deber ser se derivan las posibilidades y, al mismo tiempo, los límites de la fuerza normativa de una Constitución. ${ }^{13}$

En tal virtud, la relación la concebimos como un esquema circular, en el que la Constitución pretende ser una guía para la sociedad y conformar la realidad social, pero a la vez se nutre de lo que acontece en los ámbitos económico, político, social, cultural y tecnológico, entonces, tendremos una mejor comprensión de la misma.

$\mathrm{Al}$ conceder tal importancia a la Constitución de un país, conviene que nos preguntemos, ¿quiénes son los que deciden qué diseño constitucional es el mejor para una determinada sociedad?, ¿con base en qué hacen la elección de las instituciones?, ¿cómo funciona en la práctica el diseño que se adoptó?, ¿cuáles son los factores que obligan, en determinado momento, a sustituirlo o bien a modificarlo? Sobre estas y otras preguntas se han realizado estudios muy interesantes de Derecho comparado como el de Negretto referente a Argentina, Colombia y Ecuador con resultados muy interesantes y ejemplificativos de la importancia de conocer los orígenes de la elección constitucional. ${ }^{14} \mathrm{~A}$ las anteriores preguntas agrego la siguiente, ¿ise condiciona la eficacia de la norma constitucional por no observar la técnica constitucional?

Las anteriores preguntas se refieren tanto al origen del diseño constitucional como a la evolución de las instituciones a través del tiempo, pues pensamos que ambos aspectos son claves para tener cabal comprensión del tema que se estudia. El origen es de suma importancia, pues nos permite identificar los acontecimientos que motivaron la reforma o la sustitución de la Constitución, además "podría ayudar a determinar en qué casos las instituciones realmente tienen un papel causal para explicar ciertos resultados importantes", ${ }^{15}$ aunque también es indispensable conocer la evolución que tiene a lo largo del tiempo, pues como es probable que los constituyentes no prevean el universo de problemas que se van a presentar ni los efectos que en la práctica se van a presentar al ponerla en vigor, de ahí que sea necesario que se utilicen ambos tipos de análisis. El autor citado se enfoca al

13 Hesse, Konrad, Escritos de Derecho Constitucional, trad. Pedro Cruz Villalón y Miguel Azpitarte Sánchez, Madrid, Fundación Coloquio Jurídico Europeo/Centro de Estudios Políticos y Constitucionales, 2012, Colección Democracia y Derechos, p. 88.

14 Véase Negretto, Gabriel, La política del cambio constitucional en América Latina, México, Fondo de Cultura Económica, 2015, p. 15.

15 Idem 
Esta obra forma parte del acervo de la Biblioteca Jurídica Virtual del Instituto de Investigaciones Jurídicas de la UNAM

estudio de los orígenes de las instituciones, pero reconoce: “[...] una agenda de investigación más rica y completa sobre las instituciones debería vincular el momento de su creación con el de su conservación y cambio." $16 \mathrm{Y}$ una vez que se toma la decisión de hacer modificaciones a la Constitución o de crear una nueva, se reúnen los legisladores con pretensiones muy concretas de alcanzar resultados cooperativos o distributivos: "Las teorías cooperativas destacan el hecho de que los reformadores eligen reglas constitucionales con base en los beneficios colectivos que éstas generarían [...] De acuerdo con las teorías distributivas, los actores políticos eligen instituciones que les permiten incrementar sus oportunidades para ganar elecciones y ocupar cargos públicos. ${ }^{17}$

Lo anterior significa que hay una doble lógica, de ahí que "el contenido de la elección constitucional está determinado tanto por la evaluación que hacen los reformadores acerca del desempeño de las estructuras constitucionales preexistentes como por sus expectativas electorales y recursos de poder."18 Esa teoría política, no cabe la menor duda, es de gran utilidad para conocer los motivos de la elección constitucional, pues en cada caso habrá que determinar si pesan más los resultados cooperativos o bien los resultados distributivos, para comprender el origen y los efectos que se susciten en el mundo fáctico.

Antes de continuar, cabe aclarar que por "diseño" entendemos: "la creación de una forma de promover resultados valiosos en un contexto particular que sirva de base para la acción." 19 También ha sido definido como "la justa correspondencia del objeto diseñado con su entorno."20

Por su parte, Carla Huerta considera que los tres tipos primordiales de diseño institucional son los siguientes: "a) Constructivo: pretende crear una nueva realidad o modo de interacción entre gobernantes y gobernados.- b) Justificatorio: legitimador de una realidad cambiante, más bien legaliza una situación.- c). Correctivo: propone adecuar una o varias instituciones con el objeto de corregir aspectos disfuncionales o inoperantes, o bien, adecuarlo

16 Ibidem, p. 16. Señala que existen tres tipos de acontecimientos que motivan la sustitución o reforma de una Constitución: "Transformaciones políticas a nivel del Estado o del régimen, cambios en el equilibrio de poderes entre actores partidarios, y crisis institucionales derivadas de un desempeño deficiente de la Constitución", pp. 69 y 70.

17 Ibídem, pp. 74 y 76.

18 Ibídem, p. 79.

19 Bobrow, Davis B. y Drizeck, John S. Policy analysis by design, Pittsburgh Press, 1987, p. 49.

20 Goodin, Robert E., Teoría del diseño institucional, trad. María Luz Melón, Barcelona, Gedisa, 2003, p. 56. 
Esta obra forma parte del acervo de la Biblioteca Jurídica Virtual del Instituto de Investigaciones Jurídicas de la UNAM

a los criterios conductores del modelo vigente." ${ }^{21}$ Además, agrega que las etapas en las que se lleva a cabo son: la preparatoria: que es en la que se fija el objetivo, se identifica la institución a reformar, se crea o reconfigura la institución, según sea el caso, se determina el grado de cambio, se efectúa el cálculo de operatividad de las instituciones y análisis de las eventuales significados de otras normas; la de elaboración: que es propiamente la reforma constitucional y la integración a la norma suprema, y de consolidación: que es cuando se fija el significado a través de la interpretación o el cambio de significado por mutación. ${ }^{22}$

$\mathrm{Al}$ pasar por el proceso constituyente o de reforma constitucional, es necesario que se utilice una técnica constitucional muy depurada para que quede un texto constitucional claro y comprensible, con coherencia interna, con principios que guíen la interpretación, con contenidos ad hoc para alcanzar determinados objetivos, que se busque que tenga eficacia en la realidad a través de su obediencia, de ahí que como expresa Atienza se pueda hablar de diferentes tipos de racionalidad: lingüística, jurídico-formal, pragmática, teleológica y ética. ${ }^{23}$

\section{EL USO DE LA TÉGNICA Y EL DISEÑO CONSTITUCIONALES EN EL CASO MEXICANO}

Con base en el marco teórico-conceptual fijado con antelación, pretendemos hacer el análisis del caso mexicano y para ello se hace la propuesta de una clasificación de los problemas que se presentan en la práctica.

Así pues, identificamos los siguientes casos: a). En los que quienes realizan reformas constitucionales desconocen la técnica constitucional y, por tanto, habrá problemas de ambigüedad y falta de sistematicidad, entre otros; b). En los que se conoce la técnica constitucional, pero por la premura de aprobar una reforma la atropellan, y c). Se conoce la técnica constitucional, pero, premeditadamente, se rompe con la misma, porque así lo

21 Huerta Ochoa, Carla, "Constitución y diseño institucional", en Boletín Mexicano de Derecho Comparado, México, IIJ-UNAM, 2011, [En línea 18 de marzo de 2016]. Disponible en Biblioteca Jurídica Virtual. http://wrere.juridicas.unam.mx/publica/rev/boletin/cont/99/art/art3. $\underline{h t m}$, pp. 11 y 12 .

22 Ibidem, pp. 13 y 14.

23 Atienza, Manuel, “Contribución para una teoría de la legislación”, en Carbonell, Miguel y Pedroza de la Llave, Susana Thalía, Elementos de técnica legislativa, México, Porrúa/ UNAM, 2010, pp. $65-84$. 
Esta obra forma parte del acervo de la Biblioteca Jurídica Virtual del Instituto de Investigaciones Jurídicas de la UNAM

marcan diversos intereses políticos que pueden ser favorables o contrarios a los intereses colectivos y nacionales.

$\mathrm{El}$ primer caso, se dio mucho durante el siglo XX, pues los órganos revisores de las constituciones locales consagraron, en los textos, disposiciones que eran francamente reglamentarias y nada tenían que hacer en los mismos, además había ambigüedad y falta de sistematicidad. El segundo caso se refiere, básicamente, a la premura de agotar el procedimiento para reformar la Constitución o expedir una nueva, y produce errores que, a la postre, se tratan de enmendar mediante la "fe de erratas", o bien, situaciones ya más de fondo en las que se acorta el periodo de discusión y no se delibera a profundidad sobre las normas, como es el caso del Constituyente de Querétaro en el que se tuvo el tiempo limitado de dos meses para expedir la Constitución, y se pasaron por alto aspectos tan importantes como los referentes a los ingresos que deberían tener los municipios mexicanos para poder llevar a cabo sus funciones y prestar los servicios públicos, así como el establecimiento de un mecanismo para defenderse cuando se invadiera su esfera de competencia. ${ }^{24} \mathrm{Y}$, en cuanto al tercer caso, que en nuestra práctica constitucional ha servido para incluir derechos sociales en la Constitución, pero también, como aseveró Diego Valadés ser utilizada como "técnica del engaño y ocultamiento." ${ }^{25}$ A continuación daremos algunos ejemplos de esta última parte de la clasificación propuesta.

Primer caso: inclusión de derechos sociales en la Constitución de 1917. La Constitución mexicana que actualmente nos rige con casi cien años de existencia fue creada por el Congreso Constituyente que se reunió en Querétaro del primero de diciembre de 1916 al 31 de enero de 1917, como producto de la Revolución Mexicana de 1910.

En tal Congreso hubo excluidos, pues no podían ser electos quienes "hubieran ayudado con las armas o sirviendo en empleos públicos a los gobiernos o facciones hostiles a la causa constitucionalista". ${ }^{26}$ En tal virtud,

24 "De este modo la autonomía financiera, y con ella la libertad municipal, han quedado a merced de la legislatura y del ejecutivo que de acuerdo a su conveniencia política pueden aumentar o disminuir los recursos municipales [...] la asamblea olvidó en la agonía de la discusión otro aspecto de vital importancia para la libertad del municipio: la forma de resolver los conflictos de éste con las autoridades del Estado [...] De este modo el municipio libre ingresó a la Constitución con los dos defectos sustanciales que acabamos de señalar [...]" Tena

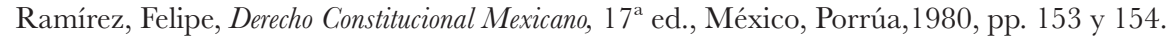

25 Valadés, Diego, op. cit., nota 10.

$26 \mathrm{Al}$ realizar un estudio comparado entre los congresos norteamericano y mexicano, Víctor Niemeyer se pregunta ¿Representaron genuinamente los constructores de ambas constituciones a sus países y a las facciones políticas en aquel entonces?", y se responde: "En México se puede sostener que no, pues los requisitos para diputado especificaban que no 
Esta obra forma parte del acervo de la Biblioteca Jurídica Virtual del Instituto de Investigaciones Jurídicas de la UNAM

eran representantes populares en su mayoría afines a la "casusa constitucionalista", de ahí que sea de suma importancia analizar a detalle el mensaje de Venustiano Carranza que dirigió al Congreso Constituyente, ${ }^{27}$ en el que explica los motivos que apoyaban el proyecto de reformas a la Constitución de 1857, aunque cabe aclarar que la redacción definitiva del texto no es únicamente conforme a los ideales e intereses de dicha causa, sino que el diseño constitucional que se contenía en la iniciativa de reformas, se combina con otros y sufre modificaciones, por tanto, no queda intacto, pues hubo otras influencias de tipo social que finalmente convergieron en el documento definitivo, y que terminó por ser un híbrido. ${ }^{28}$ Afirman María del Refugio González y José Antonio Caballero Juárez: "La Constitución de 1917, en su versión primera, ofrece una combinación de varios modelos de Estado mediante la cual es posible identificar elementos procedentes de diversas épocas." 29

A partir de entonces, es que se habló de un Estado social (Estado democrático y social de derecho) que en concepción de Mario de la Cueva es una "organización política y jurídica en la cual se reconoce la estructura grupal de la sociedad y la necesidad de armonizar los intereses de (los) grupos sociales, económicos, políticos y culturales, cada vez más complejos, a través

eran elegibles los que 'hubieran ayudado con las armas o sirviendo en empleos públicos a los gobiernos o facciones hostiles a la casusa constitucionalista.' Esta estipulación eliminó a toda persona que hubiera servido en el gobierno de Victoriano Huerta, y efectivamente excluyó a los partidarios de Francisco Villa y Emiliano Zapata que habían luchado y continuaban luchando en contra de los constitucionalistas encabezados por Venustiano Carranza [...]", no obstante, reconoce que por los puntos de vista que se expusieron sí fue una asamblea representativa. Niemeyer, Víctor, "El Congreso Constituyente norteamericano de 1787 y el Congreso Constituyente mexicano de 1916-1917. Comparación y contraste”, en Derecho Constitucional Comparado: México y Estados Unidos, México, Instituto de Investigaciones Jurídicas, UNAM, 1990, p. 74.

27 Tena Ramírez, Felipe, Leyes fundamentales de México 1808 - 1992, 12ª . ed., México, Porrúa, 1980, pp. $745-764$.

28 "Por su génesis, por el contexto en el que se dio y por sus resultados, la Constitución de 1917 fue un producto ‘híbrido’ entre el espíritu liberal y el restaurador.” González, María del Refugio, "A casi cien años de la Constitución de 1917. Una primera reflexión”. Conferencia inaugural del seminario internacional "La tradición constitucional en México y la Constitución de 1917, organizado por el CIDE y la UAM, presentada el 17 de junio de 2015. [En línea 18 de marzo de 2016]. Disponible en: http://derechoenaccion.cide.edu/a-casi-100-anos-de-laconstitucion-de-1917-una-primera-reflexion.

29 González, María del Refugio y Caballero Juárez, José Antonio, "El proceso de formación del Estado de Derecho en México. Los modelos de Estado en la Constitución de 1917", en Serna de la Garza, José Ma. Y Caballero Juárez, José Antonio, Estado de Derecho y transición jurídica, México, UNAM, 2002, p, 49. 
Esta obra forma parte del acervo de la Biblioteca Jurídica Virtual del Instituto de Investigaciones Jurídicas de la UNAM

de los principios de justicia social". ${ }^{30}$ Pero, precisamente, con la inclusión de los artículos que consagraron derechos sociales se rompía con la técnica constitucional que en aquel momento se consideraba que era la adecuada, como especificamos en el apartado anterior, según se acercara o se alejara del contenido del artículo 16 de la Declaración de los Derechos del Hombre y del Ciudadano de 1789. Al respecto, el diputado Fernando Lizardi aclaraba lo que en su opinión debería contener una Constitución:

[...] En primer lugar, un tratado garantías individuales [...] En segundo lugar debe contener la manera política en que el pueblo ejerza su soberanía [...] La tercer parte se refiere a las relaciones de los diversos órganos del Poder Público. Y la cuarta parte debe referirse a las relaciones entre el Poder Público y una multitud, una asociación, principalmente la Iglesia $[\ldots]^{31}$

No obstante lo anterior, hubo quien se encargó de justificar el apartarse de lo que en aquel momento se consideraba que era uno de los aspectos de la técnica constitucional, ya que fue lo que dio el signo distintivo a la Constitución mexicana, me refiero a Heriberto Jara, quien manifestó al respecto:

[… ¿Quién ha hecho la pauta de las Constituciones? ¿Quién ha señalado los centímetros que debe tener una Constitución, quién ha dicho cuántos renglones, cuántos capítulos y cuántas letras son las que deben formar parte de una Constitución? [...] Es ridículo sencillamente, eso ha quedado reservado al criterio de los pueblos, eso ha obedecido a las necesidades de los mismos pueblos; la formación de la Constitución no ha sido otra cosa sino el resultado de la experiencia, el resultado de los deseos, el resultado de los anhelos del pueblo, condensados en eso que se ha dado en llamar Constituciones.

Una corriente dentro del constitucionalismo que ha ganado fuerte consenso considera, es que las constituciones deben concentrarse en consagrar lo fundamental y dejar todo el aspecto reglamentario para las leyes infraconstitucionales, con lo cual coincidimos, empero en el ejemplo citado nos sumamos a lo expuesto por Sergio García Ramírez: “[...] Entendimos que la obra del constituyente sería vana si no reflejaba con fidelidad-y espíritu combativo algunas de las pretensiones primordiales -germinales, inclusivede los revolucionarios convertidos en diputados [...] Los artículos que con-

30 Cueva, Mario de la, "La Constitución Política", en varios autores. Derechos del Pueblo mexicano. México a través de sus Constituciones, t. I: Doctrinal constitucional, México, LII Legislatura, Cámara de Diputados del Congreso de la Unión, 1985, p. 43.

31 Lizardi, Fernando, diputado por Guanajuato, en la $15^{\mathrm{a}}$. sesión ordinaria. Diario de los Debates, ed. Conmemorativa, t. I, pp. 755 y sigs. 
Esta obra forma parte del acervo de la Biblioteca Jurídica Virtual del Instituto de Investigaciones Jurídicas de la UNAM

tienen las pretensiones correspondientes - 27 y el 123- serían 'lo propio' de la nueva Constitución, 'lo que determina su originalidad". 32

Segundo caso: crisis de representación politica. Ahora bien, al analizar el régimen político consagrado por la Constitución, advertimos que se trata de una democracia, concretamente, de una democracia representativa. En su diseño se prevé que la ciudadanía elija a sus representantes y espera de éstos que al llegar al cargo de elección popular correspondiente, hagan realidad la voluntad de aquella, de tal manera que las decisiones sea en beneficio de las personas a las que representan y no de intereses personales o de grupo que sean contrarios al interés popular.

La democracia de la Modernidad es, sin duda, de tipo representativa, muy diferente a la del modelo griego que era de "cara a cara" en las asambleas a las que asistían los ciudadanos y participaban con voz y voto en los asuntos de la comunidad, puesto que hoy, por regla general, la toma de decisiones se hace a través de representantes, quienes deben velar por los intereses de la nación, y de ninguna manera actuar conforme a intereses particulares, ya que de acontecer lo anterior, se rompe la representación política y florece la de intereses, en otras palabras, es someter al representante al mandato obligatorio.

Esta es una de las decisiones políticas fundamentales adoptada en la Constitución mexicana, como lo advertimos de la lectura del artículo 40 en la que establece que la "forma de gobierno" es un república, democrática, representativa, laica y federal, en donde el pueblo ejerce su soberanía a través de los poderes de la Unión, y en otros artículos regula la elección que se da de los titulares cuyo origen sea popular. Sin embargo, en la práctica, vemos cómo en el ámbito legislativo, este principio, en un número considerable de ocasiones, se ha convertido en letra muerta, se ha pisoteado sin misericordia ${ }^{33}$ y el contenido de las normas jurídicas que emanan de los órganos depositarios de dicho poder, ha sido contrario al interés nacional, de tal manera que se degrada la representación política para convertirse en una representación de intereses, no obstante que los legisladores pretendan por todos los medios justificarse y convencer a la ciudadanía que en el caso de que se trate, no hay una separación tajante entre tales intereses: que los

32 García Ramírez, Sergio, "Estado Democrático y Social de Derecho", en Boletín Mexicano de Derecho Comparado, México, IIJ-UNAM, 2011, Biblioteca Jurídica Virtual. http://werere. juridicas.unam.mx/publica/rev/boletin/cont/98/art/art4.htm, p. 4.

33 "Jamás una norma constitucional ha sido tan violado como la prohibición de mandato imperativo; jamás un principio ha sido tan menospreciado como el de la representación política." Bobbio, Norberto, El futuro de la democracia, trad. de José F. Fernández Santillán, $3^{\mathrm{a}}$. ed., México, Fondo de Cultura Económica, 2001, p. 31. 
Esta obra forma parte del acervo de la Biblioteca Jurídica Virtual del Instituto de Investigaciones Jurídicas de la UNAM

intereses del grupo a los que se sirve, son los mismos que los nacionales. La realidad es que las y los representantes mexicanos son portadores de intereses, lo que pretendía erradicar la democracia al privilegiar a la representación política, de ahí que sea uno de los déficits de la democracia mexicana. ${ }^{34}$

Sin duda, este es un elemento que nos permite demostrar la afirmación de que existe una crisis de representación política por la desconfianza que existe en la ciudadanía respecto a sus representantes, pues ya sabe que aunque en campaña se le prometa que se va a actuar en favor de los intereses colectivos, en la práctica se actúa de otra manera, de tal manera que existe mucho desánimo y desconfianza hacia la política, las y los políticos y los partidos políticos. Además, si a esto agregamos que en determinados procesos electorales no se ha respetado la voluntad del electorado y se han impuesto ganadores, se agrava el problema.

Son múltiples los casos que se pueden enumerar en los que la negociación ha sustituido a la deliberación, se aprueban unas cosas a cambio de otras, esto es, lo que conviene a los intereses de un grupo, si éste también accede a favorecer en algunos aspectos los de otro grupo que formen una mayoría, de ahí que se llegue a "acuerdos meramente auto-interesados entre los miembros de las diferentes ramas de gobierno." 35 También puede acontecer que en aras de hacer valer sus intereses sobre los de otros, no se llegue a tal negociación y haya bloqueo entre los órganos depositarios de los poderes públicos, lo cual también es en detrimento de los intereses colectivos.

En tal virtud, en ambos casos, quien sale perdiendo es la ciudadanía, en uno porque los grupos satisficieron intereses propios, y en otro porque hubo bloqueo entre ellos, pero en los dos sin tomar en cuenta los intereses colectivos y el interés nacional, de ahí que esto viene a reforzar la hipótesis de la crisis de representación en México y, por ende, del aumento de la desconfianza de la ciudadanía tanto en las y los políticos como en las instituciones.

Una de las acciones que se llevó a cabo con el fin de "inyectar oxígeno" a nuestra incipiente democracia, es a través de diversos mecanismos.

34 Norberto Bobbio considera que es una de las promesas incumplidas de la democracia y que lo expresa con exactitud en una afirmación y en una interrogación dentro de su discurso: "Quien representa intereses particulares tiene siempre un mandato imperativo. ¿Dónde podemos encontrar un representante que no represente intereses particulares? La respuesta es obvia, no lo vamos a encontrar en los sindicatos de los cuales depende la estipulación de los convenios, como los acuerdos nacionales sobre la organización y el costo del trabajo, que tienen una gran importancia política. ¿En el Parlamento? ¿Pero qué es lo que representa la disciplina de partido si no (sic) una abierta violación de la prohibición de mandato imperativo?" Idem.

35 Gargarella, Roberto, Crisis de la representación politica, $3^{\text {a }}$ ed., México, Fontamara, 2014, p. 84 . 
Esta obra forma parte del acervo de la Biblioteca Jurídica Virtual del Instituto de Investigaciones Jurídicas de la UNAM

Se tomó la decisión de hacer reformas con base en el diseño constitucional que proponía mecanismos de democracia semidirecta y el Poder Revisor introdujo la iniciativa ciudadana y la consulta popular. También se crearon las llamadas "candidaturas independientes", para facilitar que las y los ciudadanos llegaran a puestos de elección popular sin necesidad de ser postulados por los partidos políticos reconocidos legalmente, lo cual vino a ser un incentivo para postularse como candidato así como para asistir el día de la jornada electoral a depositar el sufragio en las urnas.

$\mathrm{Al}$ respecto, consideramos que si bien las razones explícitas que acompañaron al diseño constitucional de esos mecanismos de democracia semidirecta fue para alentar la participación ciudadana, en la práctica ello no ha sucedido así, puesto que en buena medida quedaron condicionados por un mal uso de la técnica constitucional y la fijación de candados que dificultaron y obstruyeron la realización de la consulta popular, tal como se pretende demostrar a continuación.

En efecto, debido a la crisis de representación política, se realizó un diseño constitucional contenido en las reformas constitucionales, con la finalidad de abrir cauces a la participación ciudadana en la toma de decisiones. Uno de esos mecanismos fue la consulta popular, que quedó consagrada en la fracción VIII del el artículo 35 constitucional, en calidad de derecho de tipo político, ya que las y los ciudadanos tenemos derecho a votar en temas de trascendencia nacional, cuyo resultado puede ser vinculatorio si la participación alcanza al menos el cuarenta por ciento de quienes estén inscritos en la lista nominal de electores. Aunado a lo anterior, quien convoca no son únicamente nuestros representantes, sino también la propia ciudadanía, en un número equivalente, al menos, al dos por ciento de los inscritos en la lista nominal de electores.

No me cabe la menor duda que los motivos que sustentan la decisión de consultar a la ciudadanía en temas de trascendencia, es hartamente positiva, y que es acorde a los valores que inspiran al régimen democrático, sin embargo, la forma en que está diseñada la institución aunada a los problemas de técnica constitucional, dificulta su puesta en práctica. A continuación trataremos de explicar esta aseveración.

En primer lugar, consideramos que los porcentajes de ciudadanos que se exigen para convocar a la consulta popular y para que su resultado sea vinculatorio, son altos, pues en lo relativo al primero se pide el dos por ciento y el segundo el cuarenta, ambos de la lista nominal de electores. Coincidimos con el dictamen que se elaboró en la Cámara de Diputados, de 25 de octubre de 2011, en el sentido de que hubiera sido preferible para alentar 
Esta obra forma parte del acervo de la Biblioteca Jurídica Virtual del Instituto de Investigaciones Jurídicas de la UNAM

la participación ciudadana, que fuera de uno y de veinticinco por ciento, respectivamente, pues de otra manera se "pone en riesgo el objetivo" de la reforma. No obstante, el Senado insistió en mantener esos porcentajes, a lo que finalmente accedió la Cámara de Diputados.

Por otra parte, consideramos que no se utilizó la técnica constitucional adecuada, pues se emplearon términos que no se definieron, para referirse a temas que no pueden ser objeto de consulta y en la práctica han hecho nugatorio el derecho de referencia. Quedaron plasmados los siguientes temas: la restricción de derechos humanos reconocidos en la Constitución, los principios consagrados en el artículo 40 constitucional, la materia electoral, los ingresos y gastos del Estado, la seguridad nacional y la organización, funcionamiento y disciplina de la Fuerza Armada permanente.

En la práctica se realizó la petición ciudadana al reunirse el porcentaje mínimo para solicitar al Congreso de la Unión que convocara a consulta popular, en octubre de 2014, pero no se logró el objetivo y no se llevó a cabo debido a que la Suprema Corte de Justicia de la Nación determinó que era inconstitucional la materia de la consulta.

En uno de los casos se analizó el tema prohibido para consultarse de lo "electoral", empero no se estableció su significado en la Constitución y ello ameritó que la Suprema Corte de Justicia de la Nación recurriera a criterios en los que se había pronunciado, a través de acciones de inconstitucionalidad, para determinar su alcance. En dicha consulta, se proponía que se preguntara a la ciudadanía sobre la conformación de las cámaras del Congreso de la Unión: “¿Estás de acuerdo en que se modifique la Constitución para que se eliminen 100 de las 200 diputaciones federales plurinominales y las 32 senadurías plurinominales?" La interpretación que se dio al término "electoral" fue en sentido amplio y no se restringió al régimen normativo de los procesos electorales, pues "se veía reducida la participación de los partidos políticos y, por otro, se afectaban los efectos que tendría la votación de la ciudadanía sobre el grado de representatividad deseado, amén de que dicha disminución tiene un impacto sobre la forma en que operarán los principios de mayoría relativa y representación proporcional para asegurar que no exista sobrerrepresentación y subrepresentación de alguno de los partidos." 36 Independientemente que coincidamos o no con el criterio de la Suprema Corte, nos interesa resaltar que dependiendo de la interpretación que se diera a la palabra "electoral" se realizaría la consulta popular o no, ya que no se definió constitucionalmente tal término.

36 Gaceta del Semanario fudicial de la Federación, libro 12, Tomo I, noviembre de 2015, Pleno y Salas, pp. 326 y 327. 
Esta obra forma parte del acervo de la Biblioteca Jurídica Virtual del Instituto de Investigaciones Jurídicas de la UNAM

Después de esta exposición es que nos preguntamos, ¿̇no se calculó que debido a los porcentajes tan altos que se piden para convocar a consulta popular y para que el resultado sea vinculatorio, así como la ambigüedad y vaguedad de algunas palabras en los temas prohibidos para consulta, se obstaculizaría sobremanera poner en práctica a dicha institución de democracia semidirecta, o bien, fue premeditado para que quedara únicamente en el papel la participación del pueblo en la toma de decisiones?

De igual manera, otra de las peticiones de consulta que se dio fue sobre lo energético, su realización o no dependía de la interpretación relativa a uno de los temas prohibidos de consulta, de acuerdo con el artículo 35 fracción VIII, constitucional, los "ingresos y gastos del Estado", en concreto, sobre el término "ingresos". El caso se refería al otorgamiento de contratos o concesiones a particulares nacionales o extranjeros, para la explotación del petróleo, el gas, la refinación, la petroquímica y la industria eléctrica, pero consideró el Pleno de la Suprema Corte de Justicia de la Nación que la materia era inconstitucional, empero coincidimos con el ministro José Ramón Cossío, en el sentido de que se debió interpretar "ingresos" en su acepción más amplia, habida cuenta que se trataba del "ejercicio de un derecho político con rango y características de derecho humano". ${ }^{37}$ Entonces, no coincido con la técnica empleada para realizar la interpretación por parte de la mayoría de las y los ministros del Alto Cuerpo Colegiado.

Caso de la Reforma Energética: Un caso que es muy conveniente comentar por el mal uso que se le dio a la técnica constitucional, es el referente a la llamada "Reforma Energética". Una crítica certera fue la que hizo Diego Valadés al proyecto de reformas, en lo que él llamó: "La Constitución desfigurada". Nos concretaremos a mencionar tres aspectos que comenta: el primero es relativo a la utilización de términos ambiguos como "asignaciones", que según dice: "servirá para todo lo que se desee"; el segundo, en cuanto a los artículos transitorios, menciona que se contienen derechos a favor de las empresas, no obstante que no forman parte del texto constitucional y su existencia es efimera, es decir, son de "eficacia perentoria", por lo que la técnica sirvió como "técnica de ocultamiento y engaño", pues "de los 21 transitorios, 11 contienen disposiciones permanentes que deberían formar parte del cuerpo constitucional," y, tercero, de las seis mil novecientos palabras de la iniciativa, más de seis mil correspondían a los transitorios y solamente el resto a los artículos que se pretendían reformar ${ }^{38}$ - y que a la postre así se hizo - Por la abundancia en el contenido de los artículos transitorios y por

37 Voto particular del ministro José Ramón Cossío en Ibidem, p. 374.

38 Valadés, Diego, op. cit., nota 10. 
Esta obra forma parte del acervo de la Biblioteca Jurídica Virtual del Instituto de Investigaciones Jurídicas de la UNAM

la falta de técnica constitucional, Miguel Carbonell consideró que resultaba preocupante lo que acontecía con nuestra Constitución, ya que "sufre un proceso acelerado de 'ensanchamiento' que la está dejando irreconocible y que la ha vuelto todavía más farragosa de lo que ya era." 39

Respecto a los artículos transitorios es necesario ampliar nuestros comentarios, habida cuenta que su redacción es también parte importante de la técnica constitucional, ya que marca las reglas de transición de una norma jurídica que deja de tener vigencia a la nueva que surge, pero como bien lo dice Diego Valadés, "su objeto se agota en el tiempo."

Como sabemos, una reforma constitucional debe estar respaldada por una exposición de motivos en la que se expresen las razones que impulsan la modificación de una determinada disposición; una parte dispositiva compuesta por los artículos a través de los cuales se persigue obtener los resultados esperados, así como una parte final, en la que se establecen los llamados artículos transitorios, que consagran, entre otros aspectos, precisamente, el régimen transitorio, por ejemplo, conceder una plazo a los estados para adecuar sus constituciones y leyes locales a una reforma de la Constitución federal; también contienen cláusulas de entrada en vigor de la reforma, así como cláusulas derogatorias que dejan sin vigencia a determinadas normas jurídicas. ${ }^{40}$ En tal virtud, los artículos transitorios no deben ser excluidos de redactarse conforme a la técnica constitucional, pues se corre el riesgo que sean contrarios al contenido del propio texto constitucional.

\section{Gonclusiones}

El objetivo que se persiguió en este trabajo fue analizar la técnica y el diseño constitucionales en el caso mexicano, por tal motivo se fijó un marco teórico-conceptual que sirviera de base para hacer el estudio respectivo. Primero intentamos definir lo que es la técnica constitucional, y dijimos que debe ser planteada en una relación de medio a fin y se compone de una serie de reglas que son utilizadas para formular un texto constitucional o introducirle reformas así como para su aplicación, con la finalidad de que sea claro, comprensible y sistematizado, con contenidos fundamentales congruentes con los objetivos fijados y con la pretensión de tener incidencia en

39 Carbonell, Miguel, "La Constitución transitoria", en El Universal de 12 de diciembre de 2013.

40 Véase Gretel, (Grupo de Estudios de Técnica Legislativa), Curso de técnica legislativa, Madrid, Centro de Estudios constitucionales, 1989. citado por Atienza, Manuel, Tras la justicia, Barcelona, Ariel Derecho, 2003, pp. 202 y 203. 
Esta obra forma parte del acervo de la Biblioteca Jurídica Virtual del Instituto de Investigaciones Jurídicas de la UNAM

el terreno de lo fáctico. Luego adoptamos una definición de diseño y nos planteamos algunas preguntas sobre los diseños constitucionales, en cuanto a su origen y evolución, a las cuales agregamos la siguiente: ¿condiciona la técnica constitucional a la eficacia de las reformas constitucionales? Llegamos a la conclusión que sí y para facilitar el análisis de lo que acontece en México, se propuso una clasificación de los casos en los que se hace a un lado la técnica constitucional, ya sea en las reformas constitucionales o en la sustitución de la continuación: a). Hay veces que quienes realizan reformas constitucionales desconocen la técnica constitucional y, por tanto, el resultado se hace consistir en problemas de ambigüedad, de falta de sistematicidad, entre otros; $b$ ). En otras ocasiones se conoce la técnica constitucional, pero por la premura de aprobar una reforma se atropella aquélla, y c). En otros casos, se conoce la técnica constitucional, pero, premeditadamente, se rompe con la misma, porque así lo marcan diversos intereses.

Con base en dicho análisis, se llegó a la conclusión de que se dan los tres casos en México. Respecto a los dos primeros tan solo se enunciaron los ejemplos sin profundizar en la cita de los datos que nos den los pormenores de los mismos, para centrarnos en el tercero, habida cuenta que consideramos que es muy peligroso, sobre todo en el ámbito político, pues aunque puede ser en favor de intereses colectivos como cuando se incluyeron derechos sociales en el texto constitucional de 1917, también puede ser como "técnica del engaño y ocultamiento", como en el caso de la reforma energética, en contra de tales intereses. Conclusiones a las que llegamos después de analizar los diseños constitucionales correspondientes.

En suma, es necesario estudiar en cada caso el diseño constitucional y remontarnos al origen de las reformas para saber cuáles eran los resultados esperados, luego saber cómo quedaron finalmente plasmadas en la Constitución, e identificar si hay alguna falla en la técnica constitucional empleada, ya sea por desconocimiento, por apresuramiento en la aprobación de las reformas respectivas o si deliberadamente se violó la técnica constitucional para obstaculizar o hacer nugatoria la aplicación de la norma constitucional.

\section{REFERENCIAS BIBLIOGRÁFICAS}

Atienza, Manuel, Tras la justicia, Barcelona, Ariel Derecho, 2003. "Contribución para una teoría de la legislación", en Carbonell, Miguel y Pedroza de la Llave, Susana Thalía, Elementos de técnica legislativa, México, Porrúa/UNAM, 2010. 
Esta obra forma parte del acervo de la Biblioteca Jurídica Virtual del Instituto de Investigaciones Jurídicas de la UNAM

Bobbio, Norberto, El futuro de la democracia, trad. de José F. Fernández Santillán, $3^{a}$. ed., México, Fondo de Cultura Económica, 2001.

Bobrow, Davis B. y Drizeck, John S. Policy analysis by design, Pittsburgh Press, 1987.

Carbonell, Miguel, "La Constitución transitoria", en El Universal de 12 de diciembre de 2013.

Cueva, Mario de la, "La Constitución Política", en varios autores. Derechos del Pueblo mexicano. México a través de sus Constituciones, t. I: Doctrinal constitucional, México, LII Legislatura, Cámara de Diputados del Congreso de la Unión, 1985.

ENCICLOPEDIA Furídica. [En línea 18 de marzo de 2016]. Disponible en http:// wrwenciclopedia-juridica.biz14.com/d/t\%C3\%A9cnica-jur\%C3\%ADdica/ t\%C3\%A9cnica-jur\%C3\%ADdica.htm.

García Ramírez, Sergio, "Estado Democrático y Social de Derecho", en Boletín Mexicano de Derecho Comparado, México, IIJ-UNAM, 2011, Biblioteca Jurídica Virtual. http://wrere.juridicas.unam.mx/publica/rev/boletin/cont/98/ art/art4.htm.

GARGarella, Roberto, Crisis de la representación política, $3^{\mathrm{a}}$ ed., México, Fontamara, 2014.

GonzÁlez, María del Refugio y Caballero Juárez, José Antonio, "El proceso de formación del Estado de Derecho en México. Los modelos de Estado en la Constitución de 1917”, en Serna de la Garza, José Ma. y Caballero Juárez, José Antonio, Estado de Derecho y transición jurídica, México, UNAM, 2002.

GonzÁLez, María del Refugio, "A casi cien años de la Constitución de 1917. Una primera reflexión". Conferencia inaugural del seminario internacional "La tradición constitucional en México y la Constitución de 1917, organizado por el CIDE y la UAM, presentada el 17 de junio de 2015. [En línea 18 de marzo de 2016]. Disponible en: http://derechoenaccion.cide. edu/a-casi-100-anos-de-la-constitucion-de-1917-una-primera-reflexion.

Goodin, Robert E., Teoría del diseño institucional, trad. de María Luz Melón, Barcelona, Gedisa, 2003.

Gretel, (Grupo de Estudios de Técnica Legislativa), Curso de técnica legislativa, Madrid, Centro de Estudios constitucionales, 1989.

Hesse, Konrad, Escritos de Derecho Constitucional, trad. de Pedro Cruz Villalón y Miguel Azpitarte Sánchez, Madrid, Fundación Coloquio Jurídico Europeo/Centro de Estudios Políticos y Constitucionales, 2012, Colección Democracia y Derechos. 
Esta obra forma parte del acervo de la Biblioteca Jurídica Virtual del Instituto de Investigaciones Jurídicas de la UNAM

Huerta Ochoa, Carla, "Constitución y diseño institucional", en Boletín Mexicano de Derecho Comparado, México, IIJ-UNAM, 2011, [En línea 18 de marzo de 2016]. Disponible en Biblioteca Jurídica Virtual http://werre.juridicas.unam.mx/publica/rev/boletin/cont/99/art/art3.htm.

Linares Quintana, Segundo V., Tratado de la Ciencia del Derecho Constitucional, Buenos Aires, Plus Ultra, t. III.

NegretTo, Gabriel, La política del cambio constitucional en América Latina, México, Fondo de Cultura Económica, 2015.

Niemeyer, Víctor, "El Congreso Constituyente norteamericano de 1787 y el Congreso Constituyente mexicano de 1916-1917. Comparación y contraste", en Derecho Constitucional Comparado: México y Estados Unidos, México, Instituto de Investigaciones Jurídicas, UNAM, 1990.

RoldÁn Xopa, José, "Crónicas de la reforma energética (II). La 'técnica' constitucional'. [En línea 18 de marzo de 2016]. Disponible en https:// joseroldanxopa.wordpress.com/2014/01/05/cronicas-de-la-reforma-nergetica-ii/.

Tena Ramírez, Felipe, Derecho Constitucional Mexicano, $17^{\mathrm{a}}$ ed., México, Porrúa, 1980.

VALADÉS, Diego, "La Constitución desfigurada", [En línea 18 de marzo de 2016]. Disponible en http://wwrerreforma.com/aplicacioneslibre/preacceso/articulo/default.aspx:id=18212 Eurlredirect=http://wrewereforma.com/aplicaciones / editoriales/editorial.aspx?id=18212. 
Esta obra forma parte del acervo de la Biblioteca Jurídica Virtual del Instituto de Investigaciones Jurídicas de la UNAM

\title{
LA DINÁMICA DE LA CONSTITUCIÓN EN MÉXICO. GIRGUNSPEGGIONES ENTRE LA NOVEDAD Y LA REVISIÓN CONSTITUGIONAL
}

\author{
Isidro DE LOS SANTOS OLIVO*
}

\begin{abstract}
SUMARIO: I. Las Reformas en la Constitución Mexicana de 1917 y en la Constitución de Estados Unidos de América. Un Apunte Comparado. II. Sobre los Principios del Régimen Constitucional de Supremacia y Rigidez de la Constitución. III. La Apertura Constitucional y la Tensión ContinuidadCambio en la Ley Fundamental. ¿Reforma o Nueva Constitución a cien años del Pacto de 1917?
\end{abstract}

\section{LAS REFORMAS EN LA CONSTITUCiÓN MEXICANA DE 1917 Y EN LA CONSTITUCiÓN DE EsTADOS UNIDOS DE AMÉRICA. UN APUNTE GOMPARADO}

La Constitución Mexicana de 1917 ya no tiene la extensión de origen. Inicialmente contaba aproximadamente con $22,286^{1}$ palabras y, propiamente, a un siglo de su promulgación, se ha triplicado; esto es, ha crecido más de tres veces con relación a la extensión del texto inicial pues, en la actualidad, el documento, sin considerar los artículos transitorios, tiene alrededor de

* Profesor-Investigador de la División de Estudios de Posgrado de la Facultad de Derecho de la Universidad Autónoma de San Luis Potosí, México. Miembro del Sistema Nacional de Investigadores.

1 Para este propósito, se consultó el texto original de 1917, el cual es reproducido por el Instituto de Investigaciones Jurídicas de la UNAM en la siguiente dirección electrónica: http://wrere.juridicas.unam.mx/infjur/leg/conshist/pdf/1917.pdf

Esta cifra que señala la cantidad de palabras de la presente cita, es la que arroja la función predeterminada por el programa Office Word. Si consideramos en el texto a los diputados constituyentes, que también se recogen en el instrumento constitucional original en consulta, se proyectan 23,617 palabras. 
Esta obra forma parte del acervo de la Biblioteca Jurídica Virtual del Instituto de Investigaciones Jurídicas de la UNAM

69,856² palabras. En este momento, el Código Político Mexicano, incluyendo los artículos transitorios, la nota de vigencia (relativas al Decreto en materia política-electoral, publicadas en el Diario Oficial de la Federación el 10 de Febrero de 2014) y, su última reforma publicada en el mismo instrumento, el 15 de agosto de 2016, consta de 123,278 palabras.

La secular Constitución de nuestro país, desde que fue promulgada el 5 de febrero de 1917 (entró en vigor el $1^{\circ}$ de mayo de ese año), ha sido reformada en cientos de veces. Ello ha propiciado - cosa obvia - el enorme crecimiento de su bosque jurídico. Por paradójico que resulte, ya que se trata de una Constitución rígida, ha tenido más reformas que artículos. En febrero de 2014, nuestra Carta Magna había experimentado $561^{3}$ reformas. Con la reforma al Código Político del 1917, publicada en el Diario Oficial de la Federación el 15 de agosto de 2016, las modificaciones llegaron a ser 699.4

Tomando en cuenta el inmenso crecimiento que ha experimentado la citada Ley Fundamental, se puede apreciar que, el modelo constitucional mexicano, contrasta con la bicentenaria Constitución de Estados Unidos de América de 1787, la que cuenta con sólo 7 artículos (y sus respectivas secciones). Este texto, habitualmente, se puede leer con buena dicción en 20 minutos y, a lo largo de sus 229 años de existencia, solo se ha reformado en $27^{5}$ ocasiones y, si se me apura, únicamente en 17 , ya que, las primeras

2 Este número de palabras corresponde exclusivamente a los artículos que conforman el texto de la Constitución Política de los Estados Unidos Mexicanos, sin incluir los artículos transitorios. La suma se obtiene con el mismo procedimiento indicado en la anterior cita.

El texto está disponible para su consulta en la siguiente página virtual de la Cámara de Diputados del Congreso de la Unión, de los Estados Unidos Mexicanos: http://wrwrediputados.gob.mx/LeyesBiblio/pdf/1_29ene16.pdf.

3 Así lo indica Viridiana Ríos en su artículo Rarezas Constitucionales, publicado en la Revista Nexos el $1^{\circ}$ de febrero de 2014. Según ella, "si se consideran fe de erratas, reformas a artículos transitorios y aclaraciones, el número total de reformas de 1917 a 2013 asciende a 573 (Cámara de Diputados, 2013)". Disponible en: http://wrwre.nexos.com.mx/?p=18391

$4 \mathrm{Al}$ respecto, también fue consultada la página virtual de la Cámara de Diputados del Congreso de la Unión, donde está disponible la cantidad de reformas realizadas por Periodo Presidencial, iniciando con la presidencia de Álvaro Obregón. De esta forma, se sumaron todos los artículos reformados, que correspondieron a cada Periodo. El conteo se realizó desde el ciclo del presidente Obregón, hasta incluir los artículos reformados, en el actual sexenio del presidente Enrique Peña Nieto. El último Decreto de Reforma que fue consultado para este propósito fue publicado el 15 de agosto de 2016. Consúltese en este sentido: http://wrwre. diputados.gob.mx/LeyesBiblio/ref/cpeum_per.htm

5 Las enmiendas desarrolladas a lo largo de la vigencia de la Constitución de los Estados Unidos de América pueden consultarse en la siguiente dirección electrónica: https://www. law.cornell.edu/constitution que corresponde al Legal Information Institute. 
Esta obra forma parte del acervo de la Biblioteca Jurídica Virtual del Instituto de Investigaciones Jurídicas de la UNAM

10 enmiendas se llevaron a cabo en 1791, por los mismos autores ${ }^{6}$ de tan magistral documento, para establecer los derechos humanos que correspondieron al Bill Of Rights, ${ }^{7}$ inspirados por el Bill Of Rights inglés de 1689 y, asimismo, por la declaración de Derechos de Virginia de 1776.

Hay que destacar que, la Constitución de Estados Unidos de América, se ha modificado sin abusar del procedimiento de reforma y, sobretodo, hay que resaltar que, las enmiendas, han respetado su núcleo, su fórmula política. ${ }^{8}$ Esto permite mantener su legado conceptual en el devenir histórico; en su largo recorrido constitucional ha podido desplegar su cauce a las nuevas realidades socio-políticas, preservando su identidad, la sustancia constitucional. Ha sido capaz de normar el proceso político, adaptándose al cambio que la sociedad política demanda, sin destruir sus cimientos, manteniendo con ello, la regularidad jurídica.

Por exclusión, el texto constitucional permite cierta apertura, de manera que pueda ajustarse a las circunstancias históricas, políticas, económicas y sociales que se van sucediendo, de las diversas sociedades políticas. La Constitución de Estados Unidos es paradigmática en este caso, ya que han sido escasas sus reformas, sin que ello, haya sido un impedimento para amoldarse a los emergentes contextos y exigencias de su plural ciudadanía política. Su magistral construcción normativa-institucional, permitió edificar un original y singular modelo de organización y práctica constitucionales. La Constitución de 1787 es considerada rígida, pues establece un procedimiento más agravado que para la modificación o elaboración de las normas del sistema jurídico, lo cual no significa que, no sea considerada, una Ley Fundamental elástica.

Merced a su elasticidad, se propicia la apertura constitucional en una comunidad pluricultural, lo que posibilita una conexión con la realidad político-

6 En este sentido, véase el discurso de ingreso a la Real Academia de Ciencias Morales y Políticas de Pablo Lucas Verdú como miembro de número, recogido en La Constitución en la Encrucijada (Palingenesia Iuris Politici), Ed. Real Academia de Ciencias Morales y Políticas, Madrid, 1994, p. 38.

7 La Declaración de Derechos Humanos (Bill of Rights) de la Constitución de los Estados Unidos de América, inicialmente se conformó por las diez primeras enmiendas. Su contenido, seguido de un texto que las explica, pueden examinarse en el Legal Information Institute, en la siguiente página electrónica: https://www.law.cornell.edu/constitution/billofrights

8 La fórmula política de la Constitución es un concepto acuñado por Pablo Lucas Verdú. Primeramente, dicho término fue concebido como "la expresión ideológica, jurídicamente organizada en una estructura social". Después, al reflexionar posteriormente sobre esta definición, el profesor de la complutense la complementó de la siguiente manera: “...la fórmula política de una Constitución es una expresión ideológica, inspirada en valores, jurídicamente organizada en una estructura social". Véase, respectivamente, Curso de Derecho Político, volumen IV. Ed. Tecnos, Madrid, 1984, p. 837; y, La Constitución en la Encrucïada... Cit. Supra, p. 36. 
Esta obra forma parte del acervo de la Biblioteca Jurídica Virtual del Instituto de Investigaciones Jurídicas de la UNAM

social. "La apertura constitucional, — sostiene Pablo Lucas Verdú- como la sociedad abierta en cuanto se consideran manifestaciones del espíritu democrático, implican la relación de entrambas con la publicidad, el pluralismo, la alternancia en el poder y la tolerancia, valores fundantes de una democracia". ${ }^{9}$ La técnica de la Reforma, en Estados Unidos de Norteamérica, ha sido manejada cautelosamente, lo que ha permitido ajustar, a la Constitución real y vigente, los cambios trascendentales que ha experimentado su ciudadanía, por casi dos siglos y medio. "Gracias a esa elasticidad nos recuerda el mismo Lucas Verdú - y al espíritu cívico de sus dirigentes, y de su mismo pueblo, ha podido alcanzar más de 200 años de vigencia". ${ }^{10}$

Se puede comprobar que, en la bicentenaria vida constitucional americana se ha podido transitar, sin rupturas, del Congresional Goverment, al llamado Gobierno de los Fueces. Esto último, sobre todo, a partir del célebre caso de Marbury vs. Madison, en la afamada sentencia del Juez John Marshall, en 1803, ${ }^{11}$ que resuelve, seguramente, el caso más conocido en la historia constitucional de Estados Unidos de Norteamérica y que, situó, la jerarquía normativa que la Constitución debe tener en el ordenamiento jurídico de un Estado.

A partir de este trascendental asunto jurídico, quedaría afirmado el principio de Supremacía Constitucional, como una aportación sustancial en los fundamentos que definen al Estado Constitucional de Derecho. Posteriormente, con la enmienda XX a la Constitución de Estados Unidos de América se rediseñó lo relativo a los periodos presidenciales (iniciación y su culminación), así como prever en estos, las situaciones en las que no hubiere presidente electo. Estos cambios se han experimentado, sin quebrantamien-

9 La Constitución Abierta y sus Enemigos, Ed. Servicio de Publicaciones Facultad de Derecho Universidad Complutense de Madrid y Ediciones Beramar, Madrid, 1993, p. 28. Sobre el concepto de Constitución abierta que desarrolla Lucas Verdú, el profesor Ulises Coello Nuño sostiene con relación a este profesor emérito de la Complutense que, “...es el principal tratadista del idioma español sobre la Constitución abierta, por su visión normativa (derecho internacional y derecho comunitario), extranormativa (usos y convenciones, normas de corrección constitucional) y metanormativa (valores y postulados morales y de justicia material, magnitudes socio-económicas) en el método de estudio constitucional, así como también por el enorme caudal dogmático que sobre la misma ha escrito". Véase su estudio ¿Qué es una Constitución abierta?, publicado por el Instituto de Investigaciones Jurídicas de la UNAM, p. 86. Tomamos la cita de la versión electrónica, la cual puede consultarse en la siguiente dirección: http://www.juridicas.unam.mx/publica/librev/rev/facdermx/cont/243.5/art/ art3.pdf

10 La Constitución Abierta..., Cit., p. 30.

11 Cfr. el trabajo de Carbonell, Miguel, Marbury versus Madison: en los Orígenes de la Supremacía Constitucional y el Control de Constitucionalidad, en Del Rosario Rodríguez Marcos (coordinador), Supremacia Constitucional, Ed. Porrúa y Universidad Panamericana, México, 2009, pp. 33 y ss. 
Esta obra forma parte del acervo de la Biblioteca Jurídica Virtual del Instituto de Investigaciones Jurídicas de la UNAM

tos, en las instituciones fundamentales que regulan la vida política de los Estados Unidos de América.

En esa flexibilidad excepcional, el ejemplo norteamericano ha posibilitado la adaptación de su Ley Fundamental, mediante incorporaciones normativo-institucionales casuísticas, sorteando su problemática político-social, en aras de una correspondencia entre la costumbre vivida y la norma escrita. Esa es, quizás, la más importante característica de las Constituciones rígidas, “... cuyo prototipo - dice el citado maestro, Lucas Verdú - es la norteamericana ya que ha mostrado gran elasticidad para acomodarse a las diversas transformaciones sociales a lo largo de su vigencia". ${ }^{12}$

Sabido es que existen dos vías formales para intentar adaptar la cambiante realidad social, en correspondencia con la Constitución. La interpretación constitucional y la reforma constitucional. Los Estados Unidos de América han optado por la primera de ellas. "...la estructura social norteamericana - sostiene Lucas Verdú - ha cambiado extraordinariamente y ello ha repercutido en el Derecho constitucional, modificando el alcance de sus preceptos por la interpretación del Tribunal Supremo... por el efecto de los usos constitucionales y por la traslación del poder político al Ejecutivo en los últimos años. En realidad, toda Constitución cambia en su sentido objetivo, merced a las modificaciones experimentadas en la realidad político-social, donde se da la organización de la convivencia política por ella prevista. Este hecho innegable ha de tenerse en cuenta al interpretar las normas constitucionales. Esta exigencia de acomodarse a los nuevos casos que brotan con el cambio social, se patentizó en la llamada interpretación histórico-evolutiva...". ${ }^{13}$

En el Estado Mexicano, la técnica de la reforma ha sido, la vía, demasiadas veces recurrente. Mi recordado maestro Pablo Lucas Verdú afirmaba que, una buena Constitución, esto es, que se precie de contar con adecuada técnica en su estructuración, debía ser — siguiendo el ejemplo norteamericano- "breve y concisa en sus preceptos, pero, amplia e integradora en sus principios".

\section{SOBRE LOS PRINCIPIOS DEL RÉGIMEN}

\section{Gonstituaional de SupREmacía y Rigidez de la CONSTITUCión}

La dilatada marcha cronológica de la organización constitucional occidental es producto de la cultura jurídico-política euroatlántica. Y fue precisamente la cultura griega la encargada de producir inicialmente, manifestaciones en

12 La Constitución Abierta... Cit., p. 45.

13 Curso de Derecho Político, volumen II. Ed. Tecnos, Madrid, 1986, p. 537. 
Esta obra forma parte del acervo de la Biblioteca Jurídica Virtual del Instituto de Investigaciones Jurídicas de la UNAM

el reconocimiento, estructura y protección de la libertad. Como referí en otro trabajo, “...el estudio sistemático de la Constitución y su respectivo desarrollo doctrinal es relativamente reciente. No obstante las reflexiones en torno al concepto y finalidad de la Constitución se inician con los griegos. La organización política de las sociedades en el mundo occidental, se ha articulado, desde antiguo, mediante una Constitución. En la cultura helénica se puede encontrar el origen remoto de la concepción constitucional. La exaltada cultura jurídico-política euroatlántica, articulada en un espacio geopolítico, cuya filosofía fue entender el mundo y la vida, que permitiera la idea de la libertad como presupuesto inherente de la condición humana y de su propia dignidad". ${ }^{14}$

Fue precisamente en el siglo $\mathrm{V}$ a.c., denominado siglo de oro del pueblo griego o siglo de Pericles, cuando la polis ateniense experimentó su más grande evolución. Ya Jellinek recuerda que, en dicha época, merced a la dilatación de la cultura, se va fortaleciendo la esfera de la libertad individual, propiciando la generación de instituciones de Derecho privado protectoras de la propiedad, la sucesión, etcétera. Asimismo, en el ámbito del Derecho público se reconocieron los derechos políticos, en tanto derechos individuales. Este extraordinario florecimiento de la cultura propició el nacimiento de la Ciencia política, pues, las ideas políticas superan la esfera de grupos o castas para formar parte del conocimiento del pueblo. "El hombre - comenta Francisco Porrúa - forma parte íntegramente de esa comunidad política, y por ello implícitamente tiene derecho a participar en la vida de la polis, derecho que le es reconocido de manera expresa, y además, aunque no se le reconociera expresamente, disfrutaba también de capacidad jurídica privada". ${ }^{15}$

Protágoras ya anticipaba el examen de la Constitución y, junto con Critias, fueron precursores en el estudio y colección de las Constituciones antiguas. Estos dos referentes fueron perentorios para Aristóteles, quien desarrolló “el estudio más sistemático de la Constitución de las polis griegas de su tiempo, por ello puede considerársele como iniciador del Derecho constitucional comparado". ${ }^{16}$

14 De los Santos Olivo, Isidro, El Derecho Constitucional como Ciencia de la Libertad y Cultura de la Democracia. Consideraciones Metodológicas para su Estudio., Recogido en las Memorias del X Congreso Iberoamericano de Derecho Constitucional. El trabajo puede consultarse en la siguiente página electrónica: http://congreso.pucp.edu.pe/derechoconstitucional2009/docs/ pdf/PONENCIAS-MESAS/MESA $\% 204 /$ DE $\% 20$ LOS $\% 20$ SANTOS $\% 20$ OLIVO, $\% 20$ Isidro\%20_Mexico_\%20-\%20El\%20Derecho\%20Constitucional....pdf

15 Teoría del Estado, Ed. Porrúa, México, 1993, p. 56.

16 Cfr. Lucas Verdú, Pablo, Reflexiones en Torno y Dentro del Concepto de Constitución, la Constitución como Norma y como Integración Política, Revista de Estudios Políticos (Nueva Época), $\mathrm{N}^{\circ}$ 
Esta obra forma parte del acervo de la Biblioteca Jurídica Virtual del Instituto de Investigaciones Jurídicas de la UNAM

No vamos a detenernos, con relación a esta argumentación, en la organización constitucional del mundo antiguo que, si bien contó con una ordenación política - no obstante de reconocerse la esclavitud, así como innegables limitaciones en la participación política-, se anticiparon ciertas libertades individuales, manifestándose a partir del siglo V A.C., llamado siglo de oro griego. Esto no significa que se podía hablar, rigurosamente, de un régimen constitucional. Ya sabemos que, como lo recuerda Francisco Porrúa Pérez, “... la distinción radical entre la organización política griega y el Estado moderno, que no ha sido deformado por las concepciones transpersonalistas, la dio el humanismo, ingrediente que se incorporó a la organización política, al pensamiento humano, al difundirse el Cristianismo, que tiene como base de sus postulados precisamente el núcleo fundamental del humanismo". ${ }^{17}$

Ahora bien, interesa resaltar que, la operación de fundar y estructurar un Estado Constitucional, que se apoye en un estatuto jurídico fundamental, que incorpora un diseño institucional con pesos y contrapesos, con límites a la autoridad, evitando la concentración del poder, así como el reconocimiento y garantía de los Derechos y libertades públicas, es producto de los procesos revolucionarios burgueses, que superaron el antiguo régimen. Como se sabe, el Estado Constitucional tiene unas coordenadas temporo-espaciales ${ }^{18}$ muy bien definidas. Es producto de los movimientos revolucionarios anglo-americano y francés. A partir de este preludio, las ideas liberales empezaron a expandirse en Europa, América y, sucesivamente, en otros continentes.

Inicialmente, se puede afirmar que, el Estado Constitucional de Derecho o Régimen Representativo Constitucional, se fundamenta en unos principios, válidos universalmente, e intercambiables en los regímenes democráticos, que son los que corresponden a la cultura jurídico-política euroatlántica. Conviene recordar aquí, que, el Estado Constitucional, tiene ciertos prenotados, es decir, se parte de unas premisas que identifican plenamente al Estado Constitucional de Derecho. El artículo 16 de la Declaración Francesa de los Derechos del Hombre y del Ciudadano de 1789 ya anticipaba la materia inexorable que identifica a toda Norma Fundante, al indicar que: "Toute Société dans laquelle la garantie des Droits n'est pas assurée ni la séparation des Pouvoirs determinée, n'a ponit de

83, enero-marzo de 1994, Madrid, pp. 11 y ss.

17 Teoría del Estado, Cit., p. 56.

18 Peralta Martínez, Ramón, La Constitución como Sistema de Libertades, Ed. Actas, Madrid, 2008, p 31. 
Esta obra forma parte del acervo de la Biblioteca Jurídica Virtual del Instituto de Investigaciones Jurídicas de la UNAM

Constitution" ${ }^{19}$ Por consiguiente, toda sociedad política que tenga la pretensión de cuadrar la ordenación de su convivencia dentro de los esquemas de la democracia política representativa y, que, pueda ser adjetivada como constitucional, debe contar con estos dos grandes componentes.

Ni duda cabe que, toda sociedad política arreglada a una Constitución, cuenta con unos presupuestos, que permiten definir e identificar una organización jurídica-política democrática. En esta línea, nos señala Pedro de Vega que: "El Estado constitucional cimienta su estructura en dos pilares fundamentales: por un lado, en el principio político democrático; por otro en el principio jurídico de supremacía constitucional". ${ }^{20}$ A su vez, siguiendo esta idea y como legado del constitucionalismo, hay que tomar en cuenta el principio liberal que, revela, primordialmente, dos grandes premisas: el principio orgánico-estructural de la separación de poderes y, por otra parte, el reconocimiento y garantía los Derechos Humanos. ${ }^{21}$

La fuerza normativa y, desde luego, la eficacia de la Constitución, estribarán, en buena medida, entre otras cuestiones, en la adecuada técnica de la confección de sus normas e instituciones jurídicas, así como, en la intensidad y/o la conexión que propicien en el medio social que pretendan regular. En definitiva, lo más importante, sin duda alguna, para este propósito, es la educación democrática e instrucción cívica, que refleje la madurez ciudadana en la sociedad política de todo Estado.

México no fue ajeno al movimiento constitucional occidental, puesto que recibió el arsenal de principios, figuras, categorías e institutos que conforman la dogmática de la ciencia constitucional. Una vez que toda Asamblea Constituyente ha cristalizado la obra para la cual fue convocada, o sea, construir la Constitución, ésta se convierte en el centro de referencia esencial de toda la estructura jurídico-política del Estado. En este proceso, como nos señala Kelsen, hay una transición de la soberanía popular (de carácter sociopolítico), a una soberanía técnico-jurídica de la Constitución. Esto es, por un acto volitivo y soberano del pueblo, todos, gobernantes y gobernados, quedan sujetos a la Constitución. El reconocimiento expreso de la soberanía

19 La trascripción corresponde al artículo 16 de la "Déclaration de Droits de l'Homme et du Citoyen de 1789". Este precepto y la Declaración completa, pueden consultarse en la siguiente dirección electrónica: https://wrerrelegifrance.gouv.fr/Droit-francais/Constitution/Declaration-des-Droits-de-l-Homme-et-du-Citoyen-de-1789

20 La Reforma Constitucional y la Problemática del Poder Constituyente, Ed. Tecnos, Madrid, 1991, p. 15.

21 Para profundizar en los principios del Estado Constitucional que desarrolla Pedro de Vega García, consúltese su trabajo Constitución y Democracia en la obra La Constitución de la Monarquía Parlamentaria, autores varios, Ed. Fondo de Cultura Económica, Madrid, 1983. 
Esta obra forma parte del acervo de la Biblioteca Jurídica Virtual del Instituto de Investigaciones Jurídicas de la UNAM

popular, propiamente, lo encontramos en la mayoría de las constituciones. Inicialmente, en el caso de México, el artículo 39 de la Constitución Federal establece que: "La soberanía nacional reside esencial y originariamente en el pueblo". Este artículo hay que interpretarlo de forma sistemática con los demás dispositivos constitucionales relativos y, específicamente, con los artículos 40, 41,128 y 133.22 De la afirmación recogida en el dispositivo 39 y, teniendo presentes los demás artículos correspondientes, se colige que, el pueblo, mantiene su soberanía en la Constitución, ya que ésta es obra suya.

La Constitución se convierte así, por voluntad soberana del pueblo, en Lex Superior. Ante esta situación, la Constitución es considerada el origen de toda producción normativa y, a su vez, la fuente última de validez de la legislación secundaria.

No olvidemos que toda Norma Fundamental tiene la pretensión de durar, de generar un clima de estabilidad, continuidad y seguridad jurídica. Siguiendo este aserto, emerge el principio de rigidez constitucional, teorizado, inicialmente, por James Bryce. ${ }^{23}$ La rigidez constitucional vendría a ser “... aquel sistema formal propio de las Constituciones escritas, que establece, reflexivamente, un modo distinto del seguido por la legislación ordinaria para producir, modificar y derogar las normas constitucionales, lo cual se traduce, precisamente, en la existencia de determinados obstáculos técnicos que evitan que los preceptos constitucionales se reformen fácilmente consiguiendo, de este modo, su continuidad". ${ }^{24}$ La rigidez refuerza el principio

22 Se transcriben los respectivos artículos o, su parte conducente según corresponda, de la vigente Constitución de los Estados Unidos Mexicanos. Artículo 40. "Es voluntad del pueblo mexicano constituirse en una República representativa, democrática, laica y federal, compuesta por Estados libres y soberanos en todo lo concerniente a su régimen interior, y por la Ciudad de México, unidos en una federación establecida según los principios de esta ley fundamental". Artículo 41. "El pueblo ejerce su soberanía por medio de los Poderes de la Unión, en los casos de la competencia de éstos, y por los de los Estados y la Ciudad de México, en lo que toca a sus regímenes interiores, en los términos respectivamente establecidos por la presente Constitución Federal y las particulares de cada Estado y de la Ciudad de México, las que en ningún caso podrán contravenir las estipulaciones del Pacto Federal...". Artículo 128. "Todo funcionario público, sin excepción alguna, antes de tomar posesión de su encargo, prestará la protesta de guardar la Constitución y las leyes que de ella emanen”. Artículo 133. "Esta Constitución, las leyes del Congreso de la Unión que emanen de ella y todos los tratados que estén de acuerdo con la misma, celebrados y que se celebren por el Presidente de la República, con aprobación del Senado, serán la Ley Suprema de toda la Unión. Los jueces de cada entidad federativa se arreglarán a dicha Constitución, leyes y tratados, a pesar de las disposiciones en contrario que pueda haber en las Constituciones o leyes de las entidades federativas".

$23 \mathrm{Al}$ respecto, su conocida obra Constituciones Flexibles y Constituciones Rígidas, estudio preliminar de Pablo Lucas Verdú, Ed. Centro de Estudios Constitucionales, Madrid, 1988.

24 Lucas Verdú, Pablo, Curso de Derecho Político, Vol. II, Ed. Tecnos, Madrid, 1986, pp. 592 y 593 . 
Esta obra forma parte del acervo de la Biblioteca Jurídica Virtual del Instituto de Investigaciones Jurídicas de la UNAM

de supremacía constitucional, puesto que, "La Constitución - nos recuerda Pedro de Vega - solo podrá definirse jurídicamente como ley suprema cuando para su modificación se exige - conforme a la idea de rigidez - un procedimiento distinto, más agravado y complejo que el que se sigue para la modificación o derogación de las leyes ordinarias". ${ }^{25}$

Completando esta idea, el principio de rigidez se conforma como primer mecanismo de resguardo de la Constitución, convirtiéndose en una garantía de estabilidad y continuidad de la distribución constitucional.

La Constitución Política de los Estados Unidos Mexicanos recoge el principio de Rigidez constitucional en el artículo 135, ya que establece una votación calificada de dos terceras partes de los individuos presentes del Congreso de la Unión y, a su vez, las reformas tienen que ser aprobadas por la mayoría de las legislaturas de los estados y la de la Ciudad de México. Ante el cúmulo de reformas que ha experimentado la Ley Mayor Mexicana, no obstante de ser una Constitución formalmente rígida, en la realidad ha devenido, en una Constitución materialmente flexible.

\author{
III. LA APERTURA CONSTITUCIONAL \\ Y LA TENSIÓN GONTINUIDAD-CAMBIO \\ EN LA LEY FUNDAMENTAL. ¿REFORMA O NUEVA \\ Constitución a Cien AÑos del Pacto De 1917?
}

El mayor reconocimiento que le podemos conceder a nuestra Carta Magna, es respetarla y aplicarla, ahora que está próxima a cumplir 100 años. Este aniversario, la convierte en una Constitución añeja, que ha sido capaz de sortear - con todas las vicisitudes que ello conlleva- las grandes dificultades políticas y sociales a lo largo de un siglo de su vigencia. En principio, toda Constitución debe ser capaz de normar el proceso político para el cual fue elaborada. Las Constituciones cuentan con telos y una ratio. No tener presente este último aserto conllevaría al mayor de los despropósitos en una comunidad política. De ahí que podamos afirmar que, quizás con excesivo optimismo, la Constitución de 1917 (con todos los reparos que se puedan establecer), ha cumplido con un mínimo de eficacia. Recordemos que es un Código Político Centenario.

Ahora bien, hace una década escribí lo siguiente: "en estos tiempos de crisis e inestabilidad política en nuestro país, han arremetido voces contra la vigente Constitución general de 1917, al grado de manifestar que es ne-

\footnotetext{
25 La Reforma Constitucional... Cit.; pp. 40-41.
} 
Esta obra forma parte del acervo de la Biblioteca Jurídica Virtual del Instituto de Investigaciones Jurídicas de la UNAM

cesario el establecimiento de una nueva Constitución. Por ello, la tensión permanencia-cambio constitucional es un tema del mayor calado político y social y exige un correcto tratamiento en el derecho constitucional patrio". ${ }^{26}$

Carl Schmitt nos recuerda que "El primer ejemplo de una moderna Constitución escrita es el Instrument of Government de Cromwell, del año 1656. El mismo Cromwell se manifestó acerca de la finalidad de este instrumento: había que dar una regla permanente, inviolable frente a las cambiantes revoluciones mayoritarias del Parlamento: en todo Gobierno necesitaba haber algo de fundamental, algo como una Gran Carta que fuera permanente e inviolable". ${ }^{27}$

Una cosa es reformar la Constitución y, otra, muy distinta, es establecer una nueva. En la dialéctica permanencia y cambio constitucional, hay que tener cuidado para proporcionar los argumentos jurídicos que la teoría debe de suministrar, para mantener la congruencia científica y/o el rigor que exige el método constitucional y, así, mantener vigente, en esa construcción dogmática, el principio de no contradicción.

Para pretender aportar alguna respuesta a este cometido, es menester contestar, al menos, dos cuestiones perentorias: ¿Es posible elaborar una Nueva Constitución mediante el procedimiento de reforma o revisión constitucional? ¿Cómo localizar el punto de conexión y/o equilibrio entre, por una parte, la estabilidad y permanencia que deben caracterizar a toda Ley Fundamental, lo que conlleva a la continuidad del Estado constitucional y; por otra, la adaptación y/o la regulación que la efervescencia de la vida político-social exige, merced a la dinámica que toda comunidad experimenta mediante el cambio y las transformaciones, realizadas a través del proceso histórico?

La técnica de la reforma constitucional fue establecida, a mi juicio, no solo como inicial mecanismo de protección constitucional, sino como instrumento de garantía, para la permanencia y continuidad de la comunidad política, del Estado de Derecho, propiamente. Un juicio inicial indica, implícitamente que, en aras de sostener la estabilidad normativa-institucional que demanda todo Estado Constitucional, tiene que cuidar el mecanismo de reforma de la Constitución, para que su quintaesencia, su núcleo, (iden-

26 De los Santos Olivo, Isidro, La Constitución en la encrucijada. Permanencia y cambio constitucional en la democracia mexicana, en la obra colectiva de Diego Valadés y Miguel Carbonell (Coordinadores), El Estado Constitucional Contemporáneo. Culturas y Sistemas furídicos Comparados, Ed. Instituto de Investigaciones Jurídicas de la UNAM, México, 2006.

27 Cfr. Teoría de la Constitución, (trad. De Francisco Ayala), Ed., Revista de Derecho Privado, Madrid, 1934, pp. 45 y 46. Citado, asimismo, por Lucas Verdú, Pablo, Curso de Derecho... Vol. II, Cit., p. 418. 
Esta obra forma parte del acervo de la Biblioteca Jurídica Virtual del Instituto de Investigaciones Jurídicas de la UNAM

tidad mediante las decisiones políticas fundamentales), no se dañe o altere. Esto manejado adecuadamente, facilitará la pervivencia de la Ley Mayor, en el correr de los años. En palabras de Pablo Lucas Verdú: "Toda Constitución aparece abierta en el tiempo (in die Zeit hineinoffen) puesto que nunca será perfecta y completa, ya que la vida que pretende ordenar, es vida histórica y, por ende, sometida a cambios. El derecho constitucional solo puede evidenciarse y calcularse de modo limitado pagando el precio de numerosos cambios del texto constitucional. Esta apertura constitucional no significa su disolución en un dinamismo total. Si así fuera, la Constitución sería incapaz de orientar la vida de la comunidad. La Constitución no sería abierta, sino fijase, de modo vinculatorio, lo que no debe de quedar abierto. Intenta establecer un momento fijo estimado como algo decisivo que opera estabilizando". ${ }^{28}$

En el tratamiento de la reforma constitucional deben de cuidarse aquellos principios que figuran los fundamentos del orden de toda comunidad. Son principios rectores que identifican la unidad política y permiten las funciones estatales de manera continua. Si no yerro, la apertura y elasticidad en la Constitución no significa, no puede entenderse, en ningún caso, que la Ley Fundamental quede disuelta en esa dinámica que el cambio constitucional, mediante la reforma, requiere. Pensar lo contrario, implicaría socavar sus cimientos, sus decisiones políticas fundamentales, su núcleo. La apertura constitucional significa, entendida fielmente, que la misma Ley Fundamental, afirma de forma entrelazada, lo que no debe de aperturarse. Así lo señala Lucas Verdú: “... una apertura constitucional desmesurada conduciría, a la postre, a una destrucción, o por lo menos erosión, de los elementos vinculantes que preserva la identidad de la Constitución a través de sus modificaciones y de sus recepciones... toda apertura constitucional, sin ignorar los elementos normativos y extra normativos susceptibles de inspirarse, incorporar e integrarse en el orden constitucional propio, debe siempre estar atenta para que su núcleo, su forma política no se altere o destruya". ${ }^{29}$

Por consiguiente, en los umbrales de constitucionalismo se pudo apreciar una apertura en los textos fundamentales, mediante la incorporación de preceptos e instituciones liberales en su contenido normativo. Ello implicó un cambio drástico en la organización de la estructura política y, en la concepción misma de la democracia, todo lo cual implicaba una superación y, a su vez, una apertura, con relación al antiguo régimen, cuya consecuencia

\footnotetext{
28 La Constitución Abierta... Cit. p. 51.

29 Ibidem, pp. 59 y 60.
} 
Esta obra forma parte del acervo de la Biblioteca Jurídica Virtual del Instituto de Investigaciones Jurídicas de la UNAM

fue el establecimiento del Estado liberal Burgués de Derecho, el primigenio Estado constitucional. Sobre estas consideraciones remito a un trabajo donde he desarrollado consideraciones en torno a la apertura constitucional. ${ }^{30}$

Reformar la Constitución no debe de entenderse, el destruirla. Es menester, en el tratamiento adecuado de la teoría constitucional, desentrañar el apropiado significado de los conceptos rigidez, reforma, apertura, elasticidad, continuidad y estabilidad constitucionales. Insistamos, reformar no es crear una nueva constitución, ya que tiene límites, puesto que, "Una apertura de la Constitución - concluye inexorablemente Pablo Lucas Verdú - que hiere su techo ideológico, conmueve su organización jurídica o revoluciona su infraestructura socioeconómica, implica: sea su tergiversación, sea su subversión latente o patente, en definitiva una revolución. Si es así, ya no cabe hablar de apertura constitucional, sino de sustitución, pacífica o violenta, del ordenamiento fundamental. Decían los máximos representantes contra revolucionarios - y en esto tenían razón - que si fuera necesario revisar una Constitución, siempre habría que emprender esa tarea con temblor y temor. Actualizando esa expresión, la apertura constitucional y la reforma del texto fundamental, han de hacerse cautelosamente, de modo que no se hiera su forma política, su esencia". ${ }^{31}$

Con relación a la permanencia de una Constitución, y a su adaptación mediante el cambio o reforma a las nuevas realidades político-sociales que experimenta toda sociedad política, conviene reproducir lo que he referido en uno de los trabajos ya citado, líneas arriba: “...toda Norma Fundamental tiene la pretensión de durar, de generar un clima de estabilidad, continuidad y seguridad jurídica. Ello dependerá, en principio, del alcance, significado y concepto de Constitución que se tenga, producto del desarrollo cultural en el ámbito político y cívico que haya experimentado una comunidad. Asimismo, no hay que olvidar que, la sociedad es cambiante, exige movimiento, está en constante devenir histórico. La encrucijada constitucional se presenta, por lo general, en las constituciones rígidas que, deben sortear, la tensión permanencia-cambio. El meollo de esta cuestión estriba, en principio, en encontrar una armonía entre la estabilidad con la que debe de contar una Constitución a través del proceso histórico, y su respectiva adaptación a la cambiante sociedad que exige una renovación de la norma-

30 Apertura y Estabilidad Constitucional en las Entidades Federativas, en la obra Derecho Constitucional Estatal. Memorias del VI y VII Congresos Nacionales de Derecho Constitucional de los Estados, Gámiz Parral, máximo et. Al. Ed. Instituto de Investigaciones Colectivas de la UNAM, México 2009, pp. 475 y ss.

31 La Constitución Abierta... Cit. p. 60. 
Esta obra forma parte del acervo de la Biblioteca Jurídica Virtual del Instituto de Investigaciones Jurídicas de la UNAM

tiva fundamental. En otras palabras, toda Constitución es elaborada por sus autores con la intención de permanecer, pues debe de respetarse el principio democrático ya que, es el pueblo, quien en uso de su soberanía y el poder constituyente fija y establece las reglas jurídicas que deben regular su convivencia política. Pero la comunidad por su propia naturaleza está en constante evolución y, lógicamente la materia jurídica-fundamental no hay que concebirla como algo inmutable y acabado de la sociedad; antes bien, como un continuo fluir que se renueva y es capaz de adaptarse a las vertiginosas transformaciones políticas, sociales, económicas que experimenta todo contingente social, pues la Constitución, es, ante todo $<<$ vividura $>>$ ". 32

Hemos comentado en el contenido de este breve estudio y, particularmente en este parágrafo, la dicotomía que se presenta en el estado mexicano de contar con una nueva constitución o reformar la vigente. Hemos expresado, asimismo, nuestra posición, contrastando los diferentes enfoques de algunos autores más significativos en esta temática. Todo ello con arreglo a la dogmática constitucional. Como corolario de las anteriores reflexiones, consideramos y aunque resulte reiterativo que, el mejor homenaje que le podemos hacer a nuestra Carta Magna mexicana a un siglo de su existencia, es conocerla, respetarla, aplicarla, es decir, que cumpla con la teleología para la cual fue elaborada. Se trata, hacer de la Constitución, un documento eficaz que sea capaz de controlar el proceso político en tanto instrumento regulador de la convivencia ciudadana. Si no tomamos conciencia de ello, las reformas seguirán decantándose de manera interminable y, lo más grave, sin aportar soluciones a los complejos problemas que padecemos. En esta perspectiva se inscriben las palabras de Carla Huerta, al aseverar "no es necesario seguir reformando la Constitución para precisar sus supuestos o adicionar nuevas formas de control, sino que se debe de obligar a la autoridad a cumplir con sus deberes constitucionales, para hacer eficaz la Constitución", ${ }^{33}$ sosteniendo más adelante que, "Las respuestas a la falta de ejercicio de control son más bien de orden político, que consecuencia un deficiente diseño institucional". ${ }^{34}$

Es necesario la conformación de una conciencia constitucional que, conexione a la opinión pública, con el instrumento que hace posible la convivencia política en términos pacíficos. Ya con exactitud lapidaria, el gran profe-

32 La Constitución en la encrucijada... Cit.

33 Véase su obra Mecanismos Constitucionales para el Control del Poder Político, Ed. Instituto de Investigaciones Jurídicas de la UNAM, México, 1988. Citado por Jorge Carpizo en ise necesita una nueva Constitución...?, Cit., p. 146.

34 Ídem, p. 146. 
Esta obra forma parte del acervo de la Biblioteca Jurídica Virtual del Instituto de Investigaciones Jurídicas de la UNAM

sor Rodolfo Reyes, en el prólogo de la obra La Organización Política de México (edición española), del eminente constitucionalista chiapaneco Emilio Rabasa, manifestaba ciertos requerimientos esenciales, que definen el ser constitucional de todo Estado "...si por el entendemos lo que es debido; es decir la positiva relación entre el individuo y el Estado, la verdadera adaptación de la costumbre vivida a la ley escrita". ${ }^{35}$ La revolución que hay que experimentar es la de las conciencias; esto es, una reforma antropológica, social, cultural que permita la propagación de la cultura política-democrática en el acervo general de los ciudadanos. Una vez alcanzada la madurez política en el pueblo, que posibilite una conciencia de vida nacional, que se propague la educación política, la instrucción cívica y el respeto en las instituciones liberales, se estará en condiciones de generar un sentimiento constitucional, el cual, depositado en una base jurídica, coadyuvará en la materialización del Estado de Derecho, que comienza en la propia Constitución.

Por ello, es presupuesto inexorable que exista y se exprese en la conciencia colectiva, tanto de gobernantes como de gobernados, la voluntad política de acercarse al conocimiento cabal de su Constitución. Para lograr ese alto cometido, nada mejor que las palabras del universal Don Miguel de Unamuno. En este sentido, el rector magnífico de la Universidad de Salamanca, solía invertir el aforismo escolástico que señala: "Nada es querido sin ser previamente conocido"; afirmando que: "Nada se conoce sin ser previamente querido". Con el debido conocimiento de la Ley fundamental, se estará en condiciones de fomentar una voluntad y, una actitud, para el respeto espontáneo y esencial que exige la Constitución por sí misma, en cuanto obra soberana del pueblo, como principal expresión de civilidad de toda sociedad libre.

35 Rabasa, Emilio, La Organización Política de México, Ed. América, Madrid, s/f, p. XV. 
Esta obra forma parte del acervo de la Biblioteca Jurídica Virtual del Instituto de Investigaciones Jurídicas de la UNAM

\title{
LA DINÁMICA DEL GAMBIO CONSTITUGIONAL EN MÉXICO: HACIA UNA AGENDA DE INVESTIGACIÓN
}

\author{
José Ma. SERnA DE LA GARZA*
}

SUMARIO: I. Introducción. II. Las dos dimensiones del debate: descriptiva y normativa. III. Conclusión.

\section{INTRODUCGIÓN}

Hasta el día en que se escriben estas líneas (febrero de 2016), la Constitución mexicana de 1917 ha tenido 640 modificaciones. Como es bien sabido, a través de muchas de estas reformas y adiciones se han introducido en el texto constitucional un sinnúmero de artículos de naturaleza reglamentaria; ha habido una verdadera explosión de artículos transitorios; se ha generado un texto de gran densidad normativa; se ha perdido de sistematicidad y coherencia; las reformas han tenido por consecuencia dificultar la lectura y comprensión de la Constitución por parte de ciudadanos y expertos por igual.

La preocupación por la trayectoria que ha tenido nuestra Constitución, llevó al Instituto de Investigaciones Jurídicas de la UNAM (IIJ) a integrar un grupo de investigadores, coordinado por los doctores Diego Valadés y Héctor Fix Fierro, para generar un diagnóstico y una propuesta. Esta última consiste en la reordenación y consolidación del texto de la Constitución mexicana.

No es este el espacio para dar detalles de dicha propuesta. ${ }^{1}$ Pero por lo menos recordaré aquí sus rasgos principales:

1. No se trata de diseñar una nueva Constitución, sino de dar un diseño nuevo a la Constitución vigente. Se trata de hacer un cambio estruc-

* Investigador del Instituto de Investigaciones Jurídicas de la UNAM.

1 La propuesta se puede ver en: $\underline{h t p: / / w w w 2 . j u r i d i c a s . u n a m . m x / c o n s t i t u c i o n-r e o r d e n a d a-c o n-}$ solidada//. 
Esta obra forma parte del acervo de la Biblioteca Jurídica Virtual del Instituto de Investigaciones Jurídicas de la UNAM

tural y formal, que no toque las decisiones jurídico-político fundamentales contenidas en la Constitución vigente.

2. Se propone reordenar el texto constitucional:

A. Reubicando disposiciones constitucionales conforme a criterios sistémicos y técnicos

B. Pero respetando la ubicación de los artículos que pueden considerarse como "emblemáticos" de la Constitución: 1, 3, 14 y 16, 27, 103 y $107,115,123$, y 130.

3. Se propone también consolidar el texto constitucional, lo cual implica:

A. Mejorar la puntuación y redacción

B. Sintetizar contenidos

C. Suprimir redundancias e inconsistencias

D. Articular la redacción de párrafos reordenados

E. Mejorar la presentación sistemática en apartados, fracciones e incisos.

4. Por último, se propone trasladar el contenido de las partes consideradas como de naturaleza "reglamentaria", a una Ley de Desarrollo Constitucional, de jerarquía infra constitucional, pero supra legal.

Ahora bien, lo que deseo expresar en este ensayo es que esta propuesta es la punta del iceberg de todo un proyecto de investigación más ambicioso y profundo, en el que están involucrados investigadoras e investigadores del IIJ, en particular de las áreas de derecho constitucional y filosofía del derecho (si bien la discusión interna ha involucrado a prácticamente todo el IIJ). De esta forma, quisiera aprovechar este espacio para explicar el esquema de ese proyecto, sus vertientes y aristas, en las que hemos avanzado, hay que reconocerlo, de manera asimétrica, es decir, más en unas líneas que en otras. Con esta explicación, mi objetivo es dibujar un marco general que pueda provocar discusiones, opiniones, posturas y perspectivas en los debates que se avecinan, rumbo al centenario de la Constitución mexicana de 1917.

\section{LAS DOS DIMENSIONES DEL DEBATE: DESGRIPTIVA Y NORMATIVA}

En primer lugar, considero que es posible distinguir entre la dimensión descriptiva-explicativa y la dimensión normativa-prescriptiva de la discusión. 
Esta obra forma parte del acervo de la Biblioteca Jurídica Virtual del Instituto de Investigaciones Jurídicas de la UNAM

\section{Dimensión descriptiva-explicativa}

En esta dimensión se han planteado diversas preguntas:

\section{A. ¿Qué dinámica de cambio ha tenido la Constitución mexicana de 1917?}

En relación con esta pregunta podemos encontrar el ya referido diagnóstico que se ha hecho en el IIJ; como otros diagnósticos que se han realizado, la atención se ha centrado en la frecuencia y el número de reformas constitucionales experimentadas por nuestra norma fundamental desde 1921 hasta la fecha. En relación con este punto, sólo quisiera mencionar dos cosas.

En primer lugar, en el mundo moderno, no es tan raro tener tasas elevadas de reforma constitucional. Como lo ha afirmado Detlef Nolte, las reformas constitucionales son fenómenos recurrentes en América Latina, tanto reformas parciales (enmiendas) como la promulgación de una nueva constitución. En ese aspecto, América Latina no es tan diferente en comparación con otras regiones del mundo, como por ejemplo Europa. Asimismo, concluye este autor que tampoco los países de América Latina difieren respecto a la rigidez de sus constituciones. Las constituciones latinoamericanas son en promedio un poco menos rígidas que las constituciones en otras partes del mundo. Al mismo tiempo, existe una gran variación con respecto a la frecuencia de reformas constitucionales entre los diferentes países latinoamericanos. ${ }^{2}$

De las 200 constituciones vigentes al comienzo del siglo XXI más de la mitad han sido renovadas o reformadas en forma substancial en las tres

2 En su estudio, Nolte describe los distintos métodos para determinar la dificultad de reformas una Constitución, es decir, su rigidez, a saber: a) Método que toma en cuenta las mayorías necesarias (simple, absoluta, dos tercios) para aprobar la reforma constitucional; b) Método que cuenta el número de puntos de veto en el proceso de reforma constitucional (como por ejemplo el número de votaciones en órganos legislativos compuestos de manera diferente, referendum, la aprobación por los parlamentos de los estados miembros en sistemas federales, etc.); c) Método que combina el número de puntos de veto con las mayorías requeridas en el proceso de reforma constitucional. Nolte, Detlef, "Reformas constitucionales en América Latina", German Institute of Global and Area Studies, Colloque international Le constitutionnalisme latino-américain aujourd'hui, entre renouveau juridique et essor démocratique, Centre de Philosophie Juridique et politique, Université de Cergy-Pontoise, 4 de Abri del 2013, pp. 19-20. 
Esta obra forma parte del acervo de la Biblioteca Jurídica Virtual del Instituto de Investigaciones Jurídicas de la UNAM

décadas anteriores. ${ }^{3}$ Asimismo, estudios recientes documentan que las reformas constitucionales son frecuentes en democracias enraizadas. En este sentido, Lorenz ha encontrado que hubo reformas constitucionales en 32 de 39 democracias estables en el periodo 1993-2002, y que en promedio fueron 5.8 reformas por año (y país). ${ }^{4}$ En contraste, como señalan Casar y Marván, en el caso mexicano, en los 30 años transcurridos entre 1982 y 2012 , el promedio anual de decretos de reforma constitucional promulgados fue de 3.6. ${ }^{5}$

El punto que deseo resaltar con estos datos es que la reforma constitucional frecuente es signo de nuestro tiempo. Cierto que en México la tasa de cambio constitucional es más elevada, pero tampoco podemos decir que se trata de una experiencias exóticas o totalmente extrañas como fenómeno.

En segundo lugar, deseo resaltar que, como lo dijo Diego Valadés desde 1994, las críticas a la dinámica de reforma constitucional en México se han dirigido más al número que al contenido de las reformas. ${ }^{6} \mathrm{Me}$ atrevo a añadir que las críticas tampoco se han dirigido a explicar los efectos de esa dinámica, ni la estructura y naturaleza de la deliberación pública que ha llevado a tantas reformas constitucionales. Quizás sea más productivo enfocarnos en estos temas.

\section{B. ¿Qué factores explican esa dinámica?}

Todavía dentro de la dimensión descriptiva-explicativa, surge otra pregunta: ¿Por qué se ha dado esta dinámica? En relación con esta cuestión considero que se puede encontrar explicaciones internas a la Constitución, o bien explicaciones externas a la Constitución, en los términos que se expone a continuación.

\section{a. Explicaciones internas a la Constitución}

En este tipo de explicación, la pregunta relevante es la siguiente: ¿Qué hay dentro de la Constitución que explique esta dinámica? A su vez, esta

3 Hart, Vivien. Democratic Constitution Making, Washington D.C., United States Institute of Peace (Special Report 107), 2003, p. 2.

4 Lorenz, Astrid, 2005. How to measure constitutional rigidity, fournal of Theoretical Politics vol. 17, no. 3, 2005, pp. 339- 361. Citada por Nolte, op. cit., p. 4.

5 Casar, Ma. Amparo y Marván, Ignacio, Reformar sin Mayorías, La dinámica del cambio constitucional en México: 1997-2012, Taurus, México, 2014, p. 16.

6 "La Constitución no es adorno ni es obstáculo; es eje de los cambios". Valadés, Diego, Constitución y Política, UNAM, México, 1994, pp. 78-79. 
Esta obra forma parte del acervo de la Biblioteca Jurídica Virtual del Instituto de Investigaciones Jurídicas de la UNAM

pregunta nos lleva a fijarnos en diversos factores, como lo son: i) el procedimiento de reforma constitucional; ii) el carácter reglamentario original de la Constitución mexicana de 1917; iii) la edad de la Constitución; y iv) la extensión de la Constitución.

\section{i) El procedimiento de la reforma constitucional}

En relación con este tema, la pregunta relevante sería la siguiente: ¿hay algo dentro del procedimiento de reforma constitucional previsto en el artículo 135, que induzca o produzca de alguna manera la dinámica de cambio que ha tenido nuestro texto constitucional? Cabe mencionar que en la literatura especializada, este enfoque se vincula con el tema de los factores institucionales que explican el cambio constitucional. Así, al examinar el procedimiento surgen varios temas, tales como: los presupuestos sobre los que descansa el procedimiento de reforma constitucional; la configuración normativa del procedimiento, con sus incentivos y efectos; y las funciones del procedimiento de reforma constitucional. En este ensayo me concentraré nada más en los presupuestos del procedimiento de reforma.

En relación con este tema, resulta pertinente mencionar que debido que el procedimiento de reforma constitucional en México es parcialmente parecido al previsto en el artículo $\mathrm{V}$ de la Constitución de los EUA, comparte con él varios de sus presupuestos, mismos que han sido identificados por Lutz. $^{7}$ Este autor identifica cuatro presupuestos, al que añadimos uno más (en el inciso 5) de la siguiente lista), para completar un esquema de cinco presupuestos del procedimiento de reforma constitucional en México, en los siguientes términos:

1) La doctrina de la soberanía popular: la idea de que el pueblo es la fuente última del poder, lo cual incluye el poder de cambiar la norma constitucional. Por ello, se institucionalizó en la propia constitución dicho poder.

2) La naturaleza humana imperfecta, pero perfectible; presupuesto que, aplicado a las instituciones, significa que el ser humano puede aprender de la experiencia, y así mejorar el diseño de las instituciones constitucionales para atender los problemas de la comunidad política.

7 Lutz, Donald, "Toward a Theory of Constitutional Amendment", en Levinson, Sanford (ed.), Responding to Imperfection, The Theory and Practice of Constitutional Amendment, Princeton University Press, 1995, pp. 238-240. 
Esta obra forma parte del acervo de la Biblioteca Jurídica Virtual del Instituto de Investigaciones Jurídicas de la UNAM

3) La eficacia del proceso deliberativo: el arreglo constitucional se hizo bajo el presupuesto de que toda decisión política requiere de un lento proceso deliberativo, y bajo la idea de que, mientras más importante es la decisión, más deliberación debe haber. ${ }^{8}$

4) La distinción entre legislación ordinaria y norma constitucional (jerárquicamente superior): la idea de que los temas y asuntos constitucionales son más importantes que los temas legislativos, y que por tanto los primeros deben estar sujetos a un proceso deliberativo más estricto; y además, que lo constitucional debe dirigir y limitar la legislación ordinaria.

5) La idea de que la participación de las legislaturas locales en el procedimiento de reforma constitucional son un factor de equilibrio, en el marco del sistema federal. Es decir, la reforma constitucional requiere un amplio consenso político y también un amplio consenso "territorial", por llamarle de una forma.

Fijados estos presupuestos, pudiéramos adelantar una hipótesis para el caso mexicano: estos presupuestos no se cumplen en la realidad de la reforma constitucional mexicana. Ni se da una amplia participación del pueblo en las reformas constitucionales; ni se dan amplios procesos deliberativos que involucren a toda la sociedad; ni el proceso deliberativo es más estricto; ni las legislaturas locales son un factor de equilibrio en el marco del sistema federal. Cabe señalar que esta hipótesis se vincula con otro tema relevante en la literatura: los límites de las explicaciones institucionales para explicar el cambio constitucional; es decir, factores institucionales como variables independientes que expliquen la dinámica de cambio de una constitución, a lo cual regresaremos más adelante.

ii) El carácter reglamentario original de la Constitución mexicana

Jorge Carpizo ha observado que desde 1917, los artículos 27 y 123 de la Constitución nacieron con una inclinación reglamentaria: se deseaba ser preciso para que no se fuera a desvirtuar los mandatos contenidos en esos artículos emblemáticos con posterioridad. ${ }^{9}$ Pero igualmente señala este au-

8 Igualmente, la idea de que el grado de consenso necesario para la toma de decisiones constitucionales es mucho más amplio que el requerido para las decisiones de la política "normal".

9 Carpizo, Jorge, "La Reforma Constitucional en México. Procedimiento y Realidad", Boletín Mexicano de Derecho Comparado, No. 131, 2011, p. 376. 
Esta obra forma parte del acervo de la Biblioteca Jurídica Virtual del Instituto de Investigaciones Jurídicas de la UNAM

tor que esa tendencia ha seguido y más aún, se ha extendido, por diversas razones: por considerarse que si el mandato se encuentra en la Constitución tiene más probabilidades de ser cumplido; por la existencia de "una feria de desconfianzas" entre los partidos políticos y para asegurar que los acuerdos políticos realmente se cumplan, se exige incluir en el texto constitucional verdaderas minucias jurídicas. Además, afirma Carpizo que es una cuestión de cultura política, pues por un lado se desconfía del cumplimiento del precepto constitucional, y por el otro se le siente como una garantía, en una situación ambivalente y paradójica. ${ }^{10}$

Por su parte, y desde una perspectiva comparada, Ginsburg y Melton han identificado como un factor de estabilidad y durabilidad de las constituciones, lo que llaman "especificidad". En este sentido, una estrategia que puede ayudar a que las constituciones sobrevivan, consiste en tratar de anticipar fuentes relevantes de presión y considerarlas en el texto constitucional, haciendo más específica la negociación constitucional. Al preverse en la constitución posibles escenarios de conflictos futuros, quienes diseñan una constitución pueden minimizar problemas de conducta estratégica en las interacciones entre los actores políticos. ${ }^{11}$

En Brasil ha pasado algo parecido a la "inclinación reglamentaria" que ha experimentado nuestro texto constitucional, y diversos especialistas se han preguntado las razones de que esto haya sucedido así. Específicamente: ¿qué puede llevar a un gobierno a implementar su agenda de políticas públicas modificando la Constitución, en vez de hacerlo por la vía infraconstitucional? ${ }^{12}$ Según autores como Gonçalves y Bastos, ningún gobierno buscaría implementar su agenda por medio de reformas constitucionales, a menos de que estuviese realmente obligado a hacerlo. ¿Por qué en Brasil lo han hecho así entonces? Una de las razones posibles, es la intención de proteger ciertas decisiones constitucionalizándolas. Otra razón sería debido a que la Constitución de Brasil de inicio contenía políticas públicas, implementar políticas alternativas necesariamente ha requerido la modificación de la Constitución. ${ }^{13}$

10 Idem.

11 Ginsburg, Tom y Melton, James, "Does the Constitutional Amendment Rule Matter at All, Amendment Cultures and the Challenges of Measuring Amendment Difficulty", Chicago Coase-Sandor Institute for Law and Economics Working Paper No. 682 (2d Series), Public Law and Legal Theory Working Paper No. 472, Mayo 2014, p. 36.

12 Goncalves Couto, Cláudio y Bastos Arantes, Rogério, "Constituçâo, Governo e Democracia No Brasil”, Revista Brasileira de Ciencias Sociais, vol. 21, no. 61, 2006, p. 42.

13 Idem. 
Esta obra forma parte del acervo de la Biblioteca Jurídica Virtual del Instituto de Investigaciones Jurídicas de la UNAM

\section{iii) La edad de la Constitución}

En la literatura de la ciencia política se pueden ver explicaciones como las Rosalind Dixon, quien ha encontrado una correlación positiva entre la edad acumulativa de una constitución, y la frecuencia con la que ésta es reformada. Según esta autora, la razón es que mientras más añeja es una constitución, hay mayor margen para que las demandas por introducir cambios constitucionales emerjan en respuesta al cambio en las circunstancias y concepciones sociales. ${ }^{14}$ A la misma conclusión han llegado Ginsburg y Melton, si bien éstos autores han observado que las constituciones son diseñadas para estabilizar y facilitar la política, pero existe la posibilidad de que las constituciones sobrevivan su utilidad y creen patologías en el proceso político que distorsionen la democracia. ${ }^{15}$

\section{iv) La extensión de la Constitución}

Finalmente, autores como Lutz han llegado a la conclusión que uno de los factores que explican la frecuencia con la que se reforma una constitución, es su extensión. ${ }^{16}$ Es decir, mientras más extensa es una constitución, es más probable que se reforme con mayor frecuencia. Ello es así, en razón de que las constituciones extensas tienden a tener un número más elevado de disposiciones detalladas, que establecen políticas públicas que requieren de frecuentes cambios cuando se convierten en obsoletas o incapaces de adaptarse a ambientes cambiantes. ${ }^{17}$ De manera similar, Ginsburg y Melton han encontrado que la extensión de una constitución está positivamente correlacionada con la tasa de cambio constitucional. ${ }^{18} \mathrm{Y}$ a la misma conclusión ha llegado Rosalind Dixon. ${ }^{19}$

14 Dixon, Rosalind, Constitutional Amendment Rules: A Comparative Perspective", Chicago Public Law and Legal Theory Working Paper No. 347, The Law School, The University of Chicago, Mayo 2011, p. 106.

15 Ginsburg y Melton, op. cit., p. 9.

16 Lutz, Donald S., Principles of Constitutional Design, Cambridge University Press, New York, 2006, p. 155. Citado por Negretto, Gabriel L., "Replacing and Amending Constitutions: The Logic of Constitutional Change in Latin America" Law and Society Review, vol. 46, no. 4, 2012, p. 759 .

17 Negretto, Gabriel L., "Replacing and Amending Constitutions: The Logic of Constitutional Change in Latin America" Law and Society Review, vol. 46, no. 4, 2012, p. 759.

18 Ginsburg y Melton, op. cit., p. 21.

19 Dixon, op. cit., p. 106. 
Esta obra forma parte del acervo de la Biblioteca Jurídica Virtual del Instituto de Investigaciones Jurídicas de la UNAM

\section{b. Explicaciones externas a la Constitución}

En esta perspectiva, la pregunta relevante es: ¿hay algo fuera de la Constitución que explique la dinámica del cambio constitucional en México? En relación con esta pregunta hay al menos dos respuestas posibles: i) La naturaleza y características del sistema político; y ii) La cultura política.
i) Naturaleza y características del sistema político (el sistema de partidos)

Casar y Marván han realizado un estudio muy profundo y detallado desde esta perspectiva. Cierto es que las características del sistema de partido hegemónico que entre 1929 y 1997 mantuvo la mayoría absoluta en ambas cámaras del Congreso de la Unión, permitió al presidente de la República controlar todos los hilos del mecanismo de reforma a la Constitución. Sin embargo, con la llegada del multipartidismo el ritmo de reformas constitucionales no solamente se mantuvo, sino que incluso se aceleró. Como reportan estos autores, la frecuencia de la reforma constitucional se incrementó notablemente a partir de 1982: de los 206 decretos de reforma constitucional promulgados en los 95 años comprendidos entre 1917 y 2012 98 decretos (48 por ciento) se promulgaron antes de 1982, mientras que 108 (52 por ciento), lo fueron entre 1982 y 2012. Pero lo que más llama la atención es que de estos últimos, 39 decretos correspondieron al período 19821997 y 69 al período 1997-2012, es decir, el período en que ya no existía el sistema de partido hegemónico, sino lo que se ha dado en llamar "gobierno dividido". ${ }^{20}$

En esta línea de análisis, Casar y Marván se preguntaron: ¿Por qué la clase política mexicana ha recurrido de manera tan frecuente a la modificación de la Constitución? Y proponen varias hipótesis como posibles respuestas:

i. La clase política mexicana tiene una fe enorme en la capacidad para transformar la realidad y, en ese sentido, los reformadores están a por una suerte de "fetichismo constitucional". ${ }^{21}$

20 Casar y Marván, op. cit., p. 14.

21 "Un fetiche es un objeto de culto al cual se le atribuyen poderes mágicos o sobrenaturales y el fetichismo es la cualidad de un objeto para ostentar un poder que no le pertenece por naturaleza." Además, cuestionan estos autores la capacidad de transformación de la realidad vía la reforma constitucional, por las deficiencias en la ejecución y concreción de las refor- 
Esta obra forma parte del acervo de la Biblioteca Jurídica Virtual del Instituto de Investigaciones Jurídicas de la UNAM

ii. Dar rango constitucional a una norma asegura su inamovilidad. Pero esta hipótesis es contradicha por la realidad de la facilidad con que se reforma la Constitución.

iii. Por medio del reformismo constitucional los legisladores justifican su trabajo y se comunica con la idea de un Congreso eficaz.

iv. Las reformas constitucionales son muy abundantes porque el costo de aprobarlas es muy bajo y porque los propios legisladores no se hacen cargo ni de sus implicaciones ni de su viabilidad. ${ }^{22}$

En mi opinión, en el fondo lo que estas hipótesis sugieren es que hay un serio problema en nuestro sistema representativo. De alguna forma, el hiper-reformismo constitucional es un síntoma de la baja calidad de la representación política en nuestro país, y ello se refleja en el uso que la clase política hace del procedimiento de la reforma constitucional. Además, no hay que perder de vista que con la constitucionalización de ciertos temas específicos que interesan a los promotores de las reformas, dichos temas quedan "blindados" en contra de impugnaciones por inconstitucionalidad (ya que los diversos mecanismos de control de constitucionalidad no proceden contra reformas constitucionales).

\section{ii) La cultura política (concepciones de qué es y para qué es una Constitución)}

Después de examinar los méritos de las variables institucionales para explicar la frecuencia y ritmo de la reforma de las constituciones, Ginsburg y Melton proponen que la idea de una "cultura de reforma", es decir, ciertos atributos presentes en cada sociedad, es un importante factor para explicar los patrones de reforma dentro de un sistema constitucional. ${ }^{23} \mathrm{~A}$ su

mas (por ejemplo, no expidiendo las leyes reglamentarias correspondientes, o no proveyendo los recursos institucionales, materiales y humanos para hacerlas valer). Casar y Marván, op. cit., pp. 51-52.

22 "A los legisladores les agrada venderse como progresistas y abanderados de las mejores causas aunque sepan que buena parte de las reformas serán irrealizables. Hay una dosis de irresponsabilidad en esta conducta de constituir un mundo normativamente sin hacerse cargo de la realidad". Ibid, p. 53.

23 Reconocen estos autores que las explicaciones culturales han estado fuera de moda en las ciencias sociales en las últimas décadas, en parte por la dificultad de definir el concepto de cultura. Ginsburg, Tom y Melton, James, "Does the Constitutional Amendment Rule Matter at All, Amendment Cultures and the Challenges of Measuring Amendment Difficulty", Chicago Coase-Sandor Institute for Law and Economics Working Paper No. 682 (2d Series), Public Law and Legal Theory Working Paper No. 472, Mayo 2014, p. 2. 
Esta obra forma parte del acervo de la Biblioteca Jurídica Virtual del Instituto de Investigaciones Jurídicas de la UNAM

vez, estos autores definen "cultura de reforma" de la siguiente manera: es un conjunto de actitudes sobre la deseabilidad de la reforma, independientemente del asunto sustantivo a considerarse y del grado de presión para el cambio. En otras palabras, existe un nivel básico de resistencia al cambio constitucional formal; al elevarse ese nivel básico, la viscosidad del proceso de reforma constitucional disminuye, incluso bajo arreglos condiciones institucionales idénticas. ${ }^{24}$

Asimismo, señalan Ginsburg y Melton que en algunos países la constitución se ve como un texto sagrado que no debe ser tocado excepto para temas de la mayor importancia, mientras que en otros, en donde la constitución es de poca significación normativa, podría observarse diferentes valores asignados a la estabilidad del texto. Si esto es cierto, entonces la tasa de cambio constitucional en un país determinado puede reflejar no solamente factores institucionales, o presiones causadas por el cambio social y político, sino los diferentes pesos que se da a la constitución misma. ${ }^{25}$ Por último, y después de realizar un análisis cuantitativo, que buscó asignar poder explicativo a distintas variables independientes, llegaron los mencionados autores a la conclusión que el mejor predictor de las tasas de cambio constitucional, es la cultura de reforma, y no así las variables institucionales. ${ }^{26}$

Resulta interesante reiterar que en su análisis de la reforma constitucional en México, Jorge Carpizo señaló que "también ha sido determinante la cultura política de los actores [...] que desea garantizar lo alcanzado incorporándolo en la Constitución en la forma más detallada posible, lo que, a su vez, auspicia más reformas constitucionales, ya que para nuevas precisiones o reglas de la situación, hay que alterar la Constitución de nueva cuenta." ${ }^{27}$

De manera similar, Dixon ha concluido que los procedimientos de reforma constitucional no son el factor exclusivo para explicar la tasa de cambio constitucional. Hay por lo menos otros dos factores: la configuración de los partidos políticos en un momento dado; y las actitudes populares en

24 Ibid., p. 12.

25 Ibid., p. 13.

26 Los distintos diseños normativos para la reforma pueden ser: propuesta por un actor en particular o grupo de legisladores; lecturas múltiples en el congreso o parlamento; aprobación por diferentes legislaturas con una elección intermedia; varios niveles de super-mayoría legislativa; aprobación por el poder ejecutivo nacional; aprobación por parte del electorado; revisión por la corte constitucional; ratificación por los gobiernos subnacionales; o bien la convocatoria de asamblea constituyente. De hecho, Ginsburg y Melton concluyen que quienes diseñan una Constitución tienen poca influencia sobre la flexibilidad de su producto. Ginsburg y Melton, op. cit., "Does the Constitutional Amendment Rule....", pp. 5-6 y 22.

27 Carpizo, op. cit., p. 579. 
Esta obra forma parte del acervo de la Biblioteca Jurídica Virtual del Instituto de Investigaciones Jurídicas de la UNAM

relación con la constitución y el constitucionalismo. Para esta autora, sólo en los países que tengan muchos partidos pequeños o coaliciones políticas fluidas, la mayoría calificada del procedimiento de reforma habrá de ser significativo. Por otro lado, mientras más está la población identificada con la constitución, mayor será el esfuerzo y el costo de persuasión que tendrán que pagar quienes intenten el cambio vía la reforma constitucional. ${ }^{28}$

Por último en relación con este apartado, debemos mencionar que otro factor externo mencionado en la literatura especializada y no suficientemente explorado, es el llamado efecto de difusión: la influencia que la reforma constitucional en unos países, cercanos culturalmente o vecinos, ejerce sobre la reforma en otros países. ${ }^{29}$

Ahora bien, todavía en la dimensión descriptiva-explicativa, pero ya tendiendo el puente hacia la dimensión normativa-prescriptiva, podemos plantear la siguiente pregunta: ¿Ha tenido aspectos positivos esa dinámica? En caso afirmativo, ¿cuáles han sido?

El tema ha sido debatido, y hay opiniones encontradas. Algunos ven que este desarrollo ha sido solamente negativo y contraproducente. ${ }^{30}$ Por mi parte, considero que ha habido algunos aspectos positivos, que resumiría en tres conceptos: adaptabilidad, inclusión y gobernabilidad. En relación con la adaptabilidad, podemos decir, siguiendo a Ginsburg y Melton, que es la habilidad del sistema constitucional de adaptarse a los cambios del ambiente y entorno, lo cual le permite mantenerse "en equilibrio". Estos autores también han visto en la adaptabilidad de una constitución un factor para explicar su longevidad. ${ }^{31}$ Respecto de la inclusión, cambios constitucionales en temas de derecho electoral y de derechos sociales referidos al bienestar social e igualdad, pueden ser vistos como derechos condicionantes del juego político, en la medida que mantienen la adhesión social al pacto político democrático ${ }^{32}$ Con ello se legitima el texto constitucional y se contribuye a su longevidad. ${ }^{33}$ Finalmente, muchas reformas al texto constitucional de 1917

28 Dixon, op. cit., p. 107.

29 Nolte, op. cit., p. 6.

30 Entre los autores que enfatizan los aspectos negativos de la dinámica de la reforma constitucional en México, Carpizo ha identificado a Felipe Tena Ramírez, Ignacio Burgoa, Miguel Carbonell y José Barragán Barragán. Carpizo, op. cit., p. 581.

31 Ginsburg y Melton, op. cit, "Does the Constitutional Amendment Rule....", pp. 37-38.

32 Goncalves y Bustos distinguen esos derechos condicionantes, de los derechos operacionales fundamentales para la vida democrática. Goncalves y Bustos, op. cit., p. 51.

33 Ginsburg y Melton han señalado que el nivel de inclusión es un factor que influye en la durabilidad o longevidad de las constituciones, puesto que está vinculado al tema de la legitimidad del texto. Un proceso de elaboración y aprobación del texto constitucional 
Esta obra forma parte del acervo de la Biblioteca Jurídica Virtual del Instituto de Investigaciones Jurídicas de la UNAM

han contribuido a mantener la gobernabilidad del país. Por ejemplo, las reformas constitucionales en materia electoral, particularmente la trayectoria iniciada desde 1977, son un claro ejemplo de cómo las correspondientes modificaciones al texto constitucional adaptaron al sistema político a las condiciones cambiantes; incluyeron a importantes fuerzas políticas antes excluidas del juego político contribuyendo con ello a la legitimidad del Estado y de la propia Constitución, abonando todo ello a garantizar la gobernabilidad del país.

Por otra parte, coincido con los aspectos positivos que Jorge Carpizo ve en general en el proceso de reforma constitucional: la realidad del país fue cambiando de manera acelerada en lo social, lo político y lo económico, entre 1917 y la actualidad. Ante esa circunstancia, lo que este autor denomina la "Constitución jurídica" tenía que modificarse. ${ }^{34}$ En este proceso, la realidad se fue imponiendo y la clase gobernante fue abriendo las puertas para que la sociedad plural se manifestara en el sistema político. No le quedaba otra-señala este autor- por la presión social y política. Y así se llegó a la alternancia en el poder en 2000 de manera pacífica. Asimismo, las reformas constitucionales se aceleraron a partir de 1988 porque las exigencias políticas y sociales se multiplicaron y fortalecieron. ${ }^{35}$

Pero dicho lo anterior también debemos preguntarnos: ${ }_{\mathrm{H} H a}$ habido aspectos negativos de esa dinámica? ¿Se generan o no problemas en el sistema constitucional mexicano a partir de esa dinámica? En caso afirmativo, ¿cómo podríamos describir la problemática que esa dinámica provoca en el sistema constitucional mexicano?

Ante esta pregunta, consideramos que sí ha habido aspectos negativos, mismos que han sido identificados en el diagnóstico que el IIJ ha realizado sobre la trayectoria de la reforma constitucional en México y el estado en que se encuentra nuestro texto constitucional, a saber:

a. Presencia de disposiciones duplicadas

b. Uso variable e inconsistente de la terminología

c. Disparidad en el alcance y profundidad de la regulación

incluyente abona en una percepción generalizada de legitimidad, lo cual le da estabilidad y durabilidad a los acuerdos constitucionales. Una Constitución aprobada en secreto, o excluyendo a importantes fracciones de la sociedad, compromete severamente la legitimidad del mismo. Ginsburg y Melton, op. cit, "Does the Constitutional Amendment Rule....", pp. 19 у $35-37$.

34 Afirma el autor: "Si hubiera permanecido estática, es probable que los cambios hubieran sido violentos". Carpizo, op. cit., p. 583.

35 Ibid., pp. 583-585. 
Esta obra forma parte del acervo de la Biblioteca Jurídica Virtual del Instituto de Investigaciones Jurídicas de la UNAM

d. Desorden y falta de sistema en la materia regulada en los artículos constitucionales

e. Deficiente ubicación de las disposiciones constitucionales

f. Errores en la actualización del texto

g. Artículos reglamentarios en exceso

Asimismo, a lo anterior añadiríamos un elemento más: el empleo excesivo de artículos transitorios de las reformas a la constitución y su exagerada densidad normativa. Esto nos ha llevado a una especie de constitución paralela, a través de artículos que se han convertido en una extraña especie de "leyes de desarrollo constitucional".

Para cerrar esta sección, haremos una última referencia a los efectos que la dinámica de cambio constitucional ha generado y a la estructura de la deliberación política que ha llevado a la aprobación de las reformas a la Constitución. En relación con el primer tema, adelantamos dos hipótesis: se ha afectado las funciones jurídicas de la Constitución ${ }^{36}$ y se ha afectado las funciones políticas de la Constitución. No abundaré en este ensayo en el examen y validación o desechamiento de estas hipótesis. Pero por lo menos mencionaré un par de cosas: primero, que las funciones jurídicas de la Constitución se refieren a los operadores jurídicos, a las actividades de interpretación y aplicación de la constitución. Por su parte, las funciones políticas se refieren a cómo esta dinámica es producto de y a la vez afecta las relaciones entre los actores políticos, pero también se refiere a la relación entre la Constitución y los ciudadanos. Es decir, con la comprensión que se tiene sobre la constitución, su adhesión a ella y sus valores, el sentido de identidad y pertenencia a la constitución y al Estado.

¿Contribuye el desarrollo que ha tenido nuestro texto constitucional a una mejor comprensión, interpretación y aplicación de la Constitución por parte de los operadores jurídicos?; ¿Contribuye es mismo desarrollo a una mejor comprensión de la Constitución por parte de los ciudadanos, y a promover en ellos un sentido de adhesión a ella, a sus valores, a generar un sentido de identidad de pertenencia a la propia Constitución y al Estado? Considero que la respuesta en ambos casos difícilmente podría ser afirmativa.

Por otro último, está el tema de la forma en que se estructura la deliberación política en nuestro país. Está pendiente explorar a profundidad cuál es la relación entre las reglas y procedimientos formales para la reforma de la constitución, y la naturaleza del debate público que rodea a una reforma

36 Ver ensayo de Francisca Pou en este volumen. 
Esta obra forma parte del acervo de la Biblioteca Jurídica Virtual del Instituto de Investigaciones Jurídicas de la UNAM

constitucional. ${ }^{37}$ ¿Es un proceso cerrado que excluye? , o ¿es un proceso abierto que incluye? En mi opinión, se trata de un proceso cerrado y elitista, lo cual tiene que ver con la calidad de nuestro sistema de representación política, y la relación entre los ciudadanos y los partidos políticos, como ya apuntamos líneas arriba.

\section{Dimensión normativa}

\section{A. ¿Debemos o no alterar esa dinámica de cambio que ha tenido la Constitución mexicana de 1917?}

Si con base en los conceptos y elementos explicados en la sección descriptiva-explicativa llegásemos a la conclusión de que sí debemos alterar dicha dinámica de cambio, entonces: ¿en qué opciones pudiera pensarse para cambiar esa dinámica?

Hasta el momento, se han discutido 3 opciones: modificar el procedimiento de reforma constitucional; reordenar y consolidar el texto de la constitución; y expedir una nueva constitución. ¿Qué podríamos decir de cada una de estas opciones?

\section{a. Modificar el procedimiento de reforma constitucional}

Cambiar el procedimiento previsto en el artículo 135 de nuestra norma fundamental tiene el potencial de alterar la dinámica del cambio constitucional que hemos examinado en el presente trabajo. Pero no cualquier cambio tiene ese potencial. Detlef Nolte ha demostrado que, para América Latina, el número de puntos de veto en el procedimiento de reforma constitucional tiene poco impacto respecto de la frecuencia de cambios constitucionales. Para este autor, es más importante de diferenciar entre categorías de puntos de veto. En particular, considera Nolte que el referendum (especialmente el referendum obligatorio), así como el requerimiento de aprobar la reforma constitucional por dos legislaturas diferentes (con elecciones por medio), disminuyen la frecuencia de reformas constitucionales. ${ }^{38}$

37 Dixon, op. cit., p. 102.

38 Nolte, Detlef, "Reformas constitucionales en América Latina", German Institute of Global and Area Studies, Colloque international Le constitutionnalisme latino-américain aujourd'hui, entre renouveau juridique et essor démocratique, Centre de Philosophie Juridique et politique, Université de Cergy-Pontoise, 4 de Abril 2013, pp. 26-27. 
Esta obra forma parte del acervo de la Biblioteca Jurídica Virtual del Instituto de Investigaciones Jurídicas de la UNAM

En el caso de México, consideramos que una reforma que introduzca el referendum para poder modificar la Constitución, sí podría alterar la dinámica de reforma que hemos tenido hasta ahora. Y no solamente por una cuestión de alterar la frecuencia de los cambios, sino por un prurito democrático: el debate de reforma constitucional ha sido sumamente cerrado, controlado por unos cuantos actores, y ello ha ido en contra de los presupuestos básicos del procedimiento de reforma previsto en el artículo 135 (presupuestos que tienen que ver con el principio democrático y con el principio federal).

Cabe recordar que en el proceso constituyente de 1857 hubo una ardua discusión en cuanto al procedimiento de reforma constitucional. El debate se centró en el tema de si era o no conveniente que el electorado tuviera participación dentro del mencionado procedimiento, a través de un referendum, después de que las cámaras del Congreso de la Unión y las legislaturas estatales hubieran aprobado una reforma, siguiendo en parte el modelo de la Constitución estadounidense. Como lo ha referido Diego Valadés, por un lado estaban personajes como Francisco Zarco, Guillermo Prieto y Espiridión Moreno, quienes básicamente opinaban que el pueblo no tenía los conocimientos para opinar sobre reformas constitucionales que implicaban cuestiones políticas o administrativas complejas; o bien que sería incongruente que una asamblea aprobara toda la Constitución, y ésta estableciera que, para ser reformada, tuviera que intervenir el pueblo entero; o que tenía más derecho a conocer de las reformas las legislaturas estatales que el pueblo todo. ${ }^{39}$

Por otro lado, diputados como Melchor Ocampo José María Mata y Francisco de P. Cendejas quienes en esencia defendían la idea de que había que confiar en el buen sentido de pueblo; asimismo, consideraban estos constituyentes que sí había las condiciones para discutir los proyectos de reforma a través de medios idóneos como la prensa, la tertulia y la tribuna, lo que permitiría al pueblo formarse un criterio para emitir su voto afirmativo o negativo en relación con una propuesta de reforma constitucional. ${ }^{40}$

Eventualmente, el constituyente del 57 descartó la opción de participación ciudadana en el proceso de reforma, y aprobó un artículo 127 que después pasó a ser el artículo 135 de la Constitución de 1917, ${ }^{41}$ el cual hasta

39 Valadés, Diego, La Constitución Reformada, UNAM, México, 1987, p. 29.

40 Idem.

41 El procedimiento de reforma constitucional previsto en el artículo 135 de nuestra Carta magna, proviene directamente del artículo 127 de la Constitución de 1857. A su vez, este procedimiento sigue parcialmente el modelo establecido por la Constitución de los EUA para su reforma, en su artículo V. En éste, se prevén dos procedimientos de reforma constitu- 
Esta obra forma parte del acervo de la Biblioteca Jurídica Virtual del Instituto de Investigaciones Jurídicas de la UNAM

ahora ha tenido dos reformas: la de 1966, por la cual se facultó a la comisión permanente del Congreso de la Unión para realizar el cómputo de los votos de las legislaturas de las entidades federativas y la declaratoria de que la adición o reforma ha sido aprobada. ${ }^{42} \mathrm{El}$ objetivo de esta reforma fue evitar el tener que esperar hasta que iniciara el periodo de sesiones ordinarias, o bien a que se convocase a sesiones extraordinarias del Congreso, para poder hacer dicha declaratoria. Y la de 2016, que tuvo como objeto incorporar a la legislatura de la Ciudad de México dentro del procedimiento de reforma. ${ }^{43}$

El referendum para la reforma constitucional contribuiría a romper con la lógica oligárquica de la reforma constitucional. Como ha señalado Valadés, ante la profesionalización de la política y los límites de la democracia representativa, es necesario buscar nuevas formas que permitan en cuadrar, institucionalmente, las legítimas aspiraciones de participación colectiva en la toma de decisiones que, por su naturaleza, tienen efectos sobre la comunidad. ${ }^{44}$

Ahora bien, también es preciso mencionar que modificar en este sentido el procedimiento de reforma constitucional, podría detener la dinámica que hasta ahora hemos tenido, pero no resuelve los problemas que ya están en la Constitución a los que nos hemos referido en ese ensayo.

\section{b. Reordenar el texto de la Constitución mexicana y canalizar la dinámica de cambio acelerado hacia leyes constitucionales u orgánicas}

Una segunda opción es la propuesta por Diego Valadés y Héctor Fix Fierro en el estudio académico "Constitución Política de los Estados Unidos Mexicanos, Texto reordenado y consolidado". Ya nos hemos referido

cional. Uno, a través de convenciones nacional y estatales electas para tal efecto (que nunca ha sido utilizado); y otro, por el voto de las dos terceras partes de los integrantes de cada una de las cámaras del Congreso, y el voto aprobatorio de al menos tres cuartas partes de las legislaturas de los Estados de la unión americana.

42 El decreto de reforma fue publicado en el D.O.F. el 21 de octubre de 1966.

43 El decreto de reforma fue publicado en el D.O.F. el 29 de enero de 2016.

$44 \mathrm{Al}$ defender la propuesta de incorporar el referendum en el proceso de reforma constitucional, Valadés reflexiona sobre cuál es el verdadero alcance de la democracia representativa, en sistemas políticos en los cuales la política se ha profesionalizado; los órganos legislativos atienden a compromisos de carácter corporativo; las entidades parlamentarias se han convertido, esencialmente, en órganos de ratificación de propuestas enviadas por el Ejecutivo. "Más que una realidad política, la democracia representativa contemporánea es una declaración programática, casi un símbolo.” Valadés, op. cit., p. 275. 
Esta obra forma parte del acervo de la Biblioteca Jurídica Virtual del Instituto de Investigaciones Jurídicas de la UNAM

en este ensayo a dicha propuesta. ${ }^{45}$ Añadiremos ahora que en uno de sus últimos trabajos publicados, Jorge Carpizo propuso tres ideas relativas a la reforma constitucional en México:

i) La introducción de verdaderas leyes constitucionales u orgánicas

ii) Una revisión general de carácter gramatical y técnico al texto constitucional, $\mathrm{y}$

iii) La introducción de la iniciativa popular y el refrendo al procedimiento de reforma constitucional. ${ }^{46}$

También señalaremos en cuanto a esta propuesta, que la idea de extraer de la Constitución normas de naturaleza reglamentaria, para enviarlas a una ley de desarrollo constitucional, de alguna forma supone la distinción entre principios básicos del Estado, y políticas públicas. A su vez, esta distinción puede tornarse borrosa, por lo que considero útil para consolidar la propuesta tratar de encontrar algún criterio objetivo que nos permita hacer dicha distinción con mayor seguridad.

En este sentido, resulta interesante mencionar que al examinar la Constitución de Brasil, Gonçalves y Bustos han generado un modelo de análisis constitucional, al distinguir tres dimensiones de la vida política democrática insertas en el texto constitucional: polity, politics y policy. Polity se refiere a los aspectos fundamentales del ordenamiento político relativos a la estructura del régimen o sistema; se trata de las reglas que tienen (dimensión estática). Un acuerdo institucional básico que en principio no tiene carácter controvertido (generalidad y relativa neutralidad), pues son producto del consenso mínimo pactado entre los diversos actores políticos. Politics es la dimensión que se refiere a la competencia política por los cargos y las interacciones de conflicto y cooperación para la decisión sobre políticas gubernamentales (dimensión dinámica). Policy se refiere al contenido material de las acciones estatales probables o deseables, que son resultado del juego político (se caracterizan por su especificidad y por ser objeto de controversia). ${ }^{47}$ Conceptos como estos pueden servir para construir criterios de distinción entre lo que llaman materias constitucionales y materias no constitucionales. ${ }^{48}$

45 Vid supra nota 1.

46 Carpizo, op. cit., pp. 587-588.

47 Goncalves y Bustos, op. cit., pp. 46-49.

48 Frederick Schauer se pregunta ¿Qué es lo constitucional en una Constitución? Ver Schauer, Frederick, "Amending the Presuppositions of a Constitution", en Levinson, S., op. cit., p. 145. Esta pregunta (y sus posibles respuestas) está vinculada con el tema de la inconstitucionalidad de una reforma constitucional. 
Esta obra forma parte del acervo de la Biblioteca Jurídica Virtual del Instituto de Investigaciones Jurídicas de la UNAM

Es interesante hacer una referencia al proceso de reforma de la Constitución Suiza que derivó en un texto renovado de 1999, el cual se basó en diagnóstico muy parecido al que se ha hecho en México respecto de nuestra propia Constitución. En efecto, en su momento se dijo que en sus 150 años de vigencia, la Constitución suiza de 1874 había sido objeto de 136 modificaciones, lo cual había llevado a un conjunto normativo dispar, confuso, obscuro y de difícil lectura, tanto de las disposiciones esenciales, como de las "accesorias". Por otra parte, se afirmó que la Constitución vigente en aquel momento no daba cuenta de todo el derecho constitucional en vigor. Se había convertido en una constitución de expertos, extraña a los ciudadanos. Por ello, uno de los objetivos principales de la propuesta consistió en diseñar una constitución exhaustiva, comprensible y por tanto próxima a los ciudadanos. Una constitución escrita en el "lenguaje de nuestro tiempo"- se argumentó- favorecería la identificación de los ciudadanos con la misma, y daría un nuevo sustento democrático al derecho constitucional en vigor. Se reforzaría con ello la relación entre las autoridades y la población así como la confianza en el Estado. ${ }^{49}$

Como otro efecto esperado, se dijo que un texto constitucional renovado fortalecería la capacidad de acción del Estado y la eficacia de las instituciones. Con la corrección de los defectos formales y materiales de la Constitución, la reforma podría mejorar las condiciones marco de la acción estatal y reforzar las instituciones suizas. La capacidad de acción del Estado y el funcionamiento de las instituciones democráticas podrían mejorarse, con el fin de permitir una mejor previsibilidad de la acción del estado y a la vez, reforzar la credibilidad al interior y al exterior del país.

Finalmente, se aseveró que se buscaría reafirmar las bases del Estado a fin de responder a los desafíos futuros; y que Suiza necesitaba un fundamento constitucional renovado para el próximo siglo; la herencia política suiza debía ser transmitida a los ciudadanos de una forma nueva. ${ }^{50}$

La opción de reordenar y consolidar el texto constitucional tiene el potencial de detener la dinámica de cambio constitucional acelerado, que introduce reglamentos y políticas públicas en la Constitución, y también de canalizar ese impulso y los acuerdos entre actores políticos hacia leyes de desarrollo constitucional. Sin embargo, no hay que olvidar el tema de la cultura constitucional, que podría seguir impulsando a los actores políticos a preferir reformar la Constitución y no las leyes de desarrollo constitucional.

49 Distintos documentos referidos al proceso que llevó a la Constitución de Suiza de 1999 se pueden encontrar en: wwrw.bj.admin.ch/bj/fr/home/staat/gesetzgebung/archiv/bundesverfassung.html.

50 Idem. 
Esta obra forma parte del acervo de la Biblioteca Jurídica Virtual del Instituto de Investigaciones Jurídicas de la UNAM

\section{c. Una nueva Constitución}

Finalmente, hay quienes afirman que lo que más conviene al país en estos momentos en ponernos a pensar en una nueva Constitución. ${ }^{51}$ En otro trabajo nos hemos referido con detalle a esta opción. ${ }^{52}$ En este ensayo me limitaré a señalar que en mi opinión en el momento en que escribo estas líneas no existen las condiciones para convocar a un congreso constituyente que diseñe y apruebe una nueva constitución, en sustitución de la de 1917. Pero, ¿cuáles serían estas condiciones?

En un interesante y profundo estudio sobre la reforma constitucional en América Latina, Gabriel Negretto se hace una pregunta parecida: ¿en qué circunstancias se ha decidido realizar el cambio constitucional no a través de reformas parciales, sino por medio de la aprobación de una nueva constitución en América Latina? Desde una perspectiva descriptiva, nos dice que las constituciones son reemplazadas cuando fracasan en operar como "estructuras de gobernanza"; cuando su diseño impide que intereses políticos en competencia se acomoden a ambientes cambiantes; cuando las crisis constitucionales son frecuentes y cuando los actores políticos no tienen la capacidad de implementar cambios por medio de reformas o interpretación judicial. ${ }^{53}$ En mi opinión, estas condiciones no están dadas en México en el momento en que el presente ensayo se escribe (lo que no excluye que puedan darse en el futuro).

Como comentario final para cerrar este apartado, simplemente mencionaré que la opción de una nueva Constitución podría contribuir a ordenar y sistematizar los asuntos constitucionales, pero por sí sola no detendría la dinámica de reforma que hasta ahora hemos tenido.

\section{GONCLUSIÓN}

Termino mi reflexión sobre la dinámica del cambio constitucional en México con tres últimas ideas. En primer lugar, considero que las tres opciones a las que me he referido en el apartado anterior no son excluyentes. Se podría pensar, por ejemplo en reordenar y consolidar la Constitución y reformar el

51 Académicos y políticos que se inclinan por esta opción son: Miguel Carbonell, Cuauhtémoc Cárdenas, Jaime Cárdenas y Porfirio Muñoz Ledo.

52 Serna de la Garza, José Ma., La Reforma del Estado en América Latina: los casos de Brasil, Argentina y México, UNAM, México, 1998.

53 Negretto, Gabriel L., "Replacing and Amending Constitutions: The Logic of Constitutional Change in Latin America" Law and Society Review, vol. 46, no. 4, 2012, pp. 749-750. 
Esta obra forma parte del acervo de la Biblioteca Jurídica Virtual del Instituto de Investigaciones Jurídicas de la UNAM

artículo 135 de ésta, para establecer el referendum constitucional; o bien, se podría pensar en términos de etapas: consolidar y reordenar el texto constitucional, en tanto se dan o se construyen las condiciones para una nueva constitución.

En segundo lugar, debemos tener presente que la percepción de la legitimidad del origen de una constitución es importante para determinar las distintas estrategias de cambio constitucional, es decir, reforma parcial o nueva constitución. Una constitución o una reforma constitucional de origen popular, o percibida como producto de un amplio e inclusivo consenso político y social, es muy distinta a una constitución percibida como producto de la negociación egoísta entre las élites políticas alejadas de las preocupaciones de la ciudadanía. ${ }^{54} \mathrm{Y}$ aquí aparece con toda su fuerza el tema de la desconfianza de los ciudadanos hacia los políticos y los legisladores. Es el tema de la poca calidad de nuestro sistema de representación política. Es también el tema de la creación de mecanismos a través de los cuales la ciudadanía pueda participar en la "conversación constitucional" dominadas por las élites. ${ }^{55}$

Por último, como recuerda Jon Elster, es importante distinguir entre constitución y constitucionalismo. La primera es un documento escrito, la segunda es un estado mental, una expectativa, una norma, por la cual la política debe conducirse de acuerdo con reglas y convenciones, escritas o no escritas, de las cuales no pueden ser cambiadas fácilmente. Las constituciones pueden existir sin constitucionalismo, si son percibidas como meras herramientas de políticas públicas o como instrumentos para beneficiar intereses de corto plazo o partidistas. Por el contrario, el constitucionalismo puede existir sin constitución escrita, si las reglas del juego no escritas son aceptadas ampliamente. ${ }^{56}$

54 Negretto, op. cit., p. 776.

55 Vivien Hart habla del surgimiento de un "constitucionalismo conversacional", vinculado con el derecho a participar en la creación de una Constitución. Bajo esta idea, el proceso es tan importante como el contenido de una Constitución. Constituciones hechas por las élites carecen del elemento crucial de la legitimidad. Por ello, la manufactura de una Constitución debe ser una conversación en la que participen todos los interesados, abierto a la entrada de nuevos actores y temas, tratando de encontrar una fórmula para que la Constitución sea sostenible y no solamente estable. Hart, op. cit., pp. 1-3.

56 Elster, Jon, "Constitutionalism in Eastern Europe: An Introduction", The University of Chicago Law Review, vol. 58, no. 2, Primavera, 1991, p. 465. 
Esta obra forma parte del acervo de la Biblioteca Jurídica Virtual del Instituto de Investigaciones Jurídicas de la UNAM

\title{
LOS PROBLEMAS DE TÉGNICA CONSTITUCIONAL EN MÉXICO
}

\author{
José María SOBERANES DÍEZ*
}

\begin{abstract}
SUMARIO: I. Introducción. II. Los sistemas de numeración constitucional. III. La ubicación de las normas constitucionales. IV. Los organismos constitucionales autónomos. V. Las erratas constitucionales.
\end{abstract}

\section{INTRODUCGIÓN}

México destaca por la cantidad de modificaciones formales a su Constitución vigente desde 1917. Hasta el 31 de enero de 2016 tenemos 225 decretos de reforma constitucional, a las que deben de sumarse 13 fes de erratas y 2 aclaraciones, con lo cual, tenemos 244 versiones distintas de Texto Fundamental. Si consideramos que en cada decreto pueden reformarse varios artículos, y sumamos cada cambio a un precepto, tenemos más de seiscientas modificaciones.

A la luz de ello, deberíamos cuestionarnos si aún rige la "Constitución de 1917" en nuestro país, o si más bien se encuentra en vigor la "Constitución mexicana", a secas y sin considerar ninguna fecha, pues su contenido es más bien el producto de una constante voluntad constituyente de los representantes populares.

$\mathrm{Al}$ modificar tantas veces la Constitución se han cometido errores. Estos errores pueden valorarse desde una perspectiva material en el que, desde el punto de vista político o analizando el contenido jurídico de las nuevas disposiciones, puede realizarse un juicio de valor. Pero también pueden hacerse desde del punto de vista formal, es decir, atendiendo a las equivocaciones que se han cometido en el manejo de una técnica constitucional.

* Profesor-investigador de la Universidad Panamericana. Investigador Nacional II del Sistema Nacional de Investigadores del CONACYT. 
Esta obra forma parte del acervo de la Biblioteca Jurídica Virtual del Instituto de Investigaciones Jurídicas de la UNAM

Podría parecer que este segundo análisis es superficial, pues en nada varía el valor normativo o la vigencia de los preceptos constitucionales. Sin embargo, su análisis es importante porque permite advertir la poca importancia que los órganos legitimados para reformarla le dan a la Constitución. En pocas palabras, la Constitución no se toma en serio.

Este análisis puede servir, además, como base para realizar un trabajo de stematización constitucional en México, en el que se corrijan los errores formales, permitiendo un mejor manejo de la Constitución, lo que redundará en una cultura constitucional de mayor calidad, como el que ha emprendido el Instituto de Investigaciones Jurídicas bajo la atinada coordinación de los doctores Diego Valadés y Héctor Fix Fierro. ${ }^{1}$

Por estas razones, en el presente trabajo pretendemos dar cuenta con los errores formales y distorsiones que tiene el texto actual tras las reformas. Estas distorsiones las encontramos en los sistemas de numeración (apartado II), en la ubicación de algunas normas (apartado III), en el dispar tratamiento de la autonomía constitucional (apartado IV), y en las erratas del texto (apartado V).

\section{LOS SISTEMAS DE NUMERACIÓN CONSTITUCIONAL}

Se ha reformado cientos de veces la Constitución mexicana, pero no se le ha aumentado ningún solo artículo. Siguen siendo 136 desde 1917. Parecería que existe un dogma de que no pueden agregarse preceptos, o una especial aprecio por la cifra resultante del proceso constituyente de Querétaro.

Eso ha provocado el aumento considerable en la densidad de contenidos que tiene cada uno de los artículos, los que muchas veces tocan temas variopintos. Si quisiéramos determinar qué regula cada uno, tendríamos problemas. En algunos es sencillo: el $2^{\circ}$ se refiere a los indígenas, el tercero a la educación y el 89 a las facultades del Presidente.

Pero en otros casos, esto es difícil. Por ejemplo, en el caso del artículo $4^{\circ}$, que consagra una serie de derechos y de principios que no pueden clasificarse fácilmente. La mayoría son derechos sociales, pero también está el interés superior de la infancia, la igualdad entre mujeres y varones, o el derecho a la identidad.

Esto hace necesario que existan formas de identificación de los preceptos, es decir, divisiones formales entre sus distintos contenidos. La forma más tradicional en la técnica legislativa mexicana es dividir los artículos en

1 Valdés, Diego y Fix Fierro, Héctor, Constitución Politica de los Estados Unidos Mexicanos. Texto reordenado y consolidado. Con las reformas y adiciones hasta el 10 de julio de 2015. Ley de Desarrollo Constitucional. Anteproyecto. Estudio académico., México, UNAM, 2016. 
Esta obra forma parte del acervo de la Biblioteca Jurídica Virtual del Instituto de Investigaciones Jurídicas de la UNAM

párrafos, fracciones y, en su caso, las fracciones en incisos. Esta parece ser la regla general, pues es utilizada por la Constitución en veintiocho ocasiones. ${ }^{2}$ Sin embargo, en muchos otros preceptos se usan otras técnicas de clasificación diferentes, que rompen la unidad constitucional. Estos casos son:

\begin{tabular}{|c|c|}
\hline Artículo & Criterio de clasificación \\
\hline 20 & En apartados, y después en fracciones. \\
\hline 60 & En apartados, y después en fracciones. \\
\hline 20 & En apartados, y después en fracciones. \\
\hline 21 & En incisos \\
\hline 28 & $\begin{array}{l}\text { Tiene dos listas de fracciones cada una referida a un párrafo distinto, por } \\
\text { lo que para identificarlos hay que señalar el párrafo y después la fracción. }\end{array}$ \\
\hline 30 & En incisos (en mayúscula a diferencia del 21), y después en fracciones. \\
\hline 35 & En fracciones, después en bases (1a, 2a, etc.), y finalmente en incisos. \\
\hline 37 & En incisos (en mayúscula a diferencia del 21), y después en fracciones. \\
\hline 41 & En fracciones, después en apartados, finalmente en incisos. \\
\hline 72 & En apartados. \\
\hline 73 & $\begin{array}{l}\text { En primer lugar, en fracciones. Después, hay tres criterios. El primero es: en } \\
\text { las fracciones III, y XVI, a las que siguen bases. El segundo es en la fracción } \\
\text { XXI, a la que siguen bases. El tercero es en fracciones, bases e inicios, usado } \\
\text { en la fracción XXIX. }\end{array}$ \\
\hline 102 & En apartados y después en fracciones \\
\hline 116 & En fracciones, después incisos y finalmente en bases. \\
\hline 122 & Se divide en apartados, después fracciones y finalmente incisos. \\
\hline 123 & $\begin{array}{l}\text { En dos apartados y después en fracciones. Tras ello, hay dos criterios. El } \\
\text { primero es dividir una fracción en bases, que sólo se unas en la fracción } \\
\text { XXXI. El segundo, usado en el resto de las fracciones es continuar } \\
\text { dividiendo en incisos. }\end{array}$ \\
\hline 130 & En incisos. \\
\hline
\end{tabular}

2 Así se hace en los artículos 3o, 22, 27, 31, 36, 38, 42, 54, 55, 71, 74, 76, 77, 78, 79, 82, 89, 95, 99, 103, 105, 107, 109, 115, 117, 118, 121 у 127. 
Esta obra forma parte del acervo de la Biblioteca Jurídica Virtual del Instituto de Investigaciones Jurídicas de la UNAM

Como se ve, no hay una unidad en la numeración constitucional. Hay veces que los apartados van antes de las fracciones, y hay veces que es al revés. También hay ocasiones en que no se divide originariamente en fracciones sino en bases o en incisos.

Hay casos en los que dentro de un mismo precepto no se sigue una unidad en su numeración, como es el caso de los artículos 73 y 123, que se siguen dos o tres tipos de reglas de clasificación, con lo que no hay coherencia interna al respecto.

El tabú por un número no sólo se tiene respecto a los artículos que conforman la Constitución, sino también respecto a las fracciones concernientes al artículo 73 constitucional, que no se ha querido aumentar de treinta. En realidad ese artículo tiene cuarenta y nueve fracciones, considerando que dos fracciones están derogadas (la IV y la VI), y que existen veintidós fracciones XXIX identificadas con letras. Sin embargo, se ha preferido que la última formalmente sea la XXX, lo que es extraño en un Texto Fundamental.

\section{LA UBICACIÓN DE LAS NORMAS CONSTITUGIONALES}

Apuntábamos que nunca se ha aumentado el número de artículos constitucionales. Tampoco se ha hecho respecto a sus división en nueve títulos. Los primeros tres no tienen nombre, y sólo se identifican por un número, mientras que los últimos seis además del número tienen un nombre. Los tres innominados se dividen en capítulos: el primero en cuatro, el segundo el dos y el tercero en cuatro. El capítulo II del Título Tercero, referido al Poder Legislativo de la Unión, se divide a su vez en cinco secciones.

Dentro de esta ordenación, sin embargo, existen disposiciones que no son acordes con la materia que regula el capítulo o el título correspondiente, producto de las reformas y del afán de no cambiar la estructura constitucional. De esta forma, el capítulo I del Título Primero, relativo a los derechos humanos y sus garantías, regula aspectos orgánicos y distintos a los derechos fundamentales como:

1. El establecimiento de un Sistema Nacional de Evaluación Educativa, y la organización y funcionamiento del Instituto Nacional para la Evaluación de la Educación (art. $3^{\circ}$, fracción IX).

2. La organización y funcionamiento del organismo responsable de garantizar el cumplimiento del derecho de acceso a la información pública y a la protección de datos personales (artículo $6^{\circ}$, párrafo cuarto, apartado A, fracción VIII). 
Esta obra forma parte del acervo de la Biblioteca Jurídica Virtual del Instituto de Investigaciones Jurídicas de la UNAM

3. El mandato de establecer un organismo público descentralizado con el objeto de proveer el servicio de radiodifusión sin fines de lucro (artículo 6.párrafo cuarto, apartado B, fracción V).

4. El establecimiento de un Sistema Nacional de Información Estadística y Geográfica y el organismo encargado de normar y coordinar dicho sistema (artículo 26, apartado B)

5. El establecimiento, organización y funcionamiento del Consejo Nacional de Evaluación de la Política de Desarrollo Social (artículo 26, apartado $\mathrm{C}$ )

6. El mandato de establecer un fideicomiso público denominado Fondo Mexicano del Petróleo para la Estabilización y el Desarrollo (artículo 28, párrafo sexto)

7. El establecimiento, organización y funciones del Banco Central (artículo 28 párrafos sexto y séptimo)

8. El mandato de establecer dentro del Poder Ejecutivo de órganos reguladores en materia energética, denominados Comisión Nacional de Hidrocarburos y Comisión Reguladora de Energía. (artículo 28 párrafo octavo).

9. El establecimiento, organización y funcionamiento de la Comisión Federal de Competencia Económica (artículo 28, párrafo decimoquinto, decimoséptimo y siguientes)

10. El establecimiento, organización y funcionamiento de la Comisión Federal de Competencia Económica (artículo 28, párrafo decimosexto y siguientes)

De la misma forma, dentro del capítulo relativo a los derechos humanos existen una serie de normas que más que a libertades se refieren a cuestiones económicas, y que han sido denominadas el capítulo económico de la Constitución, tales como:

1. Las condiciones para prestar servicios de telecomunicación y radiodifusión (art. 6, apartado C, fracciones II y III).

2. Los límites a la publicidad y a la propaganda (art. 6, apartado C, fracción IV)

3. La rectoría estatal del desarrollo nacional (art. 25, párrafo primero).

4. La coordinación estatal de economía. (art. 25, párrafo segundo).

5. Sectores que integran desarrollo económico (art. 25, párrafo tercero).

6. La determinación de la exclusividad de participación pública en las áreas estratégicas (art. 25, párrafo cuarto). 
Esta obra forma parte del acervo de la Biblioteca Jurídica Virtual del Instituto de Investigaciones Jurídicas de la UNAM

7. La posibilidad de otros sectores de participar en las áreas prioritarias (art. 25, párrafo quinto).

8. Los apoyos a sectores privado y social (art. 25, párrafo sexto).

9. El mandato de apoyo al sector social (art. 25, párrafo séptimo).

10. La protección del sector privado (art. 25, párrafo octavo).

11. El sistema de planeación democrática para el desarrollo nacional (art. 26, apartado A).

12. La definición de los bienes en los que la Nación ejerce dominio directo (art. 27, párrafo cuarto).

13. La definición de las aguas propiedad de la Nación (art. 27, párrafo quinto)

14. Las modalidades del dominio de bienes propiedad de la Nación (art. 27, párrafo sexto).

15. La posibilidad de que los particulares participen en las actividades de explotación de la electricidad y el petróleo (art. 27, párrafos sexto y séptimo).

16. El aprovechamiento de la energía nuclear (art. 27, párrafo octavo).

17. La determinación de la zona económica exclusiva (art. 27, párrafo noveno).

18. La prohibición de monopolios y su castigo (art. 28, párrafos primero y segundo).

19. Las bases para la fijación de precios máximos (art. 28, párrafo tercero).

20. La enumeración de las áreas estratégicas (art. 28, párrafo cuarto).

21. El mandato de establecer empresas estatales para las áreas estratégicas (art. 28, párrafo quinto).

22. La posibilidad de concesionar la prestación de servicios públicos (art. 28, párrafos decimo primero y decimo segundo).

23. La posibilidad de otorgar subsidios (art. 28, párrafos decimo tercero y decimo cuarto)

El Capítulo IV del Título Tercero se refiere al Poder Judicial de la Federación. Sin embargo, encontramos disposiciones que regulan a órganos que no integran dicho poder, como es el caso de la Fiscalía General de la República (art. 102, apartado A), o los organismos públicos de defensa de los derechos humanos, especialmente la Comisión Nacional de los Derechos Humanos (art. 102, apartado B).

Advirtiendo estas normas con una incorrecta topografía constitucional, tal vez podría conseguirse un mayor orden contando con un cuarto capítulo en el Título Primero relativo a cuestiones económicas, así como un quinto capítulo en el Título Tercero referente a los organismos constitucionales autónomos. 
Esta obra forma parte del acervo de la Biblioteca Jurídica Virtual del Instituto de Investigaciones Jurídicas de la UNAM

\section{LOS ORGANISMOS CONSTITUCIONALES AUTÓNOMOS}

Los órganos constitucionales autónomos se han multiplicado en los últimos dos años. En los últimos diez años del siglo XX se crearon tres: el Banco de México, el Instituto Federal Electoral (ahora Instituto Nacional Electoral), y la Comisión Nacional de los Derechos Humanos; en la primera década de este siglo se creó uno, el Instituto Nacional de Estadística y Geografía; y entre 2013 y 2014 se crearon seis, más del doble que en las dos décadas anteriores, que son el Instituto Nacional para la Evaluación de la Educación, el Consejo Nacional de Evaluación de la Política de Desarrollo Social, el Instituto Federal de Acceso a la Información y Protección de Datos, la Comisión Federal de Competencia Económica, el Instituto Federal de Telecomunicaciones, y la Fiscalía General de la República.

Respecto a todos éstos, también encontramos mucha variedad en cuanto a su regulación. Esto empieza desde la denominación de ese género, pues a veces se les denomina "organismos con autonomía reconocida en esta Constitución", 3 "organismos a los que esta Constitución otorgue autonomía", "organismos constitucionales autónomos", ${ }^{5}$ o simplemente "organismos autónomos". 6

Pero esta disparidad de tratamientos puede advertirse más claramente en los términos en que se le concede la autonomía a cada uno de ellos, como puede advertirse en este cuadro:

\begin{tabular}{|l|l|}
\hline \multicolumn{1}{|c|}{ Organismo } & \multicolumn{1}{c|}{ Autonomía } \\
\hline $\begin{array}{l}\text { Instituto Nacional para } \\
\text { la Evaluación de la } \\
\text { Educación. }\end{array}$ & $\begin{array}{l}\text { Organismo público autónomo, con personalidad jurídica y } \\
\text { patrimonio propio. } \\
\text { (Artículo 2, fracción IX, primer párrafo) }\end{array}$ \\
\hline $\begin{array}{l}\text { Instituto Federal de } \\
\text { Acceso a la Información } \\
\text { y Protección de Datos } \\
\text { El nombre no se lo da la } \\
\text { Constitución) }\end{array}$ & $\begin{array}{l}\text { Organismo autónomo, especializado, imparcial, colegiado, } \\
\text { con personalidad jurídica y patrimonio propio, con plena } \\
\text { autonomía técnica, de gestión, capacidad para decidir sobre } \\
\text { el ejercicio de su presupuesto y determinar su organización } \\
\text { interna. } \\
\text { (Artículo 3 } \\
\text { primer párrafo) }\end{array}$ \\
\hline
\end{tabular}

3 Artículo 75, párrafo tercero.

4 Artículo 108, párrafo primero.

5 Artículo 105, fracción I, inciso 1), y artículo 110, párrafo primero.

6 Artículo 127, párrafo primero. 
Esta obra forma parte del acervo de la Biblioteca Jurídica Virtual del Instituto de Investigaciones Jurídicas de la UNAM

\begin{tabular}{|c|c|}
\hline Organismo & Autonomía \\
\hline $\begin{array}{l}\text { Instituto Nacional de } \\
\text { Estadística y Geografía } \\
\text { (El nombre no se lo da la } \\
\text { Constitución) }\end{array}$ & $\begin{array}{l}\text { Organismo con autonomía técnica y de gestión, personalidad } \\
\text { jurídica y patrimonio propios. (Artículo 26, apartado B, } \\
\text { párrafo segundo) }\end{array}$ \\
\hline $\begin{array}{l}\text { Consejo Nacional de } \\
\text { Evaluación de la Política } \\
\text { de Desarrollo Social }\end{array}$ & $\begin{array}{l}\text { Órgano autónomo, con personalidad jurídica y patrimonio } \\
\text { propios. (Artículo 26, apartado } \mathrm{C} \text {, primer párrafo) }\end{array}$ \\
\hline $\begin{array}{l}\text { Banco de México } \\
\text { (El nombre no se lo da la } \\
\text { Constitución, pues solo lo } \\
\text { denomina banco central) }\end{array}$ & $\begin{array}{l}\text { Autónomo en el ejercicio de sus funciones y en su } \\
\text { administración. (Artículo 28, párrafo sexto) }\end{array}$ \\
\hline $\begin{array}{l}\text { Comisión Federal de } \\
\text { Competencia Económica }\end{array}$ & $\begin{array}{l}\text { Órgano autónomo, con personalidad jurídica y patrimonio } \\
\text { propio. (Artículo 28, párrafo decimo quinto) }\end{array}$ \\
\hline $\begin{array}{l}\text { Instituto Federal de } \\
\text { Telecomunicaciones }\end{array}$ & $\begin{array}{l}\text { Órgano autónomo, con personalidad jurídica y patrimonio } \\
\text { propio. (Artículo 28, párrafo decimo sexto) }\end{array}$ \\
\hline $\begin{array}{l}\text { Instituto Nacional } \\
\text { Electoral }\end{array}$ & $\begin{array}{l}\text { Organismo público autónomo dotado de personalidad } \\
\text { jurídica y patrimonio propios. } \\
\text { (Artículo } 41 \text {, fracción } \mathrm{V} \text {, apartado A, primer párrafo) }\end{array}$ \\
\hline $\begin{array}{l}\text { Fiscalía General de la } \\
\text { República }\end{array}$ & $\begin{array}{l}\text { Órgano público autónomo, dotado de personalidad jurídica } \\
\text { y de patrimonio propios. (Artículo 102, apartado A, primer } \\
\text { párrafo) }\end{array}$ \\
\hline $\begin{array}{l}\text { Comisión Nacional de los } \\
\text { Derechos Humanos }\end{array}$ & $\begin{array}{l}\text { autonomía de gestión y presupuestaria, personalidad jurídica } \\
\text { y patrimonio propios. (Artículo 102, apartado B, cuarto } \\
\text { párrafo) }\end{array}$ \\
\hline
\end{tabular}

De este cuadro puede desprenderse la distinta autonomía que tiene casa una, y puede advertirse que se les concede personalidad y patrimonio propios a todos, salvo al El Instituto Federal de Acceso a la Información y Protección de Datos y al Banco de México; que se les reconoce autonomía técnica al Instituto Federal de Acceso a la Información y Protección de Datos y al Instituto Nacional de Estadística y Geografia; que se le da autonomía de gestión al Instituto Federal de Acceso a la Información y Protección de Datos, al Instituto Nacional de Estadística y Geografía y a la Comisión Nacional de los Derechos Humanos; que se le reconoce autonomía de organización interna al Instituto Federal de Acceso a la Información y Protección de Datos; se le dota de autonomía en el ejercicio de sus funciones al Banco 
Esta obra forma parte del acervo de la Biblioteca Jurídica Virtual del Instituto de Investigaciones Jurídicas de la UNAM

de México; y que sólo a la Comisión Nacional de los Derechos Humanos se le da autonomía presupuestaria.

\section{LAS ERRATAS CONSTITUCIONALES}

Errar es humano. Con más de doscientos decretos de reforma constitucional, es lógico que existan deslices en las publicaciones. Por ese motivo, es lógico que se hayan corregido las equivocaciones en las impresiones, que son las fes de erratas. Hasta el momento se han publicado trece fes de erratas ${ }^{7}$ y dos aclaraciones ${ }^{8}$

Sin embargo, éstas no han sido suficientes para corregir todos los errores que se han producido a lo largo de casi un siglo. De una lectura hemos detectado que existen veintiún erratas en el texto constitucional vigente.

Cabe aclarar que si bien un editor podría corregirlas en una publicación particular, jurídicamente debemos de atender única y exclusivamente al texto publicado en el Diario Oficial de la Federación, ${ }^{9}$ por ser el único medio que debe de tomarse en cuenta para conocer el contenido normativo, es decir, el único texto auténtico.

A la luz de ello, y atendido a esas publicaciones es que encontramos esas erratas, que a continuación sistematizamos en un cuadro en el que se anota la ubicación de cada párrafo, la reproducción textual de cada uno siguiendo la publicación en el Diario Oficial, así como la explicación de la errata.

\begin{tabular}{|c|c|c|}
\hline Precepto & Trascripción textual & Erratas \\
\hline $\begin{array}{l}\text { Artículo } 27, \\
\text { párrafo quinto }\end{array}$ & $\begin{array}{l}\text { "Son propiedad de la Nación las } \\
\text { aguas de los mares territoriales } \\
\text { en la extensión y términos que } \\
\text { fije [sic] Derecho Internacional; } \\
\text { las aguas marinas interiores; } \\
\text { las de las lagunas y esteros que } \\
\text { se comuniquen permanente o } \\
\text { intermitentemente con el mar; }\end{array}$ & $\begin{array}{l}\text { Este precepto tiene dos erra- } \\
\text { tas: } \\
\text { 1. Debería tener el artículo } \\
\text { "el" antes de señalar "Derecho } \\
\text { Internacional" } \\
\text { 2. Debería decir "inter- } \\
\text { mitentes" en vez de "inter- } \\
\text { minentes" }\end{array}$ \\
\hline
\end{tabular}

7 Estas fes de erratas se publicaron en las siguientes fechas: 6 de febrero de 1917, 14 de marzo de 1951, 7 de enero de 1961, 17 de marzo de 1975, 13 de enero de 1978, 9 de marzo de 1993, 23 de agosto de 1993, 6 de septiembre de 1993, 6 de septiembre de 1993, 6 de septiembre de 1993, 3 de enero de 1995, 12 de abril de 2000, y 25 de junio de 2009.

8 Publicadas el 22 de octubre de 1966, y el 3 de marzo de 1934.

9 Conforme a los artículos 1o., 2o., 3o., 4o. y 8o. de la Ley del Diario Oficial de la Federación y Gacetas Gubernamentales, la única publicación que da validez jurídica a una norma es el propio Diario Oficial de la Federación 
Esta obra forma parte del acervo de la Biblioteca Jurídica Virtual del Instituto de Investigaciones Jurídicas de la UNAM

\begin{tabular}{|c|c|c|}
\hline Precepto & Trascripción textual & Erratas \\
\hline & $\begin{array}{l}\text { las de los lagos interiores de } \\
\text { formación natural que estén } \\
\text { ligados directamente a corrientes } \\
\text { constantes; las de los ríos y sus } \\
\text { afluentes directos o indirectos, } \\
\text { desde el punto del cauce en que } \\
\text { se inicien las primeras aguas } \\
\text { permanentes, intermitentes o } \\
\text { torrenciales, hasta su desem- } \\
\text { bocadura en el mar, lagos, } \\
\text { lagunas o esteros de propiedad } \\
\text { nacional; las de las corrientes } \\
\text { constantes o interminentes [sic]y } \\
\text { sus afluentes directos o indirectos, } \\
\text { cuando el cauce de aquéllas en } \\
\text { toda su extensión o en parte de } \\
\text { ellas, sirva de límite al territorio } \\
\text { nacional o a dos entidades fede- } \\
\text { rativas, o cuando pase de una } \\
\text { entidad federativa a otra o cruce } \\
\text { la línea divisoria de la República; } \\
\text { [...]" }\end{array}$ & \\
\hline $\begin{array}{l}\text { Artículo 27, décimo } \\
\text { párrafo, fracción } \\
\text { XIX, primer } \\
\text { párrafo. }\end{array}$ & $\begin{array}{l}\text { "XIX.- Con base en esta } \\
\text { Constitución, el Estado dispondrá } \\
\text { las medidas para la expedita } \\
\text { y honesta impartición de la } \\
\text { justicia agraria, con objeto de } \\
\text { garantizar la seguridad jurídica } \\
\text { en la tenencia de le [sic] tierra } \\
\text { ejidal, comunal y de la pequeña } \\
\text { propiedad, y apoyará la asesoría } \\
\text { legal de los campesinos" }\end{array}$ & $\begin{array}{l}\text { Hay una error mecanográfico, } \\
\text { pues señala "le tierra", cuando } \\
\text { debería decir "la tierra", para } \\
\text { que fuera correcto el uso del } \\
\text { artículo femenino. }\end{array}$ \\
\hline $\begin{array}{l}\text { Artículo 28, primer } \\
\text { párrafo. }\end{array}$ & $\begin{array}{l}\text { "En los Estados Unidos } \\
\text { Mexicanos quedan prohibidos } \\
\text { los monopolios, la [sic] prácticas } \\
\text { monopólicas, los estancos y las } \\
\text { exenciones de impuestos en los } \\
\text { términos y condiciones que fijan } \\
\text { las leyes. El mismo tratamiento } \\
\text { se dará a ls [sic] prohibiciones a } \\
\text { título de protección a la industria" }\end{array}$ & $\begin{array}{l}\text { En este párrafo hay dos } \\
\text { erratas: } \\
\text { 1.- Debería de usar el artículo } \\
\text { "las" pues se refiere a prácticas } \\
\text { monopólicas que es plural. } \\
\text { 2.- Hay un error de dedo al } \\
\text { usar el artículo "la", que pone } \\
\text { como "ls". }\end{array}$ \\
\hline
\end{tabular}


Esta obra forma parte del acervo de la Biblioteca Jurídica Virtual del Instituto de Investigaciones Jurídicas de la UNAM

\begin{tabular}{|c|c|c|}
\hline Precepto & Trascripción textual & Erratas \\
\hline $\begin{array}{l}\text { Artículo 28, } \\
\text { séptimo párrafo. }\end{array}$ & $\begin{array}{l}\text { “[..] La conducción del } \\
\text { banco estará a cargo de } \\
\text { personas cuya designación será } \\
\text { hecha por el Presidente de la } \\
\text { República con la aprobación } \\
\text { de la Cámara de Senadores o } \\
\text { de la Comisión Permanente, } \\
\text { en su caso; desempeñarán su } \\
\text { encargo por períodos cuya } \\
\text { duración y escalonamiento } \\
\text { provean al ejercicio autónomo } \\
\text { de sus funciones; sólo podrán } \\
\text { ser removidas por causa grave } \\
\text { y no podrán tener ningún otro } \\
\text { empleo, cargo o comisión, con } \\
\text { excepción de aquéllos en que } \\
\text { actúen en representación del } \\
\text { banco y de los no remunerados } \\
\text { en asociaciones docentes, } \\
\text { científicas, culturales o de } \\
\text { beneficiencia [sic].[...].” }\end{array}$ & $\begin{array}{l}\text { Hay un error de dedo pues } \\
\text { menciona asociaciones de } \\
\text { "beneficiencia" y no de } \\
\text { beneficencia. }\end{array}$ \\
\hline Artículo 47. & $\begin{array}{l}\text { "El Estado del [sic] Nayarit } \\
\text { tendrá la extensión territorial } \\
\text { y límites que comprende } \\
\text { actualmente el Territorio de } \\
\text { Tepic." }\end{array}$ & $\begin{array}{l}\text { Utiliza mal la contración } \\
\text { "del", pues debería usar } \\
\text { simplemente el prefijo "de". }\end{array}$ \\
\hline $\begin{array}{l}\text { Artículo } 72, \\
\text { apartado } \mathrm{C} \text {, primer } \\
\text { párrafo. }\end{array}$ & $\begin{array}{l}\text { "El proyecto de ley o decreto } \\
\text { desechado en todo o en parte } \\
\text { por el Ejecutivo, será devuelto, } \\
\text { con sus observaciones, a la } \\
\text { Cámara de su origen. Deberá } \\
\text { ser discutido de nuevo por ésta,, } \\
\text { [sic] y si fuese confirmado por las } \\
\text { dos terceras partes del número } \\
\text { total de votos, pasará otra vez a } \\
\text { la Cámara revisora. Si por esta } \\
\text { fuese sancionado por la misma } \\
\text { mayoría, el proyecto será ley o } \\
\text { decreto y volverá al Ejecutivo } \\
\text { para su promulgación." }\end{array}$ & $\begin{array}{l}\text { Se publicó incorrectamente } \\
\text { con dos comas tras el "ésta" } \\
\text { que sigue al primer punto y } \\
\text { seguido. }\end{array}$ \\
\hline
\end{tabular}


Esta obra forma parte del acervo de la Biblioteca Jurídica Virtual del Instituto de Investigaciones Jurídicas de la UNAM

\begin{tabular}{|c|c|c|}
\hline Precepto & Trascripción textual & Erratas \\
\hline $\begin{array}{l}\text { Artículo } 72, \\
\text { segundo apartado } \\
\text { I. }\end{array}$ & $\begin{array}{l}\text { I [sic].- El Ejecutivo de la Unión } \\
\text { no puede hacer observaciones } \\
\text { a las resoluciones del Congreso } \\
\text { o de alguna de las Cámaras, } \\
\text { cuando ejerzan funciones de } \\
\text { cuerpo electoral o de jurado, lo } \\
\text { mismo que cuando la Cámara } \\
\text { de Diputados declare que debe } \\
\text { acusarse a uno de los altos } \\
\text { funcionarios de la Federación por } \\
\text { delitos oficiales. }\end{array}$ & $\begin{array}{l}\text { Este es uno de los errores más } \\
\text { graves, pues se publicaron dos } \\
\text { apartados que se identifican } \\
\text { con la letra "I". Esto puede } \\
\text { generar problemas en la } \\
\text { citación. Este debió de ser el } \\
\text { apartado "J". }\end{array}$ \\
\hline $\begin{array}{l}\text { Artículo } 73, \\
\text { fracción XXIX, } 5^{\circ} \text {, } \\
\text { inciso e) }\end{array}$ & $\begin{array}{l}\text { "e).- Aguamiel y productos de su } \\
\text { fermentación; y [sic]" }\end{array}$ & $\begin{array}{l}\text { Termina con la conjunción } \\
\text { copulativa "y", porque el } \\
\text { inciso f) era el último; sin } \\
\text { embargo, en } 1949 \text { se añadió } \\
\text { un inciso g), de forma que ya } \\
\text { no es la penúltima posibilidad } \\
\text { de establecer contribuciones, } \\
\text { siendo necesario que terminara } \\
\text { con un punto y coma. }\end{array}$ \\
\hline $\begin{array}{l}\text { Artículo 73, } \\
\text { fracción XXIX-L }\end{array}$ & $\begin{array}{l}\text { "XXIX-L.- Para expedir leyes } \\
\text { que establezcan la concurrencia } \\
\text { del gobierno federal, de los } \\
\text { gobiernos de las entidades } \\
\text { federativas y de los municipios, } \\
\text { en el ámbito de sus respectivas } \\
\text { competencias, en materia de } \\
\text { pesca y acuacultura, así como } \\
\text { la participación de los sectores } \\
\text { social y privado, y [sic]" }\end{array}$ & $\begin{array}{l}\text { Termina con la conjunción } \\
\text { copulativa "y", porque era } \\
\text { la penúltima fracción; sin } \\
\text { embargo, desde } 2004 \text { ya no } \\
\text { es la penúltima, por lo que } \\
\text { debería de terminar con un } \\
\text { punto y coma. }\end{array}$ \\
\hline $\begin{array}{l}\text { Artículo 90, } \\
\text { segundo párrafo. }\end{array}$ & $\begin{array}{l}\text { "La [sic] leyes determinarán las } \\
\text { relaciones entre las entidades } \\
\text { paraestatales y el Ejecutivo } \\
\text { Federal, o entre éstas y las } \\
\text { Secretarías de Estado." }\end{array}$ & $\begin{array}{l}\text { No hay concordancia entre el } \\
\text { singular del artículo "la" y el } \\
\text { plural usado en el sustantivo y } \\
\text { del verbo. Debería decir "Las } \\
\text { leyes determinarán..." }\end{array}$ \\
\hline
\end{tabular}


Esta obra forma parte del acervo de la Biblioteca Jurídica Virtual del Instituto de Investigaciones Jurídicas de la UNAM

\begin{tabular}{|c|c|c|}
\hline Precepto & Trascripción textual & Erratas \\
\hline $\begin{array}{l}\text { Artículo } 111, \\
\text { párrafo sexto. }\end{array}$ & $\begin{array}{l}\text { "Las declaraciones y resoluciones } \\
\text { de la [sic] Cámaras de Diputados } \\
\text { Senadores [sic] son inatacables." }\end{array}$ & $\begin{array}{l}\text { En este párrafo hay dos erratas: } \\
\text { 1.- No hay concordancia } \\
\text { en la frase porque usa el } \\
\text { artículo singular "la" para dos } \\
\text { sustantivos. Debería estar en } \\
\text { plural. } \\
\text { 2.- Falta la conjunción copu- } \\
\text { lativa "y" entre las palabras } \\
\text { "Diputados" y "Senadores", } \\
\text { pues de otra forma se piensa } \\
\text { que es un solo órgano. }\end{array}$ \\
\hline $\begin{array}{l}\text { Artículo } 115, \\
\text { fracción I, tercer } \\
\text { párrafo. }\end{array}$ & $\begin{array}{l}\text { "Las Legislaturas locales, por } \\
\text { acuerdo de las dos terceras } \\
\text { partes de sus integrantes, podrán } \\
\text { suspender ayuntamientos, decla- } \\
\text { rar que éstos han desaparecido y } \\
\text { suspender o revocar el mandato } \\
\text { a alguno de sus miembros, por } \\
\text { alguna de las causas graves que } \\
\text { la ley local prevenga, siempre } \\
\text { y cuando sus miembros hayan } \\
\text { tenido oportunidad suficiente } \\
\text { para rendir las pruebas y hacerlos } \\
\text { [sic] alegatos que a su juicio } \\
\text { convengan." }\end{array}$ & $\begin{array}{l}\text { En la parte final, en vez de } \\
\text { usar el pronombre "los", se } \\
\text { publicó, haciendo parecer } \\
\text { que se trata de una partícula } \\
\text { enclítica. }\end{array}$ \\
\hline $\begin{array}{l}\text { Artículo } 116, \\
\text { párrafo segundo, } \\
\text { fracción III, } \\
\text { párrafo quinto. }\end{array}$ & $\begin{array}{l}\text { "Los magistrados durarán en } \\
\text { el ejercicio de su encargado } \\
\text { [sic] el tiempo que señalen las } \\
\text { Constituciones Locales, podrán } \\
\text { ser reelectos, y si lo fueren, sólo } \\
\text { podrán ser privados de sus } \\
\text { puestos en los términos que de- } \\
\text { terminen las Constituciones y } \\
\text { las Leyes de Responsabilidades } \\
\text { de los Servidores Públicos de los } \\
\text { Estados." }\end{array}$ & $\begin{array}{l}\text { Utiliza la palaba "encargado" } \\
\text { en vez de "encargo", que } \\
\text { de acuerdo al contexto es la } \\
\text { correcta. }\end{array}$ \\
\hline
\end{tabular}


Esta obra forma parte del acervo de la Biblioteca Jurídica Virtual del Instituto de Investigaciones Jurídicas de la UNAM

\begin{tabular}{|c|c|c|}
\hline Precepto & Trascripción textual & Erratas \\
\hline $\begin{array}{l}\text { Artículo } 117 \text {, } \\
\text { fracción VII. }\end{array}$ & $\begin{array}{l}\text { "VII.- Expedir ni mantener en } \\
\text { vigor leyes o disposiciones fiscales } \\
\text { que importen diferencias de } \\
\text { impues [sic] o requisitos por razón } \\
\text { de la procedencia de mercancías } \\
\text { nacionales o extranjeras, ya sea } \\
\text { que esta diferencia se establezca } \\
\text { respecto de la producción similar } \\
\text { de la localidad, o ya entre } \\
\text { producciones semejantes de } \\
\text { distinta procedencia." }\end{array}$ & $\begin{array}{l}\text { Le faltaron tres letras (tos) para } \\
\text { concluir la palabra impuestos a } \\
\text { la que quería referirse. }\end{array}$ \\
\hline $\begin{array}{l}\text { Artículo } 121, \\
\text { fracción } \mathrm{V} \text {. }\end{array}$ & $\begin{array}{l}\text { "V.- Los títulos profesionales } \\
\text { expedidos por las autoridades } \\
\text { de un Estado, con sujeción a sus } \\
\text { leyes, serás [sic] respetados en los } \\
\text { otros." }\end{array}$ & $\begin{array}{l}\text { Utiliza incorrectamente el } \\
\text { futuro del verbo ser, pues } \\
\text { menciona "serás", propio de la } \\
\text { segunda persona del singular, y } \\
\text { no "serán" que es el correcto } \\
\text { por referirse a los títulos } \\
\text { personales, que deberían } \\
\text { conjugarse de acuerdo a la } \\
\text { tercera persona del plural. }\end{array}$ \\
\hline $\begin{array}{l}\text { Artículo } 123, \\
\text { apartado A, } \\
\text { fracción XII, } \\
\text { párrafo cuarto. }\end{array}$ & $\begin{array}{l}\text { "Además, en esos mismos centros } \\
\text { de trabajo, cuando su población } \\
\text { exceda de dosicentos [sic] } \\
\text { habitantes, deberá reservarse } \\
\text { un espacio de terreno, que no } \\
\text { será menor de cinco mil metros } \\
\text { cuadrados, paraelestablecimiento } \\
\text { de mercados públicos, instalación } \\
\text { de edificios destinados a los } \\
\text { servicios municipales y centros } \\
\text { recreativos." }\end{array}$ & $\begin{array}{l}\text { Hay un error mecanográfico } \\
\text { en la palabra "doscientos" pues } \\
\text { dice "dosicentos", invirtiendo } \\
\text { el orden de la i y de la c. }\end{array}$ \\
\hline $\begin{array}{l}\text { Artículo } 123, \\
\text { apartado A, } \\
\text { fracción XXI. }\end{array}$ & $\begin{array}{l}\text { "XXI.- Si el patrono se negare } \\
\text { a someter sus diferencias al } \\
\text { arbitraje o a aceptar el laudo } \\
\text { pronunciado por la Junta, se dará } \\
\text { por terminado el contrato de } \\
\text { trabajo y quedará abligado [sic] } \\
\text { a indemnizar al obrero con el } \\
\text { importe de tres meses de salario, } \\
\text { además de la responsabilidad que } \\
\text { le resulte del conflicto. Esta dispo- }\end{array}$ & \\
\hline
\end{tabular}


Esta obra forma parte del acervo de la Biblioteca Jurídica Virtual del Instituto de Investigaciones Jurídicas de la UNAM

\begin{tabular}{|c|c|c|}
\hline Precepto & Trascripción textual & Erratas \\
\hline & $\begin{array}{l}\text { sición no será aplicable en los } \\
\text { casos de las acciones consignadas } \\
\text { en la fracción siguiente. Si la } \\
\text { negativa fuere de los trabajadores, } \\
\text { se dará por terminado el contrato } \\
\text { de trabajo." }\end{array}$ & $\begin{array}{l}\text { Hay un error mecanográfico } \\
\text { en la palabra "obligado", } \\
\text { pues menciona "abligado" } \\
\text { sustituyendo la primera o por } \\
\text { una a. }\end{array}$ \\
\hline $\begin{array}{l}\text { Artículo } 123, \\
\text { apartado A, } \\
\text { fracción XXI. }\end{array}$ & $\begin{array}{l}\text { "XXII.- [...] La Ley determinará } \\
\text { los casos en que el patrono podrá } \\
\text { ser eximido de la obligación de } \\
\text { cumplir el contrato, mediante } \\
\text { el pago de una indemnización. } \\
\text { Igualmente tendrá la obligación } \\
\text { de indemnizar al trabajador } \\
\text { con el importe de tres meses } \\
\text { de salario, cuando se retire del } \\
\text { servicio por falta de probidad } \\
\text { del patrono o por recibir de él } \\
\text { malos tratamientos, ya sea en su } \\
\text { persona o en la de su cónyuge, } \\
\text { padres, hijos o hermanos. El } \\
\text { patrono no podrá eximirse de } \\
\text { esta responsabilidad, cuando los } \\
\text { malos tratamientos provengan } \\
\text { de dependientes o familiares que } \\
\text { obren con el consentimieto [sic] o } \\
\text { tolerancia de él." }\end{array}$ & $\begin{array}{l}\text { Hay un error mecanográfico en } \\
\text { la palabra "consentimiento", } \\
\text { pues se publicó como "consen- } \\
\text { timieto", faltando una n entre } \\
\text { la e final y la t. }\end{array}$ \\
\hline $\begin{array}{l}\text { Artículo } 123, \\
\text { apartado A, } \\
\text { fracción XXXI, } \\
\text { inciso a), numeral } \\
21 .\end{array}$ & $\begin{array}{l}\text { 20.- Vidriera, exclusivamente por } \\
\text { lo que toca a la fabricación de } \\
\text { vidrio plano, liso o labrado, o de } \\
\text { envases de vidrio; y [sic] }\end{array}$ & $\begin{array}{l}\text { Termina con la conjunción } \\
\text { copulativa "y", porque era la } \\
\text { industria; sin embargo, desde } \\
1990 \text { ya no es la penúltima, por } \\
\text { lo que debería de terminar con } \\
\text { un punto y coma. }\end{array}$ \\
\hline $\begin{array}{l}\text { Artículo } 123, \\
\text { apartado B, } \\
\text { primera fracción } \\
\text { XI . }\end{array}$ & $\begin{array}{l}\text { XI [sic].- Los trabajadores } \\
\text { sólo podrán ser suspendidos o } \\
\text { cesados por causa justificada, en } \\
\text { los términos que fije la ley. }\end{array}$ & $\begin{array}{l}\text { Este es uno de los errores más } \\
\text { graves, pues se publicaron } \\
\text { dos fracciones "XI". Parece } \\
\text { que esto es un error, porque } \\
\text { la primera (a la que nos } \\
\text { referimos) va después de la } \\
\text { fracción VIII y antes de la X, } \\
\text { de suerte que suponemos que } \\
\text { más bien es la fracción IX, y } \\
\text { que están inversas las letras del } \\
\text { número romano. }\end{array}$ \\
\hline
\end{tabular}


Esta obra forma parte del acervo de la Biblioteca Jurídica Virtual del Instituto de Investigaciones Jurídicas de la UNAM

\title{
LA REFORMA CONSTITUCIONAL EN MÉXICO: ALGUNAS NOTAS PARA ORIENTAR LA REVISIÓN DEL CORPUS CONSTITUCIONAL
}

\author{
Enrique URIBE ARZATE* \\ Martha Guadalupe Bustamante MedRanO**
}

\begin{abstract}
SUMARIO: I. Introducción. II. La cuestión epistemológica. III. Vectores de análisis. IV. Prospectiva. V. Entreveramiento. VI. Fuentes de consulta.
\end{abstract}

\section{INTRODUCGIÓN}

La reforma constitucional en las entidades federativas, presenta algunas debilidades inherentes a la naturaleza misma de las Cartas constitucionales locales. La fragilidad aludida es evidente en los alcances y límites que la propia Constitución Política de los Estados Unidos Mexicanos impone a las Constituciones locales.

Desde el acotamiento visible en lo prescrito por el artículo 124, pasando por las reglas y supuestos marcados en el artículo 76, es incontestable que el sistema jurídico-político de México, está asentado en una irrefrenable presencia y prevalencia de "lo federal" en los espacios locales.

En el caso del proceso de reforma constitucional contenido en las constituciones locales - por cierto idéntico al que prescribe el artículo 135 de la Carta Magna-, la regla sigue siendo la misma: la reedición de las reglas de operación marcadas para la Constitución federal, están repetidas sin vacilación en las Constituciones de las entidades federativas.

* Doctor en Derecho por la Facultad de Derecho de la Universidad Nacional Autónoma de México, Profesor investigador de tiempo completo en la Facultad de Derecho de la Universidad Autónoma del Estado de México, Investigador Nacional Nivel II en el Sistema Nacional de Investigadores del Consejo Nacional de Ciencia y Tecnología.

** Asistente de investigación en el Centro de Investigación en Ciencias Jurídicas, Justicia Penal y Seguridad Pública de la Facultad de Derecho de la Universidad Autónoma del Estado de México. 
Esta obra forma parte del acervo de la Biblioteca Jurídica Virtual del Instituto de Investigaciones Jurídicas de la UNAM

De entrada, debemos preguntarnos si esta forma de operación de "lo local", es la más adecuada y más funcional, en el propósito de mantener la unidad y coherencia del sistema jurídico político del Estado mexicano; tal vez sea así.

En este caso, lo que nos interesa destacar, es la inoperancia de la reforma constitucional prevista en las constituciones locales que están lastradas por el contenido del artículo 135 de la Carta Magna; el proceso local de reforma constitucional, es una burda copia en todas las constituciones locales; a saber dos terceras partes de diputados del Congreso local y la mayoría de los ayuntamientos.

En este caso, nos parece que lo más interesante no se halla en el análisis del mimetismo ya referido, sino en el estudio de los efectos pragmáticos que el diseño de este mecanismo puede tener en la vida constitucional de las entidades federativas e incluso, llevado al extremo, en el estudio crítico que nos permita saber si tiene algún sentido asentar en los ordenamientos constitucionales de las entidades federativas, idénticas instituciones a las de "la federación", mecanismos repetitivos, copias y procesos que a priori nos llevan a la afirmación de que el diseño jurídico político de la federación, no tiene un adecuado sustento local; es decir que el Estado mexicano, organizado bajo el modelo federal, no tiene la debida articulación y los apoyos idóneos en las instituciones locales que son, a fin de cuentas, las que en una federación irrigan y potencian al Estado federal ${ }^{1}$.

Con esto no queremos decir que cada entidad federativa deba tener instituciones exclusivas, incluso contrapuestas a las de cualquier otro espacio local. Al margen de lo que nominalmente establezcan las constituciones locales, es evidente que la tarea jurisdiccional en cada entidad federativa recaerá en un órgano de esta naturaleza; las tareas de tipo electoral o las relativas a la transparencia, de igual modo, estarán marcadas por idénticos principios que derivan de la Constitución Federal.

Nuestro planteamiento gira en torno a la ilusión o peor aún, a la simulación que podemos avizorar en los contenidos de las constituciones locales con respecto a procesos tan importantes como el de reforma constitucional. Como este hay, sin duda, muchos otros temas y materias que siguen la misma suerte. En el plano epistemológico, seguramente el diseño atiende el principio de supremacía constitucional, este sí, privativo y exclusivo de la Constitución federal y, por eso, los ordenamientos locales deben seguir la

1 Para una mejor comprensión de la dinámica del sistema federal, puede verse Serna de la Garza, José María, El sistema federal mexicano, UNAM, Instituto de Investigaciones Jurídicas, México, 2008 
Esta obra forma parte del acervo de la Biblioteca Jurídica Virtual del Instituto de Investigaciones Jurídicas de la UNAM

misma orientación y repetir sin más, lo que el texto de la Carta Magna con todo su imperium señala.

Ergo, la revisión que aquí nos ocupará, se focaliza en el interés de proponer la convocatoria de un Congreso Constituyente -obviamente federalque se encargue de revisar a fondo nuestro entramado constitucional y pueda marcar las directrices constitucionales ciertas para la mejor articulación de la Carta Magna con las constituciones locales, bajo la advertencia de que tal vez éstas, ni siquiera deban llamarse así2.

Sin duda, este debate forma parte de otro asunto de mayor calado que se refiere a la forma de llevar a cabo la reforma de la Constitución federal, dado el anacronismo del ya citado artículo 135 .

Próximos al centenario de la Constitución mexicana, nos parece que su mejor homenaje transita por doble vía: una vertiente es el cumplimiento a sus prescripciones normativas; el otro, se vincula a la necesidad de una revisión integral que permita identificar y definir las decisiones esenciales y, al mismo tiempo, establecer límites claros a los alcances de la reforma constitucional fácil y trepidante que ha definido a nuestra Carta Magna particularmente en los últimos lustros.

\section{LA GUESTIÓN EPISTEMOLÓGICA}

Para la concepción que nos ocupa es menester desarrollar una perspectiva epistemológica que permita abordar nuestra temática por una ruta distinta a las que marcan la ortodoxia y las posiciones acríticas inercia. Por ello, comenzamos afirmando que la Constitución es mucho más que normas ${ }^{3}$.

La Constitución rompe de este modo, con el cartabón acrisolado en el léxico y las normas y en el limitado alcance del lenguaje jurídico ${ }^{4}$.

Por ello, podemos decir que la Constitución tiene una lectura inmediata en las letras que integran su articulado; pero al margen de esto, su más completa aprehensión nos permite concebirla como el entreveramiento jurídico-político de tipo generacional que vincula a los habitantes con su patria.

Esto y no otra cosa es la constitución de un pueblo.

2 Un autor que cuestiona esto es Covián Andrade, Miguel, Teoría constitucional, Centro de Estudios de Ingeniería Política y Constitucional, México, 2004

3 Sobre esto puede verse la obra de nuestra autoría, intitulada El sistema de justicia constitucional en México, Miguel Ángel Porrúa, México, 2006.

4 Esta temática representa una de las áreas de mayor interés y utilidad, para la comprensión de lo que aquí tratamos 
Esta obra forma parte del acervo de la Biblioteca Jurídica Virtual del Instituto de Investigaciones Jurídicas de la UNAM

En el caso concreto de México, desde principios del siglo XIX, los habitantes de esta tierra avistaron la libertad como algo esencial a los seres humanos y así lo plasmaron desde los primeros ensayos constitucionales; el Bando de Hidalgo, los Sentimientos de la Nación -por sólo mencionar dos de ellos-, no son nominalmente constituciones, pero tienen contenido y esencia constitucional.

De este modo, a lo largo de casi dos siglos, las sucesivas generaciones de mexicanos nos hemos ido eslabonando en el intento de construir un país fuerte y promisorio, sólido y propicio para la realización personal. Cualquier asomo de tipo constitucional debe tener esta plasticidad; de lo contrario, aunque esté plasmado en la norma constitucional, carece de constitucionalidad.

Esta es a nuestro juicio, la aproximación epistemológica más acorde con las necesidades y demandas de los mexicanos de hoy; esto desde luego, no significa una ruptura con los principios y anhelos de libertad e independencia que desde 1810 han representado la máxima directriz de los mexicanos; empero, nuevos tiempos requieren nuevas reglas y hoy, el Estado mexicano necesita que sobre las bases firmes de un diseño institucional adecuado, podamos volver dúctiles y maleables los modos de operación de lo público que a causa de las posturas teóricas desgastadas, han limitado durante décadas nuestros márgenes de acción y nos han impedido avanzar en la consecución de mejores escenarios para la vida colectiva.

Para ilustrarlo mejor, la corrupción que sigue enquistada en los modos de operación de la actividad pública, debe ser motivo de una atención prioritaria al momento de plantear cualquier homenaje en el próximo centenario de la Constitución; vgr. si el sistema presidencial merece ser revisado, y si los modos de producción legislativa deben ser controlados a priori, nos parece que la reforma constitucional integral debe darnos a los mexicanos herramientas viables y eficaces para evitar el abuso de poder y la emisión de normas inconstitucionales (incluyendo las propias reformas al texto de la Carta Magna).

La inercia en los modos de operación agrícola, nos colocó de pronto -y lo hemos advertido muy tarde- en la dependencia alimentaria del exterior; por eso, la reforma integral debe revisar a fondo el tema de la tenencia de la tierra, pero con la atención focalizada en su uso y su abuso por parte de los nuevos terratenientes que de manera asombrosa pasan desapercibidos para el gobierno. De modo similar, creímos que el petróleo serviría para detonar el desarrollo, y por no generar investigación ni inversión en las energías renovables (eólica, solar, etc.), nos sumimos en la crisis energética cuyo más visible fracaso es PEMEX; si bien la crisis es global, lamentablemente vamos rezagados en la adopción de políticas públicas que apuesten por otro tipo 
Esta obra forma parte del acervo de la Biblioteca Jurídica Virtual del Instituto de Investigaciones Jurídicas de la UNAM

de energías que nosotros apenas comenzamos a valorar; y ni qué decir en el tema de los transportes, pues por lo menos en lo que a trenes se refiere, México se quedó atorado en el siglo XIX.

En fin, el campo groseramente fraccionado no es costeable; la equívoca reforma de 1992 al artículo 27 sepultó al ejido y ahora en lugar de maíz, hay siembra de fraccionamientos con pequeñas y míseras viviendas mal construidas que fomentan la ilusión de tener una "casa"; nunca hemos sido un pueblo pesquero y ni siquiera tenemos la cultura del consumo de productos del mar; a pesar de ello, el mar inmenso sigue esperándonos. ¿Astilleros? Es seguro que un porcentaje elevado de mexicanos no sabe qué es esto, ni la enorme posibilidad que tenemos de ser una potencia en este campo.

En esta concepción de lo constitucional anudada a la realidad, bien podemos sostener que la Constitución normativa es la más sencilla manifestación de lo constitucional; la Constitución es, en realidad, vida, programa y acción.

La Constitución escrita fue condensada en un conjunto de artículos (136), con los cuales en 1916 se pretendió hacer visibles las demandas esenciales del pueblo mexicano.

Pero la "dimensión" constitucional desborda las letras y enunciados del texto. La Constitución se expresa en forma de normas, pero por sus "contenidos esenciales" es mucho más que normas jurídicas.

La Constitución "viva" es manifestación cotidiana, vivencial, pragmática. Se materializa a cada momento en el ser y hacer del pueblo, en el accionar de las instituciones, mediante el ejercicio del poder de todos, el poder "público" (la soberanía convertida en potestas).

No realizamos la retrospección de lo constitucional hasta sus orígenes, pues nuestras reflexiones sólo abarcan la Constitución actual. A fin de cuentas en su texto se han recogido las luchas y anhelos de los mexicanos desde 1810 .

La Constitución es por eso, desiderátum e historia eslabonada a través del suceder generacional.

\section{VECTORES DE ANÁLISIS}

Con lo que hemos señalado líneas atrás, queda clara la manifestación de nuestras ideas en el sentido de que "lo constitucional" no se agota en el texto de la Constitución escrita. Es posible que juristas de viejo cuño aleguen de inmediato la imposibilidad "jurídica" de sostener esto.

Sin embargo, nos parece que pretender que la Constitución escrita es el "todo constitucional", constituye una afirmación insostenible dada la dinámi- 
Esta obra forma parte del acervo de la Biblioteca Jurídica Virtual del Instituto de Investigaciones Jurídicas de la UNAM

ca y los procesos constitucionales asentados en las dimensiones sociológica, antropológica, cultural, económica, internacional que inciden y configuran lo constitucional - aun cuando no se vacíen en algún texto con este nombre-

Para ilustrar mejor esto, baste con citar en vía de ejemplo, la irreductible e incontenible exigencia de los ciudadanos de que el gobierno transparente sus procesos de asignación para la construcción de grandes obras como carreteras, puentes o aeropuertos, para confirmar que la transparencia es hoy, indudablemente, una cuestión de naturaleza constitucional que evidentemente no preocupó ni a Hidalgo, ni a Morelos ni a Carranza, pero sí a nosotros.

La Carta Magna, la única Carta Magna que tenemos que es la Constitución Política de los Estados Unidos Mexicanos, debe recoger en su articulado los principios y las manifestaciones de mayor envergadura y que por su naturaleza atemporal ${ }^{5}$, deben ser parte esencial de lo constitucional de México.

Luego de un análisis que ha intentado comprender de manera holística el quid constitucional, estos son los grandes vectores que podemos identificar como lo esencial de lo constitucional - en letras y fuera de ellas-; es decir, se trata de cuestiones que pueden estar ya en el texto constitucional y también de otras que posiblemente no hayan recibido este tratamiento, pero que en nuestra concepción, deben ser tratadas en el lenguaje constitucional diseñado para tal fin. Id. est., la Constitución de México, no puede ser omisa sobre esto.

Para tal fin, hemos agrupado en los siguientes acápites los contenidos esenciales de la Constitución mexicana:

\section{Soberanía}

La máxima expresión de la libertad de un pueblo es la soberanía. Más allá de los complejos procesos de globalización, la soberanía es el ingrediente esencial de la autodeterminación, del orden jurídico ${ }^{6}$, de la democracia ${ }^{7}$ y del ejercicio de las potestades de los órganos del Estado.

5 Sobre este principio, puede verse Uribe Arzate, Enrique y De Paz González, Isaac, "Los efectos de los derechos fundamentales en el tiempo", en Boletín Mexicano de Derecho Comparado, Nueva Serie, año XLVIII, número 144, septiembre-diciembre de 2015, UNAM, Instituto de Investigaciones Jurídicas, México.

6 Dice Kelsen. "En efecto, una ciencia del derecho-como conocimiento de un objeto particular- sólo es posible si se parte de la concepción de que existe una soberanía del derecho (o del Estado, lo cual es lo mismo), es decir, si se reconoce el orden jurídico como un sistema de normas autónomo y que, por consiguiente, no se deriva de ningún orden superior”, Kelsen, Hans, et. al., Ficciones jurídicas, Fontamara, México, 2013, p. 49.

7 Vid., Ferrajoli, Luigi, La democracia a través de los derechos, el constitucionalismo garantista como modelo teórico y como proyecto político, Trotta, Madrid, 2014, especialmente el capítulo IV relativo 
Esta obra forma parte del acervo de la Biblioteca Jurídica Virtual del Instituto de Investigaciones Jurídicas de la UNAM

La soberanía es la potentia que permite la configuración de fenómenos constitucionales; es decir, se trata del poder del pueblo capaz de generar fenómenos - evidentemente humanos-que pueden ser tildados como "algo" constitucional. El lenguaje constitucional, en todo caso, funge en doble vía durante este proceso, como continente y como contenido.

\section{Poder público}

Visible como capacidad y atributo, el poder público, poder desnudo domesticado por el derecho, con su traducción en potestas, es la expresión del querer colectivo. No hay más fuente de poder para quienes gobiernan que el que les otorga la voluntad soberana. Con esto no descubrimos nada y tampoco emitimos ninguna afirmación novedosa.

Lo cierto es que el poder público tiene una doble circulación; de inicio lo otorga el pueblo a los gobernantes; en sentido contrario, el pueblo, puede -y debe- retirar esa potestad cuando su depositario incurre en abuso o no ejercicio de sus atribuciones.

La primera parte no ha tenido mayor desarrollo en los últimos años; la otra sí, pues se trata de poner límites y controles al ejercicio del poder. En esta vertiente, un adecuado sistema de responsabilidades es condición esencial para la buena marcha del Estado.

\section{Ser y deber ser del pueblo del Estado}

Por absurdo que pueda parecer, es pertinente que como entramado colectivo, nos preguntemos: ¿qué somos?; ¿a qué aspiramos?; ¿es clara nuestra vía communis?, es decir, ¿tenemos certidumbre y objetividad acerca del camino que de manera colectiva deseamos transitar?

La Constitución debe poner en mayúsculas y subrayado, el derrotero de nuestro ser colectivo. Es inaudito que tengamos que recurrir a reiterados ejercicios de interpretación del articulado de la Carta Magna para encontrar en algún resquicio de sus letras el quid de los mexicanos.

\section{Quid del Estado}

En el mismo sentido que lo señalado en el párrafo previo, la Constitución debe enunciar claramente el qué y para qué del Estado (sus instituciones,

a La actual crisis de la democracia constitucional. 
Esta obra forma parte del acervo de la Biblioteca Jurídica Virtual del Instituto de Investigaciones Jurídicas de la UNAM

estructura, funcionamiento). Un Estado sin dirección, es lo más cercano a un pueblo sin concreción, sin futuro.

\section{Paz y seguridad}

Esta es otra de las tareas fundamentales del Estado visible desde la Constitución escrita. Lo elemental que la Constitución debe prever en sus principales declaraciones y propósitos, es la paz en su interior y la seguridad más amplia para sus habitantes.

\section{Desarrollo y progreso}

Entre sus prolegómenos de mayor claridad, la Constitución debe establecer un programa. Debe asentar sin cortapisas, cuál es el fin que el Estado persigue y cómo se piensa que puede lograrlo.

Lejos de afirmaciones esquivas o vagas, la Constitución debe ser puntual en la definición de lo que desde la norma jurídica se mira como ruta y destino. Nos parece que por lo menos debe señalar la viabilidad del progreso en un marco de paz y solidaridad entre los mexicanos; la realización humana como concreción de la res pública; el acrecentamiento de la patria como misión particular y colectiva.

\section{Democracia y responsabilidad ciudadana (no sólo participación ciudadana)}

Entre las definiciones que más concreción demandan, está la democracia y los modos de intervención de los ciudadanos en este campo.

Más allá de las complejidades técnicas que se han ido adhiriendo a este concepto milenario, nos parece que su naturaleza esencial e infaltable para la vida humana, exige sencillez en su concepción, pero particularmente, una práctica cotidiana visible en actos concretos de ciudadanos responsables; ; mientras esto no cuaje en nuestra sociedad, los artificios electorales

8 Dominique Rousseau ha llamado a este proceso la "democracia continua", pues “... no se agota en los momentos electorales, sino que se construye multiplicando en el tiempo los ritmos políticos diversos y las formas institucionales variadas en el sistema", cit., por Ruiz Soroa, José María, El esencialismo democrático, Trotta, Madrid, 2010, p. 46 
Esta obra forma parte del acervo de la Biblioteca Jurídica Virtual del Instituto de Investigaciones Jurídicas de la UNAM

seguirán abarcando la mayor parte de los elementos que integran la concepción de la democracia real, efectiva, cercana a nosotros.

Ojalá podamos cumplir con lo que dice el actual artículo $3^{\circ}$ de nuestra Carta Magna que concibe a la democracia como "un sistema de vida fundado en el constante mejoramiento económico, social y cultural del pueblo".

\section{Los derechos vitales: Dignidad, libertad, igualdad, seguridad}

(primero jurídica, luego humana)

Las definiciones concernientes a los derechos humanos, deben concretarse en una concepción que todavía no se ha desarrollado y que muy pronto cambiará la nomenclatura por derechos vitales.

Dentro de poco, los derechos a votar o transitar - que no dejarán de ser fundamentales- serán ubicados detrás de los verdaderos derechos esenciales necesarios para hacer posible la vida humana: la dignidad con una estructura real y tangible, el derecho al agua (sobre todo al agua de consumo humano), el derecho a la seguridad jurídica e instrumental, garante de la seguridad humana verdaderamente trascendente.

Este punto requiere un desglose en dos FASES:

\section{A. FASE I.- Los derechos humanos (declarativo-prescriptivos)}

La Constitución y sólo ella, puede y debe plasmar con acuciosidad y sin dejar resquicios a las interpretaciones sesgadas, los derechos vitales. En esta parte declarativo-prescriptiva el nivel epistemológico del planteamiento debe servir para generar un "catálogo mínimo-esencial" de los derechos que a nadie deben faltar: Educación, Salud, Trabajo, Desarrollo, etc.

\section{B. FASE II.- La era de los derechos asegurados}

Hemos sostenido que derechos sin garantías, es una aporía ${ }^{9}$.

Por eso, luego de la concreción de los derechos en el sitial de la estática jurídica, es necesario arribar a la proyección dinámica que deberá dotar

9 Vid. Uribe Arzate, Enrique, "Una aproximación epistemológica a la dimensión vivencial pragmática de los derechos humanos", en Boletín Mexicano de Derecho Comparado, volumen 44, número 132, UNAM, Instituto de Investigaciones Jurídicas, México, 2011. 
Esta obra forma parte del acervo de la Biblioteca Jurídica Virtual del Instituto de Investigaciones Jurídicas de la UNAM

de su correspondiente envoltura protectora a cada derecho; esto es, deberá establecer con puntualidad qué mecanismos de naturaleza procesal constitucional, deberán respaldar el ejercicio y vivencia de cada derecho, en el entendido de que la variedad de derechos vitales va a requerir un amplio catálogo de garantías.

\section{Estado protagónico en América}

Ante lo inexorable y definitorio de la ubicación geográfica de México, nos parece procedente y plausible la recuperación del liderazgo — tal vez apenas germinal - que en algún tiempo tuvo nuestro país. Incluso, es tiempo ya de proyectar desde las líneas de la Constitución qué otros propósitos ${ }^{10}$ puede plantearse México para los años por venir.

No está de más pensar que miramos con esperanza - a veces sin sustento - hacia el norte y los socios comerciales desiguales poca atención nos prestan; en cambio, poco miramos hacia centro y Sudamérica, donde México puede apuntalar su presencia con la consecuente posibilidad de afianzar beneficios y oportunidades - con sustento- para los mexicanos.

\section{Estado responsable y con presencia a nivel global}

Siendo el mundo una sola dimensión común a todos los habitantes, el constitucionalismo mexicano no puede darse el lujo de pasar de largo frente a los problemas y los retos que nos hermanan y nos hacen iguales con cualquier otro habitante de la tierra.

Hasta ahora, las ideas sobre la marcha y operación de la aldea global, se han focalizado y, por eso mismo, se han agotado en la economía y en sus complejos indicadores y consecuencias. La globalidad que ya deberíamos comenzar a reemplazar por la palabra identidad, paulatinamente va cerrando las brechas culturales y ante lo homogéneo de nuestros problemas, también los habitantes nos hemos empezado a estandarizar.

Con esto no queremos dar paso a interpretaciones erróneas, pues la dignidad humana y los atributos personales de cada ser humano lo hacen diferente e irremplazable; en lo colectivo, las características físicas — raciales si

10 Un interesante estudio sobre esto, lo realizó en 1792 Von Humboldt, Wilhelm, Los límites de la acción del Estado, Tecnos, Madrid, 2009. Destacan desde luego la seguridad y la libertad como propósitos esenciales de la actividad de la organización jurídico-política por antonomasia. 
Esta obra forma parte del acervo de la Biblioteca Jurídica Virtual del Instituto de Investigaciones Jurídicas de la UNAM

se quiere decir-, culturales de cada pueblo, su lengua, su pasado e historia particulares, no puede ser suplantados por esta visión estándar a que nos referimos. Cada pueblo es también único.

Lo que intentamos señalar es que el proceso de identización ${ }^{11}$ (la vieja globalización) nos ha hecho iguales; más bien, nos ha acercado a la comprensión y al convencimiento de que todos somos iguales. ${ }^{12}$

La Constitución mexicana debe prohijar e impulsar reciamente este principio.

\section{PRospectiva}

Una vez identificados los grandes vectores que guían y dan cuerpo a lo constitucional de México, creemos que en la lista que sigue podemos identificar los contenidos del nuevo diseño que un constituyente debe considerar al momento de llevar a cabo los trabajos de revisión constitucional.

\section{Constitución para potenciar la vida digna ${ }^{13}$}

A. NUEVOS DERECHOS: (... a la luz de la tesis de los derechos adquiridos o "sobre los derechos humanos imprescriptibles")

11 Ante la falta de una expresión lingüística más adecuada, nos permitimos acuñar ésta (casi un barbarismo) que - paradójicamente-, puede desbastar nuestras malformaciones culturales y prejuicios, desde el momento mismo en que comprendemos que el otro -sin importar nacionalidad, raza, condición económica, religiosa, etc.-, es tan idéntico a nosotros que cualquier agravio a él, es una afrenta a nosotros y a toda la humanidad. Tal vez esto explique la solidaridad y los sentimientos de cercanía y dolor con las víctimas de los atentados terroristas - en París, en Bélgica o en Estados Unidos - y con los que mueren a causa de la miseria, el narcotráfico o la guerra en Siria, en Etiopía o en México. Como podemos ver, el término utilizado en la antropología cultural, poco tiene que ver con la ontología de la construcción del individuo; sobre esto puede verse Gómez Redondo, Carmen, "Identización: la construcción discursiva del individuo", en Arte, individuo y sociedad, volumen 24, número 1, 2012, Universidad Complutense de Madrid

12 Una opinión diferente es del tenor siguiente: "El proceso e identificación de lo humano está además, como puede suponerse, condicionado por intereses parciales y por ideologías. Así se ha construido un "ser humano europeo u occidental", al que se pretende elevar a categoría universal e imponer a otras sociedades de culturas muy distintas", López Calera, Nicolás, "¿y si los derechos humanos no tienen un puesto en el derecho”, en Squella, Agustín y López Calera, Nicolás, Derechos humanos: ¿invento o descubrimiento?, Fundación Coloquio Jurídico Europeo, Fontamara, México, 2010, p. 114

13 "El desarrollo de la cultura está vinculado estrechamente a una progresiva toma de conciencia de la dignidad humana", Olmeda García, Marina del Pilar, Universalización de los derechos humanos, Bosch, México, 2014, p. 160 
Esta obra forma parte del acervo de la Biblioteca Jurídica Virtual del Instituto de Investigaciones Jurídicas de la UNAM

a. El derecho fundamental al agua potable y a la tierra cultivable

$b$. El derecho fundamental a la recreación y el deporte

c. El derecho fundamental de acceso a la cultura

$d$. El derecho fundamental a la inclusión social

e. El derecho fundamental a la información

$f$. El derecho fundamental a migrar

g. El derecho fundamental a la familia

B. NUEVAS GARANTÍAS

a. Proceso constitucional de provisión

b. Juicio de Amparo cultural

c. Hábeas Data

d. Hábeas Familiae

\section{Constitución para atenuar la miseria}

a. Políticas públicas de tipo preventivo

b. Políticas públicas de tipo correctivo

3. Constitución para la Paz (convivencia humana, solidaridad e inclusión)

4. Constitución para impulsar y hacer florecer la cultura (un rico pasado, un futuro promisorio en acción)

a. Pluralidad cultural y pervivencia étnica

$b$. Tradiciones y lenguas (tesoro inmanente e inmaterial)

5. Constitución para el Desarrollo y el Bienestar

a. El petróleo y otros males

b. La cuestión agraria (regeneración agraria)

c. De cara al mar (industria pecuaria, astilleros)

d. Desarrollo sustentable (energía eólica, solar, etc., alimentación, ecología)

e. Acrecentamiento de la patria (definiciones territoriales, no provincias, no secesión) 
Esta obra forma parte del acervo de la Biblioteca Jurídica Virtual del Instituto de Investigaciones Jurídicas de la UNAM

Ulteriores desarrollos científicos nos mostrarán los vericuetos de estos ásperos caminos, todavía no descubiertos, ni inventados, ni hollados.

Por ahora es suficiente con decir que los grandes trazos de esta visión prospectiva, deben tener en el instrumentos llamado Constitución la herramienta, la maquinaria, la técnica y la ciencia para volverlo asequible.

\section{ENTREVERAMIENTO}

En vía de conclusión general de todo lo antes expresado, podemos plantear el siguiente ejercicio dialéctico:

LO CONSTITUCIONAL TIENE GARÁGTER BIFRONTE Y NATURALEZA COMPLEJA

1. Por un lado, el necesario artificio ideado para su conocimiento, comprensión y aplicación, se da en la vertiente del lenguaje,

LENGUAJE que se plasma en

LA NORMA (enunciado y prescripción)

LENGUAJE, enunciado y prescripción que se acuñan en

EL CÓDIGO (corpus que llamamos Constitución)

2. Por otra parte, lo constitucional es mirado con una mirada cercana a la presbicia

La visión concéntrica focaliza esta categoría en

EL ESTADO (derrotero, concreción, espacio y límite de lo constitucional)

Luego entonces, lenguaje limitado y visión errática, nos han llevado a una pobrísima concepción de lo constitucional y, en consecuencia, a una vida jurídico-política-social poco propicia para el desarrollo y la acción. Ergo, las transformaciones sociales deben pasar la criba de la reforma constitucional; de lo contrario, si los fenómenos sustantivos y las demandas ciudadanas, no se suben al lenguaje del texto constitucional en el marco del Estado, no son nada; no existen desde el punto de vista constitucional y, evidentemente, tampoco pueden ser alegados ni sostenidos como algo valioso para la sociedad mexicana. 
Esta obra forma parte del acervo de la Biblioteca Jurídica Virtual del Instituto de Investigaciones Jurídicas de la UNAM

Esto choca abiertamente con las mutaciones constitucionales ${ }^{14}$ (por lo menos con las de naturaleza fáctica); pues mientras los fenómenos de la realidad se agitan vivamente y producen importantes transformaciones, la Constitución-código, permanece inalterada e inmóvil en los límites de sus letras.

Por eso, poco fluye la vida cotidiana a través del articulado rígido y cerrado del texto constitucional.

En consecuencia, nos parece que las tareas de reingeniería constitucional del constituyente mexicano, deben comenzar por la superación del reducto intelectual que nos ha aprisionado en la ignara y primitiva concepción de lo constitucional, sólo en el texto de la Carta Magna, sólo en letras porque solamente éstas puedan ser manifestación inequívoca de lo que merece ser llamado o categorizado como "algo" constitucional y sólo desde la antañona referencia al Estado-territorio (aunque éste se halle en crisis y resquebrajado).

El reto intelectual es volver permeable lo que es tangible: permitir la absorción e incorporación de lo constitucional al texto normativo-constitucional.

El nuevo diseño constitucional aquiescente con esta necesidad, tendrá que poner especial atención en la posibilidad y pertinencia de que México adopte una nueva forma de aprehensión de los fenómenos que permita su pronta incorporación al texto de la Carta Magna.

Tendremos que diferenciar para ello, el núcleo constitucional (la verdadera constitución) de lo constitucional accesorio.

Este puede ser el homenaje pertinente, la celebración mesurada, el festejo propicio para el pueblo de México, no para la Constitución que -siendo texto-, es a fin de cuentas instrumento para la vida humana de los mexicanos de hoy, de ahorita y de los que todavía no nacen y que seguramente querrán nacer y vivir en un país de cimientos y textura constitucional.

\section{FUenTES DE CONSULTA}

Covián Andrade Miguel, Teoría constitucional, Centro de Estudios de Ingeniería Política y Constitucional, México, 2004.

14 Esta temática la hemos abordado en otro trabajo; Vid., Uribe Arzate Enrique y Correa Esquivel, Grisel Alejandra, "Mutaciones constitucionales y la problemática de su control en el Estado constitucional”, en Revista de Derecho, número 38, julio-diciembre de 2012, Universidad del Norte, Barranquilla, Colombia. 
Esta obra forma parte del acervo de la Biblioteca Jurídica Virtual del Instituto de Investigaciones Jurídicas de la UNAM

FERRAJOLI, Luigi, La democracia a través de los derechos, el constitucionalismo garantista como modelo teórico y como proyecto político, Trotta, Madrid, 2014.

Gómez REDOndo, Carmen, "Identización: la construcción discursiva del individuo", en Arte, individuo y sociedad, volumen 24, número 1, 2012, Universidad Complutense de Madrid.

Kelsen, Hans, et. al., Ficciones jurídicas, Fontamara, México, 2013.

López CaLera, Nicolás, “ ¿y si los derechos humanos no tienen un puesto en el derecho", en Squella, Agustín y López Calera, Nicolás, Derechos humanos: ¿invento o descubrimiento?, Fundación Coloquio Jurídico Europeo, Fontamara, México, 2010.

Olmeda García, Marina del Pilar, Universalización de los derechos humanos, Bosch, México, 2014.

Ruiz SoroA, José María, El esencialismo democrático, Trotta, Madrid, 2010.

SERNA DE LA GARZA, José María, El sistema federal mexicano, UNAM, Instituto de Investigaciones Jurídicas, México, 2008.

URIBE ARZATE, Enrique, "Una aproximación epistemológica a la dimensión vivencial pragmática de los derechos humanos", en Boletín Mexicano de Derecho Comparado, volumen 44, número 132, UNAM, Instituto de Investigaciones Jurídicas, México, 2011. xico, 2006 .

URIBE Arzate Enrique y Correa Esquivel, Grisel Alejandra, "Mutaciones constitucionales y la problemática de su control en el Estado constitucional", en Revista de Derecho, número 38, julio-diciembre de 2012, Universidad del Norte, Barranquilla, Colombia.

Uribe ARZATE, Enrique y De Paz González, Isaac, "Los efectos de los derechos fundamentales en el tiempo", en Boletín Mexicano de Derecho Comparado, Nueva Serie, año XLVIII, número 144, septiembre-diciembre de 2015, UNAM, Instituto de Investigaciones Jurídicas, México.

Von Humboldt, Wilhelm, Los límites de la acción del Estado, Tecnos, Madrid, 2009. 
Esta obra forma parte del acervo de la Biblioteca Jurídica Virtual del Instituto de Investigaciones Jurídicas de la UNAM

\title{
LA DINÁMICA DEL CAMBIO CONSTITUCIONAL EN SINALOA Y LA PROTEGGIÓN DE LOS DEREGHOS HUMANOS DE LA POBLACIÓN INDÍGENA
}

\author{
Gonzalo ARMIENTA HERnÁNDEZ* \\ Karla Elizabeth MARISCAL URETA**
}

\begin{abstract}
SUMARIO: I. Introducción. II. Origen y la función de la Constitución. III. La Constitución como ley suprema. IV. El control constitucional. V. Facultades reservadas a la federación y facultades de los Estados. VI. Los nuevos paradigmas constitucionales. VII. La protección de los derechos de los pueblos indígenas en el constitucionalismo local en Sinaloa. VIII. Conclusiones. IX. Bibliografia.
\end{abstract}

\section{INTRODUCAIÓN}

El control constitucional puede entenderse como aquellos mecanismos previstos por la propia norma constitucional para asegurar su vigencia y el éxito de su cumplimiento, de tal manera que sin control no se garantiza la tutela efectiva de los derechos que ampara la ley fundamental. Así púes, en momentos de reflexión sobre el camino y el destino del constitucionalismo resulta significativo no perder de vista que lo principal en la Constitución es el orden democrático que establece los límites del poder y legitima a sus órganos, y además instrumenta los mecanismos adecuados para garantizar su aplicación.

Es importante destacar la estrecha relación que guardan los paradigmas, los derechos y los principios constitucionales, y que son éstos los que sostienen la estructura de gobierno y del propio Estado, por ello, si están reconocidos por el texto constitucional federal, en una federación deben a su vez cumplirse por y en los Estados federados, e incluirse en los textos constitucionales locales, de lo contrario la omisión legislativa de origen local transgrede el principio de la supremacía constitucional y el propio principio democrático del Estado. 
Esta obra forma parte del acervo de la Biblioteca Jurídica Virtual del Instituto de Investigaciones Jurídicas de la UNAM

\section{ORIGEN Y FUNGIÓN DE LA CONSTITUCIÓN}

Hablar del origen y la función del texto fundamental 'Constitución', nos remite necesariamente a hacer un poco de historia, tomando de referente a la constitución de Filadelfia de 1787 la cual derivó de la Declaración de independencia de los Estados Unidos que fue promulgada en 1776, misma que podemos catalogar como la primera constitución moderna.

En este orden de ideas, Miguel Carbonell, nos comenta que el fundamento de la Declaración es contractualista, pues su justificación atendió principalmente a tres factores:

a) la noción de convenant de las colonias importantes de Inglaterra; los convenants servían para determinar el origen de algunas comunidades religiosas y la adhesión a ellas por parte de sus miembros; b) el funcionamiento en los primeros territorios colonizados de las compañías por acciones que habían financiado las expediciones de colonización; y c) la necesidad de alcanzar un autogobierno, que debía surgir de un rechazo al poder de la monarquía y que, en algún sentido, tenía que ser creado en el vacío. ${ }^{1}$

La referida Declaración de Independencia no constituía un listado de artículos sino más bien postulados en su mayoría derivados del derecho natural. Destacan los tres aspectos antes mencionados, los que constituyen los cimientos de los derechos humanos y de la forma de gobierno democrática esencia de todas las constituciones modernas, lo cual se corrobora en la siguiente cita textual de la Declaración:

....sostenemos como evidentes por sí mismas dichas verdades: que todos los hombres son creados iguales; que son dotados por su Creador de ciertos derechos inalienables; que entre estos están la vida, la libertad y la búsqueda de la felicidad; que para garantizar estos derechos se instituyen entre los hombres los gobiernos, que derivan sus poderes legítimos del consentimiento de los gobernados ${ }^{2}$

Como se puede apreciar el tema de los derechos humanos y de la forma de gobierno se trata de manera directa en la Declaración, reconociendo como un derecho natural el derecho a la vida, a la libertad y a la búsqueda

1 Carbonell, Miguel, Introducción al derecho constitucional, México, Tirant lo Blanch, 2015, p. 14 .

2 Véase http://biblio.juridicas.unam.mx/libros/6/2698/22.pdf, consultada el 14 de diciembre 2015 . 
Esta obra forma parte del acervo de la Biblioteca Jurídica Virtual del Instituto de Investigaciones Jurídicas de la UNAM

de la felicidad y como un derecho positivo, el que proviene de los hombres, cuando crean instituciones como lo es el gobierno, para proteger éstos derechos naturales, con lo cual se da nacimiento a la parte dogmatica y orgánica de las actuales constituciones.

De ninguna manera podemos soslayar otro antecedente de nuestra Constitución, ya que muchos postulados de la denominada parte dogmática se basaron en el mismo, me refiero a la Declaración de los Derechos del Hombre y del ciudadano, del 26 de agosto de 1789, que derivó de la Revolución francesa.

Coincidiendo con Miguel Carbonell ${ }^{3}$, la citada Declaración conjuntamente con la Constitución Federal de los Estados Unidos de 1787 representa una especie de acta de nacimiento del constitucionalismo. Lo anterior, en virtud de que fue el primer documento que recogió de manera estructurada la forma de gobernó y las aspiraciones de entonces sociedad americana traducidas en derechos.

Ahora bien, podemos encontrarnos con un gran número de definiciones de lo que se considera Constitución, desde aquellas con contenido meramente enunciativo hasta con contenido filosófico. Héller citado por Vanossi ${ }^{4}$ sostiene que la Constitución sólo puede ser entendida en una concepción total, la cual abarca dos elementos imprescindibles, éstos son la constitución no normada y la constitución normada, señalando que la primera pertenece al ámbito de la normalidad, esto es el mundo del ser lo cual quiere decir que es objeto de ciencia de la realidad la cual está formada por motivaciones naturales comunes como la tierra, la sangre, el contagio síquico, la imitación y la comunidad de historia y de cultura, y que la constitución normada pertenece al ámbito de la normatividad al mundo del deber ser, siendo objeto de la ciencia cultural que la estudia mediante la dogmática del derecho.

De la misma manera Vanossi haciendo un estudio más amplio del razonamiento de Heller, analiza el concepto de lo que se debe entender por Constitución y señala que:

...la constitución normada, puede ser constitución normada extrajurídicamente y constitución normada jurídicamente. La primera (normada extrajurídicamente) consiste en principios éticos del derecho, tales como la costumbre, la moral, la religión, la urbanidad y la moda. Estos principios resultan imprescindibles como normas sociales de ordenación y como coadyuvantes

3 Carbonell, Miguel, op. cit., p. 20.

4 Vanossi, J., Teoría Constitucional, Argentina, De Palma Editores, 2000, p. 105 
Esta obra forma parte del acervo de la Biblioteca Jurídica Virtual del Instituto de Investigaciones Jurídicas de la UNAM

en la labor interpretativa de los jueces. O sea que se trata de una normatividad extrajurídica: sea social o convencional. La segunda (normada jurídicamente) es la constitución organizada, es decir, la constitución normada por el derecho conscientemente establecido y asegurado. En el terreno de esta última "constitución" se habla, según los casos, de "constitución jurídica destacada" de "constitución jurídica objetivada" y, en sentido muy restringido, de "constitución escrita". 5

Carpizo citando a Carl Schmitt refiere a la Constitución en sentido relativo y en sentido positivo manifestando lo siguiente:

La Constitución en sentido relativo significa la ley constitucional que atiende a un criterio formal, es decir, no interesa la importancia de las normas que contenga esa Carta Magna, sino por el hecho de estar esas reglas en el Código Supremo, estos preceptos tienen la categoría de constitucionales. La importancia del sentido relativo estriba en que los preceptos constitucionales generalmente siguen un proceso más complejo para su modificación que las leyes secundarias. A su vez, el sentido positivo de Constitución significa "decisión política del titular del poder constituyente" son determinaciones, decisiones que afectan al mismo ser social. Las decisiones fundamentales son los principios rectores del orden jurídico. Los que marcan y señalan el ser del orden jurídico, son la esencia misma de ese derecho. ${ }^{6}$

Miguel Carbonell al definir la Constitución se refiere a que existen conceptos absolutos, relativos, positivos, ideales, pactistas, históricos, sociológicos, materiales, racional-normativos, entre otros, y el por su parte la define desde tres puntos de vista como:

...un ordenamiento jurídico de tipo liberal; como un conjunto de normas jurídicas que contiene las disposiciones en algún sentido fundamentales de un Estado; como un documento normativo que tiene ese nombre; y como una norma dotada de ciertas características, es decir, que tiene un régimen jurídico particular. ${ }^{7}$

Podemos seguir citando un importante número de definiciones, sin embargo, con las anteriormente analizadas nos podemos dar una idea clara de sus diferentes acepciones en donde se concluye que debe ser el Código

\footnotetext{
5 Ibidem, p. 106.

6 Carpizo, Jorge, Estudios constitucionales, México, UNAM, Instituto de Investigaciones Jurídicas, 1983, p. 47.

7 Carbonell, Miguel, op. cit., p 44.
} 
Esta obra forma parte del acervo de la Biblioteca Jurídica Virtual del Instituto de Investigaciones Jurídicas de la UNAM

supremo que rige a una sociedad y que se encuentra por encima de las demás leyes internas de un país, que tiene sentido contractual en tanto los ciudadanos ceden un poco de su soberanía para constituir el poder público organizado a través de la norma que se tiene a bien llamar 'Constitución' en la cual se pacta la forma de gobierno y su representación así como los derechos reconocidos y las formas de su defensa y del propio orden propuesto en la norma fundamental, como se dice, es el gran pacto o contrato social que envuelve al Estado.

Al respecto, se han establecido por los constitucionalistas dos tipos de Constituciones: las abiertas y las cerradas, las rígidas y las flexibles

Referente indispensable para analizar el modelo de constituciones abiertas es Zagrebelsky que considera que para que estemos ante la presencia de una verdadera constitución abierta, se requiere que permita la espontaneidad de la vida social y reconozca la constante evolución de la sociedad bajo el principio de ciencias sociales conocido como la dialéctica. Así entonces, Zagrebelsky señala textualmente en su libro El Derecho Dúctil: “...constituciones abiertas, constituciones que permitan, dentro de los límites constitucionales, tanto la espontaneidad de la vida social como la competición para asumir la dirección política, condiciones ambas para la supervivencia de una sociedad pluralista y democrática." 8

Luego entonces, se puede apreciar que una Constitución abierta se reafirma democrática cuando no establece valores absolutos, pues los valores absolutos son propios de sistemas dictatoriales, es por ello que si queremos aspirar a la formación de Estados democráticos es indispensable que cuenten con constituciones abiertas.

En contraste, las Constituciones rígidas son aquellas que cuentan con un procedimiento especial para su reforma y no obstante, la gran cantidad de reformas del ordenamiento constitucional, mientras dichas reformas se lleven a cabo a través del procedimiento especial siguen siendo Constituciones rígidas. En el caso de la Constitución Federal de México, el artículo 135 establece que puede ser adicionada o reformada siempre que “...el Congreso de la Unión, por el voto de las dos terceras partes de los individuos presentes, acuerden las reformas o adiciones, y que éstas sean aprobadas por la mayoría de las legislaturas de los Estados." Por lo que, pese a muchas reformas nuestra Constitución sigue considerándose rígida.

8 Zagebelsky, Gustavo, El derecho dúctil, España, Editorial Trotta, 1995, p. 14. 
Esta obra forma parte del acervo de la Biblioteca Jurídica Virtual del Instituto de Investigaciones Jurídicas de la UNAM

\section{LA CONSTITUCión COMO LEY SUPREMA}

La constitución de un país es su norma fundamental, ya que se encuentra por encima de las demás normas las cuales se pueden considerar como secundarias frente a la constitución, autores como Eduardo Espin son muy claros al señalar que todas las demás normas del ordenamiento jurídico son normas secundarias ya que esta deriva del poder constituyente:

Frente a la Constitución, en tanto que normas cuya validez deriva de una decisión del poder constituyente, todas las demás normas integrantes del ordenamiento jurídico son normas secundarias, pues su validez se fundamenta en la propia Constitución, al estar elaboradas de acuerdo con las prescripciones de ésta tanto en relación con el procedimiento como con su contenido material. ${ }^{9}$

Congruente con estas ideas vinculadas a que la Constitución es una ley suprema por provenir de una decisión del constituyente el investigador peruano Palomino Manchego nos indica que:

En la medida que el constituyente es resultado de la intención popular depositada en el poder soberano que la representa, su significado es mucho más relevante que el de cualquier otra expresión jurídica. Ninguna otra norma puede, por consiguiente, equiparársele, pues toda expresión de derecho que no tenga su nacimiento en la voluntad constituyente carece de los mismos supuestos de legitimidad que acompañan a una Constitución. ${ }^{10}$

A raíz de la reforma constitucional en el capítulo primero denominado: de los derechos humanos, mucho se ha discutido cual es la norma fundamental de un país, si son los tratados internacionales o la Constitución. Al respecto, la interpretación conforme, significa que los tribunales al resolver un asunto deben de buscar una interpretación de la norma incompatible con la ley suprema conforme a la propia ley suprema, así lo señala Espín:

El principio de interpretación conforme a la Constitución supone, en primer lugar, que los poderes públicos y, muy especialmente, los tribunales deben de

9 López Guerra, Luis, Espin Eduardo y otros, Derecho Constitucional, España, Tirant lo Blanch, 2003, p. 44.

10 Palomino Manchego, José F., Constitución, supremacía constitucional y teoría de las fuentes del derecho, en Memoria del X Congreso Iberoamericano de Derecho Constitucional, Lima, Instituto Iberoamericano de Derecho Constitucional, 2009, p. 261. 
Esta obra forma parte del acervo de la Biblioteca Jurídica Virtual del Instituto de Investigaciones Jurídicas de la UNAM

buscar en lo posible, antes de considerar una norma incompatible con la norma suprema, una interpretación de la misma conforme a la Constitución. ${ }^{11}$

Desde un punto de vista global de protección a los derechos humanos, la interpretación conforme nos conduce a interpretar la norma no sólo conforme al ordenamiento constitucional sino también a los tratados internacionales dándole mayor contenido a la supremacía constitucional, pues hoy las constituciones nacionales no solo reconocen y protegen derechos humanos nacidos en el orden interno sino también aquellos que provienen de fuente supranacional y que al estar contenidos en tratados internacionales son norma suprema pues forman parte del constitucionalismo. Lo que indica que los derechos humanos son universales por ello, deben ser aplicables al ser humano sin importar fronteras, Ruipérez es atinado al considerar lo siguiente:

...el proceso de globalización depara también la inviabilidad del principio de supremacía constitucional. La Constitución, en efecto, deja de ser en la actualidad aquella norma jurídica suprema que, como tal, se impone por igual a gobernantes y a gobernados, y respecto de la cual todas las demás normas jurídicas, cualquiera que sea su forma y origen, se encuentran subordinadas y han de ceder, en caso de conflicto, ante ella. ${ }^{12}$

Congruente con lo anterior la supremacía constitucional no se opone a la protección supranacional de los derechos humanos, por ello el Derecho Internacional de los Derechos Humanos encuentra cabida en el Derecho Constitucional, vinculándose cada vez más, con criterios que protejan de una forma más integral a la persona, así estamos frente a una nueva paradoja de la soberanía, pues en el ejercicio soberano de una nación se decide suscribir determinado pacto internacional por ello, es parte de su orden normativo nacional y debe cumplirse bajo el principio de 'pacta sun servan$d a^{\prime}$, pero también de la defensa de la Constitución.

\section{EL CONTROL CONSTITUCIONAL}

$\mathrm{El}$ orden jurídico constitucional para mantenerse vigente necesariamente requiere que exista un órgano de control constitucional que sea el que de-

11 López Guerra, Luis, op. Cit., p. 45.

12 Ruipérez, Javier, El constitucionalismo democrático en los tiempos de la globalización, México, Universidad Nacional Autónoma de México, 2005, p. 196. 
Esta obra forma parte del acervo de la Biblioteca Jurídica Virtual del Instituto de Investigaciones Jurídicas de la UNAM

termine si las normas secundarias se encuentran acorde con la ley suprema, y si ésta propia ley no se vulnera con las reformas a la Constitución, al respecto Espin indica:

...en los sistemas continentales, admitida la superioridad de la norma constitucional en tanto que obra del poder constituyente a la que debe ajustarse la actuación de todos los poderes públicos, incluido el legislativo, se impone la necesidad ineludible de establecer un sistema de control de la constitucionalidad de las normas, en especial de las leyes, para evitar que contradigan cualquier precepto constitucional. ${ }^{13}$

Luego entonces, los medios de control constitucional han dado nacimiento a una nueva rama del derecho denominada Derecho Procesal Constitucional, el cual precisamente nace con el caso Marbury versus Madison con la sentencia trascendental emitida por el juez Marshall en el año 1803, sin embargo, no se le puede quitar mérito a Hans Kelsen, el cual denominó a esta disciplina del derecho como justicia constitucional, y a Mauro Cappelletti que la estructuró científicamente.

Zagrebelsky ${ }^{14}$ al referirse a las diversas concepciones del control de constitucionalidad de leyes señala dos tipos básicos de control el referente al modelo francés y al norteamericano, por lo que hace al modelo francés señala que se ha desarrollado como instrumento de tutela objetiva de la Constitución más que como garantía de los derechos debido a que se ha mantenido durante mucho tiempo el dogma de la omnipotencia de la asamblea parlamentaria y de la ley y porque además el gobierno de los jueces se considera como la peor de las aberraciones constitucionales ${ }^{15}$. Por lo que se refiere al modelo Norteamericano o control de constitucionalidad de derecho subjetivo establece que en este modelo tiene lugar en procedimientos judiciales sobre controversias que afectan de manera concreta a los derechos de las partes y en los que las razones del legislador no encuentran ningún espacio de defensa autónoma.

En síntesis, podemos concluir que en el modelo francés no importa el derecho subjetivo de las partes que pudieran haber propiciado el control de la constitucionalidad de la ley y en el modelo Estadounidense para que exista el control de la constitucionalidad se requiere que exista una controversia y por lo tanto la existencia de derechos subjetivos y el órgano de control analizará el caso concreto controvertido.

13 López Guerra, Luis, op. cit., p.45.

14 Ibidem, p. 62.

15 Zagrebelsky, Gustavo, op. cit., p. 61. 
Esta obra forma parte del acervo de la Biblioteca Jurídica Virtual del Instituto de Investigaciones Jurídicas de la UNAM

Este es un tema especialmente polémico, pues existen diversas opiniones sobre el órgano que debe ejercer el control, desde los ideólogos que señalan que ni el Poder Ejecutivo ni el judicial pueden ser órganos de control constitucional de las leyes ya que de permitirlo se rompería la independencia e igualdad de los tres poderes hasta los que nos enseñan que el Poder Judicial es el idóneo para ejercer el control constitucional de las Leyes.

La corriente de pensamiento mayormente aceptadas en la última década de 1700 fueron las que consideraron que en lugar de reclamar el ejercicio de un control judicial los tribunales consideraban que las leyes inconstitucionales eran nulas y que la Constitución era aplicable tanto al poder judicial como a los otros poderes.

El propio Kramer en su obra Constitucionalismo popular y control de constitucionalidad cita un extracto de la acusación del Juez de la Corte Peterson en Vanhorne's Lessee v. Dorrance:

Considero que es una posición clara; que si una ley del legislativo pone en cuestión un principio constitucional, la primera debe ceder, y ser rechazada con fundamento en su incompatibilidad. Entiendo que se trata de una posición igualmente clara y saludable, que en el caso será el deber de la Corte respetar la Constitución, y declarar la ley nula o invalida. La Constitución es el fundamento de la autoridad legislativa; ella reside en los cimientos de toda ley y es una regla y un comando que debe guiar tanto a los Legisladores como a los jueces. Es un principio importante, que, en la discusión de cuestiones de este tipo, jamás debe perderse de vista, que en este país, el Poder Judicial no es un subordinado, sino un poder coordinado, del gobierno. ${ }^{16}$

Destacan en este tipo de discusiones los juristas Estadounidenses con opiniones como las de Spencer Roane, citado por Kramer, el cual expuso que era ilógico decir que los jueces debían permanecer ciegos ante las consideraciones constitucionales. ${ }^{17}$

También existía una corriente de opinión en la cual se argumentaba que el poder judicial no podía tener un control constitucional, y al respecto Zephaniah Swift enfatizaba que el poder legislativo no puede estar bajo el control del poder judicial:

Los legislativos no están bajo el control o la superintendencia del poder judicial, si aprobaran leyes inconstitucionales, serían responsables ante el pueblo,

16 Kramer, Larry D., Constitucionalismo populary control de constitucionalidad, España, Marcial Pons, 2011 , p. 137.

17 Ibidem, p. 133. 
Esta obra forma parte del acervo de la Biblioteca Jurídica Virtual del Instituto de Investigaciones Jurídicas de la UNAM

que podría destituir de sus puestos a los legisladores en el curso de elecciones y designar personas que derogaran las leyes inconstitucionales. Su seguridad contra todo cercenamiento depende de este poder del pueblo sobre el legislativo, y no de la vigilancia del departamento judicial. ${ }^{18}$

El caso Marbury Vs Madison consistió en un proceso judicial derivado de una querella política como consecuencia de las elecciones presidenciales de 1800, que se instauró ante la Corte Suprema de los Estados Unidos el cual fue resuelto el 24 de febrero de 1803, en cuya sentencia se afirma la capacidad para realizar el denominado control de constitucionalidad por parte de los tribunales judiciales, es decir la capacidad del poder judicial para dejar sin efectos una ley contraria a la Constitución.

En países como México en donde existe una clara división de poderes el control constitucional no puede ser absoluto pues nos encontramos competencias como la política en donde el medio de control constitucional por excelencia, el juicio de amparo es improcedente como en el modelo Estadounidense, sin embargo, en países como Francia el control de la constitución es en todo tipo de asuntos, lo cual es entendible pues el órgano de control constitucional se encuentra al margen de la separación de poderes.

Lo anterior resulta paradójico ya que el principio de separación de poderes surge precisamente en Europa y es en los Estados Unidos de Norte América en donde esta separación se le sigue considerando casi como un dogma.

$\mathrm{Al}$ respecto Claude Tron nos dice que, "una característica que distingue a los sistemas judiciales en los Estados Democráticos de Derecho, es precisamente el contar con medio de control constitucional que le permita al ciudadano defender sus derechos fundamentales, frente a los actos de autoridad que los restrinjan, transgredan o vulneren" ${ }^{19}$

En México nuestra carta fundamental es clara en señalar cuales son esos medios de control, señalando al juicio de amparo, las acciones y controversias constitucionales, el juicio de revisión constitucional y de protección de derechos políticos electorales, el juicio político, la facultad de investigación de la Suprema Corte y el Ombudsman. A éstos medios de control constitucional se les encuentra inmersos en el denominado Derecho Procesal Constitucional.

18 Ibídem, p. 138.

19 Claude Tron, Jean, “¿Qué hay del interés legítimo? (Primera parte), Revista del instituto de la fudicatura Federal, México, Poder Judicial de la Federación, Instituto de la Judicatura Federal, No. 33, 2012, p. 271. 
Esta obra forma parte del acervo de la Biblioteca Jurídica Virtual del Instituto de Investigaciones Jurídicas de la UNAM

Uno de los juristas que más ha aportado a esta nueva rama del derecho es Fix Zamudio y ha definido al Derecho procesal constitucional como la “...disciplina científica que estudia los instrumentos establecidos en los diversos ordenamientos jurídicos para la resolución de los conflictos o controversias de carácter estrictamente constitucional, ya sea que dicha decisión se encomiende a los tribunales especializados en sentido propio, o bien a los tribunales de mayor jerarquía o inclusive a los jueces ordinarios......al menos en sus primeras etapas" ${ }^{20}$

De conformidad a lo señalado por Gil Rendón ${ }^{21}$ el objeto del Derecho Procesal Constitucional es el estudio de las garantías constitucionales y su finalidad el conocimiento de las normas jurídicas que regulan los procesos y procedimientos constitucionales que dirimen controversias, conflictos o cuestiones constitucionales.

El artículo 105 de la Constitución Política Mexicana es el sustento de nuestro Derecho Procesal Constitucional conjuntamente con el 103 y 107 sustento de nuestro juicio de amparo. Y en concordancia, podemos señalar tres figuras básicas de control de constitucionalidad en México: las controversias constitucionales, la acción de inconstitucionalidad y el juicio de amparo.

Sobre estas cuestiones del control constitucional en México se ha producido una verdadera dinámica del cambio, sobre todo en materia de acciones de inconstitucionalidad al permitirles ser parte a los partidos políticos para la materia electoral y a las Comisiones de Derechos Humanos en lo relativo a leyes que contravengan derechos humanos constitucionales, así como en materia de amparo a la luz de las reformas constitucionales de 2011 y en derechos humanos y de la nueva Ley de Amparo.

En corolario, la Constitución como presupuesto fundamental del Estado para ser real garante del orden pactado, debe estar provista de garantías o procesos constitucionales que aseguren el reconocimiento y respeto a los derechos en ella contenidos, así como a los de fuente internacional, además de restituir el orden constitucional cuando éste haya sido quebrantado, por lo tanto, los esquemas de protección y justicia constitucional deben diseñarse en armonía y ser eficaces para la defensa efectiva de los derechos.

20 Fix Zamudio, Héctor, Breves reflexiones sobre el concepto y contenido del derecho procesal constitucional, en el libro Derecho procesal constitucional, México, Colegio de secretarios de la Suprema Corte de Justicia de la Nación, 2001, p.94.

21 Gil Rendón, Raymundo, El nuevo Derecho Procesal Constitucional, México, Editorial UBIJUS, 2012, p. 27. 
Esta obra forma parte del acervo de la Biblioteca Jurídica Virtual del Instituto de Investigaciones Jurídicas de la UNAM

No obstante, tratándose del control constitucional a través del juicio de amparo, tenemos que al restringirse el amparo para las reformas constitucionales se vulnera el principio de supremacía en tanto que se expone a la voluntad de legislador el contenido de la norma fundente del Estado. Lo cual es un riesgo significativo para el mantenimiento del orden constitucional y los derechos que éste protege. Fenómeno que se está advirtiendo en temas estructurales como explotación minera, energéticos, recursos naturales, entre otros.

\section{FACULTADES RESERVADAS A LA FEDERAGIÓN Y FACULTADES DE LOS ESTADOS}

$\mathrm{El}$ sistema federal es un pacto que se establece en el texto constitucional con la expresión de la voluntad de pueblo a través de sus representantes, puede decirse que en el convergen dos órdenes jurídicos, uno central que funciona como eje y otro complementario que en conjunto estructuran el Estado. Así éstos dos órdenes buscan cumplir con al menos dos funciones, por un lado separar y delimitar el poder público a través de una división vertical de dicho poder y proteger a las minorías como integrador de la sociedad.

El sistema federal en México, se enuncia en principio de conformidad al artículo 124 constitucional, que nos dice que aquellas facultades que no están expresamente concedidas por esta Constitución a los funcionarios federales, se entienden reservadas a los Estados, lo cual se ha considerado como la manera en que la Constitución distribuye las competencias entre Estados y Federación.

$\mathrm{El}$ artículo 124 constitucional no se puede interpretar como un precepto aislado pues se encuentra íntimamente vinculado con los artículos $40 \mathrm{y}$ primer párrafo del artículo 41 de la misma Constitución que establecen

Artículo 40. Es voluntad del pueblo mexicano constituirse en una República representativa, democrática, laica, federal, compuesta de Estados libres y soberanos en todo lo concerniente a su régimen interior; pero unidos en una federación establecida según los principios de esta ley fundamental

Artículo 41. El pueblo ejerce su soberanía por medio de los Poderes de la Unión, en los casos de la competencia de éstos, y por los de los Estados, en lo que toca a sus regímenes interiores, en los términos respectivamente establecidos por la presente Constitución Federal y las particulares de los Estados, las que en ningún caso podrán contravenir las estipulaciones del Pacto Federal 
Esta obra forma parte del acervo de la Biblioteca Jurídica Virtual del Instituto de Investigaciones Jurídicas de la UNAM

Como se puede apreciar de la lectura de estos artículos la competencia para gobernar en México no sólo corresponde a la federación y a las entidades federativas pues la competencia originaria le corresponde al pueblo por medio de los poderes de la unión y de los poderes de los Estados. Al respecto señala Barragán Barragán:

Son los habitantes de las entidades locales, los que, en su condición de pueblo estable y determinado; o en condición de nación en estado de constituyente, detentan la soberanía absoluta, en primer lugar, son también los que, en segundo lugar, se erigen en asamblea constituyente; son los que, en tercer lugar, resuelven aprobar una determinada Constitución; y, por último, son los que determinan ejercer dicho poder de soberanía por medio de los poderes de la Federación y por medio de ,os poderes de las entidades locales. ${ }^{22}$

Se infiere del artículo 124 que las facultades que le otorga la Constitución a las entidades federativas son por exclusión pues las facultades que no se encuentren reservadas a la federación serán competencia de los Estados.

La Constitución establece de la misma manera en forma expresa cuales son las facultades reservadas a la federación destacando la materia de armas consignada en el artículo 10, las comprendidas en el artículo 27, 28 y desde luego las establecidas en el artículo 73 que establece la facultad del Congreso de la Unión en las materias ahí indicadas.

De la misma manera existen facultades concurrentes como es el caso de la materia educativa la cual se encuentra regulada por el artículo 3 constitucional.

Como ya se analizó nuestra Constitución Nacional contiene facultadas reservadas a la Federación, las cuales no pueden ser ejercidas por los Estados, y la Constitución consigna de la misma manera facultades que requieren las Entidades Federativas instrumentar en sus propias legislaciones ya sea porque así lo mandata la norma fundamental, porque resultan convenientes para el desarrollo democrático de cada Estado o lo que es más importante por tratarse de derechos humanos, sin embargo muchas de estas atribuciones no han sido instrumentadas constituyéndose en muchas ocasiones omisiones legislativas graves.

Como ya mencionábamos en el resumen de nuestra aportación, existen nuevos paradigmas constitucionales que las cartas fundamentales de las entidades federativas aún no han incorporado o bien lo han hecho de forma incipiente, en algunas de las Constituciones de los Estados como es el caso

22 Barragán Barragán José, El federalismo mexicano visión histórica constitucional, México , Universidad Nacional Autónoma de México, 2007, p. 95. 
Esta obra forma parte del acervo de la Biblioteca Jurídica Virtual del Instituto de Investigaciones Jurídicas de la UNAM

del control constitucional, la protección ecológica, la reglamentación de la autonomía de los pueblos indígenas el control de convencionalidad, la perspectiva de género, y el interés superior del niño, es por ello que ahora resulta fundamental el estudio de la comisión legislativa para la consolidación de nuestro sistema federal, pues en muchos casos las legislaturas estatales están renuentes a su incorporación en sus respectivas constituciones, ya sea porque son contrariaos a los intereses locales o bien porque no existe urgencia política en poner las putas constitucionales a vapor.

\section{LOS NUEVOS PARADIGMAS GONSTITUCIONALES}

Por paradigma constitucional, entendemos todo aquel criterio que renueva significativamente o rediseña el sentido de la norma constitucional en determinada materia. En este orden de ideas, el control constitucional resulta relevante además de por ser un mandato Constitucional para que las entidades federativas contemplen y cumplan, indudablemente porque en la actualidad en un país Federal no se puede concebir normas legisladas por los Congresos Estatales que no tengan mecanismos de control interno.

Éstos paradigmas, son entendidos como nuevos vértices que dan vida a la norma suprema, en éste orden de ideas tratándose de los derechos humanos con motivo de la sentencia dictada por la Corte Interamericana de Derechos Humanos en el caso Radilla Pacheco, se dieron importantes reformas a nivel constitucional en el año de 2011 en México, a través de las que el Estado mexicano para dar el debido cumplimiento a través de la actuación del Poder Judicial documento el expediente Varios 912/2010 visto ante la Suprema Corte de Justicia de la Nación siendo ministro ponente Margarita Beatriz Luna Ramos y cuyo engrose estuvo a cargo del ministro José Ramón Cossío Díaz, las cuales advirtieron en esencia lo siguiente:

1)Debe realizarse el control de convencionalidad ex officio en materia de derechos humanos a cargo del Poder Judicial, el que deberá adecuarse al modelo de control de constitucionalidad existente en nuestro país.

2) Si los jueces no pueden hacer una declaración general sobre la invalidez o expulsar del orden jurídico las normas que consideren contrarias a los derechos humanos contenidos en la Constitución y en los tratados sí están obligados a dejar de aplicar las normas inferiores dando preferencia a las contenidas en la Constitución y en los tratados.

3)Los jueces nacionales deben observar los derechos humanos establecidos en la Constitución Mexicana y en los tratados internacionales de los que el Estado Mexicano sea parte, así como los criterios emitidos por el Poder Judi- 
Esta obra forma parte del acervo de la Biblioteca Jurídica Virtual del Instituto de Investigaciones Jurídicas de la UNAM

cial de la Federación al interpretarlos y acudir a los criterios interpretativos de la Corte Interamericana para evaluar si existe alguno que resulte más favorable y procure una protección más amplia del derecho que se pretende proteger.

4)El parámetro de análisis del control de convencionalidad-constitucionalidad que deberán ejercer todos los jueces del país, se integra de la manera siguiente:

a.Todos los derechos humanos contenidos en la Constitución Federal (con fundamento en los artículos 1o. y 133), así como la jurisprudencia emitida por el Poder Judicial de la Federación;

b.Todos los derechos humanos contenidos en tratados internacionales en los que el Estado Mexicano sea parte;

5)Los criterios vinculantes de la Corte Interamericana de Derechos Humanos derivados de las sentencias en las que el Estado Mexicano haya sido parte.

6)los criterios orientadores de la jurisprudencia y precedentes de la citada Corte, cuando el Estado Mexicano no haya sido parte.

7) $\mathrm{Al}$ ejercer el control de convencionalidad ex officio en materia de derechos humanos, deberá realizar los siguientes pasos:

a.Interpretación conforme en sentido amplio, al interpretar el orden jurídico a la luz y conforme a los derechos humanos reconocidos en la Constitución y en los tratados internacionales en los cuales el Estado Mexicano sea parte, favoreciendo en todo tiempo a las personas con la protección más amplia;

b.Interpretación conforme en sentido estricto, cuando hay varias interpretaciones jurídicamente válidas, los jueces deben, partiendo de la presunción de constitucionalidad de las leyes, preferir aquella que hace a la ley acorde a los derechos humanos reconocidos en la Constitución y en los tratados internacionales en los que el Estado Mexicano sea parte;

c.Inaplicación de la ley cuando las alternativas anteriores no son posibles.

8)La Suprema Corte de Justicia de la Nación, aun como tribunal constitucional, no es competente para analizar, revisar, calificar o decidir si una sentencia dictada por la Corte Interamericana de Derechos Humanos.

9)Las autoridades no jurisdiccionales del país en el ámbito de sus competencias tienen la obligación de aplicar las normas correspondientes haciendo la interpretación más favorable a la persona para lograr su protección más amplia, sin tener la posibilidad de inaplicar o declarar su incompatibilidad.

Por su parte respecto al nacimiento terminológico del control de convencionalidad en el Sistema Interamericano de Derechos Humanos se dice que "se lo debemos al ex presidente de la Corte Interamericana de Derechos 
Esta obra forma parte del acervo de la Biblioteca Jurídica Virtual del Instituto de Investigaciones Jurídicas de la UNAM

Humanos, Sergio García Ramírez" . ${ }^{23}$ Y sobre la adopción del mencionado control de convencionalidad el Dr. Ferrer Mac-Gregor, juez de la Corte Interamericana de Derechos Humanos nos refiere lo siguiente:

En el caso mexicano, la intensidad del control difuso de convencionalidad aumentó al haber aceptado recientemente la SCJN el control difuso de constitucionalidad (por la nueva) interpretación que se hace del articulo 133 en relación con el vigente artículo primero constitucional, apartándose de su tradicional jurisprudencia, es decir, ahora tienen los jueces locales dentro de su competencia la posibilidad de inaplicar la norma inconstitucional/inconvencional al caso particular, lo que les permite ejercer de oficio el control difuso de convencionalidad con una intensidad fuerte. ${ }^{24}$

De manera que, el control de convencionalidad según estimación de Ferrer Mac-Gregor, puede ser difuso en el caso de que la convencionalidad ya no sea aplicada por la Corte Interamericana de Derechos Humanos sino por los Estados nacionales, aunque cabe la reserva de anotar que para algunos autores no opera dicho control, particularmente nuestra posición si coincide con la expuesta por Ferrer, en el sentido de que el control de convencionalidad reviste un mecanismo de aplicación en donde por un lado se encuentra la Corte Interamericana de Derechos Humanos aplicándolo de manera concentrada y por el otro los Estados nacionales a quienes corresponde su aplicación de manera difusa.

Ahora bien, si ha constituido un paradigmático cambio en la dinámica constitucional adoptar la protección de los derechos humanos contenidos en los tratados internacionales considerándolos como norma constitucional de fuente internacional, lo ha sido también el incorporar los criterios de la Corte Interamericana al orden jurídico nacional y trasladar esto a la tutela de los derechos humanos y al diseño de los mecanismos de control constitucional.

Lo señalado con anterioridad ha sido un camino polémicamente recorrido por autoridades, ciudadanos y operadores jurídicos más tratándose del constitucionalismo local, en virtud de que la tradición había estado más a favor del control concentrado de la constitución que del control difuso de la constitucionalidad.

23 Castilla Juárez, Karlos A., “`Control interno o difuso de Convencionalidad? Una mejor idea: la garantía de los tratados", Anuario Mexicano de Derecho Internacional, México, UNAM, Instituto de Investigaciones Jurídicas, volumen XIII, 2013, p. 68.

24 Ferrer Mac-Gregor, Eduardo, "Interpretación conforme y control difuso de convencionalidad. El nuevo paradigma para el juez mexicano", en Carbonell, Miguel y Salazar, Pedro (coords.), La reforma constitucional de derechos humanos: nuevo paradigma, México, UNAM, Instituto de Investigaciones Jurídicas, No. 609, 201 1, pp. 342-344. 
Esta obra forma parte del acervo de la Biblioteca Jurídica Virtual del Instituto de Investigaciones Jurídicas de la UNAM

No obstante al advertirse en el artículo primero constitucional a partir de 2011, que todas las autoridades, en el ámbito de sus competencias, tienen la obligación de promover, respetar, proteger y garantizar los derechos humanos de conformidad con los principios de universalidad, interdependencia, indivisibilidad y progresividad, se sientan las bases para consolidar el control difuso de la constitucionalidad que si bien puede extenderse a operadores jurídicos locales, éstos no pueden declarar la inconstitucionalidad de un acto o norma a la luz de la constitución federal si lo pueden hacer en defensa del orden constitucional local en tribunales o salas constitucionales locales, o inclusive en el orden federal absteniéndose de aplicar la norma inconstitucional, es decir, inaplicandola, lo cual ésta además soportado por criterios de nuestro tribunal constitucional federal.

Lo anterior constituye un importante cambio en la dinámica de la defensa constitucional en el ámbito local, al respecto la constitución del Estado de Sinaloa en su artículo primero prevé que: ....el Estado de Sinaloa, como parte integrante de los Estados Unidos Mexicanos, se constituye en un Estado democrático de derecho, cuyo fundamento y objetivo último es la protección de la dignidad humana y de los derechos humanos", en virtud de lo cual reafirma la estructura del sistema federal.

Asimismo, señala que toda persona es titular de los derechos humanos reconocidos en la Constitución Política de los Estados Unidos Mexicanos y en la presente Constitución, así como de los previstos en los instrumentos internacionales incorporados al orden jurídico mexicano, y reproduce el texto de la constitución federal específicamente del artículo primero en el artículo número 4, del ámbito local, en lo que respecta a lo siguiente:

...Todas las autoridades, en el ámbito de sus competencias, tienen la obligación de promover, respetar, proteger y garantizar los derechos humanos de conformidad con los principios de universalidad, interdependencia, indivisibilidad y progresividad. En consecuencia, el Estado deberá prevenir, investigar, sancionar y reparar las violaciones a los derechos humanos, en los términos que establezca la ley.

Además, desglosa los siguientes derechos: a una alimentación nutritiva, suficiente y de calidad a fin de poder desarrollarse plenamente y conservar sus capacidades físicas y mentales, sin que padezcan hambre y malnutrición; al acceso, disposición y saneamiento de agua para consumo personal y doméstico en forma suficiente, salubre, aceptable y asequible en condiciones de igualdad y sin discriminación de ningún tipo, a fin de no poner en riesgo su supervivencia; a un medio ambiente sano para su desarrollo y bienestar; a dis- 
Esta obra forma parte del acervo de la Biblioteca Jurídica Virtual del Instituto de Investigaciones Jurídicas de la UNAM

frutar una vida libre de violencia; a preservar la forma de vida de sus pueblos indígenas, y elevar el bienestar social de sus integrantes; a la libertad de investigación científica y de creación, interpretación y difusión cultural, así como derecho a obtener los beneficios que le corresponda por razón de las producciones científicas, literarias o artísticas de que sea autor; a que toda persona practique deporte y goce de la recreación, para lo cual promoverá la cultura fisica y creará oportunidades que permitan presenciar, organizar y participar en dichas actividades y a la igualdad ante la ley entre hombre y mujer.

Ahora bien, como podemos percatarnos de la lectura a los derechos que manifiesta la Constitución del Estado de Sinaloa, éstos son prerrogativas que también consagra la Constitución federal, algunas de ellas con algunas palabras más en el ámbito local sinaloense pero nada más, limitándose a manifestar en todos los casos que: “...la Ley determinará las medidas que deberán llevar a cabo...", para la tutela y preservación de los derechos.

Lo anterior puede obedecer a un lógica de técnica legislativa en los textos constitucionales que se limitan a reconocer los derechos para ser desglosados y reglamentados en una ley independiente, lo que debe cuidarse en éstos casos es que en la ley comentada, no se limite el derecho, pero mucho más que la ley exista, y decimos tal aseveración porque en el caso de Sinaloa a pesar de que de manera textual la constitución local reconoce derechos ya avalados por el pacto federal e inclusive en el marco del artículo cuarto hace alusión a los derechos del orden federal y de los tratados internacionales, sujeta la reglamentación de éstos a la ley que corresponda pero no en todas las materias se ha dado a la tarea de exhortar la creación de las leyes que mandata al poder legislativo local.

Además de lo anterior en Sinaloa aún no se cuenta con un mecanismo de control local, y el capítulo relativo a la Comisión Estatal de Derechos Humanos solo se adecuo mínimamente después de las reformas federales en ésta materia.

\section{LA PROTECGIÓN DE LOS DERECHOS}

DE LOS PUEBLOS INDÍGENAS EN EL GONSTITUGIONALISMO LOCAL EN SINALOA

Martínez de Bringas ${ }^{25}$ nos dice que los derechos humanos, en cuanto construcción moderna, constituyen un discurso adecuado para centrar y ubicar

25 Martínez de Bringas, Asier, "Derechos Humanos y Diversidad(es) cultural(es). Los retos de la interculturalidad", Derechos y libertades", Revista de filosofia del derecho y derechos humanos, 
Esta obra forma parte del acervo de la Biblioteca Jurídica Virtual del Instituto de Investigaciones Jurídicas de la UNAM

las exigencias de las diversidades culturales al dar estricta medida de las disposiciones individuales y colectivas de grupos y pueblos; de las agresiones y conculcaciones a las que las diversidades han sido sometidas y expuestas; al otorgar posibilidades de defensa mediante el artificio normativo de la titularidad de derechos.

Particularmente en el caso de los derechos de los pueblos indígenas son reconocidos en nuestro texto constitucional federal de manera específica en el artículo 2 que señala lo siguiente: “...A. Esta Constitución reconoce y garantiza el derecho de los pueblos y las comunidades indígenas a la libre determinación y, en consecuencia, a la autonomía...., ahora bien, para dar cumplimiento a dicho postulado la misma Constitución federal desglosa una serie de requisitos, entre los que destaca el contar con la calidad de pueblos indígenas o bien integrante de éstos.

No obstante, entidades como Sinaloa se limitan a prever en el texto constitucional local lo siguiente:

En el Estado de Sinaloa se reconoce el pluralismo cultural y el derecho a preservar la forma de vida de sus pueblos indígenas, y elevar el bienestar social de sus integrantes. La ley protegerá y promoverá el desarrollo de sus lenguas, culturas, religión, la educación bilingüe, usos, costumbres, tradiciones, prácticas democráticas, patrimonio étnico y artesanal, medio ambiente, recursos, medicina tradicional y formas específicas de organización social, y garantizará a sus integrantes el efectivo acceso a la jurisdicción del Estado. Las personas de la tercera edad y las que tengan capacidades diferentes deben recibir apoyo y protección permanentes. El Estado y los municipios establecerán un sistema permanente de apoyo a las personas de la tercera edad para permitirles una vida digna y decorosa; y, promoverán la habilitación, rehabilitación e integración de las personas con capacidades diferentes con el objeto de facilitar su pleno desarrollo. Toda persona que habite o transite en el territorio del Estado, sin importar su procedencia o condición migratoria, será tratado humanamente y con el respeto debido a la dignidad inherente al ser humano y a su identidad cultural.

Sin embargo a la fecha y pese a que en Estado cada día tenemos mayor población de pueblos originarios que se desplazan a trabajar en los campos pesqueros y agrícolas, y que se quedan asentados en su mayoría permanentemente en el territorio sinaloense en donde reproducen sus costumbres y

España, Instituto de Derechos Humanos Bartolome de las Casas-Universidad Carlos III de Madrid, No. 26, enero 2012, p. 113. 
Esta obra forma parte del acervo de la Biblioteca Jurídica Virtual del Instituto de Investigaciones Jurídicas de la UNAM

organización, todavía no se cuenta con la ley a la que refiere el texto constitucional local para reglamentar en el ámbito local los derechos.

Los referidos derechos humanos se violentan por las legislaturas estatales al ser una función esencial para el correcto desarrollo de las actividades de todo estado de derecho, generar normas que permitan la sana convivencia de todo gobernado, teniendo esto especial relevancia cuando por medio de ellas se busca garantizar la vigencia y protección de los derechos fundamentales establecidos en la Constitución y en los Tratados Internacionales que México ha signado en esta materia, que son el eje y el marco que se debe de tomar como referencia para que el Estado pueda desenvolver su función, constituyendo en sí como un límite por un lado y por otra parte como un paradigma de actuación de la autoridad, cuando sea conminada a ello por el propio Constituyente.

Los mandatos y acciones establecidas en la Ley Suprema, adquieren especial relevancia, sobre todo cuando el efecto es dotar de contenido y eficacia a un derecho fundamental, el cual contempla una serie de postulados que representan aspiraciones programáticas, así como de posiciones y estatus de los titulares de esos derechos, siendo indispensable el desarrollo de esas tareas por el legislador ordinario, y más aun cuando el propio constituyente le impone esa obligación, buscando se hagan efectivos los derechos previstos en la propia Norma Fundamental como un sistema de posiciones jurídicas que incluyen derechos, así como libertades y competencias de las autoridades establecidas de forma genérica en la Constitución y que deben ser reglamentadas en las leyes secundarias para poder hacerlas efectivas

Por lo tanto, la omisión legislativa es la falta de desarrollo por parte del Poder Legislativo del Estado, durante un tiempo excesivo, de la norma que es de obligatoria y concreta realización, de forma que se impide su eficaz aplicación; esto es, incumple con el desarrollo de determinadas cláusulas constitucionales a fin de tornarlas operativas y esto sucede debido al silencio del legislador local alterando el contenido normativo o provoca situaciones contrarias a la Constitución. Pudiéndose deducir que cuando la norma constitucional ordena practicar determinados actos o actividades en las condiciones establecidas, pero el destinatario o el obligado a realizarlos "Legislador Estatal", no lo hace en los términos exigidos, ni en tiempo hábil la omisión no se reduce a un simple no hacer, sino que presupone una exigencia constitucional de acción y una inacción cualificada.

Lo anterior responde a que, para hacer efectivos los derechos fundamentales, se deben de cumplir con dos principios esenciales, el primero llamado de legalidad que, en tratándose de ciertos derechos fundamentales, 
Esta obra forma parte del acervo de la Biblioteca Jurídica Virtual del Instituto de Investigaciones Jurídicas de la UNAM

especialmente los sociales, exige que ciertas prestaciones sean impuestas como obligaciones a los poderes públicos y no abandonadas al arbitrio administrativo, por lo que legislativamente es necesario se cumplan los presupuestos vinculantes e identifiquen con claridad los órganos y procedimientos; y, el segundo, es el jurisdiccional, imponiendo que las lesiones a los derechos fundamentales deben ser justiciables y reparadas, especialmente cuando se incide en grupos vulnerables, o se desatiende el mínimo vital.

Por lo tanto, es necesario para obtener la efectividad de éstos derechos fundamentales disponer de acciones judiciales conducentes a que sean aplicables y exigibles jurídicamente los derechos humanos, lo que requiere de una normativa jurídica adecuada.

Ahora bien, no obstante que existe el mandato constitucional para legislar en ciertas materias y sobre determinadas situaciones, como los derechos humanos, advertimos que aún existen, sobre todo en los Estados como el de Sinaloa, temas pendientes en la agenda legislativa local en forma absoluta como de forma parcial, lo que se traduce en graves omisiones legislativas como la que se da por ejemplo en materia indígena.

Sin embargo, pese a que los de la voz, hemos formulado y promovido demanda de amparo por la omisión legislativa para lograr hacer efectivo el mandato de la constitución local de crear un ley en materia indígena, dicha demanda no prosperó sobreseyéndose, apoyando la improcedencia en tesis de la Corte Nacional, que asumen la independencia del Poder Legislativo como aquella que no le permite al Judicial pronunciarse sobre mandatos constitucionales no cumplidos, lo cual nos parece contrario al principio de supremacía constitucional y al propio principio democrático, en virtud de que no se trata de quebrantar la división de poderes, pues no se estará indicando al legislativo que plasmar en el cuerpo de la norma sino se deberá hacer cumplir el mandato constitucional del orden local para que éste emita una ley indígena, lo cual ante el sobreseimiento no prospera y agrava la circunstancia para la protección de los derechos de los miembros de comunidades indígenas, además de que ya se encuentran en un Estado que no cuenta con órganos de control constitucional local para la defensa de los derechos.

\section{CONCLUSIONES}

Primera. Al ser la Constitución el máximo ordenamiento de un territorio soberano, requiere para su cumplimiento medios de control constitucional tanto a nivel federal como local. En un país con forma de Estado federal como 
Esta obra forma parte del acervo de la Biblioteca Jurídica Virtual del Instituto de Investigaciones Jurídicas de la UNAM

el de México, los Estados que lo conforman al tener sus propias constituciones deben de contar de la misma manera con medios de control constitucional.

Segunda. Existen nuevos paradigmas constitucionales derivados de los derechos humanos, los cuales ya se encuentran integrados dentro del texto de la Constitución Federal, pero que aún no han sido incorporados a la mayoría de las Constituciones de los Estados, sin embargo pese a ello y la dinámica del cambio del constitucionalismo tanto en el ámbito federal como local aún tenemos temas pendientes de tutela normativa efectiva además de tutela judicial efectiva.

Tercera. No es viable limitar el juicio de amparo o declararlo improcedente en el caso de reformas constitucionales u omisiones legislativas, sobre todo en las Entidades Federativas que no cuentan con los medios de control constitucional, argumentando que no puede quebrantarse del principio de división de poderes, pues lo que se plantea es que la sentencia inste a los legisladores para cumplir con su mandato constitucional, en la forma y contenido que determinen las leyes aplicables.

Cuarta. Ahora bien, en el caso de los derechos de los miembros de las comunidades o pueblos indígenas, encontramos elementos muy importantes a destacar, por un lado la vulnerabilidad de la total fragilidad de la víctima frente a la omnipotencia y poderío del Estado y sus agentes, la falta de acceso a la justicia e impunidad, la pobreza, el habla limitada del idioma oficial, la discriminación entre pobladores no indígenas y entre indígenas de diferentes regiones, entre otras.

\section{BIBLIOGRAFÍA}

BARRAGÁN BARRAGÁn, José, El federalismo mexicano visión histórica constitucional, México, Universidad Nacional Autónoma de México, 2007.

Carbonell, Miguel, Introducción al derecho constitucional, México, Tirant lo Blanch, 2015.

CARPIZO, Jorge, Estudios constitucionales, México, UNAM, Instituto de Investigaciones Jurídicas, 1983.

Castilla Juárez, Karlos A., “¿Control interno o difuso de Convencionalidad? Una mejor idea: la garantía de los tratados", Anuario Mexicano de Derecho Internacional, México, UNAM, Instituto de Investigaciones Jurídicas, volumen XIII, 2013.

Claude Tron, Jean, ¿¿Qué hay del interés legítimo? (Primera parte), Revista del instituto de la Fudicatura Federal, México, Poder Judicial de la Federación, Instituto de la Judicatura Federal, No. 33, 2012. 
Esta obra forma parte del acervo de la Biblioteca Jurídica Virtual del Instituto de Investigaciones Jurídicas de la UNAM

KRAMER, Larry D., Constitucionalismo popular y control de constitucionalidad, España, Marcial Pons, 2011.

FERRER MAC-GREGOR, Eduardo, "Interpretación conforme y control difuso de convencionalidad. El nuevo paradigma para el juez mexicano", en Carbonell, Miguel y Salazar, Pedro (coords.), La reforma constitucional de derechos humanos: nuevo paradigma, México, UNAM, Instituto de Investigaciones Jurídicas, No. 609, 2011.

FIX-ZAMUDio, Héctor, Breves reflexiones sobre el concepto y contenido del derecho procesal constitucional, en el libro Derecho procesal constitucional, México, Colegio de secretarios de la Suprema Corte de Justicia de la Nación, 2001.

Gil Rendón, Raymundo, El nuevo Derecho Procesal Constitucional, México, Editorial UBIJUS, 2012.

LÓPEz GuerrA, Luis, Espin Eduardo y otros, Derecho Constitucional, España, Tirant lo Blanch, 2003.

MaRTínez DE BRINGaS, Asier, "Derechos Humanos y Diversidad(es) cultural(es). Los retos de la interculturalidad", Derechos y libertades", Revista de filosofia del derecho y derechos humanos, España, Instituto de Derechos Humanos Bartolome de las Casas-Universidad Carlos III de Madrid, No. 26, enero 2012.

Palomino Manchego, José F., Constitución, supremacía constitucional y teoría de las fuentes del derecho, en Memoria del X Congreso Iberoamericano de Derecho Constitucional, Lima, Instituto Iberoamericano de Derecho Constitucional, 2009.

RUIPÉREZ, Javier, El constitucionalismo democrático en los tiempos de la globalización, México, Universidad Nacional Autónoma de México, 2005.

VAnossi, Teoría Constitucional, Argentina, De Palma Editores, 2000.

Zagebelsky, Gustavo, El derecho dúctil, España, Editorial Trotta, 1995.

\section{Direcciones electrónicas}

http://biblio.juridicas.unam.mx/libros/6/2698/22.pdf, consultada el 14 de diciembre 2015

\section{Legislación}

Constitución Política de los Estados Unidos Mexicanos

Constitución del Estado de Sinaloa 
Esta obra forma parte del acervo de la Biblioteca Jurídica Virtual del Instituto de Investigaciones Jurídicas de la UNAM

\section{LOS RETOS DEL GONSTITUCIONALISMO DEL SIGLO XXI, BAJO LA ÓPTICA DE LA GONSTITUGIÓN DE 1917}

\section{Daniel Montero Zendejas*}

Constitución de 1917. Derribadora de ídolos, azote de tiranos: producto de mil luchas, ansiedades y dolores, levantó del paria la frente que yacía en los suelos; conmovió espíritus alojados en las sombras. Devolvió la fe a nuestros hogares; e hizo patria, dignificando a sus hijos... haciéndolos hombres... consagrándolos... Constitución de 1917, tienes un nombre de redención sublime para amarte y comprenderte: $\mathrm{Y}$ ese nombre es: LIBERTAD

Román ROSAS Y REYES ${ }^{1}$

SUMARIO: I. Introducción. II. La constitución social de 1917. Una asignatura pendiente. III. El constitucionalismo social del siglo XX. IV. Los retos de la teoría constitucional. V. El constitucionalismo en la era presente. VI. Conclusiones. VII. Bibliografia.

* Doctor en Derecho, Profesor Investigador de Tiempo Completo, Definitivo, Titular "C" de la Universidad Autónoma del Estado de Morelos, Profesor por oposición de la Facultad de Derecho de la Universidad Nacional Autónoma de México, SNI II, Miembro de la Asociación Iberoamericana de Derecho Constitucional, Sección México, Miembro del Claustro de Sor Juana de la Facultad de Derecho-UNAM, Miembro Académico Internacional de Honor por la Universidad Católica del Uruguay, Socio de la Fundación Internacional de Ciencias Penales, Research-senior of International Center of Economic Penal Studies, Miembro de número de la Asociación Iberoamericana de Filosofía Práctica, con Estancias académicas en la Universidades de Salerno, Italia, Católica y de la República, Uruguay.

1 Tomado del Álbum familiar de Pilar Ruiz, Fosé, Morelia, Michoacán, 1917. 
Esta obra forma parte del acervo de la Biblioteca Jurídica Virtual del Instituto de Investigaciones Jurídicas de la UNAM

Congregarnos en este estado de San Luis Potosí, centro de la República y escenario de diferentes y diversos actos que han construido la historia nacional, con motivo del análisis, dinámica, modificaciones y transformación de nuestra Carta Magna en esta centuria, significa un escenario alentador para la discusión de los diversos tópicos nacionales que se encuadran en nuestro cambio constitucional.

Tierra de hombres y mujeres que han alentado la fuera de nuestras instituciones. En este estado nacieron Samuel de los Santos, Arturo Méndez, Rafael Martínez Mendoza, Rafael Nieto, Gregorio A. Tello, Rafael Curiel Gallegos y Cosme Dávila. Todos ellos con una herencia para la nación y para las generaciones del mañana.

\section{INTRODUCCIÓN}

A casi cien años de su promulgación y como parte del inicio de su festejo en este estado de la República, nos hemos reunido muchos de los constitucionalistas que abrazamos a la Constitución como eje de nuestro actuar cotidiano y como parte sustantiva de lo que significa la relación ciudadanoestado.

Definir lo que es la Constitución desde la perspectiva de Schmitt,, "Lasalle, Heller, Duverger, Crossman, Loewenstein"3 y una pléyade de estudiosos de esta materia, significaría sin omitir su aportación histórica en la dogmática jurídica de nuestros días redundante, más aún para los escenarios de este milenio que vive el estado mexicano, donde la violencia, inseguridad, corrupción y fenómenos de desplazados, desaparecidos y ejecutados; al igual que con las demás anomias que padece, pareciera anular su vigencia y rectoría en un estado de derecho que nos recuerda lo sentenciado por Kelsen: " ... donde no hay estado de derecho no hay estado...".

Es por ello, que la sabiduría humana se encuentra en los principios generales del derecho. Tanto de esos principios generales como de las grandes fórmulas interpretativas se fueron derivando poco a poco leyes correspondientes a etapas históricas o a condiciones de la realidad muy concretas. De esta suerte, no obstante que cambiaron las situaciones que motivaron y explicaron la existencia de leyes, desaparecidas con el paso del tiempo, de

\footnotetext{
2 Véase: Schmitt, Carl, El concepto de lo político, Folios ediciones, México, 1985.

3 Véase: Montero Zendejas Daniel, Derecho constitucional comparado, Porrúa, México, 2006.

4 Kelsen, Hans, Teoría pura del derecho, Eudeba, Buenos Aires, 1970, p.77.
} 
Esta obra forma parte del acervo de la Biblioteca Jurídica Virtual del Instituto de Investigaciones Jurídicas de la UNAM

ellas pudieron siempre derivarse principios de carácter más general e intemporal, no referidos a cuestiones singulares sino a casos muy generales. El tiempo, otras realidades y nuevas al igual que distintas leyes incorporaron cada vez mas esencia a dichos criterios, que en un momento dado llegaron a ser considerados parte fundamental del derecho y del estado.

Por esto reiteramos la utilidad del estudio del derecho y con él, de nuestra Constitución. Los juristas han sabido desprender de una realidad y de las leyes propias de una etapa lineamientos generales que constituyen útiles referencias en periodos largos de tiempo, en muchas partes y épocas aun en países con distinta tradición jurídica, prevalece el humanismo y la razón de ser del hombre enclavado en una sociedad dinámica. Esta es la razón que justifica el derecho comparado y de su ejercicio como parte importante de los estudios jurídicos que conllevan al acuerdo en el marco de la posmodernidad y de una mundialidad que nos hermana a todos.

De las constituciones de los diversos países, nuestra nación ha orientado su esfuerzo para las grandes conquistas que el ser humano en su deambular en este planeta ha consolidado, independientemente de su ubicación, raza, credo e idioma. Los valores y principios se han proyectado desde su gestación en una conducta social irrenunciable pues su proyección hacia el futuro, no obstante los cambios, realidad y circunstancias forman parte de un destino común.

Esto explica la importancia del derecho en la prevención del futuro. Según se contempla el porvenir, quizás más en el tiempo actual está lleno de sombras de penumbra e incertidumbre, de acontecimientos imprevisibles, de dramáticas consecuencias, que por definición no pueden preverse por medio de proyecciones lineales, ni por diseño mecánico de escenarios o cálculos de tecnología virtual.

Desde el nacimiento de la cultura occidental los principios generales del derecho han sido los portadores básicos de la cultura legal. Son por decirlo, en palabras de la rica tradición jurídica, los baluartes de la interpretación, exégesis y creación de normas de derecho, que responden a épocas o tiempos muy concretos de la realidad social. De esta forma estos principios han sido los grandes maestros para la aplicación concreta de las normas en los casos singulares y generales; el flujo del tiempo ha incorporado nuevas formas de enfoque y líneas de interpretación a tales principios.

De esta forma, el estudio del derecho se ha convertido en el instrumento fundamental en las relaciones sociales y a pesar de un mundo que experimenta en este milenio con más agudeza las relaciones económicas de libre 
Esta obra forma parte del acervo de la Biblioteca Jurídica Virtual del Instituto de Investigaciones Jurídicas de la UNAM

mercado, los científicos sociales consideramos que la cultura de la legalidad es el principio rector de una sociedad en evolución.

El estudio del derecho comparado nos ha permitido analizar las transformaciones de cada institución en su propio contexto y establecer criterios de valoración de las propias a la luz del desarrollo social. Así, la vigencia del derecho comparado constituye un eje fundamental para analizar el presente, pero adicionalmente preparar los escenarios futuros de las sociedades democráticas. Es más, en el mundo globalizado al que pertenecemos el derecho comparado se ha transformado en el mecanismo de interpretación y aplicación normativa.

La construcción de escenarios para el futuro se encuentra soportado en dos grandes pilares. El primero, la legislación propia que debe caminar al llamado de todas las voces expresadas en su pluralidad y el segundo, se encuentra en la comparación de nuestros propios sistemas con las realidades más avanzadas en sus valores. Sin embargo, el grado de previsibilidad no es absoluto, por ello, es necesario estar siempre atento a las voces de la disidencia que confirman o niegan en su caso, los avances de la sociedad moderna.

En ese sentido, por muy avanzada que esté la ciencia en materia de análisis de escenarios posibles, no existe límite a la propia libertad humana. Por ello la voz del pueblo es siempre la mejor forma de escuchar sobre el futuro deseado.

Así, la mejor manera de hacer real el futuro es construirlo con la mano firme del pueblo a través de su Constitución. No hay posibilidad de desaciertos en este sentido, porque el pueblo y su Constitución se han apoyado en los valores universales y pactos no expresados que nos han guiado en la constante línea para la edificación de nuestra historia. Lo que nos lleva a concluir que el imaginario colectivo es la construcción de esa historia en la voz de su derecho y de las leyes que nos permiten la convivencia pacífica y ordenada. Un pueblo sin ley seria como un ente inanimado que se pierde en el espacio virtual de la tecnología moderna, si rumbo ni destino; sin principio ni fin, en otras palabras, la teoría del caos se haría realidad.

El estado mexicano ha entrado en esa concepción de exigencia de una cultura de la legalidad y del respeto a sus leyes y Constitución; sin embargo, existen voces en el espacio común que vuelcan su inconformidad a los grandes cambios que en nombre de reformas estructurales lo sentencian a un mundo de desigualdad social y de incertidumbre donde la ley del talión reencuentra su esencia. 
Esta obra forma parte del acervo de la Biblioteca Jurídica Virtual del Instituto de Investigaciones Jurídicas de la UNAM

\section{LA CONSTITUCIÓN SOCIAL DE 1917. \\ UNA ASIGNATURA PENDIENTE}

Justicia social que enaltece a la precursora de los derechos sociales para dar paso a una nueva generación de hombres comprometidos con el ideario de la revolución: Luis Cabrera, Machorro, Mújica, Carranza, Jara; vierten a la norma fundamental la lucha por encontrar en todo el esfuerzo liberal, un eco que asegure por la vía del derecho, una reforma social fundamentada en la reforma agraria, el derecho al trabajo y una educación laica, obligatoria y gratuita.

Si bien el constitucionalismo de las cartas magnas de 1824 y 1857 -ésta en especial- son copia fiel de otros textos, que apoyados en la experiencia trataron de darle el sesgo que el país demandaba; sin embargo, la Constitución vigente es la esencia que sintetiza la lucha del campesino, del obrero y de las clases menos favorecidas del desarrollo social.

En medio de esta transición en los inicios del siglo XX en la efervescencia de una lucha armada, la cual significaba para el campesino, obrero y demás sectores de la población marginada un cambio en su forma de vida; cambio que en esa confrontación de ideas que venimos presentando las décadas que han transcurrido parecieran tener un retroceso y que la población cayera nuevamente a las manos de la desesperación por no encontrar un camino viable que le asegure un bienestar social acorde a lo que pretendió la revolución de 1910.

No se trata de recordar la nostalgia de una revolución, un constituyente y una Carta magna que sintetiza tanto lucha como deseos o anhelos no concretados; tampoco pretendemos regresar a épocas o modelos ideológicos que se encontraban en la mesa de la discusión teórica para comparar y a testificar sus bondades o defectos. El muro de Berlín, la transformación de la Unión de Repúblicas Socialistas Soviéticas, la apertura de Cuba, contrastan la elección democrática del pueblo chileno por el socialismo. Modelos todos ellos que gravitan en el esquema de la cientificidad social por lograr un mundo más justo y equilibrado. Lejos estaban del pensamiento liberal del constituyente del 17 la ecología, la carencia de agua, y el rol de los hidrocarburos como de la telecomunicación; empero, continua la lucha y la vigencia de nuestra Constitución cuando apreciamos en nuestro país marginación, pobreza y miseria extrema.

Aquí radica, entre otros conceptos, la vigencia de nuestro Constitucionalismo Social. 
Esta obra forma parte del acervo de la Biblioteca Jurídica Virtual del Instituto de Investigaciones Jurídicas de la UNAM

El presente artículo se inscribe en los principios del constitucionalismo social como una vertiente de la lucha política y de la conquista del poder que prevalece en la actualidad y que alteró el rumbo de un proyecto de estado cuyo interés supremo era la construcción de una estructura política ajena al poder económico. Los cambios en la cosmogonía internacional trajeron como resultado la modificación que visualiza que por encima del poder político se encuentra el económico.

En esta axiología se encuentra presente John Turner cuando levantaba su pluma para condenar la acción del dictador y "... acusarlo de haber restablecido la esclavitud y el peonaje en México...". ${ }^{5}$

\section{Derecho laboral}

En materia laboral las premisas fundamentales en las que osciló el debate en el congreso constituyente bajo las siguientes premisas:

a) Establecer máximo de ocho horas de trabajo y un salario mínimo en la proporción siguiente: un peso para la generalidad del país, en que el promedio de los salarios es inferior al citado, y de más de un peso para aquellas regiones en la que la vida es más cara y en las que este salario no bastaría para salvar de la miseria al trabajador.

b) Reglamentación del servicio doméstico y del trabajo a domicilio.

c) Adoptar medidas para que con el trabajo a destajo los patronos no burlen la aplicación del trabajo máximo y salario mínimo.

d) Prohibir en lo absoluto el empleo de niños menores de catorce años.

e) Obligar a los dueños de minas, fábricas, talleres, etc., a mantener las mejores condiciones de higiene en sus propiedades y a guardar los lugares de peligro en un estado que preste seguridad a la vida de los operarios.

f) Obligar a los patrones o propietarios rurales a dar alojamiento higiénico a los trabajadores cuando la naturaleza del trabajo de éstos exija que reciban albergue de dichos patronos o propietarios.

g) Obligar a los patronos a pagar indemnización por accidentes de trabajo.

5 Turner, John, México bárbaro, ERA, México, 1977, p. 102. 
Esta obra forma parte del acervo de la Biblioteca Jurídica Virtual del Instituto de Investigaciones Jurídicas de la UNAM

\section{Derecho agrario}

La reforma agraria que en voz de los diputados constituyentes dejaron en claro en sus discursos los siguientes principios que adoptó el artículo 27 constitucional:

a) Declarar nulas las deudas de los jornaleros del campo para con sus amos.

b) Adoptar medidas para que los dueños de las tierras no abusen de los medieros.

c) Obligar a los arrendadores de campos y casas que indemnicen a los arrendatarios de sus propiedades por las mejoras necesarias que dejen en ellas.

d) Prohibir a los patronos, bajo severas penas, que paguen al trabajador de cualquier otro modo que no sea con dinero en efectivo; prohibir y castigar que se impongan multas a los trabajadores o se les hagan descuentos de su jornal o se retarde el pago de la raya por más de una semana o se niegue al que se separe del trabajo el pago inmediato de lo que tiene ganado; suprimir las tiendas de raya.

e) Obligar a todas las empresas o negociaciones a no ocupar entre sus empleados y trabajadores sino una minoría de extranjeros. No permitir en ningún caso que trabajos de la misma clase se paguen peor al mexicano que al extranjero en el mismo establecimiento, o que a los mexicanos se les pague en otra forma que a los extranjeros. ${ }^{6}$

f) Hacer obligatorio el descanso dominical.

No debe olvidarse que todos estos postulados y algunos análogos fueron enarbolados durante la lucha revolucionaria y muchos quedaron plasmados en la Constitución de 1917.

Es aquí precisamente que el constitucionalismo que privó por muchos años en el siglo pasado fuera el reflejo de ese ideario y del sentir nacional como una expresión coherente de la búsqueda de derechos sociales que se manifestaban en el mundo después de la revolución francesa y de nuestro país en 1910.

6 Véase Sector Energético, PEMEX-exploración-refinación. Comisión Federal de Electricidad. Sector Telecomunicaciones, periodo 2000-2015, donde se contrasta con la propuesta constituyente. 
Esta obra forma parte del acervo de la Biblioteca Jurídica Virtual del Instituto de Investigaciones Jurídicas de la UNAM

\section{EL CONSTITUGIONALISMO SOGIAL DEL SIGLO XX}

La Constitución de 1917 vino a marcar una nueva ruta al derecho constitucional, la que nos permite establecer una categórica diferenciación, al señalar dos etapas primordiales dentro de la evolución liberal de esta disciplina: el antiguo y nuevo derecho constitucional. El nuevo derecho constitucional, es decir el que se dio a partir de la Constitución de 1917, difiere sustancialmente del anterior, por el contenido eminentemente social que lo nutre y transformó casi por completo imagen y esencia de este último. Y es que habiendo ella captado las innegables bondades de las leyes fundamentales de 1824 y 1857, supo dar una serie de pasos hacia adelante que habría de desembocar en la ruptura de la estructura política clásica de las constituciones, para incrustar el elemento social. Consagró, los principios del pensamiento liberal cuya esencia de justicia social impregnó su contenido.

Si bien es cierto que con nuestra Constitución de 1917, nació un nuevo concepto del Derecho Constitucional que formó la estructura de los definidos como los estados modernos, es también verídico que por su visionario contenido impactó regímenes de añejas estructuras constitucionales, como las euroasiáticas.

México ha ofrecido al mundo entero su doctrina constitucional: sin abandonar el régimen de libertades que supone el liberalismo individualista, al que contempla con su proteccionismo económico y así podemos hablar de un espíritu socio-liberal; en otras palabras entendió el constituyente de 1917 la trascendencia que la economía tendría en un futuro en donde los contrastes de la lucha social se establecerían bajo los principios del libre mercado y del neoliberalismo.

La Declaración de los Derechos del Hombre y del Ciudadano de 1789 condensó la filosofía política individualista y liberal, que nutrió a todas las leyes fundamentales de ese siglo y del posterior. Su objeto era la conservación de los derechos naturales e imprescindibles del hombre y asegurar al mismo tiempo la libertad de las fuerzas económicas frente al estado ya que la no intervención de este en la vida económica de los hombres era, la característica fundamental de las constituciones del pasado. Frente a ellas la Constitución mexicana nutrió al estado con un carácter positivo obligando a éste a actuar con un sentido de equilibrio, bajo el denominador común de la dignidad humana.

Pareciera que el ciclo en la construcción y transformación del estado y de sus leyes fuera repetitivo; del individualismo al colectivismo y de éste nuevamente al individualismo más devastador que el primero. Esa es la his- 
Esta obra forma parte del acervo de la Biblioteca Jurídica Virtual del Instituto de Investigaciones Jurídicas de la UNAM

toria del hombre y su relación con los factores de producción que el estado en su etapa inicial alentó, desarrolló y consolidó bajo el sentimiento de un crecimiento económico que atenta en este siglo XXI contra todo, aún en contra de la entelequia definida como el propio estado.

En este orden de ideas y cuando el liberalismo económico empezó a ser enjuiciado por haberse mostrado incapaz de resolver una serie de situaciones que él mismo engendró, con su doctrina abstencionista del laissez faire; laissez passer, la Constitución de 1917 conformó un régimen liberal que garantizaba la armonía social bajo el principio de igualdad jurídica libertad y distribución de la riqueza, al conformar una clase media producto de su gesta revolucionaria.

La Constitución de 1917 sembró en todo el mundo la semilla de la justicia social e hizo suya garantías que consagraban la etapa reivindicatoria de las masas obreras y campesinas para proyectarlas en la principal fuerza motriz de cambio y de reivindicación social con una educación básica, laica, gratuita y obligatoria.

México ha ventilado en las ideas políticas y del conocimiento su doctrina constitucional, ha abanderado un régimen de libertades y garantías que las vinculan con las tesis de respeto y reconocimiento a los derechos humanos inalienables e imprescriptibles. Su contenido ha favorecido a lo largo de estas décadas un andamiaje constitucional cuya transformación se ha ido acoplando a las necesidades de un nuevo mundo.

Las reformas constitucionales se han dado bajo los conceptos de modernidad y competitividad que las manecillas del cambio han exigido. La radiografía de las sociedades de nuestro tiempo mantienen esa búsqueda orgánica y dogmatica que en su seno se estructuran para brindar a los legisladores de nuestro tiempo luces que la herencia constituyente mantiene en el texto constitucional y que se niegan a abdicar los pilares revolucionarios que fueron origen en el despertar del siglo pasado.

"... las constituciones deben su origen -dice al respecto Mirkine Guetzevitch- $^{7}$ a la guerra y a los movimientos revolucionarios que han sido su consecuencia"... en tanto que efectuamos el análisis formal de todas ellas, debemos en primer lugar, reconocer que el nuevo derecho constitucional europeo es una confirmación de los principios democráticos.

De la misma manera, Karl Loewenstein afirma en su Teoría de la Constitución:

7 Véase Guetzevitch en Montero Zendejas, Daniel, Hacia un nuevo constitucionalismo, Gobierno del estado de Veracruz, México, 2001, p. 29. 
Esta obra forma parte del acervo de la Biblioteca Jurídica Virtual del Instituto de Investigaciones Jurídicas de la UNAM

“... como postulados expresamente formulados, los derechos fundamentales socioeconómicos no son absolutamente nuevos: alguno de ellos, como el derecho al trabajo, fueron recogidos en la constitución francesa de 1793 y 1848. Pero es sólo en nuestro siglo, tras a primera y en mayor grado todavía, tras la segunda guerra mundial, cuando se han convertido en el equipaje estándar del constitucionalismo. Fueron proclamados por primera vez, en la Constitución mexicana de 1917, que con un gran salto se ahorro todo el camino para realizarlos: todas las riquezas naturales fueron nacionalizadas y el estado asumió completamente por lo menos en el papel, la responsabilidad social para garantizar una digna existencia de sus ciudadanos. La Constitución de Weimar contribuyó esencialmente a popularizar y extender os derechos sociales; su catalogo de derechos fundamentales es una curiosa mezcla entre un colectivismo moderno y un liberalismo clásico...". ${ }^{8}$

La revolución rusa habría de suprimir por completo todo germen individual en aras de un sistema colectivo que devendría en totalitarismo; pues aquella no parece haber sido un golpe de estado que dio el poder en Rusia al partido comunista. No le fue posible al pueblo ruso pasar del absolutismo Zarista al régimen democrático que algunos pretendieron. La esencia de este movimiento inspirado en la lucha de clases y en los principios rectores de las revoluciones liberales y que se cristalizaron sus ideales en sus constituciones; no germinó como sus forjadores la concibieron. La de nuestro país permaneció con ese espíritu que ha logrado subsistir a las hipótesis de modernidad, tecnocracia y globalización de fines del siglo XX y principios de este milenio.

Si bien la Constitución se ha desdibujado de acuerdo al Diario de los Debates de 1916-1917, con las consecuentes reformas a lo largo de este siglo de vigencia, conserva el liberalismo social que la caracterizó frente a otros países cuyos procesos revolucionarios concluyeron en una Constitución promulgada por las fuerzas que motivaron ese movimiento social.

Esa capacidad visionaria que el legislador de 1917 otorgó a la norma fundamental, mantiene los ideales de justicia, educación, igualdad y libertad para todos los mexicanos. Las voces por lograr instaurar de acuerdo al 135 constitucional un congreso constituyente para deliberar y construir una nueva Constitución ante los fenómenos de la globalización y de los grande retos que una delincuencia organizada multinacional con crisis en los distintos rubros que atañe la convivencia pacífica y organizada de una sociedad; los principios generales del derecho aludidos al inicio de ésta exposición, fortalecen a éste cuerpo normativo que el poder constituyente de Queréta-

8 Loewinstein Karl, Teoría de la constitución, Ariel, Barcelona, 1965, p. 117. 
Esta obra forma parte del acervo de la Biblioteca Jurídica Virtual del Instituto de Investigaciones Jurídicas de la UNAM

ro le imprimiera con una visión de futuro y de reivindicación social que los gobiernos posrevolucionarios y plurales en un pacto de civilidad y de alternancia no han podido consumar.

\section{LOS RETOS DE LA TEORÍA CONSTITUCIONAL}

Aplaudimos foros de esta naturaleza que animan la discusión de los grandes retos nacionales, de los desafíos mundiales, de las necesidades de la humanidad, de la búsqueda de nuevos horizontes en la construcción de paradigmas innovadores que solucionan el debate de frases alentadoras de gobiernos y la cruda realidad que los envuelve en la cotidianeidad y que ante estos efectos los ideales de un puñado de hombres mostraron que el rumbo de un estado cuyo afán democrático es el de la vigencia del estado de derecho consagrado en igualdad, libertad y justicia social para todos.

Este capítulo de nuestra evolución nacional debe ser analizado en la óptica de las reformas estructurales del gobierno actual y de las administraciones del cambio avaladas por los gobiernos que lograron el triunfo en el primer decenio de este milenio bajo las siglas del partido acción nacional.

Nuestra Constitución ha incorporado reformas y adiciones a lo largo de casi un siglo. Estos cambios han sido las necesidades sociopolíticas a fin de adecuarla a la cambiante realidad que regula. A diferencia de lo que sucedió en otros países que adoptaron posiciones extremas ante la magnitud de los problemas sociales a resolver, los legisladores mexicanos dieron cabida a importantísimas normas de carácter social, sin sacrificar los principios liberales por los que tanto se luchó para lograr una Constitución con espíritu social. Es decir, México armonizó principios liberales con fórmulas sociales al adoptar el primero en el mundo la democracia social; mientras que otros pueblos abandonaban por completo todo concepto liberal en pos de una postura social que llego a abolir la propiedad privada, en el despertar del siglo pasado. Trotsky y el "Ejército Rojo" enmarcaron ésta disyuntiva con los resultados conocidos por todos nosotros, sin omitir los trabajos realizados por Rosa Luxemburgo sobre el particular.

El desarrollo nacional se ha visto colapsado en diferentes etapas del peregrinar de nuestra Constitución y de su interpretación por parte de los gobiernos en turno, así podemos apreciar que una legislación nacionalizó la banca para que años después la mayor parte de sus integrantes la privatizara. Este tipo de contradicciones que la coyuntura internacional o el populismo democrático o también los compromisos asumidos por gobiernos que por su arribo al poder han comprometido la riqueza nacional trastocando 
Esta obra forma parte del acervo de la Biblioteca Jurídica Virtual del Instituto de Investigaciones Jurídicas de la UNAM

los fines que la Constitución republicana, democrática y producto de una revolución protegiera.

Los retos del caudillismo, del caciquismo, de las clases políticas emergentes, de una familia revolucionaria, tecnócratas y demás arribistas al poder, que en su estilo personal de gobierno han empañado los ideales cristalinos que la Constitución adoptó como una respuesta a la entrega de millares de mexicanos que ofrendaron su vida por un México libre e igualitario. La Constitución de 1917 ha sido testigo de los cambios, modificaciones, reformas y demás iniciativas emitidas por las diversas legislaturas que han amenazado, en ocasiones su trascendencia y la síntesis histórica de su devenir en el concierto de las naciones.

Los debates vividos para su promulgación se encuentran almacenados como una referencia de su lucha social. Como pasar por alto las intervenciones de Cabrera, Machorro, Martínez Escobar, Mújica, Jara, Rouaix, y demás mexicanos comprometidos con su tiempo.

“... yo puedo decir y conmigo mucho señores diputados que no solamente no tenemos esa preparación, ni en derecho constitucional ni en ninguno de los otros derechos la tenemos; por tanto y en vista de que nosotros resolvemos estas cuestiones de trascendencia después de oír el pro y el contra, porque para votar más que nuestros conocimientos nos lleva nuestro instinto revolucionario..." 9

Francisco Mújica referente al artículo 27 y en discusión con Hilario Medina cuestionó:

"... ¿y vamos a dejar eso de esa manera, nada más porque la ley lo permite? ¿Vamos a consentirlo? Entonces, ¡maldita la revolución, mil veces maldita, si fuésemos a consentir en esa injusticia! (Aplausos) ....". Algunas veces, hombres revolucionarios que en aquel tiempo habían sido consecuentes con sus principios escribían en la prensa: ¡Sí para que haya justicia, estorba la ley, abajo la ley! Esto explica lo que venimos a hacer esta noche al reivindicar todas esas propiedades, despojados al amparo de una ley creada para favorecer a los poderosos y bajo cuyo amparo se cometieron grandes injusticias. Deshagamos nosotros ahora esas injusticias y devolvamos a cada quien lo suyo...". ${ }^{10}$

Quizás no haya ninguna afirmación más veraz que vinculo la revolución de 1910 con la nueva Constitución que la de Luis Espinoza, oriundo

9 Tomado del Diario de los Debates II, 1916-1917, Congreso de la Unión, México, 1973, p. 507.

10 Ibídem. 
Esta obra forma parte del acervo de la Biblioteca Jurídica Virtual del Instituto de Investigaciones Jurídicas de la UNAM

de Chiapas pero constituyente de Oaxaca, durante la discusión sobre el artículo 3 cuando señaló:

“... la revolución en estos instantes solemnes es este congreso constituyente. La guerra armada no fue, no ha sido más que un medio para llegar a la realización de este congreso constituyente, allá fue la guerra material, aquí es la guerra de ideas; este es el fruto de aquella, y por tanto, ciudadanos aquí estamos en plena revolución, en la revolución de ideas...". ${ }^{11}$

Bajo esta perspectiva podemos encontrar fragmentos que colapsan el ideario del congreso constituyente en voz de Rafael Martínez de Escobar, de Esteban Baca Calderón, de Francisco Martin del Campo, de Uriel Avilés, de José María Truchuelo, de David Pastrana Jaimes, diputado de Puebla que por su trascendencia mencionamos refiriéndose al poder judicial "... recordará usted querido compañero -refiriéndose a Truchuelo- mis esfuerzos para que el poder judicial tenga su origen en la elección libre y directa del pueblo para que sea no un simple tribunal sujeto a las intrigas de los influyentes, sino el verdadero interprete de la justicia nacional...". ${ }^{12}$

Como se aprecia en éste inicio de milenio las contradicciones ante los preceptos señalados son abismalmente diametrales. ¿Dónde quedó el espíritu del constituyente en la integración de la Suprema Corte de Justica con los ministros designados en la actualidad?

La respuesta es obvia. La partidocracia y los clanes del poder han logrado la anulación de posiciones plasmadas en un diario cuyo patrimonio es de todos nosotros y que permanece solo como parte de una letra muerta que inhibe y entierra el espíritu de un cambio en la esencia de lo que es y debe ser el poder al servicio de una idea, de una nación, de un estado.

De igual manera, recordemos al constituyente originario de esta tierra en la que hoy reflexionamos acerca de nuestra Constitución, me refiero a Rafael Martínez Mendoza quien expresara: “... si los individuos que dictamos la constitución de 1917 no seguimos luchando porque se mantengan incólumes los principios de libertad y justicia proclamados en ella, nuestra labor como constituyentes será nula y despreciable, pues de nada sirve dar buenas leyes a un pueblo sino se lucha por su aplicación y sostenimiento...". ${ }^{13}$

En síntesis, podemos observar la retorica usada por los constituyentes pero también sus emociones y anhelos por lograr que después de una lucha revolucionaria los mexicanos de las generaciones siguientes pudieran

11 Ibidem, p. 1118.

12 Tomado del Álbum de David Pastrana Faimes, México, 1973.

13 Tomado del Álbum de la familia Álvarez, Secretaría de Educación Pública, México, 1971, p. 17 . 
Esta obra forma parte del acervo de la Biblioteca Jurídica Virtual del Instituto de Investigaciones Jurídicas de la UNAM

albergar mejores condiciones de vida bajo el anhelo patriótico de un México mejor.

Ante ese panorama, se pretender mostrar en el desarrollo de este Congreso lo que privó en el gran Teatro Iturbide, hoy de la República con casi un siglo de distancia. Por lo que el México de nuestros antepasados, no es el México de hoy, ni su lucha, ni tampoco por conquistas ya concluidas a lo largo de esta centuria.

Los desafíos de nuestro tiempo contemplan nuevos protagonistas, nuevas maneras de ver y apreciar un mundo globalizado, cuyos efectos los tenemos frente a nosotros día a día.

La intención es crear una conciencia de esa lucha por la justicia, la libertad y la igualdad. Paradigmas que en el ciclo liberal de la historia constitucional y de la evolución del estado aparece el debate reiterado entre el ser y el deber ser; desde la construcción de una democracia definida en el artículo 3 y con el aseguramiento de una educación laica y gratuita.

En cada uno de sus artículos originales cuya redacción presentaba esa lucha por encontrar el camino del progreso, crecimiento, desarrollo económico para todos los mexicanos, contrastan con el México del siglo XXI, donde las reformas estructurales en materia de hidrocarburos, comunicaciones y la formación de un Instituto Nacional Electoral con los antagonismos que representa desde su integración como su permanencia para orientar el juego democrático de las fuerzas políticas nacionales; aniquila el debate en materia de lucha política que en Querétaro en 1917 se realizó.

Pensar que el partido político nacido de la Revolución con el ex presidente Calles, es el mismo que hoy dirige el ex gobernador y paisano de Sonora Manlio Fabio Beltrones, resultaría tautológico y ocioso el pretender realizar una comparación desde su ideario y la manera en que se ha conducido en los últimos lustros.

En este orden de ideas, la pregunta que subsiste con las grandes transformaciones y modificaciones a la letra constitucional con reformas, adiciones y demás mecanismos legislativos que se han incorporado en este siglo y con las intenciones de ex presidentes como el caso de Vicente Fox, de hacer una nueva Constitución la pregunta obligada es: ¿sí verdaderamente nuestra Constitución es obsoleta y no responde a las exigencias de nuestro tiempo?

La respuesta es obvia, más aún cuando el debate axiológico nos lleva a las siguientes preguntas:

¿Cómo argumentar y justificar esa relación dialéctica entre la normalidad y la normatividad? ¿Cómo lograr hacer compatible el precepto cons- 
Esta obra forma parte del acervo de la Biblioteca Jurídica Virtual del Instituto de Investigaciones Jurídicas de la UNAM

titucional frente a una sociedad demandante de justicia, transparencia, rendición de cuentas y poner fin a la impunidad, simulación, nepotismo y corrupción de nuestros días?

¿Cómo poder lograr las metas que el constituyente del 17 plasmó y que continúan como grandes desafíos de nuestros días: "justicia distributiva... a trabajo igual, salario igual"; riqueza nacional, reforma agraria y todo una serie de apotegmas que repercuten en una evolución científica pero que se aleja día a día de su esencia y causas que la originaron?

¿Cómo omitir los pronunciamientos de Palavicini frente a una reforma educativa donde las metas y la calidad de la educación no está clara para éste siglo?

¿Dónde queda la libertad de expresión cuando la autoridad alienta la desinformación que junto con la red propicia un estado de indefensión? Ante éste fenómeno asociaciones como "Artículo 19" se orientan para garantizar junto con las demás organizaciones civiles ese derecho bajo la denuncia de violación a derechos humanos, desaparición forzada y demás manifestaciones de represión para los comunicadores y medios de comunicación; verbigracia, lo sucedido en el estado de Veracruz, Tamaulipas, Coahuila, entre otros.

Es cierto, vivimos tiempos de transformaciones vertiginosas que nuestros legisladores del siglo pasado no habrían podido contemplar con un mundo que se achica con la internet, con la culminación de esa cadena de delitos de alto impacto que se sintetiza en el lavado de dinero y que es utilizado para actos de terrorismo; tampoco habrían podido visualizar que doscientas cuarenta familias concentraran el producto interno bruto del mundo, mucho menos una globalización económica que estandariza a la población y la sumerge en esa disyuntiva de marginación, pobreza y miseria extrema. También es verídico que los tiempos de cambio son tiempos de contradicción y reflexión, por lo que nos congratulamos que este Congreso sea el escenario para analizar alcances, contradicciones y retrocesos del pensamiento del constituyente del 17 en este inicio de siglo.

\section{EL CONSTITUCIONALISMO EN LA ERA PRESENTE}

Maurice Duverger en su obra "Derecho constitucional e instituciones políticas" nos dice que el derecho constitucional pasa a ser mas de instituciones políticas que de la Constitución. En ese esquema desarrollamos las siguientes consideraciones que marcan un hito en la historia constitucional de nuestro país. 
Esta obra forma parte del acervo de la Biblioteca Jurídica Virtual del Instituto de Investigaciones Jurídicas de la UNAM

La reforma de 2011 que incorpora tanto derechos humanos como los tratados internacionales como norma suprema de nuestro país, ajusta las manecillas de un cambio en el modelo de justicia penal.

Los esfuerzos del constituyente permanente por continuar el camino de nuestra Constitución y su ideario a inicios del siglo pasado se ha visto colapsado pues pareciera que el rumbo de nuestro país frente a la modernidad y la globalización se desdibujara para entender la competitividad y el libre mercado.

Los cambios en la teoría del estado y en su rol como una hechura del hombre para el hombre parecieran anularse frente a la incipiente y cada vez mayor pérdida de la cultura de la legalidad. Tanto el monopolio de la violencia como el derecho de la criminalidad son expresiones que auspician la reflexión cada vez más profunda para ubicar al estado en su justa dimensión; más aún cuando nos recuerda a Antonio cuando escribía que el estado liberal encogido en hombro ya no cree en nada ni siquiera en sí mismo. ${ }^{14}$

El derecho procesal constitucional como una expresión acabada de las controversias constitucionales y de los cambios que ubican a la Suprema Corte de Justicia como tal, un tribunal constitucional que sumada a las reformas en los diferentes ámbitos de nuestro país hacen que esta disciplina sea una nueva herramienta que la modernidad nos ofrece para hacer velar y salvaguardar tanto derechos humanos como garantías constitucionales.

En esa vertiente de evolución garantista, los anhelos y metas de lo que nuestra Constitución en su origen consagró reflejan dos realidades; una el perfeccionamiento de instituciones democráticas y legales para garantizar la convivencia pacífica y ordenada entre los integrantes de la sociedad global; la otra, un mundo desigual donde la existencia de leyes, como un fenómeno de congestión normativa pretendiera resolver los fenómenos de desigualdad, hambre y miseria de nuestra población y sobre todo que exalta la incapacidad de los gobiernos por lograr una meta fundamental que la Constitución del 17 consagró: libertad, igualdad y justicia.

La enumeración que hemos desarrollado en el texto de este trabajo para reflejar objetivamente el deseo del poder constituyente de 1917 frente a los últimos gobiernos sexenales en nuestro país, no tienen carácter limitativo sino un carácter ejemplificativo, los artículos que son bastión o que fueron parte de una herencia del siglo XIX como el 130 se tradujeron en meras citas referenciales como otros tantos de un pasado que los gobiernos posrevolucionarios agotaron. Sin embargo, otros preceptos como el 29 en

14 Véase Antonio en Montero Zendejas, Daniel, La desaparición del estado, Porrúa, México, 1999, p. 176. 
Esta obra forma parte del acervo de la Biblioteca Jurídica Virtual del Instituto de Investigaciones Jurídicas de la UNAM

donde la Constitución señaló la suspensión de garantías en materia de invasión, perturbación grave de la paz pública y cualquier otro caso que pusiera a la sociedad en grande peligro o conflicto, congruente también con el 49 y 131 enfatizan la consideración anterior, pues los más de setenta y cinco mil desplazados por concepto de violencia e inseguridad así como los más de cien mil ejecutados y desaparecidos en la guerra del narcotráfico del ex presidente Calderón, significó también, un mero concepto en el anecdotario de nuestra evolución científica.

La teoría constitucional que se ha robustecido del garantismo, de tribunales internacionales, de medidas que alientan un cambio significativo en el modelo de justicia peal que bajo los principios de presunción de inocencia, oralidad, contradicción, publicidad, inmediatez, y oportunidad, ofrecen en este nuevo paradigma de justicia para todos el respeto al debido proceso que seguramente apelarán a él la población penitenciaria de casi doscientos cincuenta mil internos recluidos en los más de cuatrocientos cincuenta centros penitenciarios. Empero también en este rubro se reflejan las grandes contradicciones pues la población menesterosa, la más desfavorecida del desarrollo económico de un país que aclama cambios significativos en pro de su población son los que las estadísticas reclaman para su atención y también para los que se encuentran privados de la libertad.

En síntesis, el constitucionalismo de nuestros días se ha fortalecido en la perspectiva de las ideas que nutren la teoría jurídica, al prevalecer esa disonancia entre los que tienen todo y los que carecen también de todo y cuya única riqueza es su pobreza.

Ante ese panorama la Corte Interamericana de Derechos Humanos, la Corte de Justicia de Naciones Unidas, el Consejo de Seguridad y la Corte Penal Internacional, forman parte de una radiografía evolutiva de las sociedades en cambio y en ese escenario internacional también los desafíos persisten y se agudizan con el llamado Estado Islámico y lo que significa Siria en el Medio Oriente.

México en ese concierto internacional bajo la apertura democrática y en nombre de esta forma de gobierno ha pretendido consolidar un Tribunal Constitucional donde su integración responde a intereses espurios y no de un avance coherente y congruente con el servicio civil de carrera; más aún las tendencias partidistas, intereses hegemónicos y diferentes contradicciones hacen que la justicia continúe siendo la aspiración mayor que el pueblo pretende alcanzar retomando los principios e ideario de un constitucionalismo social que amalgamó las primeras décadas del siglo pasado a millares de mexicanos. 
Esta obra forma parte del acervo de la Biblioteca Jurídica Virtual del Instituto de Investigaciones Jurídicas de la UNAM

Sean estas reflexiones en este universo de colegas y estudiosos del constitucionalismo una parada en el camino de nuestro derecho constitucional. Una reflexión que alimente el principio y el decálogo del abogado, el entender que sólo con la ley y su vigencia nuestro texto constitucional junto con sus metas y el espíritu del constituyente que la animó, podremos ser merecedores del título que nos distingue.

\section{GONCLUSIONES}

1. El presente artículo pretende mostrar al lector la necesidad de unir el ser con el deber ser que constituye la expresión constitucional y democrática de creación de instituciones o reformulación de las mismas para lograr los preceptos que enarbolaron los legisladores que se definió como poder constituyente de 1917.

2. Si bien es cierto que los avances legislativos y la existencia legal casi para todo el comportamiento delincuencial de la sociedad de nuestro tiempo, continua la asignatura de la certidumbre jurídica que presupone la cultura de la legalidad y el fortalecimiento de un estado que la garantiza por encima de la impunidad, simulación y corrupción.

3. La vigencia de nuestra Constitución se consolida día a día ante los fenómenos de desigualdad, trato preferente para extranjeros, inversionistas y demás núcleos de capital trasnacional que han atentado contra las empresas estratégicas y soberanas de nuestro país.

4. En materia de derecho social nuestra Constitución no ha agotado sus metas y mucho menos el ideario que le dio vida. El peso que contempló como salario mínimo para alimentar una familia y asegurar su dignidad, en su proyección a un siglo de distancia de trabajo igual, salario igual, la canasta básica se transforma en espejismo.

5. En materia de reforma agraria el ejido se exterminó, las granjas y terrenos son alquilados para las empresas trasnacionales. El sector campesino se erosionó y nuestra producción en actividades económicas primarias se han desplomado con la premisa del mercado libre; quiere decir, que es más redituable importar que producir.

6. La integración de los poderes públicos, la reforma política, la legislación electoral y los organismos encargados de su vigilancia y de pulsar una democracia sin rostro, han hecho que el abstencionismo y la desconfianza a la autoridad electoral como al proceso mismo de la elección sea solo un proceso de legalidad y no de legitimidad. El costo democrático en un país con tanta carencia económica se traduce 
Esta obra forma parte del acervo de la Biblioteca Jurídica Virtual del Instituto de Investigaciones Jurídicas de la UNAM

a la afrenta social que propicia el gobierno en turno para justificar el monopolio del poder.

\section{BIBLIOGRAFÍA}

Pastrana Jaimes, David, Albúm, México, 1973.

Congreso de la Unión, Diario de los Debates II, 1916-1917, Congreso de la Unión, México, 1973.

Kelsen, Hans, Teoría pura del derecho, Eudeba, Buenos Aires, 1970.

Loewenstein Karl, Teoría de la constitución, Ariel, Barcelona, 1965.

Montero Zendejas, Daniel, La desaparición del estado, Porrúa, México, 1999.

, Hacia un nuevo constitucionalismo, Gobierno del estado de Veracruz, México, 2001.

-, Derecho constitucional comparado, Porrúa, México, 2006.

Schmiтt, Carl, El concepto de lo politico, Folios ediciones, México, 1985.

-, Legalidad y legitimidad, Tecnos, Madrid, 1973.

TURner, John, México bárbaro, ERA, México, 1977. 
Esta obra forma parte del acervo de la Biblioteca Jurídica Virtual del Instituto de Investigaciones Jurídicas de la UNAM

\title{
BALANCE Y PERSPECTIVAS \\ DE LA REFORMA CONSTITUGIONAL \\ PENAL DEL 18 DE JUNIO DEL 2008 A FEBRERO DEL 2016
}

\section{Rafael SÁNCHEZ VÁZQUEZ}

\begin{abstract}
"El esfuerzo de la educación; es decir, la proclamación de los derechos para los hombres de la era contemporánea, ha bastado para hacerlos ilustrados y aun sabios, si se quiere; pero no ha servido para darles capitales ni materias. Se han hechos abogados y médicos sin clientela, agricultores sin hacienda, ingenieros y geógrafos, sin canales ni caminos, artesanos muy hábiles, pero sin recursos. La sociedad en su parte material se ha quedado la misma; la tierra, en pocas manos; los capitales, acumulados; la circulación, estancada". "Todos los que estaban fuera de las ventajas positivas de tal estado de cosas buscaron su bienestar en la política y se hicieron agitadores. Y todos los que disfrutaban esas ventajas la saborearon y se hicieron egoístas."
\end{abstract}

Ponciano ARRIAGA ${ }^{1}$

\footnotetext{
1 Arriaga, Ponciano: Voto particular, sobre el Derecho de propiedad, como Miembro de la Comisión de Constitución, en la sesión del 23 de junio de 1856. Cit. por Zarco, Francisco, Historia del Congreso Extraordinario Constituyente 1856 y 1857, Extracto de todas sus sesiones y documentos parlamentarios de la época, $1^{\mathrm{a}}$ ed., México, Imprenta de Ignacio Cumplido, Calle de los Rebeldes, núm. 2, 1857, p. 549.
} 
Esta obra forma parte del acervo de la Biblioteca Jurídica Virtual del Instituto de Investigaciones Jurídicas de la UNAM

"La reforma en marcha contiene avances y retrocesos, aciertos y errores, todos ellos muy notables. No es posible -sería injusto y temerario- emitir un juicio uniforme sobre este movimiento normativo, de condición heterogénea. Pertenece a la categoría de las "reformas ambiguas", si se me permite la expresión, que al lado de notables pasos adelante ofrece desaciertos y soluciones peligrosas. Estas militan contra el orden penal democrático y ponen en predicamento derechos y garantías de los ciudadanos. Por eso he comparado la reforma con un vaso de agua fresca, cristalina, que invita a saciar la sed, en el que alguien hubiese dejado caer, sin embargo, unas gotas de veneno. Ya se verá el efecto general que esta inquietante mezcla produce en la fisiología de la nación."

Sergio GARCÍA RAMÍREZ ${ }^{2}$

"La reciente reforma constitucional al sistema de justicia penal y de seguridad pública puede definirse como la transformación más profunda del proceso penal mexicano moderno; en efecto, desde el Congreso Constituyente de 1916, no ha existido una reforma que tenga la misma amplitud de miras y de objetivos. Ahora, una vez aprobado el nuevo texto constitucional, se abre una nueva etapa: la implementación de los principios y directrices de la reforma en el ámbito del proceso penal ordinario, etapa que, evidentemente, será una de las labores más delicadas para todos los operadores jurídicos en nuestro país."

Carlos F. NATARÉN NANDAYAPA ${ }^{3}$

2 García Ramírez, Sergio, La reforma penal constitucional (2007-2008). ¿Democracia o autoritarismo?, México, Porrúa, 2008, p. 537.

3 Natarén Nandayapa, Carlos F., "Breves Reflexiones sobre algunos de los retos en el diseño del nuevo proceso penal ordinario", en García Ramírez, Sergio y de González Ma- 
Esta obra forma parte del acervo de la Biblioteca Jurídica Virtual del Instituto de Investigaciones Jurídicas de la UNAM

\begin{abstract}
SUMARIO: I. Introducción. II. Algunos indicadores acerca de la administración, procuración e impartición de la justicia penal en México. III. Breves consideraciones sobre el Sistema Procesal Penal Acusatorio vía los fuicios Orales en México desde la perspectiva del garantismo de Luigi Ferrajoli. IV. Diagnóstico actual sobre la implementación del Sistema Procesal Penal Acusatorio vía los Juicios Orales en México, a partir de la Reforma del 18 de junio de 2008 hasta el primer trimestre del 2016. V. Reflexiones finales. VI. Bibliografia.
\end{abstract}

\title{
I. INTRODUCGIÓN
}

Con mucho agrado participo en el VII Congreso Nacional de Derecho Constitucional con sede en esta hermosa ciudad de incuestionable legado histórico, San Luis Potosí, México; tierra del prócer de la patria Don Ponciano Arriaga, quien, además, se distinguió por tener un pensamiento progresista, crítico y comprometido socialmente.

Además, me permito felicitar, entre otros, al Dr. Diego Valadés, Presidente del Instituto Iberoamericano de Derecho Constitucional, al Dr. Domingo García Belaude, Secretario General Ejecutivo del Instituto Iberoamericano de Derecho Constitucional, al Dr. Pedro Salazar Ugarte, Director del Instituto de Investigaciones Jurídicas de la Universidad Nacional Autónoma de México. Igualmente, a los convocantes y coordinadores generales del congreso al Dr. José Ma. Serna de la Garza, Vicepresidente del Instituto Iberoamericano de Derecho Constitucional; y al Dr. Isidro de los Santos Olivo, Profesor Investigador de la Universidad Autónoma de San Luis Potosí. Por otra parte, me permito señalar que, la presente investigación formo parte de la Mesa III: La reforma de las constituciones locales en el marco del sistema federal mexicano, la cual se diserto durante la tarde del día miércoles 3 de febrero del presente año. Consecuentemente, el tema objeto de la presente investigación consistió en: Balance y perspectivas de la Reforma Constitucional Penal del 18 de junio del 2008 a febrero del 2016.

Ahora bien, de manera esquemática presento esta modesta investigación con algunas consideraciones que nos permitan orientar nuestra contribución, en los siguientes términos:

El verdadero mal del siglo XX que fenece, es la corrupción generalizada que preside a la cultura mundial. Así pues, la corrupción no sólo la identificamos en la esfera pública sino también la que se desarrolla en el ámbito

riscal, Olga Islas (coords.), La Reforma Constitucional en Materia Penal fornadas de Fusticia Penal, México, IIJUNAM-INACIPE, 2009, p. 229. 
Esta obra forma parte del acervo de la Biblioteca Jurídica Virtual del Instituto de Investigaciones Jurídicas de la UNAM

privado. A fin de evitar la corrupción, se torna oportuno el reconocer la misma responsabilidad penal, administrativa y social entre el corruptor y el corrupto. ${ }^{4}$

La imagen de la justicia en la prensa, la opinión pública o incluso en el medio de la profesión jurídica, es y ha sido, en general desfavorable y pareciera reflejar una crisis persistente y difundida, lo que, por un lado, pudiera atribuirse en parte al desconocimiento público de las condiciones y la dinámica internas de esta institución, pero por el otro, bien puede reflejar un deterioro relativo pero real. Las razones de tal preocupación son múltiples. Un marco de referencia próximo quizá sea la pérdida de legitimidad del Estado y sus instituciones, como consecuencia de las dificultades, reales o supuestas, que éstas enfrentan para solucionar algunos de los más apremiantes problemas sociales (como el desempleo), especialmente en época de una prolongada crisis económica. De ahí la necesidad de hacer más eficientes, dichas instituciones, mediante la reducción de costos o, al menos, a través de un mejor aprovechamiento de los recursos y de una mayor productividad. ${ }^{5}$

La moral pública en México se encuentra enferma, es necesario un cambio de mentalidad, por el bien del país. Empero son vicios muy antiguos y arraigados en nuestra sociedad. Los conoció y sufrió la sociedad colonial durante casi tres siglos. Los mismos perduraron durante los siglos XIX, XX y sigue en los primeros nueve años del siglo XXI. Consecuentemente, cuando los servidores públicos son incompetentes, irresponsables, no comprometidos con su labor o corruptos, una combinación de algunos de estos aspectos, y que giran en torno al poder, dinero, corrupción, impunidad y mentiras. Así pues, dichas actitudes ponen en riesgo las mejores instituciones, ya que se encaminan ineluctablemente al fracaso. Además, no podemos pasar por alto que dichas conductas y actitudes egoístas y mezquinas redundan en perjuicio de las mayorías que viven en la pobreza, ya que carecen de lo mínimo necesario para desarrollarse. ${ }^{6}$

De ahí que la Reforma Constitucional tanto del 18 de junio de 2008, que establece el sistema Penal Acusatorio oral y garantista, como la del 10 de junio de 2011, sobre la Constitucionalidad de los Derechos Humanos, genera paradigmas novedosos tanto en la interpretación como en la aplicación del Sistema Jurídico Mexicano vigente, toda vez, que ahora se cons-

4 Castro, Juventino, La mutación estructural del derecho en México, México, Porrúa, 1998, pp. 60 a 63.

5 Fix Fierro, Héctor, "La eficiencia de la justicia (una aproximación y una propuesta)", en Cuadernos para la Reforma de la fusticia, México, UNAM, 1995, pp.11 y 12.

6 Cffr. Carpizo, Jorge, Moral pública y libertad de expresión, México, Jus, 2009, pp. 11 y 23 ss. 
Esta obra forma parte del acervo de la Biblioteca Jurídica Virtual del Instituto de Investigaciones Jurídicas de la UNAM

truye una cultura jurídica en favor del principio pro persona, a través de lo estipulado tanto en los tratados como en las convenciones internacionales signados por el Estado Mexicano. Además, es un cambio de paradigmas, en cuanto a la concepción teórico metodológico del Sistema Jurídico Mexicano. Ahora, se trata de alejarse del exacerbado positivismo jurídico vía la exégesis del Derecho. Consecuentemente, la atención será en torno al Realismo Jurídico, bajo el esquema garantista de Luigi Ferrajoli.

\section{ALGUNOS INDICADORES ACERCA}

DE LA ADMINISTRACIÓN, PROGURACIÓN E IMPARTICIÓN DE LA JUSTICIA PENAL EN MÉXICO

De acuerdo a la investigación realizada por Efrén Arellano Trejo, se identifican en la República Mexicana los siguientes datos sobre la incidencia delictiva y su impacto en la opinión pública:

1) Crecimiento inusitado de la delincuencia. ${ }^{7}$

2) El número de delitos con violencia están entre los diez más altos en el mundo. Tan solo 80,000 muertos con motivo de la guerra contra el crimen organizado 2006-2012, y en el 2013 mil muertos por cada mes que transcurre.

3) Por cada delito denunciado existe dos o tres que no lo son.

4) La impunidad es mayor al 95 por ciento. Algunos cálculos, que incluyen delitos no denunciados, estiman que sólo son remitidos a un juez 2 por ciento de quienes delinquen.

5) La delincuencia dispersa, que obtiene bajos montos, afecta a la mayoría de la población. El asalto en vía y transporte públicos, que presumiblemente son robos con bajos montos, es el delito padecido por el mayor número de ciudadanos. A su vez, es el delito que menos se denuncia. ${ }^{8}$

6) Más del 40 al 50 por ciento de la población justifica la justicia por propia mano. Más de la mitad de la población considera que la ley se aplica en beneficio de unos cuantos o para defender a la gente con poder. Esta situación, más los altos niveles de impunidad, explican

7 Cfr. Arellano Trejo, Efrén, Los desafios de la delincuencia en México (Incidencia delictiva y su impacto en la opinión pública), México, Centro de Estudios Sociales y de Opinión Pública, Cámara de Diputados, s.a. p. 1.

8 Cfr. Arellano Trejo, Efrén, op. cit., p. 2. 
Esta obra forma parte del acervo de la Biblioteca Jurídica Virtual del Instituto de Investigaciones Jurídicas de la UNAM

en gran medida que cuatro de cada diez ciudadanos justifiquen la justicia por propia mano.

De acuerdo con la Encuesta Internacional sobre Criminalidad y Victimización 2004 (ENICRIV), durante el periodo que va de enero de 1999 al primer semestre de 2004, en México más de 30 millones de personas mayores de 18 años fueron víctimas de la delincuencia. Dicho en otros términos, en 47 por ciento de los hogares mexicanos por lo menos un miembro fue víctima de uno o más delitos. ${ }^{9}$

La cercanía entre la comisión del delito y la detención pone de manifiesto otro rasgo peligroso de la justicia penal mexicana, la policía detiene en muchas ocasiones sin orden judicial. La Constitución permite en el artículo 16 , detener a una persona cuando es sorprendida en flagrancia o cuando se trate de un caso urgente, siempre que se trate de delito grave y no se pueda obtener la orden judicial respectiva. Se calcula que el $40 \%$ de las detenciones se realizan sin la orden de aprehensión que debe emitir un juez. ${ }^{10}$ Las encuestas realizadas a la población penitenciaria, señalan que, el 92\% de los casos, a los detenidos no les fue mostrada la orden de aprehensión. ${ }^{11}$

El $71 \%$ de los detenidos en el Distrito Federal no tuvo asistencia de abogado mientras estuvo privado de su libertad ante el Ministerio Público; del 30\% que sí tuvo asistencia de abogado, la mayoría (70\%) no pudo hablar con él a solas. Ya ante el juez que conoció de la acusación en su contra, el $60 \%$ de los detenidos no fueron informados de que tenían derecho a no declarar. ${ }^{12}$

El 80\% de los detenidos nunca habló con el juez que lo condenó; en el $71 \%$ de los casos, el juzgador no estuvo presente durante la declaración del detenido (ya en sede judicial). ${ }^{13}$

Además, cabe resaltar, que durante muchos años, el Sistema Procesal Penal Inquisitivo Mixto, ha contribuido a fortalecer las deficiencias del sis-

9 Instituto Ciudadano de Estudios sobre la Inseguridad (ICESI) y Oficina de las Naciones Unidas contra la Droga y el Delito, Encuesta Internacional sobre Criminalidad y Victimización (ENICRIV-204), www.icesi.org.mx, fecha de consulta 18 de marzo de 2004. Cit. por Arellano Trejo, Efrén, op. cit., p. 3.

10 Zepeda, Crimen sin castigo, cit., p. 245. Cit. por Carbonell, Miguel, y Ochoa Reza, Enrique, ¿Qué son y para qué sirven los juicios orales?, México, Porrúa, 2008, p. 4.

11 Bergman, Marcelo y otros, delincuencia, marginalidad y desempeño institucional. Resultados de la segunda encuesta a población en reclusión en el Distrito Federal y el Estado de México, México, CIDE, 2006, p. 35. Cit. por Idem.

12 Zepeda, Crimen sin castigo, cit., pp. 252-253. Cit. por Ibidem, pp. 4 y 5.

13 Bergman, Marcelo (coordinador), delincuencia, marginalidad y desempeño institucional, cit., p. 47. Cit. por Supra. Ibidem, p. 5. 
Esta obra forma parte del acervo de la Biblioteca Jurídica Virtual del Instituto de Investigaciones Jurídicas de la UNAM

tema penal mexicano, al contrarrestar la legalidad y legitimidad del Estado, y cada vez más lo alejan de la aspiración de fortalecer a las instituciones del Estado de Derecho Democrático.

Por su parte, el jurista y criminólogo Luis Rodríguez Manzanera, considera lo siguiente: un derecho penal que ya no ve a la readaptación, que ya no ve al diagnóstico y pronóstico, que ya no ve al tratamiento del hombre, es decir, un derecho penal puramente vindicativo, al grado que lo estamos viendo, la única solución aparente dentro del sistema penal actual vigente es aumentar penas, lo cual parece casi una broma, la competencia no es como apoderarse de la tribuna, sino haber quien propone la pena más alta, si un partido dice que cincuenta años el otro dice que ochenta, etcétera. El riesgo terrible aquí, y no solo en México, es que sigue flotando la amenaza de la reimplantación de la pena de muerte, porque como 500 años de prisión no funcionan, pues entonces pena de muerte. ¿Este es el derecho penal que nosotros queremos? ${ }^{14}$

Al principio de 2007, en una circunstancia de criminalidad exacerbada, impotencia estatal para contenerla y profunda exasperación social, volvieron a la escena las propuestas reformadoras de la Constitución, que en esta oportunidad adoptaron, sobre todo, soluciones jurídicas imperantes en los Estados Unidos de América, de donde provienen algunas evangelizaciones que hemos recibido con notable diligencia. ${ }^{15}$

La misma reforma contiene novedades preocupantes, de signo autoritario, que conspiran contra el sistema penal de la sociedad democrática y ponen en predicamento derechos y garantías individuales. Estas novedades podrían imprimir un viraje pernicioso a los avances alcanzados con gran trabajo y ensombrecer el rumbo y el destino del orden penal mexicano. ${ }^{16} \mathrm{Se}$ halla a la vista el peligro de "guantanamizar" la justicia penal mexicana. ${ }^{17}$

En atención, a una investigación de campo realizada por Raúl Guillén López, se llegó a los siguientes resultados de la muestra, se evidenció que el Ministerio Público, durante la averiguación previa, acredita el cuerpo del delito y la probable responsabilidad penal con pruebas desahogadas ante él mismo, sin asistencia ni participación de la defensa, y en secreto, a excepción

14 Rodríguez Manzanera, Luis, "La necesidad del acercamiento de la criminología en la procuración e impartición de justicia”, en Rafael Sánchez Vázquez (coord.), Administración, Procuración e impartición de justicia. Memoria del Congreso Nacional e Internacional, Puebla, México, Benemérita Universidad Autónoma de Puebla, Facultad de Derecho y Ciencias Sociales e Instituto de Investigaciones Jurídico Políticas BUAP, 2008, p. 369.

15 García Ramírez, Sergio, La reforma penal... op. cit., p. VII.

16 Ibidem, p. IX.

17 Idem. 
Esta obra forma parte del acervo de la Biblioteca Jurídica Virtual del Instituto de Investigaciones Jurídicas de la UNAM

de la declaración ministerial en la que por cierto frecuentemente se cometen irregularidades; como ya se dijo, no en pocas ocasiones las pruebas desahogadas en dichas condiciones sirven no sólo para acreditar el cuerpo del delito, sino también son suficientes para demostrar la plena responsabilidad penal (ambos elementos son suficientes para dictar sentencia), es decir, la investigación del delito se realiza, principalmente, durante la etapa de averiguación previa, donde el indiciado tiene menos oportunidad de defenderse. ${ }^{18}$

Por lo que toca a la defensa, cuando no ofrece pruebas durante el periodo de instrucción, lo cual ocurre frecuentemente, ya sea porque el inculpado confiesa la comisión del delito, por no estimarlo necesario o por descuido, se presenta una situación inaceptable como lo es que el juez no conozca a los testigos de cargo. La información en la que se apoya para dictar sentencia le llega de segunda mano (testimonios que no le constan, en los que no participó). Son testimonios que tampoco le constan a la defensa, ya que tampoco participa en el desahogo de tales diligencias probatorias. Cabe destacar lo relacionado con la actividad de los defensores públicos, pues con sus enormes cargas de labores es difícil que desempeñen su trabajo en condiciones adecuadas; esta situación afecta de manera considerable el debido cumplimiento de la garantía de defensa adecuada. ${ }^{19}$

El Estado mexicano reconoce en tratados internacionales, el principio de presunción de inocencia, lo cual implica que excepcionalmente se deba dictar la prisión preventiva; sin embargo, por lo que concierne a Sonora (y a México, en general) pasa todo lo contrario, pues no se respeta este principio, debido a que se aplica el criterio de delitos graves y no graves. En los primeros - delitos graves - sin excepción alguna, se impone dicha medida cautelar a los inculpados, en franca contradicción a la normatividad internacional que también forma parte del derecho positivo mexicano. ${ }^{20}$

Desde el establecimiento de esta figura en el marco constitucional (1993), se han venido incrementando los delitos considerados como graves, lo que trae como consecuencia la sobrepoblación penitenciaria. Cabe resaltar que la mencionada figura jurídica se encuentra contemplada en el artículo 187 del CPPES*, y es conforme al artículo 20, apartado "A", fracción I, de la CPEUM**.

18 Guillén, López, Raúl, Cruz Covarrubias, Armando E., La justicia penal en México. Un estudio de caso, México, Instituto de Investigaciones Jurídicas de la UNAM, 2008, p. 81.

19 Guillén López, Raúl y Cruz Covarrubias, Armando E., op. cit., p. 82.

20 Idem.

* Código Procesal Penal del Estado de Sonora.

** Constitución Política de los Estado Unidos Mexicanos. 
Esta obra forma parte del acervo de la Biblioteca Jurídica Virtual del Instituto de Investigaciones Jurídicas de la UNAM

Así pues, la fórmula de delitos graves y no graves no es inconstitucional, pero contradice lo establecido en los tratados internacionales. De ahí que resulte incongruente la firma de tales ordenamientos jurídicos en los que nuestro país se compromete a respetar dichos documentos, y por otra parte, en su ley fundamental hace caso omiso a ellos. ${ }^{21}$

El modelo procesal penal contempla derechos a favor del inculpado, como por ejemplo, el de ser juzgado en audiencia pública por un juez (principio de publicidad); sin embargo, los juzgados no cuentan con la infraestructura necesaria, y mucho menos existe la cultura de la participación ciudadana en audiencias celebradas durante las etapas de instrucción y juicio. Por lo anterior, en la práctica, esta garantía individual no se satisface cabalmente.

Dificilmente se puede hablar de respeto a principios elementales rectores del proceso penal, como son el de inmediación (que las pruebas se practiquen ante quien va juzgar, es decir, el juez), pues una gran cantidad de ellas se desahogan ante un órgano diverso; es decir, el Ministerio Público, que en la etapa de proceso se convierte en parte acusadora. Inclusive, en las pruebas que se desahogan en la etapa judicial, el juez no siempre se encuentra presente. ${ }^{22}$

Además, cabe resaltar otro problema palpable, el cual, tiene que ver con las irregularidades que se cometen cotidianamente por los operadores tanto de la procuración como de la impartición de la justicia, a este respecto, Raúl Guillen López y Armando Cruz Covarrubias, consideran que: por parte de los jueces, debido a que firman diligencias (declaraciones testimoniales, careos, declaraciones preparatorias y otras) en las que no están presentes; sin bien, ello se debe a la carga laboral, no tiene justificación desde el punto de vista legal. Del mismo modo, los defensores y el Ministerio Público incurren en este tipo de responsabilidades al firmar las actas que fueron celebradas, violando no sólo las formalidades del procedimiento, sino también derechos y garantías individuales del inculpado. ${ }^{23}$

La justicia local en México es un tema que, paradójicamente, a pesar de su trascendencia para el funcionamiento del Estado, ha estado casi olvidado. A pesar de que se trata de una de las áreas que ha sufrido directamente el menosprecio y la subordinación institucional, mediante los efectos de un régimen caracterizado por la centralización y el autoritarismo, los Poderes Judiciales locales continúan siendo espacios vitales de vinculación entre al-

\footnotetext{
21 Guillén López, Raúl y Cruz Covarrubias, Armando E., op. cit., p. 83.

22 Guillén López, Raúl y Cruz Covarrubias, Armando E., op. cit., p. 84.

23 Idem.
} 
Esta obra forma parte del acervo de la Biblioteca Jurídica Virtual del Instituto de Investigaciones Jurídicas de la UNAM

gunos sectores de la sociedad y el Estado, así como mecanismos de legitimidad de un régimen formalmente fundado en el derecho. ${ }^{24}$

Por otra parte, (es decir, desde hace más de once años a la fecha) hoy resulta un clamor popular la necesidad de transformar radicalmente todo el proceso penal en México para dejar atrás su naturaleza inquisitoria, donde la carga de la prueba queda en manos del acusado y el Ministerio Público (órgano de procuración de justicia dependiente del Ejecutivo) juega el papel de parte e investigador de los delitos simultáneamente. Son múltiples los temas que tienen que ser estudiados con detalle para formular una propuesta global. Entre otros, los especialistas han mencionado los siguientes: derechos de las víctimas; tortura; jurisdicción militar; arraigo domiciliario; justicia de menores; debido proceso legal; derechos de los reclusos; instrucción de los procesos penales y administración de justicia; responsabilidad de autoridades encargadas de las procuración de justicia, seguridad pública y garantías ciudadanas. ${ }^{25}$

Con fecha 11 de agosto 2003, el Pleno de la Suprema Corte de Justicia de la Nación, aprobó la propuesta de realizar una consulta nacional sobre la Reforma del Sistema de Impartición de Justicia. Durante el primer semestre de 2004, se celebraron 40 foros para que los participantes entregaran sus ponencias. El 31 de agosto de 2004, se recibieron 5,844 trabajos, que fueron clasificados en 28 temas de su análisis se identificaron más de 11,000 propuestas y se pusieron al conocimiento público vía internet. Se prepararon 34 diagnósticos de percepción ciudadana. Durante los día 30 de noviembre, 1 y 2 de diciembre 2005, se reunieron los impartidores de justicia del país para discutir los rubros que habrá de seguir el proceso de Reforma Judicial, a través de la Declaración de Juríca. ${ }^{26}$

En síntesis, el libro Blanco contiene un diagnóstico actual de las debilidades y fortalezas que esquematizan la administración, procuración e impartición de la justicia en nuestro país. Consecuentemente, es altamente significativa la experiencia contenida en dicho diagnóstico, toda vez, que nos permite construir una agenda para la justicia en México. ${ }^{27}$

24 Concha Cantú, Hugo Alejandro y Caballero Juárez, José Antonio, Diagnóstico sobre la administración de justicia en las entidades federativas. Un estudio institucional sobre la justicia local en México, México, Instituto de Investigaciones de Jurídicas de la UNAM, 2001, p. XXI.

25 Concha Cantú, Hugo Alejandro y Caballero Juárez, José Antonio, Diagnóstico ... op. cit., p. 322.

26 Caballero Juárez, José Antonio, López Ayllón, Sergio y Oñarte Laborde, Alfonso, Libro Blanco de la Reforma Judicial. Una agenda para la justicia en México, México, Suprema Corte de Justicia de la Nación, 2006, pp. 22, 23 y 24.

27 Caballero Juárez, José Antonio, et al, op. cit., pp. 24 a 26. 
Esta obra forma parte del acervo de la Biblioteca Jurídica Virtual del Instituto de Investigaciones Jurídicas de la UNAM

En relación a los problemas que se presentan sobre la procuración e impartición de la justicia en nuestro país, cabe hacer mención de lo siguiente: Existen varias opiniones, una de ellas consiste en expresar que la política judicial persigue, entre otros resultados, por una parte, el dar un paliativo a los problemas de la indigencia en que viven más del 70\% de los mexicanos. Dicha problemática, se arrastra desde hace muchos años y en las últimas dos décadas con la puesta en práctica de las políticas neoliberales se ha agudizado la pobreza. De ahí, la razón de ser de las recomendaciones de impulsar la Reforma Judicial por parte de los organismos financieros: Banco Mundial y Fondo Monetario Internacional como estrategias que contribuyen en el desarrollo económico, político y social de nuestros países, en especial para beneficiar a los más pobres de Latinoamérica, y, por la otra parte, contrarrestar la opinión casi generalizada que tiene la sociedad respecto a los problemas de credibilidad, legitimidad, transparencia, en relación a los operadores que están al frente de las instituciones que administran, procuran e imparten justicia en México.

\section{BREVES CONSIDERAGIONES SOBRE}

EL SISTEMA PROCESAL PENAL ACUSATORIO VÍA

LOS JUICIOS ORALES EN MÉXICO

DESDE LA PERSPECTIVA DEL GARANTISMO

DE LUIGI FERRAJOLI

Iniciamos el desarrollo del presente apartado con la génesis y desarrollo del Sistema Penal Acusatorio. A este respecto, cabe destacar que, existe una apreciación generalizada acerca de que el sistema penal acusatorio aparece en la época de la República Romana. Empero, en atención a otras fuentes se considera al Gran Sanhedrin de la cultura jurídica Hebrea como el antecedente más lejano del sistema penal acusatorio.

El Gran Sanhedrin funcionaba en un estrado semicircular, lo que permitía que cada uno de sus miembros pudiera observar a cada uno de sus colegas y mirar directamente al acusado, al acusador y a los testigos, lo que constituía la mejor oportunidad para examinar en detalle sus respectivos rostros mientras hacían sus declaraciones. Este detalle puede ser considerado como la etapa inicial de lo que se conoce en la actualidad como psicología judicial. ${ }^{28}$ Los jueces debían examinar a los testigos mediante una

28 Álvarez Román, Jesús Antonio, El derecho en las culturas orientales, Babilonia, Israel, el Mundo Árabe Islámico, Jus, México, 1983, p. 48. 
Esta obra forma parte del acervo de la Biblioteca Jurídica Virtual del Instituto de Investigaciones Jurídicas de la UNAM

detallada interrogación y contra-interrogación. Una serie de preguntas se referían al momento exacto (fecha del mes, día de la semana, hora del día, etcétera) y al lugar (dentro de la parte urbana o en despoblado) en que el presunto crimen fue cometido; al tipo de arma utilizada y si les constaba que la víctima era un israelita. Una vez que estas preguntas se consideraban satisfactoriamente contestadas, los jueces formulaban otras relacionadas con la identificación de la víctima y del acusado, así como con las circunstancias particulares que pudieron rodear la comisión del delito. ${ }^{29}$

$\mathrm{Al}$ paso de los años, encontramos que tanto en Grecia como en la Roma republicana, el proceso penal tiene una estructura esencialmente acusatoria, a causa del carácter predominantemente privado de la acusación y de la consiguiente naturaleza arbitral tanto del juez como del juicio. Si, en efecto, el paso de la venganza de sangre al derecho penal se realiza con la atribución de las funciones de enjuiciamiento y sancionadoras a un órgano imparcial y muy pronto público, la titularidad de la acusación permanece largo tiempo en manos de la parte ofendida o de su grupo familiar, en una época posterior, transferirse a la sociedad y, por su cauce a cada ciudadano particular. Es precisamente de esta naturaleza privada o polar $-\mathrm{y}$ en cualquier caso voluntaria- de la acción penal de donde derivan en el proceso romano ordinario, los caracteres clásicos del sistema acusatorio, es decir, la discrecionalidad de la acción, la carga acusatoria de la prueba, la naturaleza del proceso como controversia basada en la igualdad de las partes, la atribución a éstas de toda la actividad probatoria y hasta de la disponibilidad de las pruebas, la publicidad y oralidad del juicio, el papel de árbitro y espectador reservado al juez, tanto más dado su carácter popular. ${ }^{30}$ Así pues, el proceso se vuelve acusatorio, confundiéndose en las primeras jurisdicciones bárbaras con los ritos de las ordalías y los duelos judiciales, evolucionando después en la forma de la disputatio y del contradictorio, elaborados entre el fin del primer milenio y el siglo XII, se desarrolla y consolida en Inglaterra y en el mundo anglosajón en las formas del adversary system. ${ }^{31}$ No por casualidad, las primeras formas de proceso inquisitivo se desarrollaron en la Roma imperial con las causas de oficio por los delicta publica, comenzando por los crimina laesae maiestatis de subversión y conjura, en los que

29 Drapkin S., Israel, "La administración de justicia en el antiguo derecho hebreo", en Criminalia. 50 años. Academia mexicana de ciencias penales-Porrúa, México, año L, núms. 7-12, Julio-diciembre 1984, p. 140.

30 Ferrajoli, Luigi, Derecho y razón. Teoría del garantismo penal, Prologo de Norberto Bobbio, trad. al castellano por Perfecto Andrés Ibáñez, et al., $1^{\text {a }}$ ed. 1995, 2ª ed. 1997, $3^{\text {a }}$ ed. 1998, $4^{\text {a }}$ ed. Madrid, Trotta, 2000, p. 564.

31 Ferrajoli, Luigi, op. cit., p. 564. 
Esta obra forma parte del acervo de la Biblioteca Jurídica Virtual del Instituto de Investigaciones Jurídicas de la UNAM

se considera ofendido un directo interés del príncipe y la parte perjudicada se identifica con el estado. Una vez venido a menos el sentimiento cívico y el hábito de libertad que en la república habían hecho posible el funcionamiento de la iniciativa acusatoria por parte de cualquier ciudadano, «la acusación pública fue sustituida por la fatal denuncia» y por la «oculta calumnia», que se convirtieron en un «instrumento de la tiranía». Nació así, con la cognitio extra ordinem, el proceso inquisitivo, tramitado y decidido ex officio, en secreto y sobre documentos escritos, por magistrados estatales delegados del príncipe (los irenarchi, los curiosi, los nunciatores, los stationarii), basado en la detención del acusado y su utilización como fuente de prueba, muy pronto acompañada de la tortura. ${ }^{32}$

La batalla cultural y política contra la irracionalidad y la arbitrariedad del proceso inquisitivo forma parte de alguno de los motivos que animaron a la Ilustración reformadora. De Thomasius a Montesquieu, de Beccaria a Voltaire, de Verri a Filangieri y Pagano, todo el pensamiento ilustrado fue concorde al denunciar la inhumanidad de la tortura y el carácter despótico de la inquisición, así como en el redescubrimiento del valor garantista de la tradición acusatoria, recibida en el ordenamiento inglés del antiguo proceso romano. Fue por ello natural que la Revolución Francesa adoptase -en la fase inmediatamente posterior a 1789- el sistema acusatorio, basado en la acción popular, el jurado, el juicio contradictorio, la publicidad y oralidad del juicio y la libre convicción del juez. Pero la experiencia acusatoria no duró en el continente europeo más que los años de la Revolución. Ya el código termidoriano de 1795 y después el napoleónico de 1808 dieron vida a aquel «monstruo, nacido de la unión del proceso acusatorio con el inquisitivo», que fue el llamado "proceso mixto», predominantemente inquisitivo en la primera fase, escrita, secreta, dominada por la acusación pública y exenta de la participación del imputado, privado de libertad durante la misma; tendencialmente acusatorio en la fase sucesiva del enjuiciamiento, caracterizada por el juicio contradictorio, oral y público con intervención de la acusación y la defensa, pero destinado a convertirse en mera repetición o escenificación de la primera fase. ${ }^{33}$

El modelo napoleónico del proceso mixto se difundió durante el siglo pasado en toda Europa, echando sólidas raíces sobre todo en Italia. Impuesto al reino de Italia contra el proyecto de codificación elaborado por Romagnosi en 1806, fue recogido por el código borbónico de 1819, el de Parma de 1820, el pontificio de 1831, el toscano de 1838 y los piamonteses

32 Ferrajoli, Luigi, op. cit., pp. 564 y 565.

33 Ibidem, p. 566. 
Esta obra forma parte del acervo de la Biblioteca Jurídica Virtual del Instituto de Investigaciones Jurídicas de la UNAM

de 1847 y 1859; y se conservó ininterrumpidamente, con variaciones sólo marginales en el código italiano de 1865, en el de 1913 y, finalmente en el Código Rocco de 1930. ${ }^{34}$

La Reforma Constitucional Penal en México del 18 de junio de 2008, gira en torno a dos ejes fundamentales y son a saber: por un lado, el establecer el Sistema Penal Acusatorio mediante los Juicios Orales, los Medios Alternativos para la Solución de Controversias, y el otro eje fundamental consiste en la Reforma a la Seguridad Pública, la cual, en ocasiones se contrapone al modelo garantista que subyace en el Sistema Penal Acusatorio. Empero dichas reformas, se sustentan en el realismo jurídico, ${ }^{35} \mathrm{el}$ cual, se opone al exacerbado formalismo jurídico que acompaña al Sistema Penal Inquisitorial Mixto, que surge y se desarrolla en el positivismo decimonónico, que actualmente es altamente cuestionado por la ciudadanía, ya que, dicha tendencia ha motivado una pérdida de la confianza tanto en las instituciones como en quienes se dedican a procurar e impartir la justicia, por su falta de credibilidad y legitimidad tanto de sus actuaciones como de sus resoluciones.

Por otra parte, es incuestionable que existe un nexo importante entre el sistema penal acusatorio y el modelo garantista. En cambio, es característica significativa para el sistema inquisitorial su vinculación con el modelo autoritario y de eficacia represiva. Otro rasgo importante de la reforma en comento es el sustento teórico a través del garantismo.

A este respecto, el Jurista Italiano Ferrajoli, en su obra denominada "Derecho y razón", nos proporciona los elementos teóricos y metodológicos acerca de la epistemología garantista en el sistema procesal penal, y que a continuación mencionamos, a través de 3 acepciones, y son a saber:

1. Una primera acepción, «garantismo» designa un modelo normativo de derecho, por lo que respecta al derecho penal, el modelo de «estricta legalidad». 36

34 Supra. Ibidem, pp. 566 y 567.

35 Véase Sánchez Vázquez Rafael, Metodología de la Ciencia del Derecho, $9^{a}$ ed. México, Porrúa, 2014, p. 216.

36 1) Del estado de derecho, que en el plano epistemológico se caracteriza como un sistema cognoscitivo o de poder mínimo, en el plano político como una técnica de tutela capaz de minimizar la violencia y de maximizar la libertad y en el plano jurídico como un sistema de vínculos impuestos a la potestad punitiva del estado en garantía de los derechos de los ciudadanos. En consecuencia, es «garantista» todo sistema penal que se ajusta normativamente a tal modelo y lo satisface de manera efectiva. (Ferrajoli, Luigi, op. cit., pp. 851 y 852.) 
Esta obra forma parte del acervo de la Biblioteca Jurídica Virtual del Instituto de Investigaciones Jurídicas de la UNAM

2. Una segunda acepción, «garantismo» designa una teoría jurídica de la «validez» y de la «efectividad» como categorías distintas no sólo entre sí, sino también respecto de la «existencia» o «vigencia» de las normas. ${ }^{37}$

3. En una tercera acepción, «garantismo» designa una filosofía política que impone al Derecho y al Estado la carga de la justificación externa conforme a los bienes y a los intereses cuya tutela y garantía constituye precisamente la finalidad de ambos. ${ }^{38}$

"La epistemología garantista. El derecho penal de los ordenamientos desarrollados es un producto predominantemente moderno. Los principios sobre los que se funda su modelo garantista clásico - la estricta legalidad, la materialidad y lesividad de los delitos, la responsabilidad personal, el juicio oral y contradictorio entre partes y la presunción de inocencia- en gran parte son, como es sabido, el fruto de la tradición jurídica ilustrada y liberal". 39

"Los distintos principios garantistas se configuran, antes que nada, como un esquema epistemológico de identificación de la desviación penal encaminado a asegurar, respecto de otros modelos de derecho penal históricamente concebidos y realizados, el máximo grado de racionalidad y de fiabilidad del juicio y, por tanto, de limitación de la potestad punitiva y de tutela de la persona contra la arbitrariedad". ${ }^{40}$

Son dos elementos que configuran el esquema garantista y son a saber: uno relativo a la definición legislativa y el otro a la comprobación jurisdiccional de la desviación punible. Y corresponden a sendos conjuntos de garantías, las penales y las procesales del sistema punitivo al que dan fundamento". Consecuentemente, de ahora en adelante denominaré a la reserva

37 2) En este sentido, la palabra garantismo expresa una aproximación teórica que mantiene separados el «ser» y el «deber ser» en el derecho; e incluso propone, como cuestión teórica central, la divergencia existente en los ordenamientos complejos entre modelos normativos (tendencialmente garantistas) y prácticas operativas (tendencialmente anti-garantistas), interpretándola mediante la antinomia -dentro de ciertos límites fisiológica y fuera de ellos patológica- que subsiste entre validez (e inefectividad) de los primeros y efectividad (e invalidez) de las segundas. (Ibidem, p. 852.)

38 3) En este último sentido el garantismo presupone la doctrina laica de la separación entre derecho y moral, entre validez y justicia, entre punto de vista interno y punto de vista externo en la valoración del ordenamiento, es decir, entre «ser» y «deber ser» del derecho. Y equivale a la asunción de un punto de vista únicamente externo, a los fines de la legitimación y de la deslegitimación ético-política del derecho y del estado. (Ibidem, p. 853.)

39 Supra. Ibidem, p. 33.

40 Ferrajoli, Luigi, op. cit., pp. 33 y 34. 
Esta obra forma parte del acervo de la Biblioteca Jurídica Virtual del Instituto de Investigaciones Jurídicas de la UNAM

de ley «principio de mera legalidad», que, como quiera que se la formule es una norma dirigida a los jueces, a quienes prescribe la aplicación de las leyes, y usaré la expresión de «principio de estricta legalidad» para designar la reserva absoluta de ley, que es una norma dirigida al legislador, a quien prescribe la taxatividad y la precisión empírica de las formulaciones legales. ${ }^{41}$

Ahora bien, la teoría general del derecho, ha considerado, que el principio de estricta legalidad no admite «normas constitutivas», sino sólo «normas regulativas» de la desviación punible: por tanto, no normas que crean o constituyen ipso iure las situaciones de desviación sin prescribir nada, sino sólo reglas de comportamiento que establecen una prohibición, es decir, una modalidad deóntica cuyo contenido no puede ser más que una acción respecto de la que sea aléticamente posible tanto la omisión como la comisión, una exigible y la otra no forzosa y, por tanto, imputable a la culpa o responsabilidad de su autor. Así pues, dos logros fundamentales de la teoría clásica del derecho penal y de la civilización jurídica liberal se traban con esta concepción. El primero es la garantía para los ciudadanos de una esfera intangible de libertad, asegurada por el hecho de que al ser punible sólo lo que está prohibido por la ley, nada de lo que la ley no prohíbe es punible, sino que es libre o está permitido. El segundo es la igualdad jurídica de los ciudadanos ante la ley. Las acciones o los hechos, cualquiera que los cometa, pueden realmente ser descritos por las normas como «tipos objetivos» de desviación y, en cuanto tales, ser previstos y probados como presupuestos de iguales tratamientos penales; mientras que toda prefiguración normativa de «tipos subjetivos» de desviados no puede dejar de referirse a diferencias personales, antropológicas, políticas o sociales y, por tanto, de concluir en discriminaciones apriorísticas. ${ }^{42}$

"El juez no es una máquina automática en la que por arriba se insertan los hechos y por abajo se sacan las sentencias, acaso con la ayuda de algún empujón cuando los hechos no se adaptan perfectamente a ella. La idea de un perfecto silogismo judicial que permita la verificación absoluta de los hechos legalmente punibles corresponde a una ilusión metafísica, en efecto, tanto las condiciones de uso del término «verdadero» como los criterios de aceptación de la «verdad» en el proceso, exigen inevitablemente decisiones dotadas de márgenes más o menos amplios de discrecionalidad. En consecuencia, en la actividad judicial existen espacios de poder específicos y en parte insuprimibles, siendo tarea del análisis filosófico distinguir y explicar para permitir su reducción y control, el poder de comprobación probatoria

\footnotetext{
41 Ibidem, pp. 34 y 35.

42 Supra. Ibidem, pp. 35 y 36.
} 
Esta obra forma parte del acervo de la Biblioteca Jurídica Virtual del Instituto de Investigaciones Jurídicas de la UNAM

o de verificación fáctica; el poder de connotación o de comprensión equitativa; el poder de disposición o de valoración ético-política". ${ }^{43}$

"En el desarrollo del sistema garantista se encuentran razones que muestran que las decisiones en cuestión aseguran la justicia de acuerdo con el Estado Social y Democrático de Derecho. Una de las características del sistema acusatorio es el respeto a los derechos de las personas, el llamado garantismo, el cual nace como un concepto elaborado y con límites acotados, al cual Ferrajoli hace importantes aportaciones como respetar los derechos fundamentales de todos. En este esquema lo que hay que lograr es que se busque el equilibrio respetando por igual los derechos de las partes en el juicio". ${ }^{44}$

Por su parte, Sergio García Ramírez, plantea lo siguiente "es posible respetar los derechos de todos, porque respetar derechos no es generar un régimen de privilegios, sino hacer un marco de legalidad, una democracia, un sistema democrático al cual todos nos debemos atener, preponderantemente las autoridades, así como al principio de legalidad, de modo que no haya atropello, no haya menoscabo de los derechos de nadie", ${ }^{45}$ y esto sería respetar los derechos humanos por medio de este modelo garantista con una buena política criminal.

Es así, que se requiere de la búsqueda de los derechos humanos por medio del uso, según Ferrajoli, "desde los principios sobre los que se funda su modelo garantista clásico, la estricta legalidad, la materialidad y lesividad de los delitos, la responsabilidad personal, el juicio oral y contradictorio de las partes y la presunción de inocencia, en gran parte son, el fruto de la tradición jurídica ilustrada y liberal". ${ }^{46}$

Por lo tanto, dentro del desarrollo garantista nos encontramos que se "enlazan con una tradición autoritaria mucho más antigua y nunca realmente interrumpida. Esta tradición es el fruto irreflexivo y consolidado de las practicas legislativas, jurisdiccionales o policiales, pero también enlaza doctrinas y modelos teóricos y políticos del derecho penal todo o en parte antiéticos, de los esquemas pre modernos de la inquisición a las modernas teorías de la prevención especial, de la defensa social o del tipo normativo de autor, en sus múltiples variantes moralistas, antropológicas, decisionistas y eficientistas". ${ }^{47}$

43 Ferrajoli, Luigi, op. cit., pp. 36 y 38.

44 Ibidem, pp. 38 y 39.

45 García Ramírez, Sergio y De González, Mariscal Olga, La reforma constitucional en materia penal. Fornada de justicia penal, México, INACIPE-UNAM, 2009, p. 20.

46 Ferrajoli, Luigi, op. cit., p. 33.

47 Ibidem, p. 40. 
Esta obra forma parte del acervo de la Biblioteca Jurídica Virtual del Instituto de Investigaciones Jurídicas de la UNAM

"La selección de los elementos teóricamente esenciales en los dos modelos: acusatorio o inquisitorial, está, además, inevitablemente condicionada por juicios de valor, a causa del nexo que sin duda cabe establecer entre sistema acusatorio y modelo garantista, y, por otra parte, entre sistema inquisitivo, modelo autoritario y eficacia represiva. Todo esto hace todavía más esencial distinguir en el plano metodológico, con toda claridad, la noción teórica y convencional de los dos modelos, de la reconstrucción de sus rasgos empíricos en las diversas experiencias históricas, para evitar operaciones ideológicas de falsificación histórica, o construcciones teóricas lógicamente inconsistentes y axiológicamente inservibles. Aunque esta reconstrucción pueda aportar luz acerca de los nexos funcionales que ligan los diversos elementos de cada modelo teórico, en la experiencia práctica no aparecen nunca en estado puro, sino siempre mezclados con otros, que no son ni lógica ni axiológicamente necesarios. Ello depende de espontáneas y contingentes dinámicas histórico-políticas, o de explícitas opciones legislativas en forma de compromisos, o también del hecho de que muchos principios que responden a una u otra tradición han terminado por afirmarse en la época moderna como universalmente válidos y por figurar, en consecuencia, al menos sobre el papel, en todos los ordenamientos procesales evolucionados, piénsese, por ejemplo, en el carácter público y no privado de la acusación, de ascendencia inquisitiva, o bien en la libre convicción del juez, en el principio de contradicción y en los derechos de defensa, de extracción acusatoria". ${ }^{4}$

Hechas estas indispensables consideraciones previas, me parece que la dicotomía «acusatorio/inquisitivo» es útil para designar una doble alternativa: ante todo, la que se da entre dos modelos opuestos de organización judicial y, en consecuencia, entre dos figuras de juez; y, en segundo lugar, la que existe entre dos métodos de averiguación judicial igualmente contrapuestos y, por tanto, entre dos tipos de juicio. Precisamente, se puede llamar acusatorio a todo sistema procesal que concibe al juez como un sujeto pasivo rígidamente separado de las partes y al juicio como una contienda entre iguales iniciada por la acusación, a la que compete la carga de la prueba, enfrentada a la defensa en un juicio contradictorio, oral y público y resuelta por el juez según su libre convicción. A la inversa, llamaré inquisitivo a todo sistema procesal donde el juez procede de oficio a la búsqueda, recolección y valoración de las pruebas, llegándose al juicio después de una instrucción escrita y secreta de la que están excluidos o, en cualquier caso, limitados la contradicción y los derechos de la defensa. Es claro que a los dos mode-

48 Ferrajoli, Luigi, op. cit., pp. 563 y 564. 
Esta obra forma parte del acervo de la Biblioteca Jurídica Virtual del Instituto de Investigaciones Jurídicas de la UNAM

los se pueden asociar sistemas diversos de garantías, tanto orgánicas como procesales: si el sistema acusatorio favorece modelos de juez popular y procedimientos que valorizan el juicio contradictorio como método de investigación de la verdad, el sistema inquisitivo tiende a privilegiar estructuras judiciales burocratizadas y procedimientos fundados en poderes de instrucción del juez, acaso compensados por vínculos de pruebas legales y por pluralidad de grados en el enjuiciamiento. Forma paralela, a las cambiantes vicisitudes de los regímenes políticos — unas veces democráticos, otros despóticos-, de los que siempre han sido expresión. ${ }^{49}$

A partir del movimiento iusnaturalista liberal de finales del siglo XVIII, y de los siglos XIX y XX, se fortalece una visión más humanitaria y tolerante, toda vez que ésta es considerada tanto en la declaración de los derechos del buen pueblo de Virginia de 1776, así como en la declaración de los derechos del hombre y del ciudadano de la Revolución Democrática Burguesa de Francia de 1789. En dichas declaraciones se establecen los principios referentes al debido proceso legal que fortalece al sistema penal acusatorio. El cual, acepta y da validez al principio de presunción de inocencia que es más congruente con el Estado de Derecho Democrático. En tal virtud, se convierte en un antídoto en contra del sistema penal inquisitorial.

Históricamente, identificamos en la República mexicana, la presunción de la inocencia en los Sentimientos de la Nación de José María Morelos y Pavón, en su proyecto de Constitución de Apatzingán de $1814 .{ }^{50}$ No obstante, hubo necesidad de que transcurrieran más de 194 años, para que se establezca en la Constitución Política de los Estados Unidos Mexicanos el principio de presunción de inocencia, tal y como lo menciona actualmente el artículo 20 constitucional vigente, en su apartado B. De los derechos de toda persona imputada: fracción I. A que se presuma su inocencia mientras no se declare su responsabilidad mediante sentencia emitida por el juez de la causa, (producto de la reforma penal constitucional de 2007-2008).

$\mathrm{El}$ sistema penal inquisitorio mixto, comparte entre otras características a las siguientes:

Excesivo formalismo, es decir, lo que no se encuentra dado en el expediente no existe para el proceso. Todo gira en torno a lo que existe en las fojas del expediente. También cabe resaltar que el expediente del proceso se integra con diligencias sigilosas hasta llegar al extremo del ocultamiento

\footnotetext{
49 Ibidem, p. 564.
}

50 Artículo 30. Todo ciudadano se reputa inocente, mientras no se declare culpado. (Los derechos del Pueblo Mexicano. México a través de sus Constituciones, t. I, México, Manuel Porrúa- Cámara de Diputados L Legislatura, 1978, p. 337.) 
Esta obra forma parte del acervo de la Biblioteca Jurídica Virtual del Instituto de Investigaciones Jurídicas de la UNAM

de datos, favorece la detención del acusado, y en consecuencia, el fortalecimiento de la prisión preventiva.

Sin lugar a dudas, el sistema de procesamiento penal inquisitorio es un obstáculo al desarrollo y fortalecimiento de las instituciones del Estado de Derecho Social Democrático. Consecuentemente, favorece a los regímenes autoritarios.

El sistema penal inquisitorial mixto, en ocasiones se distingue por su irracionalidad y arbitrariedad de obtener de parte del acusado la aceptación de su supuesta culpabilidad, a través de prácticas psicológicas y físicas que esquematizan el temor, el miedo, hasta llegar a generar estados de angustia, ansiedad y de esa manera aceptar conductas no realizadas por el acusado.

Habida cuenta, a todo lo antes manifestado, consideramos que se torna oportuno resaltar lo siguiente: el sistema penal acusatorio es más a fin al Modelo del Estado de Derecho Social Democrático, en donde se da prioridad al respeto a las garantías y derechos fundamentales del ser humano, a la transparencia, a las audiencias públicas, a buscar la verdad real histórica sustentada en los derechos y obligaciones tanto de la parte acusadora como del acusado, en donde se hace énfasis al principio de presunción de inocencia y del debido proceso legal. En tal virtud estamos en presencia de un nuevo paradigma de procurar e impartir justicia menos formalista alejada de lo inquisitorial y de lo autoritario.

Consecuentemente, el sistema penal acusatorio facilita las condiciones subjetivas y objetivas para fortalecer y desarrollar un régimen democrático respetuoso del Estado del Derecho.

Ahora bien, de la lectura y análisis que se haga del contenido textual del artículo 20 de la Constitución Política de los Estados Unidos Mexicanos vigente (Reforma publicada el 18 de junio de 2008), identificamos que en el apartado A, con X fracciones, se establecen los principios generales del sistema penal acusatorio vía los juicios orales. En su apartado B, con sus IX fracciones se regulan los derechos de toda persona imputada, y en el apartado $\mathrm{C}$, con VII fracciones, se mencionan los derechos de la víctima o del ofendido. Habida cuenta a lo antes expresado, se desprenden los lineamientos teóricos y metodológicos que esquematizan al sistema penal acusatorio, de naturaleza garantista, respetuoso de la dignidad humana, y demás derechos fundamentales tanto del acusador como del acusado.

El sistema acusatorio se caracteriza por el respeto y tolerancia a las garantías esenciales que protegen los derechos humanos, y que permiten una mayor credibilidad y legitimidad para quienes procuran e imparten justicia, con el propósito de fortalecer a las instituciones del Estado de Derecho Social Democrático. 
Esta obra forma parte del acervo de la Biblioteca Jurídica Virtual del Instituto de Investigaciones Jurídicas de la UNAM

Sin embargo, existen disposiciones normativas en la referida reforma constitucional penal del 18 de junio de 2008, que contradicen dichos principios generando ambigüedades, ya que, por un lado se tiene a un sistema penal garantista congruente con un Estado de Derecho Social Democrático, y por el otro, de manera simultánea se hace énfasis de un sistema penal del enemigo a través del arraigo domiciliario y demás expresiones que violentan las garantías fundamentales de los ciudadanos mexicanos.

Por todo lo anteriormente expuesto, se debe señalar que al establecer el principio de presunción de inocencia y del debido proceso legal, se pretende que el acusado ya no esté obligado a demostrar que es inocente, por el contrario, el Ministerio Público será el que tenga la obligación de probar que el acusado es culpable, y tanto éste como el juez tendrán como obligación esclarecer los hechos.

Hoy día, el orden penal sustantivo y el orden penal adjetivo se hallan en estado de sitio por la tensión que existe entre la protección de los derechos humanos y la atención a la seguridad pública, o dicho desde otra perspectiva, el control del crimen y el debido proceso. ${ }^{51}$

Incuestionablemente, que el sistema penal acusatorio es un parteaguas que limita la sobrevivencia del sistema penal inquisitorial que se refugió en el sistema mixto, y que, hasta ahora prevalece en la gran mayoría de las entidades federativas, por una parte, y por la otra, en dicha reforma penal constitucional, de acuerdo al artículo $\mathrm{X}$ transitorio, se da un plazo de 8 años a partir de su vigencia para el efecto de capacitar al personal así como instrumentar la infraestructura material necesaria. Empero, lo que no se ha manifestado es que se requiere de un cambio teórico metodológico de pensar y hacer el Derecho. Es decir, es necesario dejar de hacer el formalismo jurídico, ahora se requiere un cambio de paradigma que se sustente en el realismo jurídico.

Sin embargo, es preocupante que en México la reforma constitucional penal del 2008, hasta el momento, tenga poca aceptación en los diferentes sectores de la sociedad mexicana, encontrando escepticismo en la ciudadanía, poca credibilidad en los abogados postulantes, agentes del ministerio público, jueces, magistrados, docentes de las Escuelas y Facultades de Derecho. Ahora bien, dicha problemática suele presentarse con cierta frecuencia en el ámbito profesional y socio-cultural de los abogados, ya que, tienen determinada simpatía por la ideología conservadora. La cual, es respetuosa del Establishment. De ahí que no deba extrañarnos que se haga presente

51 García Ramírez, Sergio, op. cit., p. 524. 
Esta obra forma parte del acervo de la Biblioteca Jurídica Virtual del Instituto de Investigaciones Jurídicas de la UNAM

y tenga el impacto de alta resonancia, el título del libro: "El derecho como obstáculo al cambio social”*, bajo la autoría de Eduardo Novoa Monreal.

Actualmente, en todo lo ancho y largo de la República Mexicana se ha desbordado un ambiente de intranquilidad social mostrado por el narcotráfico y el crimen organizado, lo cual desaprobamos categóricamente. No obstante genera un ambiente de frustración y de nostalgia, el ver transitar a los militares por nuestras calles, a plena luz del día, dicha vivencia es acorde a situaciones de emergencia en donde la presencia militar es adecuada y cotidiana. Empero, no es lo deseable, cuando el Estado deja de ser interventor y se convierte en un Estado policía, vigilante, es decir, se transita de un estado que promueve la seguridad social por un estado de seguridad pública. Es decir, con el neoliberalismo económico el Estado de Bienestar se reduce por no decir que casi se extingue y da paso al Estado de Malestar, que se distingue por dar mayor prioridad a la seguridad policiaca, dejando a un lado, la seguridad social, la cual, nos conlleva a replantear como prioridad el respeto a la vida y a la seguridad humana. Ahora, se torna inaplazable hablar y hacer realidad la seguridad humana.

Lo antes mencionado, nos lleva a la reflexión a que se refería el jurista Don Sergio García Ramírez, cuando habla acerca del vaso de agua cristalina con unas gotas de veneno, como una cuestión intimidadora, que violenta a los fines del Estado de Derecho Social Democrático sustentado en el garantismo, para pasar a un modelo cercano al derecho penal del enemigo, el cual se sustenta en un Estado vigilante y autoritario, ya que le es más fácil comprar pistolas para combatir a los del crimen organizado, que establecer políticas públicas que permitan la prevención al delito, y de esa manera fortalecer la paz social, con alternativas más racionales y humanitarias.

Actualmente, resulta evidente el avance que el derecho internacional ha tenido en materia de derechos humanos, lo que ha provocado que el objeto de estudio de la interpretación constitucional se expanda, y no sólo esté al margen de lo previsto en el texto constitucional o de las leyes secundarias. ${ }^{52}$

Por esa razón, la eficacia de un precepto de derecho interno, como podría ser un artículo constitucional, en mucho depende del enfoque internacional que sobre su contenido se vierta. ${ }^{53}$

* Novoa Monreal, Eduardo, El derecho como obstáculo al cambio social, México, Siglo XXI, 1975, p. 210.

Nota: Novoa Monreal, Eduardo: Penalista Chileno que participo en el gabinete del gobierno democrático de Salvador Allende, que fue derrocado, a través del golpe militar encabezado por Augusto Pinochet (1973).

52 Carpizo, Enrique, Derechos Fundamentales. Interpretación Constitucional. La Corte y los Derechos, $1^{\text {a }}$ ed. 2011, $1^{\text {a }}$ reimpresión, México, Porrúa, 2011, pp. 15 y 16.

53 Carpizo, Enrique, op. cit., p. 16. 
Esta obra forma parte del acervo de la Biblioteca Jurídica Virtual del Instituto de Investigaciones Jurídicas de la UNAM

En términos concretos, la observancia de estos instrumentos internacionales, sobre todo en tratándose de proteger los derechos humanos, reviste una importancia significativa, pues es a partir de ellos que el operador jurídico deberá ajustar su labor interpretativa de los derechos y libertades fundamentales en aras de lograr, cuando menos, el mínimo de protección otorgado por la jurisdicción internacional. ${ }^{54}$

Lo lamentable parece ocurrir en la actualidad, pues lejos de utilizarse el derecho comparado y los tratados internacionales como fuente de maximización y protección de los derechos fundamentales o humanos. Algunos de nuestros magistrados constitucionales mantienen cierta indiferencia respecto a las nuevas tendencias de interpretación constitucional, y en su lugar recomienden privilegiar aquellos mecanismos de interpretación jurídica que permitan conocer los motivos de la reforma constitucional, los dictámenes de las comisiones del Congreso, el propio debate en el Parlamento y la finalidad del legislador; en pocas palabras, analizar la voluntad de los legisladores para entender un precepto constitucional..$^{55}$

Por último, cabe señalar que, el destacado jurista Don Jorge Carpizo, considera que: cualquier sugerencia de unificación de los diversos códigos, implica una tendencia centralizadora y cierta degradación de las entidades federativas según los defensores de la multiplicidad de códigos, ya que tal disminución competencial equivaldría a una intervención y ataque a la soberanía de los estados. ${ }^{56}$

Y estas ideas, por desgracia, se han vuelto tabú. Los argumentos en contra de la unificación legislativa están cargados de elementos emocionales, y es difícil convencer a esas personas que la unificación legislativa de los códigos civiles, penales y de procedimientos, no hace a nuestro sistema ni más ni menos federal.

Entre los argumentos más importantes en contra de la unificación se pueden citar los siguientes:

a) Sería una nueva disminución a las ya debilitadas facultades de los estados miembros, lo que desde el punto de vista político redundaría en el fortalecimiento de la federación. ${ }^{57}$

54 Carpizo, Enrique, op. cit., p. 53.

55 Cfr. Tesis P.XXVIII/98. Cit. por Ibidem, p. 59.

56 Carpizo, Jorge, "El sistema federal mexicano", en Camargo, Pedro Pablo, Carpizo, Jorge, et al., Los sistemas federales del continente americano, México, IIJUNAM-FCE, 1972, p. 536.

57 Carpizo, Jorge, op. cit., p. 537. 
Esta obra forma parte del acervo de la Biblioteca Jurídica Virtual del Instituto de Investigaciones Jurídicas de la UNAM

En otras palabras, sería un factor centralizador en el sistema mexicano; $y$

b) No se puede aplicar un mismo código en regiones donde imperan diferentes costumbres y tradiciones, ya que existen divergencias y situaciones diversas en comunidades separadas por kilómetros de distancia.

Por su parte, José Nieves Luna, señala como argumentos que se han realizado en contra de la unificación legislativa, a los siguientes:

A) De manera expresa en el discurso abierto. ${ }^{58}$

1. Reconocimiento de diferencias culturales y étnicas en distintas partes del país.

2. Afectación a las "soberanías" de los estados de la República.

3. Posturas críticas a lo que algunos consideran tendencias centralizadoras.

B)De manera implícita (por no formar parte del discurso abierto).

1. Intereses políticos regionales sobre el monopolio discrecional del proceso penal dirigido.

2. Manipulación de la normativa procesal en función de circunstancias ocasionales.

3. Utilización de reformas en materia penal como instrumento de clientelismo político o con fines electorales y ajenos a los intereses reales de la sociedad en cuanto a la preeminencia de la obtención de la regulación de un debido proceso penal, como parte del reconocimiento de los derechos fundamentales. ${ }^{59}$

Existe una opinión acerca de que lo que observamos en el Código Nacional de Procedimientos Penales es una homologación del Código Modelo CONATRIB, sin embargo, se dejaron a un lado cuestiones estructurales que son indispensables para el procedimiento penal, debido a que no se abordan en la legislación criterios y parámetros que abordaba el Código Modelo, deja a un lado algunos principios indispensables, abarcándolos en su conjunto con el debido proceso, cuestiones que dejan al arbitrio del juzgador cuestiones de decisión.

58 Luna Castro, José Nieves, "La unificación de la normatividad procesal penal en México, como exigencia de la garantía del debido proceso. Análisis evolutivo desde la perspectiva constitucional", Quid Iuris, México, año 8, vol. 22, septiembre-noviembre 2013, p. 87, http://www.juridicas.unam.mx/publica/librev/rev/qdiuris/cont/22/cnt/cnt5.pdf.

59 Luna Castro, José Nieves, op. cit., p. 87. 
Esta obra forma parte del acervo de la Biblioteca Jurídica Virtual del Instituto de Investigaciones Jurídicas de la UNAM

Beneficios del Código Nacional de Procedimientos Penales: ${ }^{60}$

- Favorece y da fortalecimiento a la armonización legislativa.

- Fortalece las capacidades y herramientas de las instituciones encargadas de investigar, procesar y sancionar las conductas delictivas a nivel estatal y Federal.

- Favorece las condiciones para lograr una justicia pronta y expedita.

- Fortalece la armonización legislativa.

- Permite esclarecer los hechos delictivos con mayor rapidez y eficacia para determinar con certeza si existe o no responsabilidad penal.

- Incentiva la denuncia ciudadana, indispensable contra la impunidad, con procesos de investigación más ágiles, eficaces y eficientes.

- Permite acelerar la aplicación del modelo acusatorio Adversarial y oral, con el cual el acceso a la justicia será más transparente, ágil y equitativo.

- Con el principio de publicidad se dará transparencia a los juicios penales, disminuyendo la discrecionalidad y propiciando la legalidad en los involucrados en el sistema de justicia, lo cual, fortalece las prácticas sociales que identifican al Estado de Derecho Democrático.

- Se fortalecen y homologan los instrumentos para asegurar el debido proceso y el respeto irrestricto a los derechos humanos del ofendido y del imputado.

- La sociedad contará con profesionales del derecho, capaces de brindar asesoría legal en cualquier entidad del país, a partir de reglas claras y uniformes.

- Se incluyen figuras que permiten soluciones alternas al conflicto, como la aplicación de un acuerdo reparatorio, por mediación o conciliación, para evitar que se llegue a una pena de encarcelamiento, estableciendo un sistema de justicia restaurativo y no solo de represión penal.

$60 \quad C f r$ r. http://www.misionpolitica.com/anteriores/columnas/tema-principal-de-lasemana/80300-a-la-congeladora-el-nuevo-codigo-nacional-de-procedimientos-penales. Fecha de consulta: 18 de marzo de 2016. 
Esta obra forma parte del acervo de la Biblioteca Jurídica Virtual del Instituto de Investigaciones Jurídicas de la UNAM

\section{DiAGNÓSTICO ACTUAL SOBRE LA IMPLEMENTACIÓN DEL SISTEMA PROCESAL PENAL ACUSATORIO VÍA LOS JUICIOS ORALES EN MÉXICO, A PARTIR DE LA REFORMA DEL 18 DE JUNIO DE 2008} HASTA EL PRIMER TRIMESTRE DEL 2016

Como ya se mencionó, el 18 de junio de 2008, se publicó en el Diario Oficial de la Federación, la Reforma Constitucional Penal que comprende a los siguientes artículos de la Ley Fundamental: 16, 17, 18, 19, 20, 21, y 22, las fracciones XXI y XXIII del artículo 73; la fracción VII del artículo 115 y la fracción XIII del apartado B del artículo 123, todo ellos de la Constitución Política de los Estados Unidos Mexicanos.

Dicha Reforma Constitucional aborda dos ejes temáticos importantes, y son a saber:

- El Sistema Penal Acusatorio Oral.

— La seguridad Pública.

Para los efectos de la presente investigación, únicamente, se tratará lo referente al Sistema Penal Acusatorio Oral.

En ese orden de ideas, de acuerdo a la Secretaría Técnica del Consejo de Coordinación para la implementación del Sistema de Justicia Penal, al 31 de julio de 2015, el Sistema de Justicia Penal Acusatorio (SJPA) está operando en 6 entidades federativas en la totalidad de su territorio (Chihuahua, Durango, Estado de México, Morelos, Nuevo León y Yucatán) y en otras 25 entidades está operando parcialmente, a saber: Aguascalientes, Baja California, Baja California Sur, Campeche, Coahuila, Chiapas, Colima, Distrito Federal, Guanajuato, Guerrero, Hidalgo, Jalisco, Michoacán, Nayarit, Oaxaca, Puebla, Querétaro, Quintana Roo, San Luis Potosí, Sinaloa, Tabasco, Tamaulipas, Tlaxcala, Veracruz y Zacatecas. El Estado de Sonora tiene previsto entrar en operación en 2016 para completar el 100\% de la implementación del SJPA. ${ }^{61}$

Por otra parte, no se advierte en las instituciones educativas que ofertan los estudios de Derecho la actualización, tanto de sus planes como de sus

61 SETEC, Nueva Metodología para Clasificación y Estratificación de Entidades Federativas, en http://www.setec.gob.mx/es/SETEC/Nueva_Metodologia_para_ Clasificacion_y_Estratificacion_de_Entidades_Federativas. Fecha de consulta: 12 de enero de 2016. 
Esta obra forma parte del acervo de la Biblioteca Jurídica Virtual del Instituto de Investigaciones Jurídicas de la UNAM

programas de estudios para el efecto de informar y formar a los docentes y menos a los estudiantes sobre el Sistema Penal Acusatorio vía los Juicios Orales.

Igualmente, la ciudadanía en términos generales desconoce el contenido y alcance de la Reforma Constitucional Penal del 18 de junio de 2008.

Lo trascendente de la reforma constitucional en materia de justicia penal es evaluar sí efectivamente la reforma será la herramienta que logre imprimirle a la esfera de impartición de justicia efectividad en su funcionamiento. La efectividad se deberá reflejar en certeza para inhibir, prevenir y sancionar bajo una condición de equidad las conductas antisociales; además de brindar certidumbre a la sociedad en general recuperando así la estabilidad y tranquilidad perdida, al mismo tiempo que, de igual manera, brinde seguridad jurídica en cuanto a la vigencia efectiva de los derechos fundamentales. De no ser así, solo se habrá cambiado de referencia nominativa a las instituciones, brindando una perspectiva aparente de contar con un texto constitucional actualizado o vanguardista, pero que en realidad no producirá un cambio sustancial en las esferas de administración, procuración e impartición de justicia como se pretende creer con la Reforma Constitucional Penal del 18 de junio de 2008.

Con fecha 2 de diciembre de 2012, el Pacto por México ${ }^{62}$ fue suscrito por el Presidente de la República Mexicana Lic. Enrique Peña Nieto, y los Presidentes de los partidos políticos más representativos de México: PRI, PRD y PAN, han convenido en realizar un consenso y de manera estratégica hacer realidad los siguientes puntos: 1. Sociedad de Derechos y Libertades; 2. Crecimiento Económico, Empleo y Competitividad; 3. Seguridad y Justicia; 4. Transparencia, Rendición de Cuentas y Combate a la Corrupción; 5. Gobernabilidad Democrática.

Por lo que respecta al punto 3 del Pacto por México, cabe hacer mención de los siguientes acuerdos:

Acuerdos para la Seguridad y la Justicia.

1. Implantar un Plan Nacional de Prevención y Participación Comunitaria.

2. Reformar los cuerpos de policías.

3. Implantar en todo el país el nuevo sistema de justicia penal, acusatorio y oral.

62 Pacto por México. Información obtenida en la siguiente dirección electrónica, http:// pactopormexico.org/. Fecha de consulta: 17 de mayo de 2013. 
Esta obra forma parte del acervo de la Biblioteca Jurídica Virtual del Instituto de Investigaciones Jurídicas de la UNAM

Para que la justicia se pueda impartir con mayor rapidez, eficacia y transparencia en todo el país, se tomarán medidas necesarias tanto a nivel federal como estatal para cumplir con las metas y tiempos establecidos. (Compromiso 77)63

4. Implantar en todo el país un Código Penal y un Código de Procedimientos Penales Únicos.

Se creará un Código Penal Único para homogeneizar las causales del delito en todo el país y así lograr acciones más coordinadas y eficaces de las policías y los sistemas de justicia. (Compromiso 78)

Se legislará un Código de Procedimientos Penales Único para todo el país, con la finalidad de establecer elementos procesales homogéneos y congruentes con el establecimiento de un sistema penal acusatorio y oral. (Compromiso 79)64

5. Reforma a la Ley de Amparo.

6. Reforma integral del sistema penitenciario.

Actualmente, de acuerdo con el artículo segundo transitorio del Código Nacional de Procedimientos Penales, 24 estados de la República Mexicana han realizado la declaratoria de inicio de vigencia a nivel Federal del Código Nacional de Procedimientos Penales. ${ }^{65}$

\section{"ARTÍCULO SEGUNDO. Vigencia}

Este Código entrará en vigor a nivel federal gradualmente en los términos previstos en la Declaratoria que al efecto emita el Congreso de la Unión previa solicitud conjunta del Poder Judicial de la Federación, la Secretaría de Gobernación y de la Procuraduría General de la República, sin que pueda exceder del 18 de junio de 2016.

En el caso de las Entidades federativas y del Distrito Federal, el presente Código entrará en vigor en cada una de ellas en los términos que establezca la Declaratoria que al efecto emita el órgano legislativo correspondiente, previa solicitud de la autoridad encargada de la implementación del Sistema de Justicia Penal Acusatorio en cada una de ellas.

En todos los casos, entre la Declaratoria a que se hace referencia en los párrafos anteriores y la entrada en vigor del presente Código deberán mediar sesenta días naturales. ${ }^{\prime} 6$

63 Idem.

64 Idem.

65 Cámara de Diputados, en http://wrwre.diputados.gob.mx/LeyesBiblio/declara/cnpp.htm. Fecha de consulta: 08 de marzo de 2016.

66 Cámara de Diputados, en http://wrere.diputados.gob.mx/LeyesBiblio/pdf/CNPP_120116. pdf. Fecha de consulta: 08 de marzo de 2016. 
Esta obra forma parte del acervo de la Biblioteca Jurídica Virtual del Instituto de Investigaciones Jurídicas de la UNAM www.juridicas.unam.mx https://biblio.juridicas.unam.mx/bjv Libro completo en: https://goo.gl/8cEQmT

BALANCE Y PERSPECTIVAS DE LA REFORMA CONSTITUGIONAL PENAL...

\begin{tabular}{|c|c|c|c|}
\hline \multicolumn{4}{|c|}{$\begin{array}{l}\text { Declaratorias de inicio de vigencia del código nacional } \\
\text { de procedimientos penales en las entidades federativas }{ }^{67}\end{array}$} \\
\hline \multicolumn{4}{|c|}{ Declaratorias de Vigencia a Nivel Federal: } \\
\hline $\begin{array}{l}\text { Durango } \\
\text { Declaratoria: 17-09- } \\
2014 \\
\text { DOF: 24-09-2014 } \\
\text { Inicio de Vigencia: } \\
24-11-2014\end{array}$ & $\begin{array}{l}\text { Puebla } \\
\text { Declaratoria: 17- } \\
\text { 09-2014 } \\
\text { DOF: 24-09-2014 } \\
\text { Inicio de Vigencia: } \\
\text { 24-11-2014 }\end{array}$ & $\begin{array}{l}\text { Yucatán } \\
\text { Declaratoria: 02- } \\
\text { 12-2014 } \\
\text { DOF: 12-12-2014 } \\
\text { Inicio de Vigencia: } \\
\text { 16-03-2015 }\end{array}$ & $\begin{array}{l}\text { Zacatecas } \\
\text { Declaratoria: 02-12- } \\
2014 \\
\text { DOF: 12-12-2014 } \\
\text { Inicio de Vigencia: } \\
\text { 16-03-2015 }\end{array}$ \\
\hline $\begin{array}{l}\text { Baja California Sur } \\
\text { Declaratoria: 21-04- } \\
2015 \\
\text { DOF: 29-04-2015 } \\
\text { Inicio de Vigencia: } \\
01-08-2015\end{array}$ & $\begin{array}{l}\text { Guanajuato } \\
\text { Declaratoria: } 21- \\
04-2015 \\
\text { DOF: 29-04-2015 } \\
\text { Inicio de Vigencia: } \\
\text { 01-08-2015 }\end{array}$ & $\begin{array}{l}\text { Querétaro } \\
\text { Declaratoria: } 21- \\
04-2015 \\
\text { DOF: 29-04-2015 } \\
\text { Inicio de Vigencia: } \\
01-08-2015\end{array}$ & $\begin{array}{l}\text { San Luis Potosí } \\
\text { Declaratoria: 21-04- } \\
2015 \\
\text { DOF: 29-04-2015 } \\
\text { Inicio de Vigencia: } \\
\text { 01-08-2015 }\end{array}$ \\
\hline $\begin{array}{l}\text { Chiapas } \\
\text { Declaratoria: 22-09- } \\
2015 \\
\text { DOF: 25-09-2015 } \\
\text { Inicio de Vigencia: } \\
\text { 30-11-2015 }\end{array}$ & $\begin{array}{l}\text { Chihuahua } \\
\text { Declaratoria: 22- } \\
09-2015 \\
\text { DOF: 25-09-2015 } \\
\text { Inicio de Vigencia: } \\
\text { 30-11-2015 }\end{array}$ & $\begin{array}{l}\text { Coahuila } \\
\text { Declaratoria: 22- } \\
09-2015 \\
\text { DOF: 25-09-2015 } \\
\text { Inicio de Vigencia: } \\
\text { 30-11-2015 }\end{array}$ & $\begin{array}{l}\text { Nayarit } \\
\text { Declaratoria: 22-09- } \\
2015 \\
\text { DOF: 25-09-2015 } \\
\text { Inicio de Vigencia: } \\
\text { 30-11-2015 }\end{array}$ \\
\hline $\begin{array}{l}\text { Oaxaca } \\
\text { Declaratoria: 22-09- } \\
2015 \\
\text { DOF: 25-09-2015 } \\
\text { Inicio de Vigencia: } \\
\text { 30-11-2015 }\end{array}$ & $\begin{array}{l}\text { Sinaloa } \\
\text { Declaratoria: 22- } \\
09-2015 \\
\text { DOF: 25-09-2015 } \\
\text { Inicio de Vigencia: } \\
\text { 30-11-2015 }\end{array}$ & $\begin{array}{l}\text { Tlaxcala } \\
\text { Declaratoria: 22- } \\
09-2015 \\
\text { DOF: 25-09-2015 } \\
\text { Inicio de Vigencia: } \\
\text { 30-11-2015 }\end{array}$ & $\begin{array}{l}\text { Aguascalientes } \\
\text { Declaratoria: 22-09- } \\
2015 \\
\text { DOF: 25-09-2015 } \\
\text { Inicio de Vigencia: } \\
\text { 29-02-2016 }\end{array}$ \\
\hline $\begin{array}{l}\text { Colima } \\
\text { Declaratoria: 22-09- } \\
2015 \\
\text { DOF: 25-09-2015 } \\
\text { Inicio de Vigencia: } \\
\text { 29-02-2016 }\end{array}$ & $\begin{array}{l}\text { Estado de México } \\
\text { Declaratoria: 22- } \\
09-2015 \\
\text { DOF: 25-09-2015 } \\
\text { Inicio de Vigencia: } \\
\text { 29-02-2016 }\end{array}$ & $\begin{array}{l}\text { Hidalgo } \\
\text { Declaratoria: 22- } \\
09-2015 \\
\text { DOF: 25-09-2015 } \\
\text { Inicio de Vigencia: } \\
\text { 29-02-2016 }\end{array}$ & $\begin{array}{l}\text { Morelos } \\
\text { Declaratoria: 22-09- } \\
2015 \\
\text { DOF: 25-09-2015 } \\
\text { Inicio de Vigencia: } \\
\text { 29-02-2016 }\end{array}$ \\
\hline $\begin{array}{l}\text { Nuevo León } \\
\text { Declaratoria: 22-09- } \\
2015 \\
\text { DOF: 25-09-2015 } \\
\text { Inicio de Vigencia: } \\
\text { 29-02-2016 }\end{array}$ & $\begin{array}{l}\text { Quintana Roo } \\
\text { Declaratoria: 22- } \\
\text { 09-2015 } \\
\text { DOF: 25-09-2015 } \\
\text { Inicio de Vigencia: } \\
\text { 29-02-2016 }\end{array}$ & $\begin{array}{l}\text { Tabasco } \\
\text { Declaratoria: 22- } \\
09-2015 \\
\text { DOF: 25-09-2015 } \\
\text { Inicio de Vigencia: } \\
\text { 29-02-2016 }\end{array}$ & $\begin{array}{l}\text { Distrito Federal } \\
\text { Declaratoria: 22-09- } \\
2015 \\
\text { DOF: 25-09-2015 } \\
\text { Inicio de Vigencia: } \\
\text { 29-02-2016 }\end{array}$ \\
\hline
\end{tabular}

67 Cámara de Diputados; en http://wrere.diputados.gob.mx/LeyesBiblio/declara/cnpp.htm. Fecha de consulta: 08 de marzo de 2016. 
Esta obra forma parte del acervo de la Biblioteca Jurídica Virtual del Instituto de Investigaciones Jurídicas de la UNAM

\begin{tabular}{|c|c|c|c|}
\hline \multicolumn{4}{|c|}{ Declaratorias de Vigencia por Estado remitida a la Cámara de Diputados: } \\
\hline $\begin{array}{l}\text { Puebla } \\
\text { Aprobación: 14-03- } \\
2014\end{array}$ & $\begin{array}{l}\text { Quintana Roo } \\
\text { Aprobación: 10- } \\
04-2014\end{array}$ & $\begin{array}{l}\text { Guerrero } \\
\text { Aprobación: } 31 \text { - } \\
07-2014\end{array}$ & $\begin{array}{l}\text { Tabasco } \\
\text { Aprobación: 05-08- } \\
2014\end{array}$ \\
\hline $\begin{array}{l}\text { Colima } \\
\text { Aprobación: 26-08- } \\
2014\end{array}$ & $\begin{array}{l}\text { Zacatecas } \\
\text { Aprobación: 30- } \\
\text { 10-2014 }\end{array}$ & $\begin{array}{l}\text { Guanajuato } \\
\text { Aprobación: 13- } \\
\text { 11-2014 }\end{array}$ & $\begin{array}{l}\text { Nuevo León } \\
\text { Aprobación: 25-11- } \\
2014\end{array}$ \\
\hline $\begin{array}{l}\text { Chiapas } \\
\text { Aprobación: 27-11- } \\
2014 \\
\text { Reforma 21-09- } \\
2015\end{array}$ & $\begin{array}{l}\text { Morelos } \\
\text { Aprobación: 12- } \\
\text { 12-2014 }\end{array}$ & $\begin{array}{l}\text { Tlaxcala } \\
\text { Aprobación: 25- } \\
\text { 11-2014 }\end{array}$ & $\begin{array}{l}\text { Oaxaca } \\
\text { Aprobación: 22-10- } \\
2014\end{array}$ \\
\hline $\begin{array}{l}\text { Tamaulipas } \\
\text { Declaratorias } \\
\text { parciales: } \\
\text { Aprobación: 30-04- } \\
2014 \\
\text { Aprobación: 28-01- } \\
2015\end{array}$ & $\begin{array}{l}\text { Chihuahua } \\
\text { Aprobación: 26- } \\
02-2015\end{array}$ & & \\
\hline
\end{tabular}

Cabe señalar que, una de las inconsistencias de la actual reforma es el no tener simultáneamente en aplicación el Código Nacional Penal, es decir, se ha armonizado por una parte la materia adjetiva o procedimental del Sistema Penal Acusatorio, sin embargo, hasta el momento no se tiene la armonización de un Código nacional Penal, ya que, cada entidad federativa de la República Mexicana, tiene su propio Código Penal. Consecuentemente, cabe resaltar, que la reforma del 18 de junio del 2008, es incompleta a pesar de que se dieron ocho años de vacatio legis para ponerla en práctica.

Igualmente, cabe resaltar que, de acuerdo con el artículo décimo primero transitorio del Código Nacional de Procedimientos Penales, se prevé la implementación de los siguientes protocolos de investigación y de actuación del personal sustantivo en los lugares en donde entre en operación el referido sistema penal acusatorio, los cuales, a continuación se presentan:

"ARTÍCULO DÉCIMO PRIMERO. Adecuación normativa y operativa A la entrada en vigor del presente Código, en aquellos lugares donde se inicie la operación del proceso penal acusatorio, tanto en el ámbito federal como en el estatal, se deberá contar con el equipamiento necesario y con protocolos de investigación y de actuación del personal sustantivo y los manuales de procedimientos para el personal administrativo, pudiendo pre- 
Esta obra forma parte del acervo de la Biblioteca Jurídica Virtual del Instituto de Investigaciones Jurídicas de la UNAM www.juridicas.unam.mx https://biblio.juridicas.unam.mx/bjv Libro completo en: https://goo.gl/8cEQmT

BALANCE Y PERSPECTIVAS DE LA REFORMA CONSTITUCIONAL PENAL...

verse la homologación de criterios metodológicos, técnicos y procedimentales, para lo cual podrán coordinarse los órganos y demás autoridades involucradas."

\begin{tabular}{|c|c|c|}
\hline \multicolumn{3}{|c|}{ Protocolos de investigación y de actuación del personal sustantivo } \\
\hline $\begin{array}{l}\text { Protocolo nacional de ac-tua- } \\
\text { ción primer respondiente. }{ }^{69}\end{array}$ & $\begin{array}{l}\text { Protocolo de actuación etapa del } \\
\text { juicio. }^{70}\end{array}$ & $\begin{array}{l}\text { Protocolo de actuación etapa } \\
\text { intermedia. }{ }^{71}\end{array}$ \\
\hline $\begin{array}{l}\text { El presente protocolo tie- } \\
\text { ne por objeto establecer } \\
\text { las actuaciones que deberá } \\
\text { ejecutar el Primer Respon- } \\
\text { diente al momento en que } \\
\text { tenga conocimiento de la } \\
\text { existencia de un hecho que } \\
\text { la ley señale como delito, la } \\
\text { detención de las personas } \\
\text { que participaron en el mis- } \\
\text { mo, la preservación del lu- } \\
\text { gar de los hechos, el registro } \\
\text { de sus actuaciones, la pues- } \\
\text { ta a disposición de objetos y } \\
\text { personas ante el Ministerio } \\
\text { Público. }\end{array}$ & $\begin{array}{l}\text { A efecto de proporcionar al Mi- } \\
\text { nisterio Público los elementos } \\
\text { básicos para esta etapa, se pre- } \\
\text { senta este protocolo diseñado } \\
\text { desde la perspectiva ministerial, } \\
\text { con los elementos teórico-prác- } \\
\text { ticos necesarios para contribuir } \\
\text { en la toma de decisiones y a su } \\
\text { vez delimitar los roles de los in- } \\
\text { tervinientes. }\end{array}$ & $\begin{array}{l}\text { Establece los criterios so- } \\
\text { bre las actuaciones que de- } \\
\text { ben realizarse en la etapa } \\
\text { intermedia y proporciona } \\
\text { los elementos teórico-prác- } \\
\text { ticos necesarios para con- } \\
\text { tribuir en la toma de deci- } \\
\text { siones, asimismo, delimita } \\
\text { los roles de los sujetos que } \\
\text { intervienen. }\end{array}$ \\
\hline $\begin{array}{l}\text { Marco jurídico: } \\
\text { - Constitución Política de los } \\
\text { Estados Unidos Mexicanos. } \\
\text { Código Nacional de Procedi- } \\
\text { mientos Penales. • Ley General } \\
\text { del Sistema Nacional de Segu- } \\
\text { ridad Pública. } \bullet \text { Ley General de } \\
\text { Víctimas. • Declaración Univer- } \\
\text { sal de los Derechos Humanos } \bullet \\
\text { Pacto Internacional de Derechos } \\
\text { Civiles y Políticos. • Con- } \\
\text { vención Americana sobre } \\
\text { Derechos Humanos. • De- } \\
\text { claración Americana de } \\
\text { los Derechos y Deberes del } \\
\text { Hombre. • Código de con- } \\
\text { ducta para funcionarios en- }\end{array}$ & $\begin{array}{l}\text { Sustento jurídico: } \\
\text { Artículos } 1^{\circ}, 14,16,17,18,19 \text {, } \\
20,21,22 \text { y } 102 \text { A, de la Cons- } \\
\text { titución Política de los Estados } \\
\text { Unidos Mexicanos. Artículo } \\
14 \text { del Pacto Internacional de } \\
\text { Derechos Civiles y Políticos. } \\
\text { Artículos } 1,2 \text { y } 8 \text { de la Con- } \\
\text { vención Americana sobre De- } \\
\text { rechos Humanos. Artículos } 1^{\circ} \text {, } \\
6^{\circ}, 7^{\circ}, 8^{\circ}, 9^{\circ}, 10,13,29 \text { al } 39 \\
\text { del Código Penal Federal.Ar- } \\
\text { tículos } 1^{\circ}, 2^{\circ}, 133 \text { fracción II, } \\
211 \text { fracción III, } 348 \text { al } 413 \text { y } \\
\text { décimo primero transitorio del } \\
\text { Código Nacional de Procedi- } \\
\text { mientos Penales. Artículos } 1 \text {, }\end{array}$ & $\begin{array}{l}\text { Marco jurídico: } \\
\text { Artículos } 1^{\circ}, 14,16,17,18 \text {, } \\
19,20,21,22 \text { y } 102 \text { A de la } \\
\text { Constitución Política de los } \\
\text { Estados Unidos Mexica- } \\
\text { nos. Artículo 14, del Pacto } \\
\text { Internacional de Derechos } \\
\text { Civiles y Políticos. Artícu- } \\
\text { los } 1,2 \text { y } 8 \text { de la Conven- } \\
\text { ción Americana sobre De- } \\
\text { rechos Humanos (pacto de } \\
\text { San José Costa Rica). Artí- } \\
\text { culos } 1^{\circ}, 6^{\circ}, 7^{\circ}, 8^{\circ}, 9^{\circ}, 10 \text {, } \\
13,29 \text { al } 39, \text { del Código } \\
\text { Penal Federal. Artículos } 1^{\circ}, \\
2^{\circ}, 133 \text { fracción I, } 183 \text { al } \\
210,211 \text { fracción II, } 334 \text { al } \\
347 \text { y décimo primero tran- }\end{array}$ \\
\hline
\end{tabular}

68 Cámara de Diputados, en http://www.diputados.gob.mx/LeyesBiblio/pdf/ CNPP_120116.pdf. Fecha de consulta: 08 de marzo de 2016.

69 http://wrew.secretariadoejecutivo.gob.mx/docs/pdfs/normateca/protocolos/ProtocoloPrimerRespondienteV1.pdf. Fecha de consulta: 15 de marzo de 2016.

70 http://wrew.pgjebcs.gob.mx/FEPADE/Protocolos\%20Sistema\%20Acusatorio/Protocolo\%20 GUICIO.pdf. Fecha de consulta: 15 de marzo de 2016.

71 http://wrere.pgjebcs.gob.mx/FEPADE/Protocolos\%20Sistema\%20Acusatorio/Protocolo\%20Intermedia.pdf. Fecha de consulta: 15 de marzo de 2016. 
Esta obra forma parte del acervo de la Biblioteca Jurídica Virtual del Instituto de Investigaciones Jurídicas de la UNAM

\begin{tabular}{|c|c|c|}
\hline \multicolumn{3}{|c|}{ Protocolos de investigación y de actuación del personal sustantivo } \\
\hline $\begin{array}{l}\text { Protocolo nacional de ac-tua- } \\
\text { ción primer respondiente. }\end{array}$ & $\begin{array}{l}\text { Protocolo de actuación etapa del } \\
\text { juicio }\end{array}$ & $\begin{array}{l}\text { Protocolo de actuación etapa } \\
\text { intermedia }\end{array}$ \\
\hline $\begin{array}{l}\text { cargados de hacer cum- } \\
\text { plir la ley. Leyes Locales: } \\
\text { Constitución Estatal o el } \\
\text { Estatuto de Gobierno del } \\
\text { Distrito Federal. • Leyes re- } \\
\text { lacionadas con la Seguridad } \\
\text { Pública de los Estados e Ins- } \\
\text { tituciones policiales. • Ley } \\
\text { Orgánica de la Procuradu- } \\
\text { ría o Fiscalía del Estado. } \\
\text { Tesis número P./J.38/200, } \\
\text { de la Novena Época, visible } \\
\text { en el Semanario Judicial de } \\
\text { la Federación y su Gaceta, } \\
\text { con el número de regis- } \\
\text { tro } 192080 \text {, bajo el rubro: } \\
\text { Ejército, Armada y Fuer- } \\
\text { za Aérea. su participación } \\
\text { en auxilio de las autorida- } \\
\text { des civiles es constitucional } \\
\text { (interpretación del artícu- } \\
\text { lo } 129 \text { de la constitución). } \\
\text { - Tesis número P./J. 37/ } \\
\text { 2000, la Novena Época, } \\
\text { visible en el Semanario Ju- } \\
\text { dicial de la Federación y su } \\
\text { Gaceta, con el número de } \\
\text { registro 192081, bajo el ru- } \\
\text { bro: Ejército, Fuerza Aérea } \\
\text { y Armada. pueden actuar } \\
\text { acatando órdenes del presi- } \\
\text { dente, con estricto respeto } \\
\text { a las garantías individuales, } \\
\text { cuando sin llegarse a situa- } \\
\text { ciones que requieran la sus- } \\
\text { pensión de aquéllas, hagan } \\
\text { temer, fundadamente, que } \\
\text { de no enfrentarse de inme- } \\
\text { diato sería inminente caer } \\
\text { en condiciones graves que } \\
\text { obligarían a decretarla. }\end{array}$ & $\begin{array}{l}7,10,11,12,14,16,18,26,27 \\
42,43,125 \text { y } 128 \text { de la Ley Ge- } \\
\text { neral de Víctimas. }\end{array}$ & $\begin{array}{l}\text { sitorio del Código Nacio- } \\
\text { nal de Procedimientos } P^{-} \\
\text {nales. Artículos } 1,7,10,11 \text {, } \\
12,14,16,18,26,27,42 \text {, } \\
43,125 \text { y } 128 \text { de la Ley Ge- } \\
\text { neral de Víctimas. }\end{array}$ \\
\hline
\end{tabular}


Esta obra forma parte del acervo de la Biblioteca Jurídica Virtual del Instituto de Investigaciones Jurídicas de la UNAM www.juridicas.unam.mx

BALANCE Y PERSPECTIVAS DE LA REFORMA CONSTITUCIONAL PENAL...

\begin{tabular}{|c|c|c|}
\hline \multicolumn{3}{|c|}{ Protocolos de investigación y de actuación del personal sustantivo } \\
\hline $\begin{array}{l}\text { Protocolo nacional de actuación } \\
\text { policia con capacidades para } \\
\text { procesar el lugar de la interven- } \\
\text { ción. }^{72}\end{array}$ & Protocolo de la cadena de custodia. ${ }^{73}$ & $\begin{array}{l}\text { Guía nacional cadena de cus- } \\
\text { todia. }^{74}\end{array}$ \\
\hline $\begin{array}{l}\text { Primer Respondiente. Es } \\
\text { la primera autoridad con } \\
\text { funciones de seguridad pú- } \\
\text { blica en el lugar de la inter- } \\
\text { vención. }\end{array}$ & & $\begin{array}{l}\text { Objetivo: Formular la acu- } \\
\text { sación, ofrecer y lograr la } \\
\text { admisión de los medios de } \\
\text { prueba y depurar los he- } \\
\text { chos controvertidos que se- } \\
\text { rán materia de juicio. }\end{array}$ \\
\hline $\begin{array}{l}\text { El presente Protocolo, tie- } \\
\text { ne como fin establecer las } \\
\text { directrices que deberán se- } \\
\text { guir la Policía con capaci- } \\
\text { dades para procesar al mo- } \\
\text { mento de su intervención, } \\
\text { desde la búsqueda, locali- } \\
\text { zación, identificación, fija- } \\
\text { ción, recolección, y en su } \\
\text { caso embalaje de los obje- } \\
\text { tos relacionados con la in- } \\
\text { vestigación, hasta la entre- } \\
\text { ga a la bodega de indicios, } \\
\text { a los servicios periciales, o } \\
\text { en su caso, al lugar que co- } \\
\text { rresponda para su análisis, } \\
\text { siendo éste un factor fun- } \\
\text { damental para la adecuada } \\
\text { investigación. } \\
\text { También tiene como fin, } \\
\text { establecer los lineamientos } \\
\text { de coordinación, comuni- } \\
\text { cación y colaboración recí- } \\
\text { proca entre las Policías de } \\
\text { Primer Respondiente, con } \\
\text { capacidades para proce- } \\
\text { sar y de Investigación, en } \\
\text { el ámbito de sus competen- } \\
\text { cias, para el procesamiento } \\
\text { del lugar de intervención. }\end{array}$ & $\begin{array}{l}\text { Que sirva como marco regula- } \\
\text { torio en las Entidades Federati- } \\
\text { vas, para el correcto manejo de } \\
\text { los indicios o evidencias, con el } \\
\text { propósito de garantizar su inte- } \\
\text { gridad y evitar su pérdida, des- } \\
\text { trucción, alteración o deterioro, } \\
\text { manteniendo un respeto irres- } \\
\text { tricto a las garantías fundamen- } \\
\text { tales de las personas sometidas } \\
\text { al proceso penal. } \\
\text { Cadena de custodia: } \\
\text { Es el registro fiel del curso se- } \\
\text { guido por los indicios o eviden- } \\
\text { cia desde su descubrimiento por } \\
\text { parte de una autoridad, policía } \\
\text { o agente del Ministerio Público, } \\
\text { hasta que la autoridad com- } \\
\text { petente ordene su conclusión, } \\
\text { según se trate de Averiguación } \\
\text { Previa, Carpeta de Investiga- } \\
\text { ción o Proceso Penal. }\end{array}$ & $\begin{array}{l}\text { La presente Guía, repre- } \\
\text { senta un instrumento base } \\
\text { para la articulación de los } \\
\text { esfuerzos de todos los ser- } \\
\text { vidores públicos que inter- } \\
\text { vengan en la Cadena de } \\
\text { Custodia, desde la preser- } \\
\text { vación del lugar de la inter- } \\
\text { vención, hasta su procesa- } \\
\text { miento y traslado, además } \\
\text { de brindar la estandariza- } \\
\text { ción de las actividades que } \\
\text { garanticen la trazabilidad } \\
\text { y continuidad de los indi- } \\
\text { cios o elementos materiales } \\
\text { probatorios. }\end{array}$ \\
\hline
\end{tabular}

72 http://wrew.secretariadoejecutivo.gob.mx/normateca/normateca.php. Fecha de consulta: 15 de marzo de 2016.

73 http://wrere.sitioswerweb.com/miguel/PROTOCOLO_CADENA_DE_CUSTODIA.pdf. Fecha de consulta: 15 de marzo de 2016.

74 http://wrerw.secretariadoejecutivo.gob.mx/normateca/normateca.php. Fecha de consulta: 15 de marzo de 2016. 
Esta obra forma parte del acervo de la Biblioteca Jurídica Virtual del Instituto de Investigaciones Jurídicas de la UNAM

\begin{tabular}{|c|c|c|}
\hline \multicolumn{3}{|c|}{ Protocolos de investigación y de actuación del personal sustantivo } \\
\hline $\begin{array}{l}\text { Protocolo nacional de actuación } \\
\text { policía con capacidades para } \\
\text { procesar el lugar de la inter- } \\
\text { vención. }\end{array}$ & Protocolo de la cadena de custodia & $\begin{array}{l}\text { Guía nacional cadena de } \\
\text { custodia }\end{array}$ \\
\hline $\begin{array}{l}\text { Constitución Política de } \\
\text { los Estados Unidos Mexi- } \\
\text { canos. } \\
\text { Ley General del Sistema } \\
\text { Nacional de Seguridad Pú- } \\
\text { blica. } \\
\text { Ley General de Víctimas. } \\
\text { Leyes relacionadas con ser- } \\
\text { vicios de emergencia. } \\
\text { Código Nacional de Pro- } \\
\text { cedimientos Penales. Código } \\
\text { Penal Federal. } \\
\text { Declaración Universal de } \\
\text { los Derechos Humanos. } \\
\text { Declaración Americana de } \\
\text { los Derechos y Deberes del } \\
\text { Hombre. } \\
\text { Convención Americana so- } \\
\text { bre Derechos Humanos. } \\
\text { Pacto Internacional de De- } \\
\text { rechos Civiles y Políticos. } \\
\text { Código de conducta para } \\
\text { funcionarios encargados de } \\
\text { hacer cumplir la ley. } \\
\text { Manual de la escena del } \\
\text { delito y las pruebas mate- } \\
\text { riales. Sensibilización del } \\
\text { personal no forense sobre } \\
\text { su importancia. }\end{array}$ & $\begin{array}{l}\text { Constitución Política de los Es- } \\
\text { tados Unidos Mexicanos; Ley } \\
\text { General del Sistema Nacional } \\
\text { de Seguridad Pública; Código } \\
\text { Federal de Procedimientos Pe- } \\
\text { nales; Acuerdo A/002/10, del } \\
\text { Procurador General de la Repú- } \\
\text { blica por el que se establecen los } \\
\text { lineamientos que deberán ob- } \\
\text { servar todos los servidores pú- } \\
\text { blicos para la debida preserva- } \\
\text { ción y procesamiento del lugar } \\
\text { de hechos o del hallazgo y de los } \\
\text { indicios, huellas o vestigios del } \\
\text { hecho delictuoso, así como los } \\
\text { instrumentos, objetos o produc- } \\
\text { tos del delito, publicado en el } \\
\text { Diario Oficial de la Federación } \\
\text { el } 3 \text { de febrero de } 2010, \text { y Los } \\
\text { Códigos de Procedimientos Pe- } \\
\text { nales o sus equivalentes de cada } \\
\text { una de las Entidades Federati- } \\
\text { vas que fundamentan la actua- } \\
\text { ción de los peritos y del manejo } \\
\text { de las evidencias. }\end{array}$ & $\begin{array}{l}\text { Constitución Política de } \\
\text { los Estados Unidos Mexi- } \\
\text { canos. } \\
\text { Ley General del Sistema } \\
\text { Nacional de Seguridad Pú- } \\
\text { blica. } \\
\text { Código Nacional de Proce- } \\
\text { dimientos Penales. } \\
\text { Código Penal Federal. } \\
\text { Declaración Universal de } \\
\text { los Derechos Humanos. } \\
\text { Convención Americana so- } \\
\text { bre Derechos Humanos. } \\
\text { Convención de Viena con- } \\
\text { tra el tráfico ilícito de estu- } \\
\text { pefacientes y substancias } \\
\text { Psicotrópicas de la ONU. } \\
\text { Convención de Palermo } \\
\text { sobre Delincuencia Orga- } \\
\text { nizada transnacional. } \\
\text { Convención de las Nacio- } \\
\text { nes Unidas contra la Co- } \\
\text { rrupción (ONU). } \\
\text { Convención Internacional } \\
\text { para la protección de todas } \\
\text { las personas contra las des- } \\
\text { apariciones forzadas. } \\
\text { Convención contra la tor- } \\
\text { tura y otros tratos o penas } \\
\text { crueles, inhumanos o de- } \\
\text { gradantes. } \\
\text { Código de conducta para } \\
\text { funcionarios encargados de } \\
\text { hacer cumplir la ley. } \\
\text { Manual de la escena del } \\
\text { delito y las pruebas mate- } \\
\text { riales. Sensibilización del } \\
\text { personal no forense sobre } \\
\text { su importancia. } \\
\text { Constitución Estatal o Es- } \\
\text { tatuto de Gobierno del } \\
\text { Distrito Federal. }\end{array}$ \\
\hline
\end{tabular}


Esta obra forma parte del acervo de la Biblioteca Jurídica Virtual del Instituto de Investigaciones Jurídicas de la UNAM

BALANCE Y PERSPECTIVAS DE LA REFORMA CONSTITUCIONAL PENAL...

\begin{tabular}{|c|c|c|}
\hline \multicolumn{3}{|c|}{ Protocolos de investigación y de actuación del personal sustantivo } \\
\hline $\begin{array}{l}\text { Protocolo nacional de actuación } \\
\text { policia con capacidades para }\end{array}$ & Protocolo de la cadena de custodia & $\begin{array}{l}\text { Guía nacional cadena de } \\
\text { custodia }\end{array}$ \\
\hline & & $\begin{array}{l}\text { Leyes relacionadas con la } \\
\text { Seguridad Pública e Ins- } \\
\text { tituciones Policiales de la } \\
\text { Entidades Federativas. } \\
\text { Leyes Orgánicas de las } \\
\text { Procuradurías Generales o } \\
\text { Fiscalías del Estado. } \\
\text { Códigos Penales de las En- } \\
\text { tidades Federativas } \\
\text { Acuerdo A/009/15 de la } \\
\text { Procuraduría General de } \\
\text { la República, por el que } \\
\text { se establecen las directri- } \\
\text { ces que deberán observar } \\
\text { los servidores públicos que } \\
\text { intervengan en materia de } \\
\text { Cadena de Custodia. } \\
\text { Acuerdo A/006/12, del } \\
\text { Secretario de Seguridad } \\
\text { Pública, por el que se emi- } \\
\text { ten los lineamientos gene- } \\
\text { rales para la regulación del } \\
\text { procesamiento de indicios } \\
\text { y Cadena de Custodia en } \\
\text { la Secretaría de Seguridad } \\
\text { Publica. } \\
\text { Instrumentos normativos } \\
\text { en materia de Cadena de } \\
\text { Custodia de las entidades } \\
\text { federativas. } \\
\text { Protocolo Nacional de Ac- } \\
\text { tuación de Primer Respon- } \\
\text { diente. } \\
\text { Protocolo Nacional de Po- } \\
\text { licía con Capacidades para } \\
\text { Procesar el Lugar de la In- } \\
\text { tervención. }\end{array}$ \\
\hline $\begin{array}{l}\text { Objetivo. } \\
\text { Dotar a las Policías con } \\
\text { capacidades para proce- } \\
\text { sar, de un instrumento en } \\
\text { el que se homologuen las } \\
\text { directrices de su actuación, }\end{array}$ & $\begin{array}{l}\text { Objetivo. } \\
\text { Establecer los procedimientos } \\
\text { técnicos científicos necesarios } \\
\text { para garantizar, la preserva- } \\
\text { ción del lugar de hechos y/o } \\
\text { del hallazgo, así como de los in- }\end{array}$ & $\begin{array}{l}\text { Garantizar la mismidad y } \\
\text { autenticidad de los indi- } \\
\text { cios o elementos materiales } \\
\text { probatorios, mediante acti- } \\
\text { vidades de control y elabo- } \\
\text { ración de registros, que de- }\end{array}$ \\
\hline
\end{tabular}


Esta obra forma parte del acervo de la Biblioteca Jurídica Virtual del Instituto de Investigaciones Jurídicas de la UNAM

\begin{tabular}{|l|l|l|}
\hline \multicolumn{2}{|c|}{ Protocolos de investigación y de actuación del personal sustantivo } \\
\hline $\begin{array}{l}\text { Protocolo nacional de actuación } \\
\text { policía con capacidades para } \\
\text { procesar el lugar de la inter- } \\
\text { vención. }\end{array}$ & Protocolo de la cadena de custodia & $\begin{array}{l}\text { Guía nacional cadena de } \\
\text { custodia }\end{array}$ \\
\hline $\begin{array}{l}\text { de conformidad a las mejo- } \\
\text { res prácticas, para la apli- } \\
\text { cación de la metodología } \\
\text { criminalística en el lugar } \\
\text { de intervención, para la in- } \\
\text { vestigación criminal. }\end{array}$ & $\begin{array}{l}\text { dicios y evidencias para garan- } \\
\text { tengan sus características de de } \\
\text { originalidad y autenticidad, } \\
\text { garantizando así. }\end{array}$ & $\begin{array}{l}\text { muestren la continuidad y } \\
\text { trazabilidad de la Cadena } \\
\text { de Custodia, con el fin de } \\
\text { de pruebararlos como en en proceso } \\
\text { penal. }\end{array}$ \\
\hline
\end{tabular}

Protocolos de investigación y de actuación del personal sustantivo

\begin{tabular}{|c|c|}
\hline $\begin{array}{l}\text { Protocolo nacional de actuación } \\
\text { traslado. }{ }^{75}\end{array}$ & $\begin{array}{l}\text { Protocolo nacional de actuación } \\
\text { seguridad en salas. }{ }^{76}\end{array}$ \\
\hline $\begin{array}{l}\text { Se pretende asegurar que } \\
\text { las autoridades que inter- } \\
\text { vienen en el traslado, se } \\
\text { coordinen y comuniquen } \\
\text { de manera efectiva para } \\
\text { dar cumplimiento a la pla- } \\
\text { neación, ejecución y des- } \\
\text { tino del traslado, lo ante- } \\
\text { rior, con estricto apego a } \\
\text { los derechos humanos de } \\
\text { las personas que estén bajo } \\
\text { su custodia al momento en } \\
\text { que se estén trasladando. } \\
\text { Con todo lo anterior, se } \\
\text { fortalecen las capacidades } \\
\text { de investigación del Esta- } \\
\text { do Mexicano, ya que los } \\
\text { traslados, preferentemente } \\
\text { serán realizados por cuer- } \\
\text { pos policiales y/o personal } \\
\text { capacitado. }\end{array}$ & $\begin{array}{l}\text { Tiene por objeto establecer los } \\
\text { principios que regirán las ac- } \\
\text { tuaciones de los integrantes de } \\
\text { las instituciones de seguridad } \\
\text { pública, que lleven a cabo la } \\
\text { actividad de custodia del im- } \\
\text { putado y seguridad en salas, de } \\
\text { una manera homogénea y efi- } \\
\text { caz, como una parte importan- } \\
\text { te en el proceso que el nuevo } \\
\text { sistema señala. }\end{array}$ \\
\hline $\begin{array}{l}\text { Constitución Política de los } \\
\text { Estados Unidos Mexicanos. } \\
\text { Ley General del Sistema Na- } \\
\text { cional de Seguridad Pública. }\end{array}$ & $\begin{array}{l}\text { Constitución Política de los Es- } \\
\text { tados Unidos Mexicanos. Có- } \\
\text { digo Nacional de Procedimien- } \\
\text { tos Penales. Ley General del }\end{array}$ \\
\hline
\end{tabular}

75 http://wrere.secretariadoejecutivo.gob.mx/normateca/normateca.php. Fecha de consulta: 16 de marzo de 2016.

76 http://wrere.secretariadoejecutivo.gob.mx/docs/pdfs/normateca/protocolos/ProtocoloSeguridadSalasV1.pd. Fecha de consulta: 16 de marzo de 2016. 
Esta obra forma parte del acervo de la Biblioteca Jurídica Virtual del Instituto de Investigaciones Jurídicas de la UNAM

BALANCE Y PERSPECTIVAS DE LA REFORMA CONSTITUCIONAL PENAL...

\begin{tabular}{|c|c|c|}
\hline \multicolumn{3}{|c|}{ Protocolos de investigación y de actuación del personal sustantivo } \\
\hline $\begin{array}{l}\text { Protocolo nacional de actuación } \\
\text { traslado }\end{array}$ & $\begin{array}{l}\text { Protocolo nacional de actuación } \\
\text { seguridad en salas }\end{array}$ & \\
\hline $\begin{array}{l}\text { Ley Federal de Responsa- } \\
\text { bilidades Administrativas } \\
\text { de los Servidores Públicos. } \\
\text { Ley de Aviación Civil. } \\
\text { Ley de Navegación y Co- } \\
\text { mercio Marítimo. } \\
\text { Código Nacional de Proce- } \\
\text { dimientos Penales. } \\
\text { Código Penal Federal. } \\
\text { Protocolo Homologado } \\
\text { para la Investigación del } \\
\text { Delito de Tortura. } \\
\text { Protocolo Homologado } \\
\text { para la Investigación del } \\
\text { Delito de Desaparición } \\
\text { Forzada. } \\
\text { Declaración Universal de } \\
\text { los Derechos Humanos. } \\
\text { Convención Americana so- } \\
\text { bre Derechos Humanos. } \\
\text { Pacto Internacional de De- } \\
\text { rechos Civiles y Políticos. } \\
\text { Convención Internacional } \\
\text { sobre la protección de to- } \\
\text { das las personas contra las } \\
\text { Desapariciones Forzadas. } \\
\text { Convención Interamerica- } \\
\text { na sobre Desaparición For- } \\
\text { zada de Personas. } \\
\text { Convención contra la de } \\
\text { Tortura y otros Tratos } \\
\text { Crueles, Inhumanos o De- } \\
\text { gradantes. } \\
\text { Código de Conducta para } \\
\text { Funcionarios encargados } \\
\text { de hacer cumplir la Ley. } \\
\text { Reglas mínimas para el } \\
\text { Tratamiento de los Reclu- } \\
\text { sos de la oficina del alto } \\
\text { Comisionado de las Nacio- } \\
\text { nes Unidas para los Dere- } \\
\text { chos Humanos. } \\
\text { Tratados internacionales } \\
\text { en los que el Estado Mexi- } \\
\text { cano sea parte. }\end{array}$ & $\begin{array}{l}\text { Sistema Nacional de Seguri- } \\
\text { dad Pública. Ley General de } \\
\text { Víctimas. Instrumentos Inter- } \\
\text { nacionales: Declaración Uni- } \\
\text { versal de los Derechos Huma- } \\
\text { nos. Pacto Internacional de } \\
\text { Derechos Civiles y Políticos. } \\
\text { Convención Americana sobre } \\
\text { Derechos Humanos. Declara- } \\
\text { ción Americana de los Dere- } \\
\text { chos y Deberes del Hombre. } \\
\text { Código de conducta para fun- } \\
\text { cionarios encargados de hacer } \\
\text { cumplir la ley. Leyes Locales: } \\
\text { Constitución Estatal y/o el Es- } \\
\text { tatuto de Gobierno del Distri- } \\
\text { to Federal. Leyes relacionadas } \\
\text { con la Seguridad Pública de los } \\
\text { Estados e Instituciones Policia- } \\
\text { les. Ley Orgánica de la Procu- } \\
\text { raduría o Fiscalía del Estado. }\end{array}$ & \\
\hline
\end{tabular}


Esta obra forma parte del acervo de la Biblioteca Jurídica Virtual del Instituto de Investigaciones Jurídicas de la UNAM

\begin{tabular}{|c|c|c|}
\hline \multicolumn{3}{|c|}{ Protocolos de investigación y de actuación del personal sustantivo } \\
\hline $\begin{array}{l}\text { Protocolo nacional de actuación } \\
\text { traslado }\end{array}$ & $\begin{array}{l}\text { Protocolo nacional de actuación } \\
\text { seguridad en salas }\end{array}$ & \\
\hline $\begin{array}{l}\text { Constitución Estatal y/o el } \\
\text { Estatuto de Gobierno del } \\
\text { Distrito Federal. } \\
\text { Leyes relacionadas con la } \\
\text { Seguridad Pública de los } \\
\text { Estados e Instituciones po- } \\
\text { liciales. } \\
\text { Ley Orgánica de la Procu- } \\
\text { raduría o Fiscalía del Esta- } \\
\text { do. } \\
\text { Código Penal de la Entidad } \\
\text { Federativa. }\end{array}$ & & \\
\hline $\begin{array}{l}\text { Objetivo. } \\
\text { Dotar a aquellas autorida- } \\
\text { des que realicen el traslado } \\
\text { de personas, de un instru- } \\
\text { mento en el que se homolo- } \\
\text { guen los lineamientos de su } \\
\text { actuación y coordinación, } \\
\text { de conformidad a lo que } \\
\text { establece la Constitución } \\
\text { Política de los Estados Uni- } \\
\text { dos Mexicanos, los trata- } \\
\text { dos internacionales de los } \\
\text { que el Estado Mexicano es } \\
\text { parte y el Código Nacional } \\
\text { de Procedimientos Penales. }\end{array}$ & $\begin{array}{l}\text { Objetivo. } \\
\text { Que los integrantes de las ins- } \\
\text { tituciones de seguridad públi- } \\
\text { ca, que realicen funciones de } \\
\text { seguridad en salas y custodia } \\
\text { del imputado, cuenten con un } \\
\text { instrumento en el que se homo- } \\
\text { loguen los procedimientos, li- } \\
\text { neamientos y las funciones que } \\
\text { desempeñarán en las salas de } \\
\text { audiencia, para minimizar las } \\
\text { situaciones de riesgo que se } \\
\text { pueden presentar durante la } \\
\text { participación del Imputado, } \\
\text { Acusado o Sentenciado en la } \\
\text { misma, o de las personas asis- } \\
\text { tentes a la audiencia, con abso- } \\
\text { luto apego a los principios que } \\
\text { rigen su actuar, conforme a lo } \\
\text { establecido en la Constitución } \\
\text { Política de los Estados Unidos } \\
\text { Mexicanos, los Tratados Inter- } \\
\text { nacionales en los que el Estado } \\
\text { Mexicano sea parte y el Códi- } \\
\text { go Nacional de Procedimientos } \\
\text { Penales. }\end{array}$ & \\
\hline
\end{tabular}

La homologación de las legislaciones procesales estatales a la Nacional es indispensable, esta unificación en cuestión adjetiva marca un gran avance para México, debido a que la justicia no necesariamente triunfa cuando puede adquirirse un derecho, sino en la manera cómo se protege ese derecho. 
Esta obra forma parte del acervo de la Biblioteca Jurídica Virtual del Instituto de Investigaciones Jurídicas de la UNAM

\section{REFLEXIONES FINALES}

Sin lugar a dudas, el sistema de procesamiento penal inquisitorio es un obstáculo al desarrollo y fortalecimiento de las instituciones del Estado de Derecho Social Democrático. Consecuentemente, favorece a los regímenes autoritarios, y por ende, cobijan la arbitrariedad y la corrupción.

Además, cabe resaltar, que el sistema penal inquisitorial mixto, en ocasiones se distingue por su irracionalidad y arbitrariedad de obtener de parte del acusado la aceptación de su supuesta culpabilidad, a través de prácticas psicológicas y físicas que esquematizan el temor, el miedo, hasta llegar a generar estados de angustia, ansiedad, terror y de esa manera aceptar conductas no realizadas por el acusado.

La Reforma Constitucional Penal del 18 de junio de 2008, implica una separación con la concepción positivista decimonónica del Derecho. La cual, se caracteriza por el culto a la exegesis y al formalismo del Derecho. Ahora se trata de dar un salto cualitativo para integrarse al Realismo Jurídico, en donde, se deja de practicar únicamente la exegesis y se abre una perspectiva del conocimiento más plural y menos formalista.

En cambio, el sistema procesal penal acusatorio facilita las condiciones subjetivas y objetivas para fortalecer y desarrollar un régimen democrático respetuoso del Estado del Derecho.

Ahora bien, es prudente mencionar que dicha reforma enfrenta, entre otros, problemas a los siguientes:

- La práctica profesional tanto de los abogados postulantes como de los que procuran e imparten justicia obstaculiza la eficacia y eficiencia del sistema procesal penal acusatorio vía juicios orales, toda vez, que han sido formados o deformados, por una parte, por el paradigma del positivismo decimonónico que descansa en el formalismo exegético, y por la otra, en instituciones de educación superior eminentemente sustentados en los modelos anquilosados de la Universidad Napoleónica. Deformados por la enseñanza tradicional del Derecho, que es harto discursiva, memorizante, pasiva y receptiva.

- Se enfrenta la carencia tanto de infraestructura humana debidamente actualizada y capacitada. Así como de la ausencia de infraestructura material. Así pues, para hacer realidad tan sólo, al Sistema Penal Acusatorio vía los Juicios Orales y de los medios alternativos para resolver controversias en forma clara y rápida se requiere de 
Esta obra forma parte del acervo de la Biblioteca Jurídica Virtual del Instituto de Investigaciones Jurídicas de la UNAM

un presupuesto mayor a los 10,000 millones de dólares. Dicha exigencia, se torna en una meta difícil de lograr.

- La práctica profesional de los abogados postulantes de formación tradicional generalmente se les identifica con el sistema penal inquisitorial. Así como de la expresión mixta del referido sistema.

- La inveterada práctica de los operadores del Derecho que procuran e imparten la justicia penal en México, en un alto porcentaje de estos funcionarios: de agentes del ministerio público, jueces, magistrados, y demás funcionarios de la Judicatura son escépticos o se resisten a los cambios que trae consigo la reforma penal constitucional, a través del sistema penal acusatorio.

- Un factor que viene a alterar a lo que se diseñó y programo con la Reforma Constitucional Penal del 18 de junio del 2008, que establece en los transitorios una vacatio legis hasta el 2016, es la severa crisis económica mundial que impacta a nuestra economía nacional dentro del contexto de la globalización. Dicha crisis aflora internacionalmente desde el año 2011, pero que se ha venido recrudeciendo aún más en estos últimos años. A este respecto, cabe citar, la caída del precio del petróleo que está muy por debajo de lo presupuestado y que a partir del segundo semestre del año 2015 y en estos primeros meses del año 2016, generan un panorama dramático de empobrecimiento sin parangón alguno, toda vez, que todavía se espera una baja mayor en el precio del crudo del petróleo mexicano. Lamentablemente, dicha crisis económica obstaculizara el desarrollo tanto de la infraestructura material y humana que se requieren para la aplicación eficaz y eficiente del Sistema Procesal Penal Acusatorio Oral y Garantista.

- Además, cabe cuestionarse en los siguientes términos: Las facultades, escuelas y demás instituciones de educación superior que ofertan los estudios de la licenciatura en Derecho en México, no informan ni forman adecuadamente a los estudiantes de Derecho y futuros abogados para sacar adelante esta reforma constitucional penal. Toda vez, que en las aulas, lamentablemente, en la gran mayoría de las instituciones que ofertan los estudios de derecho, en nuestro país permea la docencia tradicional, que se caracteriza por ser pasiva, receptiva, acrítica, memorística, etcétera, he ahí uno de los puntos de fragilidad académica que inhiben el desarrollo de conocimientos y competencias que les permita la generación de estrategias para argumentar y debatir la defensa de la víctima y la 
Esta obra forma parte del acervo de la Biblioteca Jurídica Virtual del Instituto de Investigaciones Jurídicas de la UNAM

contra argumentación en favor del presunto responsable. Dichas deficiencias, obstaculizan el desarrollo y fortalecimiento de la Reforma Constitucional Penal, que establece el Sistema Penal Acusatorio vía los Juicios Orales.

- La falta de actualización de los contenidos de los programas de estudios de las disciplinas tanto del Derecho Constitucional como del Derecho Penal sustantivo y adjetivo en un alto porcentaje de las instituciones de educación superior que ofertan los estudios de derecho en todo lo largo y ancho de la República Mexicana retardaran las novedades teóricas y prácticas que contextualizan a la reforma penal constitucional en México vigente a partir del 18 de junio del año 2008. Además, se requiere de prácticas docentes que hagan a un lado los métodos y técnicas del modelo tradicional de la enseñanza del Derecho. Ahora, se requiere de los métodos y técnicas activas del proceso de enseñanza-aprendizaje del Derecho, por ejemplo: el preseminario; seminarios; el método del caso, de análisis de jurisprudencia, etc. Es decir, se requiere un modelo de docencia activo, que genere un proceso de enseñanza-aprendizaje activo, dinámico, dialógico y participativo.

- La inercia genera oposición en un alto porcentaje de los profesores de las academias de derecho penal, ya que cuestionan a priori, los beneficios que puedan lograrse con el sistema penal acusatorio, que teóricamente descansa en el garantismo como una expresión más a fin al Estado de Derecho Social Democrático.

Por otra parte, con la promulgación del Código Nacional de Procedimientos Penales, inicia una nueva etapa en la vida jurídica del país; es una gran oportunidad para que las instituciones de procuración e impartición de justicia, se modernicen y recuperen la confianza ciudadana a partir de resultados transparentes.

El Código Nacional Procesal Penal debe adecuarse a instrumentos jurídicos internacionales vigentes. Si bien algunos de estos aspectos han sido ya considerados. Empero, existen otros temas sensibles, por ejemplo, lo referente a los pueblos indígenas no han sido abordados adecuadamente o han sido dejados de lado, por lo cual debería prestarse especial atención a su contenido.

Sin embargo, aún se encuentra pendiente el Código Penal Único, estando en el límite de tiempo para la implementación en toda la República Mexicana, del Sistema Penal Acusatorio, mediante los Juicios Orales. 
Esta obra forma parte del acervo de la Biblioteca Jurídica Virtual del Instituto de Investigaciones Jurídicas de la UNAM

\section{BIBLIOGRAFÍA}

Álvarez Román, Jesús Antonio, El derecho en las culturas orientales, Babilonia, Israel, el Mundo Arabe Islámico, Jus, México, 1983.

ARELLANO Trejo, Efrén, Los desafios de la delincuencia en México (Incidencia delictiva y su impacto en la opinión pública), México, Centro de Estudios Sociales y de Opinión Pública, Cámara de Diputados, s.a.

Caballero Juárez, José Antonio, López Ayllón, Sergio y Oñarte Laborde, Alfonso, Libro Blanco de la Reforma Fudicial. Una agenda para la justicia en México, México, Suprema Corte de Justicia de la Nación, 2006.

CÁMARA de Diputados, en http://www.diputados.gob.mx/LeyesBiblio/declara/cnpp.htm.

CÁmARA de Diputados, en http://www.diputados.gob.mx/LeyesBiblio/ pdf/CNPP_120116.pdf.

Carbonell, Miguel, y Ochoa Reza, Enrique, ¿Qué son y para qué sirven los juicios orales?, México, Porrúa, 2008.

Garpizo, Enrique, Derechos Fundamentales. Interpretación Constitucional. La Cortey los Derechos, $1^{\text {a }}$ ed. 2011, 1ª reimpresión, México, Porrúa, 2011.

CARPIZO, Jorge, "El sistema federal mexicano", en Camargo, Pedro Pablo, Carpizo, Jorge, et al., Los sistemas federales del continente americano, México, IIJUNAM-FGE, 1972.

CARPIZO, Jorge, Moral pública y libertad de expresión, México, Jus, 2009.

Concha Cantú, Hugo Alejandro y Caballero Juárez, José Antonio, Diagnóstico sobre la administración de justicia en las entidades federativas. Un estudio institucional sobre la justicia local en México, México, Instituto de Investigaciones de Jurídicas de la UNAM, 2001.

DRAPKIN S., Israel, "La administración de justicia en el antiguo derecho hebreo", en Criminalia. 50 años. Academia mexicana de ciencias penales-Porrúa, México, año L, núms. 7-12, Julio-diciembre 1984.

Ferrajoli, Luigi, Derecho y razón. Teoría del garantismo penal, Prologo de Norberto Bobbio, trad. al castellano por Perfecto Andrés Ibáñez, et al., $1^{\mathrm{a}}$ ed. 1995, $2^{a}$ ed. 1997, $3^{a}$ ed. 1998, $4^{\text {a }}$ ed. Madrid, Trotta, 2000.

FIX Fierro, Héctor, "La eficiencia de la justicia (una aproximación y una propuesta)", en Cuadernos para la Reforma de la fusticia, México, UNAM, 1995.

GARCía Ramírez, Sergio, La reforma penal constitucional (2007-2008). ¿Democracia o autoritarismo?, México, Porrúa, 2008.

García Ramírez, Sergio y De González, Mariscal Olga, La reforma constitucional en materia penal. Fornada de justicia penal, México, INACIPE-UNAM, 2009. 
Esta obra forma parte del acervo de la Biblioteca Jurídica Virtual del Instituto de Investigaciones Jurídicas de la UNAM

Guillén, López, Raúl, Cruz Covarrubias, Armando E., La justicia penal en México. Un estudio de caso, México, Instituto de Investigaciones Jurídicas de la UNAM, 2008.

Http://wrere.Misionpolitica.Com/anteriores/columnas/tema-principal-de-lasemana/80300-a-la-congeladora-el-nuevo-codigo-nacional-de-procedimientos-penales. Fecha de consulta: 18 de marzo de 2016.

Http://www.Pgjebcs.Gob.Mx/fepade/protocolos\%20sistema\%20acusatorio/protocolo\%20intermedia.Pdf.

Http://wwwe.Pgjebcs.Gob.Mx/fepade/protocolos\%20sistema\%20acusatorio/protocolo\%20juicio.Pdf.

Http://wrere.Secretariadoejecutivo.Gob.Mx/docs/pdfs/normateca/protocolos/protocoloprimerrespondientev1.Pdf.

Http://wrere.Secretariadoejecutivo.Gob.Mx/docs/pdfs/normateca/protocolos/protocoloseguridadsalasv1.Pd.

Http://wrere.Secretariadoejecutivo.Gob.Mx/normateca/normateca.Php.

Http://wrere.Sitioswrerweb.Com/miguel/protocolo_cadena_de_custodia.Pdf

Los derechos del Pueblo Mexicano. México a través de sus Constituciones, t. I, México, Manuel Porrúa- Cámara de Diputados L Legislatura, 1978.

LunA Castro, José Nieves, "La unificación de la normatividad procesal penal en México, como exigencia de la garantía del debido proceso. Análisis evolutivo desde la perspectiva constitucional", Quid Iuris, México, año 8, vol. 22, septiembre-noviembre 2013, http://www.juridicas.unam.mx/publica/librev/rev/qdiuris/cont/22/cnt/cnt5.pdf.

NATARÉn Nandayapa, Carlos F., "Breves Reflexiones sobre algunos de los retos en el diseño del nuevo proceso penal ordinario", en García Ramírez, Sergio y de González Mariscal, Olga Islas (coords.), La Reforma Constitucional en Materia Penal Fornadas de Justicia Penal, México, IIJUNAM-INACIPE, 2009

NOvOA Monreal, Eduardo, El derecho como obstáculo al cambio social, México, Siglo XXI, 1975.

PACTO por México. Información obtenida en la siguiente dirección electrónica, http://pactopormexico.org/.

RODRÍGUEz Manzanera, Luis, "La necesidad del acercamiento de la criminología en la procuración e impartición de justicia”, en Rafael Sánchez Vázquez (coord.), Administración, Procuración e impartición de justicia. Memoria del Congreso Nacional e Internacional, Puebla, México, Benemérita Universidad Autónoma de Puebla, Facultad de Derecho y Ciencias Sociales e Instituto de Investigaciones Jurídico Políticas BUAP, 2008. 
Esta obra forma parte del acervo de la Biblioteca Jurídica Virtual del Instituto de Investigaciones Jurídicas de la UNAM

Sánchez Vázquez Rafael, Metodología de la Ciencia del Derecho, $9^{a}$ ed. México, Porrúa, 2014.

SETEC, Nueva Metodología para Clasificación y Estratificación de Entidades Federativas, en http://www.setec.gob.mx/es/SETEC/Nueva_Metodologia_para_Clasificacion_y_Estratificacion_de_Entidades_Federativas.

V. Castro, Juventino, La mutación estructural del derecho en México, México, Porrúa, 1998.

ZARCO, Francisco, Historia del Congreso Extraordinario Constituyente 1856 y 1857, Extracto de todas sus sesiones y documentos parlamentarios de la época, $1^{a}$ ed., México, Imprenta de Ignacio Cumplido, Calle de los Rebeldes, núm. 2, 1857. 
Esta obra forma parte del acervo de la Biblioteca Jurídica Virtual del Instituto de Investigaciones Jurídicas de la UNAM

\title{
EL MODELO MEXICANO DE GOBIERNOS DE COALICIÓN
}

\author{
Francisco Tortolero Cervantes*
}

SUMARIO: I. Introducción. II. Antecedentes. El significado de la reforma. III. A la búsqueda de un punto medio entre dos sistemas. IV. ¿Qué hacer para que funcionen los gobiernos de gabinete?. V. Reflexiones finales.

\section{INTRODUCCIÓN}

Agradezco a las instituciones organizadoras, la Universidad Autónoma de San Luis Potosí y el Instituto de Investigaciones Jurídicas de la UNAM, y a los responsables respectivos, Isidro de los Santos y José María Serna, por la invitación a participar en esta mesa del Congreso Nacional. Celebro que esta edición se efectúe en San Luis Potosí, por las razones que voy a retomar en seguida.

Mi ensayo parte de una reforma constitucional que analizo siguiendo las líneas que trazó nuestro apreciado colega Diego Valadés en la conferencia magistral que nos antecedió. Parafraseo su afirmación, en el sentido de que nuestra constitución ha tenido unos desarrollos recientes que con frecuencia se identifican con la imagen que proyecta un espejismo. Muchas promesas sin cumplir; una excesiva generación de normas, pero márgenes de cumplimiento que se difuminan en el paisaje y dejan mucho que desear. ${ }^{1}$ $\mathrm{Y}$ sin embargo, son transformaciones que debemos entender sin asumir la posición catastrofista de quienes anuncian el advenimiento de tiempos caóticos, donde el inmovilismo se antepone al cambio.

* Investigador en el Instituto de Investigaciones Jurídicas de la UNAM.

1 Las reticencias respecto de la funcionalidad de los gobiernos de coalición se ha manifestado consistentemente por una parte de quienes han estudiado su problemática, en Mainwaring, Scott y Soberg Shugart (eds), Presidentialism and democracy in Latin America, New York, Cambridge University Press, 1997. 
Esta obra forma parte del acervo de la Biblioteca Jurídica Virtual del Instituto de Investigaciones Jurídicas de la UNAM

Coincido en que los académicos (y no sólo los actores políticos) debemos asumir una actitud responsable. Para comprender a cabalidad los alcances de las coaliciones de gobierno, empiezo afirmando que no solo se trata de una reforma constitucional que ya está aprobada y que entrará en vigor en menos de tres años. También vale la pena observar que entre sus disposiciones contiene elementos que bien podrían incidir positivamente en erradicar una situación anómala del sistema, presente desde hace décadas entre quienes participan de las negociaciones políticas al más alto nivel del gobierno.

A todos viene bien que los partidos estén de acuerdo, por fin, en reducir el inmovilismo (léase los bloqueos sistemáticos) en los que suelen colocarse los gobiernos frente a las asambleas representativas. Pues lo que no se puede esconder es que los riesgos de parálisis legislativa se han presentado desde que la alternancia partidista apareció en el mapa político de nuestro país, en 1997.

Mencionaba hace un momento que me parecía ideal que este evento académico se lleve a cabo en San Luis Potosí, no solo porque los estados han sido laboratorios donde las adaptaciones y las innovaciones constitucionales suelen arrojar resultados preliminares que, más frecuentemente de lo que solemos admitir, son luego llevadas al plano nacional. También porque tengo la ocasión de hablar de gobiernos de coalición en uno de los estados donde se generó un modelo funcional de oposición partidista en los años 80's del siglo pasado. ${ }^{2} \mathrm{Y}$ que esa experiencia fue determinante para darnos cuenta de que el país podía sobrevivir si una verdadera oposición existía.

Vale la pena aludir en esta sede el concepto que hoy tenemos de la oposición, ${ }^{3}$ a treinta años de distancia. Pues me preocupa que sea la oposición legislativa uno de los elementos que podría sufrir consecuencias irreversibles tras la entrada en vigor de la mencionada reforma constitucional. Esto, sin contar que el esquema de Gobiernos de Coalición (en adelante $\mathrm{GC}$ ) podría replicarse, introduciéndose en alguna o todas las constituciones de los estados. De ser así, esperemos que al menos se tengan en cuenta al-

2 Para una descripción sobre el movimiento político opositor de Salvador Nava Martínez (acusado de encabezar un movimiento contrarrevolucionario de inspiración sinarquista por el aparato del partido oficial), véase en Fernández Menéndez, Jorge, "Las variaciones del navismo", Cuadernos de Nexos, (consultado en versión electrónica), 1 de julio de 1991.

3 Voy a tratar de adaptar algunas nociones que son comúnmente evocadas dentro del esquema del parlamentarismo mayoritario, asumiendo que la expresión de oposición es consubstancial al esquema democrático, en Pasquino, Gianfranco, L'opposizione, Bari, Laterza, 1995, 98 p. 
Esta obra forma parte del acervo de la Biblioteca Jurídica Virtual del Instituto de Investigaciones Jurídicas de la UNAM

gunos elementos que, a primera vista, aparecen en el tablero institucional y que trataré de al menos referir en esta ponencia.

Mi intervención se va a dividir en dos partes, donde sigo el esquema antes sugerido, a saber, de tratar primero de entender qué parte de esta reforma proyecta un espejismo. Y en un segundo momento, pretendo sortear cualquier atisbo catastrofista, al plantear algunos lineamientos que acaso permitirían al sistema echar a andar una institución sin antecedentes en nuestro sistema constitucional, en condiciones que me parecen poco propicias para generar un esquema de gobiernos responsables. Esto lo planteo sabedor que el papel de los académicos se enfoca a plantear de qué forma las instituciones pueden leerse en su mejor luz. Y no en el sentido opuesto.

En un apartado preliminar, abordaré los antecedentes inmediatos que, desde mi punto de vista, propiciaron optar por esta ruta institucional; a saber, la implementación del Pacto por México en 2012. Así, en las dos partes del trabajo abordaré por qué me parece que hicimos a un lado la oportunidad institucional de tomarnos en serio la parlamentarización del régimen. Y luego, analizaré las implicaciones que ya no se pueden echar atrás, para insistir sobre algunas nociones que a partir de ahora se deberían replantear a efecto de conferirle una mejor operatividad y sentido a este modelo de gobierno. Que por cierto, se inspiró en la necesidad de evitar la parálisis que la academia ha advertido atinadamente ya desde hace varios años, ${ }^{4}$ que se centra en la forma de evitar las consecuencias negativas de los gobiernos divididos.

\section{ANTECEDENTES. EL SIGNIFICADO DE LA REFORMA}

Al día siguiente de tomar protesta, para asumir el cargo de Presidente de la República, Enrique Peña Nieto firmaba un acuerdo con los presidentes de los dos partidos con mayor representación en el Congreso. El punto común era acotar las consecuencias del modelo de los gobiernos divididos. La intención, avanzar en la aprobación de leyes pendientes de ser aprobadas debido a la falta de acuerdos partidistas. ${ }^{5}$ Este llamado Pacto por México pretendía dar fin a las diferencias partidistas en nombre del interés común.

4 Lujambio, Alonso, "Adiós a la excepcionalidad: Régimen presidencial y gobierno dividido en México", en Córdova, Lorenzo y Valadés, Diego (eds), Estrategias y propuestas para la Reforma del Estado, México, Instituto de Investigaciones Jurídicas de la UNAM, 2002.

5 Entrevistados al momento de la firma por la prensa francesa, Gustavo Madero (PAN) consideraba que la firma no comprometía ni la capacidad de crítica ni las facultades de control al gobierno: "entramos en un período de unidad nacional"; por su parte, Jesús Zambra- 
Esta obra forma parte del acervo de la Biblioteca Jurídica Virtual del Instituto de Investigaciones Jurídicas de la UNAM

Bajo este esquema (que en términos parlamentarios podría asemejarse al de gran coalición), el Congreso tardó un tiempo muy corto para aprobar una agenda sumamente ambiciosa, desplegada en numerosos ámbitos del gobierno. ${ }^{6}$ Mientras los partidos publicitaban la hazaña como un logro compartido, apareció en la prensa internacional una primera plana difícil de olvidar, donde el balance del primer año de la nueva administración colocaba al Presidente como virtual salvador de la patria. ${ }^{7}$ En fechas muy cercanas a este encabezado, fue publicada una reforma al artículo 89 constitucional, ${ }^{8}$ que adiciona una atribución en su fracción XVII, si bien, dejaba pendiente la entrada en vigor al 1 de diciembre de 2018. Por primera vez se contemplaba en México la posibilidad de funcionar bajo el esquema de gobiernos de coalición.

\section{Las facultades y obligaciones del Presidente de la república son las siguientes:}

Fracc. XVII.- En cualquier momento, optar por un gobierno de coalición con uno o varios de los partidos políticos representados en el Congreso de la Unión. El gobierno de coalición se regulará por el convenio y el programa respectivos, los cuales deberán ser aprobados por mayoría de los miembros presentes de la Cámara de Senadores. El convenio establecerá las causas de la disolución del gobierno de coalición.

La iniciativa había sido propuesta desde 2011 por el senador Beltrones. De un mero análisis gramatical del texto aprobado, este esquema de gobierno autoriza al Ejecutivo a actuar haciendo un compromiso con alguna fracción senatorial de un partido distinto al suyo. El convenio de coalición implica que los partidos coaligados admiten apoyar un programa de gobierno (sea durante un tiempo determinado, o hasta que sus incisos se cumplan a cabalidad). A cambio, los firmantes conceden a sus dirigencias partidistas un número de secretarías de estado (también determinadas en el convenio)

no (PRD) afirmaba: "estamos listos para asumir el riesgo como el partido de izquierda más importante, actuando de manera responsable". El candidato perdedor de las presidenciales, Andrés Manuel López Obrador simplemente se apartó del pacto y fundó un nuevo partido (MORENA, que desde entonces ha asumido la cuestionable estrategia de retirarse de cualquier debate importante). "Le pacte du Mexique ou le retour du PRI au pouvoir" L'Humanité, 4 de diciembre 2012.

6 Referidas como reformas estructurales, se tradujeron en la aprobación de leyes trazadas sobre tres ejes: derechos (educación, amparo y sistema adversarial); instituciones (transparencia y elecciones) y economía (energía, impuestos, trabajo, sistema financiero, competencia económica y telecomunicaciones), Gómez Camacho, Juan José, 'Guest Editorial'. European Foreign Affairs Review 20, no. 2, 2015, p. 149-154.

7 "Saving Mexico", encabezado en Time Magazine International (para Asia, Africa, Europa y Pacífico Sur), 24 de febrero 2014.

8 Diario Oficial de la Federación de 10 de febrero 2014 
Esta obra forma parte del acervo de la Biblioteca Jurídica Virtual del Instituto de Investigaciones Jurídicas de la UNAM

que serán asumidas por notables de cada organización política involucrada. Un pacto que, a falta de controles, puede resultar tan cupular y oligárquico como se quiera plantear. En un país donde las cúpulas y las oligarquías nunca han tenido problemas para llevarse bien. ${ }^{9}$

\section{A LA BÚSQUEDA DE UN PUNTO MEDIO ENTRE DOS SISTEMAS}

Desde hace poco más de una década, nuestro colega Diego Valadés ya hablaba de la parlamentarización de los regímenes presidenciales. ${ }^{10}$ En una dirección que pareciera semejante, los europeos han estado constatando, desde hace relatívamente poco tiempo, que el régimen parlamentario se estaba presidencializando. ${ }^{11}$ Pero debo aclarar que aquella ruta, que se antoja semejante, no debe entenderse como comparable ni complementaria. Pues aquello que ocurre en Europa corresponde más a una necesidad de hacer eficientes a las administraciones, y se relaciona con un período de crisis institucional donde confluyen fenómenos muy complejos a los que vamos a referir más adelante.

Pues bien, a partir de la reforma, materia del presente comentario, nuestro nuevo marco constitucional parece alejarse de una interesante evolución, que podría conducir a nuestro sistema de gobierno a quedar menos concentrado en el Ejecutivo. Y como adelanté, el efecto que se generaría, más bien me parece ser el contrario. Para justificar por qué considero que los GC parecen generar una mayor concentración de poderes en el ejecutivo, parto de razones institucionales que iré enunciando,

1. El sistema parlamentario se distingue del presidencial por la existencia de una relación de confianza entre el gobierno y el parlamento. ${ }^{12} \mathrm{O}$ al menos, de éste frente a la mayoría de aquél. Pero también en la existencia de una serie de mecanismos para echar por delante la responsabilidad politica del gobierno (y de quienes lo integran), erigiendo al electorado como fiel de la balanza; o si se prefiere, del ciudadano común como vigilante permanente $y$ constante de la actuación del gabinete actual.

9 "No me avergüenzo de mis amigos y pido respeto a mi fiesta: jefe Diego", Excélsior de 15 de marzo 2016.

10 Valadés, Diego, La Parlamentarización de los Sistemas Presidenciales, México, Instituto de Investigaciones Jurídicas, UNAM, 2008, 256 p.

11 Rosanvallon, Pierre, Le Bon Gouvernement, Paris, Le Seuil, 2015, section III, p. 215-297.

12 Colliard, Jean-Claude, Les régimes parlementaires contemporains, Paris, Presses de la FNSP, 1978. 
Esta obra forma parte del acervo de la Biblioteca Jurídica Virtual del Instituto de Investigaciones Jurídicas de la UNAM

2. Nada de esto fue inscrito en el nuevo texto constitucional. En ninguna parte de la iniciativa del Senador Beltrones fue consagrada la noción de confianza en el gabinete. Me refiero a la "liga de confianza" del gobierno frente al congreso, o acaso alguna otra manifestación tangible del apoyo permanente que deben expresar los representantes populares (encarnados por la mayoría de los diputados de un país). Pues bien, en primer lugar, el convenio de coalición se entabla con el Senado.

En los regímenes parlamentarios, la confianza es una manifestación popular, no territorial. La explicación de este punto se encuentra en el parlamentarismo histórico. ${ }^{13}$ En épocas remotas, se concibió que los ministros del Rey (es decir, su gabinete) fueran los ejecutores de aquella voluntad unipersonal. Y que los llamados "parlamentarios" (notables del reino) servirían para debatir las decisiones. ${ }^{14}$ Unos actuaban para ejercer la autoridad; los otros, para controlarla y crear leyes.

3. De acuerdo al manual del sistema parlamentario, escrito por siglos de prácticas políticas en Europa, ¿cuál es ese elemento de negociación, o de presión? pues simple y llanamente, la permanencia del actual gabinete en el ejercicio de las funciones de gobierno. ${ }^{15}$ Pero también su corolario, encarnado por la posibilidad de hacer dimitir a la asamblea popular en bloque, a través de la declaratoria de disolución (no quiero dejar escapar la ocasión para señalar que al referir a este término, los latinoamericanos pensamos siempre en golpes de Estado). Aclaro que esa modalidad de disolución (esto es, la del modelo parlamentario) está siempre secundada de elecciones anticipadas en plazos perentorios.

Adicionalmente, me parece necesario replantear para qué pensamos que sirven las asambleas representativas, pues desde que en México iniciamos este largo proceso de democratización, parece que su percepción no ha quedado clara. En los regímenes democráticos, los parlamentos se han convertido en Cámaras de registro. ${ }^{16}$ Esto significa que han dejado de ser los

13 Silvester, Christopher, The Pimlico Compation to Parliament: A Literary Anthology, London, Random House, 1996, capítulo 2, p. 65-118

14 En Francia, un número reducido de Barones, cercanos al Rey, eran convocados cuatro veces al año en fechas fijas espaciadas durante el año para reunirse in parlamento. El Parlamento de Paris fue creado en 1250. Aunque en realidad, el espacio fue creado para impartir justicia y tramitar litigios. La transformación de esta especie de Corte real en una asamblea de consejeros del Rey se fue gestando siglos más tarde. Lebigre, Arlette, La fustice du Roi: La vie Fudiciaire dans l'ancienne France, Paris, Albin Michel, 1988p. 32.

15 Bagehot, Walter, The English Constitution, 2nd ed., Oxford University Press, 1872, cap. 1, p. 1-29.

16 La expresión ha sido atribuida a Walter Bagehot, quien consideraba que la Cámara de los Lords era semejante a un anemómetro, cuya función no es presevar a Inglaterra de 
Esta obra forma parte del acervo de la Biblioteca Jurídica Virtual del Instituto de Investigaciones Jurídicas de la UNAM

espacios en donde las grandes decisiones nacionales se toman. Aunque reivindican su papel como sitios en donde las grandes negociaciones se llevan a cabo. Los diputados de la minoría saben que les será material y matemáticamente imposible evitar que la mayoría decida. ${ }^{17}$ Es por eso que las Comisiones deben estar siempre integradas por, al menos, una parte de las voluntades que expresan opciones distintas a las de la mayoría. Para propiciar que quede constancia de las posturas de la minoría frente a las de la mayoría.

4. Y aquí enuncio acaso el efecto que me parece el más riesgoso que podría derivarse del reacomodo los elementos del sistema. Me refiero a la virtual desaparición del peso específico que se podría atribuir a la oposición parlamentaria una vez que los pactos de coalición entren en vigor en México. Debido a que, con el esquema aprobado, la reforma pareció olvidar incluir alguna suerte de amenaza o al menos algún recurso para censurar al gobierno de coalición (en bloque, o individualmente, por secretarías de estado).

La moción de censura, con diversas modalidades, fue uno de los mecanismos de defensa que los sistemas parlamentarios concibieron a favor de la oposición. ${ }^{18}$ Nuestro constituyente concibió apenas una débil manifestación de aquella atribución de la minoría de la asamblea, a través de una tibia posibilidad de "reprobar" a alguno de los secretarios de Estado que dejaran de contar con la confianza de las élites dirigentes de los partidos que firmaron el convenio de coalición con el Presidente...

En el herramental parlamentario, existen algunos mecanismos que pudieron haberse concebido para disminuir el riesgo de rechazo de un proyecto de ley controvertido, impulsado por el Gabinete. Específicamente, me refiero a la atribución contenida en el emblemático artículo 49-3 de la Constitución de la V República francesa, que consiste en una convocatoria

una tempestad sino la de tranquilizar a su población; para indicarle que una tragedia no se ha acercado suficientemente a la costa (todavía), en G. Valbert, "Le Nouveau Bill de réforme électorale et la Chambre des Lords" Revue des Deux Mondes, 3 période, tome 65, 1884, p. 201-212.

17 Madison, James, The Federalist Papers, New York, Haskell House Publishers, no. 10, 1971 (1787), p. 41-48.

18 La oposición parlamentaria sólo tiene sentido cuando se le considera frente a una mayoría que sostenga al gabinete en turno. Perdería toda su influencia si se le sitúa frente a una asamblea incapaz de censurar al gobierno. Dentro de los sistemas parlamentarios con esquema bicameral (como Alemania, Francia o España), esta segunda posibilidad la encarna el Senado. Aunque también, cualquier asamblea sin capacidades de presión al gabinete, en Lévade, Anne, "Le statut de l'opposition parlementaire comme objet juridique", en Rozenberg, Olivier y Eric Thiers, L'opposition parlementaire, Paris, La Documentation Française, 2013, p. 115. 
Esta obra forma parte del acervo de la Biblioteca Jurídica Virtual del Instituto de Investigaciones Jurídicas de la UNAM

para poner a competir la responsabilidad del gabinete contra el voto automático de un proyecto legislativo. Esta ingeniosa modalidad permite al gobierno adoptar una ley sin que sea necesario someterla a votación frente a los diputados... La ley en cuestión se estima adoptada, siempre y cuando no sea presentada ante el pleno de los diputados una moción de censura durante las 24 hrs siguientes a que se deposite el proyecto de ley respectivo para su confirmación. Desde hace años, las críticas frente a este mecanismo no son pocas; se suele señalar el poco margen con el que cuentan los parlamentarios para evitar que el gobierno avance en la aprobación de su agenda legislativa. ${ }^{19}$ Pero al menos, la herramienta permite a la asamblea conservar una posibilidad (así sea tímida) de presionar al Gabinete.

Con algún mecanismo semejante, el esquema mexicano de gobiernos de gabinete podría demostrar, de manera acaso más responsable y transparente (frente a los senadores que decidieron apoyar el pacto) que la intención del gobierno va en un sentido que fue predeterminado. Y que ya serán los electores quienes se encarguen de pronunciarse en las próximas elecciones.

5. Por otra parte, mencionaba que la censura al gobierno tiene como corolario la posibilidad para el Ejecutivo de disolver la asamblea popular, precipitando o detonando primero la crisis que en la ortodoxia parlamentaria, la censura habría generado en su lugar. ${ }^{20}$ Así podríamos entender que la disolución se vuelve un mecanismo de disuasión hacia la minoría de la asamblea.

Aunque cabe advertir que en uno y otro casos, la reacción que se genera al detonar los mecanismos, son los de una crisis controlada: si la censura triunfa en la Cámara, el gabinete dimite (en conjunto o por ministros individuales). La mayoría de la misma asamblea actúa para que se forme un nuevo gobierno; se vota su investidura. Y todo regresa a la normalidad cuando el nuevo Gabinete es nombrado, al quedar sustentado por una nueva coalición de partidos en el parlamento.

En el camino opuesto, donde el Ejecutivo ha disuelto al parlamento, los diputados constreñidos a dejar sus curules, tendrán que regresar a sus distritos a hacer campaña, buscando el voto de sus electores, una vez más. El arbitraje sería, por consiguiente, popular: los electores asumirían la tarea de pronunciarse a favor de uno de los dos bloques: el del ejecutivo que disuelve,

19 Elgie, Robert, "From the exception to the rule: the use of article 49-3 of the Constitution since 1958", Modern \& Contemporary France, volume 1, issue 1, 1993, p. 17-26.

20 Lauvaux, Phillipe, Phillipe, La dissolution des assemblées parlementaires, Préf. A. Mathiot, Paris, Economica, 1983, 519 p. 
Esta obra forma parte del acervo de la Biblioteca Jurídica Virtual del Instituto de Investigaciones Jurídicas de la UNAM

o el de los diputados que tuvieron que dimitir por no compartir el programa que propone el gobierno. ${ }^{21}$ Cabe mencionar además que hasta aquí, prácticamente todo lo descrito son usos parlamentarios. No requirieron ser llevados a la Constitución para ser respetados.

Adicionalmente, el esquema genera una suerte de competencia virtuosa entre dos proyectos: el del jefe del Ejecutivo frente al de la mayoría de la asamblea. Si el segundo gana, el ejecutivo tendrá que ceder (cuando existe separación entre jefe de estado y de gobierno, este último es quien tendría que dimitir, junto con su gabinete). ${ }^{22}$ Pues bien, partiendo de reglas escritas ahora en nuestra constitución, la disolución de la coalición existirá en México pero como un simple deseo materializado unilateralmente, desde la Presidencia de la República (sin repercusiones institucionales colaterales en el sistema). A no ser que se lleguen a presentar unas determinadas hipótesis que previamente habrían sido establecidas en el pacto de coalición, como motivos para disolver al actual gabinete.

En el esquema del parlamentarismo clásico, al disolver, el Presidente tendría que comprometer todo un programa, o acaso la confirmación de alguna ley (normalmente), ante los electores. ${ }^{23}$ En efecto, podría disolver con relativa facilidad (tras haberlo consultado con los líderes de las cámaras; o como jefe de gobierno - el Primer Ministro- podría disolver luego de haberlo consultado con el Jefe de Estado - sea éste rey o presidente de la República-. Pues bien, ninguna de estas posibilidades fueron pensadas para México.

Tratando de evitar toda lectura catastrofista de la reforma a nuestro sistema de gobierno, voy a tratar de exponer las partes que pudieran ser funcionales. Aunque también, los riesgos que antes de su entrada en vigor, se podrían advertir por el abuso en el empleo de los gobiernos de coalición.

21 Hasta 1993 (que cayó en desuso), en Francia existió la práctica parlamentaria con la que el gobierno emitía "una declaración de política general", equivalente a un voto de confianza inicial, a favor de su programa. Esta declaración era solicitada a la asamblea en cuanto se formaba el gobierno; en Avril, Pierre, "Renforcer le Parlement, qu'est-ce à dire?" Pouvoirs, 146, 2013, p. 11.

22 Norton, Philip, "Old institution, new institutionalism: Parliament and Government in the UK", Parliaments in Western Eurpoe, London, Frank Cass, 1998, p. 17-42.

23 Pudo incluso haberse concebido una atribución (que el esquema semi-presidencial francés dejó en desuso desde 1993), que acaso podría servir como elemento pedagógico para dar a conocer el programa actual del gabinete. Se trata de la llamada Declaración de Política General implícito en el art. 49 de la Constitución de la V República. Se asemeja a un voto de investidura del gobierno (que sigue vigente en España), y que permite al menos manifestar con toda claridad un voto a los diputados de la minoría; en Avril, Pierre, "Renforecer le Parlement, qu'est-ce à dire?’, Pouvoirs, no. 146, 2013, p. 11. 
Esta obra forma parte del acervo de la Biblioteca Jurídica Virtual del Instituto de Investigaciones Jurídicas de la UNAM

\section{IV. ¿QUÉ HAGER PARA QUE FUNCIONEN LOS GOBIERNOS DE GABINETE?}

No cabe duda que debemos aprender de la experiencia parlamentaria europea, para darnos cuenta que llevó siglos a los sistemas de gobierno encontrar las dos prioridades de la existencia del modelo de gabinete: lograr que los gobiernos sean viables, al mismo tiempo que operativos. ${ }^{24}$ Son viables cuando pueden contar con la confianza de la mayoría. Son operativos o efectivos cuando el diseño institucional y las prácticas políticas permiten que el propio gabinete sea capaz de reagrupar a su mayoría.

En esta segunda parte, voy a referirme a algunos instrumentos que se formularon desde el siglo pasado, para asegurar la estabilidad de los gobiernos en términos de mecanismos de racionalización del parlamentarismo. Acaso su mera descripción permita sugerir cuáles de estos podrían servir, desde la tradición del parlamentarismo, para trazar paralelos en el ámbito de los sistemas presidenciales.

La intención no es la de encontrar la salida simplista ante la problemática que va a distar de ser fácil, una vez que esta reforma constitucional entre en vigor. Mi propósito es más bien la de aportar algunos elementos técnicos para la discusión en torno a la manera como nuestro sistema presidencial podría evolucionar en el sentido de garantizar una mayor estabilidad, pero también, una más clara expresión de la responsabilidad política de quienes toman decisiones.

1. Racionalizar un proceso o una institución significa dejar que sea irradiado por el derecho. ${ }^{25}$ Llevado este término al plano de lo normativo, implica la búsqueda de mayores condiciones de estabilidad. Sin embargo, se ha señalado la necesidad de distinguir lo racional de lo razonable. ${ }^{26}$ Llevado en

24 Tras la Revolución Francesa, se diseñó un esquema dualista de gobierno, en el que un Consejo (electo directamente por el pueblo) se reunía a deliberar y a definir el programa de gobierno, para que los ministros (designados por la asamblea) ejecutaran ese programa en los temas puntuales que les habían sido encargados. Troper, Michel, "Discours du 24 avril 1793: Saint Just et le problème du pouvoir exécutif", Annales Historiques de la Révolution Française, no. 191, 1968.

25 La construcción del concepto es atribuída a un comparatista ucraniano contemporáneo de Hans Kelsen, que vivió y escribió en Francia (1892-1955), Mirkine-Guetzévich, Boris, Modernas tendencias del derecho constitucional, Madrid, Reus, 2011 (1933), 352 p.

$26 \mathrm{El}$ actuar racional implica la selección de formas de cumplir objetivos puntuales, desde un punto de vista individual. Lo razonable implica acciones solidarias, y no solo se preocupa por la actuación individual, sino por la colectiva. Ante el ejercicio incontrolado del poder, la voluntad del más fuerte prevalece, Diego Valadés, citando a John Rawls, Political Liberalism, New York, Cambridge University Press, 1993, p. 48. 
Esta obra forma parte del acervo de la Biblioteca Jurídica Virtual del Instituto de Investigaciones Jurídicas de la UNAM

cambio al plano político (de los sistemas de gobierno), racionalizar implicaba que en vez de ser nombrados por las mayorías electorales, los gobiernos quedarían designados por las asambleas. El principio mayoritario reduciría su grado de abstracción (al ser ligado al pueblo) para concretarse en un universo medible (que podía depositarse en la mayoría de los legisladores). Por virtud de la liga de confianza, las legislaturas expresaban una supremacía jurídica, mientras los Ejecutivos, una política.

En el parlamentarismo de inspiración clásica (como en el régimen de asamblea de la IV República francesa) reinaba la costumbre; en el racionalizado (instaurado con la V República de Charles de Gaulle), reinaban las normas. En el primer esquema, la inestabilidad de los ministerios parecía bailar al son de frágiles acuerdos partidistas. En el esquema racionalizado, el derecho estaría presente en todas las fases, concentrado en la asamblea representativa, encargado de estabilizar a los gobiernos. Fomentar la eficacia de los gobiernos implicaba dificultar el ejercicio de facultades del esquema parlamentario tradicional.

Por otro lado, el esquema racionalizado dejaba a un lado la percepción de tener a dos ramas del poder (la ejecutiva y la legislativa) confrontadas, una frente a la otra por el predominio de la decisión colectiva. ${ }^{27}$ Mecanismos como la disolución frente al voto de censura dejaban de operar en términos de cotidianeidad para restringirse a la solución de crisis ministeriales.

2. Si hablamos en términos de activos y pasivos, la responsabilidad política podría entenderse como la carga que se deriva de ejercer el poder. ${ }^{28}$ Con base en los lineamientos de un gobierno responsable, los activos y los pasivos están llamados a permanecer en equilibrio. La rendición de cuentas se desprende de una elección democrática; o si se prefiere, de la voluntad electoral, manifestada jurídicamente en las urnas.

$\mathrm{Al}$ aceptar el ejercicio de la autoridad, el actor político también acepta someterse a controles institucionales. Pero esos controles no sólo provienen de instituciones (sobre todo parlamentarias), sino también de los ciudadanos. En suma, ser responsable implica un compromiso con el pasado (hablando de rendición de cuentas), aunque también con el futuro (por referir a la voluntad de cumplir con metas determinadas). ${ }^{29}$ Una vez que los actores políticos admiten esta particular forma de dependencia, construyen

27 Vile, M.J., "Rise and fall of Parliamentary Government", Constitutionalism and the Separation of Powers, Second Edition, Indianapolis, Liberty Fund, 1998, p. 233.

28 Beaud, Olivier and Jean-Michel Blanquer, La responsabilité des gouvernants, Paris, Descartes \& Cie, 1999, p. 12.

29 Baranger, Denis, Parlementarisme des origines, Paris, Presses Universitaires Françaises, 2002, p. 25. 
Esta obra forma parte del acervo de la Biblioteca Jurídica Virtual del Instituto de Investigaciones Jurídicas de la UNAM

(de manera mucho más sólida) una legitimidad que les pregonan sus cogobernados.

¿Pero qué pasa si los ciudadanos sufren los excesos o la arbitrariedad en el uso del poder? Dado que el jefe de Estado no podría responder directamente (recordando esa antigua afirmación de que el rey no puede actuar mal), los secretarios de Estado sí que podrían responder en su lugar. ${ }^{30}$ Aún así, para el parlamentarismo de los orígenes, toda respuesta de esta clase tenía un contenido criminal.

A efecto de evitar que el poder real fuera comprometido (junto con la estabilidad del reino), toda respuesta a una acusación (emprendida bajo la forma del procedimiento de impeachment) era elaborada por la Cámara de los Comunes, y resuelta por la de los Lords. La investigación (siempre criminal) iba dirigida hacia alguno de los ministros del Rey. En caso de ser encontrado responsable, la sanción era de orden penal. Hacia los 1700's, las tensiones entre el Rey y la representación en la Cámara de los Comunes aumentó. Como solución, los miembros del gabinete propusieron que en vez de seguir este procedimiento criminal contra uno de sus pares, aceptarían todos dimitir en bloque. ${ }^{31}$ De esta manera se logró desmantelar un proceso penal a través de una renuncia voluntaria de todo el gabinete. Surgía la noción de responsabilidad política del gobierno frente al parlamento, que desde entonces se erigió como piedra angular del sistema parlamentario.

De igual manera, el impeachment evolucionó por su cuenta, al ser exportado al régimen presidencial. Entre las particularidades en Estados Unidos, se optó porque el procedimiento incluiría no sólo al Presidente sino en términos generales, a los más altos funcionarios de la administración.

En México, sin embargo, se excluyó al Presidente de ser sometido a juicio político (lo más cercano al impeachment), al menos durante el ejercicio de sus funciones. ${ }^{32}$ Con ello se aseguró un régimen aparentemente estabilizador, en el que el ejecutivo federal es prácticamente irresponsable,

30 Como lo expresó el diputado Querido Moheno en los tiempos convulsos de la Revolución mexicana: "queremos quitar ministros para no tener que derrocar presidentes", del Diario de los Debates de 6 de diciembre de 1912 y 19 de febrero de 1913, cit. por Valadés, Diego, Problemas y perspectivas del sistema presidencial mexicano, Toluca, Instituto Electoral del Estado de México, 2011 , p. 49.

31 En el esquema de Westminster, el procedimiento de impeachment cayó en desuso hacia 1742; la responsabilidad se impuso desde entonces en términos de rendición de cuentas y no de pena corporal, en Woodhouse, Diana, Ministers and Parliament: Accountability in Theory and Practice, Oxford, Clarendon Press, 1994.

32 Por lo inusual que sería ver perseguido al presidente por delitos de traición a la patria o por delitos graves del orden común, del art. 108 fracc. II de la Constitución. 
Esta obra forma parte del acervo de la Biblioteca Jurídica Virtual del Instituto de Investigaciones Jurídicas de la UNAM

políticamente hablando (lo cual podría ser inherente al sistema). Lo que se vuelve menos normal es que nadie de sus subordinados en el gobierno asuma responsabilidades políticas. El clamor popular pide cárcel. Igual que en la Inglaterra de los 1700 's. No parece para cuando trazarse una ruta civilizada que permita asumir responsabilidades sin tener que pensar en penas corporales.

3. Buena parte de los sistemas presidenciales funcionan bajo el esquema de gobierno dividido. Esta discordancia endémica del sistema, entre el partido de quien gana la presidencia y de quien gana la mayoría en el Congreso, ha sido incluso anunciada como el germen del colapso del presidencialismo. ${ }^{33}$ El declive del sistema también se explica a partir de elementos del contexto institucional. Entre los más importantes, la imposibilidad de que el sistema de partidos regrese a un esquema mayoritario.

La fragmentación partidista en México pareció impuesta por la presión que, en su momento, ejercieron las fuerzas políticas minoritarias (p.e., para promover el aumento de la representación proporcional en el sistema electoral). En 1993, se buscó normalizar la existencia de senadores de oposición. Con el esquema de financiamiento de partidos y la amplia base territorial favorables al partido oficial, parecía difícil que algún senador de oposición llegara a obtener algún escaño. Aquello generó el consenso para otra reforma constitucional al régimen electoral, con lo que se agregaron dos senadores por entidad federativa. Uno se atribuye a la primera minoría, y el otro va para ser integrado en una lista nacional plurinominal (compuesta por las cúpulas de cada partido). Valdría la pena replantear el esquema, pues con la muy ardua competencia partidista que existe a veinte años de distancia, podríamos regresar al esquema de dos senadores por entidad sin temer por otro desbalance a favor de un sólo partido. Claro está, que aunque muy probablemente se lograra integrar un senado plural, las dirigencias partidistas se verían afectadas a sí mismas ante la reducción de escaños.

Los partidos políticos están en crisis; han dejado de hacer un frente común con la ciudadanía. El desencanto los excede, si bien el esquema que éstos han generado al interior (con bases burocráticas y clientelares que se extienden sin cesar) conducen a su propia extinción. Sin necesidad de que hablemos de la llamada cartelización de los partidos políticos, ${ }^{34}$ es fácil justi-

33 Mainwaring, S. y Sugart, S.M. (eds), Presidencialismo y democracia en América Latina, Buenos Aires, Paidós, 2002; Linz, Juan and Arturo Valenzuela, The Breakdown of Democracies, Baltimore, Johns Hopkins Univesity Press, 1997.

34 Los partidos se comportan como cárteles, cuya casi único objetivo es la propia subsistencia. El fenómeno en México se ha acrecentado por el predominio del financiamiento público sobre el privado; ver sus lineamientos en Katz, Richard S. y Peter Mair, "La transfor- 
Esta obra forma parte del acervo de la Biblioteca Jurídica Virtual del Instituto de Investigaciones Jurídicas de la UNAM

ficar que el régimen competitivo que desborda al bipartidismo ha terminado imperando contra cualquier posibilidad de cooperación entre fracciones parlamentarias. De ahí que la parálisis que anquilosa al sistema de partidos se traslade, indefectiblemente, a los gobiernos; y más todavía a los gobiernos de coalición. ${ }^{35}$

Por lo anterior, tal vez sea este el momento de volver a poner en la mesa la espinosa cuestión de la segunda vuelta electoral ${ }^{36}$ y la insistencia en reducir el zoclo de participación electoral para restringir el financiamiento público a aquellas formaciones políticas que cuenten con una verdadera representatividad. Suprimir a los partidos que sólo están parasitando al sistema se impone como ruta indispensable para aclarar el camino de la deliberación y la negociación intra-partidista, que entre otras decisiones, permita llegar a acuerdos. Entre estos acuerdos, en la cúspide de las prioridades, se encontraría la formación de gobiernos de coalición.

4. La idea de racionalizar al presidencialismo, en términos de fijar en blanco y negro reglas que contribuyan a su propia estabilidad, tampoco puede implicar fórmulas absolutas. Recientemente, en los sistemas parlamentarios, se habló de replantear el justo medio de la racionalización del parlamentarismo. Incluso se habló de una reparlamentarización, en el sentido de restaurar controles más efectivos a los actos del Ejecutivo. ${ }^{37}$ La tónica esta compuesta por una noción más unívoca de la responsabilidad política y la rendición de cuentas (en el sentido inglés de Accountability). La limitación de poderes se encuentra ante fenómenos cada vez más complejos, que comprometen el sentido de universalidad de los derechos.

La complejidad de los problemas (por solo referir a la crisis de las oleadas de migración ilegal y las rachas de ataques terroristas ocurridos en Europa desde finales de 2015), ayudan muy poco a conservar los esquemas de

mation des modèles d'organisation et de démocratie dans les partis: L'émergence du PartiCartel", Aucante, Johann and Alexandre Dézé, Systèmes de partis dans les démocraties occidentales: le modèle du parti-cartel en question, Paris, Presses de Sciences Po, 2008, p. 35-47

35 Nolhen, Dieter, "El poder ejecutivo en el presidencialismo, alternativas en debate", Ellis, Andrew, J. Jesus Orozco Henríquez y Daniel Zovatto, Cómo hacer que funcione el sistema presidencial: Making presidentialism work, UNAM-Idea International, 2009. p. 24, p 41-42.

36 Coincido en que instaurar este llamado sistema de Ballotage (tanto en presidenciales como en legislativas) contribuiría a generar legislaturas menos fragmentadas, cuya composición permitiría a las fracciones pronunciarse con mayor claridad para tener una postura frente a las políticas impulsadas por el Ejecutivo, Cheibub, José Antonio, "Reforming Presidential and Semi-Presidential Democracies", in Ellis et al., cit. n. 35, 2009. p. 24

37 En Francia, un antiguo Primer Ministro planteó la necesidad de permitir una más cercana supervisión de los ministerios por parte de la Asamblea Nacional, en Balladur, Edouard, Une Ve République plus démocratique, Paris, La Documentation Française, 2007, p. 4-6. 
Esta obra forma parte del acervo de la Biblioteca Jurídica Virtual del Instituto de Investigaciones Jurídicas de la UNAM

controles al gobierno. Los europeos han tenido que aceptar, a su pesar, una nueva forma de organización del poder, donde el legislativo termina plegándose a la acción del gobierno y no al revés.

Un desplazamiento del centro de gravedad de los gobiernos, desde la sede del parlamento hacia la cabeza del Ejecutivo, se está produciendo en prácticamente todos los sistemas parlamentarios, donde la personalización del jefe del gobierno parece el ingrediente culminante de la representación. Pero también de la acción de gobierno. Este nuevo esquema pone en la mesa ya no sólo cuál es el perfil ideal del representante popular, sino también las reglas del juego en su relación con quienes lo eligieron.

En nuestro continente, en cambio, el aumento en las potestades del Ejecutivo parecen corresponder a realidades como el combate al tráfico de drogas o la disminución de las notorias desigualdades; a manera de repulsión contra un esquema económico liberal que no funcionó. Esto implica que aunque la magnitud de nuestros problemas sea equiparable a la que enfrentan los europeos, en México parecemos estar intentando producir un efecto contrario: en vez de exigir mayores controles al Ejecutivo, le estamos pavimentando el camino para dejar los estándares de negociación ya no a una asamblea popular, sino a un pacto (desprovisto de requisitos de transparencia o de apego a la voluntad mayoritaria). De nuevo, una invitación abierta a que las oligarquías se sigan entendiendo por encima de sus bases representativas y de sus plataformas partidistas.

5. Patologías que parecían enterradas junto con los totalitarismos, tienen ahora brotes peligrosísimos. Me refiero a la llegada de coaliciones de gobierno encabezadas por partidos de extrema derecha (en Hungría, Austria, Estonia). ${ }^{38}$ El discurso de los extremos es atizado por la actual fiebre anti-inmigrante en Europa, aunque también la idea de superioridad racial en Estados Unidos.

Sin embargo, la academia debe estar consciente de los riesgos de dotar de poderes excesivos a los Ejecutivos. Pues si bien, parece ser una consecuencia de las crisis, también puede desbordar con mucha facilidad en esquemas de gobierno que se vuelvan incontrolados e incontrolables. Como si no hubiera necesidad de frenar sus excesos, se amplía el uso de autorizaciones temporales para actuar (pensemos en el refrendo constante de las leyes de urgencia posteriores a los atentados del 13 de noviembre en Francia). En términos del esquema mexicano de gobiernos de coalición, nada impediría que en el centro del convenio de coalición, se acuerden facultades de excep-

38 Mudde, Cass, On extremism and democracy in Europe, New York, Rutledge, 2016, p. 157. 
Esta obra forma parte del acervo de la Biblioteca Jurídica Virtual del Instituto de Investigaciones Jurídicas de la UNAM

ción al Ejecutivo federal, por solo poner un ejemplo de los excesos a los que se podría llegar.

Los nuevos equilibrios de este sistema de gobierno requieren de antídotos; o si se prefiere, de nociones que viajen de un continente a otro, como la de gobierno abierto, o bien las de transparencia o de democracia en red. ${ }^{39}$ Este nuevo conjunto conceptual, en el que pretenden fundirse las aspiraciones democráticas actuales con las calidades ideales de los representantes y las reglas de organización del poder, parecen un mejor marco analítico para el constitucionalismo.

Los gobiernos de cercanía con la ciudadanía han generado una suerte de culto a la impersonalidad. ${ }^{40}$ En términos actuales, se dibujan los contornos de un modelo donde el ciudadano común ejerce de forma más directa funciones que estuvieron reservadas al parlamento, donde el poder no es una cosa, sino una relación. La liga de confianza con los gobernantes se tiende así partiendo de un cuadro ideal de exigencias con el personaje que encabeza el gobierno, de suerte que el resultado ideal del sistema sea generar una democracia de confianza.

En un esquema totalmente opuesto, el modelo mexicano de gobiernos de coalición deja a un lado al elector. No solo porque estos acuerdos se centren en la Cámara de Senadores y no en la de Diputados, sino porque confían en que los firmantes de un "convenio" de coalición van a ceñirse a la voluntad de sus representados.

Si esto no fuera suficiente para dudar de su efectividad, el esquema mexicano parece utilizar como parapeto a los partidos (aunque en realidad se trate de sus cúpulas). En vez de visibilizar y ampliar en rango de responsabilidad política de quienes gobiernan, los estamos dejando canibalizarse en torno a los intereses cupulares de los dirigentes partidistas.

39 Las señales institucionales de actores políticos de primera línea, como los senadores Beltrones, Escudero y Gamboa, se han manifestado en contra de una intención ciudadana de permitir más y mejores controles a los funcionarios públicos. Por sólo mencionar la negativa a que se conocieran las declaraciones patrimoniales personales, como parte de una iniciativa ciudadana (conocida por la prensa como Ley 3 de 3), formulada por académicos y actores de la sociedad civil. Todo indica que la cuestión quedará fuera de la discusión parlamentaria del Sistema Nacional Anticorrupción, pendiente de aprobación parlamentaria. Véase en Roldán Xopa, José, Josefina Cortés y Max Kaiser, Iniciativa Ciudadana de Ley General de Responsabilidades Administrativas, http://ley3de3.mx/wp-content/uploads/2016/02/ Ley3de3_LEY_IniciativaCiudadanaDeLey General DeResponsabilidadesAdministrativas_ Documento.pdf

40 Rosanvallon, Pierre, cit. n. 11, 2015, p. 51. 
Esta obra forma parte del acervo de la Biblioteca Jurídica Virtual del Instituto de Investigaciones Jurídicas de la UNAM

\section{REFLEXIONES FINALES}

Junto a estos lineamientos constitucionales ya aprobados, ha sido elaborado en el seno del Centro de Estudios Parlamentarios del Senado y el Instituto de Investigaciones Jurídicas un anteproyecto de ley reglamentaria que plantea una propuesta que vale la pena analizar, en espera de esperar a que esos contenidos sean discutidos y eventualmente aprobados por el legislador ordinario. ${ }^{41}$ Por lo pronto, me permito mencionar algunas nociones que, aunque ya no quedaron en la reforma constitucional materia de este comentario, podrían ser retomadas para tratar de incluirlas en la ley secundaria que guíe la formación del esquema de gobiernos de coalición.

Nuestros políticos desconocen, o quieren hacer oídos sordos, de la noción de responsabilidad (y aquí, no me refiero a la penal, sino a la política).

Nuestras instituciones lograron, a costa de muchos años y recursos, garantizar que para detentar el poder se tiene que ser electo democráticamente. Pero no se ha normalizado de la misma forma el hecho de concebir al ejercicio del poder como rodeado de otros mecanismos de validación constante y permanente. La responsabilidad se vuelve la piedra angular; el eslabón perdido entre gobernantes y gobernados. Da poder a los primeros y facultades de control a los segundos. Ser responsable, politicamente, implica someterse a limitaciones que hacen patente esa relación.

¿Y qué clase de responsabilidad puede generar el modelo que instauramos en la fracción xvii de nuestro nuevo artículo 89? No podemos negar que esta noción de responsabilidad también llegó a un punto muerto en Europa. La elección directa de los Ejecutivos alimenta la idea de una liga de confianza frente al electorado, sustituyendo con ello la responsabilidad frente al parlamento. La fatiga de las estructuras de gobierno vuelve cada vez más difícil imputar una conducta a un funcionario específico. Por eso que en ocasiones, no quede más que regresar a la criminalización de los políticos como única catarsis con que cuenta el ciudadano.

El político responsable debe entender que está formando parte de una ficción, que es la que permite mantenerse en el puesto porque goza de la confianza pública. Es decir, mantener la confianza frente a quienes lo eligieron. De que se coaliguen, mejor luego hablamos.

41 Barceló, Daniel y Diego Valadés (eds.), Estudio sobre el sistema presidencial mexicano que contiene anteproyecto de ley del Gobierno de Coalición, México, Unam-Cedip, 2016, p. 19. 